Prepared in cooperation with the State of Wisconsin and local agencies

\title{
Water-Quality and Lake-Stage Data for Wisconsin Lakes, Water Years 2008-2011
}

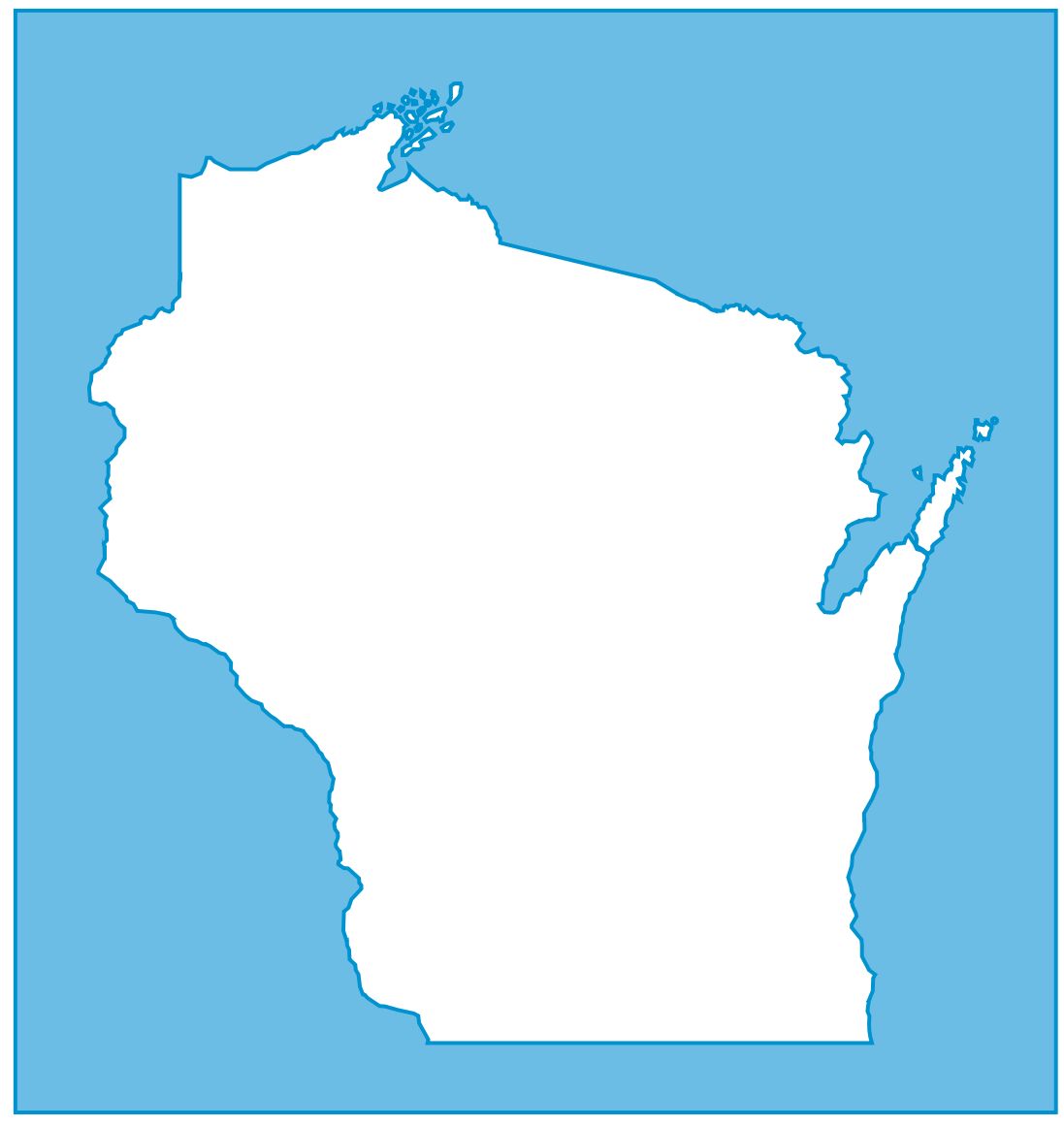

Open-File Report 2012-1238 



\section{Water-Quality and Lake-Stage Data for Wisconsin Lakes, Water Years 2008-2011}

A report by the Wisconsin Water Science Center Lake-Studies Team-

S. Bridgett Manteufel, Daniel L. Olson, Dale M. Robertson, and Gerald L. Goddard

Prepared in cooperation with the State of Wisconsin and with other agencies

Open-File Report 2012-1238 


\section{U.S. Department of the Interior SALLY JEWELL, Secretary}

\section{U.S. Geological Survey Suzette M. Kimball, Director}

\section{U.S. Geological Survey, Reston, Virginia: 2012}

For more information on the USGS - the Federal source for science about the Earth, its natural and living resources, natural hazards, and the environment—visit http://www.usgs.gov or call 1-888-ASK-USGS.

For an overview of USGS information products, including maps, imagery, and publications, visit http://store.usgs.gov.

Any use of trade, firm, or product names is for descriptive purposes only and does not imply endorsement by the U.S. Government.

Although this information product, for the most part, is in the public domain, it also may contain copyrighted materials as noted in the text. Permission to reproduce copyrighted items must be secured from the copyright owner.

Suggested citation:

Manteufel, S.B., Olson, D.L., Robertson, D.M., and Goddard, G.L., 2012, Water-quality and lake-stage data for Wisconsin lakes, water years 2008-2011: U.S. Geological Survey Open-File Report 2012-1238, 554 p., http://dx.doi.org/10.3133/ofr20121238.

ISSN 2328-1258 (online) 


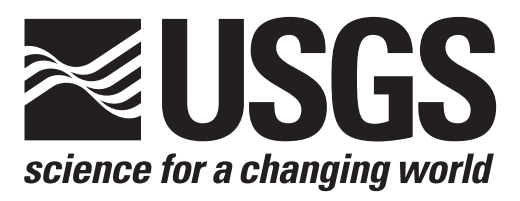

\section{Water-Quality and Lake-Stage Data for Wisconsin Lakes, Water Year 2008}





\section{CONTENTS}

Introduction

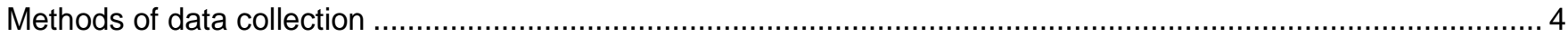

Explanation of physical and chemical characteristics of lakes ……............................................................. 13

Water temperature and thermal stratification ................................................................................ 13

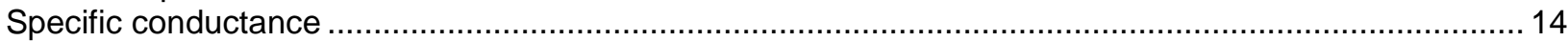

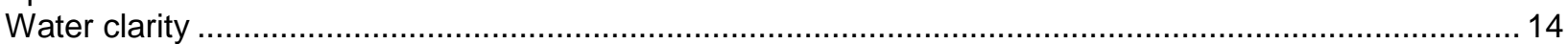

$\mathrm{pH}$

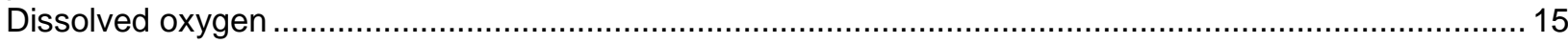

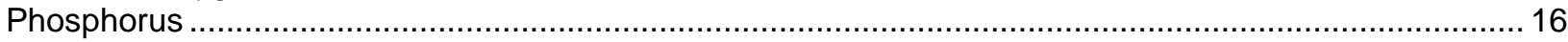

Nitrogen

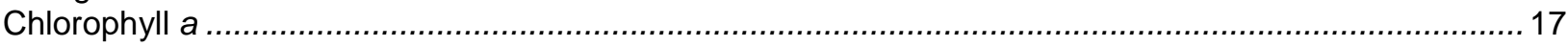

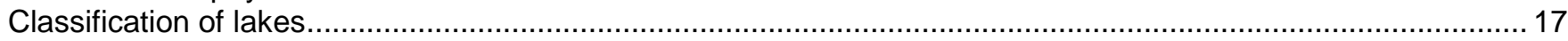

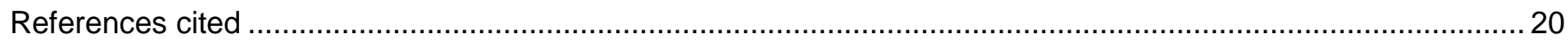

Lake data.

Beulah

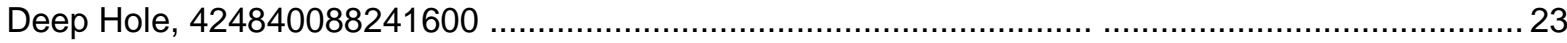

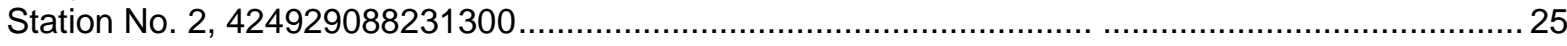

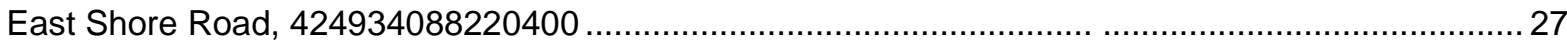

Big Cedar

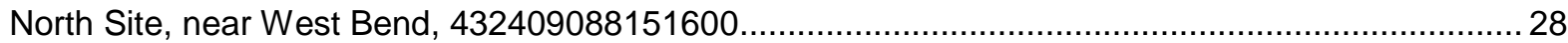

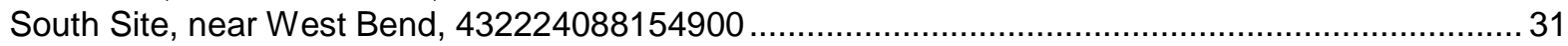

Delavan

near Delavan, 423706088363400 .......................................................................................... 34

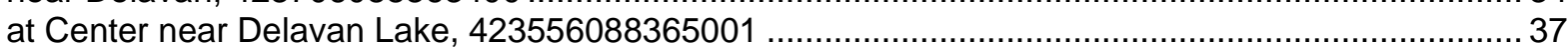

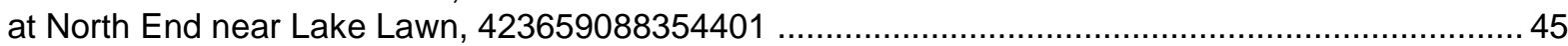

at SW End near Delavan Lake, 423526088380101 ................................................................... 45

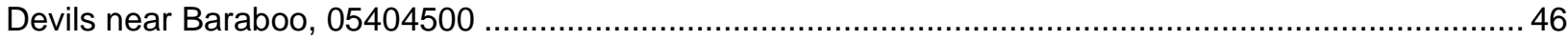

Geneva

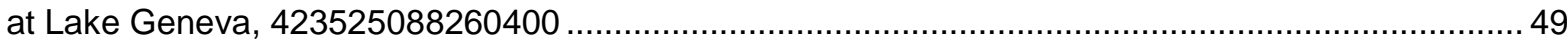

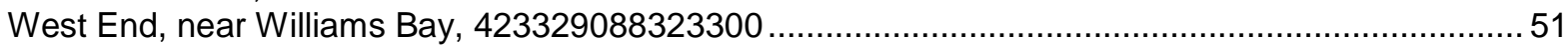

Green

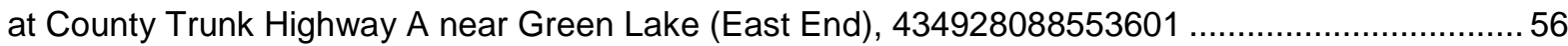

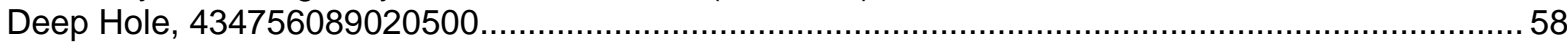

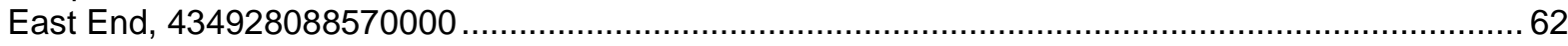

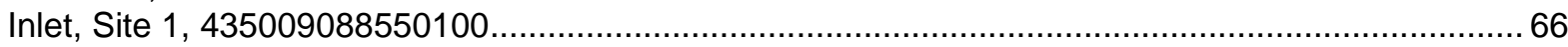

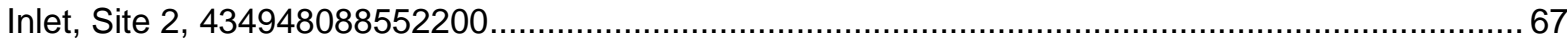

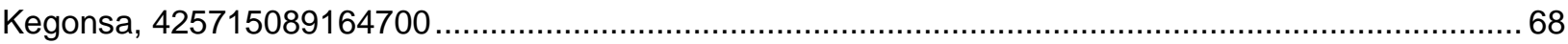

Koshkonong near Newville, 05427235 ................................................................................... 70

Little Cedar

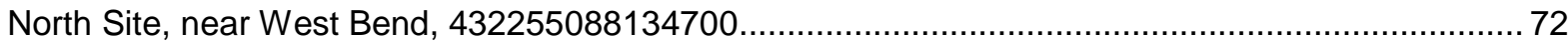

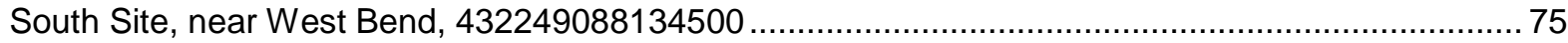

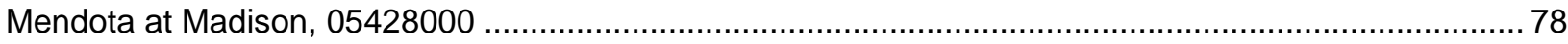

Mercer

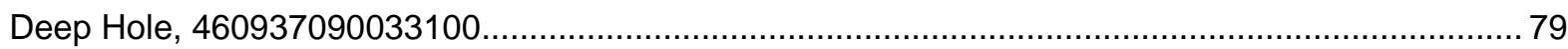

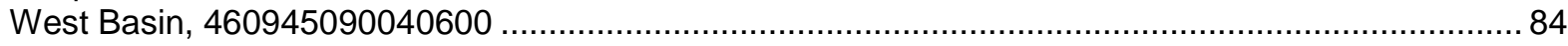

Middle Genesee at Genesee Lake Road, near Oconomowoc, 430251088284700 ................................. 88

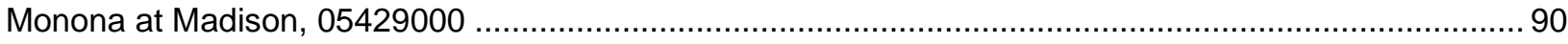

Oconomowoc

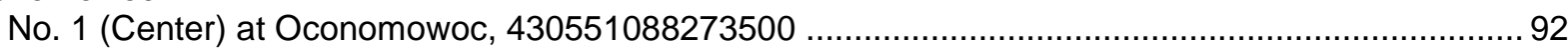

No. 2 (off Hewitt Point) at Oconomowoc, 430609088262200 ………………................................... 95

Okauchee

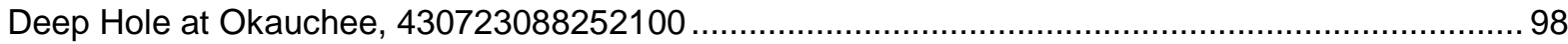

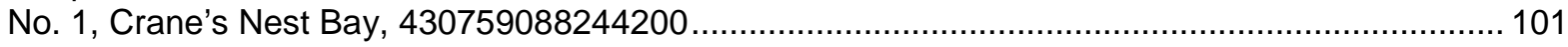




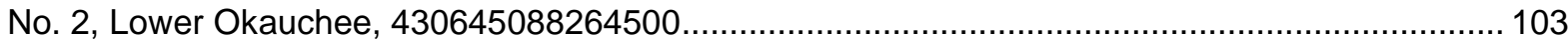

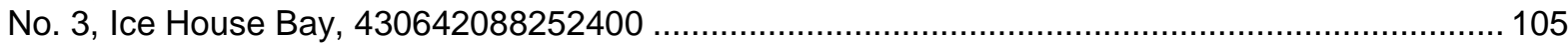

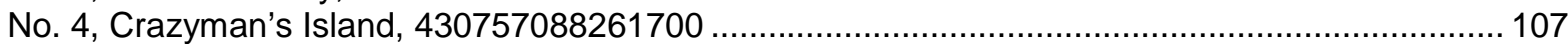

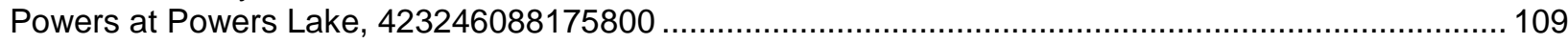

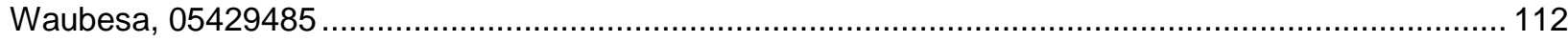

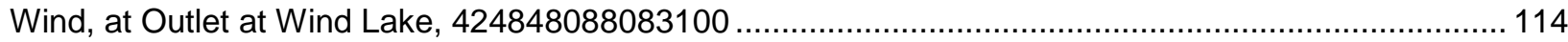

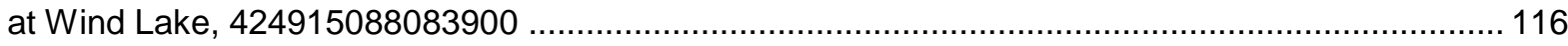

Winnebago

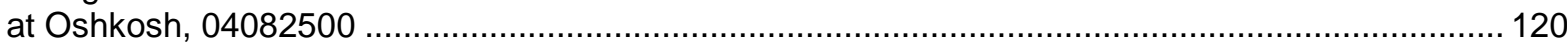

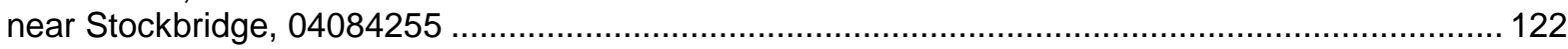

Wisconsin Water Science Center publications pertaining to lakes .............................................................. 124

Appendix - Quality-Assurance/Quality-Control Plan ............................................................................. 135

\section{FIGURE}

Figure 1. Map showing location of USGS lake water-quality and lake-stage stations in Wisconsin ................... 2

\section{TABLES}

Table 1. Discontinued lake stations ....

2. Parameter identification numbers and laboratory reporting levels $(L R L)$ for chemical parameters commonly measured in lakes, and analyzed at the National Water-Quality Laboratory (NWQL) or the Wisconsin State Laboratory of Hygiene (WSLH).... 
CONVERSION FACTORS, VERTICAL DATUM, AND ABBREVIATED WATER-QUALITY UNITS

\begin{tabular}{rrl}
\hline Multiply & By & To Obtain \\
mile (mi) & 1.609 & kilometer \\
pound (lb) & 453.6 & gram \\
acre & 0.4048 & hectare \\
foot (ft) & 0.3048 & meter \\
meter (m) & 3.281 & foot \\
gallon $(\mathrm{gal})$ & 3.785 & liter \\
square mile $\left(\mathrm{mi}^{2}\right)$ & 2.590 & square kilometer \\
& & \\
Temperature, in degrees Celsius $\left({ }^{\circ} \mathrm{C}\right)$ can be converted to degrees Fahrenheit $\left({ }^{\circ} \mathrm{F}\right)$ by use of the following \\
& equation & \\
& ${ }^{\circ} \mathrm{F}=1.8\left({ }^{\circ} \mathrm{C}\right)+32$ & \\
\hline
\end{tabular}

Sea level: In this report "sea level" refers to the National Geodetic Vertical Datum of 1929 (NGVD of 1929)-a geodetic datum derived from a general adjustment of the first-order level nets of both the United States and Canada, formerly called Sea Level Datum of 1929.

Abbreviated water-quality units: Chemical concentrations and water temperature are given in metric units. Chemical concentration is given in milligrams per liter $(\mathrm{mg} / \mathrm{L})$ or micrograms per liter $(\mu \mathrm{g} / \mathrm{L})$. Milligrams per liter is a unit expressing the concentration of chemical constituents in solution as weight (milligrams) of solute per unit volume (liter) of water. One thousand micrograms per liter is equivalent to one milligram per liter. For water with dissolved-solids concentrations less than $7,000 \mathrm{mg} / \mathrm{L}$, the numerical values for concentrations expressed as $\mathrm{mg} / \mathrm{L}$ and $\mu \mathrm{g} / \mathrm{L}$ are the same as for concentrations in parts per million and parts per billion, respectively.

Specific conductance of water is expressed in microsiemens per centimeter at 25 degrees Celsius $(\mu \mathrm{S} / \mathrm{cm})$. This unit is equivalent to micromhos per centimeter $(\mathrm{mmho} / \mathrm{cm})$ at 25 degrees Celsius, formerly used by the U.S. Geological Survey. 


\section{WATER-QUALITY AND LAKE-STAGE DATA FOR WISCONSIN LAKES, WATER YEAR 2008 By Wisconsin Water Science Center Lake-Studies Team}

\section{INTRODUCTION}

The U.S. Geological Survey (USGS), in cooperation with local and other agencies, collects data at selected lakes throughout Wisconsin. These data, accumulated over many years, provide a data base for developing an improved understanding of the water quality of lakes. To make these data available to interested parties outside the USGS, the data are published annually in this report series. The locations of water-quality and lake-stage stations in Wisconsin for water year 2008 are shown in figure 1. A water year is the 12-month period from October 1 through September 30. It is designated by the calendar year in which it ends. Thus, the period October 1, 2007 through September 30, 2008 is called "water year 2008."

The purpose of this report is to provide information about the chemical and physical characteristics of Wisconsin lakes. Data that have been collected at specific lakes, and information to aid in the interpretation of those data, are included in this report. Data collected include measurements of in-lake water quality and lake stage. Time series of Secchi depths, surface total phosphorus and chlorophyll a concentrations collected during non-frozen periods are included for all lakes. Graphs of vertical profiles of temperature, dissolved oxygen, $\mathrm{pH}$, and specific conductance are included for sites where these parameters were measured. Descriptive information for each lake includes: location of the lake, area of the lake's watershed, period for which data are available, revisions to previously published records, and pertinent remarks. Additional data, such as streamflow and water quality in tributary and outlet streams of some of the lakes, are published in another volume: "Water Resources Data-Wisconsin, 2008."

Water-resources data, including stage and discharge data at most streamflow-gaging stations, are available through the World Wide Web on the Internet. The Wisconsin Water Science Center's home page is at http://wi.water.usgs.gov/. Information on the Wisconsin Water Science Center's Lakes Program is found at http://wi.water.usgs.gov/lakes/index.html and http://wi.water.usgs.gov/projects/index.html. 


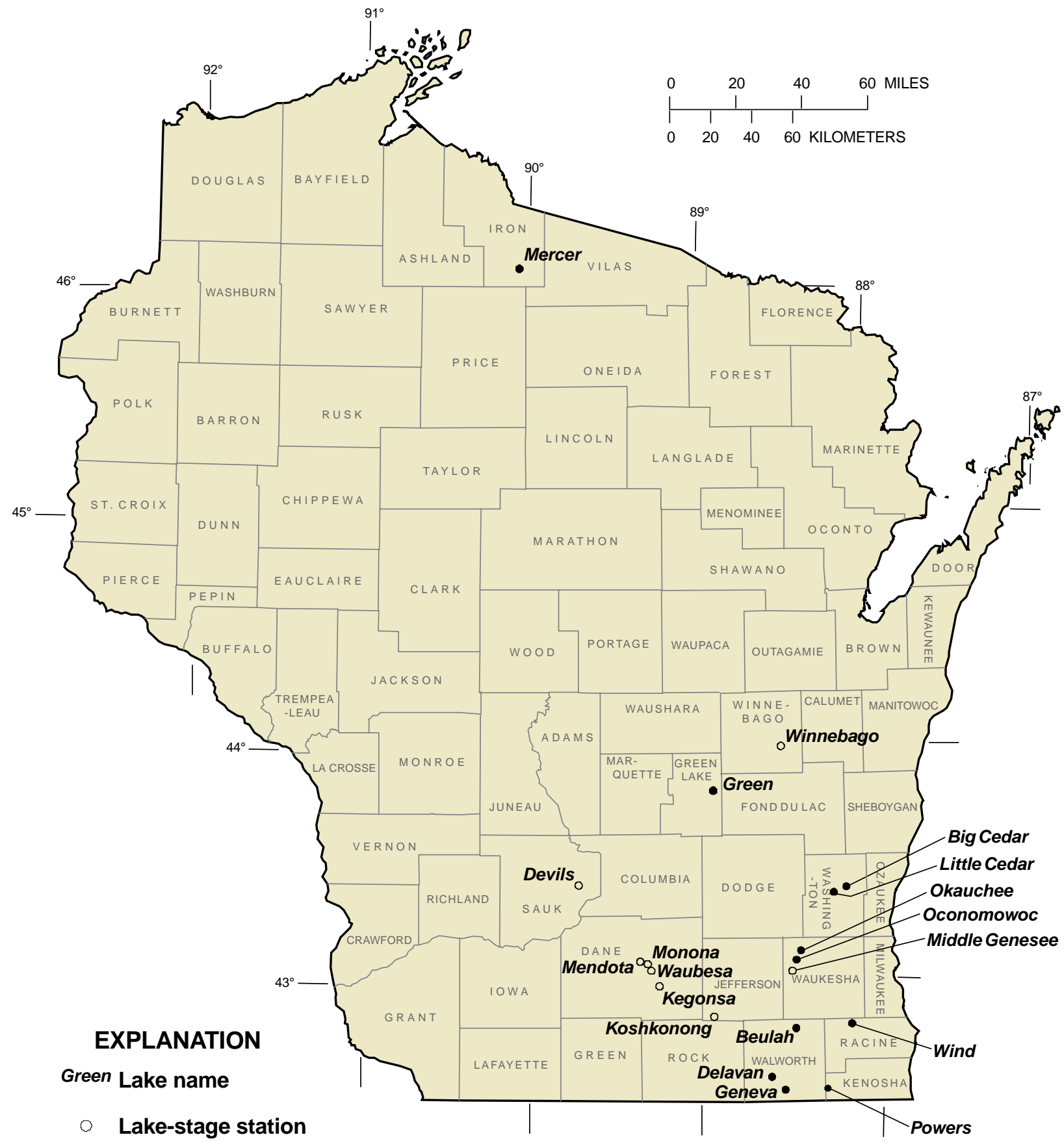

- Lake water-quality and stage station

Note: at some lakes more than one site may be monitored.

Figure 1. Location of USGS lake water-quality and lake-stage stations in Wisconsin. 
The USGS has done cooperative lake monitoring with local and other agencies since 1983. Cooperators in 2008 included:

Big Cedar Lake Protection and Rehabilitation District

Dane County

Delavan Lake Sanitary District

Geneva Lake Environmental Agency

Green Lake Sanitary District

Lake Beulah Management District

Little Cedar Lake Protection and Rehabilitation District

Middle Genesee Lake District

Mercer School District (Mercer Lake Association)

Powers Lake District

Rock County Public Works Department

U.S. Army Corps of Engineers

Village of Oconomowoc Lake

Wind Lake Management District

Wisconsin Department of Natural Resources 
Lake data-collection sites are identified by a unique identification number. Lake waterquality sites are identified by a 15-digit number that is a concatenation of the site's latitude, longitude, and a two-digit sequence number. The sequence number is used to distinguish between sites located at the same latitude-longitude designation. The site identification number is permanently assigned to the site; actual latitude and longitude of the site are subject to update and are stored separately. For some lakes, which have historical records of lake stage, an eight-to-ten digit number is assigned according to downstream order. Gaps are left in the numerical series to allow for new stations; hence, the numbers are not consecutive. The first two digits of the complete eight-to-ten digit number, such as 04087000 or 054310157 , designate the major river basin. For example, "04" designates the St. Lawrence River Basin and "05" designates the Upper Mississippi River Basin.

The water-quality lake stations that were discontinued prior to water year 2008 are listed in table 1. Discontinued lake-stage stations are not included in this table.

This report is the culmination of a concerted effort by a number of people who collected, compiled, analyzed, verified, and organized the data, and who typed, edited, and assembled the report. The authors had primary responsibility for assuring that the information contained herein is accurate, complete, and adheres to USGS policy and established guidelines. Technicians in charge of the field offices are: B.W. Olson (Merrill), and S.A. March (Middleton). The data were collected and processed by G.L. Goddard, S.B. Manteufel, B.W. Olson, D.L. Olson, P.C. Reneau, J.G. Schuler, and B.J. Siebers. S.B. Manteufel assembled, edited, and formatted the report. Additional assistance in preparation of the report was provided by M.M. Greenwood, L.L. Nelson, and D.L. Olson.

\section{METHODS OF DATA COLLECTION}

Depth profiles of water temperature, dissolved oxygen, $\mathrm{pH}$, and specific conductance were collected using multi-parameter meters. Prior to measurements, the meters were calibrated using standards for $\mathrm{pH}$ and conductance, and dissolved oxygen was calibrated using the air calibration method. Generally, field measurements in profiles were made at 0.5-m intervals if the maximum depth of the lake was $5 \mathrm{~m}$ or less and at 1.0-m intervals if the maximum depth was greater than $5 \mathrm{~m}$. 
Table 1. Discontinued lake stations

\begin{tabular}{|c|c|c|}
\hline Station name & Site identification number & Period of record \\
\hline Alma Lake near St. Germain & 455426089254700 & $\begin{array}{l}\text { Oct. 1984-Sept. } 1990 \text {, } \\
\text { May } 1992-S e p t .1996\end{array}$ \\
\hline Balsam Lake, off Cedar Island, at Balsam Lake & 452755092264600 & Feb. 1991-Aug. 1994 \\
\hline off Little Narrows, near Balsam Lake & 452858092265300 & May 1991-Aug. 1994 \\
\hline off Rock Island, near Balsam Lake & 452754092234300 & May 1991-Aug. 1994 \\
\hline Balsam Lake near Birchwood & 453907091345800 & $\begin{array}{l}\text { Mar. 1993-Aug. 1994, } \\
\text { Mar. 1996-Aug. 1997, } \\
\text { Mar.-Sept. } 2001\end{array}$ \\
\hline Bass Lake near Shawano & 445215088300300 & Feb. 1990-Aug. 1992 \\
\hline Bear Lake at Deep Hole near Haugen & 453754091490900 & Mar. 1992-Aug. 1993 \\
\hline Beaver Dam Lake, South end, at Beaver Dam & 432814088515000 & June-Oct. 1991 \\
\hline North end, near Beaver Dam & 433122088545700 & June-Oct. 1991 \\
\hline Benedict Lake near Powers Lake & 423201088180800 & May 1998-Aug. 2000 \\
\hline Big Blacksmith Lake near Keshena & 445401088334500 & Feb. 1990-Aug. 1992 \\
\hline Big Hills (Hills) Lake near Wild Rose & 440912089092000 & $\begin{array}{l}\text { June 1983-Aug. 1984, } \\
\text { Feb.-Aug. 1987, } \\
\text { Feb.-Aug. 1990, } \\
\text { Feb.-Aug. 1993, } \\
\text { Feb.-Aug. 1996, } \\
\text { Feb.-Aug. } 1999\end{array}$ \\
\hline Big Muskego Lake, at North Site, near Muskego & 425301088061300 & Feb.-Aug. 1988 \\
\hline Research Base, near Muskego & 425235088075300 & May-June 1994 \\
\hline Big Round Lake near Milltown & 453142092180100 & Feb.-Sept. 2001 \\
\hline Big St. Germain Lake, near St. Germain & 455557089311000 & Feb. 1992-Aug. 1996 \\
\hline near Lake Tomahawk & 05390750 & 1991-2001 \\
\hline Big Sand Lake, Deep Hole, near Hertel & 454910092134000 & Feb.-Sept. 2001 \\
\hline East Site, near Hertel & 454921092124300 & Feb.-Sept. 2001 \\
\hline Big Sissabagama Lake, near Stone Lake & 454724091303600 & $\begin{array}{l}\text { Apr. 1986-Sept. 1996, } \\
\text { Oct. 1997-Sept. } 2002\end{array}$ \\
\hline North Site, near Stone Lake & 454800091312900 & Mar. 1998-Sept. 2001 \\
\hline Booth Lake near East Troy & 424800088254800 & $\begin{array}{l}\text { Feb. 1992-Aug. 1994, } \\
\text { Feb. 2001-Aug. } 2003\end{array}$ \\
\hline Buffalo Lake, Center Site, at Packwaukee & 434558089260600 & May 1998-Sept. 2001 \\
\hline East End, at Montello & 434720089201600 & May 1998-Sept. 2001 \\
\hline West End, near Endeavor & 434414089282400 & May 1998-Sept. 2001 \\
\hline
\end{tabular}


Table 1. Discontinued lake stations--continued

\begin{tabular}{|c|c|c|}
\hline Station name & Site identification number & Period of record \\
\hline Butternut Lake, near Park Falls & 455854090310300 & Oct. 2002-Oct. 2004 \\
\hline Deep Hole, near Park Falls & 455803090310800 & Mar. 2003-Sept. 2004 \\
\hline North Site, near Butternut & 455904090303400 & Mar. 2003-Sept. 2004 \\
\hline Far South Site, near Park Falls & 455651090312700 & Mar. 2003-Sept. 2004 \\
\hline Denoon Lake at Wind Lake & 425044088100300 & Feb. 1991-Aug. 1996 \\
\hline Druid Lake near Hartford & 431643088243300 & Feb. 1991-Sept. 1996 \\
\hline Eagle Lake near Kansasville & 05544500 & $\begin{array}{l}\text { 1936-64, 1975-77, } \\
\text { 1979, } \\
\text { Feb. 1993-Sept. } 1996\end{array}$ \\
\hline Eagle Lake, at Deep Hole, near Kansasville & 424207088072400 & Feb. 1993-Aug. 1996 \\
\hline Eagle Spring Lake at Eagleville & 425103088261500 & Apr. 1991-Sept. 2001 \\
\hline Elizabeth Lake near Twin Lakes & 423051088155300 & Feb. 1995-Sept. 1997 \\
\hline Fish Lake near Sauk City & 05406050 & $\begin{array}{l}\text { Nov. 1966-Sept. 1981, } \\
\text { Apr. 1985-May 1987, } \\
\text { May 1988, Apr. 1989- } \\
\text { Oct. 1990, Oct. 1990- } \\
\text { Nov. 1996, Nov. 1996- } \\
\text { Sept. } 2004\end{array}$ \\
\hline Fowler Lake, Center, at Oconomowoc & 430653088294601 & $\begin{array}{l}\text { Jan.-Dec. 1984, } \\
\text { Oct. 1986-Sept. } 1996\end{array}$ \\
\hline Fox Lake Deep Hole at Fox Lake & 433458088560600 & June 1991-Mar. 1993 \\
\hline Geneva Lake, Geneva Bay, at Lake Geneva & 423455088263800 & Apr. 1997-Feb. 1999 \\
\hline Williams Bay, at Williams Bay & 423420088320500 & Apr. 1997-Feb. 1999 \\
\hline Center, near Lake Geneva & 423402088301400 & Apr. 1997-Mar. 1999 \\
\hline East End, near Lake Geneva & 423421088272300 & Apr. 1997-May 2000 \\
\hline Hemlock Lake near Mikana & 453421091333700 & $\begin{array}{l}\text { Mar. 1993-Aug. 1994, } \\
\text { Mar. 1996-Aug. 1997, } \\
\text { Mar.-Sept. } 2001\end{array}$ \\
\hline Hooker Lake at Salem & 423335088060300 & Feb. 1992-Aug. 1993 \\
\hline Kawaguesaga, Deep Hole, near Minocqua & 455208089435800 & May-Sept. 2003 \\
\hline South Site, near Minocqua & 455145089442600 & May-Sept. 2003 \\
\hline Kirby Lake near Cumberland & 453554092042101 & Nov. 1995-Oct. 1996 \\
\hline (Site 1) near Cumberland & 453608092035801 & Nov. 1995-Nov. 1996 \\
\hline (Site 2) near Cumberland & 453601092035301 & Nov. 1995-Nov. 1996 \\
\hline
\end{tabular}


Table 1. Discontinued lake stations--continued

\begin{tabular}{|c|c|c|}
\hline Station name & Site identification number & Period of record \\
\hline (Site 3) near Cumberland & 453612092034901 & Nov. 1995-Nov. 1996 \\
\hline (Site 4) near Cumberland & 453603092035701 & Nov. 1995-Nov. 1996 \\
\hline (Site 5) near Cumberland & 453608092041201 & Nov. 1995-Nov. 1996 \\
\hline (Site 6) near Cumberland & 453555092040901 & Nov. 1995-Nov. 1996 \\
\hline Lac La Belle at Oconomowoc & 430733088305900 & $\begin{array}{l}\text { Feb. 1984-Aug. 1985, } \\
\text { Apr. -Aug. 1991, } \\
\text { Feb. 2001-Aug. } 2003\end{array}$ \\
\hline NW, at Oconomowoc & 430809088313900 & Feb. 1984-Aug. 1985 \\
\hline SE, at Oconomowoc & 430707088301400 & Feb. 1984-Aug. 1985 \\
\hline Lake Blass at Lake Delton & 433545089482400 & Mar. 1989-Aug. 1990 \\
\hline Lake Desair near Rice Lake & 453446091465100 & Aug. 2004 \\
\hline $\begin{array}{l}\text { Lake Keesus, } \\
\text { East Bay, near Merton } \\
\text { North Bay, near Merton }\end{array}$ & $\begin{array}{l}430957088183400 \\
431006088191000\end{array}$ & $\begin{array}{l}\text { Apr. 1991-Aug. } 1995 \\
\text { Apr. 1991-Aug. } 1995\end{array}$ \\
\hline Lake Morris at Mount Morris & 440654089120500 & Jun. 1983-Sept. 1989 \\
\hline $\begin{array}{l}\text { Lake Nebagamon, Northeast Bay, at Lake } \\
\text { Nebagamon }\end{array}$ & 463050091412300 & May 1992-Aug. 1995 \\
\hline Southeast Bay, at Lake Nebagamon & 462928091413500 & Mar. 1992-Sept. 1995 \\
\hline West Bay, at Lake Nebagamon & 463034091425300 & May 1992-Aug. 1995 \\
\hline Lake Noquebay near Crivitz & 451511087550900 & $\begin{array}{l}\text { Feb. 1987-Aug. 1988, } \\
\text { Apr. 1991-Aug. } 1994\end{array}$ \\
\hline East End, near Crivitz & 451540087525700 & Apr. 1991-Aug. 1994 \\
\hline Lamotte Lake near Shawano & 445305088361200 & Feb. 1990-Aug. 1992 \\
\hline $\begin{array}{l}\text { Lauderdale Lakes at Lauderdale } \\
\text { Mill, at Lauderdale }\end{array}$ & $\begin{array}{l}424554088332700 \\
424555088335700\end{array}$ & $\begin{array}{l}\text { Oct. 1993-Oct. } 1994 \\
\text { Nov. 1993-Nov. 1994, } \\
\text { Aug. } 2002\end{array}$ \\
\hline Green, Auxiliary, Number 1, near Lauderdale & 424640088341900 & June 1999-Sept. 2000 \\
\hline Green, near Lauderdale & 424652088341500 & $\begin{array}{l}\text { Nov. 1993-Nov. 1994, } \\
\text { Aug. } 2002\end{array}$ \\
\hline Legend Lake (site 1) near Shawano & 445342088312700 & Feb. 1990-Feb. 1992 \\
\hline Little Arbor Vitae near Woodruff & 455446089370300 & Feb. 1991-Sept. 2002 \\
\hline Little Green Lake, at Center, near Markesan & 434412088590700 & Feb. 1991-Aug. 2003 \\
\hline Little Muskego Lake at Muskego & 425425088083500 & Oct. 1986-Aug. 2002 \\
\hline Little Rock Lake near Woodruff & 455946089415702 & Oct. 1983-Sept. 1996 \\
\hline Little St. Germain Lake, near Eagle River & 05390700 & (a) \\
\hline Upper East Bay, at St. Germain & 455532089253900 & $\begin{array}{l}\text { Dec. 1996-Mar. 97, } \\
\text { Mar. 1999, } \\
\text { Mar. 2000-Aug. } 2003\end{array}$ \\
\hline
\end{tabular}


Table 1. Discontinued lake stations--continued

\begin{tabular}{|c|c|c|}
\hline Station name & Site identification number & Period of record \\
\hline Northeast Bay, near St. Germain & 455545089262500 & $\begin{array}{l}\text { Apr. 1991-Aug. 1994, } \\
\text { Aug. 1996-Aug. 1997, } \\
\text { Mar. 1999-Aug. } 2003\end{array}$ \\
\hline South Bay, near St. Germain & 455437089270800 & $\begin{array}{l}\text { Apr. 1991-Aug. 1994, } \\
\text { Aug. 1996-Aug. 1997, } \\
\text { Mar. 1999-Aug. } 2003\end{array}$ \\
\hline West Bay, at St. Germain & 455428089282400 & $\begin{array}{l}\text { Apr. 1991-Aug. 1994, } \\
\text { Aug. 1996-Aug. 1997, } \\
\text { Mar. 1999-Aug. } 2003\end{array}$ \\
\hline Little Sand Lake - Site No. 2 - near Mole Lake & 452826088544101 & May1996-Sept. 2003 \\
\hline Long (Kee Nong Go-Mong) Lake at Wind Lake & 424937088103400 & $\begin{array}{l}\text { Feb. 1988-Aug. 1989, } \\
\text { Feb. 1991-Aug. } 1996\end{array}$ \\
\hline Loon Lake near Shawano & 445009088303700 & Feb. 1991-Aug. 1993 \\
\hline Lost Lake near Beaver Dam & 432640088580500 & June-Oct. 1991 \\
\hline \multicolumn{3}{|l|}{ McKenzie Lakes } \\
\hline \multicolumn{3}{|l|}{ McKenzie (Big McKenzie) } \\
\hline Deep Hole, near Spooner & 455507092013500 & Feb. 1987-Aug. 1998 \\
\hline Northern Site, near Spooner & 455540092022000 & June 1997-Aug. 1998 \\
\hline South Site, near Spooner & 455437092022300 & June 1997-Aug. 1998 \\
\hline Lower McKenzie, near Webb Lake & 455902092011900 & June 1997-Aug. 1998 \\
\hline Middle McKenzie, near Spooner & 455635092021800 & June 1997-Aug. 1998 \\
\hline Mary (Marie) Lake at Twin Lakes & 423128088151200 & Feb. 1995-Aug. 1997 \\
\hline Max Lake near Woodruff & 460128089423501 & Mar. 1988-Dec. 1996 \\
\hline Mead Lake, East Bay near Willard & 444720090445000 & Apr. 1991-Aug. 1995 \\
\hline West Bay near Willard & 444733090460100 & Feb. 1991-Sept. 1995 \\
\hline \multicolumn{3}{|l|}{ Minocqua Lake } \\
\hline Deep Hole, at Minocqua & 455214089412800 & May-Sept. 2003 \\
\hline North Bay, at Minocqua & 455232089424100 & May-Sept. 2003 \\
\hline South Bay, at Minocqua & 455206089425200 & May-Sept. 2003 \\
\hline Montello Lake at Montello & 434748089195800 & Feb. 1995-Aug. 1998 \\
\hline Moon Lake near St. Germain & 455504089260500 & Feb. 1992-Aug. 1996 \\
\hline Morgan Lake near Fence & 454622088324801 & Oct. 1987-Sept. 1998. \\
\hline Moshawquit Lake near Shawano & 445352088295800 & Feb. 1990-Aug. 1992 \\
\hline \multicolumn{3}{|l|}{ Muskego (Big Muskego) } \\
\hline Auxiliary Number 1 , near Muskego & 425329088054000 & June 1996-Aug. 2000 \\
\hline Bass Bay, near Muskego & 425344008807010 & Feb. 1988-Aug. 2002 \\
\hline
\end{tabular}


Table 1. Discontinued lake stations--continued

\begin{tabular}{|c|c|c|}
\hline Station name & Site identification number & Period of record \\
\hline near Wind Lake & 425109088075000 & $\begin{array}{l}\text { Oct. 1987-Sept. 1989, } \\
\text { Jan. 1991-Sept. } 2002\end{array}$ \\
\hline South Site, near Muskego & 425212088072800 & Feb. 1988-Aug. 2002 \\
\hline Muskellunge Lake near Eagle River & 455700089224900 & June 2000-Aug. 2001 \\
\hline $\begin{array}{l}\text { Muskellunge Lake, near Lake Outlet near Eagle } \\
\text { River }\end{array}$ & 455706089232400 & Nov. 2000-Oct. 2001 \\
\hline Nagawicka Lake, at Deep Hole, at Delafield & 430417088230300 & Feb. 2003-Sept. 2004 \\
\hline \multicolumn{3}{|l|}{ Namekagon Lakes } \\
\hline Garden, near Cable & 461224091033200 & Mar. 1998-Aug. 1999 \\
\hline Jackson, near Cable & 461457091065900 & Mar. 1998-Aug. 1999 \\
\hline \multicolumn{3}{|l|}{ Namekagon } \\
\hline Deep Hole, near Cable & 461308091065100 & Mar. 1998-Aug. 1999 \\
\hline East Basin, near Cable & 461228091044300 & Mar. 1998-Aug. 1999 \\
\hline Northeast Basin, near Cable & 461410091050700 & Mar. 1998-Aug. 1999 \\
\hline Park Lake (site 1) at Pardeeville & 433239089175800 & $\begin{array}{l}\text { Feb. 1986-Aug. 1987, } \\
\text { May-Nov. } 1993\end{array}$ \\
\hline (site 2) at Pardeeville & 433226089175500 & May-Nov. 1993 \\
\hline (site 3) at Pardeeville & 433245089173000 & May-Nov. 1993 \\
\hline (site 4) at Pardeeville & 433257089165100 & May-Nov. 1993 \\
\hline Pike Lake near Hartford & 431916088200501 & Dec. 1998-Dec. 2000 \\
\hline Pike Lake-QW Site-near Hartford & 431835088200600 & Feb.-Aug. 2000 \\
\hline Potter Lake near Mukwonago & 423246088175800 & Feb. 1993-Sept. 2007 \\
\hline Pretty Lake, at Deep Hole, near Dousman & 425722088295000 & Feb. 1993-Aug. 1997 \\
\hline Puckaway Lake, West Basin, near Marquette & 434515089124000 & Apr. 2005-Sept. 2007 \\
\hline East Basin, near Marquette & 43454208907300 & Apr. 2005-Sept. 2007 \\
\hline River site, near Marquette & 434824089083200 & Apr. 2005-Sept. 2007 \\
\hline Red Cedar Lake, at Mikana & 453522091360600 & $\begin{array}{l}\text { Mar. 1993-Aug. 1994, } \\
\text { Mar. 1996-Aug. 1997, } \\
\text { Oct. 2000-Sept. } 2001\end{array}$ \\
\hline Deep Hole, near Mikana & 453725091345100 & $\begin{array}{l}\text { Mar. 1993-Aug. 1994, } \\
\text { Mar. 1996-Aug. 1997, } \\
\text { Mar. -Sept. } 2001\end{array}$ \\
\hline South End, at Mikana & 453519091352500 & $\begin{array}{l}\text { Mar. 1993-Aug. 1994, } \\
\text { Mar. 1996-Aug. 1997, } \\
\text { Mar. -Sept. } 2001\end{array}$ \\
\hline Rice Lake at Deep Hole near Whitewater & 424629088415700 & Apr.-Nov. 1991 \\
\hline Round Lake near Shawano & 445328088335000 & Feb. 1990-Aug. 1992 \\
\hline Sand Lake (Deep Hole) near Keshena & 445321088323101 & June-Aug. 1992 \\
\hline
\end{tabular}


Table 1. Discontinued lake stations--continued

\begin{tabular}{|c|c|c|}
\hline Station name & Site identification number & Period of record \\
\hline Shell Lake at Shell Lake & 05334000 & Aug. 1936-Sept. 1999 \\
\hline Silver Lake near Oconomowoc & 430436088293300 & Apr. 1992-Aug. 1996 \\
\hline Silver Lake near West Bend & 432322088125000 & Feb. 1996-Aug. 1997 \\
\hline Sinissippi Lake, off Anthony Is., at Hustisford & 432113088361100 & Feb. 1991-Aug. 1993 \\
\hline off Butternut Is., near Hustisford & 432240088363900 & Apr. 1991-Aug. 1993 \\
\hline off Sam Point, near Hustisford & 432300088374200 & Apr. 1991-Aug. 1993 \\
\hline Spirit Lake near Keshena & 445400088320100 & Apr.-Aug. 1992 \\
\hline Spooner Lake, Deep Hole, near Spooner & 455034091493300 & June 2002-Aug. 2004 \\
\hline Southeast Site, near Spooner & 454945091483900 & June 2002-Aug. 2004 \\
\hline Stewart Lake at Mt. Horeb & 430117089442701 & May 1992-Sept. 1993 \\
\hline Tichigan Lake near Waterford & 424854088123300 & $\begin{array}{l}\text { Mar. 1994-Aug. 1996, } \\
\text { Apr. 2003-Aug. } 2004\end{array}$ \\
\hline Tombeau Lake near Powers Lake & 423153088184800 & May 1998-Aug. 2000 \\
\hline Twin Lake, East Twin, near Westfield & 435430089350700 & June 2002-Aug. 2004 \\
\hline West Twin, near Westfield & 435438089352300 & June 2002-Aug. 2004 \\
\hline
\end{tabular}

In most lakes, water samples were collected at two depths - near the surface and near the bottom. Chemical analyses of water samples were performed using standard analytical methods by either the USGS National Water Quality Laboratory (Wershaw and others, 1987; Fishman and Friedman, 1989; Fishman, 1993) or the Wisconsin State Laboratory of Hygiene (Wisconsin State Laboratory of Hygiene, 1993). Analyses for dissolved constituents were performed on samples that were filtered in the field through a $0.45-\mathrm{mm}$ (micrometer) pore-size filter. Total or total recoverable constituents were determined by analyzing unfiltered water samples. Preservation and shipment of samples followed standard protocols established by the laboratories. Water-quality data were archived in the Water Quality Data Base (QWDATA) of the National Water Information System (NWIS). Additional descriptive information about waterquality data is available in the data report: "Water Resources Data - Wisconsin, 2008". NWIS parameter codes and minimum laboratory reporting levels for chemical constituents are given in table 2. The parameter code for turbidity has changed from 00076 to 63675 or 63676 because the method of testing has changed. 
Records of lake stage are considered complete when one or more manual or automatic measurements were obtained per day. Partial records of lake stage result when measurements were less frequent than daily. A complete description of manual or automatic measurements of lake stage is described by Rantz and others (1982). 
Table 2. Parameter identification numbers and laboratory reporting levels (LRL) for chemical parameters commonly measured in lakes, and analyzed at the National Water Quality Laboratory (NWQL) or the Wisconsin State Laboratory of Hygiene (WSLH).

\begin{tabular}{|c|c|c|c|c|c|c|c|c|c|}
\hline \multirow[b]{4}{*}{ Parameter Name } & \multirow[b]{4}{*}{ Units } & \multirow[b]{4}{*}{$\begin{array}{c}\text { CAS } \\
\text { Number }^{1}\end{array}$} & \multirow[b]{4}{*}{$\begin{array}{l}\text { Parameter } \\
\text { Code }^{2}\end{array}$} & \multicolumn{4}{|c|}{ (NWQL) } & \multicolumn{2}{|c|}{ (WSLH) } \\
\hline & & & & \multirow{2}{*}{\multicolumn{2}{|c|}{$\begin{array}{l}\text { Standard } \\
\text { Analysis }\end{array}$}} & \multirow{2}{*}{\multicolumn{2}{|c|}{$\begin{array}{l}\text { Low-Level } \\
\text { Analysis }\end{array}$}} & \multirow[b]{3}{*}{ LRL } & \multirow[b]{3}{*}{$\begin{array}{l}\text { Test } \\
\text { Code }\end{array}$} \\
\hline & & & & & & & & & \\
\hline & & & & LRL & $\begin{array}{l}\text { Lab } \\
\text { Code }\end{array}$ & LRL & $\begin{array}{l}\text { Lab } \\
\text { Code }\end{array}$ & & \\
\hline Calcium, diss. (Ca) & $\mathrm{mg} / \mathrm{L}$ & $7440-70-2$ & 00915 & 0.020 & 659 & 0.002 & 1895 & 0.02 & I230IUD \\
\hline Magnesium, diss. (Mg) & $\mathrm{mg} / \mathrm{L}$ & $7439-95-4$ & 00925 & 0.004 & 663 & 0.001 & 1897 & 0.02 & I390IUD \\
\hline Sodium, diss. (Na) & $\mathrm{mg} / \mathrm{L}$ & $7440-23-5$ & 00930 & 0.09 & 675 & 0.025 & 1898 & 0.09 & I80IUD \\
\hline Potassium, diss. (K) & $\mathrm{mg} / \mathrm{L}$ & $7440-09-7$ & 00935 & 0.24 & 54 & 0.01 & 833 & 0.3 & I540IUD \\
\hline Sulfate, diss. (SO4) & $\mathrm{mg} / \mathrm{L}$ & $14808-79-8$ & 00945 & 0.31 & 1572 & 0.01 & 1263 & 1.0 & I600DLD \\
\hline Chloride, diss. (Cl) & $\mathrm{mg} / \mathrm{L}$ & $16887-00-6$ & 00940 & 0.29 & 1571 & 0.01 & 1259 & 0.1 & I240ELD \\
\hline Fluoride, diss. (F) & $\mathrm{mg} / \mathrm{L}$ & $16984-48-8$ & 00950 & 0.100 & 31 & 0.01 & 1260 & 0.03 & I330FLD \\
\hline Iron, diss. (Fe) & $(\mu \mathrm{g} / \mathrm{L})$ & $7439-89-6$ & 01046 & 10 & 645 & 3 & 1896 & 10 & I370IUD \\
\hline Manganese, diss. (Mn) & $(\mu \mathrm{g} / \mathrm{L})$ & $7439-96-5$ & 01056 & 2.2 & 648 & 1 & 1793 & 0.4 & I400IUD \\
\hline Silica, diss. (SiO2) & $\mathrm{mg} / \mathrm{L}$ & $7631-86-9$ & 00955 & 0.1 & 56 & 0.02 & 1899 & 0.008 & I560LLD \\
\hline $\begin{array}{l}\text { Nitrogen, } \mathrm{NO} 2+\mathrm{NO} 3 \text {, } \\
\text { diss. }\end{array}$ & $\mathrm{mg} / \mathrm{L}$ & -- & 00631 & 0.05 & 1975 & 0.005 & 1979 & 0.01 & I460MLD \\
\hline $\begin{array}{l}\text { Nitrogen, ammonia, } \\
\text { diss. }\end{array}$ & $\mathrm{mg} / \mathrm{L}$ & $7664-41-7$ & 00608 & 0.02 & 1976 & 0.002 & 1980 & 0.013 & I440NLD \\
\hline $\begin{array}{l}\text { Nitrogen, amm.+org., } \\
\text { total }^{4}\end{array}$ & $\mathrm{mg} / \mathrm{L}$ & $17778-88-0$ & 00625 & 0.100 & 1985 & -- & -- & 0.2 & I470BLT \\
\hline $\begin{array}{l}\text { Nitrogen, } \\
\text { amm.+org.,diss. }\end{array}$ & $\mathrm{mg} / \mathrm{L}$ & -- & 00623 & -- & -- & -- & -- & -- & I470DLD \\
\hline Nitrogen, total $\left.\right|^{5}$ & $\mathrm{mg} / \mathrm{L}$ & -- & 00600 & -- & -- & -- & -- & -- & -- \\
\hline Nitrogen, dissolved & $\mathrm{mg} / \mathrm{L}$ & -- & 00602 & -- & -- & -- & -- & -- & -- \\
\hline Phosphorus, total & $\mathrm{mg} / \mathrm{L}$ & $7723-14-0$ & 00665 & 0.05 & 1984 & 0.004 & 2333 & 0.005 & I520PLT \\
\hline Phosphorus, ortho, diss. & $\mathrm{mg} / \mathrm{L}$ & $14265-44-2$ & 00671 & 0.01 & 1262 & 0.002 & 1978 & 0.002 & I530CLD \\
\hline $\begin{array}{l}\text { Chlorophyll a, } \\
\text { phytoplankton }\end{array}$ & $(\mu \mathrm{g} / \mathrm{L})$ & $479-61-8$ & 70953 & 0.1 & 586 & -- & -- & -- & -- \\
\hline $\begin{array}{l}\text { Chlorophyll a, } \\
\text { phytoplankton }\end{array}$ & $(\mu \mathrm{g} / \mathrm{L})$ & $479-61-8$ & 32210 & -- & -- & -- & -- & 0.26 & I250UNF \\
\hline
\end{tabular}

1: CAS (Chemical Abstracting Services) number = unique identification for each constituent

2: Parameter Code - unique number for storage of data in database

3: Calculated as difference between total ammonia + organic nitrogen and ammonia nitrogen

4: Also known as Total Kjeldahl Nitrogen (TKN)

5: Calculated as sum of TKN + Nitrogen as $(\mathrm{NO} 2+\mathrm{NO} 3)$ 


\section{EXPLANATION OF PHYSICAL AND CHEMICAL CHARACTERISTICS OF LAKES}

Following are brief, generalized explanations of some of the common measurements of water quality and some of the physical processes occurring in lakes that influence these measures of water quality. More detailed explanations of water-quality data and lake processes are given by Wetzel (1983), Hem (1985), and Shaw and others (1993).

\section{Water Temperature and Thermal Stratification}

Water temperature in lakes is important because of its role in stratification and because of the temperature dependence of many chemical reactions and life processes of aquatic organisms. The extent of thermal stratification in lakes depends on the interaction between the lake's shape, water clarity, solar heating, and wind-driven mixing. Complete mixing of the lake is usually inhibited by thermal stratification in summer and by ice cover in winter. Thermal stratification affects water quality and the distribution of organisms in the lake. Summer thermal stratification can occur in any lake, but in Wisconsin it commonly occurs in lakes deeper than about $6 \mathrm{~m}$ (Shaw and others, 1993).

The density of water increases with decreasing temperature down to a temperature of $4^{\circ} \mathrm{C}$, then decreases with decreasing temperature between $4^{\circ} \mathrm{C}$ and the freezing point of water $\left(0^{\circ} \mathrm{C}\right)$. For a brief period in the spring after the ice is out, water temperature is usually uniform through the entire water column and wind action causes the lake to mix completely. This process is known as "spring turnover." As the lake absorbs the sun's energy, the surface water becomes warmer and its density decreases, making it more resistant to complete mixing. The difference in density caused by different water temperatures can prevent warm and cold water from mixing. In most lakes, therefore, a density "barrier" forms between the warmer surface water (epilimnion) and the underlying colder water (hypolimnion). This barrier is often marked by a sharp temperature gradient known as the "thermocline (metalimnion)." During the stratified summer period, these three distinct layers of lake water are often present. As the temperature difference between surface and deep water increases, this "stratified" condition stabilizes and can persist until surface temperatures decrease in the fall, which decreases the stability of the stratification. The mixing of the lake water in the fall is known as "fall turnover." 
Thermal stratification may also occur under ice cover in the winter. In the winter, the coldest water (near $0^{\circ} \mathrm{C}$ ) under the ice at the surface of the lake is less dense than water deeper in the lake with warmer temperatures.

\section{Specific Conductance}

Specific conductance is a measure of the ability of water to conduct an electrical current and is an indicator of the concentration of dissolved solids in the water. Because conductance is temperature related, reported values are normalized at $25^{\circ} \mathrm{C}$ and are termed specific conductance. As the concentration of dissolved minerals increases, specific conductance increases. During winter and summer thermal stratification, concentrations of dissolved constituents near the lake bottom increase due to the decomposition of materials settling from the epilimnion, or release of dissolved materials (such as iron, manganese, and phosphorus) from the bottom sediments during anoxic periods. Therefore, differences in specific conductance with depth indicate differences in concentrations of dissolved solids.

\section{$\underline{\text { Water Clarity }}$}

Water clarity, or transparency, is commonly measured using a Secchi disc. The range of depths within which photosynthetic activity occurs depends largely on depth of light penetration, which is influenced by water clarity. A Secchi disc, most commonly an 20-cm.-diameter disc with alternating black-and-white quadrants, is lowered to a depth at which it is no longer visible. This depth is referred to as the Secchi depth. Clarity can be reduced by algae, zooplankton, water color, and suspended sediment. Algae are often the most dominant influence on clarity in lakes and, therefore, Secchi depth is usually correlated with the algal abundance. Secchi depths are generally the least during summer when algal populations are largest.

\section{pH}

The $\mathrm{pH}$ is a measure of the acidity of the water. It is defined as the negative logarithm of hydrogen-ion concentration and varies over a 14-unit log scale, with a pH of 7 being neutral. Values less than 7 indicate acidic conditions; the lower the value, the stronger the acidity. Values greater than 7 indicate alkaline conditions. The $\mathrm{pH}$ of water is influenced in part by photosynthesis and respiration of planktonic algae and aquatic plants. It is important because it affects the solubility of many chemical constituents, and because aquatic organisms have 
limited $\mathrm{pH}$ tolerances. Planktonic algae and aquatic plants produce oxygen and consume carbon dioxide as they photosynthesize during daytime; they consume oxygen and produce carbon dioxide when they respire at night. Carbon dioxide combines with the water molecule to form carbonic acid; therefore respiration causes a decrease in $\mathrm{pH}$ at night and photosynthesis during the day causes an increase in $\mathrm{pH}$. The result is a daily cycle in $\mathrm{pH}$. Because phytoplankton are usually concentrated in the near-surface water, changes in $\mathrm{pH}$ in the epilimnion are more extreme than in the hypolimnion, where less photosynthesis usually occurs.

Lakes having good fish populations and productivity generally have a $\mathrm{pH}$ between 6.7 and 8.2. Values of $\mathrm{pH}$ greater than 8.5 have been shown to cause the release of phosphorus from lake sediments (James and Barko, 1991).

\section{Dissolved Oxygen}

Dissolved oxygen is one of the most critical factors affecting a lake ecosystem because it is essential to most aquatic organisms, and it is involved in many chemical reactions. Very low dissolved oxygen concentrations can control some types of chemical reactions. The solubility of oxygen in water is inversely related to temperature-that is, oxygen solubility decreases as water temperature increases. This relation is important because at warmer temperatures the metabolic rate of organisms increases but less oxygen is available for respiration. The primary sources of dissolved oxygen are from the air and from photosynthesis. The minimum dissolved oxygen concentration specified in national water-quality criteria for early life stages of warmwater aquatic life is 5.0 mg/L (U.S. Environmental Protection Agency, 1986).

In early summer, if thermal stratification develops, the metalimnion restricts the surface supply of dissolved oxygen to the hypolimnion. The hypolimnion can become isolated from the atmosphere. Thus, as summer progresses, the dissolved oxygen concentration can decrease in response to decomposition of dead algae that settle from the epilimnion and in response to the biological and chemical oxygen demand of the sediments. The oxygen demand from these processes may completely deplete the oxygen (anoxia) in the water near the lake bottom. The oxygen depletion then progresses upward but usually is confined to the hypolimnion.

Anoxia in the hypolimnion is common in stratified eutrophic (nutrient-rich) lakes in Wisconsin. Complete anoxia, however, is often not detected because of meter constraints. During anoxic conditions, many aquatic organisms cannot survive, but many other species 
(primarily bacteria) actually function only in such conditions. Therefore, a shift from oxic to anoxic conditions produces a rapid and dramatic change in the biological community and chemical environment. Anoxia also can cause release of phosphorus from the bottom sediments. This phosphorus then mixes throughout the water column during spring and fall turnover.

\section{Phosphorus}

Phosphorus is one of the essential nutrients for plant growth. High phosphorus concentrations can cause dense algal populations (blooms) and can therefore be a major cause of eutrophication in lakes. When phosphorus concentrations exceed $0.025 \mathrm{mg} / \mathrm{L}$ at the time of spring overturn in lakes and reservoirs, these water bodies may occasionally experience excess or nuisance growth of algae or other aquatic plants (U.S. Environmental Protection Agency, 1986). In many regions of the country, including the upper Midwest, other nutrients, particularly nitrogen, tend to be in abundant supply. Phosphorus is often the nutrient in shortest supply, therefore limiting or controlling plant growth. About 90 percent of the lakes in Wisconsin are limited by phosphorus (Shaw and others, 1993). In water, dissolved orthophosphate is that part of total phosphorus that is most readily available for use by algae.

Internal phosphorus recycling occurs in many lakes. Phosphorus used by algae, aquatic plants, fish, and zooplankton is stored within these organisms. As these organisms die and decompose, this phosphorus is returned to the lake water and sediments. Anoxia in the hypolimnion makes phosphorus more soluble, adding further to the release of phosphorus from the falling particles and the lake sediments. During spring and fall turnover the phosphorus, which was released from the bottom sediments into the hypolimnion during anoxia, is mixed throughout the lake. The phosphorus is then available for algal growth. These phenomena are part of the internal-recycling processes of lakes.

\section{Nitrogen}

Nitrogen, like phosphorus, is an essential nutrient for plant and algal growth. Usually in Wisconsin lakes, nitrogen is in abundant supply from the atmosphere and other sources. If phosphorus is abundant relative to algal needs, nitrogen can become the limiting nutrient. In that case, algal blooms are more likely to be triggered by increases in nitrogen than by increases in phosphorus. Some bluegreen algal species can fix nitrogen from the atmosphere 
(Wetzel, 1983). Therefore, in situations where other types of algae are excluded because of a shortage of nitrogen, the nitrogen-fixing bluegreen algae have a competitive advantage and may be present in abundance.

Lakes with a nitrogen to phosphorus ratio larger than 15 to 1 near the surface may generally be considered phosphorus limited; a ratio from 10 to 1 to 15 to 1 indicates a transition situation; and a ratio smaller than 10 to 1 generally indicates nitrogen limitation. Total nitrogen is the sum of ammonia, organic nitrogen, and nitrate-plus-nitrite nitrogen. The near-surface concentration is commonly used to compute the total nitrogen to phosphorus ratio because most algal species grow near the lake surface.

\section{Chlorophyll a}

Chlorophyll $a$ is a photosynthetic pigment found in algae (Wetzel, 1983) and other green plants. Its concentration, therefore, is commonly used as a measure of the density of the algal population in a lake. Chlorophyll a concentrations are generally highest during summer when algal populations are highest. Moderate populations of desirable algae are important in the food chain; however, excessive populations or algal blooms are undesirable. Algal blooms can cause taste and odor problems, and limit light penetration needed to support growth of submerged aquatic plants. Certain species of bluegreen algae can produce toxins (Rapavich and others, 1987).

\section{CLASSIFICATION OF LAKES}

Two methods are commonly used to classify and evaluate Wisconsin lakes according to their water quality or trophic state: Lillie and Mason's (1983) water-quality index and Carlson's (1977) trophic state index (TSI). In previous USGS data reports, a modification of Carlson's trophic state index for Wisconsin lakes by Lillie and others (1993) had been used; however, this approach did not properly classify oligotrophic and highly euthrophic lakes and, therefore, was discontinued. 
Lillie and Mason's (1983) water quality indices for Wisconsin lakes were developed based on summer measurements of total phosphorus and chlorophyll a concentrations, and Secchi depth from a random set of lakes in Wisconsin. These data were used to classify the lakes's water quality as shown below:

\begin{tabular}{lccc}
\hline Water-quality index & $\begin{array}{c}\text { Total phosphorus } \\
\text { range }(\mathrm{mg} / \mathrm{L})\end{array}$ & $\begin{array}{c}\text { Chlorophyll a range } \\
(\mu \mathrm{g} / \mathrm{L})\end{array}$ & $\begin{array}{c}\text { Water clarity range } \\
(\text { Secchi depth, in } \\
\text { meters })\end{array}$ \\
\hline "Excellent" & $<0.001$ & $<1.0$ & $>6.0$ \\
"Very good" & $.001-.009$ & $1.0-4.9$ & $3.0-6.0$ \\
"Good" & $.010-.029$ & $5.0-9.9$ & $2.0-2.9$ \\
"Fair" & $.030-.049$ & $10.0-14.9$ & $1.5-1.9$ \\
"Poor" & $.050-.149$ & $15.0-30.0$ & $1.0-1.4$ \\
"Very poor" & $>.150$ & $>30.0$ & $<1.0$ \\
\hline
\end{tabular}

Carlson's (1977) TSI approach to lake classification assigns numerical ranges to the three trophic conditions generally used to describe the wide range of lake water-quality conditions. Oligotrophic lakes are typically clear, algal populations and phosphorus concentrations are low, and the deepest water is likely to contain oxygen throughout the year. Mesotrophic lakes typically have a moderate supply of nutrients, experience moderate algal blooms, and have occasional oxygen depletions at depth. Eutrophic lakes are nutrient rich with relatively severe water-quality problems, such as frequent seasonal algal blooms, oxygen depletion in lower parts of the lakes, and poor clarity. When eutrophic conditions are very severe, the lake is considered hypereutrophic.

Carlson's (1977) TSI values are also based on near-surface total phosphorus and chlorophyll a concentrations, and Secchi depths. The indices were developed to place these three characteristics on similar scales to allow comparison of different lakes. TSI values based on phosphorus concentrations $\left(\mathrm{TSI}_{\mathrm{P}}\right)$, Secchi depths $\left(\mathrm{TSI}_{\mathrm{SD}}\right)$, and chlorophyll a concentrations $\left(\mathrm{TSI}_{\mathrm{C}}\right)$ typically are computed only for measurements collected during the open-water period.

TSI values for a lake can be calculated using the following equations (Carlson, 1977): 
$\mathrm{TSI}_{\mathrm{P}}=4.15+14.42 \times($ In [total phosphorus concentration $\left.\times 1,000]\right)$

$\mathrm{TSI}_{\mathrm{SD}}=60.0-14.41 \times($ In Secchi depth)

$\mathrm{TSI}_{\mathrm{C}}=30.6+9.81 \times($ In chlorophyll a concentration)

where: total phosphorus is in milligrams per liter,

Secchi depth is in meters, and

chlorophyll $a$ is in micrograms per liter.

The three main trophic conditions are defined with the following boundaries for total phosphorus, Secchi disc, and chlorophyll a:

\begin{tabular}{lcccc}
\hline Trophic level & $\begin{array}{c}\text { Trophic State } \\
\text { Index }\end{array}$ & $\begin{array}{c}\text { Total phosphorus } \\
(\mathrm{mg} / \mathrm{L})\end{array}$ & Secchi depth $(\mathrm{m})$ & $\begin{array}{c}\text { Chlorophyll a } \\
(\mu \mathrm{g} / \mathrm{L})\end{array}$ \\
\hline
\end{tabular}

Eutrophic

Mesotrophic

$-50$

0.024--------

$-2.0---------$

$-7.2--\cdot-\cdot----$

-40----------

$-0.012$

4.0

$-2.6----\cdot---$

Oligotrophic 


\section{REFERENCES CITED}

Carlson, R.E., 1977, A trophic state index for lakes: Limnology and Oceanography, March, v. 22, no. 2, p. 361-369.

Fishman, M.J., ed., 1993, Methods of analysis by the U.S. Geological Survey National Water Quality Laboratory-Determination of inorganic and organic constituents in water and fluvial sediments: U.S. Geological Survey Open-File Report 93-125, 217 p.

Fishman, M.J., and Friedman, L.C., eds., 1989, Methods for determination of inorganic substances in water and fluvial sediments ( $3^{\text {rd }}$ ed.): U.S. Geological Survey Techniques of Water-Resources Investigations, book 5, chap. A1, 545 p.

Hem, J.D., 1985, Study and interpretation of the chemical characteristics of natural water ( ${ }^{\text {rd }}$ ed.): U.S. Geological Survey Water-Supply Paper 2254, 263 p.

James, W.F., and Barko, J.W., 1991, Littoral-pelagic phosphorus dynamics during nighttime convective circulation: Limnology and Oceanography, v. 36, no. 5, p. 946-960.

Lillie, R.A., Graham, S., and Rasmussen, P., 1993, Trophic-State Index equations and regional predictive equations for Wisconsin lakes: Wisconsin Department of Natural Resources Research Management Findings No. 35, 4 p.

Lillie, R.A., and Mason, J.W., 1983, Limnological characteristics of Wisconsin lakes: Wisconsin Department of Natural Resources Technical Bulletin No. 138, 116 p.

Rantz, S.E., and others, 1982, Measurement and computation of streamflow: U.S. Geological Survey Water-Supply Paper 2175, 631 p.

Rapavich, W.M., Sonzogni, W.C., Standridge, J.H., Vennie J.G., and Wedepohl, R.E., 1987, Incidence of algal toxins in Wisconsin water experiencing blue-green algae blooms: Wisconsin State Laboratory of Hygiene and Wisconsin Department of Natural Resources, Informational Paper, 8 p. 
Shaw, B., Mechenich, C., and Klessig, L., 1993, Understanding Lake Data: University of Wisconsin Extension, G3582: Madison, Wis., 19 p.

U.S. Environmental Protection Agency, 1986, Quality Criteria for Water 1986: U.S.

Environmental Protection Agency publication, EPA 440/5-86-001 [variously paged].

Wershaw, R.L., Fishman, M.J., Grabbe, R.R., and Lowe, L.E., eds., 1987, Methods for the determination of organic substances in water and fluvial sediments: U.S. Geological Survey Techniques of Water-Resources Investigations, book 5, chap. A3, 80 p.

Wetzel, R.G., 1983, Limnology (2 ${ }^{\text {nd }}$ ed.): New York, W.B. Saunders, 767 p.

Wisconsin Department of Natural Resources, 1992, Wisconsin water quality assessmentReport to Congress, 1992: Wisconsin Department of Natural Resources Publ-WR25492-REV, 220 p.

Wisconsin State Laboratory of Hygiene, Environmental Sciences Section, 1993, Manual of analytical methods, inorganic chemistry unit: Wisconsin State Laboratory of Hygiene, revised November 1993 [variously paged]. 


\section{LAKE DATA}

Remarks codes and symbols used in the following tables:

$[<$, less than; --, not available; E, estimated] 


\section{LAKE BEULAH AT DEEP HOLE NEAR EAST TROY, WI}

LOCATION.--Lat 4248'40", long 88²4'16", in SW 1/4 NW 1/4 NW 1/4 sec.17, T.4 N., R.18 E., Walworth County, Hydrologic Unit 07120006, near East Troy.

SURFACE AREA.--1.30 mi².

PERIOD OF RECORD.--August 2007 to current year.

REMARKS.--Lake sampled at the deep hole at a depth of $19 \mathrm{~m}$. Water-quality analyses by Wisconsin State Laboratory of Hygiene.

WATER-QUALITY DATA, DECEMBER 3, 2007 - AUGUST 26, 2008

(Milligrams per liter unless otherwise indicated)

Date

00078 Secchi-depth $(\mathrm{m})$

00098 Sampling depth $(\mathrm{m})$

00010 Water Temperature $\left({ }^{\circ} \mathrm{C}\right)$

$00400 \mathrm{pH}$ (standard units)

00095 Specific conductance $(\mu \mathrm{S} / \mathrm{cm})$

00300 Dissolved oxygen

32210 Chlorophyll a, phytoplankton $(\mu \mathrm{g} / \mathrm{L})$

00665 Phosphorus, Total (as P)

00671 Orthophosphate, dissolved (as P)

00600 Total nitrogen

00631 Nitrate + nitrite, dissolved (as N)

00608 Ammonia, dissolved (as $\mathrm{N}$ )

00625 Ammonia + organic nitrogen, total (as N)

00900 Hardness (as $\mathrm{CaCO} 3$ )

00417 Acid neutralizing capacity (as $\mathrm{CaCO} 3$ )

00915 Calcium, dissolved (Ca)

00925 Magnesium, dissolved (Mg)

00930 Sodium, dissolved $(\mathrm{Na})$

00935 Potassium, dissolved (K)

00940 Chloride, dissolved (Cl)

00945 Sulfate, dissolved (SO4)

00955 Silica, dissolved (SiO2)

01046 Iron ( $\mu \mathrm{g} / \mathrm{L})$

01056 Manganese $(\mu \mathrm{g} / \mathrm{L})$

00081 Apparent color (PCU)

63675 Turbidity (NTU)

70300 Solids, dissolved (at $180 \mathrm{C}^{\circ}$ )

\begin{tabular}{ccc} 
& Mar. 4 \\
\hline & -- & \\
0.5 & 9.0 & 17 \\
0.9 & 2.4 & 2.8 \\
7.4 & 7.6 & 7.4 \\
586 & 596 & 624 \\
12.1 & 8.9 & 5.8 \\
-- & -- & -- \\
0.011 & 0.011 & 0.030 \\
0.003 & 0.003 & 0.016 \\
1.1 & 1.5 & 2.0 \\
0.67 & 0.986 & 1.42 \\
0.046 & 0.14 & 0.219 \\
0.45 & 0.52 & 0.57 \\
300 & 310 & 320 \\
244 & 250 & 262 \\
62.5 & 64.9 & 69.7 \\
35.5 & 35.2 & 36.1 \\
10 & 9.8 & 9.7 \\
1.9 & 1.8 & 1.8 \\
23.7 & 23.4 & 23.8 \\
29.5 & 30.4 & 31.4 \\
15.2 & 16 & 17.1 \\
$<100$ & $<100$ & $<100$ \\
$<1.6$ & $<1.6$ & 40 \\
-- & -- & -- \\
$<1.0$ & $<1.0$ & $<1.0$ \\
-- & -- & -- \\
& &
\end{tabular}

\begin{tabular}{|c|c|c|c|c|}
\hline \multicolumn{5}{|c|}{ Aug. 26} \\
\hline & & 2.6 & & \\
\hline 2.0 & 8.0 & 14 & 17 & 18 \\
\hline 23.5 & 13.8 & 7.4 & 6.8 & 6.6 \\
\hline 8.3 & 7.4 & 7.2 & 7.2 & 7.2 \\
\hline 504 & 553 & 560 & 565 & 575 \\
\hline 9.3 & 0.2 & 0.2 & 0.2 & 0.2 \\
\hline 7.45 & -- & -- & -- & -- \\
\hline 0.012 & 0.012 & 0.011 & 0.029 & 0.026 \\
\hline$<.002$ & $<.002$ & $<.002$ & $<.002$ & $<.002$ \\
\hline -- & 1.0 & 1.4 & 1.1 & -- \\
\hline$<.019$ & 0.361 & 0.986 & 0.16 & $<.019$ \\
\hline$<.015$ & 0.144 & 0.026 & 0.412 & 0.792 \\
\hline 0.58 & 0.66 & 0.42 & 0.94 & 1.4 \\
\hline 250 & 280 & 280 & 290 & 290 \\
\hline 218 & 234 & 244 & 249 & 257 \\
\hline 47.6 & 55.6 & 60.8 & 61 & 62.5 \\
\hline 32.5 & 33.2 & 32.1 & 32.3 & 32.5 \\
\hline 8.9 & 8.9 & 9.0 & 9.0 & 9.1 \\
\hline 1.4 & 1.6 & 1.7 & 1.8 & 1.8 \\
\hline 20.9 & 21.1 & 21.3 & 21.4 & 22.1 \\
\hline 26.3 & 27.6 & 28.1 & 27.9 & 23.7 \\
\hline 10.3 & 11.3 & 16 & 17.7 & 19.7 \\
\hline$<100$ & $<100$ & $<100$ & $<100$ & $<100$ \\
\hline$<.5$ & 20 & 100 & 330 & 630 \\
\hline -- & -- & -- & -- & -- \\
\hline$<1.0$ & $<1.0$ & $<1.0$ & $<1.0$ & $<1.0$ \\
\hline 298 & 308 & 336 & 334 & 342 \\
\hline
\end{tabular}


424840088241600 LAKE BEULAH AT DEEP HOLE NEAR EAST TROY, WI

LAKE-DEPTH PROFILES, DECEMBER 3, 2007 TO AUGUST 26, 2008

$12-03-07$
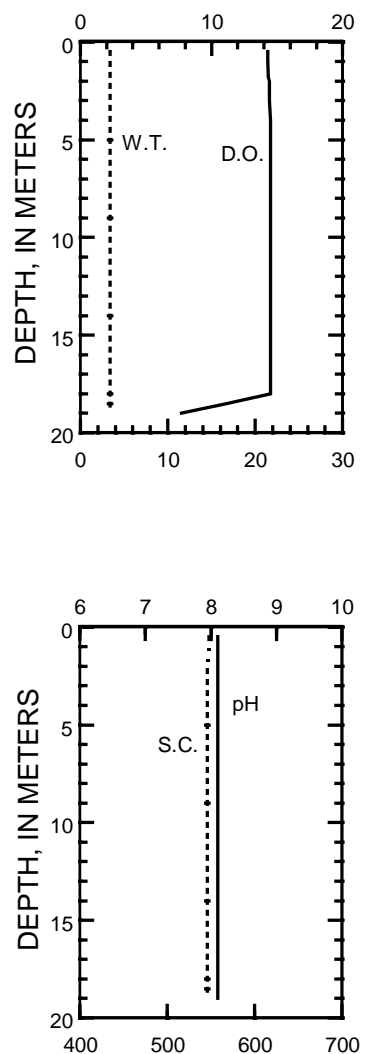

$03-04-08$

DISSOLVED OXYGEN (D.O.), IN MILLIGRAMS PER LITER
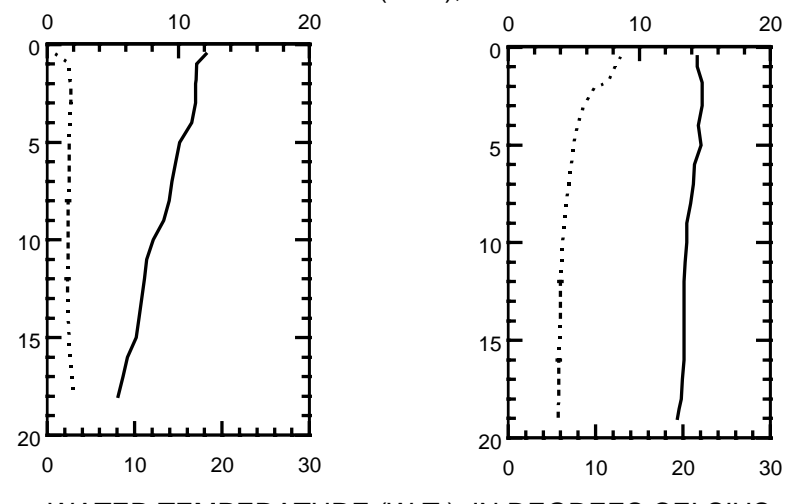

WATER TEMPERATURE (W.T.), IN DEGREES CELSIUS
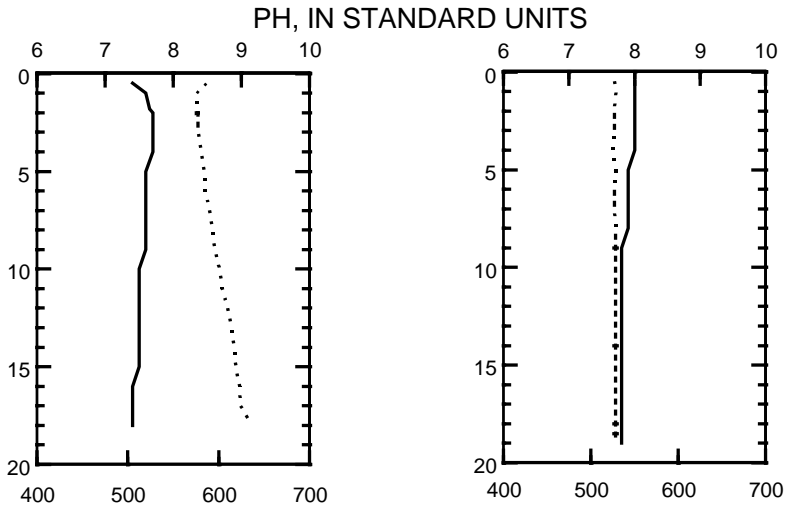

08-26-08
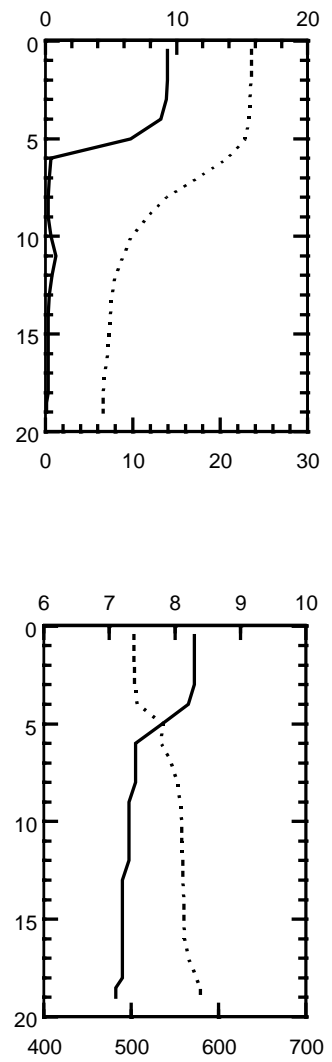

SPECIFIC CONDUCTANCE (S.C.), IN MICROSIEMENS PER CENTIMETER AT 25 DEGREES CELSIUS 


\section{LAKE BEULAH STATION 2 NEAR EAST TROY, W}

LOCATION.--Lat 4249'29", long 88²3'13", in SE 1/4 NE 1/4 NE 1/4 sec.8, T.4 N., R.18 E., Walworth County, Hydrologic Unit 07120006, near East Troy. SURFACE AREA.--1.30 $\mathrm{mi}^{2}$.

PERIOD OF RECORD.--August 2007 to current year.

REMARKS.--Lake sampled at a depth of $15 \mathrm{~m}$. Water-quality analyses by Wisconsin State Laboratory of Hygiene.

Date

00078 Secchi-depth $(\mathrm{m})$

00098 Sampling depth $(\mathrm{m})$

00010 Water Temperature $\left({ }^{\circ} \mathrm{C}\right)$

$00400 \mathrm{pH}$ (standard units)

00095 Specific conductance $(\mu \mathrm{S} / \mathrm{cm})$

00300 Dissolved oxygen

32210 Chlorophyll a, phytoplankton $(\mu \mathrm{g} / \mathrm{L})$

00665 Phosphorus, Total (as P)

00671 Orthophosphate, dissolved (as P)

00600 Total nitrogen

00631 Nitrate + nitrite, dissolved (as N)

00608 Ammonia, dissolved (as N)

00625 Ammonia + organic nitrogen, total (as N)

00900 Hardness (as $\mathrm{CaCO} 3$ )

00417 Acid neutralizing capacity (as $\mathrm{CaCO}$ )

00915 Calcium, dissolved (Ca)

00925 Magnesium, dissolved (Mg)

00930 Sodium, dissolved $(\mathrm{Na})$

00935 Potassium, dissolved (K)

00940 Chloride, dissolved (Cl)

00945 Sulfate, dissolved (SO4)

00955 Silica, dissolved (SiO2)

01046 Iron ( $\mu \mathrm{g} / \mathrm{L})$

01056 Manganese $(\mu \mathrm{g} / \mathrm{L})$

00081 Apparent color (PCU)

63675 Turbidity (NTU)

70300 Solids, dissolved (at $180 \mathrm{C}^{\circ}$ )

WATER-QUALITY DATA, MARCH 4 - AUGUST 26, 2008

(Milligrams per liter unless otherwise indicated)

March 4

$\begin{array}{cccc}0.5 & -- & 15 & 4.0 \\ 1.1 & 2.7 & 3.4 & 12.3 \\ 7.6 & 7.7 & 7.2 & 8.2 \\ 524 & 562 & 622 & 477 \\ 12.7 & 10.2 & 3.4 & 14.8 \\ -- & -- & -- & 2.66 \\ 0.013 & 0.011 & 0.029 & 0.022 \\ 0.003 & 0.003 & 0.006 & <.002 \\ 0.82 & 1.1 & 0.98 & 0.85 \\ 0.101 & 0.42 & 0.138 & 0.38 \\ 0.219 & 0.133 & 0.294 & 0.1 \\ 0.72 & 0.67 & 0.84 & 0.47 \\ 260 & 290 & 290 & 250 \\ 209 & 235 & 235 & 206 \\ 47 & 57.1 & 55.6 & 49 \\ 34.9 & 34.7 & 36.5 & 30.8 \\ 11.9 & 10.4 & 17.6 & 10.5 \\ 2 & 1.9 & 2.4 & 1.7 \\ 27.2 & 24.4 & 40.4 & 24.5 \\ 27.5 & 28.4 & 27.4 & 25.3 \\ 14.6 & 14.7 & 15.3 & 9.59 \\ <100 & <100 & <100 & <100 \\ <.5 & <.5 & 80 & <.5 \\ -- & -- & -- & 10 \\ <1.0 & <1.0 & <1.0 & <1.0 \\ -- & -- & -- & 286\end{array}$

August 26

$\begin{array}{ccccc} & & 4.2 & & \\ 2.0 & 9.0 & 12 & 14 & 15 \\ 23.9 & 12.5 & 8.3 & 7.4 & 7 \\ 8.4 & 7.4 & 7.2 & 7.2 & 7.1 \\ 454 & 507 & 514 & 520 & 529 \\ 9.0 & 1.4 & 0.3 & 0.2 & 0.2 \\ 3.98 & -- & -- & -- & - \\ 0.009 & 0.008 & 0.014 & 0.026 & 0.031 \\ <.002 & <.002 & <.002 & <.002 & <.002 \\ -- & 0.76 & 0.86 & -- & - \\ <.019 & 0.242 & 0.135 & <.019 & <.019 \\ <.015 & 0.085 & 0.268 & 0.482 & 0.748 \\ 0.52 & 0.52 & 0.73 & 1.1 & 1.4 \\ 220 & 240 & 250 & 260 & 260 \\ 181 & 208 & 218 & 220 & 225 \\ 35.1 & 47.1 & 50.3 & 50.9 & 50.9 \\ 31.6 & 30.8 & 30.9 & 31.6 & 31.5 \\ 11.3 & 10.6 & 10.4 & 10.6 & 9.9 \\ 1.6 & 1.7 & 1.8 & 1.8 & 1.6 \\ 25.7 & 24.3 & 24.2 & 23.9 & 24.6 \\ 24.9 & 25.5 & 25.4 & 24.8 & 22.3 \\ 10.5 & 11.3 & 14.4 & 15.8 & 17.4 \\ <100 & <100 & <100 & <100 & <100 \\ <1.6 & <1.6 & 110 & 190 & 250 \\ -- & -- & -- & -- & -- \\ <1.0 & <1.0 & <1.0 & <1.0 & 1.8 \\ 268 & 294 & 300 & 300 & 308\end{array}$


424929088231300 LAKE BEULAH STATION 2 NEAR EAST TROY, WI

LAKE-DEPTH PROFILES, MARCH 4 TO AUGUST 26, 2008

03-04-08
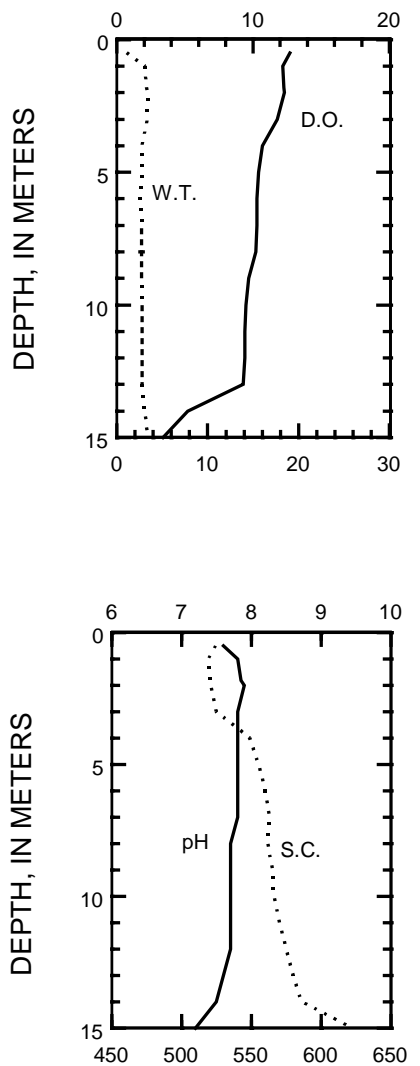

04-21-08

DISSOLVED OXYGEN (D.O.), IN MILLIGRAMS PER LITER

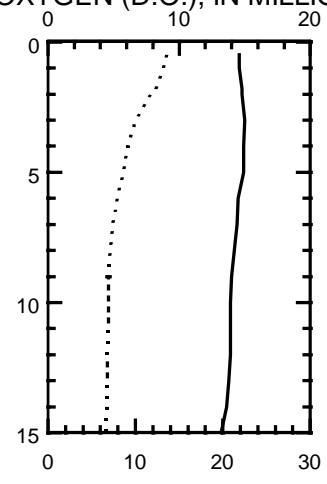

WATER TEMPERATURE (W.T.), IN DEGREES CELSIUS

$\mathrm{PH}$, IN STANDARD UNITS

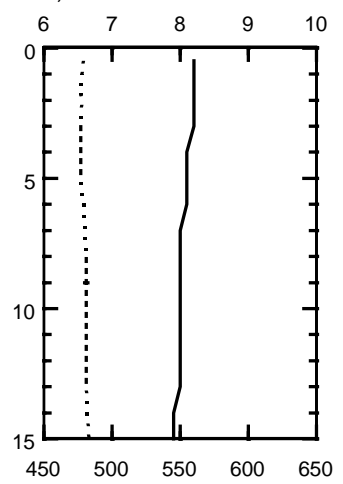

08-26-08
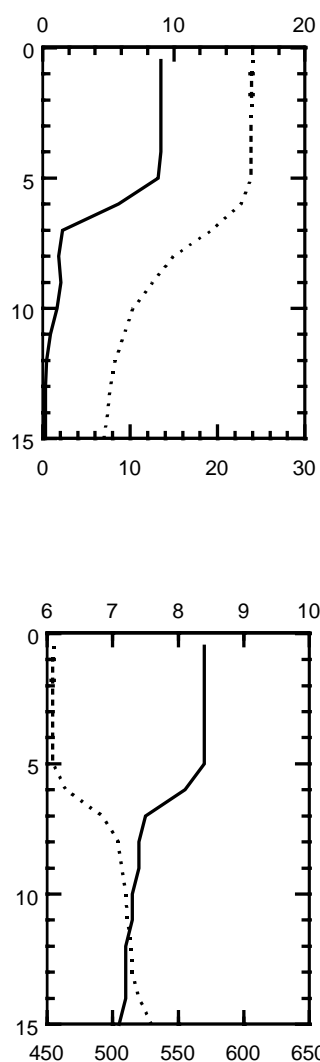

SPECIFIC CONDUCTANCE (S.C.), IN MICROSIEMENS PER CENTIMETER AT 25 DEGREES CELSIUS 


\section{LAKE BEULAH NEAR EAST SHORE ROAD AT EAST TROY, WI}

LOCATION.--Lat 4249'34", long 88²2'04", in SE 1/4 NE 1/4 NE 1/4 Sec.9, T.4 N., R.18 E., Walworth County, Hydrologic Unit 07120006, at East Troy. SURFACE AREA.--1.30 mi².

PERIOD OF RECORD.--December 2007.

REMARKS.--Water-quality analyses by Wisconsin State Laboratory of Hygiene.

WATER-QUALITY DATA, DECEMBER 3, 2007

(Milligrams per liter unless otherwise indicated)

Date

00078 Secchi-depth $(\mathrm{m})$

00098 Sampling depth $(\mathrm{m})$

00010 Water Temperature $\left({ }^{\circ} \mathrm{C}\right.$

$00400 \mathrm{pH}$ (standard units)

00095 Specific conductance $(\mu \mathrm{S} / \mathrm{cm})$

00300 Dissolved oxygen

32210 Chlorophyll a, phytoplankton ( $\mu \mathrm{g} / \mathrm{L}$ )

00665 Phosphorus, Total (as P)

00671 Orthophosphate, dissolved (as P)

00600 Total nitrogen

00631 Nitrate + nitrite, dissolved (as N)

00608 Ammonia, dissolved (as $\mathrm{N}$ )

00625 Ammonia + organic nitrogen, total (as N)

00900 Hardness (as CaCO3)

00417 Acid neutralizing capacity (as $\mathrm{CaCO} 3$ )

00915 Calcium, dissolved (Ca)

00925 Magnesium, dissolved (Mg)

00930 Sodium, dissolved $(\mathrm{Na})$

00935 Potassium, dissolved (K)

00940 Chloride, dissolved (Cl)

00945 Sulfate, dissolved (SO4)

00955 Silica, dissolved ( $\mathrm{SiO} 2)$

01046 Iron $(\mu \mathrm{g} / \mathrm{L})$

01056 Manganese $(\mu \mathrm{g} / \mathrm{L})$

00081 Apparent color (PCU)

63675 Turbidity (NTU)

70300 Solids, dissolved (at $180 \mathrm{C}^{\circ}$ )

\begin{tabular}{c} 
Dec. 3 \\
\hline-- \\
0.5 \\
0.6 \\
8.2 \\
514 \\
17 \\
0.98 \\
0.017 \\
0.005 \\
0.83 \\
0.039 \\
0.277 \\
0.79 \\
220 \\
192 \\
39.2 \\
30.8 \\
13.2 \\
1.8 \\
31.6 \\
25.9 \\
15.2 \\
$<100$ \\
$<1.6$ \\
-- \\
$<1.0$ \\
-- \\
\end{tabular}




\section{BIG CEDAR LAKE, NORTH SITE, NEAR WEST BEND, W}

LOCATION.--Lat 43²4'09", long 88¹5'16", in NE 1/4 SW 1/4 Sec. 20, T.11 N., R.19 E., Washington County, Hydrologic Unit 04040003, near West Bend.

SURFACE AREA.--1.46 $\mathrm{mi}^{2}$

PERIOD OF RECORD.--February 2000 to current year.

REMARKS.--Lake sampled on north side at a depth of $12 \mathrm{~m}$. Water-quality analyses by Wisconsin State Laboratory of Hygiene.

WATER-QUALITY DATA, FEBRUARY 29 TO AUGUST 27, 2008

(Milligrams per liter unless otherwise indicated)

Date

00078 Secchi-depth $(m)$

00098 Sampling depth $(\mathrm{m})$

00010 Water Temperature $\left({ }^{\circ} \mathrm{C}\right.$

$00400 \mathrm{pH}$ (standard units)

00095 Specific conductance $(\mu \mathrm{S} / \mathrm{cm})$

00300 Dissolved oxygen

32210 Chlorophyll a, phytoplankton ( $\mu \mathrm{g} / \mathrm{L})$

00665 Phosphorus, Total (as P)

\begin{tabular}{cccccc}
\multicolumn{2}{c}{ Feb. 29 } & & \multicolumn{2}{c}{ Apr. 24 } \\
\cline { 1 - 2 } \cline { 5 - 5 } 0.5 & -- & & & \multicolumn{2}{c}{1.7} \\
1.6 & 13 & & 0.5 & 12 \\
7.1 & 4.5 & & 13.9 & 7.8 \\
590 & 7.1 & & 8.1 & 7.7 \\
10.5 & 776 & & 560 & 557 \\
-- & 0.6 & & 11.8 & 8.3 \\
0.012 & -- & & 6.6 & -- \\
& 0.034 & & 0.013 & 0.013
\end{tabular}

\begin{tabular}{cc}
\multicolumn{3}{c}{ Jun. 26} \\
\hline \multicolumn{3}{c}{2.6} \\
0.5 & 11 \\
24.1 & 13.2 \\
8.4 & 7.4 \\
544 & 595 \\
9.2 & 0.5 \\
4.52 & -- \\
0.017 & 0.044
\end{tabular}

\begin{tabular}{|c|c|}
\hline \multicolumn{2}{|c|}{ Jul. 22} \\
\hline \multicolumn{2}{|c|}{2.6} \\
\hline 0.5 & 11.5 \\
\hline 25.5 & 14.1 \\
\hline 8.7 & 7.4 \\
\hline 545 & 603 \\
\hline 8.6 & 0.4 \\
\hline 2.6 & -- \\
\hline 0.014 & 0.040 \\
\hline
\end{tabular}

\begin{tabular}{cc}
\multicolumn{3}{c}{ Aug. 27 } \\
\hline \multicolumn{2}{c}{2.2} \\
0.5 & 11.5 \\
23.5 & 24.3 \\
8.6 & 7.2 \\
544 & 651 \\
8.3 & 0.3 \\
6.31 & -- \\
0.017 & 0.042
\end{tabular}


432409088151600 BIG CEDAR LAKE, NORTH SITE, NEAR WEST BEND, WI

LAKE-DEPTH PROFILES, FEBRUARY 29 TO AUGUST 27, 2008

02-29-08

04-24-08

06-26-08

07-22-08

08-27-08

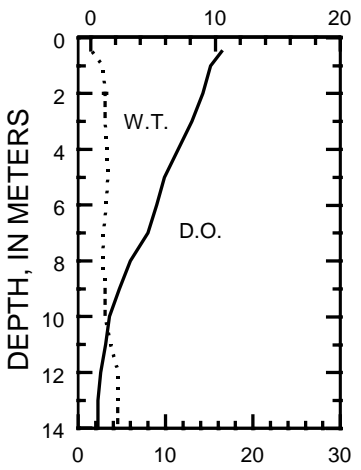

DISSOLVED OXYGEN (D.O.), IN MILLIGRAMS PER LITER
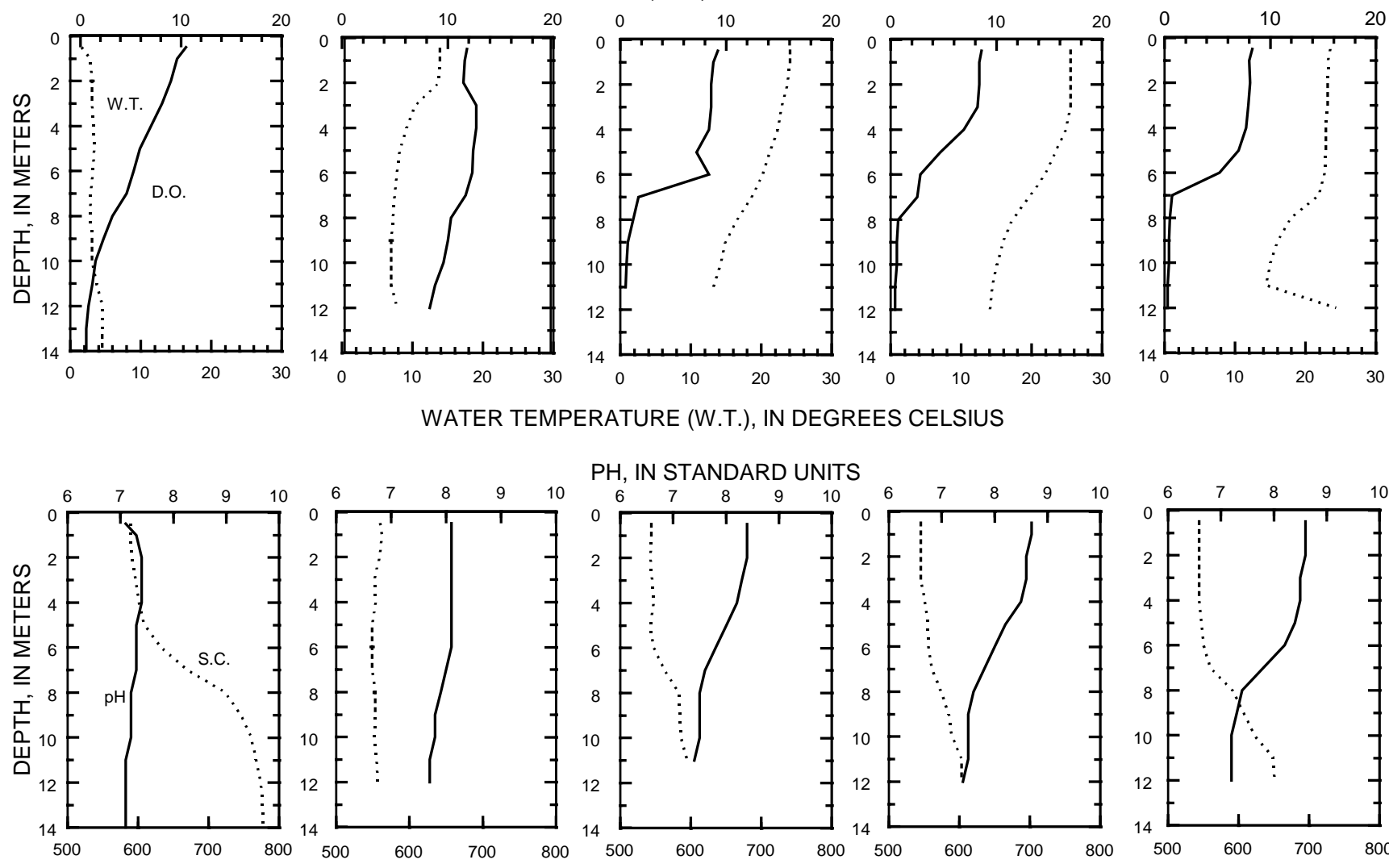

$\mathrm{PH}$, IN STANDARD UNITS
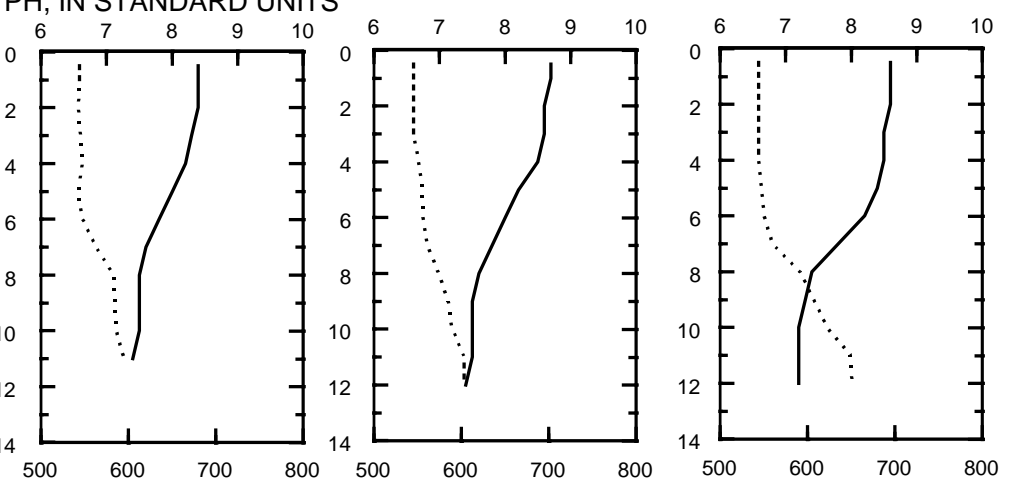

SPECIFIC CONDUCTANCE (S.C.), IN MICROSIEMENS PER CENTIMETER AT 25 DEGREES CELSIUS 

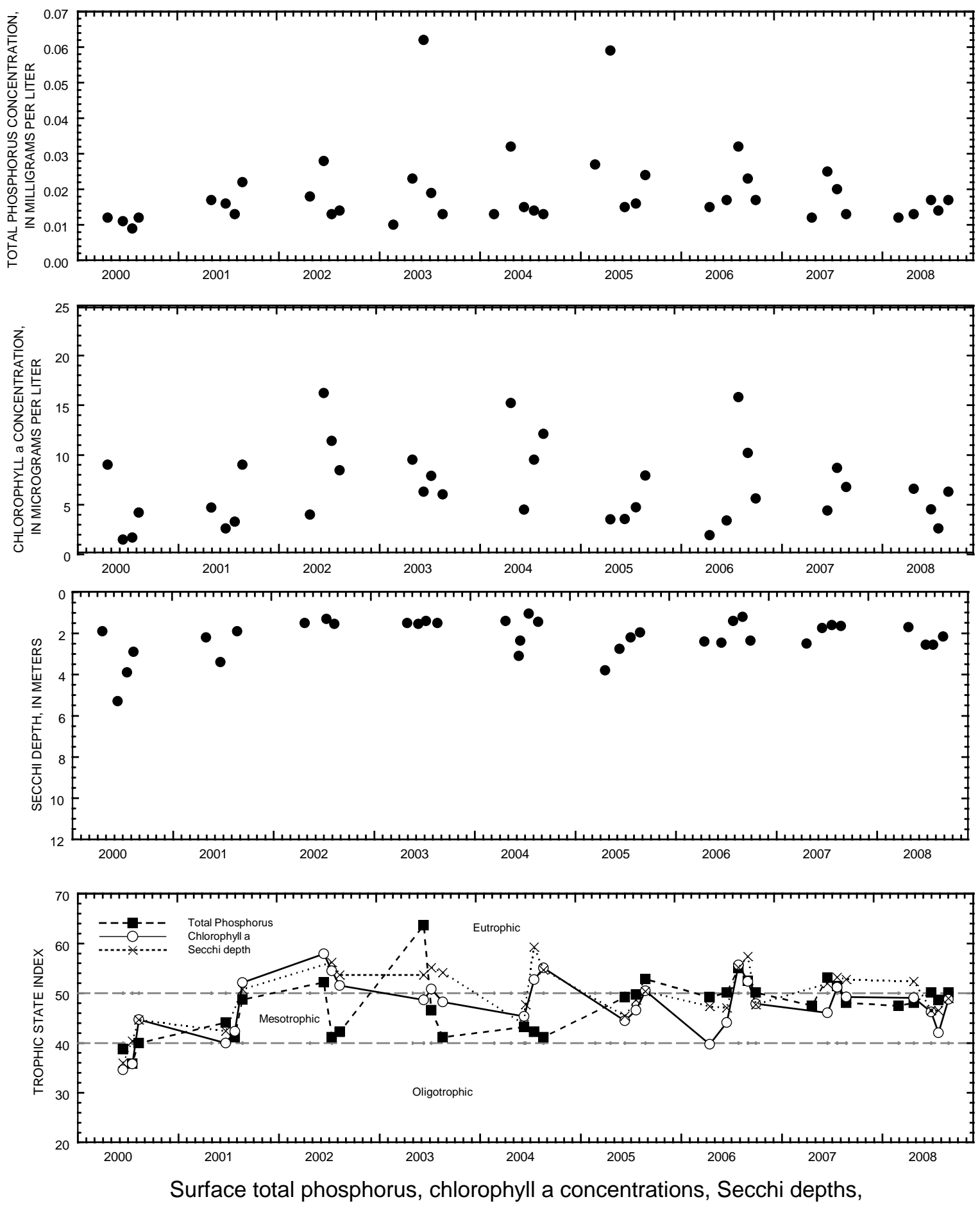

and TSI data for Big Cedar Lake, North Site, near West Bend, Wisconsin. 
432224088154900 BIG CEDAR LAKE, SOUTH SITE, NEAR WEST BEND, WI

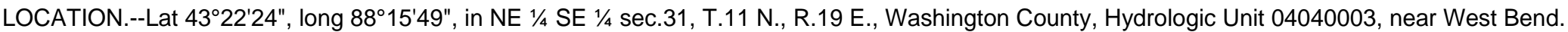

SURFACE AREA.--1.46 $\mathrm{mi}^{2}$

PERIOD OF RECORD.--February 2000 to current year.

REMARKS.--Lake sampled on south side at deep hole. Water-quality analyses by Wisconsin State Laboratory of Hygiene.

WATER-QUALITY DATA, FEBRUARY 29 TO AUGUST 27, 2008

(Milligrams per liter unless otherwise indicated)

Date

00078 Secchi-depth $(m)$

00098 Sampling depth $(\mathrm{m})$

00010 Water Temperature $\left({ }^{\circ} \mathrm{C}\right)$

$00400 \mathrm{pH}$ (standard units)

00095 Specific conductance $(\mu \mathrm{S} / \mathrm{cm})$

00300 Dissolved oxygen

32210 Chlorophyll a, phytoplankton $(\mu \mathrm{g} / \mathrm{L})$

00665 Phosphorus, Total (as P)

00671 Orthophosphate, dissolved (as P)

00600 Total nitrogen

00631 Nitrate + nitrite, dissolved (as N)

00608 Ammonia, dissolved (as N)

00625 Ammonia + organic nitrogen, total (as N)

00623 Ammonia + organic nitrogen, dissolved (as N)

00900 Hardness (as CaCO3)

00417 Acid neutralizing capacity (as $\mathrm{CaCO}$ )

00915 Calcium, dissolved ( $\mathrm{Ca}$ )

00925 Magnesium, dissolved (Mg)

00930 Sodium, dissolved $(\mathrm{Na})$

00935 Potassium, dissolved (K)

00940 Chloride, dissolved (Cl)

00945 Sulfate, dissolved (SO4)

00955 Silica, dissolved (SiO2)

01046 Iron $(\mu \mathrm{g} / \mathrm{L})$

01056 Manganese $(\mu \mathrm{g} / \mathrm{L})$

00081 Apparent color (PCU)

63675 Turbidity (NTU)

70300 Solids, dissolved (at $180 \mathrm{C}^{\circ}$ )

\begin{tabular}{|c|c|c|c|}
\hline \multicolumn{2}{|c|}{ Feb. 29} & \multicolumn{2}{|c|}{ Apr. 24} \\
\hline \multicolumn{2}{|c|}{--} & \multicolumn{2}{|c|}{5.9} \\
\hline 0.5 & 29 & 0.5 & 30 \\
\hline 0.2 & 2.7 & 9.8 & 4.0 \\
\hline 7.5 & 7.5 & 7.8 & 7.8 \\
\hline 565 & 578 & 549 & 540 \\
\hline 13.6 & 4.8 & 12 & 11.2 \\
\hline -- & -- & 0.86 & -- \\
\hline 0.009 & 0.12 & 0.009 & 0.012 \\
\hline-- & -- & 0.006 & -- \\
\hline-- & -- & 1 & -- \\
\hline -- & -- & 0.478 & -- \\
\hline -- & -- & 0.02 & -- \\
\hline-- & -- & 0.54 & -- \\
\hline -- & -- & -- & -- \\
\hline-- & -- & 240 & -- \\
\hline-- & -- & 190 & -- \\
\hline -- & -- & 38.3 & -- \\
\hline -- & -- & 35 & -- \\
\hline-- & -- & 23.4 & -- \\
\hline -- & -- & 1.8 & -- \\
\hline-- & -- & 50.3 & -- \\
\hline-- & -- & 21.5 & -- \\
\hline-- & -- & 3.61 & -- \\
\hline -- & -- & $<100$ & -- \\
\hline -- & -- & $<1.6$ & -- \\
\hline-- & -- & 5 & -- \\
\hline -- & -- & $<1.0$ & -- \\
\hline -- & -- & 306 & -- \\
\hline
\end{tabular}

\begin{tabular}{|c|c|}
\hline \multicolumn{2}{|c|}{ Jun. 26} \\
\hline \multicolumn{2}{|c|}{2.3} \\
\hline 0.5 & 29 \\
\hline 23.2 & 5.1 \\
\hline 8.3 & 7.3 \\
\hline 531 & 556 \\
\hline 10.7 & 4.0 \\
\hline 7.7 & -- \\
\hline 0.012 & 0.072 \\
\hline -- & -- \\
\hline-- & -- \\
\hline-- & -- \\
\hline-- & -- \\
\hline-- & -- \\
\hline-- & -- \\
\hline-- & -- \\
\hline-- & -- \\
\hline-- & -- \\
\hline-- & -- \\
\hline-- & -- \\
\hline-- & -- \\
\hline -- & -- \\
\hline-- & -- \\
\hline-- & -- \\
\hline-- & -- \\
\hline-- & -- \\
\hline-- & -- \\
\hline -- & -- \\
\hline -- & -- \\
\hline
\end{tabular}

0.5
25
8.
530
8.6
2.91
0.012
0.006
-
0.201
$<.015$
-
0.51
-
-
-
-
-
-
-
-
-
-
-
-
-
-

Jul. 22

0.5

8.6

530

8.6

2.91

0.012

0.006

0.201

$<.015$

0.51

--

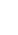

$-$

$-$

$-$

--

$-$

$--$

$-$

Aug. 27

29.5

5.2

7.4

560

0.8

0.076

--

$--$

$--$

--

--

--

$-$

--

--

--

--

$-$

--

--

-- 
432224088154900 BIG CEDAR LAKE, SOUTH SITE, NEAR WEST BEND, WI

LAKE-DEPTH PROFILES, FEBRUARY 29 TO AUGUST 27, 2008

02-29-08

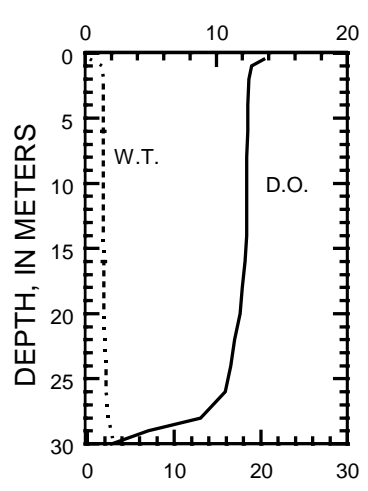

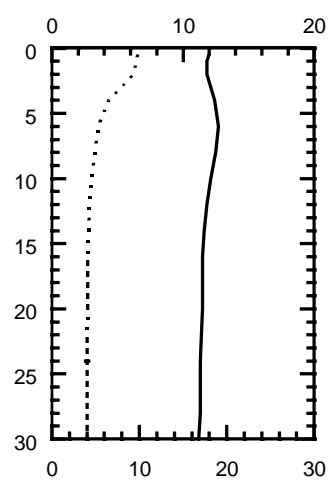

04-24-08

06-26-08

07-22-08

08-27-08

DISSOLVED OXYGEN (D.O.), IN MILLIGRAMS PER LITER
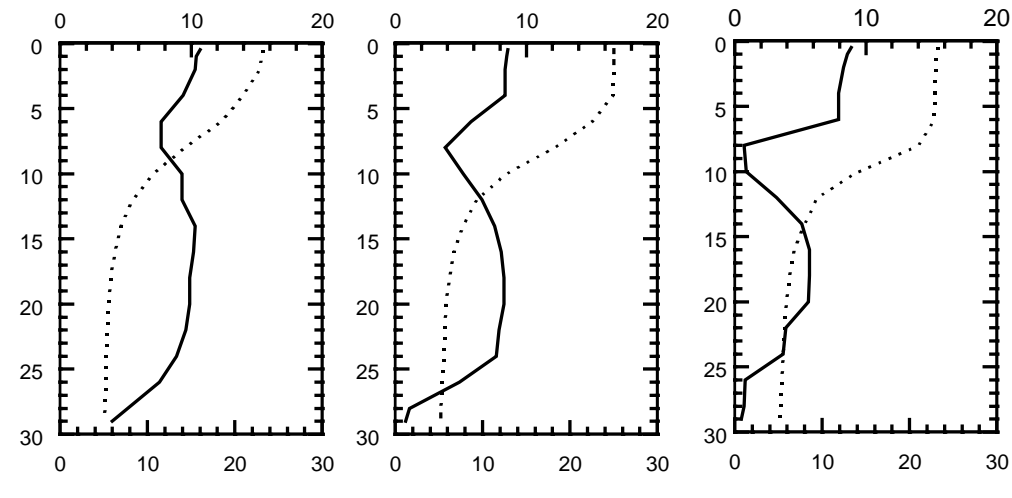

WATER TEMPERATURE (W.T.), IN DEGREES CELSIUS

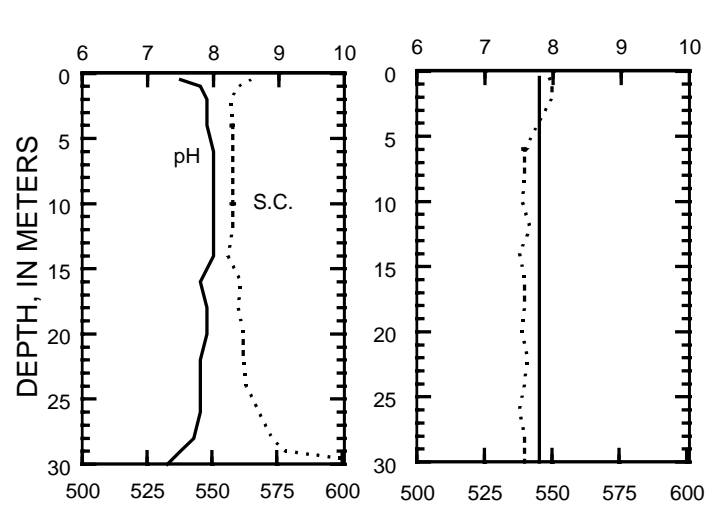

PH, IN STANDARD UNITS
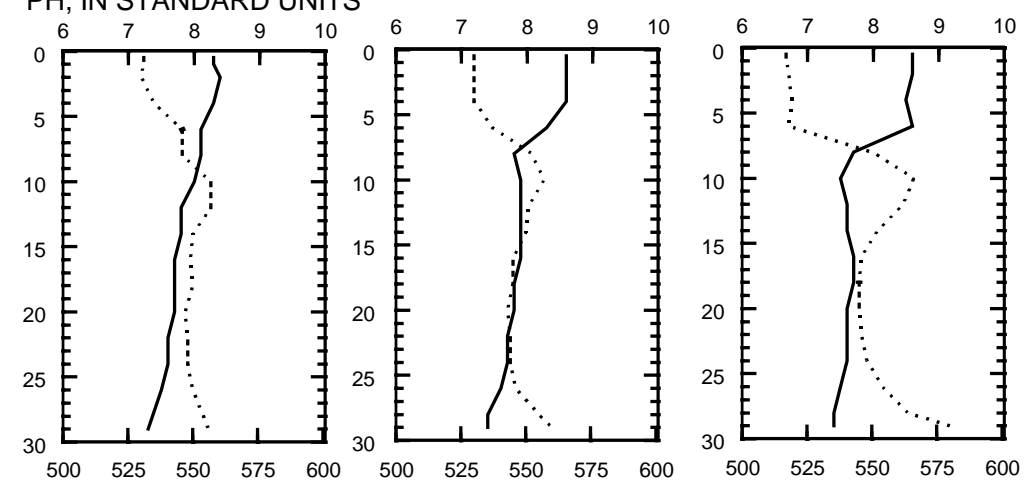

SPECIFIC CONDUCTANCE (S.C.), IN MICROSIEMENS PER CENTIMETER AT 25 DEGREES CELSIUS 

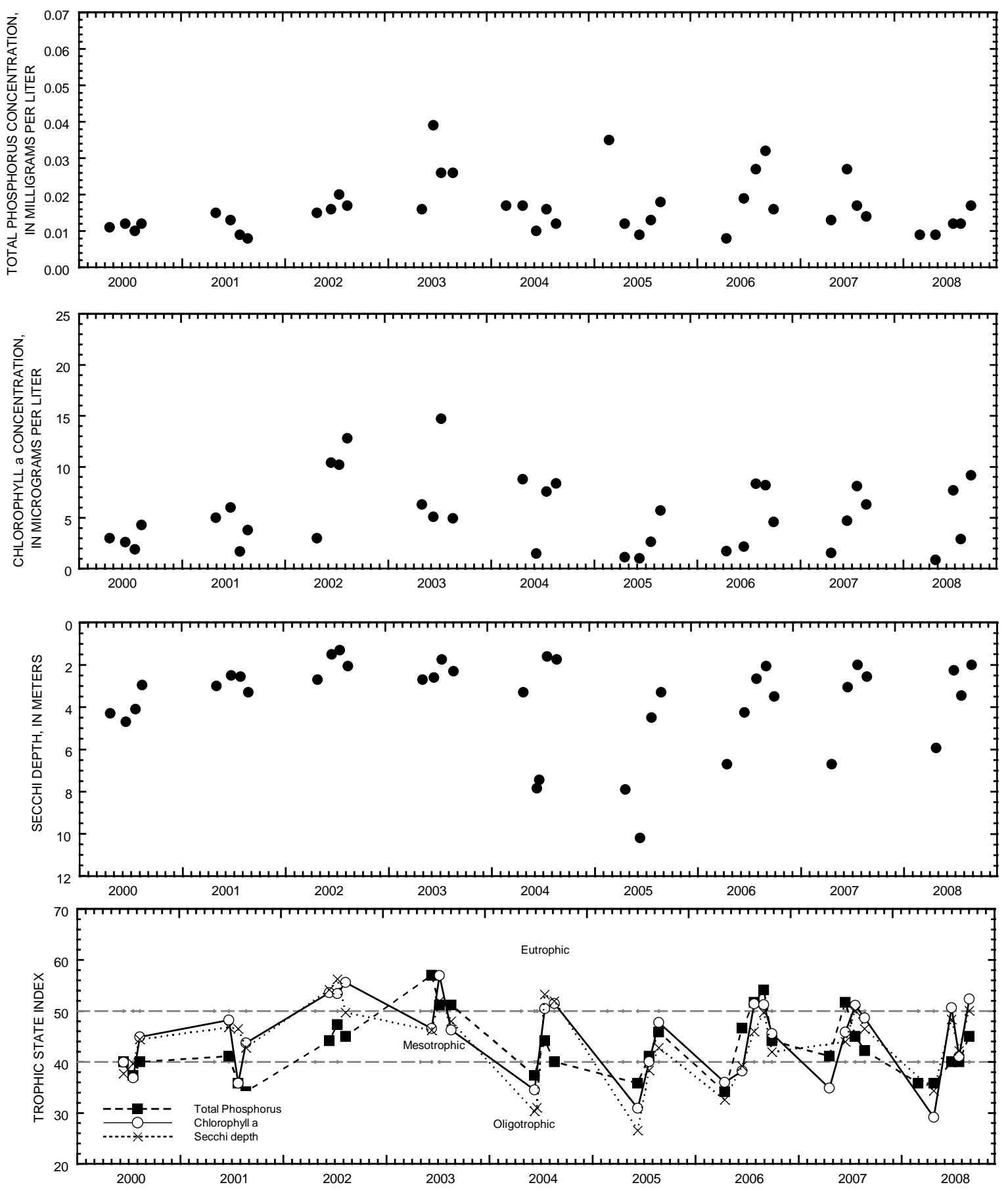

Surface total phosphorus, chlorophyll a concentrations, Secchi depths, and TSI data for Big Cedar Lake, South Site, near West Bend, Wisconsin. 


\section{DELAVAN LAKE NEAR DELAVAN, WI}

LOCATION.--Lat 42 $36^{\prime} 27^{\prime \prime}$, long $88^{\circ} 36^{\prime} 19^{\prime \prime}$ referenced to North American Datum of 1927 , in SW $1 / 4$ NE $1 / 4$ Sec.28, T.2 N., R.16 E., Walworth County, WI, Hydrologic Unit 07090001, at Delavan Lake Sanitary District Lift Station No. 2 at Delavan Lake Yacht Club, 1.0 mi southeast of outlet, and 2.7 mi southeast of Delavan.

SURFACE AREA.--3.24 $\mathrm{mi}^{2}$.

DRAINAGE AREA.--41.4 $\mathrm{mi}^{2}$, of which $2.30 \mathrm{mi}^{2}$ probably is noncontributing.

PERIOD OF RECORD.--October 1983 to current year. October 1983 to September 1985 data published in Water Resources Investigation series report "Water Quality and Hydrology of Delavan Lake in Southeastern Wisconsin" by Stephen J. Field and Marvin D. Duerk.

GAGE.--Water-stage recorder. Datum of gage is $922.92 \mathrm{ft}$ above NGVD of 1929. Prior to Sept. 5, 1989, staff gage at bridge on North Shore Drive at same datum.

REMARKS.--Lake was ice covered from Jan. 17 to Mar. 25. Lake levels controlled by Delavan Lake Sanitary District.

EXTREMES FOR PERIOD OF RECORD.--Maximum gage height observed, 6.53 ft, Aug. 27, 2007; minimum daily, $-4.44 \mathrm{ft}$, Nov. 6, 1989 (lake drawn down for lake rehabilitation program).

EXTREMES FOR CURRENT YEAR.--Maximum gage height, 5.89 ft, June 9 and 13; minimum, $4.77 \mathrm{ft}$, Aug. 2. 
GAGE HEIGHT, FEET

WATER YEAR OCTOBER 2007 TO SEPTEMBER 2008

DAILY MEAN VALUES

[e, estimated]

\begin{tabular}{|c|c|c|c|c|c|c|c|c|c|c|c|c|}
\hline Day & Oct & Nov & Dec & Jan & Feb & Mar & Apr & May & Jun & Jul & Aug & Sep \\
\hline 1 & 5.03 & 4.94 & 5.02 & 5.11 & 5.02 & 5.05 & 5.14 & 4.99 & 5.09 & 5.07 & 4.83 & 4.86 \\
\hline 2 & 5.05 & 4.94 & 5.09 & 5.08 & 4.99 & 5.04 & 5.09 & 5.00 & 5.08 & 5.08 & 4.83 & 4.86 \\
\hline 3 & 5.04 & 4.94 & 5.13 & 5.04 & 4.98 & 5.23 & 5.03 & 5.02 & 5.06 & 5.17 & 4.83 & 4.87 \\
\hline 4 & 5.03 & 4.96 & 5.13 & 5.01 & 5.01 & 5.33 & 5.07 & 5.01 & 5.04 & 5.19 & 4.88 & 4.98 \\
\hline 5 & 5.02 & 4.95 & 5.13 & 4.97 & 5.03 & 5.22 & 5.04 & 4.99 & 5.22 & 5.19 & 4.92 & e5.08 \\
\hline 6 & 5.03 & 4.95 & 5.11 & 4.96 & 5.08 & 5.09 & 5.03 & 5.00 & 5.39 & 5.17 & 4.93 & 5.04 \\
\hline 7 & 5.04 & 4.93 & 5.09 & 5.07 & 5.07 & 5.06 & 5.05 & 5.02 & 5.29 & 5.16 & 4.92 & 4.99 \\
\hline 8 & 5.04 & 4.94 & 5.09 & 5.38 & 5.06 & 5.04 & 5.05 & 5.02 & 5.28 & 5.34 & 4.90 & 4.97 \\
\hline 9 & 5.05 & 4.94 & 5.10 & 5.46 & 5.03 & 5.02 & 5.19 & 5.02 & 5.74 & 5.25 & 4.89 & 4.96 \\
\hline 10 & 5.03 & 4.93 & 5.09 & 5.37 & 5.00 & 5.02 & 5.17 & 5.02 & 5.82 & 5.15 & 4.88 & 4.95 \\
\hline 11 & 5.02 & 4.94 & 5.11 & 5.28 & 4.96 & 5.00 & 5.40 & 5.04 & 5.67 & 5.25 & 4.87 & 4.94 \\
\hline 12 & 5.00 & 4.94 & 5.14 & 5.18 & 4.94 & 5.01 & 5.38 & 5.05 & 5.51 & 5.53 & 4.87 & 4.94 \\
\hline 13 & 4.99 & 4.95 & 5.12 & 5.06 & 4.93 & 5.08 & 5.29 & 5.03 & 5.77 & 5.57 & 4.87 & 5.07 \\
\hline 14 & 5.02 & 4.94 & 5.13 & 4.97 & 4.93 & 5.19 & 5.16 & 5.01 & 5.79 & 5.42 & 4.88 & 5.16 \\
\hline 15 & 5.05 & 4.93 & 5.09 & 4.99 & 4.92 & 5.16 & 5.08 & 4.98 & 5.63 & 5.30 & 4.88 & 5.19 \\
\hline 16 & 5.11 & 4.92 & 5.09 & 5.02 & 4.93 & 5.07 & 5.02 & 4.96 & 5.44 & 5.20 & 4.87 & 5.14 \\
\hline 17 & 5.11 & 4.93 & 5.04 & 5.06 & 5.01 & 5.00 & 5.01 & 4.96 & 5.24 & 5.09 & 4.87 & 5.09 \\
\hline 18 & 5.12 & 4.94 & 5.00 & 5.07 & 5.07 & 5.01 & 5.01 & 4.96 & 5.08 & 5.00 & 4.87 & 5.08 \\
\hline 19 & 5.10 & 4.95 & 5.00 & 5.09 & 5.09 & 5.02 & 5.01 & 4.96 & 4.97 & 4.95 & 4.86 & 5.06 \\
\hline 20 & 5.08 & e4.97 & 5.02 & 5.12 & 5.09 & 5.03 & 5.00 & 4.97 & 4.98 & 4.91 & 4.86 & 5.05 \\
\hline 21 & 5.04 & 4.98 & 5.01 & 5.11 & 5.07 & 5.06 & 4.99 & 4.97 & 5.00 & 4.85 & 4.86 & 5.05 \\
\hline 22 & 5.01 & 4.98 & 5.00 & 5.12 & 5.07 & 5.10 & 5.01 & 4.98 & 5.01 & 4.86 & 4.89 & 5.04 \\
\hline 23 & 5.00 & 4.98 & 5.09 & 5.09 & 5.06 & 5.08 & 5.02 & 4.98 & 5.02 & 4.87 & 4.89 & 5.03 \\
\hline 24 & 4.99 & 4.97 & 5.17 & 5.07 & 5.03 & 5.07 & 5.02 & 4.98 & 5.02 & 4.87 & 4.89 & 5.02 \\
\hline 25 & 4.99 & 4.99 & 5.20 & 5.06 & 5.01 & 5.04 & 5.09 & 4.98 & 5.03 & 4.86 & 4.89 & 5.01 \\
\hline 26 & 4.98 & 4.98 & 5.21 & 5.05 & 5.02 & 5.07 & 5.21 & 5.08 & 5.03 & 4.85 & 4.88 & 5.01 \\
\hline 27 & 4.97 & 5.00 & 5.24 & 5.01 & 5.00 & 5.11 & 5.18 & 5.08 & 5.04 & 4.85 & 4.88 & 5.00 \\
\hline 28 & 4.97 & 5.00 & 5.23 & 5.00 & 5.02 & 5.10 & 5.11 & 5.05 & 5.06 & 4.85 & 4.88 & 5.00 \\
\hline 29 & 4.96 & 5.00 & 5.20 & 4.99 & 5.06 & 5.03 & 5.07 & 5.04 & 5.08 & 4.85 & 4.88 & 5.00 \\
\hline 30 & 4.96 & 4.99 & 5.17 & 5.01 & --- & 4.97 & 5.02 & 5.09 & 5.08 & 4.84 & 4.87 & 5.00 \\
\hline 31 & 4.95 & --- & 5.14 & 5.00 & --- & 5.01 & --- & 5.11 & --- & 4.84 & 4.86 & --- \\
\hline Mean & 5.03 & 4.96 & 5.11 & 5.09 & 5.02 & 5.07 & 5.10 & 5.01 & 5.25 & 5.08 & 4.88 & 5.01 \\
\hline Max & 5.12 & 5.00 & 5.24 & 5.46 & 5.09 & 5.33 & 5.40 & 5.11 & 5.82 & 5.57 & 4.93 & 5.19 \\
\hline Min & 4.95 & 4.92 & 5.00 & 4.96 & 4.92 & 4.97 & 4.99 & 4.96 & 4.97 & 4.84 & 4.83 & 4.86 \\
\hline
\end{tabular}




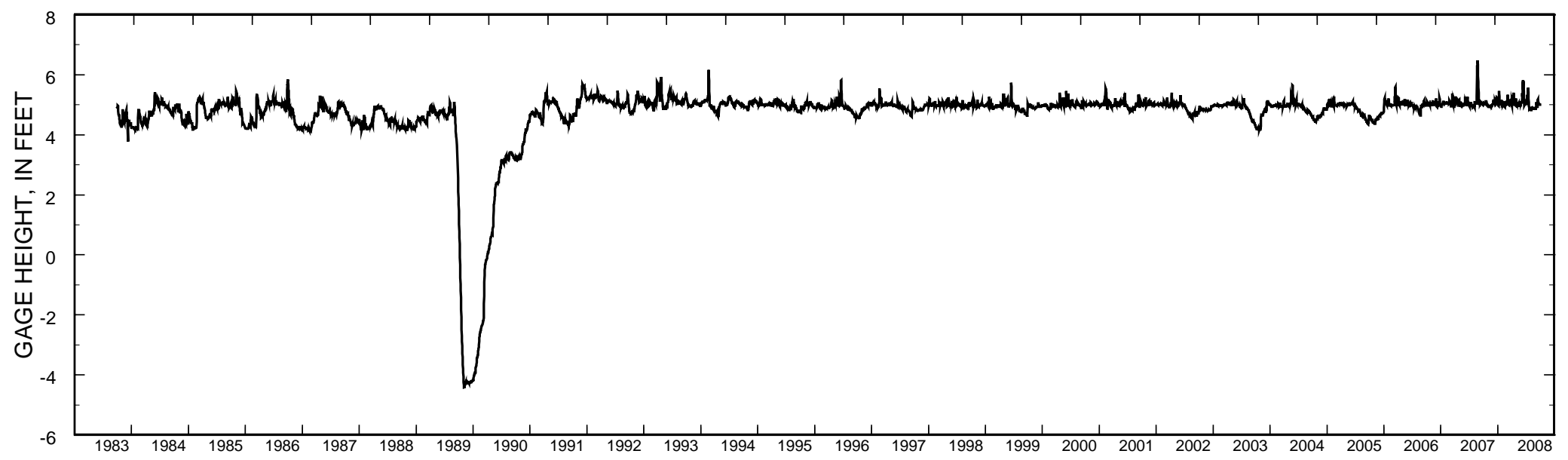

Stage hydrograph for Delavan Lake, 1983 - 2008. 


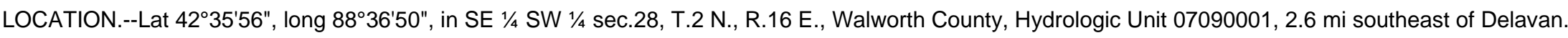

SURFACE AREA.--3.24 $\mathrm{mi}^{2}$.

DRAINAGE AREA.--41.4 $\mathrm{mi}^{2}$, of which $2.3 \mathrm{mi}^{2}$ is non-contributing

PERIOD OF RECORD.--October 1983 to current year.

REMARKS.--Lake ice-covered during February measurements. Water-quality analyses done by the U.S. Geological Survey National Water Quality Laboratory. Samples for determination of chlorophyll a concentration are collected from the top $0.5 \mathrm{~m}$ of the lake and analyzed by the Wisconsin State Laboratory of Hygiene. A "*" indicates data collected by the Delavan Lake Sanitary District.

WATER-QUALITY DATA, OCTOBER 3, 2007 TO JANUARY 9, 2008

(Milligrams per liter unless otherwise indicated)

Date

00078 Secchi-depth $(m)$

00098 Sampling depth $(\mathrm{m})$

00010 Water Temperature $\left({ }^{\circ} \mathrm{C}\right)$

$00400 \mathrm{pH}$ (standard units)

00095 Specific conductance $(\mu \mathrm{S} / \mathrm{cm})$

00300 Dissolved oxygen

32210 Chlorophyll a, phytoplankton $(\mu \mathrm{g} / \mathrm{L})$

00665 Phosphorus, Total (as P)

00671 Orthophosphate, dissolved (as P)

00600 Total nitrogen

00631 Nitrate + nitrite, dissolved (as N)

00608 Ammonia, dissolved (as N)

00625 Ammonia + organic nitrogen, total (as N)

\begin{tabular}{|c|c|c|}
\hline Oct. 3* & Oct. $12 *$ & Oct. $17^{*}$ \\
\hline 1.5 & 1.2 & 1.5 \\
\hline 0.5 & 0.5 & 0.5 \\
\hline 19 & 17 & 16 \\
\hline -- & -- & -- \\
\hline -- & -- & -- \\
\hline-- & -- & -- \\
\hline-- & -- & -- \\
\hline 0.07 & 0.09 & 0.09 \\
\hline-- & -- & -- \\
\hline-- & -- & -- \\
\hline-- & -- & -- \\
\hline-- & -- & -- \\
\hline-- & -- & -- \\
\hline
\end{tabular}

\begin{tabular}{c} 
Oct. $24^{*}$ \\
\hline 1.2 \\
0.5 \\
15.1 \\
-- \\
-- \\
-- \\
-- \\
0.11 \\
-- \\
-- \\
-- \\
-- \\
--
\end{tabular}

\begin{tabular}{c} 
Nov. $1^{*}$ \\
\hline 1.2 \\
0.5 \\
13 \\
-- \\
-- \\
-- \\
-- \\
0.10 \\
-- \\
-- \\
-- \\
-- \\
--
\end{tabular}

\begin{tabular}{c} 
Nov. $13^{*}$ \\
\hline 2.6 \\
0.5 \\
10 \\
-- \\
-- \\
-- \\
-- \\
0.06 \\
-- \\
-- \\
-- \\
-- \\
--
\end{tabular}

\begin{tabular}{ccccc}
\multicolumn{2}{c}{ Nov. 13} & & Jan. $9^{*}$ \\
\cline { 1 - 2 } 0.5 & 2.4 & & & 4.3 \\
10 & & & 0.5 \\
8.5 & & & 0.0 \\
540 & 542 & & -- \\
11.8 & 11.2 & & -- \\
7.36 & -- & & -- \\
0.066 & 0.06 & & 0.065 \\
0.035 & 0.038 & & -- \\
-- & -- & & -- \\
$<.016$ & -- & & -- \\
0.025 & -- & & -- \\
0.65 & -- & & --
\end{tabular}


423556088365001 DELAVAN LAKE AT CENTER NEAR DELAVAN LAKE, WI

WATER-QUALITY DATA, MAY 4 TO MAY 15, 2008

(Milligrams per liter unless otherwise indicated)

Date

00078 Secchi-depth $(m)$

00098 Sampling depth $(\mathrm{m})$

00010 Water Temperature $\left({ }^{\circ} \mathrm{C}\right)$

$00400 \mathrm{pH}$ (standard units)

00095 Specific conductance $(\mu \mathrm{S} / \mathrm{cm})$

00300 Dissolved oxygen

32210 Chlorophyll a, phytoplankton $(\mu \mathrm{g} / \mathrm{L})$

00665 Phosphorus, Total (as P)

00671 Orthophosphate, dissolved (as P)

00600 Total nitrogen

00631 Nitrate + nitrite, dissolved (as N)

00608 Ammonia, dissolved (as $\mathrm{N}$ )

00625 Ammonia + organic nitrogen, total (as N)

00900 Hardness (as $\mathrm{CaCO} 3$ )

00410 Acid neutralizing capacity (as $\mathrm{CaCO}$ )

00915 Calcium, dissolved (Ca)

00925 Magnesium, dissolved (Mg)

00930 Sodium, dissolved $(\mathrm{Na})$

00935 Potassium, dissolved (K)

00940 Chloride, dissolved (C)

00950 Fluoride, dissolved (F)

00945 Sulfate, dissolved (SO4)

00955 Silica, dissolved (SiO2)

01046 Iron ( $\mu \mathrm{g} / \mathrm{L})$

01056 Manganese $(\mu \mathrm{g} / \mathrm{L})$

00080 Apparent color (PCU)

63676 Turbidity (NTU)

70300 Solids, dissolved (at $180 \mathrm{C}^{\circ}$ )

\begin{tabular}{|c|c|c|c|c|c|c|c|c|}
\hline \multicolumn{2}{|c|}{ Mar. 4} & Apr. 9* & Apr. $15^{*}$ & Apr. 21* & \multicolumn{2}{|c|}{ Apr. 21} & \multirow{2}{*}{$\frac{\text { May } 6^{*}}{3.4}$} & \multirow{2}{*}{$\begin{array}{c}\text { May } 15^{*} \\
4.9\end{array}$} \\
\hline & & 1.8 & 1.5 & 2.0 & & & & \\
\hline 0.5 & 16 & 0.5 & 0.5 & 0.5 & 0.5 & 16 & 0.5 & 0.5 \\
\hline 0.7 & 3.3 & 2.0 & 4.5 & 10 & 11.3 & 5.6 & 11 & 15.6 \\
\hline 8.4 & 7.4 & -- & -- & -- & 8.6 & 8.1 & -- & -- \\
\hline 582 & 972 & -- & -- & -- & 532 & 545 & -- & -- \\
\hline 15.8 & 3.5 & -- & -- & -- & 18.3 & 13.2 & -- & -- \\
\hline 12.6 & -- & -- & -- & -- & 7.62 & -- & -- & -- \\
\hline 0.052 & 0.111 & 0.06 & 0.05 & 0.04 & 0.044 & 0.079 & 0.03 & 0.04 \\
\hline 0.013 & 0.087 & -- & -- & -- & E.003 & 0.037 & -- & -- \\
\hline 0.87 & -- & -- & -- & -- & 1.2 & 1.3 & -- & -- \\
\hline 0.209 & -- & -- & -- & -- & 0.42 & 0.416 & -- & -- \\
\hline 0.037 & -- & -- & -- & -- & 0.039 & 0.228 & -- & -- \\
\hline 0.67 & -- & -- & -- & -- & 0.73 & 0.91 & -- & -- \\
\hline-- & -- & -- & -- & -- & 230 & 230 & -- & -- \\
\hline -- & -- & -- & -- & -- & 190 & 192 & -- & -- \\
\hline-- & -- & -- & -- & -- & 42.4 & 41.2 & -- & -- \\
\hline -- & -- & -- & -- & -- & 30.9 & 30.2 & -- & -- \\
\hline-- & -- & -- & -- & -- & 30.1 & 30.2 & -- & -- \\
\hline-- & -- & -- & -- & -- & 2.96 & 2.96 & -- & -- \\
\hline -- & -- & -- & -- & -- & 59.3 & 60.3 & -- & -- \\
\hline -- & -- & -- & -- & -- & 0.19 & 0.18 & -- & -- \\
\hline -- & -- & -- & -- & -- & 21.5 & 21.2 & -- & -- \\
\hline -- & -- & -- & -- & -- & 0.9 & 2.2 & -- & -- \\
\hline -- & -- & -- & -- & -- & $<8$ & $<8$ & -- & -- \\
\hline -- & -- & -- & -- & -- & 1.4 & 115 & -- & -- \\
\hline -- & -- & -- & -- & -- & 18 & 20 & -- & -- \\
\hline -- & -- & -- & -- & -- & 2.4 & 2.5 & -- & -- \\
\hline -- & -- & -- & -- & -- & 334 & 332 & -- & -- \\
\hline
\end{tabular}


423556088365001 DELAVAN LAKE AT CENTER NEAR DELAVAN LAKE, WI

Date

00078 Secchi-depth (m)

00098 Sampling depth $(\mathrm{m})$

00010 Water Temperature $\left({ }^{\circ} \mathrm{C}\right.$

$00400 \mathrm{pH}$ (standard units)

00095 Specific conductance $(\mu \mathrm{S} / \mathrm{cm})$

00300 Dissolved oxygen

32210 Chlorophyll a, phytoplankton ( $\mu \mathrm{g} / \mathrm{L})$

00665 Phosphorus, Total (as P)

00671 Orthophosphate, dissolved (as P)

00600 Total nitrogen

00631 Nitrate + nitrite, dissolved (as N)

00608 Ammonia, dissolved (as N)

00625 Ammonia + organic nitrogen, total (as N)

Date

00078 Secchi-depth $(m)$

00098 Sampling depth $(\mathrm{m})$

00010 Water Temperature $\left({ }^{\circ} \mathrm{C}\right)$

$00400 \mathrm{pH}$ (standard units)

00095 Specific conductance $(\mu \mathrm{S} / \mathrm{cm})$

00300 Dissolved oxygen

32210 Chlorophyll a, phytoplankton ( $\mu \mathrm{g} / \mathrm{L}$ )

00665 Phosphorus, Total (as P)

00671 Orthophosphate, dissolved (as P)

Total nitrogen

00631 Nitrate + nitrite, dissolved (as N)

00608 Ammonia, dissolved (as $\mathrm{N}$ )

00625 Ammonia + organic nitrogen, total (as N)
WATER-QUALITY DATA, MAY 19 TO JULY 23, 2008

(Milligrams per liter unless otherwise indicated)

\begin{tabular}{cccc}
\multicolumn{5}{c}{ May 19 } \\
\hline \multicolumn{5}{c}{8.8} \\
0.5 & 11 & 14 & 16 \\
14 & 12.9 & 10.8 & 10.3 \\
8.3 & 8.2 & 7.8 & 7.6 \\
578 & 578 & 584 & 592 \\
9.8 & 9.0 & 4.9 & 0.8 \\
0.59 & -- & -- & -- \\
0.04 & 0.051 & 0.106 & 0.198 \\
0.02 & 0.03 & 0.076 & 0.149 \\
1.1 & -- & -- & -- \\
0.416 & -- & -- & -- \\
0.133 & -- & -- & -- \\
0.66 & -- & -- & --
\end{tabular}

May $28^{*}$

June $4^{*}$

June $10^{*}$

June $17^{*}$

0.5

14.5

0.5

17

0.5

19

0.5

$-$

$-$

--

0.04

--

--

--

$$
\text { -- }
$$

June 23

\begin{tabular}{cccc}
\multicolumn{5}{c}{ June 23 } \\
\hline \multicolumn{5}{c}{2.0} \\
0.5 & 8 & 11 & 16 \\
22.7 & 20.2 & 15.5 & 14.2 \\
8.7 & 8 & 7.6 & 7.5 \\
541 & 560 & 586 & 593 \\
12.7 & 6.6 & 1.8 & 0.2 \\
15.8 & -- & -- & -- \\
0.063 & 0.046 & 0.161 & 0.263 \\
$<.006$ & $<.006$ & 0.071 & 0.179 \\
1.5 & -- & -- & -- \\
0.686 & -- & -- & -- \\
0.027 & -- & -- & -- \\
0.86 & -- & -- & --
\end{tabular}

\begin{tabular}{|c|c|c|c|}
\hline July $1^{*}$ & July $9 *$ & July $16^{*}$ & July $23^{*}$ \\
\hline 2.1 & 3.0 & 2.1 & 2.1 \\
\hline 0.5 & 0.5 & 0.5 & 0.5 \\
\hline 22 & 24 & 24 & 24.5 \\
\hline -- & -- & -- & -- \\
\hline -- & -- & -- & -- \\
\hline -- & -- & -- & -- \\
\hline -- & -- & -- & -- \\
\hline 0.04 & 0.04 & 0.04 & 0.03 \\
\hline -- & -- & -- & -- \\
\hline -- & -- & -- & -- \\
\hline -- & -- & -- & -- \\
\hline -- & -- & -- & -- \\
\hline -- & -- & -- & -- \\
\hline
\end{tabular}


423556088365001 DELAVAN LAKE AT CENTER NEAR DELAVAN LAKE, WI

WATER-QUALITY DATA, JULY 23 TO SEPTEMBER 2, 2008

(Milligrams per liter unless otherwise indicated)

Date

00078 Secchi-depth $(\mathrm{m})$

00098 Sampling depth $(\mathrm{m})$

00010 Water Temperature $\left({ }^{\circ} \mathrm{C}\right)$

$00400 \mathrm{pH}$ (standard units)

00095 Specific conductance $(\mu \mathrm{S} / \mathrm{cm})$

00300 Dissolved oxygen

32210 Chlorophyll a, phytoplankton ( $\mu \mathrm{g} / \mathrm{L})$

00665 Phosphorus, Total (as P)

00671 Orthophosphate, dissolved (as P)

00600 Total nitrogen

00631 Nitrate + nitrite, dissolved (as N)

00608 Ammonia, dissolved (as N)

00625 Ammonia + organic nitrogen, total (as N)

\begin{tabular}{cccc}
\multicolumn{5}{c}{ July 23} \\
\hline & \multicolumn{5}{c}{1.9} & \\
0.5 & 5 & 13 & 16 \\
25.8 & 25.1 & 15.4 & 14.3 \\
8.6 & 8.6 & 7.3 & 7.2 \\
526 & 527 & 599 & 612 \\
12.6 & 11.7 & 0.1 & 0.1 \\
4.9 & -- & -- & -- \\
0.038 & 0.037 & 0.32 & 0.53 \\
E.004 & E.004 & 0.301 & 0.505 \\
0.98 & -- & -- & -- \\
0.252 & -- & -- & -- \\
0.104 & -- & -- & -- \\
0.73 & -- & -- & --
\end{tabular}

July $30 *$

Aug. 6*

$0.5 \quad 0.5$

$26 \quad 25$

-- --

$-$

0.046

$\begin{array}{ll}-- & -- \\ -- & --\end{array}$
Date

00078 Secchi-depth $(\mathrm{m})$

00098 Sampling depth $(\mathrm{m})$

00010 Water Temperature $\left({ }^{\circ} \mathrm{C}\right.$

$00400 \mathrm{pH}$ (standard units)

00095 Specific conductance $(\mu \mathrm{S} / \mathrm{cm})$

00300 Dissolved oxygen

32210 Chlorophyll a, phytoplankton ( $\mu \mathrm{g} / \mathrm{L}$ )

00665 Phosphorus, Total (as P)

00671 Orthophosphate, dissolved (as P)

00600 Total nitrogen

00631 Nitrate + nitrite, dissolved (as N)

00608 Ammonia, dissolved (as N)

00625 Ammonia + organic nitrogen, total (as N)
Aug. 18

$\begin{array}{ccc} & & \\ 0.5 & 7 & \\ 24.6 & 24 & \\ 8.6 & 8.4 & 7.6 \\ 492 & 497 & 516 \\ 9.8 & 7 & 0.7 \\ 45.8 & -- & \\ 0.043 & 0.041 & 0.04 \\ \text { E.003 } & \text { E.003 } & \\ -- & -- & \\ <.016 & -- & \\ 0.031 & -- & \\ 0.75 & -- & \end{array}$

\begin{tabular}{|c|c|c|}
\hline Aug. 19* & Aug. $27^{*}$ & Sept. $2^{*}$ \\
\hline 1.5 & 1.4 & 1.5 \\
\hline 0.5 & 0.5 & 0.5 \\
\hline 24 & 23 & 24 \\
\hline -- & -- & -- \\
\hline -- & -- & -- \\
\hline -- & -- & -- \\
\hline-- & -- & -- \\
\hline 0.043 & 0.053 & 0.04 \\
\hline-- & -- & -- \\
\hline-- & -- & -- \\
\hline -- & -- & -- \\
\hline-- & -- & -- \\
\hline-- & -- & -- \\
\hline
\end{tabular}


423556088365001 DELAVAN LAKE AT CENTER NEAR DELAVAN LAKE, WI

WATER-QUALITY DATA, SEPTEMBER 10 TO SEPTEMBER 23, 2008

(Milligrams per liter unless otherwise indicated)

Date

00078 Secchi-depth $(\mathrm{m})$

00098 Sampling depth $(\mathrm{m})$

00010 Water Temperature $\left({ }^{\circ} \mathrm{C}\right)$

$00400 \mathrm{pH}$ (standard units)

00095 Specific conductance $(\mu \mathrm{S} / \mathrm{cm})$

00300 Dissolved oxygen

32210 Chlorophyll a, phytoplankton ( $\mu \mathrm{g} / \mathrm{L})$

00665 Phosphorus, Total (as P)

00671 Orthophosphate, dissolved (as P)

00600 Total nitrogen

00631 Nitrate + nitrite, dissolved (as N)

00608 Ammonia, dissolved (as N)

00625 Ammonia + organic nitrogen, total (as N)

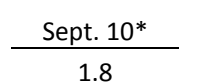

1.8

0.5

21

$--$

$-$

$--$

0.047

$--$

$-$

$--$

$-$

\begin{tabular}{c} 
\\
\hline \\
0.5 \\
21.4 \\
8.2 \\
514 \\
9.0 \\
19.5 \\
0.057 \\
$<.006$ \\
E.69 \\
E.015 \\
$<.020$ \\
0.68
\end{tabular}

Sept. 17

1.7

11

$\begin{array}{lll}19.7 & 14.8 & 13.9\end{array}$

$7.6 \quad 7.0$

$\begin{array}{lll}528 & 637 & 682\end{array}$

$\begin{array}{lll}4.2 & 0.1 & 0.1\end{array}$

$\begin{array}{llll}4- & -- & -\end{array}$

$\begin{array}{lll}0.084 & 0.52 & 0.86\end{array}$

$\begin{array}{lll}0.049 & 0.459 & 0.79\end{array}$

$--$

$-$

$--$
Sept. $23^{*}$

2.4

0.5

21

$-$

$-$

$--$

0.045 
423556088365001 DELAVAN LAKE AT CENTER NEAR DELAVAN LAKE, WI

LAKE-DEPTH PROFILES, NOVEMBER 13, 2007 TO MAY 19, 2008

11-13-07
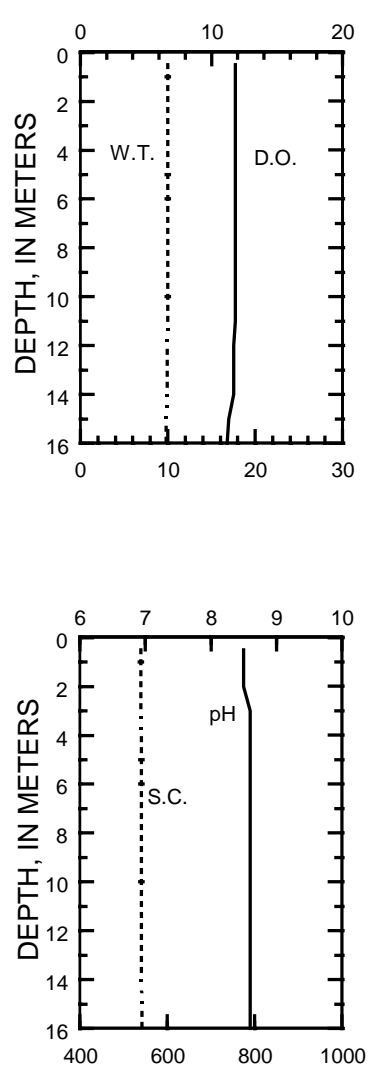

03-04-08

$04-21-08$

DISSOLVED OXYGEN (D.O.), IN MILLIGRAMS PER LITER

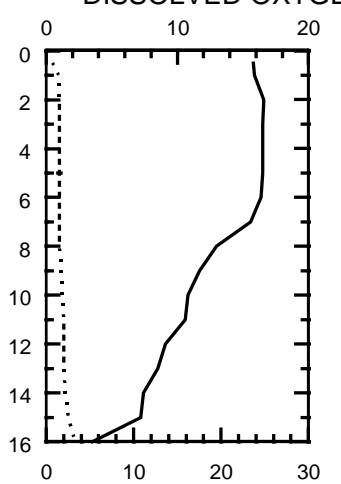

WATER TEMPERATURE (W.T.), IN DEGREES CELSIUS

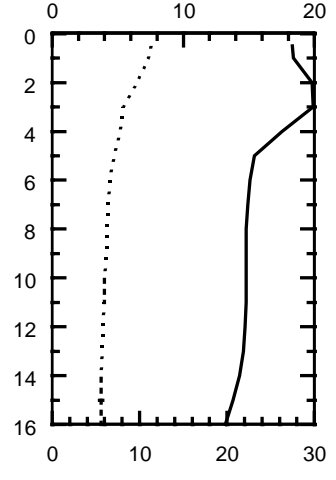

H, IN STANDARD UNITS
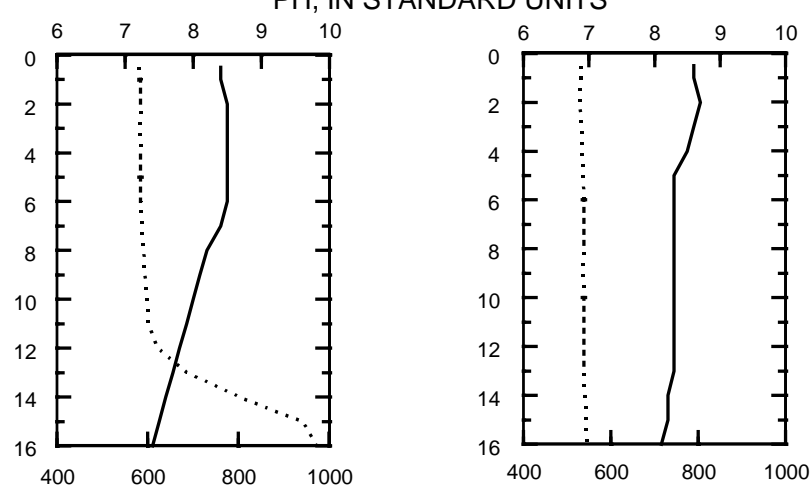

05-19-08
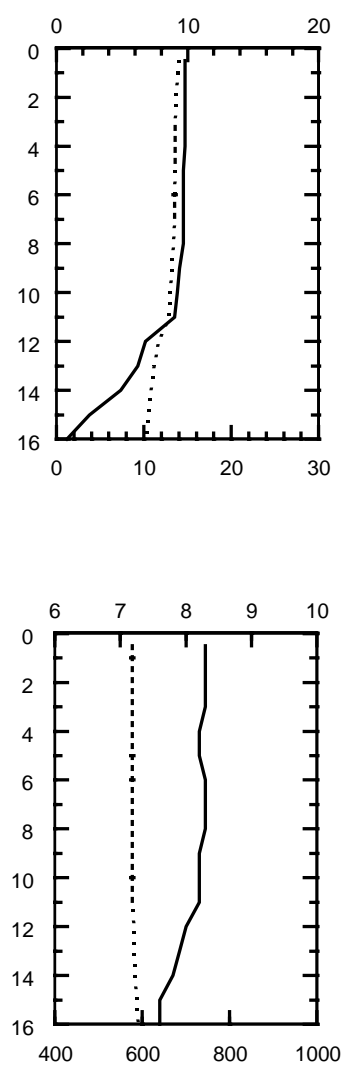

SPECIFIC CONDUCTANCE (S.C.), IN MICROSIEMENS PER CENTIMETER AT 25 DEGREES CELSIUS 
423556088365001 DELAVAN LAKE AT CENTER NEAR DELAVAN LAKE, WI

LAKE-DEPTH PROFILES, JUNE 23 TO SEPTEMBER 17, 2008

06-23-08
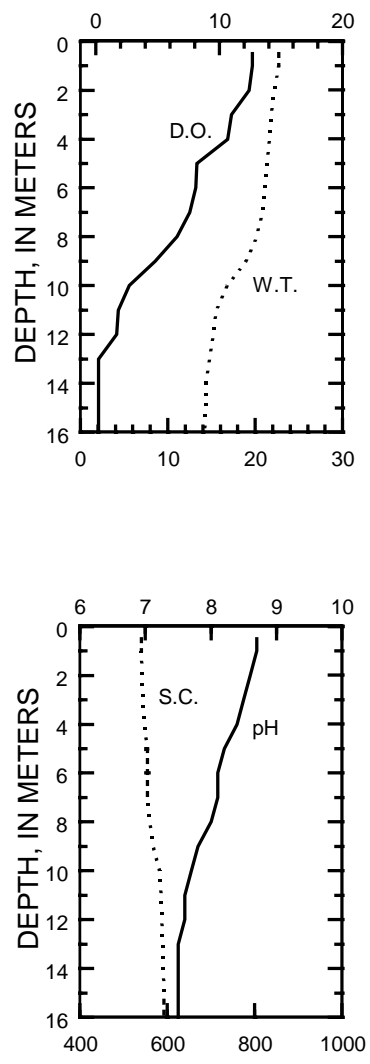

07-23-08

DISSOLVED

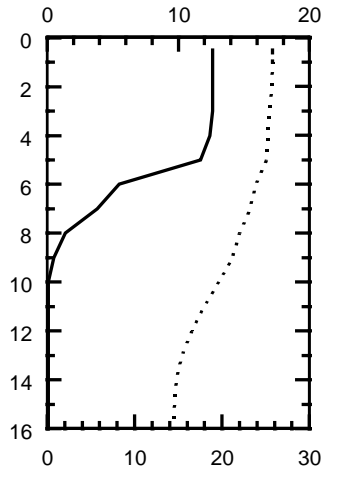

WATER TEMPERATURE (W.T.), IN DEGREES CELSIUS

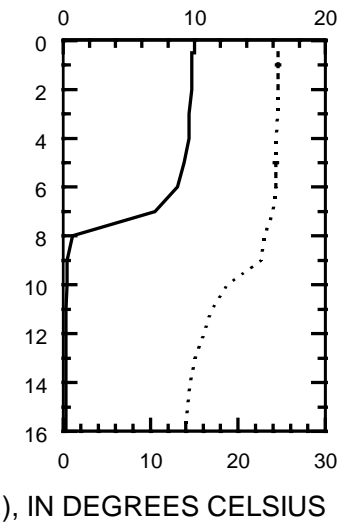

$\mathrm{PH}$, IN STANDARD UNITS

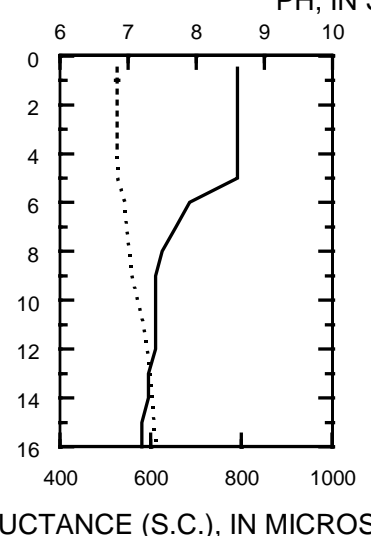

09-17-08
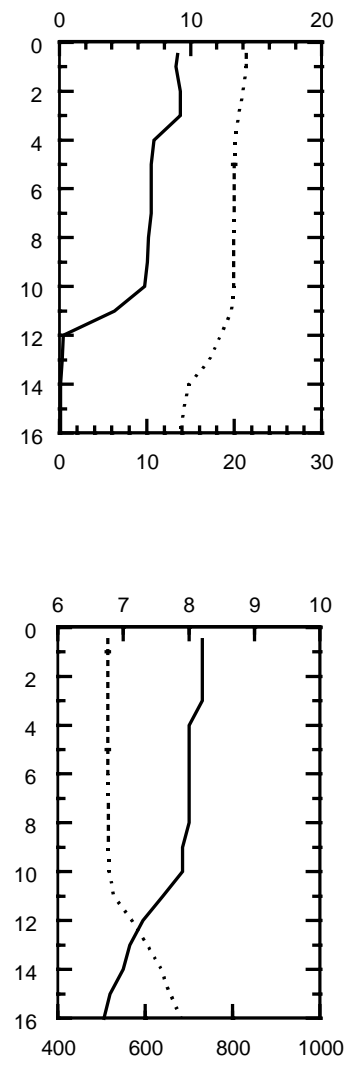

SPECIFIC CONDUCTANCE (S.C.), IN MICROSIEMENS PER CENTIMETER AT 25 DEGREES CELSIUS 

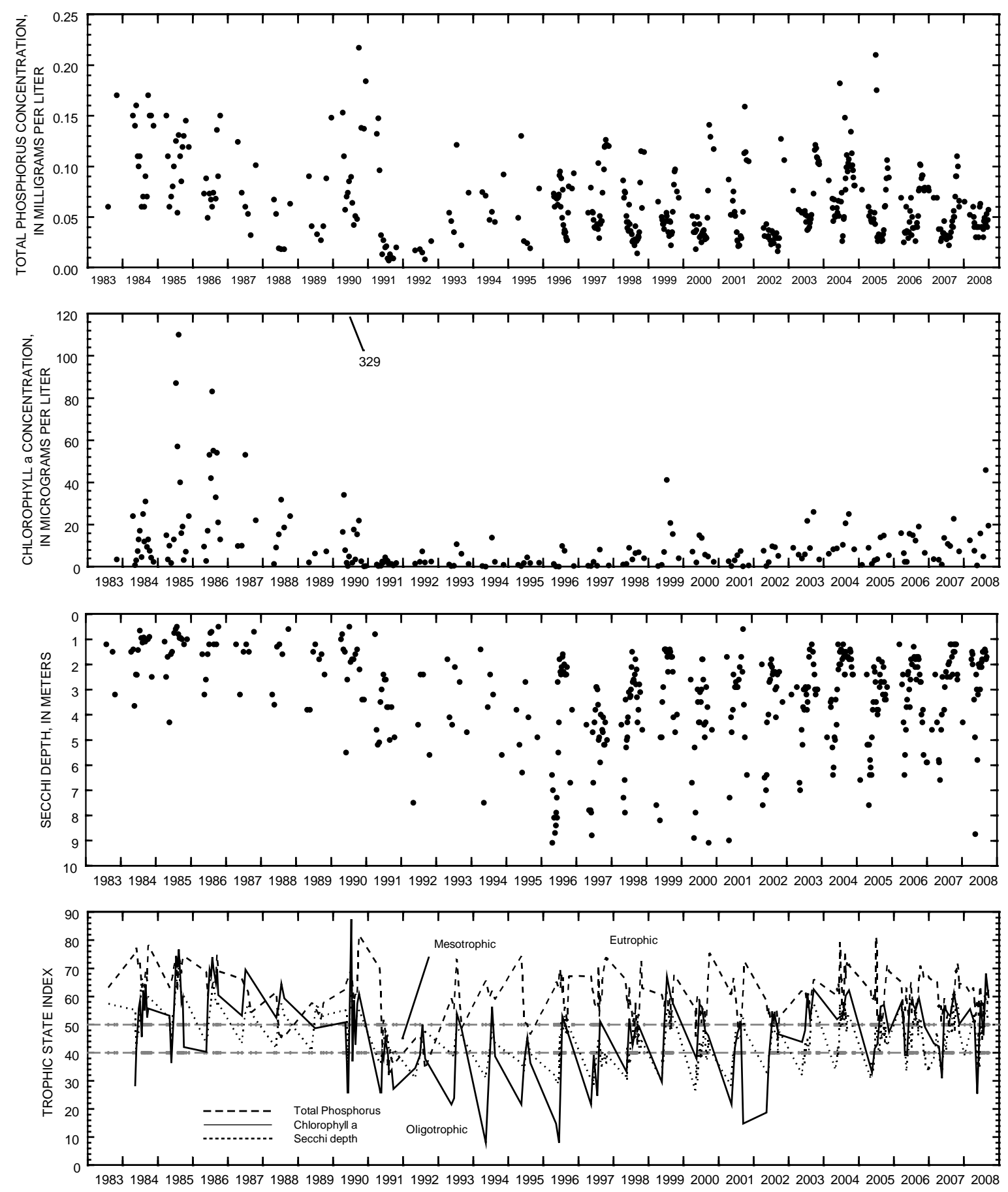

Surface total phosphorus, chlorophyll a concentrations, Secchi depths, and TSI data for Delavan Lake, at Center, near Delavan, Wisconsin. 


\section{DELAVAN LAKE, AT NORTH END, NEAR LAKE LAWN, WI}

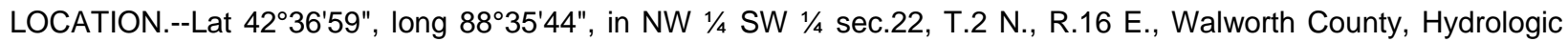
Unit 07090001, 2.6 mi southeast of Delavan.

SURFACE AREA--3.24 $\mathrm{mi}^{2}$.

DRAINAGE AREA.--41.4 $\mathrm{mi}^{2}$, of which $2.3 \mathrm{mi}^{2}$ is non-contributing.

PERIOD OF RECORD.--October 1983 to current year.

\begin{tabular}{|c|c|c|c|c|c|}
\hline Date & Apr. 21 & May 19 & June 23 & July 23 & Aug. 18 \\
\hline 00078 Secchi-depth (m) & 2.0 & 7.9 & 3.8 & 2.2 & 1.5 \\
\hline
\end{tabular}

\section{DELAVAN LAKE, AT SW END, NEAR DELAVAN LAKE, WI}

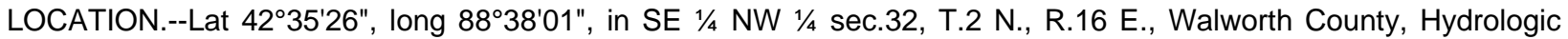
Unit 07090001, 2.6 mi southeast of Delavan.

SURFACE AREA--3.24 $\mathrm{mi}^{2}$.

DRAINAGE AREA.--41.4 $\mathrm{mi}^{2}$, of which $2.3 \mathrm{mi}^{2}$ is non-contributing.

PERIOD OF RECORD.--October 1983 to current year.

\begin{tabular}{|c|c|c|c|c|c|}
\hline Date & Apr. 21 & May 19 & June 23 & July 23 & Aug. 18 \\
\hline 00078 Secchi-depth (m) & 2.6 & 8.0 & 2.3 & 1.9 & 2.0 \\
\hline
\end{tabular}




\section{DEVILS LAKE NEAR BARABOO, WI}

LOCATION.--Lat 4325'35", long 8943'40" referenced to North American Datum of 1927, in SW 1/4 SE 1/4 sec.13, T.11 N., R.6 E., Sauk County, WI, Hydrologic Unit 07070004, in Devils Lake State Park, 3.5 mi south of Baraboo.

SURFACE AREA.--0.56 $\mathrm{mi}^{2}$.

DRAINAGE AREA.--4.79 $\mathrm{mi}^{2}$.

PERIOD OF RECORD.--June 1922 to August 1930, June to August 1932, June 1934 to September 1981 (fragmentary). October 1981 to September 1984, data unpublished in district files. October 1984 to current year.

REVISED RECORDS.--WDR WI-78-1: Drainage area.

GAGE.--Water-stage recorder installed July 17, 1991. Datum of gage is $955.00 \mathrm{ft}$, above NGVD of 1929.

REMARKS.--Lake normally has no surface outlet. However, during and after extreme rainfall in June, water spilled out of the north end of the lake. Water removed from lake by siphon October 1-25, April 17-May 29, and June 5-September 30.

EXTREMES FOR PERIOD OF RECORD.--Maximum gage height observed, $14.83 \mathrm{ft}$, June 12, 2008; minimum observed, $1.49 \mathrm{ft}$, Feb. 8, 1965.

EXTREMES FOR CURRENT YEAR.--Maximum recorded gage height, $14.83 \mathrm{ft}$, June 12, 2008; minimum recorded, $7.90 \mathrm{ft}$, Nov. 30 and Dec. 1. 
GAGE HEIGHT, FEET

WATER YEAR OCTOBER 2007 TO SEPTEMBER 2008

DAILY MEAN VALUES

\begin{tabular}{|c|c|c|c|c|c|c|c|c|c|c|c|c|}
\hline Day & Oct & Nov & Dec & Jan & Feb & Mar & Apr & May & Jun & Jul & Aug & Sep \\
\hline 1 & 8.71 & 8.38 & 7.97 & 8.15 & 8.60 & 8.83 & 9.65 & 11.80 & 11.32 & 12.96 & 12.22 & 10.84 \\
\hline 2 & 8.70 & 8.37 & 8.06 & 8.15 & 8.61 & 8.84 & 9.71 & 11.84 & 11.30 & 12.91 & 12.17 & 10.79 \\
\hline 3 & 8.79 & 8.35 & 8.05 & 8.15 & 8.61 & 8.91 & 9.77 & 11.88 & 11.32 & 12.85 & 12.12 & 10.72 \\
\hline 4 & 8.76 & 8.34 & 8.05 & 8.15 & 8.62 & 8.94 & 9.82 & 11.88 & 11.31 & 12.80 & 12.14 & 10.71 \\
\hline 5 & 8.73 & 8.31 & 8.06 & 8.14 & 8.63 & 8.96 & 9.90 & 11.86 & 11.68 & 12.74 & 12.13 & 10.70 \\
\hline 6 & 8.72 & 8.29 & 8.06 & 8.16 & 8.68 & 8.96 & 10.02 & 11.85 & 11.84 & 12.68 & 12.08 & 10.66 \\
\hline 7 & 8.70 & 8.27 & 8.07 & 8.19 & 8.71 & 8.97 & 10.12 & 11.89 & 11.92 & 12.65 & 12.02 & 10.62 \\
\hline 8 & 8.69 & 8.26 & 8.07 & 8.26 & 8.71 & 8.98 & 10.20 & 11.87 & 12.50 & 12.69 & 11.97 & 10.57 \\
\hline 9 & 8.64 & 8.24 & 8.07 & 8.33 & 8.71 & 8.98 & 10.35 & 11.84 & 12.87 & 12.65 & 11.92 & 10.52 \\
\hline 10 & 8.59 & 8.23 & 8.06 & 8.36 & 8.70 & 8.98 & 10.47 & 11.82 & 13.00 & 12.61 & 11.86 & 10.48 \\
\hline 11 & 8.55 & 8.22 & 8.07 & 8.41 & 8.71 & 8.99 & 10.78 & 11.82 & 13.57 & 13.01 & 11.81 & 10.44 \\
\hline 12 & 8.51 & 8.21 & 8.08 & 8.43 & 8.71 & 8.99 & 10.91 & 11.82 & 13.93 & 13.18 & 11.77 & 10.41 \\
\hline 13 & 8.48 & 8.20 & 8.07 & 8.46 & 8.71 & 9.00 & 10.97 & 11.80 & 14.45 & 13.15 & 11.73 & 10.41 \\
\hline 14 & 8.47 & 8.15 & 8.07 & 8.48 & 8.73 & 9.02 & 10.99 & 11.79 & 14.11 & 13.11 & 11.68 & 10.39 \\
\hline 15 & 8.45 & 8.11 & 8.07 & 8.49 & 8.74 & 9.06 & 11.01 & 11.78 & 13.93 & 13.07 & 11.63 & 10.37 \\
\hline 16 & 8.48 & 8.09 & 8.06 & 8.49 & 8.74 & 9.08 & 11.03 & 11.74 & 13.79 & 13.02 & 11.58 & 10.33 \\
\hline 17 & 8.47 & 8.06 & 8.06 & 8.52 & 8.79 & 9.09 & 11.04 & 11.70 & 13.70 & 12.98 & 11.54 & 10.29 \\
\hline 18 & 8.55 & 8.05 & 8.06 & 8.54 & 8.83 & 9.12 & 11.10 & 11.67 & 13.65 & 12.93 & 11.50 & 10.25 \\
\hline 19 & 8.59 & 8.04 & 8.05 & 8.54 & 8.84 & 9.14 & 11.13 & 11.64 & 13.59 & 12.89 & 11.46 & 10.21 \\
\hline 20 & 8.58 & 8.03 & 8.05 & 8.54 & 8.83 & 9.17 & 11.14 & 11.61 & 13.54 & 12.87 & 11.41 & 10.17 \\
\hline 21 & 8.57 & 8.03 & 8.05 & 8.55 & 8.83 & 9.25 & 11.14 & 11.58 & 13.47 & 12.82 & 11.36 & 10.14 \\
\hline 22 & 8.55 & 8.03 & 8.05 & 8.57 & 8.83 & 9.32 & 11.15 & 11.55 & 13.41 & 12.78 & 11.32 & 10.10 \\
\hline 23 & 8.52 & 8.02 & 8.11 & 8.57 & 8.83 & 9.34 & 11.16 & 11.51 & 13.36 & 12.74 & 11.28 & 10.06 \\
\hline 24 & 8.49 & 8.00 & 8.13 & 8.57 & 8.83 & 9.35 & 11.15 & 11.46 & 13.30 & 12.66 & 11.22 & 10.03 \\
\hline 25 & 8.47 & 7.99 & 8.13 & 8.58 & 8.83 & 9.36 & 11.39 & 11.43 & 13.24 & 12.61 & 11.17 & 9.99 \\
\hline 26 & 8.46 & 7.98 & 8.12 & 8.59 & 8.83 & 9.38 & 11.77 & 11.41 & 13.19 & 12.55 & 11.12 & 9.95 \\
\hline 27 & 8.45 & 7.96 & 8.13 & 8.59 & 8.83 & 9.41 & 11.81 & 11.37 & 13.14 & 12.49 & 11.07 & 9.91 \\
\hline 28 & 8.44 & 7.96 & 8.14 & 8.59 & 8.83 & 9.43 & 11.83 & 11.33 & 13.13 & 12.44 & 11.02 & 9.87 \\
\hline 29 & 8.43 & 7.94 & 8.15 & 8.59 & 8.83 & 9.45 & 11.83 & 11.30 & 13.07 & 12.38 & 10.98 & 9.84 \\
\hline 30 & 8.42 & 7.92 & 8.15 & 8.60 & --- & 9.47 & 11.81 & 11.34 & 13.01 & 12.33 & 10.93 & 9.79 \\
\hline 31 & 8.40 & --- & 8.15 & 8.60 & --- & 9.53 & --- & 11.33 & --- & 12.28 & 10.89 & --- \\
\hline Mean & 8.56 & 8.13 & 8.08 & 8.43 & 8.75 & 9.14 & 10.84 & 11.66 & 12.99 & 12.77 & 11.58 & 10.32 \\
\hline Max & 8.79 & 8.38 & 8.15 & 8.60 & 8.84 & 9.53 & 11.83 & 11.89 & 14.45 & 13.18 & 12.22 & 10.84 \\
\hline Min & 8.40 & 7.92 & 7.97 & 8.14 & 8.60 & 8.83 & 9.65 & 11.30 & 11.30 & 12.28 & 10.89 & 9.79 \\
\hline
\end{tabular}




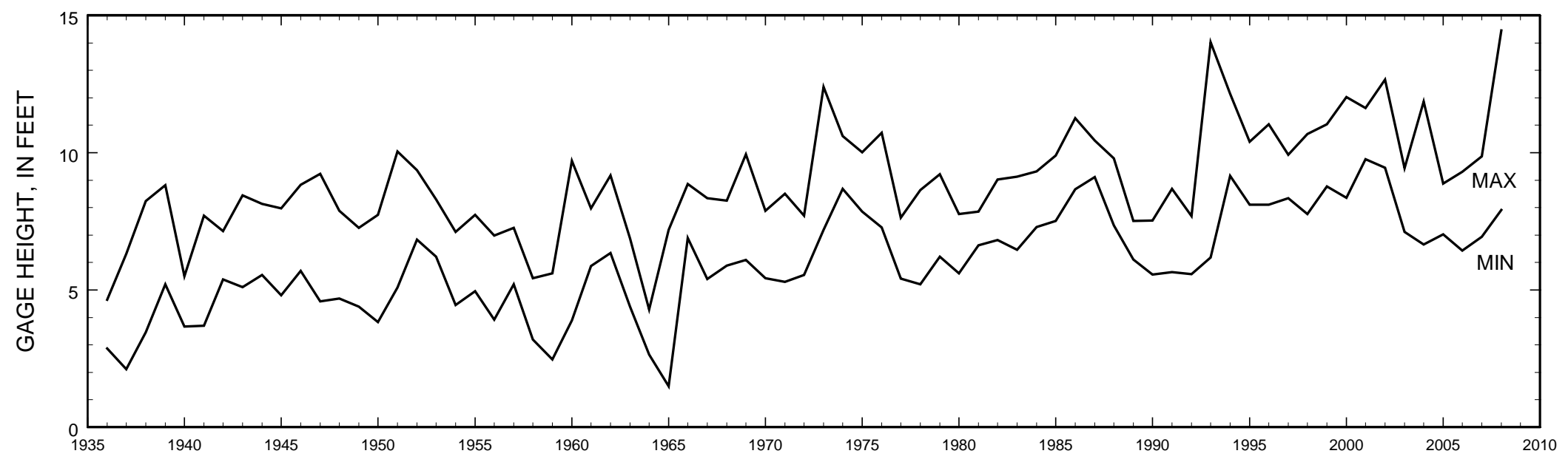

Annual minimum and maximum water levels for Devils Lake, 1936-2008. 
LOCATION.--Lat 42³5'25", long 88²6'04" referenced to North American Datum of 1927, in SE 1/4 NW 1/4 sec.36, T.2 N., R.17 E., Walworth County, WI, Hydrologic Unit 07120006, at Geneva Lake dam at Center Street at Lake Geneva.

SURFACE AREA.--8.22 $\mathrm{mi}^{2}$.

DRAINAGE AREA.--28.7 $\mathrm{mi}^{2}$.

PERIOD OF RECORD.--October 1997 to August 2002, December 2002 to current year.

GAGE.--Water-stage recorder. Datum of gage is $862.08 \mathrm{ft}$ above NGVD of 1929. Intermittent staff-gage readings January to March.

REMARKS.--Gage-height telemeter at station.

EXTREMES FOR PERIOD OF RECORD.--Maximum gage height, 3.35 ft, Aug. 20, 2007; minimum gage height, $1.44 \mathrm{ft}$, Nov. 5 , 2005 (affected by wind).

EXTREMES FOR CURRENT YEAR.--Maximum gage height observed, $3.25 \mathrm{ft}$ (affected by wind), June 15; minimum gage height, 2.11 $\mathrm{ft}$ (affected by wind), Nov. 28, but may have been lower during period when the float was frozen in the well.

\section{GAGE HEIGHT, FEET \\ WATER YEAR OCTOBER 2007 TO SEPTEMBER 2008 \\ DAILY MEAN VALUES}

\begin{tabular}{|c|c|c|c|c|c|c|c|c|c|c|c|c|}
\hline Day & Oct & Nov & Dec & Jan & Feb & Mar & Apr & May & Jun & Jul & Aug & Sep \\
\hline 1 & 2.49 & 2.39 & --- & --- & --- & --- & 2.69 & 2.74 & 2.67 & 2.64 & 2.61 & 2.39 \\
\hline 2 & 2.50 & 2.38 & --- & --- & --- & --- & 2.67 & 2.76 & 2.66 & 2.63 & 2.59 & 2.39 \\
\hline 3 & 2.52 & 2.37 & --- & e2.53 & --- & --- & 2.66 & 2.77 & 2.64 & 2.64 & 2.58 & 2.39 \\
\hline 4 & 2.50 & 2.37 & --- & --- & --- & --- & 2.68 & 2.76 & 2.64 & 2.63 & 2.61 & 2.45 \\
\hline 5 & 2.50 & 2.37 & --- & e2.40 & --- & --- & 2.66 & 2.75 & 2.72 & 2.62 & 2.62 & 2.53 \\
\hline 6 & 2.50 & 2.34 & --- & 2.44 & --- & --- & 2.64 & 2.73 & 2.81 & 2.61 & 2.61 & 2.52 \\
\hline 7 & 2.51 & 2.33 & --- & 2.51 & --- & --- & 2.63 & 2.73 & 2.81 & 2.61 & 2.59 & 2.51 \\
\hline 8 & 2.52 & 2.32 & --- & 2.61 & --- & --- & 2.64 & 2.71 & 2.88 & 2.72 & 2.57 & 2.50 \\
\hline 9 & 2.54 & 2.31 & --- & 2.63 & --- & --- & 2.73 & 2.70 & 3.04 & 2.70 & 2.55 & 2.50 \\
\hline 10 & 2.48 & 2.31 & --- & 2.62 & --- & --- & 2.75 & 2.68 & 3.02 & 2.71 & 2.52 & 2.49 \\
\hline 11 & 2.45 & 2.31 & --- & 2.64 & --- & $\mathrm{e} 2.41$ & 2.90 & 2.70 & 2.97 & 2.81 & 2.51 & 2.48 \\
\hline 12 & 2.43 & 2.32 & --- & 2.62 & --- & 2.44 & 2.90 & 2.70 & 2.94 & 2.97 & 2.51 & 2.48 \\
\hline 13 & 2.41 & 2.32 & --- & 2.63 & --- & 2.46 & 2.89 & 2.70 & 3.02 & 2.97 & 2.51 & 2.58 \\
\hline 14 & 2.43 & 2.33 & --- & e2.62 & --- & 2.47 & 2.87 & 2.68 & 3.00 & 2.91 & 2.53 & 2.64 \\
\hline 15 & 2.45 & 2.30 & --- & --- & --- & 2.48 & 2.85 & 2.66 & 2.97 & 2.88 & 2.51 & 2.65 \\
\hline 16 & 2.51 & 2.29 & --- & --- & --- & 2.48 & 2.84 & 2.66 & 2.92 & 2.84 & 2.51 & 2.64 \\
\hline 17 & 2.51 & 2.28 & --- & --- & --- & 2.47 & 2.80 & 2.65 & 2.89 & 2.82 & 2.50 & 2.62 \\
\hline 18 & 2.56 & 2.28 & --- & --- & --- & 2.48 & 2.78 & 2.63 & 2.83 & 2.79 & 2.49 & 2.60 \\
\hline 19 & 2.57 & 2.29 & --- & --- & --- & 2.48 & 2.77 & 2.61 & 2.80 & 2.82 & 2.46 & 2.59 \\
\hline 20 & 2.52 & 2.29 & e2.28 & --- & --- & 2.48 & 2.76 & 2.61 & 2.79 & 2.84 & 2.46 & 2.59 \\
\hline 21 & 2.51 & 2.30 & 2.30 & --- & --- & 2.51 & 2.75 & 2.59 & 2.77 & 2.82 & 2.45 & 2.58 \\
\hline 22 & 2.49 & 2.31 & 2.36 & --- & e2.56 & 2.56 & 2.74 & 2.58 & 2.75 & 2.78 & 2.46 & 2.57 \\
\hline 23 & 2.49 & 2.31 & 2.52 & --- & --- & 2.55 & 2.73 & 2.56 & 2.72 & 2.76 & 2.47 & 2.57 \\
\hline 24 & 2.47 & 2.31 & --- & --- & --- & 2.53 & 2.72 & 2.56 & 2.71 & 2.74 & 2.45 & 2.57 \\
\hline 25 & 2.44 & 2.31 & --- & --- & --- & 2.53 & 2.78 & 2.57 & 2.69 & 2.72 & 2.43 & 2.56 \\
\hline 26 & 2.44 & 2.28 & --- & --- & --- & 2.53 & 2.88 & 2.66 & 2.69 & 2.71 & 2.41 & 2.55 \\
\hline 27 & 2.45 & 2.28 & --- & --- & --- & 2.55 & 2.81 & 2.62 & 2.68 & 2.69 & 2.40 & 2.55 \\
\hline 28 & 2.43 & 2.27 & --- & --- & --- & 2.56 & 2.80 & 2.61 & 2.70 & 2.66 & 2.41 & 2.53 \\
\hline 29 & 2.44 & 2.27 & --- & --- & --- & 2.56 & 2.79 & 2.61 & 2.68 & 2.66 & 2.41 & 2.53 \\
\hline 30 & 2.42 & $\mathrm{e} 2.25$ & --- & --- & --- & 2.54 & 2.76 & 2.67 & 2.66 & 2.65 & 2.40 & 2.53 \\
\hline 31 & 2.41 & --- & --- & --- & --- & --- & --- & 2.69 & --- & 2.63 & 2.39 & --- \\
\hline Mean & 2.48 & 2.31 & --- & --- & --- & --- & 2.76 & 2.67 & 2.80 & 2.74 & 2.50 & 2.54 \\
\hline Max & 2.57 & 2.39 & --- & --- & --- & --- & 2.90 & 2.77 & 3.04 & 2.97 & 2.62 & 2.65 \\
\hline Min & 2.41 & 2.25 & --- & --- & --- & --- & 2.63 & 2.56 & 2.64 & 2.61 & 2.39 & 2.39 \\
\hline
\end{tabular}




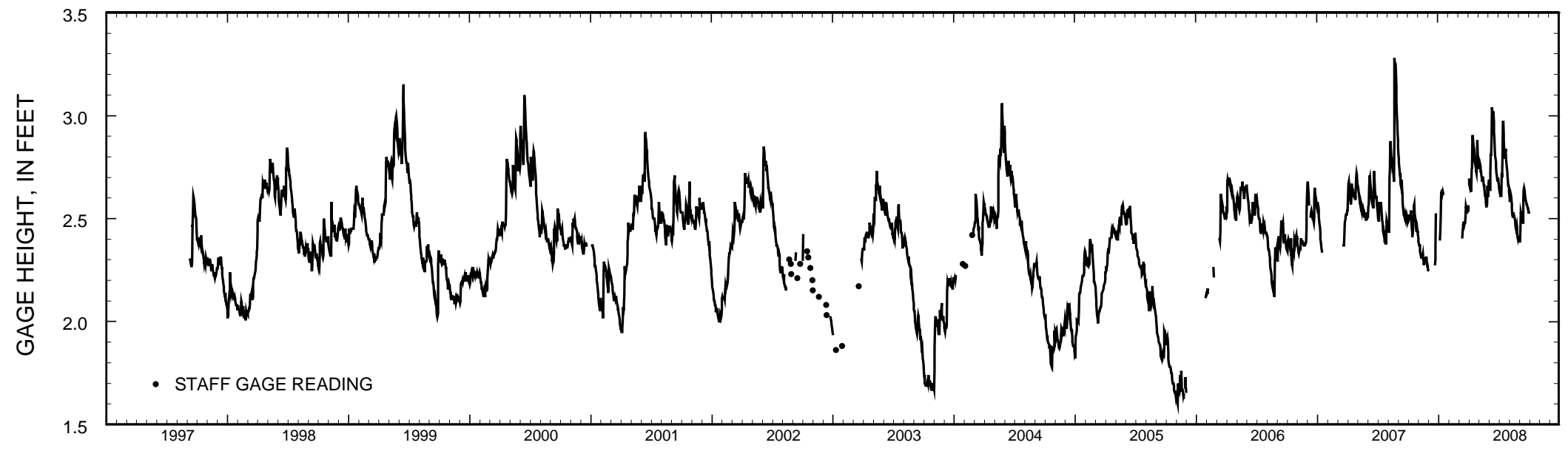

Stage hydrograph for Geneva Lake, 1997-2008. 


\section{GENEVA LAKE AT WEST END NEAR WILLIAMS BAY, W}

LOCATION.--Lat $42^{\circ} 33^{\prime 2} 9^{\prime \prime}$, long $88^{\circ} 32^{\prime} 33^{\prime \prime}$, in NE 1/4 SE 1/4 Sec.12, T.1 N., R.16 E., Walworth County, Hydrologic Unit 07120006, 1.3 mi south of Williams Bay.

SURFACE AREA.--8.22 $\mathrm{mi}^{2}$.

DRAINAGE AREA.--28.7 $\mathrm{mi}^{2}$.

PERIOD OF RECORD.--April 1997 to current year.

REMARKS.--Lake sampled at deep hole at a depth of about $43 \mathrm{~m}$. Water-quality analyses done by Wisconsin State Laboratory of Hygiene. Samples for determination of chlorophyll a concentration are collected from the top $0.5 \mathrm{~m}$ of the lake.

WATER-QUALITY DATA, NOVEMBER 13, 2007 TO JUNE 23, 2008 (Milligrams per liter unless otherwise indicated)

Date

00078 Secchi-depth $(\mathrm{m})$

00098 Sampling depth $(\mathrm{m})$

00010 Water Temperature $\left({ }^{\circ} \mathrm{C}\right)$

$00400 \mathrm{pH}$ (standard units)

00095 Specific conductance $(\mu \mathrm{S} / \mathrm{cm})$

00300 Dissolved oxygen

32210 Chlorophyll a, phytoplankton ( $\mu \mathrm{g} / \mathrm{L}$ )

00665 Phosphorus, Total (as P)

00671 Orthophosphate, dissolved (as P)

00600 Total nitrogen

00631 Nitrate + nitrite, dissolved (as N)

00608 Ammonia, dissolved (as N)

00625 Ammonia + organic nitrogen, total (as N)

00900 Hardness (as $\mathrm{CaCO} 3$ )

00417 Acid neutralizing capacity (as $\mathrm{CaCO} 3$ )

00915 Calcium, dissolved (Ca)

00925 Magnesium, dissolved (Mg)

00930 Sodium, dissolved ( $\mathrm{Na}$ )

00935 Potassium, dissolved (K)

00940 Chloride, dissolved (Cl)

00955 Silica, dissolved (SiO2)

01046 Iron $(\mu \mathrm{g} / \mathrm{L})$

01056 Manganese $(\mu \mathrm{g} / \mathrm{L})$

00081 Apparent color (PCU)

63675 Turbidity (NTU)

70300 Solids, dissolved (at $180 \mathrm{C}^{\circ}$ )

\begin{tabular}{|c|c|c|c|c|c|}
\hline \multicolumn{4}{|c|}{ Nov. 13} & \multicolumn{2}{|c|}{ Apr. 23} \\
\hline \multicolumn{4}{|c|}{4.3} & \multicolumn{2}{|c|}{6.6} \\
\hline 0.5 & 22 & 30 & 42 & 0.5 & 41.5 \\
\hline 11 & 10.8 & 7.9 & 7.2 & 7.2 & 3.7 \\
\hline 8.2 & 8.4 & 7.6 & 7.6 & 8.3 & 8.3 \\
\hline 518 & 518 & 529 & 532 & 519 & 529 \\
\hline 10.7 & 10.2 & 1.6 & 0.1 & 15.2 & 13.9 \\
\hline 8.36 & -- & -- & -- & 1.68 & \\
\hline 0.010 & 0.007 & 0.036 & 0.052 & 0.024 & 0.017 \\
\hline$<.002$ & -- & -- & -- & 0.004 & $<.002$ \\
\hline -- & -- & -- & -- & 0.43 & 0.61 \\
\hline$<.019$ & -- & -- & -- & 0.079 & 0.096 \\
\hline$<.015$ & -- & -- & -- & 0.016 & 0.019 \\
\hline 0.42 & -- & -- & -- & 0.35 & 0.51 \\
\hline -- & -- & -- & -- & 230 & 230 \\
\hline -- & -- & -- & -- & 181 & 183 \\
\hline -- & -- & -- & -- & 35.7 & 35.9 \\
\hline -- & -- & -- & -- & 34.8 & 35.2 \\
\hline -- & -- & -- & -- & 20.4 & 20.6 \\
\hline-- & -- & -- & -- & 1.9 & 2 \\
\hline-- & -- & -- & -- & 40.4 & 41.3 \\
\hline -- & -- & -- & -- & 1.83 & 2.36 \\
\hline-- & -- & -- & -- & $<100$ & $<100$ \\
\hline-- & -- & -- & -- & $<.5$ & $<.5$ \\
\hline -- & -- & -- & -- & 5 & 5 \\
\hline -- & -- & -- & -- & $<1.0$ & $<1.0$ \\
\hline -- & -- & -- & -- & 280 & 276 \\
\hline
\end{tabular}

\begin{tabular}{ccccccc}
\multicolumn{7}{c}{ June 23} \\
\hline 0.5 & 7.0 & 14 & 34 & 39 & 42.5 \\
20.2 & 19.6 & 12.5 & 6.8 & 6.4 & 6.2 \\
8.5 & 8.5 & 8.3 & 8.0 & 7.9 & 7.8 \\
518 & 518 & 521 & 525 & 527 & 528 \\
10.3 & 10.3 & 10.8 & 10.1 & 9.5 & 8.8 \\
3.24 & -- & -- & -- & -- & -- \\
0.008 & 0.010 & 0.009 & 0.008 & 0.013 & 0.018 \\
$<.002$ & -- & -- & -- & -- & -- \\
-- & -- & -- & -- & -- & -- \\
$<.019$ & -- & -- & -- & -- & -- \\
$<.015$ & -- & -- & -- & -- & -- \\
0.45 & -- & -- & -- & -- & -- \\
-- & -- & -- & -- & -- & - \\
-- & -- & -- & -- & -- & -- \\
-- & -- & -- & -- & -- & -- \\
-- & -- & -- & -- & -- & -- \\
-- & -- & -- & -- & -- & - \\
-- & -- & -- & -- & -- & -- \\
-- & -- & -- & -- & -- & -- \\
-- & -- & -- & -- & -- & -- \\
-- & -- & -- & -- & -- & - \\
-- & -- & -- & -- & -- & -- \\
-- & -- & -- & -- & -- & -- \\
-- & -- & -- & -- & -- & -- \\
-- & -- & -- & -- & -- & - \\
\hline & & & & &
\end{tabular}




\section{GENEVA LAKE AT WEST END NEAR WILLIAMS BAY, WI}

WATER-QUALITY DATA, JULY 23 TO SEPTEMBER 17, 2008

(Milligrams per liter unless otherwise indicated)

Date

00078 Secchi-depth $(\mathrm{m})$

00098 Sampling depth $(\mathrm{m})$

00010 Water Temperature $\left({ }^{\circ} \mathrm{C}\right)$

$00400 \mathrm{pH}$ (standard units)

00095 Specific conductance $(\mu \mathrm{S} / \mathrm{cm})$

00300 Dissolved oxygen

32210 Chlorophyll a, phytoplankton $(\mu \mathrm{g} / \mathrm{L})$

00665 Phosphorus, Total (as P)

00671 Orthophosphate, dissolved (as P)

00600 Total nitrogen

00631 Nitrate + nitrite, dissolved (as N)

00608 Ammonia, dissolved (as N)

00625 Ammonia + organic nitrogen, total (as N)
July 23

\begin{tabular}{|c|c|c|c|c|c|}
\hline \multicolumn{6}{|c|}{ July 23} \\
\hline \multicolumn{6}{|c|}{3.3} \\
\hline 0.5 & 7.0 & 15 & 33 & 38 & 43 \\
\hline 24.8 & 24.4 & 11.8 & 6.9 & 6.5 & 6.4 \\
\hline 8.4 & 8.5 & 8.0 & 7.8 & 7.6 & 7.6 \\
\hline 514 & 514 & 525 & 528 & 531 & 532 \\
\hline 9.3 & 9.4 & 9.3 & 9.2 & 7.1 & 6.4 \\
\hline 1.99 & -- & -- & -- & -- & -- \\
\hline 0.010 & 0.010 & 0.012 & 0.005 & 0.015 & 0.033 \\
\hline$<.002$ & -- & -- & -- & -- & -- \\
\hline -- & -- & -- & -- & -- & -- \\
\hline$<.019$ & -- & -- & -- & -- & -- \\
\hline$<.015$ & -- & -- & -- & -- & -- \\
\hline 0.46 & -- & -- & -- & -- & -- \\
\hline
\end{tabular}

\begin{tabular}{cccccc}
\multicolumn{7}{c}{ Aug. 18 } \\
\hline \multicolumn{7}{c}{4.0} \\
0.5 & 9.0 & 15 & 33 & 38 & 42 \\
24.4 & 22.9 & 11.9 & 7.1 & 6.6 & 6.4 \\
8.5 & 8.3 & 7.7 & 7.6 & 7.5 & 7.4 \\
506 & 511 & 513 & 516 & 518 & 521 \\
8.6 & 6.7 & 5.8 & 6.6 & 4.4 & 1.8 \\
2.32 & -- & -- & -- & -- & -- \\
0.015 & 0.015 & 0.012 & 0.012 & 0.02 & 0.058 \\
0.002 & -- & -- & -- & -- & -- \\
-- & -- & -- & -- & -- & -- \\
$<.019$ & -- & -- & -- & -- & -- \\
$<.015$ & -- & -- & -- & -- & -- \\
0.4 & -- & -- & -- & -- & --
\end{tabular}

Date

00078 Secchi-depth $(\mathrm{m})$

00098 Sampling depth $(\mathrm{m})$

00010 Water Temperature $\left({ }^{\circ} \mathrm{C}\right)$

$00400 \mathrm{pH}$ (standard units)

00095 Specific conductance $(\mu \mathrm{S} / \mathrm{cm})$

00300 Dissolved oxygen

32210 Chlorophyll a, phytoplankton $(\mu \mathrm{g} / \mathrm{L})$

00665 Phosphorus, Total (as P)

00671 Orthophosphate, dissolved (as P)

00600 Total nitrogen

00631 Nitrate + nitrite, dissolved (as N)

00608 Ammonia, dissolved (as N)

00625 Ammonia + organic nitrogen, total (as N)

\begin{tabular}{cccccc}
\multicolumn{7}{c}{ Sept. 17 } \\
\hline 0.5 & 12 & 17 & 33 & 38 & 42 \\
20.6 & 20 & 10.9 & 7.0 & 6.7 & 6.6 \\
8.3 & 8.3 & 7.6 & 7.5 & 7.3 & 7.3 \\
516 & 517 & 526 & 528 & 531 & 532 \\
9.0 & 8.2 & 4.9 & 5.0 & 1.8 & 0.2 \\
4.38 & -- & -- & -- & -- & -- \\
0.011 & 0.011 & 0.009 & 0.010 & 0.024 & 0.064 \\
$<.002$ & $<.002$ & $<.002$ & 0.006 & 0.015 & 0.048 \\
-- & -- & 0.44 & 0.59 & 0.68 & 0.6 \\
$<.019$ & $<.019$ & 0.107 & 0.275 & 0.335 & 0.254 \\
0.015 & $<.015$ & $<.015$ & $<.015$ & $<.015$ & 0.097 \\
0.28 & 0.35 & 0.33 & 0.32 & 0.34 & 0.35
\end{tabular}


423329088323300 GENEVA LAKE AT WEST END NEAR WILLIAMS BAY, WI

LAKE-DEPTH PROFILES, NOVEMBER 13, 2007 TO JUNE 23, 2008

11-13-08
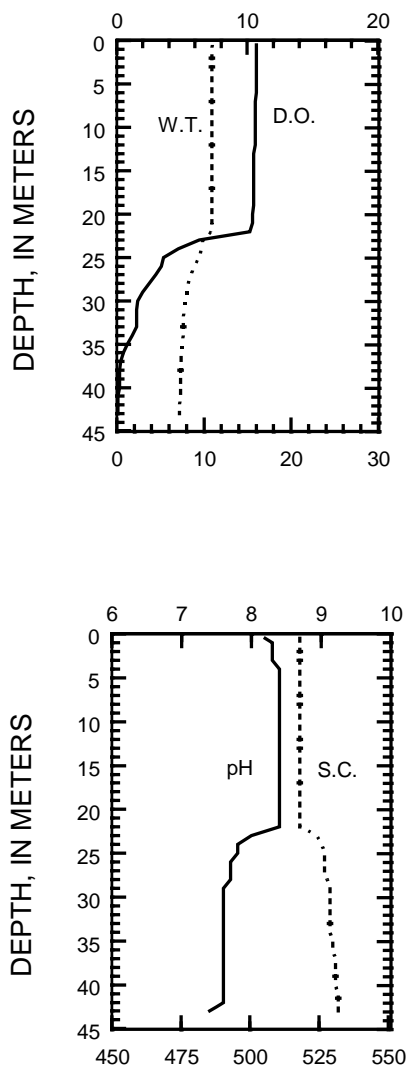

04-23-08

DISSOLVED OXYGEN (D.O.), IN MILLIGRAMS PER LITER

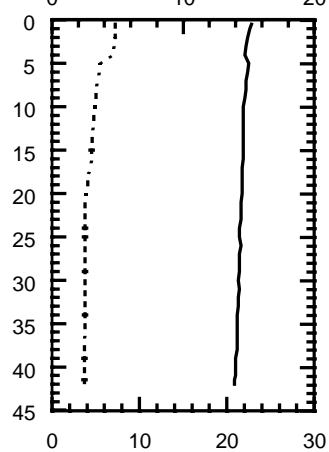

WATER TEMPERATURE (W.T.), IN DEGREES CELSIUS

$\mathrm{PH}$, IN STANDARD UNITS

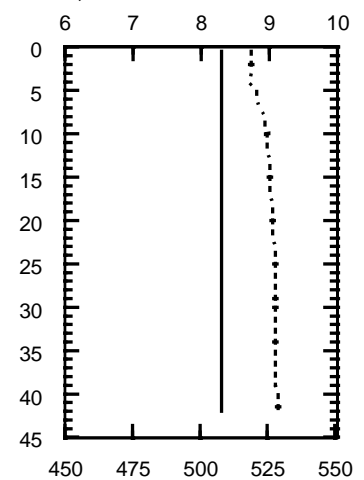

06-23-08
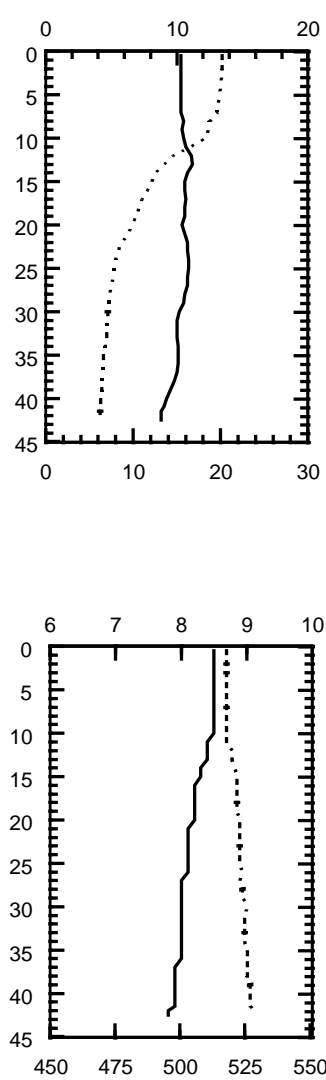

SPECIFIC CONDUCTANCE (S.C.), IN MICROSIEMENS PER CENTIMETER AT 25 DEGREES CELSIUS 
423329088323300 GENEVA LAKE AT WEST END NEAR WILLIAMS BAY, WI

LAKE-DEPTH PROFILES, JULY 23 TO SEPTEMBER 17, 2008

07-23-08
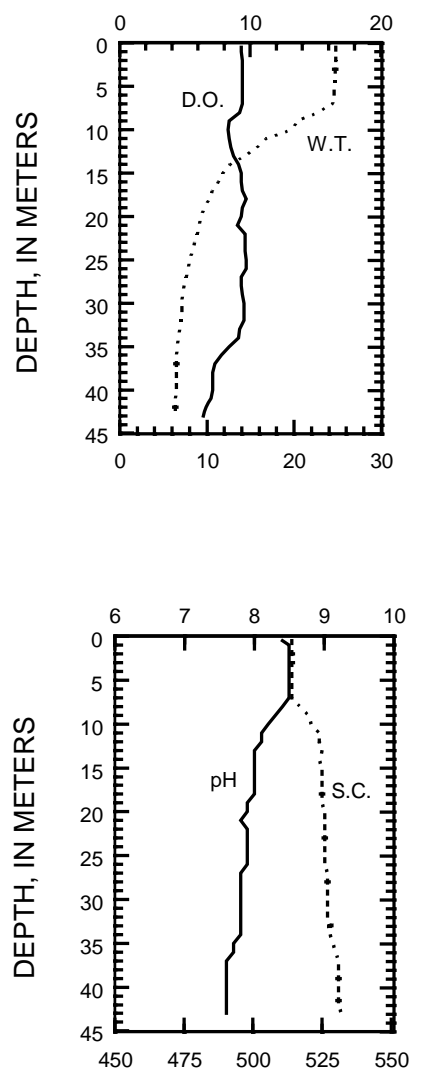

08-18-08

DISSOLVED OXYGEN (D.O.), IN MILLIGRAMS PER LITER

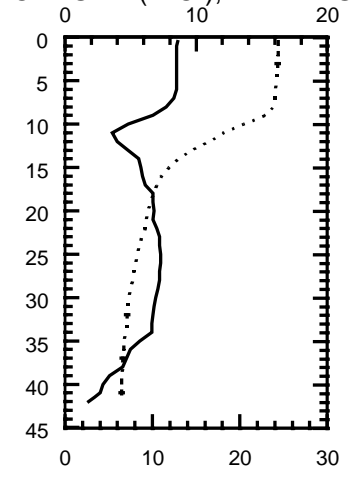

WATER TEMPERATURE (W.T.), IN DEGREES CELSIUS

$\mathrm{PH}$, IN STANDARD UNITS

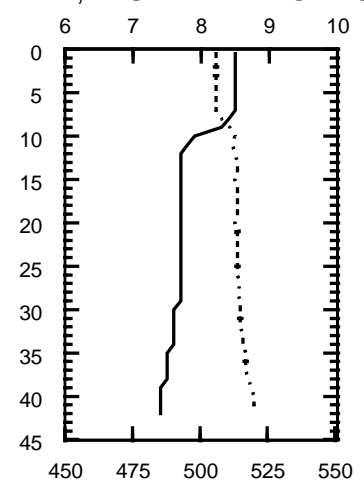

09-17-08
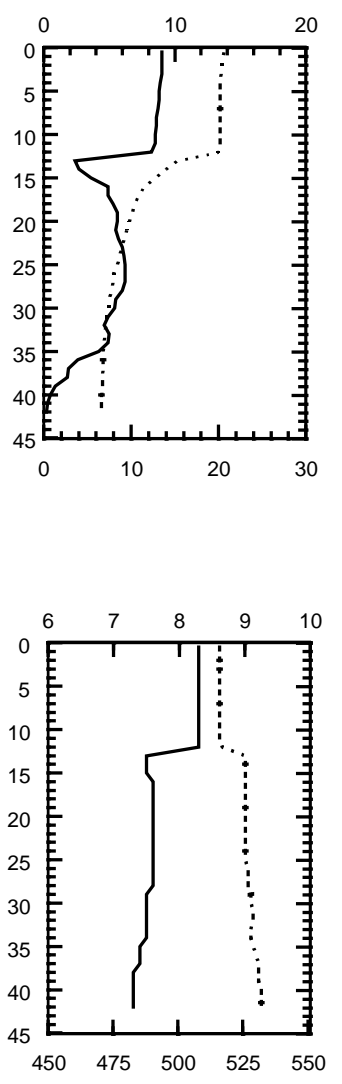

SPECIFIC CONDUCTANCE (S.C.), IN MICROSIEMENS PER CENTIMETER AT 25 DEGREES CELSIUS 

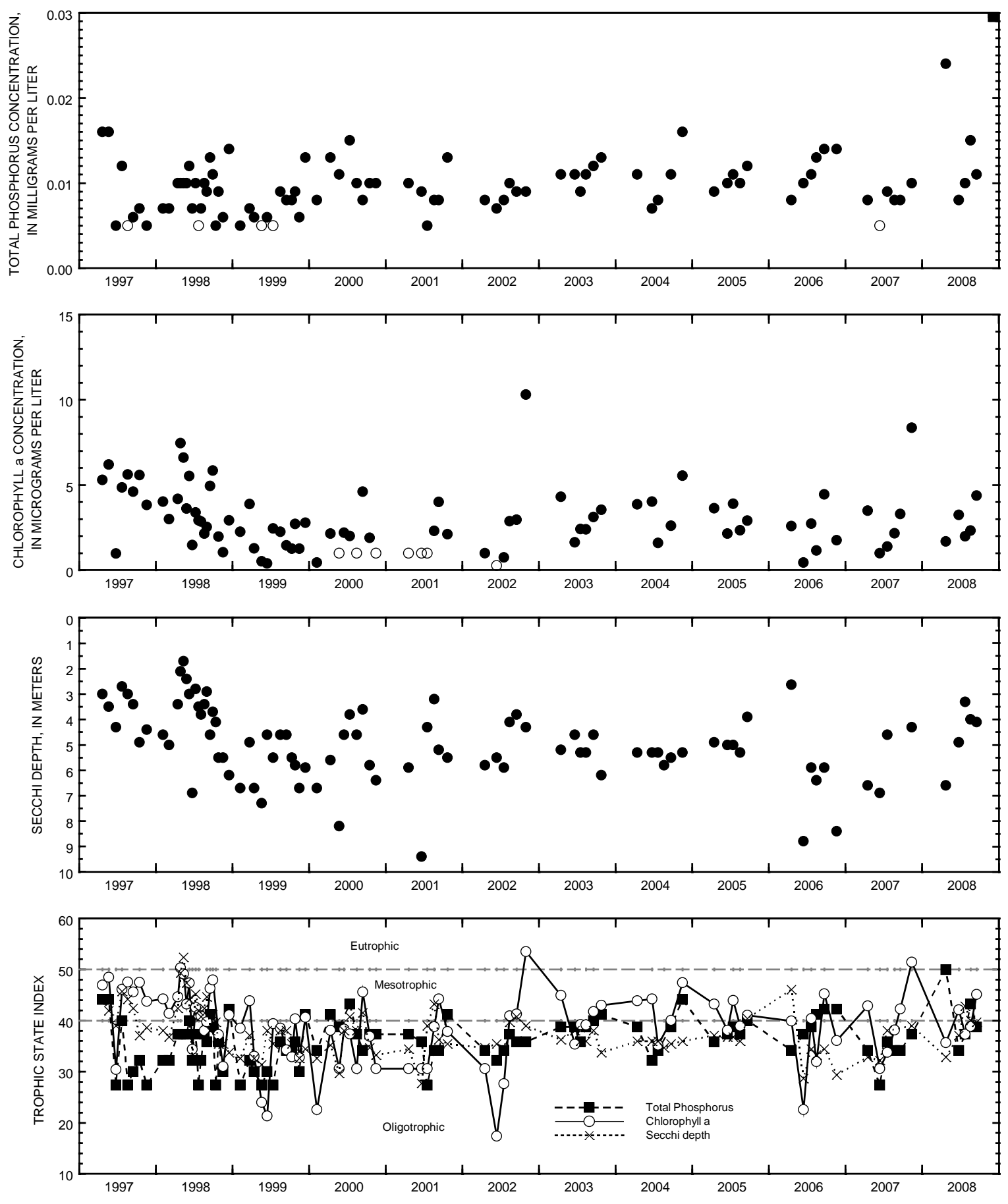

Surface total phosphorus, chlorophyll a concentrations, Secchi depths, and TSI data for Geneva Lake, West End, near Williams Bay, Wisconsin.

(Open circles on the first two plots indicate laboratory detection limit for selected analyses. Actual concentrations for these particular analyses are less than the plotted circles.) 


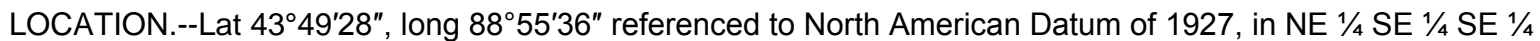
sec.27, T.16 N., R.13 E., Green Lake County, WI, Hydrologic Unit 04030201, on left bank at downstream side of County Trunk Highway A, 2.3 mi southeast of Green Lake.

SURFACE AREA.--11.48 $\mathrm{mi}^{2}$.

DRAINAGE AREA.--103 mi2; Area of Green Lake, 7,346 acres.

PERIOD OF RECORD.--October 1993 to current year.

GAGE.--Water-stage recorder. Datum of gage is $790.00 \mathrm{ft}$ above sea level.

REMARKS.--Lake level regulated by dam at outlet at Green Lake. Gage-height telemeter at station.

EXTREMES FOR PERIOD OF RECORD.--Maximum recorded gage height, $8.67 \mathrm{ft}$, June 15, 2008; minimum recorded, $5.27 \mathrm{ft}$, Nov. 5, 2005.

EXTREMES FOR CURRENT YEAR.--Maximum recorded gage height, $8.67 \mathrm{ft}$, June 15; minimum recorded gage height, $5.80 \mathrm{ft}$, Nov. 29.

\section{GAGE HEIGHT, FEET \\ WATER YEAR OCTOBER 2007 TO SEPTEMBER 2008 \\ DAILY MEAN VALUES}

[e, estimated]

\begin{tabular}{|c|c|c|c|c|c|c|c|c|c|c|c|c|}
\hline Day & Oct & Nov & Dec & Jan & Feb & Mar & Apr & May & Jun & Jul & Aug & Sep \\
\hline 1 & 6.32 & 6.20 & e6.01 & 6.20 & e6.43 & 6.12 & 6.63 & 6.76 & 6.59 & 7.23 & 6.48 & 6.25 \\
\hline 2 & 6.32 & 6.19 & e6.03 & 6.19 & e6.41 & e6.11 & 6.61 & 6.73 & 6.60 & 7.17 & 6.46 & 6.25 \\
\hline 3 & 6.36 & 6.18 & e6.04 & 6.18 & e6.38 & e6.10 & 6.60 & 6.72 & 6.61 & 7.10 & 6.44 & 6.22 \\
\hline 4 & 6.38 & 6.18 & e6.05 & 6.18 & e6.36 & 6.10 & 6.60 & 6.69 & 6.62 & 7.01 & 6.48 & 6.22 \\
\hline 5 & 6.38 & 6.12 & e6.07 & 6.18 & e6.34 & 6.10 & 6.58 & 6.66 & 6.68 & 6.94 & 6.52 & 6.24 \\
\hline 6 & 6.39 & 6.11 & e6.09 & 6.19 & e6.33 & 6.09 & 6.56 & 6.66 & 6.72 & 6.88 & 6.52 & 6.24 \\
\hline 7 & 6.39 & 6.13 & e6.10 & 6.21 & e6.31 & 6.09 & 6.55 & 6.71 & 6.76 & 6.82 & 6.50 & 6.23 \\
\hline 8 & 6.36 & 6.13 & 6.07 & 6.26 & e6.30 & 6.08 & 6.54 & 6.73 & 7.03 & 6.79 & 6.50 & 6.23 \\
\hline 9 & 6.32 & 6.12 & 6.07 & 6.30 & e6.28 & 6.08 & 6.63 & 6.72 & 7.31 & 6.74 & 6.50 & 6.22 \\
\hline 10 & 6.30 & 6.11 & 6.07 & 6.31 & e6.27 & 6.08 & 6.63 & 6.72 & 7.32 & 6.70 & 6.48 & 6.21 \\
\hline 11 & 6.29 & 6.11 & 6.07 & 6.36 & e6.26 & e6.08 & 6.75 & 6.72 & 7.29 & 6.74 & 6.48 & 6.21 \\
\hline 12 & 6.27 & 6.11 & 6.06 & 6.37 & e6.25 & e6.10 & 6.80 & 6.71 & 7.54 & 6.73 & 6.48 & 6.25 \\
\hline 13 & 6.26 & 6.10 & 6.07 & 6.40 & e6.24 & e6.11 & 6.82 & 6.71 & 8.25 & 6.68 & 6.47 & 6.26 \\
\hline 14 & 6.26 & 6.03 & 6.06 & 6.42 & e6.23 & e6.14 & 6.79 & 6.71 & 8.50 & 6.62 & 6.46 & 6.26 \\
\hline 15 & 6.25 & 6.05 & 6.06 & 6.42 & e6.22 & e6.18 & 6.76 & 6.71 & 8.57 & 6.57 & 6.45 & 6.27 \\
\hline 16 & 6.30 & 6.09 & 6.07 & 6.42 & e6.22 & e6.22 & 6.72 & 6.70 & 8.60 & e6.57 & 6.44 & 6.26 \\
\hline 17 & 6.30 & 6.07 & 6.05 & 6.45 & e6.21 & e6.26 & 6.69 & 6.68 & 8.50 & e6.59 & 6.44 & 6.27 \\
\hline 18 & 6.35 & 6.06 & 6.05 & 6.45 & e6.21 & e6.31 & 6.70 & 6.67 & 8.40 & e6.63 & 6.43 & 6.25 \\
\hline 19 & 6.30 & 6.06 & 6.04 & 6.43 & e6.19 & e6.37 & 6.71 & 6.66 & 8.28 & e6.67 & 6.39 & 6.25 \\
\hline 20 & 6.33 & 6.06 & 6.03 & 6.43 & e6.18 & e6.41 & 6.71 & 6.65 & 8.18 & e6.73 & 6.38 & 6.25 \\
\hline 21 & 6.34 & 6.06 & 6.03 & 6.44 & e6.17 & e6.45 & 6.68 & 6.64 & 8.06 & e6.77 & 6.38 & 6.24 \\
\hline 22 & 6.33 & 6.06 & 6.04 & 6.46 & 6.15 & e6.50 & 6.65 & 6.62 & 7.94 & 6.80 & 6.37 & 6.24 \\
\hline 23 & 6.31 & 6.05 & 6.19 & 6.46 & 6.15 & e6.56 & 6.63 & 6.61 & 7.83 & 6.77 & 6.36 & 6.24 \\
\hline 24 & 6.30 & 6.01 & 6.17 & e6.45 & 6.15 & e6.60 & 6.63 & 6.61 & 7.75 & 6.75 & 6.35 & 6.23 \\
\hline 25 & 6.29 & 6.01 & 6.16 & e6.43 & 6.14 & 6.61 & 6.71 & 6.60 & 7.64 & 6.71 & 6.32 & 6.22 \\
\hline 26 & 6.29 & 6.02 & 6.16 & e6.41 & 6.14 & 6.61 & 6.71 & 6.61 & 7.63 & 6.67 & 6.30 & 6.22 \\
\hline 27 & 6.27 & 5.99 & 6.17 & e6.39 & 6.13 & 6.60 & 6.78 & 6.56 & 7.53 & 6.63 & 6.29 & 6.21 \\
\hline 28 & 6.27 & 6.00 & 6.18 & e6.38 & 6.13 & 6.59 & 6.80 & 6.52 & 7.47 & 6.59 & 6.28 & 6.20 \\
\hline 29 & 6.25 & 5.93 & 6.20 & e6.37 & 6.12 & 6.58 & 6.80 & 6.51 & 7.40 & 6.56 & 6.28 & 6.19 \\
\hline 30 & 6.25 & e6.00 & 6.19 & e6.39 & --- & 6.57 & 6.78 & 6.58 & 7.32 & 6.52 & 6.27 & 6.18 \\
\hline 31 & 6.19 & --- & 6.20 & e6.43 & --- & 6.59 & --- & 6.58 & --- & 6.49 & 6.26 & --- \\
\hline Mean & 6.31 & 6.08 & 6.09 & 6.35 & 6.24 & 6.30 & 6.68 & 6.66 & 7.56 & 6.75 & 6.41 & 6.23 \\
\hline Max & 6.39 & 6.20 & 6.20 & 6.46 & 6.43 & 6.61 & 6.82 & 6.76 & 8.60 & 7.23 & 6.52 & 6.27 \\
\hline Min & 6.19 & 5.93 & 6.01 & 6.18 & 6.12 & 6.08 & 6.54 & 6.51 & 6.59 & 6.49 & 6.26 & 6.18 \\
\hline
\end{tabular}




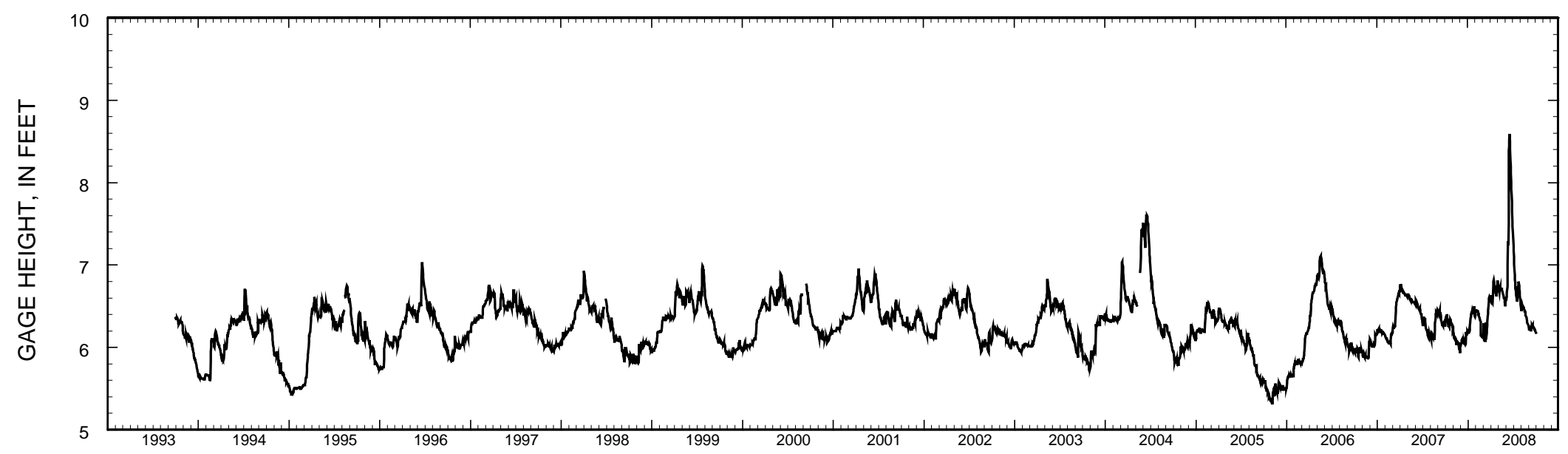

Stage hydrograph for Green Lake, 1993-2008. 
LOCATION.--Lat 4347'56", long 8902'05", in NW 1/4 SE 1/4 sec.2, T.15 N., R.12 E., Green Lake County, Hydrologic Unit 04030201, about 5 miles southwest of the City of Green Lake.

SURFACE AREA.--11.48 $\mathrm{mi}^{2}$.

PERIOD OF RECORD.--May 2004 to current year. Lake sampled by Wisconsin Department of Natural Resources prior to 2004.

REMARKS.--Water-quality analyses done by Wisconsin State Laboratory of Hygiene. A “*” indicates data that were collected by Mary Jane Bumby, Citizen Lake Monitoring Volunteer.

Date

00078 Secchi-depth $(\mathrm{m})$

00098 Sampling depth $(\mathrm{m})$

00010 Water Temperature $\left({ }^{\circ} \mathrm{C}\right.$

$00400 \mathrm{pH}$ (standard units)

00095 Specific conductance $(\mu \mathrm{S} / \mathrm{cm})$

00300 Dissolved oxygen

32210 Chlorophyll a, phytoplankton $(\mu \mathrm{g} / \mathrm{L})$

00665 Phosphorus, Total (as P)

00671 Orthophosphate, dissolved (as P)

00600 Total nitrogen

00631 Nitrate + nitrite, dissolved (as N)

00608 Ammonia, dissolved (as N)

00625 Ammonia + organic nitrogen, total (as N)

00900 Hardness (as $\mathrm{CaCO}$ )

00417 Acid neutralizing capacity (as $\mathrm{CaCO} 3$ )

00915 Calcium, dissolved (Ca)

00925 Magnesium, dissolved (Mg)

00930 Sodium, dissolved ( $\mathrm{Na}$ )

00935 Potassium, dissolved (K)

00940 Chloride, dissolved (Cl)

00945 Sulfate, dissolved (SO4)

00955 Silica, dissolved (SiO2)

01046 Iron $(\mu \mathrm{g} / \mathrm{L})$

01056 Manganese $(\mu \mathrm{g} / \mathrm{L})$

00081 Apparent color (PCU)

63675 Turbidity (NTU)

70300 Solids, dissolved (at $180 \mathrm{C}^{\circ}$ )
WATER-QUALITY DATA, OCTOBER 27, 2007 TO JUNE 24, 2008

(Milligrams per liter unless otherwise indicated)

\begin{tabular}{|c|c|c|c|c|c|c|c|c|}
\hline Oct. $27^{*}$ & \multicolumn{2}{|c|}{ Apr. 29} & May 6* & May $15^{*}$ & May $28^{*}$ & June $1^{*}$ & \multicolumn{2}{|c|}{ June 24} \\
\hline 7.6 & \multicolumn{2}{|c|}{5.5} & 5.9 & 1.8 & 1.7 & 1.4 & \multicolumn{2}{|c|}{5.1} \\
\hline 0.1 & 0.5 & 67 & 0.1 & 0.1 & 0.1 & 0.1 & 0.5 & 67.5 \\
\hline 13.3 & 4.1 & 3.8 & 11.7 & 10.0 & 12.2 & 17.2 & 21.2 & 4.4 \\
\hline-- & 8.1 & 8.0 & -- & -- & -- & -- & 8.8 & 7.4 \\
\hline-- & 513 & 517 & -- & -- & -- & -- & 484 & 525 \\
\hline-- & 14.7 & 14.4 & -- & -- & -- & -- & 11.1 & 2.0 \\
\hline-- & 2.19 & -- & -- & -- & -- & -- & 0.45 & -- \\
\hline-- & 0.053 & 0.053 & -- & -- & -- & -- & 0.029 & 0.090 \\
\hline-- & 0.023 & -- & -- & -- & -- & -- & -- & -- \\
\hline-- & 0.61 & -- & -- & -- & -- & -- & -- & -- \\
\hline-- & 0.303 & -- & -- & -- & -- & -- & -- & -- \\
\hline-- & $<.015$ & -- & -- & -- & -- & -- & -- & -- \\
\hline-- & 0.31 & -- & -- & -- & -- & -- & -- & -- \\
\hline-- & 230 & -- & -- & -- & -- & -- & -- & -- \\
\hline-- & 180 & -- & -- & -- & -- & -- & -- & -- \\
\hline-- & 33.9 & -- & -- & -- & -- & -- & -- & -- \\
\hline-- & 35 & -- & -- & -- & -- & -- & -- & -- \\
\hline -- & 19.3 & -- & -- & -- & -- & -- & -- & -- \\
\hline -- & 3.5 & -- & -- & -- & -- & -- & -- & -- \\
\hline-- & 38.8 & -- & -- & -- & -- & -- & -- & -- \\
\hline -- & -- & -- & -- & -- & -- & -- & -- & -- \\
\hline -- & 0.461 & -- & -- & -- & -- & -- & -- & -- \\
\hline -- & $<100$ & -- & -- & -- & -- & -- & -- & -- \\
\hline -- & $<.5$ & -- & -- & -- & -- & -- & -- & -- \\
\hline -- & 5 & -- & -- & -- & -- & -- & -- & -- \\
\hline -- & $<1.0$ & -- & -- & -- & -- & -- & -- & -- \\
\hline -- & 282 & -- & -- & -- & -- & -- & -- & -- \\
\hline
\end{tabular}


434756089020500 GREEN LAKE AT DEEP HOLE NEAR GREEN LAKE, WI

WATER-QUALITY DATA, JUNE 30 TO SEPTEMBER 25, 2008

(Milligrams per liter unless otherwise indicated)

Date

00078 Secchi-depth $(m)$

00098 Sampling depth $(\mathrm{m})$

00010 Water Temperature $\left({ }^{\circ} \mathrm{C}\right)$

$00400 \mathrm{pH}$ (standard units)

00095 Specific conductance $(\mu \mathrm{S} / \mathrm{cm})$

00300 Dissolved oxygen

32210 Chlorophyll a, phytoplankton ( $\mu \mathrm{g} / \mathrm{L})$

00665 Phosphorus, Total (as P)

\begin{tabular}{|c|c|c|}
\hline June $30^{*}$ & July $4 *$ & July $10^{*}$ \\
\hline 6.4 & 7.3 & 3.4 \\
\hline 0.1 & 0.1 & 0.1 \\
\hline 21.7 & 23.3 & 23.9 \\
\hline -- & -- & -- \\
\hline -- & -- & -- \\
\hline-- & -- & -- \\
\hline -- & -- & -- \\
\hline -- & -- & -- \\
\hline
\end{tabular}

Aug. 19

00078 Secchi-depth $(\mathrm{m})$

00098 Sampling depth $(\mathrm{m})$

00010 Water Temperature $\left({ }^{\circ} \mathrm{C}\right)$

$00400 \mathrm{pH}$ (standard units)

00095 Specific conductance $(\mu \mathrm{S} / \mathrm{cm})$

00300 Dissolved oxygen

32210 Chlorophyll a, phytoplankton ( $\mu \mathrm{g} / \mathrm{L}$ )

00665 Phosphorus, Total (as P)

00671 Orthophosphate, dissolved (as P)

00600 Total nitrogen

00631 Nitrate + nitrite, dissolved (as N)

00608 Ammonia, dissolved (as N)

00625 Ammonia + organic nitrogen, total (as N)

\begin{tabular}{c} 
July $18^{*}$ \\
\hline 3.5 \\
0.1 \\
23.3 \\
-- \\
-- \\
-- \\
-- \\
--
\end{tabular}

\begin{tabular}{cc}
\multicolumn{3}{c}{ July 24} \\
\hline & 2.7 \\
0.5 & 67 \\
25.1 & 4.5 \\
8.8 & 7.4 \\
481 & 521 \\
11.8 & 5.5 \\
3.31 & -- \\
0.02 & 0.124
\end{tabular}

Aug. 8*

Aug. $14^{*}$

$25.6 \quad 24.4$

$-$

$-$

$-$
24.4

$--$

$-$

$-$

\begin{tabular}{|c|c|c|c|c|c|c|}
\hline \multicolumn{3}{|c|}{ Aug. 19} & Aug. $27^{*}$ & Aug. $30^{*}$ & Sept. 9* & $19 *$ \\
\hline & 2.2 & & 2.4 & 2.4 & 2.7 & 3.2 \\
\hline 0.5 & 14 & 66 & 0.1 & 2.0 & 0.1 & 0.1 \\
\hline 23.7 & 9.5 & 4.6 & 23.9 & 25 & 21.1 & 20 \\
\hline 8.8 & 7.7 & 7.3 & -- & -- & -- & -- \\
\hline 451 & 505 & 514 & -- & -- & -- & -- \\
\hline 10 & 5.8 & 1.4 & -- & -- & -- & -- \\
\hline 13.7 & -- & -- & -- & -- & -- & -- \\
\hline 0.021 & 0.012 & 0.15 & -- & -- & -- & -- \\
\hline -- & -- & -- & -- & -- & -- & -- \\
\hline- & -- & -- & -- & -- & -- & -- \\
\hline -- & -- & -- & -- & -- & -- & -- \\
\hline-- & -- & -- & -- & -- & -- & -- \\
\hline -- & -- & -- & -- & -- & -- & -- \\
\hline
\end{tabular}

\begin{tabular}{|c|c|c|c|}
\hline \multicolumn{3}{|c|}{ Sept. 22} & \multirow{2}{*}{$\begin{array}{c}\text { Sept. } \\
25^{*}\end{array}$} \\
\hline & 3.2 & & \\
\hline 0.5 & 15 & 66 & 0.1 \\
\hline 19.7 & 11.2 & 4.7 & 20 \\
\hline 8.7 & 7.6 & 7.4 & -- \\
\hline 465 & 515 & 535 & -- \\
\hline 10.4 & 2.2 & 0.2 & -- \\
\hline 18.7 & -- & -- & -- \\
\hline 0.023 & 0.016 & 0.189 & -- \\
\hline$<.002$ & -- & -- & -- \\
\hline-- & -- & -- & -- \\
\hline$<.019$ & -- & -- & -- \\
\hline$<.015$ & -- & -- & -- \\
\hline 0.41 & -- & -- & -- \\
\hline
\end{tabular}




\section{GREEN LAKE AT DEEP HOLE NEAR GREEN LAKE, WI}

LAKE-DEPTH PROFILES, APRIL 29 TO SEPTEMBER 22, 2008

04-29-08
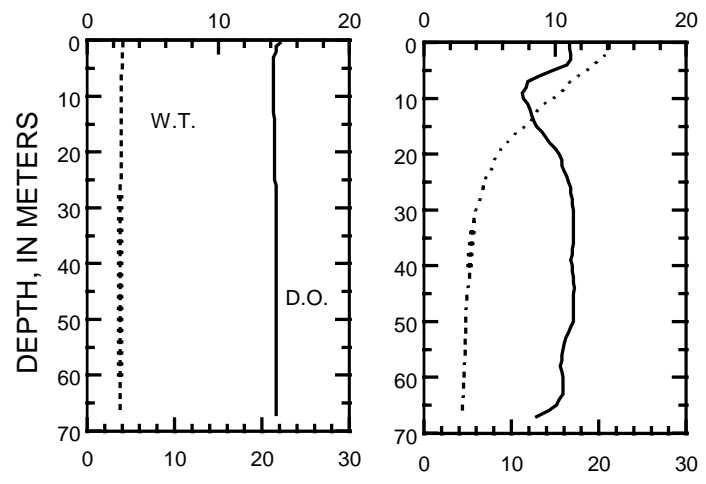

WATER TEMP

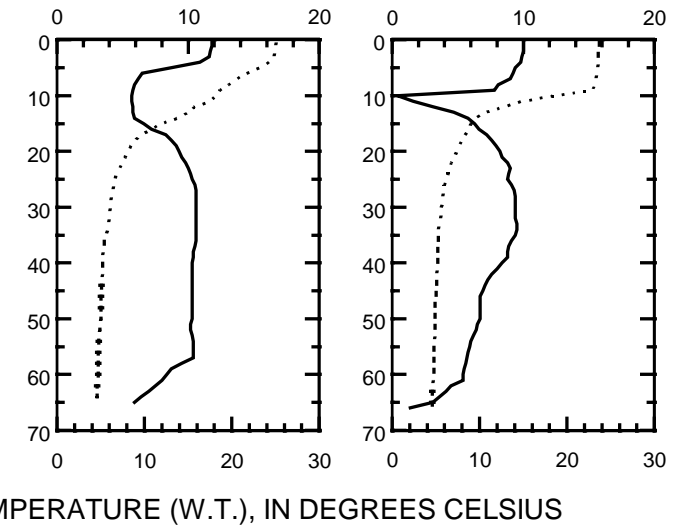

07-24-08

08-19-08

$09-22-08$

DISSOLVED OXYGEN (D.O.), IN MILLIGRAMS PER LITER
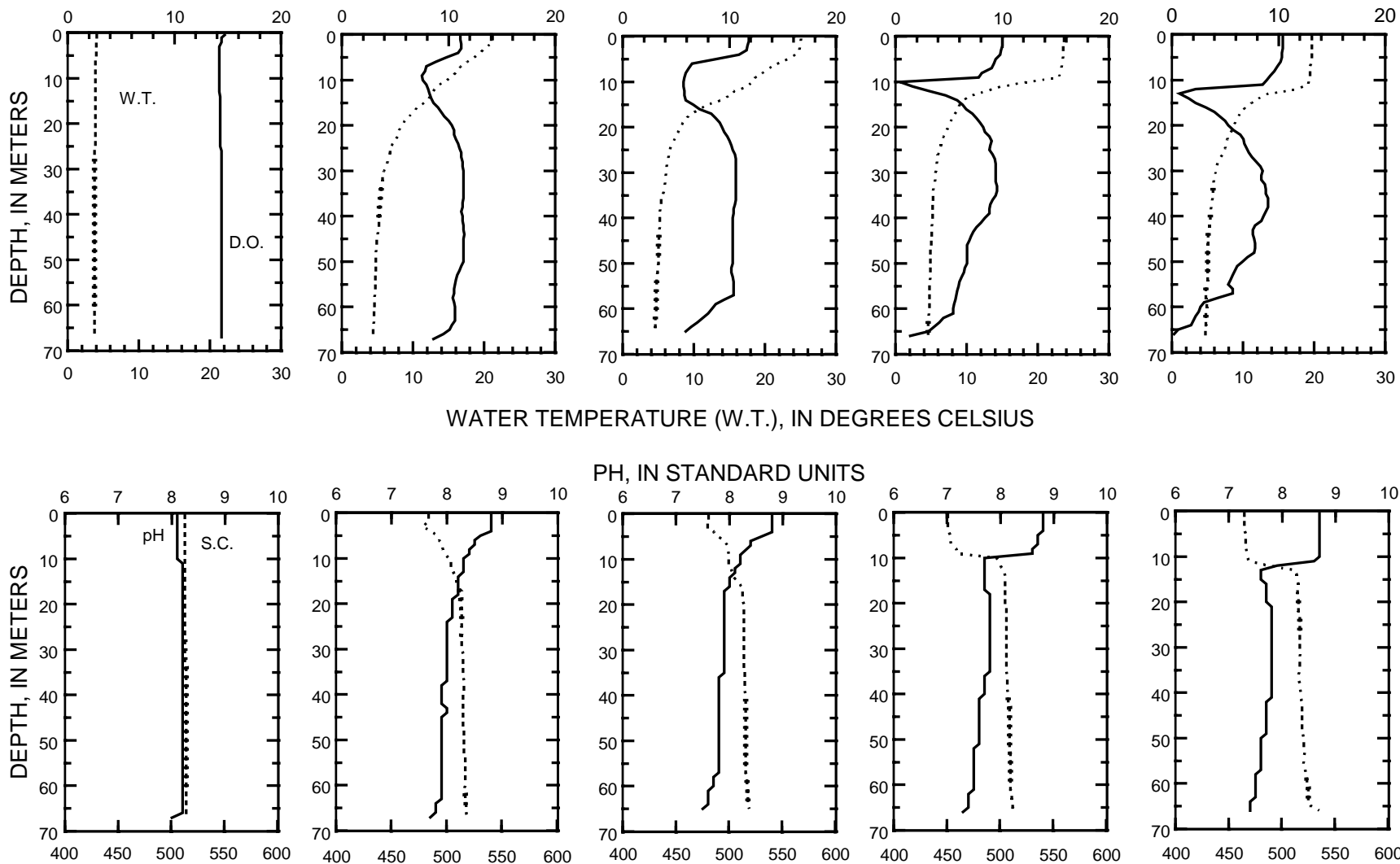

PH, IN STANDARD UNITS
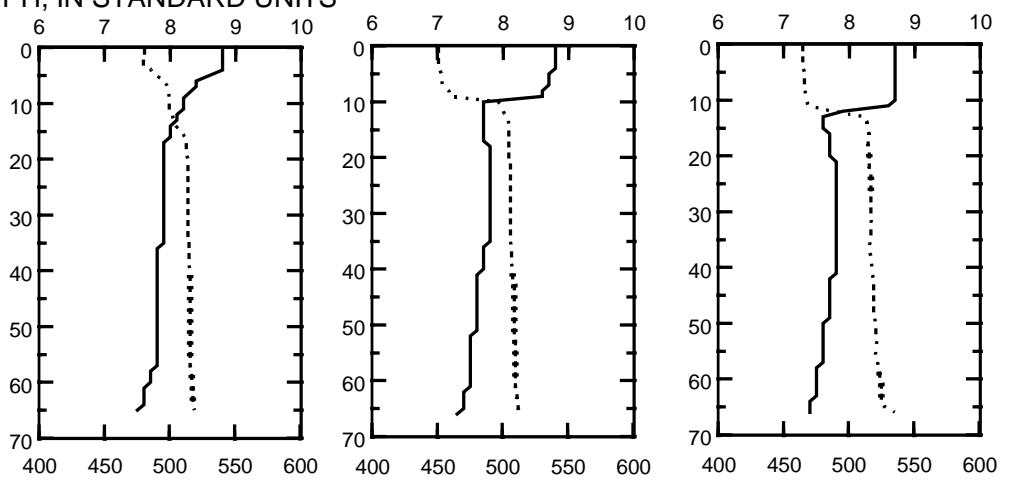

SPECIFIC CONDUCTANCE (S.C.), IN MICROSIEMENS PER CENTIMETER AT 25 DEGREES CELSIUS 

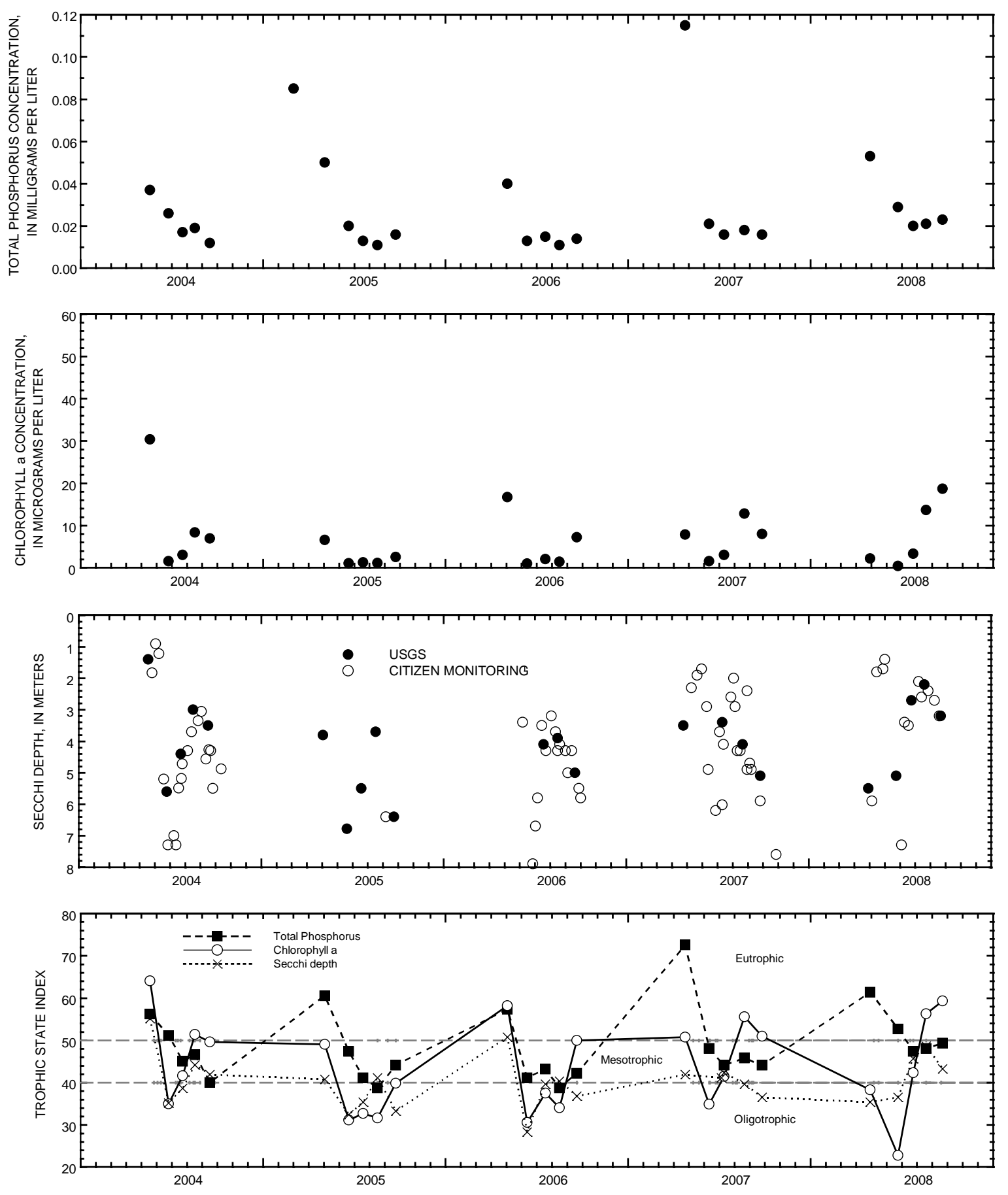

Surface total phosphorus, chlorophyll a concentrations, Secchi depths, and TSI data for Green Lake, Deep Hole, near Green Lake, Wisconsin. 


\section{GREEN LAKE AT EAST END NEAR GREEN LAKE, WI}

LOCATION.--Lat 4349'28", long $88^{\circ} 57^{\prime} 00^{\prime \prime}$, in SE 1/4 SE 1/4 Sec.28, T.16 N., R.13 E., Green Lake County, Hydrologic Unit 04030201, about one mile southeast of the City of Green Lake.

SURFACE AREA.--11.48 $\mathrm{mi}^{2}$.

PERIOD OF RECORD.--May 2004 current year. Lake sampled by Wisconsin Department of Natural Resources prior to 2004.

REMARKS.--Water-quality analyses done by Wisconsin State Laboratory of Hygiene. A "*” indicates data that were collected by Mary Jane Bumby, Citizen Lake Monitoring Volunteer.

WATER-QUALITY DATA, OCTOBER 27, 2007 TO AUGUST 19, 2008

(Milligrams per liter unless otherwise indicated)

Date

00078 Secchi-depth $(\mathrm{m})$

00098 Sampling depth $(\mathrm{m})$

00010 Water Temperature $\left({ }^{\circ} \mathrm{C}\right)$

$00400 \mathrm{pH}$ (standard units)

00095 Specific conductance $(\mu \mathrm{S} / \mathrm{cm})$

00300 Dissolved oxygen

32210 Chlorophyll a, phytoplankton ( $\mu \mathrm{g} / \mathrm{L})$

00665 Phosphorus, Total (as P)

Date

00078 Secchi-depth $(\mathrm{m})$

00098 Sampling depth $(\mathrm{m})$

00010 Water Temperature $\left({ }^{\circ} \mathrm{C}\right)$

$00400 \mathrm{pH}$ (standard units)

00095 Specific conductance $(\mu \mathrm{S} / \mathrm{cm})$

00300 Dissolved oxygen

32210 Chlorophyll a, phytoplankton ( $\mu \mathrm{g} / \mathrm{L}$ )

00665 Phosphorus, Total (as P)

\begin{tabular}{ccccc} 
Oct. $27^{*}$ & & \multicolumn{3}{c}{ Apr. 29 } \\
\cline { 1 - 1 } 5.5 & & \multicolumn{3}{c}{4.0} \\
-- & & 0.5 & & 33 \\
12.8 & & 5.0 & 4.0 \\
-- & & 7.8 & 8.2 \\
-- & & 512 & 514 \\
-- & & 15.0 & 14.3 \\
-- & & 2.48 & \\
-- & & 0.051 & 0.052
\end{tabular}

\begin{tabular}{|c|c|}
\hline May 6* & May $15^{*}$ \\
\hline 4.9 & 1.7 \\
\hline 0.1 & 0.1 \\
\hline 9.4 & 10 \\
\hline -- & -- \\
\hline -- & -- \\
\hline-- & -- \\
\hline -- & -- \\
\hline-- & -- \\
\hline
\end{tabular}

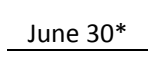

July $4 *$

July $10^{*}$

July $18^{*}$

0.1

0.1
21.7

0.1
23.3

23.3

$$
24 .
$$

0.1

\begin{tabular}{cc}
\multicolumn{3}{c}{ July 24 } \\
\hline \multicolumn{3}{c}{2.3} \\
0.5 & 33 \\
25.4 & 5.9 \\
8.9 & 7.8 \\
487 & 516 \\
12.1 & 9.1 \\
7.82 & -- \\
0.020 & 0.075
\end{tabular}

\begin{tabular}{c} 
May $28^{*}$ \\
\hline 1.8 \\
0.1 \\
13.3 \\
-- \\
-- \\
-- \\
-- \\
--
\end{tabular}

\begin{tabular}{c} 
June $1^{*}$ \\
\hline 1.4 \\
0.1 \\
17.8 \\
-- \\
-- \\
-- \\
-- \\
--
\end{tabular}

\begin{tabular}{cc}
\multicolumn{3}{c}{ June 24} \\
\hline \multicolumn{3}{c}{3.7} \\
0.5 & 33 \\
22 & 5.2 \\
8.8 & 7.8 \\
472 & 518 \\
10.8 & 10.0 \\
0.64 & -- \\
0.054 & 0.093
\end{tabular}

\begin{tabular}{c} 
Aug. 8* $^{*}$ \\
\hline 1.2 \\
0.1 \\
25.6 \\
-- \\
-- \\
-- \\
-- \\
--
\end{tabular}

\begin{tabular}{ccc} 
& Aug. 19 \\
\hline & 1.6 & \\
0.5 & 16 & 33 \\
24.4 & 13.5 & 5.7 \\
8.9 & 7.6 & 7.6 \\
447 & 501 & 509 \\
11.3 & 1.9 & 7.0 \\
25.2 & -- & -- \\
0.029 & 0.021 & 0.075
\end{tabular}


434928088570000 GREEN LAKE AT EAST END NEAR GREEN LAKE, WI

WATER-QUALITY DATA, AUGUST 27 TO SEPTEMBER 25, 2008

(Milligrams per liter unless otherwise indicated)

Date

00078 Secchi-depth $(\mathrm{m})$

00098 Sampling depth $(\mathrm{m})$

00010 Water Temperature $\left({ }^{\circ} \mathrm{C}\right)$

$00400 \mathrm{pH}$ (standard units)

00095 Specific conductance $(\mu \mathrm{S} / \mathrm{cm})$

00300 Dissolved oxygen

32210 Chlorophyll a, phytoplankton $(\mu \mathrm{g} / \mathrm{L})$

00665 Phosphorus, Total (as P)
Aug. $27^{*}$

2.4

0.1

22.8

Aug. 30*

2.3

2.0

Sept. 9*

\section{1}

21.1

$-$

$-$

$-$

$-$
Sept. 19*

3.0

0.1

21.1

--

$-$

$-$

$-$
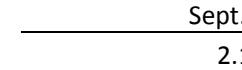

$0.5 \quad 1$

$19.7 \quad 10$

$\begin{array}{ll}8.7 & 7.6\end{array}$

$469 \quad 516$

$10.3 \quad 2.3$

0.032

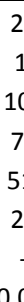

Sept. 25*

3.4

0.1

21.1 
434928088570000 GREEN LAKE AT EAST END NEAR GREEN LAKE, WI

LAKE-DEPTH PROFILES, APRIL 29 TO SEPTEMBER 22, 2008

04-29-08
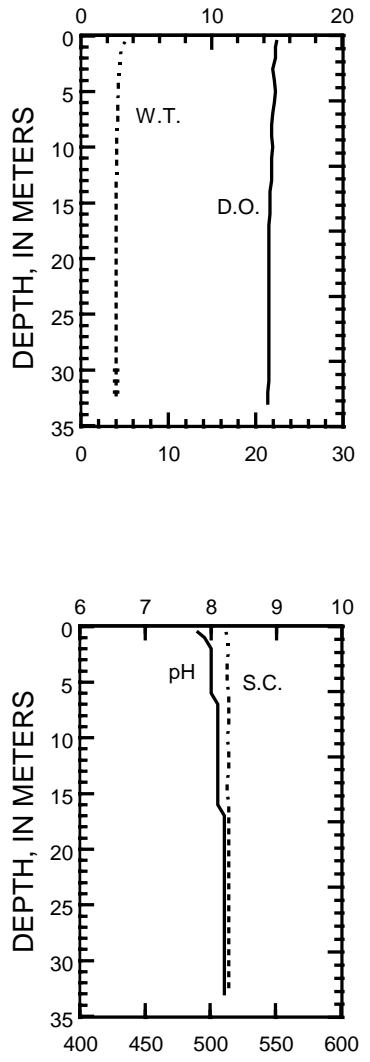

06-24-08

DISSOLVED

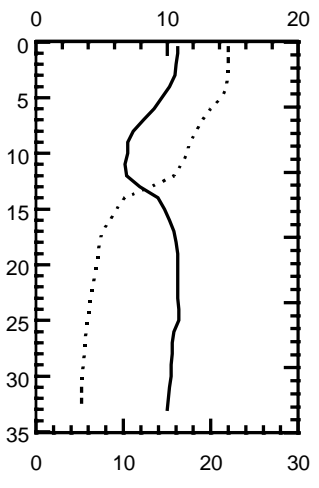

WATER TEMP

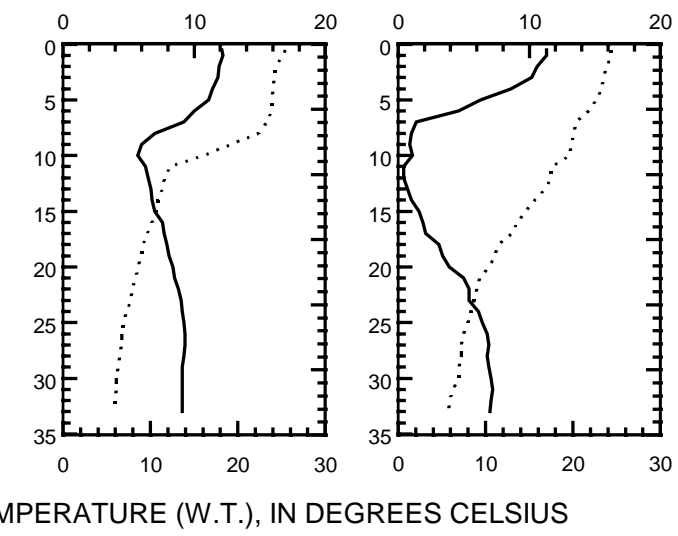

07-24-08

08-19-08

09-22-08

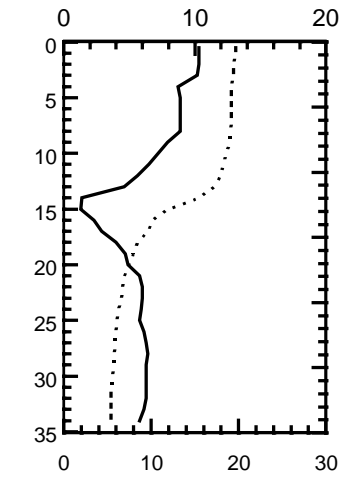

$\mathrm{PH}$, IN STANDARD UNITS
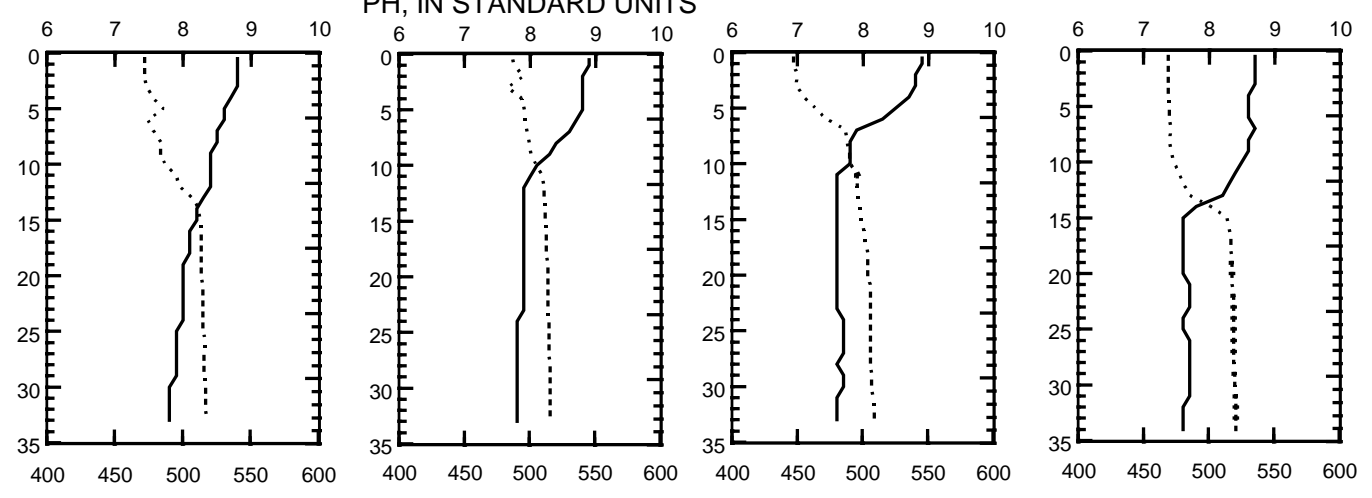

SPECIFIC CONDUCTANCE (S.C.), IN MICROSIEMENS PER CENTIMETER AT 25 DEGREES CELSIUS 

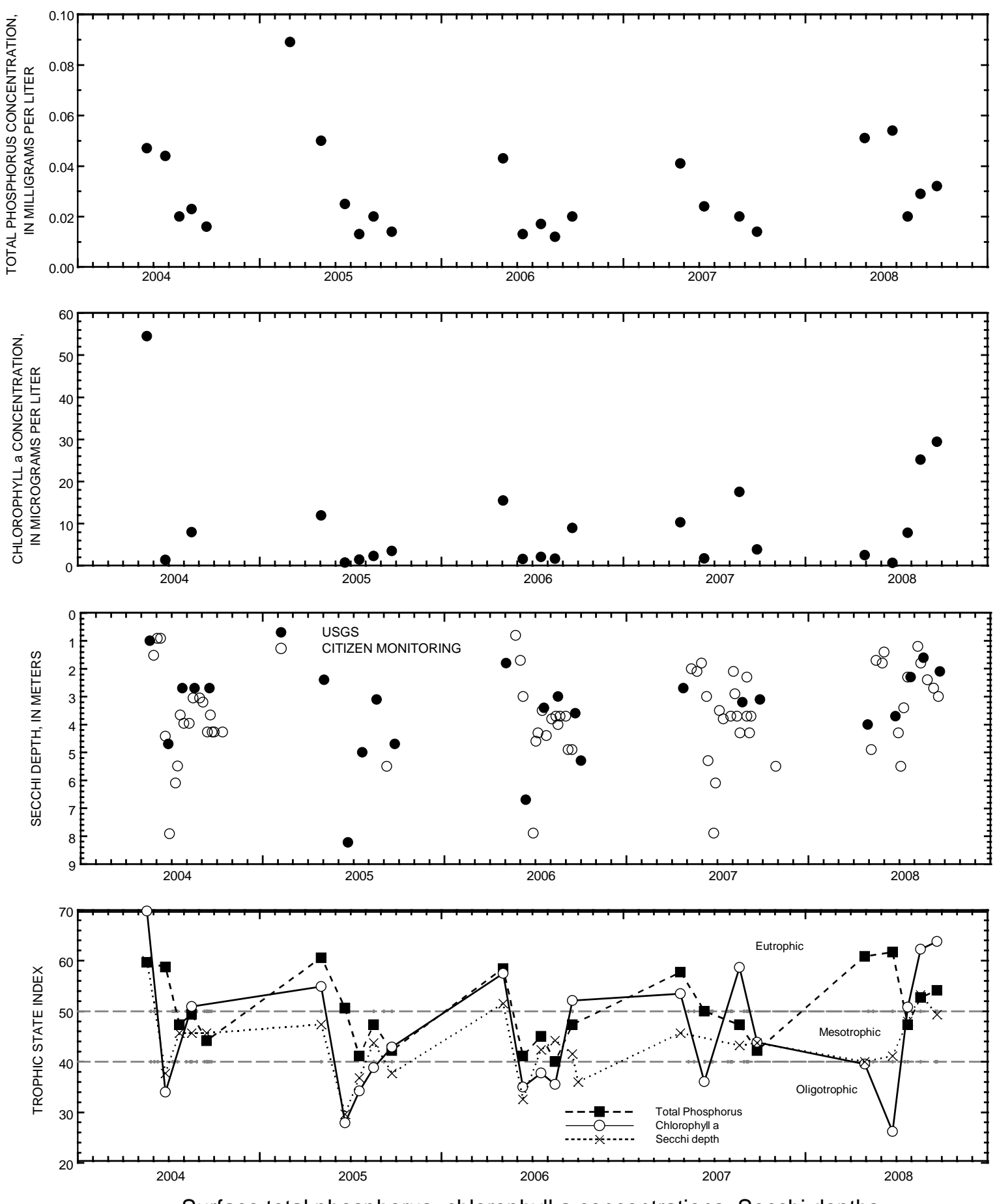

Surface total phosphorus, chlorophyll a concentrations, Secchi depths, and TSI data for Green Lake, East End, near Green Lake, Wisconsin. 


\section{GREEN LAKE INLET, SITE 1, NEAR GREEN LAKE, WI}

LOCATION.--Lat 4350'09", long 8855'01", in NE 1/4 NW 1/4 sec.26, T.16 N., R.13 E., Green Lake County, Hydrologic Unit 04030201.

PERIOD OF RECORD.--May 2006 to current year.

REMARKS.--Water-quality analyses done by Wisconsin State Laboratory of Hygiene.

WATER-QUALITY DATA, APRIL 29, 2007 TO SEPTEMBER 22, 2008

(Milligrams per liter unless otherwise indicated)

Date

0078 Secchi-depth $(\mathrm{m})$

00098 Sampling depth $(\mathrm{m})$

00010 Water Temperature $\left({ }^{\circ} \mathrm{C}\right)$

$00400 \mathrm{pH}$ (standard units)

00095 Specific conductance $(\mu \mathrm{S} / \mathrm{cm})$

0300 Dissolved oxygen

00665 Phosphorus, Total (as P)

\begin{tabular}{c} 
Apr. 29 \\
\hline 1.0 \\
0.5 \\
9.7 \\
8.0 \\
675 \\
16.7 \\
0.083
\end{tabular}

\begin{tabular}{cccc} 
June 24 & & July 24 \\
\cline { 1 - 1 } 1.0 & & 1.0 \\
0.5 & & 0.5 \\
22.2 & & 22.9 \\
7.6 & & 7.8 \\
576 & & 663 \\
6.1 & & 7.3 \\
0.24 & & 0.245
\end{tabular}

Aug. 19

Sept. 22

$0.5 \quad 0.5$

$24.9 \quad 21.7$

$8.1 \quad 8.2$

$857-948$

$9.1 \quad 12$

$0.143 \quad 0.084$ 


\section{GREEN LAKE INLET, SITE 2, NEAR GREEN LAKE, WI}

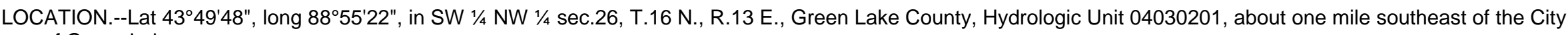
of Green Lake.

PERIOD OF RECORD.--May 2006 to current year.

REMARKS.--Water-quality analyses done by Wisconsin State Laboratory of Hygiene.

WATER-QUALITY DATA APRIL 29 TO SEPTEMBER 22, 2008

(Milligrams per liter unless otherwise indicated)

\section{Date}

00078 Secchi-depth $(\mathrm{m})$

00098 Sampling depth (m)

00010 Water Temperature $\left({ }^{\circ} \mathrm{C}\right)$

$00400 \mathrm{pH}$ (standard units)

00095 Specific conductance $(\mu \mathrm{S} / \mathrm{cm})$

00300 Dissolved oxygen

00665 Phosphorus, Total (as P)

\begin{tabular}{c} 
Apr. 29 \\
\hline 0.8 \\
0.5 \\
10.3 \\
8.0 \\
666 \\
13.3 \\
0.076
\end{tabular}

\begin{tabular}{cccc} 
June 24 & & July 24 \\
\cline { 1 - 1 } 0.9 & & 0.8 \\
0.5 & & 0.5 \\
21.7 & & 23.9 \\
7.6 & & 7.8 \\
541 & & 660 \\
6.5 & & 6.9 \\
0.23 & & 0.252
\end{tabular}

\begin{tabular}{cccc} 
Aug. 19 & & Sept. 22 \\
\cline { 1 - 1 } 1.0 & & 1.0 \\
0.5 & & 0.5 \\
24.4 & & 21.4 \\
8.2 & & 8.1 \\
824 & & 890 \\
10.2 & & 10.5 \\
0.142 & & 0.064
\end{tabular}




\section{LAKE KEGONSA AT BARBER DRIVE NEAR STOUGHTON, WI}

LOCATION.--Lat 4257'15", long 89¹6'47" referenced to North American Datum of 1927, in SW 1/4 NE 1/4 NE 1/4 Sec.26, T.6 N., R.10 E.,

Dane County, WI, Hydrologic Unit 07090001, on downstream side of bridge on Barber Drive, 3.5 mi northwest of Stoughton.

SURFACE AREA.--1.05 $\mathrm{mi}^{2}$.

DRAINAGE AREA.--386 $\mathrm{mi}^{2}$.

PERIOD OF RECORD.--October 2003 to current year.

GAGE.--Water-stage recorder. Datum of gage is $840.00 \mathrm{ft}$ above sea level (levels from Wisconsin Department of Transportation benchmark).

EXTREMES FOR PERIOD OF RECORD.--Maximum gage height observed, $5.73 \mathrm{ft}$, June 16, 2008; minimum observed, $2.07 \mathrm{ft}$, Jan.27, 2006.

EXTREMES FOR CURRENT YEAR.--Maximum gage height observed,5.73ft,June 16; minimum observed, $2.74 \mathrm{ft}$, Nov. 29.

GAGE HEIGHT, FEET

WATER YEAR OCTOBER 2007 TO SEPTEMBER 2008

DAILY MEAN VALUES

\begin{tabular}{|c|c|c|c|c|c|c|c|c|c|c|c|c|}
\hline Day & Oct & Nov & Dec & Jan & Feb & Mar & Apr & May & Jun & Jul & Aug & Sep \\
\hline 1 & 3.53 & 3.10 & 2.90 & 3.28 & 2.96 & 3.00 & 3.43 & 4.41 & 3.57 & 4.77 & 3.89 & 3.04 \\
\hline 2 & 3.54 & 3.07 & 2.98 & 3.21 & 2.96 & 2.99 & 3.44 & 4.37 & 3.56 & 4.71 & 3.82 & 3.06 \\
\hline 3 & 3.55 & 3.05 & 2.99 & 3.19 & 2.96 & 3.04 & 3.45 & 4.33 & 3.56 & 4.66 & 3.75 & 3.08 \\
\hline 4 & 3.54 & 3.03 & 2.99 & 3.16 & 2.97 & 3.08 & 3.45 & 4.27 & 3.53 & 4.59 & 3.75 & 3.15 \\
\hline 5 & 3.52 & 2.99 & 3.00 & 3.13 & 2.99 & 3.12 & 3.44 & 4.22 & 3.63 & 4.53 & 3.72 & 3.21 \\
\hline 6 & 3.50 & 2.98 & 3.02 & 3.11 & 3.03 & 3.15 & 3.43 & 4.17 & 3.71 & 4.45 & 3.65 & 3.22 \\
\hline 7 & 3.48 & 2.97 & 3.06 & 3.14 & 3.03 & 3.16 & 3.41 & 4.14 & 3.78 & 4.41 & 3.58 & 3.21 \\
\hline 8 & 3.45 & 2.96 & 3.08 & 3.23 & 3.05 & 3.15 & 3.44 & 4.10 & 3.97 & 4.41 & 3.52 & 3.21 \\
\hline 9 & 3.40 & 2.95 & 3.10 & 3.34 & 3.06 & 3.15 & 3.53 & 4.06 & 4.31 & 4.38 & 3.46 & 3.21 \\
\hline 10 & 3.34 & 2.94 & 3.11 & 3.42 & 3.04 & 3.14 & 3.66 & 4.02 & 4.52 & 4.36 & 3.40 & 3.19 \\
\hline 11 & 3.30 & 2.93 & 3.15 & 3.49 & 3.04 & 3.13 & 3.82 & 4.00 & 4.71 & 4.53 & 3.32 & 3.17 \\
\hline 12 & 3.26 & 2.93 & 3.18 & 3.52 & 3.02 & 3.11 & 3.95 & 3.98 & 4.93 & 4.64 & 3.26 & 3.16 \\
\hline 13 & 3.23 & 2.91 & 3.19 & 3.54 & 3.01 & 3.12 & 4.02 & 3.93 & 5.40 & 4.67 & 3.22 & 3.25 \\
\hline 14 & 3.23 & 2.89 & 3.18 & 3.53 & 3.00 & 3.16 & 4.07 & 3.91 & 5.57 & 4.69 & 3.19 & 3.31 \\
\hline 15 & 3.23 & 2.88 & 3.18 & 3.49 & 2.98 & 3.24 & 4.08 & 3.87 & 5.69 & 4.68 & 3.14 & 3.33 \\
\hline 16 & 3.25 & 2.87 & 3.19 & 3.46 & 2.97 & 3.31 & 4.07 & 3.83 & 5.72 & 4.68 & 3.08 & 3.31 \\
\hline 17 & 3.25 & 2.87 & 3.19 & 3.43 & 3.03 & 3.36 & 4.08 & 3.80 & 5.69 & 4.66 & 3.03 & 3.30 \\
\hline 18 & 3.32 & 2.86 & 3.18 & 3.38 & 3.08 & 3.38 & 4.09 & 3.77 & 5.64 & 4.63 & 3.00 & 3.28 \\
\hline 19 & 3.32 & 2.85 & 3.17 & 3.34 & 3.09 & 3.38 & 4.13 & 3.74 & 5.58 & 4.60 & 2.97 & 3.24 \\
\hline 20 & 3.33 & 2.86 & 3.16 & 3.30 & 3.11 & 3.38 & 4.13 & 3.71 & 5.50 & 4.58 & 2.95 & 3.20 \\
\hline 21 & 3.33 & 2.87 & 3.16 & 3.27 & 3.11 & 3.42 & 4.12 & 3.68 & 5.42 & 4.54 & 2.92 & 3.17 \\
\hline 22 & 3.34 & 2.86 & 3.17 & 3.24 & 3.10 & 3.43 & 4.10 & 3.66 & 5.35 & 4.49 & 2.92 & 3.14 \\
\hline 23 & 3.32 & 2.85 & 3.26 & 3.20 & 3.09 & 3.41 & 4.09 & 3.63 & 5.28 & 4.43 & 2.91 & 3.10 \\
\hline 24 & 3.31 & 2.83 & 3.26 & 3.16 & 3.08 & 3.38 & 4.07 & 3.60 & 5.21 & 4.36 & 2.90 & 3.07 \\
\hline 25 & 3.29 & 2.82 & 3.29 & 3.12 & 3.07 & 3.35 & 4.23 & 3.57 & 5.15 & 4.29 & 2.89 & 3.05 \\
\hline 26 & 3.26 & 2.82 & 3.31 & 3.09 & 3.06 & 3.35 & 4.32 & 3.62 & 5.09 & 4.24 & 2.87 & 3.03 \\
\hline 27 & 3.24 & 2.81 & 3.33 & 3.05 & 3.04 & 3.39 & 4.41 & 3.61 & 5.03 & 4.18 & 2.86 & 3.03 \\
\hline 28 & 3.22 & 2.79 & 3.34 & 3.01 & 3.02 & 3.40 & 4.46 & 3.55 & 4.96 & 4.13 & 2.89 & 3.03 \\
\hline 29 & 3.19 & 2.79 & 3.35 & 2.99 & 3.02 & 3.38 & 4.47 & 3.52 & 4.89 & 4.06 & 2.94 & 3.02 \\
\hline 30 & 3.16 & 2.85 & 3.33 & 2.98 & --- & 3.35 & 4.44 & 3.55 & 4.83 & 4.00 & 2.97 & 3.01 \\
\hline 31 & 3.12 & --- & 3.31 & 2.97 & --- & 3.39 & --- & 3.56 & --- & 3.95 & 3.01 & --- \\
\hline Mean & 3.33 & 2.91 & 3.16 & 3.25 & 3.03 & 3.25 & 3.93 & 3.88 & 4.79 & 4.46 & 3.22 & 3.16 \\
\hline Max & 3.55 & 3.10 & 3.35 & 3.54 & 3.11 & 3.43 & 4.47 & 4.41 & 5.72 & 4.77 & 3.89 & 3.33 \\
\hline Min & 3.12 & 2.79 & 2.90 & 2.97 & 2.96 & 2.99 & 3.41 & 3.52 & 3.53 & 3.95 & 2.86 & 3.01 \\
\hline
\end{tabular}




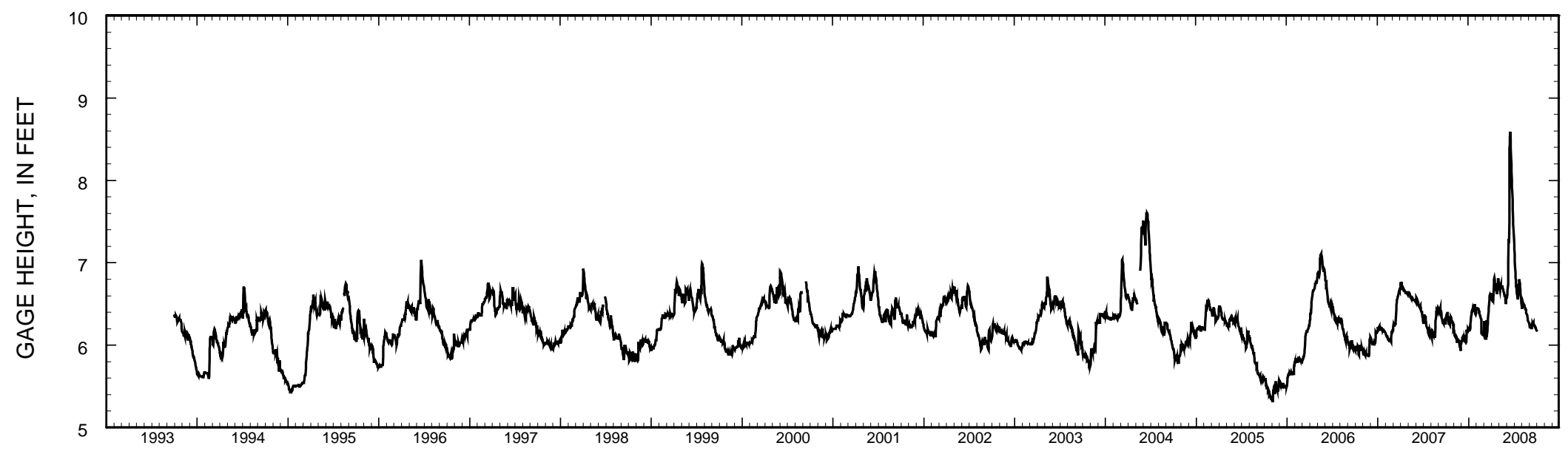

Stage hydrograph for Lake Kegonsa, 1993-2008. 


\section{LAKE KOSHKONONG NEAR NEWVILLE, WI}

LOCATION.--Lat 4251'27", long 8856'27" referenced to North American Datum of 1927, in NW 1/4 NE $1 / 4$ sec.34, T.5 N., R.13 E., Jefferson County, WI, Hydrologic Unit 07090001, $80 \mathrm{ft}$ east of Pottawatomi Trail Bridge at Bingham Point Estates, and $4.5 \mathrm{mi}$ northeast of Newville.

SURFACE AREA.-16.34 $\mathrm{mi}^{2}$

DRAINAGE AREA.--2,560 $\mathrm{mi}^{2}$.

PERIOD OF RECORD.--July 1987 to current year.

GAGE.--Water-stage recorder. Datum of gage is $770.00 \mathrm{ft}$ above NGVD of 1929 (Wisconsin Department of Transportation bench mark).

REMARKS.--Lake level regulated by dam at Indianford. Gage-height telemeter at station.

EXTREMES FOR PERIOD OF RECORD.--Maximum recorded gage height, $15.13 \mathrm{ft}$, June 21, 22, 2008; minimum recorded, $5.06 \mathrm{ft}$, Feb. 22, 2007.

EXTREMES FOR CURRENT YEAR.--Maximum recorded gage height, $15.13 \mathrm{ft}$, June 21, 22; minimum recorded gage height, $6.00 \mathrm{ft}$, Nov. 25

GAGE HEIGHT, FEET

WATER YEAR OCTOBER 2007 TO SEPTEMBER 2008

DAILY MEAN VALUES

\begin{tabular}{|c|c|c|c|c|c|c|c|c|c|c|c|c|}
\hline Day & Oct & Nov & Dec & Jan & Feb & Mar & Apr & May & Jun & Jul & Aug & Sep \\
\hline 1 & 6.51 & 6.56 & 6.08 & 7.27 & 8.30 & 7.70 & 10.67 & 11.13 & 6.92 & 13.66 & 8.05 & 6.10 \\
\hline 2 & 6.47 & 6.52 & 6.15 & 7.25 & 8.21 & 7.67 & 10.73 & 11.05 & 6.87 & 13.42 & 7.81 & 6.11 \\
\hline 3 & 6.50 & 6.50 & 6.16 & 7.22 & 8.13 & 7.73 & 10.79 & 10.97 & 6.80 & 13.18 & 7.58 & 6.12 \\
\hline 4 & 6.49 & 6.44 & 6.19 & 7.17 & 8.06 & 7.83 & 10.85 & 10.85 & 6.74 & 12.93 & 7.47 & 6.14 \\
\hline 5 & 6.49 & 6.46 & 6.23 & 7.14 & 8.00 & 7.96 & 10.85 & 10.73 & 6.88 & 12.67 & 7.36 & 6.24 \\
\hline 6 & 6.50 & 6.42 & 6.24 & 7.13 & 7.99 & 8.08 & 10.83 & 10.60 & 7.10 & 12.40 & 7.21 & 6.26 \\
\hline 7 & 6.51 & 6.31 & 6.25 & 7.21 & 7.93 & 8.19 & 10.79 & 10.48 & 7.30 & 12.16 & 7.07 & 6.28 \\
\hline 8 & 6.51 & 6.27 & 6.26 & 7.45 & 7.85 & 8.28 & 10.77 & 10.34 & 7.81 & 12.04 & 6.93 & 6.31 \\
\hline 9 & 6.53 & 6.25 & 6.26 & 7.84 & 7.79 & 8.32 & 10.80 & 10.19 & 8.91 & 11.85 & 6.82 & 6.30 \\
\hline 10 & 6.50 & 6.20 & 6.26 & 8.24 & 7.77 & 8.34 & 10.83 & 10.03 & 10.03 & 11.65 & 6.72 & 6.27 \\
\hline 11 & 6.39 & 6.17 & 6.31 & 8.59 & 7.74 & 8.33 & 11.05 & 9.93 & 10.95 & 11.61 & 6.63 & 6.23 \\
\hline 12 & 6.30 & 6.17 & 6.32 & 8.85 & 7.70 & 8.31 & 11.30 & 9.76 & 11.71 & 11.80 & 6.56 & 6.22 \\
\hline 13 & 6.26 & 6.14 & 6.32 & 9.05 & 7.66 & 8.32 & 11.47 & 9.58 & 12.53 & 11.91 & 6.51 & 6.32 \\
\hline 14 & 6.30 & 6.18 & 6.31 & 9.19 & 7.62 & 8.42 & 11.56 & 9.46 & 13.19 & 11.92 & 6.46 & 6.44 \\
\hline 15 & 6.33 & 6.15 & 6.30 & 9.17 & 7.57 & 8.57 & 11.60 & 9.29 & 13.74 & 11.85 & 6.40 & 6.47 \\
\hline 16 & 6.37 & 6.08 & 6.31 & 9.13 & 7.54 & 8.77 & 11.61 & 9.11 & 14.16 & 11.73 & 6.34 & 6.39 \\
\hline 17 & 6.35 & 6.07 & 6.31 & 9.19 & 7.57 & 8.98 & 11.62 & 8.95 & 14.48 & 11.57 & 6.25 & 6.33 \\
\hline 18 & 6.34 & 6.05 & 6.31 & 9.15 & 7.61 & 9.17 & 11.58 & 8.77 & 14.72 & 11.38 & 6.25 & 6.29 \\
\hline 19 & 6.43 & 6.05 & 6.31 & 9.04 & 7.66 & 9.35 & 11.53 & 8.57 & 14.91 & 11.17 & 6.24 & 6.32 \\
\hline 20 & 6.47 & 6.05 & 6.31 & 8.94 & 7.71 & 9.52 & 11.46 & 8.38 & 15.03 & 10.96 & 6.22 & 6.29 \\
\hline 21 & 6.52 & 6.09 & 6.31 & 8.87 & 7.74 & 9.71 & 11.39 & 8.17 & 15.09 & 10.73 & 6.21 & 6.20 \\
\hline 22 & 6.60 & 6.07 & 6.32 & 8.79 & 7.77 & 9.86 & 11.25 & 7.96 & 15.09 & 10.49 & 6.20 & 6.19 \\
\hline 23 & 6.63 & 6.05 & 6.49 & 8.69 & 7.79 & 9.97 & 11.12 & 7.78 & 15.04 & 10.23 & 6.21 & 6.24 \\
\hline 24 & 6.66 & 6.04 & 6.64 & 8.61 & 7.80 & 10.05 & 10.98 & 7.59 & 14.94 & 9.97 & 6.20 & 6.29 \\
\hline 25 & 6.65 & 6.05 & 6.77 & 8.56 & 7.80 & 10.12 & 11.01 & 7.43 & 14.82 & 9.72 & 6.16 & 6.31 \\
\hline 26 & 6.67 & 6.07 & 6.88 & 8.51 & 7.78 & 10.20 & 11.10 & 7.38 & 14.68 & 9.48 & 6.12 & 6.31 \\
\hline 27 & 6.69 & 6.08 & 7.00 & 8.44 & 7.75 & 10.30 & 11.20 & 7.25 & 14.51 & 9.23 & 6.09 & 6.32 \\
\hline 28 & 6.65 & 6.06 & 7.11 & 8.37 & 7.74 & 10.39 & 11.25 & 7.12 & 14.32 & 9.00 & 6.10 & 6.29 \\
\hline 29 & 6.64 & 6.06 & 7.20 & 8.32 & 7.72 & 10.46 & 11.25 & 7.02 & 14.12 & 8.76 & 6.14 & 6.27 \\
\hline 30 & 6.60 & 6.04 & 7.24 & 8.36 & --- & 10.49 & 11.20 & 7.02 & 13.90 & 8.54 & 6.13 & 6.27 \\
\hline 31 & 6.60 & --- & 7.26 & 8.36 & --- & 10.58 & --- & 7.00 & --- & 8.30 & 6.12 & --- \\
\hline Mean & 6.50 & 6.19 & 6.46 & 8.33 & 7.80 & 9.03 & 11.15 & 9.03 & 11.91 & 11.17 & 6.60 & 6.27 \\
\hline Max & 6.69 & 6.56 & 7.26 & 9.19 & 8.30 & 10.58 & 11.62 & 11.13 & 15.09 & 13.66 & 8.05 & 6.47 \\
\hline Min & 6.26 & 6.04 & 6.08 & 7.13 & 7.54 & 7.67 & 10.67 & 7.00 & 6.74 & 8.30 & 6.09 & 6.10 \\
\hline
\end{tabular}




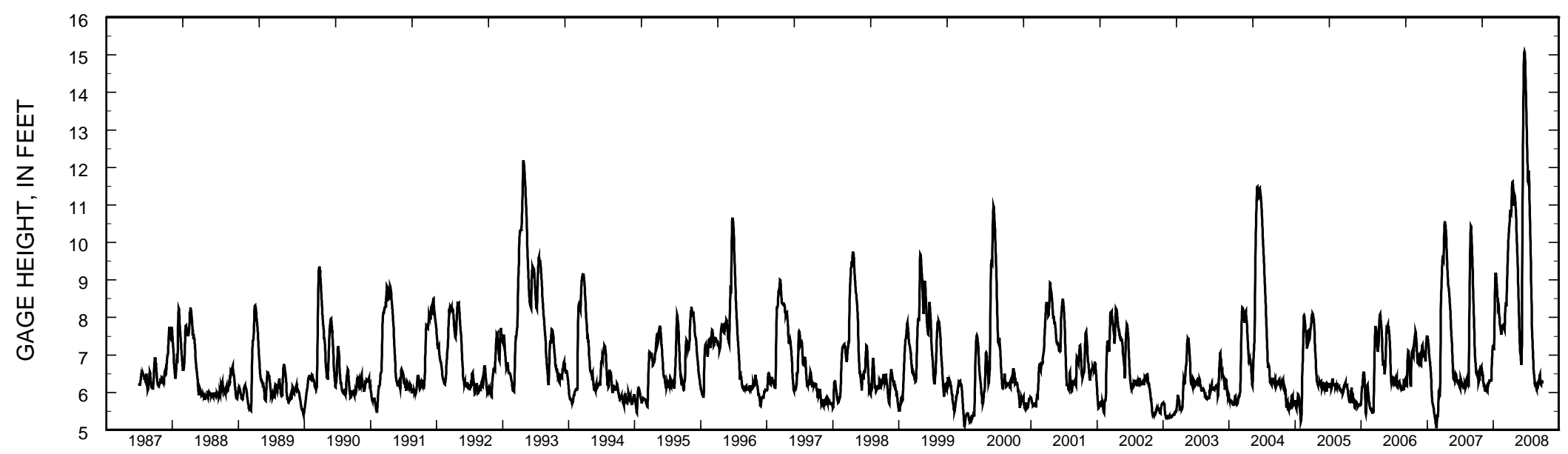

Stage hydrograph for Lake Koshkonong, 1987-2008. 


\section{LITTLE CEDAR LAKE, NORTH SITE, NEAR WEST BEND, WI}

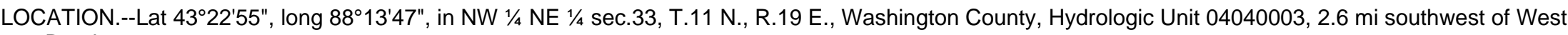
Bend.

SURFACE AREA.--0.38 $\mathrm{mi}^{2}$.

PERIOD OF RECORD.--February 1997 to August 1999, February 2003 to current year.

REMARKS.--Lake sampled at center of northern basin at deep hole. Lake ice-covered during February sampling. Water-quality analyses done by Wisconsin State Laboratory of Hygiene.

Date

00078 Secchi-depth $(m)$

00098 Sampling depth $(\mathrm{m})$

00010 Water Temperature $\left({ }^{\circ} \mathrm{C}\right.$

$00400 \mathrm{pH}$ (standard units)

00095 Specific conductance $(\mu \mathrm{S} / \mathrm{cm})$

00300 Dissolved oxygen

32210 Chlorophyll a, phytoplankton $(\mu \mathrm{g} / \mathrm{L})$

00665 Phosphorus, Total (as P)
WATER-QUALITY DATA, FEBRUARY 29 TO AUGUST 27, 2008

(Milligrams per liter unless otherwise indicated)

\begin{tabular}{cc}
\multicolumn{3}{c}{ Feb. 29 } \\
\hline \multicolumn{2}{c}{--} \\
0.5 & \\
0.2 & 6.5 \\
7.5 & 4.2 \\
580 & 7.3 \\
16.8 & 637 \\
-- & 2.2 \\
0.011 & -- \\
& 0.029
\end{tabular}

\begin{tabular}{cc}
\multicolumn{3}{c}{ Jun. 26 } \\
\hline \multicolumn{3}{c}{2.6} \\
0.5 & 7.0 \\
24.4 & 13.1 \\
8.3 & 7.4 \\
544 & 582 \\
9.3 & 0.6 \\
3.3 & -- \\
0.020 & 0.101
\end{tabular}

\begin{tabular}{cc}
\multicolumn{3}{c}{ Jul. 22 } \\
\hline \multicolumn{3}{c}{3.2} \\
0.5 & 7.0 \\
25.6 & 13.9 \\
8.3 & 7.4 \\
546 & 585 \\
7.1 & 0.6 \\
5.8 & -- \\
0.020 & 0.089
\end{tabular}

\begin{tabular}{|c|c|}
\hline \multicolumn{2}{|c|}{ Aug. 27} \\
\hline \multicolumn{2}{|c|}{3.6} \\
\hline 0.5 & 7.0 \\
\hline 24 & 14.3 \\
\hline 8.2 & 7.0 \\
\hline 549 & 600 \\
\hline 8.0 & 0.9 \\
\hline 4.7 & -- \\
\hline 0.016 & 0.075 \\
\hline
\end{tabular}




\section{LITTLE CEDAR LAKE, NORTH SITE, NEAR WEST BEND, WI}

LAKE-DEPTH PROFILES, FEBRUARY 29 TO AUGUST 27, 2008

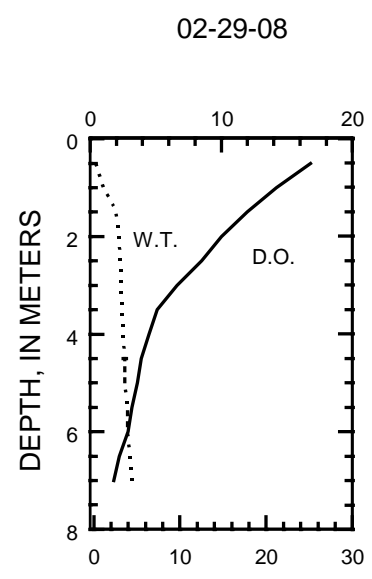

04-24-08

06-26-08

07-22-08

08-27-08

DISSOLVED OXYGEN (D.O.), IN MILLIGRAMS PER LITER
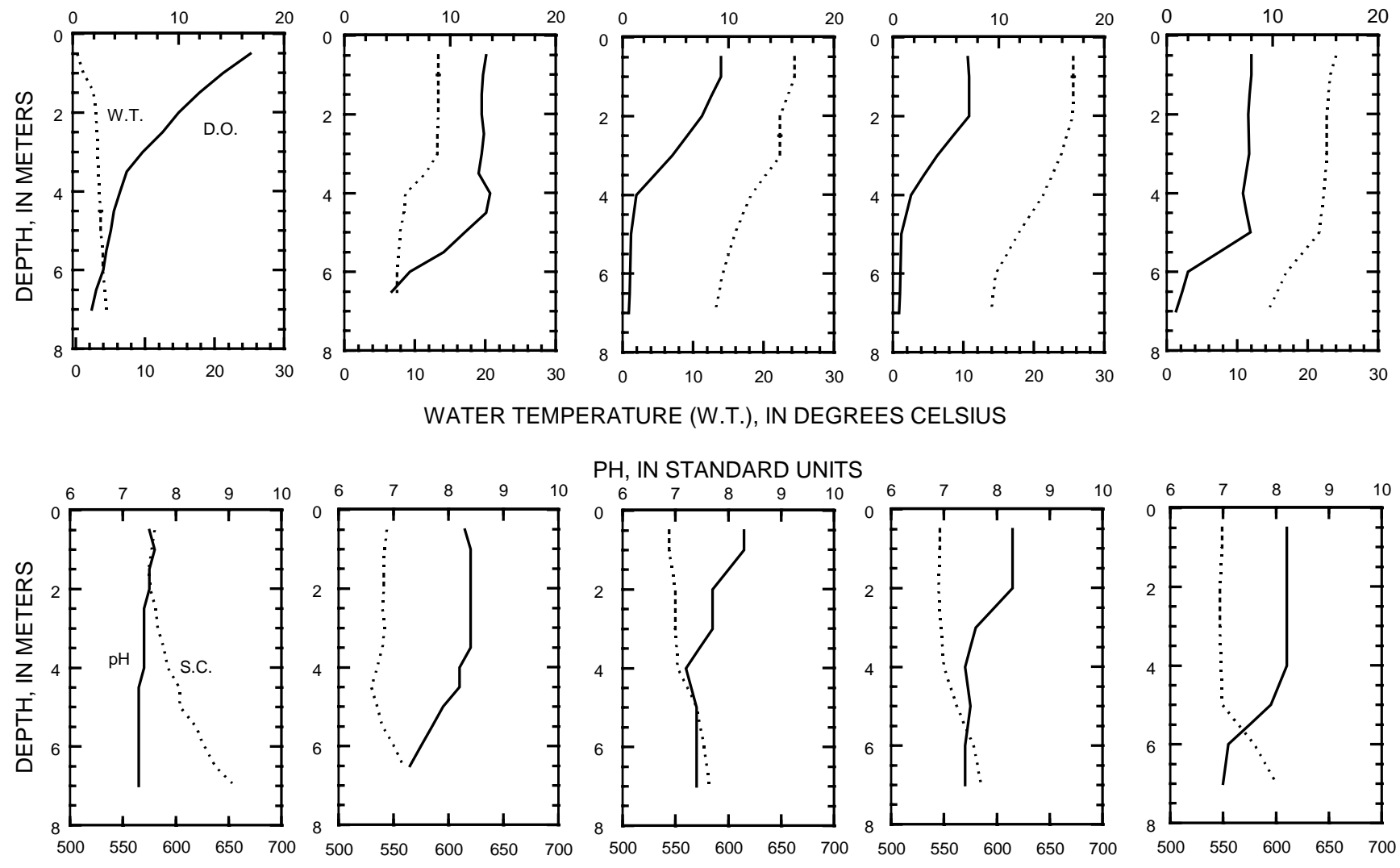

$\mathrm{PH}$, IN STANDARD UNITS
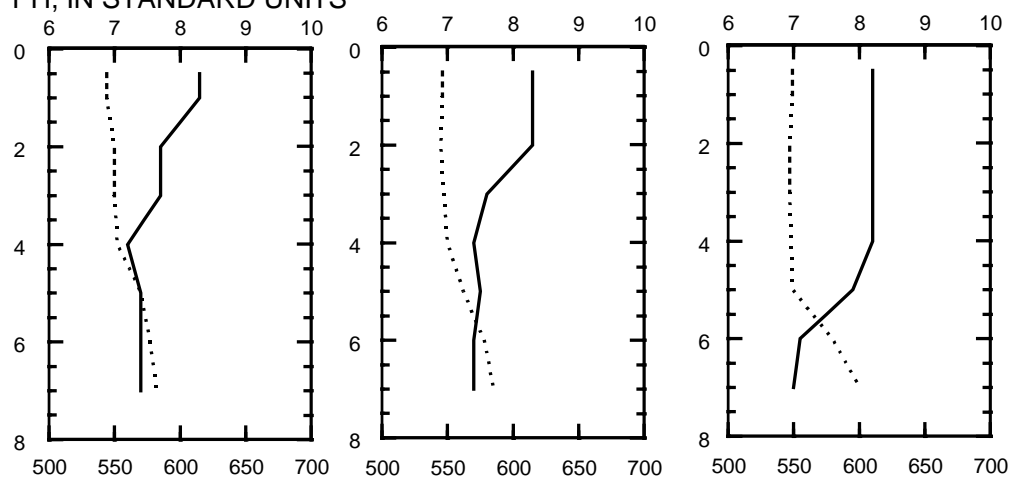

SPECIFIC CONDUCTANCE (S.C.), IN MICROSIEMENS PER CENTIMETER AT 25 DEGREES CELSIUS 

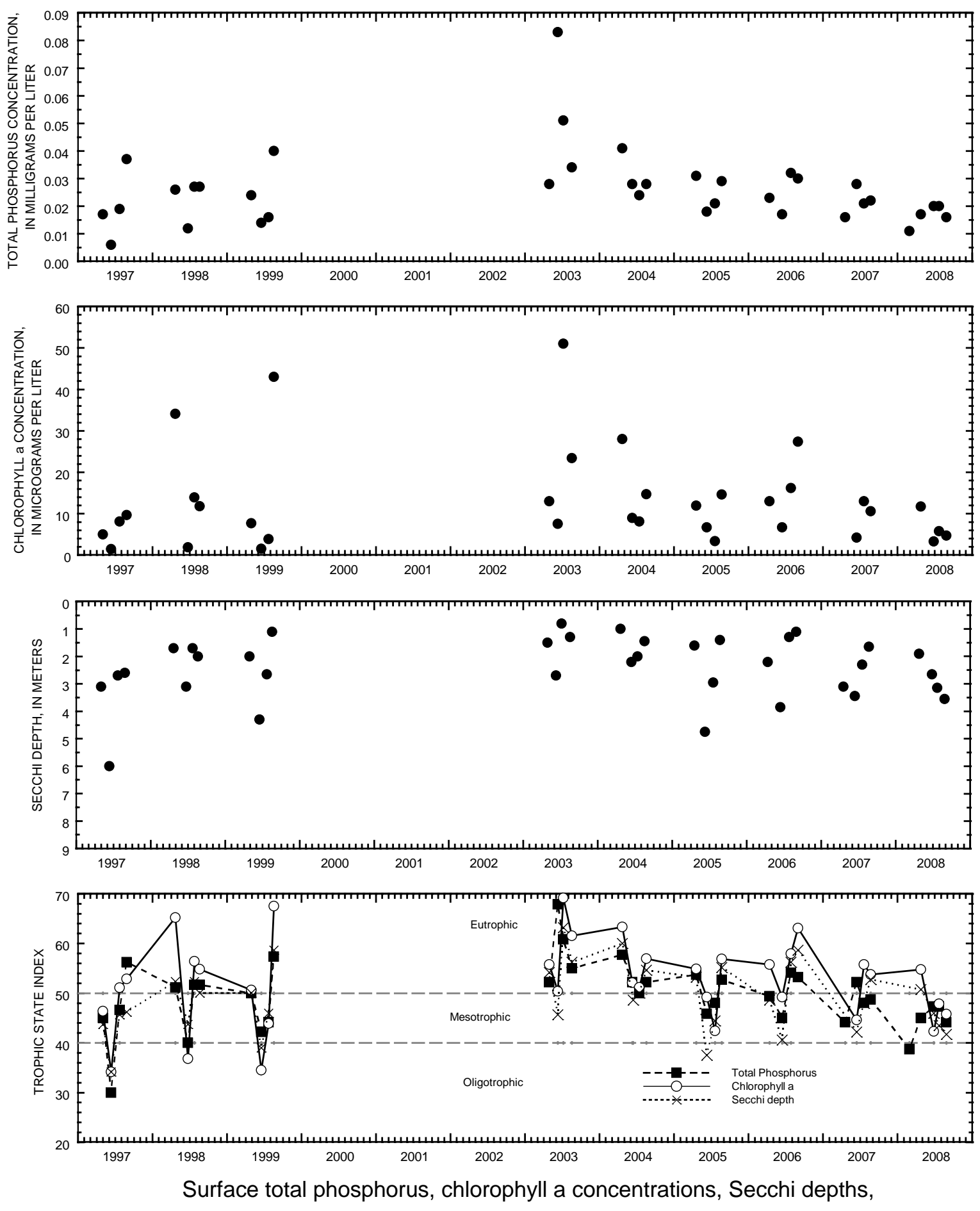
and TSI data for Little Cedar Lake, North Site, near West Bend, Wisconsin. 


\section{LITTLE CEDAR LAKE, SOUTH SITE, NEAR WEST BEND, WI}

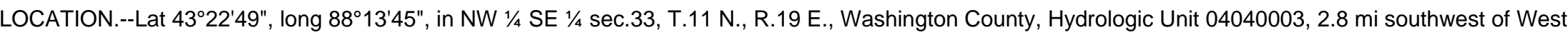
Bend.

SURFACE AREA.--0.38 $\mathrm{mi}^{2}$.

PERIOD OF RECORD.--February 1997 to August 1999, February 2003 to current year.

REMARKS.--Lake sampled in southern basin at deep hole. Lake ice-covered during February sampling. Water-quality analyses done by Wisconsin State Laboratory of Hygiene.

WATER-QUALITY DATA, FEBRUARY 29 TO AUGUST 27, 2008

(Milligrams per liter unless otherwise indicated)

Date

00078 Secchi-depth $(\mathrm{m})$

00098 Sampling depth $(\mathrm{m})$

00010 Water Temperature $\left({ }^{\circ} \mathrm{C}\right.$

$00400 \mathrm{pH}$ (standard units)

00095 Specific conductance $(\mu \mathrm{S} / \mathrm{cm})$

00300 Dissolved oxygen

32210 Chlorophyll a, phytoplankton $(\mu \mathrm{g} / \mathrm{L})$

00665 Phosphorus, Total (as P)

00671 Orthophosphate, dissolved (as P)

00600 Total nitrogen

00631 Nitrate + nitrite, dissolved (as N)

00608 Ammonia, dissolved (as N)

00625 Ammonia + organic nitrogen, total (as N)

00623 Ammonia + organic nitrogen, dissolved (as $\mathrm{N}$ )

00900 Hardness (as $\mathrm{CaCO} 3$ )

00417 Acid neutralizing capacity (as $\mathrm{CaCO}$ )

00915 Calcium, dissolved ( $\mathrm{Ca}$ )

00925 Magnesium, dissolved (Mg)

00930 Sodium, dissolved $(\mathrm{Na})$

00935 Potassium, dissolved (K)

00940 Chloride, dissolved (Cl)

00945 Sulfate, dissolved (SO4)

00955 Silica, dissolved (SiO2)

01046 Iron ( $\mu \mathrm{g} / \mathrm{L})$

01056 Manganese $(\mu \mathrm{g} / \mathrm{L})$

00081 Apparent color (PCU)

63675 Turbidity (NTU)

\begin{tabular}{|c|c|c|c|}
\hline \multicolumn{2}{|c|}{ Feb. 29} & \multicolumn{2}{|c|}{ Apr. 24} \\
\hline \multicolumn{2}{|c|}{--} & \multicolumn{2}{|c|}{2.2} \\
\hline 0.5 & 16 & 0.5 & 17 \\
\hline 0.1 & 4.1 & 13.2 & 5.2 \\
\hline 7.6 & 7.2 & 8.6 & 7.6 \\
\hline 575 & 628 & 529 & 535 \\
\hline 13.1 & 0.8 & 15.3 & 8.2 \\
\hline-- & -- & 20.1 & -- \\
\hline 0.012 & 0.262 & 0.03 & 0.031 \\
\hline -- & -- & 0.008 & -- \\
\hline-- & -- & 1.1 & -- \\
\hline -- & -- & 0.529 & -- \\
\hline -- & -- & $<.015$ & -- \\
\hline-- & -- & 0.58 & -- \\
\hline -- & -- & -- & -- \\
\hline -- & -- & 230 & -- \\
\hline-- & -- & 186 & -- \\
\hline -- & -- & 37.6 & -- \\
\hline -- & -- & 33.5 & -- \\
\hline-- & -- & 23.9 & -- \\
\hline -- & -- & 1.8 & -- \\
\hline -- & -- & 50.9 & -- \\
\hline-- & -- & 18.1 & -- \\
\hline -- & -- & 1.89 & -- \\
\hline -- & -- & $<100$ & -- \\
\hline-- & -- & $<1.6$ & -- \\
\hline -- & -- & 10 & -- \\
\hline-- & -- & $<1.0$ & -- \\
\hline
\end{tabular}

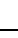

Jul. 2

4.8

0.5

25.7

535

7.4

2.36

0.012

0.004

$<.019$

$<.015$

--$$
\text { . }
$$

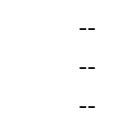

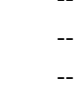$$
\text { -- }
$$ 
432249088134500 LITTLE CEDAR LAKE, SOUTH SITE, NEAR WEST BEND, WI

LAKE-DEPTH PROFILES, FEBRUARY 29 TO AUGUST 27, 2008

02-29-08
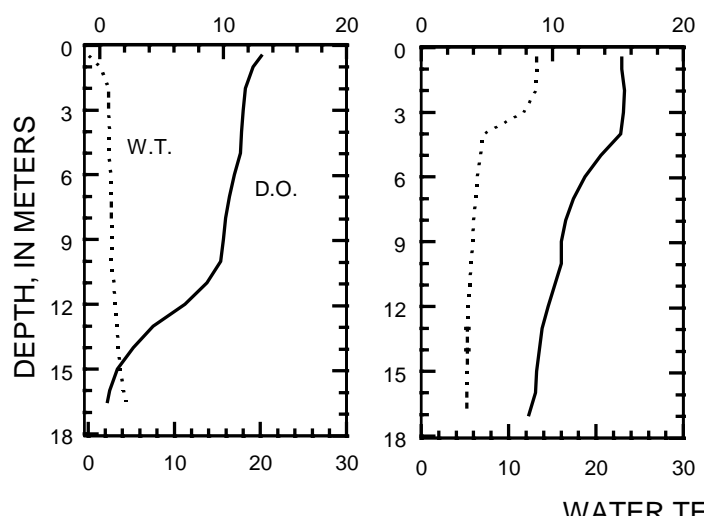

4-24-08

06-26-08

07-22-08
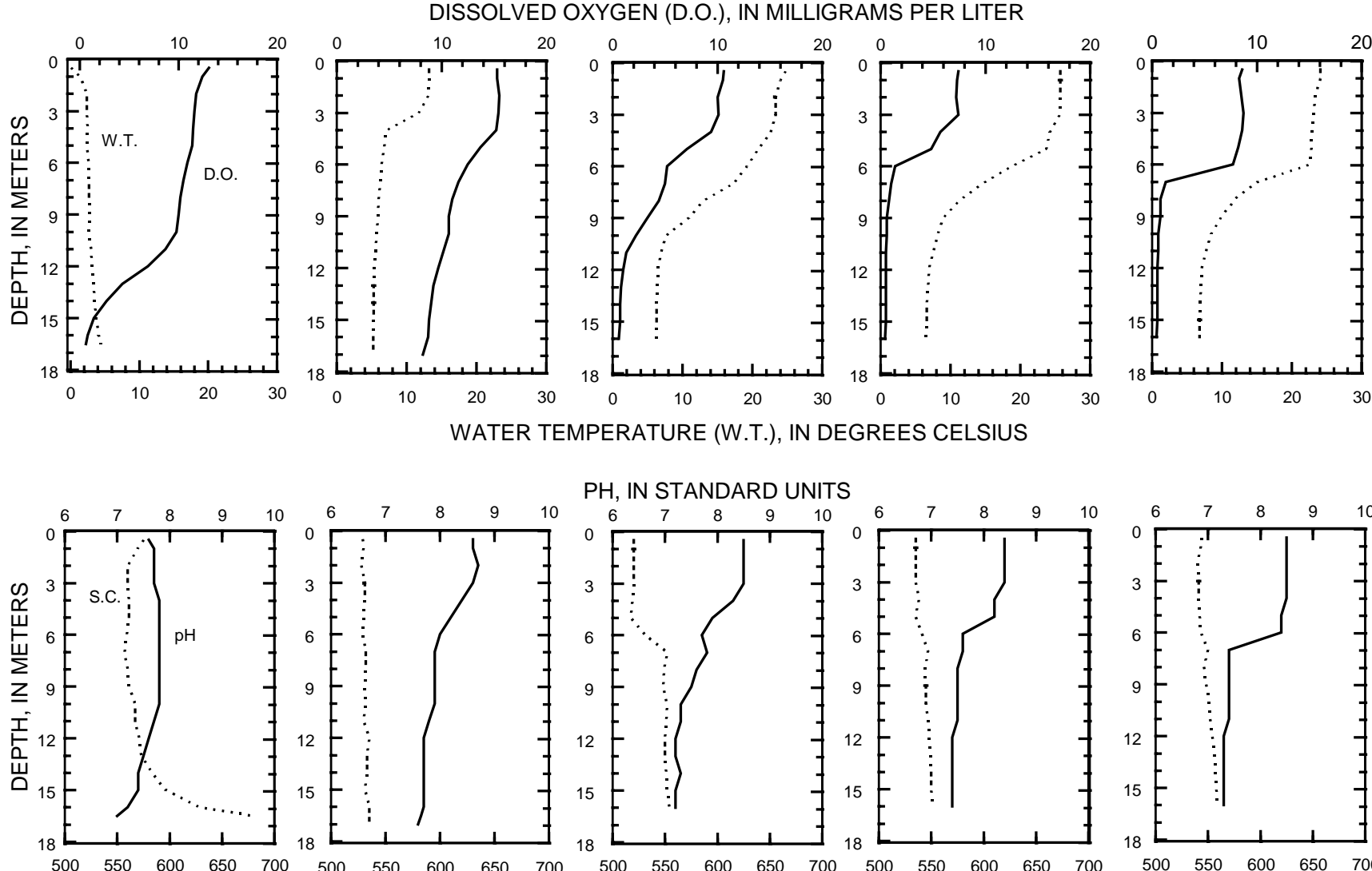

PH, IN STANDARD UNITS
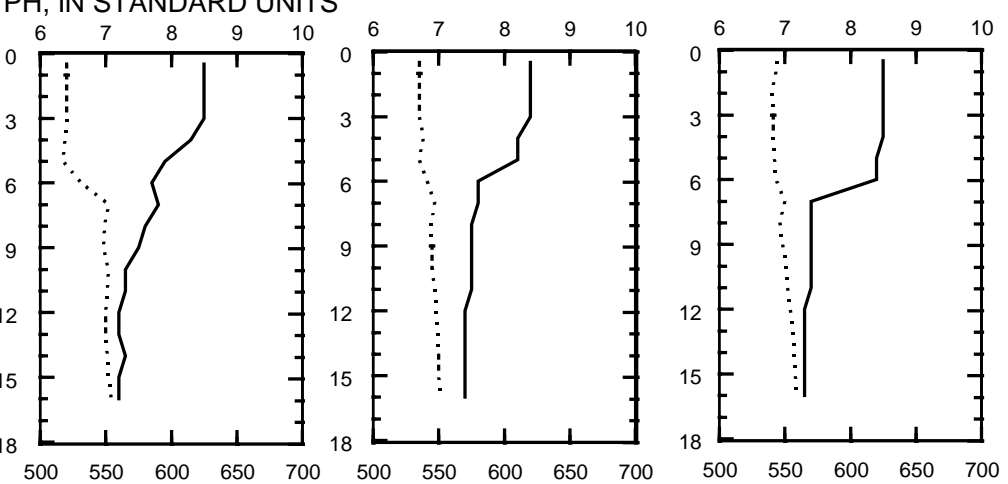

SPECIFIC CONDUCTANCE (S.C.), IN MICROSIEMENS PER CENTIMETER AT 25 DEGREES CELSIUS

08-27-08

$$
\text { 青 }
$$



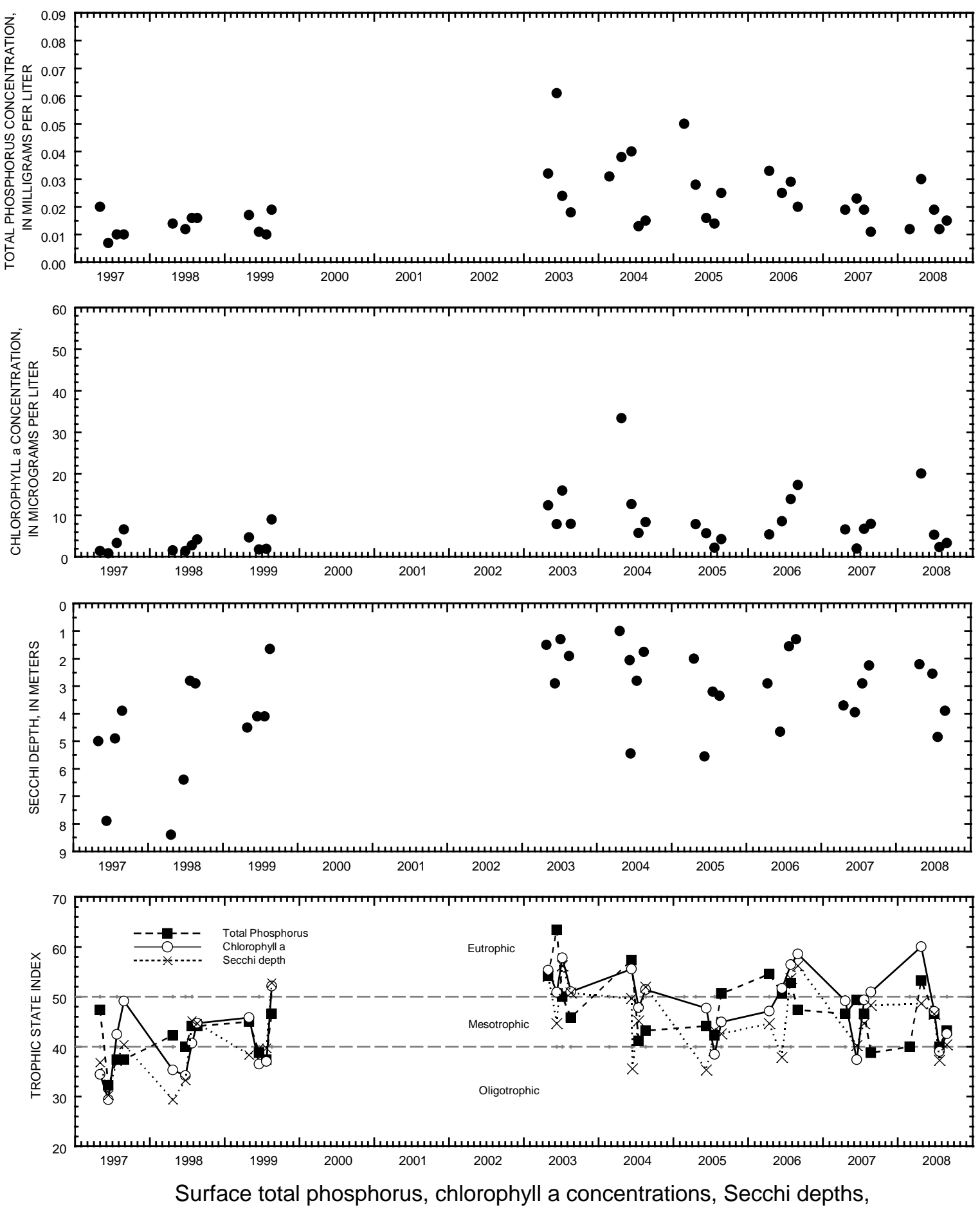
and TSI data for Little Cedar Lake, South Site, near West Bend, Wisconsin. 


\section{LAKE MENDOTA AT MADISON, WI}

LOCATION.--Lat 4305'42", long 89²2'12" referenced to North American Datum of 1927, in NW 1/4 SE 1/4 sec.12, T.7 N., R.9 E., Dane County, WI, Hydrologic Unit 07090001, in county boat house at dam at outlet, in Madison.

SURFACE AREA.-15.2 $\mathrm{mi}^{2}$.

DRAINAGE AREA.--233 $\mathrm{mi}^{2}$ of which $36.6 \mathrm{mi}^{2}$ probably is noncontributing.

PERIOD OF RECORD.--January 1916 to January 1985 (incomplete), February 1985 to current year.

REVISED RECORDS.--WDR WI-73-1: Drainage area.

GAGE.--Water-stage recorder. Datum of gage is $840.00 \mathrm{ft}$ above NGVD of 1929 , or $5.60 \mathrm{ft}$ below City of Madison datum. Prior to Oct. 1 , 1979, gage datum was $847.82 \mathrm{ft}$; prior to Nov. 15, 1971, nonrecording gage at same site.

REMARKS.--Lake level regulated by concrete dam with two 12-foot gates and 20-foot lock at outlet. Gage-height telemeter at station.

EXTREMES FOR PERIOD OF RECORD.--Maximum gage height observed, $12.75 \mathrm{ft}$, June 5, 2000; minimum observed, $8.02 \mathrm{ft}$, Feb. 24 to Mar. 10, 1920, current datum.

EXTREMES FOR CURRENT YEAR.--Maximum recorded gage height, $12.45 \mathrm{ft}$, June 14; minimum recorded, $8.76 \mathrm{ft}$, Dec. $21-22$.

\section{GAGE HEIGHT, FEET \\ WATER YEAR OCTOBER 2007 TO SEPTEMBER 2008 \\ DAILY MEAN VALUES}

[e, estimated]

\begin{tabular}{|c|c|c|c|c|c|c|c|c|c|c|c|c|}
\hline Day & Oct & Nov & Dec & Jan & Feb & Mar & Apr & May & Jun & Jul & Aug & Sep \\
\hline 1 & 10.52 & 10.05 & 9.14 & 8.89 & 9.29 & 9.44 & 10.30 & 11.13 & 10.11 & 11.36 & 11.18 & 10.19 \\
\hline 2 & 10.55 & 10.0 & 9.25 & 8.87 & 9.29 & 9.43 & 10.31 & 11.10 & 10.10 & 11.32 & 11.15 & 10.15 \\
\hline 3 & 10.60 & 9.97 & 9.21 & 8.87 & 9.29 & 9.53 & 10.32 & 11.10 & 10.09 & 11.29 & 11.10 & 10.13 \\
\hline 4 & 10.60 & 9.94 & 9.17 & 8.86 & 9.30 & 9.57 & 10.33 & 11.05 & 10.07 & 11.27 & 11.15 & 10.13 \\
\hline 5 & 10.60 & 9.93 & 9.17 & 8.85 & 9.31 & 9.59 & 10.32 & 11.00 & 10.16 & 11.24 & 11.18 & 10.15 \\
\hline 6 & 10.60 & 9.88 & 9.13 & 8.86 & 9.36 & 9.60 & 10.32 & 10.95 & 10.22 & 11.20 & 11.16 & 10.14 \\
\hline 7 & 10.60 & 9.81 & 9.12 & 8.92 & 9.38 & 9.61 & 10.31 & 10.95 & 10.24 & 11.23 & 11.13 & 10.11 \\
\hline 8 & 10.60 & 9.79 & 9.07 & 9.03 & 9.38 & 9.60 & 10.34 & 10.90 & e10.76 & 11.37 & 11.09 & 10.10 \\
\hline 9 & 10.59 & 9.76 & 9.05 & 9.12 & 9.38 & 9.60 & 10.43 & 10.84 & e11.27 & 11.39 & 11.07 & 10.08 \\
\hline 10 & 10.54 & 9.71 & 9.02 & 9.18 & 9.37 & 9.59 & 10.49 & 10.79 & 11.64 & 11.39 & 11.03 & 10.05 \\
\hline 11 & 10.46 & 9.69 & 9.03 & 9.23 & 9.37 & 9.59 & 10.80 & 10.77 & 11.84 & 11.64 & 11.00 & 10.03 \\
\hline 12 & 10.42 & 9.68 & 9.01 & 9.26 & 9.38 & 9.59 & 10.96 & 10.70 & 11.95 & 11.91 & 10.98 & 10.04 \\
\hline 13 & 10.39 & 9.64 & 8.99 & 9.27 & 9.38 & 9.59 & 11.01 & 10.64 & 12.20 & 12.00 & 10.96 & 10.11 \\
\hline 14 & 10.37 & 9.64 & 8.95 & 9.28 & 9.38 & 9.64 & 11.00 & 10.60 & 12.32 & 11.99 & 10.94 & 10.16 \\
\hline 15 & 10.36 & 9.59 & 8.93 & 9.29 & 9.37 & 9.70 & 10.96 & 10.54 & 12.38 & 11.97 & 10.91 & 10.16 \\
\hline 16 & 10.39 & 9.54 & 8.91 & 9.29 & 9.37 & 9.76 & 10.92 & 10.48 & 12.35 & 11.93 & 10.87 & 10.15 \\
\hline 17 & 10.36 & 9.52 & 8.87 & 9.29 & 9.42 & 9.81 & 10.90 & 10.44 & 12.28 & 11.88 & 10.83 & 10.14 \\
\hline 18 & 10.44 & 9.49 & 8.85 & 9.29 & 9.46 & 9.86 & 10.95 & 10.38 & 12.20 & 11.82 & 10.79 & 10.12 \\
\hline 19 & 10.47 & 9.47 & 8.82 & 9.29 & 9.47 & 9.89 & 10.98 & 10.31 & 12.12 & 11.74 & 10.75 & 10.11 \\
\hline 20 & 10.44 & 9.46 & 8.80 & 9.28 & 9.47 & 9.93 & 10.98 & 10.27 & 12.04 & 11.71 & 10.71 & 10.11 \\
\hline 21 & 10.41 & 9.45 & 8.78 & 9.28 & 9.47 & 10.01 & 10.95 & 10.20 & 11.97 & 11.66 & 10.67 & 10.11 \\
\hline 22 & 10.40 & 9.43 & 8.79 & 9.30 & 9.47 & 10.06 & 10.91 & 10.14 & 11.87 & 11.59 & 10.63 & 10.09 \\
\hline 23 & 10.36 & 9.39 & 8.88 & 9.30 & 9.47 & 10.07 & 10.86 & 10.08 & 11.78 & 11.52 & 10.61 & 10.08 \\
\hline 24 & 10.33 & 9.35 & 8.87 & 9.30 & 9.48 & 10.08 & 10.82 & 10.05 & 11.70 & 11.46 & 10.57 & 10.08 \\
\hline 25 & 10.28 & 9.32 & 8.87 & 9.30 & 9.47 & 10.09 & 11.04 & 10.02 & 11.64 & 11.40 & 10.51 & 10.08 \\
\hline 26 & 10.26 & 9.31 & 8.87 & 9.30 & 9.46 & 10.12 & 11.18 & 10.06 & 11.59 & 11.36 & 10.46 & 10.07 \\
\hline 27 & 10.24 & 9.28 & 8.88 & 9.30 & 9.45 & 10.16 & 11.20 & 10.03 & 11.53 & 11.32 & 10.40 & 10.06 \\
\hline 28 & 10.19 & 9.23 & 8.90 & 9.28 & 9.45 & 10.17 & 11.21 & 10.0 & 11.50 & 11.28 & 10.36 & 10.04 \\
\hline 29 & 10.15 & 9.21 & 8.91 & 9.28 & 9.44 & 10.18 & 11.19 & 9.98 & 11.46 & 11.24 & 10.34 & 10.03 \\
\hline 30 & 10.11 & 9.16 & 8.90 & 9.28 & --- & 10.18 & 11.16 & 10.07 & 11.40 & 11.23 & 10.29 & 10.01 \\
\hline 31 & 10.09 & --- & 8.90 & 9.29 & --- & 10.24 & --- & 10.13 & --- & 11.21 & 10.24 & --- \\
\hline Mean & 10.41 & 9.59 & 8.97 & 9.18 & 9.40 & 9.82 & 10.78 & 10.51 & 11.43 & 11.51 & 10.81 & 10.10 \\
\hline Max & 10.60 & 10.05 & 9.25 & 9.30 & 9.48 & 10.24 & 11.21 & 11.13 & 12.38 & 12.00 & 11.18 & 10.19 \\
\hline Min & 10.09 & 9.16 & 8.78 & 8.85 & 9.29 & 9.43 & 10.30 & 9.98 & 10.07 & 11.20 & 10.24 & 10.01 \\
\hline
\end{tabular}


460937090033100 MERCER LAKE, DEEP HOLE, AT MERCER, WI

LOCATION.--Lat 4609'37", long 9003'31", in SW 1/4 SE 1/4 NW 1/4 sec.36, T.43 N., R.3 E., Iron County, Hydrologic Unit 07050002, at Minocqua.

SURFACE AREA.-0.29 $\mathrm{mi}^{2}$

PERIOD OF RECORD._March to September 2008.

REMARKS.--Lake sampled in the east basin at the deep hole. Water-quality analyses done by Wisconsin State Laboratory of Hygiene.

WATER-QUALITY DATA, MARCH 20 TO JULY 25, 2008

(Milligrams per liter unless otherwise indicated)

Date

00078 Secchi-depth $(\mathrm{m})$

00098 Sampling depth $(\mathrm{m})$

00010 Water Temperature $\left({ }^{\circ} \mathrm{C}\right)$

$00400 \mathrm{pH}$ (standard units)

00095 Specific conductance $(\mu \mathrm{S} / \mathrm{cm})$

00300 Dissolved oxygen

32210 Chlorophyll a, phytoplankton ( $\mu \mathrm{g} / \mathrm{L})$

00665 Phosphorus, Total (as $\mathrm{P}$ )

00671 Orthophosphate, dissolved (as P)

00600 Total nitrogen

00631 Nitrate + nitrite, dissolved (as N)

00608 Ammonia, dissolved (as N)

00625 Ammonia + organic nitrogen, total (as N)

00900 Hardness (as $\mathrm{CaCO} 3$ )

00417 Acid neutralizing capacity (as $\mathrm{CaCO} 3$ )

00915 Calcium, dissolved (Ca)

00925 Magnesium, dissolved (Mg)

00930 Sodium, dissolved ( $\mathrm{Na}$ )

00935 Potassium, dissolved (K)

00940 Chloride, dissolved (Cl)

00945 Sulfate, dissolved (SO4)

00955 Silica, dissolved (SiO2)

01046 Iron ( $\mu \mathrm{g} / \mathrm{L})$

01056 Manganese $(\mu \mathrm{g} / \mathrm{L})$

00081 Apparent color (PTU)

63675 Turbidity (NTU)

70300 Solids, dissolved (at $180 \mathrm{C}^{\circ}$ )

\begin{tabular}{|c|c|c|c|}
\hline \multicolumn{2}{|c|}{ Mar. 20} & \multicolumn{2}{|c|}{ May 5} \\
\hline \multicolumn{2}{|c|}{-- } & \multicolumn{2}{|c|}{2.1} \\
\hline 1.0 & 5.0 & 0.5 & 6.0 \\
\hline 2.1 & 4.5 & 7.2 & 7.1 \\
\hline 7.1 & 7.1 & 6.2 & 6.9 \\
\hline 230 & 298 & 222 & 220 \\
\hline 2.6 & 0.7 & 10.7 & 10.6 \\
\hline -- & -- & 8.89 & -- \\
\hline 0.012 & 0.015 & 0.026 & 0.026 \\
\hline-- & -- & 0.006 & -- \\
\hline -- & -- & -- & -- \\
\hline-- & -- & $<.019$ & -- \\
\hline-- & -- & $<.015$ & -- \\
\hline -- & -- & 0.43 & -- \\
\hline-- & -- & 88 & -- \\
\hline-- & -- & 79 & -- \\
\hline -- & -- & 25.1 & -- \\
\hline-- & -- & 6.2 & -- \\
\hline-- & -- & 5.7 & -- \\
\hline -- & -- & 1.1 & -- \\
\hline-- & -- & 12.6 & -- \\
\hline-- & -- & $<4.5$ & -- \\
\hline-- & -- & 14.8 & -- \\
\hline-- & -- & $<100$ & -- \\
\hline-- & -- & 200 & -- \\
\hline-- & -- & 15 & -- \\
\hline-- & -- & $<1.0$ & -- \\
\hline-- & -- & 124 & -- \\
\hline
\end{tabular}

\begin{tabular}{cc}
\multicolumn{3}{c}{ June 17} \\
\hline & 3.1 \\
0.5 & 5.5 \\
17.8 & 14.3 \\
7.7 & 6.7 \\
187 & 212 \\
8.7 & 2.0 \\
4.67 & -- \\
0.023 & 0.018 \\
-- & -- \\
-- & -- \\
-- & -- \\
-- & -- \\
-- & -- \\
-- & -- \\
-- & -- \\
-- & -- \\
-- & -- \\
-- & -- \\
-- & -- \\
-- & -- \\
-- & -- \\
-- & -- \\
-- & -- \\
-- & -- \\
-- & -- \\
-- & -- \\
-- & -- \\
\hline &
\end{tabular}

\begin{tabular}{|c|c|c|c|}
\hline \multicolumn{2}{|c|}{ July 10} & \multicolumn{2}{|c|}{ July 25} \\
\hline \multicolumn{2}{|c|}{2.7} & \multicolumn{2}{|c|}{3.8} \\
\hline 0.5 & 6.0 & 0.5 & 6.0 \\
\hline 22.6 & 13.6 & 23.3 & 15.4 \\
\hline 8.3 & 7.2 & 8.1 & 6.6 \\
\hline 173 & 237 & 188 & 255 \\
\hline 8.8 & 0.4 & 9.7 & 0.5 \\
\hline 1.95 & -- & -- & -- \\
\hline 0.025 & 0.066 & 0.070 & 0.018 \\
\hline -- & -- & -- & -- \\
\hline -- & -- & -- & -- \\
\hline -- & -- & -- & -- \\
\hline -- & -- & -- & -- \\
\hline -- & -- & -- & -- \\
\hline -- & -- & -- & -- \\
\hline -- & -- & -- & -- \\
\hline-- & -- & -- & -- \\
\hline -- & -- & -- & -- \\
\hline -- & -- & -- & -- \\
\hline-- & -- & -- & -- \\
\hline -- & -- & -- & -- \\
\hline -- & -- & -- & -- \\
\hline-- & -- & -- & -- \\
\hline -- & -- & -- & -- \\
\hline -- & -- & -- & -- \\
\hline -- & -- & -- & -- \\
\hline -- & -- & -- & -- \\
\hline -- & -- & -- & -- \\
\hline
\end{tabular}


460937090033100 MERCER LAKE, DEEP HOLE, AT MERCER, WI

WATER-QUALITY DATA, AUGUST 14 TO SEPTEMBER 16, 2008

(Milligrams per liter unless otherwise indicated)

Date

00078 Secchi-depth $(m)$

00098 Sampling depth $(\mathrm{m})$

00010 Water Temperature $\left({ }^{\circ} \mathrm{C}\right.$

$00400 \mathrm{pH}$ (standard units)

00095 Specific conductance $(\mu \mathrm{S} / \mathrm{cm})$

00300 Dissolved oxygen

32210 Chlorophyll a, phytoplankton $(\mu \mathrm{g} / \mathrm{L})$

00665 Phosphorus, Total (as P)

\begin{tabular}{cc}
\multicolumn{3}{c}{ Aug. 14 } \\
\hline \multicolumn{2}{c}{3.8} \\
0.5 & 6.5 \\
22.6 & 14.8 \\
8.2 & 6.9 \\
160 & 259 \\
10.8 & 0.4 \\
2.12 & -- \\
0.047 & 0.110
\end{tabular}

\begin{tabular}{cc}
\multicolumn{3}{c}{ Aug. 31} \\
\hline \multicolumn{3}{c}{3.0} \\
0.5 & 6.5 \\
21.6 & 16.2 \\
7.8 & 6.4 \\
182 & 290 \\
9.8 & 0.2 \\
1.62 & -- \\
0.016 & 0.105
\end{tabular}

\begin{tabular}{cc}
\multicolumn{2}{c}{ Sept. 16} \\
\hline \multicolumn{2}{c}{2.6} \\
0.5 & 5.5 \\
17.0 & 16.1 \\
7.4 & 7.4 \\
180 & 180 \\
9.6 & 8.6 \\
3.33 & -- \\
0.046 & 0.020
\end{tabular}




\section{MERCER LAKE, DEEP HOLE, AT MERCER, W}

LAKE-DEPTH PROFILES, MARCH 20 TO JULY 10, 2008

03-20-08
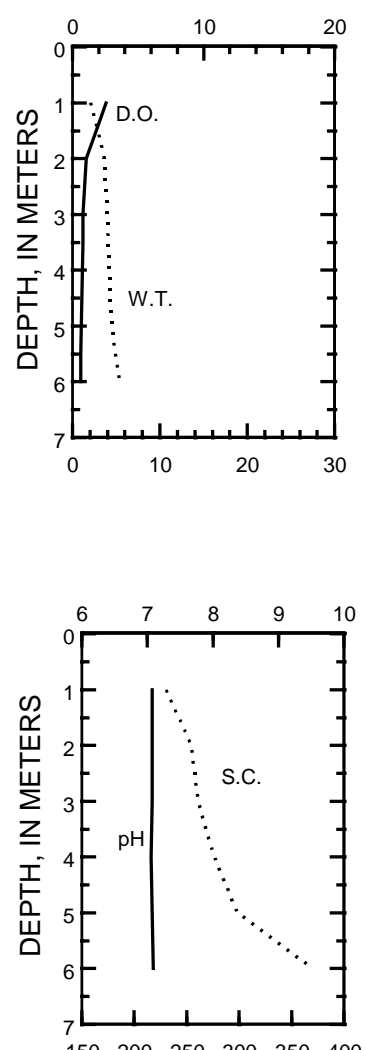

05-05-08

DISSOLVED OXYGEN (D.O.), IN MILLIGRAMS PER LITER

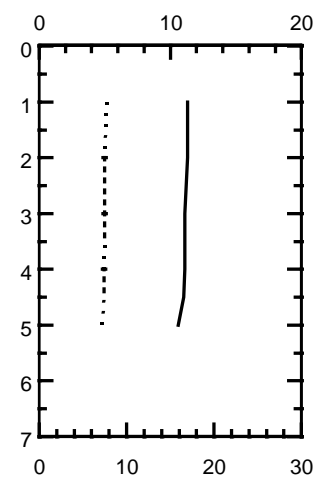

WATER TEMPERATURE (W.T.), IN DEGREES CELSIUS
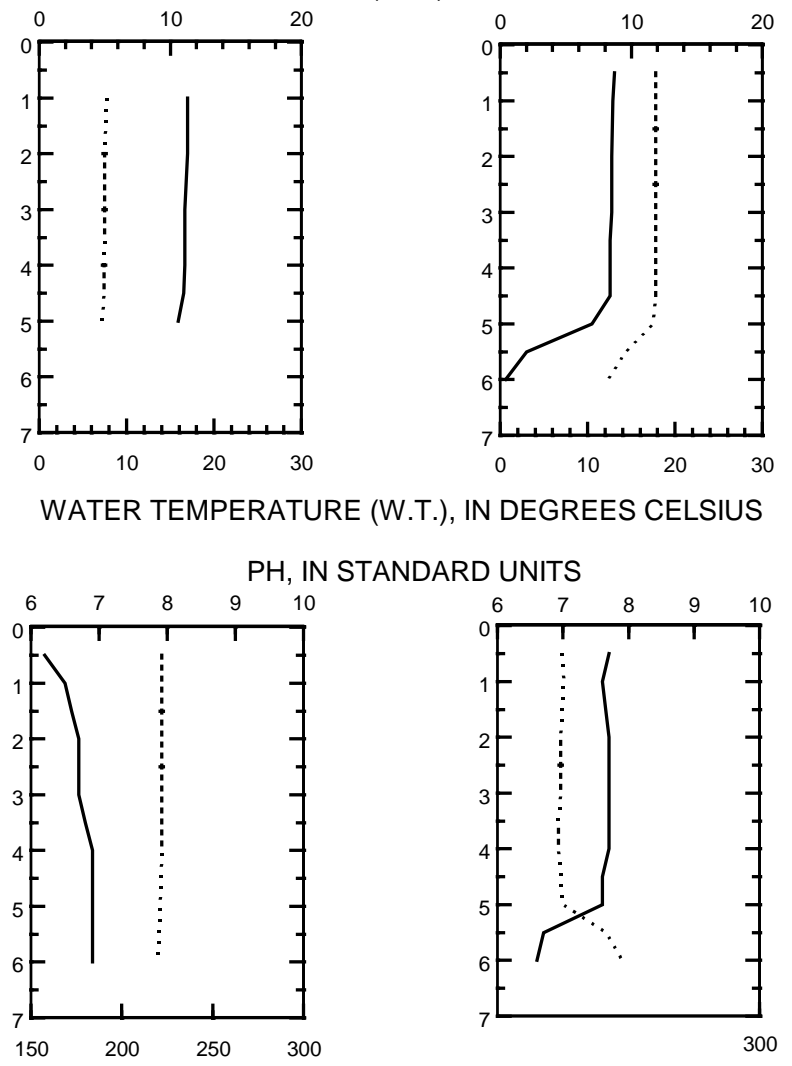
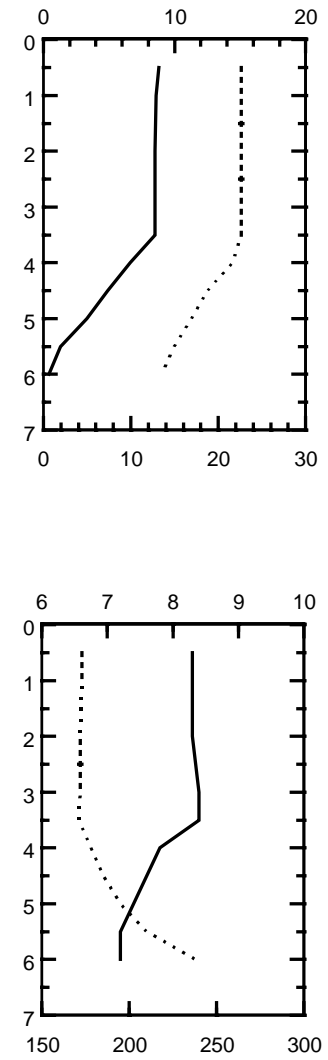

SPECIFIC CONDUCTANCE (S.C.), IN MICROSIEMENS PER CENTIMETER AT 25 DEGREES CELSIUS 
460937090033100 MERCER LAKE, DEEP HOLE, AT MERCER, WI

LAKE-DEPTH PROFILES, JULY 25 TO SEPTEMBER 16, 2008

07-25-08
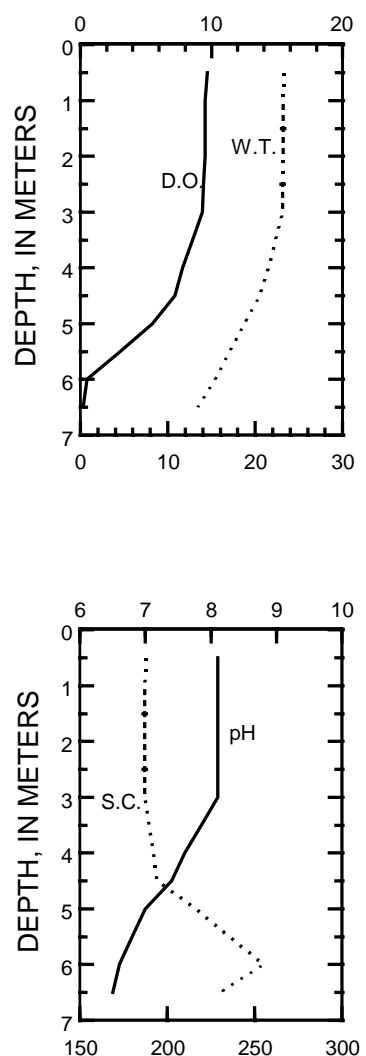

08-14-08

08-31-08

DISSOLVED OXYGEN (D.O.), IN MILLIGRAMS PER LITER
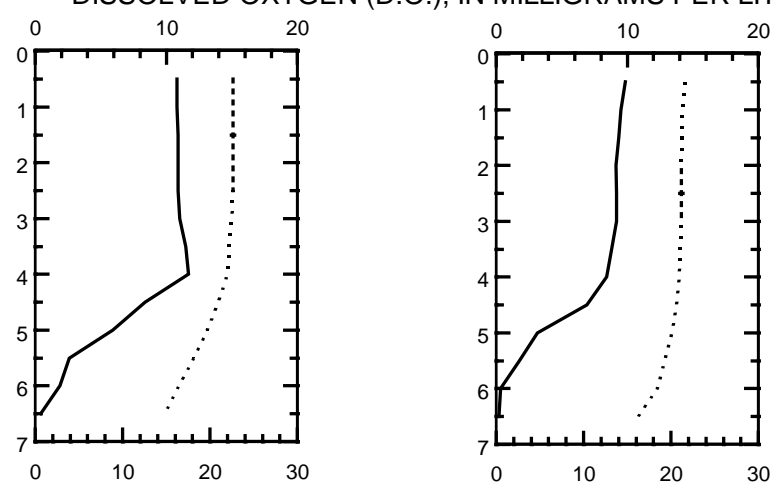

WATER TEMPERATURE (W.T.), IN DEGREES CELSIUS
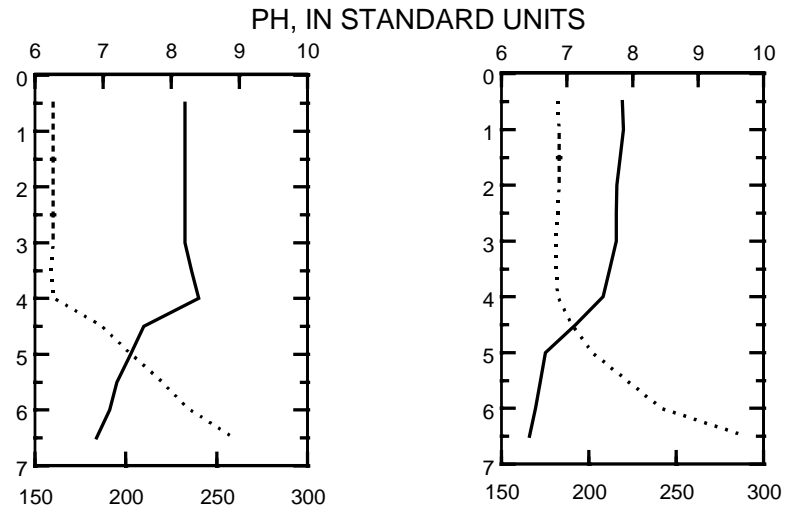

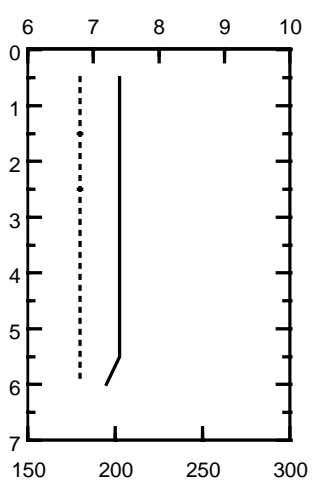

SPECIFIC CONDUCTANCE (S.C.), IN MICROSIEMENS PER CENTIMETER AT 25 DEGREES CELSIUS 

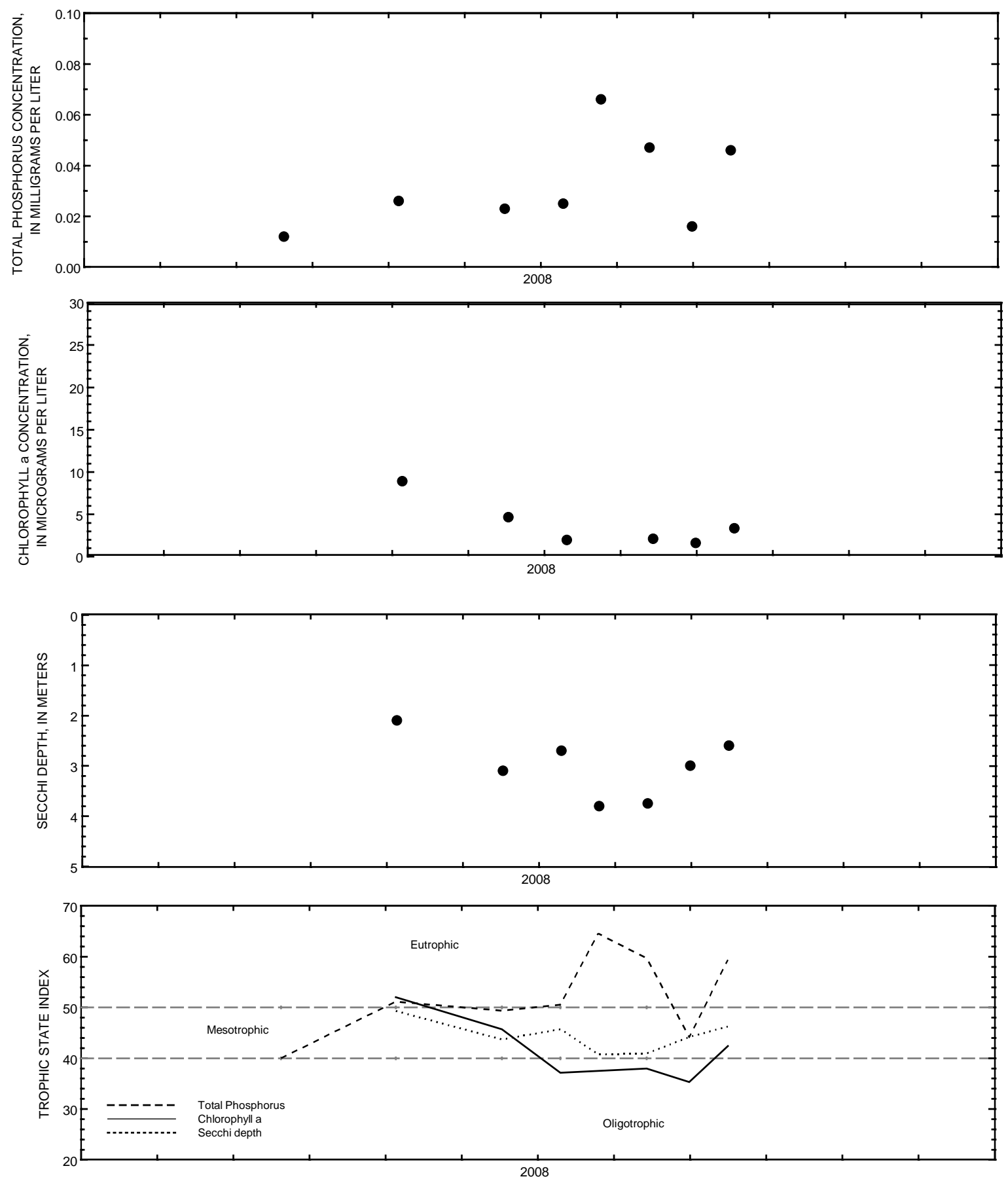

Surface total phosphorus, chlorophyll a concentrations, Secchi depths, and TSI data for Mercer Lake, Deep Hole, at Mercer, Wisconsin. 


\section{MERCER LAKE, WEST BASIN, AT MERCER, WI}

LOCATION.--Lat 4609'45", long 9004'06", in SW 1/4 SE 1/4 NW 1/4 sec.36, T.43 N., R.3 E., Iron County, Hydrologic Unit 07050002, at Mercer.

SURFACE AREA.- $-0.29 \mathrm{mi}^{2}$

PERIOD OF RECORD.-March to September 2008.

REMARKS.--Lake sampled in the west basin. Water-quality analyses done by Wisconsin State Laboratory of Hygiene.

WATER-QUALITY DATA, MARCH 20 TO SEPTEMBER 16, 2008

(Milligrams per liter unless otherwise indicated)

Date

00078 Secchi-depth $(m)$

00098 Sampling depth $(\mathrm{m})$

00010 Water Temperature $\left({ }^{\circ} \mathrm{C}\right)$

$00400 \mathrm{pH}$ (standard units)

00095 Specific conductance $(\mu \mathrm{S} / \mathrm{cm})$

00300 Dissolved oxygen

32210 Chlorophyll a, phytoplankton $(\mu \mathrm{g} / \mathrm{L})$

00665 Phosphorus, Total (as P)

\begin{tabular}{cccccc}
\multicolumn{2}{c}{ Mar. 20 } & & \multicolumn{2}{c}{ May 5 } \\
\cline { 1 - 2 } \cline { 5 - 5 } \cline { 5 - 5 } 1.0 & -- & & & \multicolumn{2}{c}{2.2} \\
2.4 & 4.0 & & 0.5 & 6.0 \\
7.2 & 7.2 & & 7.7 & 7.1 \\
233 & 383 & & 206 & 211 \\
2.4 & 0.6 & & 11.3 & 10.5 \\
-- & -- & & 7.6 & -- \\
0.013 & 0.084 & & 0.027 & 0.026
\end{tabular}

\begin{tabular}{cc}
\multicolumn{3}{c}{ June 17} \\
\hline \multicolumn{3}{c}{3.2} \\
0.5 & 6.0 \\
17.9 & 13.7 \\
7.8 & 6.6 \\
187 & 211 \\
8.4 & 1.1 \\
4.39 & -- \\
0.020 & 0.018
\end{tabular}

July 10

$\begin{array}{cc} & 3.0 \\ 0.5 & 5.5 \\ 22.6 & 16 \\ 8.7 & 7.5 \\ 164 & 190 \\ 8.9 & 0.4 \\ 0.86 & -- \\ 0.027 & 0.035\end{array}$

\begin{tabular}{cc}
\multicolumn{3}{c}{ July 25} \\
\hline \multicolumn{3}{c}{3.4} \\
0.5 & 5.0 \\
23.2 & 19.1 \\
8.1 & 6.8 \\
177 & 193 \\
10.2 & 5.2 \\
-- & -- \\
0.022 & 0.018
\end{tabular}

Date

00078 Secchi-depth $(\mathrm{m})$

00098 Sampling depth $(\mathrm{m})$

00010 Water Temperature $\left({ }^{\circ} \mathrm{C}\right)$

$00400 \mathrm{pH}$ (standard units)

00095 Specific conductance $(\mu \mathrm{S} / \mathrm{cm})$

00300 Dissolved oxygen

32210 Chlorophyll a, phytoplankton ( $\mu \mathrm{g} / \mathrm{L})$

00665 Phosphorus, Total (as P)

\begin{tabular}{cc}
\multicolumn{3}{c}{ Aug. 14} \\
\hline \multicolumn{3}{c}{3.4} \\
0.5 & 5.5 \\
22.8 & 20.4 \\
8.4 & 7.3 \\
156 & 178 \\
11.2 & 3.6 \\
1.52 & -- \\
0.040 & 0.041
\end{tabular}

\begin{tabular}{cc}
\multicolumn{3}{c}{ Aug. 31 } \\
\hline \multicolumn{3}{c}{3.4} \\
0.5 & 5.5 \\
21.9 & 20 \\
8.1 & 6.5 \\
178 & 195 \\
10.2 & 1.0 \\
2.32 & -- \\
0.015 & 0.028
\end{tabular}

\begin{tabular}{cc}
\multicolumn{3}{c}{ Sept. 16 } \\
\hline \multicolumn{3}{c}{2.9} \\
0.5 & 5.5 \\
16.9 & 15.9 \\
7.7 & 7.7 \\
170 & 170 \\
11.3 & 9.9 \\
2.3 & -- \\
0.022 & 0.018
\end{tabular}




\section{MERCER LAKE, WEST BASIN, AT MERCER, WI}

LAKE-DEPTH PROFILES, MARCH 20 TO JUNE 10, 2008

03-20-08
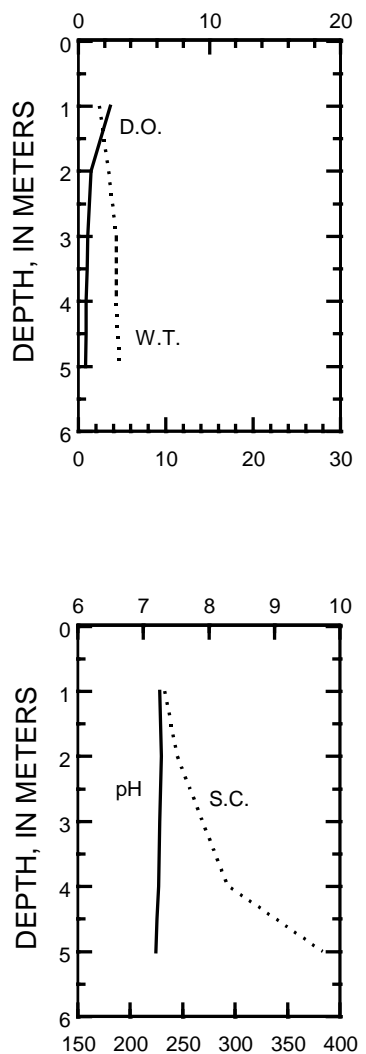

05-05-08

DISSOLVED OXYGEN (D.O.), IN MILLIGRAMS PER LITER
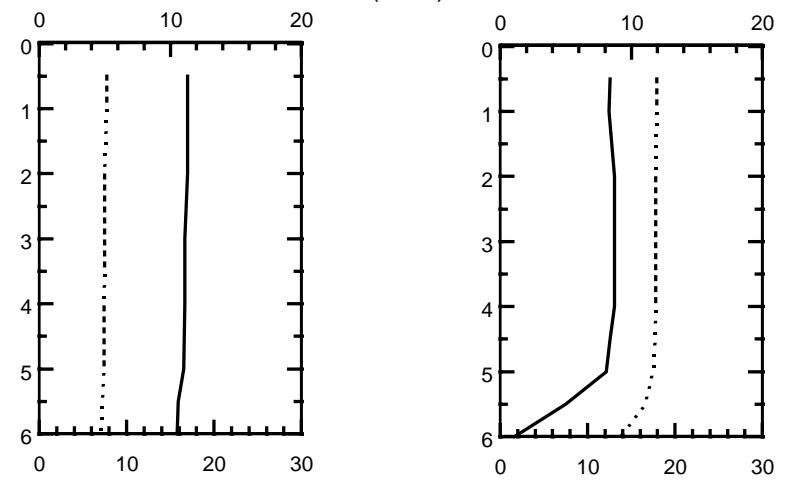

WATER TEMPERATURE (W.T.), IN DEGREES CELSIUS

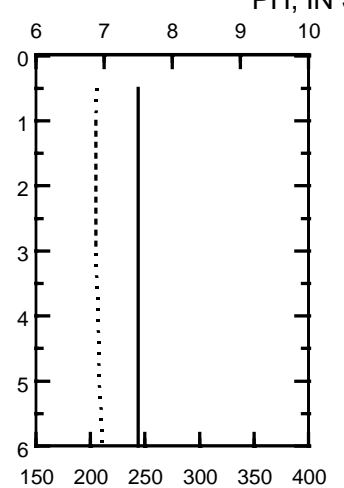

07-10-08
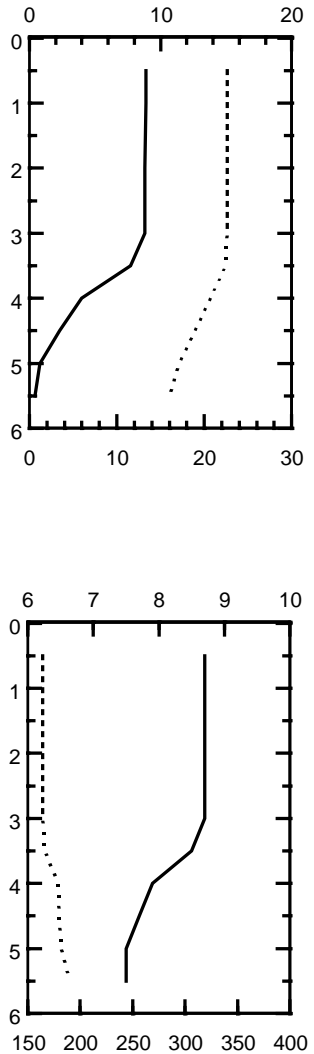

SPECIFIC CONDUCTANCE (S.C.), IN MICROSIEMENS PER CENTIMETER AT 25 DEGREES CELSIUS 


\section{MERCER LAKE, WEST BASIN, AT MERCER, WI}

LAKE-DEPTH PROFILES, JULY 25 TO SEPTEMBER 16, 2008

07-25-08
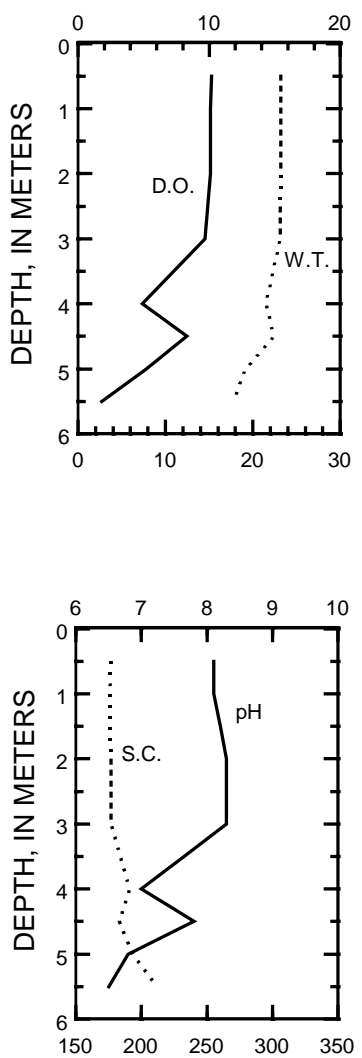

08-14-08

DISSOLVED OXYGEN (D.O.), IN MILLIGRAMS PER LITER

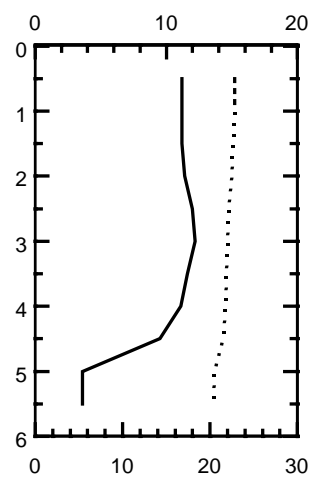

WATER TEMPERATURE (W.T.), IN DEGREES CELSIUS

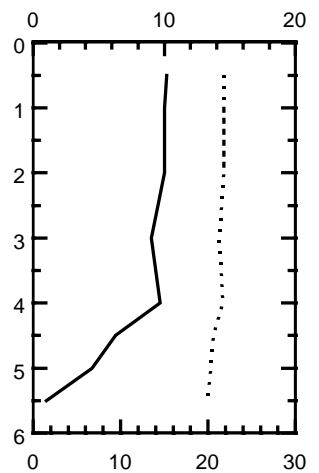

PH, IN STANDARD UNITS
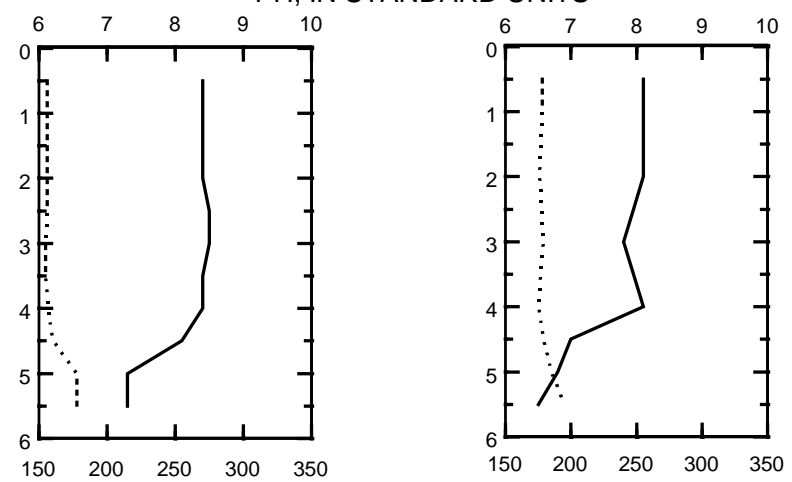

09-16-08
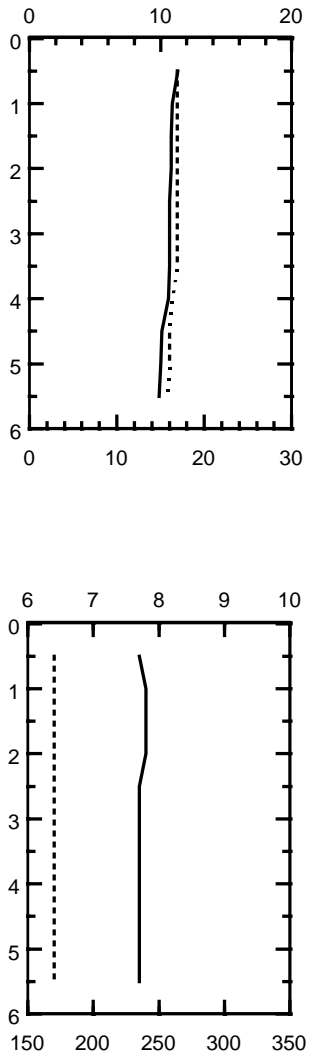

SPECIFIC CONDUCTANCE (S.C.), IN MICROSIEMENS PER CENTIMETER AT 25 DEGREES CELSIUS 

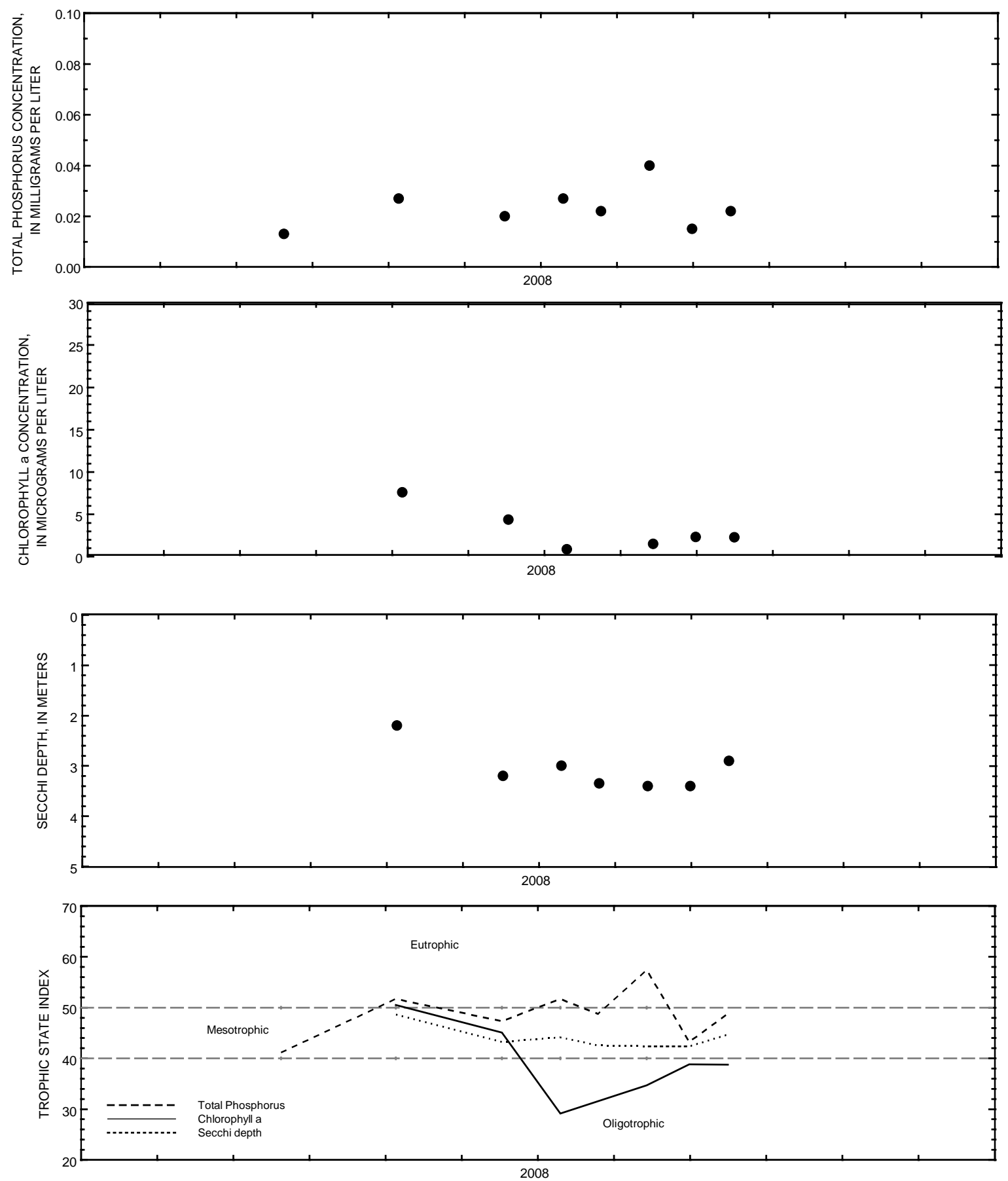

Surface total phosphorus, chlorophyll a concentrations, Secchi depths, and TSI data for Mercer Lake, West Basin, at Mercer, Wisconsin. 


\section{MIDDLE GENESEE LAKE, AT GENESEE LAKE ROAD, NEAR OCONOMOWOC, WI}

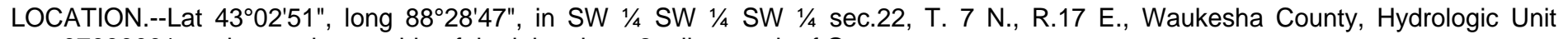
07090001, at the southwest side of the lake about 2 miles south of Oconomowoc.

SURFACE AREA.--0.17 $\mathrm{mi}^{2}$.

DRAINAGE AREA.--Unknown.

PERIOD OF RECORD.--April 1996 to current year.

GAGE.--Staff gage. Local observer, Tom Schubring provided most readings of gage. Datum of gage is about $0.0 \mathrm{ft}$ above NGVD of 1929.

EXTREMES FOR THE PERIOD OF RECORD.--Maximum observed gage height, 869.65 ft, July 12, 2008; minimum observed, 863.88 ft, Oct. 31, 2005.

EXTREMES FOR CURRENT YEAR.--Maximum observed gage height, 869.65 ft, July 12; minimum observed, 866.33 ft, Sept. 22.

\begin{tabular}{|c|c|c|c|}
\hline \multicolumn{4}{|c|}{$\begin{array}{c}\text { GAGE HEIGHT, FEET } \\
\text { WATER YEAR OCTOBER } 2007 \text { TO SEPTEMBER } 2008\end{array}$} \\
\hline Date & Gage Height, ft & Date & Gage Height, $\mathrm{ft}$ \\
\hline October 3 & 866.84 & July 10 & 869.49 \\
\hline 16 & 866.82 & 11 & 869.61 \\
\hline 26 & 866.76 & 12 & 869.65 \\
\hline 31 & 866.70 & 14 & 869.59 \\
\hline November 1 & 866.70 & 15 & 869.57 \\
\hline 8 & 866.64 & 17 & 869.53 \\
\hline 13 & 866.60 & 18 & 869.51 \\
\hline 16 & 866.58 & 20 & 869.49 \\
\hline 20 & 866.58 & 21 & 869.47 \\
\hline April 29 & 868.12 & 23 & 869.39 \\
\hline May 4 & 868.27 & 24 & 869.37 \\
\hline 6 & 868.29 & 25 & 869.35 \\
\hline 19 & 868.24 & 26 & 869.29 \\
\hline 24 & 868.16 & 27 & 869.25 \\
\hline 29 & 868.10 & 28 & 869.21 \\
\hline June 1 & 868.14 & 29 & 869.17 \\
\hline 5 & 868.20 & 30 & 869.09 \\
\hline 8 & 868.58 & 31 & 869.05 \\
\hline 9 & 868.84 & August 1 & 868.99 \\
\hline 10 & 868.92 & 2 & 868.89 \\
\hline 11 & 868.96 & 3 & 868.83 \\
\hline 29 & 869.50 & 4 & 868.83 \\
\hline July 9 & 869.51 & 5 & 868.77 \\
\hline
\end{tabular}




\begin{tabular}{|c|c|c|c|}
\hline August 6 & 868.69 & September 8 & 867.01 \\
\hline 7 & 868.61 & 9 & 866.94 \\
\hline 8 & 868.57 & 10 & 866.88 \\
\hline 10 & 868.55 & 11 & 866.83 \\
\hline 11 & 868.37 & 12 & 866.73 \\
\hline 12 & 868.31 & 13 & 866.78 \\
\hline 13 & 868.27 & 14 & 866.83 \\
\hline 16 & 868.11 & 15 & 866.78 \\
\hline 17 & 868.01 & 16 & 866.72 \\
\hline 20 & 867.81 & 17 & 866.63 \\
\hline 22 & 867.71 & 18 & 866.55 \\
\hline 26 & 867.47 & 19 & 866.50 \\
\hline 28 & 867.36 & 20 & 866.45 \\
\hline 29 & 867.31 & 21 & 866.40 \\
\hline 30 & 867.31 & 22 & 866.33 \\
\hline 31 & 867.31 & 23 & 866.35 \\
\hline September 1 & 867.29 & 24 & 866.38 \\
\hline 2 & 867.23 & 25 & 866.38 \\
\hline 3 & 867.15 & 26 & 866.39 \\
\hline 4 & 867.17 & 27 & 866.39 \\
\hline 5 & 867.15 & 28 & 866.39 \\
\hline 6 & 867.13 & 29 & 866.39 \\
\hline 7 & 867.05 & 30 & 866.41 \\
\hline
\end{tabular}


05429000 LAKE MONONA AT MADISON, WI

LOCATION.--Lat 4303'48", long 89²3'49" referenced to North American Datum of 1927, in SE 1/4 SW 1/4 sec.23, T.7 N., R.9 E., Dane County, WI, Hydrologic Unit 07090001, in Brittingham Park, in Madison.

SURFACE AREA.--5.3 $\mathrm{mi}^{2}$.

DRAINAGE AREA.--279 $\mathrm{mi}^{2}$ of which $36.6 \mathrm{mi}^{2}$ probably is noncontributing.

PERIOD OF RECORD.--September 1915 to current year (fragmentary) in reports of the Geological Survey. For 1856 to March 1917 in reports of Wisconsin Railroad Commission, volume 19.

REVISED RECORDS.--WSP 1338: Lake area. WDR WI-73-1: Drainage area.

GAGE.--Water-stage recorder. Datum of gage is $840.00 \mathrm{ft}$ above NGVD of 1929, or $5.60 \mathrm{ft}$ below City of Madison datum. Prior to Oct. 1 , 1979, datum $843.61 \mathrm{ft}$; prior to Nov. 15, 1971, nonrecording gage at same site.

REMARKS.--Lake level regulated by concrete dam with four 12-foot stop-log sections and 12-foot lock at outlet of Lake Waubesa. Gage-height telemeter at station.

EXTREMES FOR PERIOD OF RECORD.--Maximum gage height observed, $7.92 \mathrm{ft}$, June 15, 2008; minimum observed, $3.22 \mathrm{ft}$, Jan. 20,1965 , current datum.

EXTREMES FOR CURRENT YEAR.--Maximum recorded gage height, 7.92 ft, June 15; minimum recorded, $4.65 \mathrm{ft}$, Feb. 16. 
GAGE HEIGHT, FEET

WATER YEAR OCTOBER 2007 TO SEPTEMBER 2008

DAILY MEAN VALUES

[e, estimated]

\begin{tabular}{|c|c|c|c|c|c|c|c|c|c|c|c|c|}
\hline Day & Oct & Nov & Dec & Jan & Feb & Mar & Apr & May & Jun & Jul & Aug & Sep \\
\hline 1 & 6.24 & 5.32 & 4.85 & 4.76 & 4.70 & 4.69 & 5.19 & 6.18 & 5.59 & 7.37 & 6.96 & 6.52 \\
\hline 2 & 6.21 & 5.29 & 4.95 & 4.76 & 4.69 & 4.69 & 5.23 & 6.17 & 5.56 & 7.34 & 6.89 & 6.50 \\
\hline 3 & 6.18 & 5.26 & 4.95 & 4.74 & 4.67 & 4.82 & 5.25 & 6.14 & 5.56 & 7.29 & 6.84 & 6.42 \\
\hline 4 & 6.12 & 5.23 & 4.98 & 4.72 & 4.68 & 4.86 & 5.28 & 6.10 & 5.51 & 7.19 & 6.89 & 6.40 \\
\hline 5 & 6.07 & 5.18 & 5.00 & 4.70 & 4.70 & 4.86 & 5.28 & 6.09 & 5.65 & 7.11 & 6.88 & 6.40 \\
\hline 6 & 6.03 & 5.12 & 5.00 & 4.69 & 4.73 & 4.86 & 5.29 & 6.07 & 5.73 & 7.06 & 6.83 & 6.35 \\
\hline 7 & 5.98 & 5.10 & 5.01 & 4.79 & 4.75 & 4.84 & 5.28 & 6.10 & 5.82 & 7.05 & 6.78 & 6.31 \\
\hline 8 & 5.93 & 5.08 & 4.99 & 4.95 & 4.74 & 4.84 & 5.31 & 6.08 & 6.21 & 7.16 & 6.74 & 6.28 \\
\hline 9 & 5.86 & 5.06 & 4.99 & 5.02 & 4.73 & $\mathrm{e} 4.81$ & 5.44 & 6.05 & 6.92 & 7.11 & 6.70 & 6.25 \\
\hline 10 & 5.79 & 5.05 & 4.97 & 5.05 & 4.72 & e4.77 & 5.55 & 6.04 & 7.09 & 7.06 & 6.66 & 6.21 \\
\hline 11 & 5.75 & 5.04 & 5.00 & 5.06 & 4.72 & e4.70 & 5.86 & 6.03 & 7.19 & 7.37 & 6.63 & 6.19 \\
\hline 12 & 5.72 & 5.03 & 5.00 & 5.05 & 4.70 & e4.68 & 5.94 & 6.01 & 7.34 & e7.40 & 6.60 & 6.16 \\
\hline 13 & 5.69 & 5.01 & 4.99 & 5.03 & 4.69 & $\mathrm{e} 4.67$ & 5.95 & 6.00 & 7.71 & $\mathrm{e} 7.41$ & 6.60 & 6.24 \\
\hline 14 & 5.69 & 4.96 & 4.97 & 5.00 & 4.68 & $\mathrm{e} 4.71$ & 5.96 & 5.98 & 7.83 & e7.42 & 6.59 & 6.26 \\
\hline 15 & 5.68 & 4.93 & 4.96 & 4.98 & 4.67 & 4.76 & 5.97 & 5.96 & 7.90 & 7.45 & 6.57 & 6.23 \\
\hline 16 & 5.72 & 4.92 & 4.95 & 4.95 & 4.66 & 4.79 & 5.98 & 5.94 & 7.89 & 7.47 & 6.56 & 6.19 \\
\hline 17 & 5.72 & 4.91 & 4.93 & 4.93 & 4.74 & 4.80 & 5.97 & 5.92 & 7.86 & 7.46 & 6.56 & 6.16 \\
\hline 18 & 5.80 & 4.89 & 4.93 & 4.91 & 4.79 & 4.82 & 5.96 & 5.90 & 7.84 & 7.49 & 6.56 & 6.13 \\
\hline 19 & 5.78 & 4.89 & 4.91 & 4.88 & 4.79 & 4.84 & 5.97 & 5.88 & 7.83 & 7.52 & 6.56 & 6.08 \\
\hline 20 & 5.76 & 4.89 & 4.90 & 4.85 & 4.78 & 4.85 & 5.95 & 5.86 & 7.81 & 7.51 & 6.56 & 6.05 \\
\hline 21 & 5.74 & 4.89 & 4.89 & 4.82 & 4.76 & 4.91 & 5.95 & 5.85 & 7.79 & 7.48 & 6.55 & 6.03 \\
\hline 22 & 5.70 & 4.86 & 4.86 & 4.82 & 4.75 & 4.95 & 5.97 & 5.85 & 7.77 & 7.45 & 6.55 & 6.00 \\
\hline 23 & 5.66 & 4.84 & 4.94 & 4.80 & 4.74 & 4.95 & 5.98 & 5.83 & 7.74 & 7.40 & 6.53 & 5.97 \\
\hline 24 & 5.61 & 4.82 & 4.94 & 4.78 & 4.73 & 4.96 & 5.99 & 5.74 & 7.72 & 7.35 & 6.51 & 5.94 \\
\hline 25 & 5.57 & 4.81 & 4.92 & 4.76 & 4.72 & 4.97 & 6.25 & 5.68 & 7.68 & e7.33 & 6.50 & 5.91 \\
\hline 26 & 5.53 & 4.80 & 4.90 & 4.75 & 4.71 & 4.98 & 6.33 & 5.68 & 7.63 & 7.30 & 6.50 & 5.88 \\
\hline 27 & 5.49 & 4.80 & 4.88 & 4.73 & 4.70 & 5.02 & 6.31 & 5.64 & 7.60 & 7.24 & 6.50 & 5.85 \\
\hline 28 & 5.46 & 4.81 & 4.86 & 4.72 & 4.69 & 5.03 & 6.26 & 5.57 & 7.53 & 7.20 & 6.52 & 5.83 \\
\hline 29 & 5.42 & 4.80 & 4.85 & 4.72 & 4.70 & 5.04 & 6.22 & 5.53 & 7.48 & 7.14 & 6.53 & 5.79 \\
\hline 30 & 5.40 & 4.79 & 4.82 & 4.72 & --- & 5.04 & 6.20 & 5.62 & 7.43 & 7.09 & 6.52 & 5.74 \\
\hline 31 & 5.36 & --- & 4.79 & 4.71 & --- & 5.10 & --- & 5.62 & --- & 7.03 & 6.52 & --- \\
\hline Mean & 5.76 & 4.98 & 4.93 & 4.84 & 4.72 & 4.86 & 5.80 & 5.91 & 7.11 & 7.30 & 6.64 & 6.14 \\
\hline Max & 6.24 & 5.32 & 5.01 & 5.06 & 4.79 & 5.10 & 6.33 & 6.18 & 7.90 & 7.52 & 6.96 & 6.52 \\
\hline Min & 5.36 & 4.79 & 4.79 & 4.69 & 4.66 & 4.67 & 5.19 & 5.53 & 5.51 & 7.03 & 6.50 & 5.74 \\
\hline
\end{tabular}




\section{OCONOMOWOC LAKE NO. 1 (CENTER) AT OCONOMOWOC, WI}

LOCATION.--Lat 4305'51", long 88²7'35", in NW 1/4 SE 1/4 Sec.2, T.7 N., R.17 E., Waukesha County, Hydrologic Unit 07090001, at Oconomowoc. SURFACE AREA.--1.20 $\mathrm{mi}^{2}$.

PERIOD OF RECORD.--March 1986 to current year.

REMARKS.--Lake sampled near center at the deep hole. Water-quality analyses done by Wisconsin State Laboratory of Hygiene.

WATER-QUALITY DATA, FEBRUARY 27 TO AUGUST 25, 2008

(Milligrams per liter unless otherwise indicated)

Date

00078 Secchi-depth $(\mathrm{m})$

00098 Sampling depth $(\mathrm{m})$

00010 Water Temperature $\left({ }^{\circ} \mathrm{C}\right)$

$00400 \mathrm{pH}$ (standard units)

00095 Specific conductance $(\mu \mathrm{S} / \mathrm{cm})$

00300 Dissolved oxygen

32210 Chlorophyll a, phytoplankton ( $\mu \mathrm{g} / \mathrm{L})$

00665 Phosphorus, Total (as P)

00671 Orthophosphate, dissolved (as P)

00600 Total nitrogen

00631 Nitrate + nitrite, dissolved (as N)

00608 Ammonia, dissolved (as N)

00625 Ammonia + organic nitrogen, total (as N)

00623 Ammonia + organic nitrogen, dissolved (as N)

00900 Hardness (as CaCO3)

00417 Acid neutralizing capacity (as $\mathrm{CaCO} 3$ )

00915 Calcium, dissolved (Ca)

00925 Magnesium, dissolved (Mg)

00930 Sodium, dissolved $(\mathrm{Na})$

00935 Potassium, dissolved (K)

00940 Chloride, dissolved (Cl)

00945 Sulfate, dissolved (SO4)

00955 Silica, dissolved (SiO2)

01046 Iron ( $\mu \mathrm{g} / \mathrm{L})$

01056 Manganese $(\mu \mathrm{g} / \mathrm{L})$

00081 Apparent color (PCU)

63675 Turbidity (NTU)

70300 Solids, dissolved (at $180 \mathrm{C}^{\circ}$ $\begin{array}{lll}\text { Feb. } 27 & \text { Apr. } 24 & \text { June } 24\end{array}$

6.0

$\begin{array}{cc}0.5 & 18 \\ 0.6 & 3.6 \\ 7.6 & 7.5 \\ 622 & 660 \\ 14 & 5.0 \\ -- & -- \\ 0.012 & 0.028\end{array}$

0.5

$11.2 \quad 5.2$

$8.2 \quad 7.9$

594

12.4

1.29

0.012

0.006

0.59

0.147

$<.015$

0.44

280

213

53.6

35.3

2.4

47.1

29.8

7.51

$<100$

$<.5$

15

334

$\begin{array}{cc}0.5 & 18 \\ 23.5 & 7.5 \\ 8.3 & 7.5 \\ 568 & 590 \\ 8.9 & 4.4 \\ 1.33 & -- \\ 0.011 & 0.013\end{array}$

0.010

0.011

July 24

2.8

0.5

26.1

8.5

557

9.1

0.013

0.013

18

18
7.7

7.6

594

0.033

Aug. 25

1.8

0.5

23.9

8.5

557

8.4

6.43

0.012 
430551088273500 OCONOMOWOC LAKE NO. 1 (CENTER) AT OCONOMOWOC, WI

LAKE-DEPTH PROFILES, FEBRUARY 27 TO AUGUST 25, 2008

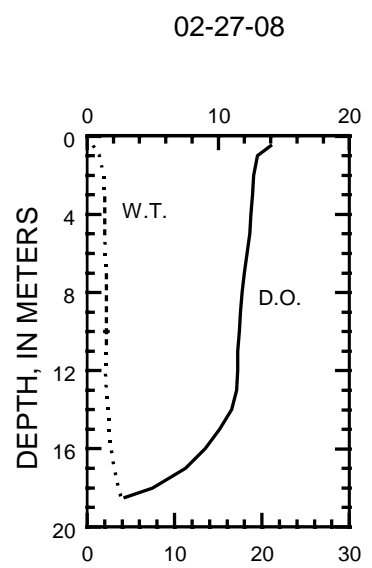

$$
\text { 04-24-08 }
$$

06-24-08

07-24-08

08-25-08

DISSOLVED OXYGEN (D.O.), IN MILLIGRAMS PER LITER
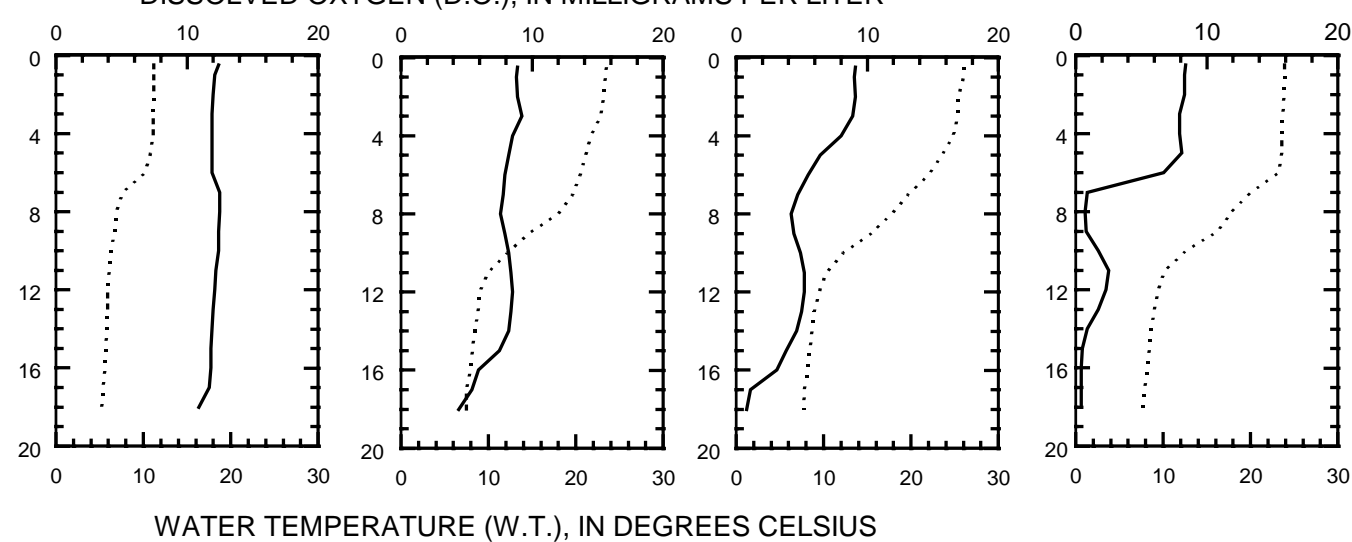

WATER TEMPERATURE (W.T.), IN DEGREES CELSIUS
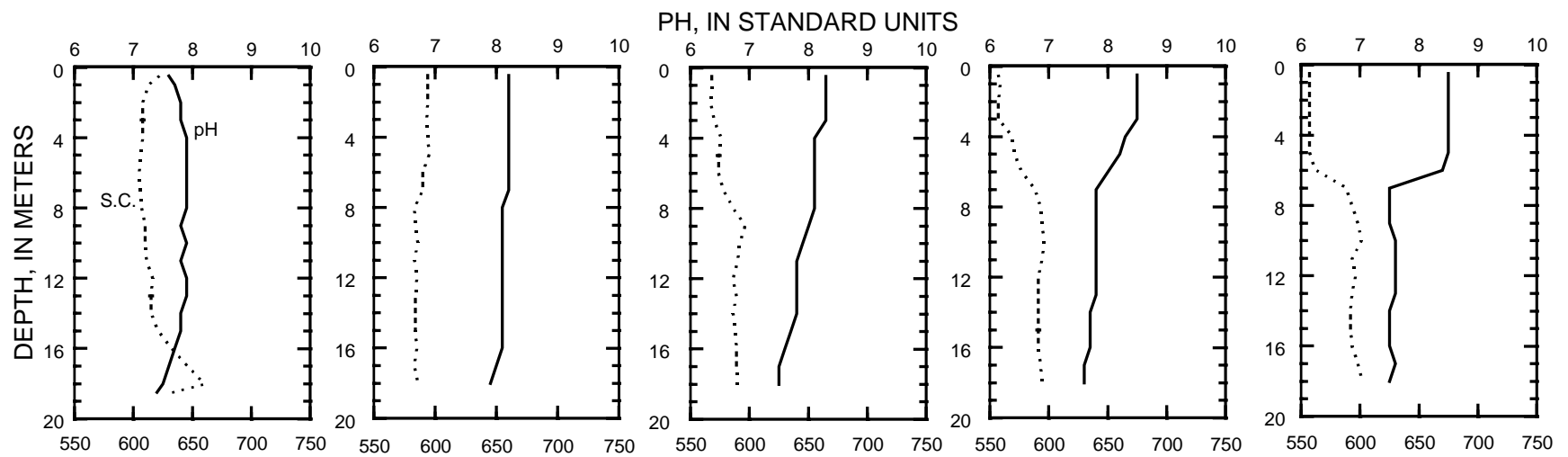

SPECIFIC CONDUCTANCE (S.C.), IN MICROSIEMENS PER CENTIMETER AT 25 DEGREES CELSIUS 

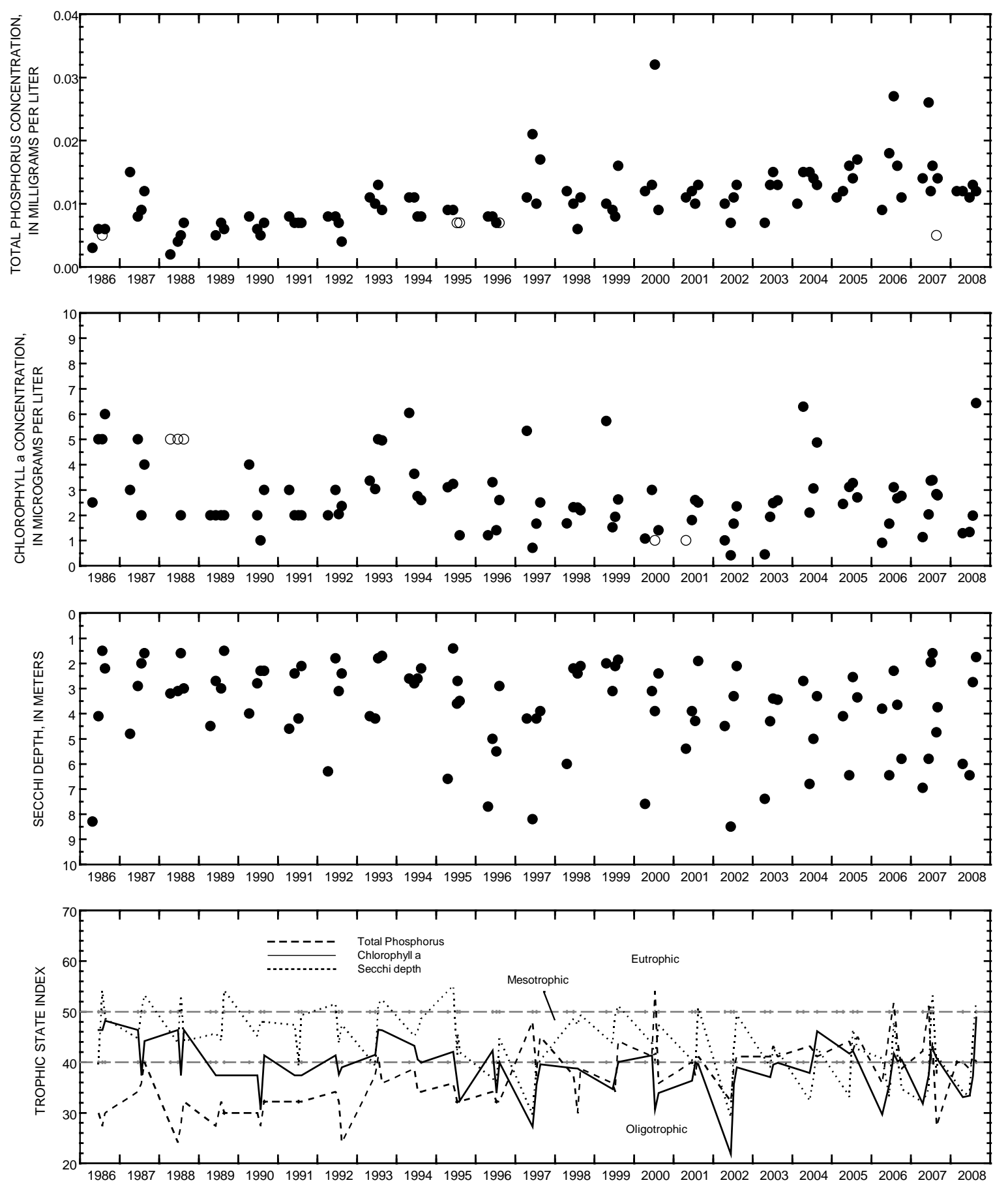

Surface total phosphorus, chlorophyll a concentrations, Secchi depths, and TSI data for Oconomowoc Lake, Center Site, at Oconomowoc, Wisconsin. 
430609088262200 OCONOMOWOC LAKE NO. 2 (OFF HEWITT POINT) AT OCONOMOWOC, WI

LOCATION.--Lat 4306'09", long 88²6'22", in NW 1/4 NW 1/4 sec.1, T.7 N., R.17 E., Waukesha County, Hydrologic Unit 07090001, at Oconomowoc.

SURFACE AREA.-1.20 $\mathrm{mi}^{2}$.

PERIOD OF RECORD.--March 1986 to current year.

REMARKS.--Lake sampled at the deepest point in northeast bay near Hewitt Point. Lake ice-covered during February sampling. Water-quality analyses done by Wisconsin State Laboratory of Hygiene.

WATER-QUALITY DATA, FEBRUARY 27 TO AUGUST 25, 2008

(Milligrams per liter unless otherwise indicated)

Date

00078 Secchi-depth $(\mathrm{m})$

00098 Sampling depth $(\mathrm{m})$

00010 Water Temperature $\left({ }^{\circ} \mathrm{C}\right.$

$00400 \mathrm{pH}$ (standard units)

00095 Specific conductance $(\mu \mathrm{S} / \mathrm{cm})$

00300 Dissolved oxygen

32210 Chlorophyll a, phytoplankton $(\mu \mathrm{g} / \mathrm{L})$

00665 Phosphorus, Total (as P)
Feb. 27

$\begin{array}{cc}0.5 & 14 \\ 2.7 & 4.6 \\ 7.6 & 7.4 \\ 648 & 740 \\ 12.6 & 3.9 \\ -- & -- \\ 0.011 & 0.012\end{array}$

Apr. 24

4.7

0.5

11.4

8.0

643

12.6

2.04

0.008

15
6.5

6.5

7.7

642

0.011
June 24

11.6

0.5

23.4

8.4

600

10.2

1.02

0.008
July 24

2.4

0.5

25.7

8.5

596

9.4

4.1

0.014
14
9.2

7.5

653
0.7$$
--
$$

0.017
Aug. 25

$0.5 \quad 14$

$24.1 \quad 9.1$

$8.6 \quad 7.5$

$608 \quad 672$

$8.3 \quad 0.4$

$3.62 \quad--$ 
430609088262200 OCONOMOWOC LAKE NO. 2 (OFF HEWITT POINT) AT OCONOMOWOC, WI

LAKE-DEPTH PROFILES, FEBRUARY 27 TO AUGUST 25, 2008

02-27-08
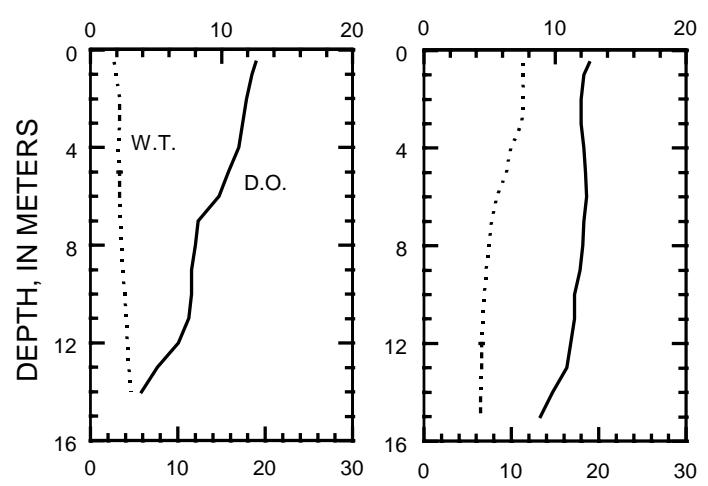

6-24-08

07-24-08

08-25-08

WATER TEMPERATURE (W.T.), IN DEGREES CELSIUS
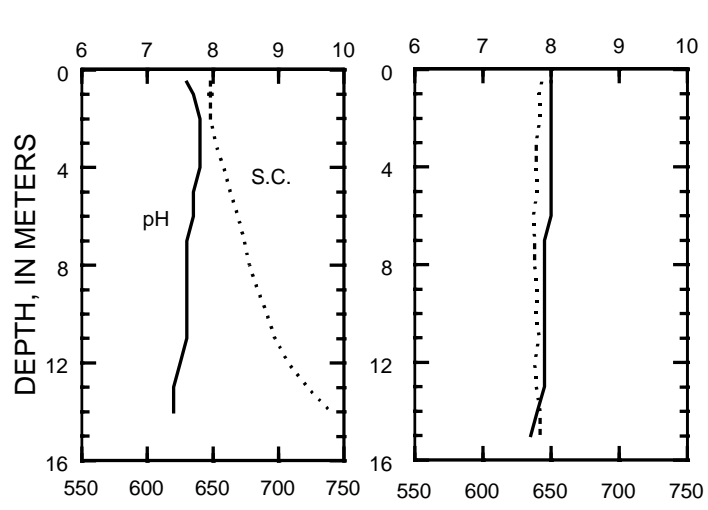

$\mathrm{PH}$, IN STANDARD UNITS
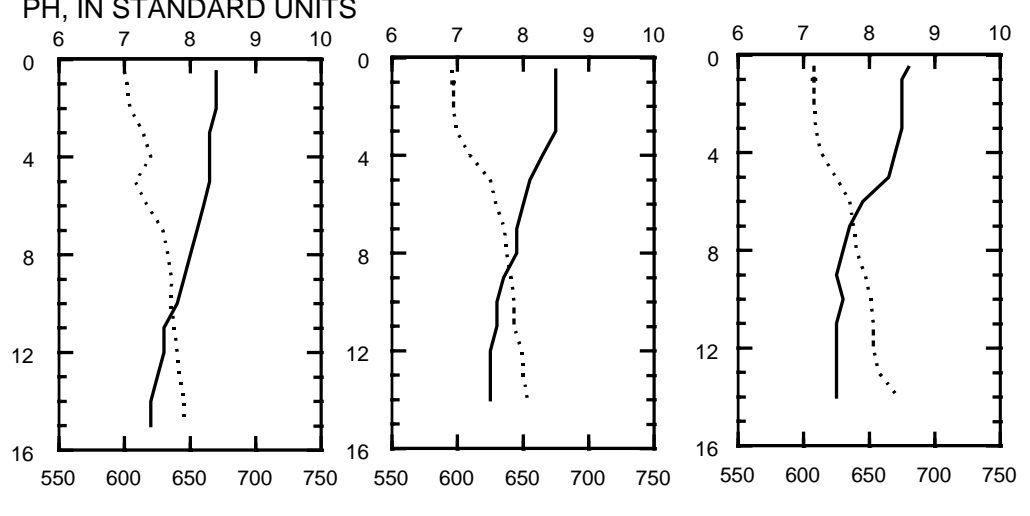

SPECIFIC CONDUCTANCE (S.C.), IN MICROSIEMENS PER CENTIMETER AT 25 DEGREES CELSIUS 

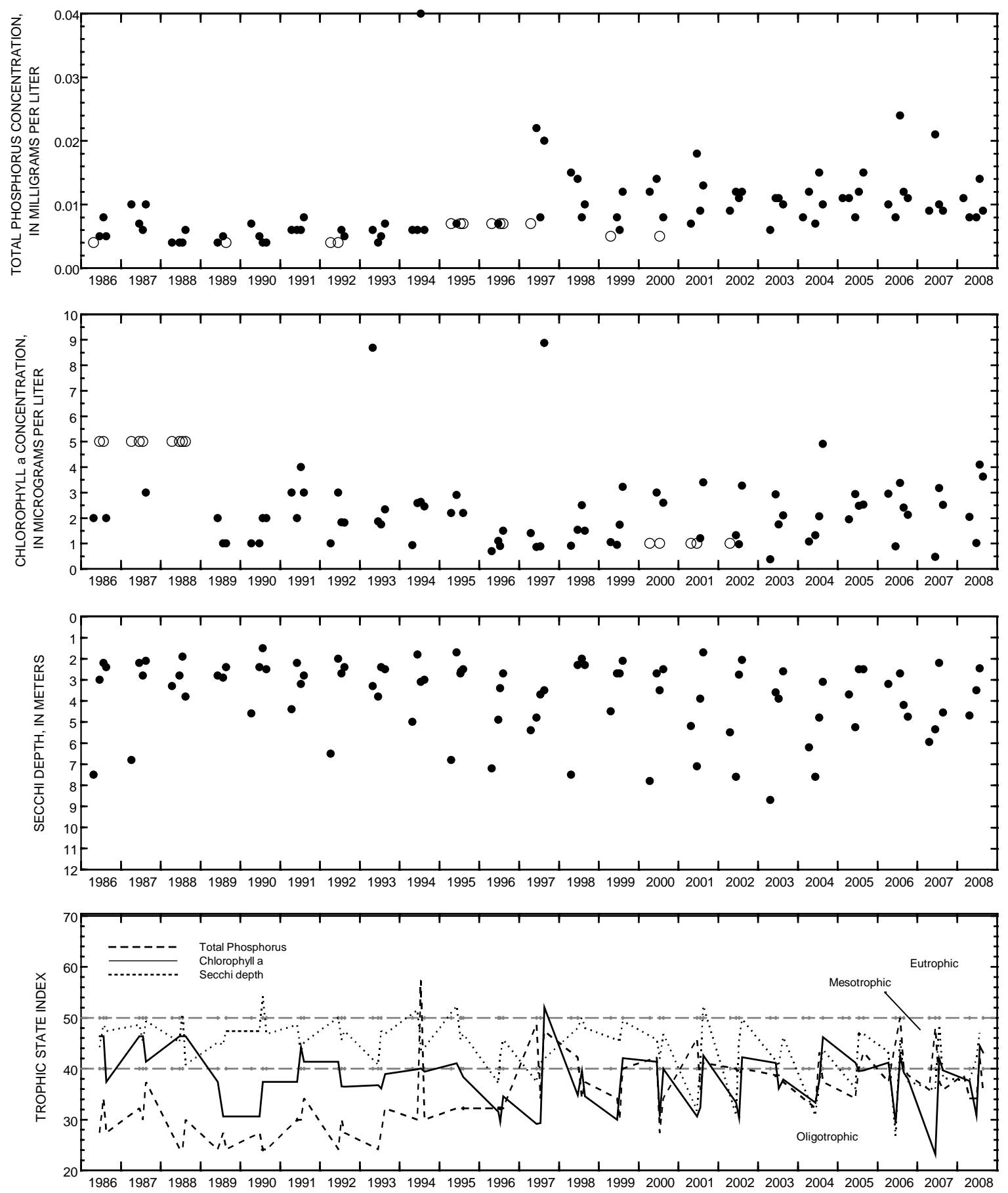

Surface total phosphorus, chlorophyll a concentrations, Secchi depths, and TSI data for Oconomowoc Lake, Hewitt Point, at Oconomowoc, Wisconsin.

(Open circles on the first two plots indicate laboratory detection limit for selected analyses. Actual concentrations for these particular analyses are less than the plotted circles.) 


\section{OKAUCHEE LAKE AT OKAUCHEE, WI}

LOCATION.--Lat 4307'23", long $88^{\circ} 25^{\prime} 21^{\prime \prime}$, in SE $1 / 4$ SE 1/4 sec.25, T.8 N., R.17 E., Waukesha County, Hydrologic Unit 07090001, at Okauchee.

DRAINAGE AREA.--80.7 $\mathrm{mi}^{2}$.

PERIOD OF RECORD.--February 1984 to September 2006, April to August 2008.

LAKE-STAGE GAGE.--Datum of gage is $869.00 \mathrm{ft}$ above NGVD of 1929.

REMARKS.--Lake sampled near center at the deep hole. Lake ice-covered during February sampling. Water-quality analyses done by Wisconsin State Laboratory of Hygiene.

Date

00078 Secchi-depth $(\mathrm{m})$

00098 Sampling depth $(\mathrm{m})$

00010 Water Temperature $\left({ }^{\circ} \mathrm{C}\right)$

$00400 \mathrm{pH}$ (standard units)

00095 Specific conductance $(\mu \mathrm{S} / \mathrm{cm})$

00300 Dissolved oxygen

32210 Chlorophyll a, phytoplankton $(\mu \mathrm{g} / \mathrm{L})$

00665 Phosphorus, Total (as P)

00671 Orthophosphate, dissolved (as P)

00600 Total nitrogen

00631 Nitrate + nitrite, dissolved (as N)

00608 Ammonia, dissolved (as $\mathrm{N}$ )

00625 Ammonia + organic nitrogen, total (as N)

00623 Ammonia + organic nitrogen, dissolved (as N)

00900 Hardness (as CaCO3)

00417 Acid neutralizing capacity (as $\mathrm{CaCO} 3$ )

00915 Calcium, dissolved (Ca)

00925 Magnesium, dissolved (Mg)

00930 Sodium, dissolved ( $\mathrm{Na}$ )

00935 Potassium, dissolved (K)

00940 Chloride, dissolved (Cl)

00945 Sulfate, dissolved (SO4)

00955 Silica, dissolved (SiO2)

01046 Iron ( $\mu \mathrm{g} / \mathrm{L})$

01056 Manganese $(\mu \mathrm{g} / \mathrm{L})$

00081 Apparent color (PTU)

63675 Turbidity (NTU)

70300 Solids, dissolved (at $180 \mathrm{C}^{\circ}$ )
WATER-QUALITY DATA, APRIL 23 TO AUGUST 25, 2008

(Milligrams per liter unless otherwise indicated)

\begin{tabular}{|c|c|c|c|c|c|c|c|}
\hline \multicolumn{2}{|c|}{ Apr. 23} & \multicolumn{2}{|c|}{ June 24} & \multicolumn{2}{|c|}{ July 24} & \multicolumn{2}{|c|}{ Aug. 25} \\
\hline \multicolumn{2}{|c|}{3.4} & \multicolumn{2}{|c|}{3.1} & \multicolumn{2}{|c|}{3.0} & \multicolumn{2}{|c|}{1.6} \\
\hline 0.5 & 28 & 0.5 & 27 & 0.5 & 27 & 0.5 & 27 \\
\hline 11.7 & 4.6 & 23.1 & 5.2 & 25.8 & 5.5 & 23.7 & 5.5 \\
\hline 8.0 & 7.8 & 8.1 & 7.3 & 8.5 & 7.5 & 8.6 & 7.4 \\
\hline 602 & 591 & 551 & 597 & 552 & 598 & 554 & 605 \\
\hline 13.7 & 11.3 & 10.5 & 1.9 & 8.7 & 1.4 & 8.4 & 0.5 \\
\hline 9.8 & -- & 10.4 & -- & 8.42 & -- & 12.7 & -- \\
\hline 0.030 & 0.023 & 0.019 & 0.015 & 0.025 & 0.043 & 0.02 & 0.041 \\
\hline 0.003 & -- & -- & -- & 0.004 & -- & -- & -- \\
\hline 1.3 & -- & -- & -- & -- & -- & -- & -- \\
\hline 0.738 & -- & -- & -- & 0.268 & -- & -- & -- \\
\hline$<.015$ & -- & -- & -- & $<.015$ & -- & -- & -- \\
\hline 0.61 & -- & -- & -- & -- & -- & -- & -- \\
\hline -- & -- & -- & -- & 0.67 & -- & -- & -- \\
\hline 290 & -- & -- & -- & -- & -- & -- & -- \\
\hline 227 & -- & -- & -- & -- & -- & -- & -- \\
\hline 59.6 & -- & -- & -- & -- & -- & -- & -- \\
\hline 34.2 & -- & -- & -- & -- & -- & -- & -- \\
\hline 18.2 & -- & -- & -- & -- & -- & -- & -- \\
\hline 2.3 & -- & -- & -- & -- & -- & -- & -- \\
\hline 41.9 & -- & -- & -- & -- & -- & -- & -- \\
\hline 29.2 & -- & -- & -- & -- & -- & -- & -- \\
\hline 6.19 & -- & -- & -- & -- & -- & -- & -- \\
\hline$<100$ & -- & -- & -- & -- & -- & -- & -- \\
\hline$<.5$ & -- & -- & -- & -- & -- & -- & -- \\
\hline 20 & -- & -- & -- & -- & -- & -- & -- \\
\hline$<1.0$ & -- & -- & -- & -- & -- & -- & -- \\
\hline 342 & -- & -- & -- & -- & -- & -- & -- \\
\hline
\end{tabular}




\section{OKAUCHEE LAKE AT OKAUCHEE, WI}

LAKE-DEPTH PROFILES, APRIL 2310 TO AUGUST 25, 2008

04-23-08
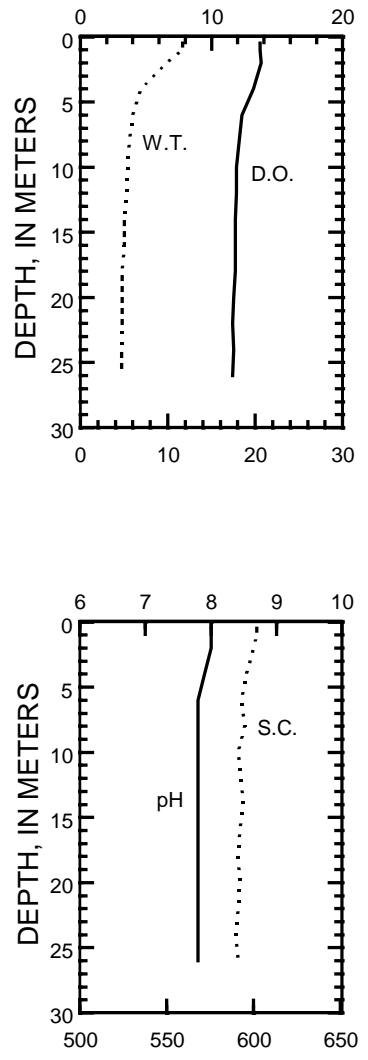

06-24-08

DISSOLVED OXYGEN (D.O.), IN MILLIGRAMS PER LITER

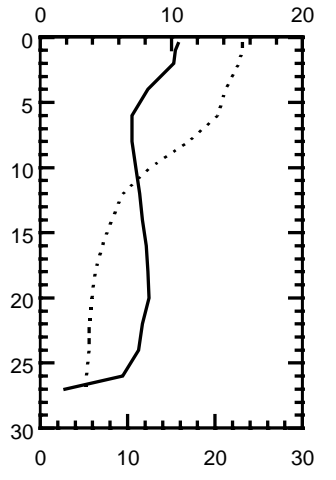

WATER TEMPERATURE (W.T.), IN DEGREES CELSIUS

$\mathrm{PH}$, IN STANDARD UNITS

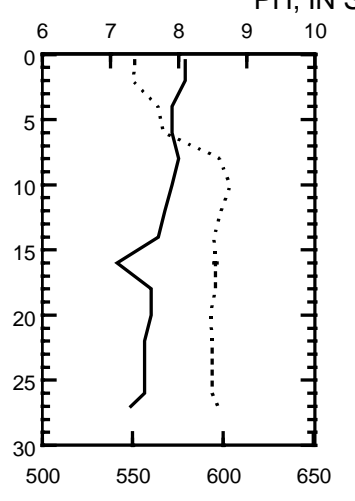

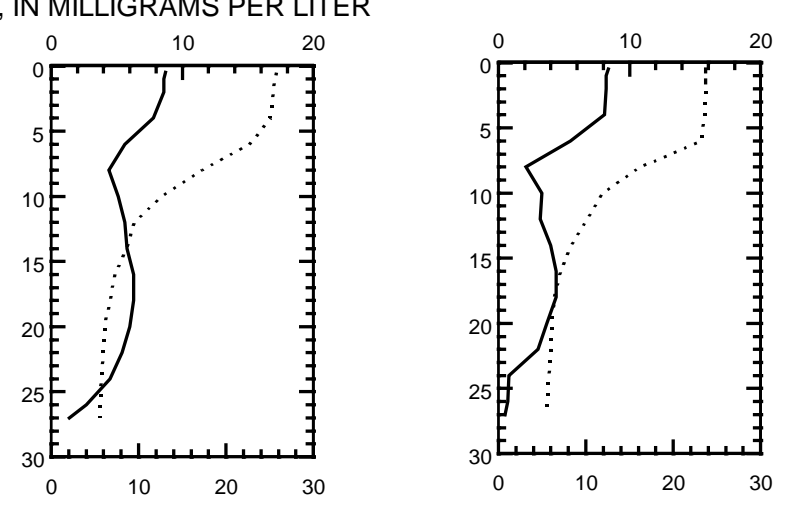

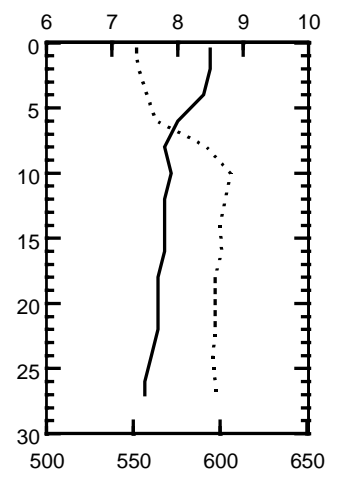

08-25-08

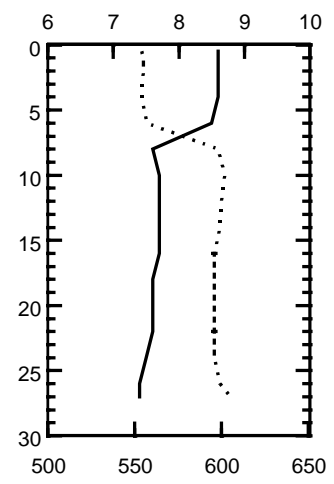

SPECIFIC CONDUCTANCE (S.C.), IN MICROSIEMENS PER CENTIMETER AT 25 DEGREES CELSIUS 

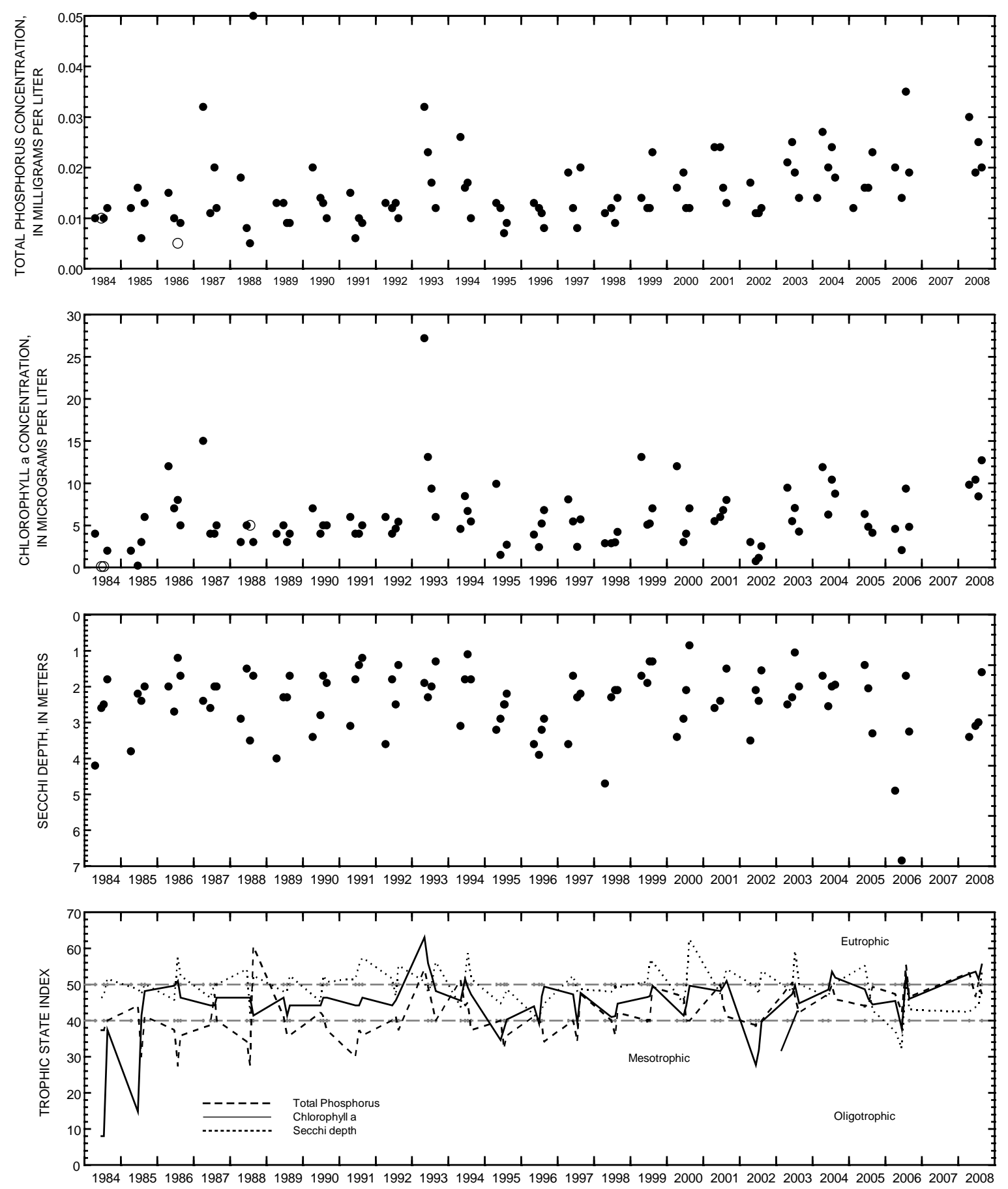

Surface total phosphorus, chlorophyll a concentrations, Secchi depths, and TSI data for Okauchee Lake, near Okauchee, Wisconsin. 
430759088244200 OKAUCHEE LAKE, NO. 1, NEAR OKAUCHEE, WI

LOCATION.--Lat 4307'59", long 88²4'42", in NE 1/4 NW 1/4 sec.30, T.8 N., R.18 E., Waukesha County, Hydrologic Unit 07090001, near Okauchee.

PERIOD OF RECORD.--April 1986 to September 2006, April to August 2008.

LAKE-STAGE GAGE.--Datum of gage is $869.00 \mathrm{ft}$ above NGVD of 1929.

REMARKS.--Lake sampled in Crane's Nest Bay, in the northeast part of the lake, at an approximate depth of 2 m. Water-quality analyses done by Wisconsin State Laboratory of Hygiene.

Date

00078 Secchi-depth $(\mathrm{m})$

00098 Sampling depth $(\mathrm{m})$

00010 Water Temperature $\left({ }^{\circ} \mathrm{C}\right)$

$00400 \mathrm{pH}$ (standard units)

00095 Specific conductance $(\mu \mathrm{S} / \mathrm{cm})$

00300 Dissolved oxygen

32210 Chlorophyll a, phytoplankton $(\mu \mathrm{g} / \mathrm{L})$

00665 Phosphorus, Total (as P)
WATER-QUALITY DATA, APRIL 23 TO AUGUST 25, 2008

(Milligrams per liter unless otherwise indicated)

\begin{tabular}{cc}
\multicolumn{3}{c}{ Apr. 23 } \\
\hline \multicolumn{3}{c}{2.1} \\
0.5 & 3.0 \\
12.1 & 10.0 \\
8.1 & 8.1 \\
618 & 601 \\
12.2 & 14.1 \\
11.8 & -- \\
0.039 & 0.038
\end{tabular}

\begin{tabular}{|c|c|}
\hline \multicolumn{2}{|c|}{ June 24} \\
\hline \multicolumn{2}{|c|}{2.2} \\
\hline 0.5 & 2.0 \\
\hline 23.1 & 21.7 \\
\hline 8.2 & 7.8 \\
\hline 526 & 527 \\
\hline 10.7 & 7.3 \\
\hline 15.1 & -- \\
\hline 0.047 & 0.042 \\
\hline
\end{tabular}

\begin{tabular}{cc}
\multicolumn{3}{c}{ Aug. 25 } \\
\hline \multicolumn{3}{c}{1.8} \\
0.5 & 1.5 \\
23.0 & 23.0 \\
8.5 & 8.5 \\
608 & 605 \\
8.8 & 8.8 \\
4.27 & -- \\
0.020 & 0.021
\end{tabular}



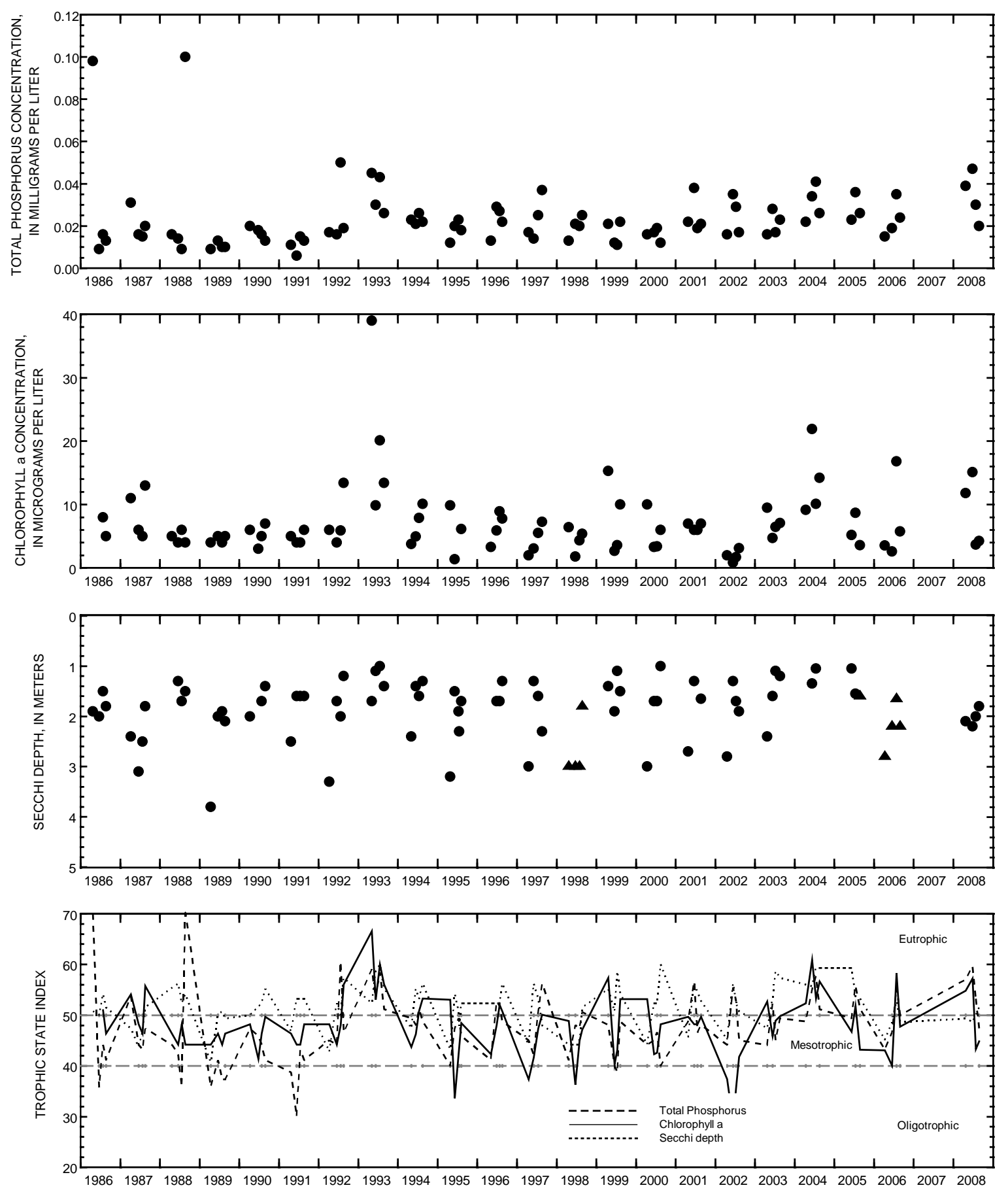

Surface total phosphorus, chlorophyll a concentrations, Secchi depths, and TSI data for Okauchee Lake, No. 1, near Okauchee, Wisconsin.

(Triangles in Secchi plot indicate maximum depth at sampling site Actual Secchi depth on these days was greater than the plotted triangles.) 


\section{OKAUCHEE LAKE, NO. 2, AT OKAUCHEE, WI}

LOCATION.--Lat 4306'45", long 88²6'45", in SE 1/4 NE 1/4 sec.35, T.8 N., R.17 E., Waukesha County, Hydrologic Unit 07090001, at Okauchee.

PERIOD OF RECORD.--April 1986 to September 2006, April to August 2008.

LAKE-STAGE GAGE.--Datum of gage is $869.00 \mathrm{ft}$ above NGVD of 1929.

REMARKS.--Lake sampled in Lower Okauchee Lake, at an approximate depth of $3 \mathrm{~m}$. Water-quality analyses done by Wisconsin State Laboratory of Hygiene.

WATER-QUALITY DATA, APRIL 23 TO AUGUST 25, 2008

(Milligrams per liter unless otherwise indicated)

Date

00078 Secchi-depth $(\mathrm{m})$

00098 Sampling depth $(\mathrm{m})$

00010 Water Temperature $\left({ }^{\circ} \mathrm{C}\right)$

$00400 \mathrm{pH}$ (standard units)

00095 Specific conductance $(\mu \mathrm{S} / \mathrm{cm})$

00300 Dissolved oxygen

32210 Chlorophyll a, phytoplankton $(\mu \mathrm{g} / \mathrm{L})$

00665 Phosphorus, Total (as P)

\begin{tabular}{cc}
\multicolumn{3}{c}{ Apr. 23} \\
\hline \multicolumn{3}{c}{2.1} \\
0.5 & 2.0 \\
13.5 & 11.9 \\
8.2 & 8.2 \\
592 & 592 \\
14.4 & 14.4 \\
4.22 & -- \\
0.024 & 0.033
\end{tabular}

\begin{tabular}{cc}
\multicolumn{3}{c}{ June 24} \\
\hline \multicolumn{3}{c}{2.8} \\
0.5 & 2.5 \\
23.3 & 22.9 \\
7.9 & 8.0 \\
555 & 555 \\
10.1 & 9.5 \\
4.21 & -- \\
0.018 & 0.016
\end{tabular}

July 24

\begin{tabular}{cc}
\multicolumn{2}{c}{2.8} \\
0.5 & 2.5 \\
26.2 & 25.6 \\
8.4 & 8.4 \\
539 & 539 \\
8.8 & 9.0 \\
3.52 & -- \\
0.018 & 0.016
\end{tabular}

\begin{tabular}{cc}
\multicolumn{3}{c}{ Aug. 25 } \\
\hline \multicolumn{3}{c}{1.4} \\
0.5 & 2.5 \\
24.1 & 23.9 \\
8.6 & 8.6 \\
530 & 529 \\
8.9 & 8.3 \\
8.27 & -- \\
0.019 & 0.021
\end{tabular}



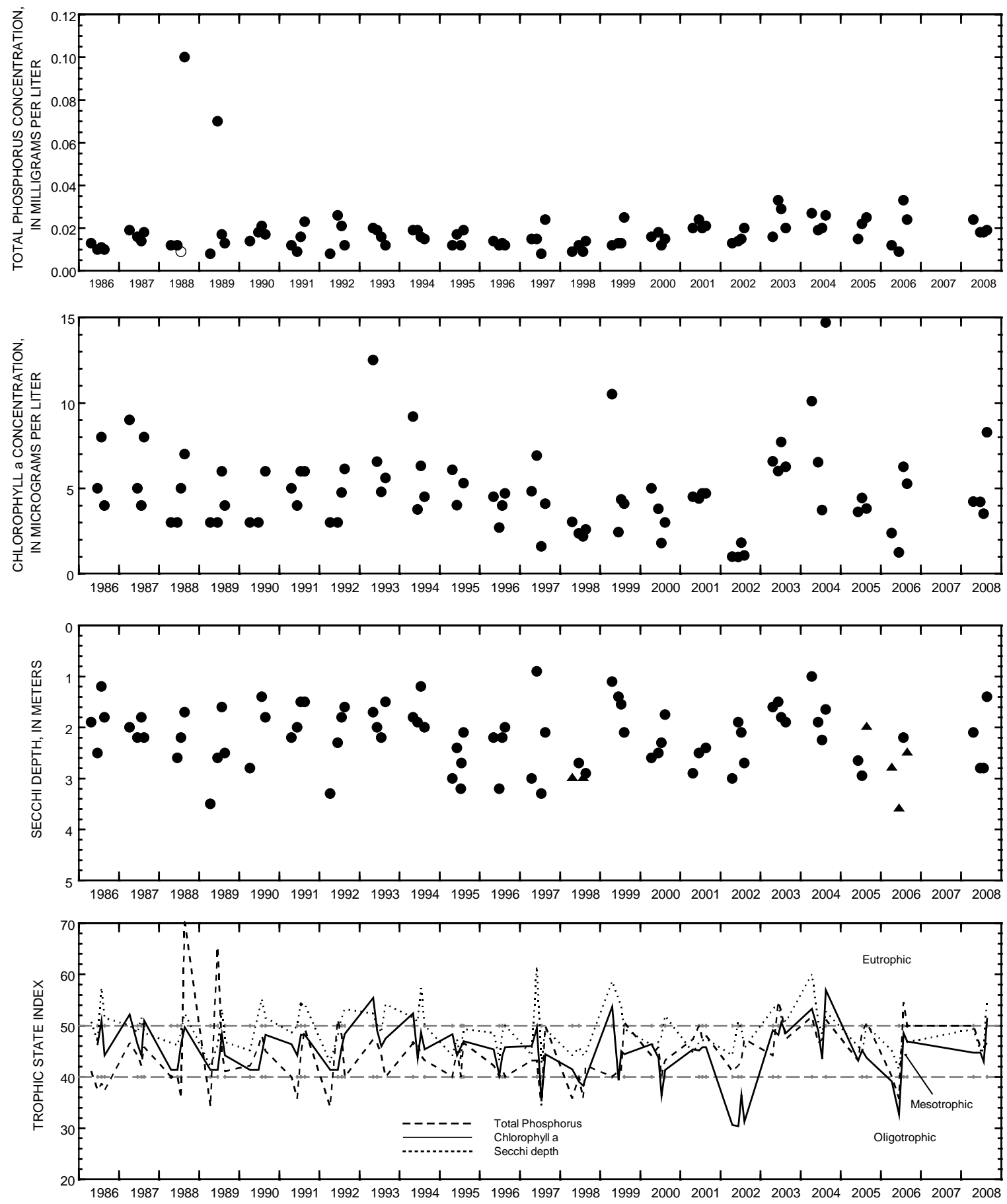

Surface total phosphorus, chlorophyll a concentrations, Secchi depths, and TSI data for Okauchee Lake, No. 2, near Okauchee, Wisconsin.

(Open circles on the first two plots indicate laboratory detection limit for selected analyses. Actual concentrations for these particular analyses are less than the plotted circles.)

(Triangles in Secchi plot indicate maximum depth at sampling site.

Actual Secchi depth on these days was greater than the plotted triangles.) 


\section{OKAUCHEE LAKE, NO. 3, AT OKAUCHEE, WI}

LOCATION.--Lat 4306'42", long $88^{\circ} 25^{\prime} 24^{\prime \prime}$, in NE 1/4 SE 1/4 sec.36, T.8 N., R.17 E., Waukesha County, Hydrologic Unit 07090001, at Okauchee.

PERIOD OF RECORD.--April 1986 to September 2006, April to August 2008.

LAKE-STAGE GAGE.--Datum of gage is $869.00 \mathrm{ft}$ above NGVD of 1929.

REMARKS.--Lake sampled in Ice House Bay, in the southern part of the lake, at an approximate depth of 5 m. Water-quality analyses done by Wisconsin State Laboratory of Hygiene.

WATER-QUALITY DATA, APRIL 23 TO AUGUST 25, 2008

(Milligrams per liter unless otherwise indicated)

Date

00078 Secchi-depth $(\mathrm{m})$

00098 Sampling depth $(\mathrm{m})$

00010 Water Temperature $\left({ }^{\circ} \mathrm{C}\right)$

$00400 \mathrm{pH}$ (standard units)

00095 Specific conductance $(\mu \mathrm{S} / \mathrm{cm})$

00300 Dissolved oxygen

32210 Chlorophyll a, phytoplankton $(\mu \mathrm{g} / \mathrm{L})$

00665 Phosphorus, Total (as P)

\begin{tabular}{cc}
\multicolumn{3}{c}{ Apr. 23 } \\
\hline \multicolumn{3}{c}{3.3} \\
0.5 & \\
11.4 & 4.0 \\
8.2 & 6.9 \\
597 & 8.0 \\
14 & 592 \\
4.11 & 12.9 \\
0.026 & -- \\
& 0.029
\end{tabular}

\begin{tabular}{cc}
\multicolumn{3}{c}{ June 24} \\
\hline \multicolumn{3}{c}{4.0} \\
0.5 & 5.0 \\
23.7 & 18.6 \\
8.5 & 7.8 \\
554 & 583 \\
10.2 & 6.7 \\
3.94 & -- \\
0.013 & 0.015
\end{tabular}

\begin{tabular}{cc}
\multicolumn{3}{c}{ July 24} \\
\hline \multicolumn{3}{c}{3.2} \\
0.5 & 4.0 \\
25.6 & 23.9 \\
8.3 & 7.7 \\
545 & 558 \\
7.7 & 2.6 \\
2.64 & -- \\
0.016 & 0.018
\end{tabular}

\begin{tabular}{cc}
\multicolumn{3}{c}{ Aug. 25 } \\
\hline \multicolumn{3}{c}{1.6} \\
0.5 & 4.5 \\
23.8 & 23.3 \\
8.5 & 8.5 \\
548 & 551 \\
7.8 & 1.7 \\
13.7 & -- \\
0.027 & 0.022
\end{tabular}



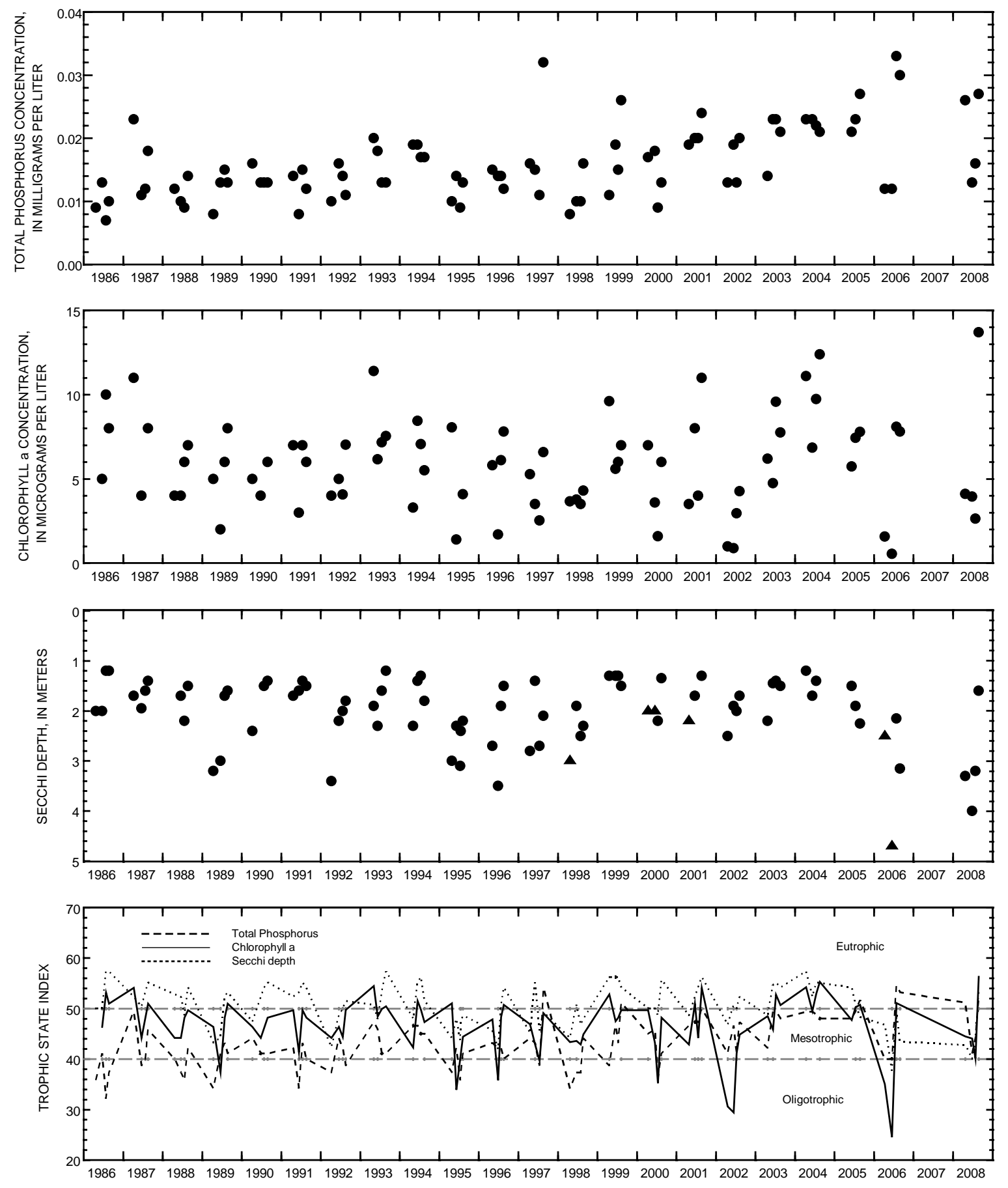

Surface total phosphorus, chlorophyll a concentrations, Secchi depths, and TSI data for Okauchee Lake, No. 3, near Okauchee, Wisconsin. 


\section{OKAUCHEE LAKE, NO. 4, AT OKAUCHEE, WI}

LOCATION.--Lat 4307'57", long 88²6'17", in NW 1/4 NW 1/4 sec.25, T.8 N., R.17 E., Waukesha County, Hydrologic Unit 07090001, at Okauchee.

PERIOD OF RECORD.--June 1986 to September 2006, April to August 2008.

LAKE-STAGE GAGE.--Datum of gage is $869.00 \mathrm{ft}$ above NGVD of 1929.

REMARKS.--Lake sampled near McDowell (Crazyman's) Island, in the northwest bay of the lake, at an approximate depth of $2 \mathrm{~m}$. Water-quality analyses done by Wisconsin State Laboratory of Hygiene.

Date

00078 Secchi-depth $(m)$

00098 Sampling depth $(\mathrm{m})$

00010 Water Temperature $\left({ }^{\circ} \mathrm{C}\right)$

$00400 \mathrm{pH}$ (standard units)

00095 Specific conductance $(\mu \mathrm{S} / \mathrm{cm})$

00300 Dissolved oxygen

32210 Chlorophyll a, phytoplankton ( $\mu \mathrm{g} / \mathrm{L})$

00665 Phosphorus, Total (as P)
WATER-QUALITY DATA, APRIL 23 TO AUGUST 25, 2008

(Milligrams per liter unless otherwise indicated)

\begin{tabular}{cc}
\multicolumn{3}{c}{ Apr. 23 } \\
\hline \multicolumn{3}{c}{1.8} \\
0.5 & \\
14.2 & 1.5 \\
8.0 & 13.9 \\
603 & 8.0 \\
12.6 & 602 \\
2.97 & 13.1 \\
0.021 & -- \\
& 0.025
\end{tabular}

\begin{tabular}{|c|c|}
\hline \multicolumn{2}{|c|}{ July 24} \\
\hline \multicolumn{2}{|c|}{1.8} \\
\hline 0.5 & 1.5 \\
\hline 26.1 & 25.8 \\
\hline 8.5 & 8.5 \\
\hline 515 & 517 \\
\hline 9.9 & 10.0 \\
\hline 1.47 & -- \\
\hline 0.014 & 0.016 \\
\hline
\end{tabular}

\begin{tabular}{cc}
\multicolumn{3}{c}{ Aug. 25 } \\
\hline \multicolumn{3}{c}{1.0} \\
0.5 & \\
23.7 & 1.5 \\
8.7 & 23.7 \\
527 & 8.7 \\
9.1 & 526 \\
8.33 & 8.7 \\
0.018 & -- \\
& 0.022
\end{tabular}



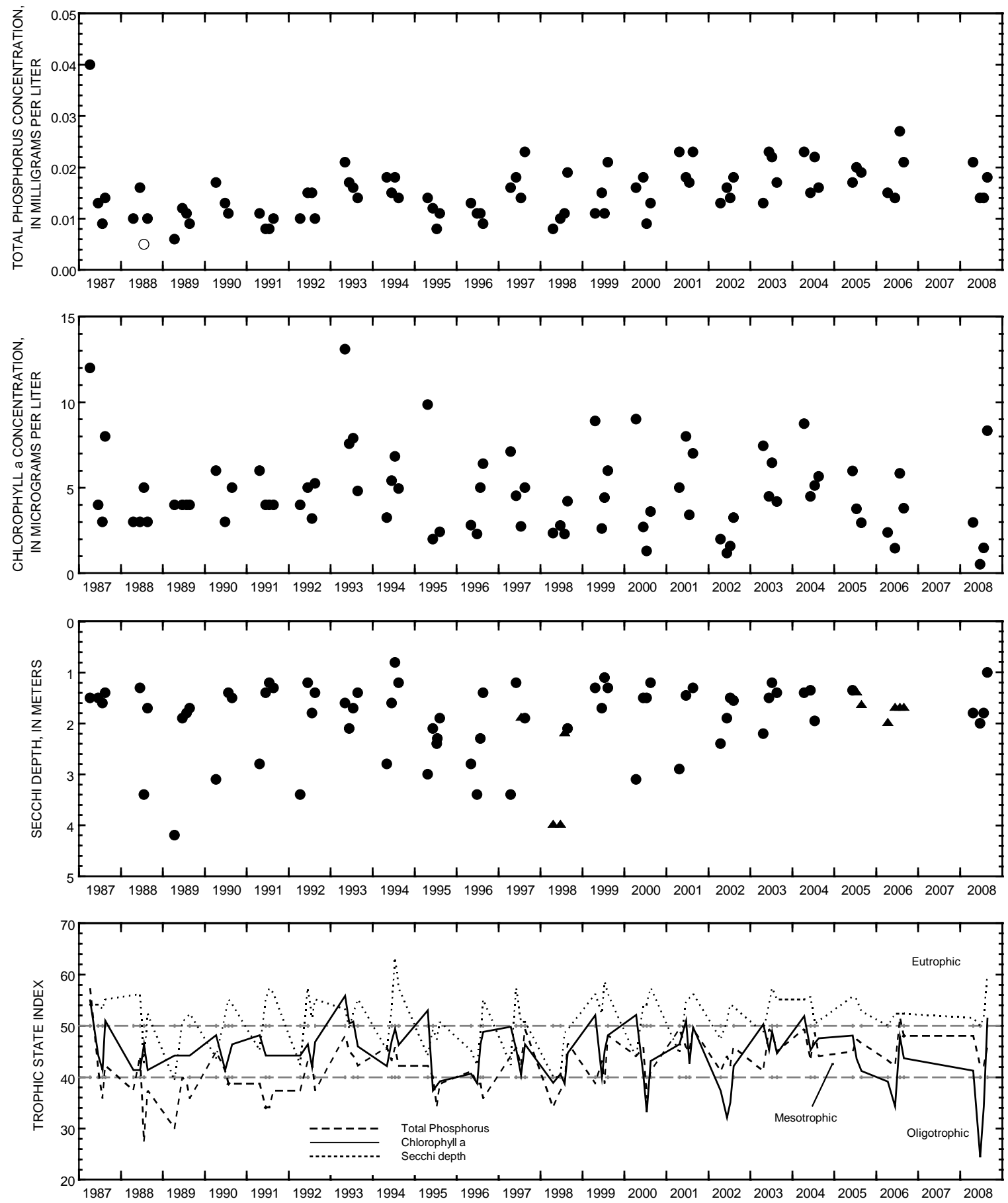

Surface total phosphorus, chlorophyll a concentrations, Secchi depths, and TSI data for Okauchee Lake, No. 4, near Okauchee, Wisconsin.

(Open circles on the first two plots indicate laboratory detection limit for selected analyses. Actual concentrations for these particular analyses are less than the plotted circles.)

(Triangles in Secchi plot indicate maximum depth at sampling site.

Actual Secchi depth on these days was greater than the plotted triangles.) 


\section{POWERS LAKE AT POWERS LAKE, W}

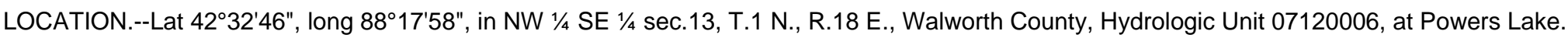

SURFACE AREA.-0.72 $\mathrm{mi}^{2}$

DRAINAGE AREA.--3.42 $\mathrm{mi}^{2}$.

PERIOD OF RECORD.--March 1986 to August 1996, and April 1998 to current year.

REMARKS.--Lake sampled near center at the deep hole. Water-quality analyses done by Wisconsin State Laboratory of Hygiene.

WATER-QUALITY DATA, JUNE 23 TO AUGUST 22, 2008

(Milligrams per liter unless otherwise indicated)

Date

00078 Secchi-depth $(\mathrm{m})$

00098 Sampling depth $(\mathrm{m})$

00010 Water Temperature $\left({ }^{\circ} \mathrm{C}\right)$

$00400 \mathrm{pH}$ (standard units)

00095 Specific conductance $(\mu \mathrm{S} / \mathrm{cm})$

00300 Dissolved oxygen

32210 Chlorophyll a, phytoplankton $(\mu \mathrm{g} / \mathrm{L})$

00665 Phosphorus, Total (as P)

00671 Orthophosphate, dissolved (as P)

00600 Total nitrogen

00631 Nitrate + nitrite, dissolved (as N)

00608 Ammonia, dissolved (as $\mathrm{N}$ )

00625 Ammonia + organic nitrogen, total (as N)

00623 Ammonia + organic nitrogen, dissolved (as N)

\begin{tabular}{|c|c|}
\hline \multicolumn{2}{|c|}{ June 23} \\
\hline \multicolumn{2}{|c|}{3.0} \\
\hline 0.5 & 10 \\
\hline 22.8 & 15.6 \\
\hline 8.4 & 7.5 \\
\hline 510 & 544 \\
\hline 9.9 & 1.4 \\
\hline 8.51 & -- \\
\hline 0.018 & 0.017 \\
\hline-- & -- \\
\hline-- & -- \\
\hline-- & -- \\
\hline-- & -- \\
\hline-- & -- \\
\hline -- & -- \\
\hline
\end{tabular}

\begin{tabular}{cc}
\multicolumn{3}{c}{ Aug. 22 } \\
\hline \multicolumn{3}{c}{2.6} \\
0.5 & 10 \\
24.7 & 15.8 \\
8.7 & 7.3 \\
507 & 574 \\
8.1 & 0.4 \\
7.04 & -- \\
0.018 & 0.052 \\
-- & -- \\
-- & -- \\
-- & -- \\
-- & -- \\
-- & -- \\
-- & --
\end{tabular}


423246088175800 POWERS LAKE AT POWERS LAKE, WI

LAKE-DEPTH PROFILES, JUNE 23 TO AUGUST 22, 2008

06-23-08
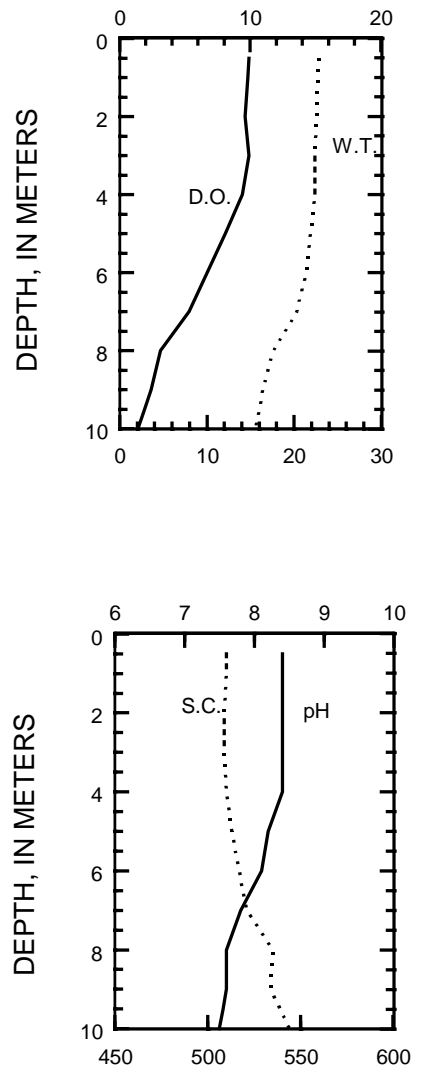

07-28-08

DISSOLVED OXYGEN (D.O.), IN MILLIGRAMS PER LITER

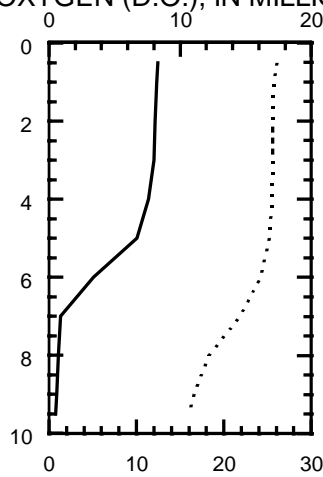

WATER TEMPERATURE (W.T.), IN DEGREES CELSIUS

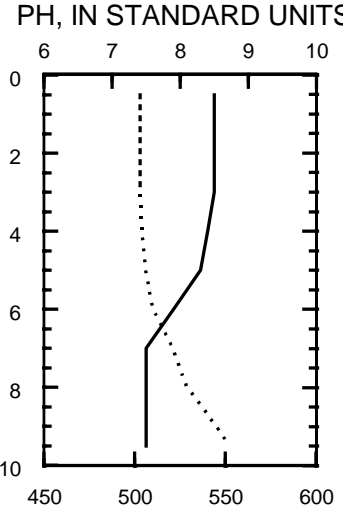

$08-22-08$
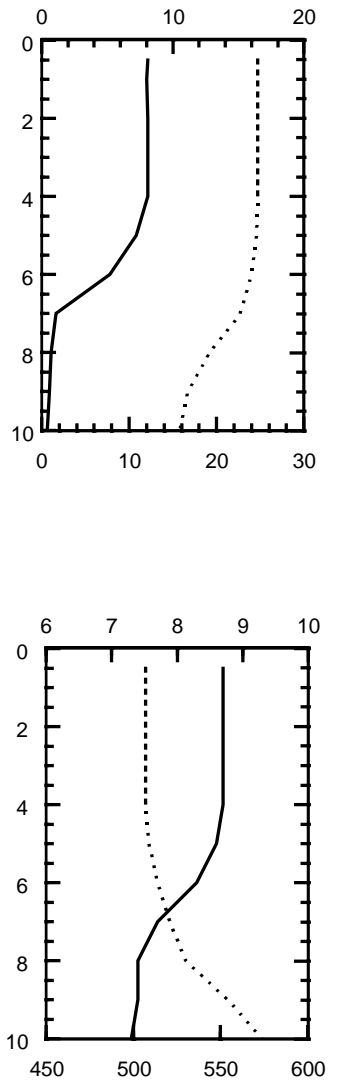

SPECIFIC CONDUCTANCE (S.C.), IN MICROSIEMENS PER CENTIMETER AT 25 DEGREES CELSIUS 

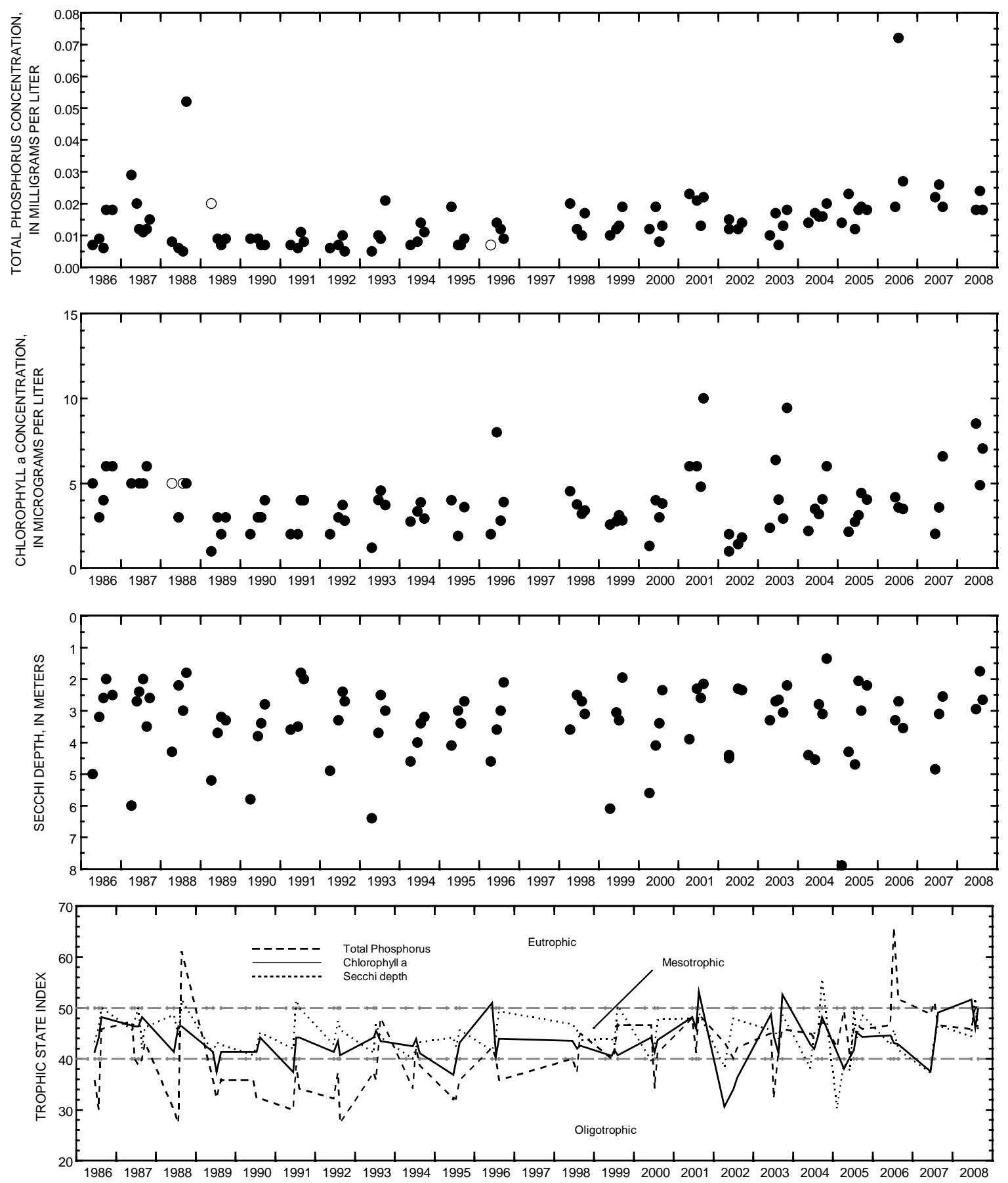

Surface total phosphorus, chlorophyll a concentrations, Secchi depths, and TSI data for Powers Lake, at Powers Lake, Wisconsin.

(Open circles on the first two plots indicate laboratory detection limit for selected analyses. Actual concentrations for these particular analyses are less than the plotted circles.) 


\section{LAKE WAUBESA AT MCFARLAND, WI}

LOCATION.--Lat 4300'32", long 89¹8'19" referenced to North American Datum of 1927, in SW $1 / 4$ SW $1 / 4$ sec.3, T.6 N., R.10 E., Dane County, WI, Hydrologic Unit 07090001, on left bank just upstream from bridge on U.S. Highway 51 , downstream of dam at outlet of Lake Waubesa and $1.0 \mathrm{mi}$ southwest of McFarland.

SURFACE AREA.--3.25 $\mathrm{mi}^{2}$.

DRAINAGE AREA.--327 $\mathrm{mi}^{2}$ of which $36.6 \mathrm{mi}^{2}$ probably is noncontributing.

PERIOD OF RECORD.--October 2003 to current year.

REVISED RECORDS.--WSP 805, WDR WI-73-1: Drainage area.

GAGE.--Water-stage recorder. Datum of gage is $840.00 \mathrm{ft}$ above NGVD of 1929 (levels by Wisconsin Department of Natural Resources).

REMARKS.--Lake level regulated by dams at outlets of Lake Mendota and Lake Waubesa. Gage-height telemeter at station.

EXTREMES FOR PERIOD OF RECORD.--Maximum gage height observed, 7.22 ft, June 15-17, 2008; minimum observed, $3.50 \mathrm{ft}$, Feb.14, 2006, current datum.

EXTREMES FOR CURRENT YEAR.--Maximum recorded gage height, $7.22 \mathrm{ft}$, June 15-17; minimum recorded, 4.30 $\mathrm{ft}$, Mar. 2. 
GAGE HEIGHT, FEET

WATER YEAR OCTOBER 2007 TO SEPTEMBER 2008

DAILY MEAN VALUES

[e, estimated]

\begin{tabular}{|c|c|c|c|c|c|c|c|c|c|c|c|c|}
\hline Day & Oct & Nov & Dec & Jan & Feb & Mar & Apr & May & Jun & Jul & Aug & Sep \\
\hline 1 & 5.73 & 4.86 & 4.46 & 4.49 & 4.41 & 4.33 & 4.85 & 5.69 & 5.18 & 6.88 & 6.60 & 6.08 \\
\hline 2 & 5.71 & 4.82 & 4.53 & 4.47 & 4.39 & 4.31 & 4.86 & 5.68 & 5.14 & 6.84 & 6.55 & 6.07 \\
\hline 3 & 5.69 & 4.80 & 4.48 & e4.44 & 4.39 & 4.42 & 4.86 & 5.67 & 5.10 & 6.81 & 6.49 & 6.05 \\
\hline 4 & 5.64 & 4.78 & 4.55 & 4.41 & 4.39 & 4.47 & 4.89 & 5.64 & 5.07 & 6.75 & 6.54 & 6.04 \\
\hline 5 & 5.58 & 4.77 & 4.64 & 4.40 & 4.40 & 4.49 & 4.89 & 5.60 & 5.17 & 6.69 & 6.55 & 6.08 \\
\hline 6 & 5.53 & 4.75 & 4.64 & 4.41 & 4.44 & 4.49 & 4.88 & 5.58 & 5.26 & 6.63 & 6.52 & 6.04 \\
\hline 7 & 5.49 & 4.70 & 4.64 & 4.52 & 4.49 & 4.47 & 4.88 & 5.59 & 5.29 & 6.61 & 6.48 & 5.99 \\
\hline 8 & 5.44 & 4.67 & 4.64 & 4.69 & 4.47 & 4.46 & 4.90 & 5.57 & 5.52 & 6.71 & 6.44 & 5.95 \\
\hline 9 & 5.40 & 4.65 & 4.63 & 4.77 & 4.44 & 4.44 & 5.04 & 5.55 & 6.13 & 6.69 & 6.40 & 5.92 \\
\hline 10 & 5.34 & 4.63 & 4.61 & 4.77 & 4.43 & 4.42 & 5.10 & 5.52 & 6.37 & 6.65 & 6.36 & 5.88 \\
\hline 11 & 5.27 & 4.61 & 4.63 & 4.79 & 4.40 & 4.41 & 5.39 & 5.53 & 6.47 & 6.91 & 6.33 & 5.84 \\
\hline 12 & 5.22 & 4.61 & 4.65 & 4.76 & 4.39 & 4.40 & 5.49 & 5.52 & 6.60 & 7.06 & 6.31 & 5.82 \\
\hline 13 & 5.18 & 4.59 & 4.63 & 4.75 & 4.39 & 4.41 & 5.50 & 5.48 & 7.05 & 7.06 & 6.30 & 5.89 \\
\hline 14 & 5.17 & 4.59 & 4.62 & 4.72 & 4.37 & 4.48 & 5.50 & 5.46 & 7.15 & 7.04 & 6.29 & 5.93 \\
\hline 15 & 5.16 & 4.58 & 4.60 & 4.69 & 4.37 & 4.54 & 5.48 & 5.45 & 7.20 & 7.01 & 6.28 & 5.92 \\
\hline 16 & 5.19 & 4.55 & 4.61 & 4.66 & 4.35 & 4.56 & 5.45 & 5.43 & 7.22 & 6.99 & 6.26 & 5.87 \\
\hline 17 & 5.18 & 4.53 & 4.59 & 4.63 & 4.39 & 4.56 & 5.46 & 5.42 & 7.21 & 6.97 & 6.25 & 5.83 \\
\hline 18 & 5.24 & 4.52 & 4.58 & 4.60 & 4.46 & 4.58 & 5.49 & 5.40 & 7.19 & 6.96 & 6.25 & 5.79 \\
\hline 19 & 5.26 & 4.50 & 4.57 & 4.58 & 4.45 & 4.60 & 5.53 & 5.39 & 7.17 & 6.96 & 6.25 & 5.75 \\
\hline 20 & 5.23 & 4.50 & 4.56 & 4.55 & 4.44 & 4.62 & 5.50 & 5.37 & 7.16 & 6.98 & 6.23 & 5.73 \\
\hline 21 & 5.20 & 4.51 & 4.54 & 4.53 & 4.43 & 4.64 & 5.47 & 5.36 & 7.14 & 6.98 & 6.21 & 5.71 \\
\hline 22 & 5.19 & 4.51 & 4.54 & 4.53 & 4.42 & 4.67 & 5.46 & 5.34 & 7.14 & 6.96 & 6.19 & 5.67 \\
\hline 23 & 5.15 & 4.50 & 4.64 & 4.51 & 4.40 & 4.66 & 5.45 & 5.32 & 7.12 & 6.93 & 6.19 & 5.64 \\
\hline 24 & 5.12 & 4.47 & 4.64 & 4.49 & 4.39 & 4.66 & 5.44 & 5.29 & 7.11 & 6.90 & 6.18 & 5.62 \\
\hline 25 & 5.07 & 4.46 & 4.62 & 4.47 & 4.38 & 4.66 & 5.72 & 5.24 & 7.09 & 6.87 & 6.16 & 5.60 \\
\hline 26 & 5.04 & 4.45 & 4.59 & 4.46 & 4.37 & 4.69 & 5.87 & 5.27 & 7.07 & 6.85 & 6.14 & 5.58 \\
\hline 27 & 5.02 & 4.45 & 4.58 & 4.45 & 4.36 & 4.71 & 5.85 & 5.23 & 7.05 & 6.82 & 6.12 & 5.54 \\
\hline 28 & 4.98 & 4.44 & 4.56 & 4.43 & 4.34 & 4.72 & 5.81 & 5.18 & 7.02 & 6.78 & 6.10 & 5.51 \\
\hline 29 & 4.94 & 4.45 & 4.56 & 4.43 & 4.33 & 4.71 & 5.77 & 5.13 & 6.98 & 6.73 & 6.10 & 5.48 \\
\hline 30 & 4.90 & 4.45 & 4.53 & 4.44 & --- & 4.70 & 5.72 & 5.18 & 6.93 & 6.70 & 6.10 & 5.46 \\
\hline 31 & 4.88 & --- & 4.51 & 4.41 & --- & 4.76 & --- & 5.21 & --- & 6.65 & 6.09 & --- \\
\hline Mean & 5.26 & 4.59 & 4.59 & 4.56 & 4.40 & 4.55 & 5.35 & 5.43 & 6.51 & 6.85 & 6.30 & 5.81 \\
\hline Max & 5.73 & 4.86 & 4.65 & 4.79 & 4.49 & 4.76 & 5.87 & 5.69 & 7.22 & 7.06 & 6.60 & 6.08 \\
\hline Min & 4.88 & 4.44 & 4.46 & 4.40 & 4.33 & 4.31 & 4.85 & 5.13 & 5.07 & 6.61 & 6.09 & 5.46 \\
\hline
\end{tabular}


LOCATION.--Lat 4248'48", long 8808'31" referenced to North American Datum of 1927, in NE 1/4 NW 1/4 sec.16, T.4 N., R.20 E., Racine County, WI, Hydrologic Unit 07120006, at Wind Lake.

SURFACE AREA.--1.46 $\mathrm{mi}^{2}$.

DRAINAGE AREA.--39.6 $\mathrm{mi}^{2}$.

PERIOD OF RECORD.--March 1985 to current year. Prior to October 2000, published as "Wind Lake Outlet".

REVISED RECORDS.--WDR WI-91-1: 1988(m).

REMARKS.--Lake level regulated by dam with two 10-foot gates at outlet. Lake ice-covered Dec. 3 to Mar. 14. Prior to October 1987, published as Wind Lake at Wind Lake, Wis. Gage-height telemeter at station.

EXTREMES FOR PERIOD OF RECORD.--Maximum gage height, 9.88 ft, June 14, 15, 2008; minimum recorded, $5.95 \mathrm{ft}$, Jan. 2 , 1996. EXTREMES FOR CURRENT YEAR.--Maximum recorded gage height, 9.88 ft, June 14, 15; minimum recorded, 7.59 ft, Feb. 25.

GAGE HEIGHT, FEET

WATER YEAR OCTOBER 2007 TO SEPTEMBER 2008 DAILY MEAN VALUES

\begin{tabular}{|c|c|c|c|c|c|c|c|c|c|c|c|c|}
\hline Day & Oct & Nov & Dec & Jan & Feb & Mar & Apr & May & Jun & Jul & Aug & Sep \\
\hline 1 & 8.17 & 8.08 & 8.11 & 7.90 & 8.11 & 8.07 & 8.36 & 8.19 & 8.28 & 8.15 & 8.15 & 7.78 \\
\hline 2 & 8.18 & 8.07 & 8.20 & 7.86 & 8.10 & 8.12 & 8.32 & 8.18 & 8.28 & 8.06 & 8.14 & 7.77 \\
\hline 3 & 8.20 & 8.09 & 8.22 & 7.86 & 8.08 & 8.13 & 8.18 & 8.18 & 8.26 & 8.06 & 8.11 & 7.77 \\
\hline 4 & 8.19 & 8.10 & 8.24 & 7.88 & 8.06 & 8.05 & 8.06 & 8.18 & 8.20 & 8.14 & 8.15 & 7.84 \\
\hline 5 & 8.19 & 8.09 & 8.28 & 7.94 & 7.99 & 7.96 & 7.91 & 8.22 & 8.28 & 8.22 & 8.18 & 7.91 \\
\hline 6 & 8.19 & 8.08 & 8.29 & 7.99 & 7.97 & 7.94 & 7.77 & 8.24 & 8.22 & 8.29 & 8.17 & 7.89 \\
\hline 7 & 8.19 & 8.07 & 8.30 & 8.07 & 7.94 & 7.96 & 7.67 & 8.22 & 8.17 & 8.35 & 8.15 & 7.87 \\
\hline 8 & 8.19 & 8.07 & 8.26 & 8.22 & 7.88 & 8.04 & 7.73 & 8.18 & 8.52 & 8.40 & 8.13 & 7.87 \\
\hline 9 & 8.18 & 8.08 & 8.24 & 8.24 & 7.87 & 8.12 & 7.99 & 8.12 & 9.14 & 8.33 & 8.12 & 7.87 \\
\hline 10 & 8.16 & 8.07 & 8.23 & 8.20 & 7.85 & 8.16 & 8.18 & 8.09 & 9.45 & 8.25 & 8.10 & 7.85 \\
\hline 11 & 8.14 & 8.07 & 8.28 & 8.14 & 7.82 & 8.10 & 8.42 & 8.17 & 9.59 & 8.33 & 8.08 & 7.84 \\
\hline 12 & 8.13 & 8.08 & 8.30 & 8.04 & 7.83 & 8.03 & 8.49 & 8.22 & 9.65 & 8.30 & 8.07 & 7.84 \\
\hline 13 & 8.12 & 8.08 & 8.25 & 7.95 & 7.90 & 8.00 & 8.48 & 8.23 & 9.82 & 8.27 & 8.06 & 7.95 \\
\hline 14 & 8.14 & 8.07 & 8.10 & 7.86 & 7.97 & 8.05 & 8.39 & 8.24 & 9.86 & 8.30 & 8.06 & 8.02 \\
\hline 15 & 8.16 & 8.07 & 8.04 & 7.79 & 8.04 & 8.10 & 8.21 & 8.26 & 9.86 & 8.33 & 8.04 & 8.05 \\
\hline 16 & 8.23 & 8.06 & 8.03 & 7.82 & 8.10 & 8.12 & 8.01 & 8.25 & 9.81 & 8.36 & 8.02 & 8.04 \\
\hline 17 & 8.23 & 8.07 & 8.00 & 7.91 & 8.21 & 8.13 & 7.99 & 8.24 & 9.70 & 8.37 & 8.00 & 8.04 \\
\hline 18 & 8.21 & 8.07 & 8.01 & 7.98 & 8.17 & 8.15 & 8.13 & 8.24 & 9.57 & 8.30 & 7.98 & 8.04 \\
\hline 19 & 8.11 & 8.07 & 8.03 & 8.02 & 8.10 & 8.17 & 8.19 & 8.23 & 9.40 & 8.18 & 7.97 & 8.04 \\
\hline 20 & 8.14 & 8.08 & 8.05 & 8.04 & 8.02 & 8.16 & 8.19 & 8.22 & 9.19 & 8.16 & 7.96 & 8.04 \\
\hline 21 & 8.22 & 8.12 & 8.06 & 8.05 & 7.93 & 8.18 & 8.17 & 8.19 & 8.96 & 8.19 & 7.94 & 8.05 \\
\hline 22 & 8.27 & 8.13 & 8.05 & 8.04 & 7.84 & 8.21 & 8.17 & 8.17 & 8.68 & 8.21 & 7.93 & 8.04 \\
\hline 23 & 8.26 & 8.11 & 8.09 & 8.00 & 7.76 & 8.14 & 8.22 & 8.13 & 8.39 & 8.22 & 7.93 & 8.04 \\
\hline 24 & 8.22 & 8.10 & 8.12 & 7.96 & 7.67 & 8.06 & 8.24 & 8.09 & 8.10 & 8.22 & 7.91 & 8.03 \\
\hline 25 & 8.19 & 8.10 & 8.13 & 7.92 & 7.64 & 7.95 & 8.27 & 8.08 & 7.97 & 8.21 & 7.89 & 8.03 \\
\hline 26 & 8.24 & 8.11 & 8.13 & 7.93 & 7.75 & 7.94 & 8.29 & 8.12 & 8.16 & 8.22 & 7.87 & 8.02 \\
\hline 27 & 8.30 & 8.10 & 8.08 & 7.93 & 7.83 & 8.03 & 8.25 & 8.15 & 8.33 & 8.20 & 7.86 & 8.01 \\
\hline 28 & 8.35 & 8.09 & 8.04 & 7.93 & 7.91 & 8.09 & 8.22 & 8.13 & 8.44 & 8.20 & 7.84 & 8.01 \\
\hline 29 & 8.34 & 8.09 & 8.01 & 7.97 & 8.01 & 8.09 & 8.19 & 8.12 & 8.43 & 8.18 & 7.84 & 8.00 \\
\hline 30 & 8.23 & 8.09 & 7.96 & 8.02 & --- & 8.06 & 8.20 & 8.22 & 8.30 & 8.18 & 7.82 & 8.00 \\
\hline 31 & 8.14 & --- & 7.93 & 8.06 & --- & 8.15 & --- & 8.27 & --- & 8.16 & 7.80 & --- \\
\hline Mean & 8.20 & 8.09 & 8.13 & 7.98 & 7.94 & 8.08 & 8.16 & 8.19 & 8.83 & 8.24 & 8.01 & 7.95 \\
\hline Max & 8.35 & 8.13 & 8.30 & 8.24 & 8.21 & 8.21 & 8.49 & 8.27 & 9.86 & 8.40 & 8.18 & 8.05 \\
\hline Min & 8.11 & 8.06 & 7.93 & 7.79 & 7.64 & 7.94 & 7.67 & 8.08 & 7.97 & 8.06 & 7.80 & 7.77 \\
\hline
\end{tabular}




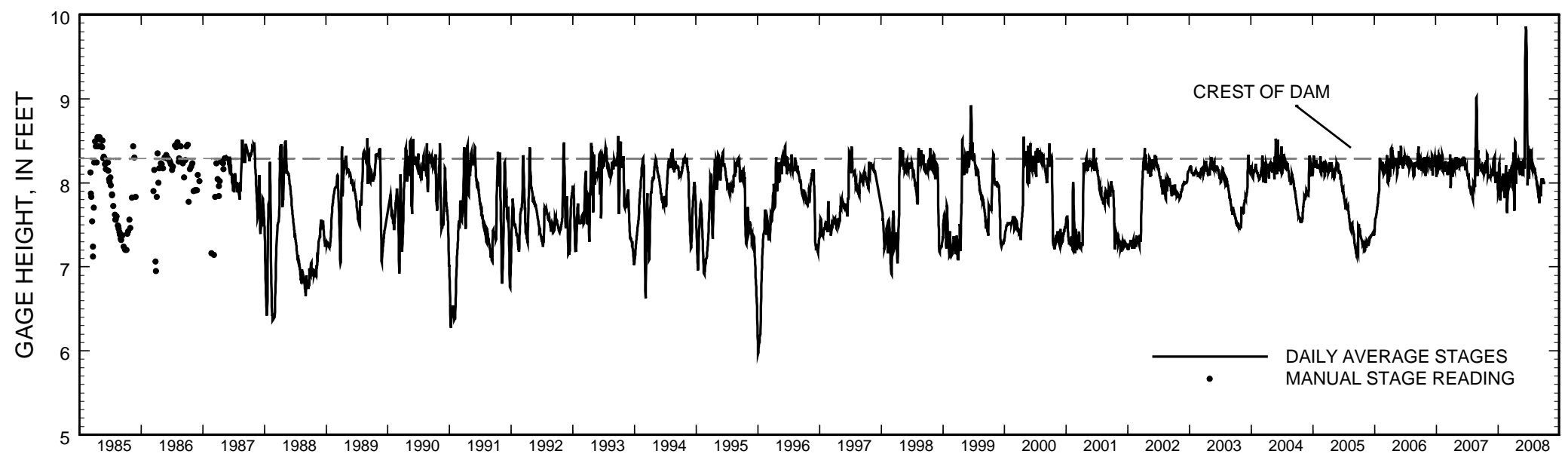

Stage hydrograph for Wind Lake, 1985-2008. 


\section{WIND LAKE AT WIND LAKE, WI}

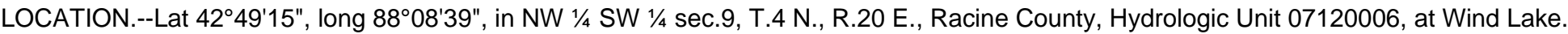
SURFACE AREA.--1.46 $\mathrm{mi}^{2}$.

PERIOD OF RECORD.--February 1985 to current year.

REMARKS.--Lake sampled near center at the deep hole. Water-quality analyses done by Wisconsin State Laboratory of Hygiene.

Date

00078 Secchi-depth $(m)$

00098 Sampling depth $(\mathrm{m})$

00010 Water Temperature $\left({ }^{\circ} \mathrm{C}\right)$

$00400 \mathrm{pH}$ (standard units)

00095 Specific conductance $(\mu \mathrm{S} / \mathrm{cm})$

00300 Dissolved oxygen

32210 Chlorophyll a, phytoplankton $(\mu \mathrm{g} / \mathrm{L})$

00665 Phosphorus, Total (as P)

00671 Orthophosphate, dissolved (as P)

00600 Total nitrogen

00631 Nitrate + nitrite, dissolved (as N)

00608 Ammonia, dissolved (as N)

00625 Ammonia + organic nitrogen, total (as N)

00623 Ammonia + organic nitrogen, dissolved (as N)

00900 Hardness (as $\mathrm{CaCO} 3$ )

00417 Acid neutralizing capacity (as $\mathrm{CaCO} 3$ )

00915 Calcium, dissolved (Ca)

00925 Magnesium, dissolved (Mg)

00930 Sodium, dissolved $(\mathrm{Na}$ )

00935 Potassium, dissolved (K)

00940 Chloride, dissolved (Cl)

00945 Sulfate, dissolved (SO4)

00955 Silica, dissolved (SiO2)

01046 Iron $(\mu \mathrm{g} / \mathrm{L})$

01056 Manganese $(\mu \mathrm{g} / \mathrm{L})$

00081 Apparent color (PTU)

63675 Turbidity (NTU)

70300 Solids, dissolved (at $180 \mathrm{C}^{\circ}$ )
WATER-QUALITY DATA, FEBRUARY 27 TO JULY 28, 2008

(Milligrams per liter unless otherwise indicated)

\begin{tabular}{|c|c|c|c|c|c|c|c|}
\hline \multirow{2}{*}{\multicolumn{2}{|c|}{ Feb. 27}} & \multicolumn{2}{|c|}{ Apr. 22} & \multicolumn{2}{|c|}{ June 23} & \multicolumn{2}{|c|}{$\underline{\text { July } 28}$} \\
\hline & & \multicolumn{2}{|c|}{2.0} & \multicolumn{2}{|c|}{1.4} & \multicolumn{2}{|c|}{1.5} \\
\hline 0.5 & 15 & 0.5 & 15 & 0.5 & 14.5 & 0.5 & 14.5 \\
\hline 2.4 & 3.3 & 14.7 & 8.1 & 23.4 & 14.3 & 26 & 14.5 \\
\hline 7.0 & 7.0 & 8.2 & 7.5 & 7.8 & 7.2 & 8.8 & 7.2 \\
\hline 784 & 964 & 626 & 668 & 531 & 661 & 540 & 678 \\
\hline 8.9 & 1.5 & 12.3 & 8.9 & 8.8 & 0.4 & 9.7 & 0.4 \\
\hline -- & -- & 25.2 & -- & 17.4 & -- & 17.2 & -- \\
\hline 0.066 & 0.136 & 0.043 & 0.047 & 0.081 & 0.244 & 0.062 & 0.428 \\
\hline -- & -- & 0.004 & -- & -- & -- & $<.002$ & -- \\
\hline -- & -- & 1 & -- & -- & -- & -- & -- \\
\hline -- & -- & 0.057 & -- & -- & -- & $<.019$ & -- \\
\hline-- & -- & $<.015$ & -- & -- & -- & $<.015$ & -- \\
\hline -- & -- & 0.97 & -- & -- & -- & -- & -- \\
\hline -- & -- & -- & -- & -- & -- & 1.1 & -- \\
\hline -- & -- & 210 & -- & -- & -- & -- & -- \\
\hline -- & -- & 148 & -- & -- & -- & -- & -- \\
\hline -- & -- & 47.5 & -- & -- & -- & -- & -- \\
\hline-- & -- & 23.4 & -- & -- & -- & -- & -- \\
\hline-- & -- & 48 & -- & -- & -- & -- & -- \\
\hline -- & -- & 3.1 & -- & -- & -- & -- & -- \\
\hline -- & -- & 88.4 & -- & -- & -- & -- & -- \\
\hline -- & -- & 31.8 & -- & -- & -- & -- & -- \\
\hline -- & -- & 0.805 & -- & -- & -- & -- & -- \\
\hline-- & -- & $<100$ & -- & -- & -- & -- & -- \\
\hline-- & -- & $<1.6$ & -- & -- & -- & -- & -- \\
\hline -- & -- & 50 & -- & -- & -- & -- & -- \\
\hline -- & -- & $<1.0$ & -- & -- & -- & -- & -- \\
\hline -- & -- & 352 & -- & -- & -- & -- & -- \\
\hline
\end{tabular}


424915088083900 WIND LAKE AT WIND LAKE, WI

WATER-QUALITY DATA, AUGUST 22, 2008

(Milligrams per liter unless otherwise indicated)

Date

00078 Secchi-depth $(m)$

00098 Sampling depth $(\mathrm{m})$

00010 Water Temperature $\left({ }^{\circ} \mathrm{C}\right.$

$00400 \mathrm{pH}$ (standard units)

00095 Specific conductance $(\mu \mathrm{S} / \mathrm{cm})$

00300 Dissolved oxygen

32210 Chlorophyll a, phytoplankton $(\mu \mathrm{g} / \mathrm{L})$

00665 Phosphorus, Total (as P)

$\begin{array}{ccc}\frac{\text { Aug. 22 }}{1.6} & & \\ 11 & & \\ 15.3 & 13 & 14 \\ 7.2 & 7.2 & 14.7 \\ 672 & 680 & 7.1 \\ 0.3 & 0.3 & 083 \\ -- & -- & -- \\ 0.417 & 0.489 & 0.518\end{array}$


424915088083900 WIND LAKE AT WIND LAKE, WI

LAKE-DEPTH PROFILES, FEBRUARY 27 TO AUGUST 22, 2008

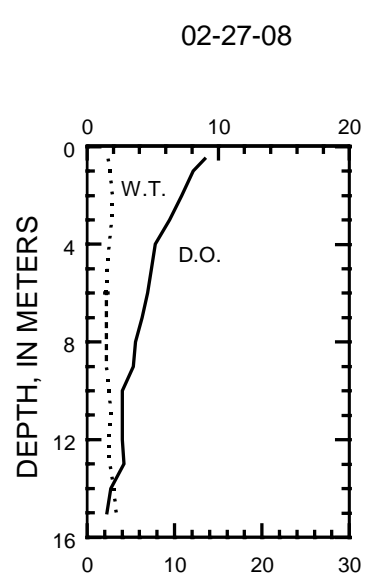

04-22-08

06-23-08

07-28-08

08-22-08

DISSOLVED OXYGEN (D.O.), IN MILLIGRAMS PER LITER
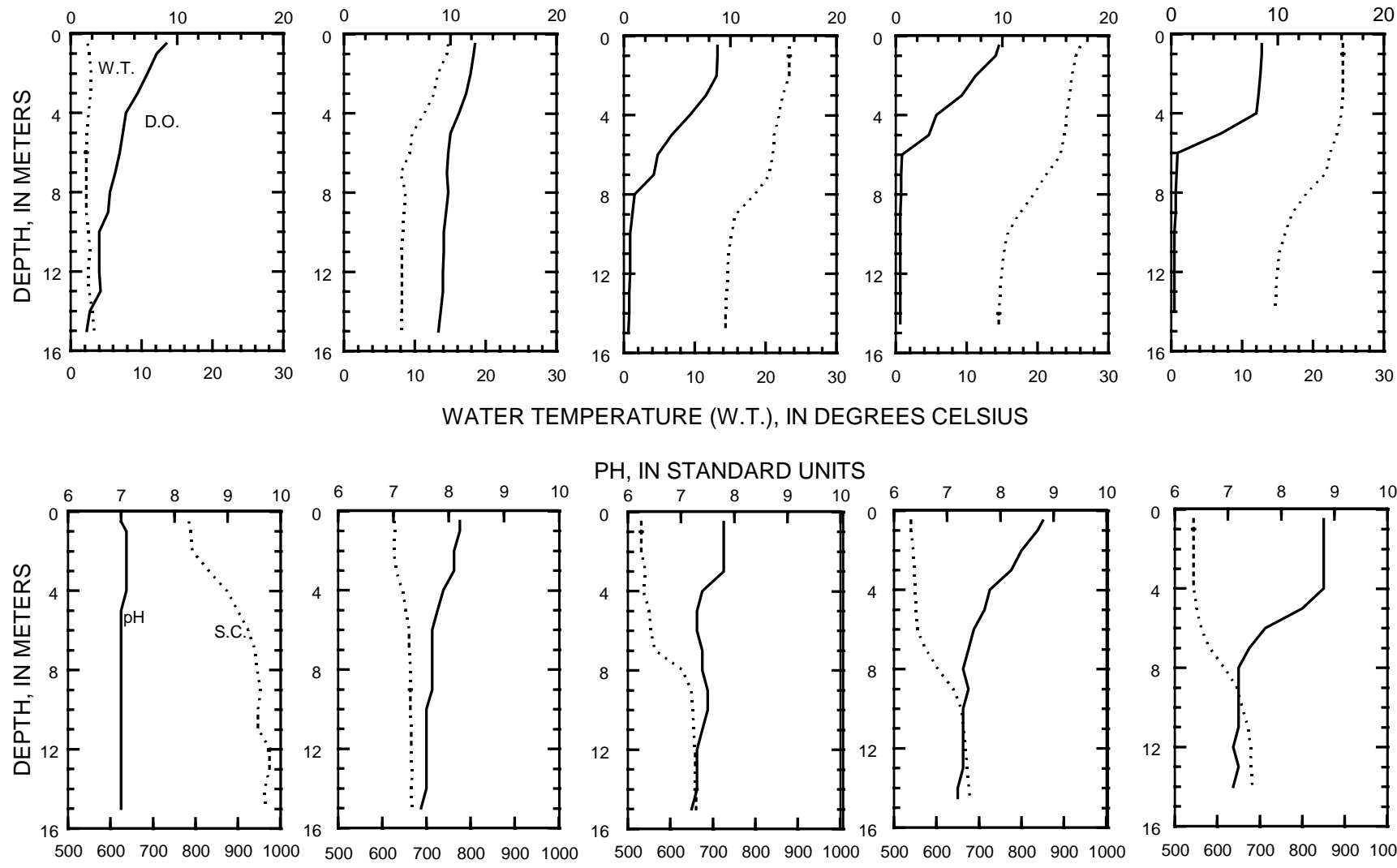

$\mathrm{PH}$, IN STANDARD UNITS
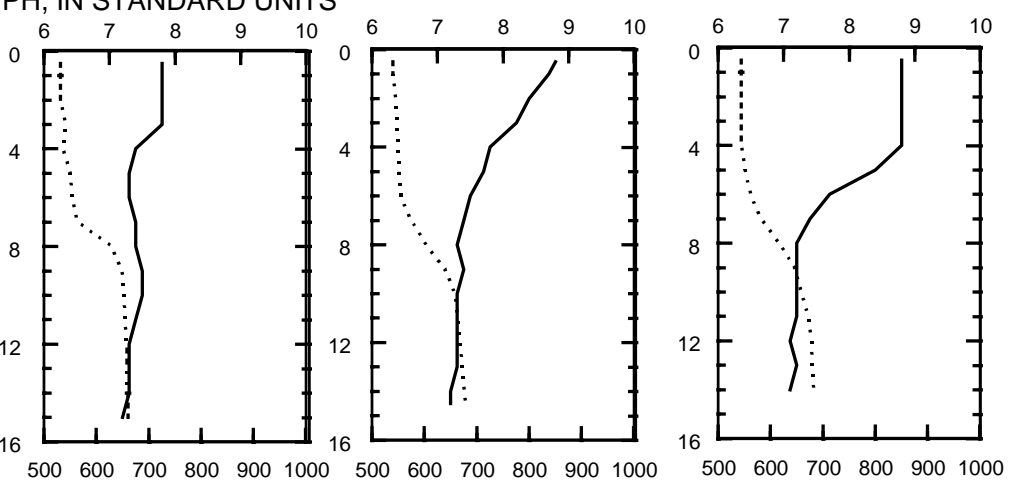

SPECIFIC CONDUCTANCE (S.C.), IN MICROSIEMENS PER CENTIMETER AT 25 DEGREES CELSIUS 

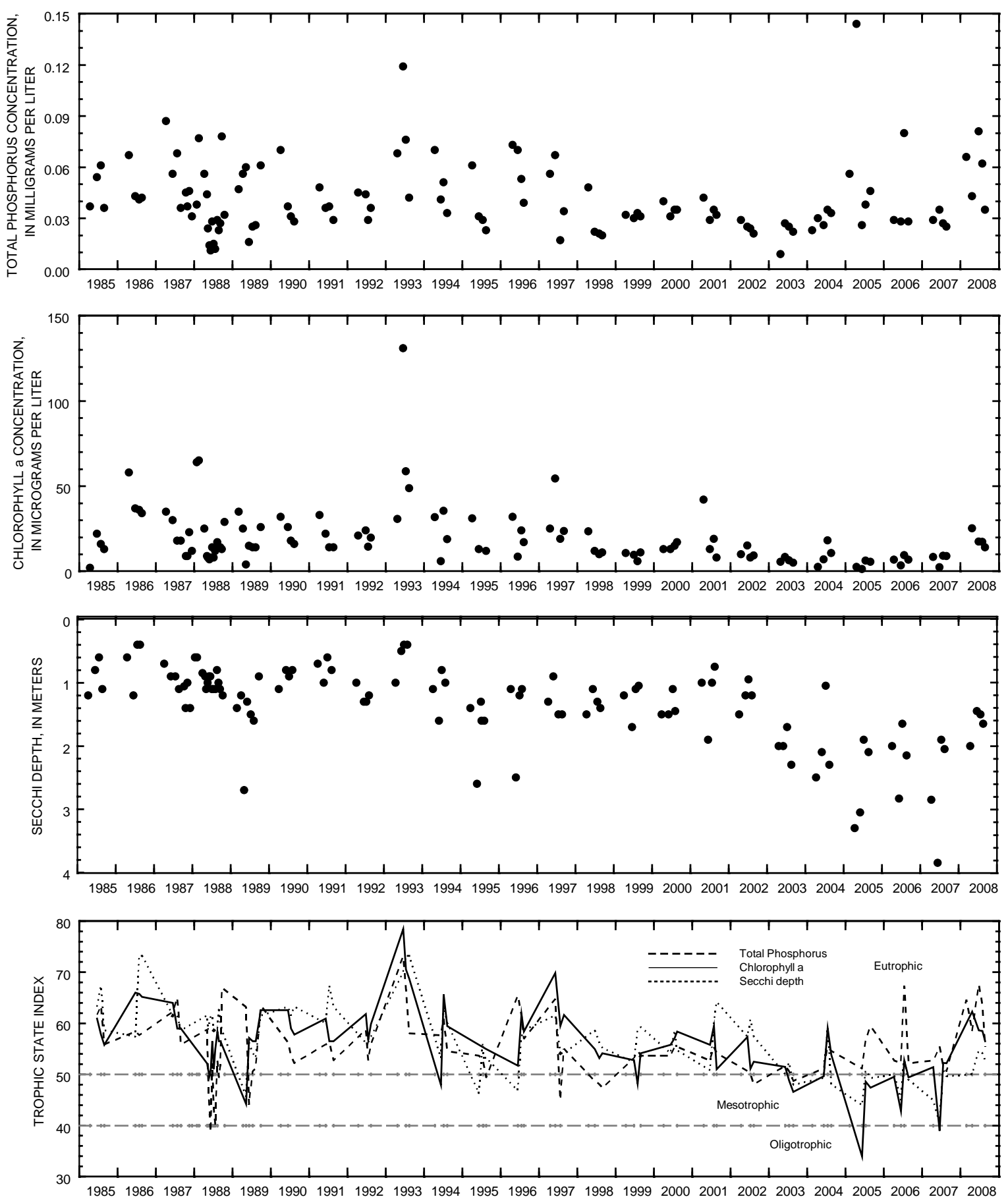

Surface total phosphorus, chlorophyll a concentrations, Secchi depths, and TSI data for Wind Lake, Deep Hole, at Wind Lake, Wisconsin. 


\section{LAKE WINNEBAGO AT OSHKOSH, WI}

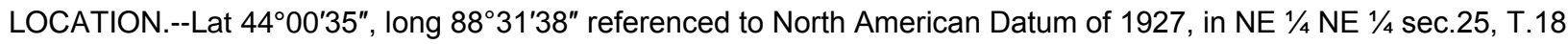
N., R.16 E., Winnebago County, WI, Hydrologic Unit 04030203, $800 \mathrm{ft}$ east of mouth of the upper Fox River.

SURFACE AREA.--215 $\mathrm{mi}^{2}$.

DRAINAGE AREA.--5,880 $\mathrm{mi}^{2}$.

PERIOD OF RECORD.--October 1938 to current year in reports of Geological Survey. Records from July 1882 to September 1938 in files of Geological Survey and U.S. Army Corps of Engineers. A report on Fox River by U.S. Army Corps of Engineers, published as House Document No. 146, 67th Congress, 2nd session, contains semimonthly records of inflow of Lake Winnebago for the period 1896-1917.

REVISED RECORDS.--WDR WI-83-1: Drainage area.

GAGE.--Water-stage recorder. Nonrecording gage read once daily October 1938 to October 1978. Datum of gage is $745.05 \mathrm{ft}$ above mean tide at New York City (levels by U.S. Army Corps of Engineers). Datum of Deuchman gage is $745.00 \mathrm{ft}$ above mean tide at New York City.

REMARKS.--Lake elevations controlled by dams at Menasha and Neenah, which are operated in the interest of navigation. Crests of both dams are at elevation $746.73 \mathrm{ft}$. Present limits of regulation are from 21 1/4 in. above the crest of Menasha to crest during navigation season, plus additional 18 in. below crest during winter. Oshkosh staff gage gives true level of lake, while Deuchman gage readings are affected by loss of head in the channel between lake and dam. Data-collection platform and gage-height telemeter at station.

EXTREMES FOR PERIOD OF RECORD.--Maximum gage height observed, $5.33 \mathrm{ft}$ (Deuchman gage) Nov. 8, 1881; Minimum observed, -2.00 ft (Deuchman gage) Nov. 28, 1891.

EXTREMES FOR CURRENT YEAR.--Maximum daily mean gage height, $3.85 \mathrm{ft}$, June 14; Minimum recorded, $1.64 \mathrm{ft}$, Mar. 12, 13, 14. 
GAGE HEIGHT, FEET

WATER YEAR OCTOBER 2007 TO SEPTEMBER 2008

DAILY MEAN VALUES

\begin{tabular}{|c|c|c|c|c|c|c|c|c|c|c|c|c|}
\hline Day & Oct & Nov & Dec & Jan & Feb & Mar & Apr & May & Jun & Jul & Aug & Sep \\
\hline 1 & 2.91 & 2.57 & 2.29 & 2.27 & 2.14 & 1.73 & 2.28 & 2.88 & 3.23 & 3.09 & 3.18 & 2.99 \\
\hline 2 & 2.92 & 2.51 & 2.31 & 2.27 & 2.12 & 1.71 & 2.31 & 2.84 & 3.22 & 3.10 & 3.22 & 2.96 \\
\hline 3 & 2.90 & 2.51 & 2.31 & 2.26 & 2.10 & 1.74 & 2.31 & 2.77 & 3.25 & 3.15 & 3.20 & 2.99 \\
\hline 4 & 2.95 & 2.50 & 2.32 & 2.25 & 2.07 & 1.74 & 2.31 & 2.81 & 3.19 & 3.13 & 3.25 & 3.01 \\
\hline 5 & 2.96 & 2.34 & 2.32 & 2.23 & 2.06 & 1.74 & 2.31 & 2.78 & 3.20 & 3.14 & 3.30 & 2.98 \\
\hline 6 & 2.96 & 2.43 & 2.31 & 2.23 & 2.05 & 1.73 & 2.32 & 2.80 & 3.13 & 3.12 & 3.25 & 2.96 \\
\hline 7 & 2.97 & 2.41 & 2.31 & 2.25 & 2.03 & 1.73 & 2.29 & 2.79 & 3.13 & 3.15 & 3.23 & 2.96 \\
\hline 8 & 2.97 & 2.36 & 2.30 & 2.31 & 2.00 & 1.71 & 2.34 & 2.83 & 3.26 & 3.17 & 3.19 & 2.95 \\
\hline 9 & 2.91 & 2.34 & 2.29 & 2.36 & 1.98 & 1.69 & 2.41 & 2.83 & 3.50 & 3.16 & 3.18 & 2.95 \\
\hline 10 & 2.95 & 2.34 & 2.28 & 2.35 & 1.95 & 1.68 & 2.57 & 2.88 & 3.50 & 3.16 & 3.13 & 2.93 \\
\hline 11 & 2.95 & 2.31 & 2.27 & 2.36 & 1.92 & 1.67 & 2.50 & 2.89 & 3.50 & 3.17 & 3.10 & 2.91 \\
\hline 12 & 2.88 & 2.31 & 2.26 & 2.37 & 1.89 & 1.65 & 2.64 & 2.93 & 3.43 & 3.11 & 3.08 & 2.93 \\
\hline 13 & 2.85 & 2.29 & 2.25 & 2.37 & 1.86 & 1.64 & 2.71 & 2.93 & 3.82 & 3.07 & 3.10 & 2.95 \\
\hline 14 & 2.84 & 2.20 & 2.25 & 2.37 & 1.87 & 1.65 & 2.74 & 2.94 & 3.85 & 3.09 & 3.12 & 2.97 \\
\hline 15 & 2.84 & 2.29 & 2.25 & 2.36 & 1.88 & 1.66 & 2.77 & 3.02 & 3.81 & 3.04 & 3.12 & 2.96 \\
\hline 16 & 2.88 & 2.30 & 2.25 & 2.33 & 1.87 & 1.67 & 2.78 & 3.03 & 3.76 & 3.07 & 3.09 & 2.92 \\
\hline 17 & 2.86 & 2.31 & 2.25 & 2.32 & 1.89 & 1.69 & 2.82 & 3.03 & 3.70 & 3.14 & 3.09 & 2.92 \\
\hline 18 & 2.88 & 2.28 & 2.25 & 2.34 & 1.92 & 1.70 & 2.89 & 3.09 & 3.70 & 3.14 & 3.10 & 2.91 \\
\hline 19 & 2.76 & 2.24 & 2.25 & 2.33 & 1.91 & 1.73 & 2.90 & 3.12 & 3.61 & 3.15 & 3.11 & 2.86 \\
\hline 20 & 2.84 & 2.28 & 2.25 & 2.32 & 1.90 & 1.77 & 2.92 & 3.11 & 3.56 & 3.18 & 3.08 & 2.88 \\
\hline 21 & 2.81 & 2.32 & 2.25 & 2.31 & 1.88 & 1.81 & 2.93 & 3.12 & 3.50 & 3.20 & 3.07 & 2.87 \\
\hline 22 & 2.79 & 2.29 & 2.24 & 2.33 & 1.86 & 1.83 & 2.92 & 3.14 & 3.46 & 3.20 & 3.04 & 2.85 \\
\hline 23 & 2.76 & 2.27 & 2.29 & 2.32 & 1.85 & 1.87 & 2.92 & 3.14 & 3.43 & 3.17 & 3.05 & 2.84 \\
\hline 24 & 2.74 & 2.23 & 2.30 & 2.31 & 1.83 & 1.91 & 2.93 & 3.13 & 3.37 & 3.15 & 3.07 & 2.84 \\
\hline 25 & 2.75 & 2.24 & 2.29 & 2.29 & 1.81 & 1.96 & 2.88 & 3.12 & 3.31 & 3.13 & 3.07 & 2.86 \\
\hline 26 & 2.69 & 2.27 & 2.27 & 2.26 & 1.79 & 2.02 & 2.74 & 3.13 & 3.27 & 3.12 & 3.04 & 2.85 \\
\hline 27 & 2.65 & 2.23 & 2.27 & 2.24 & 1.77 & 2.07 & 2.94 & 3.19 & 3.24 & 3.13 & 3.02 & 2.83 \\
\hline 28 & 2.65 & 2.28 & 2.27 & 2.21 & 1.75 & 2.12 & 3.00 & 3.14 & 3.15 & 3.15 & 3.00 & 2.83 \\
\hline 29 & 2.59 & 2.19 & 2.29 & 2.20 & 1.75 & 2.16 & 2.93 & 3.14 & 3.14 & 3.13 & 3.02 & 2.79 \\
\hline 30 & 2.59 & 2.22 & 2.28 & 2.19 & --- & 2.18 & 2.90 & 3.15 & 3.13 & 3.13 & 3.02 & 2.74 \\
\hline 31 & 2.52 & --- & 2.28 & 2.16 & --- & 2.21 & --- & 3.17 & --- & 3.17 & 3.01 & --- \\
\hline Mean & 2.82 & 2.32 & 2.28 & 2.29 & 1.92 & 1.81 & 2.67 & 3.00 & 3.41 & 3.14 & 3.11 & 2.91 \\
\hline Max & 2.97 & 2.57 & 2.32 & 2.37 & 2.14 & 2.21 & 3.00 & 3.19 & 3.85 & 3.20 & 3.30 & 3.01 \\
\hline Min & 2.52 & 2.19 & 2.24 & 2.16 & 1.75 & 1.64 & 2.28 & 2.77 & 3.13 & 3.04 & 3.00 & 2.74 \\
\hline
\end{tabular}




\section{LAKE WINNEBAGO NEAR STOCKBRIDGE, WI}

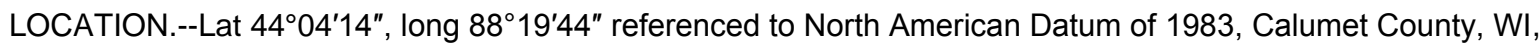
Hydrologic Unit 04030203, Stockbridge Indian Reservation, on east shore of Lake Winnebago, $300 \mathrm{ft}$ south of County Highway E and 1.6 mi west of Stockbridge.

SURFACE AREA.--215 $\mathrm{mi}^{2}$.

DRAINAGE AREA.--5,880 $\mathrm{mi}^{2}$.

PERIOD OF RECORD.--November 1982 to current year.

GAGE.--Water-stage recorder. Datum of gage is $745.05 \mathrm{ft}$ above mean tide of New York City (levels by U. S. Army Corps of Engineers).

REMARKS.--Lake elevations controlled by dams at Menasha and Neenah, which are operated in the interest of navigation. Crests of both dams are at elevation $746.73 \mathrm{ft}$. Present limits of regulation are from $21 \frac{1 / 4}{4}$ in. above the crest of Menasha dam to crest during navigation season, plus additional 18 in. below crest during winter. Datacollection platform and gage-height telemeter at station.

EXTREMES FOR PERIOD OF RECORD.--Maximum daily mean gage height, 3.85 ft, July 9, 11, 1993, June 14, 2008; minimum observed, $0.30 \mathrm{ft}$, Mar. 1, 1986.

EXTREMES FOR CURRENT YEAR.--Maximum daily mean gage height, $3.85 \mathrm{ft}$, June 14; minimum recorded, $1.47 \mathrm{ft}$, Mar. 13. 
GAGE HEIGHT, FEET

WATER YEAR OCTOBER 2007 TO SEPTEMBER 2008

DAILY MEAN VALUES

\begin{tabular}{|c|c|c|c|c|c|c|c|c|c|c|c|c|}
\hline Day & Oct & Nov & Dec & Jan & Feb & Mar & Apr & May & Jun & Jul & Aug & Sep \\
\hline 1 & 2.81 & 2.52 & 2.15 & 2.15 & 2.01 & 1.62 & 2.20 & 2.73 & 3.12 & 3.04 & 3.10 & 2.89 \\
\hline 2 & 2.83 & 2.47 & 2.24 & 2.14 & 1.98 & 1.60 & 2.21 & 2.73 & 3.12 & 3.04 & 3.12 & 2.88 \\
\hline 3 & 2.91 & 2.43 & 2.23 & 2.12 & 1.97 & 1.65 & 2.20 & 2.77 & 3.05 & 3.02 & 3.10 & 2.89 \\
\hline 4 & 2.86 & 2.38 & 2.19 & 2.11 & 1.95 & 1.64 & 2.21 & 2.76 & 3.06 & 3.05 & 3.18 & 2.81 \\
\hline 5 & 2.86 & 2.46 & 2.19 & 2.10 & 1.94 & 1.63 & 2.21 & 2.72 & 3.09 & 3.06 & 3.22 & 2.88 \\
\hline 6 & 2.88 & 2.43 & 2.17 & 2.10 & 1.93 & 1.63 & 2.20 & 2.70 & 3.13 & 3.07 & 3.21 & 2.92 \\
\hline 7 & 2.88 & 2.32 & 2.18 & 2.13 & 1.90 & 1.62 & 2.22 & 2.74 & 3.08 & 3.10 & 3.14 & 2.92 \\
\hline 8 & 2.92 & 2.23 & 2.17 & 2.19 & 1.87 & 1.61 & 2.23 & 2.72 & 3.20 & 3.14 & 3.11 & 2.89 \\
\hline 9 & 2.99 & 2.23 & 2.16 & 2.23 & 1.86 & 1.58 & 2.37 & 2.73 & 3.47 & 3.12 & 3.07 & 2.86 \\
\hline 10 & 2.92 & 2.21 & 2.15 & 2.23 & 1.85 & 1.57 & 2.25 & 2.76 & 3.48 & 3.09 & 3.00 & 2.83 \\
\hline 11 & 2.78 & 2.18 & 2.14 & 2.24 & 1.80 & 1.55 & 2.37 & 2.74 & 3.33 & 3.10 & 2.99 & 2.81 \\
\hline 12 & 2.76 & 2.20 & 2.13 & 2.23 & 1.77 & 1.54 & 2.45 & 2.83 & 3.34 & 3.13 & 2.99 & 2.83 \\
\hline 13 & 2.74 & 2.20 & 2.12 & 2.25 & 1.74 & 1.53 & 2.57 & 2.84 & 3.79 & 3.15 & 3.01 & 2.83 \\
\hline 14 & 2.70 & 2.27 & 2.13 & 2.25 & 1.76 & 1.53 & 2.66 & 2.89 & 3.85 & 3.01 & 3.00 & 2.84 \\
\hline 15 & 2.65 & 2.27 & 2.12 & 2.23 & 1.77 & 1.55 & 2.73 & 2.92 & 3.78 & 2.98 & 3.00 & 2.84 \\
\hline 16 & 2.74 & 2.16 & 2.14 & 2.20 & 1.75 & 1.57 & 2.74 & 2.98 & 3.73 & 2.98 & 3.05 & 2.87 \\
\hline 17 & 2.77 & 2.06 & 2.12 & 2.20 & 1.78 & 1.58 & 2.74 & 3.04 & 3.69 & 3.08 & 3.04 & 2.82 \\
\hline 18 & 2.76 & 2.12 & 2.12 & 2.21 & 1.82 & 1.60 & 2.78 & 3.03 & 3.61 & 3.07 & 3.03 & 2.77 \\
\hline 19 & 2.90 & 2.13 & 2.13 & 2.20 & 1.80 & 1.63 & 2.81 & 3.03 & 3.53 & 3.03 & 2.96 & 2.79 \\
\hline 20 & 2.80 & 2.14 & 2.12 & 2.19 & 1.78 & 1.67 & 2.83 & 3.05 & 3.48 & 3.11 & 2.96 & 2.77 \\
\hline 21 & 2.73 & 2.08 & 2.12 & 2.18 & 1.76 & 1.70 & 2.84 & 3.04 & 3.45 & 3.09 & 2.95 & 2.73 \\
\hline 22 & 2.69 & 2.14 & 2.11 & 2.20 & 1.74 & 1.74 & 2.84 & 3.02 & 3.39 & 3.07 & 2.97 & 2.73 \\
\hline 23 & 2.70 & 2.23 & 2.17 & 2.19 & 1.73 & 1.78 & 2.85 & 2.97 & 3.33 & 3.06 & 3.01 & 2.73 \\
\hline 24 & 2.63 & 2.28 & 2.17 & 2.18 & 1.70 & 1.82 & 2.80 & 3.00 & 3.29 & 3.08 & 2.97 & 2.75 \\
\hline 25 & 2.57 & 2.26 & 2.15 & 2.14 & 1.69 & 1.86 & 2.84 & 3.04 & 3.23 & 3.08 & 2.93 & 2.74 \\
\hline 26 & 2.56 & 2.18 & 2.15 & 2.13 & 1.68 & 1.93 & 3.12 & 3.06 & 3.20 & 3.10 & 2.90 & 2.74 \\
\hline 27 & 2.57 & 2.25 & 2.15 & 2.11 & 1.66 & 1.98 & 2.95 & 2.98 & 3.16 & 3.09 & 2.90 & 2.71 \\
\hline 28 & 2.55 & 2.20 & 2.15 & 2.08 & 1.64 & 2.03 & 2.82 & 3.03 & 3.20 & 3.03 & 2.91 & 2.68 \\
\hline 29 & 2.54 & 2.25 & 2.16 & 2.07 & 1.64 & 2.06 & 2.84 & 3.06 & 3.10 & 3.04 & 2.93 & 2.68 \\
\hline 30 & 2.51 & 2.18 & 2.15 & 2.08 & --- & 2.07 & 2.82 & 3.07 & 3.04 & 3.09 & 2.92 & 2.70 \\
\hline 31 & 2.56 & --- & 2.15 & 2.03 & --- & 2.12 & --- & 3.15 & --- & 3.09 & 2.91 & --- \\
\hline Mean & 2.74 & 2.25 & 2.15 & 2.16 & 1.80 & 1.71 & 2.59 & 2.91 & 3.34 & 3.07 & 3.02 & 2.80 \\
\hline Max & 2.99 & 2.52 & 2.24 & 2.25 & 2.01 & 2.12 & 3.12 & 3.15 & 3.85 & 3.15 & 3.22 & 2.92 \\
\hline Min & 2.51 & 2.06 & 2.11 & 2.03 & 1.64 & 1.53 & 2.20 & 2.70 & 3.04 & 2.98 & 2.90 & 2.68 \\
\hline
\end{tabular}




\section{WISCONSIN DISTRICT PUBLICATIONS PERTAINING TO LAKES}

The reports published in a U.S. Geological Survey series are for sale by the U.S. Geological Survey, Box 25425, Federal Center, Denver, CO 80225. Prepayment is required. Remittance should be sent by check or money order payable to the U.S. Geological Survey. Prices can be obtained by writing to the above address or by calling (303) 236-7476. Reprints of journal articles may be obtained by writing directly to the author at U.S. Geological Survey, 8505 Research Way, Middleton, WI 53562.

2008

Chung, E., Schladow, S.G., Perez-Losada, J., and Robertson, D.M., 2008, A linked hydrodynamic and water quality model for the Salton Sea: Hydrobiologia, v. 604, p. $57-75$.

Robertson, D.M., and Rose, W.J., 2008, Water quality, hydrology, and simulated response to changes in phosphorus loading of Butternut Lake, Price and Ashland Counties, Wisconsin, with special emphasis on the effects of internal phosphorus loading in a polymictic lake: U.S. Geol. Survey Scientific Invest. Report 2008-5053, $46 \mathrm{p}$.

Robertson, D.M., and Schladow, S.G., 2008, Response in the water quality in the Salton Sea to changes in phosphorus loading: An empirical modeling approach: Hydrobiologia, v. 604, p. 5-19.

Robertson, D.M., Schladow, S.G., and Holdren, G.C., 2008, Long-term changes in the phosphorus loading to and trophic state of the Salton Sea: Hydrobiologia, v. 604, p. 21-36.

Robertson, D.M., Garn, H.S., and Rose, W.J., 2007, Response of calcareous Nagawicka Lake, Wisconsin, to changes in phosphorus loading. Lake and Reservoir Management, Vol. 23, p. 298-312.

Walker, J.F., Saad, D.A., and Hunt, R.J., 2007, Dynamics of CFCs in northern temperate lakes and adjacent groundwater. Water Resources. Research 43(4) W04423, http://www.agu.org/pubs/crossref/2007/2005WR004647.shtml

2006

Garn, H.S., Robertson, D.M., Rose, W.J., Goddard, G.L., and Horwatich, J.A., 2006, Water quality, hydrology, and response to changes in phosphorus loading of Nagawicka Lake, a calcareous lake in Waukesha County, Wisconsin: U.S. Geological Survey Scientific Investigations Report: 2006-5273.

Hunt, R.J., Greb, S.R,, Graczyk, D.J., 2006, Evaluating the effects of nearshore development on Wisconsin lakes. USGS Fact Sheet FS-2006-3033, 4 p.

Magnuson, J.J., Benson, B.J., Lenters, J.D, and Robertson, D.M., 2006, Climate driven variability and change, Chapter 7, In Magnuson, J.J., Kratz, T.K, and Benson, B.J eds. Long-term dynamics of lakes in the landscape, Oxford University Press, p 123150. 
Saad, D.A., 2005, Pesticides in surface water, bed sediment, and ground water adjacent to commercial cranberry bogs, Lac du Flambeau Reservation, Vilas County, Wisconsin: U.S. Geological Survey Scientific Investigations Report 2005-5262, 29 p.

2005

Hunt, R.J., Feinstein, D.T., Pint, C.D., and Anderson, M.P., 2005, The importance of diverse data types to calibrate a watershed model of the Trout Lake Basin, northern Wisconsin: Journal of Hydrology doi:10.1016/j.jhydrol.2005.08.005.

Marzolf, G.R., and Robertson, D.M., 2005, Reservoir, In Encyclopedia of Hydrological Sciences: Anderson, M.G., and McDonnell, J.J., eds., v. 4, part 9, John Wiley \& Sons, p. 1675-1680.

Robertson, D.M., Rose, W.J., and Saad, D.A., 2005, Water quality, hydrology, and phosphorus loading to Little St. Germain Lake, Wisconsin, with special emphasis on the effects of winter aeration and ground-water inputs: U.S. Geological Survey Scientific Investigations Report 2005-5071, 36 p.

2004

Dupre, D.H., and Robertson, D.M., 2004, Water quality of Nippersink Creek and Wonder Lake, McHenry County, Illinois, 1994-2001: U.S. Geological Survey Scientific Investigations Report 2004-5085.

Rose, W.J., Robertson, D.M., and Mergener, E.A., 2004, Water quality, hydrology, and the effects of changes in phosphorus loading to Pike Lake, Washington County, Wisconsin, with special emphasis on inlet-to-outlet short-circuiting: U.S. Geological Survey Scientific Investigations Report 2004-5141, 32 p.

2003

Dunning, C.P., Thomas, J.C., and Lin, Y.F., 2003, Simulation of the shallow aquifer in the vicinity of Silver Lake, Washington County, Wisconsin, using analytic elements: U.S. Geological Survey Water-Resources Investigations Report 02-4204, 29 p.

Fitzpatrick, F.A., Garrison, P.J., Fitzgerald, S.A., and Elder, J.F., 2003, Nutrient, traceelement, and ecological history of Musky Bay, Lac Courte Oreilles, Wisconsin, as inferred from sediment cores: U.S. Geological Survey Water-Resources Investigations Report 02-4225, $141 \mathrm{p}$.

Fitzpatrick, F.A., and Peppler, M.C., 2003, Sedimentation and sediment chemistry, Neopit Mill Pond, Menominee Indian Reservation, Wisconsin, 2001: U.S. Geological Survey Open-File Report 03-23, 58 p.

Garn, H.S., Elder, J.F., and Robertson, D.M., 2003, Why study lakes? An overview of U.S. Geological Survey lake studies in Wisconsin: U.S. Geological Survey Fact Sheet FS-063-03, 8 p.

Graczyk, D.G., Hunt, R.J., Greb, S.R., Buchwald, C.A., and Krohelski, J.T., 2003, Hydrology, water quality, and yields, from near-shore flows to four lakes in northern Wisconsin, 1999-2001: U.S. Geological Survey Water-Resources Investigations Report 03-4144. 64 p. 
Hunt, R.J., 2003, Ground water-lake interaction modeling using the LAK3 Package for MODFLOW2000: Ground Water, vol. 41, no. 2, p. 114-118.

Hunt, R.J., Haitjema, H.M., Krohelski, J.T., and Feinstein, D.T., 2003, Simulating ground water-lake interactions: approaches and insights: Ground Water, vol. 41, no. 22, p. 227-237.

Hunt, R.J., Pint, C.D., and Anderson, M.P., 2003, Using diverse data types to calibrate a watershed model of the Trout Lake Basin, northern Wisconsin, In MODFLOW and More 2003-Understanding through modeling: Proceedings of the 5th International Conference of the International Ground Water Modeling Center. Golden, CO: Colorado School of Mines, p. 600-604.

Hunt, R.J., Saad, D.A., and Chapel, D.M., 2003, Numerical simulation of ground water flow in La Crosse County, Wisconsin and into nearby pools of the Mississippi River: U.S. Geological Survey Water-Resources Investigations Report 03-4154. 36 p.

John, R., Pint, C.D., Anderson, M.P., and Hunt, R.J., 2003, The effects of potential climate change on lake levels and lake capture zones, In MODFLOW and More 2003-Understanding through modeling: Proceedings of the 5th International Conference of the International Ground Water Modeling Center. Golden, CO: Colorado School of Mines, p. 212-216.

Magnuson, J.J., Krohelski, J.T., Kunkel, K.E., and Robertson, D.M., 2003, Wisconsin's waters and climate-historical changes and possible futures, In Wisconsin's waters: a confluence of perspectives: Transactions of the Wisconsin Academy, p. 23-36.

Pint, C.D., Hunt, R.J., and Anderson, M.P., 2003, Flow path delineation and ground water age, Allequash Basin, Wisconsin: Ground Water, vol. 41, no. 7, p. 895-902.

Robertson, D.M., Rose, W.J., and Garn, H.S., 2003, Water quality and the effects of changes in phosphorus loading, Red Cedar Lakes, Barron and Washburn Counties, Wisconsin: U.S. Geological Survey Water-Resources Investigations Report 034238, $42 \mathrm{p}$.

Robertson, D.M., Rose, W.J., and Saad, D.A., 2003, Water quality and the effects of changes in phosphorus loading to Muskellunge Lake, Vilas County, Wisconsin: U.S. Geological Survey Water-Resources Investigations Report 03-4011, 18 p.

2002

Anderson, M.P., Hunt, R.J., Krohelski, J.T., and Chung, K., 2002, Using high hydraulic conductivity nodes to simulate seepage lakes: Ground Water 40(2), p. 119-124.

Garn, H. S., 2002, Effects of lawn fertilizer on nutrient concentration in runoff from lakeshore lawns, Lauderdale Lakes, Wisconsin: USGS Water-Resources Investigations Report 02-4130, 6 p.

Kelson, V.A., Hunt, R.J., and Haitjema, H.M., 2002, Improving a regional model using reduced complexity and parameter estimation: Ground Water, vol. 40, no. 2, p. 138149. 
Krohelski, J.T., Lin, Y., Rose, W.J., and Hunt, R.J., 2002, Simulation of Fish, Mud and Crystal Lakes and the shallow ground-water system, Dane County, Wisconsin: USGS Water-Resources Investigations Report 02-20.

Krohelski, J.T., Rose, W.J., and Hunt, R.J., 2002, Hydrologic investigation of Powell Marsh and its relationship to Dead Pike Lake Vilas County, Wisconsin: USGS WaterResources Investigations Report 02-4034.

Madenjian, C.P., Fahenstiel, G.L., Johengen, T.H., Nalepa, T.F., Venderploeg, H.A., Fleischer, G.W., Schneeberger, P.J., Benjamin, D.M., Smith, E.B., Bence, J.R., Rutherford, E.S., Lavis, D.S., Robertson, D.M., Jude, D.J., and Ebener, M.P., 2002, Dynamics of the Lake Michigan food web, 1970-2000: Canadian Journal of Fisheries and Aquatic Sciences, Vol. 59, p. 736-753.

Robertson, D.M., Goddard, G.L, Mergerer, E.A., Rose, W.J., and Garrison, P.J., 2002, Hydrology and water quality of Geneva Lake, Walworth County, Wisconsin: U.S. Geological Survey Water Resources Investigations Report 02-4039, 73 p.

Robertson, D.M., and Lenz, B.N., 2002, Response of the St. Croix River Pools, Wisconsin and Minnesota, to various phosphorus-loading scenarios: U.S. Geological Survey Water-Resources Investigations Report 02-4181, 36 p.

2001

Hunt, R.J., Bradbury, K.R., and Krohelski, J.T., 2001, The effects of large-scale pumping and diversion on the water resources in Dane County, Wisconsin: USGS Fact Sheet FS-127-01, 4 p.

Hunt, R.J., Haitjema, H.M., Krohelski, J.T., and Feinstein, D.T., 2001, Simulating groundwater-lake interactions with models: MODFLOW and analytic element approaches, In MODFLOW 2001 and Other Modeling Odysseys: Proceedings of the 4th International Conference of the International Ground Water Modeling Center. Golden, CO: Colorado School of Mines, p. 328-334.

Lin, Y., Krohelski, J.T., and Hunt, R.J., 2001, Simulation of lake stage in two seepage lakes in southcentral Wisconsin using the LAK3 package for MODFLOW, In MODFLOW 2001 and Other Modeling Odysseys: Proceedings of the 4th International Conference of the International Ground Water Modeling Center. Golden, CO: Colorado School of Mines, p. 411-417.

Elder, J.F., Robertson, D.M., and Garrison, P.J., 2000, Chemical composition of surficial deposits in Geneva Lake, Wisconsin: U.S. Geological Survey Fact Sheet FS-12100 .

Elder J.F., Rybicki, N.B., Carter, V.P., and Weintraub, V., 2000, Sources and yields of dissolved carbon in northern Wisconsin stream catchments with differing amounts of peatland: Wetlands, vol. 20, no. 1, p.113-125.

Hunt, R.J., Graczyk, D.J., and Rose, W.J., 2000, Water flows in the Necedah National Wildlife Refuge: U.S. Geological Survey Fact Sheet FS-068-00, 4 p. 
Hunt, R.J., Lin, J., Krohelski, J.T., and Juckem, P.F., 2000, Simulation of the shallow hydrologic system in the vicinity of Middle Genesee Lake, Wisconsin, using analytic elements and parameter estimation: U.S. Geological Survey Water Resources Investigations Report 00-4136, 16 p.

Lathrop, R.C., Carpenter, S.R., and Robertson, D.M., 2000, Interacting factors causing exceptional water clarity in Lakes Mendota and Monona, Wisconsin: Proc. of the International Limnological Society, SIL, Dublin, Ireland, August, 1998.

Magnuson, J.J., Robertson, D.M. Wynne, R.H., Benson, B.J., Livigstone, D.M., Arai, T., Assel, R.A., Barry, R.G., Card, V., Kuusisto, E., Granin, N.G., Prowse, T.D., Stewart, K.M., and Vuglinski, V.S., 2000, Historical trends in lake and river ice cover in the northern hemisphere: Science, Vol. 289, No. 5485, p. 1743-1746.

Magnuson, J.J., Wynne, R.H., Benson, B.J., and Robertson, D.M., 2000, Lake and river ice as a powerful indicator of past and present climates: Proc. of the International Limnological Society, SIL, Dublin, Ireland, August, 1998.

Robertson, D.M., 2000, One-dimensional simulation of stratification and dissolved oxygen in McCook Reservoir, Illinois: U.S. Geological Survey Water Resources Investigations Report 00-4258, 17 p.

Robertson, D.M., Goddard, G.L., Helsel, D.R., and MacKinnon, K.L., 2000, Rehabilitation of Delavan Lake, Wisconsin: Lake and Reservoir Management, vol. 20 , vo. 3, p. $155-176$.

Robertson, D.M., and Rose, W.J., 2000, Hydrology, water quality, and phosphorus loading of Little St. Germain Lake, Vilas County, Wisconsin: U.S. Geological Survey Water Resources Investigations Report 00-4209, 8 p.

Robertson, D.M., Wynne, R.H., and Chang, W.Y.B., 2000, Variability in ice cover across the northern hemisphere during the 1900's associated with El Nino events: Proceedings of the International Limnological Society, SIL, Dublin, Ireland, August, 1998.

Saad, D.A., and Robertson, D.M., 2000, Water-resources-related information for the St. Croix Reservation and vicinity, Wisconsin: U.S. Geological Survey Water Resources Investigations Report 00-4133, 65 p.

Johnson, G.P., Hornewer, N.J., Robertson, D.M., and Olson, D.T., 2000, Methodology, data collection, and data analysis for determination of water-mixing patterns induced by aerators and mixers: U.S. Geological Survey Water Resources Investigations Report 00-4101, 72 p.

Grannemann, N.G., Hunt, R.J., Nicholas, J.R. Reilly, T.E., and Winter, T.C., 2000, The importance of ground water to the Great Lakes Region: U.S. Geological Survey Water Resources Investigations Report 00-4008, 12 p. 
Lathrop, R.C., Carpenter, S.R., and Robertson, D.M., 1999, Summer water clarity responses to phosphorus, Daphnia grazing, and internal mixing in Lake Mendota: Limnology and Oceanography, vol. 44, no. 1, p. 137-146.

Krohelski, J.T., Feinstein, D.T., and Lenz, B.N., 1999, Simulation of stage and hydrologic budget for Shell Lake, Washburn County, Wisconsin: U.S. Geological Survey WaterResources Investigations Report 99-4209, 23 p.

Panuska, J.C., and Robertson, D.M., 1999, Estimating phosphorus concentrations following alum treatment using apparent settling velocities: Lakes and Reservoir Management, vol. 15, no. 1, p. 28-38.

\section{8}

Hunt, R.J, Anderson, M.P., and Kelson, V.A., 1998, Improving a complex finitedifference ground water flow model through the use of an analytic element screening model: Ground Water, vol. 36, no. 6, p. 1011-1017.

Hunt, R.J, Anderson, M.P., and Kelson, V.A., 1998, Linking an analytic element flow code to MODFLOW - Implementation and benefits, In MODFLOW'98: Proceedings of the 3rd International Conference of the International Ground Water Center. Golden, CO: Colorado School of Mines, p 477-504.

Krabbenhoft, D.P., Gilmour, C.C., Benoit, J.M., Babiarz, C.L., Andren, A.W., and Hurley, J.P., 1998, Methyl mercury dynamics in littoral sediments of a temperate lake: Canadian Journal of Fisheries and Aquatic Sciences, vol. 55, p. 835-844.

Robertson, D.M., Elder, J.F., Goddard, G.L., and James, W.F., 1998, Dynamics in phosphorus retention in wetlands upstream of Delavan Lake, Wisconsin: Lakes and Reservoir Management, vol. 14, no. 4, p. 466-477.

Rose, W.J., and Robertson, D.M., 1998, Hydrology, water quality, and phosphorus loading of Kirby Lake, Barron County, Wisconsin: U.S. Geological Survey Fact Sheet FS-066-98, 4 p.

Walker, J.F. and Krabbenhoft, D.P., 1998, Groundwater and surface-water interactions in riparian and lake-dominated systems, In Kendall, C. and McDonnell, J.J. eds., Isotope tracers in catchment hydrology, Elsevier Publishing, New York, 839 p.

1997

Elder, J.F., Manion, B.J., and Goddard, G.L., 1997, Mesocosm experiments to assess factors affecting phosphorus retention and release in an extended Wisconsin wetland: U.S. Geological Survey Water-Resources Investigations Report 97-4272, $14 \mathrm{p}$.

Goddard, G.L., and Elder, J.F., 1997, Retention of sediments and nutrients in Jackson Creek Wetland near Delavan Lake, Wisconsin, 1993-95: U.S. Geological Survey Water-Resources Investigations Report 97-4014, 22 p. 
Hornewer, N.J., Johnson, G.P., Robertson, D.M. and Hondzo, M., 1997, Field-scale tests for determining mixing patterns associated with coarse-bubble air diffuser configurations, Egan Quarry, Illinois, In Environmental and Coastal Hydraulics: Protecting the Aquatic Habitat, Proceedings of the International Association of Hydraulic Research, San Francisco, CA, USA, p. 57-63.

Robertson, D.M., 1997, Regionalized loads of sediment and phosphorus to Lakes Michigan and Superior-High flow and long-term average: Journal of Great Lakes Research, vol. 23, p. 416-439.

1996

Anderson, W.L., Robertson, D.M., and Magnuson, J.J., 1996, Evidence of recent warming and El Nino-related variation in ice breakup of Wisconsin lakes: Limnology and Oceanography, vol. 41, p. 815-821.

Elder, J.F. and Goddard, G.L., 1996, Sediment and nutrient trapping efficiency of a constructed wetland near Delavan Lake, Wisconsin, 1993-1995: U.S. Geological Survey Fact Sheet FS-232-96.

Garn, H.S., Olson, D.L., Seidel, T.L., and Rose, W.J., 1996, Hydrology and water quality of Lauderdale Lakes, Walworth County, Wisconsin, 1993-94: U.S. Geological Survey Water-Resources Investigations Report 96-4235, 29 p.

Hunt, R.J. and Krohelski, J.T., 1996, The application of an analytical element model to investigate groundwater-lake interactions at Pretty Lake, Wisconsin: Lake and Reservoir Management, vol. 12, p. 487-495.

Imberger, J., Robertson, D.M., and Boland, K., 1996, Lake Number-A quantitative indicator of mixing to be used in water quality management: Scientific Impeller, Solna, Sweden, no. 4, p. 9-15.

Kammerer, P.A., Jr., 1996, Hydrology and water quality of Park Lake, South-central Wisconsin: U.S. Geological Survey Fact Sheet FS-197-96.

Robertson, D.M., Field, S.J, Elder, J.F., Goddard, G.L., and James, W.F., 1996, Phosphorus dynamics of Delavan Lake Inlet in southeastern Wisconsin: U.S. Geological Survey Water-Resources Investigations Report 96-4160, 18 p.

1995

Assel, R.A. and Robertson, D.M. 1995, Changes in winter air temperatures near Lake Michigan during 1851-1993, as determined from regional lake-ice records: Limnology and Oceanography, v. 40, p 165-176.

Assel, R.A., Robertson, D.M., Hoff, M.H., and Selgeby, J.H., 1995, Climatic-change implications from long-term (1823-1994) ice records near the Laurentian Great Lakes: Annals of Glaciology, vol. 21, p. 383-386.

Krabbenhoft, D.P., and Webster, K.E., 1995, Transient hydrogeological controls on the chemistry of a seepage lake: Water Resources Research, vol. 31, no. 9, p. 22952305. 
Krohelski, J.T. and Batten, W.G., 1995, Simulation of stage and the hydrologic budget of Devils Lake, Sauk County, Wisconsin: U.S. Geological Survey Open-File Report 94348, $22 \mathrm{p}$.

Wentz, D.A., Rose, W.J., and Webster, K.E., 1995, Long-term hydrologic and biogeochemical responses of a soft water seepage lake in north central Wisconsin: Water Resources Research, vol. 31, no. 1, p. 199-212.

1994

Elder, J.F., 1994, Distribution and grain-size partitioning of metals in bottom sediments of an experimentally acidified lake: Water Resources Bulletin, vol. 30, no. 2, p. 251259.

Goddard, G.L., and Field, S.J., 1994, Hydrology and water quality of Whitewater and Rice Lakes in southeastern Wisconsin, 1990-91: U.S. Geological Survey WaterResources Investigations Report 94-4101, 36 p.

Greb, S.R., and Wentz, D.A., 1994, Chemical budgets, In Klepinger, K.E., ed., RILWAS 1983-86: Wisconsin Regional Integrated Lake Watershed Acidification Study, Volume 1: Madison, Wisconsin Department of Natural Resources, PUBL-RS-90994, Chapter 7, $20 \mathrm{p}$.

Hurley, J.P., Krabbenhoft, D.P., Babiarz, C.L., and Andren, A.W., 1994, Cycling processes of mercury across sediment/water interfaces in seepage lakes, In Baker, L.A. ed., Environmental Chemistry of Lakes and Reservoirs: Advances in Chemistry Series, American Chemical Society, Washington, D.C., p. 426-449.

Krabbenhoft, D.P., Bowser, C.J., Kendall, C., and Gat, J.R., 1994, Use of oxygen-19 and deuterium to assess the hydrology of ground-water/lake systems, In Baker, L.A. ed., Environmental Chemistry of Lakes and Reservoirs: Advances in Chemistry Series, American Chemical Society, Washington, D.C., p. 67-90.

Robertson, D.M., Anderson, W., and Magnuson, J.J., 1994, Relations between El Nino/Southern Oscillation events and the climate and ice cover of lakes in Wisconsin, In Greenland, D. ed., El Nino and Long-Term Ecological Research (LTER) Sites: Publication No. 18. LTER Network Office: University of Washington, Seattle, WA, USA., p. 48-57.

Robertson, D.M. and Imberger, J. 1994, Lake Number, a quantitative indicator of mixing used to estimate changes in dissolved oxygen, Internationale Revue der gesamten Hydrobiologie, v. 79, p. 159-176.

Watras, C.J., Bloom, N.S., Hurley, J.P., Fitzgerald, W.F., Andren, A.W., Krabbenhoft, D.P., and Porcella, D.B., 1994, Sources and fates of mercury and methylmercury in Wisconsin lakes, In Watras and Huckabee eds., Mercury as a Global Pollutant: Intergration and Synthesis, Lewis Pub., Chelsea, MI., p 153-177.

Wentz, D.A., 1994, Chemistry of snowpack and ground water, In Klepinger, K.E., ed., RILWAS 1983-86: Wisconsin regional integrated lake watershed acidification study, volume 1: Madison, Wisconsin Department of Natural Resources, PUBL-RS-90994, chapter 6, $45 \mathrm{p}$. 
Wentz, D.A., Krohelski, J.T., and Rose, W.J., 1994, Hydrology, In Klepinger, K.E., ed., RILWAS 1983-86: Wisconsin regional integrated lake watershed acidification study, volume 1: Madison, Wisconsin Department of Natural Resources, PUBL-RS-90994, chapter 7, $74 \mathrm{p}$.

1993

Field, S.J., 1993, Hydrology and water quality of Powers Lake, southeastern Wisconsin: U.S. Geological Survey Water-Resources Investigations Report 90-4126, 36 p.

Field, S.J., 1993, Hydrology and water quality of Wind Lake in southeastern Wisconsin: U.S. Geological Survey Water-Resources Investigations Report 91-4107, 61 p.

House, L.B., 1993, Simulation of the effects of hypothetical residential development on water levels in Graber Pond, Middleton, Wisconsin: U.S. Geological Survey WaterResources Investigations Report 92-4029, 10 p.

House, L.B., Waschbusch, R.J., and Hughes, P.E., 1993, Water quality of an urban wet detention pond in Madison, Wisconsin, 1987-88: U.S. Geological Survey Open-File Report 93-172, $57 \mathrm{p}$.

Hughes, P.E., 1993, Hydrology, water quality, trophic status, and aquatic plants of Fowler Lake, Wisconsin: U.S. Geological Survey Water-Resources Investigations Report 91-4076, $44 \mathrm{p}$.

Rose, W.J., 1993, Hydrology of Little Rock Lake in Vilas County, north-central Wisconsin: U.S. Geological Survey Water-Resources Investigations Report 93-4139, $22 \mathrm{p}$.

Rose, W.J., 1993, Water and phosphorus budgets and trophic state, Balsam Lake, northwestern Wisconsin, 1987-1989: U.S. Geological Survey Water-Resources Investigations Report 91-4125, 28 p.

1992

Elder, J.F., Krabbenhoft, D.P, and Walker, J.F., 1992, Water, energy, and biogeochemical budgets (WEBB) program: Data availability and research at the northern temperate lakes site, Wisconsin: U.S. Geological Survey Open-File Report 92-48, $15 \mathrm{p}$.

Krabbenhoft, D.P., and Babiarz, C.L., 1992, Role of groundwater transport in aquatic mercury cycling: Water Resources Research, vol. 28, no. 12, p. 3119-3128.

Krabbenhoft, D.P., and Krohelski, J.T., 1992, Data on water quality, lake sediment, and lake-level fluctuation, St. Croix Indian Reservation, Wisconsin, 1981-87: U.S. Geological Survey Open-File Report 92-26, 53 p.

Robertson, D.M., Ragotzkie, R.A., and Magnuson, J.J. 1992, Lake ice records used to detect historical and future climatic changes: Climatic Change, v. 21, p. 407-427. 
Wentz, D.A., and Rose, W.J., 1991, Hydrology of Lakes Clara and Vandercook in northcentral Wisconsin: U.S. Geological Survey Water-Resources Investigations Report 89-4204, 24 p.

Watras, C.J., Andre, A.W., Bloom, N.S., Fitzgerald, W.F., Hurley, J.P., Krabbenhoft, D.P., Rada, R.G., Wiener, J.G., 1991, Mercury in temperate lakes: a mechanistic field study: Verhandlungen Internat. Verein. Limnologie, 24, p. 2199-2202.

Pre-1990

Walker, J.F., Pickard, S.A., and Sonzogni, W.C., 1989 Spreadsheet watershed modeling for nonpoint-source pollution management in a Wisconsin basin: Water Resources Bulletin, vol. 25, no. 1, p. 139-147.

Wentz, D.A., Garrison, P.J., and Bockheim, J.G., 1989, Section 7-Chemical inputoutput budgets, In Knauer, D., and Brouwer, S.A., eds., The Wisconsin regional integrated lake watershed acidification study (RILWAS)-1981-1983: Palo Alto, California, Electric Power Research Institute Report EA-6214, p. 7-1 to 7-30.

Wentz, D.A., and Rose, W.J., 1989, Interrelationships among hydrologic-budget components of a northern Wisconsin seepage lake and implications for aciddeposition modeling: Archives of Environmental Contamination and Toxicology, vol. 18, p. 147-155.

Wentz, D.A., Rose, W.J., and Krohelski, J.T., 1989, Section 5-Hydrologic component, in Knauer, D., and Brouwer, S.A., eds., The Wisconsin regional integrated lake watershed acidification study (RILWAS)-1981-1983: Palo Alto, California, Electric Power Research Institute Report EA-6214, p. 5-1 to 5-77.

Field, S.J., and Duerk, M.D., 1988, Hydrology and water quality of Delavan Lake in southeastern Wisconsin: U.S. Geological Survey Water-Resources Investigations Report 87-4168, 61 p.

Krug, W.R., Ostenso, N.A., and Krohelski, J.T., 1988, Prediction of the effects of mine dewatering on four lakes near Crandon, Wisconsin, by use of a water-budget model: U.S. Geological Survey Open-File Report 87-471, 63 p.

Wentz, D.A., Krohelski, J.T., Rose, W.J., Bockheim, J.G., Garrison, P.J., Knauer, D.R., and Goldstein, R.A., 1987, Hydrologic and chemical budgets of Wisconsin lakes, In Perry, R., Harrison, R.M., Bel, J.N.B., and Lester, J.N., eds., Acid Rain: Scientific and Technical Advances, Selper Ltd., London, p. 309-316.

House, L.B., 1986, Stage fluctuations of Wisconsin Lakes: Wisconsin Geological and Natural History Survey Information Circular No. 49, 84 p.

House, L.B., 1984, Effects of urbanization on three ponds in Middleton, Wisconsin: U.S. Geological Survey Water-Resources Investigations Report 84-4051, 17 p.

Krug, W.R., and House, L.B., 1984, Evaluation of alternative reservoir-management practices in the Rock River basin, Wisconsin: U.S. Geological Survey WaterResources Investigations Report 83-4186, 21 p. 
House, L.B., 1981, An assessment of streamflow, water quality, and the effects of construction on impoundment on Bridge Creek at Augusta, Wisconsin: U.S. Geological Survey Water-Resources Investigations Open-File Report 81-1192, 25 p.

Krug, W.R., 1981, Hydrologic effects of proposed changes in management practices, Winnebago Pool, Wisconsin: U.S. Geological Survey Water-Resources Investigations 80-107, 19 p.

Batten, W.G., and Hindall, S.M., 1980, Sediment deposition in the White River Reservoir, northwestern Wisconsin: U.S. Geological Survey Water-Supply Paper 2069, 30 p.

Novitzki, R.P., and Holmstrom, B.K., 1979, Monthly and annual water budgets of Lake Wingra, Madison, Wisconsin, 1971-77: U.S. Geological Survey Water-Resources Investigations 79-100, $31 \mathrm{p}$.

Rose, W.J., 1977, Hydrologic considerations associated with dredging spring ponds in Wisconsin: U.S. Geological Survey Water-Resources Investigations 77-18, 35 p.

Oakes, E.L., Hendrickson, G.E., and Zuehls, E.E., 1975, Hydrology of the Lake Wingra basin, Dane County, Wisconsin: U.S. Geological Survey Water-Resources Investigations 17-75, $31 \mathrm{p}$.

Novitzki, R.P., 1971, Hydrologic investigations of Heart Lake, Green Lake County, Wisconsin: U.S. Geological Survey Administrative Report, 9 p. 


\section{APPENDIX \\ Wisconsin Lakes Team Quality-Assurance Plan}

Most lake studies that are conducted by the USGS Wisconsin Water Science Center include water sampling and analysis to determine water quality and biological productivity. Because all sampling and analyses are subject to possible biases and variablility, rigorous sampling efforts should include quality-assurance samples. Studies conducted by the Lake Studies Team of the USGS Wisconsin Water Science Center include a quality-assurance plan each year that involves collecting three types of samples from a subset of the lakes studied each year, which include blanks, replicates, and spikes. These samples are collected and/or prepared solely for the purpose of assessing the magnitude of potential biases and variability so that the accuracy and precision of all data can be evaluated. The plan for this quality-assurance sampling is described below.

Three types of QA/QC samples are collected:

\section{Blanks:}

Provide information about accuracy and potential biases due to treatment or reagents

Replicates:

Provide information about precision (variability)

Standard additions (spikes):

Provide information about accuracy and matrix interferences

\section{Blank Sampling}

B1. A preservation blank consists of deionized water or inorganic blank water, to which is added any reagents or preservatives that are normally added to natural water samples. The blank is not taken to the field, but is shipped to the laboratory for analysis along with the natural water samples.

This blank sample is analyzed for the Nutrient Group ${ }^{1}$ and chlorophyll-a.

B2. A field blank consists of deionized water or inorganic blank water treated exactly the same as regular samples. Typically, during winter, the field blank is analyzed for total phosphorus (TP) only; during summer, it is analyzed for TP and chlorophyll-a, and in the spring it is analyzed for the Nutrient Group and chlorophyll-a.

\footnotetext{
${ }^{1}$ Nutrient Group = all phosphorus and nitrogen species that are commonly determined in lakes (total phosphorus, nitrate + nitrite, ammonia, total Kjeldahl nitrogen, total nitrogen)
} 


\section{Replicate Sampling}

Triplicate samples are taken near water surface in summer for analysis of total phosphorus and chlorophyll-a. For a portion of the sites where surface triplicates are collected, a set of triplicate samples is also sometimes taken from nearbottom water, for analysis of total phosphorus.

Triplicate samples collected in the spring are taken near the water surface for analysis of the Nutrient Group.

\section{Standard Addition Testing}

Replicate samples are collected for a standard addition (spike) test, which consists of an addition of a prepared phosphorus solution (standard) of known volume and concentration, such that the expected result of analysis is the natural water TP concentration plus the known addition. One sample from each set receives no spike (the mean of these gives the natural water TP concentration).

Data and results of replicate sampling and field blank testing in water year 2008 are shown in Table A1. 
Table A1. Analyses of replicate samples from Wisconsin lakes in water years 2004-2008. See text for procedures used. Phosphorus data in milligrams per liter; chlorophyll data in micrograms per liter. Symbol "<" indicates less than given detection limit (DL); mean and standard deviation not calculated for datasets containing values less than DL.

\begin{tabular}{|c|c|c|c|c|c|c|c|c|c|c|}
\hline Parameter & Lake & Date & \multicolumn{5}{|c|}{ Replicate Data } & Mean & $\begin{array}{l}\text { Standard } \\
\text { Deviation }\end{array}$ & $\begin{array}{r}\text { Percent } \\
\text { Standard } \\
\text { Deviation } \\
\end{array}$ \\
\hline \multirow{15}{*}{ Total Phosphorus } & Delavan & $7 / 20 / 04$ & 0.031 & 0.020 & 0.041 & & & 0.031 & 0.011 & $34.3^{\star}$ \\
\hline & Big Cedar & $8 / 18 / 04$ & 0.012 & 0.011 & 0.012 & & & 0.012 & 0.001 & 4.9 \\
\hline & Big Cedar, South & $7 / 19 / 05$ & 0.015 & 0.015 & 0.009 & \multirow{4}{*}{0.017} & \multirow{4}{*}{0.013} & 0.013 & 0.003 & 26.6 \\
\hline & Delavan & $8 / 16 / 05$ & 0.032 & 0.029 & 0.027 & & & 0.029 & 0.003 & 8.6 \\
\hline & Middle & $8 / 25 / 05$ & 0.014 & 0.012 & 0.013 & & & 0.014 & 0.002 & 13.9 \\
\hline & Puckaway, West & $7 / 18 / 05$ & 0.309 & 0.310 & 0.313 & & & 0.311 & 0.002 & 0.7 \\
\hline & Upper Nemahbin & $8 / 24 / 05$ & 0.015 & 0.017 & 0.018 & 0.039 & 0.023 & 0.022 & 0.010 & 43.5 \\
\hline & Big Cedar & 8/30/06 & 0.035 & 0.034 & \multirow[t]{2}{*}{0.032} & \multirow{3}{*}{\multicolumn{2}{|c|}{0.026}} & 0.034 & 0.002 & 4.5 \\
\hline & Delavan & $6 / 13 / 06$ & 0.062 & 0.045 & & & & 0.054 & 0.012 & 22.5 \\
\hline & Delavan & $8 / 15 / 06$ & 0.030 & 0.028 & 0.029 & & & 0.028 & 0.002 & 6.0 \\
\hline & Beulah & $8 / 30 / 07$ & 0.017 & 0.015 & & & & 0.016 & 0.001 & 8.8 \\
\hline & Delavan & $4 / 16 / 07$ & 0.040 & 0.038 & & & & 0.039 & 0.001 & 3.6 \\
\hline & Spring & 9/6/07 & 0.008 & 0.007 & & & & 0.008 & 0.001 & 9.4 \\
\hline & Beulah & $3 / 4 / 08$ & 0.010 & 0.011 & & & & 0.011 & 0.001 & 6.7 \\
\hline & Beulah & $8 / 26 / 08$ & 0.011 & 0.012 & & & & 0.012 & 0.001 & 6.1 \\
\hline \multirow{2}{*}{$\begin{array}{l}\text { Total Phosphorus, } \\
\text { near bottom }\end{array}$} & Wind & $7 / 11 / 05$ & 0.380 & 0.378 & 0.394 & & & 0.384 & 0.009 & 2.3 \\
\hline & Wind & $7 / 10 / 06$ & 0.380 & 0.378 & 0.394 & & & 0.384 & 0.009 & 2.3 \\
\hline \multirow{3}{*}{$\begin{array}{l}\text { Dissolved } \\
\text { Phosphorus }\end{array}$} & Beulah & $8 / 30 / 07$ & $<0.002$ & $<0.002$ & & & & & & \\
\hline & Beulah & $3 / 4 / 08$ & 0.001 & 0.003 & & & & 0.002 & 0.001 & 70.7 \\
\hline & Beulah & $8 / 26 / 08$ & $<0.002$ & $<0.002$ & & & & & & \\
\hline \multirow{3}{*}{ Dissolved Ammonia } & Beulah & $8 / 30 / 07$ & 0.170 & 0.190 & & & & 0.180 & 0.014 & 7.9 \\
\hline & Beulah & $3 / 4 / 08$ & 0.083 & 0.046 & & & & 0.065 & 0.026 & 40.6 \\
\hline & Beulah & $8 / 26 / 08$ & $<0.015$ & $<0.015$ & & & & & & \\
\hline \multirow{3}{*}{ Total Kjeldahl Nitrogen } & Beulah & 8/30/07 & 0.510 & 0.420 & & & & 0.465 & 0.064 & 13.7 \\
\hline & Beulah & $3 / 4 / 08$ & 0.570 & 0.450 & & & & 0.510 & 0.085 & 16.6 \\
\hline & Beulah & $8 / 26 / 08$ & 0.530 & 0.580 & & & & 0.555 & 0.035 & 6.4 \\
\hline \multirow{4}{*}{$\begin{array}{l}\text { Dissolved Nitrate plus } \\
\text { Nitrite }\end{array}$} & Delavan & $4 / 14 / 04$ & $<0.022$ & $<0.022$ & $<0.022$ & & & & & \\
\hline & Beulah & $8 / 30 / 07$ & $<0.019$ & $<0.019$ & & & & & & \\
\hline & Beulah & $3 / 4 / 08$ & 0.675 & 0.670 & & & & 0.673 & 0.004 & 0.5 \\
\hline & Beulah & $8 / 26 / 08$ & $<0.019$ & $<0.019$ & & & & & & \\
\hline \multirow{9}{*}{$\begin{array}{c}\text { Chlorophyll-a } \\
\text { (micrograms per liter) }\end{array}$} & Delavan & $7 / 20 / 04$ & 10.4 & 11.6 & 10.5 & & & 10.8 & 0.7 & 6.1 \\
\hline & Big Cedar & $8 / 18 / 04$ & 8.36 & 8.56 & 8.61 & & & 8.51 & 0.13 & 1.6 \\
\hline & Big Cedar, South & $7 / 19 / 05$ & 3.13 & 3.10 & 2.63 & & & 2.95 & 0.28 & 9.49 \\
\hline & Middle & $8 / 25 / 05$ & 4.45 & 4.48 & 4.82 & 4.70 & 4.40 & 4.58 & 0.21 & 4.48 \\
\hline & Puckaway, West & $7 / 18 / 05$ & 174.00 & 178.00 & 168.00 & & & 173.33 & 5.03 & 2.90 \\
\hline & Big Cedar, South & $8 / 29 / 06$ & 8.02 & 7.56 & 8.20 & & & 7.93 & 0.33 & 4.16 \\
\hline & Beulah & $8 / 30 / 07$ & 4.05 & 3.78 & & & & 3.92 & 0.19 & 4.88 \\
\hline & Spring & $9 / 6 / 07$ & 2.47 & 2.79 & & & & 2.63 & 0.23 & 8.60 \\
\hline & Beulah & $8 / 26 / 08$ & 6.97 & 7.45 & & & & 7.21 & 0.34 & 4.71 \\
\hline \multirow{3}{*}{ Turbidity, NTU } & Beulah & $8 / 30 / 07$ & $<1.0$ & $<1.0$ & & & & & & \\
\hline & Beulah & $3 / 4 / 08$ & $<1.0$ & $<1.0$ & & & & & & \\
\hline & Beulah & $8 / 26 / 08$ & $<1.0$ & $<1.0$ & & & & & & \\
\hline \multirow{3}{*}{ Dissolved Calcium } & Beulah & $8 / 30 / 07$ & 42.8 & 41 & & & & 41.9 & 1.273 & 3.0 \\
\hline & Beulah & $3 / 4 / 08$ & 62.8 & 62.5 & & & & 62.65 & 0.212 & 0.3 \\
\hline & Beulah & $8 / 26 / 08$ & 47.9 & 47.6 & & & & 47.75 & 0.212 & 0.4 \\
\hline \multirow{3}{*}{ Diss. Magnesium } & Beulah & $8 / 30 / 07$ & 32.7 & 31.2 & & & & 31.95 & 1.061 & 3.3 \\
\hline & Beulah & $3 / 4 / 08$ & 35.6 & 35.5 & & & & 35.55 & 0.071 & 0.2 \\
\hline & Beulah & $8 / 26 / 08$ & 32.8 & 32.5 & & & & 32.65 & 0.212 & 0.6 \\
\hline \multirow{3}{*}{ Diss. Potassium } & Beulah & $8 / 30 / 07$ & 1.5 & 1.4 & & & & 1.45 & 0.071 & 4.9 \\
\hline & Beulah & $3 / 4 / 08$ & 1.8 & 1.9 & & & & 1.85 & 0.071 & 3.8 \\
\hline & Beulah & $8 / 26 / 08$ & 1.4 & 1.4 & & & & 1.4 & 0.000 & 0.0 \\
\hline
\end{tabular}




\begin{tabular}{|c|c|c|c|c|c|c|c|}
\hline Parameter & Lake & Date & & Replicate Data & Mean & Deviation & Standard \\
\hline \multirow{3}{*}{ Dissolved Sodium } & Beulah & $8 / 30 / 07$ & 8.8 & 8.5 & 8.65 & 0.212 & 2.5 \\
\hline & Beulah & $3 / 4 / 08$ & 9.9 & 10 & 9.95 & 0.071 & 0.7 \\
\hline & Beulah & $8 / 26 / 08$ & 9 & 8.9 & 8.95 & 0.071 & 0.8 \\
\hline \multirow{4}{*}{ ANC as $\mathrm{CaCO} 3$} & Beulah & 8/30/07 & 192 & 193 & 192.5 & 0.707 & 0.4 \\
\hline & Spring & $9 / 6 / 07$ & 6.6 & 6.4 & 6.5 & 0.141 & 2.2 \\
\hline & Beulah & $3 / 4 / 08$ & 245 & 244 & 244.5 & 0.707 & 0.3 \\
\hline & Beulah & $8 / 26 / 08$ & 219 & 218 & 218.5 & 0.707 & 0.3 \\
\hline \multirow{3}{*}{ Diss. Chloride } & Beulah & $8 / 30 / 07$ & 20.3 & 20.4 & 20.35 & 0.071 & 0.3 \\
\hline & Beulah & $3 / 4 / 08$ & 23.5 & 23.7 & 23.6 & 0.141 & 0.6 \\
\hline & Beulah & $8 / 26 / 08$ & 21 & 20.9 & 20.95 & 0.071 & 0.3 \\
\hline \multirow{4}{*}{ Dissolved Silica } & Beulah & $8 / 30 / 07$ & 15.2 & 15.3 & 15.25 & 0.071 & 0.5 \\
\hline & Spring & $9 / 6 / 07$ & 0.105 & 0.111 & 0.108 & 0.004 & 3.9 \\
\hline & Beulah & $3 / 4 / 08$ & 15.3 & 15.2 & 15.25 & 0.071 & 0.5 \\
\hline & Beulah & $8 / 26 / 08$ & 10.3 & 10.3 & 10.3 & 0.000 & 0.0 \\
\hline \multirow{3}{*}{ Dissolved Sulfate } & Beulah & $8 / 30 / 07$ & 26.1 & 26.2 & 26.15 & 0.071 & 0.3 \\
\hline & Beulah & $3 / 4 / 08$ & 29.5 & 29.5 & 29.5 & 0.000 & 0.0 \\
\hline & Beulah & 8/26/08 & 26.3 & 26.3 & 26.3 & 0.000 & 0.0 \\
\hline \multirow{3}{*}{ Dissolved Iron } & Beulah & $8 / 30 / 07$ & $<100$ & $<100$ & & & \\
\hline & Beulah & $3 / 4 / 08$ & $<100$ & $<100$ & & & \\
\hline & Beulah & $8 / 26 / 08$ & $<100$ & $<100$ & & & \\
\hline \multirow{2}{*}{ Diss. Manganese } & Beulah & $8 / 30 / 07$ & $<0.5$ & $<0.5$ & & & \\
\hline & Beulah & $8 / 26 / 08$ & $<0.5$ & $<0.5$ & & & \\
\hline Dissolved Solids & Beulah & $8 / 26 / 08$ & 302 & 298 & 300 & 2.83 & 0.9 \\
\hline
\end{tabular}

*Algal bloom on lake. 
Table A2. Data from tests of blanks, 2004-2008. All data in milligrams per liter, unless otherwise indicated. $\leq=$ less than given detection limit; $\mathrm{E}=$ estimated value.

Delavan Lake. Analyses at USGS National Water Quality Laboratory, Lakewood, CO.

Parameter

Total P

Dissolved orthophosphate

Chlorophyll a

Chlorophyll b

Total Kjeldahl Nitrogen (as N)

Ammonia (as N)

Nitrate + Nitrite (as N)

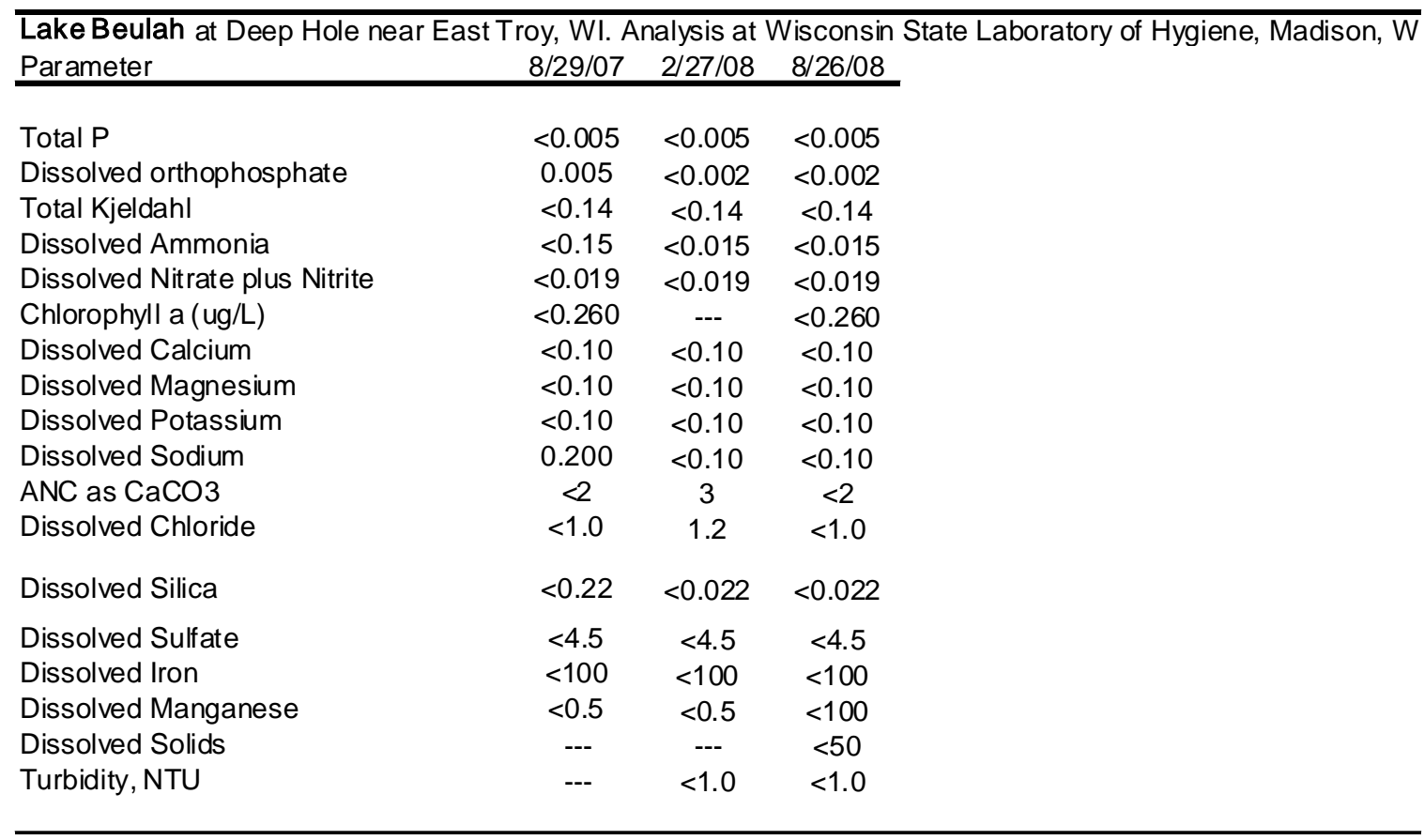

\begin{tabular}{lc}
\hline $\begin{array}{l}\text { Rolling Stone Lake near Pickerel, WI. Analysis at Wisconsin State Laboratory of Hygiene, Madison, WI } \\
\text { Parameter }\end{array}$ \\
\hline \\
\hline
\end{tabular}

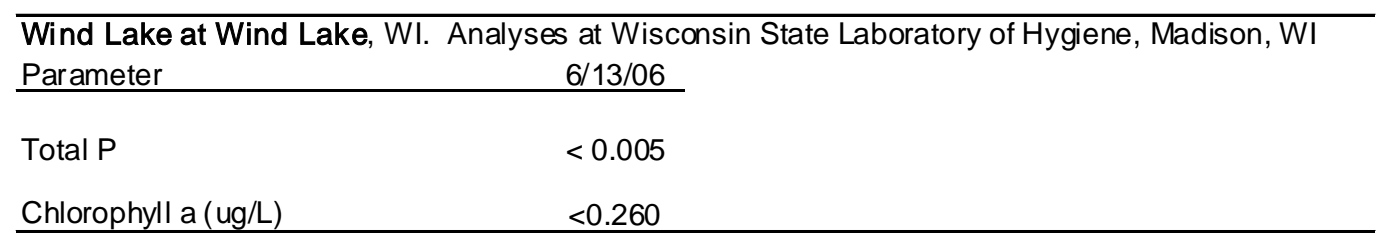


Table A3. Data (for 2004-2008) from standard addition tests using stock solution containing $5.00 \mathrm{mg} / \mathrm{L}$ phosphorus. See text for detail of procedures. All concentration data in milligrams per liter.

\begin{tabular}{|c|c|c|c|c|c|}
\hline Lake, Date & $\begin{array}{c}\frac{\text { Original }}{\text { Sample }} \\
\text { Concentration } \\
\end{array}$ & $\frac{\frac{\text { Stock Solution }}{\text { Volume Added }}}{\text { (milliliters) }}$ & $\begin{array}{l}\text { Final Expected } \\
\text { Concentration } \\
\end{array}$ & 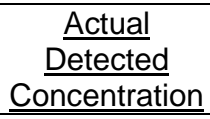 & $\begin{array}{r}\text { Percent } \\
\text { Recovery } \\
\end{array}$ \\
\hline $\begin{array}{l}\text { Delavan, } \\
\text { August 16, } \\
2005\end{array}$ & $\begin{array}{l}0.029 \\
0.029\end{array}$ & $\begin{array}{c}0.188 \\
0.75\end{array}$ & $\begin{array}{l}0.036 \\
0.059 \\
\end{array}$ & $\begin{array}{l}0.037 \\
0.063\end{array}$ & $\begin{array}{l}103 \% \\
107 \%\end{array}$ \\
\hline $\begin{array}{l}\text { No Spike data } \\
\text { in } 2006\end{array}$ & & & & & \\
\hline $\begin{array}{l}\text { No Spike data } \\
\text { in } 2007\end{array}$ & & & & & \\
\hline $\begin{array}{l}\text { No Spike data } \\
\text { in } 2008\end{array}$ & & & & & \\
\hline
\end{tabular}




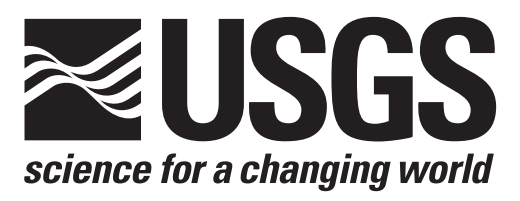

\section{Water-Quality and Lake-Stage Data for Wisconsin Lakes, Water Year 2009}






\section{CONTENTS}

Introduction

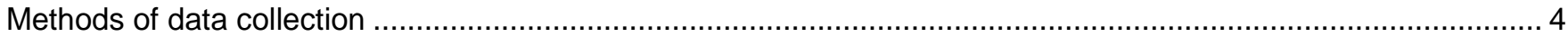

Explanation of physical and chemical characteristics of lakes ……............................................................. 13

Water temperature and thermal stratification ................................................................................. 13

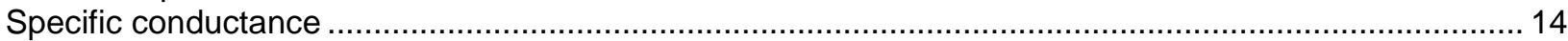

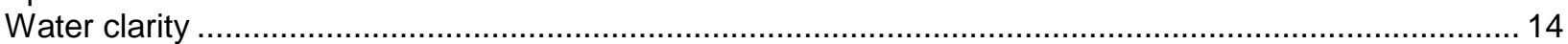

$\mathrm{pH}$

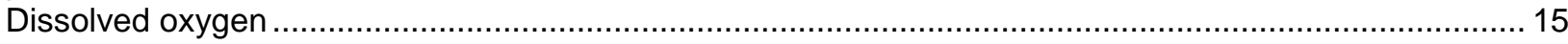

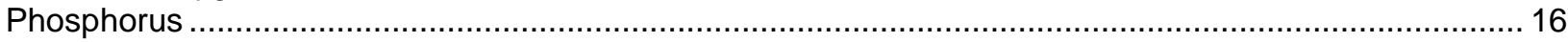

Nitrogen

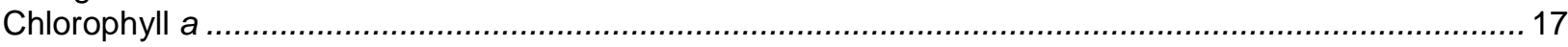

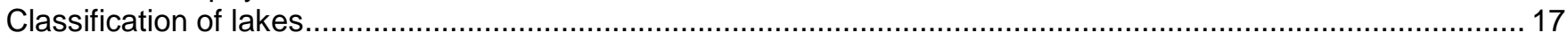

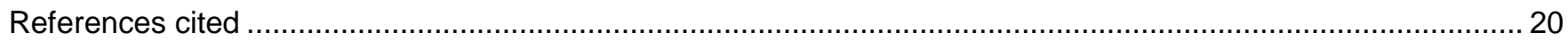

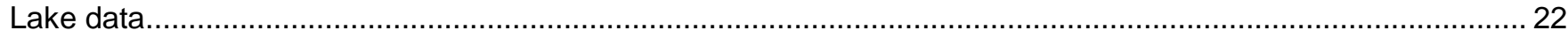

Beulah

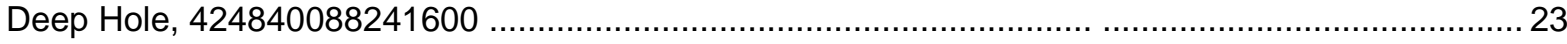

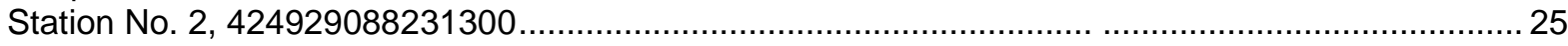

Big Cedar

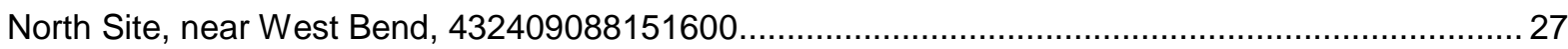

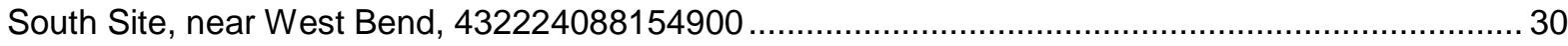

Delavan

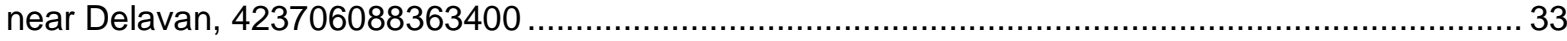

at Center near Delavan Lake, 423556088365001 .................................................................... 36

at North End near Lake Lawn, 423659088354401 ................................................................. 44

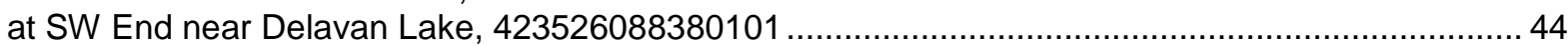

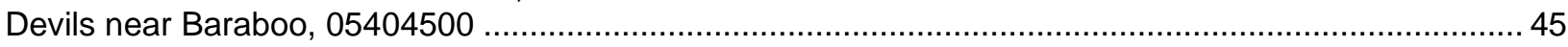

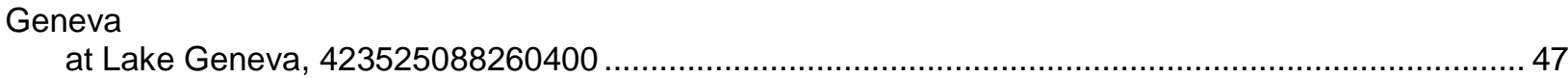

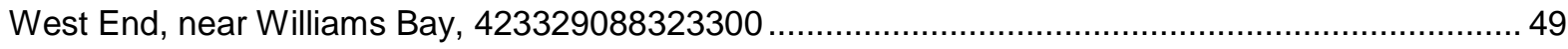

Green

at County Trunk Highway A near Green Lake (East End), 434928088553601 ................................. 54

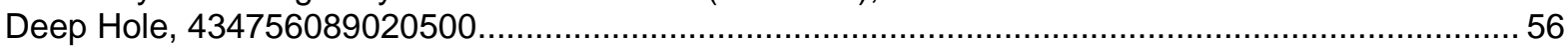

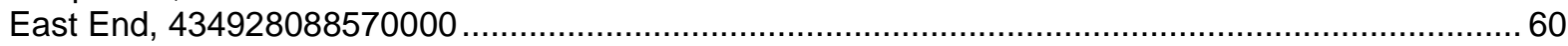

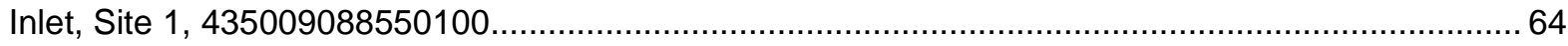

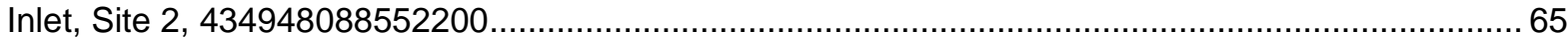

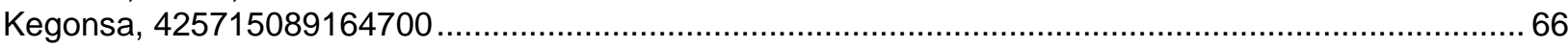

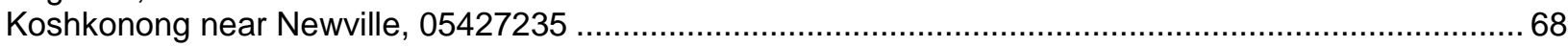

Little Cedar

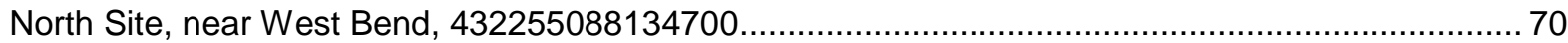

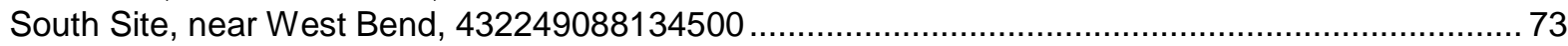

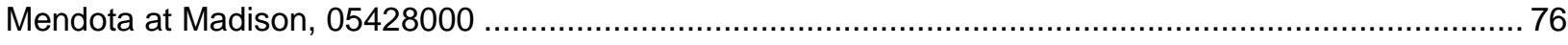

Mercer

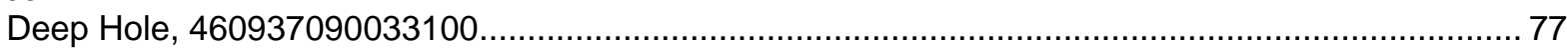

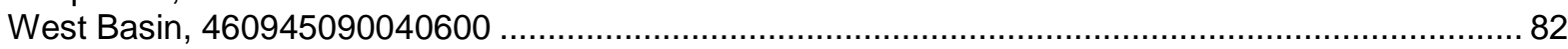

Middle Genesee at Genesee Lake Road, near Oconomowoc, 430251088284700 .................................. 86

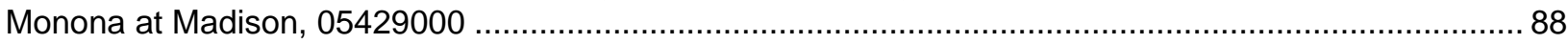

Oconomowoc

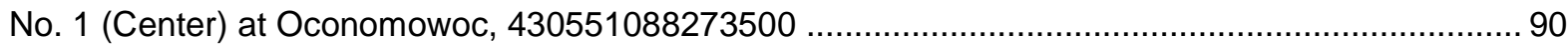

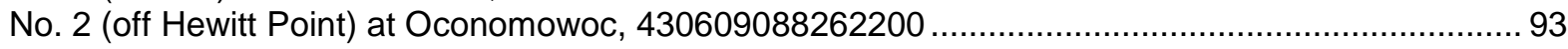

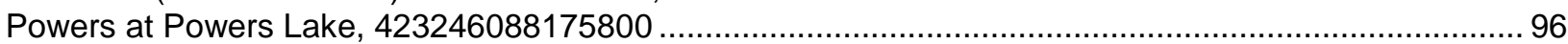

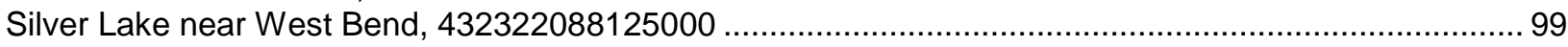

Turtle-Flambeau Flowage

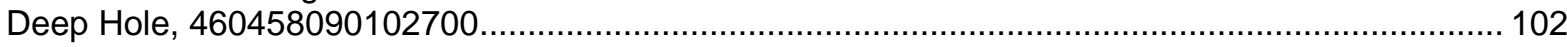




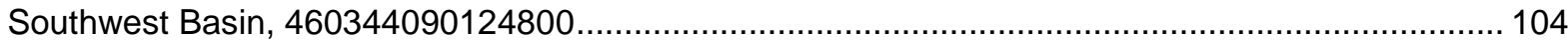

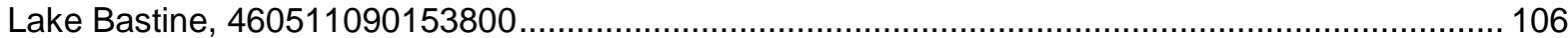

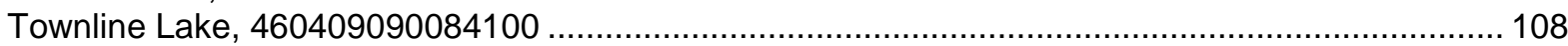

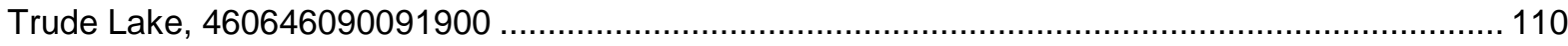

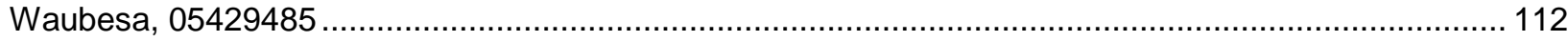

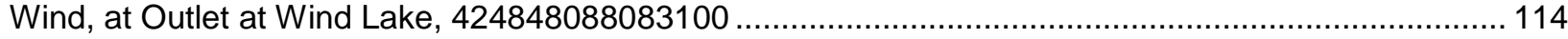

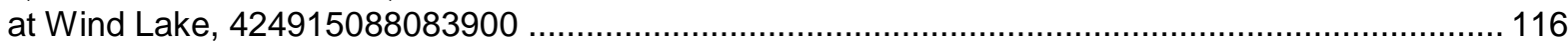

Winnebago

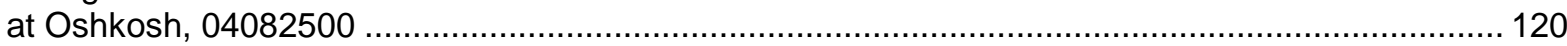

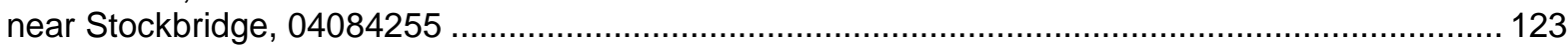

Wisconsin Water Science Center publications pertaining to lakes .............................................................. 125

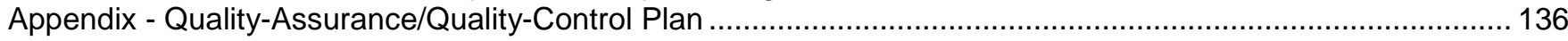

\section{FIGURE}

Figure 1. Map showing location of USGS lake water-quality and lake-stage stations in Wisconsin .................... 2

\section{TABLES}

Table 1. Discontinued lake stations

2. Parameter identification numbers and laboratory reporting levels $(L R L)$ for chemical parameters commonly measured in lakes, and analyzed at the National Water-Quality Laboratory (NWQL) or the Wisconsin State Laboratory of Hygiene (WSLH). 
CONVERSION FACTORS, VERTICAL DATUM, AND ABBREVIATED WATER-QUALITY UNITS

\begin{tabular}{rrl}
\hline Multiply & By & To Obtain \\
mile (mi) & 1.609 & kilometer \\
pound (lb) & 453.6 & gram \\
acre & 0.4048 & hectare \\
foot (ft) & 0.3048 & meter \\
meter (m) & 3.281 & foot \\
gallon $(\mathrm{gal})$ & 3.785 & liter \\
square mile $\left(\mathrm{mi}^{2}\right)$ & 2.590 & square kilometer \\
& & \\
Temperature, in degrees Celsius $\left({ }^{\circ} \mathrm{C}\right)$ can be converted to degrees Fahrenheit $\left({ }^{\circ} \mathrm{F}\right)$ by use of the following \\
& equation & \\
& ${ }^{\circ} \mathrm{F}=1.8\left({ }^{\circ} \mathrm{C}\right)+32$ & \\
\hline
\end{tabular}

Sea level: In this report "sea level" refers to either the National Geodetic Vertical Datum of 1929 (NGVD of 1929)-a geodetic datum derived from a general adjustment of the first-order level nets of both the United States and Canada, formerly called Sea Level Datum of 1929- or the North American Vertical Datum of 1988 (NAVD 88).

Abbreviated water-quality units: Chemical concentrations and water temperature are given in metric units. Chemical concentration is given in milligrams per liter $(\mathrm{mg} / \mathrm{L})$ or micrograms per liter $(\mu \mathrm{g} / \mathrm{L})$. Milligrams per liter is a unit expressing the concentration of chemical constituents in solution as weight (milligrams) of solute per unit volume (liter) of water. One thousand micrograms per liter is equivalent to one milligram per liter. For water with dissolved-solids concentrations less than $7,000 \mathrm{mg} / \mathrm{L}$, the numerical values for concentrations expressed as $\mathrm{mg} / \mathrm{L}$ and $\mu \mathrm{g} / \mathrm{L}$ are the same as for concentrations in parts per million and parts per billion, respectively.

Specific conductance of water is expressed in microsiemens per centimeter at 25 degrees Celsius $(\mu \mathrm{S} / \mathrm{cm})$. This unit is equivalent to micromhos per centimeter $(\mathrm{mmho} / \mathrm{cm})$ at 25 degrees Celsius, formerly used by the U.S. Geological Survey. 


\section{WATER-QUALITY AND LAKE-STAGE DATA FOR WISCONSIN LAKES, WATER YEAR 2009 By Wisconsin Water Science Center Lake-Studies Team}

\section{INTRODUCTION}

The U .S. Geological S urvey ( USGS), i n c ooperation w ith I ocal and other a gencies, collects dat $a$ at $s$ elected I akes throughout Wisconsin. These dat a, ac cumulated ov er m any years, provide a dat a base for developing an i mproved under standing of the water quality of lakes. T o $\mathrm{m}$ ake these dat a av ailable to i nterested par ties out side the U SGS, the dat a ar $\mathrm{e}$ published annually in this report series. The locations of water-quality and lake-stage stations in Wisconsin for water year 2009 are shown in figure 1. A water year is the 12-month period from October 1 through September 30. It is designated by the calendar year in which it ends. Thus, the period October 1, 2008 through September 30, 2009 is called "water year 2009."

The purpose of this report is to provide information about the chemical and physical characteristics of Wisconsin lakes. Data that have been collected at specific lakes, and information to aid in the interpretation of those data, are included in this report. Data collected include measurements of in-lake water quality and I ake stage. Time series of Secchi depths, surface total phosphorus and chlorophyll a concentrations collected during non-frozen periods are included for all lakes. Graphs of vertical profiles of temperature, dissolved oxygen, $\mathrm{pH}$, and specific conductance are included for sites where these parameters were measured. Descriptive information for each lake includes: location of the lake, area of the lake's watershed, period for which dat a ar e av ailable, r evisions to pr eviously publ ished r ecords, a nd per tinent remarks. Additional data, such as streamflow and water quality in tributary and outlet streams of some of the lakes, are published in another volume: "Water Resources Data-Wisconsin, 2009."

Water-resources data, including stage and discharge data at most streamflow-gaging stations, are available through the $\mathrm{W}$ orld $\mathrm{W}$ ide $\mathrm{W}$ eb on the Internet. The $\mathrm{W}$ isconsin $\mathrm{W}$ ater Science C enter's hom e pag e is at ht tp://wi.water.usgs.gov/. I nformation on $\mathrm{t}$ he Wisconsin Water S cience C enter's Lak es $P$ rogram is found at http://wi.water.usgs.gov/lakes/index.html and http://wi.water.usgs.gov/projects/index.html. 


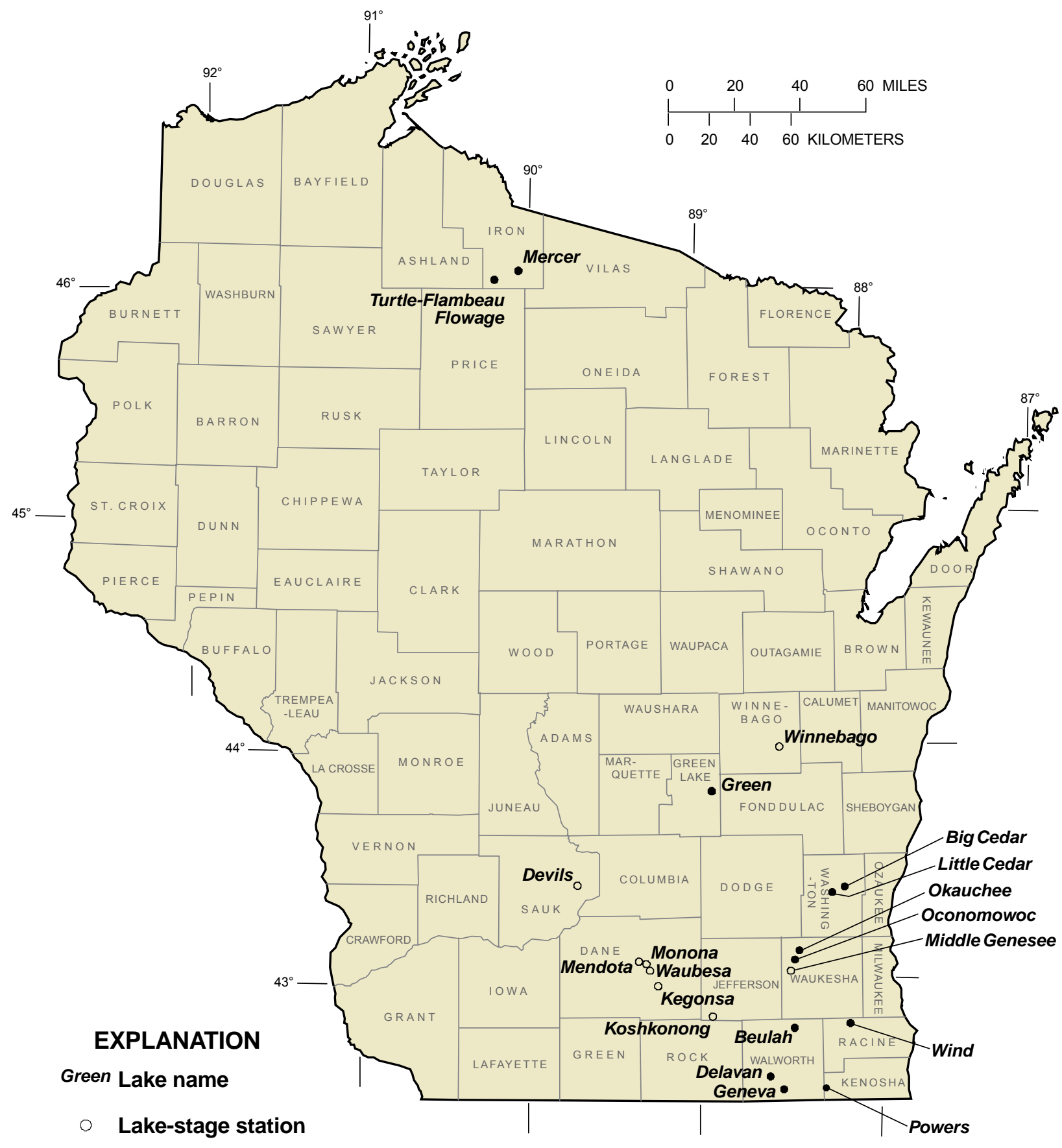

- Lake water-quality and stage station

Note: at some lakes more than one site may be monitored.

Figure 1. Location of USGS lake water-quality and lake-stage stations in Wisconsin. 
The USGS has done c ooperative lake monitoring with local and ot her agencies since 1983. Cooperators in 2009 included:

Big Cedar Lake Protection and Rehabilitation District

Dane County

Delavan Lake Sanitary District

Geneva Lake Environmental Agency

Green Lake Sanitary District

Lake Beulah Management District

Little Cedar Lake Protection and Rehabilitation District

Middle Genesee Lake District

Mercer School District (Mercer Lake Association)

Powers Lake District

Rock County Public Works Department

U.S. Army Corps of Engineers

Village of Oconomowoc Lake

Wind Lake Management District

Wisconsin Department of Natural Resources 
Lake data-collection sites are identified by a unique identification number. Lake waterquality s ites are identified by a 15 -digit nu mber that is a c oncatenation of the site's I atitude, longitude, and a $\mathrm{t}$ wo-digit s equence num ber. The sequence nu mber is us ed to di stinguish between sites located at the same latitude-longitude designation. The site identification number is per manently as signed to the s ite; ac tual I atitude and I ongitude of t he s ite ar e s ubject to update and are stored separately. For some lakes, which have historical records of lake stage, an eight-to-ten di git nu mber is as signed according to downstream order. Gaps are left in the numerical series to al low for new stations; hence, the num bers are not consecutive. The first two digits of the complete eight-to-ten digit number, such as 04087000 or 054310157 , designate the major river basin. For example, "04" designates the St. Lawrence River Basin and "05" designates the Upper Mississippi River Basin.

The water-quality lake stations that were discontinued prior to water year 2009 are listed in table 1. Discontinued lake-stage stations are not included in this table.

This report is the culmination of a concerted effort by a number of people who collected, compiled, analyzed, verified, and organized the data, and who typed, edited, and assembled the report. The authors had primary responsibility for assuring that the information contained herein is accurate, complete, and adheres to USGS policy and established guidelines. Technicians in charge of the field offices are: B.W. Olson (Merrill), and S.A. March (Middleton). The data were collected and pr ocessed by G.L. G oddard, S.B. Manteufel, B.W. Olson, D .L. Ol son, P.C. Reneau, J.G. S chuler, Z.T. S cott, and B.J. S iebers. S.B. M anteufel assembled, edi ted, and formatted the report. Additional assistance in preparation of the report was provided by M.M. Greenwood, and D.L. Olson.

\section{METHODS OF DATA COLLECTION}

Depth profiles of water temperature, dissolved oxygen, $\mathrm{pH}$, and s pecific conductance were c ollected us ing multi-parameter meters. Prior to measurements, the meters were calibrated using standards for $\mathrm{pH}$ and conductance, and dissolved oxygen was calibrated using the ai $r c$ alibration $m$ ethod. $G$ enerally, $f$ ield $m$ easurements in pr ofiles $w$ ere made at $0.5-m$ intervals if the $\mathrm{m}$ aximum dep th of the lake was $5 \mathrm{~m}$ or less and a $\mathrm{t} 1.0 \mathrm{~m}$ intervals if the maximum depth was greater than $5 \mathrm{~m}$. 
Table 1. Discontinued lake stations

\begin{tabular}{|c|c|c|}
\hline Station name & Site identification number & Period of record \\
\hline Alma Lake near St. Germain & 455426089254700 & $\begin{array}{l}\text { Oct. 1984-Sept. 1990, } \\
\text { May 1992-Sept.1996 }\end{array}$ \\
\hline Balsam Lake, off Cedar Island, at Balsam Lake & 452755092264600 & Feb. 1991-Aug. 1994 \\
\hline off Little Narrows, near Balsam Lake & 452858092265300 & May 1991-Aug. 1994 \\
\hline off Rock Island, near Balsam Lake & 452754092234300 & May 1991-Aug. 1994 \\
\hline Balsam Lake near Birchwood & 453907091345800 & $\begin{array}{l}\text { Mar. 1993-Aug. 1994, } \\
\text { Mar. 1996-Aug. 1997, } \\
\text { Mar.-Sept. } 2001\end{array}$ \\
\hline Bass Lake near Shawano & 445215088300300 & Feb. 1990-Aug. 1992 \\
\hline Bear Lake at Deep Hole near Haugen & 453754091490900 & Mar. 1992-Aug. 1993 \\
\hline Beaver Dam Lake, South end, at Beaver Dam & 432814088515000 & June-Oct. 1991 \\
\hline North end, near Beaver Dam & 433122088545700 & June-Oct. 1991 \\
\hline Benedict Lake near Powers Lake & 423201088180800 & May 1998-Aug. 2000 \\
\hline Big Blacksmith Lake near Keshena & 445401088334500 & Feb. 1990-Aug. 1992 \\
\hline Big Hills (Hills) Lake near Wild Rose & 440912089092000 & $\begin{array}{l}\text { June 1983-Aug. 1984, } \\
\text { Feb.-Aug. 1987, } \\
\text { Feb.-Aug. 1990, } \\
\text { Feb.-Aug. 1993, } \\
\text { Feb.-Aug. 1996, } \\
\text { Feb.-Aug. } 1999\end{array}$ \\
\hline Big Muskego Lake, at North Site, near Muskego & 425301088061300 & Feb.-Aug. 1988 \\
\hline Research Base, near Muskego & 425235088075300 & May-June 1994 \\
\hline Big Round Lake near Milltown & 453142092180100 & Feb.-Sept. 2001 \\
\hline Big St. Germain Lake, near St. Germain & 455557089311000 & Feb. 1992-Aug. 1996 \\
\hline near Lake Tomahawk & 05390750 & $1991-2001$ \\
\hline Big Sand Lake, Deep Hole, near Hertel & 454910092134000 & Feb.-Sept. 2001 \\
\hline East Site, near Hertel & 454921092124300 & Feb.-Sept. 2001 \\
\hline Big Sissabagama Lake, near Stone Lake & 454724091303600 & $\begin{array}{l}\text { Apr. 1986-Sept. 1996, } \\
\text { Oct. 1997-Sept. } 2002\end{array}$ \\
\hline North Site, near Stone Lake & 454800091312900 & Mar. 1998-Sept. 2001 \\
\hline Booth Lake near East Troy & 424800088254800 & $\begin{array}{l}\text { Feb. 1992-Aug. 1994, } \\
\text { Feb. 2001-Aug. } 2003\end{array}$ \\
\hline Buffalo Lake, Center Site, at Packwaukee & 434558089260600 & May 1998-Sept. 2001 \\
\hline East End, at Montello & 434720089201600 & May 1998-Sept. 2001 \\
\hline West End, near Endeavor & 434414089282400 & May 1998-Sept. 2001 \\
\hline
\end{tabular}


Table 1. Discontinued lake stations--continued

\begin{tabular}{|c|c|c|}
\hline Station name & Site identification number & Period of record \\
\hline Butternut Lake, near Park Falls & 455854090310300 & Oct. 2002-Oct. 2004 \\
\hline Deep Hole, near Park Falls & 455803090310800 & Mar. 2003-Sept. 2004 \\
\hline North Site, near Butternut & 455904090303400 & Mar. 2003-Sept. 2004 \\
\hline Far South Site, near Park Falls & 455651090312700 & Mar. 2003-Sept. 2004 \\
\hline Denoon Lake at Wind Lake & 425044088100300 & Feb. 1991-Aug. 1996 \\
\hline Druid Lake near Hartford & 431643088243300 & Feb. 1991-Sept. 1996 \\
\hline Eagle Lake near Kansasville & 05544500 & $\begin{array}{l}\text { 1936-64, 1975-77, } \\
\text { 1979, } \\
\text { Feb. 1993-Sept. } 1996\end{array}$ \\
\hline Eagle Lake, at Deep Hole, near Kansasville & 424207088072400 & Feb. 1993-Aug. 1996 \\
\hline Eagle Spring Lake at Eagleville & 425103088261500 & Apr. 1991-Sept. 2001 \\
\hline Elizabeth Lake near Twin Lakes & 423051088155300 & Feb. 1995-Sept. 1997 \\
\hline Fish Lake near Sauk City & 05406050 & $\begin{array}{l}\text { Nov. 1966-Sept. 1981, } \\
\text { Apr. 1985-May 1987, } \\
\text { May 1988, Apr. 1989- } \\
\text { Oct. 1990, Oct. 1990- } \\
\text { Nov. 1996, Nov. 1996- } \\
\text { Sept. } 2004\end{array}$ \\
\hline Fowler Lake, Center, at Oconomowoc & 430653088294601 & $\begin{array}{l}\text { Jan.-Dec. 1984, } \\
\text { Oct. 1986-Sept. } 1996\end{array}$ \\
\hline Fox Lake Deep Hole at Fox Lake & 433458088560600 & June 1991-Mar. 1993 \\
\hline Geneva Lake, Geneva Bay, at Lake Geneva & 423455088263800 & Apr. 1997-Feb. 1999 \\
\hline Williams Bay, at Williams Bay & 423420088320500 & Apr. 1997-Feb. 1999 \\
\hline Center, near Lake Geneva & 423402088301400 & Apr. 1997-Mar. 1999 \\
\hline East End, near Lake Geneva & 423421088272300 & Apr. 1997-May 2000 \\
\hline Hemlock Lake near Mikana & 453421091333700 & $\begin{array}{l}\text { Mar. 1993-Aug. 1994, } \\
\text { Mar. 1996-Aug. 1997, } \\
\text { Mar.-Sept. } 2001\end{array}$ \\
\hline Hooker Lake at Salem & 423335088060300 & Feb. 1992-Aug. 1993 \\
\hline Kawaguesaga, Deep Hole, near Minocqua & 455208089435800 & May-Sept. 2003 \\
\hline South Site, near Minocqua & 455145089442600 & May-Sept. 2003 \\
\hline Kirby Lake near Cumberland & 453554092042101 & Nov. 1995-Oct. 1996 \\
\hline (Site 1) near Cumberland & 453608092035801 & Nov. 1995-Nov. 1996 \\
\hline (Site 2) near Cumberland & 453601092035301 & Nov. 1995-Nov. 1996 \\
\hline
\end{tabular}


Table 1. Discontinued lake stations--continued

\begin{tabular}{|c|c|c|}
\hline Station name & Site identification number & Period of record \\
\hline (Site 3) near Cumberland & 453612092034901 & Nov. 1995-Nov. 1996 \\
\hline (Site 4) near Cumberland & 453603092035701 & Nov. 1995-Nov. 1996 \\
\hline (Site 5) near Cumberland & 453608092041201 & Nov. 1995-Nov. 1996 \\
\hline (Site 6) near Cumberland & 453555092040901 & Nov. 1995-Nov. 1996 \\
\hline Lac La Belle at Oconomowoc & 430733088305900 & $\begin{array}{l}\text { Feb. 1984-Aug. 1985, } \\
\text { Apr. -Aug. 1991, } \\
\text { Feb. 2001-Aug. } 2003\end{array}$ \\
\hline NW, at Oconomowoc & 430809088313900 & Feb. 1984-Aug. 1985 \\
\hline SE, at Oconomowoc & 430707088301400 & Feb. 1984-Aug. 1985 \\
\hline Lake Blass at Lake Delton & 433545089482400 & Mar. 1989-Aug. 1990 \\
\hline Lake Desair near Rice Lake & 453446091465100 & Aug. 2004 \\
\hline $\begin{array}{l}\text { Lake Keesus, } \\
\text { East Bay, near Merton } \\
\text { North Bay, near Merton }\end{array}$ & $\begin{array}{l}430957088183400 \\
431006088191000\end{array}$ & $\begin{array}{l}\text { Apr. 1991-Aug. } 1995 \\
\text { Apr. 1991-Aug. } 1995\end{array}$ \\
\hline Lake Morris at Mount Morris & 440654089120500 & Jun. 1983-Sept. 1989 \\
\hline $\begin{array}{l}\text { Lake Nebagamon, Northeast Bay, at Lake } \\
\text { Nebagamon }\end{array}$ & 463050091412300 & May 1992-Aug. 1995 \\
\hline Southeast Bay, at Lake Nebagamon & 462928091413500 & Mar. 1992-Sept. 1995 \\
\hline West Bay, at Lake Nebagamon & 463034091425300 & May 1992-Aug. 1995 \\
\hline Lake Noquebay near Crivitz & 451511087550900 & $\begin{array}{l}\text { Feb. 1987-Aug. 1988, } \\
\text { Apr. 1991-Aug. } 1994\end{array}$ \\
\hline East End, near Crivitz & 451540087525700 & Apr. 1991-Aug. 1994 \\
\hline Lamotte Lake near Shawano & 445305088361200 & Feb. 1990-Aug. 1992 \\
\hline $\begin{array}{l}\text { Lauderdale Lakes at Lauderdale } \\
\text { Mill, at Lauderdale }\end{array}$ & $\begin{array}{l}424554088332700 \\
424555088335700\end{array}$ & $\begin{array}{l}\text { Oct. 1993-Oct. } 1994 \\
\text { Nov. 1993-Nov. } 1994, \\
\text { Aug. } 2002\end{array}$ \\
\hline Green, Auxiliary, Number 1, near Lauderdale & 424640088341900 & June 1999-Sept. 2000 \\
\hline Green, near Lauderdale & 424652088341500 & $\begin{array}{l}\text { Nov. } 1993-\text { Nov. } 1994 \text {, } \\
\text { Aug. } 2002\end{array}$ \\
\hline Legend Lake (site 1) near Shawano & 445342088312700 & Feb. 1990-Feb. 1992 \\
\hline Little Arbor Vitae near Woodruff & 455446089370300 & Feb. 1991-Sept. 2002 \\
\hline Little Green Lake, at Center, near Markesan & 434412088590700 & Feb. 1991-Aug. 2003 \\
\hline Little Muskego Lake at Muskego & 425425088083500 & Oct. 1986-Aug. 2002 \\
\hline Little Rock Lake near Woodruff & 455946089415702 & Oct. 1983-Sept. 1996 \\
\hline Little St. Germain Lake, near Eagle River & 05390700 & (a) \\
\hline Upper East Bay, at St. Germain & 455532089253900 & $\begin{array}{l}\text { Dec. 1996-Mar. 97, } \\
\text { Mar. 1999, } \\
\text { Mar. 2000-Aug. } 2003\end{array}$ \\
\hline
\end{tabular}


Table 1. Discontinued lake stations--continued

\begin{tabular}{|c|c|c|}
\hline Station name & Site identification number & Period of record \\
\hline Northeast Bay, near St. Germain & 455545089262500 & $\begin{array}{l}\text { Apr. 1991-Aug. 1994, } \\
\text { Aug. 1996-Aug. 1997, } \\
\text { Mar. 1999-Aug. } 2003\end{array}$ \\
\hline South Bay, near St. Germain & 455437089270800 & $\begin{array}{l}\text { Apr. 1991-Aug. 1994, } \\
\text { Aug. 1996-Aug. 1997, } \\
\text { Mar. 1999-Aug. } 2003\end{array}$ \\
\hline West Bay, at St. Germain & 455428089282400 & $\begin{array}{l}\text { Apr. 1991-Aug. 1994, } \\
\text { Aug. 1996-Aug. 1997, } \\
\text { Mar. 1999-Aug. } 2003\end{array}$ \\
\hline Little Sand Lake - Site No. 2 - near Mole Lake & 452826088544101 & May1996-Sept. 2003 \\
\hline Long (Kee Nong Go-Mong) Lake at Wind Lake & 424937088103400 & $\begin{array}{l}\text { Feb. 1988-Aug. } 1989, \\
\text { Feb. 1991-Aug. } 1996\end{array}$ \\
\hline Loon Lake near Shawano & 445009088303700 & Feb. 1991-Aug. 1993 \\
\hline Lost Lake near Beaver Dam & 432640088580500 & June-Oct. 1991 \\
\hline \multicolumn{3}{|l|}{ McKenzie Lakes } \\
\hline \multicolumn{3}{|l|}{ McKenzie (Big McKenzie) } \\
\hline Deep Hole, near Spooner & 455507092013500 & Feb. 1987-Aug. 1998 \\
\hline Northern Site, near Spooner & 455540092022000 & June 1997-Aug. 1998 \\
\hline South Site, near Spooner & 455437092022300 & June 1997-Aug. 1998 \\
\hline Lower McKenzie, near Webb Lake & 455902092011900 & June 1997-Aug. 1998 \\
\hline Middle McKenzie, near Spooner & 455635092021800 & June 1997-Aug. 1998 \\
\hline Mary (Marie) Lake at Twin Lakes & 423128088151200 & Feb. 1995-Aug. 1997 \\
\hline Max Lake near Woodruff & 460128089423501 & Mar. 1988-Dec. 1996 \\
\hline Mead Lake, East Bay near Willard & 444720090445000 & Apr. 1991-Aug. 1995 \\
\hline West Bay near Willard & 444733090460100 & Feb. 1991-Sept. 1995 \\
\hline \multicolumn{3}{|l|}{ Minocqua Lake } \\
\hline Deep Hole, at Minocqua & 455214089412800 & May-Sept. 2003 \\
\hline North Bay, at Minocqua & 455232089424100 & May-Sept. 2003 \\
\hline South Bay, at Minocqua & 455206089425200 & May-Sept. 2003 \\
\hline Montello Lake at Montello & 434748089195800 & Feb. 1995-Aug. 1998 \\
\hline Moon Lake near St. Germain & 455504089260500 & Feb. 1992-Aug. 1996 \\
\hline Morgan Lake near Fence & 454622088324801 & Oct. 1987-Sept. 1998. \\
\hline Moshawquit Lake near Shawano & 445352088295800 & Feb. 1990-Aug. 1992 \\
\hline \multicolumn{3}{|l|}{ Muskego (Big Muskego) } \\
\hline Auxiliary Number 1, near Muskego & 425329088054000 & June 1996-Aug. 2000 \\
\hline Bass Bay, near Muskego & 425344008807010 & Feb. 1988-Aug. 2002 \\
\hline
\end{tabular}


Table 1. Discontinued lake stations--continued

\begin{tabular}{|c|c|c|}
\hline Station name & Site identification number & Period of record \\
\hline near Wind Lake & 425109088075000 & $\begin{array}{l}\text { Oct. 1987-Sept. 1989, } \\
\text { Jan. 1991-Sept. } 2002\end{array}$ \\
\hline South Site, near Muskego & 425212088072800 & Feb. 1988-Aug. 2002 \\
\hline Muskellunge Lake near Eagle River & 455700089224900 & June 2000-Aug. 2001 \\
\hline $\begin{array}{l}\text { Muskellunge Lake, near Lake Outlet near Eagle } \\
\text { River }\end{array}$ & 455706089232400 & Nov. 2000-Oct. 2001 \\
\hline Nagawicka Lake, at Deep Hole, at Delafield & 430417088230300 & Feb. 2003-Sept. 2004 \\
\hline \multicolumn{3}{|l|}{ Namekagon Lakes } \\
\hline Garden, near Cable & 461224091033200 & Mar. 1998-Aug. 1999 \\
\hline Jackson, near Cable & 461457091065900 & Mar. 1998-Aug. 1999 \\
\hline \multicolumn{3}{|l|}{ Namekagon } \\
\hline Deep Hole, near Cable & 461308091065100 & Mar. 1998-Aug. 1999 \\
\hline East Basin, near Cable & 461228091044300 & Mar. 1998-Aug. 1999 \\
\hline Northeast Basin, near Cable & 461410091050700 & Mar. 1998-Aug. 1999 \\
\hline Park Lake (site 1) at Pardeeville & 433239089175800 & $\begin{array}{l}\text { Feb. 1986-Aug. 1987, } \\
\text { May-Nov. } 1993\end{array}$ \\
\hline (site 2 ) at Pardeeville & 433226089175500 & May-Nov. 1993 \\
\hline (site 3) at Pardeeville & 433245089173000 & May-Nov. 1993 \\
\hline (site 4) at Pardeeville & 433257089165100 & May-Nov. 1993 \\
\hline Pike Lake near Hartford & 431916088200501 & Dec. 1998-Dec. 2000 \\
\hline Pike Lake-QW Site-near Hartford & 431835088200600 & Feb.-Aug. 2000 \\
\hline Potter Lake near Mukwonago & 423246088175800 & Feb. 1993-Sept. 2007 \\
\hline Pretty Lake, at Deep Hole, near Dousman & 425722088295000 & Feb. 1993-Aug. 1997 \\
\hline Puckaway Lake, West Basin, near Marquette & 434515089124000 & Apr. 2005-Sept. 2007 \\
\hline East Basin, near Marquette & 43454208907300 & Apr. 2005-Sept. 2007 \\
\hline River site, near Marquette & 434824089083200 & Apr. 2005-Sept. 2007 \\
\hline Red Cedar Lake, at Mikana & 453522091360600 & $\begin{array}{l}\text { Mar. 1993-Aug. 1994, } \\
\text { Mar. 1996-Aug. 1997, } \\
\text { Oct. 2000-Sept. } 2001\end{array}$ \\
\hline Deep Hole, near Mikana & 453725091345100 & $\begin{array}{l}\text { Mar. 1993-Aug. 1994, } \\
\text { Mar. 1996-Aug. 1997, } \\
\text { Mar. -Sept. } 2001\end{array}$ \\
\hline South End, at Mikana & 453519091352500 & $\begin{array}{l}\text { Mar. 1993-Aug. 1994, } \\
\text { Mar. 1996-Aug. 1997, } \\
\text { Mar. -Sept. } 2001\end{array}$ \\
\hline Rice Lake at Deep Hole near Whitewater & 424629088415700 & Apr.-Nov. 1991 \\
\hline Round Lake near Shawano & 445328088335000 & Feb. 1990-Aug. 1992 \\
\hline Sand Lake (Deep Hole) near Keshena & 445321088323101 & June-Aug. 1992 \\
\hline
\end{tabular}


Table 1. Discontinued lake stations--continued

\begin{tabular}{lcc}
\hline \multicolumn{1}{c}{ Station name } & Site identification number & Period of record \\
\hline Shell Lake at Shell Lake & 05334000 & Aug. 1936-Sept. 1999 \\
Silver Lake near Oconomowoc & 430436088293300 & Apr. 1992-Aug. 1996 \\
Silver Lake near West Bend & 432322088125000 & Feb. 1996-Aug. 1997 \\
Sinissippi Lake, off Anthony Is., at Hustisford & 432113088361100 & Feb. 1991-Aug. 1993 \\
$\quad$ off Butternut Is., near Hustisford & 432240088363900 & Apr. 1991-Aug. 1993 \\
$\quad$ off Sam Point, near Hustisford & 432300088374200 & Apr. 1991-Aug. 1993 \\
Spirit Lake near Keshena & 445400088320100 & Apr.-Aug. 1992 \\
Spooner Lake, Deep Hole, near Spooner & 455034091493300 & June 2002-Aug. 2004 \\
$\quad$ Southeast Site, near Spooner & 454945091483900 & June 2002-Aug. 2004 \\
Stewart Lake at Mt. Horeb & 430117089442701 & May 1992-Sept. 1993 \\
Tichigan Lake near Waterford & 424854088123300 & Mar. 1994-Aug. 1996, \\
Tombeau Lake near Powers Lake & 423153088184800 & Apr. 2003-Aug. 2004 \\
Twin Lake, East Twin, near Westfield & May 1998-Aug. 2000 \\
West Twin, near Westfield & 435430089350700 & June 2002-Aug. 2004 \\
(a) Wisconsin Valley Improvement Co. currently collects stage data for this site. & June 2002-Aug. 2004 \\
\hline
\end{tabular}

In most lakes, water samples were collected at two depths - near the surface and near the bottom. Chemical analyses of water samples were performed using standard analytical methods by either the USGS National Water Quality Laboratory (Wershaw and others, 1987; Fishman and Friedman, 1989; Fishman, 1993) or the Wisconsin State Laboratory of Hygiene (Wisconsin State Laboratory of Hygiene, 1993). Analyses for dissolved constituents were performed on samples that were filtered in the field through a $0.45-\mathrm{mm}$ (micrometer) pore-size filter. Total or total recoverable constituents were determined by analyzing unfiltered water samples. Preservation and shipment of samples followed standard protocols established by the laboratories. Water-quality data were archived in the Water Quality Data Base (QWDATA) of the National Water Information System (NWIS). Additional descriptive information about waterquality data is available in the data report: "Water Resources Data - Wisconsin, 2009". NWIS parameter codes and minimum laboratory reporting levels for chemical constituents are given in table 2. The parameter code for turbidity has changed from 00076 to 63675 or 63676 because the method of testing has changed. 
Records of lake stage are considered complete when one or more manual or automatic measurements were obtained per day. Partial records of lake stage result when measurements were less frequent than daily. A complete description of manual or automatic measurements of lake stage is described by Rantz and others (1982). 
Table 2. Parameter identification numbers and laboratory reporting levels (LRL) for chemical parameters commonly measured in lakes, and analyzed at the National Water Quality Laboratory (NWQL) or the Wisconsin State Laboratory of Hygiene (WSLH).

\begin{tabular}{|c|c|c|c|c|c|c|c|c|c|}
\hline \multirow[b]{3}{*}{ Parameter Name } & \multirow[b]{3}{*}{ Units } & \multirow[b]{3}{*}{$\begin{array}{c}\text { CAS } \\
\text { Number }^{1}\end{array}$} & \multirow[b]{3}{*}{$\begin{array}{l}\text { Parameter } \\
\text { Code }^{2}\end{array}$} & \multicolumn{4}{|c|}{ (NWQL) } & \multicolumn{2}{|c|}{ (WSLH) } \\
\hline & & & & \multicolumn{2}{|c|}{$\begin{array}{l}\text { Standard } \\
\text { Analysis }\end{array}$} & \multicolumn{2}{|c|}{$\begin{array}{l}\text { Low-Level } \\
\text { Analysis }\end{array}$} & \multirow[b]{2}{*}{ LRL } & \multirow[b]{2}{*}{$\begin{array}{l}\text { Test } \\
\text { Code }\end{array}$} \\
\hline & & & & LRL & $\begin{array}{l}\text { Lab } \\
\text { Code }\end{array}$ & LRL & $\begin{array}{l}\text { Lab } \\
\text { Code }\end{array}$ & & \\
\hline Calcium, diss. (Ca) & $\mathrm{mg} / \mathrm{L}$ & $7440-70-2$ & 00915 & 0.020 & 659 & 0.002 & 1895 & 0.02 & I230IUD \\
\hline Magnesium, diss. (Mg) & $\mathrm{mg} / \mathrm{L}$ & $7439-95-4$ & 00925 & 0.004 & 663 & 0.001 & 1897 & 0.02 & I390IUD \\
\hline Sodium, diss. (Na) & $\mathrm{mg} / \mathrm{L}$ & $7440-23-5$ & 00930 & 0.09 & 675 & 0.025 & 1898 & 0.09 & I80IUD \\
\hline Potassium, diss. (K) & $\mathrm{mg} / \mathrm{L}$ & $7440-09-7$ & 00935 & 0.24 & 54 & 0.01 & 833 & 0.3 & I540IUD \\
\hline Sulfate, diss. (SO4) & $\mathrm{mg} / \mathrm{L}$ & $14808-79-8$ & 00945 & 0.31 & 1572 & 0.01 & 1263 & 1.0 & I600DLD \\
\hline Chloride, diss. (Cl) & $\mathrm{mg} / \mathrm{L}$ & $16887-00-6$ & 00940 & 0.29 & 1571 & 0.01 & 1259 & 0.1 & I240ELD \\
\hline Fluoride, diss. (F) & $\mathrm{mg} / \mathrm{L}$ & $16984-48-8$ & 00950 & 0.100 & 31 & 0.01 & 1260 & 0.03 & I330FLD \\
\hline Iron, diss. (Fe) & $(\mu \mathrm{g} / \mathrm{L})$ & $7439-89-6$ & 01046 & 10 & 645 & 3 & 1896 & 10 & I370IUD \\
\hline Manganese, diss. (Mn) & $(\mu \mathrm{g} / \mathrm{L})$ & $7439-96-5$ & 01056 & 2.2 & 648 & 1 & 1793 & 0.4 & |400IUD \\
\hline Silica, diss. (SiO2) & $\mathrm{mg} / \mathrm{L}$ & $7631-86-9$ & 00955 & 0.1 & 56 & 0.02 & 1899 & 0.008 & I560LLD \\
\hline $\begin{array}{l}\text { Nitrogen, } \mathrm{NO} 2+\mathrm{NO} 3 \text {, } \\
\text { diss. }\end{array}$ & $\mathrm{mg} / \mathrm{L}$ & -- & 00631 & 0.05 & 1975 & 0.005 & 1979 & 0.01 & I460MLD \\
\hline $\begin{array}{l}\text { Nitrogen, ammonia, } \\
\text { diss. }\end{array}$ & $\mathrm{mg} / \mathrm{L}$ & $7664-41-7$ & 00608 & 0.02 & 1976 & 0.002 & 1980 & 0.013 & I440NLD \\
\hline $\begin{array}{l}\text { Nitrogen, amm.+org., } \\
\text { total }^{4}\end{array}$ & $\mathrm{mg} / \mathrm{L}$ & $17778-88-0$ & 00625 & 0.100 & 1985 & -- & -- & 0.2 & I470BLT \\
\hline $\begin{array}{l}\text { Nitrogen, } \\
\text { amm.+org.,diss. }\end{array}$ & $\mathrm{mg} / \mathrm{L}$ & -- & 00623 & -- & -- & -- & -- & -- & 1470DLD \\
\hline Nitrogen, total ${ }^{5}$ & $\mathrm{mg} / \mathrm{L}$ & - & 00600 & -- & -- & -- & -- & -- & -- \\
\hline Nitrogen, dissolved & $\mathrm{mg} / \mathrm{L}$ & -- & 00602 & -- & -- & -- & -- & -- & -- \\
\hline Phosphorus, total & $\mathrm{mg} / \mathrm{L}$ & $7723-14-0$ & 00665 & 0.05 & 1984 & 0.004 & 2333 & 0.005 & I520PLT \\
\hline Phosphorus, ortho, diss. & $\mathrm{mg} / \mathrm{L}$ & $14265-44-2$ & 00671 & 0.01 & 1262 & 0.002 & 1978 & 0.002 & I530CLD \\
\hline $\begin{array}{l}\text { Chlorophyll a, } \\
\text { phytoplankton }\end{array}$ & $(\mu \mathrm{g} / \mathrm{L})$ & $479-61-8$ & 70953 & 0.1 & 586 & -- & -- & -- & -- \\
\hline $\begin{array}{l}\text { Chlorophyll a, } \\
\text { phytoplankton }\end{array}$ & $(\mu \mathrm{g} / \mathrm{L})$ & $479-61-8$ & 32210 & -- & -- & -- & -- & 0.26 & I250UNF \\
\hline
\end{tabular}

1: CAS (Chemical Abstracting Services) number = unique identification for each constituent

2: Parameter Code - unique number for storage of data in database

3: Calculated as difference between total ammonia + organic nitrogen and ammonia nitrogen

4: Also known as Total Kjeldahl Nitrogen (TKN)

5: Calculated as sum of TKN + Nitrogen as (NO2+NO3) 


\section{EXPLANATION OF PHYSICAL AND CHEMICAL CHARACTERISTICS OF LAKES}

Following are brief, generalized explanations of some of the common measurements of water $q$ uality and $s$ ome of the phy sical pr ocesses occurring i $\mathrm{I}$ akes that i nfluence these measures of water quality. More detailed explanations of water-quality data and lake processes are given by Wetzel (1983), Hem (1985), and Shaw and others (1993).

\section{Water Temperature and Thermal Stratification}

Water temperature in lakes is important because of its role in stratification and because of the temperature dependence of many chemical reactions and life processes of aquatic organisms. The extent of thermal stratification in lakes depends on the interaction between the lake's shape, water clarity, solar heating, and wind-driven mixing. Complete mixing of the lake is usually i nhibited by $\mathrm{t}$ hermal s tratification i $\mathrm{n} s$ ummer and by i ce c over i $\mathrm{n} w$ inter. Thermal stratification affects water quality and the distribution of organisms in the lake. Summer thermal stratification can occur in any lake, but in Wisconsin it commonly occurs in lakes deeper than about $6 \mathrm{~m}$ (Shaw and others, 1993).

The density of water increases with decreasing temperature down to a temperature of $4^{\circ} \mathrm{C}$, then decreases with decreasing temperature between $4^{\circ} \mathrm{C}$ and the freezing point of water $\left(0^{\circ} \mathrm{C}\right)$. For a brief period in the spring after the ice is out, water temperature is usually uniform through the ent ire $w$ ater c olumn and $w$ ind action $c$ auses the $I$ ake to mix completely. $T$ his process is known as "spring turnover." As the lake absorbs the sun's energy, the surface water becomes warmer and $i$ ts density decreases, making it more resistant to complete mixing. The difference in density caused by different water temperatures can prevent warm and cold water from mixing. In m ost lakes, therefore, a dens ity "barrier" forms bet ween the warmer surface water (epilimnion) and the underlying colder water (hypolimnion). This barrier is often marked by a s harp temperature gradient known as the "thermocline (metalimnion)." D uring the stratified summer period, these three distinct layers of lake water are often present. As the temperature difference between surface and deep w ater increases, this "stratified" condition stabilizes and can persist until surface temperatures decrease in the fall, which decreases the stability of the stratification. The mixing of the lake water in the fall is known as "fall turnover." 
Thermal s tratification may al so oc cur under ice cover in the winter. In the winter, the coldest water $\left(\right.$ near $0^{\circ} \mathrm{C}$ ) under the ice at the surface of the lake is less dense than water deeper in the lake with warmer temperatures.

\section{Specific Conductance}

Specific conductance is a measure of the ability of water to conduct an electrical current and is an indicator of the concentration of dissolved solids in the water. Because conductance is temperature related, $r$ eported $v$ alues ar e nor malized at $25^{\circ} \mathrm{C}$ and ar e termed $\mathrm{s}$ pecific conductance. A s the concentration of di ssolved $m$ inerals i ncreases, specific c onductance increases. $D$ uring $w$ inter and $s$ ummer $t$ hermal s tratification, $c$ oncentrations o $f$ di ssolved constituents near the lake bottom increase due to the decomposition of materials settling from the epilimnion, or release of dissolved materials (such as iron, manganese, and phos phorus) from $\mathrm{t}$ he bot tom sediments dur ing anox ic periods. Therefore, differences $\mathrm{i} n \mathrm{~s}$ pecific conductance with depth indicate differences in concentrations of dissolved solids.

\section{Water Clarity}

Water clarity, or transparency, is commonly measured using a Secchi disc. The range of depths within which photosynthetic activity occurs depends largely on depth of light penetration, which is influenced by water clarity. A Secchi disc, most commonly a 20-cm.-diameter disc with alternating black-and-white quadrants, is lowered to a depth at which it is no longer visible. This depth is referred to as the Secchi depth. Clarity can be reduced by algae, zooplankton, water color, and suspended sediment. Algae are often the most dominant influence on clarity in lakes and, therefore, Secchi depth is usually correlated with the algal abundance. Secchi depths are generally the least during summer when algal populations are largest.

\section{pH}

The $\mathrm{pH}$ is a measure of the acidity of the water. It is defined as the negative logarithm of hydrogen-ion concentration and v aries over a 14 -unit log s cale, with a p H of 7 bei ng neutral. Values I ess than $7 \mathrm{i}$ ndicate ac idic c onditions; the I ower the value, the $\mathrm{s}$ tronger the ac idity. Values greater than 7 indicate alkaline conditions. The $\mathrm{pH}$ of water is influenced in part by photosynthesis and respiration of planktonic algae and aquatic plants. It is important because it affects the solubility of many chemical constituents, and because aquatic organisms have 
limited $\mathrm{pH}$ tolerances. Planktonic al gae and aq uatic $\mathrm{pl}$ ants $\mathrm{pr}$ oduce ox ygen and c onsume carbon dioxide as they photosynthesize during daytime; they consume oxygen and produce carbon dioxide when they respire at night. Carbon dioxide combines with the water molecule to form carbonic acid; therefore respiration causes a dec rease in $\mathrm{pH}$ at night and phot osynthesis during the day $\mathrm{c}$ auses an $\mathrm{i}$ ncrease $\mathrm{i} \mathrm{n} \mathrm{pH}$. The result is a dai ly c ycle i $\mathrm{n} \mathrm{pH}$. $\mathrm{B}$ ecause phytoplankton a re us ually c oncentrated i $\mathrm{n} t$ he near -surface $w$ ater, $\mathrm{c}$ hanges i $\mathrm{n} \mathrm{pH}$ i $\mathrm{n}$ the epilimnion are more extreme than in the hypolimnion, where less photosynthesis usually occurs.

Lakes having good fish populations and pr oductivity generally have a $\mathrm{pH}$ between 6.7 and 8.2. Values of $\mathrm{pH}$ greater than 8.5 have been shown to cause the release of phosphorus from lake sediments (James and Barko, 1991).

\section{Dissolved Oxygen}

Dissolved oxygen is one of the most critical factors affecting a lake ecosystem because it is essential to most aquatic organisms, and it is involved in many chemical reactions. Very low di ssolved oxygen c oncentrations can c ontrol s ome types of chemical reactions. The solubility of ox ygen i $\mathrm{n}$ w ater i s i nversely $r$ elated t o t emperature-that i s, ox ygen s olubility decreases as $\mathrm{w}$ ater temperature i ncreases. This $\mathrm{r}$ elation i s i mportant bec ause a $\mathrm{t} w$ armer temperatures the $\mathrm{m}$ etabolic $\mathrm{r}$ ate of or ganisms i ncreases bu $\mathrm{t} I$ ess ox ygen i s av ailable $f$ or respiration. The primary sources of dissolved oxygen are from the air and from photosynthesis. The minimum dissolved oxygen concentration specified in national water-quality criteria for early life stages of warmwater aquatic life is 5.0 mg/L (U.S. Environmental Protection Agency, 1986).

In early summer, if thermal stratification develops, the metalimnion restricts the surface supply of dissolved oxygen to the hypolimnion. The hypolimnion can become isolated from the atmosphere. Thus, as summer progresses, the dissolved oxygen concentration can decrease in response to decomposition of dead algae that settle from the epilimnion and in response to the biological and $c$ hemical ox ygen dem and of the s ediments. The ox ygen dem and from these processes may completely deplete the oxygen (anoxia) in the water near the lake bottom. The oxygen depletion then progresses upward but usually is confined to the hypolimnion.

Anoxia i $\mathrm{n}$ t he hy polimnion i s c ommon i $\mathrm{n}$ stratified eu trophic ( nutrient-rich) la kes in Wisconsin. Complete anoxia, however, is often not detected because of meter constraints. During anox ic $\mathrm{c}$ onditions, many aq uatic or ganisms $\mathrm{c}$ annot $\mathrm{s}$ urvive, but $\mathrm{m}$ any ot her $\mathrm{s}$ pecies 
(primarily bacteria) actually function only in such conditions. Therefore, a shift from oxic to anoxic conditions produces a rapid and dramatic change in the biological community and chemical environment. A noxia a Iso $\mathrm{c}$ an $\mathrm{c}$ ause $\mathrm{r}$ elease o f phos phorus from the bot tom sediments. This phos phorus then mixes throughout the $w$ ater column during s pring and fall turnover.

\section{Phosphorus}

Phosphorus i s one o f t he es sential nut rients for $\mathrm{pl}$ ant growth. $\mathrm{H}$ igh pho sphorus concentrations can cause dense algal populations (blooms) and can therefore be a major cause of eutrophication in lakes. When phosphorus concentrations exceed $0.025 \mathrm{mg} / \mathrm{L}$ at the time of spring overturn in lakes and reservoirs, these water bodies may occasionally experience excess or nuisance growth of a lgae or other aquatic plants (U.S. E nvironmental P rotection Agency, 1986). In many regions of the country, including the upper Midwest, other nutrients, particularly nitrogen, tend to be i $\mathrm{n}$ abundant s upply. Phosphorus is often the nut rient in shortest supply, therefore I imiting or controlling plant growth. A bout 90 per cent of the lakes in Wisconsin are limited by phosphorus (Shaw and others, 1993). In water, dissolved orthophosphate is that part of total phosphorus that is most readily available for use by algae.

Internal phosphorus recycling occurs in many lakes. Phosphorus used by algae, aquatic plants, fish, and zooplankton is stored within these organisms. As these organisms die and decompose, $\mathrm{t}$ his phos phorus i s $\mathrm{r}$ eturned to the $\mathrm{I}$ ake $\mathrm{w}$ ater and sediments. A noxia i $\mathrm{n}$ the hypolimnion makes phosphorus more soluble, adding further to the release of phosphorus from the falling particles and the lake sediments. D uring spring and fall turnover the phos phorus, which was released from the bot tom sediments into the hy polimnion during anoxia, is mixed throughout the lake. The phosphorus is then available for algal growth. These phenomena are part of the internal-recycling processes of lakes.

\section{Nitrogen}

Nitrogen, like phosphorus, is an e ssential nutrient for plant and al gal growth. Usually in Wisconsin I akes, ni trogen is in abundant s upply from the a tmosphere and ot her s ources. If phosphorus is abundant relative to al gal needs, nitrogen can become the limiting nut rient. In that $\mathrm{c}$ ase, al gal bl ooms ar e $\mathrm{m}$ ore l ikely $\mathrm{t} \mathrm{o}$ be $\mathrm{t}$ riggered by i ncreases i $\mathrm{n} \mathrm{n}$ itrogen than by

increases in phosphorus. Some bluegreen algal species can fix nitrogen from the atmosphere 
(Wetzel, 1983). Therefore, in situations where other types of algae are excluded because of a shortage of nitrogen, the nitrogen-fixing bluegreen algae have a competitive advantage and may be present in abundance.

Lakes with a nitrogen to phosphorus ratio larger than 15 to 1 near the surface may generally be considered phosphorus limited; a ratio from 10 to 1 to 15 to 1 indicates a transition situation; and a ratio smaller than 10 to 1 generally indicates nitrogen limitation. Total nitrogen is the s um of a mmonia, or ganic ni trogen, and nitrate-plus-nitrite nitrogen. The nea r-surface concentration is commonly us ed to c ompute the total ni trogen to ph osphorus r atio bec ause most algal species grow near the lake surface.

\section{Chlorophyll a}

Chlorophyll $a$ is a photosynthetic pigment found in algae (Wetzel, 1983) and other green plants. Its concentration, therefore, is commonly used as a measure of the density of the algal population in a I ake. Chlorophyll a concentrations are generally highest during summer when algal populations are highest. Moderate populations of desirable algae are important in the food chain; however, excessive populations or algal blooms are undesirable. Algal blooms can cause taste and odo $\mathrm{r}$ problems, and I imit I ight pene tration needed t o s upport g rowth of s ubmerged aquatic plants. Certain s pecies of bluegreen algae can produce toxins ( Rapavich and ot hers, 1987).

\section{CLASSIFICATION OF LAKES}

Two methods are commonly used to classify and evaluate Wisconsin lakes according to their water quality or trophic state: Lillie and Mason's (1983) water-quality index and Carlson's (1977) trophic state index (TSI). In p revious USGS data reports, a modification of Carlson's trophic state index for Wisconsin lakes by Lillie and others (1993) had been used; however, this approach did not properly classify oligotrophic and highly euthrophic lakes and, therefore, was discontinued. 
Lillie and Mason's ( 1983) w ater q uality indices f or Wisconsin I akes w ere dev eloped based on summer measurements of total phosphorus and chlorophyll a concentrations, and Secchi depth from a random set of lakes in Wisconsin. These data were us ed to classify the lakes's water quality as shown below:

\begin{tabular}{lccc}
\hline Water-quality index & $\begin{array}{c}\text { Total phosphorus } \\
\text { range }(\mathrm{mg} / \mathrm{L})\end{array}$ & $\begin{array}{c}\text { Chlorophyll a range } \\
(\mu \mathrm{g} / \mathrm{L})\end{array}$ & $\begin{array}{c}\text { Water clarity range } \\
(\text { Secchi depth, in } \\
\text { meters })\end{array}$ \\
\hline "Excellent" & $<0.001$ & $<1.0$ & $>6.0$ \\
"Very good" & $.001-.009$ & $1.0-4.9$ & $3.0-6.0$ \\
"Good" & $.010-.029$ & $5.0-9.9$ & $2.0-2.9$ \\
"Fair" & $.030-.049$ & $10.0-14.9$ & $1.5-1.9$ \\
"Poor" & $.050-.149$ & $15.0-30.0$ & $1.0-1.4$ \\
"Very poor" & $>.150$ & $>30.0$ & $<1.0$ \\
\hline
\end{tabular}

Carlson's (1977) TSI approach to lake classification assigns numerical ranges to the three $t$ rophic conditions generally used to describe the wide range of lake water-quality conditions. Oligotrophic I akes a re typically clear, al gal popul ations and phos phorus concentrations are low, and the deepest water is likely to contain oxygen throughout the year. Mesotrophic lakes typically have a moderate supply of nutrients, experience moderate algal blooms, and have occasional oxygen depletions at depth. Eutrophic lakes are nutrient rich with relatively s evere water-quality pr oblems, s uch as frequent seasonal a lgal bl ooms, ox ygen depletion in I ower par ts of the I akes, and poo $r$ c larity. When e utrophic c onditions ar e v ery severe, the lake is considered hypereutrophic.

Carlson's ( 1977) TSI v alues ar e al so bas ed on near -surface total $p$ hosphorus and chlorophyll a concentrations, and S ecchi depths. The indices were developed to pl ace these three characteristics on similar scales to allow comparison of different lakes. TSI values based on phosphorus concentrations $\left(\mathrm{TSI}_{\mathrm{P}}\right)$, Secchi depths $\left(\mathrm{TSI}_{\mathrm{SD}}\right)$, and chlorophyll a concentrations $\left(\mathrm{TSI}_{\mathrm{C}}\right)$ typically are computed only for measurements collected during the open-water period.

TSI values for a lake can be calculated using the following equations (Carlson, 1977): 
$\mathrm{TSI}_{\mathrm{P}}=4.15+14.42 \times($ In [total phosphorus concentration $\left.\times 1,000]\right)$

$\mathrm{TSI}_{\mathrm{SD}}=60.0-14.41 \times($ In Secchi depth $)$

$\mathrm{TSI}_{\mathrm{C}}=30.6+9.81 \times($ In chlorophyll a concentration $)$

where: total phosphorus is in milligrams per liter,

Secchi depth is in meters, and

chlorophyll $a$ is in micrograms per liter.

The $t$ hree $m$ ain $t$ rophic conditions ar e de fined $w$ ith the following boundar ies $f$ or $t$ otal phosphorus, Secchi disc, and chlorophyll a:

\begin{tabular}{|c|c|c|c|c|}
\hline Trophic level & $\begin{array}{c}\text { Trophic State } \\
\text { Index }\end{array}$ & $\begin{array}{c}\text { Total phosphorus } \\
\text { (mg/L) }\end{array}$ & Secchi depth $(\mathrm{m})$ & $\begin{array}{c}\text { Chlorophyll a } \\
(\mu \mathrm{g} / \mathrm{L})\end{array}$ \\
\hline
\end{tabular}

Eutrophic

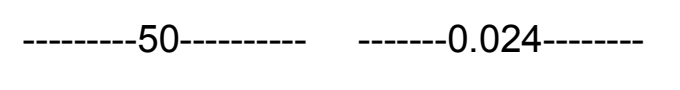

$-2.0$

$-7.2-1--\cdot--$

Mesotrophic

$--40$

$-0.012$

$-4.0$

-2.6---------

Oligotrophic 


\section{REFERENCES CITED}

Carlson, R.E., 1977, A trophic state index for lakes: Limnology and Oceanography, March, v. 22, no. 2, p. 361-369.

Fishman, M.J., ed., 1993, Methods of analysis by the U.S. Geological Survey National Water Quality Laboratory-Determination of inorganic and organic constituents in water and fluvial sediments: U.S. Geological Survey Open-File Report 93-125, 217 p.

Fishman, M.J., and Friedman, L.C., eds., 1989, Methods for determination of inorganic substances in water and fluvial sediments ( $3^{\text {rd }}$ ed.): U.S. Geological Survey Techniques of Water-Resources Investigations, book 5, chap. A1, 545 p.

Hem, J.D., 1985, Study and interpretation of the chemical characteristics of natural water ( $3^{\text {rd }}$ ed.): U.S. Geological Survey Water-Supply Paper 2254, 263 p.

James, W.F., and Barko, J.W., 1991, Littoral-pelagic phosphorus dynamics during nighttime convective circulation: Limnology and Oceanography, v. 36, no. 5, p. 946-960.

Lillie, R.A., Graham, S., and Rasmussen, P., 1993, Trophic-State Index equations and regional predictive equations for Wisconsin lakes: Wisconsin Department of Natural Resources Research Management Findings No. 35, 4 p.

Lillie, R.A., and Mason, J.W., 1983, Limnological characteristics of Wisconsin lakes: Wisconsin Department of Natural Resources Technical Bulletin No. 138, 116 p.

Rantz, S.E., and others, 1982, Measurement and computation of streamflow: U.S. Geological Survey Water-Supply Paper 2175, $631 \mathrm{p}$.

Rapavich, W.M., Sonzogni, W.C., Standridge, J.H., Vennie J.G., and Wedepohl, R.E., 1987, Incidence of algal toxins in Wisconsin water experiencing blue-green algae blooms: Wisconsin State Laboratory of Hygiene and Wisconsin Department of Natural Resources, Informational Paper, 8 p. 
Shaw, B., Mechenich, C., and Klessig, L., 1993, Understanding Lake Data: University of Wisconsin Extension, G3582: Madison, Wis., 19 p.

U.S. Environmental Protection Agency, 1986, Quality Criteria for Water 1986: U.S.

Environmental Protection Agency publication, EPA 440/5-86-001 [variously paged].

Wershaw, R.L., Fishman, M.J., Grabbe, R.R., and Lowe, L.E., eds., 1987, Methods for the determination of organic substances in water and fluvial sediments: U.S. Geological Survey Techniques of Water-Resources Investigations, book 5, chap. A3, 80 p.

Wetzel, R.G., 1983, Limnology ( $2^{\text {nd }}$ ed.): New York, W.B. Saunders, 767 p.

Wisconsin Department of Natural Resources, 1992, Wisconsin water quality assessmentReport to Congress, 1992: Wisconsin Department of Natural Resources Publ-WR25492-REV, $220 \mathrm{p}$.

Wisconsin State Laboratory of Hygiene, Environmental Sciences Section, 1993, Manual of analytical methods, inorganic chemistry unit: Wisconsin State Laboratory of Hygiene, revised November 1993 [variously paged]. 


\section{LAKE DATA}

Remarks codes and symbols used in the following tables:

[<, less than; --, not available; E, estimated] 


\section{LAKE BEULAH AT DEEP HOLE NEAR EAST TROY, WI}

LOCATION.--Lat 42 $48^{\prime} 40^{\prime \prime}$, long $88^{\circ} 24^{\prime} 16 "$ ", in SW 1/4 NW 1/4 NW 1/4 sec.17, T.4 N., R.18 E., Walworth County, Hydrologic Unit 07120006 , near East Troy. SURFACE AREA.--1.30 $\mathrm{mi}^{2}$.

PERIOD OF RECORD.--August 2007 to current year.

REMARKS.--Lake sampled at the deep hole at a depth of $19 \mathrm{~m}$. Water-quality analyses by Wisconsin State Laboratory of Hygiene.

WATER-QUALITY DATA, NOVEMBER 19, 2008 - AUGUST 24, 2009

(Milligrams per liter unless otherwise indicated)

\begin{tabular}{|c|c|c|c|c|c|c|c|c|c|c|}
\hline Parameter Code & Parameter Name & Nov. 19 & \multicolumn{2}{|c|}{ Feb. 23} & Apr. 8 & \multicolumn{5}{|c|}{ August 24} \\
\hline 32210 & 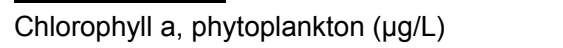 & 2.16 & \multicolumn{2}{|c|}{0.55} & $\overline{0.78}$ & & & 2.66 & & \\
\hline 00078 & Secchi-depth $(m)$ & 3.1 & \multicolumn{2}{|c|}{-- } & 5.4 & & & 6.0 & & \\
\hline 00098 & Sampling depth $(\mathrm{m})$ & 2.0 & 2.0 & 17.0 & 2.0 & 2.0 & 9.0 & 15.0 & 17.0 & 18.0 \\
\hline 00010 & Water Temperature $\left({ }^{\circ} \mathrm{C}\right)$ & 7.0 & 3.5 & 3.0 & 6.0 & 22.7 & 13.0 & 7.6 & 7.1 & 6.9 \\
\hline 00400 & $\mathrm{pH}$ (standard units) & 7.9 & 7.7 & 7.5 & 7.9 & 8.3 & 7.5 & 7.5 & 7.4 & 7.4 \\
\hline 00095 & Specific conductance $(\mu \mathrm{S} / \mathrm{cm})$ & 561 & 601 & 652 & 565 & 507 & 562 & 574 & 580 & 589 \\
\hline 00300 & Dissolved oxygen & 9.3 & 11.6 & 5.4 & 11.5 & 8.1 & 0.5 & 0.0 & 0.0 & 0.0 \\
\hline 00665 & Phosphorus, total (as P) & 0.014 & 0.013 & 0.013 & 0.013 & 0.017 & 0.024 & 0.021 & 0.022 & 0.035 \\
\hline 00631 & Nitrate plus nitrite, dissolved (as $\mathrm{N}$ ) & 0.307 & 0.673 & 0.311 & 1.180 & 0.074 & 0.500 & 0.809 & 0.650 & 0.158 \\
\hline 00608 & Ammonia, dissolved (as N) & 0.19 & 0.211 & 0.263 & 0.06 & 0.032 & 0.089 & 0.198 & 0.298 & 0.773 \\
\hline 00625 & Ammonia plus organic nitrogen, total (as $\mathrm{N}$ ) & 0.65 & 0.66 & 0.64 & 0.44 & 0.16 & 0.31 & 0.33 & 0.40 & 1.10 \\
\hline 00600 & Total nitrogen & 0.96 & 1.30 & 0.95 & 1.60 & 0.23 & 0.81 & 1.10 & 1.10 & 1.20 \\
\hline 63675 & Turbidity, (NTU) & $<1.0$ & $<1.0$ & $<1.0$ & $<1.0$ & $<1.0$ & $<1.0$ & $<1.0$ & $<1.0$ & $<1.0$ \\
\hline 00900 & Hardness (as $\mathrm{CaCO} 3$ ) & 290 & 300 & 290 & 300 & 230 & 250 & 270 & 270 & 270 \\
\hline 00915 & Calcium, dissolved $(\mathrm{Ca})$ & 58.9 & 63 & 59.2 & 63.3 & 41.7 & 50 & 58.4 & 56.7 & 58.6 \\
\hline 00925 & Magnesium, dissolved (Mg) & 33.9 & 34.7 & 35.5 & 33.9 & 31.2 & 31.1 & 31.3 & 30.4 & 31.1 \\
\hline 00417 & ANC (as $\mathrm{CaCO} 3$ ) & 246 & 258 & 252 & 252 & 209 & 225 & 249 & 250 & 259 \\
\hline 00940 & Chloride, dissolved (Cl) & 22.4 & 23 & 28.8 & 23.1 & 21.6 & 21.3 & 22 & 21.9 & 22.3 \\
\hline 00945 & Sulfate, dissolved (SO4) & 29.7 & 30.5 & 29.5 & 31.4 & 27.7 & 28.7 & 29.6 & 29.5 & 26.9 \\
\hline 00955 & Silica, dissolved (SiO2) & 15.4 & 14.8 & 14.7 & 13.2 & 11.3 & 11.1 & 15.4 & 15.5 & 18.4 \\
\hline 01046 & Iron $(\mu \mathrm{g} / \mathrm{L})$ & $<100$ & $<100$ & $<100$ & $<100$ & $<100$ & $<100$ & $<100$ & $<100$ & $<100$ \\
\hline 01056 & Manganese $(\mu \mathrm{g} / \mathrm{L})$ & $<1.0$ & $<1.0$ & 20 & $<1.0$ & $<1.0$ & $<1.0$ & 120 & 170 & 520 \\
\hline 70300 & Solids, dissolved (at $180^{\circ} \mathrm{C}$ ) & 328 & 350 & 362 & 346 & 312 & 328 & 360 & 356 & 360 \\
\hline
\end{tabular}


424840088241600 LAKE BEULAH AT DEEP HOLE NEAR EAST TROY, WI

LAKE-DEPTH PROFILES, NOVEMBER 19, 2008 TO AUGUST 24, 2009

$11-19-08$
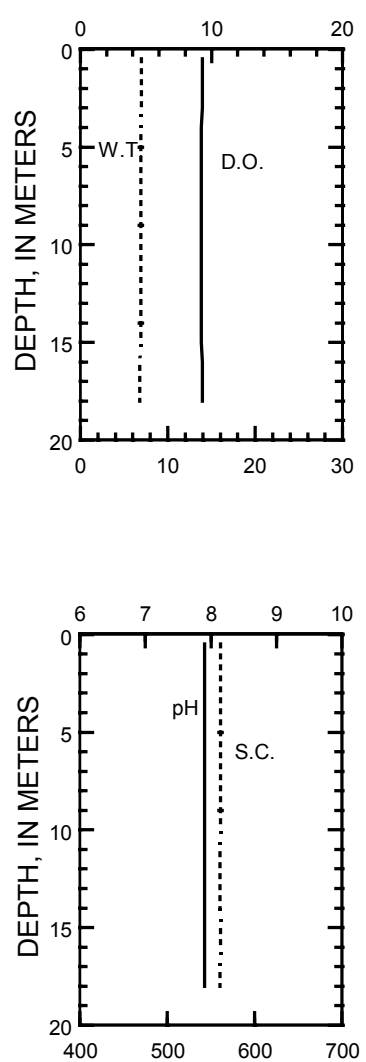

02-23-09

04-08-09

DISSOLVED OXYGEN (D.O.), IN MILLIGRAMS PER LITER

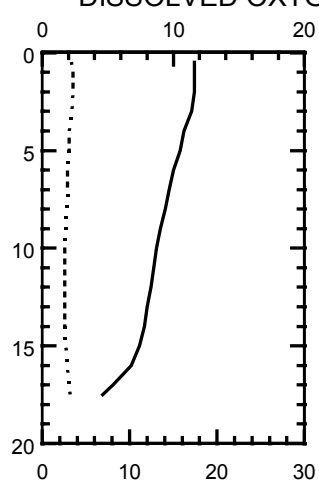

WATER TEMPERATURE (W.T.), IN DEGREES CELSIUS

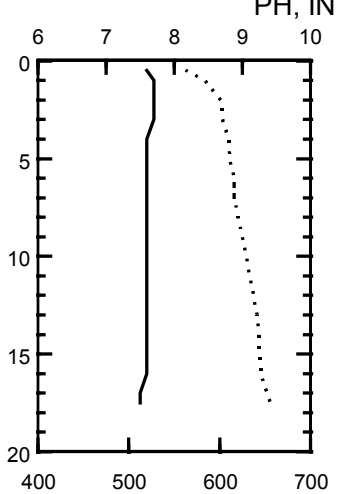

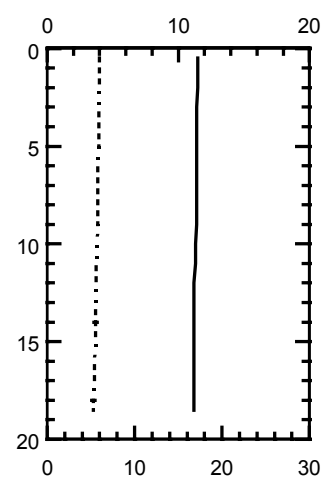
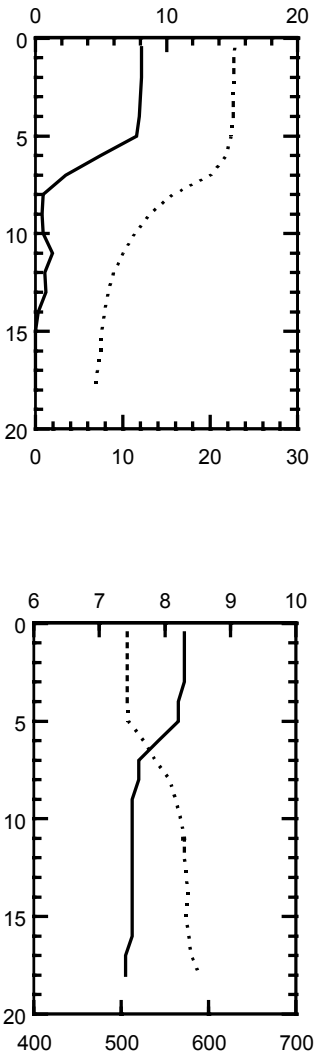

SPECIFIC CONDUCTANCE (S.C.), IN MICROSIEMENS PER CENTIMETER AT 25 DEGREES CELSIUS 
424929088231300 LAKE BEULAH STATION 2 NEAR EAST TROY, WI

LOCATION.--Lat 4249'29", long 88²3'13", in SE 1/4 NE 1/4 NE 1/4 sec.8, T.4 N., R.18 E., Walworth County, Hydrologic Unit 07120006, near East Troy. SURFACE AREA.--1.30 $\mathrm{mi}^{2}$.

PERIOD OF RECORD.--August 2007 to current year.

REMARKS.--Lake sampled at a depth of $15 \mathrm{~m}$. Water-quality analyses by Wisconsin State Laboratory of Hygiene.

WATER-QUALITY DATA, NOVEMBER 19, 2008 - AUGUST 24, 2009

(Milligrams per liter unless otherwise indicated)

\begin{tabular}{|c|c|c|c|c|c|c|c|c|c|c|}
\hline Parameter Code & Parameter Name & Nov. 19 & \multicolumn{2}{|c|}{ Feb. 23} & Apr.8 & \multicolumn{5}{|c|}{ August 24} \\
\hline 32210 & 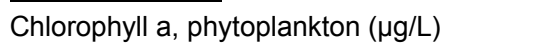 & 1.95 & \multicolumn{2}{|c|}{1.00} & $\overline{1.45}$ & & & 3.47 & & \\
\hline 00078 & Secchi-depth (m) & 4.5 & \multicolumn{2}{|c|}{--} & 4.2 & & & 4.4 & & \\
\hline 00098 & Sampling depth (m) & 2.0 & 2.0 & 14.5 & 2.0 & 2.0 & 9.0 & 13.0 & 14.0 & 14.5 \\
\hline 00010 & Water Temperature $\left({ }^{\circ} \mathrm{C}\right)$ & 6.5 & 4.1 & 3.1 & 6.6 & 22.9 & 12.4 & 8.2 & 7.9 & 7.7 \\
\hline 00400 & $\mathrm{pH}$ (standard units) & 8.1 & 7.7 & 7.5 & 8.0 & 8.4 & 7.7 & 7.5 & 7.4 & 7.4 \\
\hline 00095 & Specific conductance $(\mu \mathrm{S} / \mathrm{cm})$ & 496 & 532 & 605 & 506 & 463 & 514 & 520 & 525 & 527 \\
\hline 00300 & Dissolved oxygen & 10.7 & 17.2 & 11.7 & 12.0 & 8.1 & 3.3 & 0.0 & 0.0 & 0.0 \\
\hline 00665 & Phosphorus, total (as P) & 0.012 & 0.014 & 0.029 & 0.017 & 0.014 & 0.014 & 0.038 & 0.037 & 0.038 \\
\hline 00671 & Orthophosphate, dissolved (as P) & $<.002$ & $<.002$ & 0.018 & $<.002$ & $<.002$ & $<.002$ & $<.002$ & $<.002$ & $<.002$ \\
\hline 00631 & Nitrate plus nitrite, dissolved (as $\mathrm{N}$ ) & 0.033 & 0.077 & 1.48 & 0.31 & $<.019$ & 0.182 & $<.019$ & $<.019$ & $<.019$ \\
\hline 00608 & Ammonia, dissolved (as $\mathrm{N}$ ) & 0.173 & 0.158 & 0.301 & 0.067 & $<.015$ & 0.111 & 0.428 & 0.572 & 0.642 \\
\hline 00625 & Ammonia plus organic nitrogen, total (as $\mathrm{N}$ ) & 0.8 & 0.7 & 0.68 & 0.6 & 0.25 & 0.18 & 0.97 & 1 & 1.1 \\
\hline 00600 & Total nitrogen & 0.83 & 0.78 & 2.2 & 0.91 & -- & 0.36 & -- & -- & -- \\
\hline 63675 & Turbidity, (NTU) & $<1.0$ & $<1.0$ & $<1.0$ & $<1.0$ & $<1.0$ & $<1.0$ & $<1.0$ & $<1.0$ & $<1.0$ \\
\hline 00900 & Hardness (as CaCO3) & 240 & 250 & 330 & 260 & 200 & 230 & 240 & 240 & 240 \\
\hline 00915 & Calcium, dissolved (Ca) & 43.8 & 45.9 & 71.2 & 49.8 & 32 & 44.2 & 45.9 & 46.4 & 47 \\
\hline 00925 & Magnesium, dissolved (Mg) & 32.5 & 33.8 & 36.4 & 32.3 & 30.2 & 29.9 & 29.7 & 29.8 & 30 \\
\hline 00930 & Sodium, dissolved $(\mathrm{Na})$ & 11.1 & 12.5 & 9.7 & 11.3 & 10.4 & 10.3 & 10.1 & 10.2 & 10.3 \\
\hline 00935 & Potassium, dissolved $(\mathrm{K})$ & 1.8 & 1.8 & 1.8 & 1.7 & 1.5 & 1.6 & 1.6 & 1.6 & 1.6 \\
\hline 00417 & ANC (as $\mathrm{CaCO} 3)$ & 205 & 213 & 278 & 216 & 179 & 206 & 218 & 219 & 218 \\
\hline 00940 & Chloride, dissolved $(\mathrm{Cl})$ & 25.8 & 28.4 & 23.9 & 26 & 25.3 & 24.5 & 24.8 & 24.8 & 25.1 \\
\hline 00945 & Sulfate, dissolved (SO4) & 26.4 & 27.2 & 33.3 & 27.6 & 26.2 & 26 & 26.2 & 26 & 25.5 \\
\hline 00955 & Silica, dissolved (SiO2) & 15.4 & 12.3 & 17.7 & 10.2 & 9.13 & 8.26 & 13.1 & 14.7 & 15.1 \\
\hline 01046 & Iron $(\mu \mathrm{g} / \mathrm{L})$ & $<100$ & $<100$ & $<100$ & $<100$ & $<100$ & $<100$ & $<100$ & $<100$ & $<100$ \\
\hline 01056 & Manganese ( $\mu \mathrm{g} / \mathrm{L})$ & $<1.0$ & $<1.0$ & 90 & $<1.0$ & $<1.0$ & $<1.0$ & 90 & 150 & 180 \\
\hline 70300 & Solids, dissolved (at $180^{\circ} \mathrm{C}$ ) & 286 & 308 & 382 & 306 & 286 & 310 & 312 & 326 & 322 \\
\hline
\end{tabular}


424929088231300 LAKE BEULAH STATION 2 NEAR EAST TROY, WI

LAKE-DEPTH PROFILES, NOVEMBER 19, 2008 TO AUGUST 24, 2009

$11-19-08$
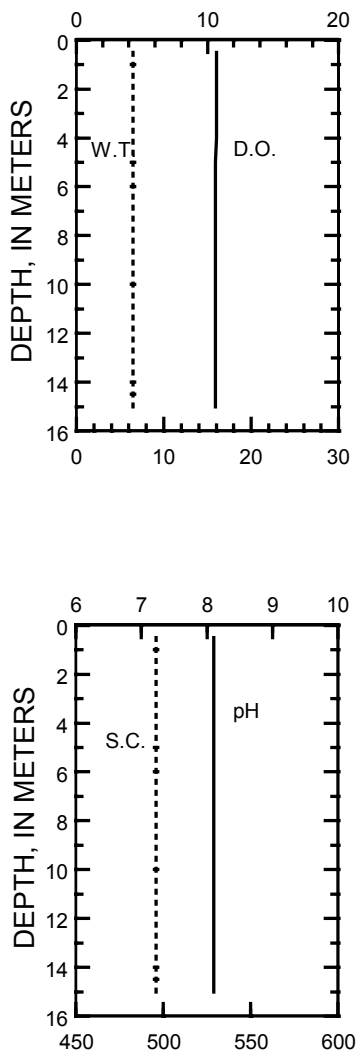

02-23-09

DISSOLVED OXYGEN (D.O.), IN MILLIGRAMS PER LITER
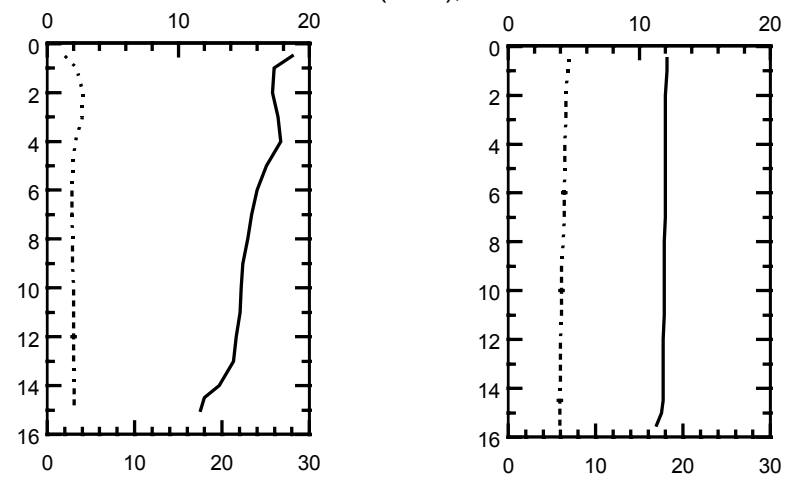

WATER TEMPERATURE (W.T.), IN DEGREES CELSIUS

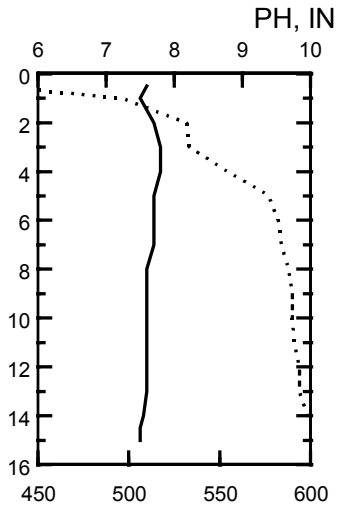

08-24-09
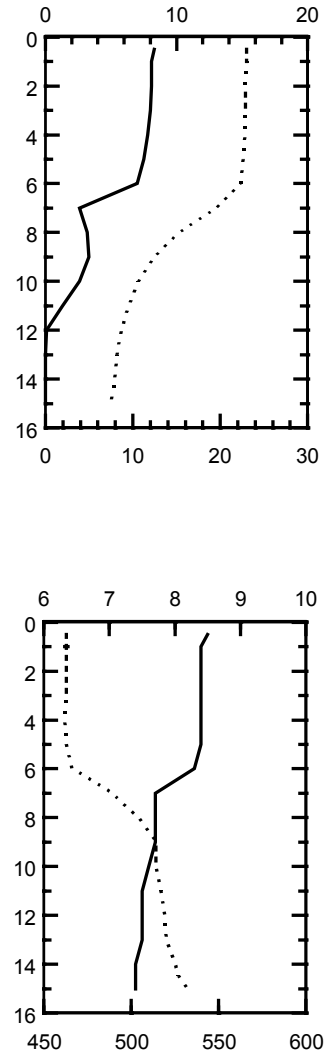

SPECIFIC CONDUCTANCE (S.C.), IN MICROSIEMENS PER CENTIMETER AT 25 DEGREES CELSIUS 


\section{BIG CEDAR LAKE, NORTH SITE, NEAR WEST BEND, WI}

LOCATION.--Lat 43²4'09", long 88¹5'16", in NE 1/4 SW 1/4 sec. 20, T.11 N., R.19 E., Washington County, Hydrologic Unit 04040003, near West Bend. SURFACE AREA.--1.46 $\mathrm{mi}^{2}$.

PERIOD OF RECORD.--February 2000 to current year.

REMARKS.--Lake sampled on north side at a depth of $12 \mathrm{~m}$. Water-quality analyses by Wisconsin State Laboratory of Hygiene.

WATER-QUALITY DATA, FEBRUARY 19 TO AUGUST 27, 2009

(Milligrams per liter unless otherwise indicated)

\begin{tabular}{|c|c|}
\hline Parameter Code & $\underline{\text { Parameter Name }}$ \\
\hline 32210 & Chlorophyll a, phytoplankton ( $\mu \mathrm{g} / \mathrm{L})$ \\
\hline 00078 & Secchi-depth $(m)$ \\
\hline 00098 & Sampling depth (m) \\
\hline 00010 & Water Temperature $\left({ }^{\circ} \mathrm{C}\right)$ \\
\hline 00400 & $\mathrm{pH}$ (standard units) \\
\hline 00095 & Specific conductance $(\mu \mathrm{S} / \mathrm{cm})$ \\
\hline 00300 & Dissolved oxygen \\
\hline 00665 & Phosphorus, total (as P) \\
\hline
\end{tabular}

\begin{tabular}{|c|c|c|c|}
\hline \multicolumn{2}{|c|}{ Feb. 19} & \multicolumn{2}{|c|}{ April 16} \\
\hline \multicolumn{2}{|c|}{-- } & \multicolumn{2}{|c|}{3.53} \\
\hline & & & \\
\hline 0.5 & 11.5 & 0.5 & \\
\hline 1.9 & 4.1 & 8.6 & \\
\hline 7.7 & 7.2 & 8.1 & \\
\hline 537 & 814 & 550 & \\
\hline 11.6 & 0.3 & 12.2 & \\
\hline 0.017 & 0.031 & 0.012 & \\
\hline
\end{tabular}

\begin{tabular}{|c|c|}
\hline \multicolumn{2}{|c|}{ June 25} \\
\hline \multicolumn{2}{|c|}{1.67} \\
\hline & \\
\hline 0.5 & 11.0 \\
\hline 28.3 & 13.5 \\
\hline 7.2 & 9.0 \\
\hline 576 & 580 \\
\hline 7.8 & 0.7 \\
\hline 0.014 & 0.03 \\
\hline
\end{tabular}

\begin{tabular}{|c|c|}
\hline \multicolumn{2}{|c|}{ July 22} \\
\hline & \\
\hline \multicolumn{2}{|c|}{2.4} \\
\hline 0.5 & 11.0 \\
\hline 21.7 & 14.1 \\
\hline 8.2 & 7.1 \\
\hline 550 & 594 \\
\hline 9.9 & 0.1 \\
\hline 0.017 & 0.052 \\
\hline
\end{tabular}

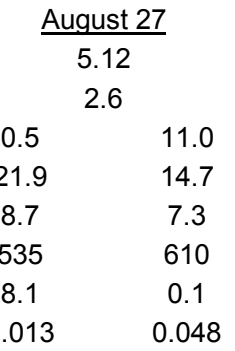


432409088151600 BIG CEDAR LAKE, NORTH SITE, NEAR WEST BEND, WI

LAKE-DEPTH PROFILES, FEBRUARY 19 TO AUGUST 27, 2009

02-19-09
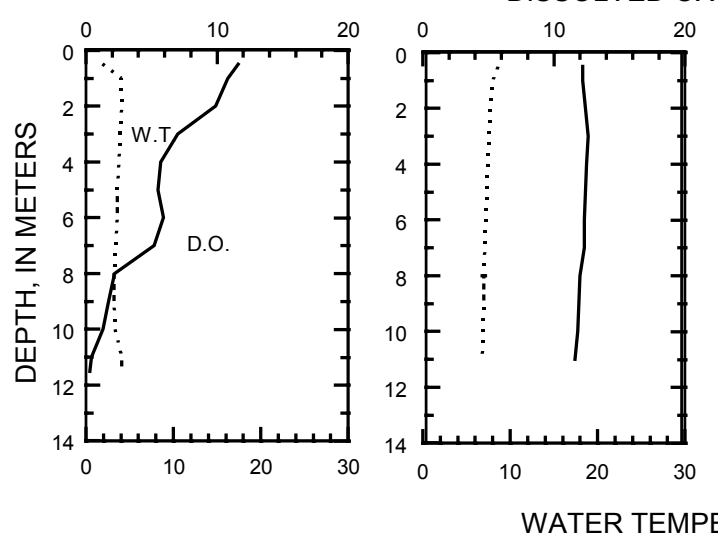

14
06-25-09

07-22-09
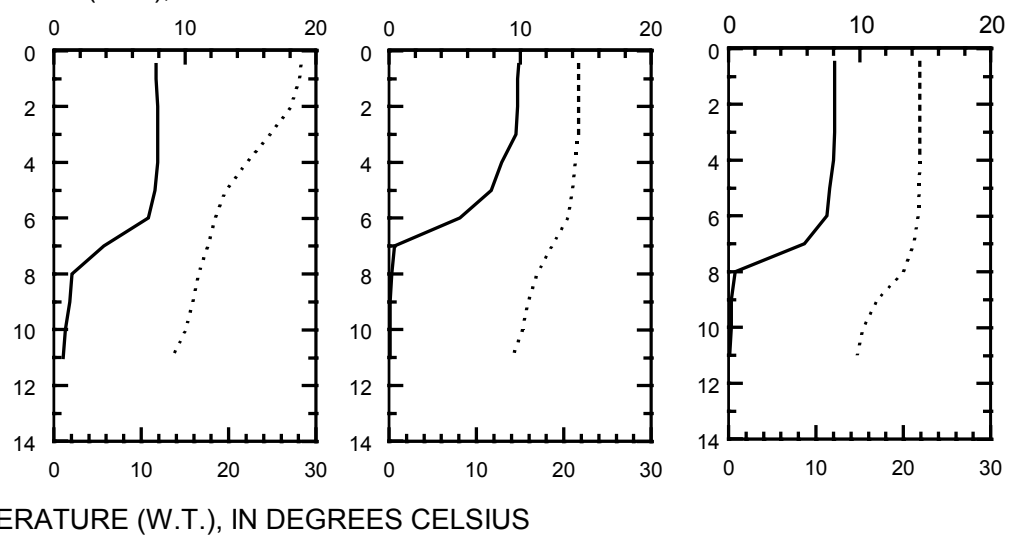

$\mathrm{PH}$, IN STANDARD UNITS
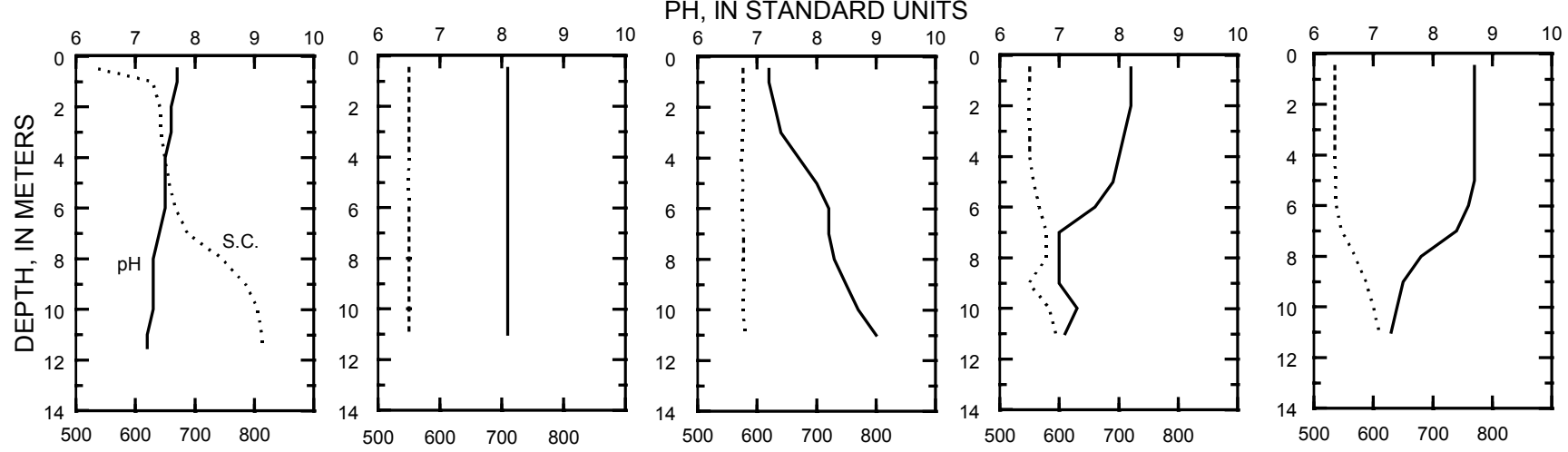

SPECIFIC CONDUCTANCE (S.C.), IN MICROSIEMENS PER CENTIMETER AT 25 DEGREES CELSIUS 

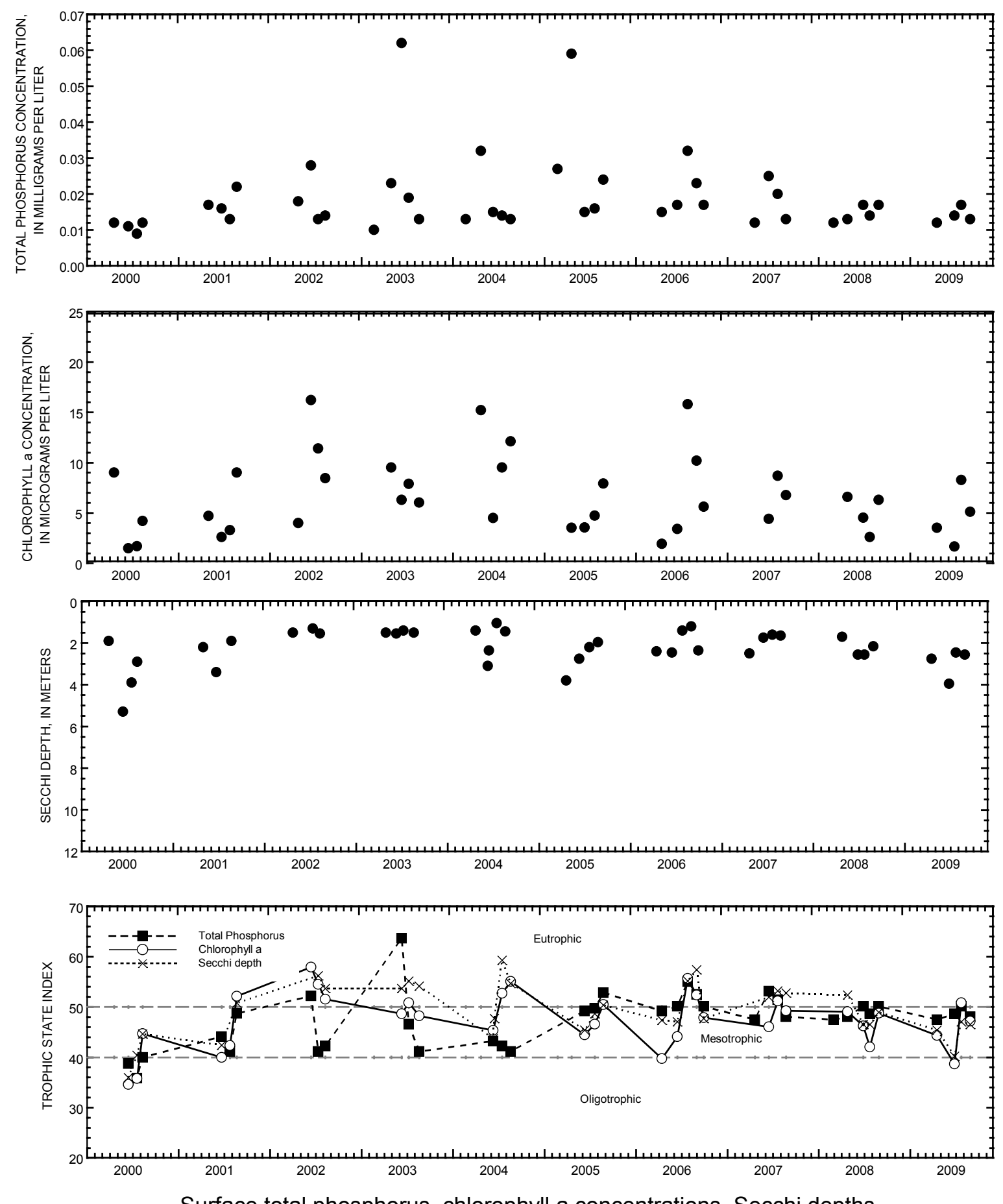

Surface total phosphorus, chlorophyll a concentrations, Secchi depths, and TSI data for Big Cedar Lake, North Site, near West Bend, Wisconsin. 
432224088154900 BIG CEDAR LAKE, SOUTH SITE, NEAR WEST BEND, WI

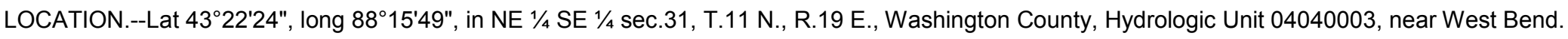

SURFACE AREA.--1.46 $\mathrm{mi}^{2}$.

PERIOD OF RECORD.--February 2000 to current year.

REMARKS.--Lake sampled on south side at deep hole. Water-quality analyses by Wisconsin State Laboratory of Hygiene.

WATER-QUALITY DATA, FEBRUARY 19 TO AUGUST 27, 2009

(Milligrams per liter unless otherwise indicated)

\begin{tabular}{|c|c|c|c|c|c|c|c|c|c|c|c|}
\hline Parameter Code & Parameter Name & \multicolumn{2}{|c|}{ Feb. 19} & \multicolumn{2}{|c|}{ April 16} & \multicolumn{2}{|c|}{ June 25} & \multicolumn{2}{|c|}{ July 22} & \multicolumn{2}{|c|}{ August 27} \\
\hline 32210 & Chlorophyll a, phytoplankton ( $\mu \mathrm{g} / \mathrm{L})$ & \multicolumn{2}{|c|}{--} & \multicolumn{2}{|c|}{4.2} & \multicolumn{2}{|c|}{2.17} & \multicolumn{2}{|c|}{3.33} & \multicolumn{2}{|c|}{8.55} \\
\hline 00078 & Secchi-depth (m) & \multicolumn{2}{|c|}{--} & \multicolumn{2}{|c|}{4.2} & \multicolumn{2}{|c|}{5.0} & \multicolumn{2}{|c|}{4.6} & \multicolumn{2}{|c|}{2.6} \\
\hline 00098 & Sampling depth (m) & 0.5 & 29.5 & 0.5 & 30 & 0.5 & 30 & 0.5 & 30 & 0.5 & 30 \\
\hline 00010 & Water Temperature $\left({ }^{\circ} \mathrm{C}\right)$ & 1.6 & 2.6 & 6.1 & 4.6 & 27.2 & 5.9 & 21.4 & 5.6 & 22 & 5.7 \\
\hline 00400 & $\mathrm{pH}$ (standard units) & 7.8 & 7.7 & 8.1 & 8 & 7.4 & 8 & 7.8 & 7 & 8.8 & 7.3 \\
\hline 00095 & Specific conductance $(\mu \mathrm{S} / \mathrm{cm})$ & 578 & 614 & 550 & 549 & 569 & 564 & 552 & 581 & 530 & 579 \\
\hline 00300 & Dissolved oxygen & 11.5 & 8.6 & 12.6 & 11.4 & 8 & 4.9 & 9.6 & 0.1 & 8.9 & 0.1 \\
\hline 00665 & Phosphorus, total (as P) & 0.017 & 0.057 & 0.012 & 0.021 & 0.011 & 0.029 & 0.013 & 0.014 & 0.011 & 0.03 \\
\hline 00671 & Orthophosphate, dissolved (as P) & -- & -- & $<.002$ & -- & -- & -- & 0.003 & -- & -- & -- \\
\hline 00631 & Nitrate plus nitrite, dissolved (as $\mathrm{N}$ ) & -- & -- & 0.542 & -- & -- & -- & 0.208 & -- & -- & -- \\
\hline 00608 & Ammonia, dissolved (as N) & -- & -- & $<.015$ & -- & -- & -- & $<.015$ & -- & -- & -- \\
\hline 00625 & Ammonia plus organic nitrogen, total (as $\mathrm{N}$ ) & -- & -- & $<.14$ & -- & -- & -- & -- & -- & -- & -- \\
\hline 00623 & Ammonia plus organic nitrogen, dissolved (as $\mathrm{N}$ ) & -- & -- & -- & -- & -- & -- & 0.4 & -- & -- & -- \\
\hline 00600 & Total nitrogen & -- & -- & -- & -- & -- & -- & -- & -- & -- & -- \\
\hline 63675 & Turbidity, (NTU) & -- & -- & $<1.0$ & -- & -- & -- & -- & -- & -- & -- \\
\hline 00081 & Apparent color, (PTU) & -- & -- & 5 & -- & -- & -- & -- & -- & -- & -- \\
\hline 00900 & Hardness (as CaCO3) & -- & -- & 240 & -- & -- & -- & -- & -- & -- & -- \\
\hline 00915 & Calcium, dissolved (Ca) & -- & -- & 40.2 & -- & -- & -- & -- & -- & -- & -- \\
\hline 00925 & Magnesium, dissolved (Mg) & -- & -- & 34.7 & -- & -- & -- & -- & -- & -- & -- \\
\hline 00930 & Sodium, dissolved $(\mathrm{Na})$ & -- & -- & 23.3 & -- & -- & -- & -- & -- & -- & -- \\
\hline 00935 & Potassium, dissolved (K) & -- & -- & 1.8 & -- & -- & -- & -- & -- & -- & -- \\
\hline 00417 & ANC (as CaCO3) & -- & -- & 199 & -- & -- & -- & -- & -- & -- & -- \\
\hline 00940 & Chloride, dissolved $(\mathrm{Cl})$ & -- & -- & 50.9 & -- & -- & -- & -- & -- & -- & -- \\
\hline 00945 & Sulfate, dissolved (SO4) & -- & -- & 23.2 & -- & -- & -- & -- & -- & -- & -- \\
\hline 00955 & Silica, dissolved (SiO2) & -- & -- & 3.66 & -- & -- & -- & -- & -- & -- & -- \\
\hline 01046 & Iron $(\mu \mathrm{g} / \mathrm{L})$ & -- & -- & $<100$ & -- & -- & -- & -- & -- & -- & -- \\
\hline 01056 & Manganese $(\mu \mathrm{g} / \mathrm{L})$ & -- & -- & $<1.0$ & -- & -- & -- & -- & -- & -- & -- \\
\hline 70300 & Solids, dissolved (at $180^{\circ} \mathrm{C}$ ) & -- & -- & 312 & -- & -- & -- & -- & -- & -- & -- \\
\hline
\end{tabular}


432224088154900 BIG CEDAR LAKE, SOUTH SITE, NEAR WEST BEND, WI

LAKE-DEPTH PROFILES, FEBRUARY 19 TO AUGUST 27, 2009

02-19-09
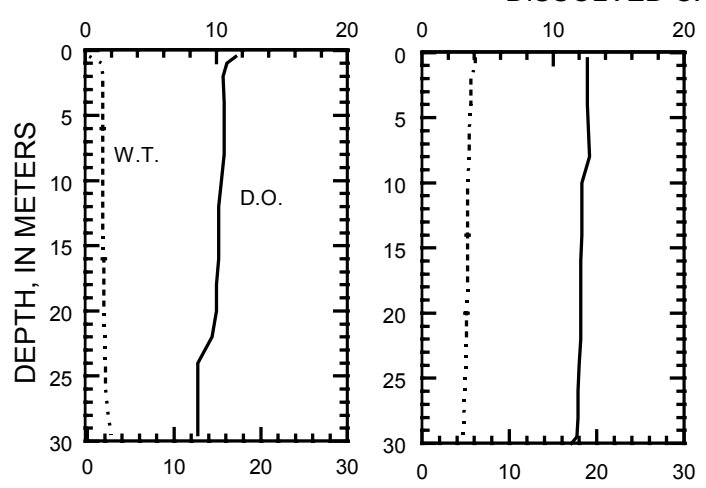

WATER TEMPER

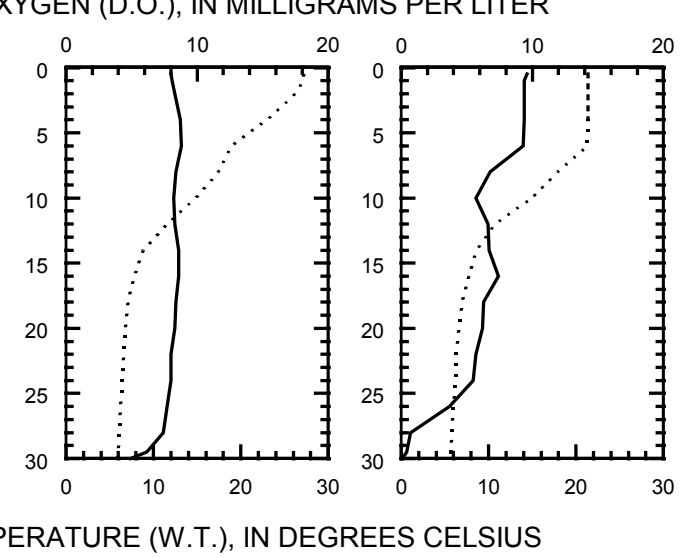

06-25-09

07-22-09

08-27-09
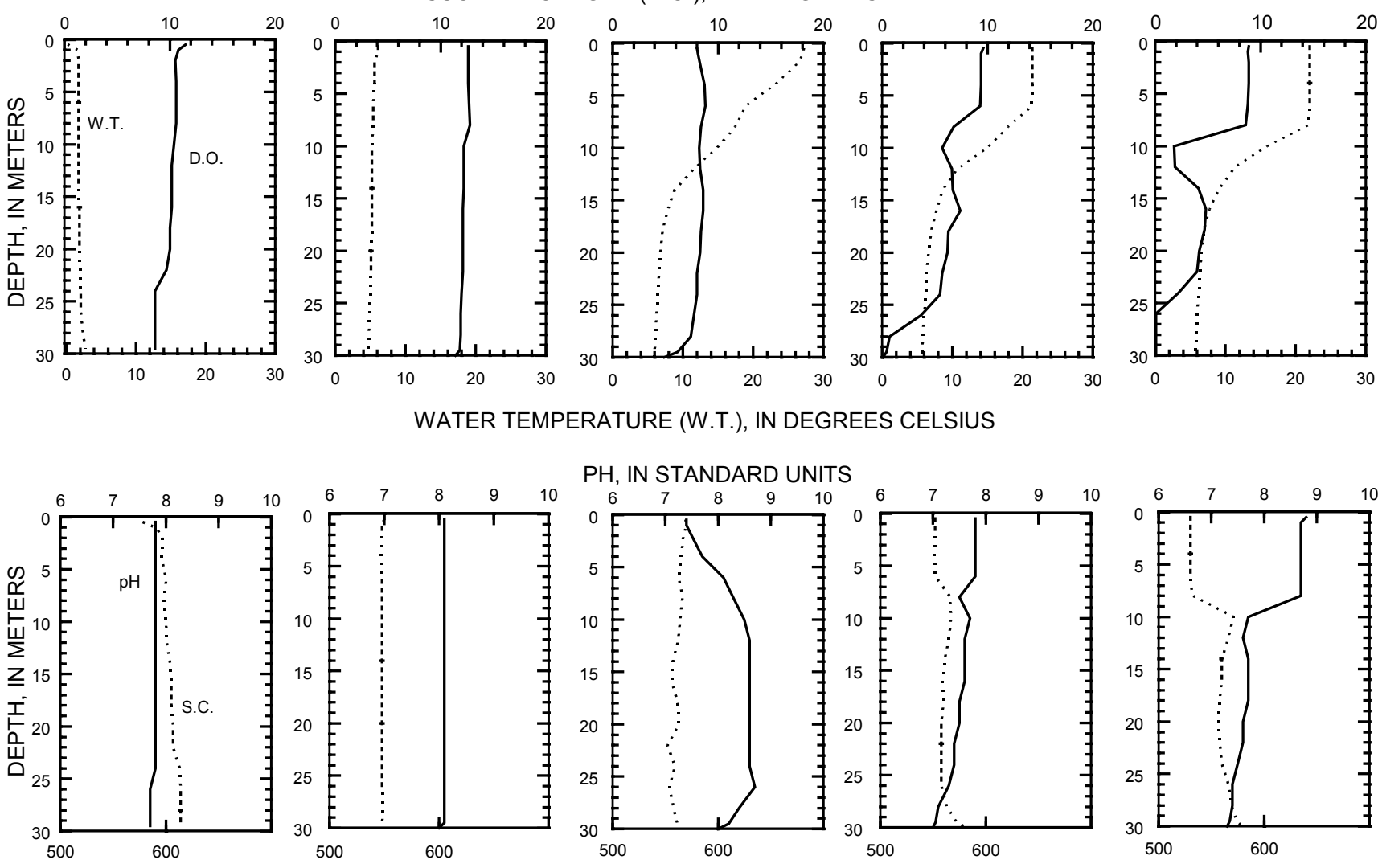

SPECIFIC CONDUCTANCE (S.C.), IN MICROSIEMENS PER CENTIMETER AT 25 DEGREES CELSIUS

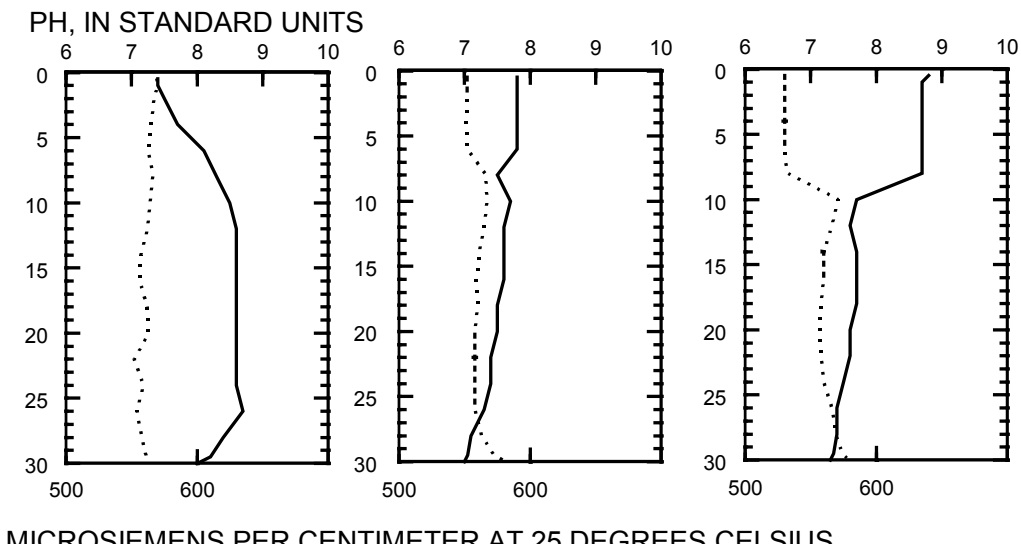



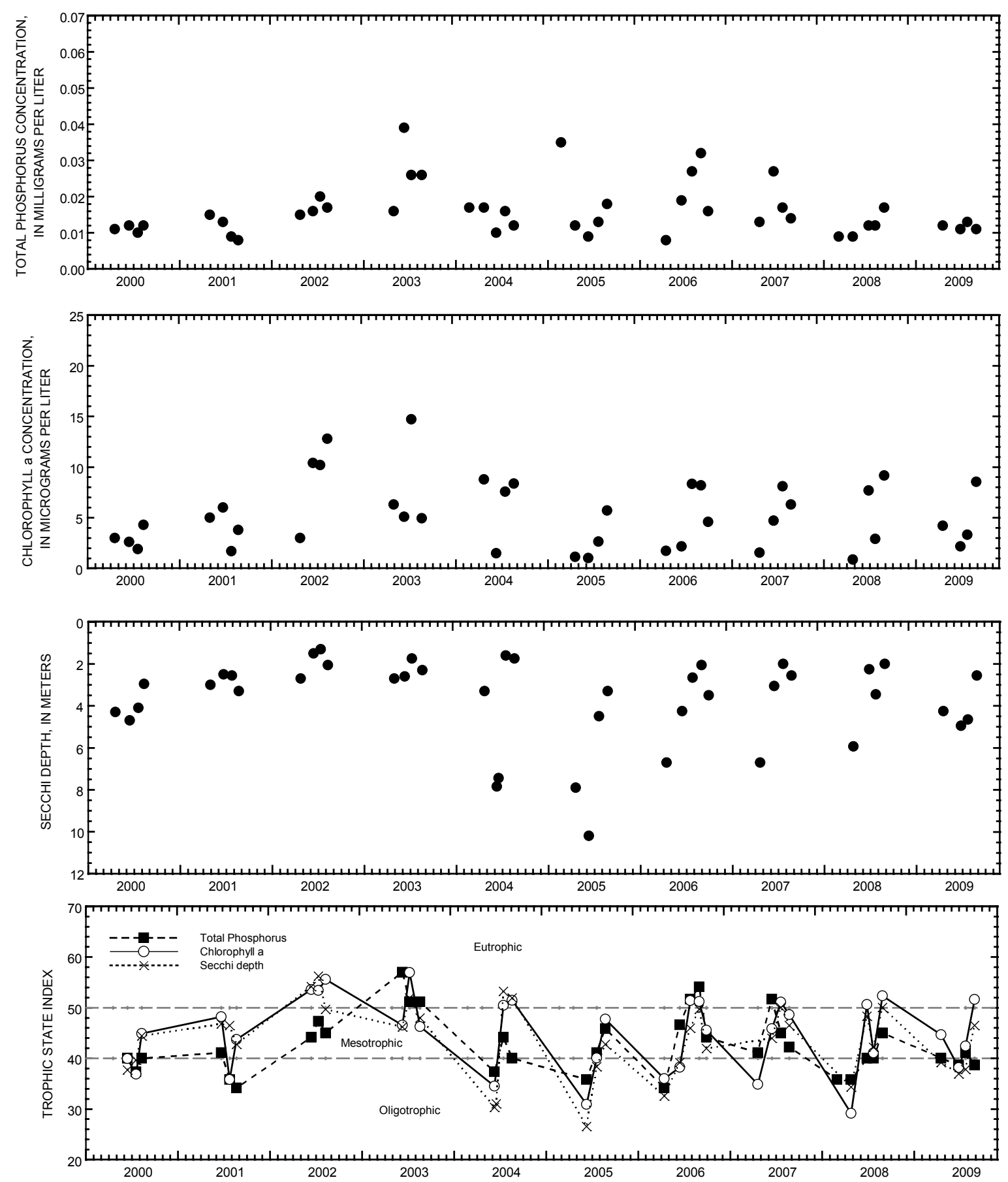

Surface total phosphorus, chlorophyll a concentrations, Secchi depths, and TSI data for Big Cedar Lake, South Site, near West Bend, Wisconsin. 


\section{DELAVAN LAKE NEAR DELAVAN, WI}

LOCATION.--Lat 42 $36^{\prime} 27^{\prime \prime}$, long $88^{\circ} 36^{\prime} 19^{\prime \prime}$ referenced to North American Datum of 1927 , in SW $1 / 4$ NE $1 / 4$ Sec.28, T.2 N., R.16 E., Walworth County, WI, Hydrologic Unit 07090001, at Delavan Lake Sanitary District Lift Station No. 2 at Delavan Lake Yacht Club, 1.0 mi southeast of outlet, and 2.7 mi southeast of Delavan.

SURFACE AREA.--3.24 $\mathrm{mi}^{2}$.

DRAINAGE AREA.--41.4 $\mathrm{mi}^{2}$, of which $2.30 \mathrm{mi}^{2}$ probably is noncontributing.

PERIOD OF RECORD.--October 1983 to current year. October 1983 to September 1985 data published in Water Resources Investigation series report "Water Quality and Hydrology of Delavan Lake in Southeastern Wisconsin" by Stephen J. Field and Marvin D. Duerk.

GAGE.--Water-stage recorder. Datum of gage is $922.92 \mathrm{ft}$ above NGVD of 1929 or $922.72 \mathrm{ft}$ above NAVD of 1988. Prior to Sept. 5, 1989, staff gage at bridge on North Shore Drive at same datum.

REMARKS.--Records good. Lake was ice covered from Dec. 16 to Mar. 18. Lake levels controlled by Delavan Lake Sanitary District.

EXTREMES FOR PERIOD OF RECORD.--Maximum gage height observed, 6.53 ft, Aug. 27, 2007; minimum daily, $-4.44 \mathrm{ft}$, Nov. 6, 1989 (lake drawn down for lake rehabilitation program).

EXTREMES FOR CURRENT YEAR.--Maximum gage height, 5.63 ft, Apr. 27; minimum, 4.92 ft, Sept. 30. 


\begin{tabular}{|c|c|c|c|c|c|c|c|c|c|c|c|c|}
\hline \multicolumn{13}{|c|}{$\begin{array}{c}\text { GAGE HEIGHT, FEET } \\
\text { WATER YEAR OCTOBER } 2008 \text { TO SEPTEMBER } 2009 \\
\text { DAILY MEAN VALUES }\end{array}$} \\
\hline \multicolumn{13}{|c|}{ [e, estimated] } \\
\hline Day & Oct & Nov & Dec & Jan & Feb & Mar & Apr & May & Jun & Jul & Aug & Sep \\
\hline 1 & 4.98 & 5.02 & 5.04 & 5.05 & 5.00 & 5.05 & 5.13 & 5.17 & 5.01 & 4.96 & 5.00 & 5.03 \\
\hline 2 & 4.96 & 5.03 & 5.02 & 5.03 & 5.01 & 5.02 & 5.08 & 5.05 & 4.99 & 4.97 & 5.00 & 5.03 \\
\hline 3 & 4.95 & 5.04 & 5.01 & 5.04 & 5.00 & 5.01 & 5.03 & 4.97 & 4.98 & 4.97 & 5.00 & 5.02 \\
\hline 4 & 4.95 & 5.05 & 5.01 & 5.06 & 5.00 & 5.00 & 5.03 & 5.00 & 4.97 & 4.99 & 5.00 & 5.00 \\
\hline 5 & 4.94 & 5.05 & 5.00 & 5.05 & 5.00 & 5.01 & 5.00 & 5.03 & 4.97 & 4.99 & 5.01 & 4.99 \\
\hline 6 & 4.95 & 5.06 & 5.01 & 5.03 & 5.00 & 5.02 & 4.98 & 5.04 & 4.97 & 5.00 & 5.00 & 4.98 \\
\hline 7 & 4.96 & 5.06 & 5.02 & 5.01 & 5.01 & 5.05 & 4.97 & 5.05 & 4.98 & 5.00 & 5.02 & 4.98 \\
\hline 8 & 5.02 & 5.05 & 5.03 & 4.98 & 5.08 & 5.15 & 4.96 & 5.02 & 5.10 & 5.00 & 5.09 & 4.99 \\
\hline 9 & 5.02 & 5.03 & 5.09 & 5.01 & 5.07 & 5.22 & 4.97 & 5.01 & 5.13 & 5.01 & 5.11 & 4.99 \\
\hline 10 & 5.02 & 5.01 & 5.10 & 5.05 & 5.08 & 5.21 & 4.97 & 4.98 & 5.03 & e5.01 & 5.06 & 4.99 \\
\hline 11 & 5.01 & 5.00 & 5.07 & 5.04 & 5.12 & 5.15 & 4.97 & 4.99 & 4.96 & 5.04 & 4.99 & 4.99 \\
\hline 12 & 5.01 & 5.03 & 5.05 & 5.02 & 5.12 & 5.04 & 4.97 & 5.00 & 4.96 & 5.03 & 4.99 & 4.99 \\
\hline 13 & 5.02 & 5.02 & 5.05 & 5.01 & 5.05 & 5.01 & 4.97 & 5.02 & 5.00 & 5.01 & 4.99 & 4.99 \\
\hline 14 & 5.03 & 5.05 & 5.06 & 4.99 & 5.00 & 4.99 & 5.00 & 5.09 & 5.00 & 4.98 & 4.99 & 5.00 \\
\hline 15 & 5.04 & 5.04 & 5.12 & 4.98 & 5.01 & 5.01 & 5.01 & 5.05 & 5.00 & 5.01 & 4.99 & 5.00 \\
\hline 16 & 5.05 & 5.02 & 5.13 & 4.96 & 5.01 & 5.02 & 5.01 & 4.97 & 4.98 & 5.00 & 4.99 & 4.98 \\
\hline 17 & 5.04 & 5.00 & 5.12 & 4.95 & 5.02 & 5.03 & 5.02 & 4.93 & 4.96 & 4.99 & 5.01 & 4.97 \\
\hline 18 & 5.03 & 4.98 & 5.08 & 4.95 & 5.04 & 5.03 & 5.02 & 4.94 & 4.95 & 4.99 & 5.02 & 4.97 \\
\hline 19 & 5.01 & 4.98 & 5.10 & 4.96 & 5.04 & 5.02 & 5.04 & 4.95 & 5.13 & 4.98 & 5.01 & 4.97 \\
\hline 20 & 5.01 & 4.96 & 5.08 & 4.97 & 5.04 & $\mathrm{e} 4.99$ & 5.13 & 4.97 & 5.40 & 4.98 & 5.02 & 4.98 \\
\hline 21 & 5.00 & 4.97 & 5.05 & 4.98 & 5.05 & e4.99 & 5.15 & 4.98 & 5.39 & 4.98 & 5.02 & 5.01 \\
\hline 22 & 4.98 & 4.97 & 5.02 & 4.98 & 5.06 & $\mathrm{e} 5.00$ & 5.13 & 4.99 & 5.28 & 5.04 & 5.01 & 5.02 \\
\hline 23 & 4.97 & 4.98 & 5.01 & 4.98 & 5.05 & e5.00 & 5.08 & 5.00 & 5.18 & 5.19 & 5.00 & 5.01 \\
\hline 24 & 5.03 & 5.00 & 5.02 & 4.99 & 5.05 & 5.05 & 5.02 & 5.00 & 5.10 & 5.17 & 5.01 & 4.97 \\
\hline 25 & 5.06 & 5.00 & 5.01 & 4.99 & 5.04 & 5.24 & 4.98 & 4.99 & 5.04 & $\begin{array}{l}5.08 \\
\end{array}$ & 5.01 & 4.96 \\
\hline 26 & 5.05 & 5.00 & 5.00 & 4.99 & 5.05 & 5.20 & 5.17 & 5.00 & 5.00 & 5.01 & 5.05 & 4.98 \\
\hline 27 & 5.02 & 5.01 & 5.08 & 4.99 & 5.18 & 5.08 & 5.58 & 5.09 & 4.99 & 5.01 & 5.10 & 4.98 \\
\hline 28 & 5.01 & 5.00 & 5.45 & 5.00 & 5.13 & 4.98 & 5.51 & 5.09 & 4.98 & 4.99 & 5.12 & 4.96 \\
\hline 29 & 5.00 & 5.01 & 5.47 & 5.00 & --- & 5.03 & 5.37 & 5.05 & 4.96 & 4.97 & 5.09 & 4.93 \\
\hline 30 & 5.01 & 5.01 & 5.34 & 5.00 & --- & 5.06 & 5.26 & 5.02 & 4.96 & 4.98 & 5.04 & 4.92 \\
\hline 31 & 5.01 & --- & 5.19 & 5.00 & --- & 5.09 & --- & 4.99 & --- & 5.00 & 5.03 & --- \\
\hline Mean & 5.00 & 5.01 & 5.09 & 5.00 & 5.05 & 5.06 & 5.08 & 5.01 & 5.04 & 5.01 & 5.02 & 4.99 \\
\hline Max & 5.06 & 5.06 & 5.47 & 5.06 & 5.18 & 5.24 & 5.58 & 5.17 & 5.40 & 5.19 & 5.12 & 5.03 \\
\hline Min & 4.94 & 4.96 & 5.00 & 4.95 & 5.00 & 4.98 & 4.96 & 4.93 & 4.95 & 4.96 & 4.99 & 4.92 \\
\hline
\end{tabular}




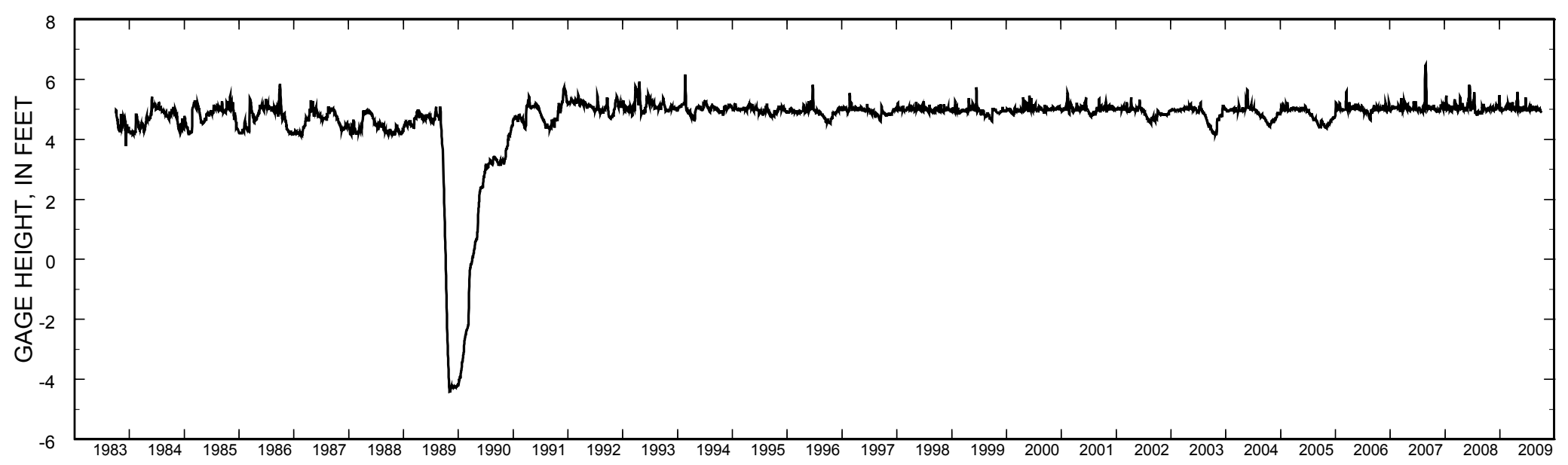

Stage hydrograph for Delavan Lake, 1983 - 2009. 
LOCATION.--Lat 42³5'56", long 88³6'50", in SE 1/4 SW 1/4 sec.28, T.2 N., R.16 E., Walworth County, Hydrologic Unit 07090001, 2.6 mi southeast of Delavan.

SURFACE AREA.--3.24 $\mathrm{mi}^{2}$.

DRAINAGE AREA.--41.4 $\mathrm{mi}^{2}$, of which $2.3 \mathrm{mi}^{2}$ is non-contributing

PERIOD OF RECORD.--October 1983 to current year.

REMARKS.--Lake ice-covered during February measurements. Water-quality analyses done by the U.S. Geological Survey National Water Quality Laboratory. Samples for determination of chlorophyll a concentration are collected from the top $0.5 \mathrm{~m}$ of the lake and analyzed by the Wisconsin State Laboratory of Hygiene. A "*" indicates data collected by the Delavan Lake Sanitary District.

\section{WATER-QUALITY DATA, OCTOBER 3, 2008 TO NOVEMBER 18, 2009}

(Milligrams per liter unless otherwise indicated)

\begin{tabular}{|c|c|c|c|c|c|c|c|c|c|}
\hline Parameter Code & Parameter Name & $\underline{\text { Oct. } 3^{*}}$ & Oct. $10^{*}$ & Oct. $13^{*}$ & Oct. $30^{*}$ & Nov. $5^{*}$ & Nov. $11^{*}$ & \multicolumn{2}{|c|}{ Nov. 18} \\
\hline 32210 & Chlorophyll a, phytoplankton ( $\mu \mathrm{g} / \mathrm{L})$ & - & - & - & - & - & - & \multicolumn{2}{|c|}{2.53} \\
\hline 00078 & Secchi-depth (m) & 1.2 & 1.5 & 1.5 & 1.8 & 3.0 & 3.7 & \multicolumn{2}{|c|}{4.3} \\
\hline 00098 & Sampling depth (m) & 0.5 & 0.5 & 0.5 & 0.5 & 0.5 & 0.5 & 0.5 & 16.0 \\
\hline 00010 & Water Temperature $\left({ }^{\circ} \mathrm{C}\right)$ & 18.0 & 16.0 & 17.0 & 11.0 & 11.0 & 9.5 & 8.0 & 7.7 \\
\hline 00400 & $\mathrm{pH}$ (standard units) & -- & -- & -- & -- & -- & -- & 7.7 & 7.7 \\
\hline 00095 & Specific conductance $(\mu \mathrm{S} / \mathrm{cm})$ & -- & -- & -- & -- & -- & -- & 536 & 536 \\
\hline 00300 & Dissolved oxygen & -- & -- & -- & -- & -- & -- & 9.8 & 9.6 \\
\hline 00665 & Phosphorus, Total (as P) & 0.262 & 0.100 & 0.091 & 0.084 & 0.074 & 0.080 & 0.079 & 0.079 \\
\hline 00671 & Orthophosphate, dissolved (as P) & -- & -- & -- & -- & -- & -- & $<.008$ & 0.023 \\
\hline 00600 & Total nitrogen & -- & -- & -- & -- & -- & -- & 0.88 & -- \\
\hline 00631 & Nitrate + nitrite, dissolved (as N) & -- & -- & -- & -- & -- & -- & 0.158 & -- \\
\hline 00608 & Ammonia, dissolved (as N) & -- & -- & -- & -- & -- & -- & E.018 & -- \\
\hline 00625 & Ammonia + organic nitrogen, total (as N) & -- & -- & -- & -- & -- & -- & 0.72 & -- \\
\hline
\end{tabular}




\section{DELAVAN LAKE AT CENTER NEAR DELAVAN LAKE, W}

WATER-QUALITY DATA, NOVEMBER 26, 2008 TO APRIL 8, 2009

(Milligrams per liter unless otherwise indicated)

\begin{tabular}{|c|c|c|c|c|c|c|c|c|c|}
\hline Parameter Code & Parameter Name & Nov. $26^{*}$ & \multicolumn{2}{|c|}{ Feb. 23} & Mar. $20^{*}$ & Mar. $26^{*}$ & Apr. $2^{*}$ & \multicolumn{2}{|c|}{ Apr. 8} \\
\hline 32210 & Chlorophyll a, phytoplankton ( $\mu \mathrm{g} / \mathrm{L})$ & -- & \multicolumn{2}{|c|}{$\overline{1.31}$} & -- & -- & -- & \multicolumn{2}{|c|}{13.2} \\
\hline 00078 & Secchi-depth (m) & 5.8 & \multicolumn{2}{|c|}{9.9} & 1.2 & 1.1 & 1.1 & \multicolumn{2}{|c|}{3.1} \\
\hline 00098 & Sampling depth (m) & 0.5 & 0.5 & 16.0 & 0.5 & 0.5 & 0.5 & 0.5 & 16.0 \\
\hline 00010 & Water Temperature $\left({ }^{\circ} \mathrm{C}\right)$ & 5.0 & 1.7 & 4.7 & 5.0 & 6.0 & 6.0 & 6.0 & 5.7 \\
\hline 00400 & $\mathrm{pH}$ (standard units) & -- & 7.7 & 7.3 & -- & -- & -- & 8.7 & 8.7 \\
\hline 00095 & Specific conductance $(\mu \mathrm{S} / \mathrm{cm})$ & -- & 485 & 840 & -- & -- & -- & 544 & 544 \\
\hline 00300 & Dissolved oxygen & -- & 18.0 & 0.8 & -- & -- & -- & 14.2 & 13.9 \\
\hline 00665 & Phosphorus, Total (as P) & 0.078 & 0.090 & 0.214 & 0.081 & 0.080 & 0.070 & 0.029 & 0.034 \\
\hline 00671 & Orthophosphate, dissolved (as P) & -- & 0.056 & 0.179 & -- & -- & -- & E.004 & E.005 \\
\hline 00600 & Total nitrogen & -- & 1 & -- & -- & -- & -- & 0.94 & 1 \\
\hline 00631 & Nitrate + nitrite, dissolved (as N) & -- & 0.331 & -- & -- & -- & -- & 0.413 & 0.381 \\
\hline 00608 & Ammonia, dissolved (as $\mathrm{N}$ ) & -- & 0.177 & -- & -- & -- & -- & E.017 & 0.047 \\
\hline 00625 & Ammonia + organic nitrogen, total (as N) & -- & 0.72 & -- & -- & -- & -- & 0.52 & 0.63 \\
\hline 00900 & Hardness (as CaCO3) & -- & -- & -- & -- & -- & -- & 220 & 230 \\
\hline 00410 & Acid neutralizing capacity (as $\mathrm{CaCO} 3$ ) & -- & -- & -- & -- & -- & -- & 192 & 192 \\
\hline 00915 & Calcium, dissolved (Ca) & -- & -- & -- & -- & -- & -- & 42.2 & 43 \\
\hline 00925 & Magnesium, dissolved (Mg) & -- & -- & -- & -- & -- & -- & 28.2 & 29.4 \\
\hline 00930 & Sodium, dissolved $(\mathrm{Na})$ & -- & -- & -- & -- & -- & -- & 28.2 & 27.2 \\
\hline 00935 & Potassium, dissolved (K) & -- & -- & -- & -- & -- & -- & 2.75 & 2.82 \\
\hline 00940 & Chloride, dissolved $(\mathrm{Cl})$ & -- & -- & -- & -- & -- & -- & 54.1 & 55 \\
\hline 00950 & Fluoride, dissolved $(\mathrm{F})$ & -- & -- & -- & -- & -- & -- & 0.19 & 0.19 \\
\hline 00945 & Sulfate, dissolved (SO4) & -- & -- & -- & -- & -- & -- & 19.9 & 19.9 \\
\hline 00955 & Silica, dissolved (SiO2) & -- & -- & -- & -- & -- & -- & $<.2$ & $<.2$ \\
\hline 01046 & Iron $(\mu \mathrm{g} / \mathrm{L})$ & -- & -- & -- & -- & -- & -- & $<4$ & $<4$ \\
\hline 01056 & Manganese ( $\mu \mathrm{g} / \mathrm{L})$ & -- & -- & -- & -- & -- & -- & 2.2 & 6.7 \\
\hline 00080 & Apparent color (PCU) & -- & -- & -- & -- & -- & -- & 12 & 15 \\
\hline 63676 & Turbidity (NTU) & -- & -- & -- & -- & -- & -- & E3.5 & E2.9 \\
\hline 70300 & Solids, dissolved (at $180 \mathrm{C}^{\circ}$ ) & -- & -- & -- & -- & -- & -- & 317 & 317 \\
\hline
\end{tabular}




\section{DELAVAN LAKE AT CENTER NEAR DELAVAN LAKE, WI}

WATER-QUALITY DATA, APRIL 16 TO JUNE 11, 2009

(Milligrams per liter unless otherwise indicated)

\begin{tabular}{|c|c|c|c|c|c|c|c|c|c|}
\hline Parameter Code & Parameter Name & Apr. $16^{*}$ & Apr. $23^{*}$ & Apr. 29* & May $7^{*}$ & \multicolumn{4}{|c|}{ May 12} \\
\hline 32210 & Chlorophyll a, phytoplankton ( $\mu \mathrm{g} / \mathrm{L})$ & -- & -- & -- & -- & \multicolumn{4}{|c|}{9.04} \\
\hline 00078 & Secchi-depth (m) & 3.0 & 3.4 & 2.7 & 4.0 & \multicolumn{4}{|c|}{4.4} \\
\hline 00098 & Sampling depth (m) & 0.5 & 0.5 & 0.5 & 0.5 & 0.5 & 9.0 & 11.0 & 16.0 \\
\hline 00010 & Water Temperature $\left({ }^{\circ} \mathrm{C}\right)$ & 8.0 & 8.0 & 10.0 & 12.5 & 13.9 & 12.3 & 11.2 & 10.4 \\
\hline 00400 & $\mathrm{pH}$ (standard units) & -- & -- & -- & -- & 8.4 & 8.2 & 8.1 & 7.8 \\
\hline 00095 & Specific conductance $(\mu \mathrm{S} / \mathrm{cm})$ & -- & -- & -- & -- & 544 & 544 & 546 & 550 \\
\hline 00300 & Dissolved oxygen & -- & -- & -- & -- & 11.1 & 8.9 & 7.0 & 4.0 \\
\hline 00665 & Phosphorus, Total (as P) & 0.025 & 0.025 & 0.036 & 0.044 & 0.034 & 0.037 & 0.051 & 0.085 \\
\hline 00671 & Orthophosphate, dissolved (as P) & -- & -- & -- & -- & $<.008$ & $<.008$ & E.005 & 0.035 \\
\hline 00600 & Total nitrogen & -- & -- & -- & -- & 0.97 & -- & -- & -- \\
\hline 00631 & Nitrate + nitrite, dissolved (as N) & -- & -- & -- & -- & 0.382 & -- & -- & -- \\
\hline 00608 & Ammonia, dissolved (as N) & -- & -- & -- & -- & E.012 & -- & -- & -- \\
\hline 00625 & Ammonia + organic nitrogen, total (as N) & -- & -- & -- & -- & 0.59 & -- & -- & -- \\
\hline Parameter Code & Parameter Name & May $22^{*}$ & May $28^{*}$ & June $3^{*}$ & June $11^{*}$ & \multicolumn{4}{|c|}{ June 11} \\
\hline 32210 & Chlorophyll a, phytoplankton ( $\mu \mathrm{g} / \mathrm{L})$ & -- & -- & -- & -- & \multicolumn{4}{|c|}{4.16} \\
\hline 00078 & Secchi-depth $(m)$ & 1.5 & 1.8 & 2.7 & 2.7 & \multicolumn{4}{|c|}{3.8} \\
\hline 00098 & Sampling depth (m) & 0.5 & 0.5 & 0.5 & 0.5 & 0.5 & 8.0 & 12.0 & 16.0 \\
\hline 00010 & Water Temperature $\left({ }^{\circ} \mathrm{C}\right)$ & 16.0 & 17.0 & 16.0 & 18.0 & 18.4 & 17.4 & 15.2 & 13.2 \\
\hline 00400 & $\mathrm{pH}$ (standard units) & -- & -- & -- & -- & 8.4 & 8.3 & 7.8 & 7.4 \\
\hline 00095 & Specific conductance $(\mu \mathrm{S} / \mathrm{cm})$ & -- & -- & -- & -- & 553 & 555 & 564 & 578 \\
\hline 00300 & Dissolved oxygen & -- & -- & -- & -- & -- & -- & -- & -- \\
\hline 00665 & Phosphorus, Total (as P) & 0.042 & 0.044 & 0.040 & 0.041 & 0.039 & 0.038 & 0.079 & 0.293 \\
\hline 00671 & Orthophosphate, dissolved (as P) & -- & -- & -- & -- & $<.008$ & $<.008$ & 0.041 & 0.182 \\
\hline 00600 & Total nitrogen & -- & -- & -- & -- & 0.72 & -- & -- & -- \\
\hline 00631 & Nitrate + nitrite, dissolved (as N) & -- & -- & -- & -- & 0.102 & -- & -- & -- \\
\hline 00608 & Ammonia, dissolved (as N) & -- & -- & -- & -- & $<.020$ & -- & -- & -- \\
\hline 00625 & Ammonia + organic nitrogen, total (as $\mathrm{N}$ ) & -- & -- & -- & -- & 0.61 & -- & -- & -- \\
\hline
\end{tabular}


423556088365001 DELAVAN LAKE AT CENTER NEAR DELAVAN LAKE, WI

WATER-QUALITY DATA, JUNE 18 TO AUGUST 11, 2009

(Milligrams per liter unless otherwise indicated)

\begin{tabular}{|c|c|c|c|c|c|c|c|c|c|c|}
\hline Parameter Code & Parameter Name & June $18^{*}$ & June $24^{*}$ & $\underline{\text { July } 1^{*}}$ & $\underline{\text { July } 8^{*}}$ & July $16^{*}$ & \multicolumn{4}{|c|}{$\underline{\text { July } 16}$} \\
\hline 32210 & 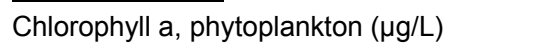 & - & -- & $\overline{--}$ & $\overline{--}$ & - & \multicolumn{4}{|c|}{$\overline{25}$} \\
\hline 00078 & Secchi-depth (m) & 2.7 & 3.0 & 3.7 & 2.1 & 2.1 & \multicolumn{4}{|c|}{1.5} \\
\hline 00098 & Sampling depth (m) & 0.5 & 0.5 & 0.5 & 0.5 & 0.5 & 0.5 & 7.0 & 12.0 & 15.5 \\
\hline 00010 & Water Temperature $\left({ }^{\circ} \mathrm{C}\right)$ & 20.0 & 26.0 & 22.0 & 23.0 & 22.0 & 23.3 & 22.3 & 14.9 & 14.2 \\
\hline 00400 & $\mathrm{pH}$ (standard units) & -- & -- & -- & -- & -- & 8.5 & 8.2 & 7.4 & 7.4 \\
\hline 00095 & Specific conductance $(\mu \mathrm{S} / \mathrm{cm})$ & -- & -- & -- & -- & -- & 535 & 543 & 571 & 580 \\
\hline 00300 & Dissolved oxygen & -- & -- & -- & -- & -- & 10.8 & 7.5 & 0.0 & 0.0 \\
\hline 00665 & Phosphorus, Total (as P) & 0.047 & 0.030 & 0.042 & 0.040 & 0.036 & 0.044 & 0.036 & 0.270 & 0.389 \\
\hline 00671 & Orthophosphate, dissolved (as P) & -- & -- & -- & -- & -- & E.004 & E.004 & 0.152 & 0.266 \\
\hline 00600 & Total nitrogen & -- & -- & -- & -- & -- & -- & -- & -- & -- \\
\hline 00631 & Nitrate + nitrite, dissolved (as N) & -- & -- & -- & -- & -- & $<.016$ & -- & -- & -- \\
\hline 00608 & Ammonia, dissolved (as $\mathrm{N}$ ) & -- & -- & -- & -- & -- & 0.075 & -- & -- & -- \\
\hline 00625 & Ammonia + organic nitrogen, total (as $\mathrm{N}$ ) & -- & -- & -- & -- & -- & 0.76 & -- & -- & -- \\
\hline Parameter Code & \multicolumn{3}{|l|}{ Parameter Name } & July $21^{*}$ & \multicolumn{2}{|r|}{$\underline{\text { July } 27^{*}}$} & \multicolumn{2}{|l|}{ Aug. $4^{*}$} & \multicolumn{2}{|r|}{ Aug. $11^{*}$} \\
\hline 32210 & \multicolumn{2}{|l|}{ Chlorophyll a, phytoplankton ( $\mu \mathrm{g} / \mathrm{L})$} & & -- & \multicolumn{2}{|r|}{--} & \multicolumn{2}{|l|}{--} & \multicolumn{2}{|r|}{--} \\
\hline 00078 & \multirow{2}{*}{\multicolumn{2}{|c|}{$\begin{array}{l}\text { Secchi-depth }(\mathrm{m}) \\
\text { Sampling depth }(\mathrm{m})\end{array}$}} & & 1.5 & \multicolumn{2}{|r|}{1.2} & \multicolumn{2}{|l|}{1.2} & \multicolumn{2}{|r|}{1.4} \\
\hline 00098 & & & & 0.5 & \multicolumn{2}{|r|}{0.5} & \multicolumn{2}{|l|}{0.5} & \multicolumn{2}{|r|}{0.5} \\
\hline 00010 & \multicolumn{2}{|l|}{ Water Temperature $\left({ }^{\circ} \mathrm{C}\right)$} & & 22.0 & \multicolumn{2}{|r|}{23.0} & \multicolumn{2}{|l|}{23.0} & \multicolumn{2}{|r|}{22.0} \\
\hline 00400 & \multicolumn{2}{|l|}{ pH (standard units) } & & -- & \multicolumn{2}{|r|}{--} & \multicolumn{2}{|l|}{--} & \multicolumn{2}{|r|}{--} \\
\hline 00095 & \multicolumn{2}{|l|}{ Specific conductance $(\mu \mathrm{S} / \mathrm{cm})$} & & -- & \multicolumn{2}{|r|}{--} & \multicolumn{2}{|l|}{--} & \multicolumn{2}{|r|}{-- } \\
\hline 00300 & \multicolumn{2}{|l|}{ Dissolved oxygen } & & -- & & -- & -- & & & -- \\
\hline 00665 & Phosphorus, Total (as P) & & & 0.046 & & 0.038 & 0.033 & & & 0.032 \\
\hline
\end{tabular}




\section{DELAVAN LAKE AT CENTER NEAR DELAVAN LAKE, W}

\section{WATER-QUALITY DATA, AUGUST 11 TO SEPTEMBER 21, 2009}

(Milligrams per liter unless otherwise indicated)

\begin{tabular}{|c|c|c|c|c|c|c|c|c|c|c|c|}
\hline$\underline{\text { Parameter Code }}$ & $\underline{\text { Parameter Name }}$ & \multicolumn{8}{|c|}{ Aug. 11} & Aug. $19^{*}$ & Aug. $25^{*}$ \\
\hline 32210 & Chlorophyll a, phytoplankton ( $\mu \mathrm{g} / \mathrm{L})$ & \multicolumn{8}{|c|}{16} & -- & -- \\
\hline 00078 & Secchi-depth (m) & \multicolumn{8}{|c|}{1.5} & 1.5 & 1.4 \\
\hline 00098 & Sampling depth (m) & 0.5 & 9.0 & 10.0 & 12.0 & 13.0 & 14.0 & 15.0 & 16.0 & 0.5 & 0.5 \\
\hline 00010 & Water Temperature $\left({ }^{\circ} \mathrm{C}\right)$ & 24.0 & 22.0 & 20.1 & 16.1 & 15.1 & 14.7 & 14.6 & 14.4 & 23.0 & 22.0 \\
\hline 00400 & $\mathrm{pH}$ (standard units) & 8.6 & 8.0 & 7.7 & 7.5 & 7.4 & 7.3 & 7.3 & 7.3 & -- & -- \\
\hline 00095 & Specific conductance $(\mu \mathrm{S} / \mathrm{cm})$ & 512 & 525 & 535 & 564 & 572 & 578 & 580 & 582 & -- & -- \\
\hline 00300 & Dissolved oxygen & 10.7 & 4.7 & 0.5 & 0.1 & 0.1 & 0.1 & 0.1 & 0.1 & -- & -- \\
\hline 00665 & Phosphorus, Total (as P) & 0.042 & 0.038 & 0.092 & 0.256 & 0.337 & 0.399 & 0.421 & 0.421 & 0.033 & 0.042 \\
\hline 00671 & Orthophosphate, dissolved (as P) & $<.008$ & $<.008$ & -- & -- & 0.196 & -- & -- & 0.33 & -- & -- \\
\hline 00600 & Total nitrogen & E.69 & -- & -- & -- & -- & -- & -- & -- & -- & -- \\
\hline 00631 & Nitrate + nitrite, dissolved (as N) & E.009 & -- & -- & -- & -- & -- & -- & -- & -- & -- \\
\hline 00608 & Ammonia, dissolved (as $\mathrm{N}$ ) & 0.08 & -- & -- & -- & -- & -- & -- & -- & -- & -- \\
\hline 00625 & Ammonia + organic nitrogen, total (as N) & 0.68 & -- & -- & -- & -- & -- & -- & -- & -- & -- \\
\hline$\underline{\text { Parameter Code }}$ & $\underline{\text { Parameter Name }}$ & $\underline{\text { Sept. } 1^{*}}$ & $\underline{\text { Sept. } 8^{*}}$ & & $\underline{\text { Sept. } 15^{*}}$ & \multicolumn{5}{|c|}{ Sept. 15} & Sept. $21^{*}$ \\
\hline 32210 & Chlorophyll a, phytoplankton $(\mu \mathrm{g} / \mathrm{L})$ & -- & -- & & -- & \multicolumn{5}{|c|}{10.8} & -- \\
\hline 00078 & Secchi-depth (m) & 1.8 & 1.8 & & 2.1 & \multicolumn{5}{|c|}{1.8} & 2.4 \\
\hline 00098 & Sampling depth (m) & 0.5 & 0.5 & & 0.5 & 0.5 & 10.0 & 13.0 & 15.0 & 16.0 & 0.5 \\
\hline 00010 & Water Temperature $\left({ }^{\circ} \mathrm{C}\right)$ & 21.0 & 21.0 & & 22.0 & 23.2 & 19.9 & 16.3 & 14.5 & 14.2 & 19.5 \\
\hline 00400 & $\mathrm{pH}$ (standard units) & -- & -- & & -- & 8.7 & 7.5 & 6.8 & 6.5 & 6.3 & -- \\
\hline 00095 & Specific conductance $(\mu \mathrm{S} / \mathrm{cm})$ & -- & -- & & -- & 519 & 549 & 602 & 626 & 648 & -- \\
\hline 00300 & Dissolved oxygen & -- & -- & & -- & 9.6 & 0.1 & 0.0 & 0.0 & 0.0 & -- \\
\hline 00665 & Phosphorus, Total (as P) & 0.053 & 0.042 & & 0.041 & 0.035 & 0.065 & 0.386 & 0.601 & 0.801 & 0.035 \\
\hline 00671 & Orthophosphate, dissolved (as P) & -- & -- & & -- & $<.008$ & $<.008$ & 0.301 & -- & 0.727 & -- \\
\hline 00600 & Total nitrogen & -- & -- & & -- & -- & -- & -- & -- & -- & -- \\
\hline 00631 & Nitrate + nitrite, dissolved (as $\mathrm{N}$ ) & -- & -- & & -- & $<.016$ & -- & -- & -- & -- & -- \\
\hline 00608 & Ammonia, dissolved (as N) & -- & -- & & -- & 0.029 & -- & -- & -- & -- & -- \\
\hline 00625 & Ammonia + organic nitrogen, total (as $\mathrm{N}$ ) & -- & -- & & -- & 0.62 & -- & -- & -- & -- & -- \\
\hline
\end{tabular}


423556088365001 DELAVAN LAKE AT CENTER NEAR DELAVAN LAKE, WI

LAKE-DEPTH PROFILES, NOVEMBER 18, 2008 TO MAY 12, 2009

$11-18-08$
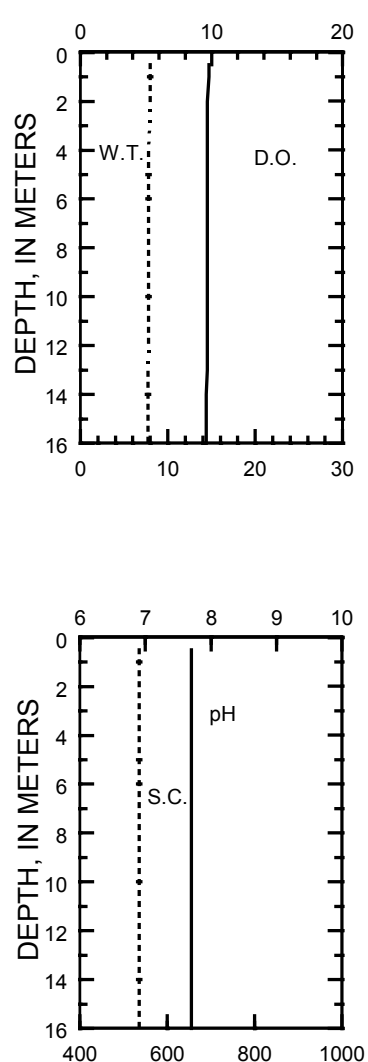

02-23-09

04-08-09

DISSOLVED OXYGEN (D.O.), IN MILLIGRAMS PER LITER
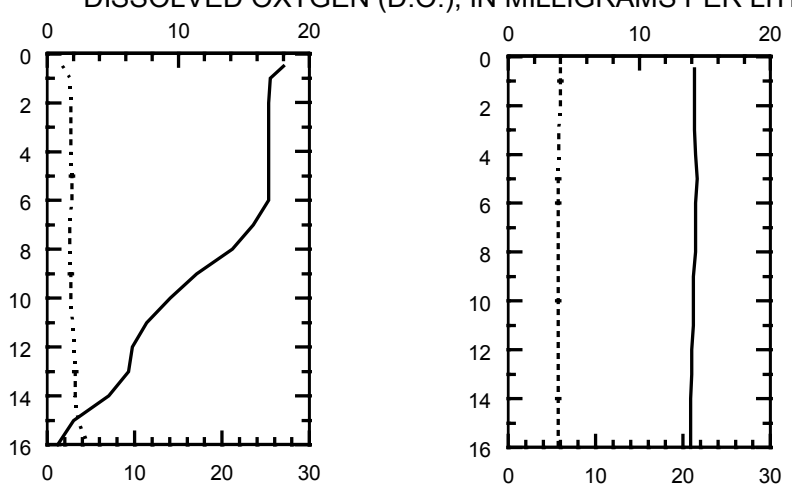

WATER TEMPERATURE (W.T.), IN DEGREES CELSIUS

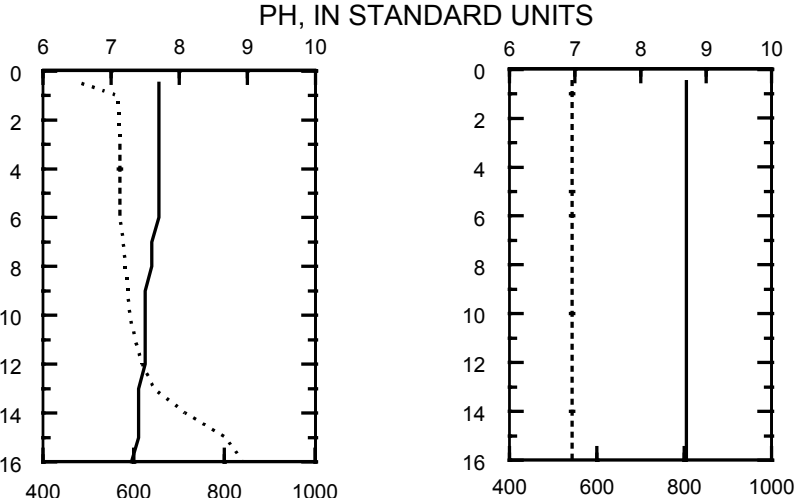

05-12-09
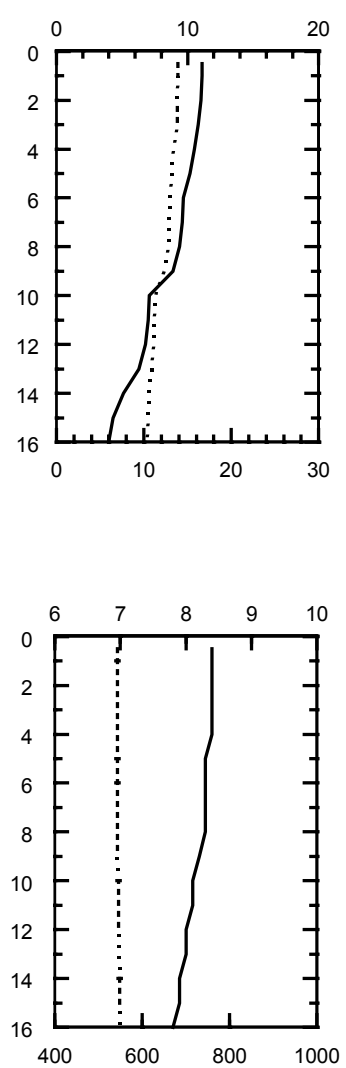

SPECIFIC CONDUCTANCE (S.C.), IN MICROSIEMENS PER CENTIMETER AT 25 DEGREES CELSIUS 
423556088365001 DELAVAN LAKE AT CENTER NEAR DELAVAN LAKE, WI

LAKE-DEPTH PROFILES, JUNE 11 TO SEPTEMBER 15, 2009

06-11-09
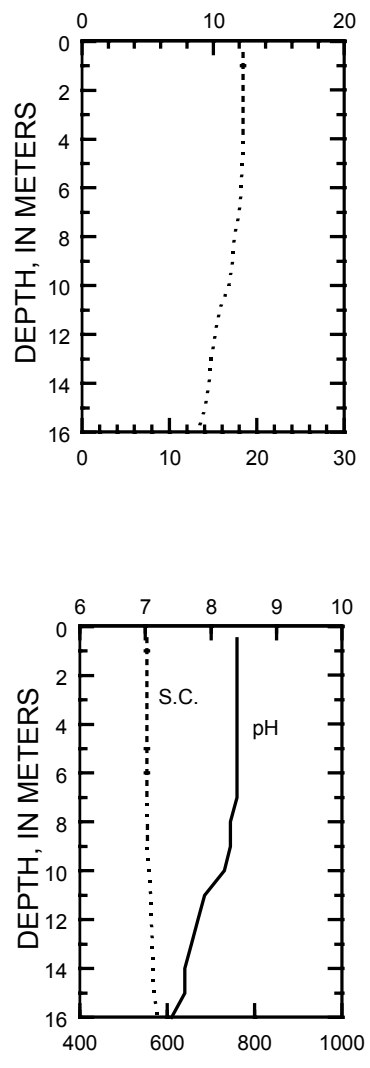

07-16-09

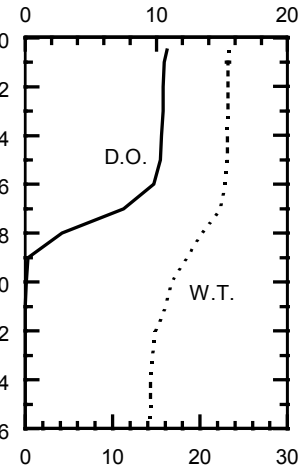

WATER TEMPERATURE (W.T.), IN DEGREES CELSIUS

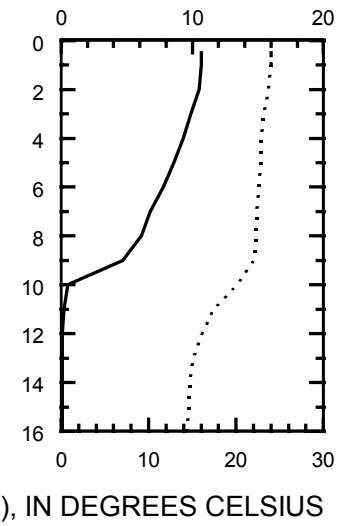

PH, IN STANDARD UNITS
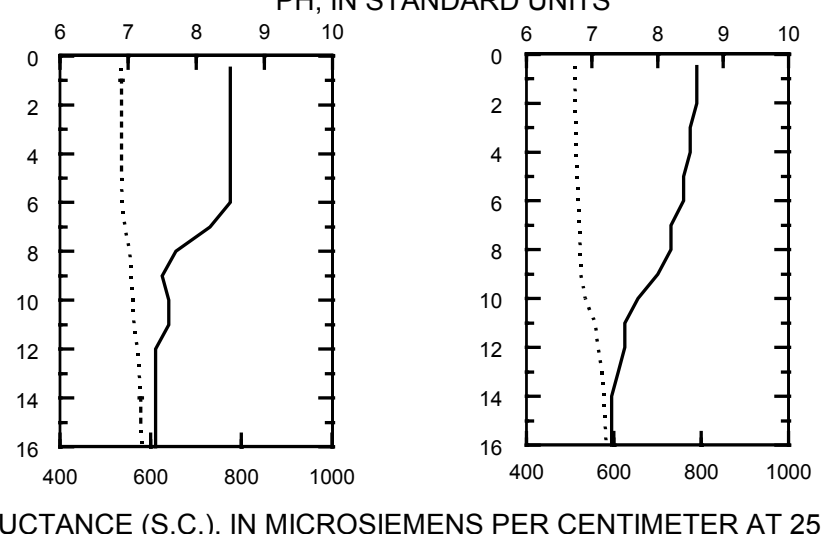

09-15-09
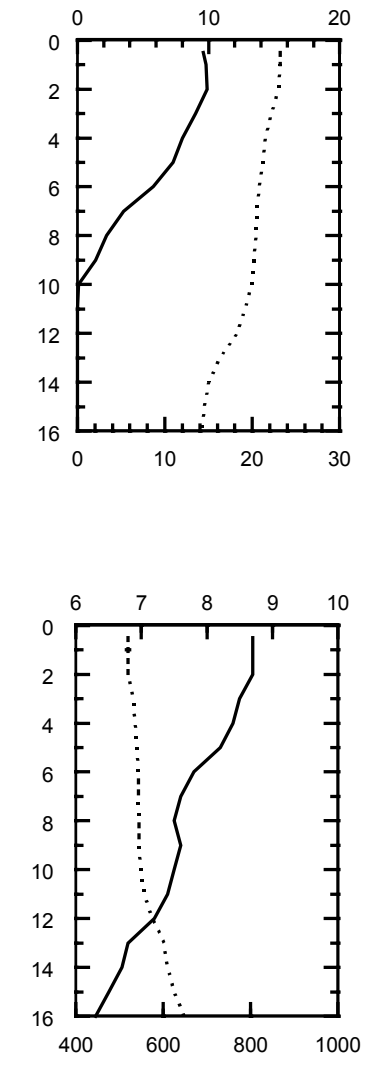

SPECIFIC CONDUCTANCE (S.C.), IN MICROSIEMENS PER CENTIMETER AT 25 DEGREES CELSIUS 

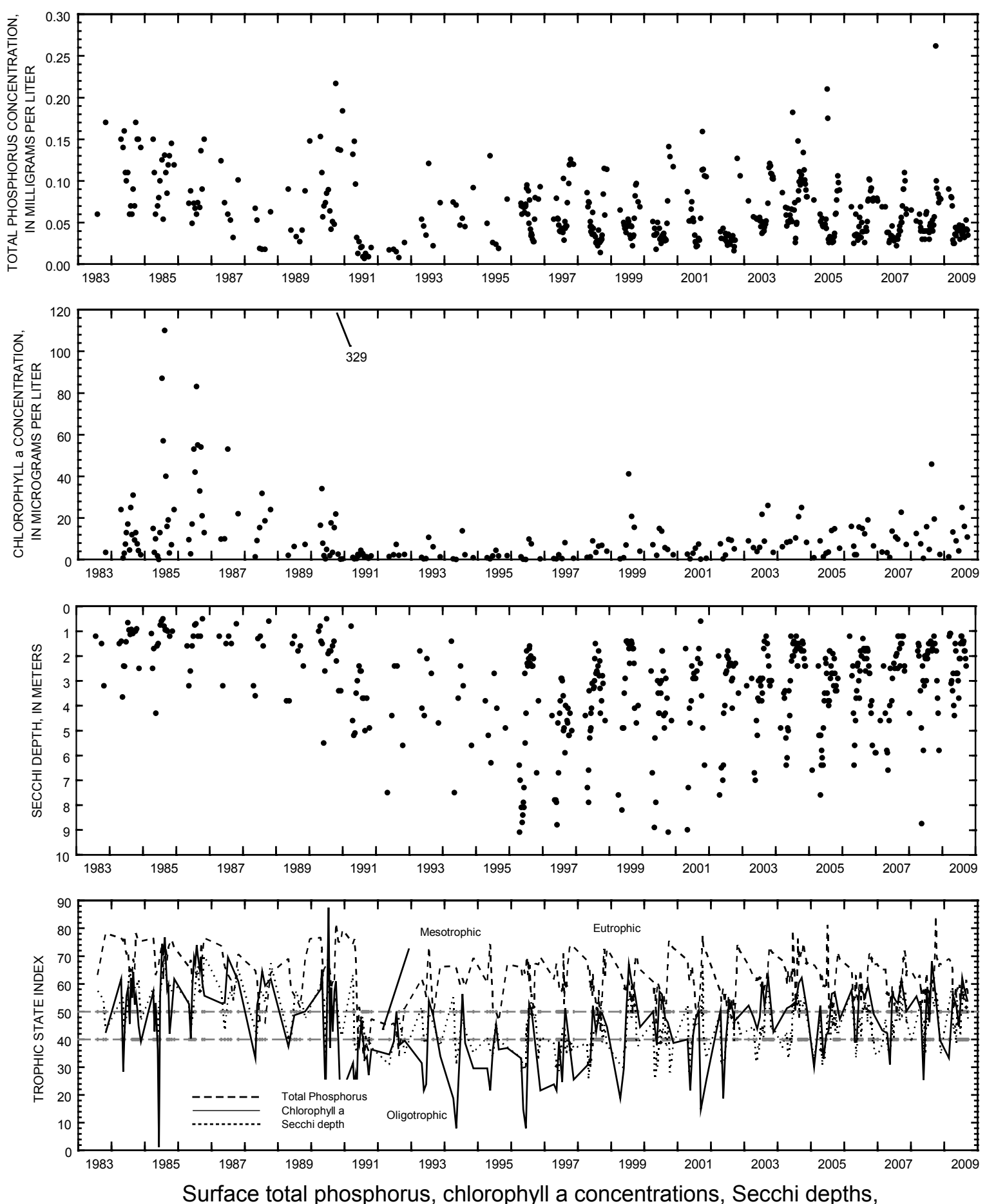
and TSI data for Delavan Lake, at Center, near Delavan, Wisconsin. 


\section{DELAVAN LAKE, AT NORTH END, NEAR LAKE LAWN, WI}

LOCATION.--Lat $42^{\circ} 36^{\prime} 59^{\prime \prime}$, long $88^{\circ} 35^{\prime} 44^{\prime \prime}$, in NW 1/4 SW 1/4 sec.22, T.2 N., R.16 E., Walworth County, Hydrologic Unit $07090001,2.6 \mathrm{mi}$ southeast of Delavan.

SURFACE AREA--3.24 $\mathrm{mi}^{2}$.

DRAINAGE AREA.--41.4 $\mathrm{mi}^{2}$, of which $2.3 \mathrm{mi}^{2}$ is non-contributing.

PERIOD OF RECORD.--October 1983 to August 2009 (discontinued).

Date

00078 Secchi-depth $(\mathrm{m})$

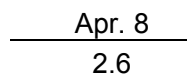

2.6

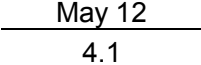

4.1
June 11

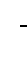

Aug. 11

\section{DELAVAN LAKE, AT SW END, NEAR DELAVAN LAKE, WI}

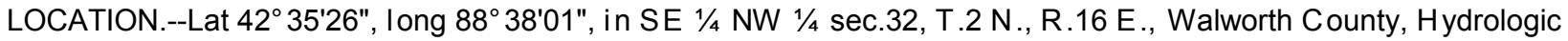
Unit 07090001, $2.6 \mathrm{mi}$ southeast of Delavan.

SURFACE AREA--3.24 $\mathrm{mi}^{2}$.

DRAINAGE AREA.--41.4 $\mathrm{mi}^{2}$, of which $2.3 \mathrm{mi}^{2}$ is non-contributing.

PERIOD OF RECORD.--October 1983 to August 2009 (discontinued).

Date

00078 Secchi-depth

(m)

\begin{tabular}{|c|c|c|c|c|}
\hline Apr. 8 & May 12 & June 11 & July 16 & Aug. 11 \\
\hline 2.7 & 5.0 & 3.5 & 1.8 & 1.8 \\
\hline
\end{tabular}




\section{DEVILS LAKE NEAR BARABOO, WI}

LOCATION.--Lat 43²5'35", long 8943'40" referenced to North American Datum of 1927, in SW 1/4 SE 1/4 sec.13, T.11 N., R.6 E., Sauk

County, WI, Hydrologic Unit 07070004, in Devils Lake State Park, 3.5 mi south of Baraboo.

SURFACE AREA.--0.56 $\mathrm{mi}^{2}$.

DRAINAGE AREA.--4.79 $\mathrm{mi}^{2}$.

PERIOD OF RECORD.--June 1922 to August 1930, June to August 1932, June 1934 to September 1981 (fragmentary). October 1981

to September 1984, data unpublished in district files. October 1984 to current year.

REVISED RECORDS.--WDR WI-78-1: Drainage area.

GAGE.--Water-stage recorder installed July 17, 1991. Datum of gage is $954.88 \mathrm{ft}$, above NAVD of 1988.

REMARKS.--Lake has no surface outlet. Water removed from lake by siphon October 1 to February 17 and September 9-30.

EXTREMES FOR PERIOD OF RECORD.--Maximum observed, 14.83 ft, June 12, 2008; minimum observed, 1.49 ft, Feb. 8, 1965.

EXTREMES FOR CURRENT YEAR.--Maximum observed, $9.77 \mathrm{ft}$, Oct. 1; minimum observed, 6.93 ft, Feb. $19,20,24$ and 26.

\begin{tabular}{|c|c|c|c|c|c|c|c|c|c|c|c|c|}
\hline \multicolumn{13}{|c|}{$\begin{array}{c}\text { GAGE HEIGHT, FEET } \\
\text { WATER YEAR OCTOBER } 2008 \text { TO SEPTEMBER } 2009 \\
\text { DAILY MEAN VALUES }\end{array}$} \\
\hline Day & Oct & Nov & Dec & Jan & Feb & Mar & Apr & May & Jun & Jul & Aug & Sep \\
\hline 1 & 9.75 & 8.84 & 8.31 & 7.90 & 7.24 & 7.00 & 8.21 & 8.60 & 8.80 & 8.61 & 8.19 & 7.99 \\
\hline 2 & 9.70 & 8.81 & 8.29 & 7.87 & 7.21 & 7.00 & 8.22 & 8.60 & 8.78 & 8.58 & 8.17 & 7.97 \\
\hline 3 & 9.67 & 8.79 & 8.26 & 7.85 & 7.19 & 7.00 & 8.22 & 8.60 & 8.76 & 8.57 & 8.14 & 7.96 \\
\hline 4 & 9.63 & 8.76 & 8.24 & 7.83 & 7.17 & 6.99 & 8.23 & 8.60 & 8.74 & 8.55 & 8.13 & 7.94 \\
\hline 5 & 9.60 & 8.74 & 8.22 & 7.81 & 7.15 & 6.99 & 8.23 & 8.60 & 8.72 & 8.54 & 8.10 & 7.93 \\
\hline 6 & 9.58 & 8.72 & 8.20 & 7.78 & 7.13 & 7.00 & 8.22 & 8.61 & 8.70 & 8.52 & 8.08 & 7.91 \\
\hline 7 & 9.56 & 8.71 & 8.18 & 7.76 & 7.12 & 7.03 & 8.21 & 8.66 & 8.68 & 8.50 & 8.08 & 7.90 \\
\hline 8 & 9.55 & 8.68 & 8.16 & 7.73 & 7.10 & 7.10 & 8.21 & 8.65 & 8.82 & 8.52 & 8.20 & 7.89 \\
\hline 9 & 9.51 & 8.65 & 8.20 & 7.72 & 7.09 & 7.16 & 8.21 & 8.75 & 8.83 & 8.50 & 8.24 & 7.87 \\
\hline 10 & 9.48 & 8.61 & 8.19 & 7.70 & 7.08 & 7.22 & 8.20 & 8.77 & 8.82 & 8.49 & 8.23 & 7.84 \\
\hline 11 & 9.45 & 8.59 & 8.16 & 7.68 & 7.07 & 7.26 & 8.19 & 8.78 & 8.80 & 8.48 & 8.22 & 7.80 \\
\hline 12 & 9.42 & 8.62 & 8.14 & 7.66 & 7.05 & 7.28 & 8.19 & 8.78 & 8.79 & 8.46 & 8.20 & 7.77 \\
\hline 13 & 9.40 & 8.62 & 8.12 & 7.65 & 7.04 & 7.29 & 8.18 & 8.81 & 8.79 & 8.44 & 8.19 & 7.74 \\
\hline 14 & 9.37 & 8.64 & 8.10 & 7.64 & 7.03 & 7.30 & 8.17 & 8.89 & 8.77 & 8.41 & 8.17 & 7.72 \\
\hline 15 & 9.35 & 8.63 & 8.09 & 7.61 & 7.01 & 7.31 & 8.16 & 8.91 & 8.75 & 8.39 & 8.15 & 7.69 \\
\hline 16 & 9.32 & 8.61 & 8.07 & 7.59 & 6.99 & 7.33 & 8.16 & 8.91 & 8.73 & 8.37 & 8.14 & 7.66 \\
\hline 17 & 9.29 & 8.59 & 8.06 & 7.57 & 6.97 & 7.39 & 8.15 & 8.91 & 8.73 & 8.34 & 8.16 & 7.63 \\
\hline 18 & 9.26 & 8.58 & 8.03 & 7.54 & 6.97 & 7.46 & 8.14 & 8.91 & 8.73 & 8.31 & 8.16 & 7.61 \\
\hline 19 & 9.23 & 8.56 & 8.08 & 7.52 & 6.95 & 7.50 & 8.14 & 8.90 & 8.81 & 8.29 & 8.14 & 7.58 \\
\hline 20 & 9.20 & 8.54 & 8.07 & 7.50 & 6.94 & 7.52 & 8.15 & 8.90 & 8.80 & 8.27 & 8.13 & 7.55 \\
\hline 21 & 9.16 & 8.52 & 8.06 & 7.48 & 6.96 & 7.54 & 8.18 & 8.88 & 8.79 & 8.27 & 8.14 & 7.53 \\
\hline 22 & 9.13 & 8.49 & 8.04 & 7.46 & 6.96 & 7.55 & 8.18 & 8.88 & 8.83 & 8.30 & 8.11 & 7.54 \\
\hline 23 & 9.10 & 8.46 & 8.02 & 7.43 & 6.96 & 7.59 & 8.18 & 8.87 & 8.83 & 8.29 & 8.09 & 7.55 \\
\hline 24 & 9.10 & 8.44 & 8.01 & 7.41 & 6.95 & 7.73 & 8.18 & 8.86 & 8.81 & 8.29 & 8.08 & 7.53 \\
\hline 25 & 9.09 & 8.42 & 7.99 & 7.39 & 6.95 & 8.00 & 8.22 & 8.84 & 8.79 & 8.27 & 8.06 & 7.51 \\
\hline 26 & 9.05 & 8.40 & 7.98 & 7.37 & 6.97 & 8.07 & 8.41 & 8.82 & 8.77 & 8.26 & 8.04 & 7.49 \\
\hline 27 & 9.02 & 8.37 & 7.97 & 7.34 & 7.01 & 8.10 & 8.52 & 8.84 & 8.75 & 8.25 & 8.03 & 7.47 \\
\hline 28 & 8.98 & 8.35 & 7.99 & 7.32 & 7.01 & 8.11 & 8.55 & 8.86 & 8.71 & 8.23 & 8.02 & 7.43 \\
\hline 29 & 8.94 & 8.33 & 7.97 & 7.30 & --- & 8.15 & 8.57 & 8.85 & 8.67 & 8.21 & 8.05 & 7.39 \\
\hline 30 & 8.91 & 8.31 & 7.95 & 7.28 & --- & 8.16 & 8.59 & 8.84 & 8.64 & 8.22 & 8.03 & 7.36 \\
\hline 31 & 8.88 & --- & 7.93 & 7.26 & --- & 8.19 & --- & 8.82 & --- & 8.21 & 8.01 & --- \\
\hline Mean & 9.31 & 8.58 & 8.10 & 7.58 & 7.05 & 7.46 & 8.25 & 8.79 & 8.76 & 8.39 & 8.13 & 7.69 \\
\hline Max & 9.75 & 8.84 & 8.31 & 7.90 & 7.24 & 8.19 & 8.59 & 8.91 & 8.83 & 8.61 & 8.24 & 7.99 \\
\hline Min & 8.88 & 8.31 & 7.93 & 7.26 & 6.94 & 6.99 & 8.14 & 8.60 & 8.64 & 8.21 & 8.01 & 7.36 \\
\hline
\end{tabular}




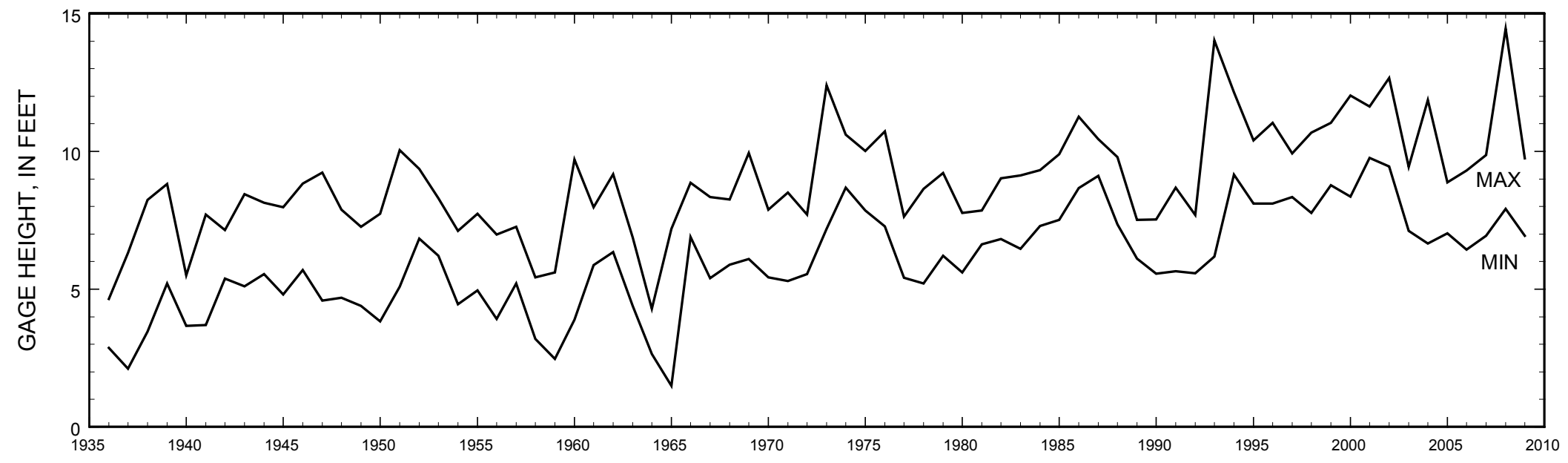

Annual minimum and maximum water levels for Devils Lake, 1936-2009. 


\section{GENEVA LAKE AT LAKE GENEVA, WI}

LOCATION.--Lat 42³5'25", long 88²6'04" referenced to North American Datum of 1927, in SE 1/4 NW 1/4 sec.36, T.2 N., R.17 E.,

Walworth County, WI, Hydrologic Unit 07120006, at Geneva Lake dam at Center Street at Lake Geneva.

SURFACE AREA.--8.22 $\mathrm{mi}^{2}$.

DRAINAGE AREA.--28.7 $\mathrm{mi}^{2}$.

PERIOD OF RECORD.--October 1997 to August 2002, December 2002 to current year.

GAGE.--Water-stage recorder. Datum of gage is $861.86 \mathrm{ft}$ above NAVD of 1988 or $862.08 \mathrm{ft}$ above NGVD of 1929. Intermittent staffgage readings during winter months.

REMARKS.--Records good except for estimated days, which are poor. Gage-height telemeter at station.

EXTREMES FOR PERIOD OF RECORD.--Maximum gage height, 3.35 ft, Aug. 20, 2007; minimum gage height, 1.44 ft, Nov. 5, 2005 (affected by wind).

EXTREMES FOR CURRENT YEAR.--Maximum gage height observed, $3.09 \mathrm{ft}$ (affected by wind), May 13; minimum gage height, 2.18 $\mathrm{ft}$ (affected by wind), Feb. 26, but may have been lower during period when the float was frozen in the well.

\begin{tabular}{|c|c|c|c|c|c|c|c|c|c|c|c|c|}
\hline \multicolumn{13}{|c|}{$\begin{array}{c}\text { GAGE HEIGHT, FEET } \\
\text { WATER YEAR OCTOBER } 2008 \text { TO SEPTEMBER } 2009 \\
\text { DAILY MEAN VALUES }\end{array}$} \\
\hline \multicolumn{13}{|c|}{ [e, estimated] } \\
\hline Day & Oct & Nov & Dec & Jan & Feb & Mar & Apr & May & Jun & Jul & Aug & Sep \\
\hline 1 & 2.51 & 2.43 & 2.46 & --- & --- & 2.44 & 2.57 & 2.84 & 2.72 & 2.66 & 2.52 & 2.52 \\
\hline 2 & 2.49 & 2.43 & 2.46 & --- & --- & $\mathrm{e} 2.42$ & 2.52 & 2.83 & 2.71 & 2.63 & 2.50 & 2.50 \\
\hline 3 & 2.46 & 2.45 & 2.46 & --- & --- & $\mathrm{e} 2.40$ & 2.52 & 2.80 & 2.69 & 2.61 & 2.49 & 2.50 \\
\hline 4 & 2.46 & 2.45 & 2.46 & --- & --- & 2.40 & 2.50 & 2.78 & 2.68 & 2.60 & 2.47 & 2.49 \\
\hline 5 & 2.45 & 2.46 & 2.45 & --- & --- & 2.39 & 2.48 & 2.76 & 2.68 & 2.60 & 2.47 & 2.49 \\
\hline 6 & 2.44 & 2.46 & 2.44 & --- & --- & 2.39 & 2.47 & 2.76 & 2.65 & 2.59 & 2.46 & 2.48 \\
\hline 7 & 2.45 & 2.48 & --- & \begin{tabular}{|l}
--- \\
\end{tabular} & --- & 2.41 & 2.46 & 2.79 & 2.64 & 2.57 & 2.47 & 2.48 \\
\hline 8 & 2.52 & 2.49 & --- & --- & 2.48 & 2.48 & 2.44 & 2.77 & 2.73 & 2.55 & 2.52 & 2.47 \\
\hline 9 & 2.50 & 2.47 & 2.45 & --- & 2.48 & 2.51 & 2.43 & 2.78 & 2.76 & 2.55 & 2.55 & 2.47 \\
\hline 10 & 2.49 & 2.45 & --- & --- & 2.50 & 2.54 & 2.43 & 2.76 & 2.74 & 2.55 & 2.56 & 2.46 \\
\hline 11 & 2.48 & 2.44 & --- & --- & 2.49 & 2.56 & 2.44 & 2.74 & 2.72 & 2.58 & 2.54 & 2.46 \\
\hline 12 & 2.49 & 2.47 & --- & --- & 2.50 & 2.53 & 2.44 & 2.72 & 2.72 & 2.57 & 2.53 & 2.46 \\
\hline 13 & 2.50 & 2.50 & --- & --- & 2.48 & 2.51 & 2.44 & 2.74 & 2.72 & 2.55 & 2.52 & 2.46 \\
\hline 14 & 2.50 & 2.51 & 2.44 & --- & 2.48 & 2.49 & 2.47 & 2.81 & 2.71 & 2.53 & 2.52 & 2.46 \\
\hline 15 & 2.50 & 2.51 & --- & --- & $\mathrm{e} 2.44$ & 2.48 & 2.47 & 2.78 & 2.70 & 2.59 & 2.51 & 2.45 \\
\hline 16 & 2.50 & 2.50 & --- & --- & e2.42 & 2.47 & 2.48 & 2.77 & 2.67 & 2.58 & 2.50 & 2.43 \\
\hline 17 & 2.49 & 2.48 & --- & --- & 2.41 & 2.46 & 2.48 & 2.74 & 2.67 & 2.56 & 2.52 & 2.43 \\
\hline 18 & 2.48 & 2.47 & $\mathrm{e} 2.46$ & --- & 2.43 & 2.45 & 2.49 & 2.73 & 2.67 & 2.53 & 2.53 & 2.42 \\
\hline 19 & 2.48 & 2.47 & --- & --- & $\mathrm{e} 2.41$ & 2.44 & 2.51 & 2.71 & 2.83 & 2.52 & 2.50 & 2.41 \\
\hline 20 & 2.47 & 2.45 & --- & --- & $\mathrm{e} 2.40$ & 2.42 & 2.59 & 2.70 & 2.96 & 2.51 & 2.53 & 2.42 \\
\hline 21 & 2.46 & 2.44 & --- & \begin{tabular}{|l|}
--- \\
\end{tabular} & e2.39 & 2.41 & 2.63 & 2.68 & 2.93 & 2.51 & 2.50 & 2.48 \\
\hline 22 & 2.44 & 2.43 & --- & e2.52 & 2.39 & 2.39 & 2.63 & 2.66 & 2.90 & 2.52 & 2.48 & 2.49 \\
\hline 23 & 2.43 & 2.43 & --- & --- & $\mathrm{e} 2.37$ & 2.38 & 2.62 & 2.65 & 2.89 & 2.55 & 2.47 & 2.51 \\
\hline 24 & 2.49 & 2.44 & --- & --- & $\mathrm{e} 2.36$ & 2.41 & 2.64 & 2.64 & 2.87 & 2.57 & 2.47 & 2.51 \\
\hline 25 & 2.53 & 2.44 & --- & --- & 2.36 & 2.53 & 2.65 & 2.61 & 2.85 & 2.55 & 2.46 & 2.50 \\
\hline 26 & 2.52 & 2.43 & --- & --- & 2.38 & 2.52 & 2.77 & 2.61 & 2.81 & 2.54 & 2.46 & 2.51 \\
\hline 27 & 2.47 & 2.44 & 2.58 & --- & 2.47 & 2.50 & 2.85 & 2.71 & 2.79 & 2.54 & 2.51 & 2.52 \\
\hline 28 & 2.46 & 2.44 & 2.73 & --- & 2.46 & 2.48 & 2.84 & 2.73 & 2.78 & 2.53 & 2.57 & 2.50 \\
\hline 29 & 2.44 & 2.43 & --- & --- & --- & 2.53 & 2.82 & 2.72 & 2.72 & 2.51 & 2.57 & 2.44 \\
\hline 30 & 2.44 & 2.43 & --- & --- & --- & 2.51 & 2.84 & 2.71 & 2.68 & 2.51 & 2.54 & 2.42 \\
\hline 31 & 2.44 & --- & --- & --- & --- & 2.52 & --- & 2.69 & --- & 2.53 & 2.52 & --- \\
\hline Mean & 2.48 & 2.46 & --- & --- & --- & 2.46 & 2.56 & 2.73 & 2.75 & 2.56 & 2.51 & 2.47 \\
\hline Max & 2.53 & 2.51 & --- & --- & --- & 2.56 & 2.85 & 2.84 & 2.96 & 2.66 & 2.57 & 2.52 \\
\hline Min & 2.43 & 2.43 & --- & --- & --- & 2.38 & 2.43 & 2.61 & 2.64 & 2.51 & 2.46 & 2.41 \\
\hline
\end{tabular}




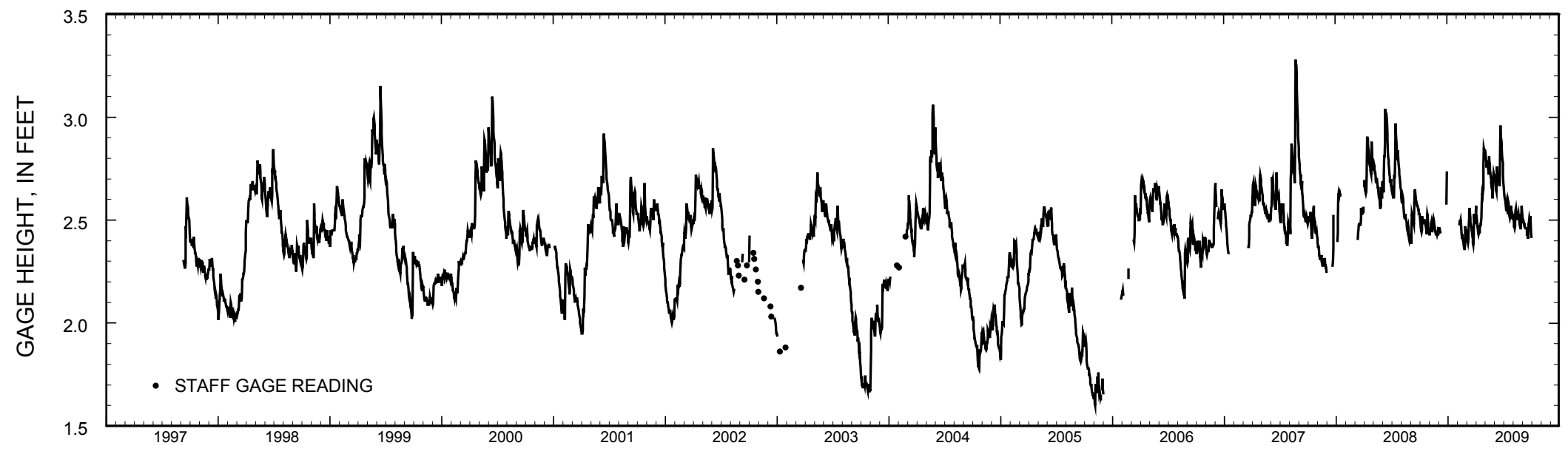

Stage hydrograph for Geneva Lake, 1997-2009. 


\section{GENEVA LAKE AT WEST END NEAR WILLIAMS BAY, W}

LOCATION.--Lat $42^{\circ} 33^{\prime} 29^{\prime \prime}$, long $88^{\circ} 32^{\prime} 33^{\prime \prime}$, in NE $1 / 4$ SE $1 / 4$ sec.12, T.1 N., R.16 E., Walworth County, Hydrologic Unit 07120006 , 1.3 mi south of Williams Bay.

SURFACE AREA.--8.22 $\mathrm{mi}^{2}$.

DRAINAGE AREA.--28.7 $\mathrm{mi}^{2}$.

PERIOD OF RECORD.--April 1997 to current year.

REMARKS.--Lake sampled at deep hole at a depth of about $43 \mathrm{~m}$. Water-quality analyses done by Wisconsin State Laboratory of Hygiene. Samples for determination of chlorophyll a concentration are collected from the top $0.5 \mathrm{~m}$ of the lake.

WATER-QUALITY DATA, NOVEMBER 18, 2008 TO JUNE 11, 2009 (Milligrams per liter unless otherwise indicated)

\section{Parameter Name}

Chlorophyll a, phytoplankton $(\mu \mathrm{g} / \mathrm{L})$

Secchi-depth $(\mathrm{m})$

Sampling depth $(m)$

Water Temperature $\left({ }^{\circ} \mathrm{C}\right)$

$\mathrm{pH}$ (standard units)

Specific conductance $(\mu \mathrm{S} / \mathrm{cm})$

Dissolved oxygen

Phosphorus, Total (as P)

Orthophosphate, dissolved (as $\mathrm{P}$ )

Nitrate + nitrite, dissolved (as $\mathrm{N}$ )

Ammonia, dissolved (as $\mathrm{N}$ )

Ammonia + organic nitrogen, total (as $\mathrm{N}$ )

Ammonia plus organic nitrogen, dissolved (as $\mathrm{N}$ )

Total nitrogen

Turbidity, (NTU)

Apparent color, (PTU)

Hardness (as CaCO3)

Calcium, dissolved $(\mathrm{Ca})$

Magnesium, dissolved $(\mathrm{Mg})$

Sodium, dissolved $(\mathrm{Na})$

Potassium, dissolved (K)

ANC (as $\mathrm{CaCO} 3$ )

Chloride, dissolved $(\mathrm{Cl})$

Sulfate, dissolved (SO4)

Silica, dissolved (SiO2)

Iron $(\mu \mathrm{g} / \mathrm{L})$

Manganese $(\mu \mathrm{g} / \mathrm{L})$

Solids, dissolved (at $180^{\circ} \mathrm{C}$

\section{November 18}

\begin{tabular}{cccc}
\multicolumn{4}{c}{ November 18 } \\
\hline \multicolumn{4}{c}{3.31} \\
\multicolumn{4}{c}{5.0} \\
0.5 & 29.0 & 36.0 & 42.0 \\
9.1 & 9.0 & 7.5 & 7.2 \\
7.7 & 7.6 & 7.1 & 7.1 \\
523 & 525 & 530 & 532 \\
9.1 & 7.5 & 0.6 & 0.2 \\
0.012 & 0.014 & 0.043 & 0.052
\end{tabular}

0.004

0.063

$<015$

0.38

$-$

$-$

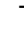

\begin{tabular}{|c|c|c|c|c|c|c|c|}
\hline \multicolumn{2}{|c|}{ April 9} & \multicolumn{6}{|c|}{ June 11} \\
\hline \multicolumn{2}{|c|}{1.53} & \multicolumn{6}{|c|}{1.81} \\
\hline \multicolumn{2}{|c|}{7.5} & \multicolumn{6}{|c|}{5.0} \\
\hline 0.5 & 42.5 & 0.5 & 11.0 & 15.0 & 33.0 & 38.0 & 42.5 \\
\hline 4.1 & 3.8 & 16.8 & 16.3 & 10.8 & 7.1 & 6.9 & 6.7 \\
\hline 8.2 & 8.3 & 8.4 & 8.4 & 8.2 & 8.0 & 7.9 & 7.9 \\
\hline 512 & 512 & 523 & 524 & 526 & 529 & 530 & 531 \\
\hline 13.4 & 12.9 & -- & -- & -- & -- & -- & -- \\
\hline 0.011 & 0.012 & 0.011 & 0.009 & 0.012 & 0.011 & 0.012 & 0.017 \\
\hline$<.002$ & $<.002$ & -- & -- & -- & -- & -- & -- \\
\hline 0.103 & 0.099 & 0.031 & -- & -- & -- & -- & -- \\
\hline$<.015$ & $<.015$ & 0.022 & -- & -- & -- & -- & -- \\
\hline 0.46 & 0.47 & 0.57 & -- & -- & -- & -- & -- \\
\hline-- & -- & & -- & -- & -- & -- & -- \\
\hline 0.56 & 0.57 & 0.6 & -- & -- & -- & -- & -- \\
\hline$<1.0$ & $<1.0$ & & & & & & \\
\hline 5 & 5 & & & & & & \\
\hline 230 & 240 & & & & & & \\
\hline 35.7 & 36.4 & & & & & & \\
\hline 34.3 & 35 & & & & & & \\
\hline 20.5 & 20.8 & & & & & & \\
\hline 1.9 & 1.9 & & & & & & \\
\hline 190 & 190 & & & & & & \\
\hline 42.9 & 41.9 & & & & & & \\
\hline 30.4 & 30.5 & & & & & & \\
\hline 2.31 & 2.34 & & & & & & \\
\hline$<100$ & $<100$ & & & & & & \\
\hline$<1.0$ & $<1.0$ & & & & & & \\
\hline 302 & 294 & & & & & & \\
\hline
\end{tabular}




\section{GENEVA LAKE AT WEST END NEAR WILLIAMS BAY, WI}

WATER-QUALITY DATA, JULY 16 TO SEPTEMBER 15, 2009

(Milligrams per liter unless otherwise indicated)

\begin{tabular}{c} 
Parameter Code \\
\hline 32210 \\
00078 \\
00098 \\
00010 \\
00400 \\
00095 \\
00300 \\
00665 \\
00671 \\
00631 \\
00608 \\
00625
\end{tabular}

Parameter Name

Chlorophyll a, phytoplankton $(\mu \mathrm{g} / \mathrm{L})$

Secchi-depth $(m)$

\begin{tabular}{cccccc}
\multicolumn{7}{c}{ July 16 } \\
\hline \multicolumn{7}{c}{3.65} \\
\multicolumn{7}{c}{3.6} \\
0.5 & 7.0 & 17.0 & 32.0 & 37.0 & 41.5 \\
22.3 & 21.7 & 10.4 & 7.2 & 6.9 & 6.8 \\
8.3 & 8.3 & 8.3 & 8.2 & 8.1 & 8.0 \\
514 & 517 & 517 & 517 & 517 & 518 \\
8.9 & 8.7 & 8.3 & 7.7 & 6.6 & 6.1 \\
0.011 & 0.012 & 0.016 & 0.009 & 0.010 & 0.014 \\
$<.002$ & -- & -- & -- & -- & - \\
$<.019$ & -- & -- & -- & -- & - \\
$<.015$ & -- & -- & -- & -- & - \\
0.47 & -- & -- & -- & -- & --
\end{tabular}

\begin{tabular}{cccccc}
\multicolumn{7}{c}{ August 11 } \\
\hline \multicolumn{7}{c}{4.64} \\
0.5 & 10.0 & 18.0 & 33.0 & 38.0 & 42.0 \\
22.9 & 21.2 & 10.4 & 7.3 & 7.0 & 6.9 \\
8.6 & 8.4 & 8.0 & 7.9 & 7.8 & 7.8 \\
507 & 510 & 513 & 515 & 518 & 519 \\
-- & -- & -- & -- & -- & -- \\
0.012 & 0.015 & 0.012 & 0.010 & 0.011 & 0.017 \\
$<.002$ & -- & -- & -- & - & - \\
$<.019$ & -- & -- & -- & -- & -- \\
0.034 & -- & -- & -- & -- & -- \\
0.48 & -- & -- & -- & -- & -
\end{tabular}

\begin{tabular}{|c|c|}
\hline Parameter Code & $\underline{\text { Parameter Name }}$ \\
\hline 32210 & Chlorophyll a, phytoplankton ( $\mu \mathrm{g} / \mathrm{L})$ \\
\hline 00078 & Secchi-depth (m) \\
\hline 00098 & Sampling depth $(m)$ \\
\hline 00010 & Water Temperature $\left({ }^{\circ} \mathrm{C}\right)$ \\
\hline 00400 & $\mathrm{pH}$ (standard units) \\
\hline 00095 & Specific conductance $(\mu \mathrm{S} / \mathrm{cm})$ \\
\hline 00300 & Dissolved oxygen \\
\hline 00665 & Phosphorus, Total (as P) \\
\hline 00671 & Orthophosphate, dissolved (as P) \\
\hline 00631 & Nitrate + nitrite, dissolved (as N) \\
\hline 00608 & Ammonia, dissolved (as $\mathrm{N}$ ) \\
\hline 00625 & Ammonia + organic nitrogen, total (as $\mathrm{N}$ ) \\
\hline 00623 & Ammonia plus organic nitrogen, dissolved (as $\mathrm{N}$ ) \\
\hline 00600 & Total nitrogen \\
\hline
\end{tabular}

\begin{tabular}{cccccc}
\multicolumn{7}{c}{ September 15 } \\
\hline \multicolumn{7}{c}{--} \\
0.5 & 12 & 16 & 33 & 38 & 42 \\
23.3 & 19.5 & 12.3 & 7.4 & 7.1 & 6.9 \\
8.5 & 7.8 & 7.3 & 7.2 & 7.1 & 6.8 \\
528 & 533 & 533 & 535 & 537 & 541 \\
8.7 & 6.4 & 4.9 & 7.4 & 4.6 & 0.5 \\
0.008 & 0.01 & 0.01 & 0.008 & 0.02 & 0.065 \\
0.002 & $<.002$ & $<.002$ & 0.002 & 0.05 & 0.012 \\
$<.019$ & $<.019$ & 0.159 & 0.269 & 0.317 & 0.176 \\
0.043 & $<.015$ & $<.015$ & $<.015$ & $<.015$ & 0.17 \\
0.45 & 0.48 & 0.41 & 0.37 & 0.42 & 0.61 \\
-- & -- & -- & -- & -- & -- \\
-- & -- & 0.57 & 0.64 & 0.74 & 0.79
\end{tabular}




\section{GENEVA LAKE AT WEST END NEAR WILLIAMS BAY, W}

LAKE-DEPTH PROFILES, NOVEMBER 18, 2008 TO JUNE 11, 2009
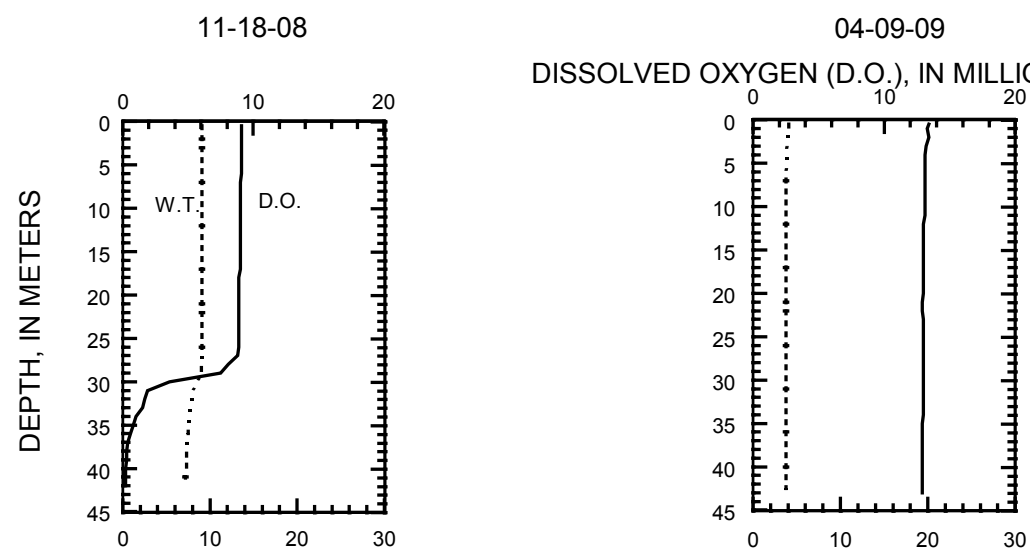

$06-11-09$

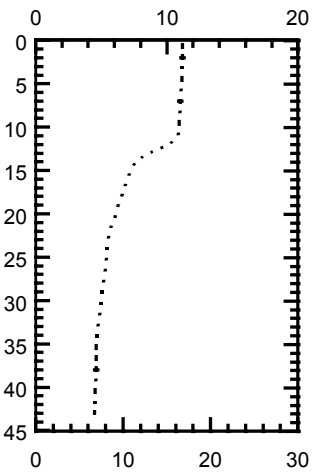

WATER TEMPERATURE (W.T.), IN DEGREES CELSIUS
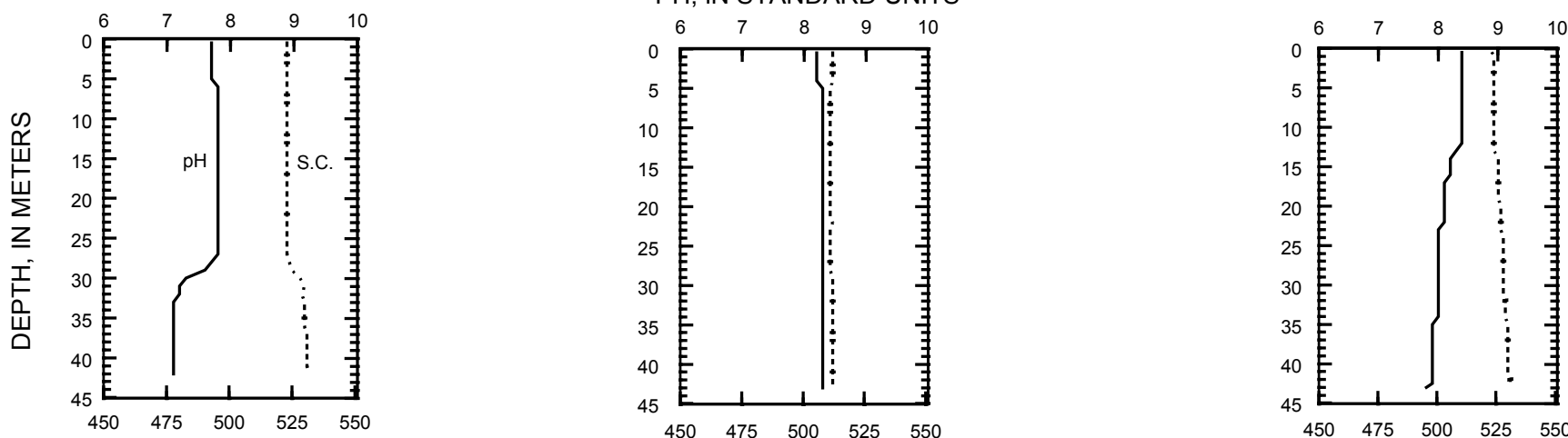

SPECIFIC CONDUCTANCE (S.C.), IN MICROSIEMENS PER CENTIMETER AT 25 DEGREES CELSIUS 
423329088323300 GENEVA LAKE AT WEST END NEAR WILLIAMS BAY, WI

LAKE-DEPTH PROFILES, JULY 16 TO SEPTEMBER 15, 2009

07-16-09
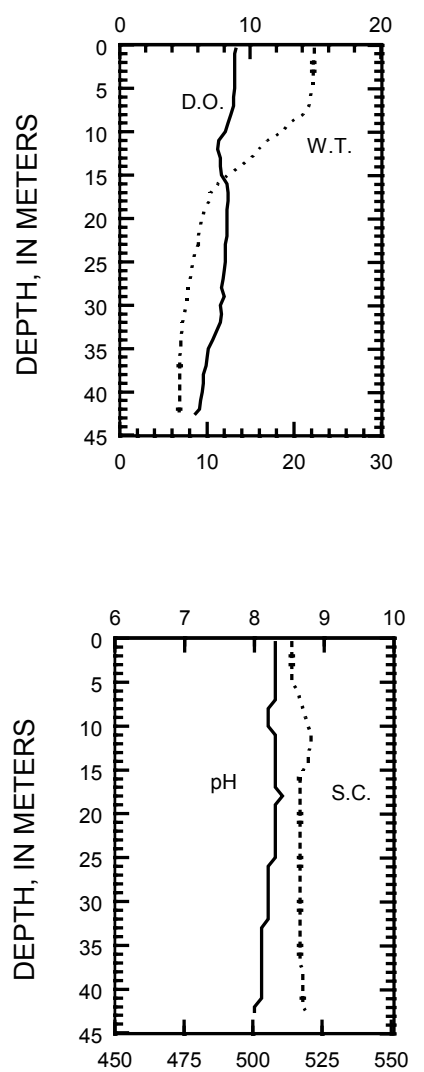

08-11-09

DISSOLVED OXYGEN (D.O.), IN MILLIGRAMS PER LITER

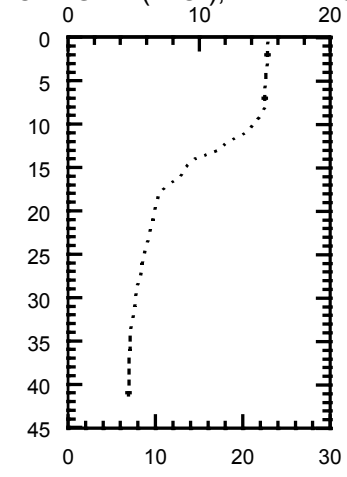

WATER TEMPERATURE (W.T.), IN DEGREES CELSIUS

PH, IN STANDARD UNITS

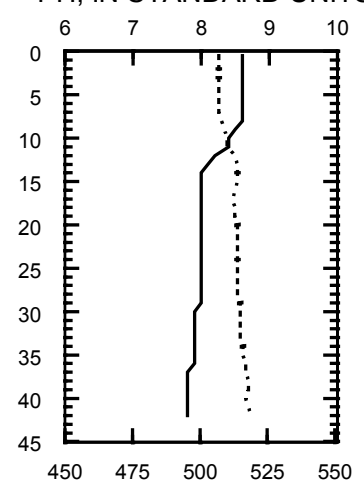

09-15-09
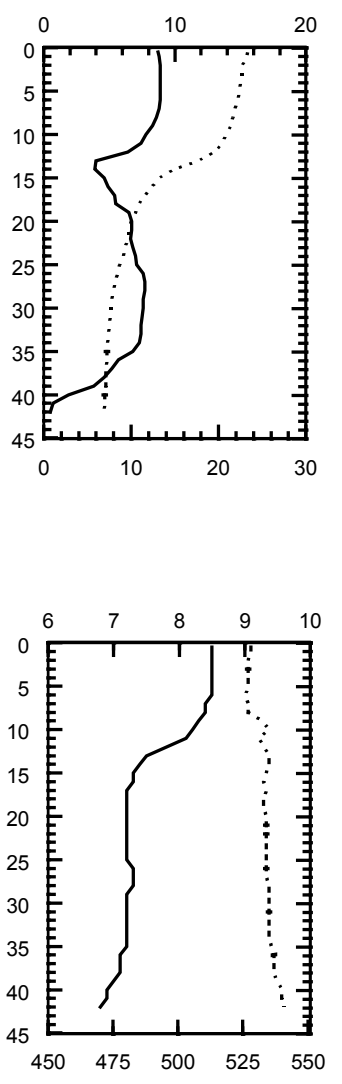

SPECIFIC CONDUCTANCE (S.C.), IN MICROSIEMENS PER CENTIMETER AT 25 DEGREES CELSIUS 

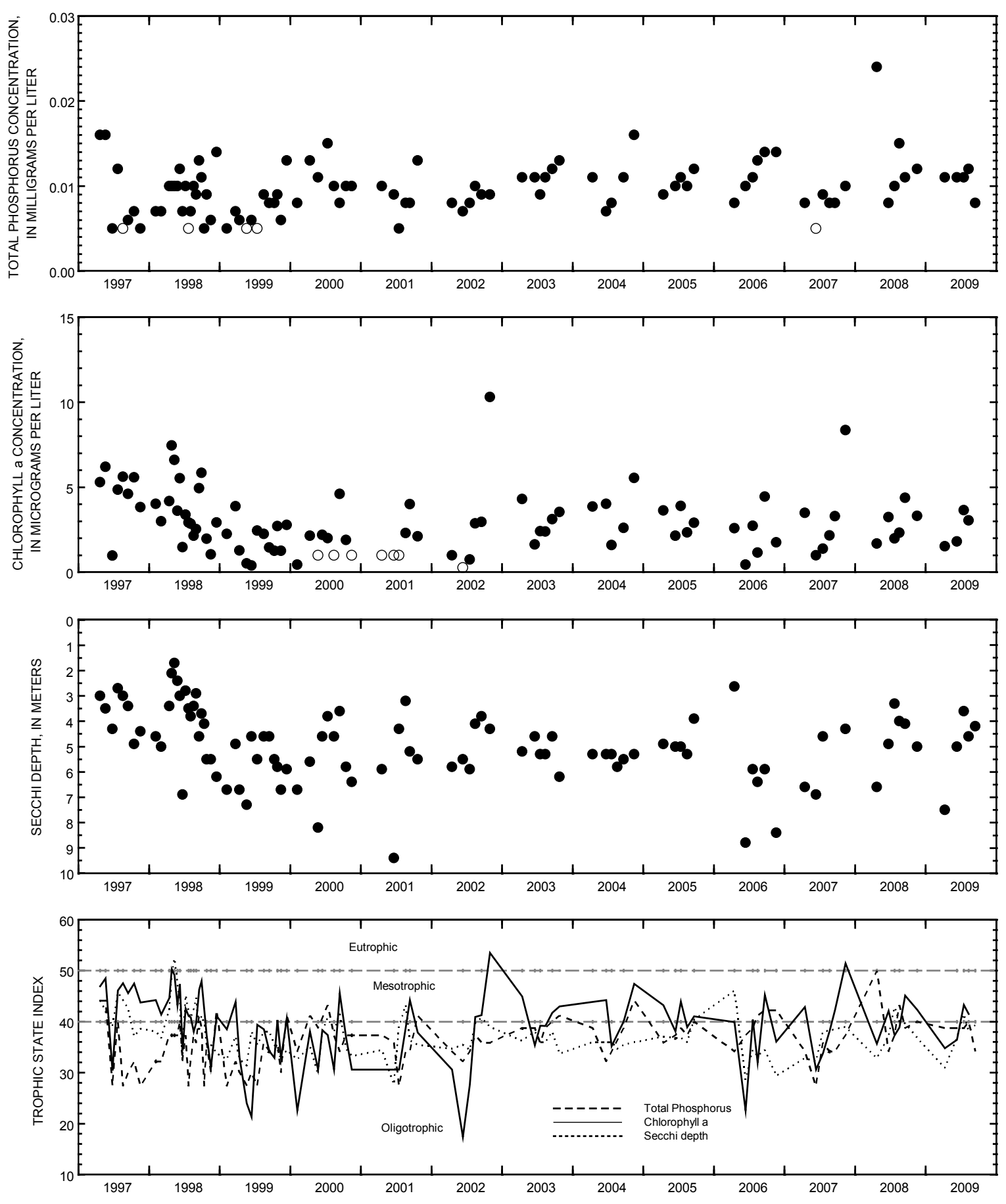

Surface total phosphorus, chlorophyll a concentrations, Secchi depths, and TSI data for Geneva Lake, West End, near Williams Bay, Wisconsin. 


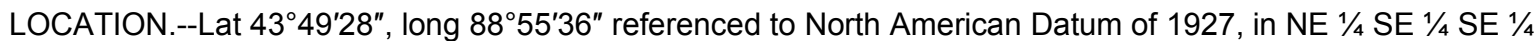
sec.27, T.16 N., R.13 E., Green Lake County, WI, Hydrologic Unit 04030201, on left bank at downstream side of County Trunk Highway A, 2.3 mi southeast of Green Lake.

SURFACE AREA.--11.48 $\mathrm{mi}^{2}$.

DRAINAGE AREA.--103 mi; Area of Green Lake, 7,346 acres.

PERIOD OF RECORD.--October 1993 to current year.

GAGE.--Water-stage recorder. Datum of gage is $790.00 \mathrm{ft}$ above sea level.

REMARKS.--Lake level regulated by dam at outlet at Green Lake. Gage-height telemeter at station.

EXTREMES FOR PERIOD OF RECORD.--Maximum recorded gage height, $8.67 \mathrm{ft}$, June 15, 2008; minimum recorded, $5.27 \mathrm{ft}$, Nov. 5, 2005.

EXTREMES FOR CURRENT YEAR.--Maximum recorded gage height, $6.65 \mathrm{ft}$, Mar. 10; minimum recorded gage height, $5.77 \mathrm{ft}$, Sept. 27.

\begin{tabular}{|c|c|c|c|c|c|c|c|c|c|c|c|c|}
\hline \multicolumn{13}{|c|}{$\begin{array}{c}\text { GAGE HEIGHT, FEET } \\
\text { WATER YEAR OCTOBER } 2008 \text { TO SEPTEMBER } 2009 \\
\text { DAILY MEAN VALUES }\end{array}$} \\
\hline \multicolumn{13}{|c|}{ [e, estimated] } \\
\hline Day & Oct & Nov & Dec & Jan & Feb & Mar & Apr & May & Jun & Jul & Aug & Sep \\
\hline 1 & 6.17 & 6.14 & 6.18 & 6.37 & 6.36 & 6.56 & 6.44 & 6.45 & 6.41 & 6.31 & 6.21 & 5.98 \\
\hline 2 & 6.15 & 6.14 & 6.18 & 6.37 & 6.35 & $\mathrm{e} 6.56$ & 6.40 & 6.43 & 6.39 & 6.30 & 6.18 & 5.98 \\
\hline 3 & 6.15 & 6.16 & 6.18 & 6.36 & 6.34 & e6.55 & 6.37 & 6.44 & 6.38 & 6.30 & 6.20 & 5.97 \\
\hline 4 & 6.14 & 6.17 & 6.18 & 6.38 & 6.34 & 6.55 & 6.34 & 6.42 & 6.37 & 6.29 & 6.17 & 5.96 \\
\hline 5 & 6.13 & 6.16 & 6.19 & 6.37 & 6.34 & 6.55 & 6.29 & 6.40 & 6.37 & 6.29 & 6.12 & 5.95 \\
\hline 6 & 6.16 & 6.17 & 6.20 & 6.36 & 6.34 & 6.53 & 6.27 & 6.41 & 6.39 & 6.28 & 6.09 & 5.95 \\
\hline 7 & 6.17 & 6.18 & 6.17 & 6.37 & 6.34 & 6.51 & 6.24 & 6.42 & 6.41 & 6.26 & 6.08 & 5.94 \\
\hline 8 & 6.19 & 6.16 & 6.17 & 6.37 & 6.34 & 6.54 & 6.20 & 6.43 & 6.49 & 6.24 & 6.13 & 5.94 \\
\hline 9 & 6.17 & 6.16 & 6.22 & 6.39 & 6.34 & 6.58 & 6.17 & 6.44 & 6.54 & 6.23 & 6.15 & 5.93 \\
\hline 10 & 6.19 & 6.16 & 6.23 & 6.39 & 6.37 & 6.61 & 6.14 & 6.45 & 6.55 & 6.23 & 6.17 & 5.93 \\
\hline 11 & 6.19 & 6.17 & 6.23 & 6.38 & 6.41 & e6.60 & 6.12 & 6.44 & 6.53 & 6.23 & 6.18 & 5.92 \\
\hline 12 & 6.20 & 6.19 & 6.22 & 6.38 & 6.43 & e6.58 & 6.12 & 6.44 & 6.49 & 6.22 & 6.16 & 5.91 \\
\hline 13 & 6.21 & 6.20 & 6.22 & 6.38 & 6.46 & 6.56 & 6.12 & 6.44 & 6.46 & 6.22 & 6.16 & 5.90 \\
\hline 14 & 6.19 & 6.23 & 6.22 & 6.38 & 6.48 & 6.53 & 6.13 & 6.46 & 6.47 & 6.20 & 6.16 & 5.90 \\
\hline 15 & 6.20 & 6.22 & 6.25 & e6.38 & 6.48 & 6.52 & 6.14 & 6.49 & 6.47 & 6.19 & 6.14 & 5.88 \\
\hline 16 & 6.22 & 6.21 & 6.20 & e6.38 & 6.49 & 6.51 & 6.15 & 6.45 & 6.44 & 6.18 & 6.13 & 5.85 \\
\hline 17 & 6.21 & 6.21 & 6.21 & 6.39 & 6.49 & 6.51 & 6.16 & 6.45 & 6.47 & 6.16 & 6.12 & 5.84 \\
\hline 18 & 6.22 & 6.21 & 6.21 & 6.39 & 6.51 & 6.50 & 6.18 & 6.44 & 6.48 & 6.15 & 6.09 & 5.84 \\
\hline 19 & 6.21 & 6.19 & 6.25 & 6.39 & 6.50 & 6.47 & 6.18 & 6.44 & 6.50 & 6.15 & 6.08 & 5.82 \\
\hline 20 & 6.20 & 6.17 & 6.27 & 6.39 & 6.51 & 6.45 & 6.23 & 6.44 & 6.51 & 6.15 & 6.08 & 5.81 \\
\hline 21 & 6.19 & e6.16 & e6.27 & 6.38 & 6.52 & 6.44 & 6.29 & 6.42 & 6.50 & 6.15 & 6.09 & 5.84 \\
\hline 22 & 6.17 & e6.16 & 6.27 & 6.38 & 6.52 & 6.41 & 6.32 & 6.42 & 6.49 & 6.17 & 6.08 & 5.85 \\
\hline 23 & 6.16 & e6.16 & 6.27 & 6.37 & 6.52 & 6.39 & 6.33 & 6.42 & 6.49 & 6.20 & 6.08 & 5.86 \\
\hline 24 & 6.19 & e6.16 & 6.28 & 6.36 & 6.52 & 6.42 & 6.34 & 6.41 & 6.48 & 6.19 & 6.07 & 5.87 \\
\hline 25 & 6.18 & e6.17 & 6.28 & 6.36 & 6.52 & 6.53 & 6.35 & 6.40 & 6.46 & 6.17 & 6.07 & 5.86 \\
\hline 26 & 6.16 & 6.17 & 6.30 & 6.36 & 6.54 & 6.53 & 6.44 & 6.41 & 6.44 & 6.23 & 6.08 & 5.86 \\
\hline 27 & 6.16 & 6.16 & 6.32 & 6.36 & 6.57 & 6.51 & 6.49 & 6.42 & 6.41 & 6.22 & e6.04 & 5.86 \\
\hline 28 & 6.15 & 6.16 & 6.37 & 6.36 & 6.57 & 6.50 & 6.49 & 6.46 & 6.39 & 6.22 & e6.02 & 5.87 \\
\hline 29 & 6.15 & 6.17 & 6.37 & 6.36 & --- & 6.50 & 6.48 & 6.45 & 6.36 & 6.24 & 6.00 & 5.84 \\
\hline 30 & 6.14 & 6.17 & 6.36 & 6.35 & --- & 6.47 & 6.48 & 6.43 & 6.33 & 6.24 & 5.99 & 5.80 \\
\hline 31 & 6.15 & --- & 6.37 & 6.36 & --- & 6.45 & --- & 6.42 & --- & 6.24 & 5.99 & --- \\
\hline Mean & 6.18 & 6.17 & 6.25 & 6.37 & 6.45 & 6.51 & 6.28 & 6.43 & 6.45 & 6.22 & 6.11 & 5.89 \\
\hline Max & 6.22 & 6.23 & 6.37 & 6.39 & 6.57 & 6.61 & 6.49 & 6.49 & 6.55 & 6.31 & 6.21 & 5.98 \\
\hline Min & 6.13 & 6.14 & 6.17 & 6.35 & 6.34 & 6.39 & 6.12 & 6.40 & 6.33 & 6.15 & 5.99 & 5.80 \\
\hline
\end{tabular}




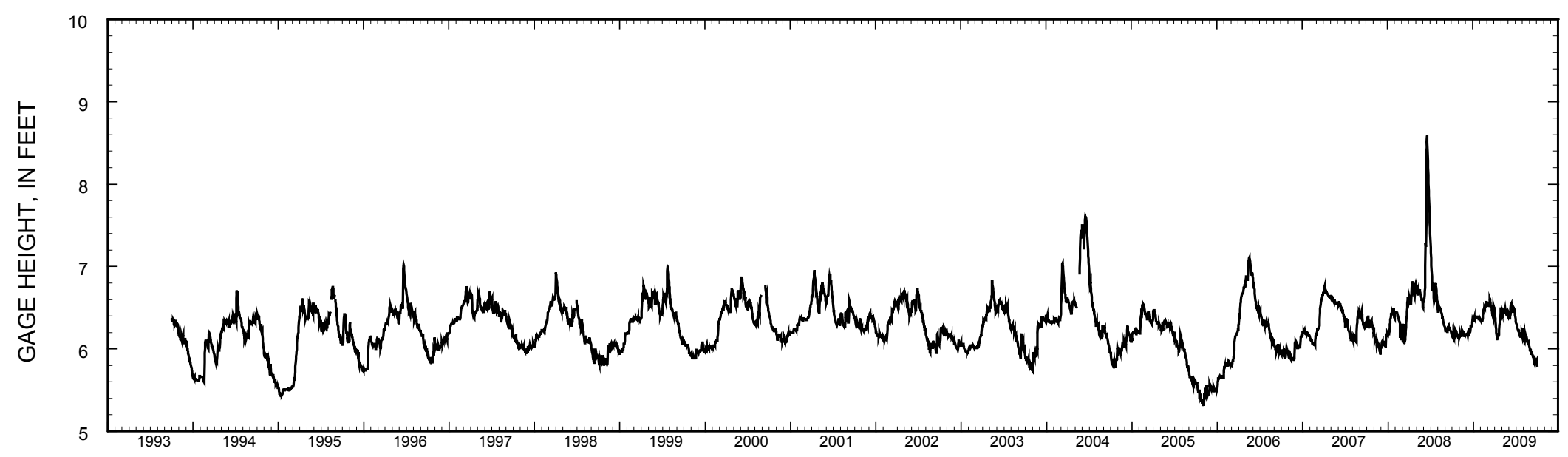

Stage hydrograph for Green Lake, 1993-2009. 
LOCATION.--Lat 4347'56", long 8902'05", in NW 1/4 SE 1/4 sec.2, T.15 N., R.12 E., Green Lake County, Hydrologic Unit 04030201, about 5 miles southwest of the City of Green Lake.

SURFACE AREA.--11.48 $\mathrm{mi}^{2}$.

PERIOD OF RECORD.--May 2004 to current year. Lake sampled by Wisconsin Department of Natural Resources prior to 2004.

REMARKS.--Water-quality analyses done by Wisconsin State Laboratory of Hygiene. A “*” indicates data that were collected by Mary Jane Bumby, Citizen Lake Monitoring Volunteer.

\begin{tabular}{|c|c|}
\hline Parameter Code & $\underline{\text { Parameter Name }}$ \\
\hline 00078 & Secchi-depth (m) \\
\hline 00098 & Sampling depth (m) \\
\hline 00010 & Water Temperature $\left({ }^{\circ} \mathrm{C}\right)$ \\
\hline 00400 & $\mathrm{pH}$ (standard units) \\
\hline 00095 & Specific conductance $(\mu \mathrm{S} / \mathrm{cm})$ \\
\hline 00300 & Dissolved oxygen \\
\hline 32210 & Chlorophyll a, phytoplankton ( $\mu \mathrm{g} / \mathrm{L})$ \\
\hline 00665 & Phosphorus, total (as P) \\
\hline 00671 & Orthophosphate, dissolved (as P) \\
\hline 00631 & Nitrate plus nitrite, dissolved (as N) \\
\hline 00608 & Ammonia, dissolved (as N) \\
\hline 00625 & Ammonia plus organic nitrogen, total (as $\mathrm{N}$ ) \\
\hline 00600 & Total nitrogen \\
\hline 63675 & Turbidity, (NTU) \\
\hline 00081 & Apparent color, (PTU) \\
\hline 00900 & Hardness (as CaCO3) \\
\hline 00915 & Calcium, dissolved (Ca) \\
\hline 00925 & Magnesium, dissolved (Mg) \\
\hline 00930 & Sodium, dissolved $(\mathrm{Na})$ \\
\hline 00935 & Potassium, dissolved $(\mathrm{K})$ \\
\hline 00417 & ANC (as $\mathrm{CaCO} 3$ ) \\
\hline 00940 & Chloride, dissolved (Cl) \\
\hline 00945 & Sulfate, dissolved (SO4) \\
\hline 00955 & Silica, dissolved (SiO2) \\
\hline 01046 & Iron $(\mu \mathrm{g} / \mathrm{L})$ \\
\hline 01056 & Manganese $(\mu \mathrm{g} / \mathrm{L})$ \\
\hline 70300 & Solids, dissolved (at $180^{\circ} \mathrm{C}$ ) \\
\hline
\end{tabular}

WATER-QUALITY DATA, OCTOBER 3, 2008 TO JUNE 10, 2009

(Milligrams per liter unless otherwise indicated)

\begin{tabular}{|c|c|c|c|c|c|c|c|}
\hline Oct. $3^{*}$ & Oct. $11^{*}$ & \multicolumn{2}{|c|}{ April 15} & May $19^{*}$ & May $29^{*}$ & May $31^{*}$ & June $10^{*}$ \\
\hline 4.3 & 4.3 & \multicolumn{2}{|c|}{6.7} & 2.9 & 1.2 & 1.2 & 1.8 \\
\hline 0.1 & 0.1 & 0.5 & 67.0 & 0.1 & 0.1 & 0.1 & 0.1 \\
\hline 16.1 & 15.6 & 2.9 & 3.1 & 10.6 & 13.3 & 15.6 & 17.2 \\
\hline -- & -- & 8.1 & 8.2 & -- & -- & -- & -- \\
\hline-- & -- & 503 & 517 & -- & -- & -- & -- \\
\hline-- & -- & 13.0 & 12.6 & -- & -- & -- & -- \\
\hline -- & -- & 1.53 & -- & -- & -- & -- & -- \\
\hline-- & -- & 0.057 & 0.058 & -- & -- & -- & -- \\
\hline-- & -- & 0.045 & -- & -- & -- & -- & -- \\
\hline-- & -- & 0.406 & -- & -- & -- & -- & -- \\
\hline-- & -- & $<.015$ & -- & -- & -- & -- & -- \\
\hline-- & -- & 0.44 & -- & -- & -- & -- & -- \\
\hline-- & -- & 0.85 & -- & -- & -- & -- & -- \\
\hline-- & -- & $<1.0$ & -- & -- & -- & -- & -- \\
\hline-- & -- & 5 & -- & -- & -- & -- & -- \\
\hline-- & -- & 230 & -- & -- & -- & -- & -- \\
\hline -- & -- & 33.9 & -- & -- & -- & -- & -- \\
\hline-- & -- & 34.4 & -- & -- & -- & -- & -- \\
\hline -- & -- & 18.6 & -- & -- & -- & -- & -- \\
\hline-- & -- & 3.3 & -- & -- & -- & -- & -- \\
\hline-- & -- & 183 & -- & -- & -- & -- & -- \\
\hline -- & -- & 38.4 & -- & -- & -- & -- & -- \\
\hline-- & -- & 30.5 & -- & -- & -- & -- & -- \\
\hline-- & -- & 1.17 & -- & -- & -- & -- & -- \\
\hline -- & -- & $<100$ & -- & -- & -- & -- & -- \\
\hline-- & -- & $<1.0$ & -- & -- & -- & -- & -- \\
\hline -- & -- & 282 & -- & -- & -- & -- & -- \\
\hline
\end{tabular}




\section{GREEN LAKE AT DEEP HOLE NEAR GREEN LAKE, WI}

WATER-QUALITY DATA, JUNE 14 TO SEPTEMBER 23, 2009

(Milligrams per liter unless otherwise indicated)

\begin{tabular}{|c|c|}
\hline Parameter Code & Parameter Name \\
\hline 00078 & $\overline{\text { Secchi-depth }(\mathrm{m})}$ \\
\hline 00098 & Sampling depth (m) \\
\hline 00010 & Water Temperature $\left({ }^{\circ} \mathrm{C}\right)$ \\
\hline 00400 & $\mathrm{pH}$ (standard units) \\
\hline 00095 & Specific conductance $(\mu \mathrm{S} / \mathrm{cm})$ \\
\hline 00300 & Dissolved oxygen \\
\hline 32210 & Chlorophyll a, phytoplankton ( $\mu \mathrm{g} / \mathrm{L})$ \\
\hline 00665 & Phosphorus, total (as P) \\
\hline Parameter Code & Parameter Name \\
\hline 00078 & Secchi-depth (m) \\
\hline 00098 & Sampling depth (m) \\
\hline 00010 & Water Temperature $\left({ }^{\circ} \mathrm{C}\right)$ \\
\hline 00400 & $\mathrm{pH}$ (standard units) \\
\hline 00095 & Specific conductance $(\mu \mathrm{S} / \mathrm{cm})$ \\
\hline 00300 & Dissolved oxygen \\
\hline 32210 & Chlorophyll a, phytoplankton ( $\mu \mathrm{g} / \mathrm{L})$ \\
\hline 00665 & Phosphorus, total (as P) \\
\hline 00671 & Orthophosphate, dissolved (as P) \\
\hline 00631 & Nitrate plus nitrite, dissolved (as N) \\
\hline 00608 & Ammonia, dissolved (as $\mathrm{N}$ ) \\
\hline 00625 & Ammonia plus organic nitrogen, total (as $\mathrm{N}$ ) \\
\hline Parameter Code & Parameter Name \\
\hline 00078 & Secchi-depth (m) \\
\hline 00098 & Sampling depth (m) \\
\hline 00010 & Water Temperature $\left({ }^{\circ} \mathrm{C}\right)$ \\
\hline 00400 & pH (standard units) \\
\hline 00095 & Specific conductance $(\mu \mathrm{S} / \mathrm{cm})$ \\
\hline 00300 & Dissolved oxygen \\
\hline 32210 & Chlorophyll a, phytoplankton ( $\mu \mathrm{g} / \mathrm{L})$ \\
\hline 00665 & Phosphorus, total (as P) \\
\hline
\end{tabular}

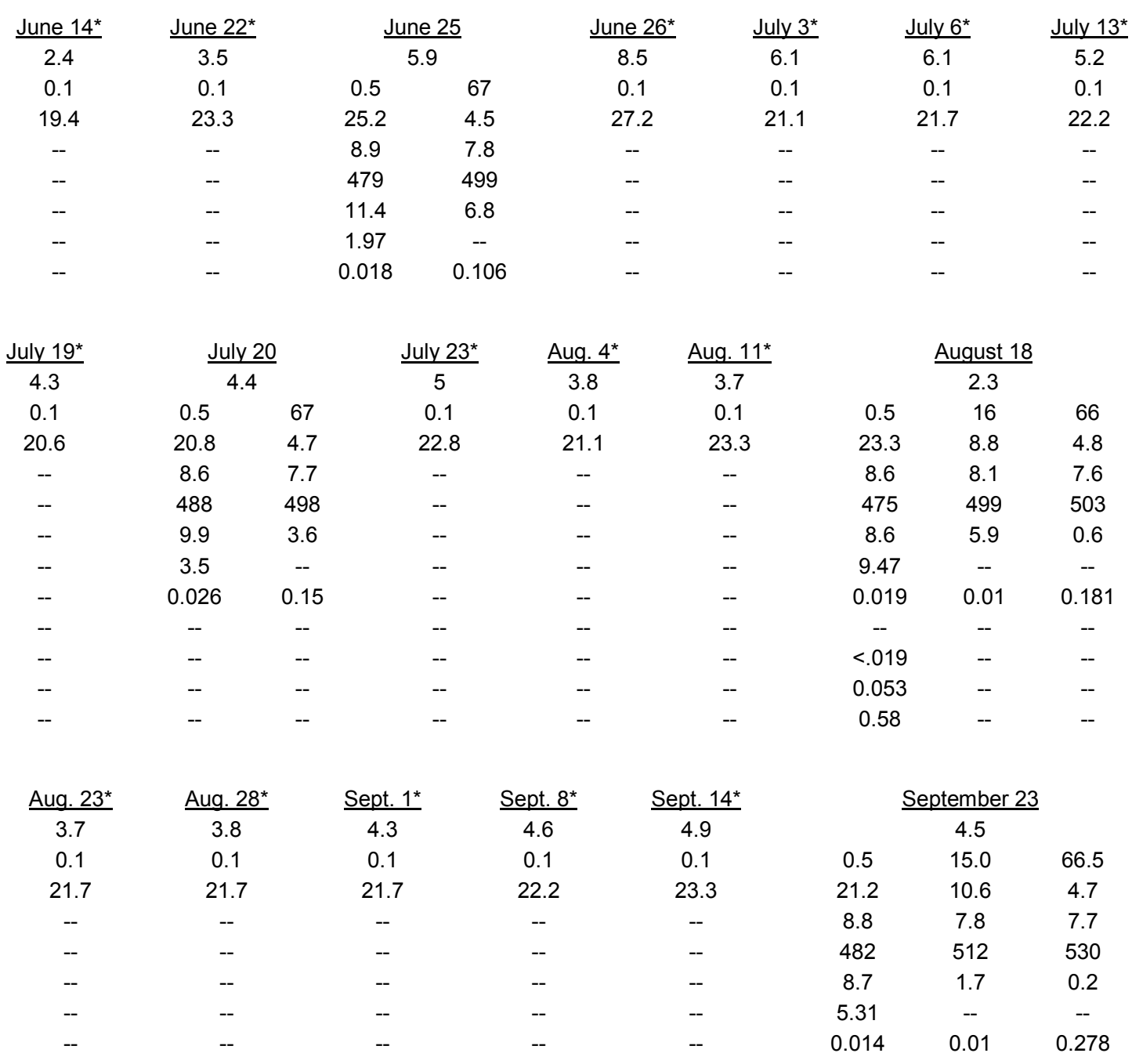


434756089020500 GREEN LAKE AT DEEP HOLE NEAR GREEN LAKE, WI

LAKE-DEPTH PROFILES, APRIL 15 TO SEPTEMBER 23, 2009

04-15-09
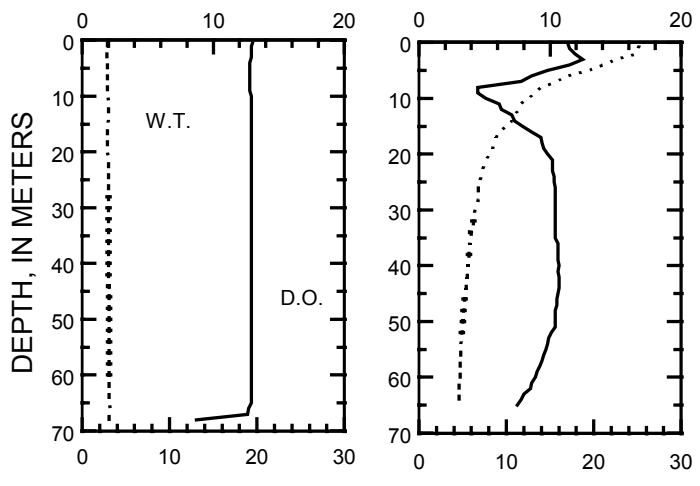

WATER TEMP
07-20-09

08-18-09

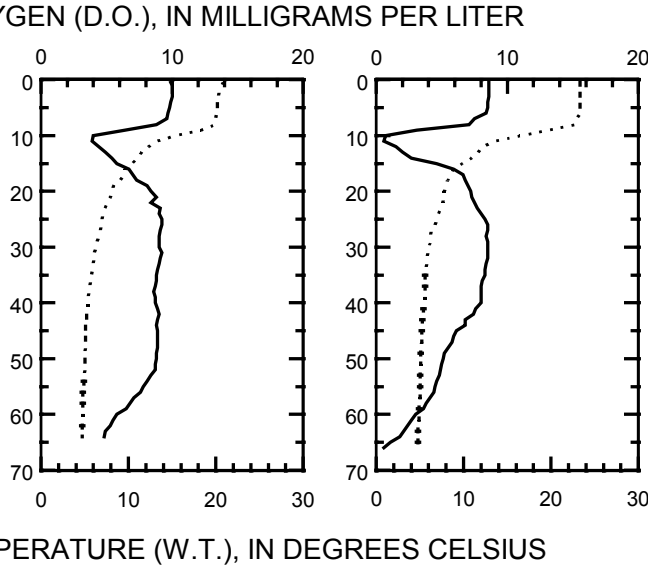

PH, IN STANDARD UNITS
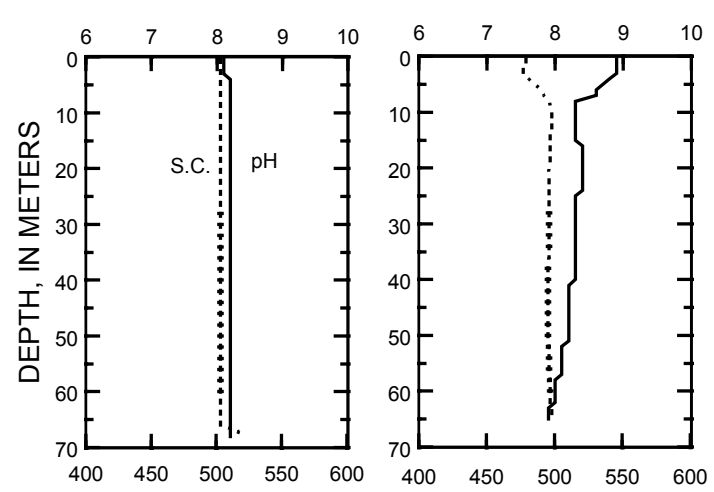

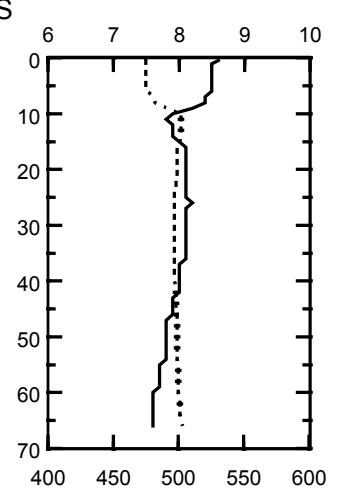

09-23-09
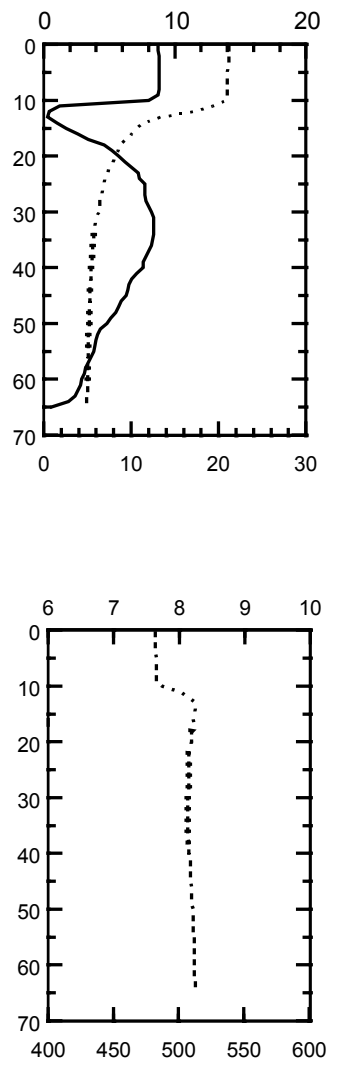

SPECIFIC CONDUCTANCE (S.C.), IN MICROSIEMENS PER CENTIMETER AT 25 DEGREES CELSIUS 

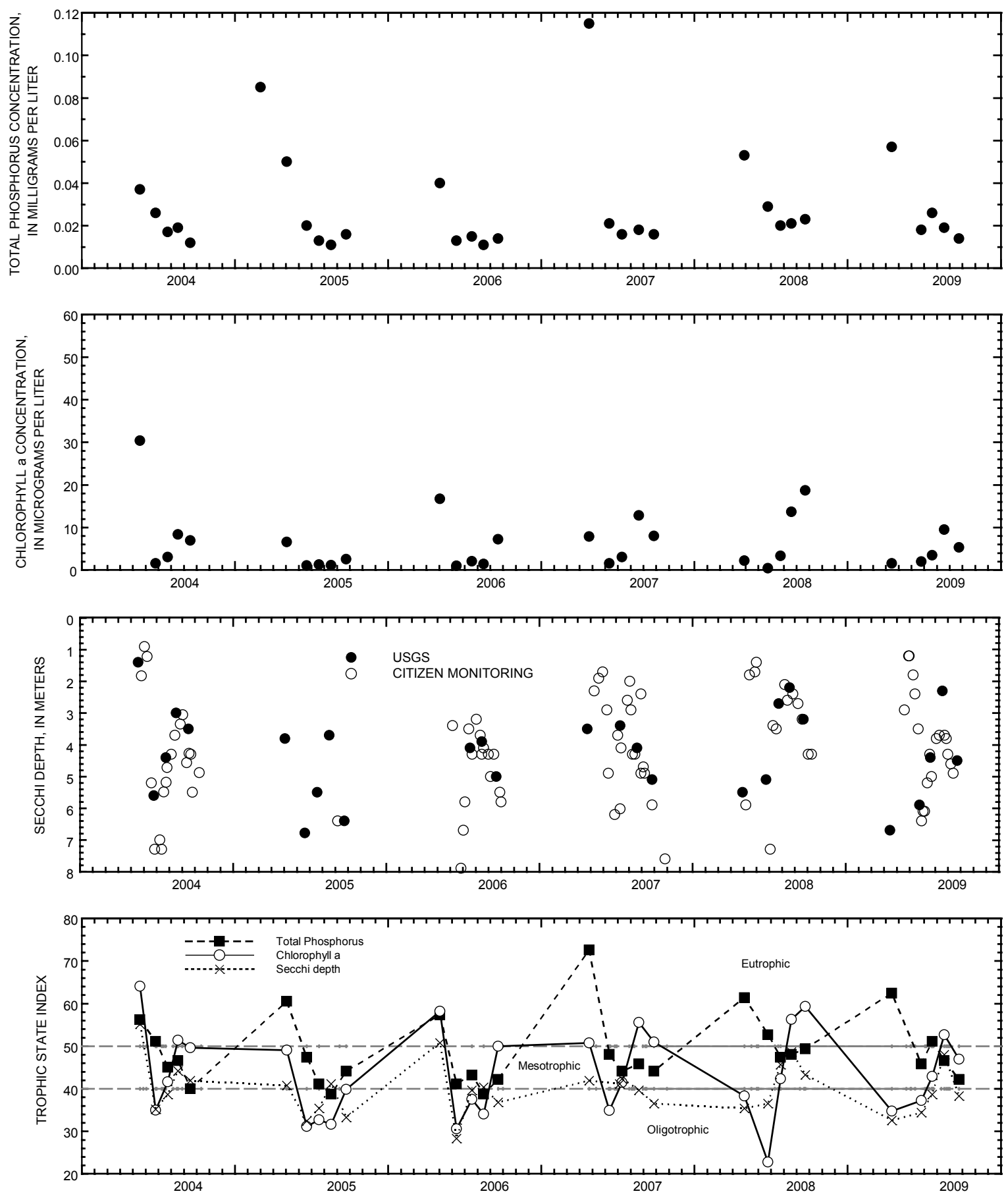

Surface total phosphorus, chlorophyll a concentrations, Secchi depths, and TSI data for Green Lake, Deep Hole, near Green Lake, Wisconsin. 


\section{GREEN LAKE AT EAST END NEAR GREEN LAKE, WI}

LOCATION.--Lat 4349'28", long $88^{\circ} 57^{\prime} 00^{\prime \prime}$, in SE 1/4 SE 1/4 sec.28, T.16 N., R.13 E., Green Lake County, Hydrologic Unit 04030201 , about one mile southeast of the City of Green Lake.

SURFACE AREA.--11.48 $\mathrm{mi}^{2}$.

PERIOD OF RECORD.--May 2004 current year. Lake sampled by Wisconsin Department of Natural Resources prior to 2004.

REMARKS.--Water-quality analyses done by Wisconsin State Laboratory of Hygiene. A "*” indicates data that were collected by Mary Jane Bumby, Citizen Lake Monitoring Volunteer.

WATER-QUALITY DATA, OCTOBER 3, 2008 TO JULY 19, 2009

(Milligrams per liter unless otherwise indicated)

\begin{tabular}{|c|c|c|c|c|c|c|c|c|c|c|}
\hline$\underline{\text { Parameter Code }}$ & Parameter Name & Oct. $3^{*}$ & Oct. $11^{*}$ & \multicolumn{2}{|c|}{ April 15} & May $19^{*}$ & May $29^{*}$ & May $31^{*}$ & June $10^{*}$ & June $14^{*}$ \\
\hline 00078 & Secchi-depth (m) & 3.0 & 3.0 & \multicolumn{2}{|c|}{4.3} & 2.6 & 1.8 & 1.2 & 1.8 & 2.7 \\
\hline 00098 & Sampling depth $(\mathrm{m})$ & 0.1 & 0.1 & 0.5 & 34.0 & 0.1 & 0.1 & 0.1 & 0.1 & 0.1 \\
\hline 00010 & Water Temperature $\left({ }^{\circ} \mathrm{C}\right)$ & 16.7 & 16.7 & 3.5 & 3.5 & 11.1 & 13.3 & 16.1 & 16.7 & 20.0 \\
\hline 00400 & $\mathrm{pH}$ (standard units) & -- & -- & 8.1 & 8.3 & -- & -- & -- & -- & -- \\
\hline 00095 & Specific conductance $(\mu \mathrm{S} / \mathrm{cm})$ & -- & -- & 503 & 506 & -- & -- & -- & -- & -- \\
\hline 00300 & Dissolved oxygen & -- & -- & 14.4 & 14.9 & -- & -- & -- & -- & -- \\
\hline 32210 & Chlorophyll a, phytoplankton $(\mu \mathrm{g} / \mathrm{L})$ & -- & -- & 3.84 & -- & -- & -- & -- & -- & -- \\
\hline 00665 & Phosphorus, total (as P) & -- & -- & 0.058 & 0.059 & -- & -- & -- & -- & -- \\
\hline Parameter Code & $\underline{\text { Parameter Name }}$ & $\underline{\text { June } 22^{*}}$ & \multicolumn{3}{|c|}{$\underline{\text { June } 25}$} & June $26^{*}$ & July $3^{*}$ & July $6^{*}$ & July $13^{*}$ & July $19^{*}$ \\
\hline 00078 & Secchi-depth (m) & 3.2 & \multicolumn{2}{|c|}{5.6} & \multicolumn{2}{|r|}{7.9} & 6.4 & 6.4 & 4.6 & 4.3 \\
\hline 00098 & Sampling depth (m) & 0.1 & 0.5 & \multicolumn{2}{|l|}{32.0} & 0.1 & 0.1 & 0.1 & 0.1 & 0.1 \\
\hline 00010 & Water Temperature $\left({ }^{\circ} \mathrm{C}\right)$ & 22.8 & 27.4 & \multicolumn{2}{|l|}{5.9} & 27.2 & 22.2 & 23.3 & 22.2 & 21.1 \\
\hline 00400 & $\mathrm{pH}$ (standard units) & -- & 8.7 & \multicolumn{2}{|l|}{8.1} & -- & -- & -- & -- & -- \\
\hline 00095 & Specific conductance $(\mu \mathrm{S} / \mathrm{cm})$ & -- & 483 & \multicolumn{2}{|l|}{498} & -- & -- & -- & -- & -- \\
\hline 00300 & Dissolved oxygen & -- & 10.3 & \multicolumn{2}{|l|}{9.3} & -- & -- & -- & -- & -- \\
\hline 32210 & Chlorophyll a, phytoplankton ( $\mu \mathrm{g} / \mathrm{L})$ & -- & 1.16 & \multicolumn{2}{|l|}{--} & -- & -- & -- & -- & -- \\
\hline 00665 & Phosphorus, total (as P) & -- & 0.018 & \multicolumn{2}{|l|}{0.068} & -- & -- & -- & -- & -- \\
\hline
\end{tabular}


434928088570000 GREEN LAKE AT EAST END NEAR GREEN LAKE, WI

WATER-QUALITY DATA, JULY 20 TO SEPTEMBER 23, 2009

(Milligrams per liter unless otherwise indicated)

\begin{tabular}{|c|c|c|c|c|c|c|c|c|c|c|c|}
\hline Parameter Code & Parameter Name & \multicolumn{2}{|c|}{ July 20} & July $23^{*}$ & Aug. $4^{*}$ & Aug. $11^{*}$ & \multicolumn{3}{|c|}{ August 18} & Aug. $23^{*}$ & Aug. $28^{*}$ \\
\hline 00078 & Secchi-depth $(\mathrm{m})$ & \multicolumn{2}{|c|}{3.6} & 4.3 & 4.3 & 2.9 & \multicolumn{3}{|c|}{2.6} & 3.0 & 3.0 \\
\hline 00098 & Sampling depth (m) & 0.5 & 34.0 & 0.1 & 0.1 & 0.1 & 0.5 & 16.0 & 31.0 & 0.1 & 0.1 \\
\hline 00010 & Water Temperature $\left({ }^{\circ} \mathrm{C}\right)$ & 22.3 & 6.0 & 22.2 & 22.2 & 24.4 & 24.3 & 9.4 & 5.9 & 21.7 & 22.2 \\
\hline 00400 & pH (standard units) & 8.7 & -- & -- & -- & -- & 8.6 & 7.9 & 7.9 & -- & -- \\
\hline 00095 & Specific conductance $(\mu \mathrm{S} / \mathrm{cm})$ & 488 & 496 & -- & -- & -- & 474 & 502 & 501 & -- & -- \\
\hline 00300 & Dissolved oxygen & 9.8 & 8.0 & -- & -- & -- & 8.9 & 4.1 & 6.5 & -- & -- \\
\hline 32210 & Chlorophyll a, phytoplankton ( $\mu \mathrm{g} / \mathrm{L})$ & 2.54 & -- & -- & -- & -- & 12 & -- & -- & -- & -- \\
\hline 00665 & Phosphorus, total (as P) & 0.018 & 0.076 & -- & -- & -- & 0.019 & 0.01 & 0.087 & -- & -- \\
\hline Parameter Code & Parameter Name & & & Sept. $1^{*}$ & Sept. $8^{*}$ & & Sept. $14^{*}$ & & & Sept. $23^{*}$ & \\
\hline 00078 & $\overline{\text { Secchi-depth }(\mathrm{m})}$ & & & 3.5 & 3.7 & & 4.3 & & & 3.3 & \\
\hline 00098 & Sampling depth $(m)$ & & & 0.1 & 0.1 & & 0.1 & & 0.5 & 19.0 & 34.0 \\
\hline 00010 & Water Temperature $\left({ }^{\circ} \mathrm{C}\right)$ & & & 21.7 & 21.7 & & 23.3 & & 20.9 & 8.9 & 5.7 \\
\hline 00400 & pH (standard units) & & & -- & -- & & -- & & 8.7 & 7.8 & 7.8 \\
\hline 00095 & Specific conductance $(\mu \mathrm{S} / \mathrm{cm})$ & & & -- & -- & & -- & & 485 & 510 & 510 \\
\hline 00300 & Dissolved oxygen & & & -- & -- & & -- & & 9.8 & 3.5 & 5.9 \\
\hline 32210 & Chlorophyll a, phytoplankton $(\mu \mathrm{g}$ & & & -- & -- & & -- & & 6.83 & -- & -- \\
\hline 00665 & Phosphorus, total (as P) & & & -- & - & & -- & & 0.016 & 0.015 & 0.093 \\
\hline
\end{tabular}


434928088570000 GREEN LAKE AT EAST END NEAR GREEN LAKE, WI

LAKE-DEPTH PROFILES, APRIL 15 TO SEPTEMBER 23, 2009

04-15-09
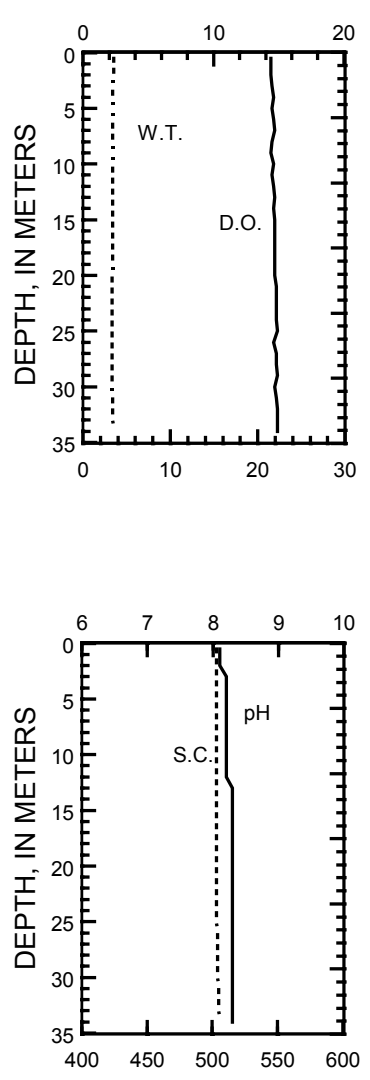

06-25-09

DISSOLVED OXYGEN (D.O.), IN MILLIGRAMS PER LITER

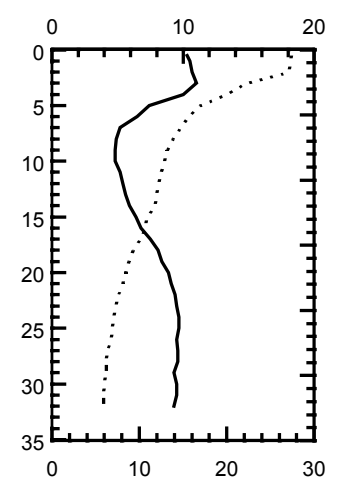

WATER TEMPI
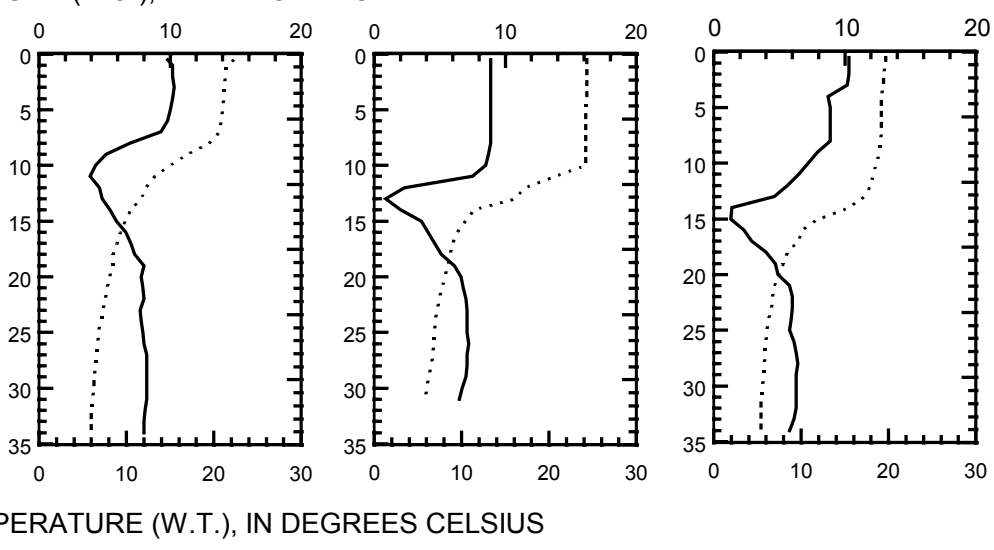

PH, IN STANDARD UNITS
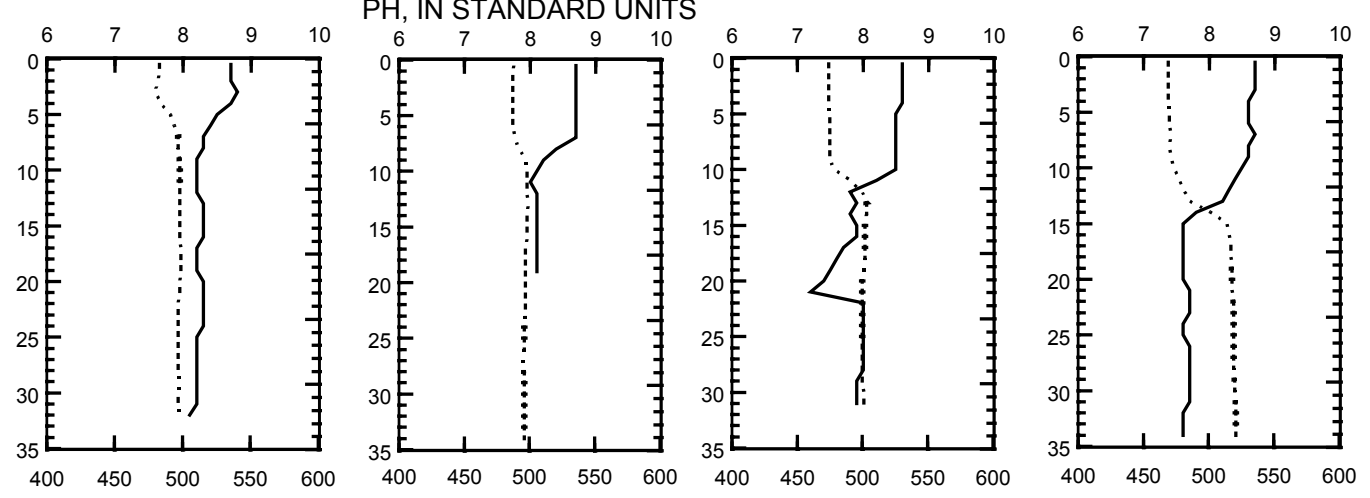

SPECIFIC CONDUCTANCE (S.C.), IN MICROSIEMENS PER CENTIMETER AT 25 DEGREES CELSIUS 

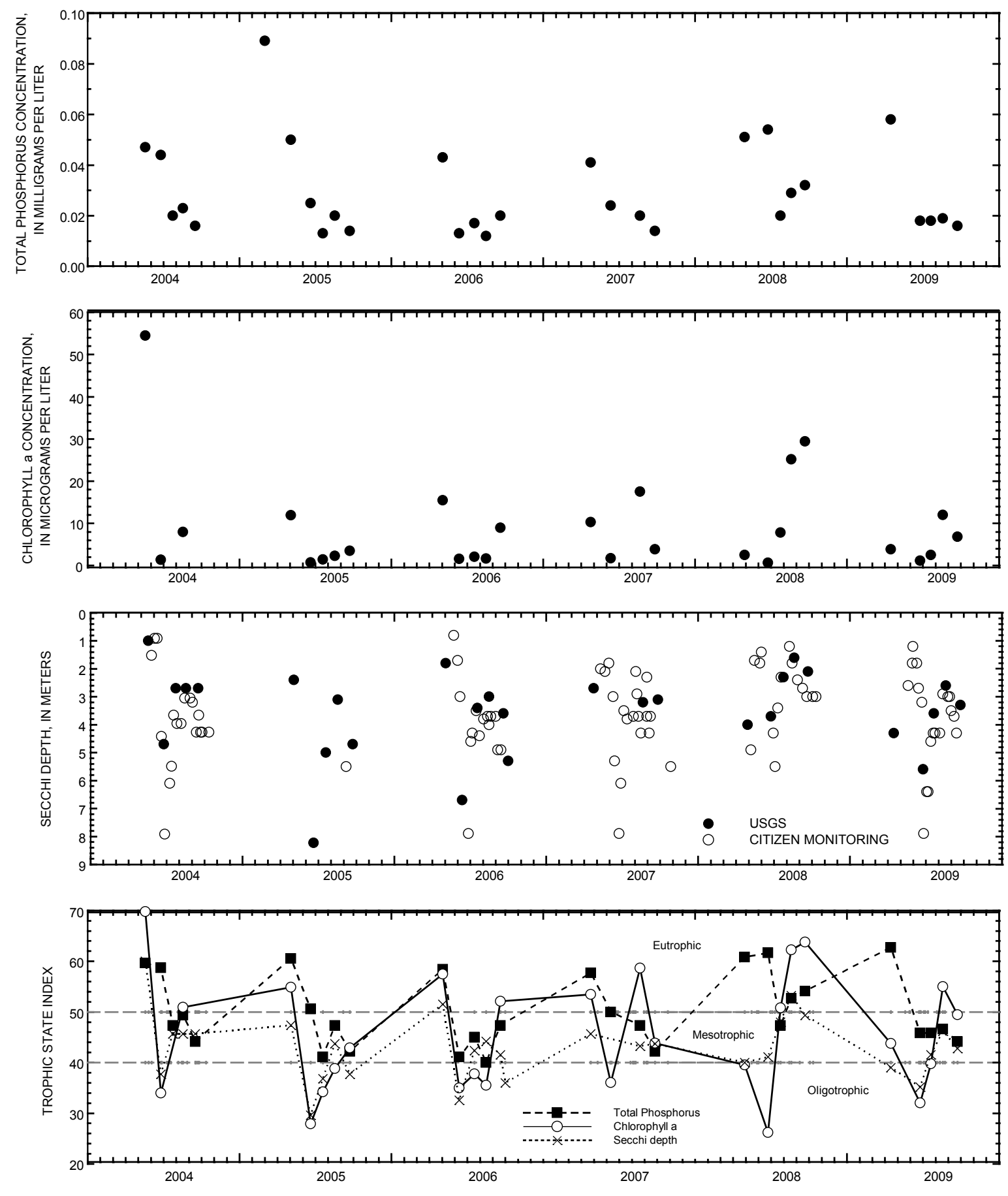

Surface total phosphorus, chlorophyll a concentrations, Secchi depths, and TSI data for Green Lake, East End, near Green Lake, Wisconsin. 
435009088550100 GREEN LAKE INLET, SITE 1, NEAR GREEN LAKE, WI

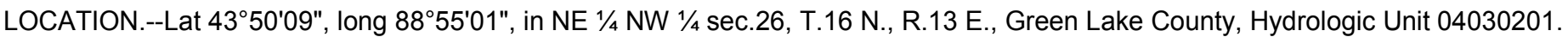

PERIOD OF RECORD.--May 2006 to current year.

REMARKS.--Water-quality analyses done by Wisconsin State Laboratory of Hygiene.

WATER-QUALITY DATA, APRIL 15, 2008 TO SEPTEMBER 23, 2009

(Milligrams per liter unless otherwise indicated)

\begin{tabular}{cll} 
Parameter Code & & Parameter Name \\
\cline { 1 - 1 } 00078 & & 00078 Secchi-depth $(\mathrm{m})$ \\
00098 & & 00098 Sampling depth $(\mathrm{m})$ \\
00010 & & 00010 Water Temperature $\left({ }^{\circ} \mathrm{C}\right)$ \\
00400 & & $00400 \mathrm{pH}$ (standard units) \\
00095 & & 00095 Specific conductance $(\mu \mathrm{S} / \mathrm{cm})$ \\
00300 & & 00300 Dissolved oxygen \\
00665 & & 00665 Phosphorus, total (as P)
\end{tabular}

$\frac{\text { Apr. } 15}{0.8}$
0.5
11.0
8.6
727
18.2
0.054

\begin{tabular}{c} 
June 25 \\
\hline 0.8 \\
0.5 \\
30.0 \\
7.7 \\
821 \\
5.2 \\
0.183
\end{tabular}

\begin{tabular}{c} 
July 20 \\
\hline 0.7 \\
0.5 \\
20.5 \\
7.6 \\
914 \\
8.6 \\
0.111
\end{tabular}

\begin{tabular}{c} 
Aug. 18 \\
\hline 0.7 \\
0.5 \\
24.6 \\
7.8 \\
946 \\
10.2 \\
0.175
\end{tabular}




\section{GREEN LAKE INLET, SITE 2, NEAR GREEN LAKE, WI}

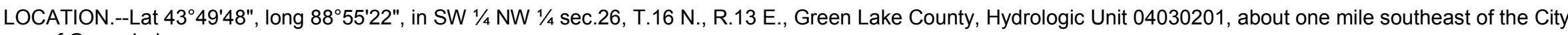
of Green Lake.

PERIOD OF RECORD.--May 2006 to current year.

REMARKS.--Water-quality analyses done by Wisconsin State Laboratory of Hygiene.

WATER-QUALITY DATA APRIL 15 TO SEPTEMBER 23, 2009

(Milligrams per liter unless otherwise indicated)

$\begin{array}{cll}\text { Parameter Code } & & \text { Parameter Name } \\ 00078 & & \text { 00078 Secchi-depth }(\mathrm{m}) \\ 00098 & & 00098 \text { Sampling depth }(\mathrm{m}) \\ 00010 & & 00010 \text { Water Temperature }\left({ }^{\circ} \mathrm{C}\right) \\ 00400 & & 00400 \mathrm{pH} \text { (standard units) } \\ 00095 & & 00095 \text { Specific conductance }(\mu \mathrm{S} / \mathrm{cm}) \\ 00300 & & 00300 \text { Dissolved oxygen } \\ 00665 & & 00665 \text { Phosphorus, total }(\text { as } \mathrm{P})\end{array}$

\begin{tabular}{cc} 
Apr. 15 & $\underline{\text { June } 25}$ \\
\hline 0.8 & 1.0 \\
0.5 & 0.5 \\
10.6 & 28.7 \\
8.6 & 7.6 \\
742 & 805 \\
14.8 & 4.3 \\
0.054 & 0.202
\end{tabular}

July 20
0.9
0.5
20.2
7.7
902
7.3
0.174

\begin{tabular}{c} 
Aug. 18 \\
\hline 0.7 \\
0.5 \\
23.7 \\
7.3 \\
934 \\
3.1 \\
0.162
\end{tabular}

$\underline{\text { Sept. } 23}$ 


\section{LAKE KEGONSA AT BARBER DRIVE NEAR STOUGHTON, WI}

LOCATION.--Lat 4257'15", long 89¹6'47" referenced to North American Datum of 1927, in SW 1/4 NE 1/4 NE 1/4 Sec.26, T.6 N., R.10 E.,

Dane County, WI, Hydrologic Unit 07090001, on downstream side of bridge on Barber Drive, 3.5 mi northwest of Stoughton.

SURFACE AREA.--1.05 $\mathrm{mi}^{2}$.

DRAINAGE AREA.--386 $\mathrm{mi}^{2}$.

PERIOD OF RECORD.--October 2003 to current year.

GAGE.--Water-stage recorder. Datum of gage is $840.00 \mathrm{ft}$ above sea level (levels from Wisconsin Department of Transportation benchmark).

EXTREMES FOR PERIOD OF RECORD.--Maximum gage height observed, $5.73 \mathrm{ft}$, June 16, 2008; minimum observed, $2.07 \mathrm{ft}$, Jan.27, 2006.

EXTREMES FOR CURRENT YEAR.--Maximum gage height observed, 4.34 ft, Mar. 28; minimum observed, $2.40 \mathrm{ft}$, Feb. 6-9.

\begin{tabular}{|c|c|c|c|c|c|c|c|c|c|c|c|c|}
\hline \multicolumn{13}{|c|}{$\begin{array}{l}\text { GAGE HEIGHT, FEET } \\
\text { OCTOBER } 2008 \text { TO SEPTEMBER } 2009 \\
\text { DAILY MEAN VALUES }\end{array}$} \\
\hline Day & Oct & Nov & Dec & Jan & Feb & Mar & Apr & May & Jun & Jul & Aug & Sep \\
\hline 1 & 3.00 & 2.88 & 3.01 & 3.22 & 2.53 & 3.07 & 4.20 & 4.13 & 3.46 & 3.37 & 3.06 & 3.15 \\
\hline 2 & 3.00 & 2.87 & 2.99 & 3.21 & 2.51 & 3.08 & 4.18 & 4.08 & 3.45 & 3.32 & 3.04 & 3.15 \\
\hline 3 & 3.02 & 2.86 & 3.03 & 3.20 & 2.48 & 3.05 & 4.13 & 4.02 & 3.42 & 3.29 & 3.01 & 3.16 \\
\hline 4 & 3.02 & 2.86 & 3.05 & 3.20 & 2.45 & 3.01 & 4.07 & 3.96 & 3.39 & 3.27 & 3.03 & 3.16 \\
\hline 5 & 3.03 & 2.85 & 3.06 & 3.18 & 2.44 & 2.98 & 4.02 & 3.89 & 3.35 & 3.23 & 3.03 & 3.16 \\
\hline 6 & 3.04 & 2.86 & 3.07 & 3.17 & 2.43 & 2.97 & 3.94 & 3.83 & 3.33 & 3.20 & 3.04 & 3.16 \\
\hline 7 & 3.06 & 2.86 & 3.03 & 3.15 & 2.42 & 3.05 & 3.87 & 3.87 & 3.30 & 3.17 & 3.05 & 3.16 \\
\hline 8 & 3.15 & 2.85 & 3.05 & 3.12 & 2.42 & 3.25 & 3.81 & 3.85 & 3.34 & 3.13 & 3.12 & 3.16 \\
\hline 9 & 3.17 & 2.84 & 3.10 & 3.12 & 2.43 & 3.41 & 3.76 & 3.87 & 3.35 & 3.08 & 3.19 & 3.16 \\
\hline 10 & 3.20 & 2.84 & 3.12 & 3.11 & 2.51 & 3.61 & 3.73 & 3.85 & 3.36 & 3.05 & 3.27 & 3.16 \\
\hline 11 & 3.22 & 2.84 & 3.13 & 3.08 & 2.61 & 3.72 & 3.68 & 3.84 & 3.35 & 3.04 & 3.27 & 3.16 \\
\hline 12 & 3.25 & 2.86 & 3.14 & 3.06 & 2.71 & 3.76 & 3.65 & 3.81 & 3.32 & 3.00 & 3.22 & 3.16 \\
\hline 13 & 3.27 & 2.86 & 3.14 & 3.03 & 2.77 & 3.77 & 3.63 & 3.80 & 3.31 & 2.98 & 3.17 & 3.16 \\
\hline 14 & 3.29 & 2.90 & 3.16 & 3.02 & 2.82 & 3.75 & 3.60 & 3.85 & 3.29 & 2.94 & 3.11 & 3.16 \\
\hline 15 & 3.30 & 2.90 & 3.18 & 3.01 & 2.82 & 3.73 & 3.57 & 3.86 & 3.28 & 2.92 & 3.09 & 3.17 \\
\hline 16 & 3.31 & 2.90 & 3.19 & 2.99 & 2.82 & 3.69 & 3.54 & 3.84 & 3.27 & 2.89 & 3.06 & 3.17 \\
\hline 17 & 3.30 & 2.89 & 3.19 & 2.96 & 2.82 & 3.67 & 3.53 & 3.82 & 3.23 & 2.88 & 3.07 & 3.16 \\
\hline 18 & 3.26 & 2.88 & 3.16 & 2.92 & 2.81 & 3.65 & 3.51 & 3.76 & 3.21 & 2.90 & 3.08 & 3.17 \\
\hline 19 & 3.22 & \begin{tabular}{|l|}
2.87 \\
\end{tabular} & 3.19 & 2.88 & \begin{tabular}{|l|}
2.77 \\
\end{tabular} & 3.63 & 3.52 & 3.72 & 3.34 & 2.93 & 3.08 & 3.18 \\
\hline 20 & 3.20 & 2.87 & 3.17 & 2.85 & 2.78 & 3.61 & 3.60 & 3.67 & 3.39 & 2.96 & 3.08 & 3.19 \\
\hline 21 & 3.17 & 2.84 & 3.15 & 2.83 & 2.80 & 3.58 & 3.65 & 3.63 & 3.42 & 3.01 & 3.09 & 3.22 \\
\hline 22 & 3.13 & 2.84 & 3.12 & 2.80 & \begin{tabular}{|l|}
2.79 \\
\end{tabular} & 3.57 & 3.68 & 3.61 & 3.46 & 3.10 & 3.09 & 3.31 \\
\hline 23 & 3.09 & 2.85 & 3.11 & 2.77 & 2.77 & 3.56 & 3.69 & 3.61 & 3.49 & 3.14 & 3.09 & 3.36 \\
\hline 24 & 3.09 & 2.88 & 3.09 & 2.75 & 2.76 & 3.70 & 3.68 & 3.62 & 3.52 & 3.17 & 3.09 & 3.36 \\
\hline 25 & 3.07 & 2.89 & 3.07 & 2.73 & 2.74 & 4.01 & 3.71 & 3.60 & 3.54 & 3.19 & 3.09 & 3.32 \\
\hline 26 & 3.03 & 2.91 & 3.06 & 2.70 & 2.82 & 4.15 & 3.90 & 3.55 & 3.54 & 3.20 & 3.11 & 3.29 \\
\hline 27 & 3.01 & 2.92 & 3.07 & 2.67 & \begin{tabular}{|l|}
2.93 \\
\end{tabular} & 4.25 & 4.00 & 3.55 & 3.53 & 3.21 & 3.12 & 3.26 \\
\hline 28 & 2.97 & 2.94 & 3.13 & 2.64 & 3.00 & 4.30 & 4.10 & 3.54 & 3.49 & 3.20 & 3.14 & 3.21 \\
\hline 29 & 2.95 & 2.96 & 3.16 & 2.61 & --- & 4.31 & 4.11 & 3.52 & 3.44 & 3.15 & 3.15 & 3.19 \\
\hline 30 & 2.91 & 2.99 & 3.19 & 2.59 & --- & 4.28 & 4.13 & 3.49 & 3.40 & 3.11 & 3.15 & 3.17 \\
\hline 31 & 2.90 & --- & 3.21 & 2.56 & --- & 4.24 & --- & 3.47 & --- & 3.10 & 3.14 & --- \\
\hline Mean & 3.12 & 2.88 & 3.11 & 2.94 & 2.68 & 3.63 & 3.81 & 3.76 & 3.39 & 3.10 & 3.11 & 3.20 \\
\hline Max & 3.31 & \begin{tabular}{|l|}
2.99 \\
\end{tabular} & 3.21 & 3.22 & \begin{tabular}{|l|}
3.00 \\
\end{tabular} & 4.31 & 4.20 & 4.13 & 3.54 & 3.37 & 3.27 & 3.36 \\
\hline Min & 2.90 & 2.84 & 2.99 & 2.56 & 2.42 & 2.97 & 3.51 & 3.47 & 3.21 & 2.88 & 3.01 & 3.15 \\
\hline
\end{tabular}




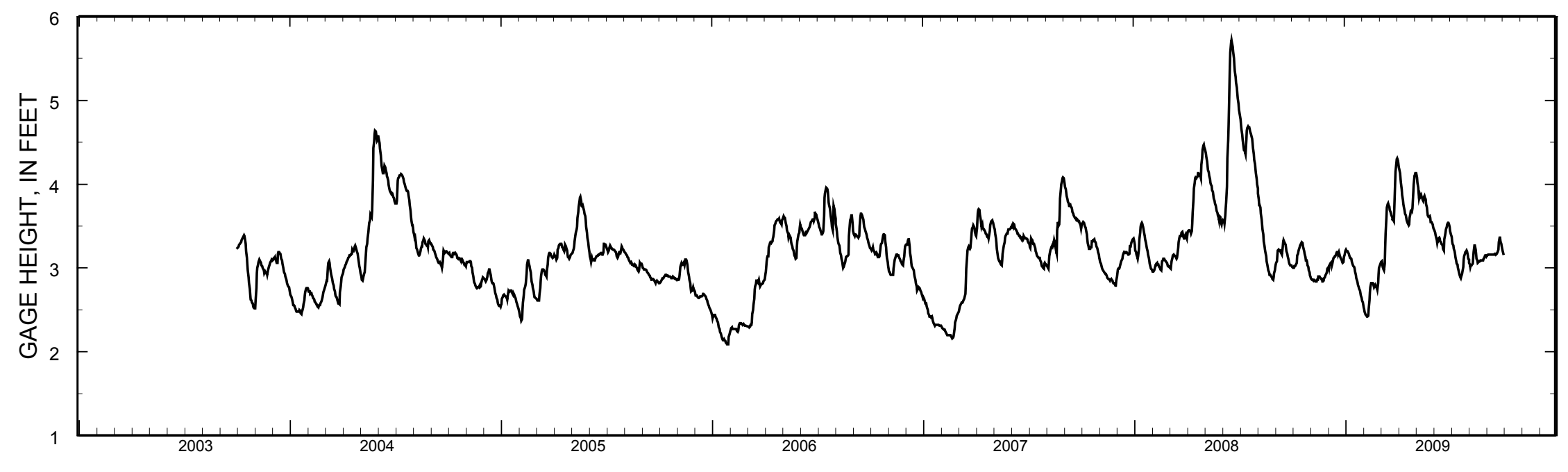

Stage hydrograph for Lake Kegonsa, 1993-2009. 


\section{LAKE KOSHKONONG NEAR NEWVILLE, WI}

LOCATION.--Lat 42 51'27", long 8856'27" referenced to North American Datum of 1927, in NW 1/4 NE 1/4 sec.34, T.5 N., R.13 E., Jefferson County, WI, Hydrologic Unit 07090001, $80 \mathrm{ft}$ east of Pottawatomi Trail Bridge at Bingham Point Estates, and $4.5 \mathrm{mi}$ northeast of Newville.

SURFACE AREA.-16.34 $\mathrm{mi}^{2}$

DRAINAGE AREA.--2,560 mi².

PERIOD OF RECORD.--July 1987 to current year.

GAGE.--Water-stage recorder. Datum of gage is $769.77 \mathrm{ft}$ above NAVD of 1988 (Wisconsin Department of Transportation bench mark). REMARKS.--Lake level regulated by dam at Indianford. Gage-height telemeter at station.

EXTREMES FOR PERIOD OF RECORD.--Maximum recorded gage height, $15.13 \mathrm{ft}$, June 21, 22, 2008; minimum recorded, $5.06 \mathrm{ft}$, Feb. 22, 2007.

EXTREMES FOR CURRENT YEAR.--Maximum recorded gage height, $11.37 \mathrm{ft}$, Mar. 29; minimum recorded gage height, $5.60 \mathrm{ft}$, Oct. 23.

\begin{tabular}{|c|c|c|c|c|c|c|c|c|c|c|c|c|}
\hline \multicolumn{13}{|c|}{$\begin{array}{c}\text { GAGE HEIGHT, FEET } \\
\text { WATER YEAR OCTOBER } 2008 \text { TO SEPTEMBER } 2009 \\
\text { DAILY MEAN VALUES }\end{array}$} \\
\hline Day & Oct & Nov & Dec & Jan & Feb & Mar & Apr & May & Jun & Jul & Aug & Sep \\
\hline 1 & 6.23 & 5.72 & 6.25 & 7.31 & 6.31 & 7.98 & 11.30 & 9.91 & 8.63 & 7.87 & 6.29 & 6.20 \\
\hline 2 & 6.20 & 5.75 & 6.21 & 7.40 & 6.28 & 8.07 & 11.31 & 9.96 & 8.51 & 7.73 & 6.28 & 6.19 \\
\hline 3 & 6.19 & 5.78 & 6.21 & 7.42 & 6.26 & 8.10 & 11.28 & 9.99 & 8.36 & 7.58 & 6.26 & 6.18 \\
\hline 4 & 6.20 & 5.81 & 6.20 & 7.43 & 6.24 & 8.09 & 11.20 & 9.99 & 8.21 & 7.42 & 6.27 & 6.17 \\
\hline 5 & 6.20 & 5.82 & 6.18 & 7.42 & 6.22 & 8.06 & 11.11 & 9.95 & 8.05 & 7.26 & 6.25 & 6.15 \\
\hline 6 & 6.20 & 5.85 & 6.18 & 7.39 & 6.19 & 8.06 & 11.01 & 9.91 & 7.89 & 7.10 & 6.23 & 6.13 \\
\hline 7 & 6.23 & 5.92 & 6.17 & 7.36 & 6.18 & 8.14 & 10.85 & 9.94 & 7.74 & 6.94 & 6.21 & 6.12 \\
\hline 8 & 6.32 & 6.02 & 6.16 & 7.32 & 6.21 & 8.37 & 10.69 & 9.92 & 7.66 & 6.78 & 6.29 & 6.13 \\
\hline 9 & 6.26 & 6.08 & 6.19 & 7.29 & 6.28 & 8.77 & 10.55 & 9.94 & 7.58 & 6.65 & 6.37 & 6.14 \\
\hline 10 & 6.24 & 6.08 & 6.19 & 7.23 & 6.43 & 9.23 & 10.39 & 9.89 & 7.51 & 6.55 & 6.41 & 6.15 \\
\hline 11 & 6.26 & 6.09 & 6.18 & 7.17 & 6.69 & 9.67 & 10.22 & 9.86 & 7.47 & 6.50 & 6.37 & 6.15 \\
\hline 12 & 6.28 & 6.14 & 6.18 & 7.11 & 7.00 & 9.99 & 10.05 & 9.80 & 7.42 & 6.39 & 6.31 & 6.16 \\
\hline 13 & 6.29 & 6.18 & 6.17 & 7.05 & 7.26 & 10.24 & 9.88 & 9.78 & 7.42 & 6.28 & 6.30 & 6.16 \\
\hline 14 & 6.31 & 6.26 & 6.18 & 7.00 & 7.48 & 10.42 & 9.72 & 9.82 & 7.41 & 6.24 & 6.29 & 6.16 \\
\hline 15 & 6.30 & 6.33 & 6.25 & 6.95 & 7.63 & 10.55 & 9.56 & 9.80 & 7.39 & 6.31 & 6.27 & 6.16 \\
\hline 16 & 6.28 & 6.36 & 6.30 & 6.90 & 7.73 & 10.66 & 9.40 & 9.83 & 7.35 & 6.30 & 6.23 & 6.15 \\
\hline 17 & 6.23 & 6.41 & 6.36 & 6.85 & 7.80 & 10.75 & 9.23 & 9.79 & 7.33 & 6.26 & 6.22 & 6.15 \\
\hline 18 & 6.09 & 6.40 & 6.39 & 6.80 & 7.84 & 10.80 & 9.05 & 9.74 & 7.32 & 6.23 & 6.23 & 6.15 \\
\hline 19 & 5.95 & 6.43 & 6.48 & 6.75 & 7.85 & 10.81 & 8.91 & 9.72 & 7.50 & 6.22 & 6.20 & 6.17 \\
\hline 20 & 5.88 & 6.47 & 6.50 & 6.70 & 7.83 & 10.78 & 8.86 & 9.68 & 7.68 & 6.23 & 6.22 & 6.19 \\
\hline 21 & 5.79 & 6.41 & 6.51 & 6.65 & 7.82 & 10.74 & 8.81 & 9.64 & 7.86 & 6.23 & 6.23 & 6.24 \\
\hline 22 & 5.69 & 6.37 & 6.51 & 6.61 & 7.78 & 10.67 & 8.75 & 9.57 & 8.06 & 6.27 & 6.22 & 6.31 \\
\hline 23 & 5.65 & 6.35 & 6.51 & 6.57 & 7.72 & 10.58 & 8.70 & 9.51 & 8.21 & 6.30 & 6.20 & 6.41 \\
\hline 24 & 5.69 & 6.35 & 6.51 & 6.54 & 7.66 & 10.63 & 8.66 & 9.43 & 8.30 & 6.29 & 6.18 & 6.41 \\
\hline 25 & 5.71 & 6.34 & 6.49 & 6.51 & 7.60 & 10.85 & 8.66 & 9.32 & 8.34 & 6.30 & 6.17 & 6.41 \\
\hline 26 & 5.76 & 6.32 & 6.48 & 6.48 & 7.59 & 11.03 & 8.79 & 9.21 & 8.34 & 6.27 & 6.19 & 6.44 \\
\hline 27 & 5.71 & 6.29 & 6.52 & 6.45 & 7.71 & 11.17 & 9.04 & 9.14 & 8.28 & 6.24 & 6.19 & 6.46 \\
\hline 28 & 5.67 & 6.28 & 6.67 & 6.42 & 7.85 & 11.26 & 9.34 & 9.06 & 8.22 & 6.27 & 6.21 & 6.59 \\
\hline 29 & 5.67 & 6.26 & 6.82 & 6.39 & --- & 11.34 & 9.57 & 8.96 & 8.12 & 6.28 & 6.26 & 6.52 \\
\hline 30 & 5.67 & 6.25 & 6.99 & 6.37 & --- & 11.32 & 9.77 & 8.86 & 8.00 & 6.28 & 6.22 & 6.48 \\
\hline 31 & 5.70 & --- & 7.16 & 6.34 & --- & 11.30 & --- & 8.74 & --- & 6.29 & 6.21 & --- \\
\hline Mean & 6.03 & 6.17 & 6.39 & 6.91 & 7.12 & 9.95 & 9.82 & 9.63 & 7.87 & 6.58 & 6.25 & 6.25 \\
\hline Max & 6.32 & 6.47 & 7.16 & 7.43 & 7.85 & 11.34 & 11.31 & 9.99 & 8.63 & 7.87 & 6.41 & 6.59 \\
\hline Min & 5.65 & 5.72 & 6.16 & 6.34 & 6.18 & 7.98 & 8.66 & 8.74 & 7.32 & 6.22 & 6.17 & 6.12 \\
\hline
\end{tabular}




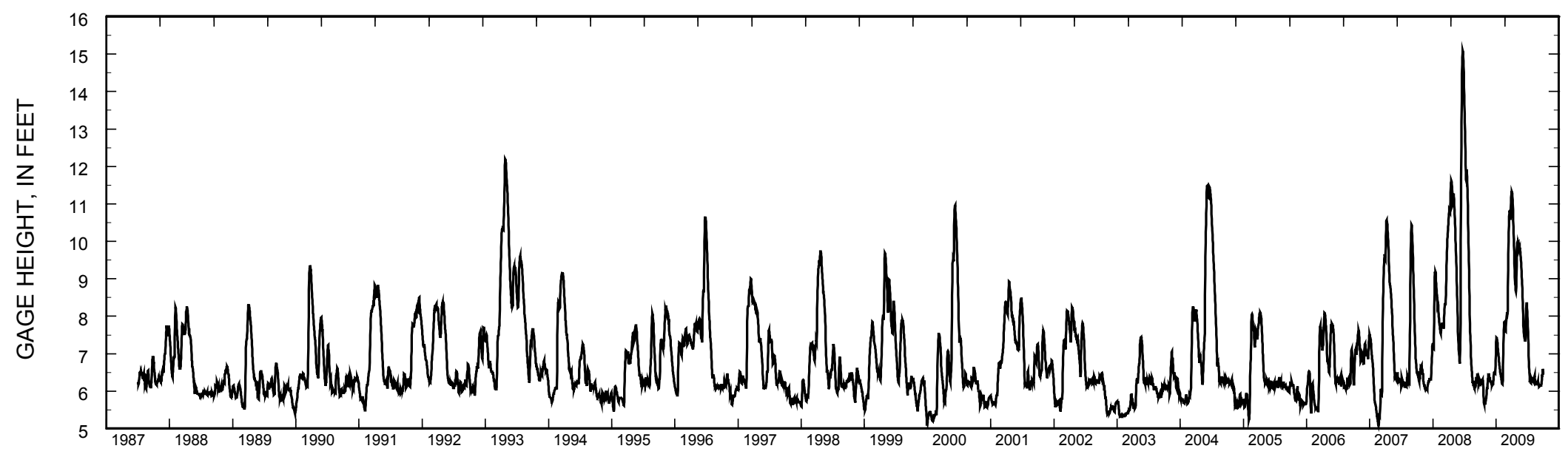

Stage hydrograph for Lake Koshkonong, 1987-2009. 


\section{LITTLE CEDAR LAKE, NORTH SITE, NEAR WEST BEND, WI}

LOCATION.--Lat 43²2'55", long 88¹3'47", in NW 1/4 NE 1/4 sec.33, T.11 N., R.19 E., Washington County, Hydrologic Unit 04040003 , 2.6 mi southwest of West Bend.

SURFACE AREA.--0.38 $\mathrm{mi}^{2}$.

PERIOD OF RECORD.--February 1997 to August 1999, February 2003 to current year.

REMARKS.--Lake sampled at center of northern basin at deep hole. Lake ice-covered during February sampling. Water-quality analyses done by Wisconsin State Laboratory of Hygiene.

WATER-QUALITY DATA, FEBRUARY 19 TO AUGUST 27, 2009

(Milligrams per liter unless otherwise indicated)

\begin{tabular}{c} 
Parameter Code \\
\hline 32210 \\
00078 \\
00098 \\
00010 \\
00400 \\
00095 \\
00300 \\
00665
\end{tabular}

Parameter Name
Chlorophyll a, phytoplankton $(\mu \mathrm{g} / \mathrm{L})$
Secchi-depth $(\mathrm{m})$
Sampling depth $(\mathrm{m})$
Water Temperature $\left({ }^{\circ} \mathrm{C}\right)$
$\mathrm{pH}$ (standard units)
Specific conductance $(\mu \mathrm{S} / \mathrm{cm})$
Dissolved oxygen
Phosphorus, total (as $\mathrm{P})$

\begin{tabular}{ccccc}
\multicolumn{2}{c}{ Feb. 19 } & \multicolumn{2}{c}{ April 16 } \\
\multicolumn{2}{c}{--} & \multicolumn{2}{c}{3.53} \\
& -- & & \multicolumn{2}{c}{3.4} \\
0.5 & 7.0 & 0.5 & 7.0 \\
0.8 & 4.7 & 9.1 & 7.2 \\
7.9 & 7.4 & 8.2 & 8.1 \\
551 & 694 & 536 & 540 \\
12.9 & 1.7 & 12.4 & 13.0 \\
0.020 & 0.029 & 0.013 & 0.015
\end{tabular}

\begin{tabular}{cc}
\multicolumn{2}{c}{ June 25} \\
\multicolumn{2}{c}{1.2} \\
& 4.4 \\
0.5 & 7.5 \\
28.6 & 16.2 \\
7.4 & 8.7 \\
541 & 571 \\
7.9 & 0.9 \\
0.014 & 0.032
\end{tabular}

\begin{tabular}{cc}
\multicolumn{3}{c}{ July 22 } \\
\multicolumn{3}{c}{8.42} \\
& 3.0 \\
0.5 & 7.0 \\
21.7 & 18.2 \\
8.3 & 7.3 \\
546 & 576 \\
9.2 & 0.0 \\
0.021 & 0.051
\end{tabular}

\begin{tabular}{cc}
\multicolumn{2}{c}{ August 27 } \\
\multicolumn{2}{c}{4.47} \\
& 4.3 \\
0.5 & 7.0 \\
22.3 & 20.6 \\
8.4 & 7.6 \\
538 & 561 \\
7.8 & 0.2 \\
0.018 & 0.021
\end{tabular}


432255088134700 LITTLE CEDAR LAKE, NORTH SITE, NEAR WEST BEND, WI

LAKE-DEPTH PROFILES, FEBRUARY 19 TO AUGUST 27, 2009

02-19-09
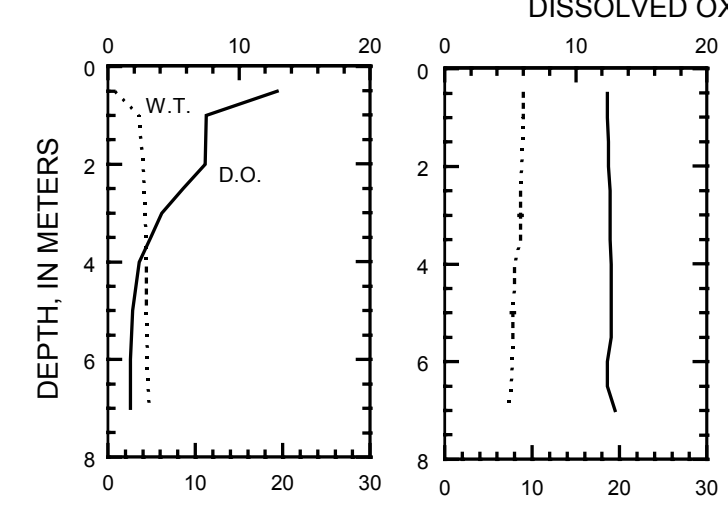

06-25-09

07-22-09

$08-27-09$
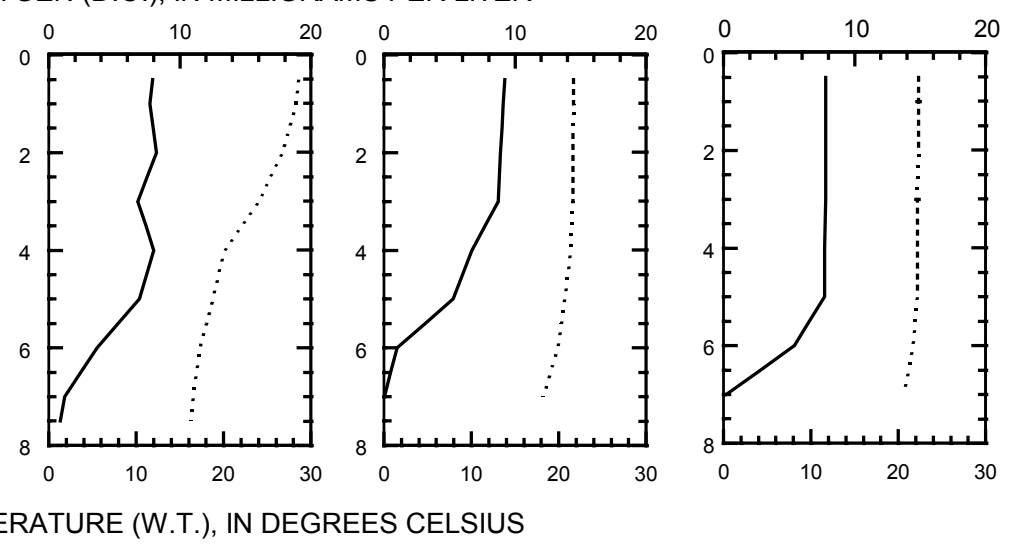

WATER TEMPERATURE (W.T.), IN DEGREES CELSIUS
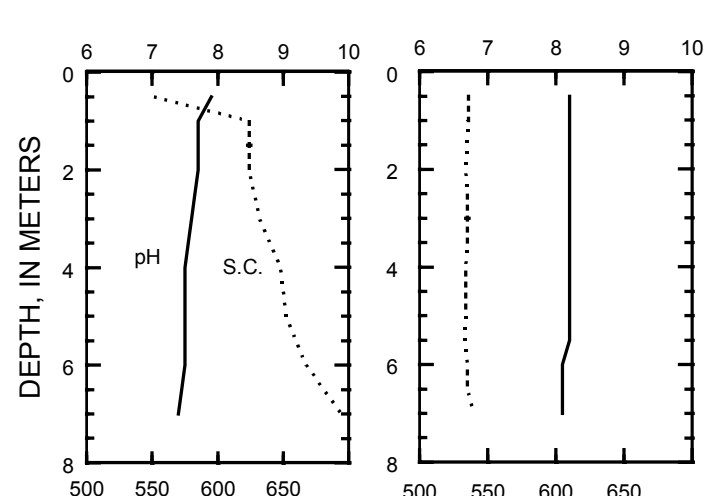

PH, IN STANDARD UNITS
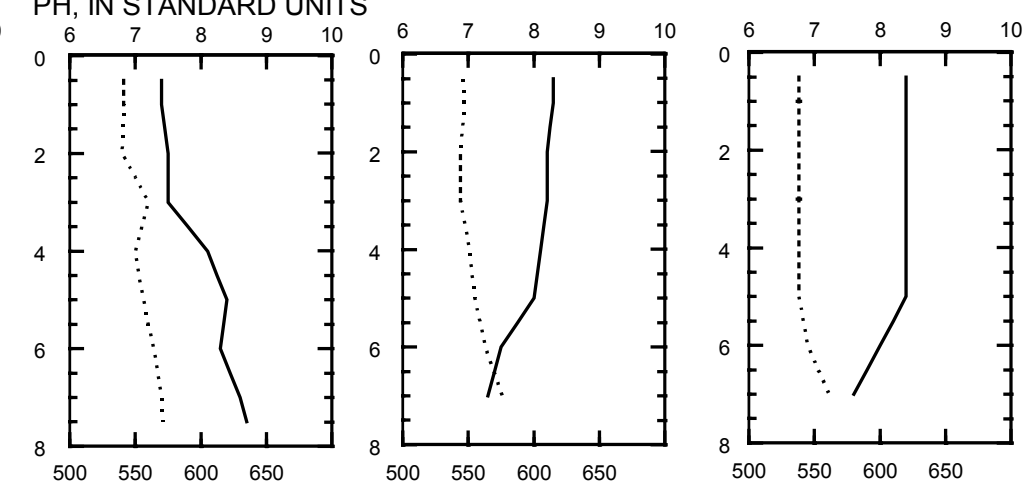

SPECIFIC CONDUCTANCE (S.C.), IN MICROSIEMENS PER CENTIMETER AT 25 DEGREES CELSIUS 

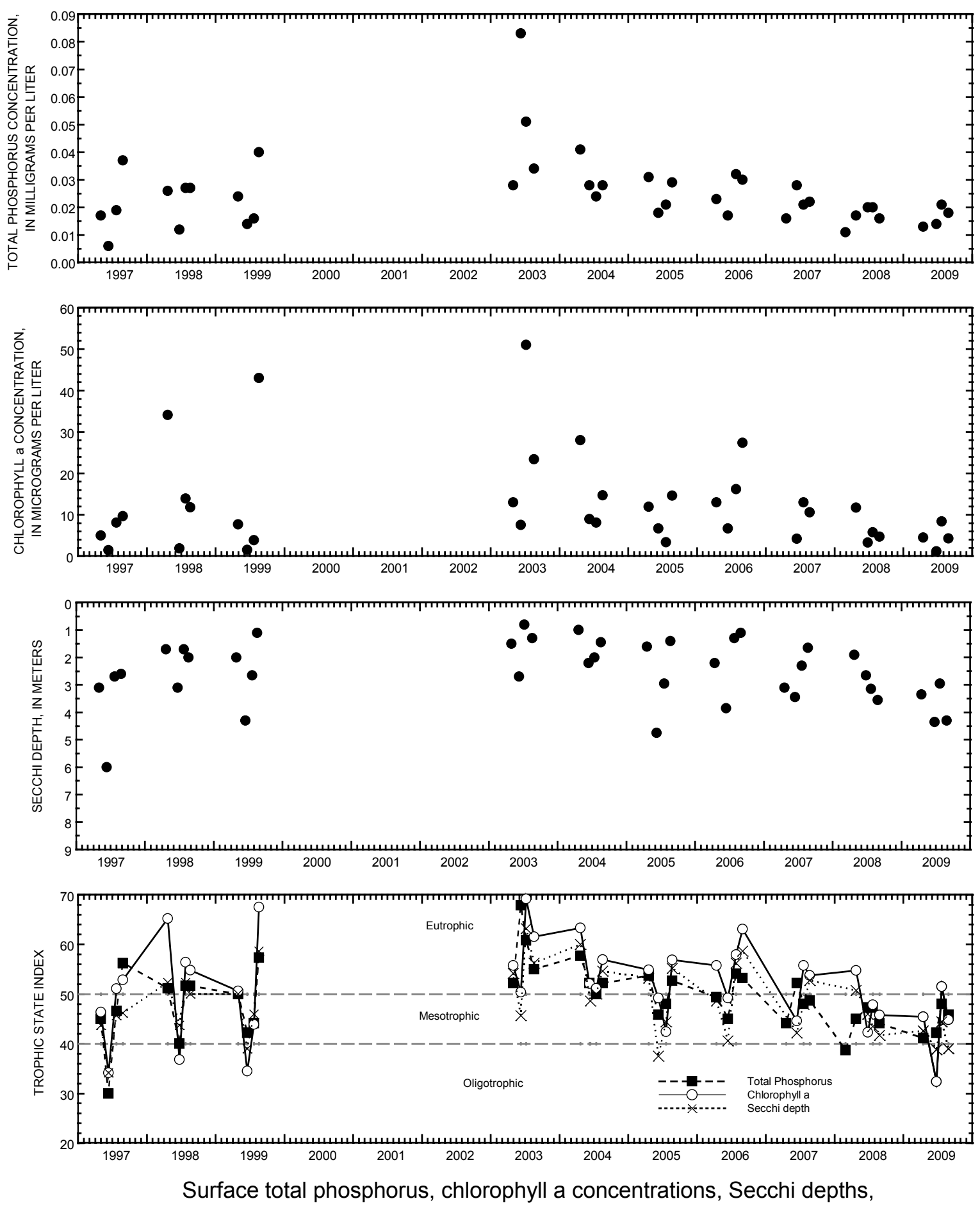
and TSI data for Little Cedar Lake, North Site, near West Bend, Wisconsin. 


\section{LITTLE CEDAR LAKE, SOUTH SITE, NEAR WEST BEND, W}

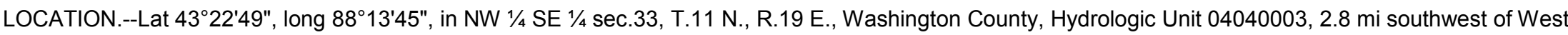
Bend.

SURFACE AREA.--0.38 $\mathrm{mi}^{2}$.

PERIOD OF RECORD.--February 1997 to August 1999, February 2003 to current year.

REMARKS.--Lake sampled in southern basin at deep hole. Lake ice-covered during February sampling. Water-quality analyses done by Wisconsin State Laboratory of Hygiene.

WATER-QUALITY DATA, FEBRUARY 19 TO AUGUST 27, 2009

(Milligrams per liter unless otherwise indicated)

\begin{tabular}{|c|c|}
\hline Parameter Code & Parameter Name \\
\hline 32210 & $\overline{\text { Chlorophyll a, phytoplankton ( } \mu \mathrm{g} / \mathrm{L})}$ \\
\hline 00078 & Secchi-depth $(m)$ \\
\hline 00098 & Sampling depth (m) \\
\hline 00010 & Water Temperature $\left({ }^{\circ} \mathrm{C}\right)$ \\
\hline 00400 & $\mathrm{pH}$ (standard units) \\
\hline 00095 & Specific conductance $(\mu \mathrm{S} / \mathrm{cm})$ \\
\hline 00300 & Dissolved oxygen \\
\hline 00665 & Phosphorus, total (as P) \\
\hline 00671 & Orthophosphate, dissolved (as P) \\
\hline 00631 & Nitrate plus nitrite, dissolved (as $\mathrm{N}$ ) \\
\hline 00608 & Ammonia, dissolved (as $\mathrm{N}$ ) \\
\hline 00625 & Ammonia plus organic nitrogen, total (as $\mathrm{N}$ ) \\
\hline 00623 & Ammonia plus organic nitrogen, dissolved (as $\mathrm{N}$ ) \\
\hline 00600 & Total nitrogen \\
\hline 63675 & Turbidity, (NTU) \\
\hline 00081 & Apparent color, (PTU) \\
\hline 00900 & Hardness (as $\mathrm{CaCO} 3$ ) \\
\hline 00915 & Calcium, dissolved $(\mathrm{Ca})$ \\
\hline 00925 & Magnesium, dissolved (Mg) \\
\hline 00930 & Sodium, dissolved $(\mathrm{Na})$ \\
\hline 00935 & Potassium, dissolved (K) \\
\hline 00417 & ANC (as CaCO3) \\
\hline 00940 & Chloride, dissolved (Cl) \\
\hline 00945 & Sulfate, dissolved (SO4) \\
\hline 00955 & Silica, dissolved (SiO2) \\
\hline 01046 & Iron $(\mu \mathrm{g} / \mathrm{L})$ \\
\hline 01056 & Manganese ( $\mu \mathrm{g} / \mathrm{L})$ \\
\hline 70300 & Solids, dissolved (at $180^{\circ} \mathrm{C}$ ) \\
\hline
\end{tabular}

\begin{tabular}{|c|c|c|c|c|c|c|c|c|c|}
\hline \multicolumn{2}{|c|}{ Feb. 19} & \multicolumn{2}{|c|}{ April 16} & \multicolumn{2}{|c|}{$\underline{\text { June } 25}$} & \multicolumn{2}{|c|}{ July 22} & \multicolumn{2}{|c|}{ August 27} \\
\hline \multicolumn{2}{|c|}{--} & \multicolumn{2}{|c|}{6.14} & \multicolumn{2}{|c|}{0.95} & \multicolumn{2}{|c|}{1.82} & \multicolumn{2}{|c|}{2.53} \\
\hline \multicolumn{2}{|c|}{-- } & \multicolumn{2}{|c|}{3.6} & \multicolumn{2}{|c|}{10.2} & \multicolumn{2}{|c|}{5.8} & \multicolumn{2}{|c|}{5.2} \\
\hline 0.5 & 14.0 & 0.5 & 17.0 & 0.5 & 16.5 & 0.5 & 16.0 & 0.5 & 16.0 \\
\hline 1.4 & 3.5 & 8.3 & 6.2 & 28.1 & 8.2 & 21.9 & 8.1 & 22.2 & 8.6 \\
\hline 7.8 & 7.5 & 8.2 & 8.2 & 7.4 & 8.4 & 8.2 & 7.2 & 8.7 & 7.4 \\
\hline 499 & 629 & 530 & 528 & 550 & 552 & 544 & 564 & 533 & 569 \\
\hline 12.2 & 0.4 & 13.5 & 12.5 & 7.4 & 2.6 & 8.8 & 0.0 & 8.4 & 0.0 \\
\hline 0.015 & 0.084 & 0.016 & 0.015 & 0.013 & 0.024 & 0.013 & 0.026 & 0.009 & 0.173 \\
\hline-- & -- & $<.002$ & -- & -- & -- & 0.004 & -- & -- & -- \\
\hline-- & -- & 0.184 & -- & -- & -- & $<.019$ & -- & -- & -- \\
\hline-- & -- & $<.015$ & -- & -- & -- & $<.015$ & -- & -- & -- \\
\hline-- & -- & 0.45 & -- & -- & -- & -- & -- & -- & -- \\
\hline-- & -- & -- & -- & -- & -- & 0.78 & -- & -- & -- \\
\hline-- & -- & 0.63 & -- & -- & -- & -- & -- & -- & -- \\
\hline-- & -- & $<1.0$ & -- & -- & -- & -- & -- & -- & -- \\
\hline-- & -- & 5 & -- & -- & -- & -- & -- & -- & -- \\
\hline-- & -- & 240 & -- & -- & -- & -- & -- & -- & -- \\
\hline-- & -- & 39.7 & -- & -- & -- & -- & -- & -- & -- \\
\hline-- & -- & 34.4 & -- & -- & -- & -- & -- & -- & -- \\
\hline-- & -- & 23.9 & -- & -- & -- & -- & -- & -- & -- \\
\hline-- & -- & 1.8 & -- & -- & -- & -- & -- & -- & -- \\
\hline-- & -- & 191 & -- & -- & -- & -- & -- & -- & -- \\
\hline-- & -- & 50.5 & -- & -- & -- & -- & -- & -- & -- \\
\hline-- & -- & 20.3 & -- & -- & -- & -- & -- & -- & -- \\
\hline-- & -- & 2.32 & -- & -- & -- & -- & -- & -- & -- \\
\hline-- & -- & $<100$ & -- & -- & -- & -- & -- & -- & -- \\
\hline-- & -- & $<1.0$ & -- & -- & -- & -- & -- & -- & -- \\
\hline-- & -- & 296 & -- & -- & -- & -- & -- & -- & -- \\
\hline
\end{tabular}


432249088134500 LITTLE CEDAR LAKE, SOUTH SITE, NEAR WEST BEND, WI

LAKE-DEPTH PROFILES, FEBRUARY 19 TO AUGUST 27, 2009

02-19-09
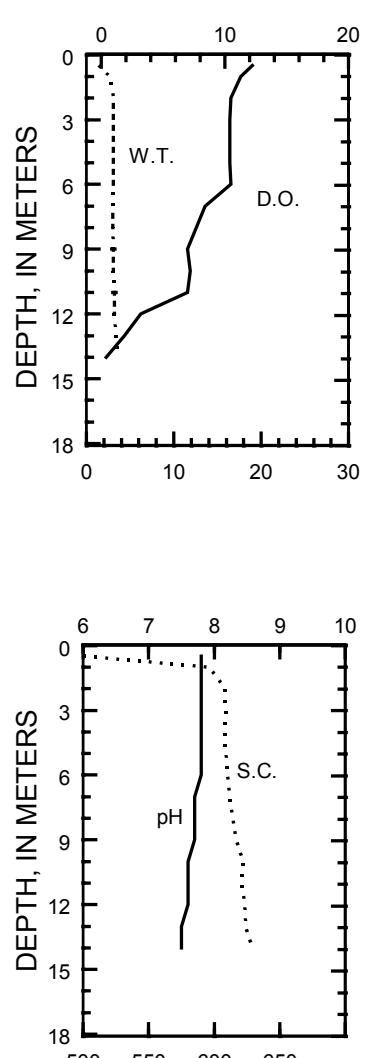

$500 \quad 550 \quad 600 \quad 650$

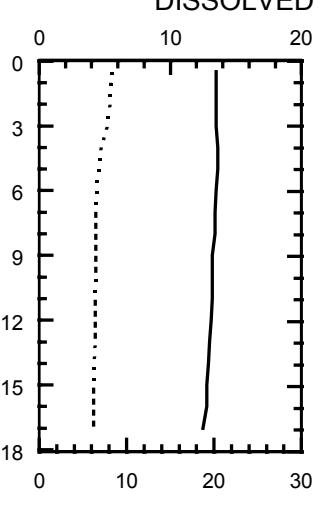

06-25-09

07-22-09

08-27-09

WATER TEMPERATURE (W.T.), IN DEGREES CELSIUS
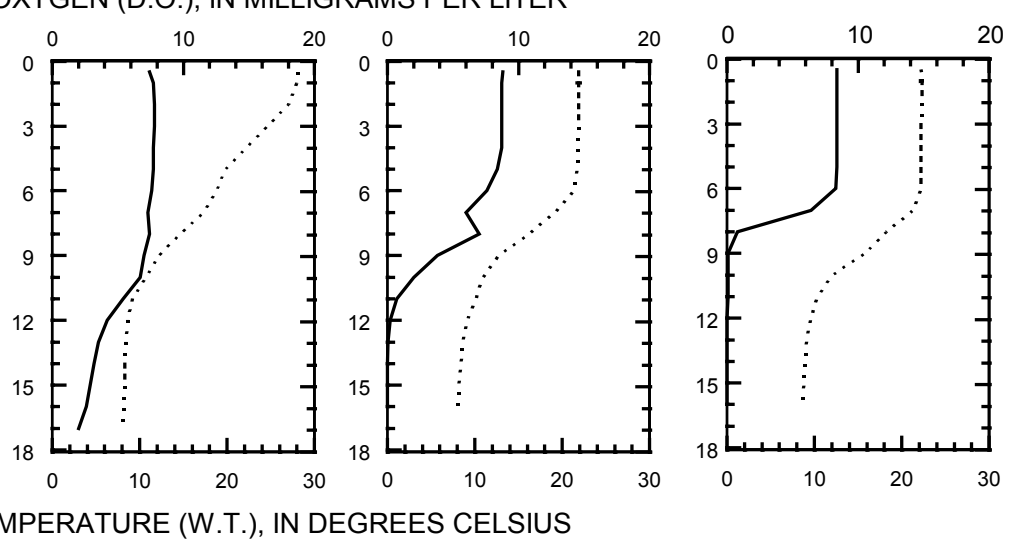

$\mathrm{PH}$, IN STANDARD UNITS
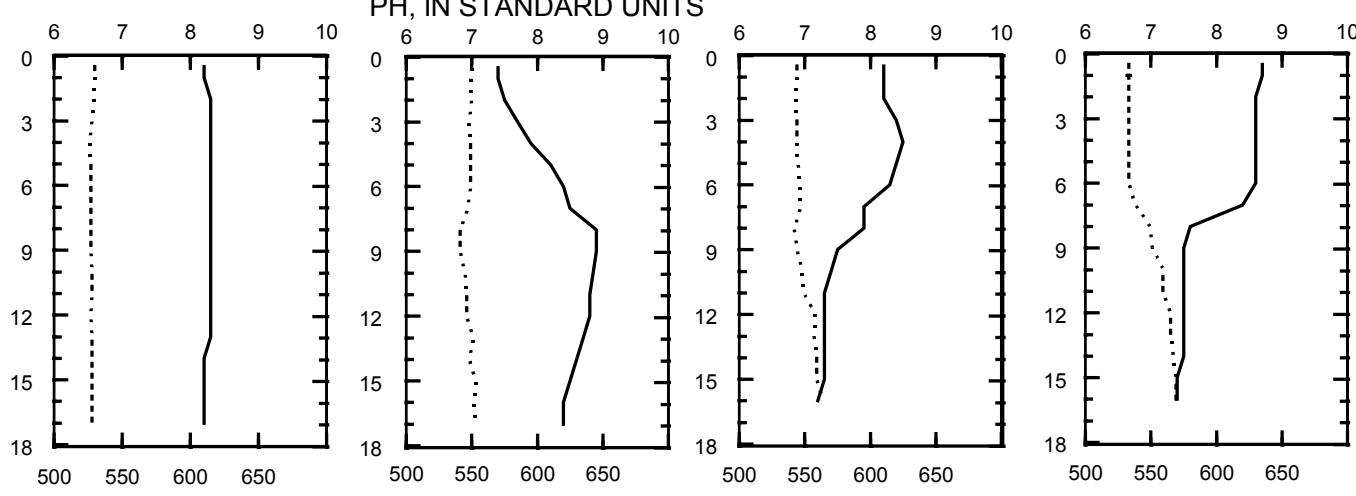

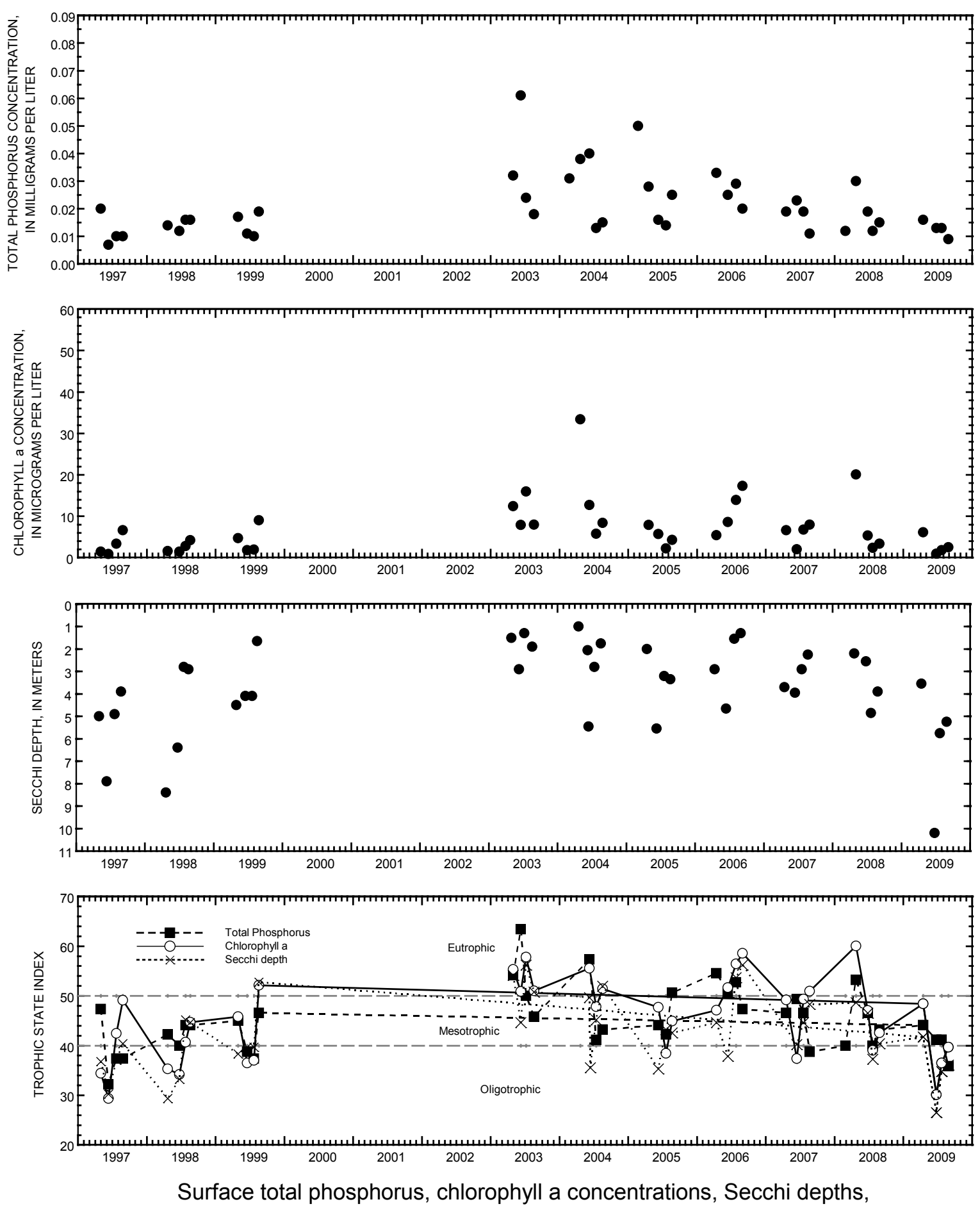
and TSI data for Little Cedar Lake, South Site, near West Bend, Wisconsin. 


\section{LAKE MENDOTA AT MADISON, WI}

LOCATION.--Lat 4305'42", long 89²2'12" referenced to North American Datum of 1927, in NW 1/4 SE 1/4 sec.12, T.7 N., R.9 E., Dane County, WI, Hydrologic Unit 07090001, in county boat house at dam at outlet, in Madison.

SURFACE AREA.-15.2 $\mathrm{mi}^{2}$.

DRAINAGE AREA.--233 $\mathrm{mi}^{2}$ of which $36.6 \mathrm{mi}^{2}$ probably is noncontributing.

PERIOD OF RECORD.--January 1916 to January 1985 (incomplete), February 1985 to current year.

REVISED RECORDS.--WDR WI-73-1: Drainage area.

GAGE.--Water-stage recorder. Datum of gage is $840.00 \mathrm{ft}$ above NGVD of 1929 , or $5.60 \mathrm{ft}$ below City of Madison datum. Prior to Oct. 1 , 1979, gage datum was $847.82 \mathrm{ft}$; prior to Nov. 15, 1971, nonrecording gage at same site.

REMARKS.--Lake level regulated by concrete dam with two 12-foot gates and 20-foot lock at outlet. Gage-height telemeter at station.

EXTREMES FOR PERIOD OF RECORD.--Maximum gage height observed, $12.75 \mathrm{ft}$, June 5, 2000; minimum observed, $8.02 \mathrm{ft}$, Feb. 24 to Mar. 10, 1920, current datum.

EXTREMES FOR CURRENT YEAR.--Maximum recorded gage height, $10.99 \mathrm{ft}$, April 1; minimum recorded, $8.30 \mathrm{ft}$, Feb. 7, 9.

\begin{tabular}{|c|c|c|c|c|c|c|c|c|c|c|c|c|}
\hline \multicolumn{13}{|c|}{$\begin{array}{c}\text { GAGE HEIGHT, FEET } \\
\text { WATER YEAR OCTOBER } 2008 \text { TO SEPTEMBER } 2009 \\
\text { DAILY MEAN VALUES }\end{array}$} \\
\hline \multicolumn{13}{|c|}{$[e$, estimated $]$} \\
\hline Day & Oct & Nov & Dec & Jan & Feb & Mar & Apr & May & Jun & Jul & Aug & Sep \\
\hline 1 & 9.98 & 9.75 & 8.99 & 8.70 & 8.37 & 9.46 & 10.94 & 10.56 & 10.06 & 10.16 & 9.99 & 10.01 \\
\hline 2 & 9.96 & 9.72 & 8.87 & 8.69 & 8.36 & 9.50 & 10.94 & 10.55 & 10.02 & 10.14 & 9.97 & 10.00 \\
\hline 3 & 9.93 & 9.70 & 8.86 & 8.67 & 8.35 & 9.52 & 10.94 & 10.53 & 9.99 & 10.12 & 9.95 & 10.0 \\
\hline 4 & 9.92 & 9.69 & 8.83 & 8.67 & 8.35 & 9.53 & 10.92 & 10.50 & 9.95 & 10.11 & 9.96 & 9.99 \\
\hline 5 & 9.91 & 9.66 & $\mathrm{e} 8.82$ & 8.65 & 8.34 & 9.55 & 10.89 & 10.46 & 9.92 & 10.11 & 9.95 & 9.98 \\
\hline 6 & 9.90 & 9.66 & $\mathrm{e} 8.81$ & 8.64 & 8.33 & 9.59 & 10.87 & 10.42 & 9.89 & 10.10 & 9.94 & 9.97 \\
\hline 7 & 9.92 & 9.66 & $\mathrm{e} 8.77$ & 8.63 & 8.33 & 9.70 & 10.82 & 10.42 & 9.86 & 10.07 & 9.93 & 9.96 \\
\hline 8 & 10.01 & 9.66 & $\mathrm{e} 8.76$ & 8.61 & 8.35 & 9.93 & 10.75 & 10.39 & 10.02 & 10.05 & 10.00 & 9.95 \\
\hline 9 & 10.01 & 9.63 & $\mathrm{e} 8.75$ & 8.61 & 8.38 & 10.21 & 10.70 & 10.50 & 10.06 & 10.04 & 10.07 & 9.94 \\
\hline 10 & 10.0 & 9.58 & $\mathrm{e} 8.74$ & 8.60 & 8.46 & 10.48 & 10.65 & 10.53 & 10.06 & 10.04 & 10.10 & 9.93 \\
\hline 11 & 9.99 & 9.55 & e8.73 & 8.58 & 8.63 & 10.68 & 10.59 & 10.51 & 10.05 & 10.07 & 10.11 & 9.92 \\
\hline 12 & 9.99 & 9.55 & $\mathrm{e} 8.72$ & 8.57 & 8.77 & 10.77 & 10.53 & 10.46 & 10.04 & 10.05 & 10.11 & 9.91 \\
\hline 13 & 9.99 & 9.54 & $\mathrm{e} 8.70$ & 8.56 & 8.85 & 10.81 & 10.47 & 10.44 & 10.04 & 10.04 & 10.10 & 9.90 \\
\hline 14 & 9.99 & 9.56 & $\mathrm{e} 8.68$ & 8.55 & 8.88 & 10.79 & 10.42 & 10.54 & 10.03 & 10.00 & 10.09 & 9.89 \\
\hline 15 & 9.99 & 9.54 & e8.67 & 8.54 & 8.89 & 10.77 & 10.35 & 10.55 & 10.00 & 10.02 & 10.08 & 9.88 \\
\hline 16 & 9.98 & 9.50 & e8.67 & 8.53 & 8.88 & 10.74 & 10.30 & 10.56 & 9.97 & 10.01 & 10.07 & 9.86 \\
\hline 17 & 9.97 & 9.46 & $\mathrm{e} 8.67$ & 8.50 & 8.87 & 10.71 & 10.24 & 10.50 & 9.98 & 9.98 & 10.08 & 9.85 \\
\hline 18 & 9.95 & 9.40 & $\mathrm{e} 8.67$ & 8.49 & 8.89 & 10.69 & 10.19 & 10.45 & 9.98 & 9.96 & 10.09 & 9.84 \\
\hline 19 & 9.93 & 9.36 & e8.66 & 8.47 & 8.88 & 10.66 & 10.16 & 10.41 & 10.16 & 9.94 & 10.06 & 9.83 \\
\hline 20 & 9.93 & 9.34 & $\mathrm{e} 8.66$ & 8.46 & 8.88 & 10.62 & 10.18 & 10.37 & 10.26 & 9.93 & 10.09 & 9.82 \\
\hline 21 & 9.91 & 9.27 & $\mathrm{e} 8.66$ & 8.44 & 8.91 & 10.58 & 10.18 & 10.34 & 10.29 & 9.94 & 10.09 & 9.83 \\
\hline 22 & 9.88 & 9.21 & $\mathrm{e} 8.65$ & 8.43 & 8.93 & 10.54 & 10.13 & 10.31 & 10.30 & 9.99 & 10.07 & 9.98 \\
\hline 23 & 9.86 & 9.17 & e8.65 & 8.42 & 8.94 & 10.51 & 10.08 & 10.28 & 10.32 & 10.0 & 10.06 & 10.19 \\
\hline 24 & 9.89 & 9.17 & $\mathrm{e} 8.65$ & 8.41 & 8.94 & 10.59 & 10.03 & 10.26 & 10.32 & 10.00 & 10.05 & 10.24 \\
\hline 25 & 9.90 & 9.13 & $\mathrm{e} 8.65$ & 8.41 & 8.95 & 10.78 & 10.06 & 10.20 & 10.32 & 10.02 & 10.04 & 10.25 \\
\hline 26 & 9.91 & 9.08 & $\mathrm{e} 8.65$ & 8.40 & 9.01 & 10.84 & 10.31 & 10.17 & 10.31 & 10.01 & 10.04 & 10.26 \\
\hline 27 & 9.87 & 9.06 & e8.66 & 8.40 & 9.23 & 10.86 & 10.46 & 10.19 & 10.27 & 10.00 & 10.03 & 10.27 \\
\hline 28 & 9.84 & 9.02 & $\mathrm{e} 8.67$ & 8.39 & 9.38 & 10.88 & 10.51 & 10.19 & 10.27 & 10.01 & 10.04 & 10.33 \\
\hline 29 & 9.82 & 8.97 & e8.68 & 8.39 & --- & 10.90 & 10.52 & 10.16 & 10.23 & 9.99 & 10.06 & 10.25 \\
\hline 30 & 9.79 & 8.96 & 8.70 & 8.38 & --- & 10.88 & 10.54 & 10.13 & 10.19 & 10.0 & 10.03 & 10.21 \\
\hline 31 & 9.77 & --- & 8.70 & 8.37 & --- & 10.91 & --- & 10.09 & --- & 10.0 & 10.01 & --- \\
\hline Mean & 9.93 & 9.42 & 8.72 & 8.52 & 8.73 & 10.42 & 10.49 & 10.39 & 10.11 & 10.03 & 10.04 & 10.01 \\
\hline Max & 10.01 & 9.75 & 8.99 & 8.70 & 9.38 & 10.91 & 10.94 & 10.56 & 10.32 & 10.16 & 10.11 & 10.33 \\
\hline Min & 9.77 & 8.96 & 8.65 & 8.37 & 8.33 & 9.46 & 10.03 & 10.09 & 9.86 & 9.93 & 9.93 & 9.82 \\
\hline
\end{tabular}


460937090033100 MERCER LAKE, DEEP HOLE, AT MERCER, WI

LOCATION.--Lat 4609'37", long 9003'31", in SW 1/4 SE 1/4 NW 1/4 sec.36, T.43 N., R.3 E., Iron County, Hydrologic Unit 07050002, at Minocqua.

SURFACE AREA. $-0.29 \mathrm{mi}^{2}$.

PERIOD OF RECORD._March 2008 to September 2009 (discontinued).

REMARKS.--Lake sampled in the east basin at the deep hole. Water-quality analyses done by Wisconsin State Laboratory of Hygiene.

WATER-QUALITY DATA, MARCH 23 TO AUGUST 5, 2009

(Milligrams per liter unless otherwise indicated)

\begin{tabular}{|c|c|c|c|c|c|c|c|c|c|c|}
\hline Parameter Code & Parameter Name & \multicolumn{2}{|c|}{ Mar. 23} & Apr. 28 & June 16 & \multicolumn{2}{|c|}{ June 29} & \multicolumn{3}{|c|}{ Aug. 5} \\
\hline 00078 & Secchi-depth (m) & \multicolumn{2}{|c|}{1.9} & 2.1 & 2.7 & \multicolumn{2}{|c|}{2.3} & & 3.2 & \\
\hline 00098 & Sampling depth (m) & 1.0 & 5.5 & 0.5 & 0.5 & 0.5 & 6.0 & 0.5 & 5.0 & 5.5 \\
\hline 00010 & Water Temperature $\left({ }^{\circ} \mathrm{C}\right)$ & 5.1 & 4.8 & 7.3 & 19.9 & 20.5 & 14.1 & 20.1 & 18.9 & 18.5 \\
\hline 00400 & $\mathrm{pH}$ (standard units) & 7.3 & 7.2 & 7.3 & 8.0 & 8.1 & 7.2 & 7.9 & 7.2 & 6.9 \\
\hline 00095 & Specific conductance $(\mu \mathrm{S} / \mathrm{cm})$ & 234 & 297 & 204 & 200 & 191 & 239 & 195 & 201 & 207 \\
\hline 00300 & Dissolved oxygen & 5.3 & 0.1 & 9.8 & 10.0 & 6.9 & 0.7 & 8.6 & 5.8 & 4.3 \\
\hline 32210 & Chlorophyll a, phytoplankton ( $\mu \mathrm{g} / \mathrm{L})$ & -- & -- & 4.24 & 2.72 & 4.23 & -- & 1.7 & -- & -- \\
\hline 00665 & Phosphorus, total (as P) & 0.026 & 0.017 & 0.030 & 0.040 & 0.048 & 0.053 & 0.023 & 0.024 & 0.142 \\
\hline 00671 & Orthophosphate, dissolved (as P) & -- & -- & 0.005 & -- & -- & -- & -- & -- & -- \\
\hline 00631 & Nitrate plus nitrite, dissolved (as N) & -- & -- & $<.019$ & -- & -- & -- & -- & -- & -- \\
\hline 00608 & Ammonia, dissolved (as N) & -- & -- & 0.022 & -- & -- & -- & -- & -- & -- \\
\hline 00625 & Ammonia plus organic nitrogen, total (as $\mathrm{N}$ ) & -- & -- & 0.59 & -- & -- & -- & -- & -- & -- \\
\hline 63675 & Turbidity, (NTU) & -- & -- & 2.4 & -- & -- & -- & -- & -- & -- \\
\hline 00081 & Apparent color, (PTU) & -- & -- & 10 & -- & -- & -- & -- & -- & -- \\
\hline 00900 & Hardness (as $\mathrm{CaCO} 3$ ) & -- & -- & 97 & -- & -- & -- & -- & -- & -- \\
\hline 00915 & Calcium, dissolved $(\mathrm{Ca})$ & -- & -- & 27.4 & -- & -- & -- & -- & -- & -- \\
\hline 00925 & Magnesium, dissolved (Mg) & -- & -- & 6.9 & -- & -- & -- & -- & -- & -- \\
\hline 00930 & Sodium, dissolved $(\mathrm{Na})$ & -- & -- & 6.1 & -- & -- & -- & -- & -- & -- \\
\hline 00935 & Potassium, dissolved (K) & -- & -- & 1.3 & -- & -- & -- & -- & -- & -- \\
\hline 00417 & $\mathrm{ANC}$ (as $\mathrm{CaCO} 3)$ & -- & -- & 84 & -- & -- & -- & -- & -- & -- \\
\hline 00940 & Chloride, dissolved (Cl) & -- & -- & 12.6 & -- & -- & -- & -- & -- & -- \\
\hline 00945 & Sulfate, dissolved (SO4) & -- & -- & $<4.5$ & -- & -- & -- & -- & -- & -- \\
\hline 00955 & Silica, dissolved (SiO2) & -- & -- & 13.4 & -- & -- & -- & -- & -- & -- \\
\hline 01046 & Iron $(\mu \mathrm{g} / \mathrm{L})$ & -- & -- & $<100$ & -- & -- & -- & -- & -- & -- \\
\hline 01056 & Manganese ( $\mu \mathrm{g} / \mathrm{L})$ & -- & -- & 100 & -- & -- & -- & -- & -- & -- \\
\hline 70300 & Solids, dissolved (at $180^{\circ} \mathrm{C}$ ) & -- & -- & 134 & -- & -- & -- & -- & -- & -- \\
\hline
\end{tabular}


460937090033100 MERCER LAKE, DEEP HOLE, AT MERCER, WI

WATER-QUALITY DATA, AUGUST 19 TO SEPTEMBER 16, 2009

(Milligrams per liter unless otherwise indicated)

\begin{tabular}{|c|c|}
\hline Parameter Code & $\underline{\text { Parameter Name }}$ \\
\hline 00078 & Secchi-depth (m) \\
\hline 00098 & Sampling depth (m) \\
\hline 00010 & Water Temperature $\left({ }^{\circ} \mathrm{C}\right)$ \\
\hline 00400 & $\mathrm{pH}$ (standard units) \\
\hline 00095 & Specific conductance $(\mu \mathrm{S} / \mathrm{cm})$ \\
\hline 00300 & Dissolved oxygen \\
\hline 32210 & Chlorophyll a, phytoplankton ( $\mu \mathrm{g} / \mathrm{L})$ \\
\hline 00665 & Phosphorus, total (as P) \\
\hline
\end{tabular}

\begin{tabular}{cc}
\multicolumn{2}{c}{$\frac{\text { Aug. } 19}{3.1}$} \\
0.5 & \\
21.9 & 5.5 \\
7.8 & 18.9 \\
182 & 6.8 \\
7.8 & 210 \\
2.49 & 2.5 \\
0.037 & -- \\
& 0.035
\end{tabular}

Sept. 2

Sept. 16

0.5

$0.5 \quad 5$

$19.3 \quad 17.9$

17.9

7.8

192

9.3

0.037

0.035

0.024 
460937090033100 MERCER LAKE, DEEP HOLE, AT MERCER, WI

LAKE-DEPTH PROFILES, MARCH 23 TO JUNE 29, 2009

03-23-09
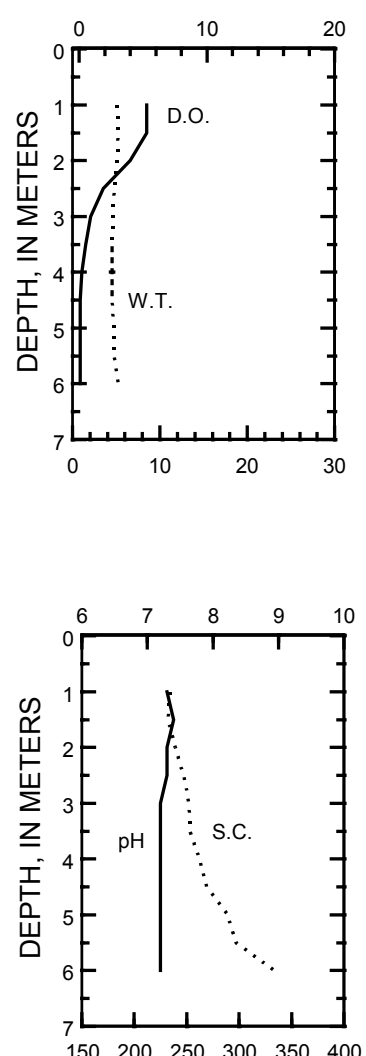

04-28-09

DISSOLVED OXYGEN (D.O.), IN MILLIGRAMS PER LITER
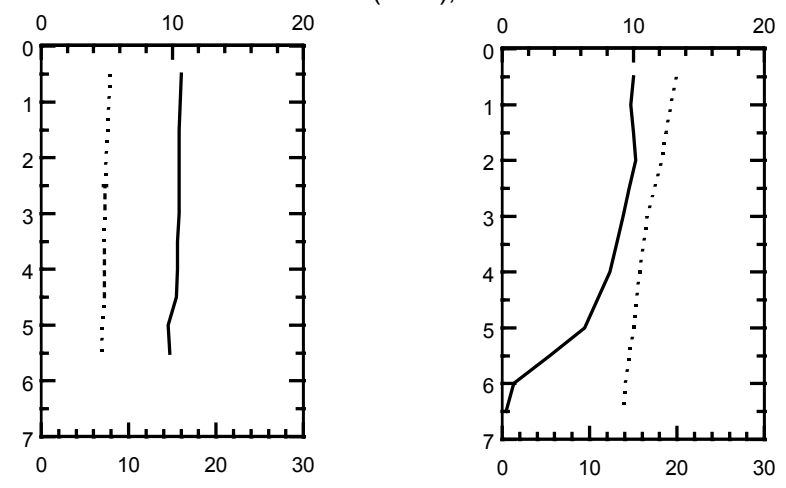

WATER TEMPERATURE (W.T.), IN DEGREES CELSIUS

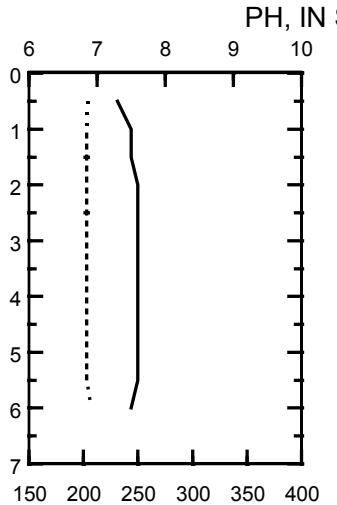

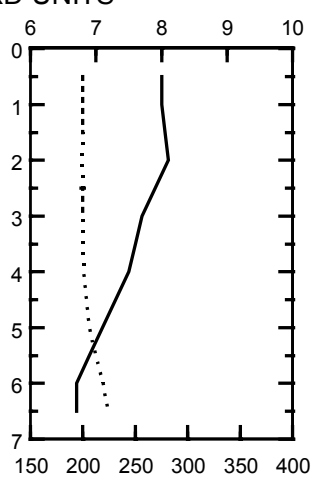

06-29-09
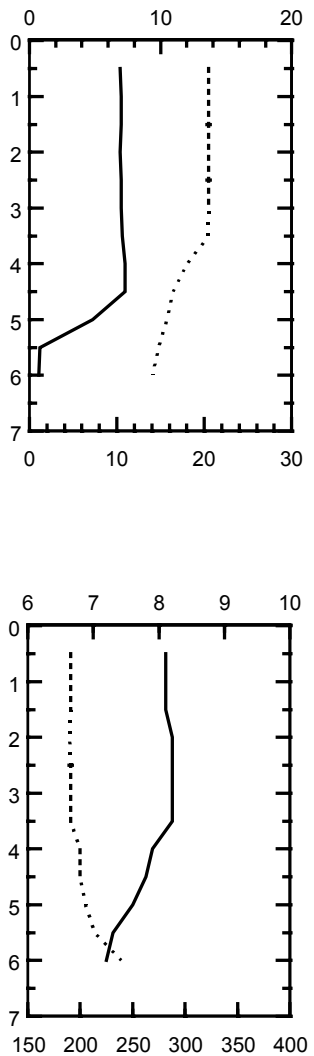

SPECIFIC CONDUCTANCE (S.C.), IN MICROSIEMENS PER CENTIMETER AT 25 DEGREES CELSIUS 
460937090033100 MERCER LAKE, DEEP HOLE, AT MERCER, WI

LAKE-DEPTH PROFILES, AUGUST 5 TO SEPTEMBER 16, 2009

08-05-09
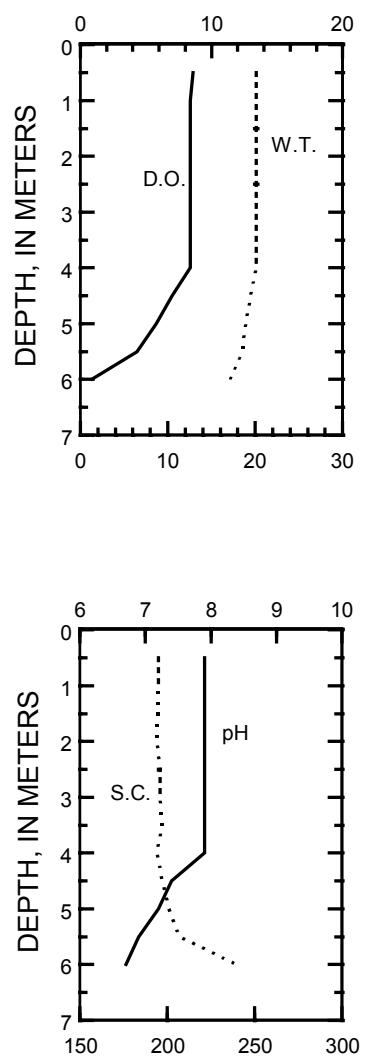

08-19-09

09-02-09

DISSOLVED OXYGEN (D.O.), IN MILLIGRAMS PER LITER
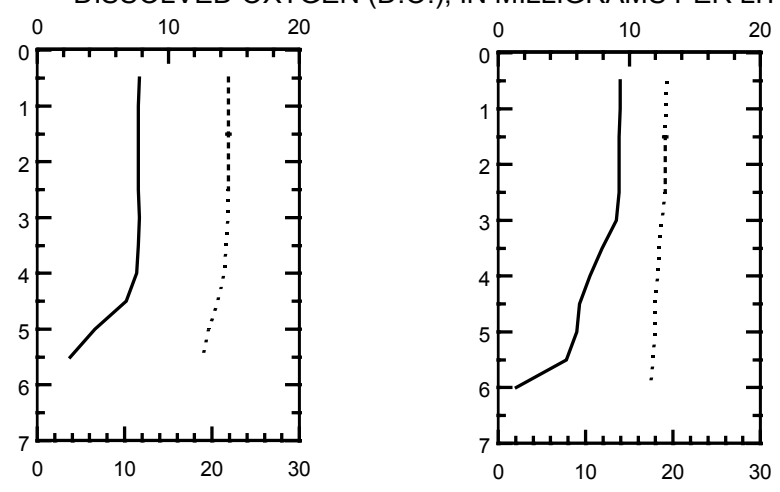

WATER TEMPERATURE (W.T.), IN DEGREES CELSIUS
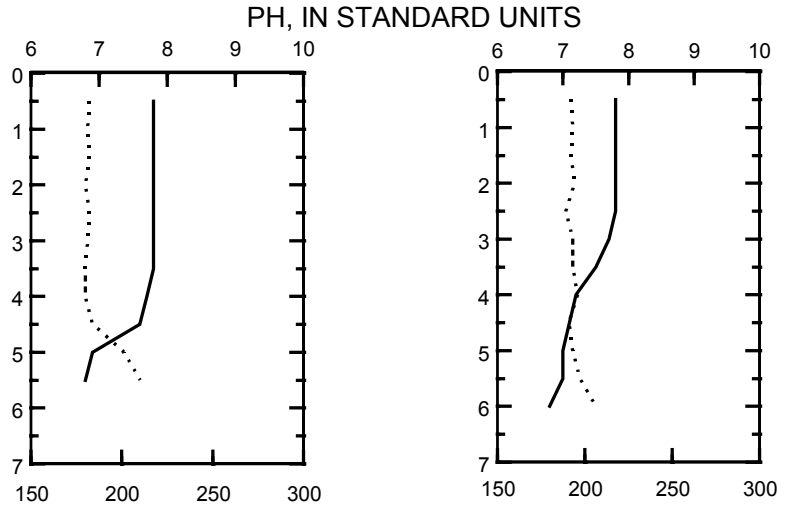

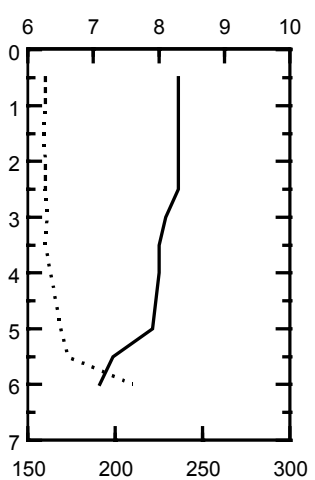

SPECIFIC CONDUCTANCE (S.C.), IN MICROSIEMENS PER CENTIMETER AT 25 DEGREES CELSIUS 

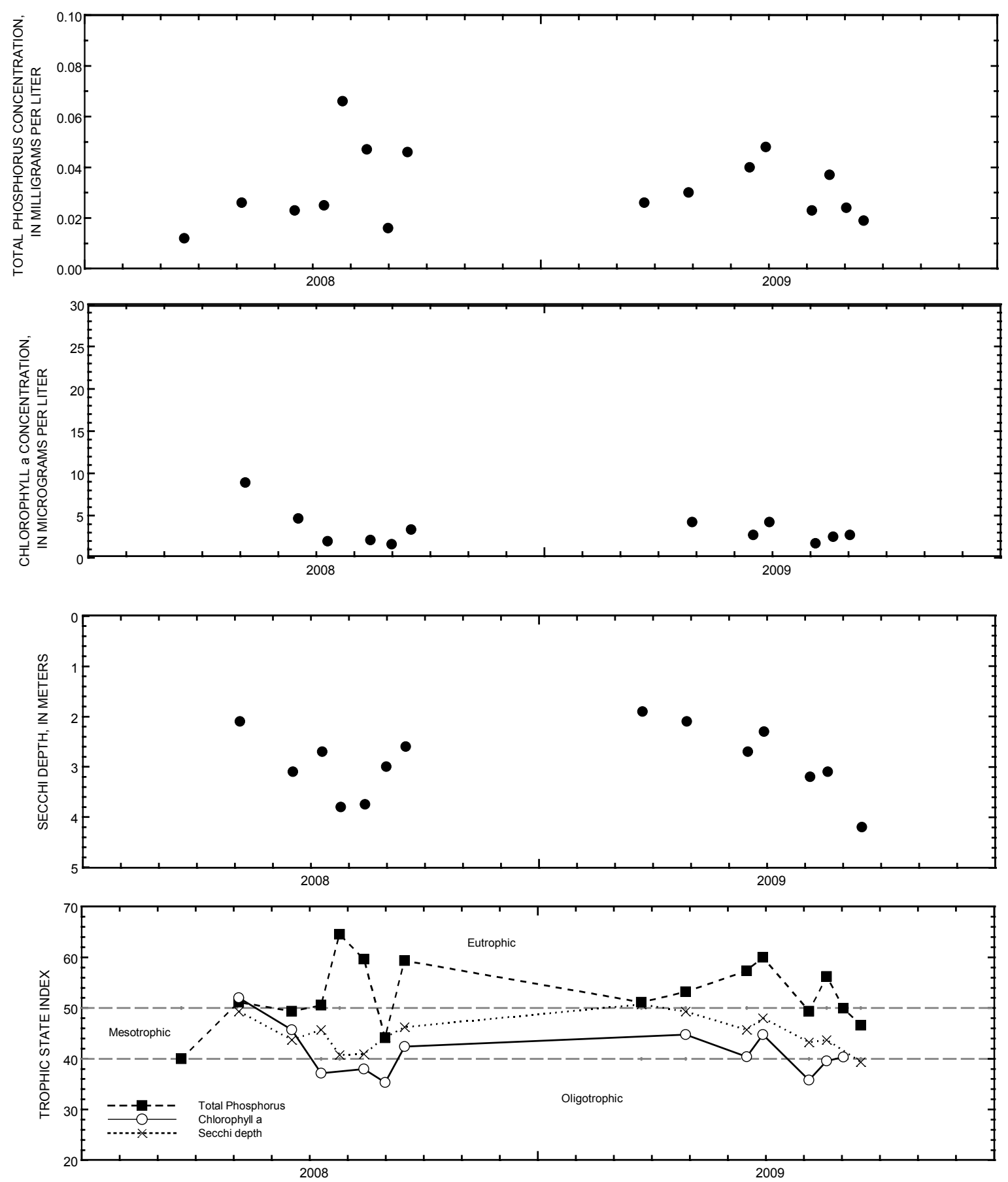

Surface total phosphorus, chlorophyll a concentrations, Secchi depths, and TSI data for Mercer Lake, Deep Hole, at Mercer, Wisconsin. 


\section{MERCER LAKE, WEST BASIN, AT MERCER, WI}

LOCATION.--Lat 4609'45", long 9004'06", in SW 1/4 SE 1/4 NW 1/4 sec.36, T.43 N., R.3 E., Iron County, Hydrologic Unit 07050002, at Mercer.

SURFACE AREA.- $-0.29 \mathrm{mi}^{2}$.

PERIOD OF RECORD.-March 2008 to current year.

REMARKS.--Lake sampled in the west basin. Water-quality analyses done by Wisconsin State Laboratory of Hygiene.

WATER-QUALITY DATA, MARCH 23 TO SEPTEMBER 16, 2009

(Milligrams per liter unless otherwise indicated)

\begin{tabular}{|c|c|}
\hline Parameter Code & Parameter Name \\
\hline 00078 & Secchi-depth $(\mathrm{m})$ \\
\hline 00098 & Sampling depth (m) \\
\hline 00010 & Water Temperature $\left({ }^{\circ} \mathrm{C}\right)$ \\
\hline 00400 & $\mathrm{pH}$ (standard units) \\
\hline 00095 & Specific conductance $(\mu \mathrm{S} / \mathrm{cm})$ \\
\hline 00300 & Dissolved oxygen \\
\hline 32210 & Chlorophyll a, phytoplankton ( $\mu \mathrm{g} / \mathrm{L})$ \\
\hline 00665 & Phosphorus, total (as P) \\
\hline Parameter Code & Parameter Name \\
\hline 00078 & Secchi-depth $(m)$ \\
\hline 00098 & Sampling depth $(\mathrm{m})$ \\
\hline 00010 & Water Temperature $\left({ }^{\circ} \mathrm{C}\right)$ \\
\hline 00400 & $\mathrm{pH}$ (standard units) \\
\hline 00095 & Specific conductance $(\mu \mathrm{S} / \mathrm{cm})$ \\
\hline 00300 & Dissolved oxygen \\
\hline 32210 & Chlorophyll a, phytoplankton ( $\mu \mathrm{g} / \mathrm{L}$ \\
\hline 00665 & Phosphorus, total (as $\mathrm{P}$ ) \\
\hline
\end{tabular}

\begin{tabular}{|c|c|c|c|}
\hline \multicolumn{2}{|c|}{ March 23} & Apr. 28 & June 16 \\
\hline \multicolumn{2}{|c|}{1.8} & 2.1 & 2.7 \\
\hline 1.0 & 5.5 & 0.5 & 0.5 \\
\hline 4.2 & 4.6 & 7.9 & 20.2 \\
\hline 7.3 & 7.3 & 7.7 & 8.0 \\
\hline 191 & 381 & 201 & 199 \\
\hline -- & 0.4 & 10.7 & 9.2 \\
\hline -- & -- & 4.84 & 3.16 \\
\hline 0.026 & 0.134 & 0.024 & 0.039 \\
\hline
\end{tabular}

\begin{tabular}{cc}
\multicolumn{2}{c}{ June 29 } \\
2.3 \\
0.5 & 5.5 \\
20.3 & 14.7 \\
8.2 & 7.3 \\
188 & 201 \\
6.8 & 0.0 \\
5.08 & -- \\
0.026 & 0.054
\end{tabular}

\begin{tabular}{cc}
\multicolumn{2}{c}{ Aug. 5} \\
3.1 & \\
0.5 & 5.5 \\
20.0 & 18.0 \\
8.0 & 6.7 \\
191 & 202 \\
8.8 & 1.8 \\
1.41 & -- \\
0.020 & 0.025
\end{tabular}

\begin{tabular}{|c|c|}
\hline \multicolumn{2}{|c|}{ Aug. 19} \\
\hline 0.5 & 5.5 \\
\hline 21.9 & 18.5 \\
\hline 7.8 & 6.6 \\
\hline 176 & 200 \\
\hline 7.7 & 0.9 \\
\hline 2.28 & -- \\
\hline 22 & .08 \\
\hline
\end{tabular}

\begin{tabular}{|c|c|}
\hline \multicolumn{2}{|c|}{ Sept. 2} \\
\hline & \\
\hline 0.5 & 5.5 \\
\hline 19.3 & 17.2 \\
\hline 7.9 & 6.9 \\
\hline 187 & 192 \\
\hline 9.9 & 4.9 \\
\hline 3.14 & -- \\
\hline 0.015 & 0.030 \\
\hline
\end{tabular}

\begin{tabular}{ccc}
\multicolumn{3}{c}{ Sept. 16 } \\
& 4.2 \\
0.5 & & 5.5 \\
21.7 & & 17.6 \\
8.4 & & 7.3 \\
159 & & 165 \\
8.8 & 0.2 \\
-- & -- \\
0.022 & & 0.047
\end{tabular}




\section{MERCER LAKE, WEST BASIN, AT MERCER, WI}

LAKE-DEPTH PROFILES, MARCH 23 TO JUNE 29, 2009

03-23-09
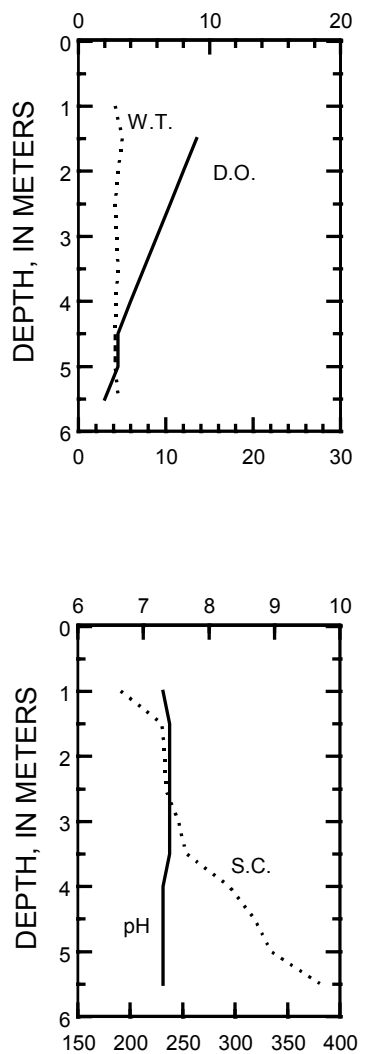

04-28-09 DISSOLVED OXYGEN (D.O.), IN MILLIGRAMS PER LITER
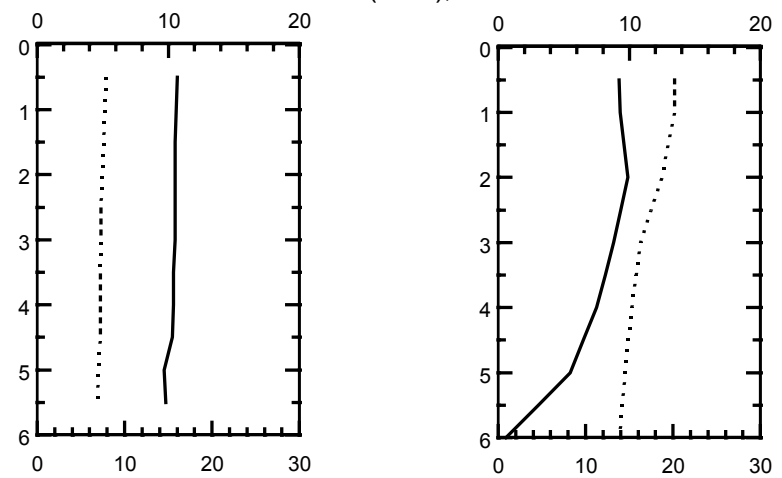

WATER TEMPERATURE (W.T.), IN DEGREES CELSIUS

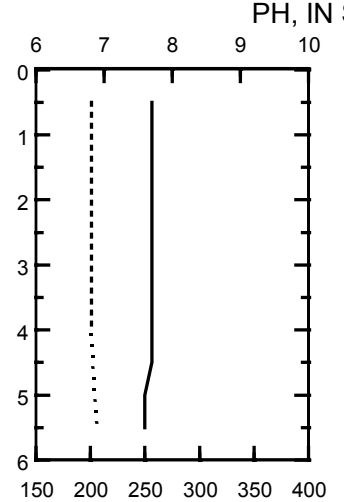

06-29-09
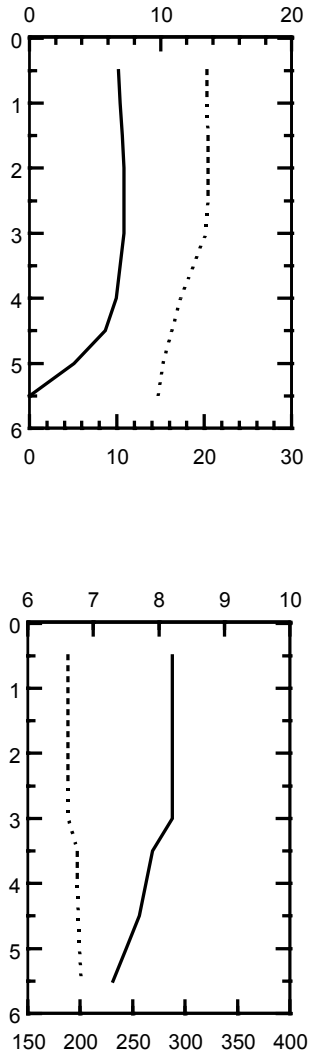

SPECIFIC CONDUCTANCE (S.C.), IN MICROSIEMENS PER CENTIMETER AT 25 DEGREES CELSIUS 


\section{MERCER LAKE, WEST BASIN, AT MERCER, WI}

LAKE-DEPTH PROFILES, AUGUST 5 TO SEPTEMBER 16, 2009

08-05-09
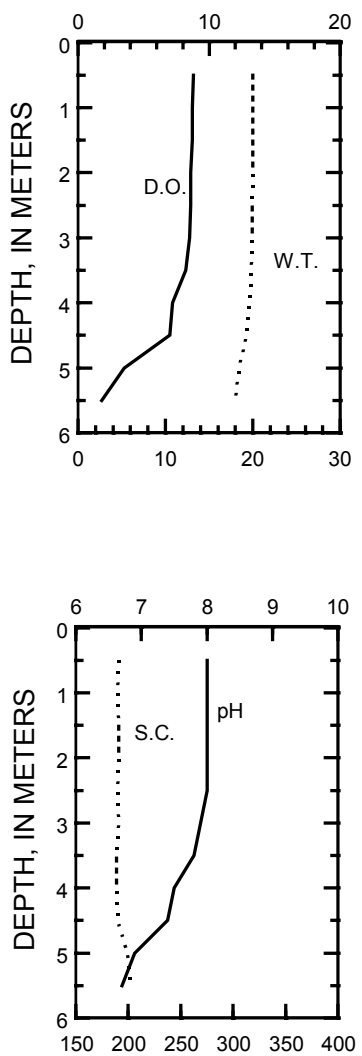

08-19-09

DISSOLVED OXYGEN (D.O.), IN MILLIGRAMS PER LITER
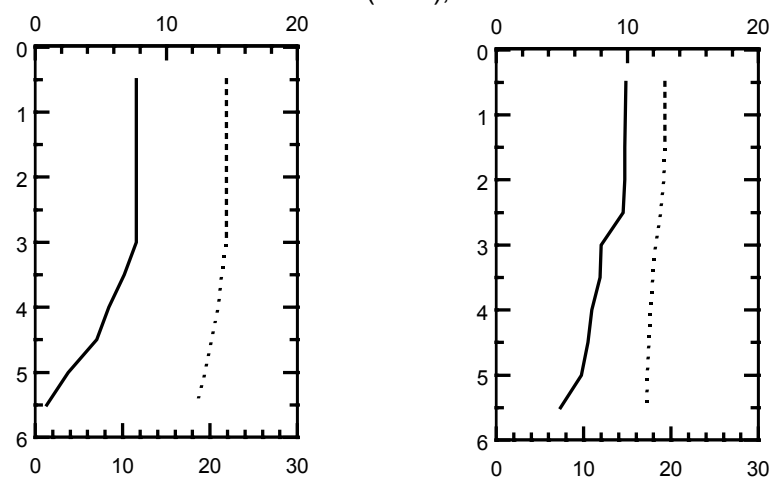

WATER TEMPERATURE (W.T.), IN DEGREES CELSIUS

PH, IN STANDARD UNITS
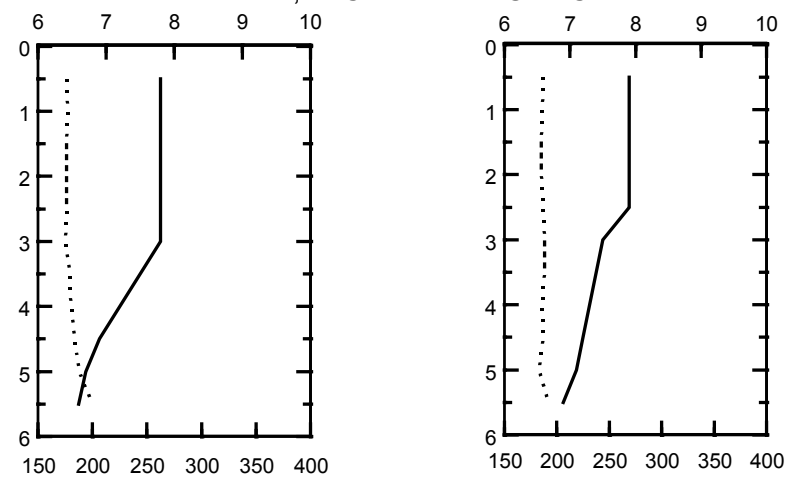

09-16-09
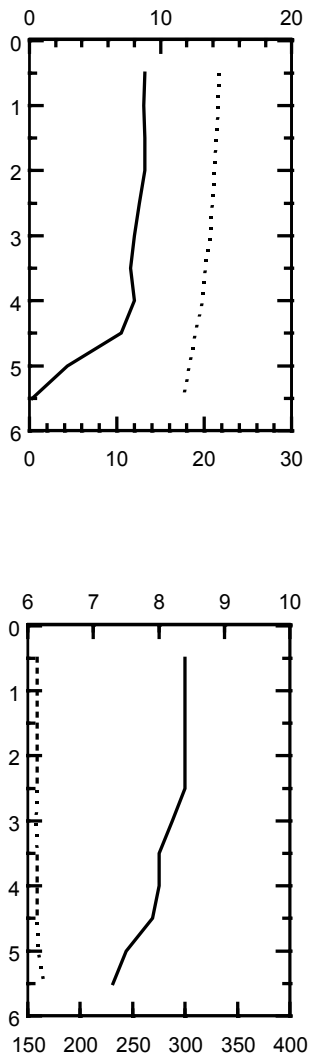

SPECIFIC CONDUCTANCE (S.C.), IN MICROSIEMENS PER CENTIMETER AT 25 DEGREES CELSIUS 

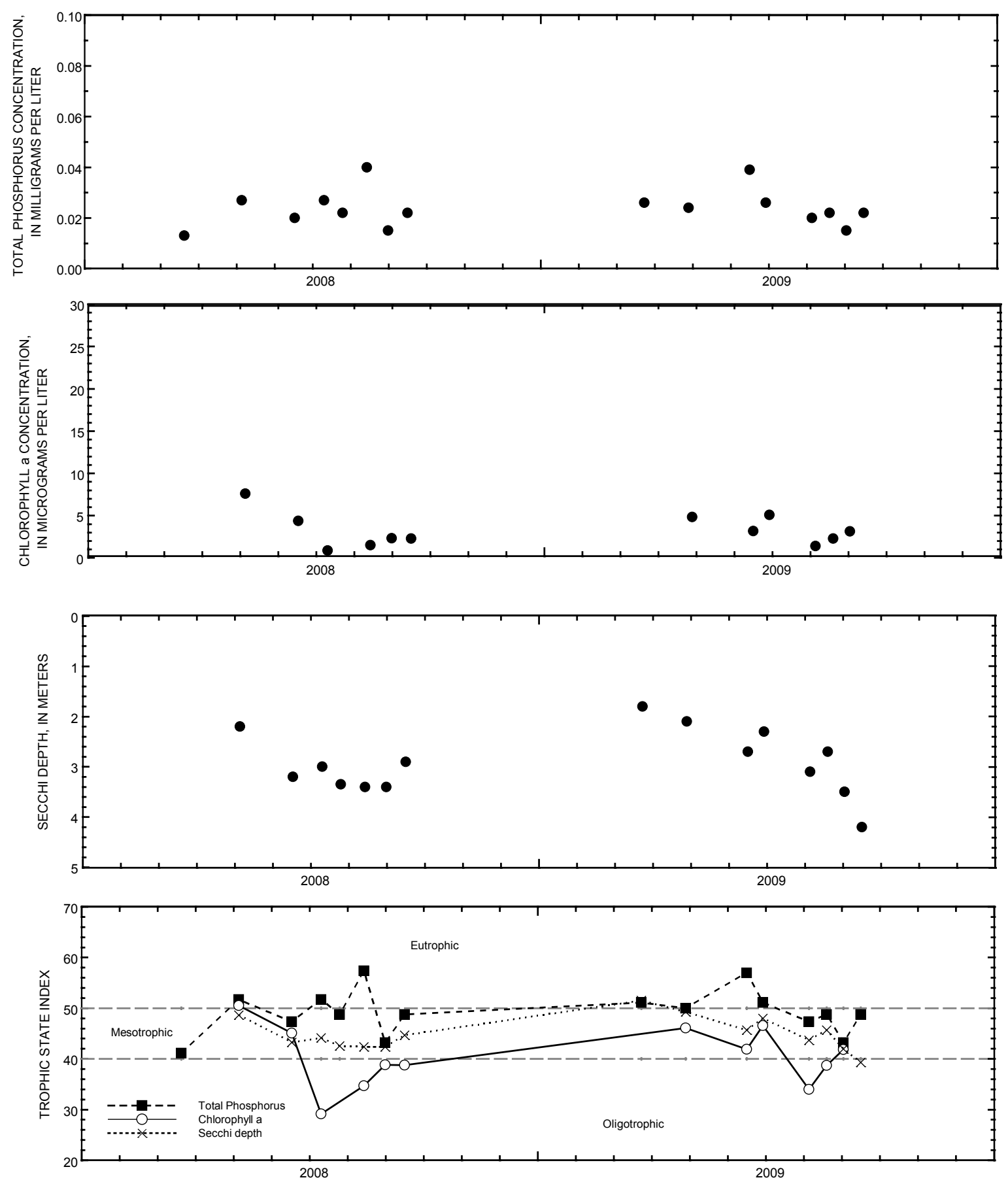

Surface total phosphorus, chlorophyll a concentrations, Secchi depths, and TSI data for Mercer Lake, West Basin, at Mercer, Wisconsin. 


\section{MIDDLE GENESEE LAKE, AT GENESEE LAKE ROAD, NEAR OCONOMOWOC, WI}

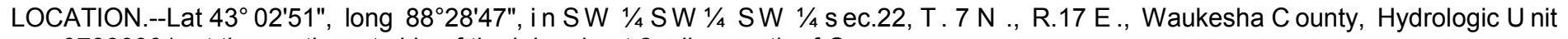
07090001, at the southwest side of the lake about 2 miles south of Oconomowoc.

SURFACE AREA.--0.17 $\mathrm{mi}^{2}$.

DRAINAGE AREA.--Unknown.

PERIOD OF RECORD.--April 1996 to current year.

GAGE.--Staff gage. Local observer, Tom Schubring provided most readings of gage. Datum of gage is about $0.0 \mathrm{ft}$ above NGVD of 1929.

EXTREMES FOR THE PERIOD OF RECORD.--Maximum observed gage height, $869.65 \mathrm{ft}$, July 12, 2008; minimum observed, 863.88 ft, Oct. 31, 2005.

EXTREMES F OR C URRENT Y EAR.--Maximum ob served gage h eight, $868.05 \mathrm{ft}$, June 22; m inimum obs erved, $866.40 \mathrm{ft}$, Oct. 3 . 


\begin{tabular}{|c|c|c|c|c|c|}
\hline \multicolumn{6}{|c|}{ GAGE H曰GHT, FT } \\
\hline \multicolumn{6}{|c|}{ WATER YEAR OCTOBER 2008 TO SEPTEMBER 2009} \\
\hline Date & Gage Height, ft & Date & Gage Height, ft & Date & Gage Height, ft \\
\hline October 3 & 866.40 & May 26 & 867.85 & July 20 & 867.52 \\
\hline 7 & 866.49 & 27 & 867.88 & 25 & 867.50 \\
\hline 8 & 866.55 & June 1 & 867.86 & 27 & 867.47 \\
\hline 14 & 866.57 & 4 & 867.81 & 29 & 867.41 \\
\hline 15 & 866.59 & 5 & 867.78 & 31 & 867.37 \\
\hline 18 & 866.60 & 8 & 867.79 & August 1 & 867.33 \\
\hline 25 & 866.63 & 9 & 867.81 & 2 & 867.31 \\
\hline 28 & 866.61 & 11 & 867.76 & 3 & 867.29 \\
\hline 31 & 866.59 & 15 & 867.73 & 4 & 867.27 \\
\hline November 2 & 866.57 & 17 & 867.70 & 6 & 867.21 \\
\hline 4 & 866.59 & 18 & 867.67 & 8 & 867.29 \\
\hline 9 & 866.61 & 19 & 867.91 & 13 & 867.21 \\
\hline 16 & 866.63 & 22 & 868.05 & 17 & 867.12 \\
\hline 21 & 866.59 & 24 & 868.03 & 21 & 867.07 \\
\hline 25 & 866.58 & 27 & 868.00 & 24 & 866.97 \\
\hline April 16 & 867.31 & 28 & 867.97 & 27 & 866.93 \\
\hline 22 & 867.41 & 30 & 867.90 & 31 & 866.87 \\
\hline May 3 & 867.71 & July 1 & 867.89 & September 1 & 866.87 \\
\hline 5 & 867.70 & 5 & 867.81 & 3 & 866.83 \\
\hline 7 & 867.77 & 9 & 867.73 & 14 & 866.69 \\
\hline 9 & 867.82 & 12 & 867.71 & 17 & 866.62 \\
\hline 10 & 867.83 & 15 & 867.73 & 19 & 866.59 \\
\hline 14 & 867.91 & 17 & 867.59 & 23 & 866.67 \\
\hline 22 & 867.89 & 19 & 867.54 & 30 & 866.63 \\
\hline
\end{tabular}




\section{LAKE MONONA AT MADISON, WI}

LOCATION.--Lat 4303'48", long 89²3'49" referenced to North American Datum of 1927, in SE 1/4 SW 1/4 sec.23, T.7 N., R.9 E., Dane County, WI, Hydrologic Unit 07090001, in Brittingham Park, in Madison.

SURFACE AREA.--5.3 $\mathrm{mi}^{2}$.

DRAINAGE AREA.--279 $\mathrm{mi}^{2}$ of which $36.6 \mathrm{mi}^{2}$ probably is noncontributing.

PERIOD OF RECORD.--September 1915 to current year (fragmentary) in reports of the Geological Survey. For 1856 to March 1917 in reports of Wisconsin Railroad Commission, volume 19.

REVISED RECORDS.--WSP 1338: Lake area. WDR WI-73-1: Drainage area.

GAGE.--Water-stage recorder. Datum of gage is $840.00 \mathrm{ft}$ above NGVD of 1929, or $5.60 \mathrm{ft}$ below City of Madison datum. Prior to Oct. 1 , 1979, datum $843.61 \mathrm{ft}$; prior to Nov. 15, 1971, nonrecording gage at same site.

REMARKS.--Lake level regulated by concrete dam with four 12-foot stop-log sections and 12-foot lock at outlet of Lake Waubesa. Gage-height telemeter at station.

EXTREMES FOR PERIOD OF RECORD.--Maximum gage height observed, $7.92 \mathrm{ft}$, June 15, 2008; minimum observed, $3.22 \mathrm{ft}$, Jan. 20,1965 , current datum.

EXTREMES FOR CURRENT YEAR.--Maximum recorded gage height, $6.21 \mathrm{ft}$, Mar. 26; minimum recorded, $4.48 \mathrm{ft}$, Feb. 26. 


\begin{tabular}{|c|c|c|c|c|c|c|c|c|c|c|c|c|}
\hline \multicolumn{13}{|c|}{$\begin{array}{c}\text { GAGE HEIGHT, FEET } \\
\text { WATER YEAR OCTOBER } 2008 \text { TO SEPTEMBER } 2009 \\
\text { DAILY MEAN VALUES }\end{array}$} \\
\hline Day & Oct & Nov & Dec & Jan & Feb & Mar & Apr & May & Jun & Jul & Aug & Sep \\
\hline 1 & 5.68 & 4.91 & 5.04 & 5.12 & 4.58 & 4.70 & 5.89 & 5.91 & 5.64 & 5.83 & 5.49 & 5.53 \\
\hline 2 & 5.64 & 4.91 & 5.04 & 5.09 & 4.55 & 4.66 & 5.85 & 5.83 & 5.62 & 5.80 & 5.47 & 5.52 \\
\hline 3 & 5.61 & 4.92 & 5.05 & 5.06 & 4.54 & 4.62 & 5.80 & 5.77 & 5.62 & 5.80 & 5.46 & 5.51 \\
\hline 4 & 5.58 & 4.92 & 5.04 & 5.04 & 4.52 & 4.58 & 5.76 & 5.72 & 5.61 & 5.80 & 5.45 & 5.50 \\
\hline 5 & 5.56 & 4.92 & 5.05 & 5.02 & 4.51 & 4.56 & 5.75 & 5.71 & 5.59 & 5.79 & 5.43 & 5.50 \\
\hline 6 & 5.55 & 4.95 & 5.07 & 5.00 & 4.51 & 4.54 & 5.68 & 5.72 & 5.58 & 5.77 & 5.41 & 5.49 \\
\hline 7 & 5.57 & 4.96 & 5.04 & 4.97 & 4.52 & 4.63 & 5.66 & 5.80 & 5.54 & 5.77 & 5.43 & 5.49 \\
\hline 8 & 5.65 & 4.94 & 5.05 & 4.94 & 4.52 & 4.90 & 5.67 & 5.80 & 5.68 & 5.77 & 5.54 & 5.48 \\
\hline 9 & 5.62 & 4.91 & 5.11 & 4.94 & 4.53 & 5.15 & 5.67 & 5.93 & 5.68 & 5.76 & 5.62 & 5.47 \\
\hline 10 & 5.60 & 4.89 & 5.10 & 4.92 & 4.59 & 5.37 & 5.67 & 5.96 & 5.69 & 5.77 & 5.65 & 5.46 \\
\hline 11 & 5.57 & 4.90 & 5.09 & 4.91 & 4.67 & 5.48 & 5.65 & 5.94 & 5.68 & 5.79 & 5.65 & 5.46 \\
\hline 12 & 5.55 & 4.93 & 5.03 & 4.89 & 4.69 & 5.52 & 5.66 & 5.93 & 5.69 & 5.79 & 5.64 & 5.44 \\
\hline 13 & 5.52 & 4.95 & 5.01 & 4.89 & 4.69 & 5.55 & 5.67 & 5.94 & 5.74 & 5.76 & 5.64 & 5.43 \\
\hline 14 & 5.47 & 5.00 & 5.03 & 4.88 & 4.72 & 5.57 & 5.66 & 6.01 & 5.77 & 5.74 & 5.63 & 5.41 \\
\hline 15 & 5.45 & 5.00 & 5.02 & 4.87 & 4.72 & 5.58 & 5.64 & 5.99 & 5.79 & 5.73 & 5.63 & 5.40 \\
\hline 16 & 5.41 & 4.99 & 4.97 & 4.86 & 4.73 & 5.58 & 5.63 & 5.92 & 5.79 & 5.69 & 5.62 & 5.39 \\
\hline 17 & 5.37 & 4.98 & 4.96 & 4.85 & 4.74 & 5.59 & 5.63 & 5.88 & 5.77 & 5.66 & 5.62 & 5.36 \\
\hline 18 & 5.34 & 5.00 & 4.95 & 4.84 & 4.74 & 5.59 & 5.63 & 5.85 & 5.77 & 5.62 & 5.59 & 5.34 \\
\hline 19 & 5.30 & 5.04 & 5.02 & 4.84 & 4.71 & 5.59 & 5.66 & 5.83 & 6.01 & 5.60 & 5.59 & 5.32 \\
\hline 20 & 5.26 & 5.04 & 5.03 & 4.83 & 4.68 & 5.59 & 5.75 & 5.79 & 6.10 & 5.58 & 5.61 & 5.29 \\
\hline 21 & 5.21 & 5.03 & 5.04 & 4.82 & 4.66 & 5.59 & 5.77 & 5.77 & 6.11 & 5.58 & 5.62 & 5.28 \\
\hline 22 & 5.17 & 5.05 & 5.03 & 4.81 & 4.62 & 5.58 & 5.79 & 5.76 & 6.13 & 5.62 & 5.60 & 5.44 \\
\hline 23 & 5.12 & 5.06 & 5.04 & 4.77 & 4.57 & 5.62 & 5.80 & 5.78 & 6.12 & 5.61 & 5.59 & 5.65 \\
\hline 24 & 5.13 & 5.07 & 5.05 & 4.73 & 4.54 & 5.79 & 5.78 & 5.79 & 6.10 & 5.59 & 5.58 & 5.65 \\
\hline 25 & 5.10 & 5.07 & 5.04 & 4.70 & 4.51 & 6.14 & 5.79 & 5.75 & 6.08 & 5.59 & 5.57 & 5.65 \\
\hline 26 & 5.04 & 5.07 & 5.05 & 4.67 & 4.55 & 6.19 & 6.07 & 5.70 & 6.05 & 5.57 & 5.58 & 5.66 \\
\hline 27 & 4.97 & 5.07 & 5.10 & 4.65 & 4.72 & 6.17 & 6.13 & 5.72 & 6.01 & 5.55 & 5.58 & 5.68 \\
\hline 28 & 4.93 & 5.05 & 5.19 & 4.63 & 4.73 & 6.09 & 6.09 & 5.70 & 5.94 & 5.54 & 5.57 & 5.70 \\
\hline 29 & 4.90 & 5.05 & 5.19 & 4.61 & --- & 6.01 & 6.02 & 5.67 & 5.89 & 5.51 & 5.57 & 5.66 \\
\hline 30 & 4.88 & 5.06 & 5.17 & 4.59 & --- & 5.95 & 5.98 & 5.65 & 5.85 & 5.51 & 5.55 & 5.65 \\
\hline 31 & 4.90 & --- & 5.14 & 4.59 & --- & 5.92 & --- & 5.63 & --- & 5.52 & 5.53 & --- \\
\hline Mean & 5.34 & 4.99 & 5.06 & 4.85 & 4.62 & 5.43 & 5.77 & 5.81 & 5.82 & 5.68 & 5.56 & 5.49 \\
\hline Max & 5.68 & 5.07 & 5.19 & 5.12 & 4.74 & 6.19 & 6.13 & 6.01 & 6.13 & 5.83 & 5.65 & 5.70 \\
\hline Min & 4.88 & 4.89 & 4.95 & 4.59 & 4.51 & 4.54 & 5.63 & 5.63 & 5.54 & 5.51 & 5.41 & 5.28 \\
\hline
\end{tabular}




\section{OCONOMOWOC LAKE NO. 1 (CENTER) AT OCONOMOWOC, WI}

LOCATION.--Lat 4305'51", long 88²7'35", in NW 1/4 SE 1/4 sec.2, T.7 N., R.17 E., Waukesha County, Hydrologic Unit 07090001, at Oconomowoc. SURFACE AREA.--1.20 $\mathrm{mi}^{2}$.

PERIOD OF RECORD.--March 1986 to current year.

REMARKS.--Lake sampled near center at the deep hole. Water-quality analyses done by Wisconsin State Laboratory of Hygiene.

WATER-QUALITY DATA, FEBRUARY 17 TO AUGUST 26, 2009

(Milligrams per liter unless otherwise indicated)

\begin{tabular}{|c|c|}
\hline$\underline{\text { Parameter Code }}$ & Parameter Name \\
\hline 32210 & Chlorophyll a, phytoplankton ( $\mu \mathrm{g} / \mathrm{L})$ \\
\hline 00078 & Secchi-depth (m) \\
\hline 00098 & Sampling depth $(\mathrm{m})$ \\
\hline 00010 & Water Temperature $\left({ }^{\circ} \mathrm{C}\right)$ \\
\hline 00400 & $\mathrm{pH}$ (standard units) \\
\hline 00095 & Specific conductance $(\mu \mathrm{S} / \mathrm{cm})$ \\
\hline 00300 & Dissolved oxygen \\
\hline 00665 & Phosphorus, total (as P) \\
\hline 00671 & Orthophosphate, dissolved (as $\mathrm{P}$ ) \\
\hline 00631 & Nitrate plus nitrite, dissolved (as $\mathrm{N}$ ) \\
\hline 00608 & Ammonia, dissolved (as $\mathrm{N}$ ) \\
\hline 00625 & Ammonia plus organic nitrogen, total (as $\mathrm{N}$ ) \\
\hline 00623 & Ammonia plus organic nitrogen, dissolved (as $\mathrm{N}$ ) \\
\hline 00600 & Total nitrogen \\
\hline 63675 & Turbidity, (NTU) \\
\hline 00081 & Apparent color, (PTU) \\
\hline 00900 & Hardness (as CaCO3) \\
\hline 00915 & Calcium, dissolved $(\mathrm{Ca})$ \\
\hline 00925 & Magnesium, dissolved (Mg) \\
\hline 00930 & Sodium, dissolved $(\mathrm{Na})$ \\
\hline 00935 & Potassium, dissolved (K) \\
\hline 00417 & ANC (as $\mathrm{CaCO} 3$ ) \\
\hline 00940 & Chloride, dissolved $(\mathrm{Cl})$ \\
\hline 00945 & Sulfate, dissolved (SO4) \\
\hline 00955 & Silica, dissolved (SiO2) \\
\hline 01046 & Iron $(\mu \mathrm{g} / \mathrm{L})$ \\
\hline 01056 & Manganese $(\mu \mathrm{g} / \mathrm{L})$ \\
\hline 70300 & Solids, dissolved (at $180^{\circ} \mathrm{C}$ ) \\
\hline
\end{tabular}

\begin{tabular}{cccc}
\multicolumn{2}{c}{ Feb. 17 } & \multicolumn{2}{c}{ March 30} \\
\multicolumn{2}{c}{--} & \multicolumn{3}{c}{3.07} \\
0.5 & 18 & 0.5 & 18 \\
2.1 & 3 & 4.3 & 4 \\
8.1 & 7.5 & 8 & 8 \\
595 & 642 & 588 & 589 \\
11.4 & 6.9 & 12.8 & 11.7 \\
0.016 & 0.019 & 0.012 & 0.012 \\
-- & -- & $<.002$ & -- \\
-- & -- & 0.501 & - \\
-- & -- & $<.015$ & -- \\
-- & -- & 0.56 & -- \\
-- & -- & -- & -- \\
-- & -- & 1.1 & -- \\
-- & -- & $<1.0$ & -- \\
-- & -- & 10 & -- \\
-- & -- & 260 & -- \\
-- & -- & 52.5 & -- \\
-- & -- & 32.1 & -- \\
-- & -- & 20.2 & -- \\
-- & -- & 2.2 & -- \\
-- & -- & 218 & -- \\
-- & -- & 47.4 & -- \\
-- & -- & 27.2 & -- \\
-- & -- & 8.67 & -- \\
-- & -- & $<100$ & -- \\
-- & -- & $<1.0$ & -- \\
-- & -- & 356 & --
\end{tabular}

\begin{tabular}{|c|c|c|c|c|c|}
\hline \multicolumn{2}{|c|}{ June 11} & \multicolumn{2}{|c|}{ July 21} & \multicolumn{2}{|c|}{ August 26} \\
\hline \multicolumn{2}{|c|}{1.91} & \multicolumn{2}{|c|}{3.46} & \multicolumn{2}{|c|}{4.11} \\
\hline \multicolumn{2}{|c|}{7.8} & \multicolumn{2}{|c|}{3.4} & \multicolumn{2}{|c|}{3.4} \\
\hline 0.5 & 18 & 0.5 & 18 & 0.5 & 18 \\
\hline 18.6 & 7.4 & 22.4 & 7.5 & 22.9 & 7.8 \\
\hline 8.5 & 7.6 & 8.3 & 7.2 & 8.6 & 7.5 \\
\hline 575 & 587 & 558 & 599 & 545 & 600 \\
\hline 9.5 & 3.7 & 9 & 0.1 & 9 & 0 \\
\hline 0.011 & 0.019 & 0.012 & 0.018 & 0.009 & 0.011 \\
\hline -- & -- & -- & -- & -- & -- \\
\hline-- & -- & -- & -- & -- & -- \\
\hline -- & -- & -- & -- & -- & -- \\
\hline -- & -- & -- & -- & -- & -- \\
\hline-- & -- & -- & -- & -- & -- \\
\hline -- & -- & -- & -- & -- & -- \\
\hline -- & -- & -- & -- & -- & -- \\
\hline-- & -- & -- & -- & -- & -- \\
\hline -- & -- & -- & -- & -- & -- \\
\hline -- & -- & -- & -- & -- & -- \\
\hline-- & -- & -- & -- & -- & -- \\
\hline-- & -- & -- & -- & -- & -- \\
\hline -- & -- & -- & -- & -- & -- \\
\hline -- & -- & -- & -- & -- & -- \\
\hline -- & -- & -- & -- & -- & -- \\
\hline-- & -- & -- & -- & -- & -- \\
\hline -- & -- & -- & -- & -- & -- \\
\hline -- & -- & -- & -- & -- & -- \\
\hline -- & -- & -- & -- & -- & -- \\
\hline -- & -- & -- & -- & -- & -- \\
\hline
\end{tabular}


430551088273500 OCONOMOWOC LAKE NO. 1 (CENTER) AT OCONOMOWOC, WI

LAKE-DEPTH PROFILES, FEBRUARY 17 TO AUGUST 26, 2009

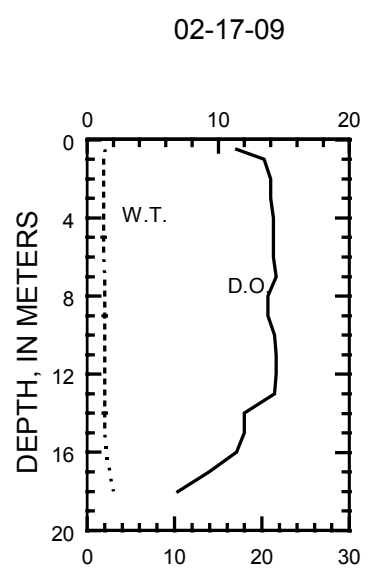

03-30-09

06-11-09

07-21-09

08-26-09

DISSOLVED OXYGEN (D.O.), IN MILLIGRAMS PER LITER
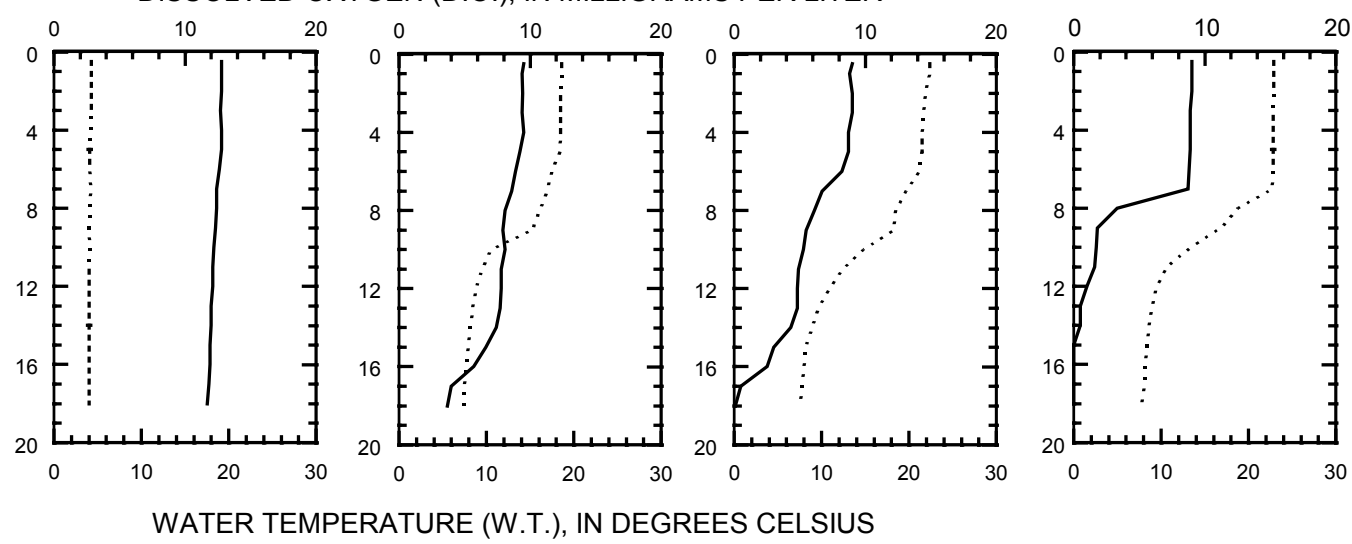

WATER TEMPERATURE (W.T.), IN DEGREES CELSIUS

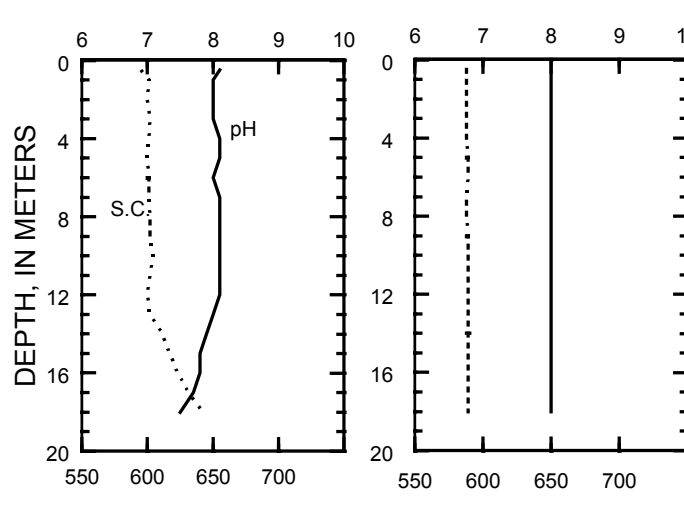

$\mathrm{PH}$, IN STANDARD UNITS
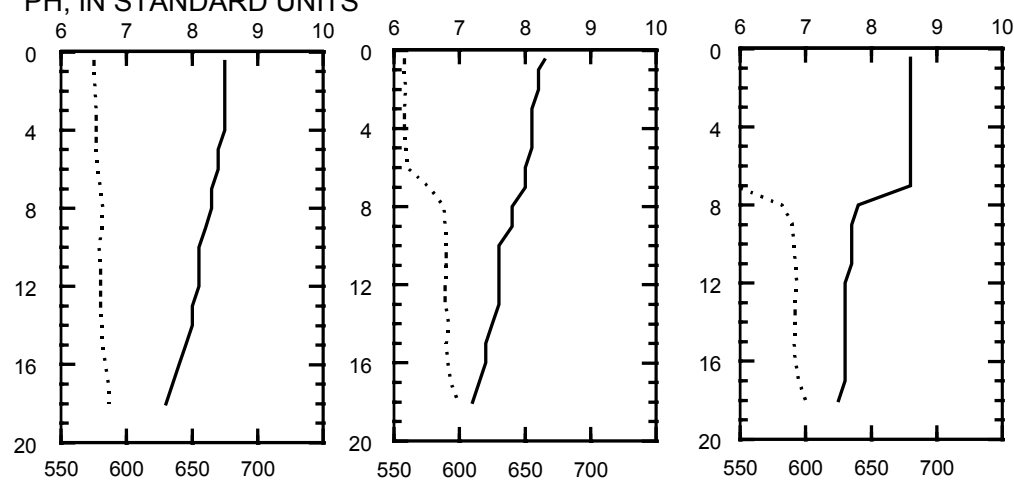

SPECIFIC CONDUCTANCE (S.C.), IN MICROSIEMENS PER CENTIMETER AT 25 DEGREES CELSIUS 

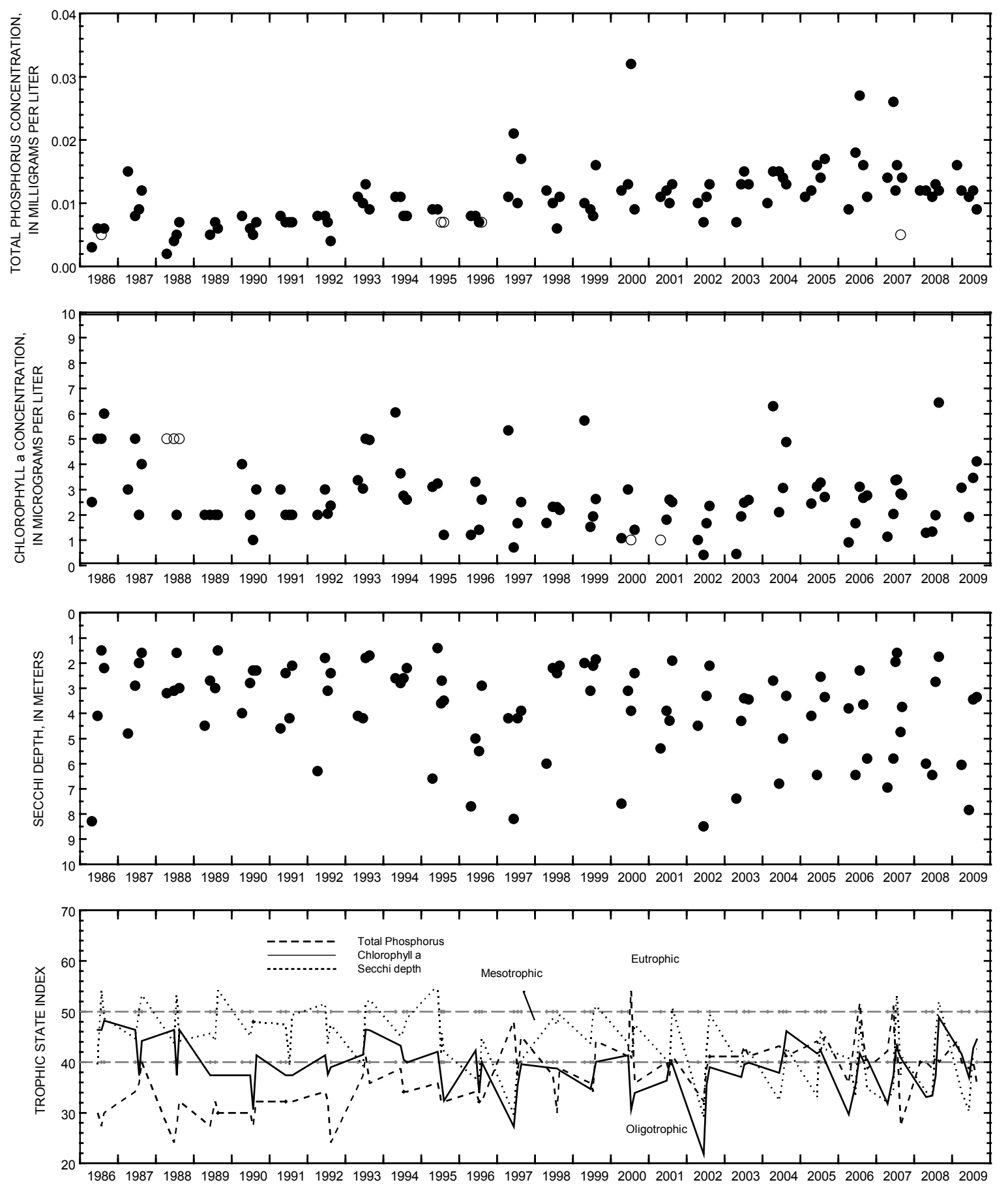

Surface total phosphorus, chlorophyll a concentrations, Secchi depths, and TSI data for Oconomowoc Lake, Center Site, at Oconomowoc, Wisconsin.

(Open circles on the first two plots indicate laboratory detection limit for selected analyses.

Actual concentrations for these particular analyses are less than the plotted circles.) 


\section{OCONOMOWOC LAKE NO. 2 (OFF HEWITT POINT) AT OCONOMOWOC, WI}

LOCATION.--Lat 4306'09", long 88²6'22", in NW 1/4 NW 1/4 sec.1, T.7 N., R.17 E., Waukesha County, Hydrologic Unit 07090001, at Oconomowoc.

SURFACE AREA.-1.20 $\mathrm{mi}^{2}$

PERIOD OF RECORD.--March 1986 to current year.

REMARKS.--Lake sampled at the deepest point in northeast bay near Hewitt Point. Lake ice-covered during February sampling. Water-quality analyses done by Wisconsin State Laboratory of Hygiene.

WATER-QUALITY DATA, FEBRUARY 17 TO AUGUST 26, 2009

(Milligrams per liter unless otherwise indicated)

\begin{tabular}{|c|c|}
\hline$\underline{\text { Parameter Code }}$ & $\underline{\text { Parameter Name }}$ \\
\hline 32210 & Chlorophyll a, phytoplankton $(\mu \mathrm{g} / \mathrm{L})$ \\
\hline 00078 & Secchi-depth $(m)$ \\
\hline 00098 & Sampling depth (m) \\
\hline 00010 & Water Temperature $\left({ }^{\circ} \mathrm{C}\right)$ \\
\hline 00400 & $\mathrm{pH}$ (standard units) \\
\hline 00095 & Specific conductance $(\mu \mathrm{S} / \mathrm{cm})$ \\
\hline 00300 & Dissolved oxygen \\
\hline 00665 & Phosphorus, total (as $\mathrm{P}$ ) \\
\hline
\end{tabular}

\begin{tabular}{|c|c|c|c|}
\hline \multicolumn{2}{|c|}{ Feb. 17} & \multicolumn{2}{|c|}{ March 30} \\
\hline \multicolumn{2}{|c|}{-- } & \multicolumn{2}{|c|}{2.3} \\
\hline \multicolumn{2}{|c|}{--} & \multicolumn{2}{|c|}{7.6} \\
\hline 0.5 & 13.5 & 0.5 & 14.0 \\
\hline 3.5 & 3.7 & 5.6 & 4.9 \\
\hline 7.8 & 7.3 & 7.9 & 7.9 \\
\hline 652 & 713 & 654 & 655 \\
\hline 12.1 & 7.0 & 13.1 & 12.9 \\
\hline 0.011 & 0.014 & 0.010 & 0.010 \\
\hline
\end{tabular}

\begin{tabular}{ccc}
\multicolumn{3}{c}{ June 11 } \\
\multicolumn{2}{c}{2.64} & \\
& 5.2 & \\
0.5 & & 14.0 \\
19.0 & & 8.1 \\
8.4 & 7.2 \\
618 & 649 \\
9.7 & 4.0 \\
0.008 & 0.021
\end{tabular}

\begin{tabular}{|c|c|}
\hline \multicolumn{2}{|c|}{ July 21} \\
\hline \multicolumn{2}{|c|}{2.17} \\
\hline & \\
\hline 0.5 & 13.0 \\
\hline 22.3 & 9.0 \\
\hline 8.1 & 7.3 \\
\hline 612 & 660 \\
\hline 8.9 & 1.6 \\
\hline 0.011 & 0.015 \\
\hline
\end{tabular}

\begin{tabular}{|c|c|}
\hline \multicolumn{2}{|c|}{ August 26} \\
\hline \multicolumn{2}{|c|}{2.97} \\
\hline & \\
\hline 0.5 & 14.5 \\
\hline 22.9 & 8.9 \\
\hline 8.6 & 7.5 \\
\hline 602 & 669 \\
\hline 9.0 & 0.0 \\
\hline 0.008 & 0.012 \\
\hline
\end{tabular}


430609088262200 OCONOMOWOC LAKE NO. 2 (OFF HEWITT POINT) AT OCONOMOWOC, WI

LAKE-DEPTH PROFILES, FEBRUARY 17 TO AUGUST 26, 2009

$02-17-09$
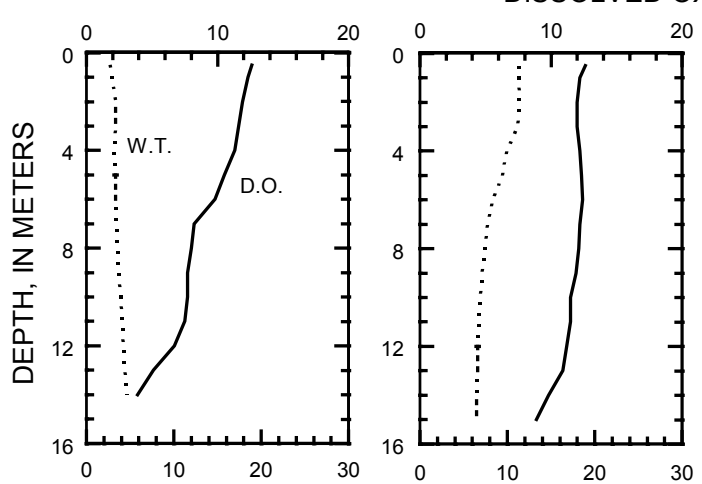

WATER TEMPERATURE (W.T.), IN DEGREES CELSIUS
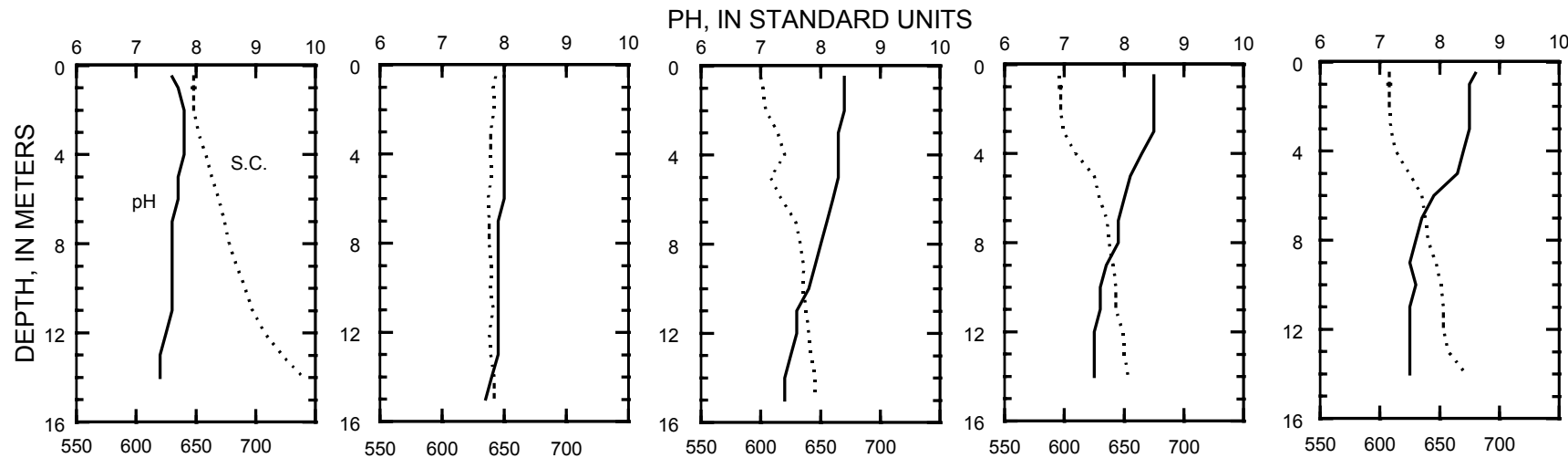

SPECIFIC CONDUCTANCE (S.C.), IN MICROSIEMENS PER CENTIMETER AT 25 DEGREES CELSIUS 

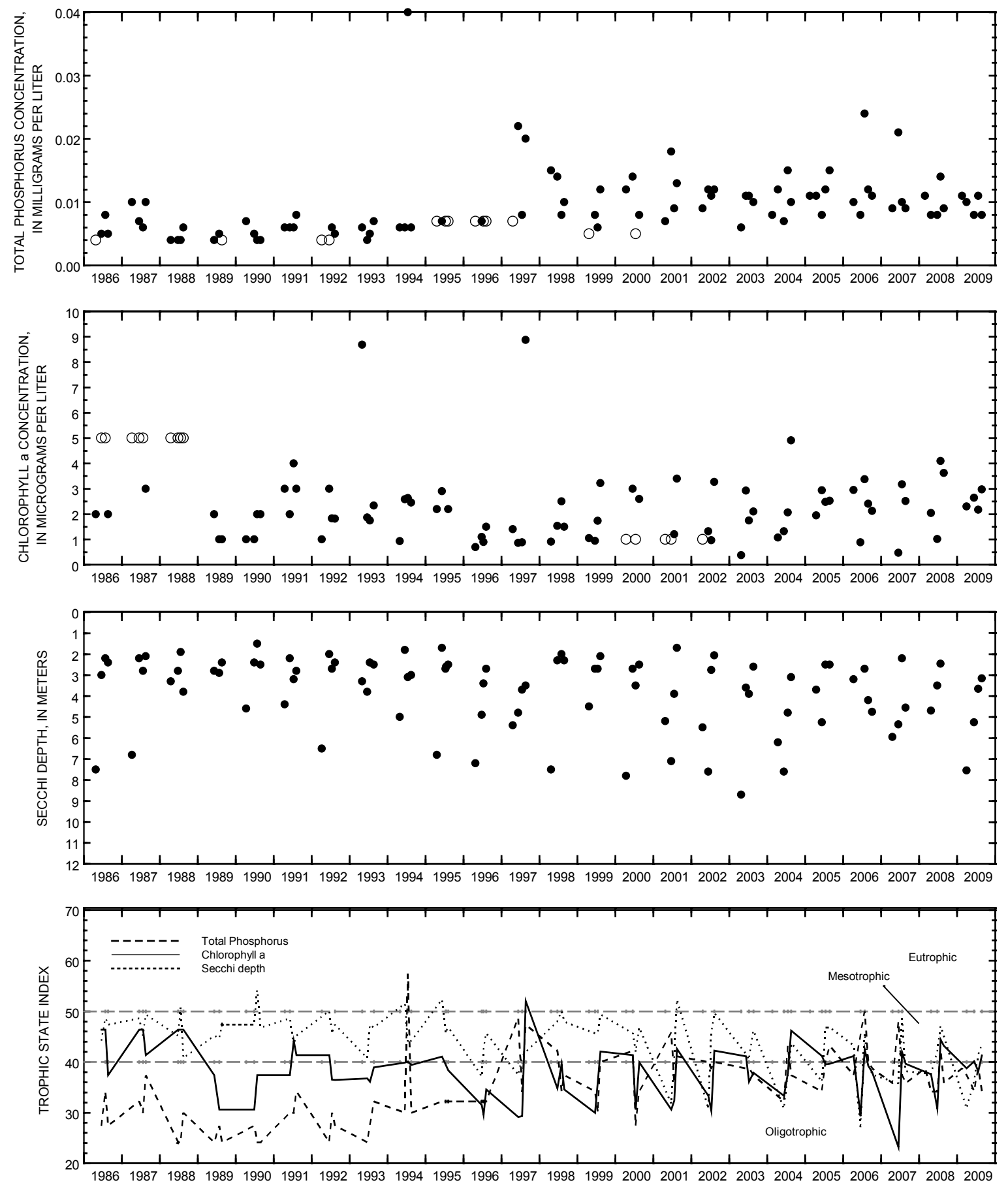

Surface total phosphorus, chlorophyll a concentrations, Secchi depths, and TSI data for Oconomowoc Lake, Hewitt Point, at Oconomowoc, Wisconsin.

(Open circles on the first two plots indicate laboratory detection limit for selected analyses. Actual concentrations for these particular analyses are less than the plotted circles.) 


\section{POWERS LAKE AT POWERS LAKE, WI}

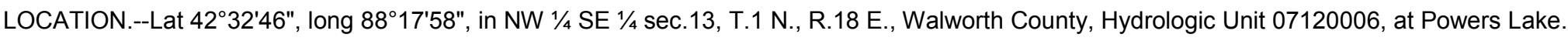
SURFACE AREA.-0.72 $\mathrm{mi}^{2}$.

DRAINAGE AREA.--3.42 $\mathrm{mi}^{2}$.

PERIOD OF RECORD.--March 1986 to August 1996, and April 1998 to current year.

REMARKS.--Lake sampled near center at the deep hole. Water-quality analyses done by Wisconsin State Laboratory of Hygiene.

WATER-QUALITY DATA, FEBRUARY 17 TO AUGUST 26, 2009

(Milligrams per liter unless otherwise indicated)

\begin{tabular}{|c|c|}
\hline Parameter Code & Parameter Name \\
\hline 32210 & Chlorophyll a, phytoplankton $(\mu \mathrm{g} / \mathrm{L})$ \\
\hline 00078 & Secchi-depth (m) \\
\hline 00098 & Sampling depth (m) \\
\hline 00010 & Water Temperature $\left({ }^{\circ} \mathrm{C}\right)$ \\
\hline 00400 & $\mathrm{pH}$ (standard units) \\
\hline 00095 & Specific conductance $(\mu \mathrm{S} / \mathrm{cm})$ \\
\hline 00300 & Dissolved oxygen \\
\hline 00665 & Phosphorus, total (as P) \\
\hline 00671 & Orthophosphate, dissolved (as P) \\
\hline 00631 & Nitrate plus nitrite, dissolved (as $\mathrm{N}$ ) \\
\hline 00608 & Ammonia, dissolved (as $\mathrm{N}$ ) \\
\hline 00625 & Ammonia plus organic nitrogen, total (as $\mathrm{N}$ ) \\
\hline 00623 & Ammonia plus organic nitrogen, dissolved (as $\mathrm{N}$ ) \\
\hline 00600 & Total nitrogen \\
\hline 63675 & Turbidity, (NTU) \\
\hline 00081 & Apparent color, (PTU) \\
\hline 00900 & Hardness (as CaCO3) \\
\hline 00915 & Calcium, dissolved $(\mathrm{Ca})$ \\
\hline 00925 & Magnesium, dissolved (Mg) \\
\hline 00930 & Sodium, dissolved $(\mathrm{Na})$ \\
\hline 00935 & Potassium, dissolved $(\mathrm{K})$ \\
\hline 00417 & ANC (as $\mathrm{CaCO}$ ) \\
\hline 00940 & Chloride, dissolved $(\mathrm{Cl})$ \\
\hline 00945 & Sulfate, dissolved (SO4) \\
\hline 00955 & Silica, dissolved (SiO2) \\
\hline 01046 & Iron $(\mu \mathrm{g} / \mathrm{L})$ \\
\hline 01056 & Manganese $(\mu \mathrm{g} / \mathrm{L})$ \\
\hline 70300 & Solids, dissolved (at $180^{\circ} \mathrm{C}$ ) \\
\hline
\end{tabular}

\begin{tabular}{|c|c|c|c|}
\hline \multicolumn{2}{|c|}{ Feb. 17} & \multicolumn{2}{|c|}{ March 30} \\
\hline \multicolumn{2}{|c|}{-- } & \multicolumn{2}{|c|}{1.61} \\
\hline \multicolumn{2}{|c|}{-- } & \multicolumn{2}{|c|}{7.2} \\
\hline 0.5 & 9.5 & 0.5 & 10.0 \\
\hline 3.5 & 3.6 & 6.2 & 6 \\
\hline 8.3 & 8.1 & 8.0 & 8.0 \\
\hline 511 & 554 & 519 & 519 \\
\hline 14.0 & 13.8 & 12.6 & 11.4 \\
\hline 0.020 & 0.014 & 0.009 & 0.012 \\
\hline-- & -- & $<.002$ & -- \\
\hline -- & -- & 0.101 & -- \\
\hline -- & -- & 0.079 & -- \\
\hline -- & -- & 0.71 & -- \\
\hline-- & -- & -- & -- \\
\hline-- & -- & 0.81 & -- \\
\hline-- & -- & $<1.0$ & -- \\
\hline-- & -- & 10 & -- \\
\hline-- & -- & 230 & -- \\
\hline-- & -- & 39.9 & -- \\
\hline-- & -- & 30.8 & -- \\
\hline-- & -- & 19 & -- \\
\hline-- & -- & 2.2 & -- \\
\hline-- & -- & 186 & -- \\
\hline-- & -- & 40.6 & -- \\
\hline-- & -- & 29.2 & -- \\
\hline-- & -- & 8.95 & -- \\
\hline-- & -- & $<100$ & -- \\
\hline-- & -- & $<1.0$ & -- \\
\hline-- & -- & 314 & -- \\
\hline
\end{tabular}

\begin{tabular}{ccc}
\multicolumn{2}{c}{ June 11} \\
\multicolumn{3}{c}{4.74} \\
0.5 & 4.6 & \\
19 & & 10.0 \\
8.4 & 17.2 \\
508 & 7.6 \\
9.5 & 518 \\
0.014 & 2.5 \\
-- & 0.017 \\
-- & -- \\
-- & -- \\
-- & -- \\
-- & -- \\
-- & -- \\
-- & -- \\
-- & -- \\
-- & -- \\
-- & -- \\
-- & -- \\
-- & -- \\
-- & -- \\
-- & -- \\
-- & -- \\
-- & -- \\
-- & -- \\
-- & -- \\
-- & -- \\
-- & -- \\
\hline & --
\end{tabular}

\begin{tabular}{|c|c|c|c|}
\hline \multicolumn{2}{|c|}{ July 21} & \multicolumn{2}{|c|}{ August 26} \\
\hline \multicolumn{2}{|c|}{3.22} & \multicolumn{2}{|c|}{5.37} \\
\hline \multicolumn{2}{|c|}{3.0} & \multicolumn{2}{|c|}{3.2} \\
\hline 0.5 & 10.0 & 0.5 & 10.0 \\
\hline 22.7 & 16.7 & 23.1 & 18.1 \\
\hline 8.4 & 7.4 & 8.6 & 7.5 \\
\hline 504 & 537 & 506 & 549 \\
\hline 9.2 & 0.1 & 8.6 & 0.3 \\
\hline 0.019 & 0.036 & 0.017 & 0.019 \\
\hline$<.002$ & -- & -- & -- \\
\hline$<.019$ & -- & -- & -- \\
\hline$<.015$ & -- & -- & -- \\
\hline -- & -- & -- & -- \\
\hline 0.68 & -- & -- & -- \\
\hline-- & -- & -- & -- \\
\hline-- & -- & -- & -- \\
\hline-- & -- & -- & -- \\
\hline -- & -- & -- & -- \\
\hline-- & -- & -- & -- \\
\hline-- & -- & -- & -- \\
\hline -- & -- & -- & -- \\
\hline -- & -- & -- & -- \\
\hline-- & -- & -- & -- \\
\hline-- & -- & -- & -- \\
\hline-- & -- & -- & -- \\
\hline-- & -- & -- & -- \\
\hline -- & -- & -- & -- \\
\hline -- & -- & -- & -- \\
\hline-- & -- & -- & -- \\
\hline
\end{tabular}




\section{POWERS LAKE AT POWERS LAKE, WI}

LAKE-DEPTH PROFILES, FEBRUARY 17 TO AUGUST 26, 2009

02-17-09
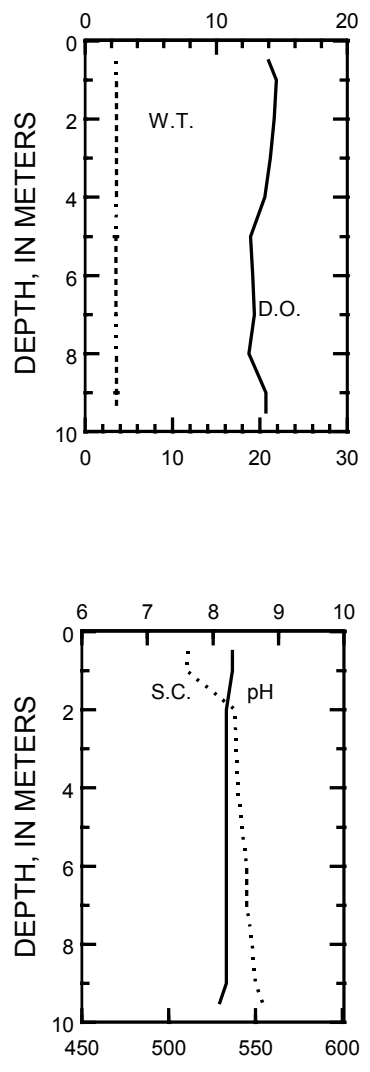

03-30-09

DISSOLVED OXYGEN (D.O.), IN MILLIGRAMS PER LITER

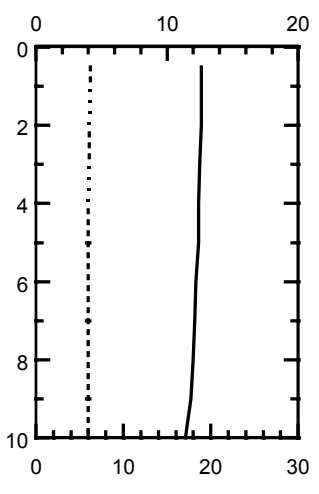

WATER TEMPERATURE (W.T.), IN DEGREES CELSIUS
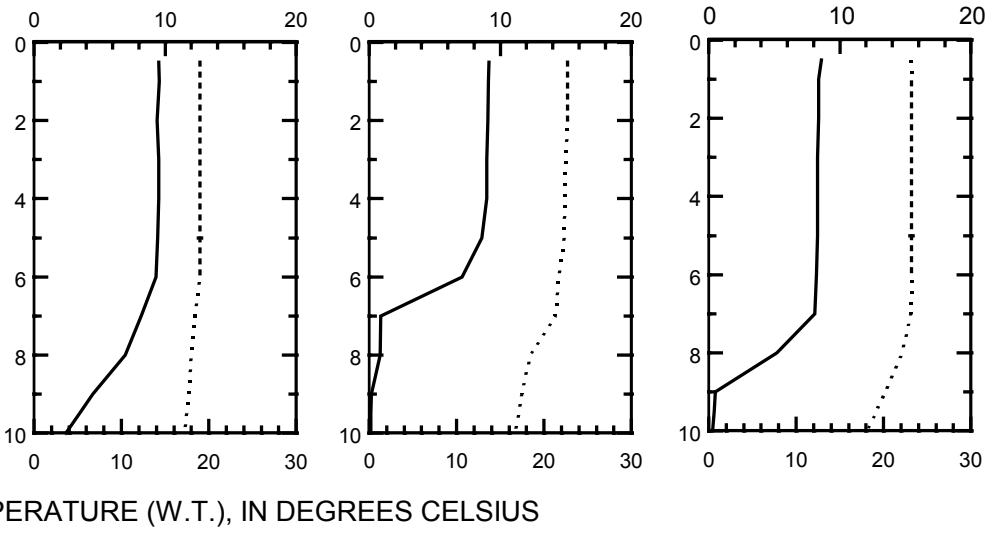

$\mathrm{PH}$, IN STANDARD UNITS
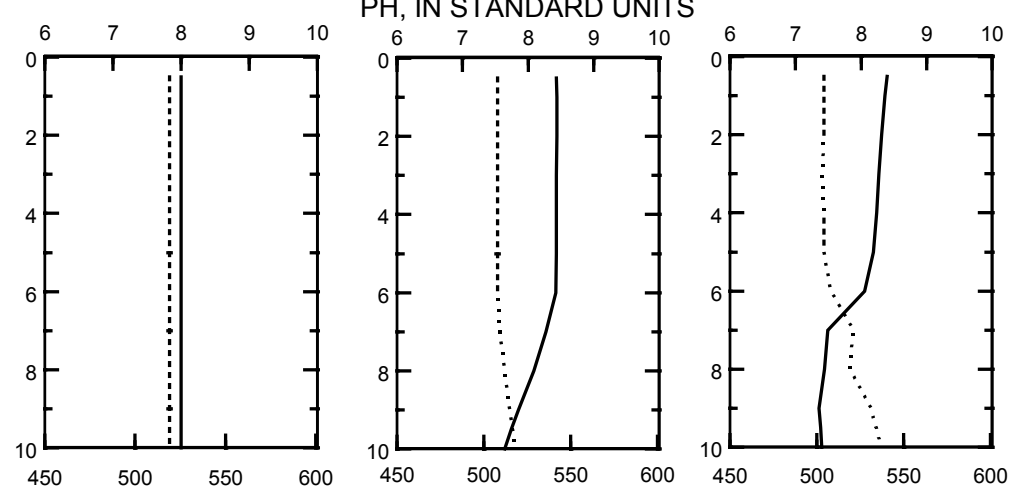

08-26-09

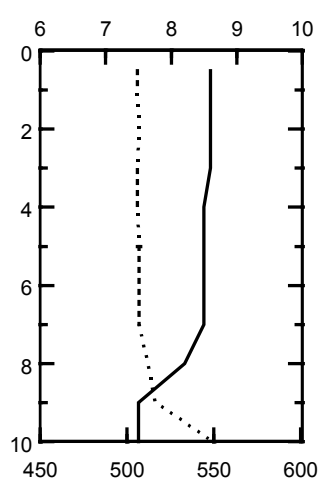

SPECIFIC CONDUCTANCE (S.C.), IN MICROSIEMENS PER CENTIMETER AT 25 DEGREES CELSIUS 

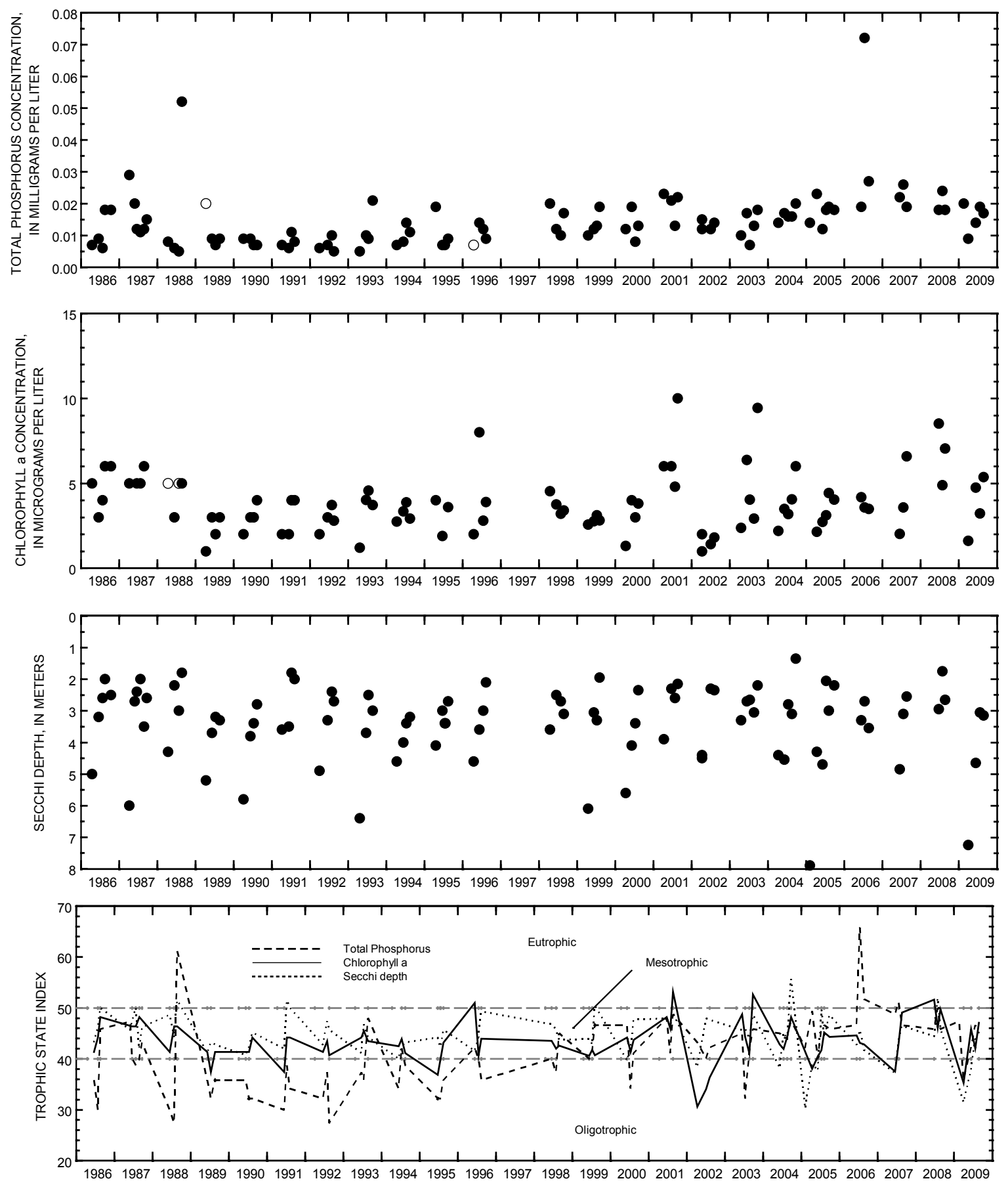

Surface total phosphorus, chlorophyll a concentrations, Secchi depths, and TSI data for Powers Lake, at Powers Lake, Wisconsin.

(Open circles on the first two plots indicate laboratory detection limit for selected analyses. Actual concentrations for these particular analyses are less than the plotted circles.) 


\section{SILVER LAKE NEAR WEST BEND, WI}

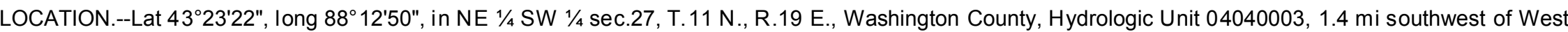
Bend.

PERIOD OF RECORD.-February 1996 to August 1997, and February to August 2009.

REMARKS.--Lake sampled at northern end of southern basin of lake at the deep hole. Water-quality analyses done by Wisconsin State Laboratory of Hygiene.

\begin{tabular}{|c|c|c|c|c|c|c|c|c|c|c|c|}
\hline \multirow[b]{2}{*}{ Parameter Code } & \multicolumn{11}{|c|}{$\begin{array}{l}\text { WATER-QUALITY DATA, FEBRUARY } 19 \text { TO AUGUST 27, } 2009 \\
\text { (Milligrams per liter unless otherwise indicated) }\end{array}$} \\
\hline & Parameter Name & \multicolumn{2}{|c|}{ Feb. 19} & \multicolumn{2}{|c|}{ April 16} & \multicolumn{2}{|c|}{ June 25} & \multicolumn{2}{|c|}{ July 22} & \multicolumn{2}{|c|}{ August 27} \\
\hline 32210 & 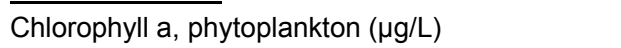 & \multicolumn{2}{|c|}{--} & \multicolumn{2}{|c|}{4.21} & \multicolumn{2}{|c|}{4.9} & \multicolumn{2}{|c|}{5.4} & \multicolumn{2}{|c|}{5.18} \\
\hline 00078 & Secchi-depth (m) & \multicolumn{2}{|c|}{--} & \multicolumn{2}{|c|}{3.2} & \multicolumn{2}{|c|}{2.8} & \multicolumn{2}{|c|}{1.8} & \multicolumn{2}{|c|}{2.2} \\
\hline 00098 & Sampling depth (m) & 0.5 & 13.5 & 0.5 & 14.0 & 0.5 & 14.0 & 0.5 & 13.0 & 0.5 & 13.5 \\
\hline 00010 & Water Temperature $\left({ }^{\circ} \mathrm{C}\right)$ & 3.0 & 4.5 & 8.7 & 5.3 & 27.9 & 7.2 & 21.7 & 7.2 & 22.0 & 7.4 \\
\hline 00400 & $\mathrm{pH}$ (standard units) & 7.9 & 7.5 & 8.1 & 7.9 & 7.3 & 8.7 & 7.9 & 7.1 & 8.3 & 7.2 \\
\hline 00095 & Specific conductance $(\mu \mathrm{S} / \mathrm{cm})$ & 600 & 685 & 555 & 553 & 554 & 574 & 539 & 592 & 528 & 629 \\
\hline 00300 & Dissolved oxygen & 12.1 & 0.2 & 12.5 & 10.0 & 7.4 & 1.1 & 9.2 & 0.0 & 8.8 & 0.0 \\
\hline 00665 & Phosphorus, total (as P) & 0.020 & 0.039 & 0.016 & 0.022 & 0.017 & 0.045 & 0.018 & 0.088 & 0.011 & 0.074 \\
\hline 00671 & Orthophosphate, dissolved (as P) & -- & -- & $<.002$ & -- & -- & -- & -- & -- & -- & -- \\
\hline 00631 & Nitrate plus nitrite, dissolved (as $\mathrm{N}$ ) & -- & -- & 0.188 & -- & -- & -- & -- & -- & -- & -- \\
\hline 00608 & Ammonia, dissolved (as N) & -- & -- & 0.158 & -- & -- & -- & -- & -- & -- & -- \\
\hline 00625 & Ammonia plus organic nitrogen, total (as $\mathrm{N}$ ) & -- & -- & 0.62 & -- & -- & -- & -- & -- & -- & -- \\
\hline 00623 & Ammonia plus organic nitrogen, dissolved (as N) & -- & -- & -- & -- & -- & -- & -- & -- & -- & -- \\
\hline 00600 & Total nitrogen & -- & -- & 0.81 & -- & -- & -- & -- & -- & -- & -- \\
\hline 63675 & Turbidity, (NTU) & -- & -- & $<1.0$ & -- & -- & -- & -- & -- & -- & -- \\
\hline 00081 & Apparent color, (PTU) & -- & -- & 5 & -- & -- & -- & -- & -- & -- & -- \\
\hline 00900 & Hardness (as CaCO3) & -- & -- & 280 & -- & -- & -- & -- & -- & -- & -- \\
\hline 00915 & Calcium, dissolved ( $\mathrm{Ca})$ & -- & -- & 52 & -- & -- & -- & -- & -- & -- & -- \\
\hline 00925 & Magnesium, dissolved (Mg) & -- & -- & 37.6 & -- & -- & -- & -- & -- & -- & -- \\
\hline 00930 & Sodium, dissolved ( $\mathrm{Na})$ & -- & -- & 12.5 & -- & -- & -- & -- & -- & -- & -- \\
\hline 00935 & Potassium, dissolved (K) & -- & -- & 1.5 & -- & -- & -- & -- & -- & -- & -- \\
\hline 00417 & ANC (as $\mathrm{CaCO} 3$ ) & -- & -- & 248 & -- & -- & -- & -- & -- & -- & -- \\
\hline 00940 & Chloride, dissolved $(\mathrm{Cl})$ & -- & -- & 27.2 & -- & -- & -- & -- & -- & -- & -- \\
\hline 00945 & Sulfate, dissolved (SO4) & -- & -- & 23.3 & -- & -- & -- & -- & -- & -- & -- \\
\hline 00955 & Silica, dissolved (SiO2) & -- & -- & 11.3 & -- & -- & -- & -- & -- & -- & -- \\
\hline 01046 & Iron $(\mu \mathrm{g} / \mathrm{L})$ & -- & -- & $<100$ & -- & -- & -- & -- & -- & -- & -- \\
\hline 01056 & Manganese $(\mu \mathrm{g} / \mathrm{L})$ & -- & -- & $<1.0$ & -- & -- & -- & -- & -- & -- & -- \\
\hline 70300 & Solids, dissolved (at $180^{\circ} \mathrm{C}$ ) & -- & -- & 320 & -- & -- & -- & -- & -- & -- & -- \\
\hline
\end{tabular}




\section{SILVER LAKE NEAR WEST BEND, WI}

LAKE-DEPTH PROFILES, FEBRUARY 19 TO AUGUST 27, 2009

02-19-09

04-16-09

06-25-09

07-22-09

08-27-09
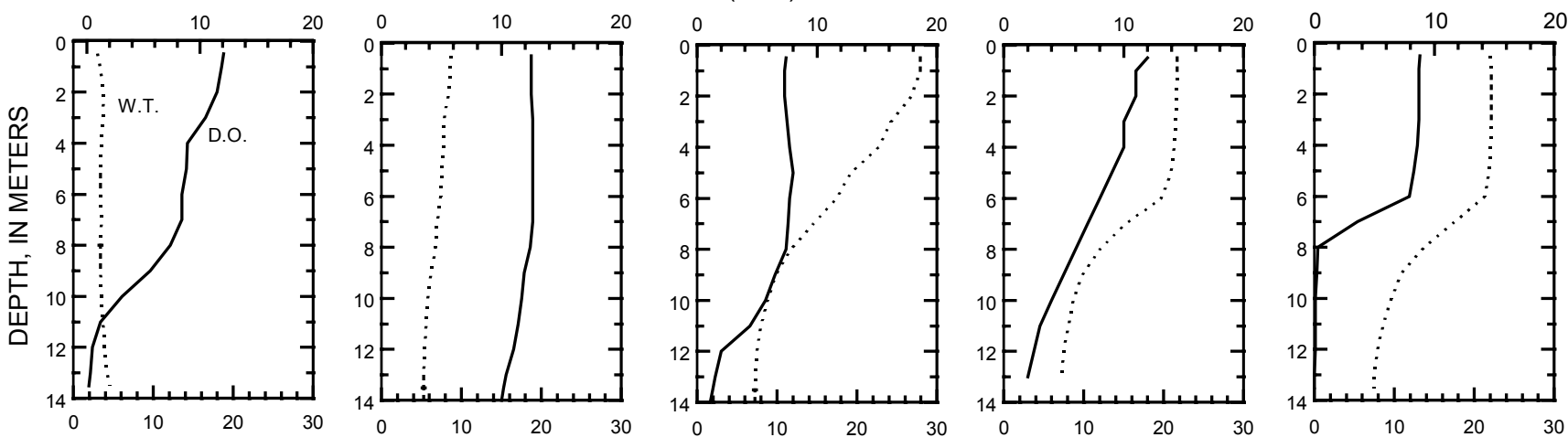

WATER TEMPERATURE (W.T.), IN DEGREES CELSIUS
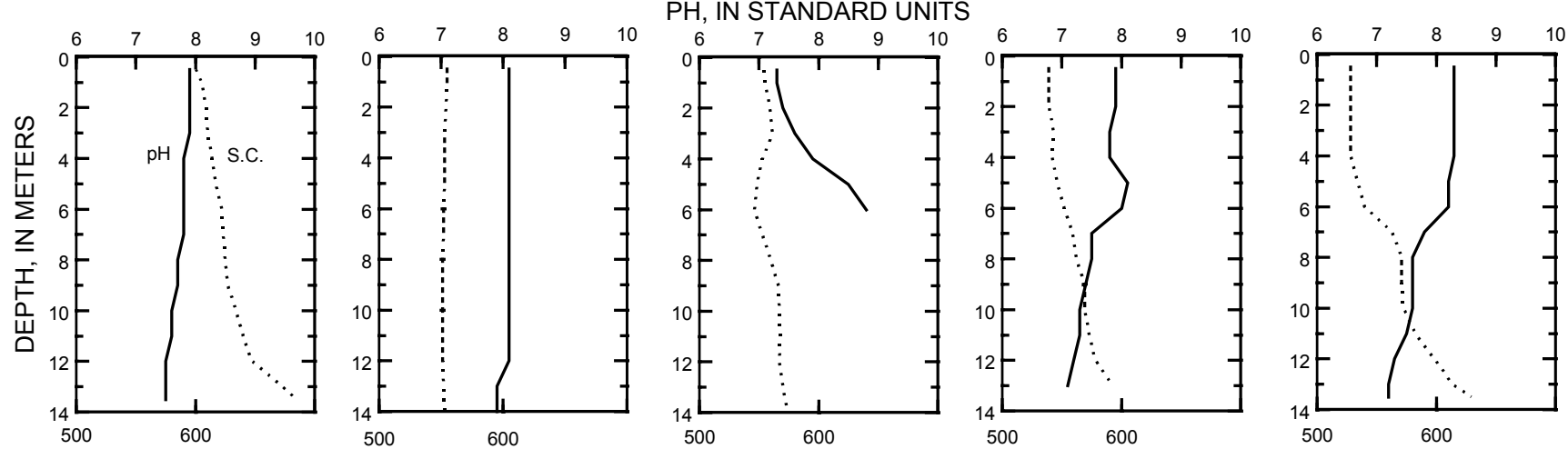

SPECIFIC CONDUCTANCE (S.C.), IN MICROSIEMENS PER CENTIMETER AT 25 DEGREES CELSIUS 

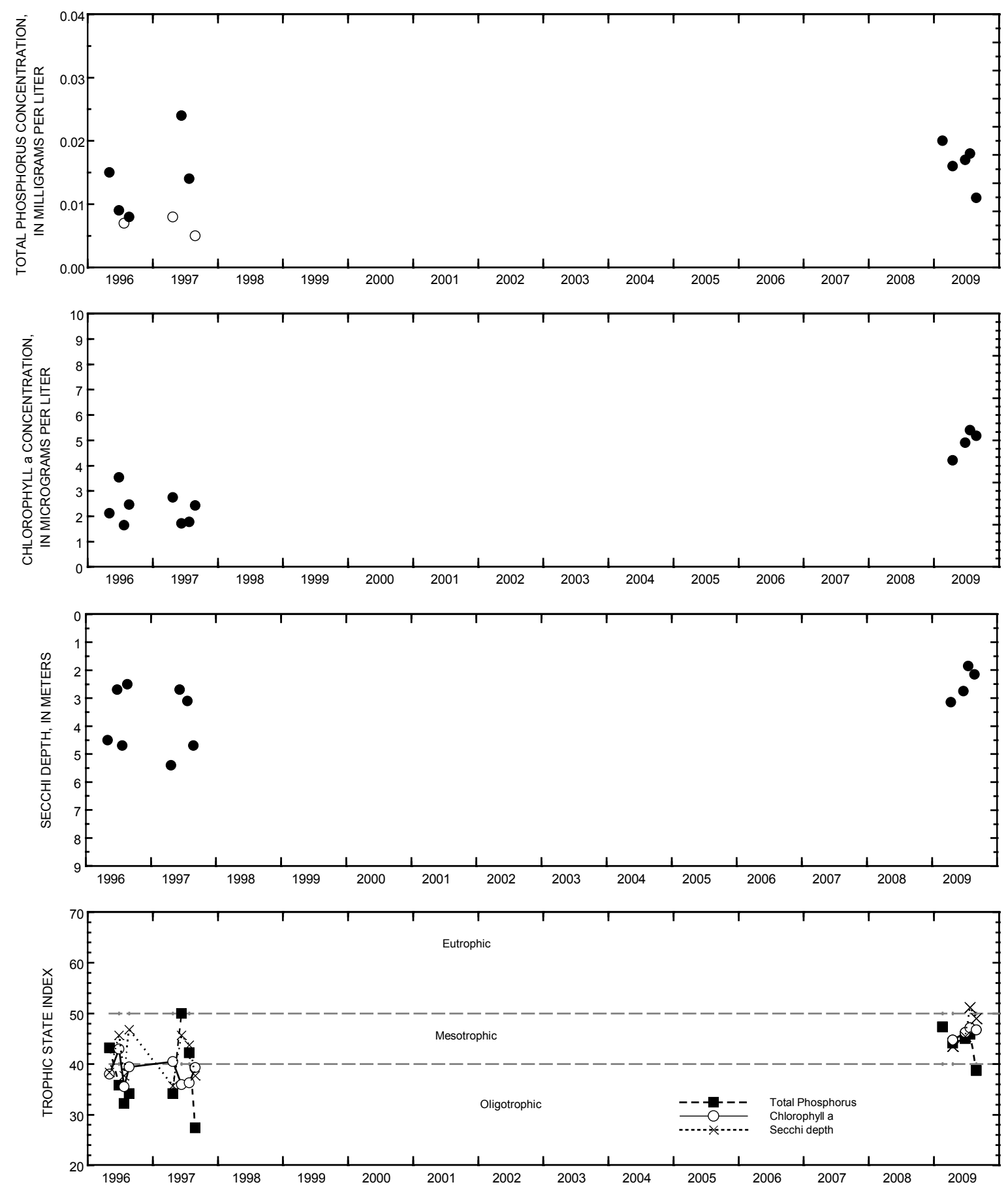

Surface total phosphorus, chlorophyll a concentrations, Secchi depths, and TSI data for Silver Lake, near West Bend, Wisconsin.

(Open circles on the first two plots indicate laboratory detection limit for selected analyses

Actual concentrations for these particular analyses are less than the plotted circles.) 


\section{TURTLE-FLAMBEAU FLOWAGE, DEEP HOLE, NEAR MERCER, WI}

LOCATION.--Lat 4604'58", long 90¹0'27", in SW 1/4 SE 1/4 SE 1/4 sec.25, T.42 W., R.2 E., Vilas County, Hydrologic Unit 07050002. PERIOD OF RECORD._April 2009 to March 2010 (discontinued).

REMARKS.--Lake sampled at the deep hole. Water-quality analyses done by Wisconsin State Laboratory of Hygiene.

WATER-QUALITY DATA, APRIL 29, 2009 TO MARCH 15, 2010

\begin{tabular}{|c|c|c|c|c|c|c|}
\hline \multirow[b]{2}{*}{$\underline{\text { Parameter Code }}$} & \multirow[b]{2}{*}{ Parameter Name } & \multicolumn{5}{|c|}{ igrams per liter unless otherwise indicated) } \\
\hline & & Apr. 29 & \multicolumn{2}{|c|}{ June 25} & \multicolumn{2}{|c|}{ Aug. 4} \\
\hline 00078 & Secchi-depth (m) & 1.8 & \multicolumn{2}{|c|}{2.1} & \multicolumn{2}{|c|}{1.5} \\
\hline 00098 & Sampling depth (m) & 0.5 & 0.5 & 13 & 0.5 & 13 \\
\hline 00010 & Water Temperature $\left({ }^{\circ} \mathrm{C}\right)$ & 7.3 & 25.7 & 9.7 & 20.1 & 10.1 \\
\hline 00400 & $\mathrm{pH}$ (standard units) & 7.6 & 8.1 & 6.9 & 7.2 & 6.8 \\
\hline 00095 & Specific conductance $(\mu \mathrm{S} / \mathrm{cm})$ & 89 & 90 & 116 & 94 & 134 \\
\hline 00300 & Dissolved oxygen & 10.8 & 10.4 & 0 & 9.6 & 0.3 \\
\hline 32210 & Chlorophyll a, phytoplankton ( $\mu \mathrm{g} / \mathrm{L})$ & 3.79 & 3.05 & -- & 3.19 & -- \\
\hline 00665 & Phosphorus, total (as P) & 0.025 & 0.045 & 0.056 & 0.034 & 0.079 \\
\hline 00671 & Orthophosphate, dissolved (as P) & 0.004 & -- & -- & -- & -- \\
\hline 00631 & Nitrate plus nitrite, dissolved (as $\mathrm{N}$ ) & $<.019$ & -- & -- & -- & -- \\
\hline 00608 & Ammonia, dissolved (as $\mathrm{N}$ ) & 0.034 & -- & -- & -- & -- \\
\hline 00625 & Ammonia plus organic nitrogen, total (as $\mathrm{N}$ ) & 0.48 & -- & -- & -- & -- \\
\hline 00623 & Ammonia plus organic nitrogen, dissolved (as $\mathrm{N}$ ) & -- & -- & -- & -- & -- \\
\hline 00600 & Total nitrogen & -- & -- & -- & -- & -- \\
\hline 63675 & Turbidity, (NTU) & $<1.0$ & -- & -- & -- & -- \\
\hline 00081 & Apparent color, (PTU) & 50 & -- & -- & -- & -- \\
\hline 00900 & Hardness (as $\mathrm{CaCO} 3$ ) & 42 & -- & -- & -- & -- \\
\hline 00915 & Calcium, dissolved (Ca) & 11.8 & -- & -- & -- & -- \\
\hline 00925 & Magnesium, dissolved (Mg) & 3.1 & -- & -- & -- & -- \\
\hline 00930 & Sodium, dissolved $(\mathrm{Na})$ & 2.2 & -- & -- & -- & -- \\
\hline 00935 & Potassium, dissolved (K) & 0.7 & -- & -- & -- & -- \\
\hline 00417 & ANC (as $\mathrm{CaCO}$ ) & 38 & -- & -- & -- & -- \\
\hline 00940 & Chloride, dissolved $(\mathrm{Cl})$ & 3.1 & -- & -- & -- & -- \\
\hline 00945 & Sulfate, dissolved (SO4) & $<4.5$ & -- & -- & -- & -- \\
\hline 00955 & Silica, dissolved (SiO2) & 8.13 & -- & -- & -- & -- \\
\hline 01046 & Iron $(\mu \mathrm{g} / \mathrm{L})$ & 600 & -- & -- & -- & -- \\
\hline 01056 & Manganese $(\mu \mathrm{g} / \mathrm{L})$ & 80 & -- & -- & -- & -- \\
\hline 70300 & Solids, dissolved (at $180^{\circ} \mathrm{C}$ ) & 64 & -- & -- & -- & -- \\
\hline
\end{tabular}


460458090102700 TURTLE-FLAMBEAU FLOWAGE, DEEP HOLE, NEAR MERCER, WI

LAKE-DEPTH PROFILES, APRIL 29, 2009 TO MARCH 15, 2010

04-29-09
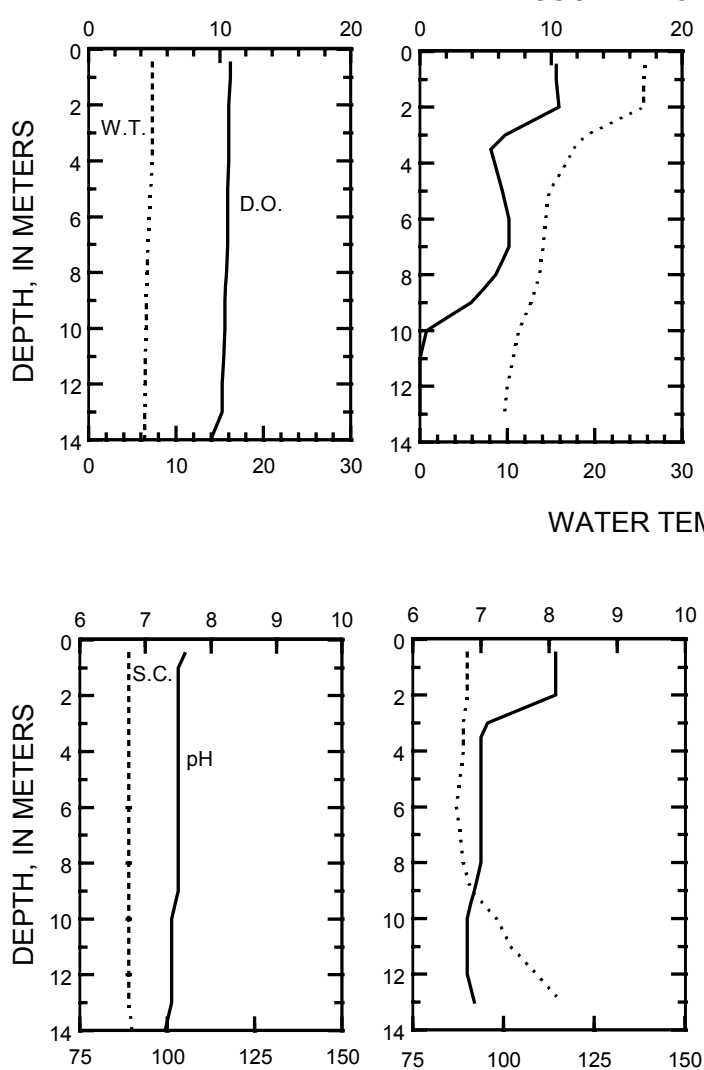

06-25-09
08-04-09

09-03-09

DISSOLVED OXYGEN (D.O.), IN MILLIGRAMS PER LITER
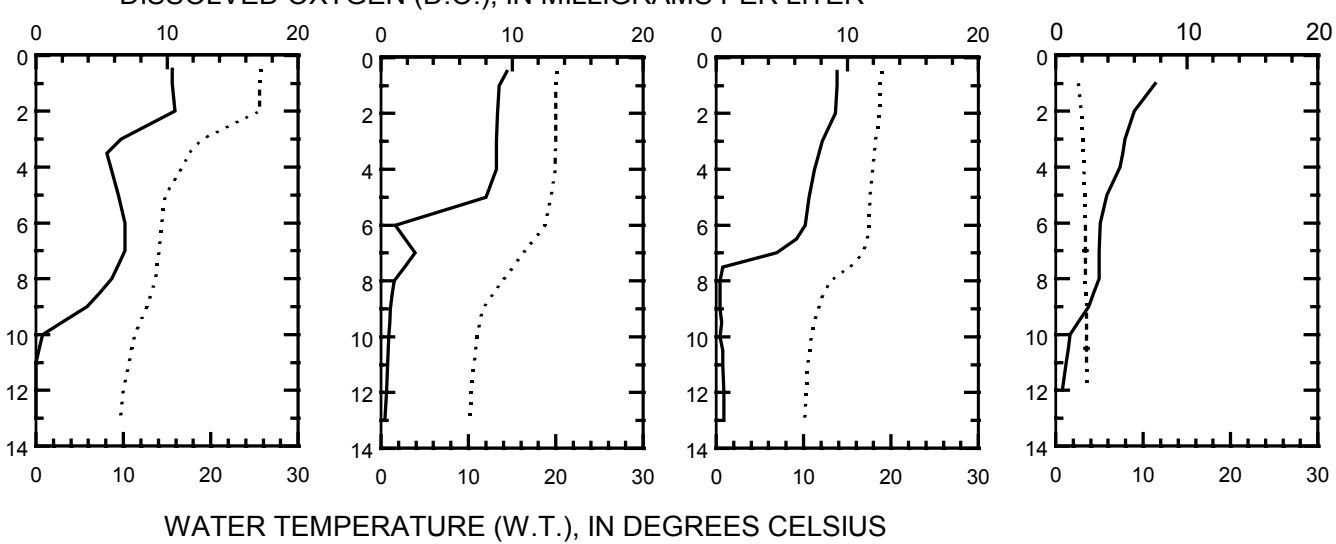

PH, IN STANDARD UNITS
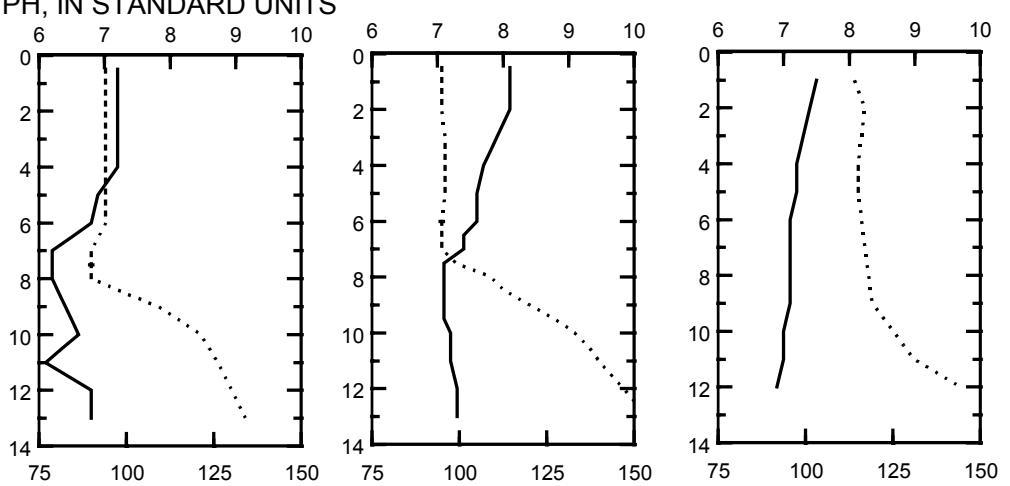

SPECIFIC CONDUCTANCE (S.C.), IN MICROSIEMENS PER CENTIMETER AT 25 DEGREES CELSIUS 


\section{TURTLE-FLAMBEAU FLOWAGE, SOUTHWEST BASIN, NEAR MERCER, WI}

LOCATION.--Lat 4603'44", long 90¹2'48", in NE 1/4 SW 1/4 NW 1/4 sec.2, T.41 N., R.2 E., Vilas County, Hydrologic Unit 07050002.

PERIOD OF RECORD._April 2009 to March 2010 (discontinued).

REMARKS.--Lake sampled in the deepest part of the southwest basin of the flowage. Water-quality analyses done by Wisconsin State Laboratory of Hygiene.

WATER-QUALITY DATA, APRIL 29 TO MARCH 15, 2010

(Milligrams per liter unless otherwise indicated)

\begin{tabular}{|c|c|c|c|c|c|c|c|c|c|c|}
\hline Parameter Code & Parameter Name & Apr. 29 & \multicolumn{2}{|c|}{ June 25} & \multicolumn{2}{|c|}{ Aug. 4} & \multicolumn{2}{|c|}{ Sept. 3} & \multicolumn{2}{|c|}{ March 15} \\
\hline 00078 & Secchi-depth (m) & 2.1 & \multicolumn{2}{|c|}{1.9} & \multicolumn{2}{|c|}{2.4} & \multicolumn{2}{|c|}{1.6} & \multicolumn{2}{|c|}{--} \\
\hline 00098 & Sampling depth (m) & 0.5 & 0.5 & 5.5 & 0.5 & 6.0 & 0.5 & 6.0 & 1.0 & 4.0 \\
\hline 00010 & Water Temperature $\left({ }^{\circ} \mathrm{C}\right)$ & 8.7 & 25.1 & 16.4 & 19.8 & 19.0 & 18.6 & 16.9 & 2.9 & 4.7 \\
\hline 00400 & $\mathrm{pH}$ (standard units) & 7.7 & 8.0 & 6.8 & 7.1 & 6.8 & 7.9 & 7.5 & 7.7 & 7.2 \\
\hline 00095 & Specific conductance $(\mu \mathrm{S} / \mathrm{cm})$ & 95 & 90 & 95 & 90 & 90 & 91 & 93 & 117 & 144 \\
\hline 00300 & Dissolved oxygen & 11.4 & 12.3 & 1.2 & 8.7 & 7.7 & 8.7 & 5.4 & 10.1 & 1.1 \\
\hline 32210 & Chlorophyll a, phytoplankton ( $\mu \mathrm{g} / \mathrm{L})$ & 1.57 & 3.63 & -- & 3.79 & -- & 5.95 & -- & -- & -- \\
\hline 00665 & Phosphorus, total (as P) & 0.027 & 0.044 & 0.036 & 0.036 & 0.029 & 0.020 & 0.026 & 0.013 & 0.118 \\
\hline 00671 & Orthophosphate, dissolved (as P) & -- & -- & -- & -- & -- & -- & -- & -- & -- \\
\hline 00631 & Nitrate plus nitrite, dissolved (as $\mathrm{N}$ ) & -- & -- & -- & -- & -- & -- & -- & 0.087 & -- \\
\hline 00608 & Ammonia, dissolved (as $\mathrm{N}$ ) & -- & -- & -- & -- & -- & -- & -- & -- & -- \\
\hline 00625 & Ammonia plus organic nitrogen, total (as $\mathrm{N}$ ) & -- & -- & -- & -- & -- & -- & -- & 0.39 & -- \\
\hline 00623 & Ammonia plus organic nitrogen, dissolved (as $\mathrm{N}$ ) & -- & -- & -- & -- & -- & -- & -- & -- & -- \\
\hline 00600 & Total nitrogen & -- & -- & -- & -- & -- & -- & -- & 0.477 & -- \\
\hline
\end{tabular}




\section{TURTLE-FLAMBEAU FLOWAGE, SOUTHWEST BASIN, NEAR MERCER, WI}

LAKE-DEPTH PROFILES, APRIL 29, 2009 TO MARCH 15, 2010

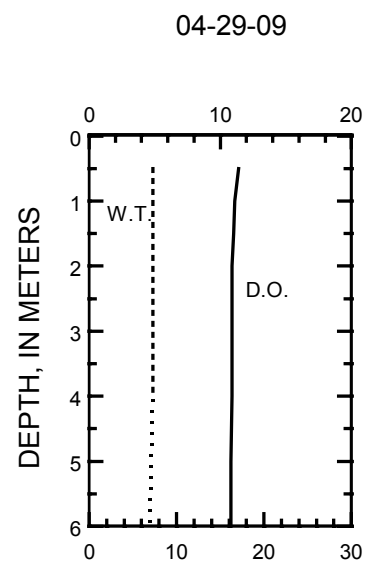

06-25-09

08-04-09

09-03-09

03-15-10

DISSOLVED OXYGEN (D.O.), IN MILLIGRAMS PER LITER
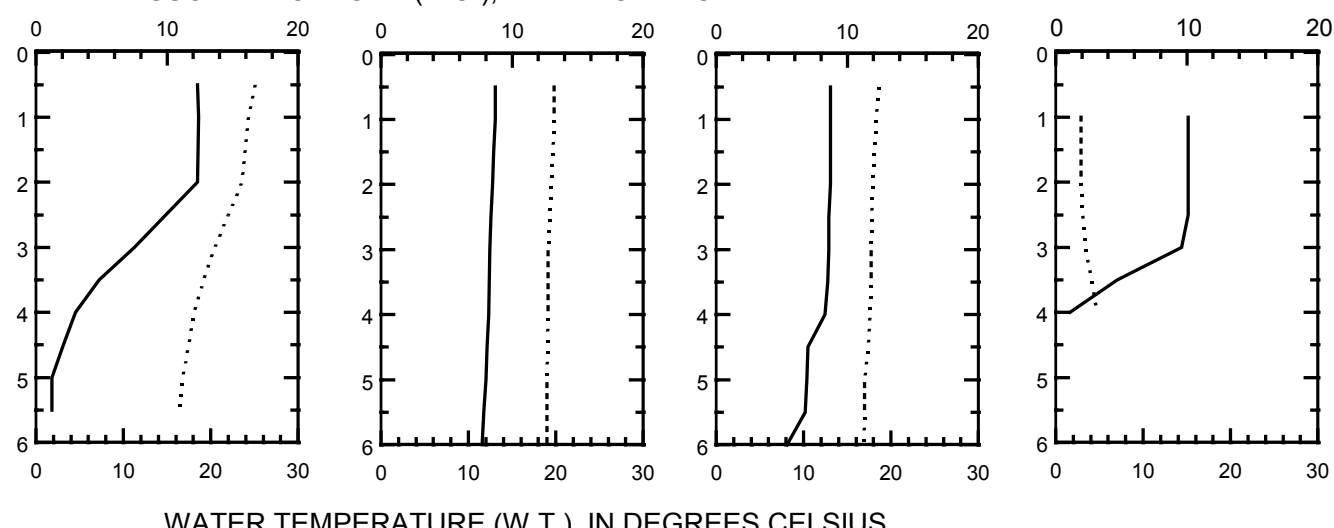

WATER TEMPERATURE (W.T.), IN DEGREES CELSIUS
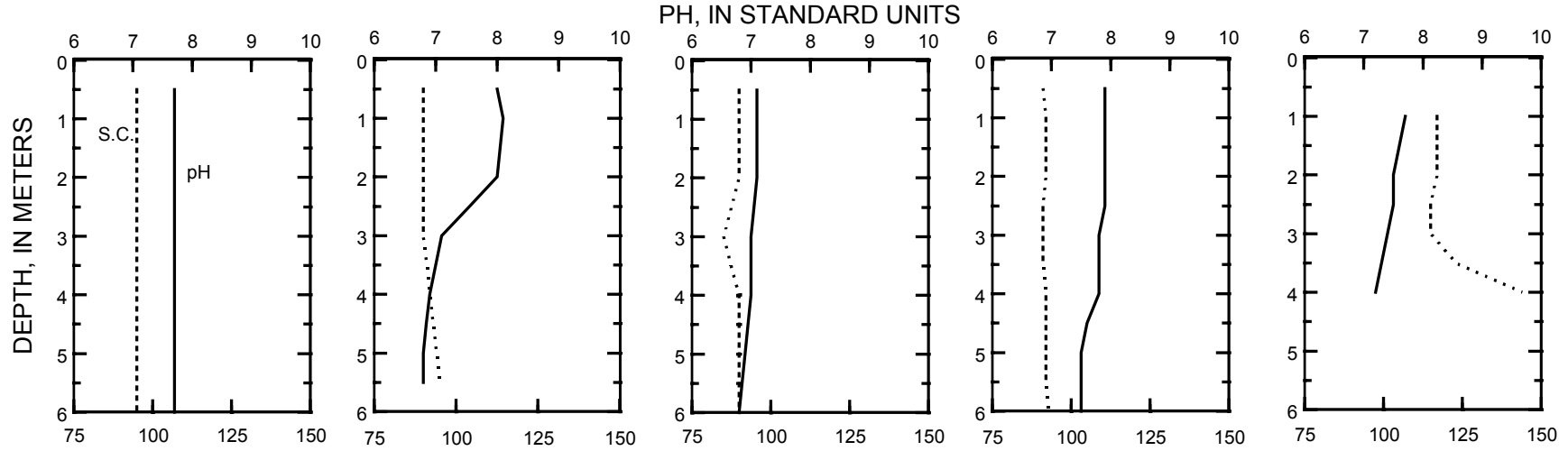

SPECIFIC CONDUCTANCE (S.C.), IN MICROSIEMENS PER CENTIMETER AT 25 DEGREES CELSIUS 


\section{LAKE BASTINE, DEEP HOLE, NEAR MERCER, WI}

LOCATION.--Lat 4605'11", long 90¹5'38", in NE 1/4 SE 1/4 SE 1/4 sec.29, T.41 N., R.2 E., Vilas County, Hydrologic Unit 07050002. PERIOD OF RECORD._April 2009 to March 2010 (discontinued).

REMARKS.--Lake sampled at the deep hole. Water-quality analyses done by Wisconsin State Laboratory of Hygiene.

WATER-QUALITY DATA, APRIL 29, 2009 TO MARCH 15, 2010

(Milligrams per liter unless otherwise indicated)

\begin{tabular}{|c|c|c|c|c|c|c|c|c|c|c|}
\hline Parameter Code & Parameter Name & Apr. 29 & \multicolumn{2}{|c|}{$\underline{\text { June } 25}$} & \multicolumn{2}{|c|}{ Aug. 4} & \multicolumn{2}{|c|}{$\underline{\text { Sept. } 3}$} & \multicolumn{2}{|c|}{ March 15} \\
\hline 00078 & Secchi-depth (m) & 1.4 & \multicolumn{2}{|c|}{2.1} & \multicolumn{2}{|c|}{1.7} & \multicolumn{2}{|c|}{1.6} & \multicolumn{2}{|c|}{--} \\
\hline 00098 & Sampling depth (m) & 0.5 & 0.5 & 11.0 & 0.5 & 12.0 & 0.5 & 11.0 & 1.0 & 9.0 \\
\hline 00010 & Water Temperature $\left({ }^{\circ} \mathrm{C}\right)$ & 7.9 & 24.7 & 7.9 & 19.9 & 8.8 & 18.2 & 9.0 & 3.0 & 4.1 \\
\hline 00400 & $\mathrm{pH}$ (standard units) & 6.9 & 7.9 & 6.8 & 7.0 & 6.9 & 7.9 & 7.3 & 7.4 & 7.0 \\
\hline 00095 & Specific conductance $(\mu \mathrm{S} / \mathrm{cm})$ & 105 & 90 & 127 & 93 & 145 & 94 & 164 & 112 & 130 \\
\hline 00300 & Dissolved oxygen & 10.5 & 11.2 & 0.0 & 8.6 & 0.4 & 8.7 & 0.3 & 11.8 & 0.5 \\
\hline 32210 & Chlorophyll a, phytoplankton ( $\mu \mathrm{g} / \mathrm{L})$ & 3.25 & 2.38 & -- & 2.86 & -- & 8.36 & -- & -- & -- \\
\hline 00665 & Phosphorus, total (as P) & 0.021 & 0.042 & 0.067 & 0.026 & 0.064 & 0.021 & 0.075 & 0.012 & 0.212 \\
\hline 00671 & Orthophosphate, dissolved (as P) & -- & -- & -- & -- & -- & -- & -- & 0.001 & -- \\
\hline 00631 & Nitrate plus nitrite, dissolved (as $\mathrm{N}$ ) & -- & -- & -- & -- & -- & -- & -- & 0.071 & -- \\
\hline 00608 & Ammonia, dissolved (as N) & -- & -- & -- & -- & -- & -- & -- & -- & -- \\
\hline 00625 & Ammonia plus organic nitrogen, total (as $\mathrm{N}$ ) & -- & -- & -- & -- & -- & -- & -- & 0.45 & -- \\
\hline 00623 & Ammonia plus organic nitrogen, dissolved (as $\mathrm{N}$ ) & -- & -- & -- & -- & -- & -- & -- & -- & -- \\
\hline 00600 & Total nitrogen & -- & -- & -- & -- & -- & -- & -- & 0.521 & -- \\
\hline
\end{tabular}




\section{LAKE BASTINE, DEEP HOLE, NEAR MERCER, WI}

LAKE-DEPTH PROFILES, APRIL 29, 2009 TO MARCH 15, 2010

04-29-09
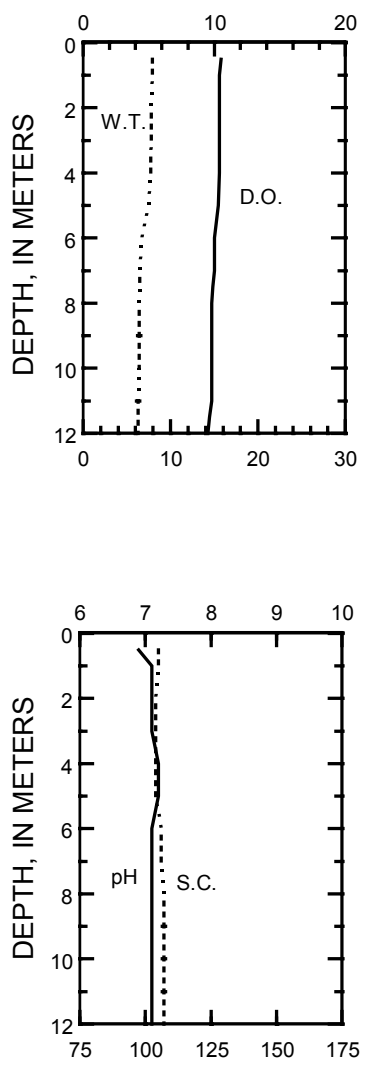

06-25-09

08-04-09

09-03-09

DISSOLVED OXYGEN (D.O.), IN MILLIGRAMS PER LITER
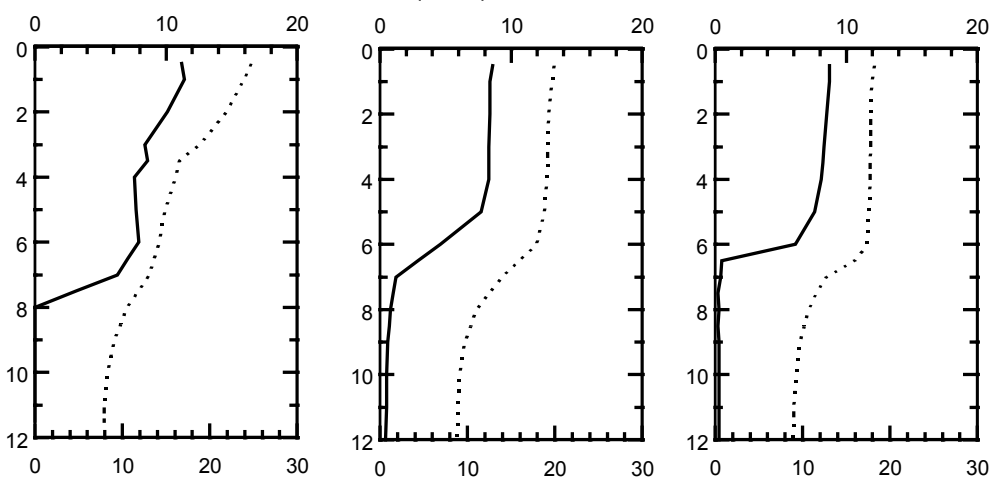

WATER TEMPERATURE (W.T.), IN DEGREES CELSIUS

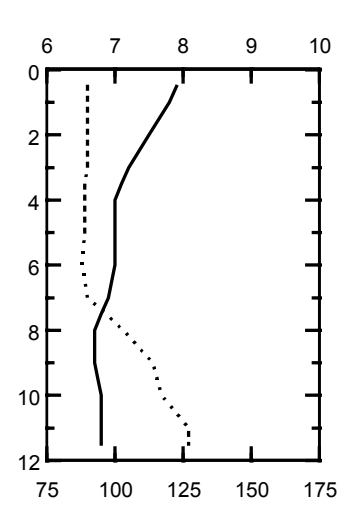

PH, IN STANDARD UNITS
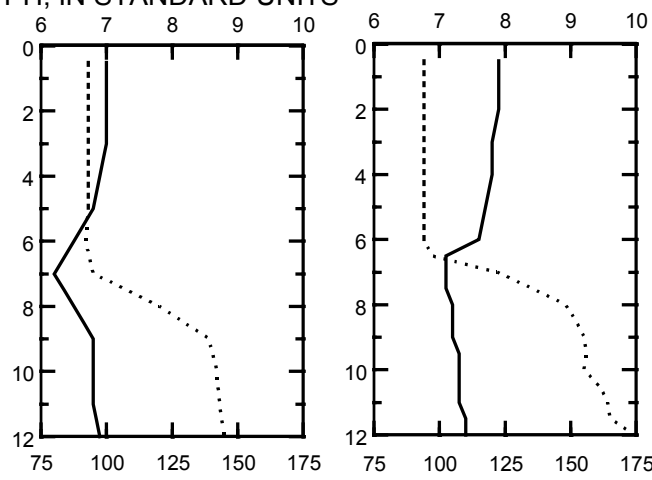

03-15-10
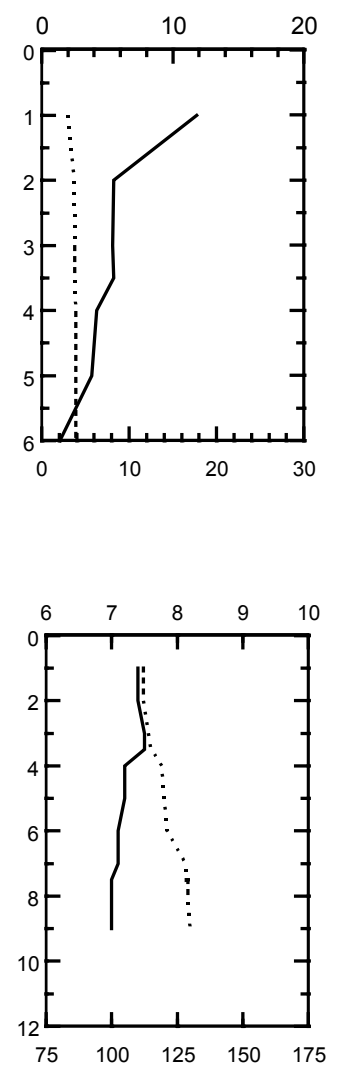

SPECIFIC CONDUCTANCE (S.C.), IN MICROSIEMENS PER CENTIMETER AT 25 DEGREES CELSIUS 


\section{TOWNLINE LAKE NEAR MERCER, WI}

LOCATION.--Lat 4604'09", long 9008'41", in NW 1/4 NW 1/4 NE 1/4 sec.5, T.41 N., R.3 E., Vilas County, Hydrologic Unit 07050002. PERIOD OF RECORD._April 2009 to March 2010 (discontinued).

REMARKS.--Lake sampled at the deep hole. Water-quality analyses done by Wisconsin State Laboratory of Hygiene.

WATER-QUALITY DATA, APRIL 29 TO MARCH 15, 2010

(Milligrams per liter unless otherwise indicated)

\begin{tabular}{|c|c|c|c|c|c|c|c|c|c|c|}
\hline Parameter Code & Parameter Name & Apr. 29 & \multicolumn{2}{|c|}{$\underline{\text { June } 25}$} & \multicolumn{2}{|c|}{ Aug. 4} & \multicolumn{2}{|c|}{$\underline{\text { Sept. } 3}$} & \multicolumn{2}{|c|}{ March 15} \\
\hline 00078 & Secchi-depth (m) & 1.2 & \multicolumn{2}{|c|}{1.8} & \multicolumn{2}{|c|}{1.2} & \multicolumn{2}{|c|}{1.6} & \multicolumn{2}{|c|}{--} \\
\hline 00098 & Sampling depth (m) & 0.5 & 0.5 & 5.0 & 0.5 & 5.0 & 0.5 & 5.0 & 1.0 & 4.0 \\
\hline 00010 & Water Temperature $\left({ }^{\circ} \mathrm{C}\right)$ & 9.4 & 25.4 & 14.0 & 19.9 & 19.6 & 18.4 & 16.5 & 4.7 & 4.0 \\
\hline 00400 & $\mathrm{pH}$ (standard units) & 7.7 & 8.0 & 6.8 & 7.1 & 7.0 & 8.0 & 7.4 & 7.7 & 7.1 \\
\hline 00095 & Specific conductance $(\mu \mathrm{S} / \mathrm{cm})$ & 76 & 81 & 90 & 83 & 83 & 84 & 84 & 93 & 108 \\
\hline 00300 & Dissolved oxygen & 10.7 & 10.8 & 0.0 & 9.7 & 8.4 & 9.1 & 5.3 & 8.7 & 2.3 \\
\hline 32210 & Chlorophyll a, phytoplankton ( $\mu \mathrm{g} / \mathrm{L})$ & 5.9 & 3.83 & -- & 6.0 & -- & 6.02 & -- & -- & -- \\
\hline 00665 & Phosphorus, total (as P) & 0.030 & 0.025 & 0.040 & 0.041 & 0.034 & 0.033 & 0.033 & 0.013 & 0.036 \\
\hline 00671 & Orthophosphate, dissolved (as P) & -- & -- & -- & -- & -- & -- & -- & 0.006 & -- \\
\hline 00631 & Nitrate plus nitrite, dissolved (as $\mathrm{N}$ ) & -- & -- & -- & -- & -- & -- & -- & 0.127 & -- \\
\hline 00608 & Ammonia, dissolved (as N) & -- & -- & -- & -- & -- & -- & -- & -- & -- \\
\hline 00625 & Ammonia plus organic nitrogen, total (as $\mathrm{N}$ ) & -- & -- & -- & -- & -- & -- & -- & 0.37 & -- \\
\hline 00623 & Ammonia plus organic nitrogen, dissolved (as $\mathrm{N}$ ) & -- & -- & -- & -- & -- & -- & -- & -- & -- \\
\hline 00600 & Total nitrogen & -- & -- & -- & -- & -- & -- & -- & 0.497 & -- \\
\hline
\end{tabular}




\section{TOWNLINE LAKE NEAR MERCER, WI}

LAKE-DEPTH PROFILES, APRIL 29, 2009 TO MARCH 15, 2010

04-29-09
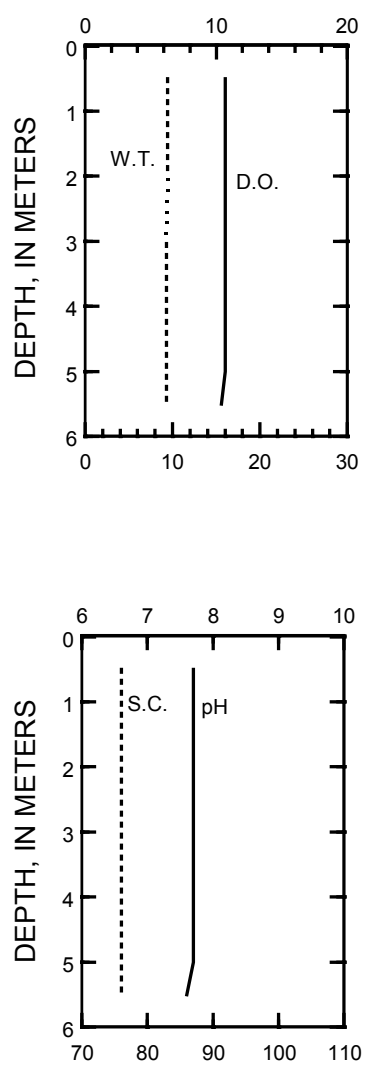

06-25-09

08-04-09

09-03-09

DISSOLVED OXYGEN (D.O.), IN MILLIGRAMS PER LITER
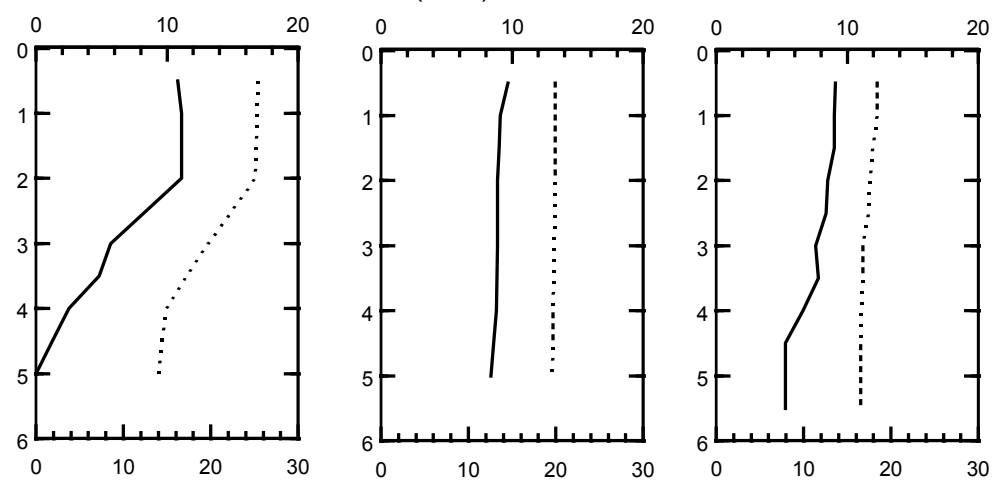

WATER TEMPERATURE (W.T.), IN DEGREES CELSIUS

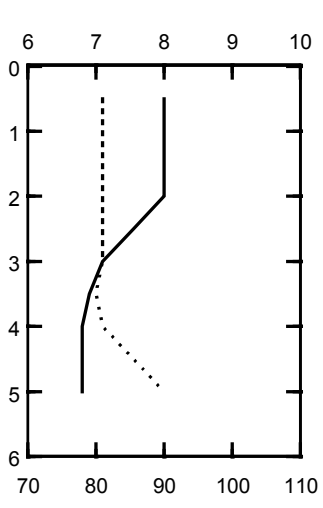

PH, IN STANDARD UNITS
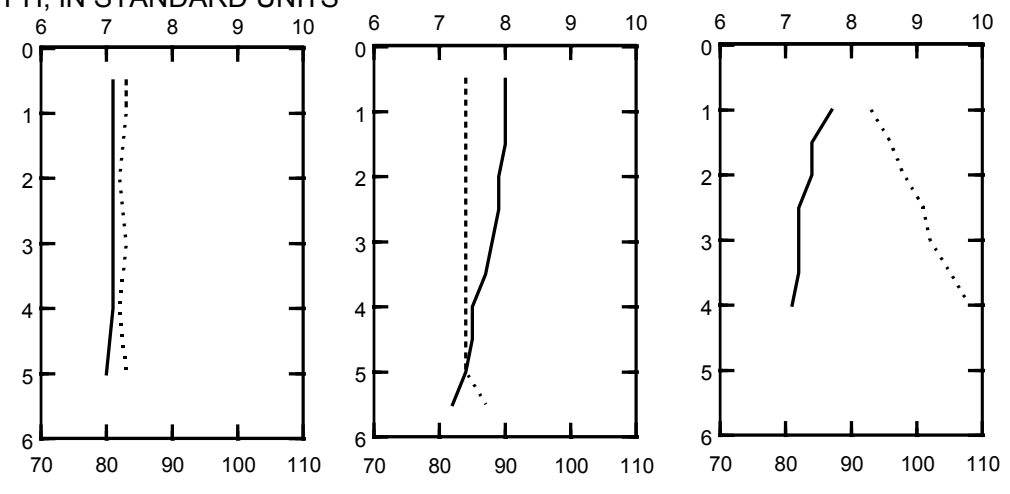

03-15-10

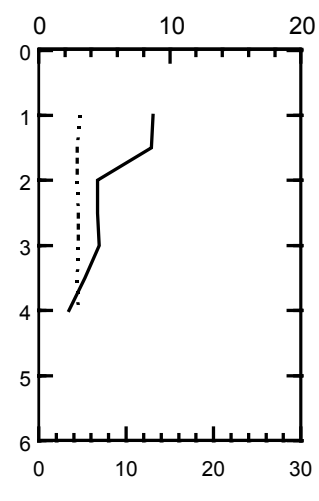

20

SPECIFIC CONDUCTANCE (S.C.), IN MICROSIEMENS PER CENTIMETER AT 25 DEGREES CELSIUS 


\section{TRUDE LAKE, DEEP HOLE, NEAR MERCER, WI}

LOCATION.--Lat 4606'46", long 9009'19", in SW 1/4 SW 1/4 SW 1/4 sec.17, T.42 N., R.3 E., Vilas County, Hydrologic Unit 07050002. PERIOD OF RECORD._April 2009 to March 2010 (discontinued).

REMARKS.--Lake sampled at the deep hole. Water-quality analyses done by Wisconsin State Laboratory of Hygiene.

\begin{tabular}{|c|c|c|c|c|c|c|}
\hline \multirow[b]{2}{*}{ Parameter Code } & \multirow[b]{2}{*}{ Parameter Name } & \multicolumn{5}{|c|}{ Ailligrams per liter unless otherwise indicated) } \\
\hline & & Apr. 28 & \multicolumn{2}{|c|}{ June 25} & \multicolumn{2}{|c|}{ Aug. 4} \\
\hline 00078 & Secchi-depth (m) & 2.8 & \multicolumn{2}{|c|}{3.2} & \multicolumn{2}{|c|}{2.3} \\
\hline 00098 & Sampling depth (m) & 0.5 & 0.5 & 13.0 & 0.5 & 13.0 \\
\hline 00010 & Water Temperature $\left({ }^{\circ} \mathrm{C}\right)$ & 7.4 & 25.0 & 12.1 & 19.4 & 12.0 \\
\hline 00400 & $\mathrm{pH}$ (standard units) & 7.5 & 8.0 & 6.7 & 7.0 & 6.6 \\
\hline 00095 & Specific conductance $(\mu \mathrm{S} / \mathrm{cm})$ & 78 & 81 & 90 & 81 & 115 \\
\hline 00300 & Dissolved oxygen & 10.8 & 8.6 & 0.0 & 8.6 & 0.4 \\
\hline 32210 & Chlorophyll a, phytoplankton ( $\mu \mathrm{g} / \mathrm{L})$ & 1.47 & 0.88 & -- & 3.08 & -- \\
\hline 00665 & Phosphorus, total (as P) & 0.018 & 0.039 & 0.082 & 0.026 & 0.032 \\
\hline 00671 & Orthophosphate, dissolved (as $\mathrm{P}$ ) & 0.003 & -- & -- & -- & -- \\
\hline 00631 & Nitrate plus nitrite, dissolved (as $\mathrm{N}$ ) & 0.058 & -- & -- & -- & -- \\
\hline 00608 & Ammonia, dissolved (as $\mathrm{N}$ ) & 0.029 & -- & -- & -- & -- \\
\hline 00625 & Ammonia plus organic nitrogen, total (as $\mathrm{N}$ ) & 0.57 & -- & -- & -- & -- \\
\hline 00623 & Ammonia plus organic nitrogen, dissolved (as N) & -- & -- & -- & -- & -- \\
\hline 00600 & Total nitrogen & 0.63 & -- & -- & -- & -- \\
\hline 63675 & Turbidity, (NTU) & $<1.0$ & -- & -- & -- & -- \\
\hline 00081 & Apparent color, (PTU) & 40 & -- & -- & -- & -- \\
\hline 00900 & Hardness (as CaCO3) & 37 & -- & -- & -- & -- \\
\hline 00915 & Calcium, dissolved (Ca) & 9.8 & -- & -- & -- & -- \\
\hline 00925 & Magnesium, dissolved (Mg) & 3 & -- & -- & -- & -- \\
\hline 00930 & Sodium, dissolved $(\mathrm{Na})$ & 1.6 & -- & -- & -- & -- \\
\hline 00935 & Potassium, dissolved (K) & 0.7 & -- & -- & -- & -- \\
\hline 00417 & ANC (as $\mathrm{CaCO} 3$ ) & 34 & -- & -- & -- & -- \\
\hline 00940 & Chloride, dissolved $(\mathrm{Cl})$ & 2.2 & -- & -- & -- & -- \\
\hline 00945 & Sulfate, dissolved (SO4) & $<4.5$ & -- & -- & -- & -- \\
\hline 00955 & Silica, dissolved (SiO2) & 8.24 & -- & -- & -- & -- \\
\hline 01046 & Iron $(\mu \mathrm{g} / \mathrm{L})$ & 100 & -- & -- & -- & -- \\
\hline 01056 & Manganese $(\mu \mathrm{g} / \mathrm{L})$ & 90 & -- & -- & -- & -- \\
\hline 70300 & Solids, dissolved (at $180^{\circ} \mathrm{C}$ ) & 58 & -- & -- & -- & -- \\
\hline
\end{tabular}

\begin{tabular}{cccc}
\multicolumn{2}{c}{ Sept. 3 } & \multicolumn{2}{c}{ March 15} \\
0.5 & 12.0 & 1.0 & 10.0 \\
20.0 & 11.9 & 2.9 & 3.6 \\
8.1 & 7.2 & 7.5 & 7.1 \\
82 & 136 & 87 & 96 \\
7.9 & 0.1 & 11.0 & 4.7 \\
4.52 & -- & -- & -- \\
0.010 & 0.058 & 0.016 & 0.018 \\
-- & -- & 0.012 & - \\
-- & -- & 0.066 & -- \\
-- & -- & -- & -- \\
-- & -- & 0.39 & - \\
-- & -- & -- & -- \\
-- & -- & 0.456 & -- \\
-- & -- & -- & -- \\
-- & -- & -- & -- \\
-- & -- & -- & -- \\
-- & -- & -- & - \\
-- & -- & -- & -- \\
-- & -- & -- & -- \\
-- & -- & -- & -- \\
-- & -- & -- & -- \\
-- & -- & -- & -- \\
-- & -- & -- & -- \\
-- & -- & -- & - \\
-- & -- & -- & -- \\
-- & -- & -- & -- \\
-- & -- & -- & --
\end{tabular}




\section{TRUDE LAKE, DEEP HOLE, NEAR MERCER, WI}

\section{LAKE-DEPTH PROFILES, APRIL 29, 2009 TO MARCH 15, 2010}

04-28-09
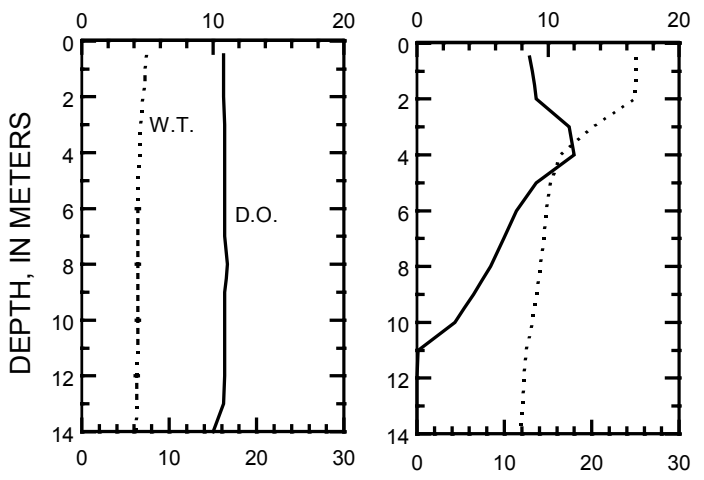

WATER TEMP
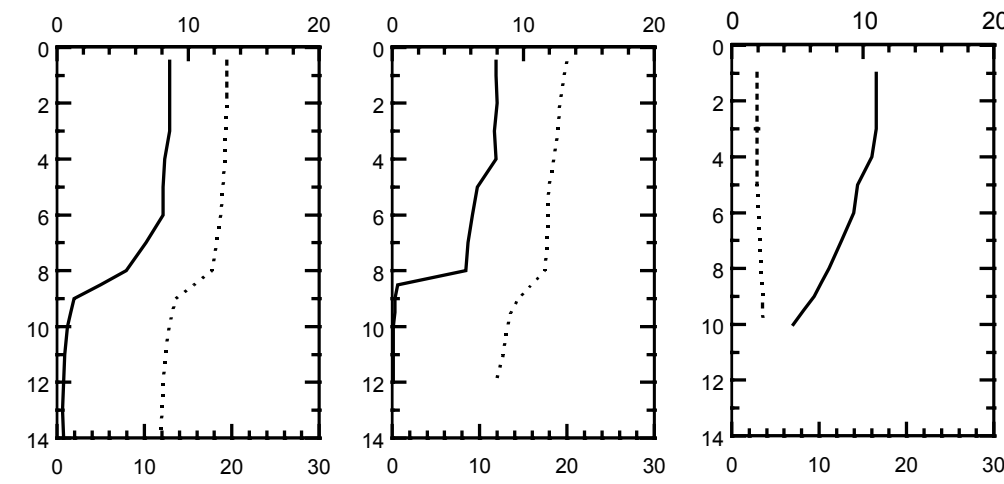

PH, IN STANDARD UNITS
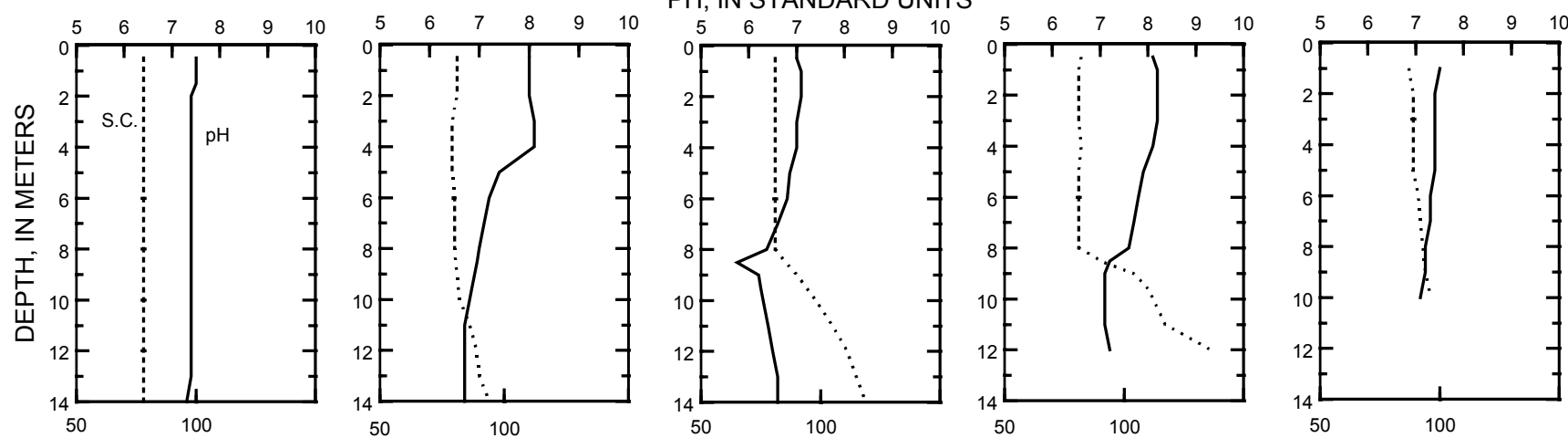

SPECIFIC CONDUCTANCE (S.C.), IN MICROSIEMENS PER CENTIMETER AT 25 DEGREES CELSIUS 


\section{LAKE WAUBESA AT MCFARLAND, WI}

LOCATION.--Lat 4300'32", long 89 $18^{\prime} 19^{\prime \prime}$ referenced to North American Datum of 1927, in SW 1/4 SW 1/4 sec.3, T.6 N., R.10 E., Dane County, WI, Hydrologic Unit 07090001, on left bank just upstream from bridge on U.S. Highway 51 , downstream of dam at outlet of Lake Waubesa and 1.0 mi southwest of McFarland.

SURFACE AREA.--3.25 $\mathrm{mi}^{2}$.

DRAINAGE AREA.--327 $\mathrm{mi}^{2}$ of which $36.6 \mathrm{mi}^{2}$ probably is noncontributing.

PERIOD OF RECORD.--October 2003 to current year.

REVISED RECORDS.--WSP 805, WDR WI-73-1: Drainage area.

GAGE.--Water-stage recorder. Datum of gage is $840.00 \mathrm{ft}$ above NGVD of 1929 (levels by Wisconsin Department of Natural Resources).

REMARKS.--Lake level regulated by dams at outlets of Lake Mendota and Lake Waubesa. Gage-height telemeter at station.

EXTREMES FOR PERIOD OF RECORD.--Maximum gage height observed, $7.22 \mathrm{ft}$, June 15-17, 2008; minimum observed, $3.50 \mathrm{ft}$, Feb.14, 2006, current datum.

EXTREMES FOR CURRENT YEAR.--Maximum recorded gage height, $5.86 \mathrm{ft}$, June 22; minimum recorded, $4.22 \mathrm{ft}$, Feb. 6-7. 


\begin{tabular}{|c|c|c|c|c|c|c|c|c|c|c|c|c|}
\hline \multicolumn{13}{|c|}{$\begin{array}{c}\text { GAGE HEIGHT, FEET } \\
\text { WATER YEAR OCTOBER } 2008 \text { TO SEPTEMBER } 2009 \\
\text { DAILY MEAN VALUES }\end{array}$} \\
\hline Day & Oct & Nov & Dec & Jan & Feb & Mar & Apr & May & Jun & Jul & Aug & Sep \\
\hline 1 & 5.41 & 4.52 & 4.70 & 4.76 & 4.29 & 4.48 & 5.52 & 5.56 & 5.28 & 5.57 & 5.29 & 5.33 \\
\hline 2 & 5.36 & 4.51 & 4.68 & 4.73 & 4.28 & 4.44 & \begin{tabular}{|l|}
5.47 \\
\end{tabular} & 5.49 & 5.28 & 5.55 & 5.27 & 5.32 \\
\hline 3 & 5.32 & 4.51 & 4.67 & 4.71 & 4.26 & 4.40 & \begin{tabular}{|c|}
5.44 \\
\end{tabular} & 5.42 & 5.28 & 5.53 & 5.26 & 5.30 \\
\hline 4 & 5.29 & 4.52 & 4.69 & 4.69 & 4.26 & 4.36 & \begin{tabular}{|l|}
5.38 \\
\end{tabular} & 5.36 & 5.27 & 5.52 & 5.26 & 5.29 \\
\hline 5 & 5.25 & 4.52 & 4.65 & 4.67 & 4.24 & 4.33 & \begin{tabular}{|l|l|}
5.34 \\
\end{tabular} & 5.31 & 5.26 & 5.52 & 5.25 & 5.28 \\
\hline 6 & 5.23 & 4.52 & 4.63 & 4.64 & 4.22 & 4.33 & 5.32 & 5.30 & 5.25 & 5.52 & 5.24 & 5.27 \\
\hline 7 & 5.21 & 4.54 & 4.68 & 4.63 & 4.23 & 4.41 & \begin{tabular}{|l|}
5.29 \\
\end{tabular} & 5.38 & 5.25 & 5.51 & 5.23 & 5.26 \\
\hline 8 & 5.28 & 4.57 & 4.67 & 4.61 & 4.24 & 4.64 & 5.25 & 5.39 & 5.38 & 5.50 & 5.34 & 5.26 \\
\hline 9 & 5.30 & 4.57 & 4.69 & 4.61 & 4.25 & 4.86 & \begin{tabular}{|l|}
5.24 \\
\end{tabular} & 5.48 & 5.43 & 5.49 & 5.42 & 5.25 \\
\hline 10 & 5.26 & 4.55 & 4.70 & 4.60 & 4.34 & 5.03 & \begin{tabular}{|l}
5.22 \\
\end{tabular} & 5.52 & 5.43 & 5.49 & 5.48 & 5.24 \\
\hline 11 & 5.22 & 4.52 & 4.70 & 4.58 & 4.41 & 5.13 & \begin{tabular}{|l|}
5.20 \\
\end{tabular} & 5.51 & 5.42 & 5.51 & 5.49 & 5.22 \\
\hline 12 & $\begin{array}{l}5.19 \\
\end{array}$ & 4.54 & 4.69 & $\begin{array}{l}4.57 \\
\end{array}$ & 4.45 & 5.14 & \begin{tabular}{|l|}
5.19 \\
\end{tabular} & 5.48 & 5.42 & 5.50 & 5.48 & 5.21 \\
\hline 13 & 5.15 & 4.55 & 4.66 & 4.57 & 4.44 & 5.14 & \begin{tabular}{|l|}
5.18 \\
\end{tabular} & 5.47 & 5.45 & 5.49 & 5.47 & 5.20 \\
\hline 14 & 5.12 & 4.59 & 4.65 & 4.55 & 4.44 & 5.14 & \begin{tabular}{|l}
5.19 \\
\end{tabular} & 5.55 & 5.48 & 5.46 & 5.45 & 5.19 \\
\hline 15 & 5.09 & 4.62 & 4.69 & 4.54 & 4.43 & 5.14 & \begin{tabular}{|l}
5.18 \\
\end{tabular} & 5.55 & 5.51 & 5.46 & 5.43 & 5.18 \\
\hline 16 & 5.05 & 4.62 & 4.68 & 4.53 & 4.42 & 5.15 & 5.18 & 5.54 & 5.52 & 5.45 & 5.42 & 5.16 \\
\hline 17 & 5.00 & 4.62 & 4.66 & 4.52 & 4.42 & 5.16 & \begin{tabular}{|l|}
5.17 \\
\end{tabular} & 5.50 & 5.53 & 5.42 & 5.42 & 5.13 \\
\hline 18 & 4.96 & 4.61 & 4.63 & 4.51 & 4.43 & 5.18 & \begin{tabular}{|l|}
5.17 \\
\end{tabular} & 5.45 & 5.54 & 5.39 & 5.42 & 5.11 \\
\hline 19 & 4.90 & 4.60 & 4.63 & 4.50 & 4.43 & 5.17 & \begin{tabular}{|l|}
5.19 \\
\end{tabular} & 5.42 & 5.71 & 5.37 & 5.40 & 5.09 \\
\hline 20 & 4.87 & 4.63 & 4.64 & 4.50 & 4.41 & 5.16 & 5.32 & 5.39 & 5.81 & 5.34 & 5.41 & 5.06 \\
\hline 21 & 4.84 & 4.65 & 4.64 & 4.49 & 4.41 & 5.15 & 5.37 & 5.38 & 5.84 & 5.32 & 5.42 & 5.07 \\
\hline 22 & 4.78 & 4.64 & 4.64 & 4.48 & 4.40 & 5.14 & 5.36 & 5.37 & 5.85 & 5.37 & 5.41 & 5.15 \\
\hline 23 & 4.74 & 4.63 & 4.64 & 4.47 & 4.36 & 5.14 & \begin{tabular}{|l|}
5.34 \\
\end{tabular} & 5.38 & 5.82 & 5.36 & 5.40 & 5.31 \\
\hline 24 & 4.73 & 4.65 & 4.64 & 4.46 & 4.32 & 5.30 & \begin{tabular}{|l|}
5.32 \\
\end{tabular} & 5.38 & 5.77 & 5.35 & 5.39 & 5.34 \\
\hline 25 & 4.74 & 4.67 & 4.64 & 4.43 & 4.29 & 5.67 & \begin{tabular}{|l|}
5.37 \\
\end{tabular} & 5.34 & 5.74 & 5.36 & 5.38 & 5.34 \\
\hline 26 & 4.72 & 4.66 & 4.65 & 4.40 & 4.33 & 5.73 & 5.64 & 5.30 & 5.71 & 5.36 & 5.37 & 5.34 \\
\hline 27 & 4.69 & 4.66 & 4.69 & 4.38 & 4.50 & 5.73 & \begin{tabular}{|l|}
5.72 \\
\end{tabular} & 5.32 & 5.67 & 5.34 & 5.37 & 5.35 \\
\hline 28 & 4.63 & 4.66 & 4.78 & 4.36 & 4.51 & 5.69 & \begin{tabular}{|l|}
5.69 \\
\end{tabular} & 5.34 & 5.66 & 5.33 & 5.37 & 5.40 \\
\hline 29 & 4.59 & 4.66 & 4.80 & 4.34 & --- & 5.66 & \begin{tabular}{|l|}
5.63 \\
\end{tabular} & 5.32 & 5.63 & 5.31 & 5.40 & 5.39 \\
\hline 30 & 4.54 & 4.66 & 4.80 & 4.32 & --- & 5.59 & \begin{tabular}{|l|}
5.60 \\
\end{tabular} & 5.30 & 5.59 & 5.31 & 5.37 & 5.35 \\
\hline 31 & 4.52 & --- & 4.79 & 4.30 & -- & 5.54 & --- & 5.28 & -- & 5.31 & 5.35 & --- \\
\hline Mean & 5.00 & 4.59 & 4.68 & 4.53 & 4.36 & 5.07 & 5.35 & 5.41 & 5.53 & 5.43 & 5.38 & 5.25 \\
\hline Max & 5.41 & 4.67 & 4.80 & 4.76 & 4.51 & 5.73 & 5.72 & 5.56 & 5.85 & 5.57 & 5.49 & 5.40 \\
\hline Min & 4.52 & 4.51 & 4.63 & 4.30 & 4.22 & 4.33 & 5.17 & 5.28 & 5.25 & 5.31 & 5.23 & 5.06 \\
\hline
\end{tabular}




\section{WIND LAKE AT OUTLET AT WIND LAKE, WI}

LOCATION.--Lat 4248'48", long 8808'31" referenced to North American Datum of 1927, in NE 1/4 NW 1/4 sec.16, T.4 N., R.20 E.,

Racine County, WI, Hydrologic Unit 07120006, at Wind Lake.

SURFACE AREA.--1.46 $\mathrm{mi}^{2}$.

DRAINAGE AREA.--39.6 $\mathrm{mi}^{2}$.

PERIOD OF RECORD.--March 1985 to current year. Prior to October 2000, published as "Wind Lake Outlet".

REVISED RECORDS.--WDR WI-91-1: 1988(m).

REMARKS.--Lake level regulated by dam with two 10-foot gates at outlet. Lake ice-covered Dec. 3 to Mar. 14. Prior to October 1987, published as Wind Lake at Wind Lake, Wis. Gage-height telemeter at station.

EXTREMES FOR PERIOD OF RECORD.--Maximum gage height, 9.88 ft, June 14, 15, 2008; minimum recorded, $5.95 \mathrm{ft}$, Jan. 2 , 1996.

EXTREMES FOR CURRENT YEAR.--Maximum recorded gage height, $8.57 \mathrm{ft}$, June 19; minimum recorded, $7.50 \mathrm{ft}$, Jan. 3.

\begin{tabular}{|c|c|c|c|c|c|c|c|c|c|c|c|c|}
\hline \multicolumn{13}{|c|}{$\begin{array}{c}\text { GAGE HEIGHT, FEET } \\
\text { WATER YEAR OCTOBER } 2008 \text { TO SEPTEMBER } 2009 \\
\text { DAILY MEAN VALUES }\end{array}$} \\
\hline Day & Oct & Nov & Dec & Jan & Feb & Mar & Apr & May & Jun & Jul & Aug & Sep \\
\hline 1 & 7.98 & 8.24 & 7.84 & 7.75 & 8.16 & 7.78 & 8.15 & 8.31 & 8.35 & 8.42 & 8.20 & 8.26 \\
\hline 2 & 7.96 & 8.26 & 7.85 & 7.60 & 8.05 & 7.68 & 8.09 & 8.29 & 8.31 & 8.42 & 8.19 & 8.26 \\
\hline 3 & 7.95 & 8.28 & 7.88 & 7.54 & 7.97 & 7.68 & 8.06 & 8.32 & 8.31 & 8.42 & 8.17 & 8.25 \\
\hline 4 & 7.93 & 8.29 & 7.91 & 7.59 & 7.98 & 7.81 & 8.01 & 8.36 & 8.30 & 8.42 & 8.17 & 8.25 \\
\hline 5 & 7.93 & 8.27 & 7.92 & 7.59 & 8.00 & 7.94 & 8.00 & 8.35 & 8.30 & 8.44 & 8.17 & 8.24 \\
\hline 6 & 7.93 & 8.24 & 7.96 & 7.60 & 8.02 & 8.08 & 8.05 & 8.33 & 8.30 & 8.43 & 8.16 & 8.24 \\
\hline 7 & 7.94 & 8.20 & 7.97 & 7.62 & 8.05 & 8.22 & 8.11 & 8.35 & 8.30 & 8.41 & 8.17 & 8.24 \\
\hline 8 & 7.99 & 8.21 & 8.00 & 7.60 & 8.10 & 8.30 & 8.19 & 8.35 & 8.37 & 8.40 & 8.29 & 8.23 \\
\hline 9 & 7.99 & 8.22 & 8.07 & 7.58 & 8.15 & 8.24 & 8.27 & 8.36 & 8.34 & 8.40 & 8.36 & 8.22 \\
\hline 10 & 7.98 & 8.21 & 8.11 & 7.56 & 8.17 & 8.19 & 8.35 & 8.33 & 8.35 & 8.37 & 8.34 & 8.22 \\
\hline 11 & 7.98 & 8.19 & 8.14 & 7.53 & 8.19 & 8.18 & 8.40 & 8.33 & 8.37 & 8.42 & 8.30 & 8.21 \\
\hline 12 & 7.98 & 8.24 & 8.17 & 7.54 & 8.18 & 8.08 & 8.41 & 8.36 & 8.38 & 8.41 & 8.28 & 8.21 \\
\hline 13 & 7.99 & 8.25 & 8.19 & 7.63 & 8.19 & 8.10 & 8.33 & 8.34 & 8.39 & 8.39 & 8.26 & 8.20 \\
\hline 14 & 7.99 & 8.26 & 8.24 & 7.71 & 8.24 & 8.19 & 8.21 & 8.38 & 8.39 & 8.36 & 8.25 & 8.20 \\
\hline 15 & 8.00 & 8.26 & 8.31 & 7.78 & 8.27 & 8.24 & 8.11 & 8.37 & 8.40 & 8.35 & 8.24 & 8.19 \\
\hline 16 & 8.01 & 8.22 & 8.33 & 7.83 & 8.26 & 8.25 & 8.11 & 8.39 & 8.40 & 8.35 & 8.22 & 8.18 \\
\hline 17 & 8.01 & 8.20 & 8.36 & 7.89 & 8.20 & 8.20 & 8.15 & 8.39 & 8.39 & 8.34 & 8.24 & 8.17 \\
\hline 18 & 8.01 & 8.16 & 8.32 & 7.94 & 8.20 & 8.22 & 8.20 & 8.39 & 8.38 & 8.33 & 8.24 & 8.16 \\
\hline 19 & 8.00 & 8.03 & 8.32 & 7.99 & 8.20 & 8.23 & 8.26 & 8.44 & 8.41 & 8.30 & 8.22 & 8.15 \\
\hline 20 & 8.01 & 7.80 & 8.29 & 8.03 & 8.17 & 8.22 & 8.30 & 8.47 & 8.36 & 8.29 & 8.22 & 8.15 \\
\hline 21 & 8.02 & 7.63 & 8.26 & 8.06 & 8.18 & 8.21 & 8.11 & 8.45 & 8.36 & 8.29 & 8.23 & 8.16 \\
\hline 22 & 8.02 & 7.63 & 8.31 & 8.10 & 8.15 & 8.24 & 8.05 & 8.39 & 8.42 & 8.30 & 8.22 & 8.17 \\
\hline 23 & 8.02 & 7.64 & 8.37 & 8.14 & 8.06 & 8.24 & 8.11 & 8.27 & 8.43 & 8.29 & 8.21 & 8.19 \\
\hline 24 & 8.06 & 7.68 & 8.39 & 8.16 & 7.95 & 8.18 & 8.18 & 8.24 & 8.36 & 8.27 & 8.20 & 8.19 \\
\hline 25 & 8.11 & 7.70 & 8.30 & 8.19 & 7.82 & 8.15 & 8.28 & 8.24 & 8.35 & 8.27 & 8.20 & 8.19 \\
\hline 26 & 8.13 & 7.71 & 8.15 & 8.21 & 7.77 & 8.14 & 8.39 & 8.26 & 8.41 & 8.26 & 8.28 & 8.20 \\
\hline 27 & 8.14 & 7.72 & 8.07 & 8.24 & 7.86 & 8.17 & 8.27 & 8.32 & 8.41 & 8.25 & 8.28 & 8.20 \\
\hline 28 & 8.16 & 7.74 & 8.16 & 8.26 & 7.84 & 8.21 & 8.31 & 8.35 & 8.40 & 8.25 & 8.29 & 8.23 \\
\hline 29 & 8.18 & 7.75 & 8.18 & 8.29 & --- & 8.32 & 8.32 & 8.35 & 8.36 & 8.23 & 8.30 & 8.20 \\
\hline 30 & 8.19 & 7.78 & 8.09 & 8.30 & --- & 8.30 & 8.28 & 8.34 & 8.36 & 8.22 & 8.29 & 8.18 \\
\hline 31 & 8.21 & --- & 7.95 & 8.24 & --- & 8.21 & --- & 8.34 & --- & 8.21 & 8.27 & --- \\
\hline Mean & 8.03 & 8.03 & 8.14 & 7.87 & 8.09 & 8.14 & 8.20 & 8.35 & 8.37 & 8.34 & 8.24 & 8.20 \\
\hline Max & 8.21 & 8.29 & 8.39 & 8.30 & 8.27 & 8.32 & 8.41 & 8.47 & 8.43 & 8.44 & 8.36 & 8.26 \\
\hline Min & 7.93 & 7.63 & 7.84 & 7.53 & 7.77 & 7.68 & 8.00 & 8.24 & 8.30 & 8.21 & 8.16 & 8.15 \\
\hline
\end{tabular}




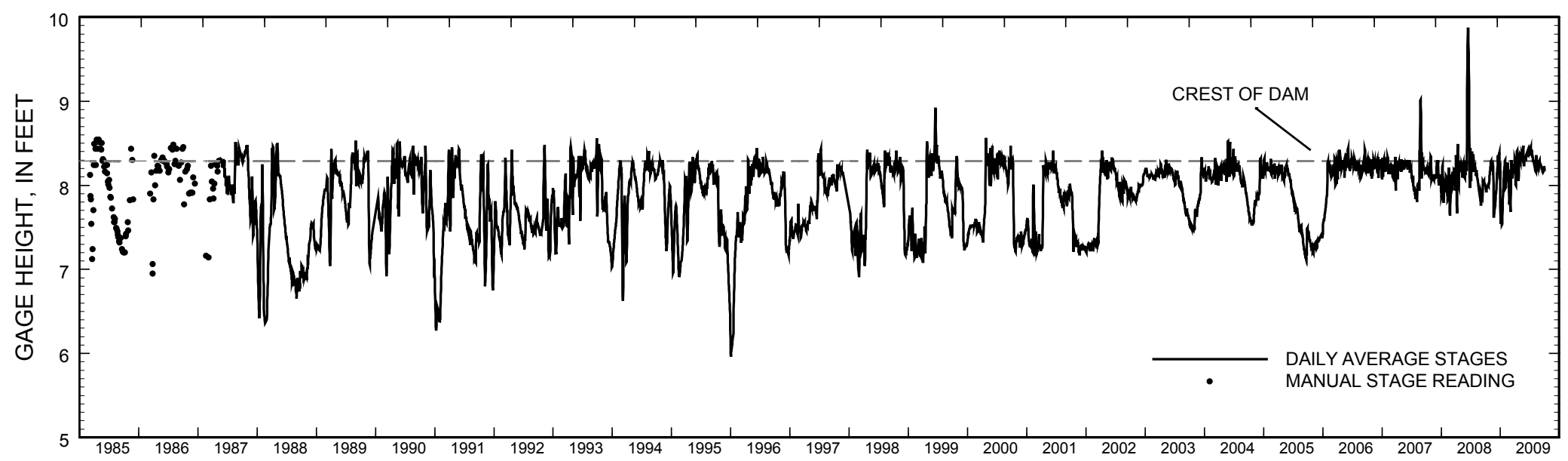

Stage hydrograph for Wind Lake, 1985-2009. 


\section{WIND LAKE AT WIND LAKE, WI}

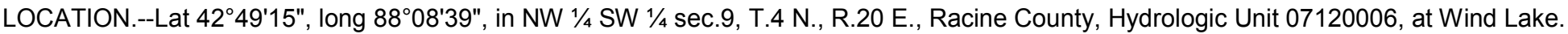
SURFACE AREA.--1.46 $\mathrm{mi}^{2}$

PERIOD OF RECORD.--February 1985 to current year.

REMARKS.--Lake sampled near center at the deep hole. Water-quality analyses done by Wisconsin State Laboratory of Hygiene.

WATER-QUALITY DATA, FEBRUARY 17 TO JULY 21, 2009

(Milligrams per liter unless otherwise indicated)

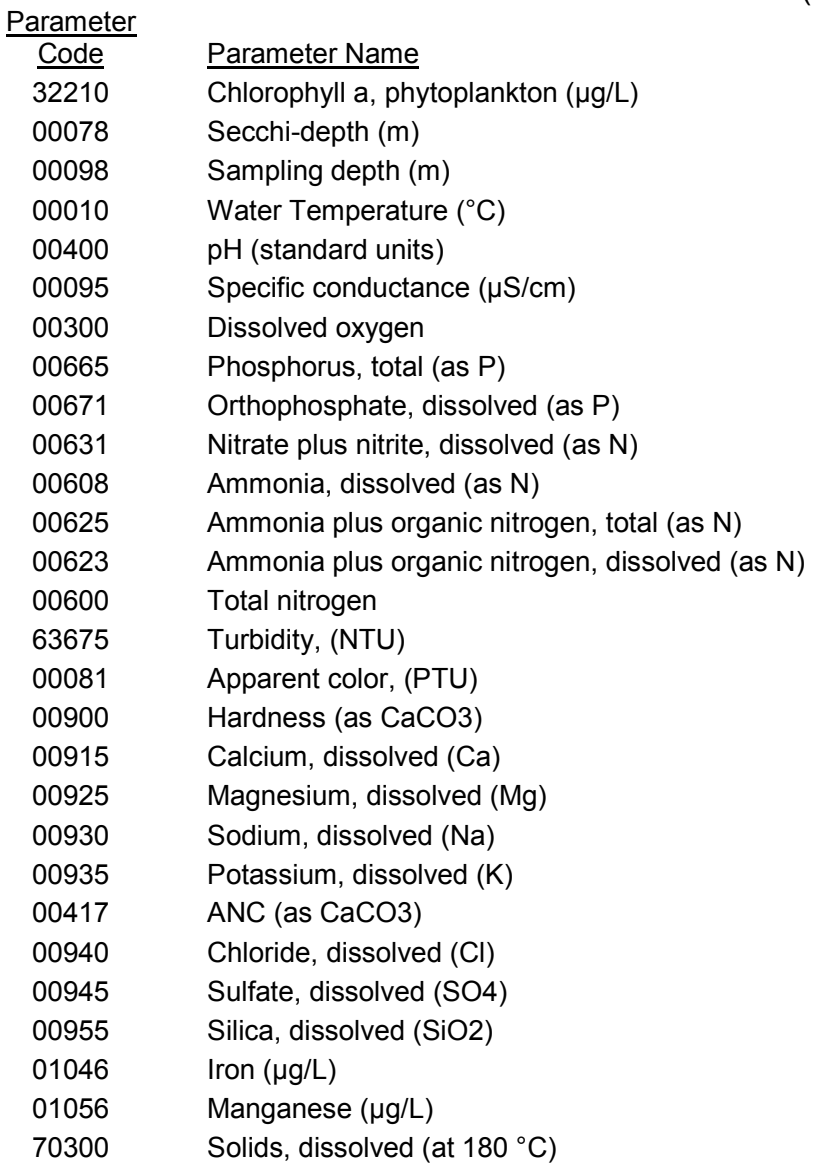

\begin{tabular}{|c|c|c|c|c|c|c|c|}
\hline \multicolumn{2}{|c|}{ Feb. 17} & \multicolumn{2}{|c|}{ March 30} & \multicolumn{2}{|c|}{ June 11} & \multicolumn{2}{|c|}{ July 21} \\
\hline \multicolumn{2}{|c|}{--} & \multicolumn{2}{|c|}{12.2} & \multicolumn{2}{|c|}{0.84} & \multicolumn{2}{|c|}{8.59} \\
\hline \multicolumn{2}{|c|}{--} & \multicolumn{2}{|c|}{2.0} & \multicolumn{2}{|c|}{4.6} & \multicolumn{2}{|c|}{2.0} \\
\hline 0.5 & 15.5 & 0.5 & 15.0 & 0.5 & 15.0 & 0.5 & 14.0 \\
\hline 4.2 & 2.9 & 5.5 & 4.8 & 18.0 & 13.0 & 22.6 & 14.7 \\
\hline 7.7 & 7.0 & 8.0 & 8.0 & 8.6 & 7.0 & 8.4 & 6.7 \\
\hline 655 & 900 & 676 & 674 & 634 & 672 & 628 & 689 \\
\hline 9.7 & 1.0 & 15.3 & 14.0 & 8.6 & 0.0 & 9.6 & 0.1 \\
\hline 0.030 & 0.086 & 0.035 & 0.038 & 0.029 & 0.126 & 0.030 & 0.136 \\
\hline-- & -- & 0.002 & -- & -- & -- & $<.002$ & -- \\
\hline-- & -- & 0.089 & -- & -- & -- & $<.019$ & -- \\
\hline-- & -- & 0.064 & -- & -- & -- & $<.015$ & -- \\
\hline-- & -- & 1 & -- & -- & -- & -- & -- \\
\hline-- & -- & -- & -- & - & -- & 1 & -- \\
\hline-- & -- & 1.1 & -- & -- & -- & -- & -- \\
\hline-- & -- & $<1.0$ & -- & -- & -- & -- & -- \\
\hline -- & -- & 30 & -- & -- & -- & -- & -- \\
\hline-- & -- & 200 & -- & -- & -- & -- & -- \\
\hline-- & -- & 44.5 & -- & -- & -- & -- & -- \\
\hline-- & -- & 22.7 & -- & -- & -- & -- & -- \\
\hline-- & -- & 54.3 & -- & -- & -- & -- & -- \\
\hline-- & -- & 2.9 & -- & -- & -- & -- & -- \\
\hline-- & -- & 157 & -- & -- & -- & -- & -- \\
\hline-- & -- & 104 & -- & -- & -- & -- & -- \\
\hline-- & -- & 30.5 & -- & -- & -- & -- & -- \\
\hline -- & -- & 0.374 & -- & -- & -- & -- & -- \\
\hline-- & -- & $<100$ & -- & -- & -- & -- & -- \\
\hline-- & -- & $<1.0$ & -- & -- & -- & -- & -- \\
\hline -- & -- & 400 & -- & -- & -- & -- & -- \\
\hline
\end{tabular}


424915088083900 WIND LAKE AT WIND LAKE, WI

WATER-QUALITY DATA, AUGUST 26, 2009

(Milligrams per liter unless otherwise indicated)

\begin{tabular}{c} 
Parameter Code \\
\hline 32210 \\
00078 \\
00098 \\
00010 \\
00400 \\
00095 \\
00300 \\
00665
\end{tabular}

Parameter Name
Chlorophyll a, phytoplankton $(\mu \mathrm{g} / \mathrm{L})$
Secchi-depth $(\mathrm{m})$
Sampling depth $(\mathrm{m})$
Water Temperature $\left({ }^{\circ} \mathrm{C}\right)$
$\mathrm{pH}$ (standard units)
Specific conductance $(\mu \mathrm{S} / \mathrm{cm})$
Dissolved oxygen
Phosphorus, total (as $\mathrm{P})$

\begin{tabular}{ccccc}
\multicolumn{5}{c}{ August 26 } \\
& \multicolumn{5}{c}{10.7} & & \\
& & 2.3 & & \\
0.5 & 7.0 & 11.0 & 14.0 & 15.0 \\
22.3 & 20.5 & 16.0 & 15.5 & 15.1 \\
8.2 & 7.5 & 7.2 & 7.2 & 7.1 \\
619 & 634 & 683 & 688 & 695 \\
7.1 & 0.2 & 0.1 & 0.1 & 0.0 \\
0.025 & 0.053 & 0.338 & 0.461 & 0.514
\end{tabular}


424915088083900 WIND LAKE AT WIND LAKE, WI

LAKE-DEPTH PROFILES, FEBRUARY 17 TO AUGUST 26, 2009

02-17-09
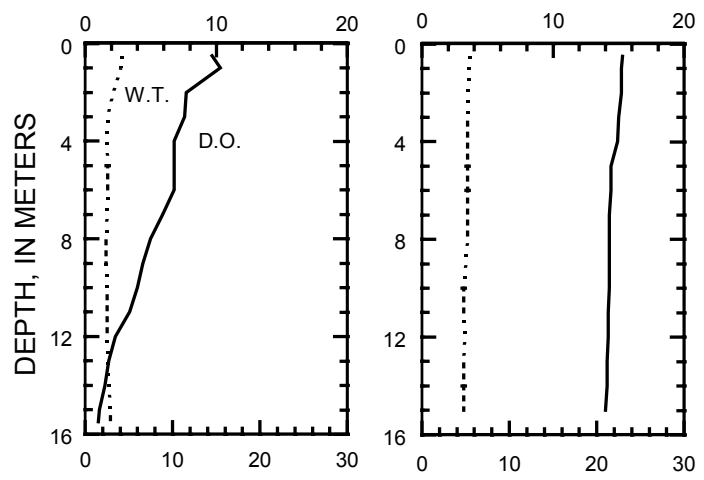

WATER TEMPE

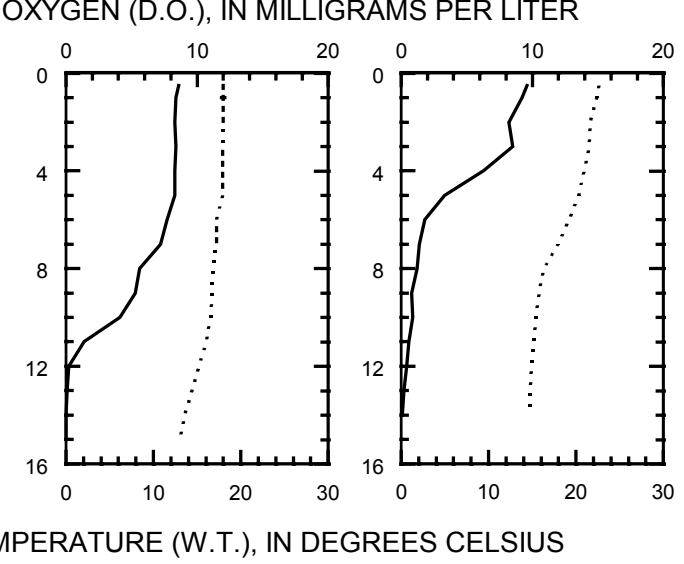

06-11-09

07-21-09

08-26-09

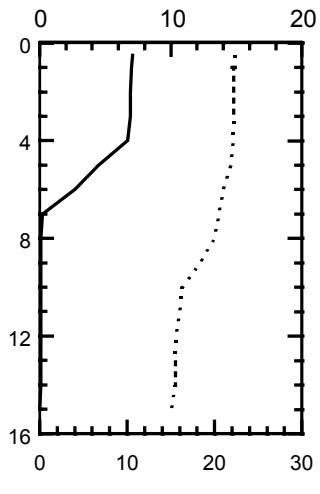

PH, IN STANDARD UNITS
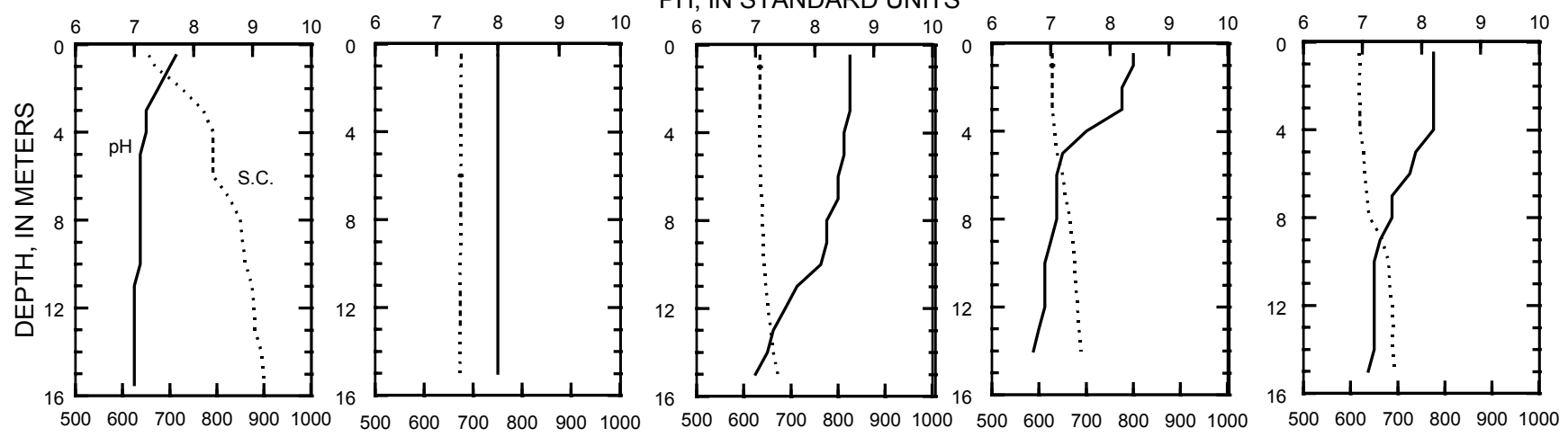

SPECIFIC CONDUCTANCE (S.C.), IN MICROSIEMENS PER CENTIMETER AT 25 DEGREES CELSIUS 

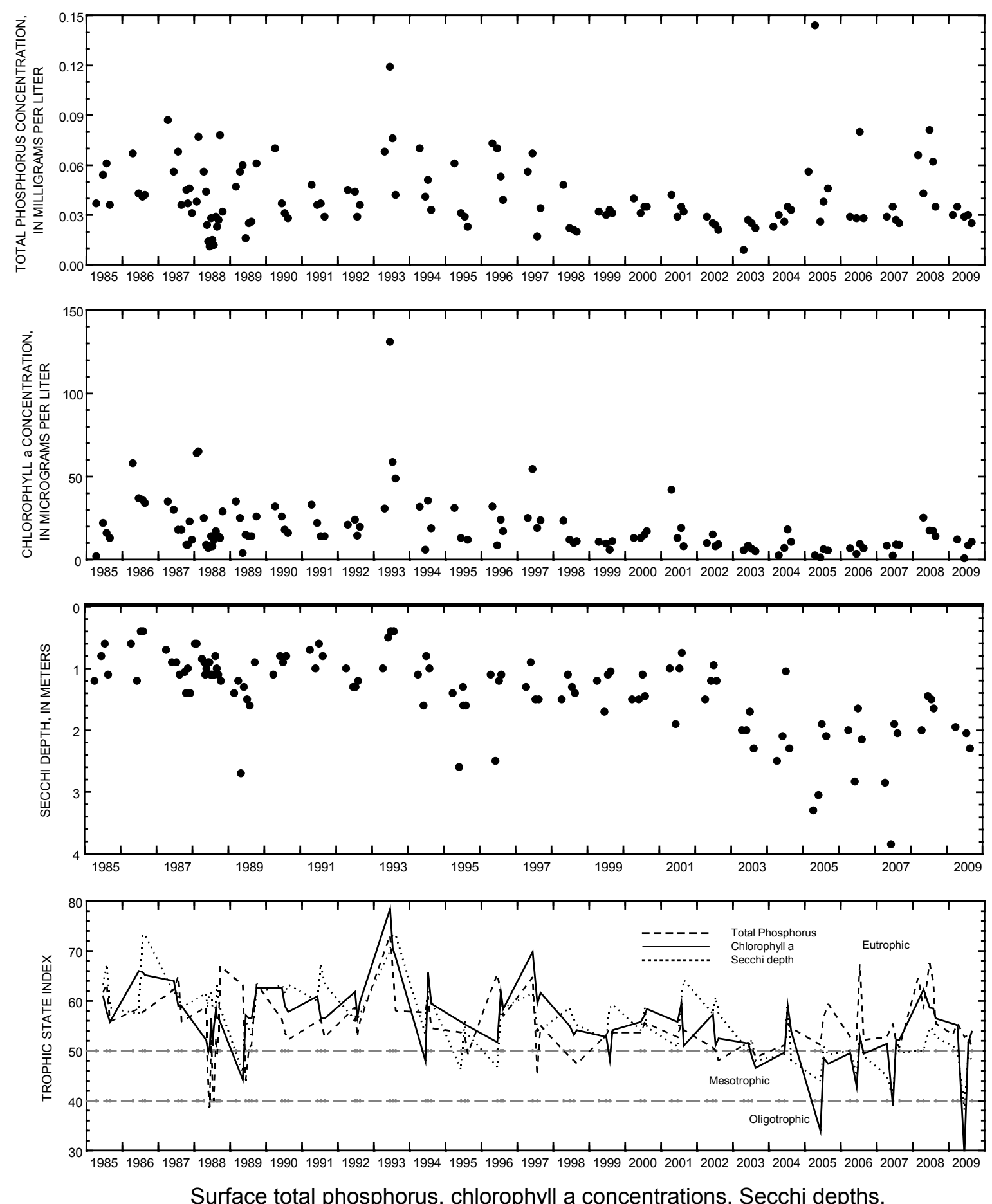

Surface total phosphorus, chlorophyll a concentrations, Secchi depths, and TSI data for Wind Lake, Deep Hole, at Wind Lake, Wisconsin. 


\section{LAKE WINNEBAGO AT OSHKOSH, WI}

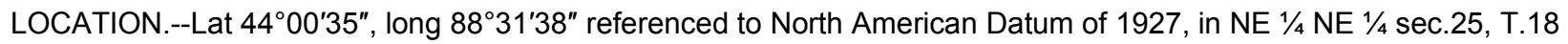
N., R.16 E., Winnebago County, WI, Hydrologic Unit 04030203, $800 \mathrm{ft}$ east of mouth of the upper Fox River.

SURFACE AREA.--215 $\mathrm{mi}^{2}$.

DRAINAGE AREA.--5,880 $\mathrm{mi}^{2}$.

PERIOD OF RECORD.--October 1938 to current year in reports of Geological Survey. Records from July 1882 to September 1938 in files of Geological Survey and U.S. Army Corps of Engineers. A report on Fox River by U.S. Army Corps of Engineers, published as House Document No. 146, 67th Congress, 2nd session, contains semimonthly records of inflow of Lake Winnebago for the period 1896-1917.

REVISED RECORDS.--WDR WI-83-1: Drainage area.

GAGE.--Water-stage recorder. Nonrecording gage read once daily October 1938 to October 1978. Datum of gage is $745.05 \mathrm{ft}$ above mean tide at New York City (levels by U.S. Army Corps of Engineers).

REMARKS.--Lake elevations controlled by dams at Menasha and Neenah, which are operated in the interest of navigation. Crests of both dams are at elevation $746.73 \mathrm{ft}$. Present limits of regulation are from $21 \frac{1 / 4}{4}$. above the crest of Menasha to crest during navigation season, plus additional 18 in. below crest during winter. Data-collection platform and gage-height telemeter at station.

EXTREMES FOR PERIOD OF RECORD.--Maximum gage height observed, 4.32 ft, Mar. 9, 1982; Minimum observed, $0.33 \mathrm{ft}$, May 17, 1960.

EXTREMES FOR CURRENT YEAR.--Maximum daily mean gage height, $3.17 \mathrm{ft}$, June 8, 10; Minimum recorded, 1.70 ft, Mar. 5, 6 . 


\begin{tabular}{|c|c|c|c|c|c|c|c|c|c|c|c|c|}
\hline \multicolumn{13}{|c|}{$\begin{array}{c}\text { GAGE HEIGHT, FEET } \\
\text { WATER YEAR OCTOBER } 2008 \text { TO SEPTEMBER } 2009 \\
\text { DAILY MEAN VALUES }\end{array}$} \\
\hline Day & Oct & Nov & Dec & Jan & Feb & Mar & Apr & May & Jun & Jul & Aug & Sep \\
\hline 1 & 2.74 & 2.42 & 2.35 & 2.41 & 1.92 & 1.75 & 2.37 & 2.56 & 3.03 & 3.01 & 2.74 & 2.86 \\
\hline 2 & 2.71 & 2.41 & 2.38 & 2.41 & 1.90 & 1.74 & 2.38 & 2.58 & 3.03 & 2.99 & 2.76 & 2.85 \\
\hline 3 & 2.72 & 2.40 & 2.40 & 2.40 & 1.88 & 1.73 & 2.38 & 2.59 & 3.08 & 3.00 & 2.76 & 2.85 \\
\hline 4 & 2.69 & 2.41 & 2.41 & 2.40 & 1.86 & 1.72 & 2.40 & 2.58 & 3.08 & 3.00 & 2.80 & 2.85 \\
\hline 5 & 2.68 & 2.41 & 2.41 & 2.40 & 1.85 & 1.70 & 2.40 & 2.56 & 3.08 & 2.98 & 2.78 & 2.85 \\
\hline 6 & 2.70 & 2.40 & 2.40 & 2.39 & 1.82 & 1.70 & 2.36 & 2.57 & 3.13 & 2.98 & 2.77 & 2.84 \\
\hline 7 & 2.68 & 2.39 & 2.40 & 2.38 & 1.81 & 1.71 & 2.34 & 2.62 & 3.12 & 2.99 & 2.78 & 2.84 \\
\hline 8 & 2.67 & 2.40 & 2.40 & 2.38 & 1.79 & 1.72 & 2.35 & 2.66 & 3.17 & 2.95 & 2.85 & 2.84 \\
\hline 9 & 2.68 & 2.42 & 2.45 & 2.37 & 1.77 & 1.77 & 2.34 & 2.74 & 3.16 & 2.94 & 2.89 & 2.84 \\
\hline 10 & 2.70 & 2.43 & 2.46 & 2.35 & 1.79 & 1.81 & 2.35 & 2.76 & 3.17 & 2.90 & 2.90 & 2.83 \\
\hline 11 & 2.68 & 2.43 & 2.45 & 2.34 & 1.80 & 1.84 & 2.35 & 2.78 & 3.15 & 2.91 & 2.90 & 2.82 \\
\hline 12 & 2.68 & 2.41 & 2.44 & 2.32 & 1.81 & 1.82 & 2.37 & 2.79 & 3.14 & 2.91 & 2.88 & 2.81 \\
\hline 13 & 2.67 & 2.42 & 2.42 & 2.31 & 1.80 & 1.81 & 2.40 & 2.74 & 3.13 & 2.90 & 2.88 & 2.81 \\
\hline 14 & 2.64 & 2.46 & 2.41 & 2.29 & 1.79 & 1.80 & 2.39 & 2.78 & 3.14 & 2.88 & 2.86 & 2.81 \\
\hline 15 & 2.64 & 2.45 & 2.41 & 2.27 & 1.78 & 1.80 & 2.40 & 2.86 & 3.14 & 2.82 & 2.88 & 2.81 \\
\hline 16 & 2.65 & 2.45 & 2.40 & 2.25 & 1.77 & 1.81 & 2.42 & 2.68 & 3.11 & 2.84 & 2.85 & 2.81 \\
\hline 17 & 2.62 & 2.43 & 2.40 & 2.23 & 1.76 & 1.82 & 2.42 & 2.80 & 3.12 & 2.83 & 2.88 & 2.76 \\
\hline 18 & 2.60 & 2.44 & 2.38 & 2.22 & 1.77 & 1.85 & 2.44 & 2.73 & 3.12 & 2.81 & 2.86 & 2.76 \\
\hline 19 & 2.55 & 2.37 & 2.40 & 2.20 & 1.77 & 1.88 & 2.46 & 2.74 & 3.06 & 2.80 & 2.88 & 2.75 \\
\hline 20 & 2.56 & 2.39 & 2.40 & 2.18 & 1.76 & 1.91 & 2.44 & 2.74 & 3.06 & 2.78 & 2.81 & 2.74 \\
\hline 21 & 2.57 & 2.38 & 2.42 & 2.16 & 1.75 & 1.95 & 2.52 & 2.76 & 3.08 & 2.76 & 2.87 & 2.75 \\
\hline 22 & 2.55 & 2.38 & 2.41 & 2.14 & 1.76 & 1.98 & 2.60 & 2.82 & 3.04 & 2.80 & 2.89 & 2.78 \\
\hline 23 & 2.50 & 2.36 & 2.40 & 2.11 & 1.75 & 2.01 & 2.55 & 2.82 & 3.04 & 2.79 & 2.88 & 2.80 \\
\hline 24 & 2.47 & 2.35 & 2.40 & 2.09 & 1.74 & 2.09 & 2.50 & 2.88 & 3.05 & 2.77 & 2.86 & 2.79 \\
\hline 25 & 2.46 & 2.34 & 2.39 & 2.07 & 1.73 & 2.22 & 2.50 & 2.89 & 3.07 & 2.76 & 2.85 & 2.79 \\
\hline 26 & 2.40 & 2.36 & 2.39 & 2.05 & 1.75 & 2.27 & 2.58 & 2.89 & 3.09 & 2.78 & 2.90 & 2.74 \\
\hline 27 & 2.46 & 2.35 & 2.40 & 2.03 & 1.78 & 2.31 & 2.58 & 2.99 & 3.06 & 2.79 & 2.89 & 2.69 \\
\hline 28 & 2.43 & 2.34 & 2.44 & 2.01 & 1.77 & 2.33 & 2.66 & 2.98 & 2.99 & 2.78 & 2.87 & 2.60 \\
\hline 29 & 2.42 & 2.37 & 2.43 & 1.99 & ---- & 2.34 & 2.62 & 3.02 & 3.01 & 2.79 & 2.87 & 2.73 \\
\hline 30 & 2.39 & 2.40 & 2.42 & 1.97 & --- & 2.38 & 2.58 & 3.01 & 3.03 & 2.79 & 2.90 & 2.67 \\
\hline 31 & 2.40 & $\begin{array}{l}--- \\
\end{array}$ & 2.42 & 1.95 & --- & 2.38 & $\begin{array}{l}--- \\
\end{array}$ & 3.06 & --- & 2.79 & 2.88 & --- \\
\hline Mean & 2.59 & 2.40 & 2.41 & 2.23 & 1.79 & 1.93 & 2.45 & 2.77 & 3.09 & 2.87 & 2.85 & 2.79 \\
\hline Max & 2.74 & 2.46 & 2.46 & 2.41 & 1.92 & 2.38 & 2.66 & 3.06 & 3.17 & 3.01 & 2.90 & 2.86 \\
\hline Min & 2.39 & 2.34 & 2.35 & 1.95 & 1.73 & 1.70 & 2.34 & 2.56 & 2.99 & 2.76 & 2.74 & 2.60 \\
\hline
\end{tabular}




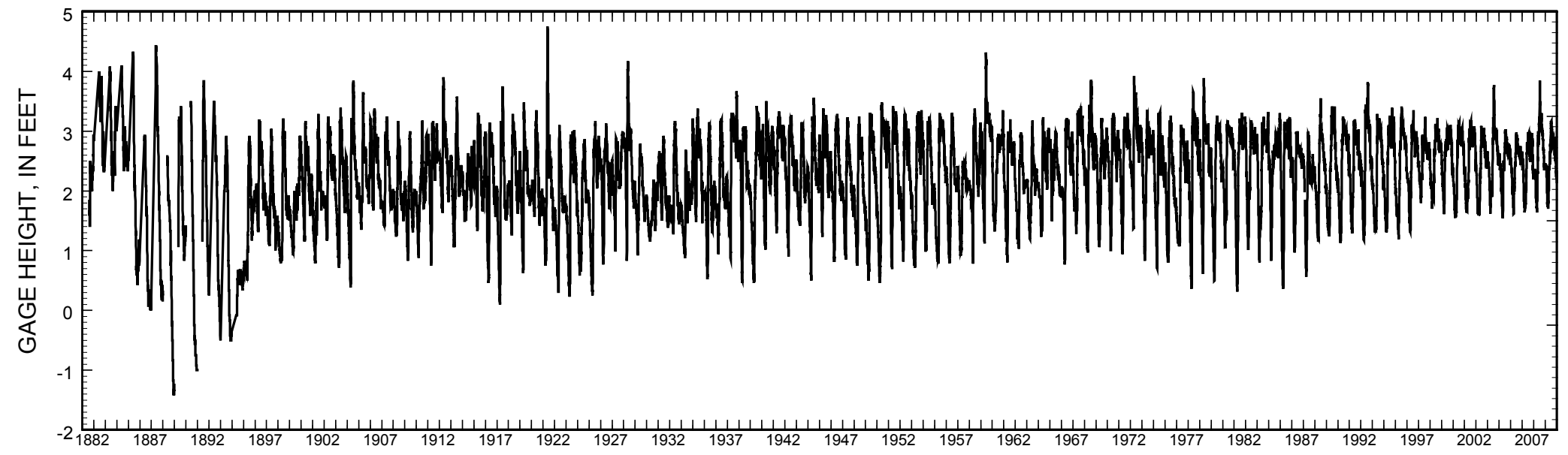

Stage hydrograph for Lake Winnebago, 1882-2010. 


\section{LAKE WINNEBAGO NEAR STOCKBRIDGE, WI}

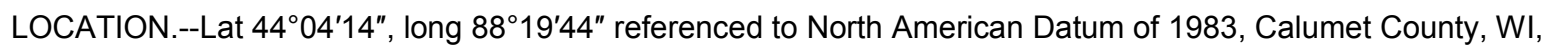
Hydrologic Unit 04030203, Stockbridge Indian Reservation, on east shore of Lake Winnebago, $300 \mathrm{ft}$ south of County Highway E and 1.6 mi west of Stockbridge.

SURFACE AREA.--215 $\mathrm{mi}^{2}$.

DRAINAGE AREA.--5,880 $\mathrm{mi}^{2}$.

PERIOD OF RECORD.--November 1982 to current year.

GAGE.--Water-stage recorder. Datum of gage is $745.05 \mathrm{ft}$ above mean tide of New York City (levels by U. S. Army Corps of Engineers).

REMARKS.--Lake elevations controlled by dams at Menasha and Neenah, which are operated in the interest of navigation. Crests of both dams are at elevation $746.73 \mathrm{ft}$. Present limits of regulation are from $211 / 4 \mathrm{in}$. above the crest of Menasha dam to crest during navigation season, plus additional 18 in. below crest during winter. Datacollection platform and gage-height telemeter at station.

EXTREMES FOR PERIOD OF RECORD.--Maximum daily mean gage height, 3.85 ft, July 9, 11, 1993, June 14, 2008; minimum observed, $0.30 \mathrm{ft}$, Mar. 1, 1986.

EXTREMES FOR CURRENT YEAR.--Maximum daily mean gage height, $3.09 \mathrm{ft}$, June 9; minimum recorded, $1.58 \mathrm{ft}$, Mar. 5, 6. 


\begin{tabular}{|c|c|c|c|c|c|c|c|c|c|c|c|c|}
\hline \multicolumn{13}{|c|}{$\begin{array}{c}\text { GAGE HEIGHT, FEET } \\
\text { WATER YEAR OCTOBER } 2008 \text { TO SEPTEMBER } 2009 \\
\text { DAILY MEAN VALUES }\end{array}$} \\
\hline Day & Oct & Nov & Dec & Jan & Feb & Mar & Apr & May & Jun & Jul & Aug & Sep \\
\hline 1 & 2.64 & 2.27 & 2.31 & 2.30 & 1.82 & 1.64 & 2.28 & 2.54 & 2.89 & 2.90 & 2.74 & 2.74 \\
\hline 2 & 2.67 & 2.28 & 2.34 & 2.31 & \begin{tabular}{|l|}
1.79 \\
\end{tabular} & 1.63 & 2.33 & 2.54 & 2.91 & 2.90 & 2.70 & 2.73 \\
\hline 3 & \begin{tabular}{|l|}
2.59 \\
\end{tabular} & 2.29 & 2.31 & 2.29 & \begin{tabular}{|l|}
1.78 \\
\end{tabular} & 1.62 & 2.34 & 2.49 & 2.94 & 2.88 & 2.70 & 2.73 \\
\hline 4 & 2.58 & 2.31 & 2.32 & 2.31 & 1.76 & $\begin{array}{l}1.02 \\
1.60\end{array}$ & 2.35 & 2.46 & 2.99 & 2.87 & 2.69 & 2.73 \\
\hline 5 & 2.56 & 2.30 & 2.30 & 2.29 & \begin{tabular}{|l|}
1.73 \\
\end{tabular} & 1.58 & 2.28 & 2.45 & 3.03 & 2.89 & 2.68 & 2.72 \\
\hline 6 & 2.53 & 2.27 & 2.31 & 2.28 & 1.71 & 1.58 & 2.27 & 2.47 & 2.94 & 2.89 & 2.67 & 2.72 \\
\hline 7 & 2.52 & 2.33 & 2.30 & 2.28 & \begin{tabular}{|l|}
1.69 \\
\end{tabular} & 1.59 & 2.34 & 2.55 & 2.92 & 2.85 & 2.65 & 2.71 \\
\hline 8 & 2.62 & 2.37 & 2.30 & 2.28 & 1.68 & 1.63 & 2.30 & 2.57 & 3.02 & 2.80 & 2.72 & 2.70 \\
\hline 9 & 2.68 & 2.44 & 2.36 & 2.26 & 1.66 & 1.66 & 2.27 & 2.57 & 3.09 & 2.81 & 2.78 & 2.70 \\
\hline 10 & 2.57 & 2.39 & 2.36 & 2.25 & 1.66 & 1.69 & 2.24 & 2.67 & 3.04 & 2.82 & 2.80 & 2.69 \\
\hline 11 & 2.56 & 2.30 & 2.35 & 2.22 & 1.69 & 1.74 & 2.27 & 2.68 & 3.00 & 2.86 & 2.78 & 2.69 \\
\hline 12 & 2.57 & 2.29 & 2.33 & 2.20 & $\begin{array}{l}1.70 \\
\end{array}$ & 1.71 & 2.28 & 2.68 & 3.01 & 2.84 & 2.78 & 2.69 \\
\hline 13 & \begin{tabular}{|l|}
2.58 \\
\end{tabular} & 2.35 & 2.30 & 2.20 & \begin{tabular}{|l|}
1.68 \\
\end{tabular} & 1.69 & 2.24 & 2.64 & 3.03 & 2.79 & 2.78 & 2.69 \\
\hline 14 & 2.61 & 2.37 & 2.30 & 2.19 & 1.68 & 1.68 & 2.27 & 2.82 & 3.03 & 2.77 & 2.79 & 2.70 \\
\hline 15 & 2.59 & 2.37 & 2.33 & 2.17 & \begin{tabular}{|l|}
1.67 \\
\end{tabular} & 1.68 & 2.33 & 2.72 & 3.01 & 2.78 & 2.78 & 2.67 \\
\hline 16 & 2.55 & 2.40 & 2.30 & 2.14 & 1.66 & 1.69 & 2.36 & 2.80 & 2.96 & 2.81 & 2.79 & 2.62 \\
\hline 17 & \begin{tabular}{|l|}
2.51 \\
\end{tabular} & 2.38 & 2.30 & 2.12 & \begin{tabular}{|l|}
1.64 \\
\end{tabular} & 1.70 & 2.37 & 2.73 & 3.00 & 2.76 & 2.78 & 2.64 \\
\hline 18 & 2.51 & 2.35 & 2.28 & 2.11 & 1.67 & 1.75 & 2.37 & 2.70 & 2.99 & 2.72 & 2.83 & 2.63 \\
\hline 19 & 2.52 & 2.33 & 2.30 & 2.09 & \begin{tabular}{|l|}
1.67 \\
\end{tabular} & 1.78 & 2.28 & 2.64 & 2.96 & 2.68 & 2.74 & 2.60 \\
\hline 20 & 2.45 & 2.31 & 2.30 & 2.07 & 1.65 & 1.82 & 2.37 & 2.69 & 3.00 & 2.67 & 2.80 & 2.60 \\
\hline 21 & 2.42 & 2.34 & 2.33 & 2.04 & 1.65 & 1.85 & 2.50 & 2.69 & 2.95 & 2.65 & 2.81 & 2.63 \\
\hline 22 & 2.35 & 2.27 & 2.31 & 2.03 & 1.66 & 1.88 & 2.44 & 2.69 & 2.92 & 2.66 & 2.76 & 2.63 \\
\hline 23 & 2.30 & 2.28 & 2.29 & 2.02 & \begin{tabular}{|l|}
1.64 \\
\end{tabular} & 1.90 & 2.38 & 2.72 & 2.94 & 2.68 & 2.74 & 2.68 \\
\hline 24 & 2.37 & 2.27 & 2.30 & 1.99 & $\begin{array}{l}1.62 \\
\end{array}$ & 1.96 & 2.38 & 2.72 & 2.96 & 2.69 & 2.77 & 2.65 \\
\hline 25 & 2.45 & 2.28 & 2.29 & 1.96 & $\begin{array}{l}1.62 \\
\end{array}$ & 2.13 & 2.35 & 2.68 & 2.97 & 2.70 & 2.79 & 2.62 \\
\hline 26 & 2.51 & 2.26 & 2.29 & 1.94 & 1.64 & 2.19 & 2.43 & 2.73 & 2.96 & 2.70 & 2.74 & 2.63 \\
\hline 27 & 2.45 & 2.29 & 2.30 & 1.92 & 1.67 & 2.22 & 2.52 & 2.76 & 2.94 & 2.69 & 2.73 & 2.70 \\
\hline 28 & 2.40 & 2.30 & 2.35 & 1.90 & $\begin{array}{ll}1.66 \\
\end{array}$ & 2.23 & 2.47 & 2.89 & 3.04 & 2.72 & 2.75 & 2.79 \\
\hline 29 & 2.33 & 2.27 & 2.33 & 1.88 & --- & 2.26 & 2.47 & 2.95 & 3.03 & 2.71 & 2.80 & 2.62 \\
\hline 30 & 2.33 & 2.21 & 2.32 & 1.86 & ---- & 2.28 & 2.48 & 2.98 & 2.95 & 2.69 & 2.76 & 2.52 \\
\hline 31 & 2.30 & --- & 2.33 & 1.83 & --- & 2.26 & --- & 2.93 & --- & 2.69 & 2.76 & --- \\
\hline Mean & 2.50 & 2.32 & 2.31 & 2.12 & 1.68 & 1.83 & 2.35 & 2.68 & 2.98 & 2.77 & 2.75 & 2.67 \\
\hline Max & 2.68 & 2.44 & 2.36 & 2.31 & 1.82 & 2.28 & 2.52 & 2.98 & 3.09 & 2.90 & 2.83 & 2.79 \\
\hline Min & 2.30 & 2.21 & 2.28 & 1.83 & 1.62 & 1.58 & 2.24 & 2.45 & 2.89 & 2.65 & 2.65 & 2.52 \\
\hline
\end{tabular}




\section{WISCONSIN DISTRICT PUBLICATIONS PERTAINING TO LAKES}

The r eports publ ished in a U .S. Geological S urvey s eries ar e f or $\mathrm{s}$ ale by the U.S. Geological S urvey, B ox 25425, Feder al C enter, D enver, C O 80225. Prepayment is required. $R$ emittance s hould be $s$ ent by $c$ heck or $m$ oney or der pay able to the $U$.S. Geological Survey. Prices can be obtained by writing to the above address or by calling (303) 236-7476. R eprints of journal articles may be obt ained by writing directly to the author at U.S. Geological Survey, 8505 Research Way, Middleton, WI 53562.

2009

Robertson, D.M., Rose, W.J., and Fitzpatrick, F.A., 2009, Water quality and hydrology of Silver Lake, Barron County, Wisconsin, with special emphasis on the responses of a terminal lake to changes in phosphorus loading and water level: U.S. Geol. Survey Scientific Invest. Report 2009-5077, 38 p.

Robertson, D.M., Rose, W.J., and Juckem, P.F., 2009, Water quality and hydrology of Whitefish Lake, Douglas County, Wisconsin, with special emphasis on the responses of an oligotrophic seepage lake to changes in phosphorus loading and water level: U.S. Geol. Survey Scientific Invest. Report 2009-5089, 41 p.

2008

Chung, E., Schladow, S.G., Perez-Losada, J., and Robertson, D.M., 2008, A linked hydrodynamic and water quality model for the Salton Sea: Hydrobiologia, v. 604, p. 57-75.

Robertson, D.M., and Rose, W.J., 2008, Water quality, hydrology, and simulated response to changes in phosphorus loading of Butternut Lake, Price and Ashland Counties, Wisconsin, with special emphasis on the effects of internal phosphorus loading in a polymictic lake: U.S. Geol. Survey Scientific Invest. Report 2008-5053, $46 \mathrm{p}$.

Robertson, D.M., and Schladow, S.G., 2008, Response in the water quality in the Salton Sea to changes in phosphorus loading: An empirical modeling approach: Hydrobiologia, v. 604, p. 5-19.

Robertson, D.M., Schladow, S.G., and Holdren, G.C., 2008, Long-term changes in the phosphorus loading to and trophic state of the Salton Sea: Hydrobiologia, v. 604, p. 21-36.

\section{7}

Robertson, D.M., Garn, H.S., and Rose, W.J., 2007, Response of calcareous Nagawicka Lake, Wisconsin, to changes in phosphorus loading. Lake and Reservoir Management, Vol. 23, p. 298-312.

Walker, J.F., Saad, D.A., and Hunt, R.J., 2007, Dynamics of CFCs in northern temperate lakes and adjacent groundwater. Water Resources. Research 43(4) W04423, http://www.agu.org/pubs/crossref/2007/2005WR004647.shtml 
Garn, H.S., Robertson, D.M., Rose, W.J., Goddard, G.L., and Horwatich, J.A., 2006, Water quality, hydrology, and response to changes in phosphorus loading of Nagawicka Lake, a calcareous lake in Waukesha County, Wisconsin: U.S. Geological Survey Scientific Investigations Report: 2006-5273.

Hunt, R.J., Greb, S.R,, Graczyk, D.J., 2006, Evaluating the effects of nearshore development on Wisconsin lakes. USGS Fact Sheet FS-2006-3033, 4 p.

Magnuson, J.J., Benson, B.J., Lenters, J.D, and Robertson, D.M., 2006, Climate driven variability and change, Chapter 7, In Magnuson, J.J., Kratz, T.K, and Benson, B.J eds. Long-term dynamics of lakes in the landscape, Oxford University Press, p 123150.

Saad, D.A., 2005, Pesticides in surface water, bed sediment, and ground water adjacent to commercial cranberry bogs, Lac du Flambeau Reservation, Vilas County, Wisconsin: U.S. Geological Survey Scientific Investigations Report 2005-5262, 29 p.

2005

Hunt, R.J., Feinstein, D.T., Pint, C.D., and Anderson, M.P., 2005, The importance of diverse data types to calibrate a watershed model of the Trout Lake Basin, northern Wisconsin: Journal of Hydrology doi:10.1016/j.jhydrol.2005.08.005.

Marzolf, G.R., and Robertson, D.M., 2005, Reservoir, In Encyclopedia of Hydrological Sciences: Anderson, M.G., and McDonnell, J.J., eds., v. 4, part 9, John Wiley \& Sons, p. 1675-1680.

Robertson, D.M., Rose, W.J., and Saad, D.A., 2005, Water quality, hydrology, and phosphorus loading to Little St. Germain Lake, Wisconsin, with special emphasis on the effects of winter aeration and ground-water inputs: U.S. Geological Survey Scientific Investigations Report 2005-5071, 36 p.

2004

Dupre, D.H., and Robertson, D.M., 2004, Water quality of Nippersink Creek and Wonder Lake, M cHenry C ounty, I llinois, 1994 -2001: U .S. G eological S urvey S cientific Investigations Report 2004-5085.

Rose, W.J., Robertson, D.M., and M ergener, E.A., 2004, Water quality, hydrology, and the e ffects of changes in phos phorus I oading to P ike La ke, Washington C ounty, Wisconsin, with s pecial em phasis on i nlet-to-outlet s hort-circuiting: U. S. Geological Survey Scientific Investigations Report 2004-5141, 32 p.

2003

Dunning, C.P., Thomas, J.C., and Lin, Y.F., 2003, Simulation of the shallow aquifer in the vicinity of Silver Lake, Washington County, Wisconsin, using analytic elements: U.S. Geological Survey Water-Resources Investigations Report 02-4204, 29 p. 
Fitzpatrick, F.A., Garrison, P.J., Fitzgerald, S.A., and Elder, J.F., 2003, Nutrient, traceelement, and ec ological hi story of Musky Bay, Lac Courte O reilles, Wisconsin, as inferred f rom sediment c ores: $U$.S. Geological S urvey Water-Resources Investigations Report 02-4225, $141 \mathrm{p}$.

Fitzpatrick, F .A., and P eppler, M .C., 2003 , S edimentation and s ediment c hemistry, Neopit Mill Pond, Menominee Indian Reservation, Wisconsin, 2001: U.S. Geological Survey Open-File Report 03-23, 58 p.

Garn, H.S., Elder, J.F., and Robertson, D.M., 2003, Why study lakes? An ov erview of U.S. Geological Survey lake studies in Wisconsin: U.S. Geological Survey Fact Sheet FS-063-03, 8 p.

Graczyk, D .G., H unt, R .J., G reb, S.R., B uchwald, C .A., and K rohelski, J .T., 2003 , Hydrology, water quality, and y ields, from near-shore flows to four lakes in northern Wisconsin, 1999-2001: U.S. Geological Survey Water-Resources Investigations Report 03-4144. 64 p.

Hunt, R.J., 2003, Ground water-lake interaction modeling using the LAK3 Package for MODFLOW2000: Ground Water, vol. 41, no. 2, p. 114-118.

Hunt, R.J., Haitjema, H.M., Krohelski, J.T., and Feinstein, D.T., 2003, Simulating ground water-lake interactions: approaches and insights: Ground Water, vol. 41, no. 22, p. 227-237.

Hunt, R.J., Pint, C.D., and Anderson, M.P., 2003, Using diverse data types to calibrate a watershed model of the Trout Lake Basin, northern Wisconsin, In MODFLOW and More 2003-Understanding through modeling: Proceedings of the 5th International Conference of $\mathrm{t}$ he I nternational $\mathrm{G}$ round Water $\mathrm{M}$ odeling $\mathrm{C}$ enter. Go Iden, CO: Colorado School of Mines, p. 600-604.

Hunt, R.J., Saad, D.A., and Chapel, D.M., 2003, Numerical simulation of ground water flow in La Crosse County, Wisconsin and into nearby pools of the Mississippi River: U.S. Geological Survey Water-Resources Investigations Report 03-4154. 36 p.

John, R ., P int, C .D., A nderson, M .P., and H unt, R .J., 2003, The e ffects of $p$ otential climate c hange on I ake I evels and I ake c apture $z$ ones, In MODFLOW and M ore 2003-Understanding $\mathrm{t}$ hrough $\mathrm{m}$ odeling: Proceedings o $\mathrm{ft}$ he $5 \mathrm{t} \mathrm{h}$ International Conference of $\mathrm{t}$ he I nternational $\mathrm{G}$ round Water $\mathrm{M}$ odeling $\mathrm{C}$ enter. Go Iden, CO: Colorado School of Mines, p. 212-216.

Magnuson, J.J., Krohelski, J.T., Kunkel, K.E., and Robertson, D.M., 2003, Wisconsin's waters and climate-historical changes and pos sible futures, In Wisconsin's waters: a confluence of perspectives: Transactions of the Wisconsin Academy, p. 23-36.

Pint, C.D., H unt, R .J., and A nderson, M.P., 2003, Fl ow pat h del ineation and g round water age, Allequash Basin, Wisconsin: Ground Water, vol. 41, no. 7, p. 895-902.

Robertson, D.M., Rose, W.J., and Garn, H.S., 2003, Water quality and the effects of changes in phosphorus loading, Red Cedar Lakes, Barron and Washburn Counties, Wisconsin: U.S. Geological Survey Water-Resources Investigations Report 034238, $42 \mathrm{p}$. 
Robertson, D.M., Rose, W.J., and S aad, D.A., 2003, Water quality and the effects of changes in phosphorus loading to Muskellunge Lake, Vilas County, Wisconsin: U.S. Geological Survey Water-Resources Investigations Report 03-4011, 18 p.

2002

Anderson, M.P., Hunt, R.J., Krohelski, J.T., and Chung, K., 2002, Using high hydraulic conductivity nodes to simulate seepage lakes: Ground Water 40(2), p. 119-124.

Garn, H . S ., 2002, E ffects of I awn f ertilizer on nut rient c oncentration i $\mathrm{n} r$ unoff from lakeshore I awns, Lauder dale Lak es, Wisconsin: U SGS Water-Resources Investigations Report 02-4130, 6 p.

Kelson, V.A., Hunt, R.J., and H aitjema, H.M., 2002, Improving a regional model using reduced complexity and parameter estimation: Ground Water, vol. 40, no. 2, p. 138149.

Krohelski, J.T., Lin, Y., Rose, W.J., and Hunt, R.J., 2002, Simulation of Fish, Mud and Crystal Lak es and $t$ he $s$ hallow $g$ round-water s ystem, Dane County, $W$ isconsin: USGS Water-Resources Investigations Report 02-20.

Krohelski, J .T., R ose, W.J., and H unt, R .J., 2 002, H ydrologic i nvestigation of $P$ owell Marsh and its relationship to Dead Pike Lake Vilas County, Wisconsin: USGS WaterResources Investigations Report 02-4034.

Madenjian, C .P., Fahen stiel, G .L., Johengen, T.H., N alepa, T.F., V enderploeg, H .A., Fleischer, G.W., Schneeberger, P.J., Benjamin, D.M., Smith, E.B., Bence, J.R., Rutherford, E.S., Lavis, D.S., Robertson, D.M., Jude, D.J., and E bener, M.P., 2002, Dynamics of the Lake Michigan food web, 1970-2000: Canadian Journal of Fisheries and Aquatic Sciences, Vol. 59, p. 736-753.

Robertson, D.M., Goddard, G.L, Mergerer, E.A., Rose, W.J., and Garrison, P.J., 2002, Hydrology and water qual ity of G eneva Lake, Walworth C ounty, Wisconsin: U.S. Geological Survey Water Resources Investigations Report 02-4039, 73 p.

Robertson, D.M., and Lenz, B.N., 2002, Response of the St. Croix River Pools, Wisconsin and Minnesota, to various phosphorus-loading scenarios: U.S. Geological Survey Water-Resources Investigations Report 02-4181, 36 p.

2001

Hunt, R.J., Bradbury, K.R., and Krohelski, J.T., 2001, The effects of large-scale pumping and diversion on the water resources in Dane County, Wisconsin: USGS Fact Sheet FS-127-01, 4 p.

Hunt, R .J., H aitjema, H.M., K rohelski, J .T., and Fei nstein, D .T., 2 001, S imulating groundwater-lake interactions with models: MODFLOW and analytic element approaches, In MODFLOW 2001 and Other Modeling Odysseys: Proceedings of the 4th I nternational C onference of the I nternational G round Water M odeling C enter. Golden, CO: Colorado School of Mines, p. 328-334. 
Lin, Y., Krohelski, J.T., and Hunt, R.J., 2001, Simulation of lake stage in two seepage lakes i $n$ s outhcentral $\mathrm{W}$ isconsin us ing t he $\mathrm{L} A K 3$ pac kage for $\mathrm{M}$ ODFLOW, In MODFLOW 2001 and $O$ ther $M$ odeling $O$ dysseys: Proceedings o $\mathrm{ft}$ he $4 \mathrm{t} \mathrm{h}$ International $C$ onference of the International $G$ round Water $M$ odeling $C$ enter. Golden, CO: Colorado School of Mines, p. 411-417.

Elder, J.F., Robertson, D.M., and Garrison, P.J., 2000, Chemical composition of surficial deposits in Geneva Lake, Wisconsin: U.S. Geological Survey Fact Sheet FS-12100 .

Elder J.F., Rybicki, N.B., Carter, V.P., and Weintraub, V., 2000, Sources and yields of dissolved carbon in northern Wisconsin stream catchments with differing amounts of peatland: Wetlands, vol. 20, no. 1, p.113-125.

Hunt, R.J., Graczyk, D.J., and Rose, W.J., 2000, Water flows in the Necedah National Wildlife Refuge: U.S. Geological Survey Fact Sheet FS-068-00, 4 p.

Hunt, R.J., Lin, J., Krohelski, J.T., and J uckem, P.F., 2000, Simulation of the s hallow hydrologic system in the vicinity of Middle Genesee Lake, Wisconsin, using analytic elements and parameter estimation: U.S. G eological Survey Water R esources Investigations Report 00-4136, 16 p.

Lathrop, R.C., Carpenter, S.R., and Robertson, D.M., 2000, Interacting factors causing exceptional water c larity in Lakes M endota and M onona, Wisconsin: $\mathrm{P}$ roc. of the International Limnological Society, SIL, Dublin, Ireland, August, 1998.

Magnuson, J.J., Robertson, D.M. Wynne, R.H., Benson, B.J., Livigstone, D.M., Arai, T., Assel, R.A., Barry, R.G., Card, V., Kuusisto, E., Granin, N.G., Prowse, T.D., Stewart, K.M., and V uglinski, V.S., 2000, Historical trends in lake and $r$ iver ice cover in the northern hemisphere: Science, Vol. 289, No. 5485, p. 1743-1746.

Magnuson, J.J., Wynne, R.H., Benson, B.J., and Robertson, D.M., 2000, Lake and river ice as a po werful indicator of past and pr esent climates: P roc. of the I nternational Limnological Society, SIL, Dublin, Ireland, August, 1998.

Robertson, D .M., 2000, O ne-dimensional s imulation of $s$ tratification a nd di ssolved oxygen i n McCook Re servoir, I llinois: U. S. G eological Survey Water Resources Investigations Report 00-4258, 17 p.

Robertson, D .M., Goddard, G.L., H elsel, D .R., and M acKinnon, K .L., 2000 , Rehabilitation of D elavan Lake, Wisconsin: Lake and $\mathrm{R}$ eservoir Management, $v$ ol. 20 , vo. 3, p. 155-176.

Robertson, D .M., and Rose, W.J., 2000 , H ydrology, w ater quality, a nd phos phorus loading of Little St. Germain Lake, Vilas County, Wisconsin: U.S. Geological Survey Water Resources Investigations Report 00-4209, 8 p.

Robertson, D.M., Wynne, R.H., and Chang, W.Y.B., 2000, Variability in ice cover across the nor thern he misphere dur ing the 190 0's associated w ith $E$ I N ino ev ents: Proceedings of the International Limnological Society, SIL, Dublin, Ireland, August, 1998. 
Saad, D.A., and Robertson, D.M., 2000, Water-resources-related information for the St. Croix Reservation and vicinity, Wisconsin: U.S. Geological Survey Water Resources Investigations Report 00-4133, 65 p.

Johnson, G.P., Hornewer, N.J., Robertson, D.M., and Olson, D.T., 2000, Methodology, data collection, and data analysis for determination of water-mixing patterns induced by aer ators and mixers: U .S. Geological S urvey Water R esources I nvestigations Report 00-4101, 72 p.

Grannemann, N.G., Hunt, R.J., Nicholas, J.R. Reilly, T.E., and Winter, T.C., 2000, The importance of ground water to the Great Lakes Region: U.S. Geological Survey Water Resources Investigations Report 00-4008, 12 p.

1999

Lathrop, R .C., C arpenter, S .R., and R obertson, D .M., 1999, Summer w ater c larity responses to phos phorus, $\mathrm{D}$ aphnia grazing, and internal $\mathrm{m}$ ixing in Lake Mendota: Limnology and Oceanography, vol. 44, no. 1, p. 137-146.

Krohelski, J.T., Feinstein, D.T., and Lenz, B.N., 1999, Simulation of stage and hydrologic budget for Shell Lake, Washburn County, Wisconsin: U.S. Geological Survey WaterResources Investigations Report 99-4209, 23 p.

Panuska, J .C., and R obertson, D .M., 1999, E stimating phos phorus c oncentrations following al um t reatment us ing appar ent s ettling v elocities: Lak es and $\mathrm{R}$ eservoir Management, vol. 15, no. 1, p. 28-38.

1998

Hunt, R .J, A nderson, M.P., and K elson, V .A., 1998 , I mproving a complex f initedifference ground water flow model through the use of an analytic element screening model: Ground Water, vol. 36, no. 6, p. 1011-1017.

Hunt, R.J, Anderson, M.P., and Kelson, V.A., 1998, Linking an analytic el ement flow code to MODFLOW - Implementation and bene fits, In MODFLOW'98: Proceedings of the 3rd International Conference of the International Ground Water Center. Golden, CO: Colorado School of Mines, p 477-504.

Krabbenhoft, D.P., Gilmour, C.C., Benoit, J.M., Babiarz, C.L., Andren, A.W., and Hurley, J.P., 1998, M ethyl $m$ ercury dy namics i $n I$ ittoral s ediments o f a $t$ emperate I ake: Canadian Journal of Fisheries and Aquatic Sciences, vol. 55, p. 835-844.

Robertson, D.M., Elder, J.F., Goddard, G.L., and James, W.F., 1998, Dynamics in phosphorus retention in wetlands upstream of Delavan Lake, Wisconsin: Lakes and Reservoir Management, vol. 14, no. 4, p. 466-477.

Rose, W.J., and R obertson, D .M., 1998, H ydrology, w ater quality, an d phos phorus loading of Kirby Lake, Barron County, Wisconsin: U.S. Geological Survey Fact Sheet FS-066-98, 4 p.

Walker, J.F. and Krabbenhoft, D.P., 1998, Groundwater and surface-water interactions in r iparian and I ake-dominated s ystems, In Kendall, C . and M cDonnell, J .J. ed s., Isotope tracers in catchment hydrology, Elsevier Publishing, New York, 839 p. 
Elder, J.F., Manion, B.J., and Goddard, G.L., 1997, Mesocosm experiments to as sess factors af fecting phos phorus $r$ etention and $r$ elease $i \mathrm{n}$ an e xtended $\mathrm{W}$ isconsin wetland: U.S. G eological S urvey Water-Resources I nvestigations R eport 97-4272, $14 \mathrm{p}$.

Goddard, G.L., and Elder, J.F., 1997, Retention of sediments and nutrients in Jackson Creek Wetland near D elavan Lak e, Wisconsin, 1993-95: U.S. G eological S urvey Water-Resources Investigations Report 97-4014, 22 p.

Hornewer, N.J., J ohnson, G .P., R obertson, D.M. and H ondzo, M., 1997, Fi eld-scale tests for det ermining $\mathrm{m}$ ixing pat terns as sociated with $\mathrm{c}$ oarse-bubble ai $r$ di ffuser configurations, Egan Quarry, Illinois, In Environmental and Coastal Hydraulics: Protecting the Aquatic Habitat, Proceedings of the International Association of Hydraulic Research, San Francisco, CA, USA, p. 57-63.

Robertson, D .M., 1997, R egionalized I oads of s ediment and phos phorus to La kes Michigan and S uperior-High flow and I ong-term av erage: J ournal of Great Lakes Research, vol. 23, p. 416-439.

1996

Anderson, W.L., Robertson, D.M., and Magnuson, J.J., 1996, Evidence of recent warming and EI Nino-related variation in ice breakup of Wisconsin lakes: Limnology and Oceanography, vol. 41, p. 815-821.

Elder, J .F. and G oddard, G .L., 1996, S ediment and nut rient t rapping efficiency of a constructed w etland near D elavan Lak e, Wisconsin, 1993-1995: U .S. G eological Survey Fact Sheet FS-232-96.

Garn, H.S., Olson, D.L., Seidel, T.L., and Rose, W.J., 1996, Hydrology and water quality of Lau derdale Lak es, Walworth C ounty, Wisconsin, 1993 -94: U .S. G eological Survey Water-Resources Investigations Report 96-4235, 29 p.

Hunt, R.J. and K rohelski, J.T., 1996, The application of an analytical element model to investigate gr oundwater-lake i nteractions at $P$ retty Lak $e$, Wisconsin: Lak e and Reservoir Management, vol. 12, p. 487-495.

Imberger, J ., R obertson, D .M., and B oland, K ., 1996, Lak e N umber-A q uantitative indicator of mixing to be used in water quality management: Scientific Impeller, Solna, Sweden, no. 4, p. 9-15.

Kammerer, $P$.A., J r., 19 96, $H$ ydrology and $w$ ater quality of $P$ ark $L$ ake, $S$ outh-central Wisconsin: U.S. Geological Survey Fact Sheet FS-197-96.

Robertson, D .M., Fi eld, S .J, E Ider, J .F., Goddard, G.L., and J ames, W.F., 199 6, Phosphorus dy namics of $D$ elavan Lak e I nlet i n s outheastern Wisconsin: U .S. Geological Survey Water-Resources Investigations Report 96-4160, 18 p. 
Assel, R.A. and R obertson, D.M. 1995, Changes in winter air temperatures near Lake Michigan dur ing 1851 -1993, as det ermined from $r$ egional I ake-ice $r$ ecords: Limnology and Oceanography, v. 40, p 165-176.

Assel, R .A., R obertson, D .M., H off, M .H., a nd S elgeby, J .H., 1995, Climatic-change implications f rom long-term ( 1823-1994) i ce r ecords nea $r$ he Lau rentian $G$ reat Lakes: Annals of Glaciology, vol. 21, p. 383-386.

Krabbenhoft, D.P., and Webster, K.E., 1995, Transient hydrogeological controls on the chemistry of a s eepage lake: Water Resources Research, vol. 31, no. 9, p. 22952305.

Krohelski, J.T. and Batten, W.G., 1995, Simulation of stage and the hydrologic budget of Devils Lake, Sauk County, Wisconsin: U.S. Geological Survey Open-File Report 94348, $22 \mathrm{p}$.

Wentz, D.A., Rose, W.J., and Webster, K.E., 1995, Long-term hy drologic and biogeochemical responses of a s oft water seepage lake in north central Wisconsin: Water Resources Research, vol. 31, no. 1, p. 199-212.

1994

Elder, J.F., 1994, Distribution and grain-size partitioning of metals in bottom sediments of an experimentally acidified lake: Water Resources Bulletin, vol. 30, no. 2, p. 251259.

Goddard, G.L., and Fi eld, S .J., 1994, Hydrology and w ater quality of Whitewater and Rice Lak es in s outheastern Wisconsin, 1990 -91: U .S. Geological S urvey WaterResources Investigations Report 94-4101, 36 p.

Greb, S.R., and Wentz, D.A., 1994, Chemical budgets, In Klepinger, K.E., ed., RILWAS 1983-86: W isconsin Regional I ntegrated La ke Watershed A cidification S tudy, Volume 1: Madison, Wisconsin Department of Natural Resources, PUBL-RS-90994, Chapter 7, 20 p.

Hurley, J .P., K rabbenhoft, D .P., B abiarz, C .L., and A ndren, A .W., 1994, C ycling processes of mercury across sediment/water interfaces in seepage lakes, In Baker, L.A. ed., Environmental Chemistry of Lakes and Reservoirs: Advances in Chemistry Series, American Chemical Society, Washington, D.C., p. 426-449.

Krabbenhoft, D.P., Bowser, C.J., Kendall, C., and Gat, J.R., 1994, Use of oxygen-19 and deuterium to assess the hydrology of ground-water/lake systems, In Baker, L.A. ed., Environmental Chemistry of Lakes and R eservoirs: Advances in Chemistry Series, American Chemical Society, Washington, D.C., p. 67-90.

Robertson, D .M., A nderson, W., and M agnuson, J .J., 1994, R elations bet ween E I Nino/Southern Oscillation ev ents and the $c$ limate and $i$ ce $c$ over o $f I$ akes $i \mathrm{n}$ Wisconsin, In Greenland, D . ed. , E I N ino and Long -Term E cological R esearch (LTER) S ites: P ublication No. 18. LTER Network Office: University of W ashington, Seattle, WA, USA., p. 48-57. 
Robertson, D.M. and Imberger, J. 1994, Lake Number, a quantitative indicator of mixing used to estimate changes in dissolved oxygen, Internationale Revue der gesamten Hydrobiologie, v. 79, p. 159-176.

Watras, C.J., Bloom, N.S., Hurley, J.P., Fitzgerald, W.F., Andren, A.W., Krabbenhoft, D.P., and Porcella, D.B., 1994, Sources and fates of mercury and methylmercury in Wisconsin I akes, In Watras a nd H uckabee ed s., M ercury as a Global P ollutant: Intergration and Synthesis, Lewis Pub., Chelsea, MI., p 153-177.

Wentz, D.A., 1994, C hemistry of snowpack and ground water, In Klepinger, K.E., ed., RILWAS 1983-86: Wisconsin regional integrated lake watershed acidification study, volume 1: Madison, Wisconsin Department of N atural R esources, P UBL-RS-90994, chapter $6,45 \mathrm{p}$.

Wentz, D.A., Krohelski, J.T., and Rose, W.J., 1994, Hydrology, In Klepinger, K.E., ed., RILWAS 1983-86: Wisconsin regional integrated lake watershed acidification study, volume 1: Madison, Wisconsin Department of N atural R esources, P UBL-RS-90994, chapter 7, $74 \mathrm{p}$.

1993

Field, S.J., 1993, Hydrology and water quality of Powers Lake, southeastern Wisconsin: U.S. Geological Survey Water-Resources Investigations Report 90-4126, 36 p.

Field, S.J., 1993, Hydrology and water quality of Wind Lake in southeastern Wisconsin: U.S. Geological Survey Water-Resources Investigations Report 91-4107, 61 p.

House, L.B., 1993, Simulation of the effects of hypothetical residential development on water levels in Graber Pond, Middleton, Wisconsin: U.S. Geological Survey WaterResources Investigations Report 92-4029, 10 p.

House, L.B., Waschbusch, R.J., and Hughes, P.E., 1993, Water quality of an urban wet detention pond in Madison, Wisconsin, 1987-88: U.S. Geological Survey Open-File Report 93-172, $57 \mathrm{p}$.

Hughes, P.E., 1993, Hydrology, water quality, trophic status, and aquatic plants of Fowler Lak e, Wisconsin: U .S. Geological S urvey Water-Resources I nvestigations Report 91-4076, 44 p.

Rose, W.J., 1993, H ydrology o f Li ttle R ock La ke i n V ilas C ounty, nor th-central Wisconsin: U.S. Geological Survey Water-Resources Investigations Report 93-4139, $22 \mathrm{p}$.

Rose, W.J., 1993, Water and phos phorus bud gets and trophic state, Balsam La ke, northwestern W isconsin, 1987 -1989: U .S. Geological S urvey Water-Resources Investigations Report 91-4125, 28 p.

1992

Elder, J.F., Krabbenhoft, D.P, and Walker, J .F., 1992, Water, energy, and biogeochemical budgets (WEBB) program: Data availability and research at the northern temperate lakes site, Wisconsin: U.S. Geological Survey Open-File Report 92-48, $15 \mathrm{p}$. 
Krabbenhoft, D.P., and B abiarz, C.L., 1992, R ole of groundwater transport in aq uatic mercury cycling: Water Resources Research, vol. 28, no. 12, p. 3119-3128.

Krabbenhoft, D.P., and Krohelski, J.T., 1992, Data on water quality, lake sediment, and lake-level fluctuation, St. Croix Indian Reservation, Wisconsin, 1981-87: U.S. Geological Survey Open-File Report 92-26, 53 p.

Robertson, D.M., Ragotzkie, R.A., and Magnuson, J.J. 1992, Lake ice records used to detect historical and future climatic changes: Climatic Change, v. 21, p. 407-427.

1991

Wentz, D.A., and Rose, W.J., 1991, Hydrology of Lakes Clara and Vandercook in northcentral Wisconsin: U.S. Geological Survey Water-Resources Investigations Report 89-4204, 24 p.

Watras, C .J., A ndre, A.W., B loom, N .S., Fi tzgerald, W.F., H urley, J .P., K rabbenhoft, D.P., Rada, R.G., Wiener, J.G., 1991, Mercury in temperate lakes: a mechanistic field study: Verhandlungen Internat. Verein. Limnologie, 24, p. 2199-2202.

\section{Pre-1990}

Walker, J.F., Pickard, S.A., and Sonzogni, W.C., 1989 Spreadsheet watershed modeling for non point-source pol lution m anagement in a Wisconsin bas in: Water Resources Bulletin, vol. 25, no. 1, p. 139-147.

Wentz, D .A., G arrison, P.J., and B ockheim, J .G., 1989 , Section 7 -Chemical i nputoutput bud gets, In Knauer, D., and B rouwer, S.A., eds., The Wisconsin regional integrated I ake w atershed acidification s tudy ( RILWAS)-1981-1983: P alo Alto, California, Electric Power Research Institute Report EA-6214, p. 7-1 to 7-30.

Wentz, D .A., and R ose, W.J., 1989 , Interrelationships am ong hy drologic-budget components o fa no rthern Wisconsin seepage I ake a nd i mplications for ac iddeposition modeling: Archives of Environmental Contamination and Toxicology, vol. 18, p. 147-155.

Wentz, D.A., Rose, W.J., and K rohelski, J.T., 1989, Section 5-Hydrologic component, in Knauer, D., and Brouwer, S.A., eds., The Wisconsin regional integrated lake watershed acidification study (RILWAS) -1981-1983: Palo Alto, California, Electric Power Research Institute Report EA-6214, p. 5-1 to 5-77.

Field, S .J., and D uerk, M.D., 1988, H ydrology and $w$ ater q uality of D elavan Lak e in southeastern W isconsin: U.S. Geological Survey W ater-Resources Investigations Report 87-4168, $61 \mathrm{p}$.

Krug, W.R., Ostenso, N.A., and Krohelski, J.T., 1988, Prediction of the effects of mine dewatering on four lakes near Crandon, Wisconsin, by use of a water-budget model: U.S. Geological Survey Open-File Report 87-471, 63 p.

Wentz, D.A., Krohelski, J.T., Rose, W.J., Bockheim, J.G., Garrison, P.J., Knauer, D.R., and Goldstein, R.A., 1987, Hydrologic and chemical budgets of Wisconsin lakes, In Perry, R., Harrison, R.M., Bel, J.N.B., and Lester, J.N., eds., Acid Rain: Scientific and Technical Advances, Selper Ltd., London, p. 309-316. 
House, L. B., 1986, Stage fluctuations of Wisconsin Lakes: Wisconsin Geological and Natural History Survey Information Circular No. 49, 84 p.

House, L.B., 1984, Effects of urbanization on three ponds in Middleton, Wisconsin: U.S. Geological Survey Water-Resources Investigations Report 84-4051, 17 p.

Krug, W.R., and H ouse, L. B., 1984 , E valuation of al ternative $r$ eservoir-management practices i $\mathrm{n}$ t he R ock River bas in, Wisconsin: U .S. G eological S urvey WaterResources Investigations Report 83-4186, 21 p.

House, L.B., 1981, An assessment of streamflow, water quality, and the effects of construction on $i$ mpoundment on $B$ ridge $C$ reek at $A$ ugusta, Wisconsin: $U$.S. Geological Survey Water-Resources Investigations Open-File Report 81-1192, 25 p.

Krug, W.R., 1981, Hydrologic effects of proposed changes in management practices, Winnebago P ool, Wisconsin: U .S. Geological S urvey Water-Resources Investigations 80-107, $19 \mathrm{p}$.

Batten, W.G., and Hindall, S.M., 1980, Sediment deposition in the White River Reservoir, nor thwestern Wisconsin: U.S. Geological Survey Water-Supply P aper 2069, 30 p.

Novitzki, R.P., and Holmstrom, B.K., 1979, Monthly and annual water budgets of Lake Wingra, Madison, Wisconsin, 1971-77: U .S. Geological S urvey W ater-Resources Investigations 79-100, $31 \mathrm{p}$.

Rose, W.J., 1977, Hydrologic considerations as sociated with dredging s pring ponds in Wisconsin: U.S. Geological Survey Water-Resources Investigations 77-18, 35 p.

Oakes, E.L., Hendrickson, G.E., and Zuehl s, E.E., 1975, Hydrology of the Lake Wingra basin, Dane County, Wisconsin: U.S. Geological Survey Water-Resources Investigations 17-75, $31 \mathrm{p}$.

Novitzki, R .P., 1971, H ydrologic i nvestigations o f H eart La ke, Green Lak e C ounty, Wisconsin: U.S. Geological Survey Administrative Report, 9 p. 


\section{APPENDIX}

\section{Wisconsin Lakes Team Quality-Assurance Plan}

Most lake studies that are conducted by the USGS Wisconsin Water Science Center include water sampling and analysis to determine water quality and biological productivity. Because all sampling and analyses are subject to possible biases and variablility, rigorous sampling efforts should include quality-assurance samples. Studies conducted by the Lake Studies Team of the USGS Wisconsin Water Science Center include a quality-assurance plan each year that involves collecting three types of samples from a subset of the lakes studied each year, which include blanks, replicates, and spikes. These samples are collected and/or prepared solely for the purpose of assessing the magnitude of potential biases and variability so that the accuracy and precision of all data can be evaluated. The plan for this quality-assurance sampling is described below.

Three types of QA/QC samples are collected:

\section{Blanks:}

Provide information about accuracy and potential biases due to treatment or reagents

Replicates:

Provide information about precision (variability)

Standard additions (spikes):

Provide information about accuracy and matrix interferences

\section{Blank Sampling}

B1. A preservation blank consists of deionized water or inorganic blank water, to which is added any reagents or preservatives that are normally added to natural water samples. The blank is not taken to the field, but is shipped to the laboratory for analysis along with the natural water samples.

This blank sample is analyzed for the Nutrient Group ${ }^{1}$ and chlorophyll-a.

B2. A field blank consists of deionized water or inorganic blank water treated exactly the same as regular samples. Typically, during winter, the field blank is analyzed for total phosphorus (TP) only; during summer, it is analyzed for TP and chlorophyll-a, and in the spring it is analyzed for the Nutrient Group and chlorophyll-a.

\footnotetext{
${ }^{1}$ Nutrient Group = all phosphorus and nitrogen species that are commonly determined in lakes (total phosphorus, nitrate + nitrite, ammonia, total Kjeldahl nitrogen, total nitrogen)
} 


\section{Replicate Sampling}

Triplicate samples are taken near water surface in summer for analysis of total phosphorus and chlorophyll-a. For a portion of the sites where surface triplicates are collected, a set of triplicate samples is also sometimes taken from nearbottom water, for analysis of total phosphorus.

Triplicate samples collected in the spring are taken near the water surface for analysis of the Nutrient Group.

\section{Standard Addition Testing}

Replicate samples are collected for a standard addition (spike) test, which consists of an addition of a prepared phosphorus solution (standard) of known volume and concentration, such that the expected result of analysis is the natural water TP concentration plus the known addition. One sample from each set receives no spike (the mean of these gives the natural water TP concentration).

Data and results of replicate sampling and field blank testing in water year 2009 are shown in Table A1. 
Table A1. Analyses of replicate samples from Wisconsin lakes in water years 2005-2009. See text for procedures used. Phosphorus data in milligrams per liter; chlorophyll data in micrograms per liter. Symbol "<" indicates less than given detection limit (DL); mean and standard deviation not calculated for datasets containing values less than DL.

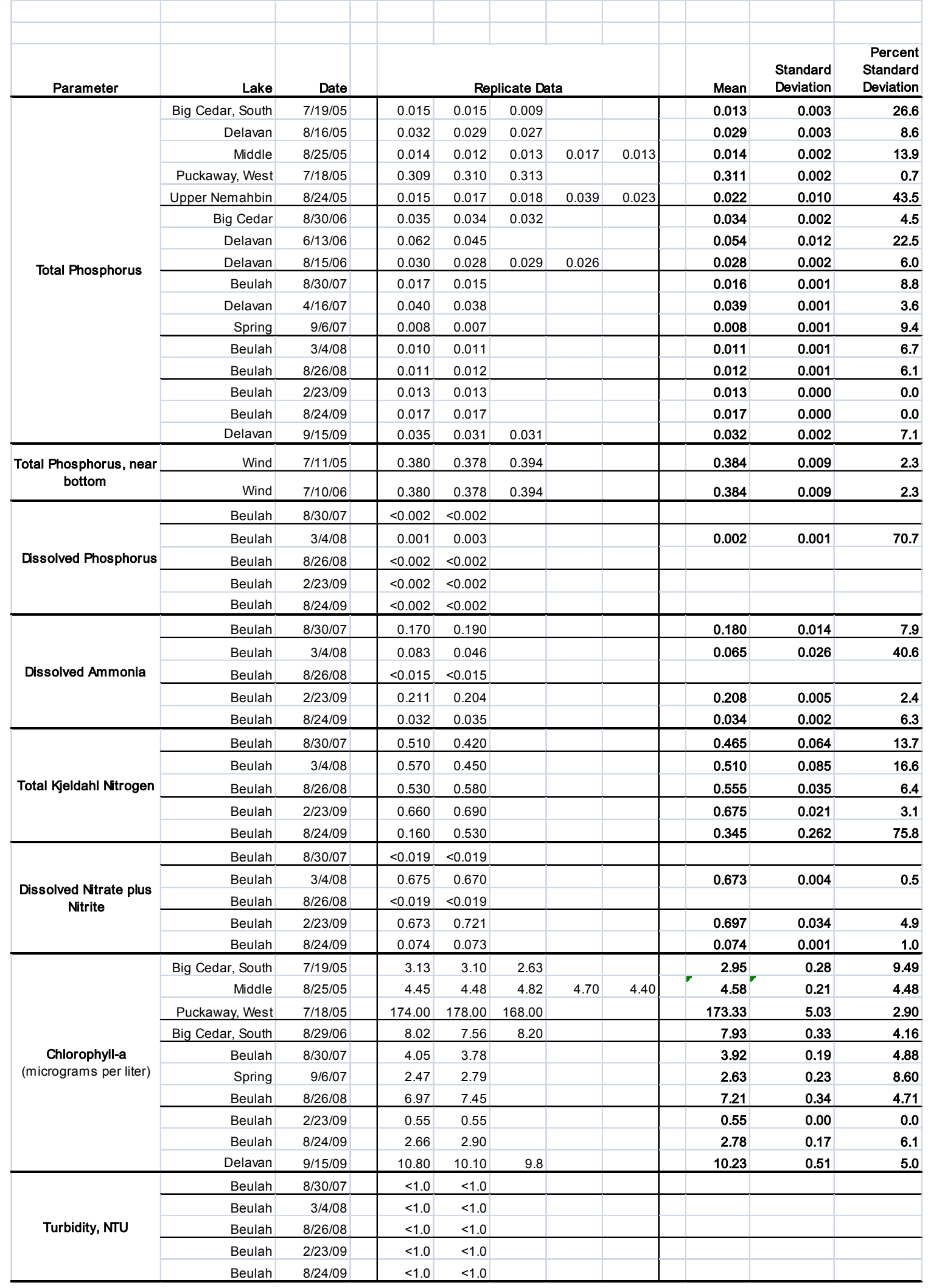




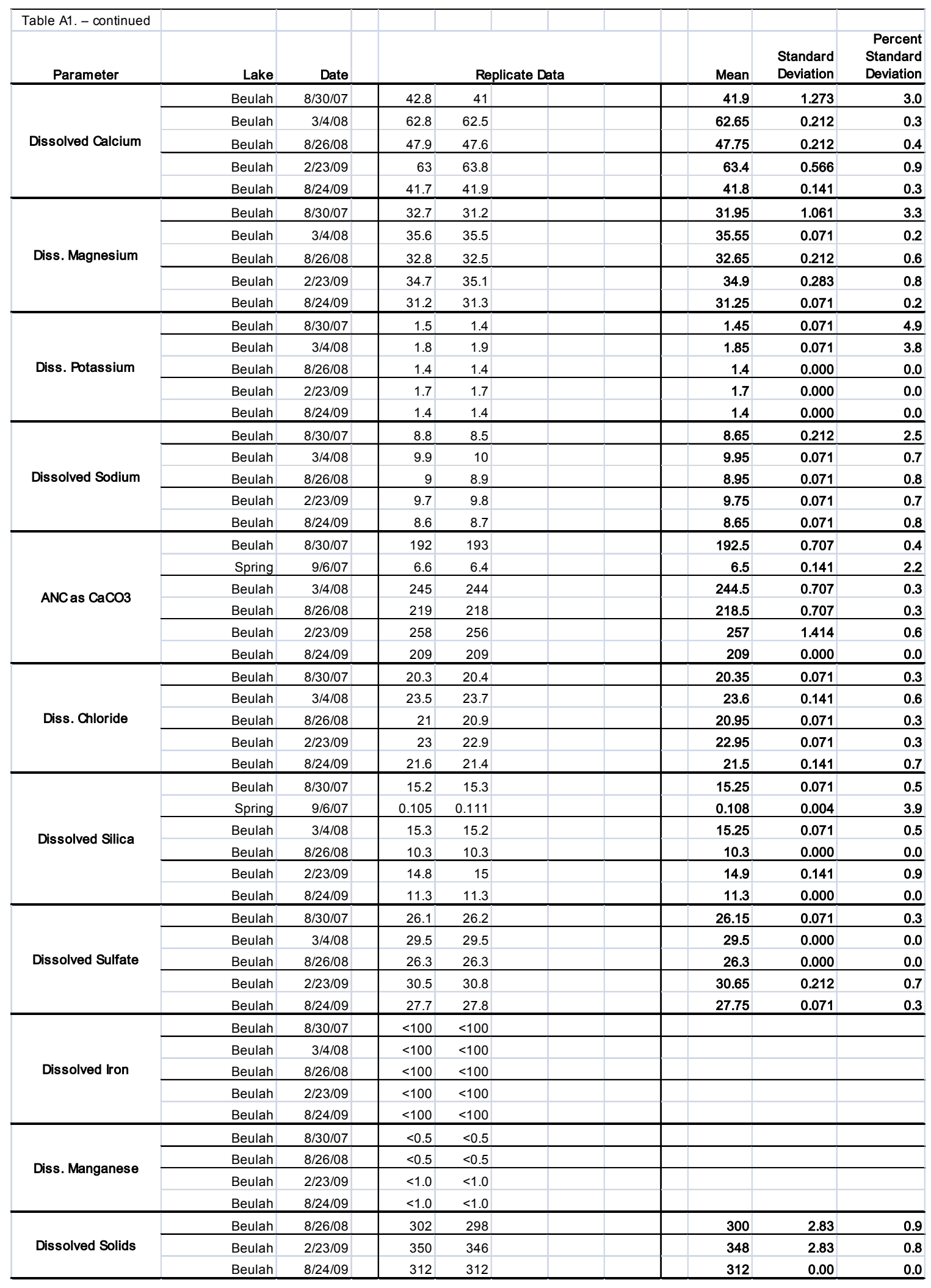




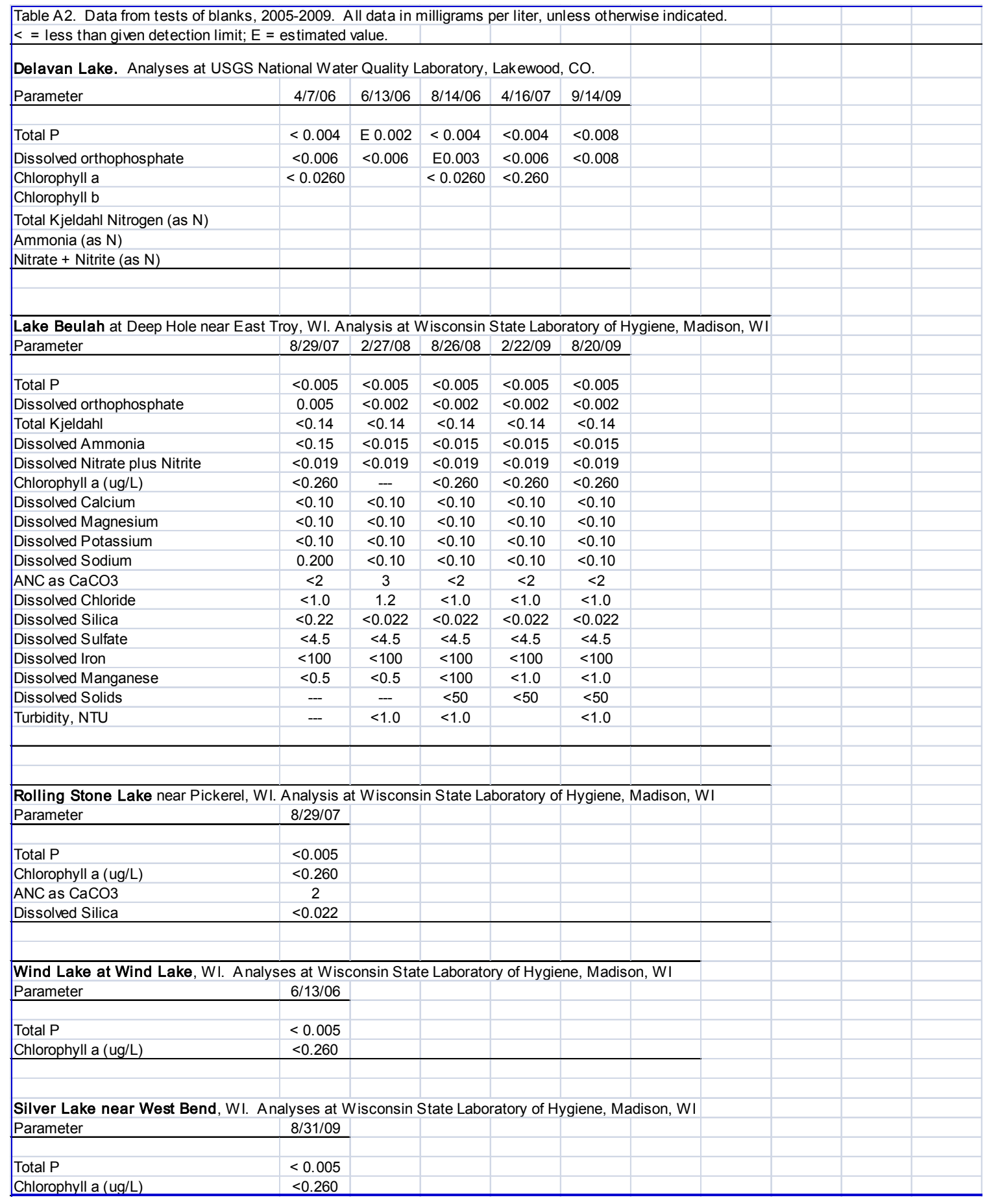


Table A3. Data (for 2005-2009) from standard addition tests using stock solution containing $5.00 \mathrm{mg} / \mathrm{L}$ phosphorus. See text for detail of procedures. All concentration data in milligrams per liter.

\begin{tabular}{|c|c|c|c|c|c|}
\hline Lake, Date & $\begin{array}{c}\frac{\text { Original }}{\text { Sample }} \\
\text { Concentration }\end{array}$ & $\frac{\frac{\text { Stock Solution }}{\text { Volume Added }}}{\text { (milliliters) }}$ & $\frac{\text { Final Expected }}{\text { Concentration }}$ & 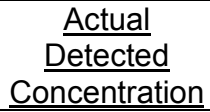 & $\underline{\text { Percent }}$ \\
\hline $\begin{array}{l}\text { Delavan, } \\
\text { August 16, } \\
2005\end{array}$ & $\begin{array}{l}0.029 \\
0.029\end{array}$ & $\begin{array}{c}0.188 \\
0.75\end{array}$ & $\begin{array}{l}0.036 \\
0.059\end{array}$ & $\begin{array}{l}0.037 \\
0.063\end{array}$ & $\begin{array}{l}103 \% \\
107 \%\end{array}$ \\
\hline $\begin{array}{l}\text { No Spike data } \\
\text { in } 2006\end{array}$ & & & & & \\
\hline $\begin{array}{l}\text { No Spike data } \\
\text { in } 2007\end{array}$ & & & & & \\
\hline $\begin{array}{l}\text { No Spike data } \\
\text { in } 2008\end{array}$ & & & & & \\
\hline $\begin{array}{l}\text { No Spike data } \\
\text { in } 2009\end{array}$ & & & & & \\
\hline
\end{tabular}





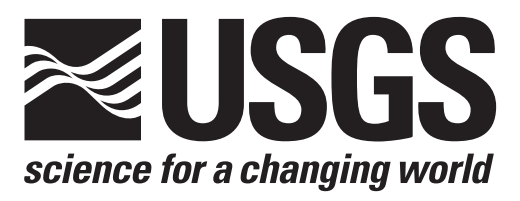

\section{Water-Quality and Lake-Stage Data for Wisconsin Lakes, Water Year 2010}





\section{CONTENTS}

Introduction

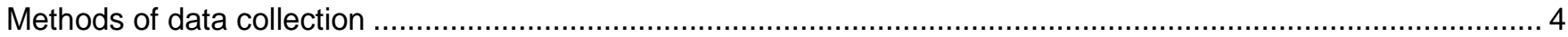

Explanation of physical and chemical characteristics of lakes ……............................................................. 13

Water temperature and thermal stratification ................................................................................. 13

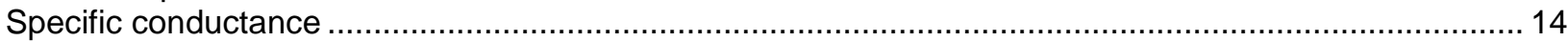

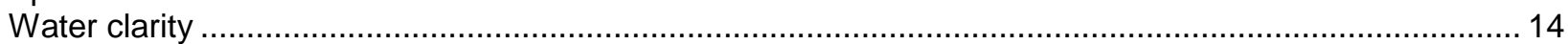

$\mathrm{pH}$

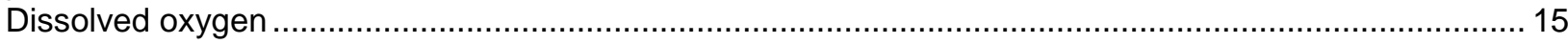

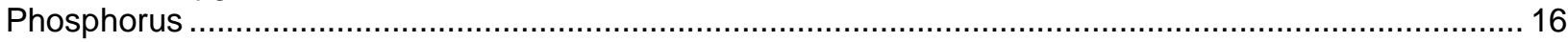

Nitrogen

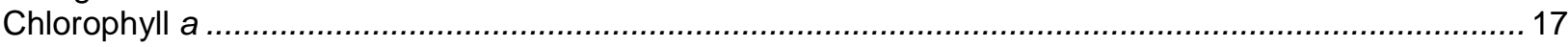

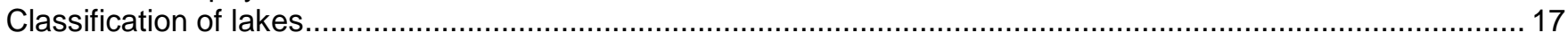

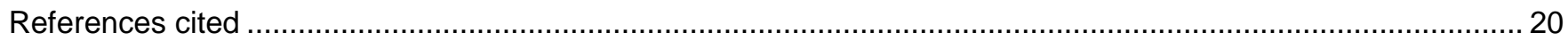

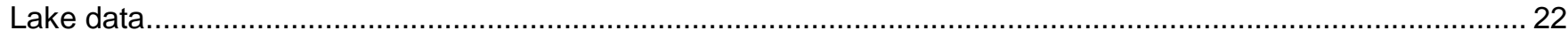

Beulah

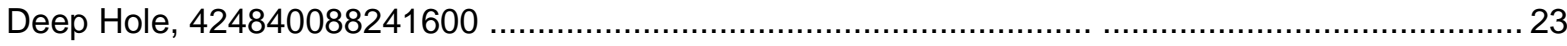

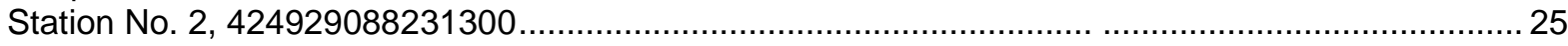

Big Cedar

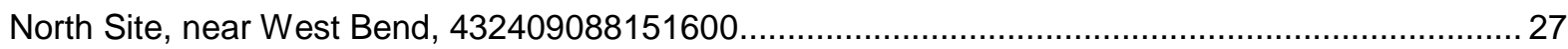

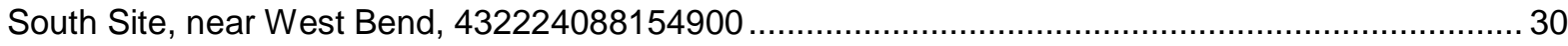

Delavan

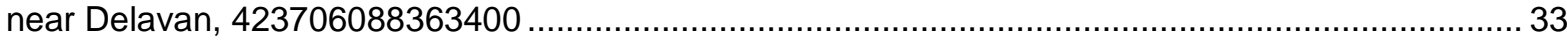

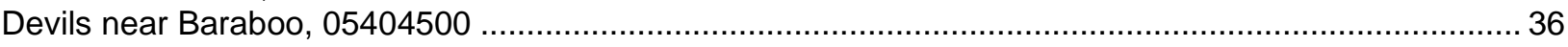

Geneva

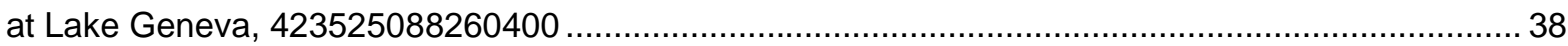

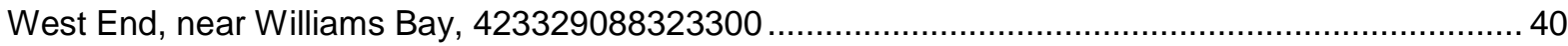

Green

at County Trunk Highway A near Green Lake (East End), 434928088553601 ................................ 45

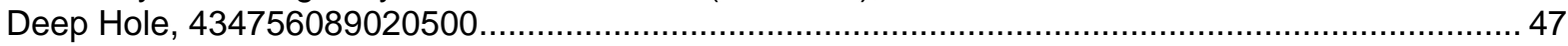

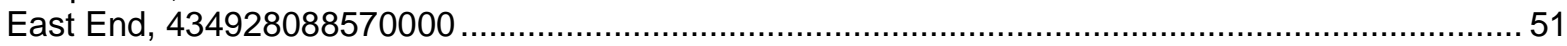

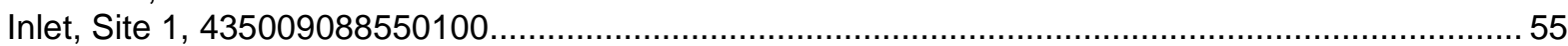

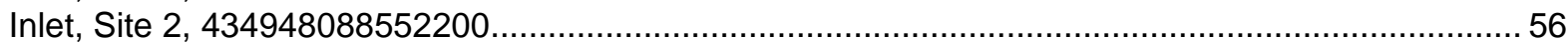

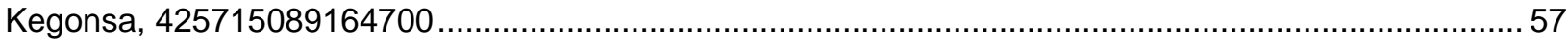

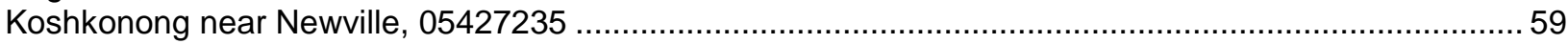

Little Cedar

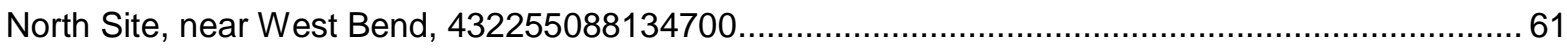

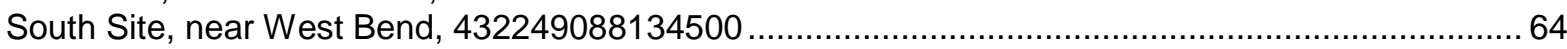

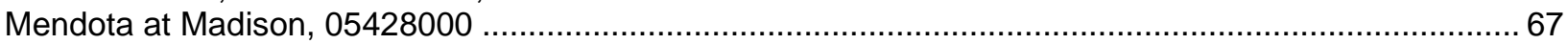

Middle Genesee at Genesee Lake Road, near Oconomowoc, 430251088284700 ..................................6 68

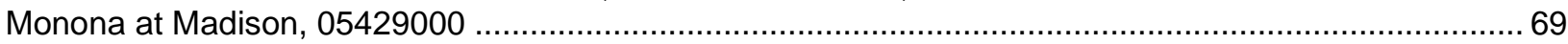

Oconomowoc

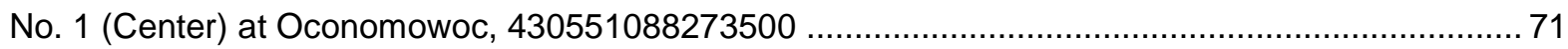

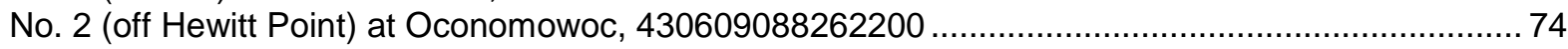

Okauchee

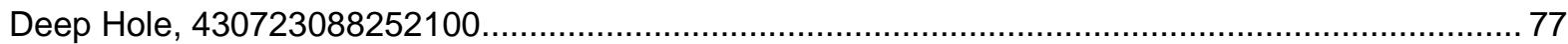

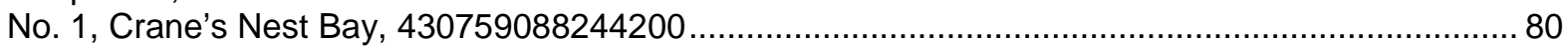

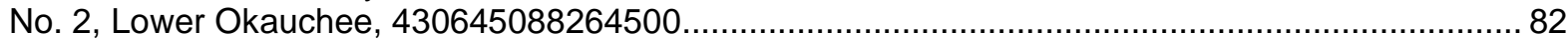

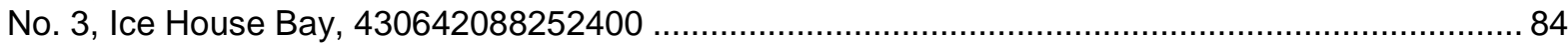

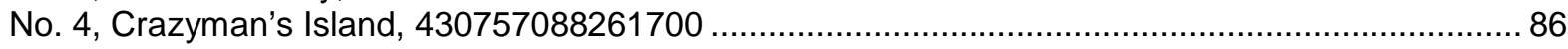

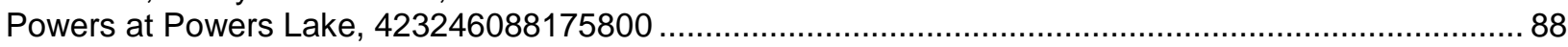

Turtle-Flambeau Flowage

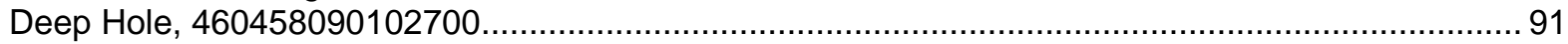

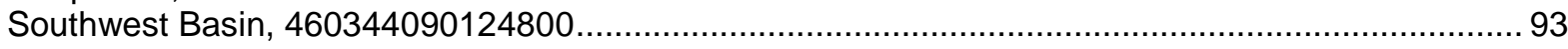




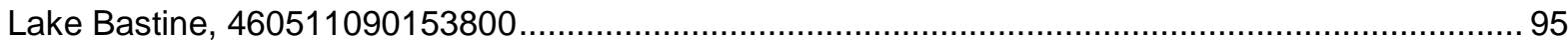

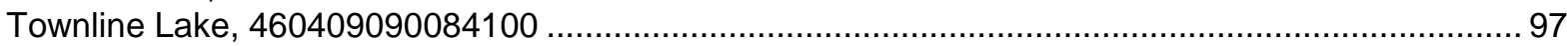

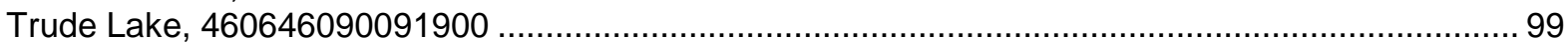

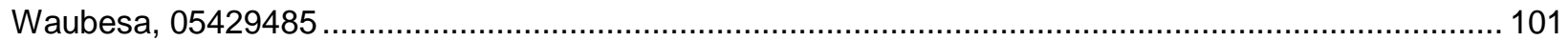

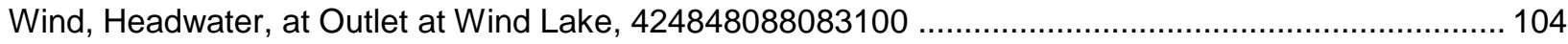

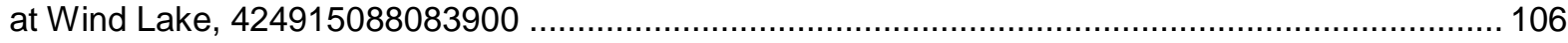

Winnebago

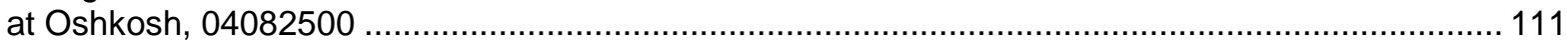

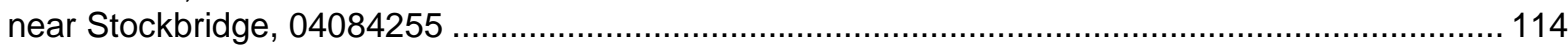

Wisconsin Water Science Center publications pertaining to lakes ............................................................. 116

Appendix - Quality-Assurance/Quality-Control Plan .......................................................................... 128

FIGURE

Figure 1. Map showing location of USGS lake water-quality and lake-stage stations in Wisconsin .................... 2

\section{TABLES}

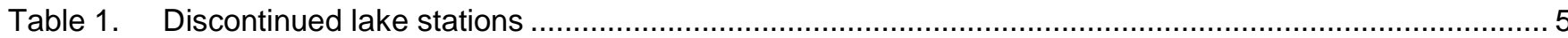

2. Parameter identification numbers and laboratory reporting levels $(L R L)$ for chemical parameters commonly measured in lakes, and analyzed at the National Water-Quality Laboratory (NWQL) or the Wisconsin State Laboratory of Hygiene (WSLH).... 
CONVERSION FACTORS, VERTICAL DATUM, AND ABBREVIATED WATER-QUALITY UNITS

\begin{tabular}{rrl}
\hline Multiply & By & To Obtain \\
mile (mi) & 1.609 & kilometer \\
pound (lb) & 453.6 & gram \\
acre & 0.4048 & hectare \\
foot (ft) & 0.3048 & meter \\
meter (m) & 3.281 & foot \\
gallon $(\mathrm{gal})$ & 3.785 & liter \\
square mile $\left(\mathrm{mi}^{2}\right)$ & 2.590 & square kilometer \\
& & \\
Temperature, in degrees Celsius $\left({ }^{\circ} \mathrm{C}\right)$ can be converted to degrees Fahrenheit $\left({ }^{\circ} \mathrm{F}\right)$ by use of the following \\
& equation & \\
& ${ }^{\circ} \mathrm{F}=1.8\left({ }^{\circ} \mathrm{C}\right)+32$ & \\
\hline
\end{tabular}

Sea level: In this report "sea level" refers to either the National Geodetic Vertical Datum of 1929 (NGVD of 1929)-a geodetic datum derived from a general adjustment of the first-order level nets of both the United States and Canada, formerly called Sea Level Datum of 1929- or the North American Vertical Datum of 1988 (NAVD 88).

Abbreviated water-quality units: Chemical concentrations and water temperature are given in metric units. Chemical concentration is given in milligrams per liter $(\mathrm{mg} / \mathrm{L})$ or micrograms per liter $(\mu \mathrm{g} / \mathrm{L})$. Milligrams per liter is a unit expressing the concentration of chemical constituents in solution as weight (milligrams) of solute per unit volume (liter) of water. One thousand micrograms per liter is equivalent to one milligram per liter. For water with dissolved-solids concentrations less than $7,000 \mathrm{mg} / \mathrm{L}$, the numerical values for concentrations expressed as $\mathrm{mg} / \mathrm{L}$ and $\mu \mathrm{g} / \mathrm{L}$ are the same as for concentrations in parts per million and parts per billion, respectively.

Specific conductance of water is expressed in microsiemens per centimeter at 25 degrees Celsius $(\mu \mathrm{S} / \mathrm{cm})$. This unit is equivalent to micromhos per centimeter $(\mathrm{mmho} / \mathrm{cm})$ at 25 degrees Celsius, formerly used by the U.S. Geological Survey. 


\section{WATER-QUALITY AND LAKE-STAGE DATA FOR WISCONSIN LAKES, WATER YEAR 2010 By Wisconsin Water Science Center Lake-Studies Team}

\section{INTRODUCTION}

The U .S. Geological S urvey ( USGS), i n c ooperation w ith I ocal and other a gencies, collects dat $a$ at $s$ elected I akes t hroughout Wisconsin. T hese dat a, ac cumulated ov er $m$ any years, provide a dat a base for developing an i mproved under standing of the water quality of lakes. T o $\mathrm{m}$ ake these dat a av ailable to i nterested par ties out side the U SGS, the dat a ar $\mathrm{e}$ published annually in this report series. The locations of water-quality and lake-stage stations in Wisconsin for water year 2010 are shown in figure 1. A water year is the 12-month period from October 1 through September 30. It is designated by the calendar year in which it ends. Thus, the period October 1, 2009 through September 30, 2010 is called "water year 2010."

The purpose of this report is to provide information about the chemical and physical characteristics of Wisconsin lakes. Data that have been collected at specific lakes, and information to aid in the interpretation of those data, are included in this report. Data collected include measurements of in-lake water quality and I ake stage. Time series of Secchi depths, surface total phosphorus and chlorophyll a concentrations collected during non-frozen periods are included for all lakes. Graphs of vertical profiles of temperature, dissolved oxygen, $\mathrm{pH}$, and specific conductance are included for sites where these parameters were measured. Descriptive information for each lake includes: location of the lake, area of the lake's watershed, period for which dat a ar e av ailable, r evisions to pr eviously publ ished r ecords, a nd per tinent remarks. Additional data, such as streamflow and water quality in tributary and outlet streams of some of the lakes, are published in another volume: "Water Resources Data-Wisconsin, 2010."

Water-resources data, including stage and discharge data at most streamflow-gaging stations, are available through the $\mathrm{W}$ orld $\mathrm{W}$ ide $\mathrm{W}$ eb on the Internet. The $\mathrm{W}$ isconsin $\mathrm{W}$ ater Science C enter's hom e pag e is at ht tp://wi.water.usgs.gov/. I nformation on t he Wisconsin Water S cience C enter's Lak es $\mathrm{P}$ rogram is f ound at http://wi.water.usgs.gov/lakes/index.html and http://wi.water.usgs.gov/projects/index.html. 


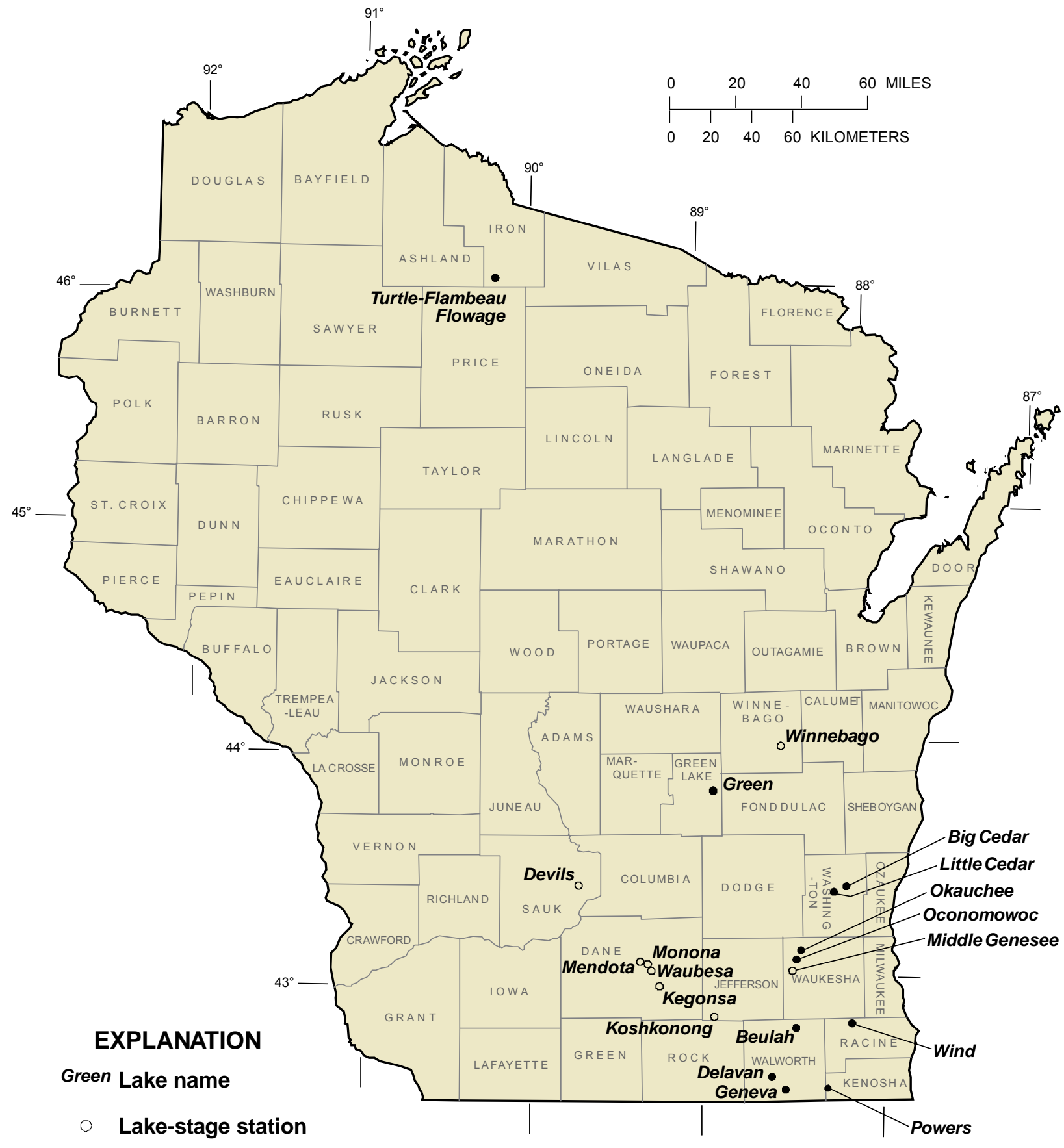

- Lake water-quality and stage station

Note: at some lakes more than one site may be monitored.

Figure 1. Location of USGS lake water-quality and lake-stage stations in Wisconsin. 
The USGS has done c ooperative lake monitoring with local and ot her agencies since 1983. Cooperators in 2010 included:

Big Cedar Lake Protection and Rehabilitation District

Dane County

Delavan Lake Sanitary District

Geneva Lake Environmental Agency

Green Lake Sanitary District

Iron County Land \& Water Conservation Department

Lake Beulah Management District

Little Cedar Lake Protection and Rehabilitation District

Middle Genesee Lake District

Okauchee Lake Management District

Powers Lake District

Rock County Public Works Department

U.S. Army Corps of Engineers

Village of Oconomowoc Lake

Wind Lake Management District

Wisconsin Department of Natural Resources 
Lake data-collection sites are identified by a unique identification number. Lake waterquality s ites are identified by a 15 -digit nu mber that is a c oncatenation of the site's I atitude, longitude, and a $\mathrm{t}$ wo-digit s equence num ber. The sequence nu mber is us ed to di stinguish between sites located at the same latitude-longitude designation. The site identification number is per manently as signed to the s ite; ac tual I atitude and I ongitude of the $s$ ite ar e s ubject to update and are stored separately. For some lakes, which have historical records of lake stage, an eight-to-ten di git nu mber is as signed according to downstream order. Gaps are left in the numerical series to al low for new stations; hence, the numbers are not consecutive. The first two digits of the complete eight-to-ten digit number, such as 04087000 or 054310157 , designate the major river basin. For example, "04" designates the St. Lawrence River Basin and "05" designates the Upper Mississippi River Basin.

The water-quality lake stations that were discontinued prior to water year 2010 are listed in table 1. Discontinued lake-stage stations are not included in this table.

This report is the culmination of a concerted effort by a number of people who collected, compiled, analyzed, verified, and organized the data, and who typed, edited, and assembled the report. The authors had primary responsibility for assuring that the information contained herein is accurate, complete, and adheres to USGS policy and established guidelines. Technicians in charge of the field offices are: B.W. Olson (Merrill), and S.A. March (Middleton). The data were collected and pr ocessed by G.L. G oddard, S.B. Manteufel, B.W. Olson, D .L. Ol son, P.C. Reneau, J.G. Schuler, Z.T. S cott, B.J. S iebers and E.F. Y ounger. S.B. Manteufel assembled, edited, and formatted the report. Additional assistance in preparation of the report was provided by M.M. Greenwood, and D.L. Olson.

\section{METHODS OF DATA COLLECTION}

Depth profiles of water temperature, dissolved oxygen, $\mathrm{pH}$, and s pecific conductance were c ollected us ing multi-parameter meters. Prior to measurements, the meters were calibrated using standards for $\mathrm{pH}$ and conductance, and dissolved oxygen was calibrated using the ai $r c$ alibration $m$ ethod. $G$ enerally, $f$ ield $m$ easurements in pr ofiles $w$ ere $m$ ade at $0.5-m$ intervals if the $\mathrm{m}$ aximum dep th of the lake was $5 \mathrm{~m}$ or less and a $\mathrm{t} 1.0 \mathrm{~m}$ i ntervals if the maximum depth was greater than $5 \mathrm{~m}$. 
Table 1. Discontinued lake stations

\begin{tabular}{|c|c|c|}
\hline Station name & Site identification number & Period of record \\
\hline Alma Lake near St. Germain & 455426089254700 & $\begin{array}{l}\text { Oct. 1984-Sept. 1990, } \\
\text { May 1992-Sept.1996 }\end{array}$ \\
\hline Balsam Lake, off Cedar Island, at Balsam Lake & 452755092264600 & Feb. 1991-Aug. 1994 \\
\hline off Little Narrows, near Balsam Lake & 452858092265300 & May 1991-Aug. 1994 \\
\hline off Rock Island, near Balsam Lake & 452754092234300 & May 1991-Aug. 1994 \\
\hline Balsam Lake near Birchwood & 453907091345800 & $\begin{array}{l}\text { Mar. 1993-Aug. 1994, } \\
\text { Mar. 1996-Aug. 1997, } \\
\text { Mar.-Sept. } 2001\end{array}$ \\
\hline Bass Lake near Shawano & 445215088300300 & Feb. 1990-Aug. 1992 \\
\hline Bear Lake at Deep Hole near Haugen & 453754091490900 & Mar. 1992-Aug. 1993 \\
\hline Beaver Dam Lake, South end, at Beaver Dam & 432814088515000 & June-Oct. 1991 \\
\hline North end, near Beaver Dam & 433122088545700 & June-Oct. 1991 \\
\hline Benedict Lake near Powers Lake & 423201088180800 & May 1998-Aug. 2000 \\
\hline Big Blacksmith Lake near Keshena & 445401088334500 & Feb. 1990-Aug. 1992 \\
\hline Big Hills (Hills) Lake near Wild Rose & 440912089092000 & $\begin{array}{l}\text { June 1983-Aug. 1984, } \\
\text { Feb.-Aug. 1987, } \\
\text { Feb.-Aug. 1990, } \\
\text { Feb.-Aug. 1993, } \\
\text { Feb.-Aug. 1996, } \\
\text { Feb.-Aug. } 1999\end{array}$ \\
\hline Big Muskego Lake, at North Site, near Muskego & 425301088061300 & Feb.-Aug. 1988 \\
\hline Research Base, near Muskego & 425235088075300 & May-June 1994 \\
\hline Big Round Lake near Milltown & 453142092180100 & Feb.-Sept. 2001 \\
\hline Big St. Germain Lake, near St. Germain & 455557089311000 & Feb. 1992-Aug. 1996 \\
\hline near Lake Tomahawk & 05390750 & 1991-2001 \\
\hline Big Sand Lake, Deep Hole, near Hertel & 454910092134000 & Feb.-Sept. 2001 \\
\hline East Site, near Hertel & 454921092124300 & Feb.-Sept. 2001 \\
\hline Big Sissabagama Lake, near Stone Lake & 454724091303600 & $\begin{array}{l}\text { Apr. 1986-Sept. 1996, } \\
\text { Oct. 1997-Sept. } 2002\end{array}$ \\
\hline North Site, near Stone Lake & 454800091312900 & Mar. 1998-Sept. 2001 \\
\hline Booth Lake near East Troy & 424800088254800 & $\begin{array}{l}\text { Feb. 1992-Aug. 1994, } \\
\text { Feb. 2001-Aug. } 2003\end{array}$ \\
\hline Buffalo Lake, Center Site, at Packwaukee & 434558089260600 & May 1998-Sept. 2001 \\
\hline East End, at Montello & 434720089201600 & May 1998-Sept. 2001 \\
\hline West End, near Endeavor & 434414089282400 & May 1998-Sept. 2001 \\
\hline
\end{tabular}


Table 1. Discontinued lake stations--continued

\begin{tabular}{|c|c|c|}
\hline Station name & Site identification number & Period of record \\
\hline Butternut Lake, near Park Falls & 455854090310300 & Oct. 2002-Oct. 2004 \\
\hline Deep Hole, near Park Falls & 455803090310800 & Mar. 2003-Sept. 2004 \\
\hline North Site, near Butternut & 455904090303400 & Mar. 2003-Sept. 2004 \\
\hline Far South Site, near Park Falls & 455651090312700 & Mar. 2003-Sept. 2004 \\
\hline Delavan Lake, Center, at Delavan & 423556088365001 & Oct. 1983-Oct. 2009 \\
\hline North end, near Lake Lawn & 423659088354401 & Oct. 1983-Oct. 2009 \\
\hline SW end, near Delavan & 423526088380101 & Oct. 1983-Oct. 2009 \\
\hline Denoon Lake at Wind Lake & 425044088100300 & Feb. 1991-Aug. 1996 \\
\hline Druid Lake near Hartford & 431643088243300 & Feb. 1991-Sept. 1996 \\
\hline Eagle Lake near Kansasville & 05544500 & $\begin{array}{l}\text { 1936-64, 1975-77, } \\
\text { 1979, } \\
\text { Feb. 1993-Sept. } 1996\end{array}$ \\
\hline Eagle Lake, at Deep Hole, near Kansasville & 424207088072400 & Feb. 1993-Aug. 1996 \\
\hline Eagle Spring Lake at Eagleville & 425103088261500 & Apr. 1991-Sept. 2001 \\
\hline Elizabeth Lake near Twin Lakes & 423051088155300 & Feb. 1995-Sept. 1997 \\
\hline Fish Lake near Sauk City & 05406050 & $\begin{array}{l}\text { Nov. 1966-Sept. 1981, } \\
\text { Apr. 1985-May 1987, } \\
\text { May 1988, Apr. 1989- } \\
\text { Oct. 1990, Oct. 1990- } \\
\text { Nov. 1996, Nov. 1996- } \\
\text { Sept. } 2004\end{array}$ \\
\hline Fowler Lake, Center, at Oconomowoc & 430653088294601 & $\begin{array}{l}\text { Jan.-Dec. 1984, } \\
\text { Oct. 1986-Sept. } 1996\end{array}$ \\
\hline Fox Lake Deep Hole at Fox Lake & 433458088560600 & June 1991-Mar. 1993 \\
\hline Geneva Lake, Geneva Bay, at Lake Geneva & 423455088263800 & Apr. 1997-Feb. 1999 \\
\hline Williams Bay, at Williams Bay & 423420088320500 & Apr. 1997-Feb. 1999 \\
\hline Center, near Lake Geneva & 423402088301400 & Apr. 1997-Mar. 1999 \\
\hline East End, near Lake Geneva & 423421088272300 & Apr. 1997-May 2000 \\
\hline Hemlock Lake near Mikana & 453421091333700 & $\begin{array}{l}\text { Mar. 1993-Aug. 1994, } \\
\text { Mar. 1996-Aug. 1997, } \\
\text { Mar.-Sept. } 2001\end{array}$ \\
\hline Hooker Lake at Salem & 423335088060300 & Feb. 1992-Aug. 1993 \\
\hline Kawaguesaga, Deep Hole, near Minocqua & 455208089435800 & May-Sept. 2003 \\
\hline South Site, near Minocqua & 455145089442600 & May-Sept. 2003 \\
\hline Kirby Lake near Cumberland & 453554092042101 & Nov. 1995-Oct. 1996 \\
\hline (Site 1) near Cumberland & 453608092035801 & Nov. 1995-Nov. 1996 \\
\hline (Site 2) near Cumberland & 453601092035301 & Nov. 1995-Nov. 1996 \\
\hline
\end{tabular}


Table 1. Discontinued lake stations--continued

\begin{tabular}{|c|c|c|}
\hline Station name & Site identification number & Period of record \\
\hline (Site 3) near Cumberland & 453612092034901 & Nov. 1995-Nov. 1996 \\
\hline (Site 4) near Cumberland & 453603092035701 & Nov. 1995-Nov. 1996 \\
\hline (Site 5) near Cumberland & 453608092041201 & Nov. 1995-Nov. 1996 \\
\hline (Site 6) near Cumberland & 453555092040901 & Nov. 1995-Nov. 1996 \\
\hline Lac La Belle at Oconomowoc & 430733088305900 & $\begin{array}{l}\text { Feb. 1984-Aug. } 1985, \\
\text { Apr. -Aug. 1991, } \\
\text { Feb. 2001-Aug. } 2003\end{array}$ \\
\hline NW, at Oconomowoc & 430809088313900 & Feb. 1984-Aug. 1985 \\
\hline SE, at Oconomowoc & 430707088301400 & Feb. 1984-Aug. 1985 \\
\hline Lake Blass at Lake Delton & 433545089482400 & Mar. 1989-Aug. 1990 \\
\hline Lake Desair near Rice Lake & 453446091465100 & Aug. 2004 \\
\hline $\begin{array}{l}\text { Lake Keesus, } \\
\text { East Bay, near Merton } \\
\text { North Bay, near Merton }\end{array}$ & $\begin{array}{l}430957088183400 \\
431006088191000\end{array}$ & $\begin{array}{l}\text { Apr. 1991-Aug. } 1995 \\
\text { Apr. 1991-Aug. } 1995\end{array}$ \\
\hline Lake Morris at Mount Morris & 440654089120500 & Jun. 1983-Sept. 1989 \\
\hline $\begin{array}{l}\text { Lake Nebagamon, Northeast Bay, at Lake } \\
\text { Nebagamon }\end{array}$ & 463050091412300 & May 1992-Aug. 1995 \\
\hline Southeast Bay, at Lake Nebagamon & 462928091413500 & Mar. 1992-Sept. 1995 \\
\hline West Bay, at Lake Nebagamon & 463034091425300 & May 1992-Aug. 1995 \\
\hline Lake Noquebay near Crivitz & 451511087550900 & $\begin{array}{l}\text { Feb. 1987-Aug. 1988, } \\
\text { Apr. 1991-Aug. } 1994\end{array}$ \\
\hline East End, near Crivitz & 451540087525700 & Apr. 1991-Aug. 1994 \\
\hline Lamotte Lake near Shawano & 445305088361200 & Feb. 1990-Aug. 1992 \\
\hline $\begin{array}{l}\text { Lauderdale Lakes at Lauderdale } \\
\text { Mill, at Lauderdale }\end{array}$ & $\begin{array}{l}424554088332700 \\
424555088335700\end{array}$ & $\begin{array}{l}\text { Oct. 1993-Oct. } 1994 \\
\text { Nov. 1993-Nov. } 1994, \\
\text { Aug. } 2002\end{array}$ \\
\hline Green, Auxiliary, Number 1, near Lauderdale & 424640088341900 & June 1999-Sept. 2000 \\
\hline Green, near Lauderdale & 424652088341500 & $\begin{array}{l}\text { Nov. } 1993-N o v .1994 \text {, } \\
\text { Aug. } 2002\end{array}$ \\
\hline Legend Lake (site 1) near Shawano & 445342088312700 & Feb. 1990-Feb. 1992 \\
\hline Little Arbor Vitae near Woodruff & 455446089370300 & Feb. 1991-Sept. 2002 \\
\hline Little Green Lake, at Center, near Markesan & 434412088590700 & Feb. 1991-Aug. 2003 \\
\hline Little Muskego Lake at Muskego & 425425088083500 & Oct. 1986-Aug. 2002 \\
\hline Little Rock Lake near Woodruff & 455946089415702 & Oct. 1983-Sept. 1996 \\
\hline Little St. Germain Lake, near Eagle River & 05390700 & (a) \\
\hline Upper East Bay, at St. Germain & 455532089253900 & $\begin{array}{l}\text { Dec. 1996-Mar. 97, } \\
\text { Mar. 1999, } \\
\text { Mar. 2000-Aug. } 2003\end{array}$ \\
\hline
\end{tabular}


Table 1. Discontinued lake stations--continued

\begin{tabular}{|c|c|c|}
\hline Station name & Site identification number & Period of record \\
\hline Northeast Bay, near St. Germain & 455545089262500 & $\begin{array}{l}\text { Apr. 1991-Aug. 1994, } \\
\text { Aug. 1996-Aug. 1997, } \\
\text { Mar. 1999-Aug. } 2003\end{array}$ \\
\hline South Bay, near St. Germain & 455437089270800 & $\begin{array}{l}\text { Apr. 1991-Aug. 1994, } \\
\text { Aug. 1996-Aug. 1997, } \\
\text { Mar. 1999-Aug. } 2003\end{array}$ \\
\hline West Bay, at St. Germain & 455428089282400 & $\begin{array}{l}\text { Apr. 1991-Aug. 1994, } \\
\text { Aug. 1996-Aug. 1997, } \\
\text { Mar. 1999-Aug. } 2003\end{array}$ \\
\hline Little Sand Lake - Site No. 2 - near Mole Lake & 452826088544101 & May1996-Sept. 2003 \\
\hline Long (Kee Nong Go-Mong) Lake at Wind Lake & 424937088103400 & $\begin{array}{l}\text { Feb. 1988-Aug. 1989, } \\
\text { Feb. 1991-Aug. } 1996\end{array}$ \\
\hline Loon Lake near Shawano & 445009088303700 & Feb. 1991-Aug. 1993 \\
\hline Lost Lake near Beaver Dam & 432640088580500 & June-Oct. 1991 \\
\hline \multicolumn{3}{|l|}{ McKenzie Lakes } \\
\hline \multicolumn{3}{|l|}{ McKenzie (Big McKenzie) } \\
\hline Deep Hole, near Spooner & 455507092013500 & Feb. 1987-Aug. 1998 \\
\hline Northern Site, near Spooner & 455540092022000 & June 1997-Aug. 1998 \\
\hline South Site, near Spooner & 455437092022300 & June 1997-Aug. 1998 \\
\hline Lower McKenzie, near Webb Lake & 455902092011900 & June 1997-Aug. 1998 \\
\hline Middle McKenzie, near Spooner & 455635092021800 & June 1997-Aug. 1998 \\
\hline Mary (Marie) Lake at Twin Lakes & 423128088151200 & Feb. 1995-Aug. 1997 \\
\hline Max Lake near Woodruff & 460128089423501 & Mar. 1988-Dec. 1996 \\
\hline Mead Lake, East Bay near Willard & 444720090445000 & Apr. 1991-Aug. 1995 \\
\hline West Bay near Willard & 444733090460100 & Feb. 1991-Sept. 1995 \\
\hline Mercer Lake, Deep Hole, at Mercer & 460937090033100 & Mar. 2008-Sept. 2009 \\
\hline West basin, at Mercer & 460945090040600 & Mar. 2008-Sept. 2009 \\
\hline \multicolumn{3}{|l|}{ Minocqua Lake } \\
\hline Deep Hole, at Minocqua & 455214089412800 & May-Sept. 2003 \\
\hline North Bay, at Minocqua & 455232089424100 & May-Sept. 2003 \\
\hline South Bay, at Minocqua & 455206089425200 & May-Sept. 2003 \\
\hline Montello Lake at Montello & 434748089195800 & Feb. 1995-Aug. 1998 \\
\hline Moon Lake near St. Germain & 455504089260500 & Feb. 1992-Aug. 1996 \\
\hline Morgan Lake near Fence & 454622088324801 & Oct. 1987-Sept. 1998. \\
\hline Moshawquit Lake near Shawano & 445352088295800 & Feb. 1990-Aug. 1992 \\
\hline \multicolumn{3}{|l|}{ Muskego (Big Muskego) } \\
\hline Auxiliary Number 1, near Muskego & 425329088054000 & June 1996-Aug. 2000 \\
\hline Bass Bay, near Muskego & 425344008807010 & Feb. 1988-Aug. 2002 \\
\hline
\end{tabular}


Table 1. Discontinued lake stations--continued

\begin{tabular}{|c|c|c|}
\hline Station name & Site identification number & Period of record \\
\hline near Wind Lake & 425109088075000 & $\begin{array}{l}\text { Oct. 1987-Sept. } 1989 \\
\text { Jan. 1991-Sept. } 2002\end{array}$ \\
\hline South Site, near Muskego & 425212088072800 & Feb. 1988-Aug. 2002 \\
\hline Muskellunge Lake near Eagle River & 455700089224900 & June 2000-Aug. 2001 \\
\hline $\begin{array}{l}\text { Muskellunge Lake, near Lake Outlet near Eagle } \\
\text { River }\end{array}$ & 455706089232400 & Nov. 2000-Oct. 2001 \\
\hline Nagawicka Lake, at Deep Hole, at Delafield & 430417088230300 & Feb. 2003-Sept. 2004 \\
\hline \multicolumn{3}{|l|}{ Namekagon Lakes } \\
\hline Garden, near Cable & 461224091033200 & Mar. 1998-Aug. 1999 \\
\hline Jackson, near Cable & 461457091065900 & Mar. 1998-Aug. 1999 \\
\hline \multicolumn{3}{|l|}{ Namekagon } \\
\hline Deep Hole, near Cable & 461308091065100 & Mar. 1998-Aug. 1999 \\
\hline East Basin, near Cable & 461228091044300 & Mar. 1998-Aug. 1999 \\
\hline Northeast Basin, near Cable & 461410091050700 & Mar. 1998-Aug. 1999 \\
\hline Park Lake (site 1) at Pardeeville & 433239089175800 & $\begin{array}{l}\text { Feb. 1986-Aug. 1987, } \\
\text { May-Nov. } 1993\end{array}$ \\
\hline (site 2) at Pardeeville & 433226089175500 & May-Nov. 1993 \\
\hline (site 3) at Pardeeville & 433245089173000 & May-Nov. 1993 \\
\hline (site 4) at Pardeeville & 433257089165100 & May-Nov. 1993 \\
\hline Pike Lake near Hartford & 431916088200501 & Dec. 1998-Dec. 2000 \\
\hline Pike Lake-QW Site-near Hartford & 431835088200600 & Feb.-Aug. 2000 \\
\hline Potter Lake near Mukwonago & 423246088175800 & Feb. 1993-Sept. 2007 \\
\hline Pretty Lake, at Deep Hole, near Dousman & 425722088295000 & Feb. 1993-Aug. 1997 \\
\hline Puckaway Lake, West Basin, near Marquette & 434515089124000 & Apr. 2005-Sept. 2007 \\
\hline East Basin, near Marquette & 43454208907300 & Apr. 2005-Sept. 2007 \\
\hline River site, near Marquette & 434824089083200 & Apr. 2005-Sept. 2007 \\
\hline Red Cedar Lake, at Mikana & 453522091360600 & $\begin{array}{l}\text { Mar. 1993-Aug. 1994, } \\
\text { Mar. 1996-Aug. 1997, } \\
\text { Oct. 2000-Sept. } 2001\end{array}$ \\
\hline Deep Hole, near Mikana & 453725091345100 & $\begin{array}{l}\text { Mar. 1993-Aug. 1994, } \\
\text { Mar. 1996-Aug. 1997, } \\
\text { Mar. -Sept. } 2001\end{array}$ \\
\hline South End, at Mikana & 453519091352500 & $\begin{array}{l}\text { Mar. 1993-Aug. 1994, } \\
\text { Mar. 1996-Aug. 1997, } \\
\text { Mar. -Sept. } 2001\end{array}$ \\
\hline Rice Lake at Deep Hole near Whitewater & 424629088415700 & Apr.-Nov. 1991 \\
\hline Round Lake near Shawano & 445328088335000 & Feb. 1990-Aug. 1992 \\
\hline Sand Lake (Deep Hole) near Keshena & 445321088323101 & June-Aug. 1992 \\
\hline
\end{tabular}


Table 1. Discontinued lake stations--continued

\begin{tabular}{|c|c|c|}
\hline Station name & Site identification number & Period of record \\
\hline Shell Lake at Shell Lake & 05334000 & Aug. 1936-Sept. 1999 \\
\hline Silver Lake near Oconomowoc & 430436088293300 & Apr. 1992-Aug. 1996 \\
\hline Silver Lake near West Bend & 432322088125000 & $\begin{array}{l}\text { Feb. 1996-Aug. } 1997 \\
\text { Feb. 2009-Aug. } 2009\end{array}$ \\
\hline Sinissippi Lake, off Anthony Is., at Hustisford & 432113088361100 & Feb. 1991-Aug. 1993 \\
\hline off Butternut Is., near Hustisford & 432240088363900 & Apr. 1991-Aug. 1993 \\
\hline off Sam Point, near Hustisford & 432300088374200 & Apr. 1991-Aug. 1993 \\
\hline Spirit Lake near Keshena & 445400088320100 & Apr.-Aug. 1992 \\
\hline Spooner Lake, Deep Hole, near Spooner & 455034091493300 & June 2002-Aug. 2004 \\
\hline Southeast Site, near Spooner & 454945091483900 & June 2002-Aug. 2004 \\
\hline Stewart Lake at Mt. Horeb & 430117089442701 & May 1992-Sept. 1993 \\
\hline Tichigan Lake near Waterford & 424854088123300 & $\begin{array}{l}\text { Mar. 1994-Aug. 1996, } \\
\text { Apr. 2003-Aug. } 2004\end{array}$ \\
\hline Tombeau Lake near Powers Lake & 423153088184800 & May 1998-Aug. 2000 \\
\hline $\begin{array}{l}\text { Turtle-Flambeau Flowage, Deep Hole, near } \\
\text { Mercer }\end{array}$ & 460458090102700 & Apr. 2009-Mar. 2010 \\
\hline SW Basin, near Mercer & 460344090124800 & Apr. 2009-Mar. 2010 \\
\hline Lake Bastine, Deep Hole, near Mercer & 460511090153800 & Apr. 2009-Mar. 2010 \\
\hline Townline Lake, near Mercer & 460409090084100 & Apr. 2009-Mar. 2010 \\
\hline Trude Lake, Deep Hole, near Mercer & 460646090091900 & Apr. 2009-Mar. 2010 \\
\hline Twin Lake, East Twin, near Westfield & 435430089350700 & June 2002-Aug. 2004 \\
\hline West Twin, near Westfield & 435438089352300 & June 2002-Aug. 2004 \\
\hline \multicolumn{3}{|c|}{ (a) Wisconsin Valley Improvement Co. currently collects stage data for this site. } \\
\hline
\end{tabular}

In most lakes, water samples were collected at two depths - near the surface and near the bottom. Chemical analyses of water samples were performed using standard analytical methods by either the USGS National Water Quality Laboratory (Wershaw and others, 1987; Fishman and Friedman, 1989; Fishman, 1993) or the Wisconsin State Laboratory of Hygiene (Wisconsin State Laboratory of Hygiene, 1993). Analyses for dissolved constituents were performed on samples that were filtered in the field through a $0.45-\mathrm{mm}$ (micrometer) pore-size filter. Total or total recoverable constituents were determined by analyzing unfiltered water samples. Preservation and shipment of samples followed standard protocols established by the laboratories. Water-quality data were archived in the Water Quality Data Base (QWDATA) of the National Water Information System (NWIS). Additional descriptive information about water- 
quality data is available in the data report: "Water Resources Data - Wisconsin, 2010". NWIS parameter codes and minimum laboratory reporting levels for chemical constituents are given in table 2. The parameter code for turbidity has changed from 00076 to 63675 or 63676 because the method of testing has changed.

Records of lake stage are considered complete when one or more manual or automatic measurements were obtained per day. Partial records of lake stage result when measurements were less frequent than daily. A complete description of manual or automatic measurements of lake stage is described by Rantz and others (1982). 
Table 2. Parameter identification numbers and laboratory reporting levels (LRL) for chemical parameters commonly measured in lakes, and analyzed at the National Water Quality Laboratory (NWQL) or the Wisconsin State Laboratory of Hygiene (WSLH).

\begin{tabular}{|c|c|c|c|c|c|c|c|c|c|}
\hline \multirow[b]{3}{*}{ Parameter Name } & \multirow[b]{3}{*}{ Units } & \multirow[b]{3}{*}{$\begin{array}{c}\text { CAS } \\
\text { Number }^{1}\end{array}$} & \multirow[b]{3}{*}{$\begin{array}{l}\text { Parameter } \\
\text { Code }^{2}\end{array}$} & \multicolumn{4}{|c|}{ (NWQL) } & \multicolumn{2}{|c|}{ (WSLH) } \\
\hline & & & & \multicolumn{2}{|c|}{$\begin{array}{l}\text { Standard } \\
\text { Analysis }\end{array}$} & \multicolumn{2}{|c|}{$\begin{array}{l}\text { Low-Level } \\
\text { Analysis }\end{array}$} & \multirow[b]{2}{*}{ LRL } & \multirow[b]{2}{*}{$\begin{array}{l}\text { Test } \\
\text { Code }\end{array}$} \\
\hline & & & & LRL & $\begin{array}{l}\text { Lab } \\
\text { Code }\end{array}$ & LRL & $\begin{array}{l}\text { Lab } \\
\text { Code }\end{array}$ & & \\
\hline Calcium, diss. (Ca) & $\mathrm{mg} / \mathrm{L}$ & $7440-70-2$ & 00915 & 0.020 & 659 & 0.002 & 1895 & 0.02 & I230IUD \\
\hline Magnesium, diss. (Mg) & $\mathrm{mg} / \mathrm{L}$ & $7439-95-4$ & 00925 & 0.004 & 663 & 0.001 & 1897 & 0.02 & I390IUD \\
\hline Sodium, diss. (Na) & $\mathrm{mg} / \mathrm{L}$ & $7440-23-5$ & 00930 & 0.09 & 675 & 0.025 & 1898 & 0.09 & I80IUD \\
\hline Potassium, diss. (K) & $\mathrm{mg} / \mathrm{L}$ & $7440-09-7$ & 00935 & 0.24 & 54 & 0.01 & 833 & 0.3 & I540IUD \\
\hline Sulfate, diss. (SO4) & $\mathrm{mg} / \mathrm{L}$ & $14808-79-8$ & 00945 & 0.31 & 1572 & 0.01 & 1263 & 1.0 & I600DLD \\
\hline Chloride, diss. (Cl) & $\mathrm{mg} / \mathrm{L}$ & $16887-00-6$ & 00940 & 0.29 & 1571 & 0.01 & 1259 & 0.1 & I240ELD \\
\hline Fluoride, diss. (F) & $\mathrm{mg} / \mathrm{L}$ & $16984-48-8$ & 00950 & 0.100 & 31 & 0.01 & 1260 & 0.03 & I330FLD \\
\hline Iron, diss. (Fe) & $(\mu \mathrm{g} / \mathrm{L})$ & $7439-89-6$ & 01046 & 10 & 645 & 3 & 1896 & 10 & I370IUD \\
\hline Manganese, diss. (Mn) & $(\mu \mathrm{g} / \mathrm{L})$ & $7439-96-5$ & 01056 & 2.2 & 648 & 1 & 1793 & 0.4 & |400IUD \\
\hline Silica, diss. (SiO2) & $\mathrm{mg} / \mathrm{L}$ & $7631-86-9$ & 00955 & 0.1 & 56 & 0.02 & 1899 & 0.008 & I560LLD \\
\hline $\begin{array}{l}\text { Nitrogen, } \mathrm{NO} 2+\mathrm{NO} 3 \text {, } \\
\text { diss. }\end{array}$ & $\mathrm{mg} / \mathrm{L}$ & -- & 00631 & 0.05 & 1975 & 0.005 & 1979 & 0.01 & I460MLD \\
\hline $\begin{array}{l}\text { Nitrogen, ammonia, } \\
\text { diss. }\end{array}$ & $\mathrm{mg} / \mathrm{L}$ & $7664-41-7$ & 00608 & 0.02 & 1976 & 0.002 & 1980 & 0.013 & I440NLD \\
\hline $\begin{array}{l}\text { Nitrogen, amm.+org., } \\
\text { total }^{4}\end{array}$ & $\mathrm{mg} / \mathrm{L}$ & $17778-88-0$ & 00625 & 0.100 & 1985 & -- & -- & 0.2 & I470BLT \\
\hline $\begin{array}{l}\text { Nitrogen, } \\
\text { amm.+org.,diss. }\end{array}$ & $\mathrm{mg} / \mathrm{L}$ & -- & 00623 & -- & -- & -- & -- & -- & 1470DLD \\
\hline Nitrogen, total ${ }^{5}$ & $\mathrm{mg} / \mathrm{L}$ & - & 00600 & -- & -- & -- & -- & -- & -- \\
\hline Nitrogen, dissolved & $\mathrm{mg} / \mathrm{L}$ & -- & 00602 & -- & -- & -- & -- & -- & -- \\
\hline Phosphorus, total & $\mathrm{mg} / \mathrm{L}$ & $7723-14-0$ & 00665 & 0.05 & 1984 & 0.004 & 2333 & 0.005 & I520PLT \\
\hline Phosphorus, ortho, diss. & $\mathrm{mg} / \mathrm{L}$ & $14265-44-2$ & 00671 & 0.01 & 1262 & 0.002 & 1978 & 0.002 & I530CLD \\
\hline $\begin{array}{l}\text { Chlorophyll a, } \\
\text { phytoplankton }\end{array}$ & $(\mu \mathrm{g} / \mathrm{L})$ & $479-61-8$ & 70953 & 0.1 & 586 & -- & -- & -- & -- \\
\hline $\begin{array}{l}\text { Chlorophyll a, } \\
\text { phytoplankton }\end{array}$ & $(\mu \mathrm{g} / \mathrm{L})$ & $479-61-8$ & 32210 & -- & -- & -- & -- & 0.26 & I250UNF \\
\hline
\end{tabular}

1: CAS (Chemical Abstracting Services) number = unique identification for each constituent

2: Parameter Code - unique number for storage of data in database

3: Calculated as difference between total ammonia + organic nitrogen and ammonia nitrogen

4: Also known as Total Kjeldahl Nitrogen (TKN)

5: Calculated as sum of TKN + Nitrogen as (NO2+NO3) 


\section{EXPLANATION OF PHYSICAL AND CHEMICAL CHARACTERISTICS OF LAKES}

Following are brief, generalized explanations of some of the common measurements of water $q$ uality and $s$ ome of t he phy sical pr ocesses oc curring i $\mathrm{I}$ akes that i nfluence these measures of water quality. More detailed explanations of water-quality data and lake processes are given by Wetzel (1983), Hem (1985), and Shaw and others (1993).

\section{Water Temperature and Thermal Stratification}

Water temperature in lakes is important because of its role in stratification and because of the temperature dependence of many chemical reactions and life processes of aquatic organisms. The extent of thermal stratification in lakes depends on the interaction between the lake's shape, water clarity, solar heating, and wind-driven mixing. Complete mixing of the lake is usually in hibited by $\mathrm{t}$ hermal $\mathrm{s}$ tratification i $\mathrm{n} s$ ummer and by i ce c over i $\mathrm{n} w$ inter. Thermal stratification affects water quality and the distribution of organisms in the lake. Summer thermal stratification can occur in any lake, but in Wisconsin it commonly occurs in lakes deeper than about $6 \mathrm{~m}$ (Shaw and others, 1993).

The density of water increases with decreasing temperature down to a temperature of $4^{\circ} \mathrm{C}$, then decreases with decreasing temperature between $4^{\circ} \mathrm{C}$ and the freezing point of water $\left(0^{\circ} \mathrm{C}\right)$. For a brief period in the spring after the ice is out, water temperature is usually uniform through the ent ire $w$ ater c olumn and $w$ ind ac tion $c$ auses the I ake to mix completely. $T$ his process is known as "spring turnover." As the lake absorbs the sun's energy, the surface water becomes warmer and $i$ ts density decreases, making it more resistant to complete mixing. The difference in density caused by different water temperatures can prevent warm and cold water from mixing. In most lakes, therefore, a dens ity "barrier" forms bet ween the warmer surface water (epilimnion) and the underlying colder water (hypolimnion). This barrier is often marked by a s harp temperature gradient known as the "thermocline (metalimnion)." D uring the stratified summer period, these three distinct layers of lake water are often present. As the temperature difference between surface and deep w ater increases, this "stratified" condition stabilizes and can persist until surface temperatures decrease in the fall, which decreases the stability of the stratification. The mixing of the lake water in the fall is known as "fall turnover." 
Thermal s tratification may al so oc cur under ice cover in the winter. In the winter, the coldest water $\left(\right.$ near $0^{\circ} \mathrm{C}$ ) under the ice at the surface of the lake is less dense than water deeper in the lake with warmer temperatures.

\section{Specific Conductance}

Specific conductance is a measure of the ability of water to conduct an electrical current and is an indicator of the concentration of dissolved solids in the water. Because conductance is temperature related, $r$ eported $v$ alues ar e nor malized at $25^{\circ} \mathrm{C}$ and ar e termed $\mathrm{s}$ pecific conductance. A s the concentration of di ssolved $m$ inerals i ncreases, specific c onductance increases. $D$ uring $w$ inter and $s$ ummer $t$ hermal s tratification, concentrations o f di ssolved constituents near the lake bottom increase due to the decomposition of materials settling from the epilimnion, or release of dissolved materials (such as iron, manganese, and phos phorus) from $\mathrm{t}$ he bot tom sediments dur ing anox ic periods. Therefore, differences i $\mathrm{ns}$ pecific conductance with depth indicate differences in concentrations of dissolved solids.

\section{Water Clarity}

Water clarity, or transparency, is commonly measured using a Secchi disc. The range of depths within which photosynthetic activity occurs depends largely on depth of light penetration, which is influenced by water clarity. A Secchi disc, most commonly a 20-cm.-diameter disc with alternating black-and-white quadrants, is lowered to a depth at which it is no longer visible. This depth is referred to as the Secchi depth. Clarity can be reduced by algae, zooplankton, water color, and suspended sediment. Algae are often the most dominant influence on clarity in lakes and, therefore, Secchi depth is usually correlated with the algal abundance. Secchi depths are generally the least during summer when algal populations are largest.

\section{pH}

The $\mathrm{pH}$ is a measure of the acidity of the water. It is defined as the negative logarithm of hydrogen-ion concentration and $v$ aries over a 14 -unit log s cale, with a p H of 7 bei ng neutral. Values I ess than $7 \mathrm{i}$ ndicate ac idic c onditions; the I ower the value, the s tronger the ac idity. Values greater than 7 indicate alkaline conditions. The $\mathrm{pH}$ of water is influenced in part by photosynthesis and respiration of planktonic algae and aquatic plants. It is important because it affects the solubility of many chemical constituents, and because aquatic organisms have 
limited $\mathrm{pH}$ tolerances. Planktonic al gae and aq uatic $\mathrm{pl}$ ants $\mathrm{pr}$ oduce ox ygen and c onsume carbon dioxide as they photosynthesize during daytime; they consume oxygen and produce carbon dioxide when they respire at night. Carbon dioxide combines with the water molecule to form carbonic acid; therefore respiration causes a dec rease in $\mathrm{pH}$ at night and phot osynthesis during the day $\mathrm{c}$ auses an $\mathrm{i}$ ncrease $\mathrm{i} \mathrm{n} \mathrm{pH}$. The result is a dai ly c ycle i $\mathrm{n} \mathrm{pH}$. $\mathrm{B}$ ecause phytoplankton a re us ually c oncentrated i $\mathrm{n} t$ he near -surface $w$ ater, $\mathrm{c}$ hanges i $\mathrm{n} \mathrm{pH}$ i $\mathrm{n}$ the epilimnion are more extreme than in the hypolimnion, where less photosynthesis usually occurs.

Lakes having good fish populations and pr oductivity generally have a $\mathrm{pH}$ between 6.7 and 8.2. Values of $\mathrm{pH}$ greater than 8.5 have been shown to cause the release of phosphorus from lake sediments (James and Barko, 1991).

\section{Dissolved Oxygen}

Dissolved oxygen is one of the most critical factors affecting a lake ecosystem because it is essential to most aquatic organisms, and it is involved in many chemical reactions. Very low di ssolved oxygen c oncentrations can c ontrol s ome types of chemical reactions. $T$ he solubility of ox ygen i $\mathrm{n}$ w ater i s i nversely $r$ elated t o t emperature-that i s, ox ygen s olubility decreases as $\mathrm{w}$ ater temperature i ncreases. This $r$ elation i s i mportant bec ause a $\mathrm{t} w$ armer temperatures the $m$ etabolic $r$ ate of or ganisms i ncreases but I ess ox ygen i s av ailable $f$ or respiration. The primary sources of dissolved oxygen are from the air and from photosynthesis. The minimum dissolved oxygen concentration specified in national water-quality criteria for early life stages of warmwater aquatic life is 5.0 mg/L (U.S. Environmental Protection Agency, 1986).

In early summer, if thermal stratification develops, the metalimnion restricts the surface supply of dissolved oxygen to the hypolimnion. The hypolimnion can become isolated from the atmosphere. Thus, as summer progresses, the dissolved oxygen concentration can decrease in response to decomposition of dead algae that settle from the epilimnion and in response to the biological and $c$ hemical ox ygen dem and of the s ediments. The ox ygen dem and from these processes may completely deplete the oxygen (anoxia) in the water near the lake bottom. The oxygen depletion then progresses upward but usually is confined to the hypolimnion.

Anoxia i $\mathrm{n}$ t he hy polimnion i s c ommon i $\mathrm{n}$ stratified eu trophic ( nutrient-rich) la kes in Wisconsin. Complete anoxia, however, is often not detected because of meter constraints. During anox ic $c$ onditions, $m$ any aq uatic or ganisms $c$ annot $s$ urvive, but $m$ any ot her $s$ pecies 
(primarily bacteria) actually function only in such conditions. Therefore, a shift from oxic to anoxic conditions produces a rapid and dramatic change in the biological community and chemical env ironment. A noxia a Iso $c$ an $c$ ause $r$ elease o $f$ phos phorus from the bot tom sediments. This phos phorus then mixes throughout the water column during s pring and fall turnover.

\section{Phosphorus}

Phosphorus i s one of t he es sential nut rients for $\mathrm{pl}$ ant growth. $\mathrm{H}$ igh pho sphorus concentrations can cause dense algal populations (blooms) and can therefore be a major cause of eutrophication in lakes. When phosphorus concentrations exceed $0.025 \mathrm{mg} / \mathrm{L}$ at the time of spring overturn in lakes and reservoirs, these water bodies may occasionally experience excess or nuisance growth of algae or other aquatic plants (U.S. E nvironmental P rotection Agency, 1986). In many regions of the country, including the upper Midwest, other nutrients, particularly nitrogen, tend to be i $\mathrm{n}$ abundant s upply. Phosphorus is often the nut rient in shortest supply, therefore I imiting or controlling plant growth. A bout 90 per cent of the lakes in Wisconsin are limited by phosphorus (Shaw and others, 1993). In water, dissolved orthophosphate is that part of total phosphorus that is most readily available for use by algae.

Internal phosphorus recycling occurs in many lakes. Phosphorus used by algae, aquatic plants, fish, and zooplankton is stored within these organisms. As these organisms die and decompose, $\mathrm{t}$ his phos phorus i s $\mathrm{r}$ eturned to the $\mathrm{I}$ ake $\mathrm{w}$ ater and sediments. A noxia i $\mathrm{n}$ the hypolimnion makes phosphorus more soluble, adding further to the release of phosphorus from the falling particles and the lake sediments. D uring spring and fall turnover the phos phorus, which was released from the bot tom sediments into the hy polimnion during anoxia, is mixed throughout the lake. The phosphorus is then available for algal growth. These phenomena are part of the internal-recycling processes of lakes.

\section{Nitrogen}

Nitrogen, like phosphorus, is an e ssential nutrient for plant and al gal growth. Usually in Wisconsin lakes, ni trogen is in abundant supply from the a tmosphere and ot her s ources. If phosphorus is abundant relative to al gal needs, nitrogen can become the limiting nut rient. In that $\mathrm{c}$ ase, al gal bl ooms ar e $\mathrm{m}$ ore l ikely $\mathrm{t} \mathrm{o}$ be $\mathrm{t}$ riggered by i ncreases i $\mathrm{n} \mathrm{n}$ itrogen than by

increases in phosphorus. Some bluegreen algal species can fix nitrogen from the atmosphere 
(Wetzel, 1983). Therefore, in situations where other types of algae are excluded because of a shortage of nitrogen, the nitrogen-fixing bluegreen algae have a competitive advantage and may be present in abundance.

Lakes with a nitrogen to phosphorus ratio larger than 15 to 1 near the surface may generally be considered phosphorus limited; a ratio from 10 to 1 to 15 to 1 indicates a transition situation; and a ratio smaller than 10 to 1 generally indicates nitrogen limitation. Total nitrogen is the s um of a mmonia, or ganic ni trogen, and nitrate-plus-nitrite nitrogen. The nea r-surface concentration is commonly us ed to c ompute the total ni trogen to ph osphorus ratio bec ause most algal species grow near the lake surface.

\section{Chlorophyll a}

Chlorophyll $a$ is a photosynthetic pigment found in algae (Wetzel, 1983) and other green plants. Its concentration, therefore, is commonly used as a measure of the density of the algal population in a I ake. Chlorophyll a concentrations are generally highest during summer when algal populations are highest. Moderate populations of desirable algae are important in the food chain; however, excessive populations or algal blooms are undesirable. Algal blooms can cause taste and odo $\mathrm{r}$ problems, and I imit I ight pene tration needed t o s upport g rowth of s ubmerged aquatic plants. Certain s pecies of bluegreen algae can produce toxins ( Rapavich and ot hers, 1987).

\section{CLASSIFICATION OF LAKES}

Two methods are commonly used to classify and evaluate Wisconsin lakes according to their water quality or trophic state: Lillie and Mason's (1983) water-quality index and Carlson's (1977) trophic state index (TSI). In p revious USGS data reports, a modification of Carlson's trophic state index for Wisconsin lakes by Lillie and others (1993) had been used; however, this approach did not properly classify oligotrophic and highly euthrophic lakes and, therefore, was discontinued. 
Lillie and Mason's ( 1983) w ater q uality indices f or Wisconsin I akes were dev eloped based on summer measurements of total phosphorus and chlorophyll a concentrations, and Secchi depth from a random set of lakes in Wisconsin. These data were us ed to classify the lakes's water quality as shown below:

\begin{tabular}{lccc}
\hline Water-quality index & $\begin{array}{c}\text { Total phosphorus } \\
\text { range }(\mathrm{mg} / \mathrm{L})\end{array}$ & $\begin{array}{c}\text { Chlorophyll a range } \\
(\mu \mathrm{g} / \mathrm{L})\end{array}$ & $\begin{array}{c}\text { Water clarity range } \\
(\text { Secchi depth, in } \\
\text { meters })\end{array}$ \\
\hline "Excellent" & $<0.001$ & $<1.0$ & $>6.0$ \\
"Very good" & $.001-.009$ & $1.0-4.9$ & $3.0-6.0$ \\
"Good" & $.010-.029$ & $5.0-9.9$ & $2.0-2.9$ \\
"Fair" & $.030-.049$ & $10.0-14.9$ & $1.5-1.9$ \\
"Poor" & $.050-.149$ & $15.0-30.0$ & $1.0-1.4$ \\
"Very poor" & $>.150$ & $>30.0$ & $<1.0$ \\
\hline
\end{tabular}

Carlson's (1977) TSI approach to lake classification assigns numerical ranges to the three $t$ rophic conditions generally used to describe the wide range of lake water-quality conditions. Oligotrophic I akes a re typically clear, al gal popul ations and phos phorus concentrations are low, and the deepest water is likely to contain oxygen throughout the year. Mesotrophic lakes typically have a moderate supply of nutrients, experience moderate algal blooms, and have occasional oxygen depletions at depth. Eutrophic lakes are nutrient rich with relatively s evere water-quality pr oblems, s uch as frequent seasonal a lgal bl ooms, ox ygen depletion in I ower par ts of the l akes, and poo $r \mathrm{c}$ larity. When e utrophic c onditions ar e v ery severe, the lake is considered hypereutrophic.

Carlson's ( 1977) TSI v alues ar e al so bas ed on near -surface total $p$ hosphorus and chlorophyll a concentrations, and Secchi depths. The indices were developed to place these three characteristics on similar scales to al low comparison of different lakes. TSI values based on phosphorus concentrations $\left(\mathrm{TSI}_{\mathrm{P}}\right)$, Secchi depths $\left(\mathrm{TSI}_{\mathrm{SD}}\right)$, and chlorophyll a concentrations $\left(\mathrm{TSI}_{\mathrm{C}}\right)$ typically are computed only for measurements collected during the open-water period.

TSI values for a lake can be calculated using the following equations (Carlson, 1977): 
$\mathrm{TSI}_{\mathrm{P}}=4.15+14.42 \times($ In [total phosphorus concentration $\left.\times 1,000]\right)$

$\mathrm{TSI}_{\mathrm{SD}}=60.0-14.41 \times($ In Secchi depth $)$

$\mathrm{TSI}_{\mathrm{C}}=30.6+9.81 \times($ In chlorophyll a concentration $)$

where: total phosphorus is in milligrams per liter,

Secchi depth is in meters, and

chlorophyll $a$ is in micrograms per liter.

The $t$ hree $m$ ain $t$ rophic conditions ar e de fined with $t$ he $f$ ollowing boundar ies $f$ or $t$ otal phosphorus, Secchi disc, and chlorophyll a:

\begin{tabular}{|c|c|c|c|c|}
\hline Trophic level & $\begin{array}{c}\text { Trophic State } \\
\text { Index }\end{array}$ & $\begin{array}{c}\text { Total phosphorus } \\
\text { (mg/L) }\end{array}$ & Secchi depth $(\mathrm{m})$ & $\begin{array}{c}\text { Chlorophyll a } \\
(\mu \mathrm{g} / \mathrm{L})\end{array}$ \\
\hline
\end{tabular}

Eutrophic

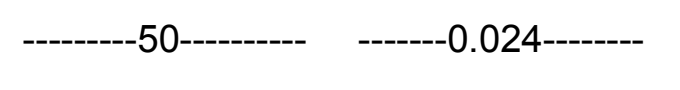

$-2.0$

$-7.2-1--\cdot--$

Mesotrophic

$--40$

$-0.012$

$-4.0$

-2.6---------

Oligotrophic 


\section{REFERENCES CITED}

Carlson, R.E., 1977, A trophic state index for lakes: Limnology and Oceanography, March, v. 22, no. 2, p. 361-369.

Fishman, M.J., ed., 1993, Methods of analysis by the U.S. Geological Survey National Water Quality Laboratory-Determination of inorganic and organic constituents in water and fluvial sediments: U.S. Geological Survey Open-File Report 93-125, 217 p.

Fishman, M.J., and Friedman, L.C., eds., 1989, Methods for determination of inorganic substances in water and fluvial sediments ( $3^{\text {rd }}$ ed.): U.S. Geological Survey Techniques of Water-Resources Investigations, book 5, chap. A1, 545 p.

Hem, J.D., 1985, Study and interpretation of the chemical characteristics of natural water ( $3^{\text {rd }}$ ed.): U.S. Geological Survey Water-Supply Paper 2254, 263 p.

James, W.F., and Barko, J.W., 1991, Littoral-pelagic phosphorus dynamics during nighttime convective circulation: Limnology and Oceanography, v. 36, no. 5, p. 946-960.

Lillie, R.A., Graham, S., and Rasmussen, P., 1993, Trophic-State Index equations and regional predictive equations for Wisconsin lakes: Wisconsin Department of Natural Resources Research Management Findings No. 35, 4 p.

Lillie, R.A., and Mason, J.W., 1983, Limnological characteristics of Wisconsin lakes: Wisconsin Department of Natural Resources Technical Bulletin No. 138, 116 p.

Rantz, S.E., and others, 1982, Measurement and computation of streamflow: U.S. Geological Survey Water-Supply Paper 2175, $631 \mathrm{p}$.

Rapavich, W.M., Sonzogni, W.C., Standridge, J.H., Vennie J.G., and Wedepohl, R.E., 1987, Incidence of algal toxins in Wisconsin water experiencing blue-green algae blooms: Wisconsin State Laboratory of Hygiene and Wisconsin Department of Natural Resources, Informational Paper, 8 p. 
Shaw, B., Mechenich, C., and Klessig, L., 1993, Understanding Lake Data: University of Wisconsin Extension, G3582: Madison, Wis., 19 p.

U.S. Environmental Protection Agency, 1986, Quality Criteria for Water 1986: U.S.

Environmental Protection Agency publication, EPA 440/5-86-001 [variously paged].

Wershaw, R.L., Fishman, M.J., Grabbe, R.R., and Lowe, L.E., eds., 1987, Methods for the determination of organic substances in water and fluvial sediments: U.S. Geological Survey Techniques of Water-Resources Investigations, book 5, chap. A3, 80 p.

Wetzel, R.G., 1983, Limnology ( $2^{\text {nd }}$ ed.): New York, W.B. Saunders, 767 p.

Wisconsin Department of Natural Resources, 1992, Wisconsin water quality assessmentReport to Congress, 1992: Wisconsin Department of Natural Resources Publ-WR25492-REV, $220 \mathrm{p}$.

Wisconsin State Laboratory of Hygiene, Environmental Sciences Section, 1993, Manual of analytical methods, inorganic chemistry unit: Wisconsin State Laboratory of Hygiene, revised November 1993 [variously paged]. 


\section{LAKE DATA}

Remarks codes and symbols used in the following tables:

[<, less than; --, not available; E, estimated] 


\section{LAKE BEULAH AT DEEP HOLE NEAR EAST TROY, WI}

LOCATION.--Lat 42 $48^{\prime} 40^{\prime \prime}$, long $88^{\circ} 24^{\prime} 16 "$ ", in SW 1/4 NW 1/4 NW 1/4 sec.17, T.4 N., R.18 E., Walworth County, Hydrologic Unit 07120006 , near East Troy. SURFACE AREA.--1.30 $\mathrm{mi}^{2}$.

PERIOD OF RECORD.--August 2007 to August 2010.

REMARKS.--Lake sampled at the deep hole at a depth of $19 \mathrm{~m}$. Water-quality analyses by Wisconsin State Laboratory of Hygiene.

WATER-QUALITY DATA, AUGUST 19, 2010

(Milligrams per liter unless otherwise indicated)

\begin{tabular}{|c|c|}
\hline Parameter Code & Parameter Name \\
\hline 32210 & Chlorophyll a $(\mu \mathrm{g} / \mathrm{L})$ \\
\hline 00078 & Secchi-depth (m) \\
\hline 00098 & Sampling depth (m) \\
\hline 00010 & Water Temperature $\left({ }^{\circ} \mathrm{C}\right)$ \\
\hline 00400 & $\mathrm{pH}$ (standard units) \\
\hline 00095 & Specific conductance $(\mu \mathrm{S} / \mathrm{cm})$ \\
\hline 00300 & Dissolved oxygen \\
\hline 00665 & Phosphorus, total (as P) \\
\hline 00671 & Orthophosphate, dissolved (as P) \\
\hline 00631 & Nitrate plus nitrite, dissolved (as $\mathrm{N}$ ) \\
\hline 00608 & Ammonia, dissolved (as N) \\
\hline 00625 & Ammonia plus organic nitrogen, total (as $\mathrm{N}$ ) \\
\hline 00600 & Total nitrogen \\
\hline 63675 & Turbidity, (NTU) \\
\hline 00900 & Hardness (as CaCO3) \\
\hline 00915 & Calcium, dissolved $(\mathrm{Ca})$ \\
\hline 00925 & Magnesium, dissolved (Mg) \\
\hline 00930 & Sodium, dissolved $(\mathrm{Na})$ \\
\hline 00935 & Potassium, dissolved (K) \\
\hline 00417 & ANC (as $\mathrm{CaCO} 3$ ) \\
\hline 00940 & Chloride, dissolved $(\mathrm{Cl})$ \\
\hline 00945 & Sulfate, dissolved (SO4) \\
\hline 00955 & Silica, dissolved (SiO2) \\
\hline 01046 & Iron $(\mu \mathrm{g} / \mathrm{L})$ \\
\hline 01056 & Manganese $(\mu \mathrm{g} / \mathrm{L})$ \\
\hline 70300 & Solids, dissolved (at $180^{\circ} \mathrm{C}$ ) \\
\hline
\end{tabular}

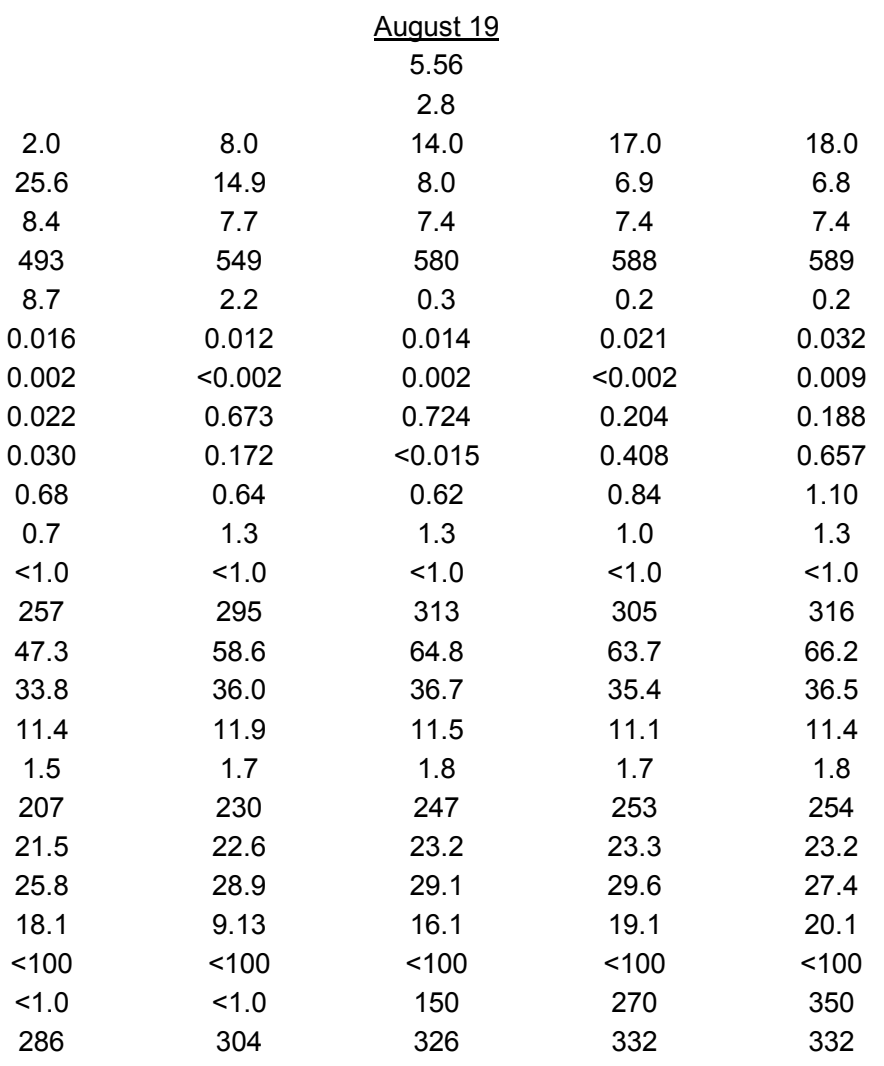


424840088241600 LAKE BEULAH AT DEEP HOLE NEAR EAST TROY, WI

LAKE-DEPTH PROFILES, AUGUST 19, 2010

08-19-10

DISSOLVED OXYGEN (D.O.), IN MILLIGRAMS PER LITER

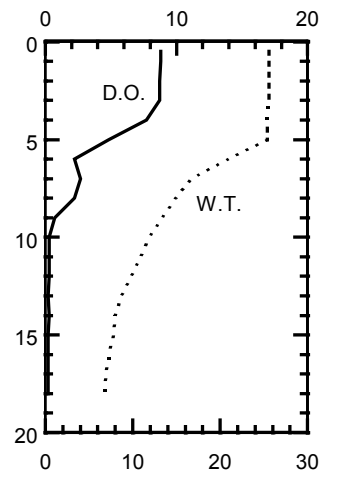

WATER TEMPERATURE (W.T.), IN DEGREES CELCIUS

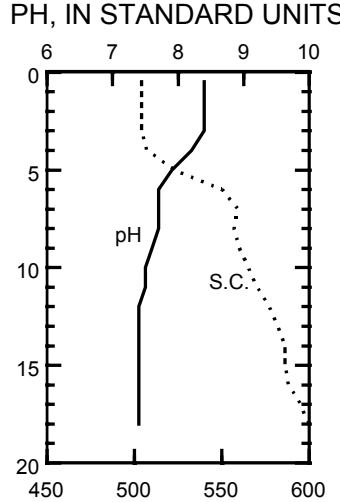

SPECIFIC CONDUCTANCE (S.C.), IN MICROSIEMENS PER CENTIMETER AT 25 DEGREES CELCIUS 
424929088231300 LAKE BEULAH STATION 2 NEAR EAST TROY, WI

LOCATION.--Lat 4249'29", long 88²3'13", in SE 1/4 NE 1/4 NE 1/4 sec.8, T.4 N., R.18 E., Walworth County, Hydrologic Unit 07120006, near East Troy. SURFACE AREA.--1.30 $\mathrm{mi}^{2}$.

PERIOD OF RECORD.--August 2007 to August 2010.

REMARKS.--Lake sampled at a depth of $15 \mathrm{~m}$. Water-quality analyses by Wisconsin State Laboratory of Hygiene.

\section{WATER-QUALITY DATA, AUGUST 19, 2010}

(Milligrams per liter unless otherwise indicated)

\begin{tabular}{c} 
Parameter Code \\
\hline 32210 \\
00078 \\
00098 \\
00010 \\
00400 \\
00095 \\
00300 \\
00665 \\
00671 \\
00631 \\
00608 \\
00625 \\
00600 \\
63675 \\
00900 \\
00915 \\
00925 \\
00930 \\
00935 \\
00417 \\
00940 \\
00945 \\
00955 \\
01046 \\
01056 \\
70300
\end{tabular}

\section{Parameter Name}

Chlorophyll a $(\mu \mathrm{g} / \mathrm{L})$

Secchi-depth $(m)$

Sampling depth $(\mathrm{m})$

Water Temperature $\left({ }^{\circ} \mathrm{C}\right)$

$\mathrm{pH}$ (standard units)

Specific conductance $(\mu \mathrm{S} / \mathrm{cm})$

Dissolved oxygen

Phosphorus, total (as P)

Orthophosphate, dissolved (as $\mathrm{P}$ )

Nitrate plus nitrite, dissolved (as $\mathrm{N}$ )

Ammonia, dissolved (as $\mathrm{N}$ )

Ammonia plus organic nitrogen, total (as $\mathrm{N}$ )

Total nitrogen

Turbidity, (NTU)

Hardness (as $\mathrm{CaCO} 3$ )

Calcium, dissolved (Ca)

Magnesium, dissolved $(\mathrm{Mg})$

Sodium, dissolved $(\mathrm{Na})$

Potassium, dissolved $(\mathrm{K})$

ANC (as $\mathrm{CaCO} 3$ )

Chloride, dissolved (Cl)

Sulfate, dissolved (SO4)

Silica, dissolved (SiO2)

Iron $(\mu \mathrm{g} / \mathrm{L})$

Manganese $(\mu \mathrm{g} / \mathrm{L})$

Solids, dissolved (at $180^{\circ} \mathrm{C}$ )

\begin{tabular}{|c|c|c|c|c|}
\hline & & $\begin{array}{c}\text { August } 1 \\
5.78 \\
2.4\end{array}$ & & \\
\hline 2.0 & 8.0 & 12.0 & 14.0 & 15.0 \\
\hline 25.7 & 15.2 & 8.3 & 6.9 & 6.6 \\
\hline 8.5 & 7.6 & 7.4 & 7.3 & 7.4 \\
\hline 463 & 496 & 560 & 578 & 587 \\
\hline 8.4 & 0.6 & 0.3 & 0.2 & 0.2 \\
\hline 0.015 & 0.016 & 0.015 & 0.032 & 0.031 \\
\hline$<.002$ & -- & -- & -- & $<.002$ \\
\hline$<.019$ & -- & -- & -- & $<.019$ \\
\hline$<.015$ & -- & -- & -- & 0.597 \\
\hline 0.50 & -- & -- & -- & 1.2 \\
\hline$<0.52$ & -- & -- & -- & $<1.2$ \\
\hline$<1.0$ & -- & -- & -- & $<1.0$ \\
\hline 220 & -- & -- & -- & 291 \\
\hline 36.0 & -- & -- & -- & 57.2 \\
\hline 31.6 & -- & -- & -- & 36.0 \\
\hline 12.6 & -- & -- & -- & 14.9 \\
\hline 1.6 & -- & -- & -- & 1.9 \\
\hline 179 & -- & -- & -- & 241 \\
\hline 25.8 & -- & -- & -- & 28.5 \\
\hline 28.4 & -- & -- & -- & 25.0 \\
\hline 14.9 & -- & -- & -- & 19.8 \\
\hline$<100$ & -- & -- & -- & $<100$ \\
\hline$<1.0$ & -- & -- & -- & 310 \\
\hline 260 & -- & -- & -- & 328 \\
\hline
\end{tabular}


424929088231300 LAKE BEULAH STATION 2 NEAR EAST TROY, WI

LAKE-DEPTH PROFILES, AUGUST 19, 2010

08-19-10

DISSOLVED OXYGEN (D.O.), IN MILLIGRAMS PER LITER

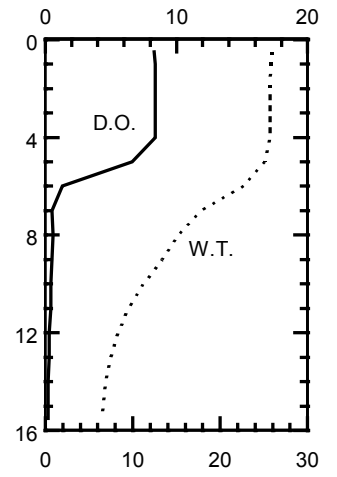

WATER TEMPERATURE (W.T.), IN DEGREES CELCIUS

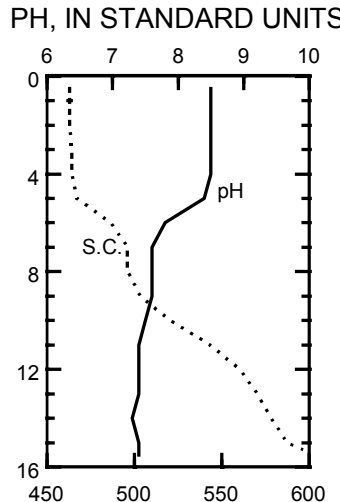

SPECIFIC CONDUCTANCE (S.C.), IN MICROSIEMENS PER CENTIMETER AT 25 DEGREES CELCIUS 


\section{BIG CEDAR LAKE, NORTH SITE, NEAR WEST BEND, WI}

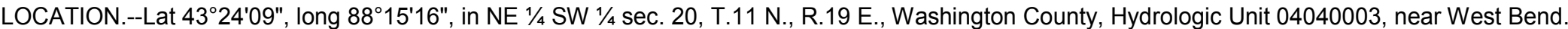

SURFACE AREA.--1.46 $\mathrm{mi}^{2}$.

PERIOD OF RECORD.--February 2000 to current year.

REMARKS.--Lake sampled on north side at a depth of $12 \mathrm{~m}$. Lake ice-covered during February sampling. Water-quality analyses by Wisconsin State Laboratory of Hygiene.

WATER-QUALITY DATA, FEBRUARY 18 TO AUGUST 24, 2010

(Milligrams per liter unless otherwise indicated)

\begin{tabular}{|c|c|}
\hline Parameter Code & $\underline{\text { Parameter Name }}$ \\
\hline 32210 & Chlorophyll a $(\mu \mathrm{g} / \mathrm{L})$ \\
\hline 00078 & Secchi-depth (m) \\
\hline 00098 & Sampling depth $(\mathrm{m})$ \\
\hline 00010 & Water Temperature $\left({ }^{\circ} \mathrm{C}\right)$ \\
\hline 00400 & $\mathrm{pH}$ (standard units) \\
\hline 00095 & Specific conductance $(\mu \mathrm{S} / \mathrm{cm})$ \\
\hline 00300 & Dissolved oxygen \\
\hline 00665 & Phosphorus, total (as P) \\
\hline
\end{tabular}

\begin{tabular}{|c|c|c|}
\hline \multicolumn{2}{|c|}{ Feb. 18} & April 5 \\
\hline & & \\
\hline & & \\
\hline 0.5 & 11.0 & 0.5 \\
\hline 2.3 & 3.5 & 11.0 \\
\hline 8.1 & 7.2 & 8.1 \\
\hline 599 & 760 & 565 \\
\hline 13.9 & 2.8 & 10.6 \\
\hline 0.026 & 0.030 & 0.008 \\
\hline
\end{tabular}

\begin{tabular}{|c|c|}
\hline \multicolumn{2}{|c|}{ June 22} \\
\hline \multicolumn{2}{|c|}{2.30} \\
\hline & \\
\hline 0.5 & 9.5 \\
\hline 24.3 & 13.0 \\
\hline 8.3 & 7.3 \\
\hline 561 & 549 \\
\hline 10.2 & 5.3 \\
\hline 0.013 & 0.024 \\
\hline
\end{tabular}

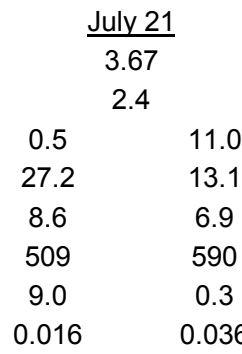

\begin{tabular}{|c|c|}
\hline \multicolumn{2}{|c|}{ August 24} \\
\hline & \\
\hline \multicolumn{2}{|c|}{2.4} \\
\hline 0.5 & 11.0 \\
\hline 25.7 & 13.5 \\
\hline 8.6 & 7.3 \\
\hline 508 & 605 \\
\hline 9.1 & 0.2 \\
\hline 0.019 & 0.058 \\
\hline
\end{tabular}


432409088151600 BIG CEDAR LAKE, NORTH SITE, NEAR WEST BEND, WI

LAKE-DEPTH PROFILES, FEBRUARY 18 TO AUGUST 24, 2010

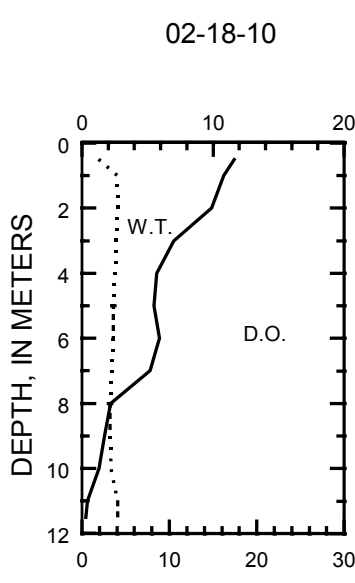

04-05-10

06-22-10

$07-21-10$

08-24-10

DISSOLVED OXYGEN (D.O.), IN MILLIGRAMS PER LITER
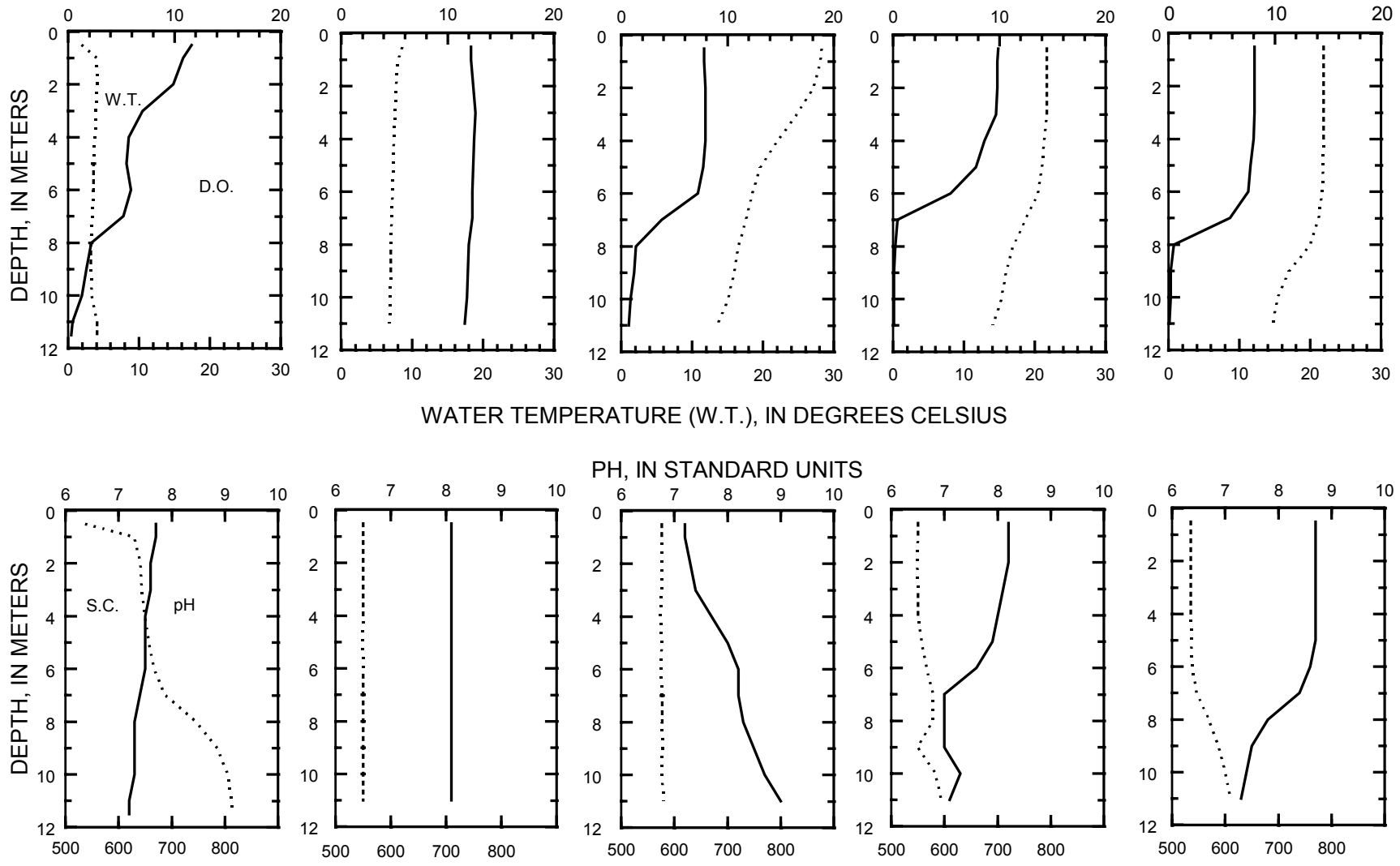

$\mathrm{PH}$, IN STANDARD UNITS
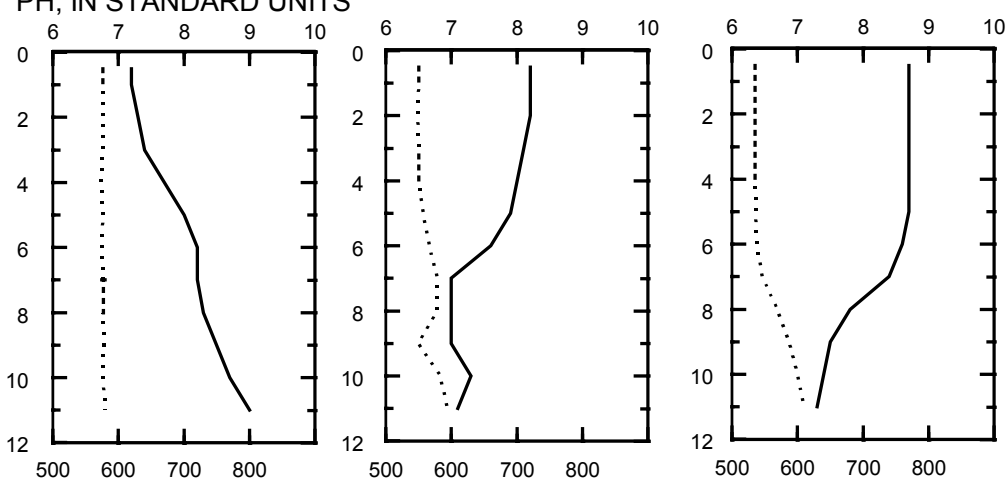

SPECIFIC CONDUCTANCE (S.C.), IN MICROSIEMENS PER CENTIMETER AT 25 DEGREES CELSIUS 

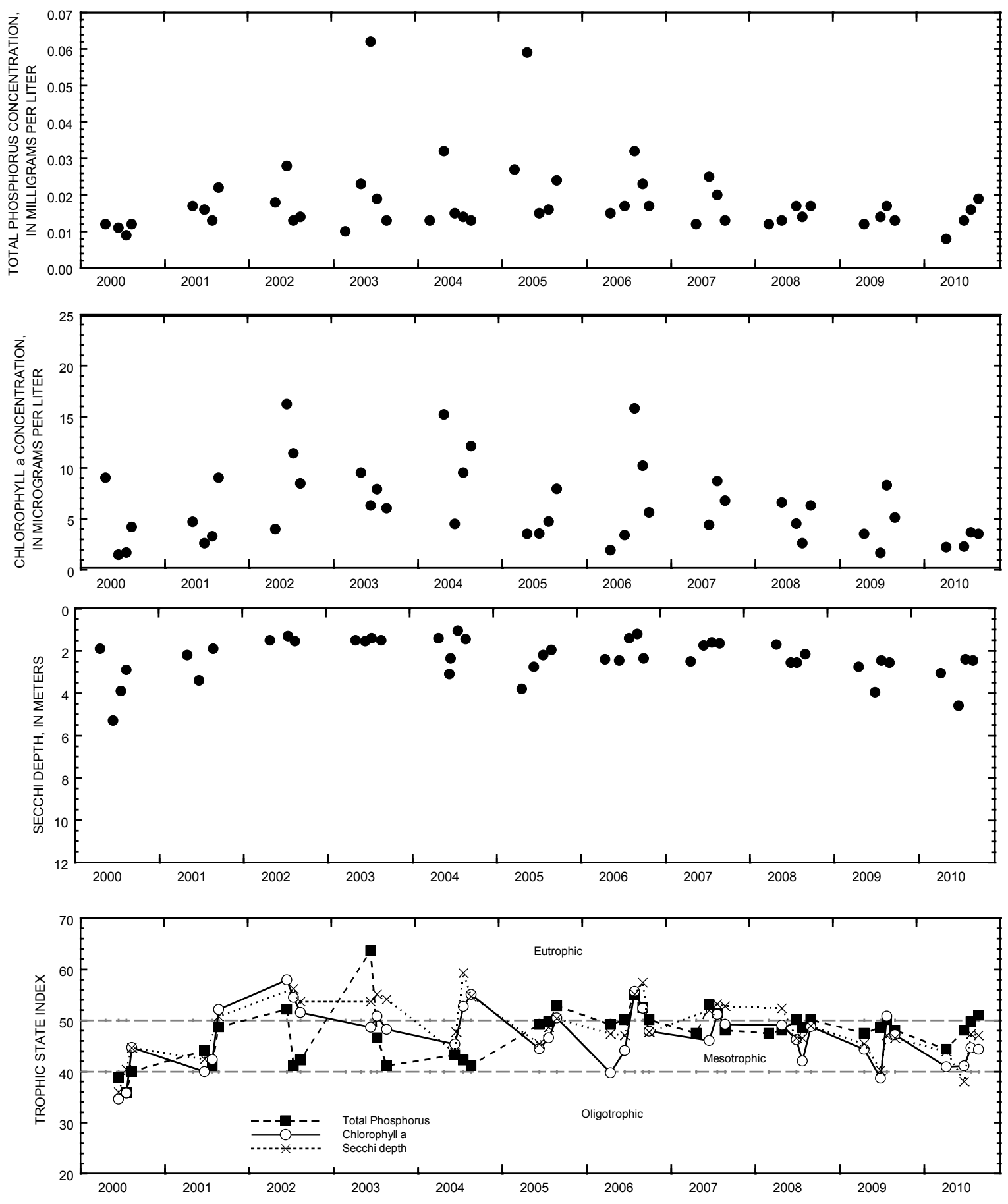

Surface total phosphorus, chlorophyll a concentrations, Secchi depths, and TSI data for Big Cedar Lake, North Site, near West Bend, Wisconsin. 
432224088154900 BIG CEDAR LAKE, SOUTH SITE, NEAR WEST BEND, WI

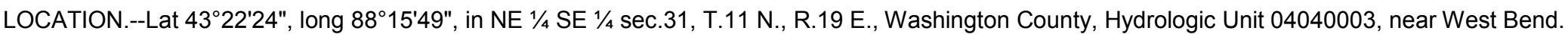

SURFACE AREA.--1.46 $\mathrm{mi}^{2}$.

PERIOD OF RECORD.--February 2000 to current year.

REMARKS.--Lake sampled on south side at deep hole. Lake ice-covered during February sampling. Water-quality analyses by Wisconsin State Laboratory of Hygiene.

WATER-QUALITY DATA, FEBRUARY 18 TO AUGUST 24, 2010

(Milligrams per liter unless otherwise indicated)

\begin{tabular}{|c|c|}
\hline Parameter Code & Parameter Name \\
\hline 32210 & $\overline{\text { Chlorophyll a }(\mu \mathrm{g} / \mathrm{L})}$ \\
\hline 00078 & Secchi-depth (m) \\
\hline 00098 & Sampling depth $(\mathrm{m})$ \\
\hline 00010 & Water Temperature $\left({ }^{\circ} \mathrm{C}\right)$ \\
\hline 00400 & $\mathrm{pH}$ (standard units) \\
\hline 00095 & Specific conductance $(\mu \mathrm{S} / \mathrm{cm})$ \\
\hline 00300 & Dissolved oxygen \\
\hline 00665 & Phosphorus, total (as P) \\
\hline 00671 & Orthophosphate, dissolved (as P) \\
\hline 00631 & Nitrate plus nitrite, dissolved (as $\mathrm{N}$ ) \\
\hline 00608 & Ammonia, dissolved (as $\mathrm{N}$ ) \\
\hline 00625 & Ammonia plus organic nitrogen, total (as $\mathrm{N}$ ) \\
\hline 00623 & Ammonia plus organic nitrogen, dissolved (as $\mathrm{N}$ ) \\
\hline 00600 & Total nitrogen \\
\hline 63675 & Turbidity, (NTU) \\
\hline 00081 & Apparent color, (PTU) \\
\hline 00900 & Hardness (as CaCO3) \\
\hline 00915 & Calcium, dissolved (Ca) \\
\hline 00925 & Magnesium, dissolved (Mg) \\
\hline 00930 & Sodium, dissolved $(\mathrm{Na})$ \\
\hline 00935 & Potassium, dissolved $(\mathrm{K})$ \\
\hline 00417 & ANC (as $\mathrm{CaCO} 3$ ) \\
\hline 00940 & Chloride, dissolved $(\mathrm{Cl})$ \\
\hline 00945 & Sulfate, dissolved (SO4) \\
\hline 00955 & Silica, dissolved (SiO2) \\
\hline 01046 & Iron $(\mu \mathrm{g} / \mathrm{L})$ \\
\hline 01056 & Manganese $(\mu \mathrm{g} / \mathrm{L})$ \\
\hline 70300 & Solids, dissolved (at $180^{\circ} \mathrm{C}$ ) \\
\hline
\end{tabular}

\begin{tabular}{|c|c|c|c|c|c|c|c|c|c|}
\hline \multicolumn{2}{|c|}{ Feb. 18} & \multicolumn{2}{|c|}{ April 5} & \multicolumn{2}{|c|}{ June 22} & \multicolumn{2}{|c|}{ July 21} & \multicolumn{2}{|c|}{ August 24} \\
\hline \multicolumn{2}{|c|}{--} & \multicolumn{2}{|c|}{1.96} & \multicolumn{2}{|c|}{3.87} & \multicolumn{2}{|c|}{4.67} & \multicolumn{2}{|c|}{3.93} \\
\hline \multicolumn{2}{|c|}{--} & \multicolumn{2}{|c|}{5.6} & \multicolumn{2}{|c|}{2.4} & \multicolumn{2}{|c|}{2.2} & \multicolumn{2}{|c|}{2.1} \\
\hline 0.5 & 30.0 & 0.5 & 30.0 & 0.5 & 29.5 & 0.5 & 32.0 & 0.5 & 30.0 \\
\hline 0.3 & 3.3 & 7.4 & 5.0 & 23.7 & 6.0 & 26.9 & 5.9 & 25.4 & 6.1 \\
\hline 8.0 & 7.3 & 8.0 & 7.8 & 8.5 & 7.4 & 8.5 & 6.8 & 8.6 & 7.4 \\
\hline 554 & 601 & 552 & 556 & 554 & 576 & 514 & 595 & 496 & 573 \\
\hline 12.4 & 4.3 & 11.0 & 10.4 & 10.6 & 1.7 & 10.2 & 0.4 & 9.5 & 0.1 \\
\hline 0.009 & 0.16 & 0.009 & -- & 0.012 & 0.008 & 0.012 & 0.019 & 0.015 & 0.081 \\
\hline-- & -- & 0.002 & -- & -- & -- & 0.003 & -- & -- & -- \\
\hline -- & -- & 0.426 & -- & -- & -- & 0.040 & -- & -- & -- \\
\hline-- & -- & $<0.015$ & -- & -- & -- & 0.019 & -- & -- & -- \\
\hline -- & -- & 0.38 & -- & -- & -- & -- & -- & -- & -- \\
\hline -- & -- & -- & -- & -- & -- & 0.44 & -- & -- & -- \\
\hline-- & -- & 0.81 & -- & -- & -- & -- & -- & -- & -- \\
\hline -- & -- & $<1.0$ & -- & -- & -- & -- & -- & -- & -- \\
\hline -- & -- & 5 & -- & -- & -- & -- & -- & -- & -- \\
\hline-- & -- & 236 & -- & -- & -- & -- & -- & -- & -- \\
\hline -- & -- & 37.6 & -- & -- & -- & -- & -- & -- & -- \\
\hline-- & -- & 34.5 & -- & -- & -- & -- & -- & -- & -- \\
\hline-- & -- & 23.1 & -- & -- & -- & -- & -- & -- & -- \\
\hline -- & -- & 1.6 & -- & -- & -- & -- & -- & -- & -- \\
\hline -- & -- & 192 & -- & -- & -- & -- & -- & -- & -- \\
\hline -- & -- & 52.3 & -- & -- & -- & -- & -- & -- & -- \\
\hline -- & -- & 22.4 & -- & -- & -- & -- & -- & -- & -- \\
\hline -- & -- & 3.14 & -- & -- & -- & -- & -- & -- & -- \\
\hline -- & -- & $<100$ & -- & -- & -- & -- & -- & -- & -- \\
\hline -- & -- & $<1.0$ & -- & -- & -- & -- & -- & -- & -- \\
\hline -- & -- & 310 & -- & -- & -- & -- & -- & -- & -- \\
\hline
\end{tabular}


432224088154900 BIG CEDAR LAKE, SOUTH SITE, NEAR WEST BEND, WI

LAKE-DEPTH PROFILES, FEBRUARY 18 TO AUGUST 24, 2010

02-18-10

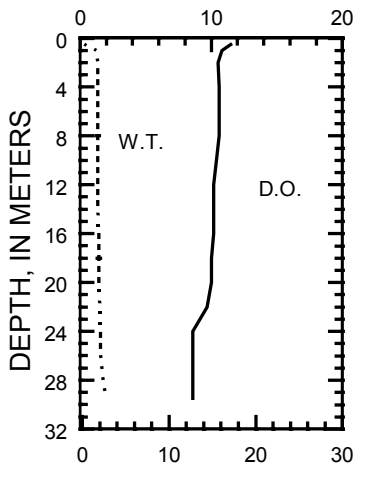

04-05-10

06-22-10

07-21-10

08-24-10

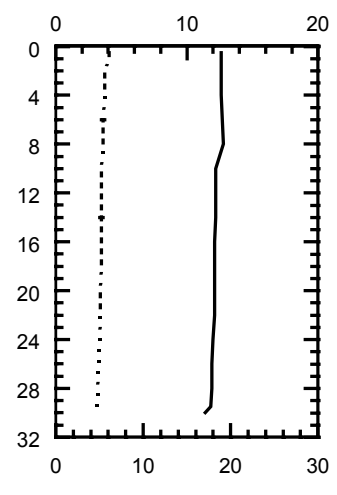

WATER TEMPERATURE (W.T.), IN DEGREES CELSIUS
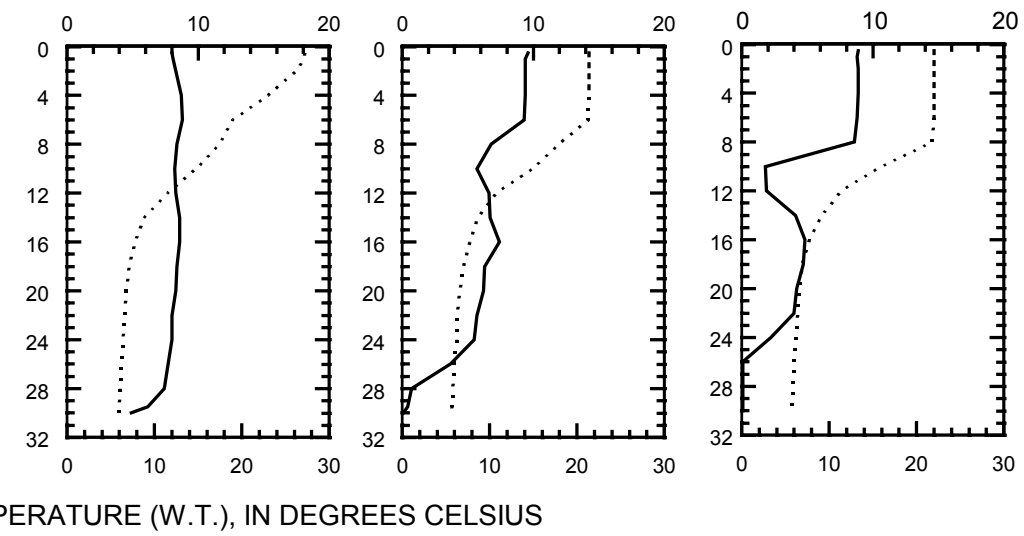
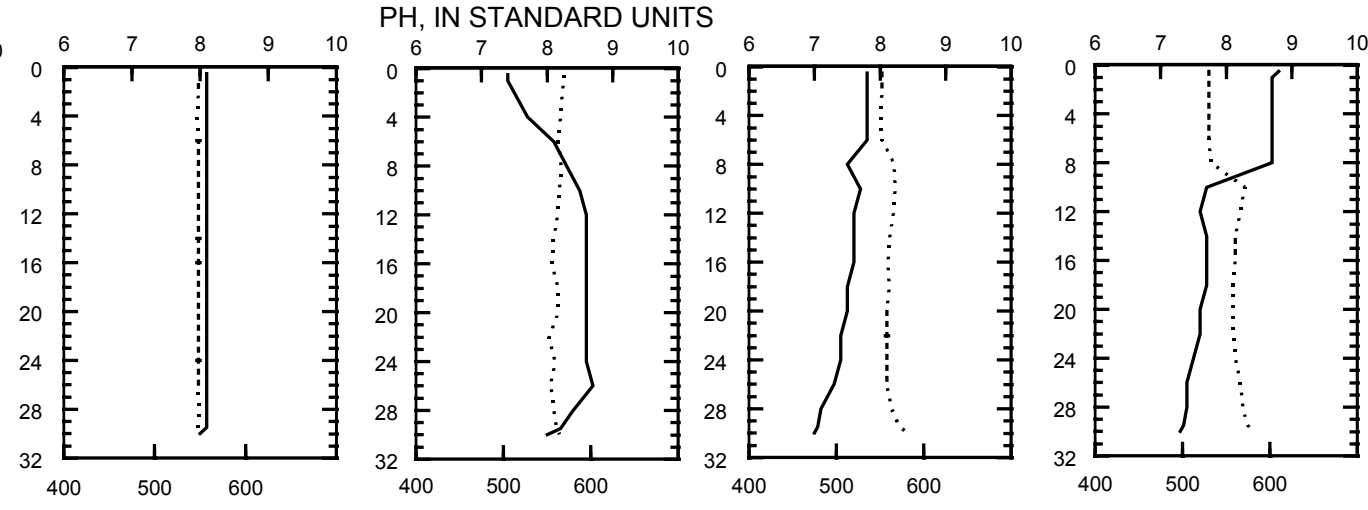

SPECIFIC CONDUCTANCE (S.C.), IN MICROSIEMENS PER CENTIMETER AT 25 DEGREES CELSIUS 

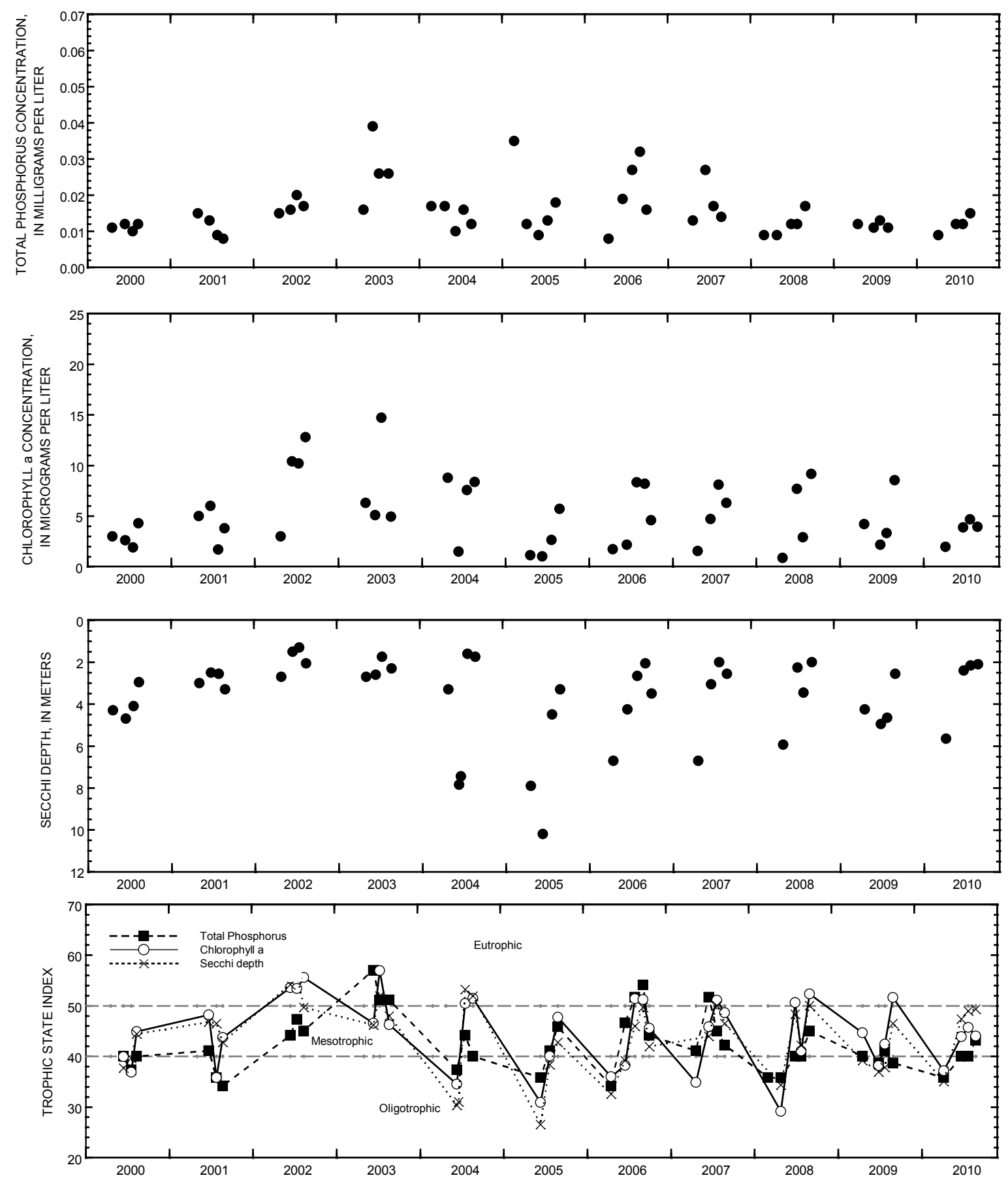

Surface total phosphorus, chlorophyll a concentrations, Secchi depths, and TSI data for Big Cedar Lake, South Site, near West Bend, Wisconsin. 


\section{DELAVAN LAKE NEAR DELAVAN, WI}

LOCATION.--Lat $42^{\circ} 36^{\prime} 27^{\prime \prime}$, long $88^{\circ} 36^{\prime} 19^{\prime \prime}$ referenced to North American Datum of 1927 , in SW $1 / 4$ NE $1 / 4$ sec.28, T.2 N., R.16 E., Walworth County, WI, Hydrologic Unit 07090001, at Delavan Lake Sanitary District Lift Station No. 2 at Delavan Lake Yacht Club, $1.0 \mathrm{mi}$ southeast of outlet, and $2.7 \mathrm{mi}$ southeast of Delavan.

SURFACE AREA.--3.24 $\mathrm{mi}^{2}$.

DRAINAGE AREA.--41.4 $\mathrm{mi}^{2}$, of which $2.30 \mathrm{mi}^{2}$ probably is noncontributing.

PERIOD OF RECORD.--October 1983 to February 2010 (discontinued). October 1983 to September 1985 data published in Water Resources Investigation series report "Water Quality and Hydrology of Delavan Lake in Southeastern Wisconsin" by Stephen J. Field and Marvin D. Duerk.

GAGE.--Water-stage recorder. Datum of gage is $922.92 \mathrm{ft}$ above NGVD of 1929 or $922.72 \mathrm{ft}$ above NAVD of 1988. Prior to Sept. 5, 1989, staff gage at bridge on North Shore Drive at same datum.

REMARKS.-Records good. Lake was ice-covered from Dec. 16-25 and Dec. 29 to Mar. 25. Lake levels controlled by Delavan Lake Sanitary District.

EXTREMES FOR PERIOD OF RECORD.--Maximum gage height observed, 6.53 ft, Aug. 27, 2007; minimum daily, $-4.44 \mathrm{ft}$, Nov. 6, 1989 (lake drawn down for lake rehabilitation program).

EXTREMES FOR CURRENT YEAR.--Maximum gage height, $5.31 \mathrm{ft}$, Dec. 26; minimum, $4.90 \mathrm{ft}$, Oct. 1 and Dec. 30. 


\begin{tabular}{|c|c|c|c|c|c|c|c|c|c|c|c|c|}
\hline \multicolumn{13}{|c|}{$\begin{array}{c}\text { GAGE HEIGHT, FEET } \\
\text { WATER YEAR OCTOBER } 2009 \text { TO SEPTEMBER } 2010 \\
\text { DAILY MEAN VALUES }\end{array}$} \\
\hline Day & Oct & Nov & Dec & Jan & Feb & Mar & Apr & May & Jun & Jul & Aug & Sep \\
\hline 1 & 4.94 & 5.11 & 5.00 & 4.95 & 4.96 & --- & --- & --- & --- & --- & --- & --- \\
\hline 2 & 5.03 & 5.07 & 4.99 & 4.96 & 4.97 & --- & --- & --- & --- & --- & --- & --- \\
\hline 3 & 5.03 & 5.03 & 4.99 & 4.96 & 4.96 & --- & --- & --- & --- & --- & --- & --- \\
\hline 4 & 5.00 & 5.01 & 4.98 & 4.95 & 4.95 & --- & --- & --- & --- & --- & --- & --- \\
\hline 5 & 4.98 & 5.03 & 4.97 & 4.96 & 4.95 & --- & --- & --- & --- & --- & --- & --- \\
\hline 6 & 4.99 & 5.04 & 4.97 & 4.97 & 4.96 & --- & --- & --- & --- & --- & --- & --- \\
\hline 7 & 4.98 & 5.04 & 4.97 & 5.00 & 4.97 & --- & --- & --- & --- & --- & --- & --- \\
\hline 8 & 4.98 & 5.04 & 4.98 & 5.00 & 4.99 & --- & --- & --- & --- & --- & --- & --- \\
\hline 9 & 5.00 & 5.05 & 5.07 & 5.01 & 5.01 & --- & --- & --- & --- & --- & --- & --- \\
\hline 10 & 5.00 & 5.04 & 5.02 & 5.00 & 5.02 & --- & --- & --- & --- & --- & --- & --- \\
\hline 11 & 4.99 & 5.03 & 4.97 & 4.99 & 5.01 & --- & --- & --- & --- & --- & --- & --- \\
\hline 12 & 4.98 & 5.02 & 4.96 & 4.98 & 4.99 & --- & --- & --- & --- & --- & --- & --- \\
\hline 13 & 4.97 & 5.01 & 4.96 & 4.98 & 4.97 & --- & --- & --- & --- & --- & --- & --- \\
\hline 14 & 4.97 & 5.00 & 4.97 & 4.97 & 4.96 & --- & --- & --- & --- & --- & --- & --- \\
\hline 15 & 4.98 & 5.01 & 4.98 & 4.96 & 4.96 & --- & --- & --- & --- & --- & --- & --- \\
\hline 16 & 5.00 & 5.00 & 4.98 & 4.96 & 4.96 & --- & --- & --- & --- & --- & --- & --- \\
\hline 17 & 5.01 & 5.00 & 4.98 & 4.96 & 4.96 & --- & --- & --- & --- & --- & --- & --- \\
\hline 18 & 5.00 & 5.02 & 4.98 & 4.95 & 4.96 & --- & --- & --- & --- & --- & --- & --- \\
\hline 19 & 5.00 & 5.04 & 4.99 & 4.96 & --- & --- & --- & --- & --- & --- & --- & --- \\
\hline 20 & 5.01 & 5.04 & 4.99 & 4.96 & --- & --- & --- & --- & --- & --- & --- & --- \\
\hline 21 & 5.01 & 5.04 & 4.99 & 4.96 & --- & --- & --- & --- & --- & --- & --- & --- \\
\hline 22 & 5.04 & 5.04 & 5.00 & 4.96 & --- & --- & --- & --- & --- & --- & --- & --- \\
\hline 23 & 5.17 & 5.05 & 5.01 & 4.95 & --- & --- & --- & --- & --- & --- & --- & --- \\
\hline 24 & 5.13 & 5.06 & 5.07 & 4.96 & --- & --- & --- & --- & --- & --- & --- & --- \\
\hline 25 & 5.05 & 5.13 & 5.17 & 5.03 & --- & --- & --- & --- & --- & --- & --- & --- \\
\hline 26 & 5.08 & 5.19 & 5.28 & 5.06 & --- & --- & --- & --- & --- & --- & --- & --- \\
\hline 27 & 5.05 & 5.21 & 5.25 & 5.01 & --- & --- & --- & --- & --- & --- & --- & --- \\
\hline 28 & 5.00 & 5.15 & 5.12 & 4.99 & --- & --- & --- & --- & --- & --- & --- & --- \\
\hline 29 & 4.99 & 5.09 & 4.99 & 4.99 & --- & --- & --- & --- & --- & --- & --- & --- \\
\hline 30 & 5.08 & 5.04 & 4.92 & 4.98 & --- & --- & --- & --- & --- & --- & --- & --- \\
\hline 31 & 5.13 & --- & 4.93 & 4.97 & --- & --- & --- & --- & --- & --- & --- & --- \\
\hline Mean & 5.02 & 5.05 & 5.01 & 4.98 & --- & --- & --- & --- & --- & --- & --- & --- \\
\hline Max & 5.17 & 5.21 & 5.28 & 5.06 & --- & --- & --- & --- & --- & --- & --- & --- \\
\hline Min & 4.94 & 5.00 & 4.92 & 4.95 & --- & --- & --- & --- & --- & --- & --- & --- \\
\hline
\end{tabular}




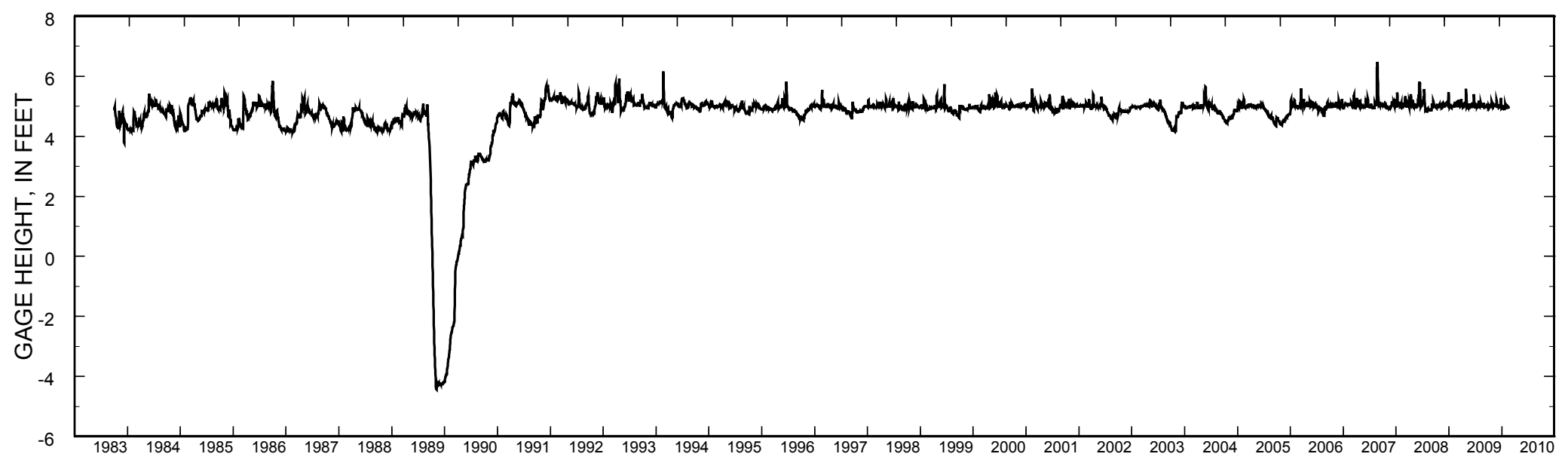

Stage hydrograph for Delavan Lake, 1983 - 2010. 
05404500 DEVILS LAKE NEAR BARABOO, WI

LOCATION.--Lat 43²5'35", long 8943'40" referenced to North American Datum of 1927, in SW 1/4 SE 1/4 sec.13, T.11 N., R.6 E., Sauk County, WI, Hydrologic Unit 07070004, in Devils Lake State Park, 3.5 mi south of Baraboo.

SURFACE AREA.--0.56 $\mathrm{mi}^{2}$.

DRAINAGE AREA.--4.79 $\mathrm{mi}^{2}$.

PERIOD OF RECORD.--June 1922 to August 1930, June to August 1932, June 1934 to September 1981 (fragmentary). October 1981 to September 1984, data unpublished in district files. October 1984 to current year.

REVISED RECORDS.--WDR WI-78-1: Drainage area.

GAGE.--Water-stage recorder installed July 17, 1991. Datum of gage is $954.88 \mathrm{ft}$, above NAVD of 1988.

REMARKS.--Lake has no surface outlet. Water removed from lake by bottom withdrawal pipe, October 1 to November2, May 13-28 and June 16 to September 30.

EXTREMES FOR PERIOD OF RECORD.--Maximum observed, 14.83 ft, June 12, 2008; minimum observed, 1.49 ft, Feb. 8, 1965.

EXTREMES FOR CURRENT YEAR.--Maximum observed, 9.78 ft, June 27; minimum observed, $6.87 \mathrm{ft}$, Nov. 17, 20 and Dec. 6.

\begin{tabular}{|c|c|c|c|c|c|c|c|c|c|c|c|c|}
\hline & & & WATE & YEAR & $\begin{array}{l}\text { AGE H } \\
\text { TOBE } \\
\text { ILY M }\end{array}$ & $\begin{array}{l}\mathrm{HT}, \mathrm{F} \\
009 \mathrm{TC} \\
\text { N VAL }\end{array}$ & $\begin{array}{l}\text { EPTEN } \\
\text { E } \\
\end{array}$ & R 201 & & & & \\
\hline Day & Oct & Nov & Dec & Jan & Feb & Mar & Apr & May & Jun & Jul & Aug & Sep \\
\hline 1 & 7.34 & 7.09 & 6.94 & 7.21 & 7.29 & 7.27 & 7.93 & 9.03 & 8.93 & 9.58 & 9.37 & 9.58 \\
\hline 2 & 7.38 & 7.06 & 6.93 & 7.21 & 7.30 & 7.26 & 7.93 & 9.06 & 8.91 & 9.53 & 9.33 & 9.62 \\
\hline 3 & 7.36 & 7.05 & 6.91 & 7.20 & 7.30 & 7.26 & 7.94 & 9.07 & 8.90 & 9.47 & 9.28 & 9.61 \\
\hline 4 & 7.34 & 7.04 & 6.91 & 7.20 & 7.30 & 7.25 & 7.94 & 9.07 & 8.90 & 9.42 & 9.24 & 9.57 \\
\hline 5 & 7.32 & 7.03 & 6.90 & 7.20 & 7.30 & 7.24 & 7.92 & 9.08 & 8.90 & 9.39 & 9.19 & 9.54 \\
\hline 6 & 7.32 & 7.03 & 6.89 & 7.19 & 7.30 & 7.24 & 8.03 & 9.07 & 8.92 & 9.37 & 9.14 & 9.51 \\
\hline 7 & 7.31 & 7.02 & 6.89 & 7.22 & 7.29 & 7.23 & 8.36 & 9.08 & 8.90 & 9.34 & 9.09 & 9.46 \\
\hline 8 & 7.28 & 7.02 & 6.89 & 7.24 & 7.30 & 7.23 & 8.52 & 9.10 & 8.94 & 9.34 & 9.17 & 9.40 \\
\hline 9 & 7.25 & 7.01 & 6.98 & 7.24 & 7.33 & 7.23 & 8.58 & 9.10 & 8.95 & 9.30 & 9.34 & 9.36 \\
\hline 10 & 7.22 & 7.00 & 6.99 & 7.24 & 7.34 & 7.30 & 8.62 & 9.10 & 8.93 & 9.25 & 9.36 & 9.33 \\
\hline 11 & 7.19 & 7.00 & 6.98 & 7.23 & 7.34 & 7.42 & 8.64 & 9.13 & 8.97 & 9.20 & 9.33 & 9.29 \\
\hline 12 & 7.17 & 6.99 & 6.97 & 7.23 & 7.33 & 7.57 & 8.65 & 9.16 & 8.97 & 9.15 & 9.30 & 9.25 \\
\hline 13 & 7.14 & 6.98 & 6.97 & 7.22 & 7.33 & 7.71 & 8.66 & 9.36 & 8.95 & 9.11 & 9.40 & 9.20 \\
\hline 14 & 7.12 & 6.95 & 6.97 & 7.22 & 7.32 & 7.81 & 8.67 & 9.41 & 8.95 & 9.07 & 9.57 & 9.16 \\
\hline 15 & 7.11 & 6.94 & 6.97 & 7.22 & 7.32 & 7.87 & 8.68 & 9.41 & 9.23 & 9.34 & 9.56 & 9.12 \\
\hline 16 & 7.09 & 6.93 & 6.97 & 7.21 & 7.32 & 7.91 & 8.68 & 9.40 & 9.67 & 9.32 & 9.52 & 9.07 \\
\hline 17 & 7.07 & 6.92 & --- & 7.21 & 7.31 & 7.93 & 8.68 & 9.38 & 9.69 & 9.28 & 9.48 & 9.03 \\
\hline 18 & 7.05 & 6.92 & --- & 7.21 & 7.31 & 7.95 & 8.67 & 9.36 & 9.72 & 9.25 & 9.44 & 8.99 \\
\hline 19 & 7.02 & 6.92 & --- & 7.20 & 7.30 & 7.97 & 8.66 & 9.33 & 9.69 & 9.21 & 9.40 & 8.95 \\
\hline 20 & 7.00 & 6.93 & --- & 7.20 & 7.30 & 7.98 & 8.66 & 9.30 & 9.66 & 9.18 & 9.41 & 8.91 \\
\hline 21 & 6.99 & 6.92 & --- & 7.19 & 7.30 & 7.99 & 8.65 & 9.28 & 9.63 & 9.13 & 9.56 & 8.88 \\
\hline 22 & 7.01 & 6.92 & --- & 7.19 & 7.30 & 7.99 & 8.64 & 9.26 & 9.62 & 9.23 & 9.54 & 8.84 \\
\hline 23 & 7.07 & 6.91 & --- & 7.19 & 7.30 & 7.99 & 8.63 & 9.23 & 9.70 & 9.43 & 9.52 & 8.83 \\
\hline 24 & 7.08 & 6.91 & --- & 7.25 & 7.30 & 7.98 & 8.66 & 9.20 & 9.71 & 9.53 & 9.48 & 8.86 \\
\hline 25 & 7.07 & 6.94 & --- & 7.29 & 7.30 & 7.98 & 8.72 & 9.17 & 9.68 & 9.56 & 9.43 & 8.81 \\
\hline 26 & 7.05 & 6.97 & --- & 7.29 & 7.29 & 7.97 & 8.74 & 9.12 & 9.71 & 9.53 & 9.38 & 8.76 \\
\hline 27 & 7.04 & 6.97 & --- & 7.30 & 7.28 & 7.96 & 8.74 & 9.08 & 9.74 & 9.50 & 9.33 & 8.72 \\
\hline 28 & 7.02 & 6.96 & --- & 7.30 & 7.28 & 7.95 & 8.73 & 9.03 & 9.72 & 9.52 & 9.28 & 8.68 \\
\hline 29 & 7.02 & 6.95 & 7.21 & 7.30 & --- & 7.95 & 8.73 & 9.01 & 9.68 & 9.50 & 9.23 & 8.65 \\
\hline 30 & 7.12 & 6.95 & 7.20 & 7.30 & --- & 7.95 & 8.79 & 8.99 & 9.63 & 9.46 & 9.19 & 8.61 \\
\hline 31 & 7.10 & --- & 7.21 & 7.29 & --- & 7.93 & --- & 8.95 & --- & 9.41 & 9.20 & --- \\
\hline Mean & 7.15 & 6.97 & --- & 7.23 & 7.31 & 7.69 & 8.52 & 9.17 & 9.32 & 9.35 & 9.36 & 9.12 \\
\hline Max & 7.38 & 7.09 & --- & 7.30 & 7.34 & 7.99 & 8.79 & 9.41 & 9.74 & 9.58 & 9.57 & 9.62 \\
\hline Min & 6.99 & 6.91 & --- & 7.19 & 7.28 & 7.23 & 7.92 & 8.95 & 8.90 & 9.07 & 9.09 & 8.61 \\
\hline
\end{tabular}




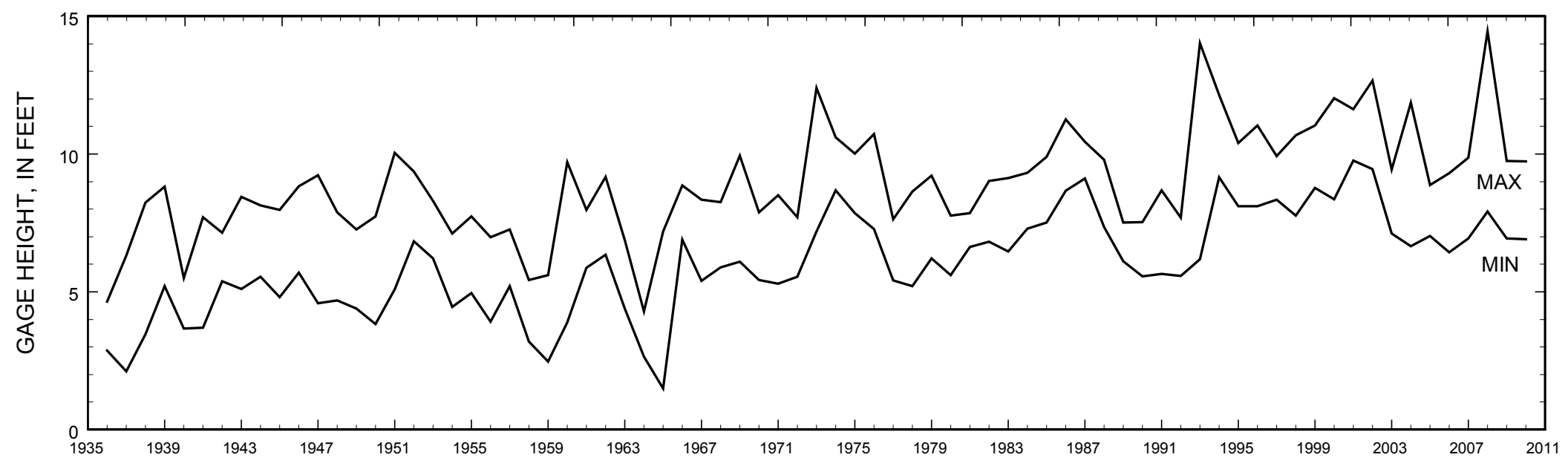

Annual minimum and maximum water levels for Devils Lake, 1936-2010. 


\section{GENEVA LAKE AT LAKE GENEVA, WI}

LOCATION.--Lat $42^{\circ} 35^{\prime 2} 25^{\prime \prime}$, long $88^{\circ} 26^{\prime} 04^{\prime \prime}$ referenced to North American Datum of 1927, in SE 1/4 NW 1/4 sec.36, T.2 N., R.17 E.,

Walworth County, WI, Hydrologic Unit 07120006, at Geneva Lake dam at Center Street at Lake Geneva.

SURFACE AREA.--8.22 $\mathrm{mi}^{2}$.

DRAINAGE AREA.--28.7 $\mathrm{mi}^{2}$.

PERIOD OF RECORD.--October 1997 to August 2002, December 2002 to current year.

GAGE.--Water-stage recorder. Datum of gage is $861.86 \mathrm{ft}$ above NAVD of 1988 or $862.08 \mathrm{ft}$ above NGVD of 1929. Intermittent staffgage readings during winter months.

REMARKS.--Records good except for estimated days, which are poor. Gage-height telemeter at station.

EXTREMES FOR PERIOD OF RECORD.--Maximum gage height, 3.35 ft, Aug. 20, 2007; minimum gage height, 1.44 ft, Nov. 5, 2005 (affected by wind).

EXTREMES FOR CURRENT YEAR.--Maximum gage height observed, $3.07 \mathrm{ft}$ (affected by wind), June 18; minimum gage height, 2.19 $\mathrm{ft}$ (affected by wind), Apr. 6.

\begin{tabular}{|c|c|c|c|c|c|c|c|c|c|c|c|c|}
\hline \multicolumn{13}{|c|}{$\begin{array}{c}\text { GAGE HEIGHT, FEET } \\
\text { WATER YEAR OCTOBER 2009 TO SEPTEMBER } 2010 \\
\text { DAILY MEAN VALUES }\end{array}$} \\
\hline \multicolumn{13}{|c|}{ [e, estimated] } \\
\hline Day & Oct & Nov & Dec & Jan & Feb & Mar & Apr & May & Jun & Jul & Aug & Sep \\
\hline 1 & 2.41 & 2.68 & 2.63 & 2.62 & 2.40 & 2.42 & 2.46 & 2.62 & 2.69 & 2.64 & 2.69 & 2.39 \\
\hline 2 & 2.50 & 2.67 & 2.61 & 2.62 & 2.40 & 2.41 & 2.47 & 2.61 & \begin{tabular}{|l|}
2.72 \\
\end{tabular} & 2.62 & 2.67 & 2.40 \\
\hline 3 & 2.49 & 2.65 & 2.60 & 2.62 & 2.41 & 2.41 & 2.48 & 2.62 & \begin{tabular}{|l}
2.71 \\
\end{tabular} & 2.60 & 2.65 & 2.46 \\
\hline 4 & 2.49 & 2.64 & 2.60 & 2.62 & 2.40 & 2.40 & 2.48 & 2.61 & \begin{tabular}{|l|}
2.70 \\
\end{tabular} & 2.59 & 2.64 & 2.40 \\
\hline 5 & 2.47 & 2.63 & 2.57 & 2.62 & 2.40 & e2.41 & 2.47 & 2.60 & \begin{tabular}{|l|}
2.68 \\
\end{tabular} & 2.57 & 2.63 & 2.37 \\
\hline 6 & 2.49 & 2.61 & 2.56 & 2.62 & 2.44 & e2.40 & 2.60 & 2.57 & 2.73 & 2.56 & 2.59 & 2.36 \\
\hline 7 & 2.47 & 2.61 & 2.55 & 2.62 & e2.43 & 2.39 & 2.64 & 2.58 & \begin{tabular}{|l|}
2.70 \\
\end{tabular} & 2.55 & 2.57 & 2.37 \\
\hline 8 & 2.46 & 2.60 & 2.54 & 2.62 & e2.43 & 2.39 & 2.68 & 2.60 & \begin{tabular}{|l|}
2.70 \\
\end{tabular} & 2.57 & 2.57 & 2.30 \\
\hline 9 & 2.46 & \begin{tabular}{|l|}
2.59 \\
\end{tabular} & 2.64 & 2.62 & 2.44 & 2.39 & 2.67 & 2.58 & \begin{tabular}{|l|}
2.73 \\
\end{tabular} & 2.55 & 2.59 & 2.28 \\
\hline 10 & 2.46 & 2.58 & 2.64 & 2.62 & 2.46 & 2.41 & 2.66 & 2.56 & \begin{tabular}{|l|}
2.69 \\
\end{tabular} & 2.54 & 2.58 & 2.26 \\
\hline 11 & 2.44 & 2.58 & e2.60 & 2.62 & 2.43 & 2.46 & 2.65 & 2.61 & 2.68 & 2.53 & 2.57 & 2.29 \\
\hline 12 & 2.43 & 2.57 & 2.64 & 2.62 & 2.42 & 2.50 & 2.63 & 2.64 & \begin{tabular}{|l|}
2.67 \\
\end{tabular} & 2.52 & 2.56 & 2.30 \\
\hline 13 & 2.42 & 2.57 & 2.62 & e2.46 & 2.41 & 2.54 & 2.62 & 2.75 & \begin{tabular}{|l|}
2.66 \\
\end{tabular} & 2.50 & 2.56 & 2.29 \\
\hline 14 & 2.40 & 2.56 & 2.58 & 2.61 & 2.40 & 2.57 & 2.63 & 2.77 & \begin{tabular}{|l|}
2.66 \\
\end{tabular} & 2.50 & 2.61 & 2.28 \\
\hline 15 & 2.42 & 2.55 & 2.58 & 2.56 & 2.38 & 2.57 & 2.63 & 2.75 & \begin{tabular}{|l|}
2.67 \\
\end{tabular} & 2.48 & 2.59 & 2.27 \\
\hline 16 & 2.43 & 2.53 & 2.58 & 2.56 & 2.38 & 2.56 & 2.62 & 2.72 & 2.69 & 2.48 & 2.55 & 2.38 \\
\hline 17 & 2.43 & 2.51 & 2.58 & 2.55 & 2.38 & 2.56 & 2.60 & 2.71 & \begin{tabular}{|l|}
2.67 \\
\end{tabular} & 2.45 & 2.51 & 2.41 \\
\hline 18 & 2.43 & 2.54 & 2.58 & 2.51 & 2.40 & 2.55 & 2.59 & 2.70 & \begin{tabular}{|l}
2.72 \\
\end{tabular} & 2.45 & 2.49 & 2.42 \\
\hline 19 & 2.43 & 2.55 & 2.58 & 2.46 & 2.41 & 2.55 & 2.58 & 2.68 & \begin{tabular}{|l|}
2.80 \\
\end{tabular} & 2.43 & 2.47 & 2.41 \\
\hline 20 & 2.42 & 2.56 & 2.58 & 2.45 & 2.43 & 2.55 & 2.58 & 2.67 & \begin{tabular}{|l}
2.76 \\
\end{tabular} & 2.42 & 2.48 & 2.40 \\
\hline 21 & 2.43 & 2.55 & 2.58 & 2.43 & 2.43 & 2.55 & 2.57 & 2.68 & 2.75 & 2.41 & 2.48 & 2.43 \\
\hline 22 & 2.46 & 2.54 & 2.52 & 2.43 & 2.44 & 2.53 & 2.56 & 2.72 & \begin{tabular}{|l|}
2.76 \\
\end{tabular} & 2.45 & 2.47 & 2.42 \\
\hline 23 & 2.57 & 2.54 & 2.49 & 2.42 & 2.44 & 2.52 & 2.55 & 2.71 & \begin{tabular}{|l|}
2.79 \\
\end{tabular} & 2.61 & 2.45 & 2.44 \\
\hline 24 & 2.59 & 2.54 & 2.54 & 2.45 & 2.44 & 2.51 & 2.56 & 2.70 & \begin{tabular}{|l|}
2.77 \\
\end{tabular} & 2.70 & 2.45 & 2.46 \\
\hline 25 & 2.57 & 2.61 & 2.65 & 2.47 & e2.43 & 2.50 & 2.60 & 2.71 & \begin{tabular}{|l|}
2.75 \\
\end{tabular} & 2.68 & 2.43 & 2.39 \\
\hline 26 & 2.61 & 2.68 & 2.68 & 2.47 & e2.41 & 2.49 & 2.60 & 2.75 & 2.75 & 2.67 & 2.41 & 2.37 \\
\hline 27 & 2.62 & 2.67 & 2.69 & 2.49 & e2.40 & 2.48 & 2.59 & 2.74 & \begin{tabular}{|l|}
2.74 \\
\end{tabular} & 2.65 & 2.40 & 2.37 \\
\hline 28 & 2.61 & 2.65 & 2.68 & 2.48 & 2.42 & 2.47 & 2.59 & 2.73 & \begin{tabular}{|l}
2.72 \\
\end{tabular} & 2.63 & 2.39 & 2.37 \\
\hline 29 & 2.61 & 2.65 & 2.66 & 2.48 & --- & 2.47 & 2.59 & 2.72 & \begin{tabular}{|l|}
2.68 \\
\end{tabular} & 2.60 & 2.38 & 2.37 \\
\hline 30 & 2.72 & 2.65 & 2.66 & 2.45 & --- & 2.46 & 2.60 & 2.71 & \begin{tabular}{|l|}
2.66 \\
\end{tabular} & 2.58 & 2.38 & 2.36 \\
\hline 31 & 2.72 & --- & 2.63 & 2.41 & --- & 2.46 & --- & 2.70 & --- & 2.69 & 2.37 & --- \\
\hline Mean & 2.50 & 2.60 & 2.60 & 2.53 & 2.42 & 2.48 & 2.58 & 2.67 & 2.71 & 2.56 & 2.52 & 2.37 \\
\hline Max & 2.72 & 2.68 & 2.69 & 2.62 & 2.46 & 2.57 & 2.68 & 2.77 & \begin{tabular}{|l|}
2.80 \\
\end{tabular} & 2.70 & 2.69 & 2.46 \\
\hline Min & 2.40 & 2.51 & 2.49 & 2.41 & 2.38 & 2.39 & 2.46 & 2.56 & \begin{tabular}{|l|}
2.66 \\
\end{tabular} & 2.41 & 2.37 & 2.26 \\
\hline
\end{tabular}




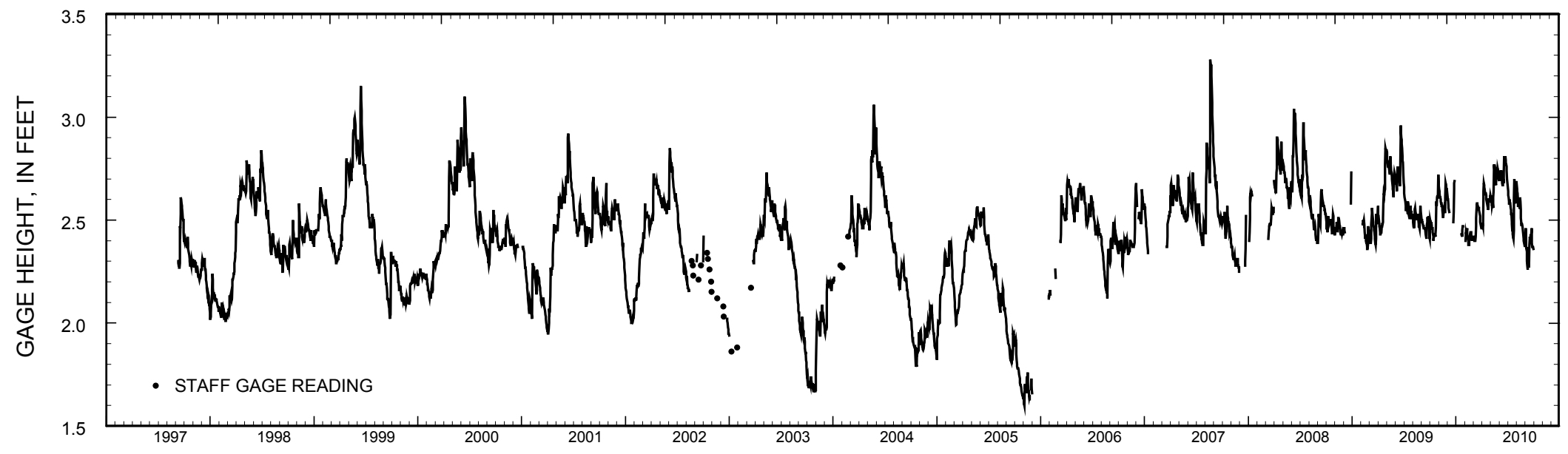

Stage hydrograph for Geneva Lake, 1997-2010. 


\section{GENEVA LAKE AT WEST END NEAR WILLIAMS BAY, WI}

LOCATION.--Lat $42^{\circ} 33^{\prime} 29^{\prime \prime}$, long $88^{\circ} 32^{\prime} 33^{\prime \prime}$, in NE $1 / 4$ SE $1 / 4$ sec.12, T.1 N., R.16 E., Walworth County, Hydrologic Unit 07120006 , 1.3 mi south of Williams Bay.

SURFACE AREA.--8.22 $\mathrm{mi}^{2}$.

DRAINAGE AREA.--28.7 $\mathrm{mi}^{2}$.

PERIOD OF RECORD.--April 1997 to current year.

REMARKS.--Lake sampled at deep hole at a depth of about $43 \mathrm{~m}$. Lake ice-covered during February sampling. Water-quality analyses done by Wisconsin State Laboratory of Hygiene. Samples for determination of chlorophyll a concentration are collected from the top $0.5 \mathrm{~m}$ of the lake.

\section{WATER-QUALITY DATA, NOVEMBER 3, 2009 TO JUNE 10, 2010} (Milligrams per liter unless otherwise indicated)

\begin{tabular}{|c|c|}
\hline Parameter Code & Parameter Name \\
\hline 32210 & Chlorophyll a $(\mu \mathrm{g} / \mathrm{L})$ \\
\hline 00078 & Secchi-depth (m) \\
\hline 00098 & Sampling depth (m) \\
\hline 00010 & Water Temperature $\left({ }^{\circ} \mathrm{C}\right)$ \\
\hline 00400 & $\mathrm{pH}$ (standard units) \\
\hline 00095 & Specific conductance $(\mu \mathrm{S} / \mathrm{cm})$ \\
\hline 00300 & Dissolved oxygen \\
\hline 00665 & Phosphorus, Total (as P) \\
\hline 00671 & Orthophosphate, dissolved (as P) \\
\hline 00631 & Nitrate + nitrite, dissolved (as N) \\
\hline 00608 & Ammonia, dissolved (as $\mathrm{N}$ ) \\
\hline 00625 & Ammonia + organic nitrogen, total (as $\mathrm{N}$ ) \\
\hline 00600 & Total nitrogen \\
\hline 63675 & Turbidity, (NTU) \\
\hline 00081 & Apparent color, (PTU) \\
\hline 00900 & Hardness (as $\mathrm{CaCO} 3$ ) \\
\hline 00915 & Calcium, dissolved $(\mathrm{Ca})$ \\
\hline 00925 & Magnesium, dissolved (Mg) \\
\hline 00930 & Sodium, dissolved $(\mathrm{Na})$ \\
\hline 00935 & Potassium, dissolved $(\mathrm{K})$ \\
\hline 00417 & ANC (as $\mathrm{CaCO} 3)$ \\
\hline 00940 & Chloride, dissolved $(\mathrm{Cl})$ \\
\hline 00945 & Sulfate, dissolved (SO4) \\
\hline 00955 & Silica, dissolved (SiO2) \\
\hline 01046 & Iron $(\mu \mathrm{g} / \mathrm{L})$ \\
\hline 01056 & Manganese $(\mu \mathrm{g} / \mathrm{L})$ \\
\hline 70300 & Solids, dissolved (at $180^{\circ} \mathrm{C}$ ) \\
\hline
\end{tabular}

\begin{tabular}{|c|c|c|c|c|c|c|c|c|c|c|c|}
\hline \multicolumn{4}{|c|}{ November 3} & \multicolumn{2}{|c|}{ April 20} & \multicolumn{6}{|c|}{ June 10} \\
\hline \multicolumn{4}{|c|}{3.14} & \multicolumn{2}{|c|}{0.75} & \multicolumn{6}{|c|}{1.36} \\
\hline \multicolumn{4}{|c|}{6.8} & \multicolumn{2}{|c|}{8.9} & \multicolumn{6}{|c|}{3.7} \\
\hline 0.5 & 28.0 & 35.0 & 42.5 & 0.5 & 42.0 & 0.5 & 7.0 & 13.0 & 33.0 & 38.0 & 42.0 \\
\hline 11.0 & 10.6 & 8.1 & 7.6 & 9.2 & 5.5 & 19.9 & 17.6 & 11.7 & 8.0 & 7.6 & 7.6 \\
\hline 7.9 & 7.7 & 7.2 & 7.0 & 8.4 & 8.3 & 8.0 & 8.1 & 8.0 & 7.9 & 7.9 & 7.9 \\
\hline 526 & 529 & 531 & 532 & 528 & 533 & 526 & 525 & 528 & 535 & 536 & 536 \\
\hline 9.9 & 7.5 & 1.8 & 0.3 & 13.0 & 13.0 & 10.8 & 11.0 & 11.6 & 9.6 & 9.2 & 9.2 \\
\hline 0.012 & 0.012 & 0.028 & 0.045 & 0.007 & -- & 0.010 & 0.013 & 0.010 & 0.008 & 0.009 & 0.009 \\
\hline$<.002$ & -- & -- & -- & $<.002$ & -- & -- & -- & -- & -- & -- & -- \\
\hline 0.086 & -- & -- & -- & 0.121 & -- & -- & -- & -- & -- & -- & -- \\
\hline 0.020 & -- & -- & -- & 0.016 & -- & -- & -- & -- & -- & -- & -- \\
\hline 0.41 & -- & -- & -- & 0.42 & -- & -- & -- & -- & -- & -- & -- \\
\hline 0.50 & -- & -- & -- & 0.54 & -- & -- & -- & -- & -- & -- & -- \\
\hline -- & -- & -- & -- & $<1.0$ & -- & -- & -- & -- & -- & -- & -- \\
\hline-- & -- & -- & -- & 5 & -- & -- & -- & -- & -- & -- & -- \\
\hline-- & -- & -- & -- & 232 & -- & -- & -- & -- & -- & -- & -- \\
\hline-- & -- & -- & -- & 36.4 & -- & -- & -- & -- & -- & -- & -- \\
\hline -- & -- & -- & -- & 34.3 & -- & -- & -- & -- & -- & -- & -- \\
\hline-- & -- & -- & -- & 20.8 & -- & -- & -- & -- & -- & -- & -- \\
\hline-- & -- & -- & -- & 1.7 & -- & -- & -- & -- & -- & -- & -- \\
\hline-- & -- & -- & -- & 187 & -- & -- & -- & -- & -- & -- & -- \\
\hline-- & -- & -- & -- & 42.5 & -- & -- & -- & -- & -- & -- & -- \\
\hline-- & -- & -- & -- & 30.3 & -- & -- & -- & -- & -- & -- & -- \\
\hline-- & -- & -- & -- & 2.44 & -- & -- & -- & -- & -- & -- & -- \\
\hline-- & -- & -- & -- & $<100$ & -- & -- & -- & -- & -- & -- & -- \\
\hline-- & -- & -- & -- & $<1.0$ & -- & -- & -- & -- & -- & -- & -- \\
\hline-- & -- & -- & -- & 286 & -- & -- & -- & -- & -- & -- & -- \\
\hline
\end{tabular}




\section{GENEVA LAKE AT WEST END NEAR WILLIAMS BAY, WI}

WATER-QUALITY DATA, JULY 29 TO SEPTEMBER 17, 2010

(Milligrams per liter unless otherwise indicated)

\begin{tabular}{clcc} 
Parameter Code & Parameter Name & \multicolumn{2}{c}{ July 29} \\
\cline { 3 - 4 } 32210 & & Chlorophyll a $(\mu \mathrm{g} / \mathrm{L})$ & \multicolumn{2}{c}{1.78} \\
00078 & Secchi-depth $(\mathrm{m})$ & 0.5 & 42.5 \\
00098 & Sampling depth $(\mathrm{m})$ & 26.5 & 7.9 \\
00010 & Water Temperature $\left({ }^{\circ} \mathrm{C}\right)$ & 8.5 & 7.3 \\
00400 & pH (standard units) & 527 & 542 \\
00095 & Specific conductance $(\mu \mathrm{S} / \mathrm{cm})$ & 9.3 & 3.0 \\
00300 & Dissolved oxygen & 0.007 & -- \\
00665 & Phosphorus, Total $($ as $\mathrm{P})$ & $<.002$ & - \\
00671 & Orthophosphate, dissolved $($ as $\mathrm{P})$ & $<.019$ & -- \\
00631 & Nitrate + nitrite, dissolved (as N) & $<.015$ & -- \\
00608 & Ammonia, dissolved (as N) & 0.34 & -- \\
00625 & Ammonia + organic nitrogen, total (as N) & $<.36$ & -- \\
00600 & Total nitrogen &
\end{tabular}

\begin{tabular}{cccccc}
\multicolumn{7}{c}{ August 19 } \\
\hline \multicolumn{7}{c}{2.61} \\
0.6 & 9.0 & 15.0 & 32.0 & 37.0 & 41.0 \\
26.2 & 24.7 & 12.5 & 8.8 & 8.3 & 8.2 \\
8.5 & 8.4 & 8.0 & 7.7 & 7.6 & 7.6 \\
535 & 537 & 533 & 538 & 539 & 540 \\
8.5 & 7.4 & 7.3 & 3.1 & 2.5 & 1.6 \\
0.010 & 0.010 & 0.012 & 0.009 & 0.009 & 0.019 \\
-- & -- & -- & -- & -- & -- \\
-- & -- & -- & -- & -- & -- \\
-- & -- & -- & -- & -- & -- \\
-- & -- & -- & -- & -- & -- \\
-- & -- & -- & -- & -- & --
\end{tabular}

\begin{tabular}{cccccc}
\multicolumn{7}{c}{ September 17 } \\
\hline \multicolumn{7}{c}{5.51} \\
\multicolumn{7}{c}{4.65} \\
0.5 & 12.0 & 17.0 & 32.0 & 37.0 & 41.0 \\
20.2 & 20.1 & 12.4 & 8.9 & 8.5 & 8.4 \\
8.5 & 8.5 & 7.9 & 7.7 & 7.6 & 7.6 \\
520 & 521 & 533 & 537 & 538 & 539 \\
9.0 & 8.8 & 5.6 & 3.2 & 1.9 & 1.7 \\
0.016 & 0.014 & 0.016 & 0.017 & 0.025 & 0.032 \\
-- & -- & -- & -- & -- & -- \\
$<.019$ & $<.019$ & 0.133 & 0.273 & 0.279 & 0.258 \\
$<.015$ & $<.015$ & 0.031 & $<.015$ & 0.022 & 0.051 \\
0.49 & 0.44 & 0.41 & 0.36 & 0.38 & 0.43 \\
$<.51$ & $<.46$ & 0.54 & 0.63 & 0.66 & 0.69
\end{tabular}




\section{GENEVA LAKE AT WEST END NEAR WILLIAMS BAY, W}

\section{LAKE-DEPTH PROFILES, NOVEMBER 3, 2009 TO JUNE 10, 2010}

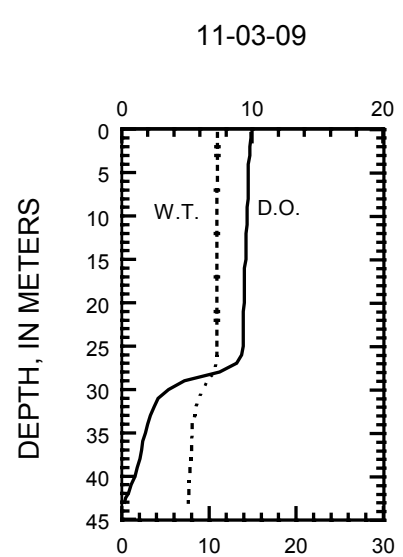

04-20-10

06-10-10

DISSOLVED OXYGEN (D.O.), IN MILLIGRAMS PER LITER
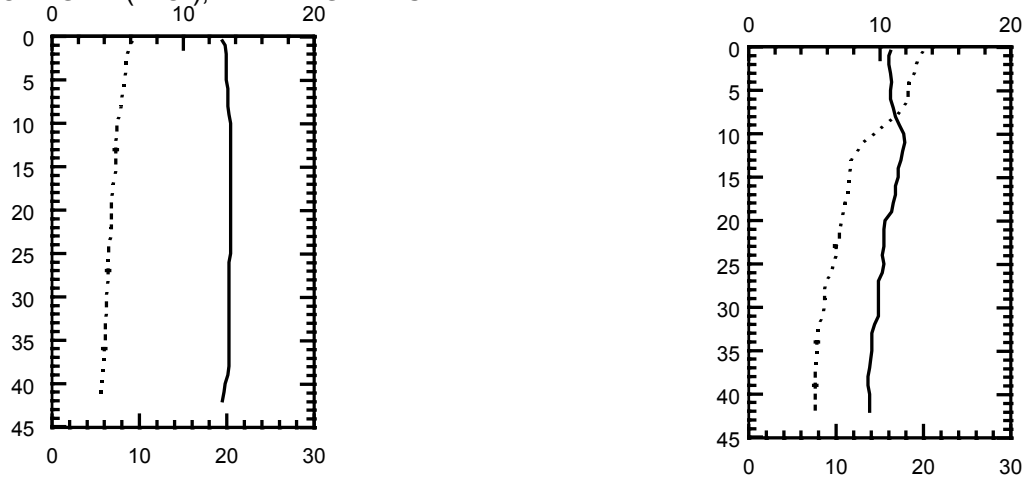

WATER TEMPERATURE (W.T.), IN DEGREES CELSIUS

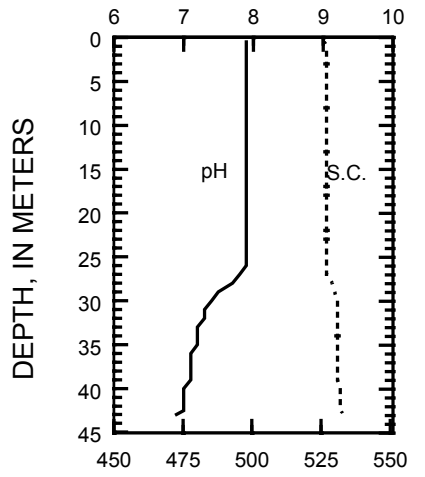

PH, IN STANDARD UNITS
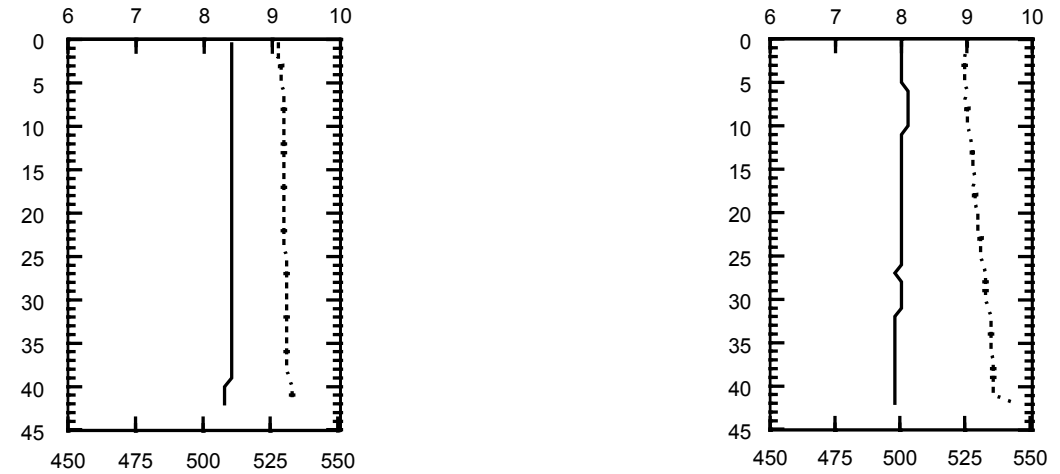

SPECIFIC CONDUCTANCE (S.C.), IN MICROSIEMENS PER CENTIMETER AT 25 DEGREES CELSIUS 
423329088323300 GENEVA LAKE AT WEST END NEAR WILLIAMS BAY, WI

LAKE-DEPTH PROFILES, JULY 29 TO SEPTEMBER 17, 2010

$07-29-10$
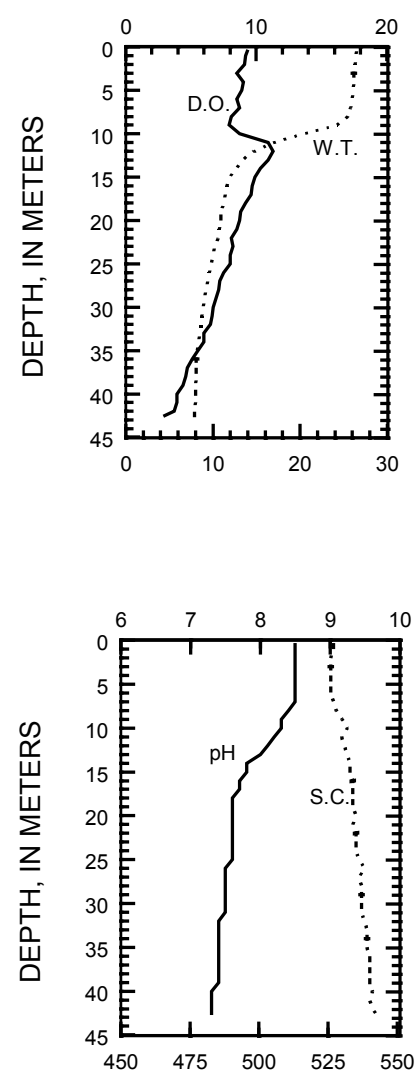

08-19-10

DISSOLVED OXYGEN (D.O.), IN MILLIGRAMS PER LITER

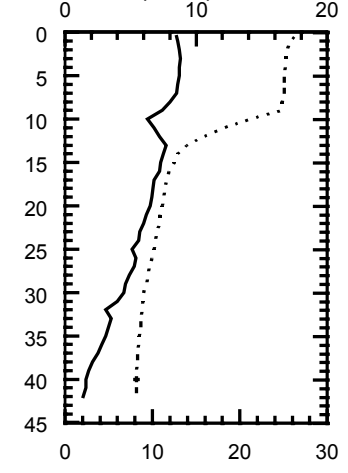

WATER TEMPERATURE (W.T.), IN DEGREES CELSIUS

PH, IN STANDARD UNITS

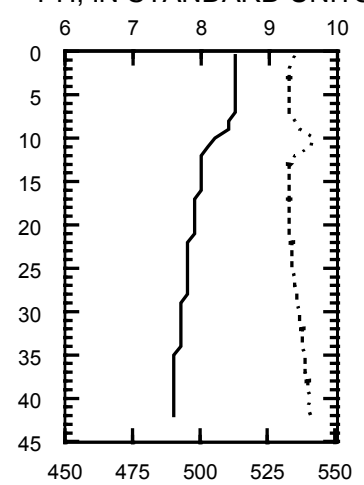

$09-17-10$
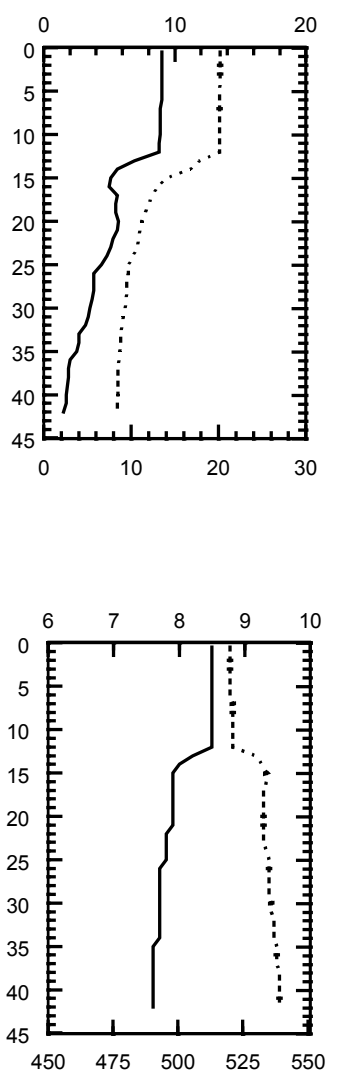

SPECIFIC CONDUCTANCE (S.C.), IN MICROSIEMENS PER CENTIMETER AT 25 DEGREES CELSIUS 

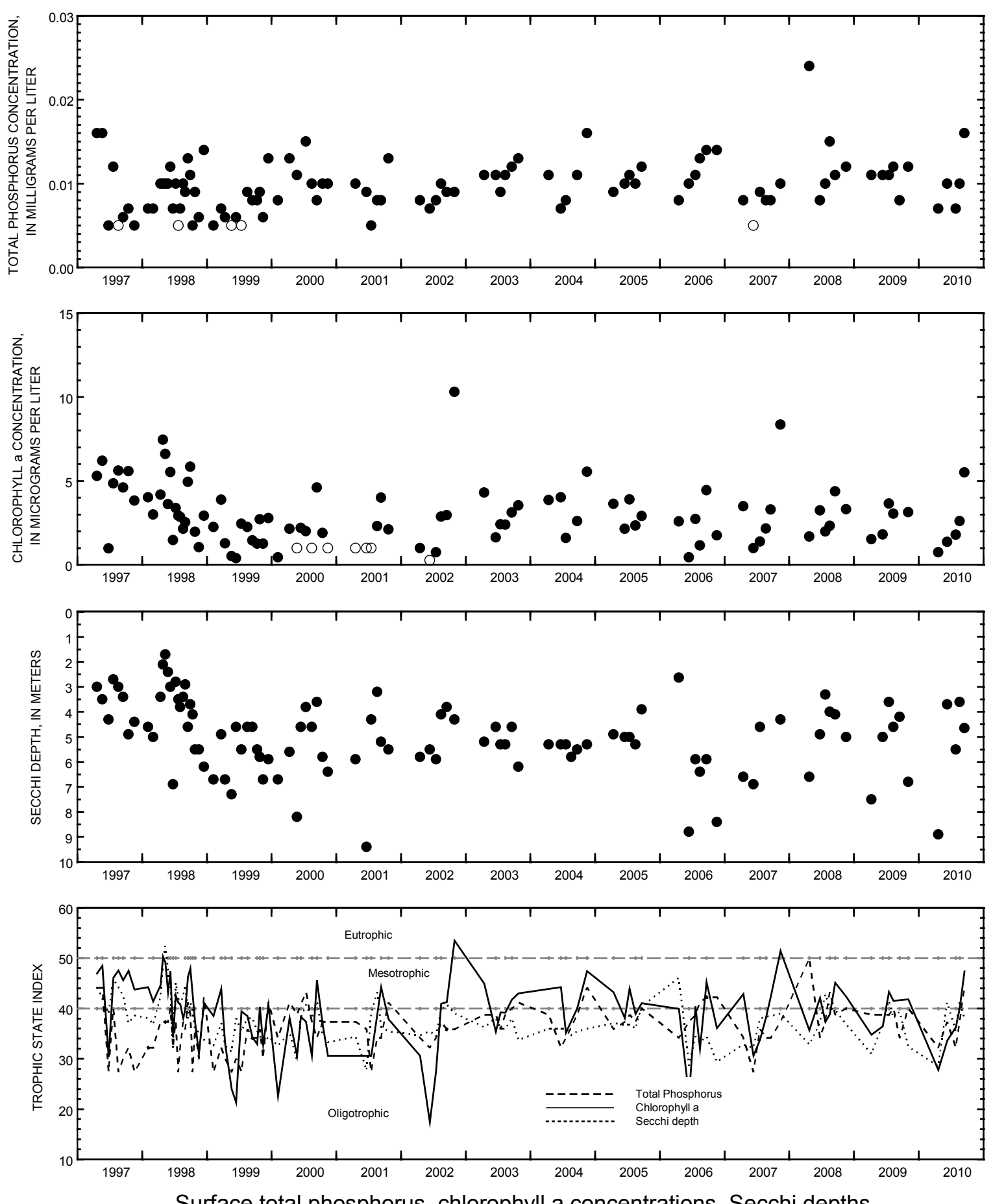

Surface total phosphorus, chlorophyll a concentrations, Secchi depths, and TSI data for Geneva Lake, West End, near Williams Bay, Wisconsin. 


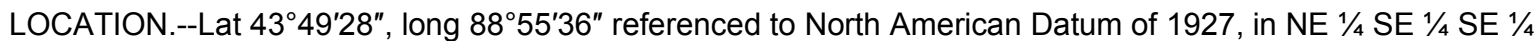
sec.27, T.16 N., R.13 E., Green Lake County, WI, Hydrologic Unit 04030201, on left bank at downstream side of County Trunk Highway A, 2.3 mi southeast of Green Lake.

SURFACE AREA.--11.48 $\mathrm{mi}^{2}$.

DRAINAGE AREA.--103 mi; Area of Green Lake, 7,346 acres.

PERIOD OF RECORD.--October 1993 to current year.

GAGE.--Water-stage recorder. Datum of gage is $790.00 \mathrm{ft}$ above sea level.

REMARKS.--Lake level regulated by dam at outlet at Green Lake. Gage-height telemeter at station.

EXTREMES FOR PERIOD OF RECORD.--Maximum recorded gage height, $8.67 \mathrm{ft}$, June 15, 2008; minimum recorded, $5.27 \mathrm{ft}$, Nov. 5, 2005.

EXTREMES FOR CURRENT YEAR.--Maximum recorded gage height, $6.96 \mathrm{ft}$, July 15; minimum recorded gage height, $5.63 \mathrm{ft}$, Oct. 1.

\begin{tabular}{|c|c|c|c|c|c|c|c|c|c|c|c|c|}
\hline \multicolumn{13}{|c|}{$\begin{array}{c}\text { GAGE HEIGHT, FEET } \\
\text { WATER YEAR OCTOBER } 2009 \text { TO SEPTEMBER } 2010 \\
\text { DAILY MEAN VALUES }\end{array}$} \\
\hline \multicolumn{13}{|c|}{ [e, estimated] } \\
\hline Day & Oct & Nov & Dec & Jan & Feb & Mar & Apr & May & Jun & Jul & Aug & Sep \\
\hline 1 & 5.78 & 6.02 & 6.04 & 6.18 & 6.16 & 6.15 & 6.41 & 6.60 & 6.52 & 6.52 & 6.51 & 6.57 \\
\hline 2 & 5.83 & 6.02 & 6.04 & 6.16 & 6.19 & 6.15 & 6.41 & 6.59 & 6.50 & 6.48 & 6.51 & 6.58 \\
\hline 3 & 5.84 & 5.99 & 6.03 & 6.16 & 6.20 & 6.14 & 6.42 & 6.55 & 6.52 & e6.47 & 6.49 & 6.56 \\
\hline 4 & 5.83 & 5.98 & 6.02 & 6.15 & e6.19 & 6.14 & 6.48 & 6.53 & 6.57 & e6.46 & 6.50 & 6.53 \\
\hline 5 & 5.83 & 5.98 & 6.02 & 6.15 & e6.19 & 6.13 & 6.49 & 6.49 & 6.56 & e6.45 & 6.49 & 6.52 \\
\hline 6 & 5.85 & 5.98 & 5.99 & 6.14 & 6.19 & 6.12 & 6.52 & 6.48 & 6.57 & e6.54 & 6.48 & 6.53 \\
\hline 7 & 5.87 & 5.99 & 5.99 & 6.15 & 6.22 & 6.12 & 6.60 & 6.46 & 6.56 & 6.52 & 6.48 & 6.51 \\
\hline 8 & 5.86 & 5.97 & 5.97 & 6.16 & 6.29 & 6.12 & 6.64 & 6.49 & 6.56 & 6.55 & 6.57 & 6.51 \\
\hline 9 & 5.84 & 5.98 & 6.08 & 6.15 & 6.30 & 6.13 & 6.63 & 6.51 & 6.58 & 6.55 & 6.63 & 6.51 \\
\hline 10 & 5.83 & 5.96 & 6.10 & 6.16 & 6.32 & 6.15 & 6.62 & 6.49 & 6.55 & 6.56 & 6.60 & 6.50 \\
\hline 11 & 5.82 & 5.95 & 6.07 & 6.16 & 6.30 & 6.21 & 6.56 & 6.50 & 6.58 & 6.62 & 6.58 & 6.51 \\
\hline 12 & 5.79 & 5.97 & 6.03 & 6.15 & 6.30 & 6.25 & 6.53 & 6.51 & 6.60 & 6.64 & 6.56 & 6.53 \\
\hline 13 & 5.79 & 5.97 & 6.04 & 6.15 & 6.31 & e6.31 & 6.51 & 6.56 & 6.59 & 6.63 & 6.55 & 6.52 \\
\hline 14 & 5.77 & 5.97 & 6.05 & 6.15 & 6.31 & 6.38 & 6.50 & 6.56 & 6.57 & 6.57 & 6.53 & 6.51 \\
\hline 15 & 5.77 & 5.97 & 6.07 & 6.15 & 6.30 & 6.39 & 6.49 & 6.56 & 6.60 & 6.83 & 6.50 & 6.50 \\
\hline 16 & 5.77 & 5.95 & 6.03 & 6.14 & 6.29 & 6.41 & 6.48 & 6.54 & 6.63 & 6.80 & 6.45 & 6.52 \\
\hline 17 & 5.76 & 5.95 & 6.01 & 6.14 & 6.28 & 6.43 & 6.48 & 6.52 & 6.61 & 6.75 & 6.42 & 6.52 \\
\hline 18 & e5.77 & 5.95 & 6.02 & 6.14 & 6.27 & 6.43 & 6.50 & 6.51 & 6.63 & 6.70 & 6.41 & 6.52 \\
\hline 19 & e5.77 & 5.98 & 6.02 & 6.14 & 6.28 & e6.42 & 6.50 & 6.51 & 6.61 & 6.65 & 6.40 & 6.51 \\
\hline 20 & e5.77 & 5.99 & 6.03 & 6.13 & 6.25 & e6.42 & 6.50 & 6.51 & 6.58 & 6.61 & 6.42 & 6.50 \\
\hline 21 & e5.80 & 5.98 & 6.04 & 6.13 & 6.21 & e6.41 & 6.48 & 6.50 & 6.56 & 6.59 & 6.48 & 6.50 \\
\hline 22 & e5.90 & 5.98 & 6.02 & 6.13 & 6.21 & 6.41 & 6.48 & 6.52 & 6.65 & 6.64 & 6.52 & 6.49 \\
\hline 23 & e5.98 & 5.97 & 6.01 & 6.13 & 6.21 & 6.40 & 6.47 & 6.54 & 6.67 & 6.77 & 6.52 & 6.51 \\
\hline 24 & e5.98 & 5.97 & 6.05 & 6.17 & 6.21 & 6.40 & 6.48 & 6.53 & 6.66 & 6.73 & 6.52 & 6.52 \\
\hline 25 & e5.96 & 6.02 & 6.13 & 6.19 & 6.20 & e6.40 & 6.55 & 6.54 & 6.63 & 6.67 & 6.51 & 6.51 \\
\hline 26 & 5.94 & 6.05 & 6.17 & 6.19 & 6.20 & e6.40 & 6.59 & 6.54 & 6.66 & 6.63 & 6.51 & 6.51 \\
\hline 27 & 5.94 & 6.05 & 6.21 & 6.18 & 6.19 & 6.40 & 6.57 & 6.54 & 6.66 & 6.59 & 6.50 & 6.50 \\
\hline 28 & 5.94 & 6.04 & 6.20 & 6.18 & 6.16 & 6.41 & 6.56 & 6.53 & e6.62 & 6.61 & 6.49 & 6.49 \\
\hline 29 & 5.94 & 6.04 & 6.18 & 6.17 & --- & 6.42 & 6.54 & 6.52 & 6.59 & 6.56 & 6.49 & 6.48 \\
\hline 30 & 6.01 & 6.04 & 6.19 & 6.16 & --- & 6.42 & 6.54 & 6.53 & 6.54 & 6.54 & 6.49 & 6.47 \\
\hline 31 & 6.02 & --- & 6.20 & 6.16 & --- & 6.41 & --- & 6.52 & --- & 6.52 & 6.49 & --- \\
\hline Mean & 5.86 & 5.99 & 6.07 & 6.15 & 6.24 & 6.31 & 6.52 & 6.53 & 6.59 & 6.60 & 6.50 & 6.51 \\
\hline Max & 6.02 & 6.05 & 6.21 & 6.19 & 6.32 & 6.43 & 6.64 & 6.60 & 6.67 & 6.83 & 6.63 & 6.58 \\
\hline Min & 5.76 & 5.95 & 5.97 & 6.13 & 6.16 & 6.12 & 6.41 & 6.46 & 6.50 & 6.45 & 6.40 & 6.47 \\
\hline
\end{tabular}




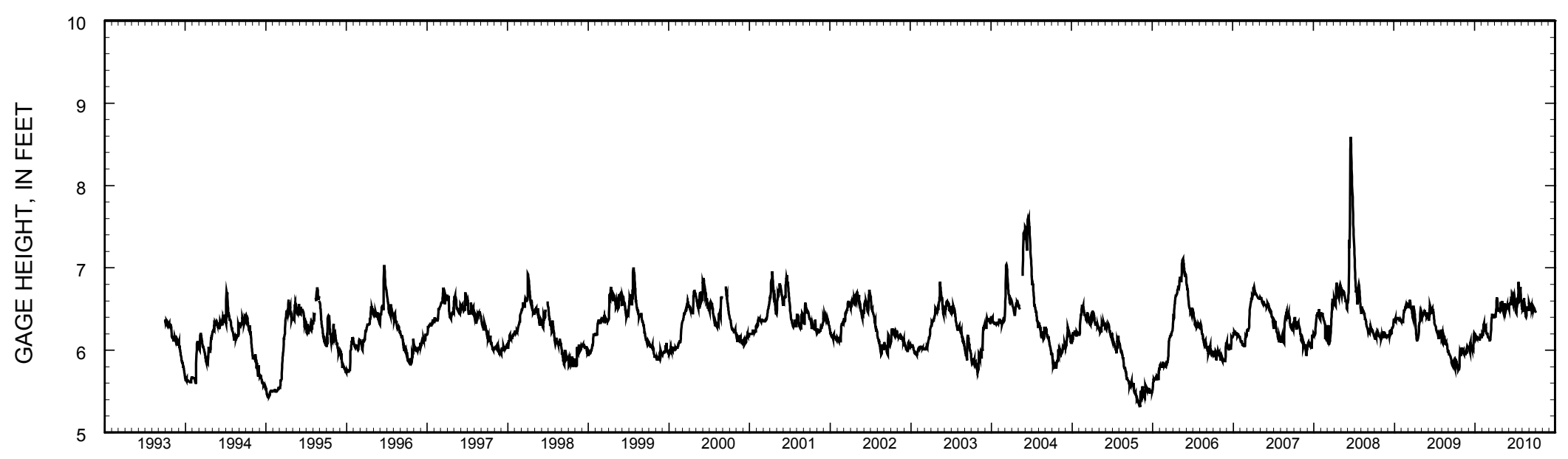

Stage hydrograph for Green Lake, 1993-2010. 
LOCATION.--Lat 4347'56", long 8902'05", in NW 1/4 SE 1/4 sec.2, T.15 N., R.12 E., Green Lake County, Hydrologic Unit 04030201, about 5 miles southwest of the City of Green Lake.

SURFACE AREA.--11.48 $\mathrm{mi}^{2}$.

PERIOD OF RECORD.--May 2004 to current year. Lake sampled by Wisconsin Department of Natural Resources prior to 2004.

REMARKS.--Water-quality analyses done by Wisconsin State Laboratory of Hygiene. A “*” indicates data that were collected by Mary Jane Bumby, Citizen Lake Monitoring Volunteer.

\begin{tabular}{|c|c|}
\hline Parameter Code & $\underline{\text { Parameter Name }}$ \\
\hline 32210 & Chlorophyll a $(\mu \mathrm{g} / \mathrm{L})$ \\
\hline 00078 & Secchi-depth (m) \\
\hline 00098 & Sampling depth (m) \\
\hline 00010 & Water Temperature $\left({ }^{\circ} \mathrm{C}\right)$ \\
\hline 00400 & $\mathrm{pH}$ (standard units) \\
\hline 00095 & Specific conductance $(\mu \mathrm{S} / \mathrm{cm})$ \\
\hline 00300 & Dissolved oxygen \\
\hline 00665 & Phosphorus, total (as P) \\
\hline 00671 & Orthophosphate, dissolved (as P) \\
\hline 00631 & Nitrate plus nitrite, dissolved (as $\mathrm{N}$ ) \\
\hline 00608 & Ammonia, dissolved (as $\mathrm{N}$ ) \\
\hline 00625 & Ammonia plus organic nitrogen, unfltrd, total (as $\mathrm{N}$ ) \\
\hline 00623 & Ammonia plus organic nitrogen, fltrd, total (as $\mathrm{N}$ ) \\
\hline 00600 & Total nitrogen \\
\hline 63675 & Turbidity, (NTU) \\
\hline 00081 & Apparent color, (PTU) \\
\hline 00900 & Hardness (as CaCO3) \\
\hline 00915 & Calcium, dissolved $(\mathrm{Ca})$ \\
\hline 00925 & Magnesium, dissolved (Mg) \\
\hline 00930 & Sodium, dissolved $(\mathrm{Na})$ \\
\hline 00935 & Potassium, dissolved $(\mathrm{K})$ \\
\hline 00417 & ANC (as $\mathrm{CaCO} 3)$ \\
\hline 00940 & Chloride, dissolved (Cl) \\
\hline 00945 & Sulfate, dissolved (SO4) \\
\hline 00955 & Silica, dissolved (SiO2) \\
\hline 01046 & Iron $(\mu \mathrm{g} / \mathrm{L})$ \\
\hline 01056 & Manganese $(\mu \mathrm{g} / \mathrm{L})$ \\
\hline 70300 & Solids, dissolved (at $180^{\circ} \mathrm{C}$ ) \\
\hline
\end{tabular}

WATER-QUALITY DATA, April 19 TO JUNE 16, 2010

(Milligrams per liter unless otherwise indicated)

\begin{tabular}{|c|c|c|c|c|c|c|}
\hline \multicolumn{2}{|c|}{ April 19} & May $20^{*}$ & May $26^{*}$ & June $3^{*}$ & June $10^{*}$ & June $16^{*}$ \\
\hline \multicolumn{2}{|c|}{4.92} & -- & -- & -- & -- & -- \\
\hline \multicolumn{2}{|c|}{2.7} & 0.9 & 1.2 & 1.4 & 1.8 & 3.7 \\
\hline 0.5 & 66.0 & 0.1 & 0.1 & 0.1 & 0.1 & 0.1 \\
\hline 7.1 & 4.0 & 16.7 & 22.2 & 22.8 & 20 & 21.7 \\
\hline 8.1 & 8.1 & -- & -- & -- & -- & -- \\
\hline 511 & 515 & -- & -- & -- & -- & -- \\
\hline 14.0 & 11.9 & -- & -- & -- & -- & -- \\
\hline 0.041 & 0.049 & -- & -- & -- & -- & -- \\
\hline 0.02 & -- & -- & -- & -- & -- & -- \\
\hline 0.224 & -- & -- & -- & -- & -- & -- \\
\hline$<.015$ & -- & -- & -- & -- & -- & -- \\
\hline 0.49 & -- & -- & -- & -- & -- & -- \\
\hline-- & -- & -- & -- & -- & -- & -- \\
\hline 0.71 & -- & -- & -- & -- & -- & -- \\
\hline$<1.0$ & -- & -- & -- & -- & -- & -- \\
\hline 5 & -- & -- & -- & -- & -- & -- \\
\hline 225 & -- & -- & -- & -- & -- & -- \\
\hline 33.6 & -- & -- & -- & -- & -- & -- \\
\hline 34.3 & -- & -- & -- & -- & -- & -- \\
\hline 18.8 & -- & -- & -- & -- & -- & -- \\
\hline 3.1 & -- & -- & -- & -- & -- & -- \\
\hline 180 & -- & -- & -- & -- & -- & -- \\
\hline 37.8 & -- & -- & -- & -- & -- & -- \\
\hline 30.9 & -- & -- & -- & -- & -- & -- \\
\hline 0.362 & -- & -- & -- & -- & -- & -- \\
\hline$<100$ & -- & -- & -- & -- & -- & -- \\
\hline$<1.0$ & -- & -- & -- & -- & -- & -- \\
\hline 276 & -- & -- & -- & -- & -- & -- \\
\hline
\end{tabular}


434756089020500 GREEN LAKE AT DEEP HOLE NEAR GREEN LAKE, WI

WATER-QUALITY DATA, JUNE 24 TO SEPTEMBER 29, 2010

(Milligrams per liter unless otherwise indicated)

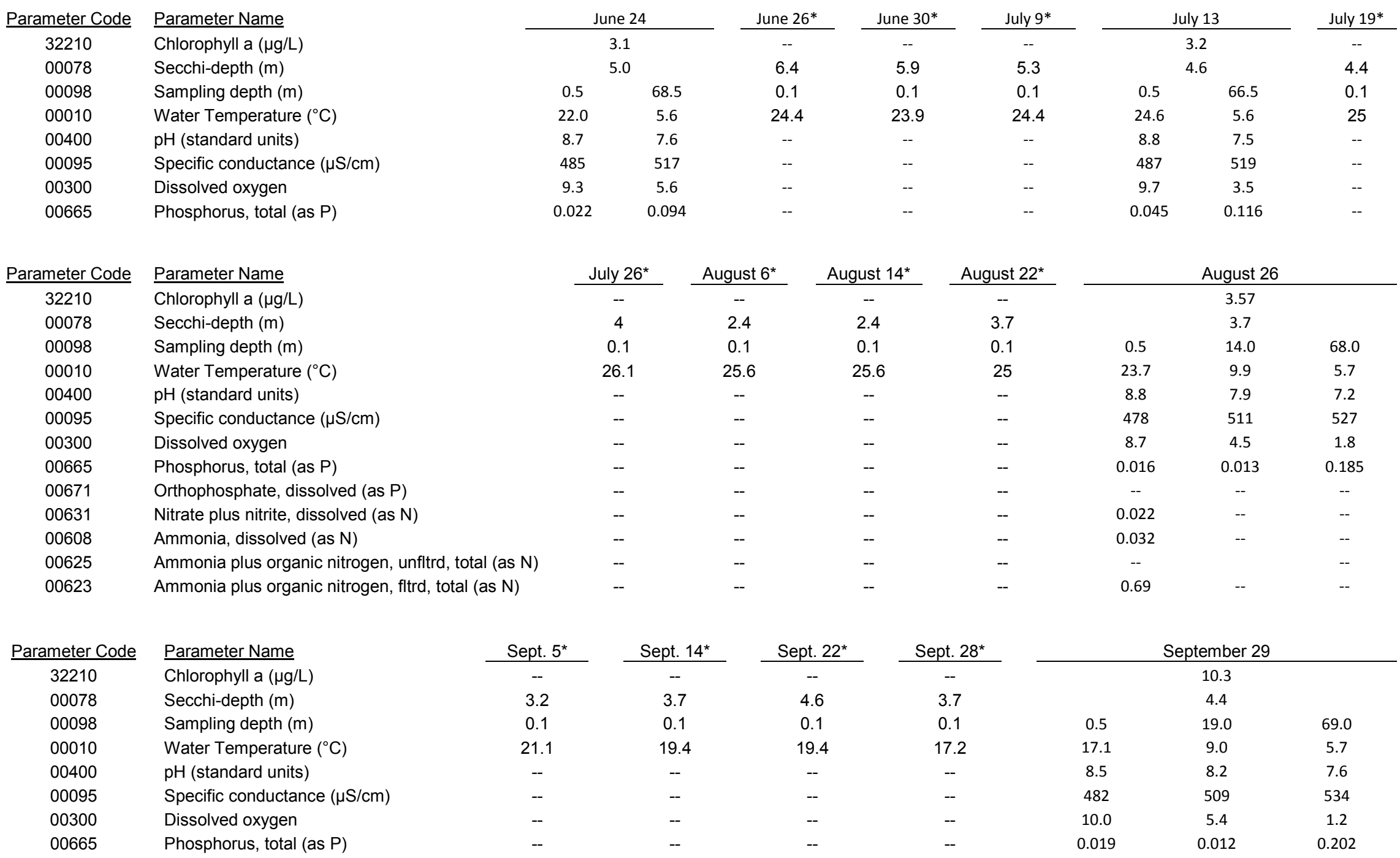


434756089020500 GREEN LAKE AT DEEP HOLE NEAR GREEN LAKE, WI

LAKE-DEPTH PROFILES, APRIL 19 TO SEPTEMBER 29, 2010

04-19-10
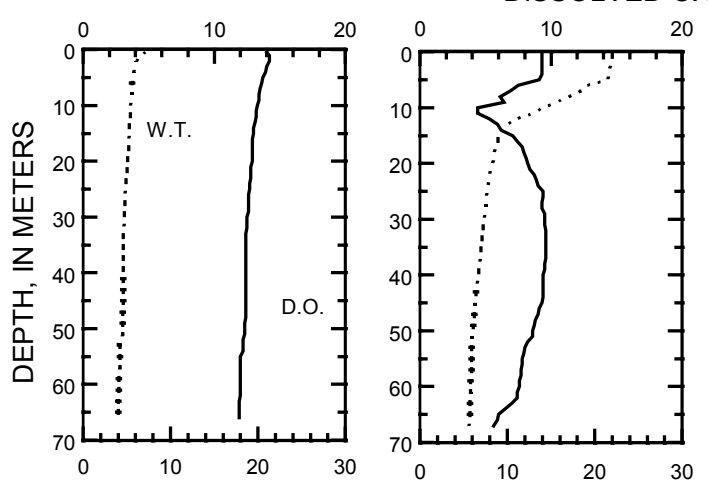

07-13-10

08-26-10

09-29-10

WATER TEMPERATURE (W.T.), IN DEGREES CELSIUS
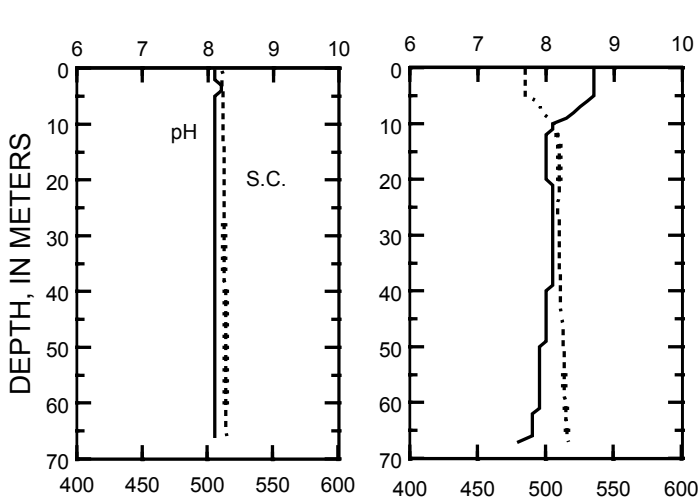

PH, IN STANDARD UNITS
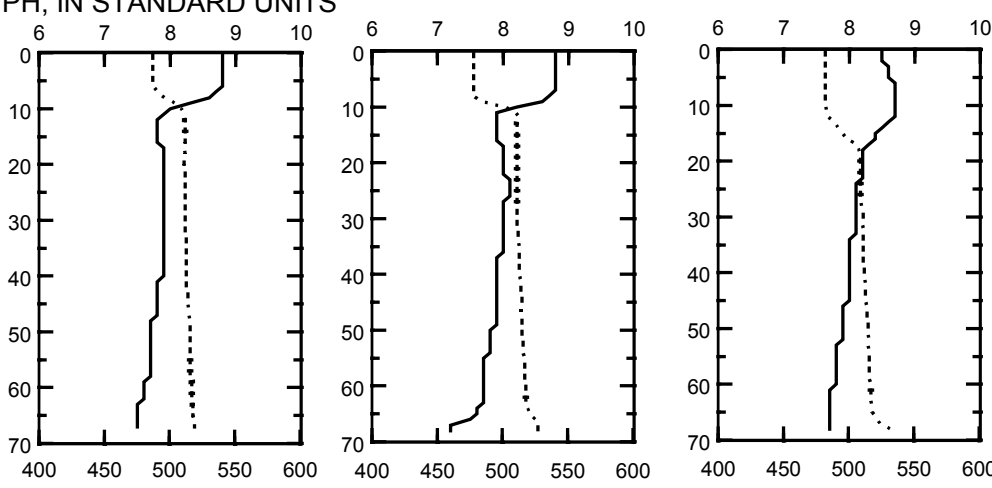

SPECIFIC CONDUCTANCE (S.C.), IN MICROSIEMENS PER CENTIMETER AT 25 DEGREES CELSIUS 

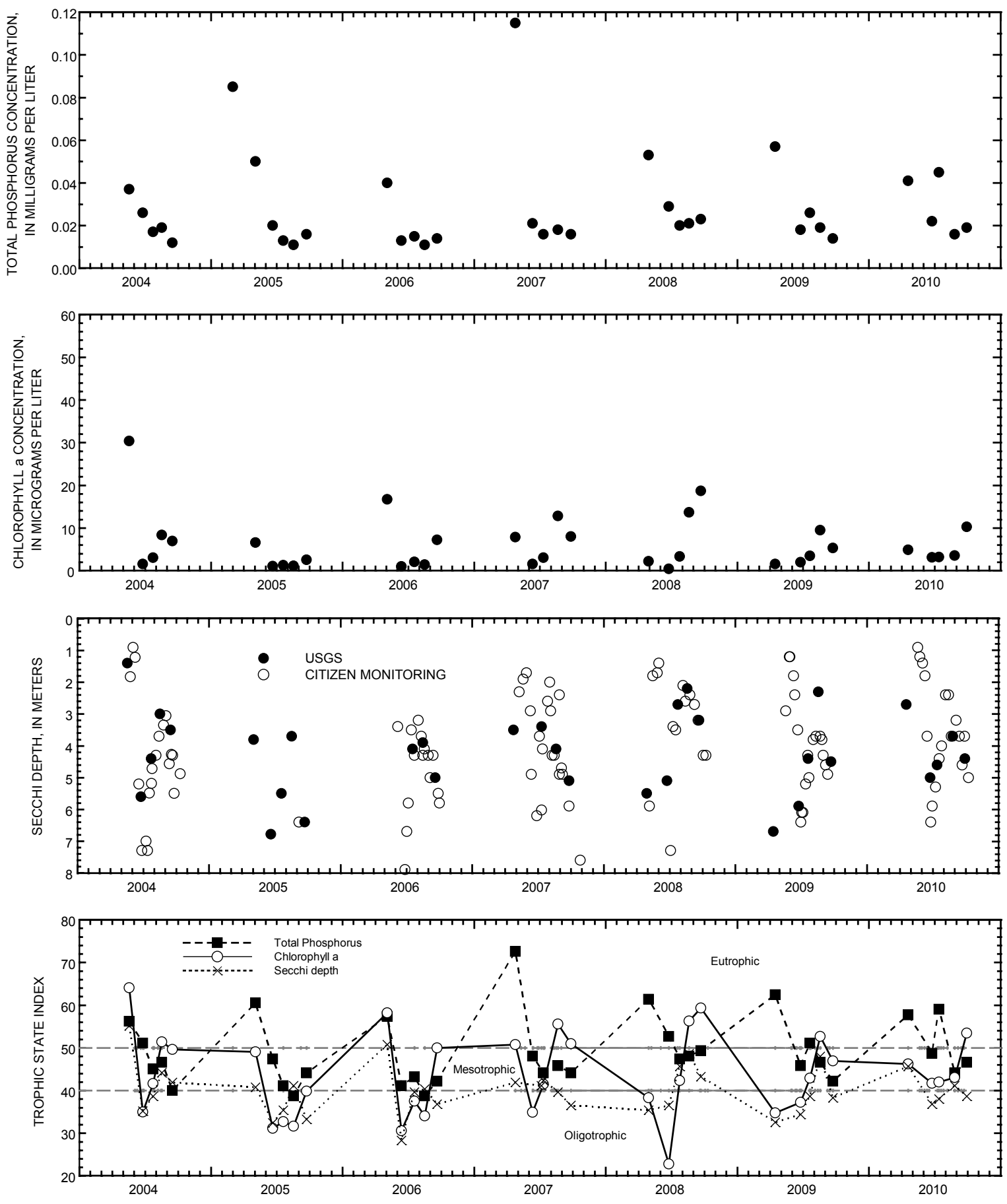

Surface total phosphorus, chlorophyll a concentrations, Secchi depths, and TSI data for Green Lake, Deep Hole, near Green Lake, Wisconsin. 


\section{GREEN LAKE AT EAST END NEAR GREEN LAKE, W}

LOCATION.--Lat 4349'28", long $88^{\circ} 57^{\prime} 00 "$, in SE 1/4 SE 1/4 sec.28, T.16 N., R.13 E., Green Lake County, Hydrologic Unit 04030201, about one mile southeast of the City of Green Lake.

SURFACE AREA.--11.48 $\mathrm{mi}^{2}$.

PERIOD OF RECORD.--May 2004 current year. Lake sampled by Wisconsin Department of Natural Resources prior to 2004.

REMARKS.--Water-quality analyses done by Wisconsin State Laboratory of Hygiene. A “*” indicates data that were collected by Mary Jane Bumby, Citizen Lake Monitoring Volunteer.

WATER-QUALITY DATA, APRIL 19 TO JULY 26, 2010

(Milligrams per liter unless otherwise indicated)

\begin{tabular}{clcc} 
Parameter Code & Parameter Name & \multicolumn{2}{c}{ April 19} \\
\hline 32210 & Chlorophyll a $(\mu \mathrm{g} / \mathrm{L})$ & \multicolumn{2}{c}{2.6} \\
00078 & Secchi-depth $(\mathrm{m})$ & 0.5 & 32.0 \\
00098 & Sampling depth $(\mathrm{m})$ & 7.9 & 4.8 \\
00010 & Water Temperature $\left({ }^{\circ} \mathrm{C}\right)$ & 8.3 & 8.2 \\
00400 & pH (standard units) & 513 & 514 \\
00095 & Specific conductance $(\mu \mathrm{S} / \mathrm{cm})$ & 14 & 12.7 \\
00300 & Dissolved oxygen & 0.036 & 0.046
\end{tabular}

\begin{tabular}{ccc} 
May $20^{*}$ & & May $26^{*}$ \\
\cline { 1 - 1 }- & & - \\
1.1 & & 0.9 \\
0.1 & & 0.1 \\
15.6 & & 22.2 \\
-- & & -- \\
-- & -- \\
-- & -- \\
-- & --
\end{tabular}

\begin{tabular}{c} 
June $3^{*}$ \\
\hline- \\
1.7 \\
0.1 \\
22.8 \\
-- \\
-- \\
-- \\
--
\end{tabular}

\begin{tabular}{c} 
June $10^{*}$ \\
\hline-- \\
1.2 \\
0.1 \\
20.6 \\
-- \\
-- \\
-- \\
--
\end{tabular}

\begin{tabular}{c} 
June $16^{*}$ \\
\hline-- \\
3.8 \\
0.1 \\
22.8 \\
-- \\
-- \\
-- \\
--
\end{tabular}

\begin{tabular}{clcc} 
Parameter Code & Parameter Name & \multicolumn{2}{c}{ June 24} \\
\hline 32210 & Chlorophyll a $(\mu \mathrm{g} / \mathrm{L})$ & \multicolumn{2}{c}{3.12} \\
00078 & Secchi-depth $(\mathrm{m})$ & \multicolumn{2}{c}{5.0} \\
00098 & Sampling depth $(\mathrm{m})$ & 24.0 & 37.0 \\
00010 & Water Temperature $\left({ }^{\circ} \mathrm{C}\right)$ & 8.8 & 6.6 \\
00400 & $\mathrm{pH}($ standard units) & 489 & 515 \\
00095 & Specific conductance $(\mu \mathrm{S} / \mathrm{cm})$ & 9.3 & 8.0 \\
00300 & Dissolved oxygen & 0.022 & 0.065 \\
00665 & Phosphorus, total $($ as $\mathrm{P})$ & &
\end{tabular}

\begin{tabular}{c} 
June $26^{*}$ \\
\hline-- \\
6.2 \\
0.1 \\
25 \\
-- \\
-- \\
-- \\
--
\end{tabular}

\begin{tabular}{c} 
June $30^{*}$ \\
\hline-- \\
4.9 \\
0.1 \\
24.4 \\
-- \\
-- \\
-- \\
--
\end{tabular}

\begin{tabular}{c} 
July $9^{*}$ \\
\hline-- \\
4.6 \\
0.1 \\
26.1 \\
-- \\
-- \\
-- \\
--
\end{tabular}

\begin{tabular}{cc}
\multicolumn{2}{c}{ July 13} \\
\hline \multicolumn{3}{c}{3.86} \\
\multicolumn{3}{c}{3.4} \\
0.5 & 32.0 \\
25.5 & 6.9 \\
8.9 & 7.8 \\
490 & 514 \\
9.3 & 8.2 \\
0.02 & 0.067
\end{tabular}

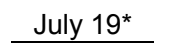

July $26^{*}$

$\begin{array}{cc}3.7 & 3.7 \\ 0.1 & 0.1 \\ 26.7 & 26.7 \\ -- & -- \\ -- & -- \\ -- & -- \\ -- & --\end{array}$


434928088570000 GREEN LAKE AT EAST END NEAR GREEN LAKE, WI

WATER-QUALITY DATA, AUGUST 6 TO SEPTEMBER 29, 2010

(Milligrams per liter unless otherwise indicated)

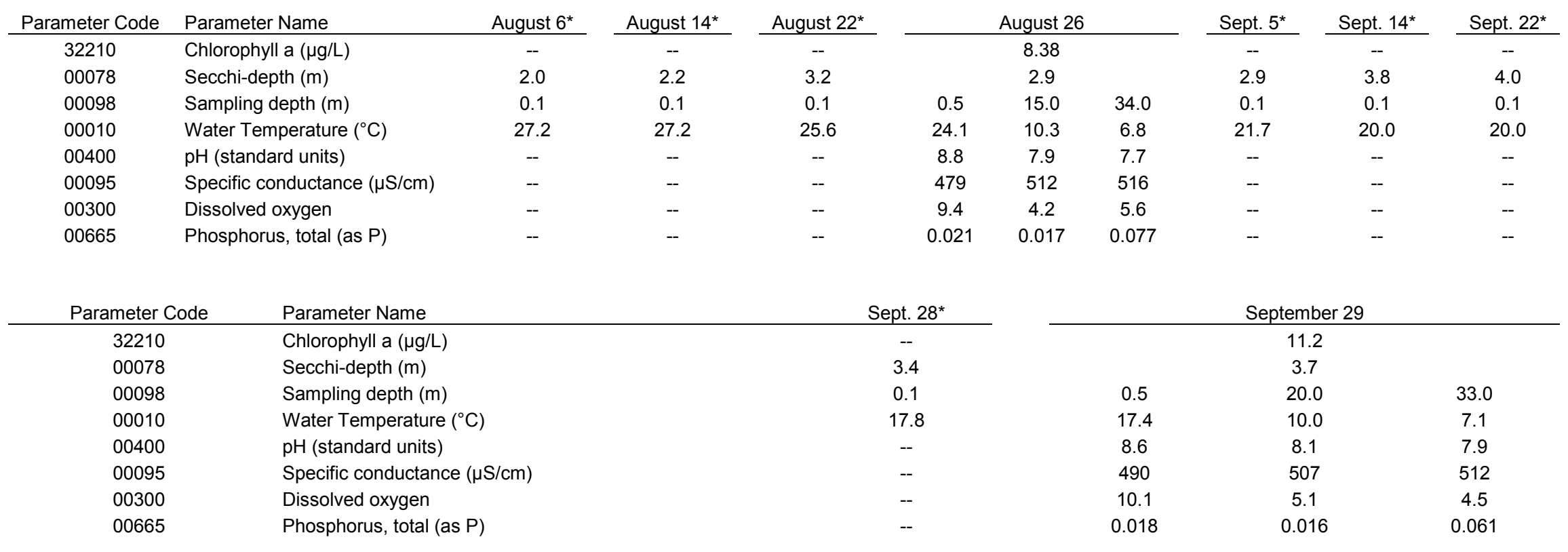


434928088570000 GREEN LAKE AT EAST END NEAR GREEN LAKE, WI

LAKE-DEPTH PROFILES, APRIL 19 TO SEPTEMBER 29, 2010

04-19-10
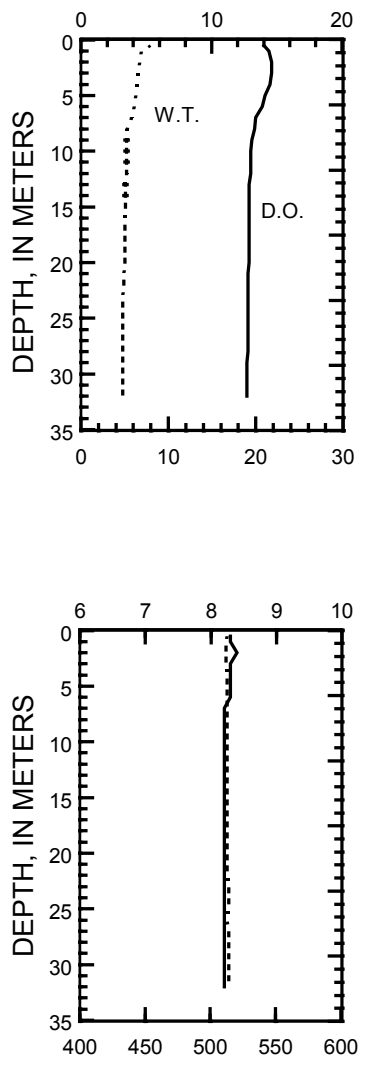

06-24-10

DISSOLVED

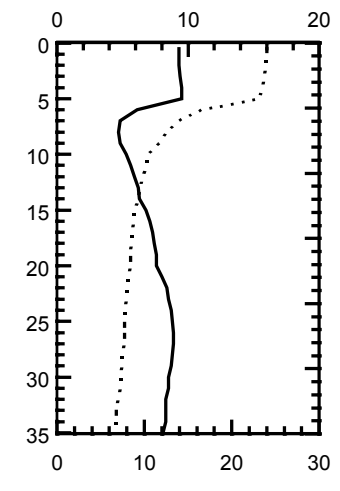

WATER TEMPE
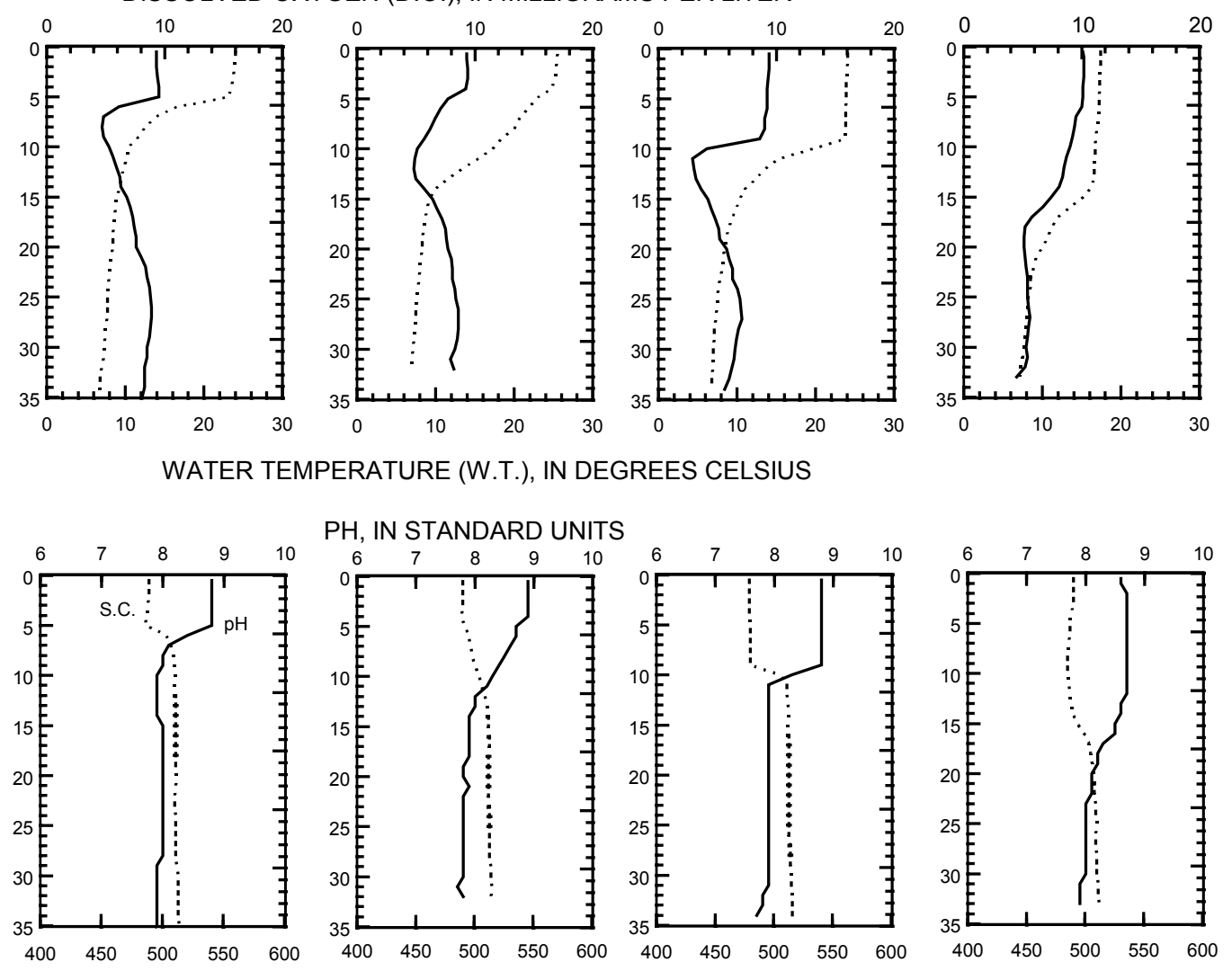

SPECIFIC CONDUCTANCE (S.C.), IN MICROSIEMENS PER CENTIMETER AT 25 DEGREES CELSIUS 

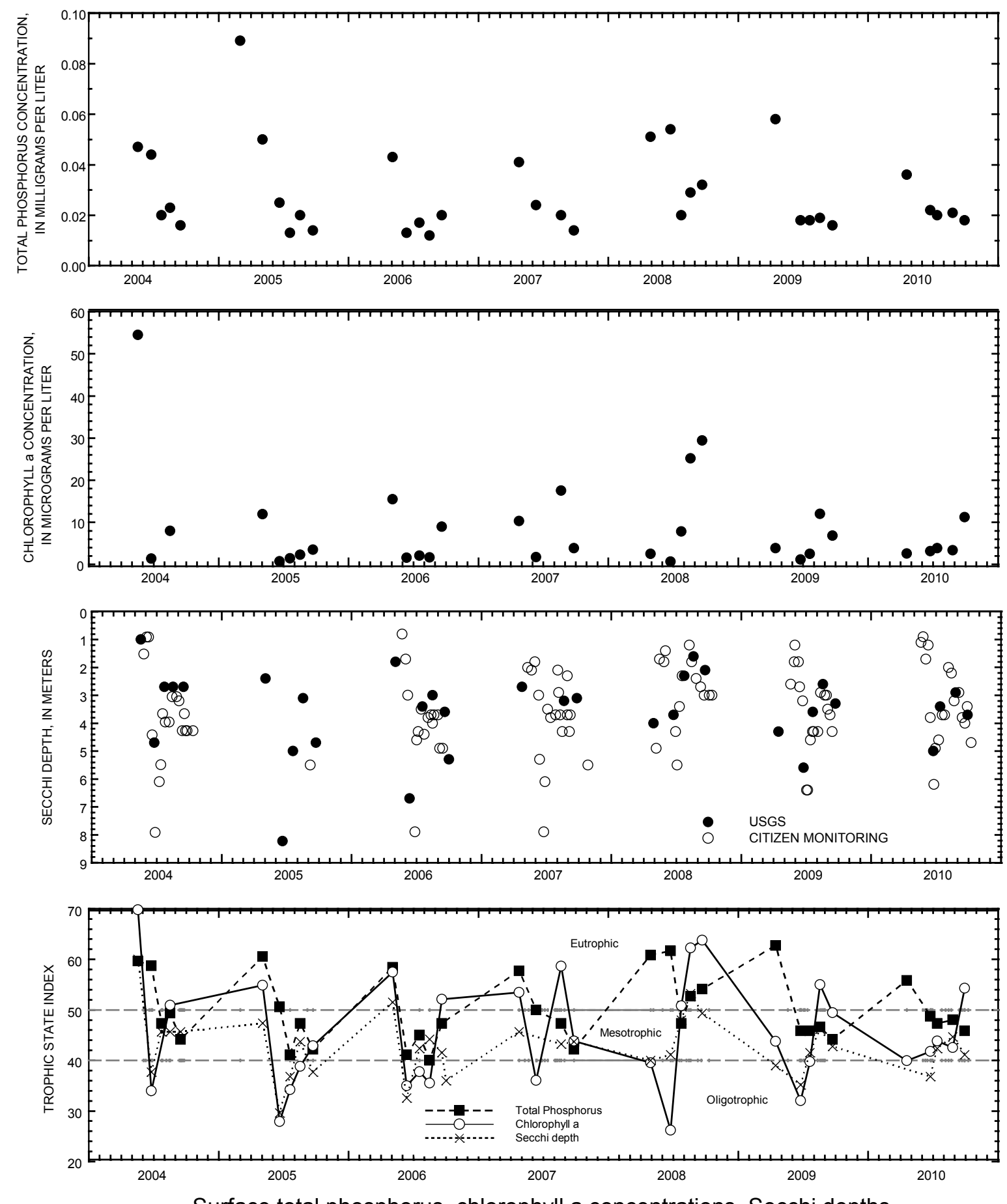

Surface total phosphorus, chlorophyll a concentrations, Secchi depths, and TSI data for Green Lake, East End, near Green Lake, Wisconsin. 


\section{GREEN LAKE INLET, SITE 1, NEAR GREEN LAKE, WI}

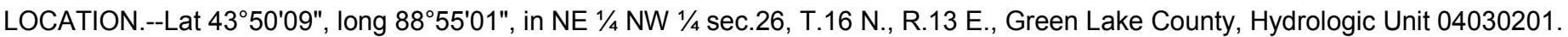

PERIOD OF RECORD.--May 2006 to current year.

REMARKS.--Water-quality analyses done by Wisconsin State Laboratory of Hygiene.

WATER-QUALITY DATA, APRIL 19 TO SEPTEMBER 29, 2010

(Milligrams per liter unless otherwise indicated)

\begin{tabular}{cll} 
Parameter Code & & Parameter Name \\
\cline { 1 - 2 } 00078 & & 00078 Secchi-depth $(\mathrm{m})$ \\
00098 & & 00098 Sampling depth $(\mathrm{m})$ \\
00010 & & 00010 Water Temperature $\left({ }^{\circ} \mathrm{C}\right)$ \\
00400 & & $00400 \mathrm{pH}$ (standard units) \\
00095 & 00095 Specific conductance $(\mu \mathrm{S} / \mathrm{cm})$ \\
00300 & 00300 Dissolved oxygen \\
00665 & 00665 Phosphorus, total (as P)
\end{tabular}

\begin{tabular}{cc} 
April 19 & June 29 \\
\hline 0.7 & 1.0 \\
0.5 & 0.1 \\
16.5 & 23.0 \\
8.4 & 7.6 \\
814 & 600 \\
13.7 & 4.0 \\
0.092 & 0.130
\end{tabular}

$\frac{\text { July } 13}{0.9}$
0.1
24.9
7.7
664
5.5
0.150

$\frac{\text { Aug. } 26}{1.0}$
0.5
22.2
7.9
830
4.6
0.175

\begin{tabular}{c} 
Sept. 29 \\
\hline 1.5 \\
0.5 \\
17.0 \\
8.1 \\
905 \\
9.8 \\
0.070
\end{tabular}




\title{
434948088552200 GREEN LAKE INLET, SITE 2, NEAR GREEN LAKE, WI
}

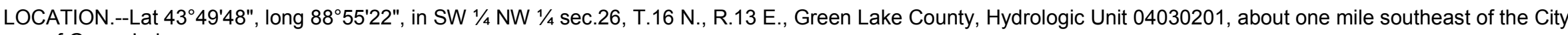
of Green Lake.

PERIOD OF RECORD.--May 2006 to current year.

REMARKS.--Water-quality analyses done by Wisconsin State Laboratory of Hygiene.

WATER-QUALITY DATA APRIL 19 TO SEPTEMBER 29, 2010

(Milligrams per liter unless otherwise indicated)

\begin{tabular}{c} 
Parameter Code \\
\hline 00078 \\
00098 \\
00010 \\
00400 \\
00095 \\
00300 \\
00665
\end{tabular}

\author{
Parameter Name \\ 00078 Secchi-depth $(\mathrm{m})$ \\ 00098 Sampling depth $(\mathrm{m})$ \\ 00010 Water Temperature $\left({ }^{\circ} \mathrm{C}\right)$ \\ $00400 \mathrm{pH}$ (standard units) \\ 00095 Specific conductance $(\mu \mathrm{S} / \mathrm{cm})$ \\ 00300 Dissolved oxygen \\ 00665 Phosphorus, total (as P)
}

\begin{tabular}{cc} 
April 19 & June 29 \\
\hline 0.8 & 1.0 \\
0.5 & 0.1 \\
15.8 & 22.3 \\
8.5 & 7.8 \\
747 & 703 \\
16.1 & 5.4 \\
0.063 & 0.177
\end{tabular}

\begin{tabular}{c} 
July 13 \\
\hline 0.8 \\
0.1 \\
24.5 \\
7.7 \\
671 \\
5.0 \\
0.144
\end{tabular}

\begin{tabular}{c} 
Aug. 26 \\
\hline 1.0 \\
0.5 \\
22.5 \\
7.9 \\
796 \\
5.6 \\
0.160
\end{tabular}

Sept. 29 


\section{LAKE KEGONSA AT BARBER DRIVE NEAR STOUGHTON, WI}

LOCATION.--Lat 4257'15", long 89¹6'47" referenced to North American Datum of 1927, in SW 1/4 NE 1/4 NE 1/4 Sec.26, T.6 N., R.10 E.,

Dane County, WI, Hydrologic Unit 07090001, on downstream side of bridge on Barber Drive, 3.5 mi northwest of Stoughton.

SURFACE AREA.--1.05 $\mathrm{mi}^{2}$.

DRAINAGE AREA.--386 $\mathrm{mi}^{2}$.

PERIOD OF RECORD.--October 2003 to current year.

GAGE.--Water-stage recorder. Datum of gage is $840.00 \mathrm{ft}$ above sea level (levels from Wisconsin Department of Transportation benchmark).

EXTREMES FOR PERIOD OF RECORD.--Maximum gage height observed, $5.73 \mathrm{ft}$, June 16, 2008; minimum observed, $2.07 \mathrm{ft}$, Jan.27, 2006.

EXTREMES FOR CURRENT YEAR.--Maximum gage height observed, $4.16 \mathrm{ft}$, June 27; minimum observed, $2.30 \mathrm{ft}$, Mar. 6-10.

\begin{tabular}{|c|c|c|c|c|c|c|c|c|c|c|c|c|}
\hline \multicolumn{13}{|c|}{$\begin{array}{c}\text { GAGE HEIGHT, FEET } \\
\text { WATER YEAR OCTOBER } 2009 \text { TO SEPTEMBER } 2010 \\
\text { DAILY MEAN VALUES }\end{array}$} \\
\hline \multicolumn{13}{|c|}{$[e$, estimated $]$} \\
\hline Day & Oct & Nov & Dec & Jan & Feb & Mar & Apr & May & Jun & Jul & Aug & Sep \\
\hline 1 & 3.15 & 3.35 & 3.26 & 3.40 & 2.67 & 2.35 & 2.56 & 3.58 & 3.48 & 4.00 & 3.53 & e3.19 \\
\hline 2 & 3.17 & 3.32 & 3.26 & 3.37 & 2.66 & 2.34 & 2.59 & 3.62 & 3.51 & 3.94 & 3.48 & e3.16 \\
\hline 3 & 3.16 & 3.28 & 3.24 & 3.34 & 2.64 & 2.34 & 2.64 & 3.63 & 3.54 & 3.88 & 3.43 & e3.22 \\
\hline 4 & 3.16 & 3.23 & 3.21 & 3.31 & 2.60 & 2.33 & 2.65 & 3.64 & 3.56 & 3.80 & 3.39 & e3.20 \\
\hline 5 & 3.16 & 3.18 & 3.20 & 3.28 & 2.58 & 2.32 & 2.69 & 3.63 & 3.60 & 3.76 & 3.33 & e3.20 \\
\hline 6 & 3.17 & 3.13 & 3.18 & 3.27 & 2.56 & 2.32 & 2.86 & 3.64 & 3.70 & 3.71 & 3.26 & e3.21 \\
\hline 7 & 3.17 & 3.09 & 3.18 & 3.26 & 2.54 & 2.31 & 3.04 & 3.67 & 3.73 & 3.67 & 3.20 & e3.19 \\
\hline 8 & 3.18 & 3.06 & 3.18 & 3.24 & 2.52 & 2.30 & 3.20 & 3.67 & 3.77 & 3.64 & 3.17 & e3.19 \\
\hline 9 & 3.17 & 3.03 & 3.28 & 3.22 & 2.52 & 2.30 & 3.29 & 3.67 & 3.80 & 3.60 & 3.21 & e3.20 \\
\hline 10 & 3.14 & 3.00 & 3.27 & 3.20 & 2.52 & 2.38 & 3.33 & 3.66 & 3.83 & 3.54 & 3.20 & e3.20 \\
\hline 11 & 3.12 & 2.98 & 3.33 & 3.17 & 2.51 & 2.50 & 3.34 & 3.69 & 3.88 & 3.49 & 3.18 & e3.17 \\
\hline 12 & 3.10 & 2.96 & 3.35 & 3.14 & 2.50 & 2.65 & 3.33 & 3.69 & 3.91 & 3.46 & 3.17 & e3.16 \\
\hline 13 & 3.10 & 2.95 & 3.40 & 3.12 & 2.48 & 2.77 & 3.31 & 3.75 & 3.92 & 3.42 & 3.23 & e3.15 \\
\hline 14 & 3.09 & 2.94 & 3.45 & 3.09 & 2.46 & 2.84 & 3.24 & 3.75 & 3.92 & 3.38 & 3.33 & e3.12 \\
\hline 15 & 3.09 & 2.94 & 3.47 & 3.06 & 2.45 & 2.87 & 3.17 & 3.75 & 3.92 & 3.37 & 3.34 & e3.10 \\
\hline 16 & 3.08 & 2.95 & 3.48 & 3.02 & 2.44 & 2.88 & 3.12 & 3.73 & 3.92 & 3.32 & 3.33 & e3.07 \\
\hline 17 & 3.06 & 2.96 & 3.48 & 2.99 & 2.43 & 2.86 & 3.06 & 3.69 & 3.90 & 3.29 & 3.34 & e3.04 \\
\hline 18 & 3.05 & 2.96 & 3.47 & 2.96 & 2.42 & 2.83 & 3.02 & 3.64 & 3.89 & 3.25 & 3.34 & e3.05 \\
\hline 19 & 3.04 & 2.98 & 3.45 & 2.93 & 2.40 & 2.80 & 2.99 & 3.60 & 3.87 & 3.22 & 3.36 & e3.04 \\
\hline 20 & 3.04 & 2.98 & 3.43 & 2.88 & 2.40 & 2.79 & 2.98 & 3.56 & 3.84 & 3.19 & 3.38 & e3.02 \\
\hline 21 & 3.04 & 3.00 & 3.39 & 2.84 & 2.39 & 2.76 & 3.02 & 3.54 & 3.85 & 3.16 & e3.39 & e3.02 \\
\hline 22 & 3.11 & 3.02 & 3.36 & 2.81 & 2.39 & 2.72 & 3.06 & 3.52 & 3.96 & 3.28 & 3.39 & e3.03 \\
\hline 23 & 3.21 & 3.02 & 3.32 & 2.77 & 2.39 & 2.68 & 3.10 & 3.50 & 4.01 & 3.50 & 3.37 & e3.01 \\
\hline 24 & 3.24 & 3.04 & 3.33 & 2.78 & 2.39 & 2.65 & 3.18 & 3.50 & 4.02 & 3.64 & 3.34 & e3.00 \\
\hline 25 & 3.27 & 3.11 & 3.39 & 2.80 & 2.38 & 2.64 & 3.32 & 3.49 & 4.02 & 3.68 & 3.30 & e2.98 \\
\hline 26 & 3.32 & 3.20 & 3.41 & 2.79 & 2.37 & 2.58 & 3.38 & 3.49 & 4.07 & 3.67 & 3.27 & 2.96 \\
\hline 27 & 3.35 & 3.23 & 3.43 & 2.76 & 2.37 & 2.55 & 3.43 & 3.50 & 4.12 & 3.66 & 3.23 & e2.94 \\
\hline 28 & 3.36 & 3.26 & 3.44 & 2.75 & 2.36 & 2.53 & 3.45 & 3.49 & 4.12 & 3.63 & 3.19 & 2.93 \\
\hline 29 & 3.36 & 3.28 & 3.44 & 2.74 & --- & 2.50 & 3.47 & 3.48 & 4.09 & 3.61 & 3.16 & 2.93 \\
\hline 30 & 3.41 & 3.27 & 3.44 & 2.72 & --- & 2.50 & 3.51 & 3.48 & 4.05 & 3.58 & e3.12 & 2.93 \\
\hline 31 & 3.37 & --- & 3.42 & 2.69 & --- & 2.52 & --- & 3.48 & --- & 3.57 & e3.09 & --- \\
\hline Mean & 3.18 & 3.09 & 3.35 & 3.02 & 2.48 & 2.57 & 3.11 & 3.60 & 3.86 & 3.55 & 3.29 & 3.09 \\
\hline Max & 3.41 & 3.35 & 3.48 & 3.40 & 2.67 & 2.88 & 3.51 & 3.75 & 4.12 & 4.00 & 3.53 & 3.22 \\
\hline Min & 3.04 & 2.94 & 3.18 & 2.69 & 2.36 & 2.30 & 2.56 & 3.48 & 3.48 & 3.16 & 3.09 & 2.93 \\
\hline
\end{tabular}




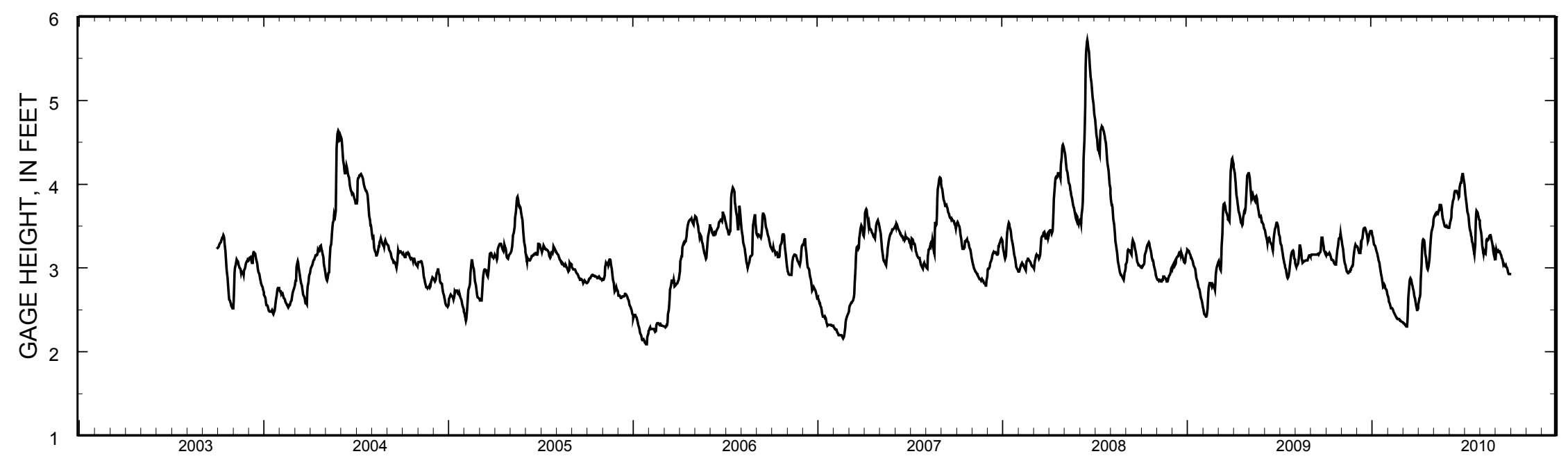

Stage hydrograph for Lake Kegonsa, 1993-2010. 


\section{LAKE KOSHKONONG NEAR NEWVILLE, WI}

LOCATION.--Lat 42 51'27", long 8856'27" referenced to North American Datum of 1927, in NW 1/4 NE 1/4 sec.34, T.5 N., R.13 E., Jefferson County, WI, Hydrologic Unit 07090001, $80 \mathrm{ft}$ east of Pottawatomi Trail Bridge at Bingham Point Estates, and $4.5 \mathrm{mi}$ northeast of Newville.

SURFACE AREA.-16.34 $\mathrm{mi}^{2}$

DRAINAGE AREA.--2,560 $\mathrm{mi}^{2}$.

PERIOD OF RECORD.--July 1987 to current year.

GAGE.--Water-stage recorder. Datum of gage is $769.77 \mathrm{ft}$ above NAVD of 1988 (Wisconsin Department of Transportation bench mark). REMARKS.--Lake level regulated by dam at Indianford. Gage-height telemeter at station.

EXTREMES FOR PERIOD OF RECORD.--Maximum recorded gage height, $15.13 \mathrm{ft}$, June 21, 22, 2008; minimum recorded, $5.06 \mathrm{ft}$, Feb. 22, 2007.

EXTREMES FOR CURRENT YEAR.--Maximum recorded gage height, $11.16 \mathrm{ft}$, July 31; minimum recorded gage height, $5.74 \mathrm{ft}$, Oct. 20.

\begin{tabular}{|c|c|c|c|c|c|c|c|c|c|c|c|c|}
\hline \multicolumn{13}{|c|}{$\begin{array}{c}\text { GAGE HEIGHT, FEET } \\
\text { WATER YEAR OCTOBER 2009 TO SEPTEMBER } 2010 \\
\text { DAILY MEAN VALUES }\end{array}$} \\
\hline Day & Oct & Nov & Dec & Jan & Feb & Mar & Apr & May & Jun & Jul & Aug & Sep \\
\hline 1 & 6.47 & 6.79 & 6.82 & 7.34 & 7.03 & 6.30 & 8.37 & 8.04 & 7.16 & 9.44 & 11.14 & 7.51 \\
\hline 2 & 6.53 & 6.90 & 6.87 & 7.35 & 6.99 & 6.30 & 8.26 & 8.05 & 7.06 & 9.37 & 11.08 & 7.41 \\
\hline 3 & 6.57 & 6.96 & 6.87 & 7.33 & 6.94 & 6.30 & 8.19 & 8.04 & 7.02 & 9.28 & 11.01 & 7.37 \\
\hline 4 & 6.59 & 7.00 & 6.87 & 7.29 & 6.89 & 6.30 & 8.06 & 8.00 & 6.99 & 9.16 & 10.92 & 7.32 \\
\hline 5 & 6.58 & 7.04 & 6.83 & 7.24 & 6.83 & 6.30 & 7.96 & 7.98 & 7.01 & 9.06 & 10.80 & 7.27 \\
\hline 6 & 6.62 & 7.03 & 6.81 & 7.19 & 6.78 & 6.31 & 7.96 & 7.91 & 7.19 & 8.94 & 10.66 & 7.26 \\
\hline 7 & 6.60 & 7.07 & 6.78 & 7.15 & 6.75 & 6.32 & 8.03 & 7.86 & 7.28 & 8.80 & 10.50 & 7.30 \\
\hline 8 & 6.54 & 7.06 & 6.76 & 7.10 & 6.71 & 6.34 & 8.14 & 7.85 & 7.39 & 8.65 & 10.35 & 7.27 \\
\hline 9 & 6.51 & 7.05 & 6.80 & 7.04 & 6.70 & 6.38 & 8.23 & 7.76 & 7.53 & 8.51 & 10.29 & 7.23 \\
\hline 10 & 6.47 & 7.00 & 6.73 & 6.98 & 6.68 & 6.52 & 8.36 & 7.68 & 7.57 & 8.37 & 10.16 & 7.18 \\
\hline 11 & 6.42 & 6.94 & 6.68 & 6.92 & 6.65 & 6.85 & 8.46 & 7.69 & 7.61 & 8.23 & 10.01 & 7.14 \\
\hline 12 & 6.38 & 6.87 & 6.63 & 6.87 & 6.61 & 7.35 & 8.50 & 7.69 & 7.64 & 8.12 & 9.86 & 7.09 \\
\hline 13 & 6.34 & 6.80 & 6.61 & 6.82 & 6.58 & 7.83 & 8.50 & 7.80 & 7.62 & 7.99 & 9.77 & 7.04 \\
\hline 14 & 6.29 & 6.77 & 6.59 & 6.78 & 6.56 & 8.22 & 8.47 & 7.93 & 7.58 & 7.85 & 9.81 & 6.97 \\
\hline 15 & 6.24 & 6.72 & 6.57 & 6.75 & 6.53 & 8.52 & 8.46 & 8.04 & 7.53 & 7.83 & 9.68 & 6.90 \\
\hline 16 & 6.12 & 6.65 & 6.54 & 6.72 & 6.51 & 8.76 & 8.45 & 8.14 & 7.50 & 7.87 & 9.52 & 6.86 \\
\hline 17 & 5.98 & 6.58 & 6.51 & 6.70 & 6.49 & 8.93 & 8.39 & 8.21 & 7.44 & 7.99 & 9.39 & 6.80 \\
\hline 18 & 5.85 & 6.52 & 6.48 & 6.69 & 6.47 & 9.03 & 8.30 & 8.24 & 7.43 & 8.13 & 9.25 & 6.82 \\
\hline 19 & 5.77 & 6.49 & 6.46 & 6.68 & 6.45 & 9.09 & 8.23 & 8.23 & 7.44 & 8.22 & 9.12 & 6.79 \\
\hline 20 & 5.75 & 6.47 & 6.44 & 6.66 & 6.44 & 9.13 & 8.16 & 8.18 & 7.40 & 8.30 & 8.98 & 6.75 \\
\hline 21 & 5.78 & 6.44 & 6.42 & 6.64 & 6.42 & 9.12 & 8.08 & 8.14 & 7.40 & 8.36 & 8.86 & 6.75 \\
\hline 22 & 5.83 & 6.43 & 6.41 & 6.62 & 6.39 & 9.10 & 7.98 & 8.08 & 7.69 & 8.50 & 8.74 & 6.74 \\
\hline 23 & 5.92 & 6.40 & 6.40 & 6.61 & 6.36 & 9.06 & 7.88 & 8.01 & 7.93 & 9.05 & 8.61 & 6.70 \\
\hline 24 & 6.02 & 6.39 & 6.43 & 6.64 & 6.35 & 9.01 & 7.86 & 7.95 & 8.34 & 9.57 & 8.48 & 6.76 \\
\hline 25 & 6.08 & 6.46 & 6.51 & 6.72 & 6.34 & 8.96 & 7.91 & 7.89 & 8.68 & 10.04 & 8.35 & 6.71 \\
\hline 26 & 6.19 & 6.59 & 6.65 & 6.84 & 6.33 & 8.87 & 7.94 & 7.85 & 8.99 & 10.43 & 8.21 & 6.65 \\
\hline 27 & 6.27 & 6.59 & 6.81 & 6.96 & 6.31 & 8.79 & 7.97 & 7.77 & 9.23 & 10.72 & 8.07 & 6.60 \\
\hline 28 & 6.36 & 6.65 & 6.96 & 7.04 & 6.31 & 8.73 & 7.99 & 7.65 & 9.40 & 10.93 & 7.95 & 6.56 \\
\hline 29 & 6.44 & 6.74 & 7.10 & 7.08 & --- & 8.63 & 7.97 & 7.52 & 9.46 & 11.03 & 7.83 & 6.51 \\
\hline 30 & 6.57 & 6.78 & 7.22 & 7.08 & --- & 8.53 & 7.99 & 7.37 & 9.47 & 11.07 & 7.69 & 6.48 \\
\hline 31 & 6.73 & --- & 7.30 & 7.07 & --- & 8.46 & --- & 7.29 & --- & 11.15 & 7.57 & --- \\
\hline Mean & 6.28 & 6.74 & 6.71 & 6.93 & 6.59 & 7.88 & 8.17 & 7.90 & 7.80 & 9.06 & 9.44 & 6.96 \\
\hline Max & 6.73 & 7.07 & 7.30 & 7.35 & 7.03 & 9.13 & 8.50 & 8.24 & 9.47 & 11.15 & 11.14 & 7.51 \\
\hline Min & 5.75 & 6.39 & 6.40 & 6.61 & 6.31 & 6.30 & 7.86 & 7.29 & 6.99 & 7.83 & 7.57 & 6.48 \\
\hline
\end{tabular}




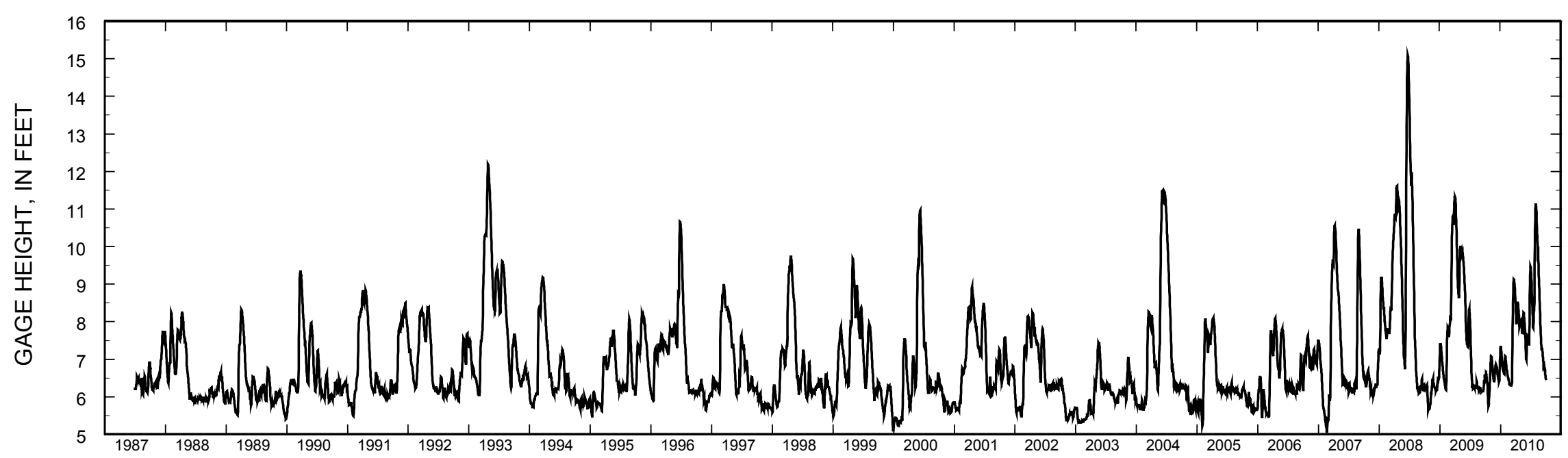

Stage hydrograph for Lake Koshkonong, 1987-2010. 


\section{LITTLE CEDAR LAKE, NORTH SITE, NEAR WEST BEND, WI}

LOCATION.--Lat 43²2'55", long 88¹3'47", in NW 1/4 NE 1/4 sec.33, T.11 N., R.19 E., Washington County, Hydrologic Unit 04040003 , 2.6 mi southwest of West Bend.

SURFACE AREA.--0.38 $\mathrm{mi}^{2}$.

PERIOD OF RECORD.--February 1997 to August 1999, February 2003 to current year.

REMARKS.--Lake sampled at center of northern basin at deep hole. Lake ice-covered during February sampling. Water-quality analyses done by Wisconsin State Laboratory of Hygiene.

WATER-QUALITY DATA, FEBRUARY 18 TO AUGUST 24, 2010

(Milligrams per liter unless otherwise indicated)

\begin{tabular}{|c|c|}
\hline Parameter Code & $\underline{\text { Parameter Name }}$ \\
\hline 32210 & Chlorophyll a $(\mu \mathrm{g} / \mathrm{L})$ \\
\hline 00078 & Secchi-depth (m) \\
\hline 00098 & Sampling depth $(\mathrm{m})$ \\
\hline 00010 & Water Temperature $\left({ }^{\circ} \mathrm{C}\right)$ \\
\hline 00400 & $\mathrm{pH}$ (standard units) \\
\hline 00095 & Specific conductance $(\mu \mathrm{S} / \mathrm{cm})$ \\
\hline 00300 & Dissolved oxygen \\
\hline 00665 & Phosphorus, total (as P) \\
\hline
\end{tabular}

\begin{tabular}{cc}
\multicolumn{2}{c}{ February 18} \\
\hline \multicolumn{2}{c}{--} \\
& - \\
0.5 & \\
0.4 & 4.0 \\
8.0 & 7.5 \\
563 & 618 \\
12.6 & 5.6 \\
0.010 & 0.014
\end{tabular}

\begin{tabular}{|c|c|}
\hline \multicolumn{2}{|c|}{ June 22} \\
\hline \multicolumn{2}{|c|}{3.92} \\
\hline \multicolumn{2}{|c|}{2.7} \\
\hline 0.5 & 8.5 \\
\hline 25.0 & 12.0 \\
\hline 8.5 & 7.1 \\
\hline 536 & 594 \\
\hline 10.8 & 0.4 \\
\hline 0.018 & 0.065 \\
\hline
\end{tabular}

\begin{tabular}{ccc}
\multicolumn{3}{c}{ July 21} \\
\hline \multicolumn{3}{c}{7.76} \\
& 1.8 & \\
0.5 & & 8.0 \\
27.9 & & 13.6 \\
7.8 & 6.8 \\
520 & 583 \\
7.6 & 0.7 \\
0.042 & 0.059
\end{tabular}

\begin{tabular}{|c|c|}
\hline \multicolumn{2}{|c|}{ August 24} \\
\hline \multicolumn{2}{|c|}{11.3} \\
\hline \multicolumn{2}{|c|}{2.0} \\
\hline 0.5 & 7.5 \\
\hline 26.4 & 14.3 \\
\hline 8.2 & 7.2 \\
\hline 518 & 589 \\
\hline 10.1 & 0.4 \\
\hline 0.031 & 0.228 \\
\hline
\end{tabular}


432255088134700 LITTLE CEDAR LAKE, NORTH SITE, NEAR WEST BEND, WI

LAKE-DEPTH PROFILES, FEBRUARY 18 TO AUGUST 24, 2010
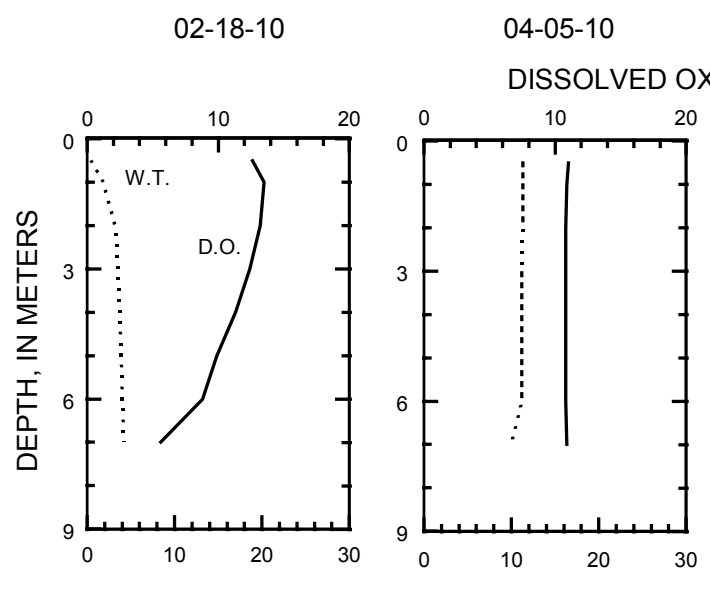

06-22-10

$07-21-10$

08-24-10

WATER TEMPERATURE (W.T.), IN DEGREES CELSIUS

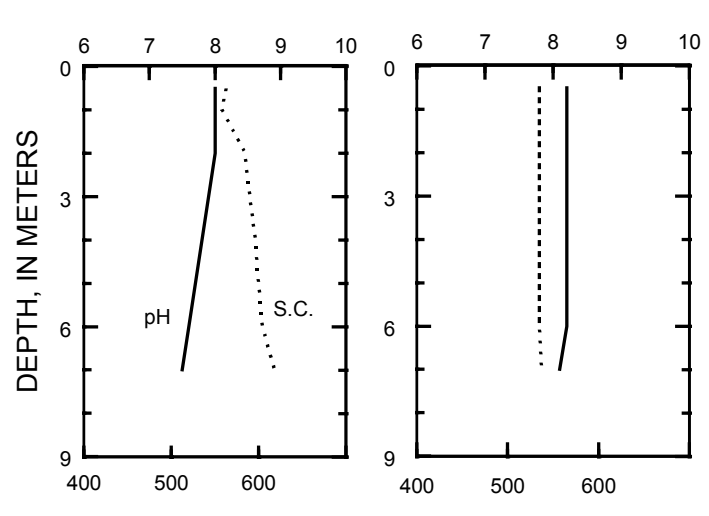

PH, IN STANDARD UNITS
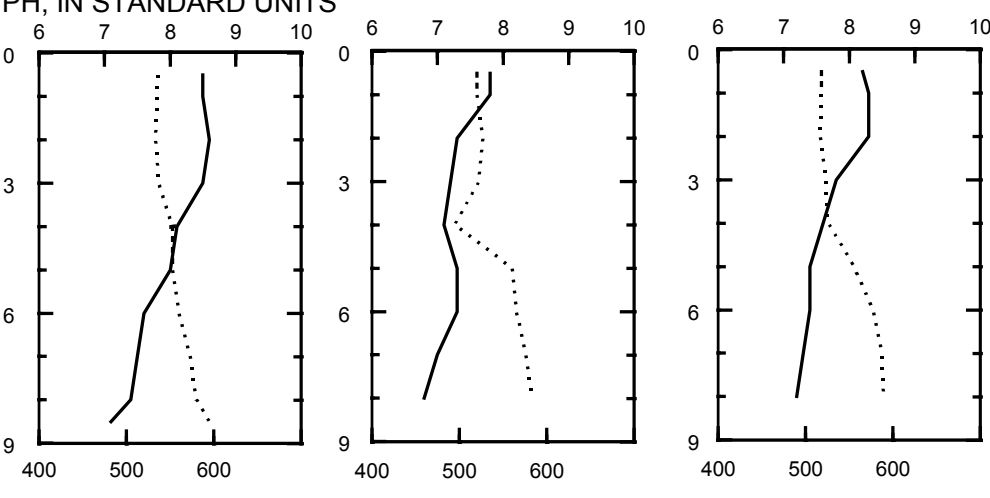

SPECIFIC CONDUCTANCE (S.C.), IN MICROSIEMENS PER CENTIMETER AT 25 DEGREES CELSIUS 

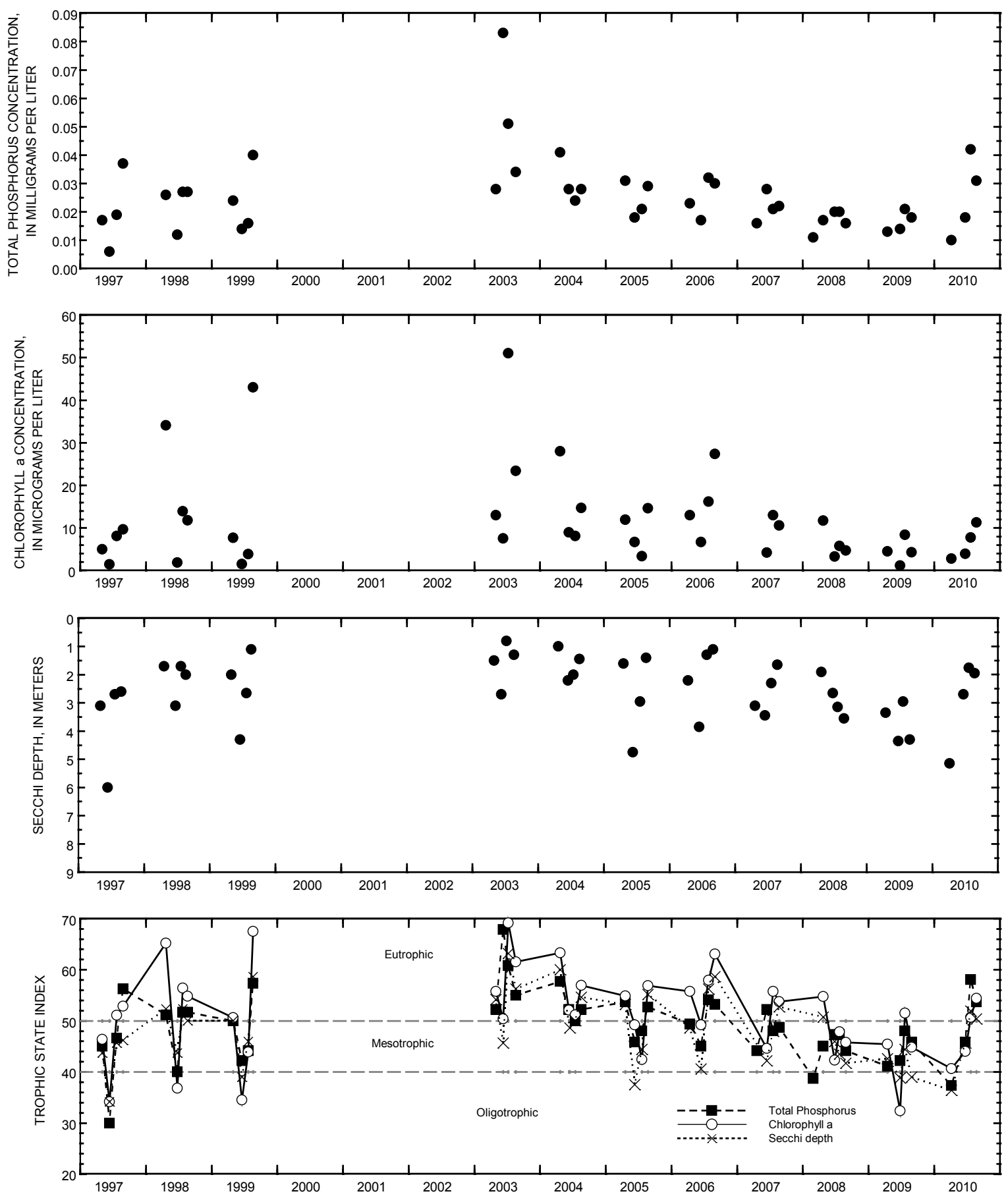

Surface total phosphorus, chlorophyll a concentrations, Secchi depths, and TSI data for Little Cedar Lake, North Site, near West Bend, Wisconsin. 


\section{LITTLE CEDAR LAKE, SOUTH SITE, NEAR WEST BEND, WI}

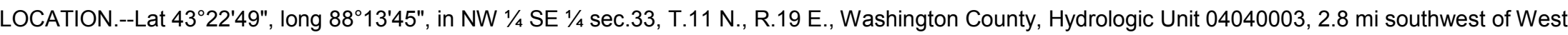
Bend.

SURFACE AREA.--0.38 $\mathrm{mi}^{2}$.

PERIOD OF RECORD.--February 1997 to August 1999, February 2003 to current year.

REMARKS.--Lake sampled in southern basin at deep hole. Lake ice-covered during February sampling. Water-quality analyses done by Wisconsin State Laboratory of Hygiene.

WATER-QUALITY DATA, FEBRUARY 18 TO AUGUST 24, 2010

(Milligrams per liter unless otherwise indicated)

\begin{tabular}{|c|c|}
\hline Parameter Code & $\underline{\text { Parameter Name }}$ \\
\hline 32210 & Chlorophyll a $(\mu \mathrm{g} / \mathrm{L})$ \\
\hline 00078 & Secchi-depth (m) \\
\hline 00098 & Sampling depth (m) \\
\hline 00010 & Water Temperature $\left({ }^{\circ} \mathrm{C}\right)$ \\
\hline 00400 & $\mathrm{pH}$ (standard units) \\
\hline 00095 & Specific conductance $(\mu \mathrm{S} / \mathrm{cm})$ \\
\hline 00300 & Dissolved oxygen \\
\hline 00665 & Phosphorus, total (as P) \\
\hline 00671 & Orthophosphate, dissolved (as P) \\
\hline 00631 & Nitrate plus nitrite, dissolved (as $\mathrm{N}$ ) \\
\hline 00608 & Ammonia, dissolved (as N) \\
\hline 00623 & Ammonia plus organic nitrogen, dissolved (as $\mathrm{N}$ ) \\
\hline 00625 & Ammonia plus organic nitrogen, total (as $\mathrm{N}$ ) \\
\hline 00600 & Total nitrogen \\
\hline 63675 & Turbidity, (NTU) \\
\hline 00081 & Apparent color, (PTU) \\
\hline 00900 & Hardness (as $\mathrm{CaCO} 3$ ) \\
\hline 00915 & Calcium, dissolved $(\mathrm{Ca})$ \\
\hline 00925 & Magnesium, dissolved (Mg) \\
\hline 00930 & Sodium, dissolved $(\mathrm{Na})$ \\
\hline 00935 & Potassium, dissolved $(\mathrm{K})$ \\
\hline 00417 & ANC (as CaCO3) \\
\hline 00940 & Chloride, dissolved $(\mathrm{Cl})$ \\
\hline 00945 & Sulfate, dissolved (SO4) \\
\hline 00955 & Silica, dissolved (SiO2) \\
\hline 01046 & Iron $(\mu \mathrm{g} / \mathrm{L})$ \\
\hline 01056 & Manganese $(\mu \mathrm{g} / \mathrm{L})$ \\
\hline 70300 & Solids, dissolved (at $180^{\circ} \mathrm{C}$ ) \\
\hline
\end{tabular}

\begin{tabular}{|c|c|c|c|}
\hline \multicolumn{2}{|c|}{ February 18} & \multicolumn{2}{|c|}{ April 5} \\
\hline \multicolumn{2}{|c|}{--} & \multicolumn{2}{|c|}{2.66} \\
\hline \multicolumn{2}{|c|}{-- } & \multicolumn{2}{|c|}{5.4} \\
\hline 0.5 & 16.0 & 0.5 & 16.0 \\
\hline 0.4 & 4.1 & 10.0 & 4.8 \\
\hline 8.2 & 7.3 & 8.2 & 7.5 \\
\hline 562 & 592 & 535 & 571 \\
\hline 13.5 & 0.9 & 12.0 & 6.8 \\
\hline 0.017 & 0.128 & 0.014 & -- \\
\hline-- & -- & 0.002 & -- \\
\hline-- & -- & 0.146 & -- \\
\hline -- & -- & 0.017 & -- \\
\hline-- & -- & -- & -- \\
\hline -- & -- & 0.36 & -- \\
\hline -- & -- & 0.51 & -- \\
\hline -- & -- & $<1.0$ & -- \\
\hline -- & -- & 5 & -- \\
\hline -- & -- & 226 & -- \\
\hline-- & -- & 35.5 & -- \\
\hline -- & -- & 33.4 & -- \\
\hline -- & -- & 23.1 & -- \\
\hline -- & -- & 1.6 & -- \\
\hline -- & -- & 183 & -- \\
\hline -- & -- & 52.7 & -- \\
\hline -- & -- & 20.4 & -- \\
\hline -- & -- & 2.46 & -- \\
\hline -- & -- & $<100$ & -- \\
\hline -- & -- & 2.1 & -- \\
\hline -- & -- & 302 & -- \\
\hline
\end{tabular}

\begin{tabular}{cc}
\multicolumn{2}{c}{ June 22 } \\
\hline \multicolumn{2}{c}{1.13} \\
\multicolumn{2}{c}{7.2} \\
0.5 & 15.5 \\
24.8 & 7.8 \\
8.4 & 7.0 \\
533 & 579 \\
10.2 & 0.6 \\
0.012 & 0.053 \\
-- & -- \\
-- & -- \\
-- & -- \\
-- & -- \\
-- & -- \\
-- & -- \\
-- & -- \\
-- & -- \\
-- & -- \\
-- & -- \\
-- & -- \\
-- & -- \\
-- & -- \\
-- & -- \\
-- & -- \\
-- & -- \\
-- & -- \\
-- & -- \\
-- & -- \\
-- & --
\end{tabular}

\begin{tabular}{|c|c|c|c|}
\hline \multicolumn{2}{|c|}{ July 21} & \multicolumn{2}{|c|}{ August 24} \\
\hline \multicolumn{2}{|c|}{2.49} & \multicolumn{2}{|c|}{4.05} \\
\hline \multicolumn{2}{|c|}{4.8} & \multicolumn{2}{|c|}{2.6} \\
\hline 0.5 & 17.0 & 0.5 & 0.5 \\
\hline 22.7 & 8.5 & 26.4 & 8.9 \\
\hline 8.4 & 6.8 & 8.4 & 7.2 \\
\hline 505 & 585 & 505 & 585 \\
\hline 8.6 & 0.4 & 8.7 & 0.1 \\
\hline 0.025 & 0.114 & 0.018 & 0.192 \\
\hline 0.003 & -- & -- & -- \\
\hline$<0.019$ & -- & -- & -- \\
\hline$<0.015$ & -- & -- & -- \\
\hline 0.40 & -- & -- & -- \\
\hline-- & -- & -- & -- \\
\hline-- & -- & -- & -- \\
\hline-- & -- & -- & -- \\
\hline-- & -- & -- & -- \\
\hline-- & -- & -- & -- \\
\hline-- & -- & -- & -- \\
\hline-- & -- & -- & -- \\
\hline-- & -- & -- & -- \\
\hline-- & -- & -- & -- \\
\hline-- & -- & -- & -- \\
\hline-- & -- & -- & -- \\
\hline-- & -- & -- & -- \\
\hline-- & -- & -- & -- \\
\hline-- & -- & -- & -- \\
\hline-- & -- & -- & -- \\
\hline-- & -- & -- & -- \\
\hline
\end{tabular}


432249088134500 LITTLE CEDAR LAKE, SOUTH SITE, NEAR WEST BEND, WI

LAKE-DEPTH PROFILES, FEBRUARY 18 TO AUGUST 24, 2010

02-18-10
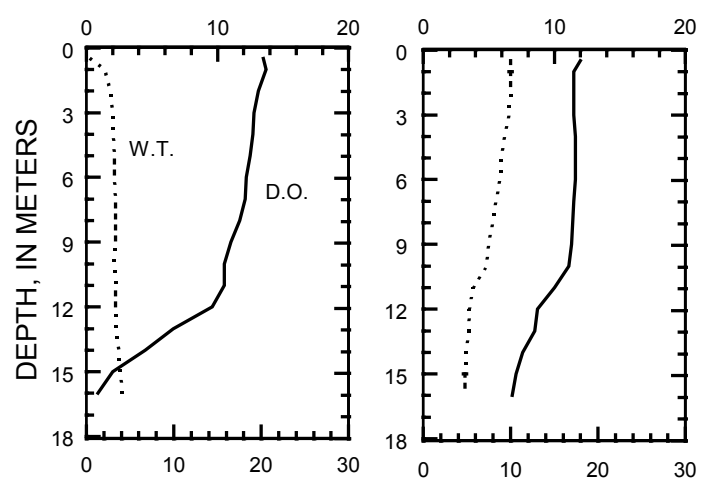

06-22-10

07-21-10

$08-24-10$

WATER TEMPERATURE (W.T.), IN DEGREES CELSIUS
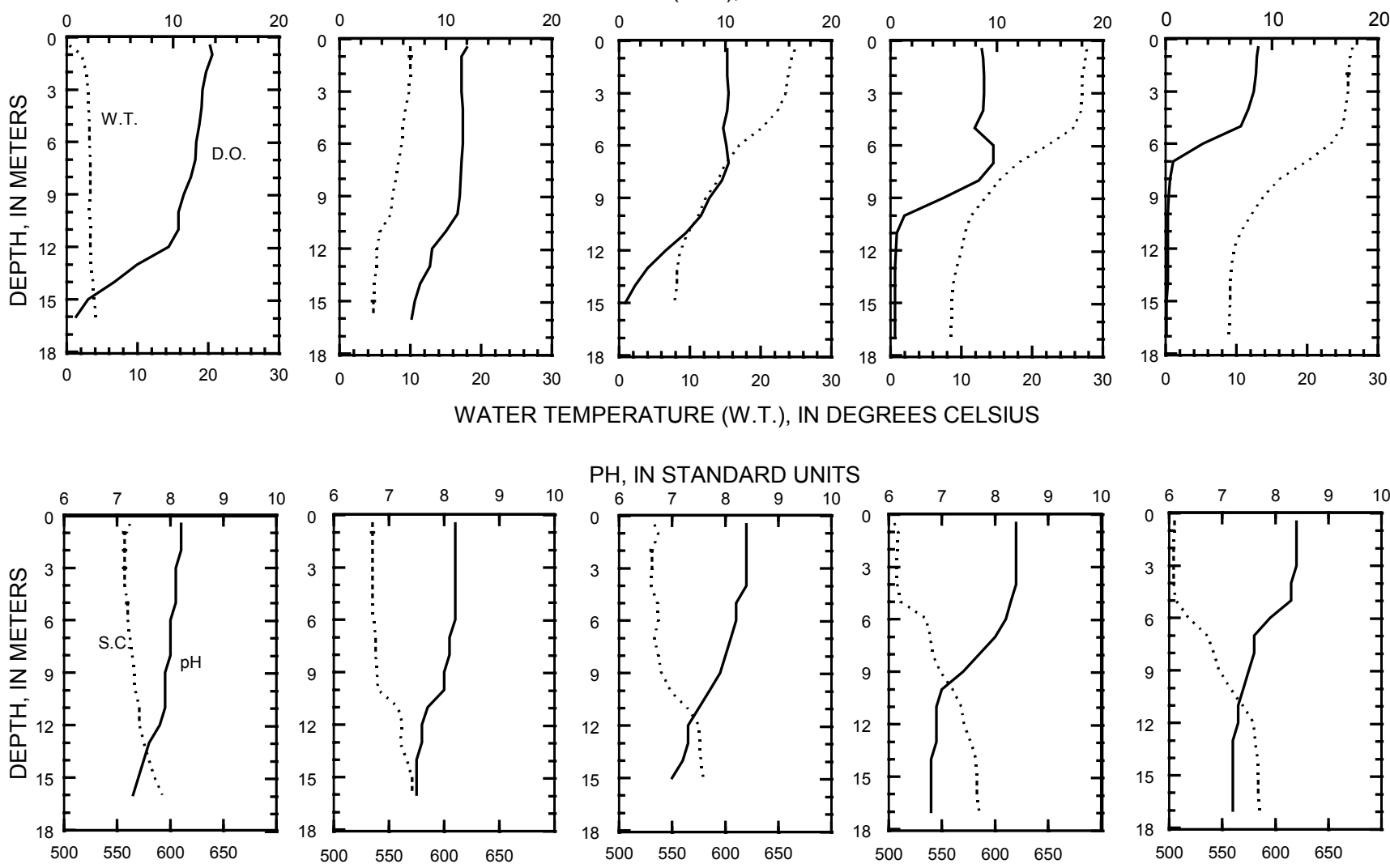

PH, IN STANDARD UNITS
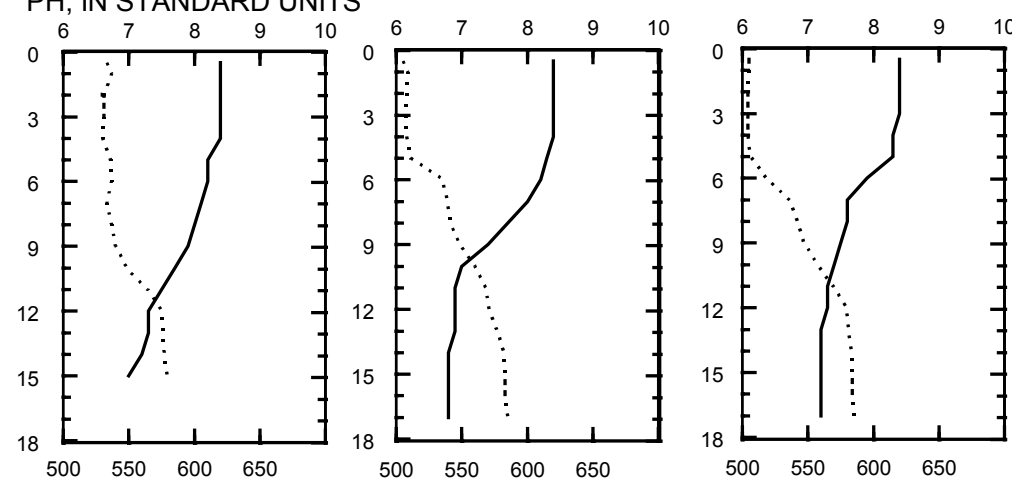

SPECIFIC CONDUCTANCE (S.C.), IN MICROSIEMENS PER CENTIMETER AT 25 DEGREES CELSIUS 

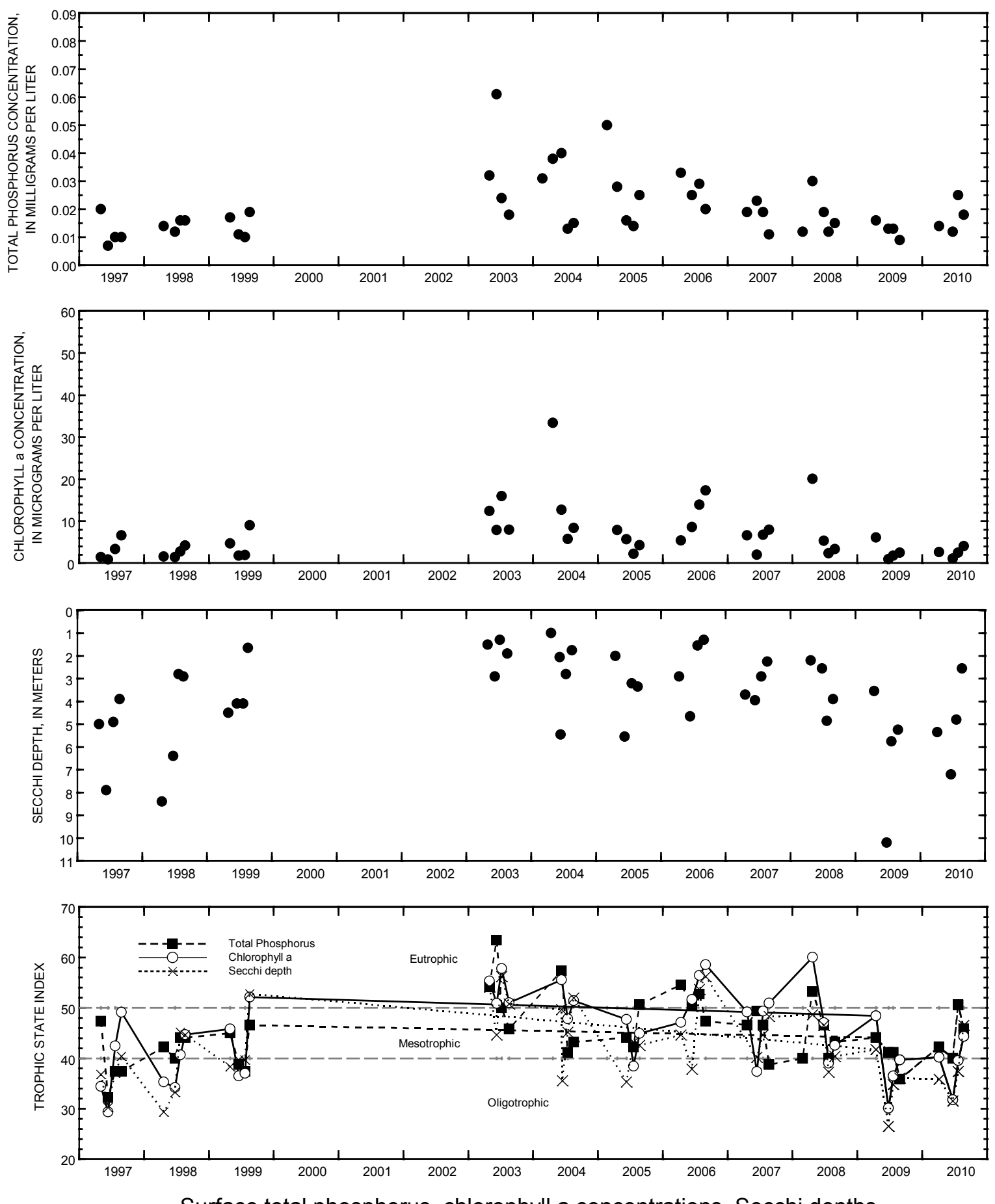

Surface total phosphorus, chlorophyll a concentrations, Secchi depths, and TSI data for Little Cedar Lake, South Site, near West Bend, Wisconsin. 


\section{LAKE MENDOTA AT MADISON, WI}

LOCATION.--Lat 4305'42", long 89²2'12" referenced to North American Datum of 1927, in NW 1/4 SE 1/4 sec.12, T.7 N., R.9 E., Dane County, WI, Hydrologic Unit 07090001, in county boat house at dam at outlet, in Madison.

SURFACE AREA.-15.2 $\mathrm{mi}^{2}$.

DRAINAGE AREA.--233 $\mathrm{mi}^{2}$ of which $36.6 \mathrm{mi}^{2}$ probably is noncontributing.

PERIOD OF RECORD.--January 1916 to January 1985 (incomplete), February 1985 to current year.

REVISED RECORDS.--WDR WI-73-1: Drainage area.

GAGE.--Water-stage recorder. Datum of gage is $840.00 \mathrm{ft}$ above NGVD of 1929, or $5.60 \mathrm{ft}$ below City of Madison datum. Prior to Oct. 1 , 1979, gage datum was $847.82 \mathrm{ft}$; prior to Nov. 15, 1971, nonrecording gage at same site.

REMARKS.--Lake level regulated by concrete dam with two 12-foot gates and 20-foot lock at outlet. Gage-height telemeter at station.

EXTREMES FOR PERIOD OF RECORD.--Maximum gage height observed, $12.75 \mathrm{ft}$, June 5, 2000; minimum observed, $8.02 \mathrm{ft}$, Feb. 24 to Mar. 10, 1920, current datum.

EXTREMES FOR CURRENT YEAR.--Maximum recorded gage height, $11.46 \mathrm{ft}$, Aug. 15; minimum recorded, $8.23 \mathrm{ft}$, Jan. 16.

\begin{tabular}{|c|c|c|c|c|c|c|c|c|c|c|c|c|}
\hline \multicolumn{13}{|c|}{$\begin{array}{l}\text { GAGE HEIGHT, FEET } \\
\text { OCTOBER } 2009 \text { TO SEPTEMBER } 2010 \\
\text { DAILY MEAN VALUES }\end{array}$} \\
\hline Day & Oct & Nov & Dec & Jan & Feb & Mar & Apr & May & Jun & Jul & Aug & Sep \\
\hline 1 & 10.19 & 10.33 & 9.27 & 8.60 & 8.42 & 8.39 & 9.29 & 9.85 & 9.97 & 10.83 & 11.29 & 11.18 \\
\hline 2 & 10.22 & 10.34 & 9.25 & 8.57 & 8.43 & 8.39 & 9.30 & 9.87 & 9.94 & 10.80 & 11.26 & 11.24 \\
\hline 3 & 10.22 & 10.32 & 9.20 & 8.54 & 8.43 & 8.40 & 9.34 & 9.88 & 9.93 & 10.77 & 11.25 & 11.32 \\
\hline 4 & 10.20 & 10.31 & 9.16 & 8.50 & 8.42 & 8.41 & 9.35 & 9.87 & 9.92 & 10.74 & 11.23 & 11.28 \\
\hline 5 & 10.17 & 10.29 & 9.09 & 8.47 & 8.42 & 8.42 & 9.37 & 9.90 & 9.96 & 10.72 & 11.21 & 11.24 \\
\hline 6 & 10.19 & 10.24 & 9.05 & 8.44 & 8.42 & 8.43 & 9.49 & 9.87 & 10.10 & 10.70 & 11.16 & 11.22 \\
\hline 7 & 10.16 & 10.23 & 9.03 & 8.43 & 8.41 & 8.44 & 9.63 & 9.90 & 10.09 & 10.71 & 11.12 & 11.21 \\
\hline 8 & 10.15 & 10.21 & 8.99 & 8.43 & 8.41 & 8.45 & 9.76 & 9.94 & 10.11 & 10.72 & 11.16 & 11.17 \\
\hline 9 & 10.14 & 10.19 & 9.11 & 8.40 & 8.44 & 8.48 & 9.81 & 9.92 & 10.17 & 10.68 & 11.25 & 11.14 \\
\hline 10 & 10.11 & 10.13 & 9.04 & 8.37 & 8.44 & 8.55 & 9.85 & 9.92 & 10.15 & 10.64 & 11.27 & 11.11 \\
\hline 11 & 10.07 & 10.08 & 8.97 & 8.34 & 8.43 & 8.65 & 9.88 & 9.98 & 10.14 & 10.58 & 11.27 & 11.11 \\
\hline 12 & 10.05 & 10.02 & 8.93 & 8.32 & 8.43 & 8.76 & 9.90 & 10.01 & 10.14 & 10.54 & 11.26 & 11.09 \\
\hline 13 & 10.02 & 9.96 & 8.89 & 8.32 & 8.43 & 8.87 & 9.90 & 10.16 & 10.13 & 10.49 & 11.29 & 11.08 \\
\hline 14 & 10.0 & 9.92 & 8.87 & 8.32 & 8.42 & 8.95 & 9.90 & 10.24 & 10.12 & 10.43 & 11.41 & 11.05 \\
\hline 15 & 9.99 & 9.86 & 8.85 & 8.32 & 8.42 & 9.00 & 9.89 & 10.26 & 10.14 & 10.52 & 11.42 & 11.02 \\
\hline 16 & 9.98 & 9.80 & 8.76 & 8.31 & 8.42 & 9.04 & 9.90 & 10.27 & 10.20 & 10.56 & 11.38 & 11.01 \\
\hline 17 & 9.96 & 9.75 & 8.75 & 8.32 & 8.42 & 9.07 & 9.87 & 10.26 & 10.19 & 10.55 & 11.35 & 10.97 \\
\hline 18 & 9.92 & 9.70 & 8.72 & 8.32 & 8.41 & 9.09 & 9.83 & 10.25 & 10.20 & 10.54 & 11.32 & 11.03 \\
\hline 19 & 9.91 & 9.66 & 8.69 & 8.31 & 8.41 & 9.12 & 9.80 & 10.22 & 10.19 & 10.49 & 11.30 & 11.03 \\
\hline 20 & 9.90 & 9.60 & 8.65 & 8.31 & 8.41 & 9.16 & 9.77 & 10.19 & 10.16 & 10.45 & 11.30 & 11.01 \\
\hline 21 & 9.89 & 9.56 & 8.61 & 8.31 & 8.41 & 9.18 & 9.74 & 10.18 & 10.16 & 10.41 & 11.31 & 11.01 \\
\hline 22 & 9.93 & 9.51 & 8.59 & 8.31 & 8.42 & 9.20 & 9.72 & 10.16 & 10.27 & 10.47 & 11.30 & 11.00 \\
\hline 23 & 10.07 & 9.46 & 8.56 & 8.30 & 8.42 & 9.21 & 9.70 & 10.13 & 10.46 & 10.79 & 11.28 & 10.98 \\
\hline 24 & 10.13 & 9.42 & 8.58 & 8.36 & 8.41 & 9.22 & 9.70 & 10.11 & 10.60 & 11.10 & 11.26 & 10.99 \\
\hline 25 & 10.14 & 9.44 & 8.65 & 8.40 & 8.41 & 9.23 & 9.78 & 10.11 & 10.67 & 11.29 & 11.23 & 10.94 \\
\hline 26 & 10.16 & 9.47 & 8.69 & 8.42 & 8.40 & 9.23 & 9.80 & 10.13 & 10.77 & 11.34 & 11.19 & 10.89 \\
\hline 27 & 10.16 & 9.42 & 8.71 & 8.43 & 8.40 & 9.24 & 9.80 & 10.17 & 10.86 & 11.35 & 11.15 & 10.85 \\
\hline 28 & 10.16 & 9.39 & 8.70 & 8.43 & 8.40 & 9.25 & 9.79 & 10.14 & 10.90 & 11.37 & 11.12 & 10.82 \\
\hline 29 & 10.16 & 9.37 & 8.67 & 8.43 & --- & 9.25 & 9.79 & 10.09 & 10.88 & 11.35 & 11.09 & 10.78 \\
\hline 30 & 10.28 & 9.32 & 8.65 & 8.43 & --- & 9.25 & 9.81 & 10.05 & 10.86 & 11.32 & 11.07 & 10.74 \\
\hline 31 & 10.33 & --- & 8.63 & 8.42 & --- & 9.27 & --- & 10.02 & --- & 11.31 & 11.07 & --- \\
\hline Mean & 10.10 & 9.84 & 8.85 & 8.39 & 8.42 & 8.89 & 9.72 & 10.07 & 10.28 & 10.79 & 11.24 & 11.05 \\
\hline Max & 10.33 & 10.34 & 9.27 & 8.60 & 8.44 & 9.27 & 9.90 & 10.27 & 10.90 & 11.37 & 11.42 & 11.32 \\
\hline Min & 9.89 & 9.32 & 8.56 & 8.30 & 8.40 & 8.39 & 9.29 & 9.85 & 9.92 & 10.41 & 11.07 & 10.74 \\
\hline
\end{tabular}




\section{MIDDLE GENESEE LAKE, AT GENESEE LAKE ROAD, NEAR OCONOMOWOC, WI}

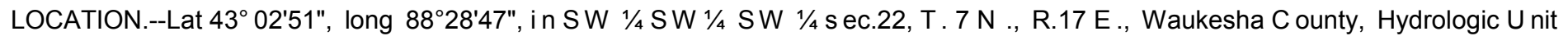
07090001 , at the southwest side of the lake about 2 miles south of Oconomowoc.

SURFACE AREA.--0.17 $\mathrm{mi}^{2}$.

DRAINAGE AREA.--Unknown.

PERIOD OF RECORD.--April 1996 to current year.

GAGE.--Staff gage. Local observer, Tom Schubring provided most readings of gage. Datum of gage is about $0.0 \mathrm{ft}$ above NGVD of 1929.

EXTREMES FOR THE PERIOD OF RECORD.--Maximum observed gage height, 869.65 ft, July 12, 2008; minimum observed, 863.88 ft, Oct. 31, 2005.

EXTREMES FOR CURRENT YEAR.--Maximum observed gage height, 868.50 ft, Aug. 9; minimum observed, $866.51 \mathrm{ft}$, Oct. 21.

GAGE HEIGHT, FT

WATER YEAR OCTOBER 2009 TO SEPTEMBER 2010

\begin{tabular}{|c|c|c|c|c|c|}
\hline Date & Gage Height, ft & Date & Gage Height, ft & Date & Gage Height, ft \\
\hline October 2 & 866.69 & June 11 & 866.74 & August 9 & 868.50 \\
\hline 10 & 866.61 & 16 & 866.84 & 12 & 868.48 \\
\hline 12 & 866.59 & 20 & 866.82 & 13 & 868.44 \\
\hline 17 & 866.53 & 22 & 866.90 & 14 & 868.48 \\
\hline 21 & 866.51 & 23 & 867.18 & 16 & 868.42 \\
\hline 24 & 866.63 & 25 & 867.40 & 18 & 868.40 \\
\hline 28 & 866.65 & 26 & 867.18 & 19 & 868.36 \\
\hline 30 & 866.71 & 27 & 867.28 & 21 & 868.38 \\
\hline November 1 & 866.69 & 30 & 867.32 & 25 & 868.28 \\
\hline 14 & 866.67 & July 1 & 867.34 & 26 & 868.26 \\
\hline 12 & 866.53 & 7 & 867.42 & 28 & 868.22 \\
\hline 27 & 866.61 & 11 & 867.42 & 31 & 868.14 \\
\hline 30 & 866.57 & 12 & 867.44 & September 1 & 868.14 \\
\hline December 6 & 866.53 & 14 & 867.42 & 4 & 868.08 \\
\hline May 19 & 866.70 & 15 & 867.70 & 8 & 868.00 \\
\hline 20 & 866.70 & 17 & 867.72 & 13 & 867.92 \\
\hline 25 & 866.68 & 23 & 868.02 & 17 & 867.80 \\
\hline 31 & 866.60 & 27 & 868.38 & 23 & 867.78 \\
\hline June 1 & 866.58 & 31 & 868.42 & 26 & 867.68 \\
\hline 3 & 866.68 & August 1 & 868.46 & 30 & 867.58 \\
\hline 6 & 866.78 & 6 & 868.44 & & \\
\hline
\end{tabular}




\section{LAKE MONONA AT MADISON, WI}

LOCATION.--Lat 4303'48", long 89²3'49" referenced to North American Datum of 1927, in SE 1/4 SW 1/4 Sec.23, T.7 N., R.9 E., Dane County, WI, Hydrologic Unit 07090001, in Brittingham Park, in Madison.

SURFACE AREA.--5.3 $\mathrm{mi}^{2}$.

DRAINAGE AREA.--279 $\mathrm{mi}^{2}$ of which $36.6 \mathrm{mi}^{2}$ probably is noncontributing.

PERIOD OF RECORD.--September 1915 to current year (fragmentary) in reports of the Geological Survey. For 1856 to March 1917 in reports of Wisconsin Railroad Commission, volume 19.

REVISED RECORDS.--WSP 1338: Lake area. WDR WI-73-1: Drainage area.

GAGE.--Water-stage recorder. Datum of gage is $840.00 \mathrm{ft}$ above NGVD of 1929, or $5.60 \mathrm{ft}$ below City of Madison datum. Prior to Oct. 1 , 1979, datum $843.61 \mathrm{ft}$; prior to Nov. 15, 1971, nonrecording gage at same site.

REMARKS.--Lake level regulated by concrete dam with four 12-foot stop-log sections and 12-foot lock at outlet of Lake Waubesa. Gage-height telemeter at station.

EXTREMES FOR PERIOD OF RECORD.--Maximum gage height observed, $7.92 \mathrm{ft}$, June 15, 2008; minimum observed, $3.22 \mathrm{ft}$, Jan. 20,1965 , current datum.

EXTREMES FOR CURRENT YEAR.--Maximum recorded gage height, 7.08 ft, Aug. 14; minimum recorded, $4.03 \mathrm{ft}$, Apr. 2. 


\begin{tabular}{|c|c|c|c|c|c|c|c|c|c|c|c|c|}
\hline \multicolumn{13}{|c|}{$\begin{array}{l}\text { GAGE HEIGHT, FEET } \\
\text { WATER YEAR OCTOBER } 2009 \text { TO SEPTEMBER } 2010 \\
\text { DAILY MEAN VALUES }\end{array}$} \\
\hline Day & Oct & Nov & Dec & Jan & Feb & Mar & Apr & May & Jun & Jul & Aug & Sep \\
\hline 1 & 5.66 & 5.29 & 5.32 & 5.15 & 4.49 & 4.29 & 4.15 & 5.16 & 5.64 & 6.41 & 6.77 & 6.65 \\
\hline 2 & 5.70 & 5.23 & 5.30 & 5.13 & 4.51 & 4.28 & 4.14 & 5.16 & 5.66 & 6.36 & 6.75 & 6.70 \\
\hline 3 & 5.67 & 5.18 & 5.26 & 5.10 & 4.50 & 4.25 & 4.14 & 5.13 & 5.69 & 6.32 & 6.73 & 6.83 \\
\hline 4 & 5.64 & 5.15 & 5.23 & 5.07 & 4.48 & 4.22 & 4.12 & 5.13 & 5.74 & 6.28 & 6.70 & 6.78 \\
\hline 5 & 5.62 & 5.13 & 5.21 & 5.05 & 4.47 & 4.20 & 4.11 & 5.08 & 5.82 & 6.27 & 6.65 & 6.75 \\
\hline 6 & 5.61 & 5.11 & 5.19 & 5.03 & 4.45 & 4.19 & 4.25 & 5.06 & 5.98 & 6.27 & 6.62 & 6.73 \\
\hline 7 & 5.59 & 5.11 & 5.17 & 5.02 & 4.44 & 4.17 & 4.39 & 5.06 & 6.01 & 6.32 & 6.59 & 6.65 \\
\hline 8 & 5.58 & 5.10 & 5.18 & 5.01 & 4.44 & 4.17 & 4.54 & 5.02 & 6.09 & 6.37 & 6.67 & 6.62 \\
\hline 9 & 5.55 & 5.10 & 5.26 & 4.99 & 4.46 & 4.17 & 4.59 & 5.00 & 6.10 & 6.33 & 6.79 & 6.58 \\
\hline 10 & 5.50 & 5.14 & 5.23 & 4.97 & 4.45 & 4.22 & 4.59 & 4.99 & 6.11 & 6.30 & 6.81 & 6.54 \\
\hline 11 & 5.46 & 5.17 & 5.23 & 4.94 & 4.43 & 4.30 & 4.58 & 5.06 & 6.13 & 6.28 & 6.79 & 6.51 \\
\hline 12 & 5.43 & 5.20 & 5.22 & 4.90 & 4.42 & 4.38 & 4.56 & 5.05 & 6.15 & 6.28 & 6.78 & 6.47 \\
\hline 13 & 5.39 & 5.23 & 5.21 & 4.84 & 4.42 & 4.42 & 4.58 & 5.19 & 6.13 & 6.27 & 6.86 & 6.43 \\
\hline 14 & 5.37 & 5.25 & 5.18 & 4.78 & 4.40 & 4.44 & 4.59 & 5.20 & 6.13 & 6.26 & 7.05 & 6.39 \\
\hline 15 & 5.35 & 5.25 & 5.15 & 4.72 & 4.40 & 4.44 & 4.61 & 5.21 & 6.14 & 6.34 & 7.03 & 6.36 \\
\hline 16 & 5.31 & 5.26 & 5.09 & 4.66 & 4.39 & 4.44 & 4.63 & 5.21 & 6.15 & 6.33 & 6.99 & 6.32 \\
\hline 17 & 5.27 & 5.27 & 5.08 & 4.62 & 4.40 & 4.43 & 4.63 & 5.19 & 6.14 & 6.33 & 6.96 & 6.29 \\
\hline 18 & 5.23 & 5.29 & 5.07 & 4.58 & 4.37 & 4.41 & 4.67 & 5.19 & 6.14 & 6.31 & 6.93 & 6.37 \\
\hline 19 & 5.20 & 5.30 & 5.04 & 4.55 & 4.37 & 4.39 & 4.72 & 5.22 & 6.11 & 6.30 & 6.89 & 6.36 \\
\hline 20 & 5.19 & 5.30 & 5.03 & 4.52 & 4.44 & 4.39 & 4.76 & 5.25 & 6.09 & 6.30 & 6.88 & 6.32 \\
\hline 21 & 5.15 & 5.30 & 5.02 & 4.49 & 4.40 & 4.37 & 4.81 & 5.31 & 6.13 & 6.28 & 6.88 & 6.29 \\
\hline 22 & 5.18 & 5.31 & 5.02 & 4.45 & 4.38 & 4.35 & 4.83 & 5.33 & 6.36 & 6.41 & 6.83 & 6.26 \\
\hline 23 & 5.30 & 5.32 & 5.02 & 4.44 & 4.38 & 4.33 & 4.86 & 5.35 & 6.48 & 6.70 & 6.79 & 6.23 \\
\hline 24 & 5.32 & 5.33 & 5.07 & 4.49 & 4.39 & 4.31 & 4.91 & 5.38 & 6.51 & 6.85 & 6.74 & 6.21 \\
\hline 25 & 5.31 & 5.39 & 5.20 & 4.52 & 4.39 & 4.29 & 5.02 & 5.45 & 6.48 & 6.91 & 6.68 & 6.19 \\
\hline 26 & 5.30 & 5.43 & 5.26 & 4.50 & 4.41 & 4.26 & 5.06 & 5.51 & 6.55 & 6.91 & 6.63 & 6.18 \\
\hline 27 & 5.27 & 5.42 & 5.27 & 4.48 & 4.39 & 4.24 & 5.08 & 5.56 & 6.59 & 6.89 & 6.59 & 6.18 \\
\hline 28 & 5.24 & 5.41 & 5.25 & 4.47 & 4.32 & 4.22 & 5.09 & 5.55 & 6.57 & 6.87 & 6.56 & 6.17 \\
\hline 29 & 5.22 & 5.39 & 5.22 & 4.45 & --- & 4.19 & 5.10 & 5.58 & 6.52 & 6.83 & 6.53 & 6.16 \\
\hline 30 & 5.33 & 5.34 & 5.21 & 4.44 & --- & 4.18 & 5.13 & 5.61 & 6.47 & 6.80 & 6.50 & 6.17 \\
\hline 31 & 5.32 & --- & 5.19 & 4.47 & --- & 4.18 & --- & 5.63 & --- & 6.80 & 6.49 & --- \\
\hline Mean & 5.40 & 5.26 & 5.17 & 4.74 & 4.42 & 4.29 & 4.64 & 5.25 & 6.16 & 6.47 & 6.76 & 6.42 \\
\hline Max & 5.70 & 5.43 & 5.32 & 5.15 & 4.51 & 4.44 & 5.13 & 5.63 & 6.59 & 6.91 & 7.05 & 6.83 \\
\hline Min & 5.15 & 5.10 & 5.02 & 4.44 & 4.32 & 4.17 & 4.11 & 4.99 & 5.64 & 6.26 & 6.49 & 6.16 \\
\hline
\end{tabular}




\section{OCONOMOWOC LAKE NO. 1 (CENTER) AT OCONOMOWOC, WI}

LOCATION.--Lat 4305'51", long 88²7'35", in NW 1/4 SE 1/4 sec.2, T.7 N., R.17 E., Waukesha County, Hydrologic Unit 07090001, at Oconomowoc. SURFACE AREA.--1.20 $\mathrm{mi}^{2}$.

PERIOD OF RECORD.--March 1986 to current year.

REMARKS.--Lake sampled near center at the deep hole. Lake ice-covered during February sampling. Water-quality analyses done by Wisconsin State Laboratory of Hygiene.

WATER-QUALITY DATA, FEBRUARY 17 TO AUGUST 26, 2010

(Milligrams per liter unless otherwise indicated)

\begin{tabular}{|c|c|c|c|c|c|c|c|c|c|c|c|}
\hline Parameter Code & Parameter Name & \multicolumn{2}{|c|}{ February 17} & \multicolumn{2}{|c|}{ April 7} & \multicolumn{2}{|c|}{ June 24} & \multicolumn{2}{|c|}{ July 27} & \multicolumn{2}{|c|}{ August 26} \\
\hline 32210 & Chlorophyll a $(\mu \mathrm{g} / \mathrm{L})$ & \multicolumn{2}{|c|}{--} & \multicolumn{2}{|c|}{2.07} & \multicolumn{2}{|c|}{3.39} & \multicolumn{2}{|c|}{6.1} & \multicolumn{2}{|c|}{5.88} \\
\hline 00078 & Secchi-depth (m) & \multicolumn{2}{|c|}{--} & \multicolumn{2}{|c|}{6.6} & \multicolumn{2}{|c|}{3.0} & \multicolumn{2}{|c|}{1.8} & \multicolumn{2}{|c|}{2.2} \\
\hline 00098 & Sampling depth (m) & 0.5 & 18.0 & 0.5 & 18.0 & 0.5 & 19.5 & 0.5 & 19.0 & 0.5 & 18.0 \\
\hline 00010 & Water Temperature $\left({ }^{\circ} \mathrm{C}\right)$ & 0.5 & 3.2 & 8.3 & 6.0 & 24.4 & 9.6 & 27.5 & 9.4 & 24.8 & 10.1 \\
\hline 00400 & $\mathrm{pH}$ (standard units) & 8.0 & 7.6 & 8.3 & 8.1 & 8.4 & 7.5 & 8.2 & 6.7 & 8.4 & 7.7 \\
\hline 00095 & Specific conductance $(\mu \mathrm{S} / \mathrm{cm})$ & 586 & 637 & 578 & 583 & 542 & 596 & 515 & 602 & 288 & 592 \\
\hline 00300 & Dissolved oxygen & 12.6 & 7.2 & 11.6 & 11.6 & 8.8 & 2.1 & 9.8 & 0.3 & 9.4 & 0.4 \\
\hline 00665 & Phosphorus, total (as P) & 0.010 & 0.027 & 0.006 & -- & 0.014 & 0.043 & 0.012 & 0.019 & 0.018 & 0.023 \\
\hline 00671 & Orthophosphate, dissolved (as P) & -- & -- & $<.002$ & -- & -- & -- & -- & -- & -- & -- \\
\hline 00631 & Nitrate plus nitrite, dissolved (as $\mathrm{N}$ ) & -- & -- & 0.273 & -- & -- & -- & -- & -- & -- & -- \\
\hline 00608 & Ammonia, dissolved (as N) & -- & -- & 0.024 & -- & -- & -- & -- & -- & -- & -- \\
\hline 00625 & Ammonia plus organic nitrogen, total (as $\mathrm{N}$ ) & -- & -- & 0.52 & -- & -- & -- & -- & -- & -- & -- \\
\hline 00600 & Total nitrogen & -- & -- & 0.79 & -- & -- & -- & -- & -- & -- & -- \\
\hline 63675 & Turbidity, (NTU) & -- & -- & $<1.0$ & -- & -- & -- & -- & -- & -- & -- \\
\hline 00081 & Apparent color, (PTU) & -- & -- & 10 & -- & -- & -- & -- & -- & -- & -- \\
\hline 00900 & Hardness (as CaCO3) & -- & -- & 249 & -- & -- & -- & -- & -- & -- & -- \\
\hline 00915 & Calcium, dissolved $(\mathrm{Ca})$ & -- & -- & 46.8 & -- & -- & -- & -- & -- & -- & -- \\
\hline 00925 & Magnesium, dissolved (Mg) & -- & -- & 32.1 & -- & -- & -- & -- & -- & -- & -- \\
\hline 00930 & Sodium, dissolved $(\mathrm{Na})$ & -- & -- & 21.6 & -- & -- & -- & -- & -- & -- & -- \\
\hline 00935 & Potassium, dissolved (K) & -- & -- & 2 & -- & -- & -- & -- & -- & -- & -- \\
\hline 00417 & $\mathrm{ANC}$ (as $\mathrm{CaCO} 3$ ) & -- & -- & 207 & -- & -- & -- & -- & -- & -- & -- \\
\hline 00940 & Chloride, dissolved $(\mathrm{Cl})$ & -- & -- & 50.7 & -- & -- & -- & -- & -- & -- & -- \\
\hline 00945 & Sulfate, dissolved (SO4) & -- & -- & 24.8 & -- & -- & -- & -- & -- & -- & -- \\
\hline 00955 & Silica, dissolved (SiO2) & -- & -- & 7.47 & -- & -- & -- & -- & -- & -- & -- \\
\hline 01046 & Iron $(\mu \mathrm{g} / \mathrm{L})$ & -- & -- & $<100$ & -- & -- & -- & -- & -- & -- & -- \\
\hline 01056 & Manganese $(\mu \mathrm{g} / \mathrm{L})$ & -- & -- & $<1.0$ & -- & -- & -- & -- & -- & -- & -- \\
\hline 70300 & Solids, dissolved (at $180^{\circ} \mathrm{C}$ ) & -- & -- & 330 & -- & -- & -- & -- & -- & -- & -- \\
\hline
\end{tabular}


430551088273500 OCONOMOWOC LAKE NO. 1 (CENTER) AT OCONOMOWOC, WI

LAKE-DEPTH PROFILES, FEBRUARY 17 TO AUGUST 26, 2010
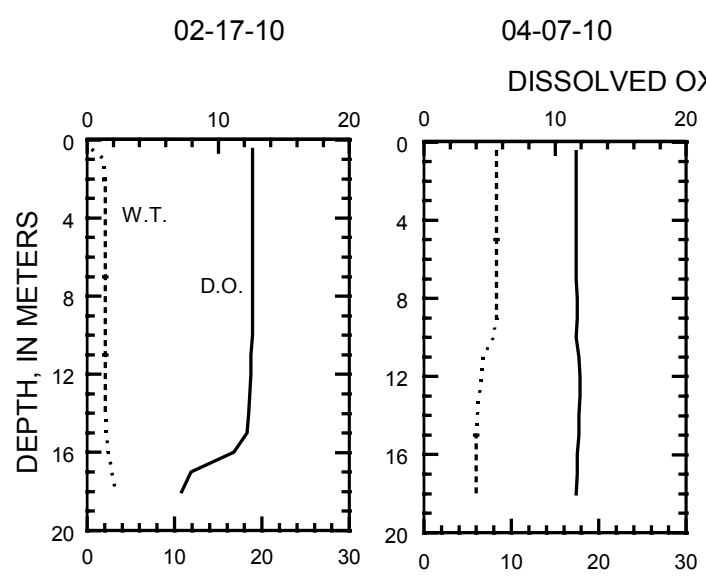

06-24-10

$07-27-10$

08-26-10

WATER TEMPERATURE (W.T.), IN DEGREES CELSIUS

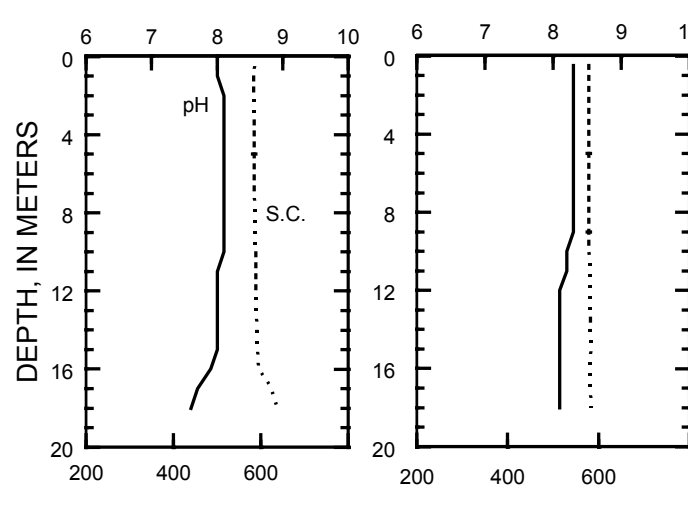

$\mathrm{PH}$, IN STANDARD UNITS
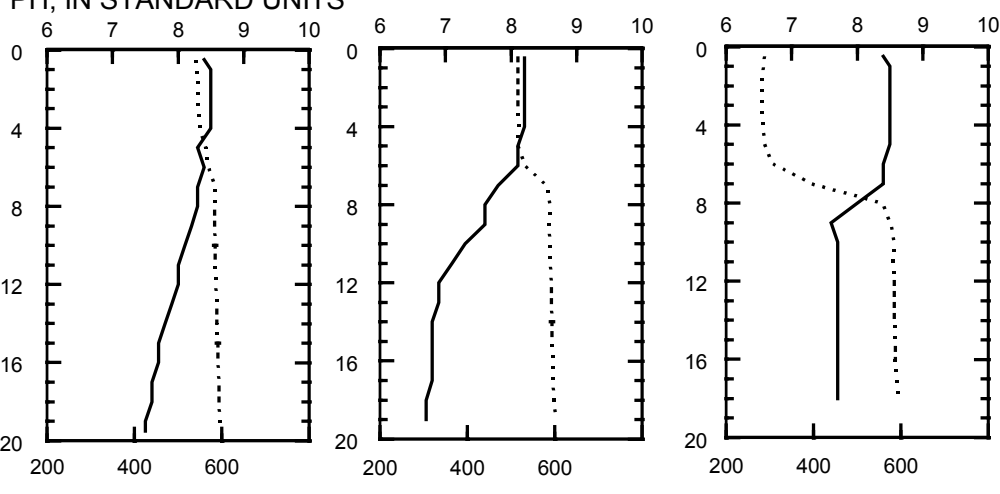

SPECIFIC CONDUCTANCE (S.C.), IN MICROSIEMENS PER CENTIMETER AT 25 DEGREES CELSIUS 

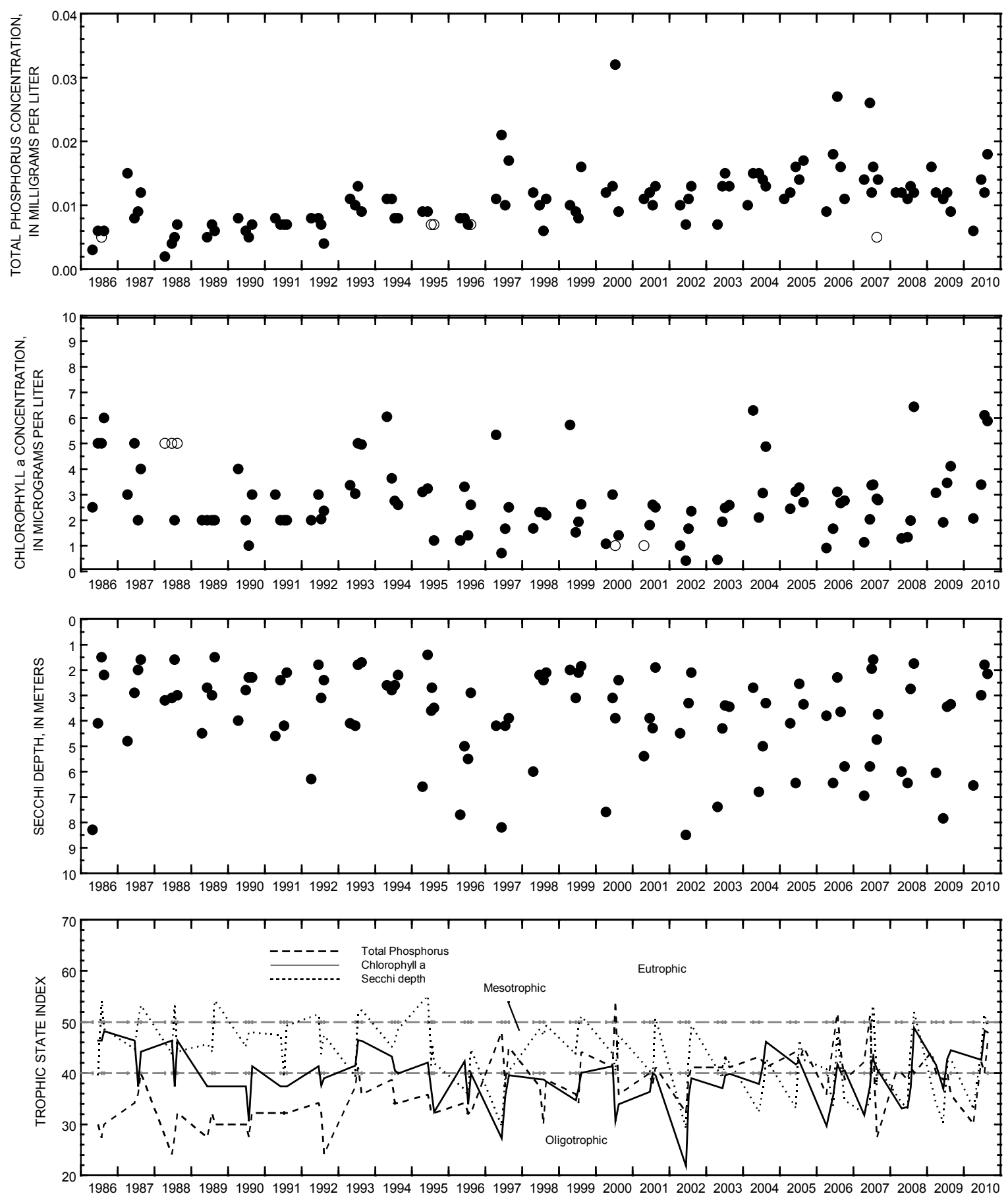

Surface total phosphorus, chlorophyll a concentrations, Secchi depths, and TSI data for Oconomowoc Lake, Center Site, at Oconomowoc, Wisconsin.

(Open circles on the first two plots indicate laboratory detection limit for selected analyses.

Actual concentrations for these particular analyses are less than the plotted circles.) 


\section{OCONOMOWOC LAKE NO. 2 (OFF HEWITT POINT) AT OCONOMOWOC, WI}

LOCATION.--Lat 4306'09", long 88²6'22", in NW 1/4 NW 1/4 sec.1, T.7 N., R.17 E., Waukesha County, Hydrologic Unit 07090001, at Oconomowoc.

SURFACE AREA. $-1.20 \mathrm{mi}^{2}$.

PERIOD OF RECORD.--March 1986 to current year.

REMARKS.--Lake sampled at the deepest point in northeast bay near Hewitt Point. Lake ice-covered during February sampling. Water-quality analyses done by Wisconsin State Laboratory of Hygiene.

WATER-QUALITY DATA, FEBRUARY 17 TO AUGUST 26, 2010

(Milligrams per liter unless otherwise indicated)

$\begin{array}{cll}\text { Parameter Code } & & \text { Parameter Name } \\ 32210 & & \text { Chlorophyll a }(\mu \mathrm{g} / \mathrm{L}) \\ 00078 & & \text { Secchi-depth }(\mathrm{m}) \\ 00098 & \text { Sampling depth }(\mathrm{m}) \\ 00010 & \text { Water Temperature }\left({ }^{\circ} \mathrm{C}\right) \\ 00400 & \mathrm{pH}(\text { standard units }) \\ 00095 & \text { Specific conductance }(\mu \mathrm{S} / \mathrm{cm}) \\ 00300 & \text { Dissolved oxygen } \\ 00665 & \text { Phosphorus, total }(\text { as } \mathrm{P})\end{array}$

\begin{tabular}{|c|c|c|c|}
\hline \multicolumn{2}{|c|}{ February 17} & \multicolumn{2}{|c|}{ April 7} \\
\hline \multicolumn{2}{|c|}{-- } & \multicolumn{2}{|c|}{1.87} \\
\hline \multicolumn{2}{|c|}{--} & \multicolumn{2}{|c|}{7.0} \\
\hline 0.5 & 12.0 & 0.5 & 14.0 \\
\hline 1.8 & 3.6 & 9.8 & 5.2 \\
\hline 7.9 & 7.6 & 8.2 & 7.5 \\
\hline 646 & 687 & 642 & 390 \\
\hline 12.3 & 9.4 & 11.5 & 8.8 \\
\hline 0.011 & 0.011 & $<.005$ & -- \\
\hline
\end{tabular}

\begin{tabular}{|c|c|}
\hline \multicolumn{2}{|c|}{ June 24} \\
\hline \multicolumn{2}{|c|}{1.64} \\
\hline \multicolumn{2}{|c|}{4.6} \\
\hline 0.5 & 16.5 \\
\hline 24.6 & 8.4 \\
\hline 8.3 & 7.3 \\
\hline 595 & 692 \\
\hline 9.1 & 2.5 \\
\hline 0.008 & 0.009 \\
\hline
\end{tabular}

\begin{tabular}{cc}
\multicolumn{3}{c}{ July 27} \\
\hline \multicolumn{2}{c}{2.88} \\
\multicolumn{2}{c}{2.8} \\
0.5 & 15.0 \\
27.4 & 8.8 \\
8.1 & 6.9 \\
557 & 699 \\
9.3 & 0.5 \\
0.009 & 0.045
\end{tabular}

\begin{tabular}{|c|c|}
\hline \multicolumn{2}{|c|}{ August 26} \\
\hline \multicolumn{2}{|c|}{2.06} \\
\hline \multicolumn{2}{|c|}{3.2} \\
\hline 0.5 & 14.5 \\
\hline 24.9 & 10.0 \\
\hline 8.4 & 7.5 \\
\hline 581 & 683 \\
\hline 8.7 & 0.5 \\
\hline 0.013 & 0.049 \\
\hline
\end{tabular}


430609088262200 OCONOMOWOC LAKE NO. 2 (OFF HEWITT POINT) AT OCONOMOWOC, WI

LAKE-DEPTH PROFILES, FEBRUARY 17 TO AUGUST 26, 2010

02-17-10
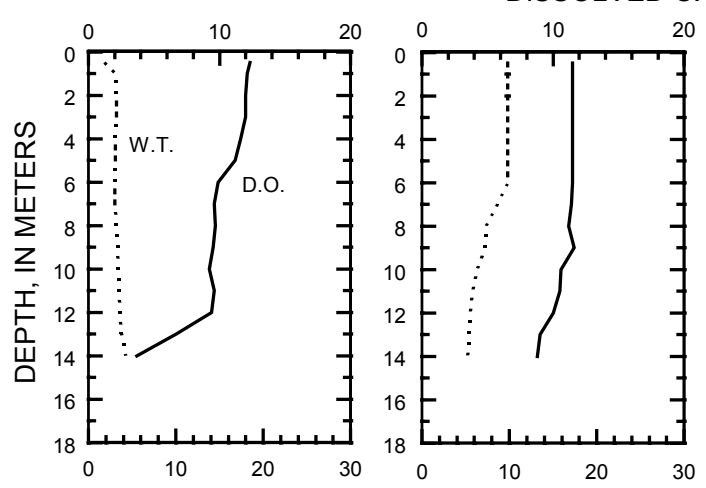

06-24-10

07-27-10

$08-26-10$

WATER TEMPERATURE (W.T.), IN DEGREES CELSIUS

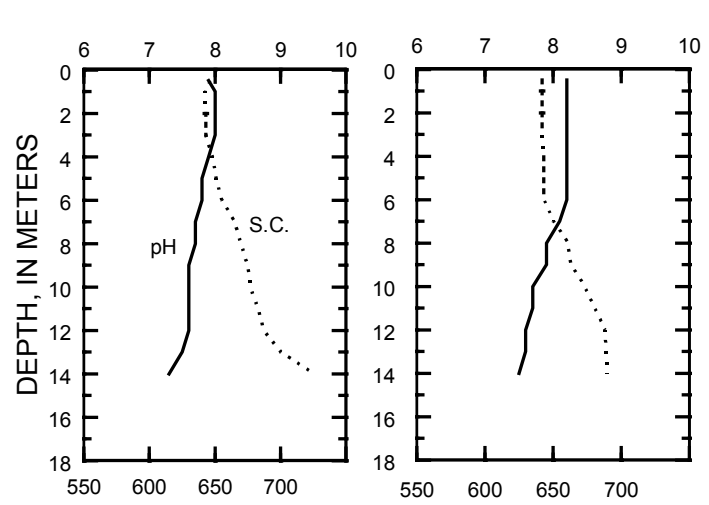

SPECIFIC CONDUCTANCE (S.C.), IN MICROSIEMENS PER CENTIMETER AT 25 DEGREES CELSIUS

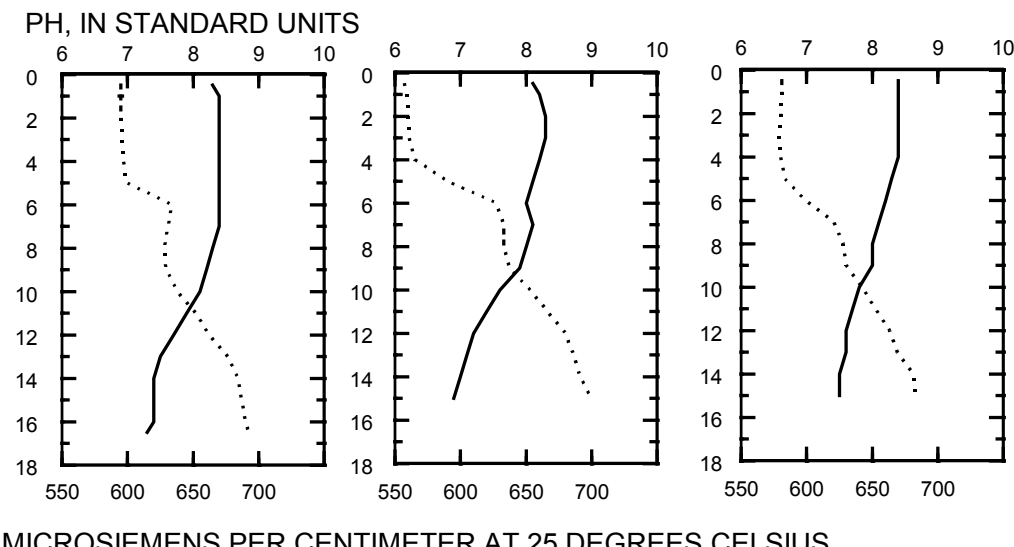



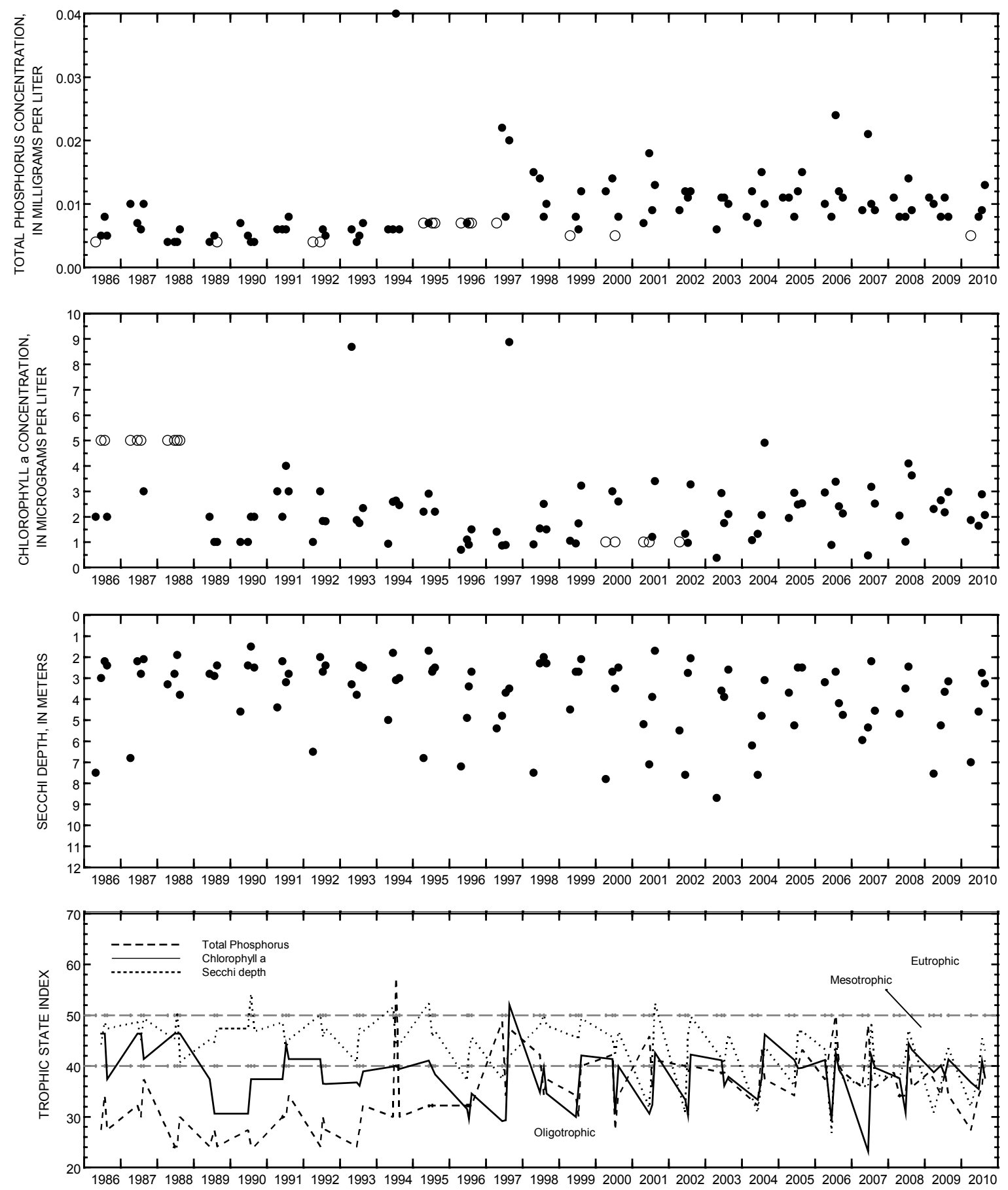

Surface total phosphorus, chlorophyll a concentrations, Secchi depths, and TSI data for Oconomowoc Lake, Hewitt Point, at Oconomowoc, Wisconsin.

(Open circles on the first two plots indicate laboratory detection limit for selected analyses. Actual concentrations for these particular analyses are less than the plotted circles.) 


\section{OKAUCHEE LAKE AT OKAUCHEE, WI}

LOCATION.--Lat 4307'23", long 88²5'21", in SE 1/4 SE 1/4 sec.25, T.8 N., R.17 E., Waukesha County, Hydrologic Unit 07090001 , at Okauchee.

DRAINAGE AREA.--80.7 $\mathrm{mi}^{2}$.

PERIOD OF RECORD.--February 1984 to September 2006, April to August 2008, April to August 2010.

REMARKS.--Lake sampled near center at the deep hole. Lake ice-covered during February sampling. Water-quality analyses done by Wisconsin State Laboratory of Hygiene.

WATER-QUALITY DATA, APRIL 8 TO AUGUST 26, 2010

(Milligrams per liter unless otherwise indicated)

\begin{tabular}{|c|c|c|c|}
\hline Parameter Code & Parameter Name & \multicolumn{2}{|c|}{ April 8} \\
\hline 32210 & Chlorophyll a $(\mu \mathrm{g} / \mathrm{L})$ & \multicolumn{2}{|c|}{3.61} \\
\hline 00078 & Secchi-depth (m) & \multicolumn{2}{|c|}{7.0} \\
\hline 00098 & Sampling depth $(\mathrm{m})$ & 0.5 & 30.0 \\
\hline 00010 & Water Temperature $\left({ }^{\circ} \mathrm{C}\right)$ & 7.8 & 5.0 \\
\hline 00400 & $\mathrm{pH}$ (standard units) & 8.3 & 7.9 \\
\hline 00095 & Specific conductance $(\mu \mathrm{S} / \mathrm{cm})$ & 582 & 587 \\
\hline 00300 & Dissolved oxygen & 12.5 & 12.9 \\
\hline 00665 & Phosphorus, total (as P) & 0.013 & -- \\
\hline 00671 & Orthophosphate, dissolved (as P) & 0.002 & -- \\
\hline 00631 & Nitrate plus nitrite, dissolved (as $\mathrm{N}$ ) & 0.391 & -- \\
\hline 00608 & Ammonia, dissolved (as $\mathrm{N}$ ) & $<.015$ & -- \\
\hline 00625 & Ammonia plus organic nitrogen, unfltrd, total (as $\mathrm{N}$ ) & 0.51 & -- \\
\hline 00600 & Total nitrogen & 0.9 & -- \\
\hline 63675 & Turbidity, (NTU) & $<1.0$ & -- \\
\hline 00081 & Apparent color, (PTU) & 15 & -- \\
\hline 00900 & Hardness (as CaCO3) & 267 & -- \\
\hline 00915 & Calcium, dissolved $(\mathrm{Ca})$ & 52.6 & -- \\
\hline 00925 & Magnesium, dissolved (Mg) & 33 & -- \\
\hline 00930 & Sodium, dissolved $(\mathrm{Na})$ & 18.5 & -- \\
\hline 00935 & Potassium, dissolved $(\mathrm{K})$ & 2 & -- \\
\hline 00417 & ANC (as $\mathrm{CaCO} 3$ ) & 223 & -- \\
\hline 00940 & Chloride, dissolved $(\mathrm{Cl})$ & 44.8 & -- \\
\hline 00945 & Sulfate, dissolved (SO4) & 24.6 & -- \\
\hline 00955 & Silica, dissolved (SiO2) & 6.74 & -- \\
\hline 01046 & Iron $(\mu \mathrm{g} / \mathrm{L})$ & $<100$ & -- \\
\hline 01056 & Manganese $(\mu \mathrm{g} / \mathrm{L})$ & $<1.0$ & -- \\
\hline 70300 & Solids, dissolved (at $180^{\circ} \mathrm{C}$ ) & 336 & -- \\
\hline
\end{tabular}

\begin{tabular}{|c|c|}
\hline \multicolumn{2}{|c|}{ June 24} \\
\hline \multicolumn{2}{|c|}{4.9} \\
\hline \multicolumn{2}{|c|}{3.9} \\
\hline 0.5 & 27.5 \\
\hline 24.8 & 6.0 \\
\hline 8.3 & 7.4 \\
\hline 556 & 601 \\
\hline 10.5 & 7.4 \\
\hline 0.017 & 0.106 \\
\hline-- & -- \\
\hline-- & -- \\
\hline-- & -- \\
\hline-- & -- \\
\hline-- & -- \\
\hline-- & -- \\
\hline-- & -- \\
\hline-- & -- \\
\hline-- & -- \\
\hline-- & -- \\
\hline -- & -- \\
\hline-- & -- \\
\hline-- & -- \\
\hline-- & -- \\
\hline-- & -- \\
\hline-- & -- \\
\hline-- & -- \\
\hline-- & -- \\
\hline-- & -- \\
\hline
\end{tabular}

\begin{tabular}{|c|c|}
\hline \multicolumn{2}{|c|}{ July 27} \\
\hline \multicolumn{2}{|c|}{14.4} \\
\hline \multicolumn{2}{|c|}{1.6} \\
\hline 0.5 & 27.5 \\
\hline 26.8 & 6.0 \\
\hline 8.4 & 7.0 \\
\hline 516 & 606 \\
\hline 10.0 & 1.8 \\
\hline 0.016 & 0.014 \\
\hline -- & -- \\
\hline-- & -- \\
\hline-- & -- \\
\hline-- & -- \\
\hline-- & -- \\
\hline-- & -- \\
\hline-- & -- \\
\hline-- & -- \\
\hline-- & -- \\
\hline-- & -- \\
\hline-- & -- \\
\hline-- & -- \\
\hline-- & -- \\
\hline-- & -- \\
\hline-- & -- \\
\hline -- & -- \\
\hline-- & -- \\
\hline-- & -- \\
\hline -- & -- \\
\hline
\end{tabular}

\begin{tabular}{cc}
\multicolumn{3}{c}{ August 26 } \\
\multicolumn{3}{c}{17.3} \\
0.5 & 2.6 \\
25.6 & 27.5 \\
8.4 & 6.5 \\
523 & 7.2 \\
10.1 & 595 \\
0.032 & 2.9 \\
-- & 0.028 \\
-- & -- \\
-- & -- \\
-- & -- \\
-- & -- \\
-- & -- \\
-- & -- \\
-- & -- \\
-- & -- \\
-- & -- \\
-- & -- \\
-- & -- \\
-- & -- \\
-- & -- \\
-- & -- \\
-- & -- \\
-- & -- \\
-- & -- \\
-- & -- \\
& -- \\
\hline & \\
\hline
\end{tabular}


430723088252100 OKAUCHEE LAKE AT OKAUCHEE, WI

LAKE-DEPTH PROFILES, APRIL 810 TO AUGUST 26, 2010

$04-07-10$
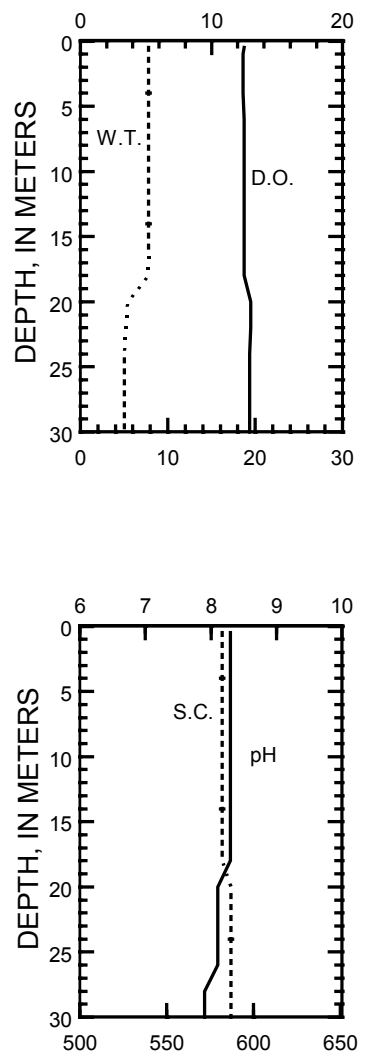

06-24-10

DISSOLVED OXYGEN (D.O.), IN MILLIGRAMS PER LITER

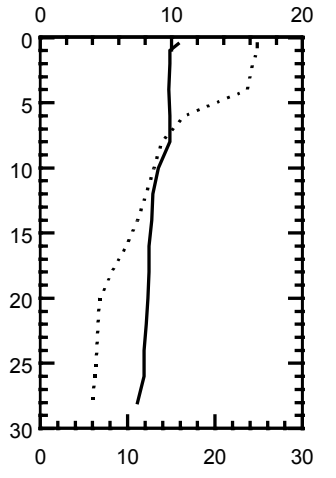

WATER TEMPERATURE (W.T.), IN DEGREES CELSIUS

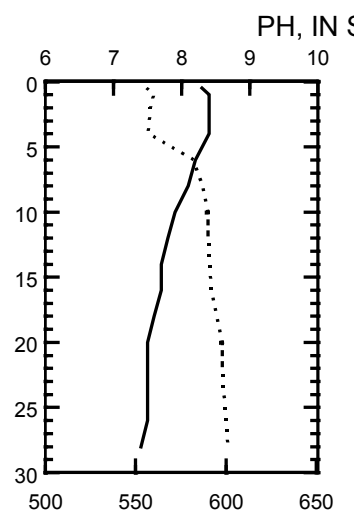

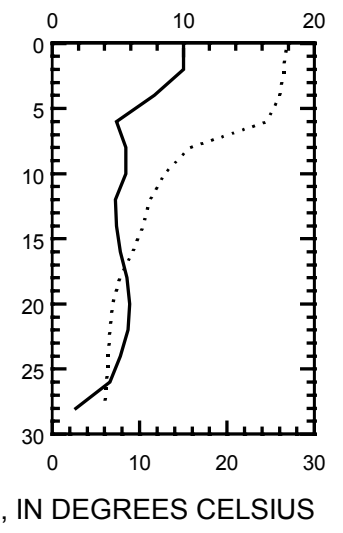

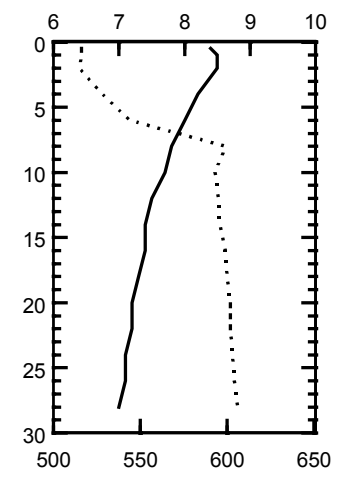

08-26-10
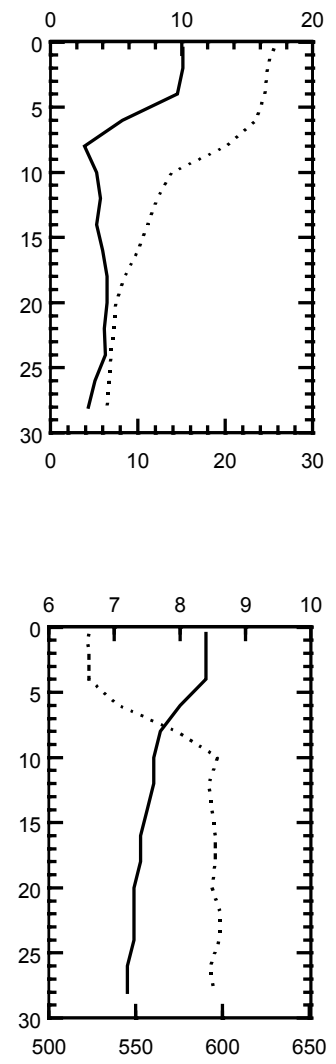

SPECIFIC CONDUCTANCE (S.C.), IN MICROSIEMENS PER CENTIMETER AT 25 DEGREES CELSIUS 

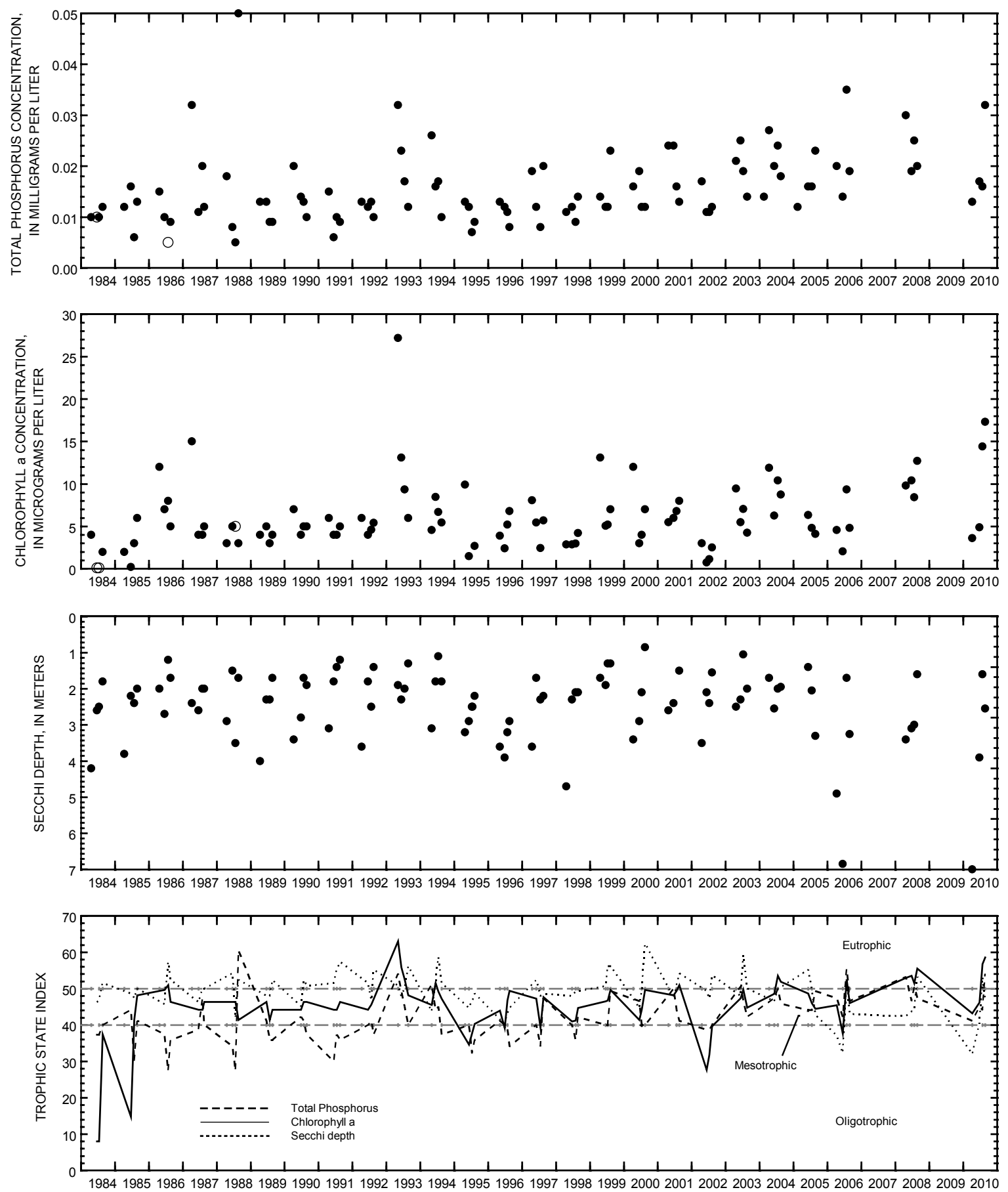

Surface total phosphorus, chlorophyll a concentrations, Secchi depths, and TSI data for Okauchee Lake, near Okauchee, Wisconsin. 
430759088244200 OKAUCHEE LAKE, NO. 1, NEAR OKAUCHEE, WI

LOCATION.--Lat 4307'59", long 88²4'42", in NE 1/4 NW 1/4 sec.30, T.8 N., R.18 E., Waukesha County, Hydrologic Unit 07090001, near Okauchee.

PERIOD OF RECORD.--April 1986 to September 2006, April to August 2008, April to August 2010.

REMARKS.--Lake sampled in Crane's Nest Bay, in the northeast part of the lake, at an approximate depth of $2 \mathrm{~m}$. Water-quality analyses done by Wisconsin State Laboratory of Hygiene.

WATER-QUALITY DATA, APRIL 8 TO AUGUST 26, 2010

(Milligrams per liter unless otherwise indicated)

\begin{tabular}{|c|c|c|c|c|c|c|c|c|c|}
\hline Parameter Code & Parameter Name & \multicolumn{2}{|c|}{ April 8} & \multicolumn{2}{|c|}{ June 24} & \multicolumn{2}{|c|}{ July 27} & \multicolumn{2}{|c|}{ August 26} \\
\hline 32210 & Chlorophyll a $(\mu \mathrm{g} / \mathrm{L})$ & \multicolumn{2}{|c|}{1.99} & \multicolumn{2}{|c|}{1.54} & \multicolumn{2}{|c|}{40.7} & \multicolumn{2}{|c|}{11.3} \\
\hline 00078 & Secchi-depth (m) & \multicolumn{2}{|c|}{2.0} & \multicolumn{2}{|c|}{$>2.1$} & \multicolumn{2}{|c|}{0.9} & \multicolumn{2}{|c|}{1.2} \\
\hline 00098 & Sampling depth (m) & 0.5 & 1.5 & 0.5 & 2.5 & 0.5 & 1.5 & 0.5 & 2.0 \\
\hline 00010 & Water Temperature $\left({ }^{\circ} \mathrm{C}\right)$ & 6.9 & 6.9 & 26.0 & 24.2 & 27.3 & 25.6 & 25.7 & 23.4 \\
\hline 00400 & $\mathrm{pH}$ (standard units) & 8.1 & 8.2 & 8.3 & 8.3 & 8.4 & 8.0 & 8.2 & 8.2 \\
\hline 00095 & Specific conductance $(\mu \mathrm{S} / \mathrm{cm})$ & 590 & 590 & 563 & 582 & 515 & 521 & 533 & 557 \\
\hline 00300 & Dissolved oxygen & -- & -- & 8.9 & 12.0 & 9.7 & 6.3 & 9.9 & 10.6 \\
\hline 00665 & Phosphorus, total (as P) & 0.011 & -- & 0.019 & -- & 0.043 & -- & 0.034 & -- \\
\hline
\end{tabular}



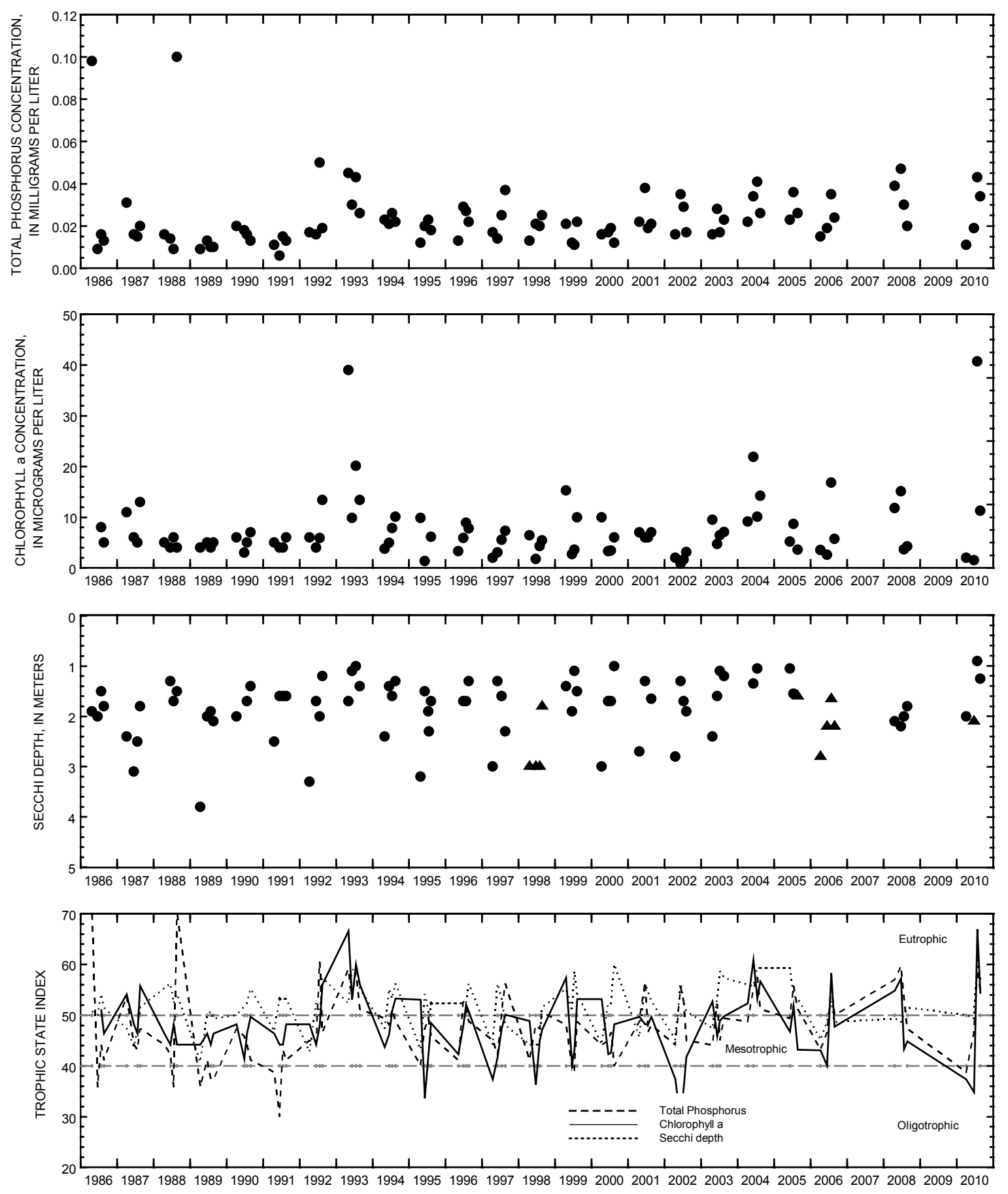

Surface total phosphorus, chlorophyll a concentrations, Secchi depths, and TSI data for Okauchee Lake, No. 1, near Okauchee, Wisconsin.

(Triangles in Secchi plot indicate maximum depth at sampling site Actual Secchi depth on these days was greater than the plotted triangles.) 


\section{OKAUCHEE LAKE, NO. 2, AT OKAUCHEE, WI}

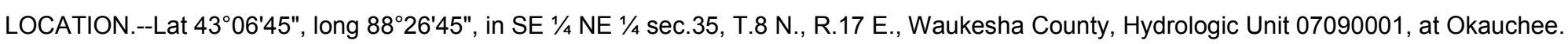

PERIOD OF RECORD.--April 1986 to September 2006, April to August 2008, April to August 2010.

REMARKS.--Lake sampled in Lower Okauchee Lake, at an approximate depth of $3 \mathrm{~m}$. Water-quality analyses done by Wisconsin State Laboratory of Hygiene.

WATER-QUALITY DATA, APRIL 8 TO AUGUST 26, 2010

(Milligrams per liter unless otherwise indicated)

\begin{tabular}{|c|c|c|c|c|c|c|c|c|c|}
\hline Parameter Code & Parameter Name & \multicolumn{2}{|c|}{ April 8} & \multicolumn{2}{|c|}{ June 24} & \multicolumn{2}{|c|}{ July 27} & \multicolumn{2}{|c|}{ August 26} \\
\hline 32210 & Chlorophyll a $(\mu \mathrm{g} / \mathrm{L})$ & \multicolumn{2}{|c|}{1.04} & \multicolumn{2}{|c|}{1.3} & \multicolumn{2}{|c|}{9.34} & \multicolumn{2}{|c|}{13.7} \\
\hline 00078 & Secchi-depth (m) & \multicolumn{2}{|c|}{2.5} & \multicolumn{2}{|c|}{$>3.8$} & \multicolumn{2}{|c|}{2.2} & \multicolumn{2}{|c|}{1.4} \\
\hline 00098 & Sampling depth (m) & 0.5 & 2.0 & 0.5 & 3.5 & 0.5 & 3.0 & 0.5 & 2.5 \\
\hline 00010 & Water Temperature $\left({ }^{\circ} \mathrm{C}\right)$ & 8.0 & 10.3 & 26.2 & 25.0 & 27.2 & 26.3 & 25.8 & 24.9 \\
\hline 00400 & $\mathrm{pH}$ (standard units) & 8.3 & 8.3 & 8.4 & 8.4 & 8.3 & 8.3 & 8.4 & 8.3 \\
\hline 00095 & Specific conductance $(\mu \mathrm{S} / \mathrm{cm})$ & 561 & 553 & 526 & 527 & 516 & 515 & 514 & 513 \\
\hline 00300 & Dissolved oxygen & -- & -- & 11.2 & 13.8 & 8.8 & 9.0 & 10.4 & 9.8 \\
\hline 00665 & Phosphorus, total (as P) & 0.007 & -- & 0.014 & -- & 0.016 & -- & 0.029 & -- \\
\hline
\end{tabular}



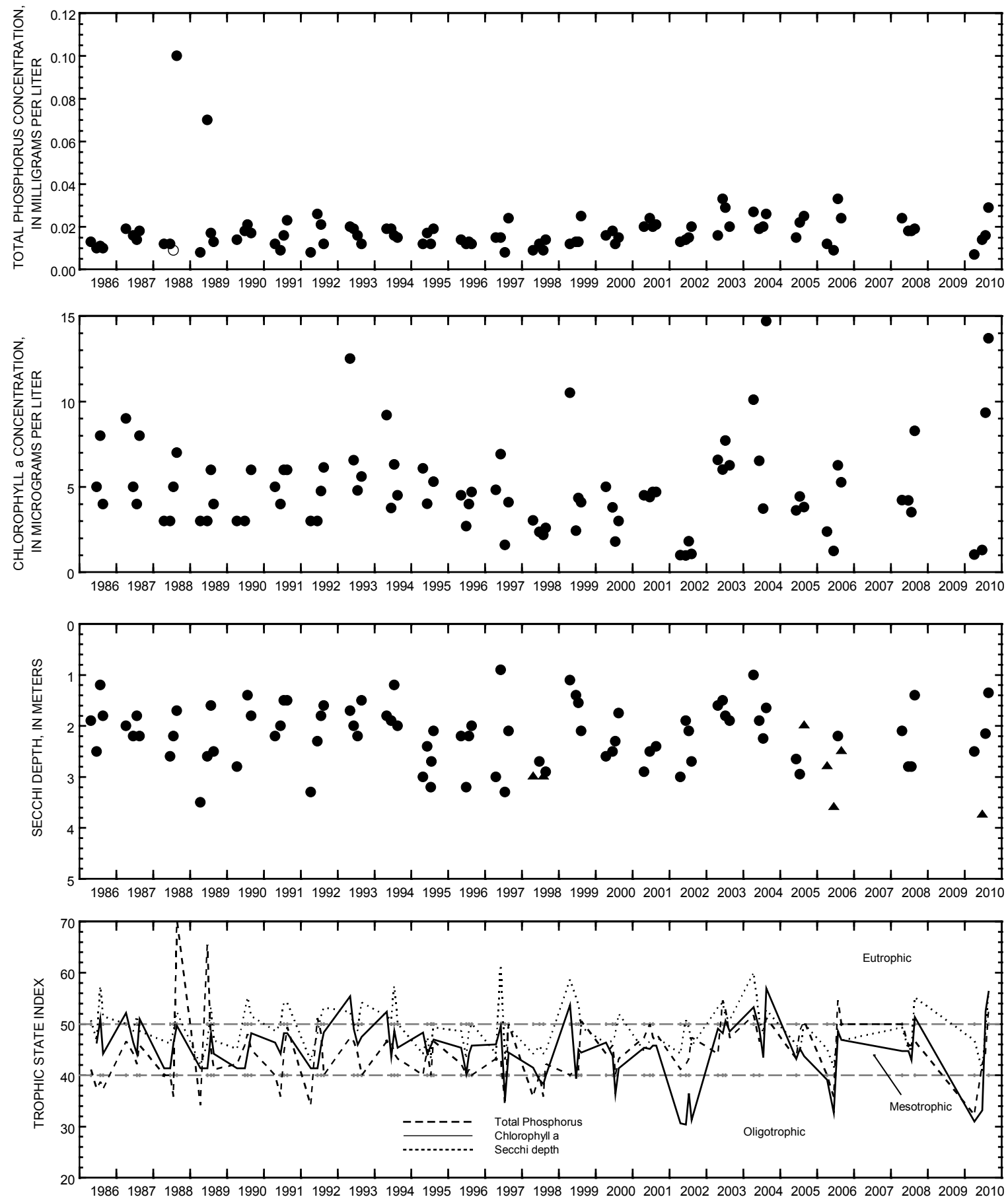

Surface total phosphorus, chlorophyll a concentrations, Secchi depths, and TSI data for Okauchee Lake, No. 2, near Okauchee, Wisconsin.

(Open circles on the first two plots indicate laboratory detection limit for selected analyses. Actual concentrations for these particular analyses are less than the plotted circles.)

(Triangles in Secchi plot indicate maximum depth at sampling site.

Actual Secchi depth on these days was greater than the plotted triangles.) 


\section{OKAUCHEE LAKE, NO. 3, AT OKAUCHEE, WI}

LOCATION.--Lat 4306'42", long 88²5'24", in NE 1/4 SE 1/4 sec.36, T.8 N., R.17 E., Waukesha County, Hydrologic Unit 07090001, at Okauchee.

PERIOD OF RECORD.--April 1986 to September 2006, April to August 2008, April to August 2010.

REMARKS.--Lake sampled in Ice House Bay, in the southern part of the lake, at an approximate depth of $5 \mathrm{~m}$. Water-quality analyses done by Wisconsin State Laboratory of Hygiene.

WATER-QUALITY DATA, APRIL 8 TO AUGUST 26, 2010

(Milligrams per liter unless otherwise indicated)

\begin{tabular}{clcc} 
Parameter Code & Parameter Name & \multicolumn{2}{c}{ April 8 } \\
\hline 32210 & Chlorophyll a $(\mu \mathrm{g} / \mathrm{L})$ & \multicolumn{2}{c}{1.71} \\
00078 & Secchi-depth $(\mathrm{m})$ & 0.5 & 4.0 \\
00098 & Sampling depth $(\mathrm{m})$ & 8.4 & 8.2 \\
00010 & Water Temperature $\left({ }^{\circ} \mathrm{C}\right)$ & 8.3 & 8.3 \\
00400 & $\mathrm{pH}$ (standard units) & 565 & 565 \\
00095 & Specific conductance $(\mu \mathrm{S} / \mathrm{cm})$ & -- & -- \\
00300 & Dissolved oxygen & 0.007 & --
\end{tabular}

\begin{tabular}{|c|c|}
\hline \multicolumn{2}{|c|}{ June 24} \\
\hline \multicolumn{2}{|c|}{0.97} \\
\hline \multicolumn{2}{|c|}{5.0} \\
\hline 0.5 & 5.3 \\
\hline 26.0 & 20.8 \\
\hline 8.5 & 8.2 \\
\hline 513 & 544 \\
\hline 11.2 & 18.3 \\
\hline 0.012 & -- \\
\hline
\end{tabular}

\begin{tabular}{ccc}
\multicolumn{3}{c}{ July 27} \\
\hline \multicolumn{3}{c}{8.35} \\
0.5 & & 4.0 \\
27.1 & & 26.4 \\
8.4 & 7.9 \\
494 & 510 \\
9.1 & 2.6 \\
0.018 & --
\end{tabular}

\begin{tabular}{ccc}
\multicolumn{3}{c}{ August 26 } \\
\hline \multicolumn{3}{c}{15.9} \\
0.5 & & 4.5 \\
25.3 & & 24.4 \\
8.3 & 8.2 \\
521 & 520 \\
8.9 & 8.1 \\
0.027 & --
\end{tabular}



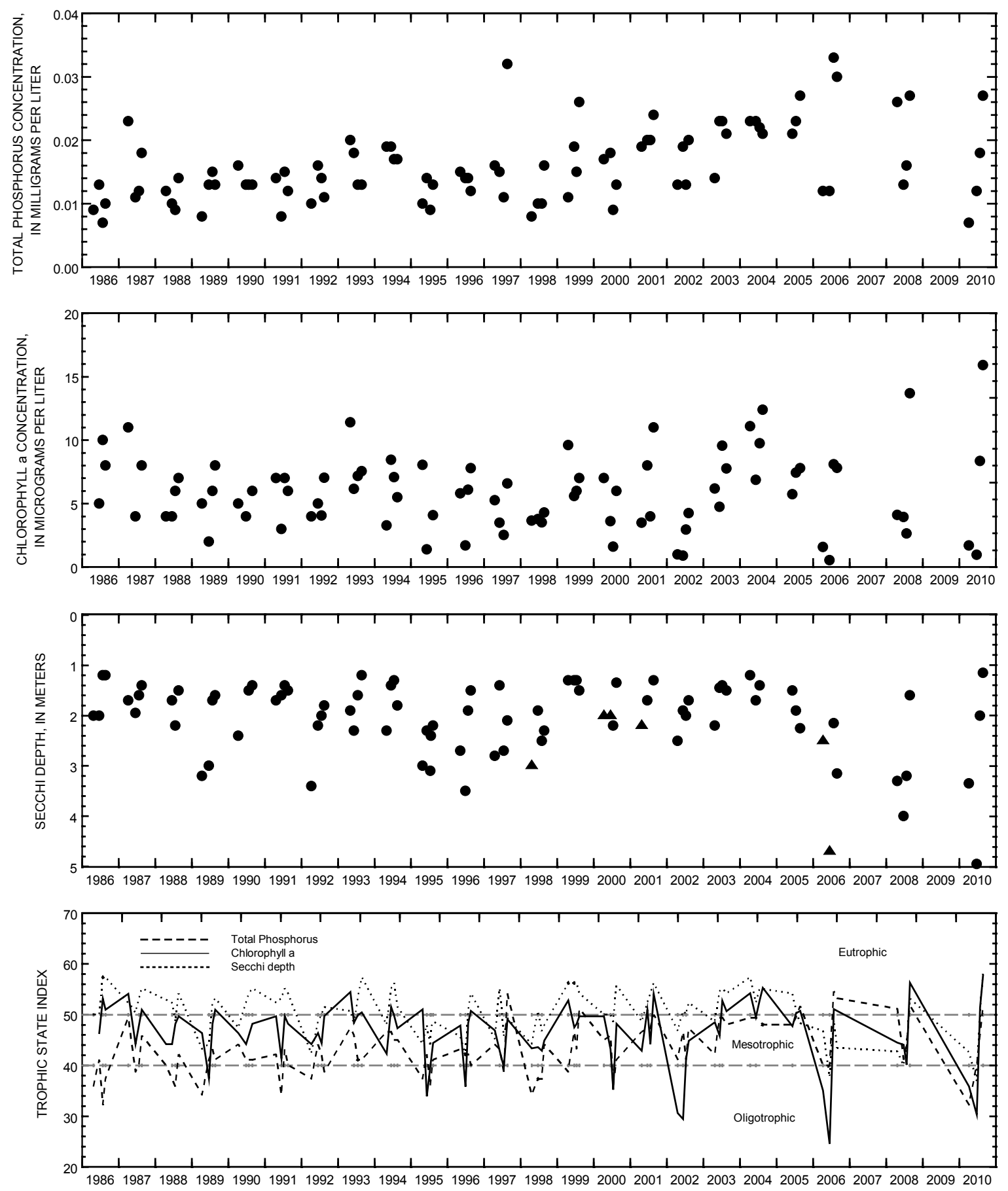

Surface total phosphorus, chlorophyll a concentrations, Secchi depths, and TSI data for Okauchee Lake, No. 3, near Okauchee, Wisconsin. 


\section{OKAUCHEE LAKE, NO. 4, AT OKAUCHEE, WI}

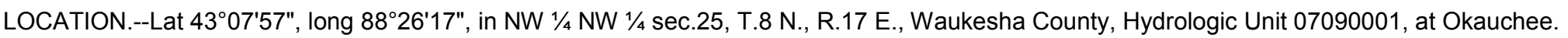

PERIOD OF RECORD.--June 1986 to September 2006, April to August 2008, April to August 2010.

REMARKS.--Lake sampled near McDowell (Crazyman's) Island, in the northwest bay of the lake, at an approximate depth of $2 \mathrm{~m}$. Water-quality analyses done by Wisconsin State Laboratory of Hygiene.

WATER-QUALITY DATA, APRIL 8 TO AUGUST 26, 2010

(Milligrams per liter unless otherwise indicated)

\begin{tabular}{|c|c|c|c|c|c|c|c|c|c|}
\hline Parameter Code & Parameter Name & \multicolumn{2}{|c|}{ April 8} & \multicolumn{2}{|c|}{ June 24} & \multicolumn{2}{|c|}{ July 27} & \multicolumn{2}{|c|}{ August 26} \\
\hline 32210 & Chlorophyll a ( $\mu \mathrm{g} / \mathrm{L})$ & \multicolumn{2}{|c|}{2.01} & \multicolumn{2}{|c|}{1.09} & \multicolumn{2}{|c|}{8.01} & \multicolumn{2}{|c|}{12.4} \\
\hline 00078 & Secchi-depth (m) & \multicolumn{2}{|c|}{2.0} & \multicolumn{2}{|c|}{$>2.0$} & \multicolumn{2}{|c|}{$>2.0$} & \multicolumn{2}{|c|}{1.4} \\
\hline 00098 & Sampling depth (m) & 0.5 & 1.5 & 0.5 & 1.75 & 0.5 & 1.5 & 0.5 & 1.5 \\
\hline 00010 & Water Temperature $\left({ }^{\circ} \mathrm{C}\right)$ & 10.2 & 8.0 & 25.9 & 25.7 & 27.3 & 27.1 & 25.3 & 24.5 \\
\hline 00400 & $\mathrm{pH}$ (standard units) & 8.3 & 8.3 & 8.6 & 8.7 & 8.3 & 8.4 & 8.2 & 8.3 \\
\hline 00095 & Specific conductance $(\mu \mathrm{S} / \mathrm{cm})$ & 553 & 561 & 494 & 495 & 504 & 504 & 528 & 523 \\
\hline 00300 & Dissolved oxygen & -- & -- & 11.4 & 12.6 & 9.8 & 10.3 & 9.6 & 10.8 \\
\hline 00665 & Phosphorus, total (as P) & 0.005 & -- & 0.016 & -- & 0.017 & -- & 0.028 & -- \\
\hline
\end{tabular}



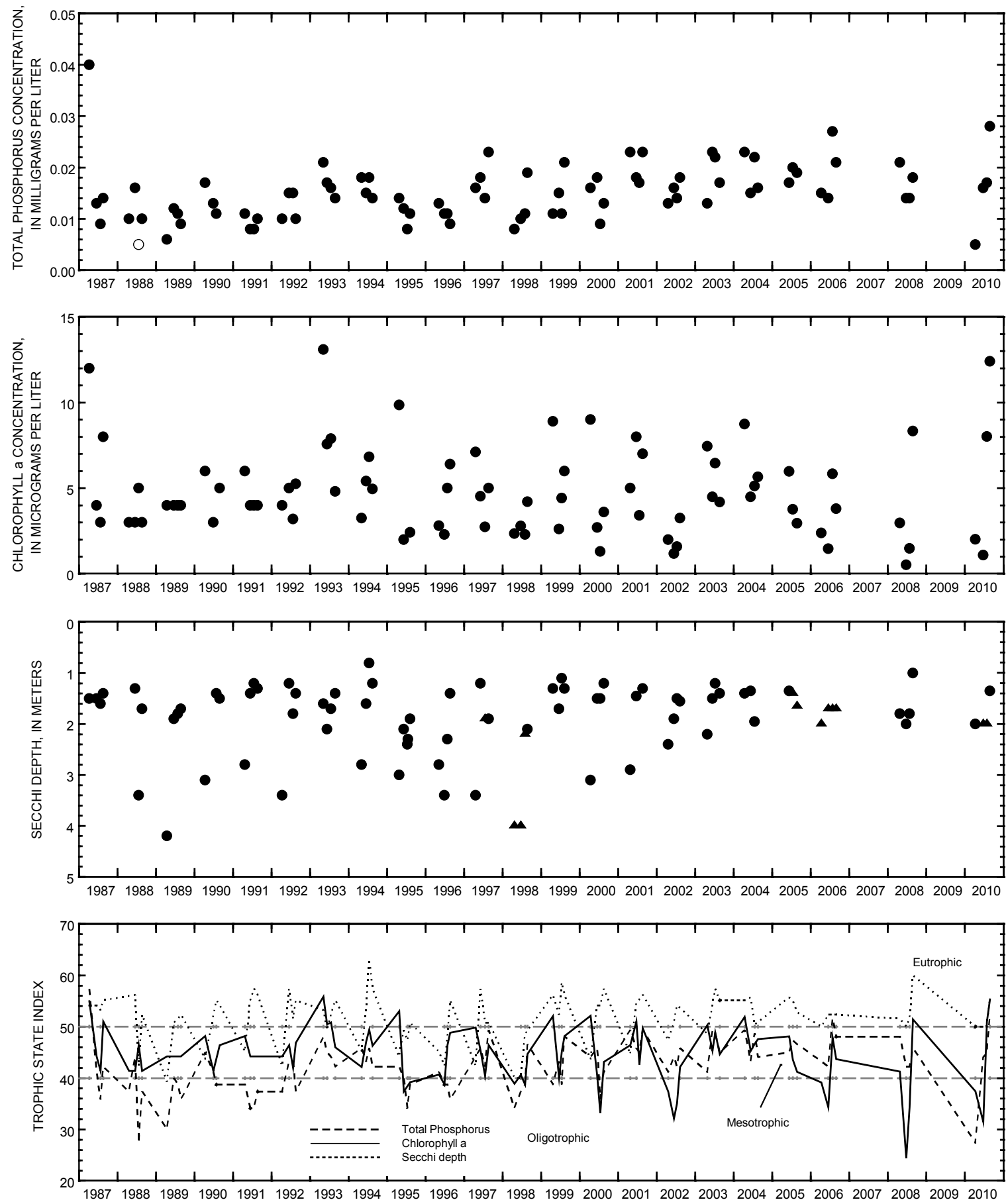

Surface total phosphorus, chlorophyll a concentrations, Secchi depths,

and TSI data for Okauchee Lake, No. 4, near Okauchee, Wisconsin.

(Open circles on the first two plots indicate laboratory detection limit for selected analyses. Actual concentrations for these particular analyses are less than the plotted circles.)

(Triangles in Secchi plot indicate maximum depth at sampling site.

Actual Secchi depth on these days was greater than the plotted triangles. 


\section{POWERS LAKE AT POWERS LAKE, WI}

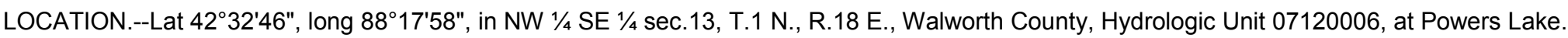

SURFACE AREA.-0.72 $\mathrm{mi}^{2}$

DRAINAGE AREA.--3.42 $\mathrm{mi}^{2}$.

PERIOD OF RECORD.--March 1986 to August 1996, and April 1998 to current year.

REMARKS.--Lake sampled near center at the deep hole. Lake ice-covered during February sampling. Water-quality analyses done by Wisconsin State Laboratory of Hygiene.

\begin{tabular}{|c|c|}
\hline Parameter Code & $\underline{\text { Parameter Name }}$ \\
\hline 32210 & Chlorophyll a $(\mu \mathrm{g} / \mathrm{L})$ \\
\hline 00078 & Secchi-depth (m) \\
\hline 00098 & Sampling depth $(\mathrm{m})$ \\
\hline 00010 & Water Temperature $\left({ }^{\circ} \mathrm{C}\right)$ \\
\hline 00400 & $\mathrm{pH}$ (standard units) \\
\hline 00095 & Specific conductance $(\mu \mathrm{S} / \mathrm{cm})$ \\
\hline 00300 & Dissolved oxygen \\
\hline 00665 & Phosphorus, total (as P) \\
\hline 00671 & Orthophosphate, dissolved (as P) \\
\hline 00631 & Nitrate plus nitrite, dissolved (as $\mathrm{N}$ ) \\
\hline 00608 & Ammonia, dissolved (as $\mathrm{N}$ ) \\
\hline 00623 & Ammonia plus organic nitrogen, dissolved (as $\mathrm{N}$ ) \\
\hline 00625 & Ammonia plus organic nitrogen, total (as N) \\
\hline 00600 & Total nitrogen \\
\hline 63675 & Turbidity, (NTU) \\
\hline 00081 & Apparent color, (PTU) \\
\hline 00900 & Hardness (as CaCO3) \\
\hline 00915 & Calcium, dissolved $(\mathrm{Ca})$ \\
\hline 00925 & Magnesium, dissolved (Mg) \\
\hline 00930 & Sodium, dissolved $(\mathrm{Na})$ \\
\hline 00935 & Potassium, dissolved (K) \\
\hline 00417 & ANC (as $\mathrm{CaCO} 3$ ) \\
\hline 00940 & Chloride, dissolved $(\mathrm{Cl})$ \\
\hline 00945 & Sulfate, dissolved (SO4) \\
\hline 00955 & Silica, dissolved (SiO2) \\
\hline 01046 & Iron $(\mu \mathrm{g} / \mathrm{L})$ \\
\hline 01056 & Manganese $(\mu \mathrm{g} / \mathrm{L})$ \\
\hline 70300 & Solids, dissolved (at $180^{\circ} \mathrm{C}$ ) \\
\hline
\end{tabular}

(Milligrams per liter unless otherwise indicated)

\begin{tabular}{|c|c|c|c|c|c|c|c|c|c|}
\hline \multicolumn{2}{|c|}{ February 17} & \multicolumn{2}{|c|}{ April 7} & \multicolumn{2}{|c|}{ June 25} & \multicolumn{2}{|c|}{ July 29} & \multicolumn{2}{|c|}{ August 30} \\
\hline \multicolumn{2}{|c|}{--} & \multicolumn{2}{|c|}{6.89} & \multicolumn{2}{|c|}{4.24} & \multicolumn{2}{|c|}{4.08} & \multicolumn{2}{|c|}{4.48} \\
\hline \multicolumn{2}{|c|}{--} & \multicolumn{2}{|c|}{4.7} & \multicolumn{2}{|c|}{2.65} & \multicolumn{2}{|c|}{2.85} & \multicolumn{2}{|c|}{2.25} \\
\hline 0.5 & 10.0 & 0.5 & 10.0 & 0.5 & 11.5 & 0.5 & 10.0 & 0.5 & 9.5 \\
\hline 0.7 & 4.8 & 11.1 & 10.5 & 25.6 & 14.1 & 27.8 & 15.5 & 25.9 & 18.3 \\
\hline 8.1 & 7.5 & 8.3 & 8.3 & 8.6 & 7.0 & 8.5 & 7.5 & 8.4 & 7.2 \\
\hline 536 & 578 & 512 & 513 & 496 & 572 & 503 & 516 & 507 & 519 \\
\hline 11.8 & 6.4 & 11.4 & 10.9 & 9.3 & 0.6 & 8.0 & 0.6 & 8.7 & 0.3 \\
\hline 0.014 & 0.015 & 0.006 & -- & 0.017 & 0.022 & 0.017 & 0.051 & 0.021 & 0.036 \\
\hline-- & -- & $<.002$ & -- & -- & -- & $<.002$ & -- & -- & -- \\
\hline-- & -- & 0.083 & -- & -- & -- & 0.025 & -- & -- & -- \\
\hline-- & -- & $<.015$ & -- & -- & -- & 0.019 & -- & -- & -- \\
\hline-- & -- & -- & -- & -- & -- & 0.65 & -- & -- & -- \\
\hline-- & -- & 0.6 & -- & -- & -- & -- & -- & -- & -- \\
\hline-- & -- & 0.68 & -- & -- & -- & -- & -- & -- & -- \\
\hline-- & -- & $<1.0$ & -- & -- & -- & -- & -- & -- & -- \\
\hline-- & -- & 10 & -- & -- & -- & -- & -- & -- & -- \\
\hline-- & -- & 223 & -- & -- & -- & -- & -- & -- & -- \\
\hline-- & -- & 38.2 & -- & -- & -- & -- & -- & -- & -- \\
\hline-- & -- & 31 & -- & -- & -- & -- & -- & -- & -- \\
\hline-- & -- & 19.5 & -- & -- & -- & -- & -- & -- & -- \\
\hline-- & -- & 2 & -- & -- & -- & -- & -- & -- & -- \\
\hline-- & -- & 182 & -- & -- & -- & -- & -- & -- & -- \\
\hline-- & -- & 42.1 & -- & -- & -- & -- & -- & -- & -- \\
\hline-- & -- & 26.6 & -- & -- & -- & -- & -- & -- & -- \\
\hline-- & -- & 8.01 & -- & -- & -- & -- & -- & -- & -- \\
\hline-- & -- & $<100$ & -- & -- & -- & -- & -- & -- & -- \\
\hline-- & -- & $<1.0$ & -- & -- & -- & -- & -- & -- & -- \\
\hline-- & -- & 292 & -- & -- & -- & -- & -- & -- & -- \\
\hline
\end{tabular}


423246088175800 POWERS LAKE AT POWERS LAKE, WI

LAKE-DEPTH PROFILES, FEBRUARY 17 TO AUGUST 30, 2010

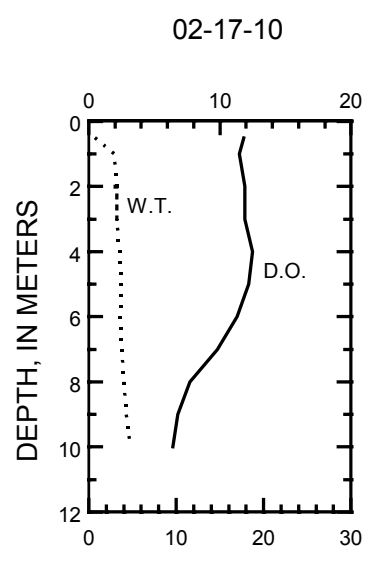

$$
\text { 04-07-10 }
$$

06-25-10

07-29-10

08-30-10
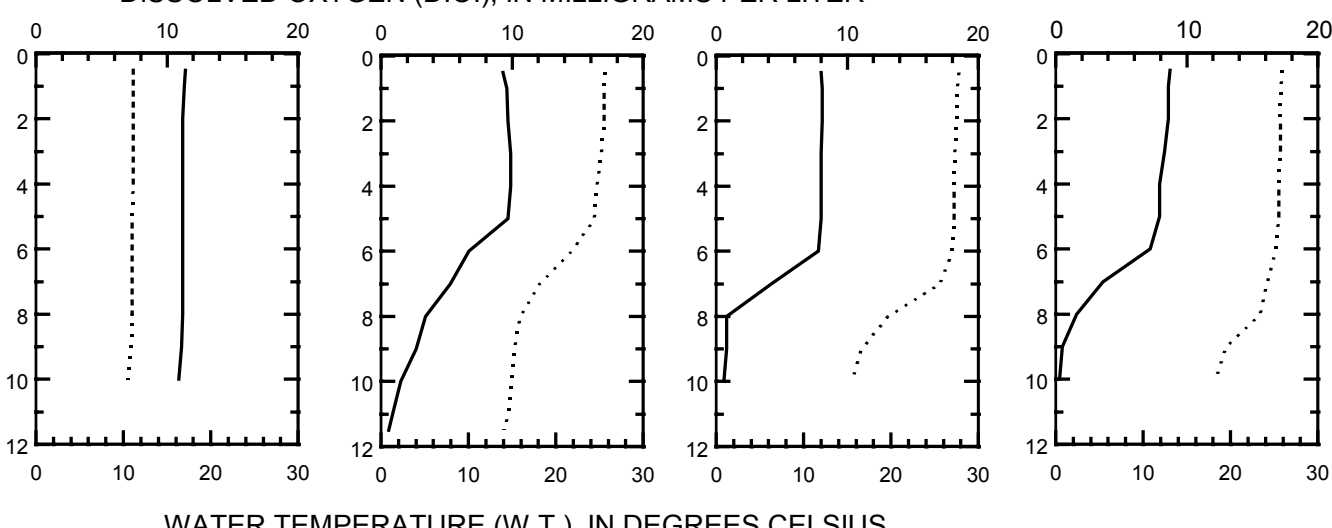

WATER TEMPERATURE (W.T.), IN DEGREES CELSIUS
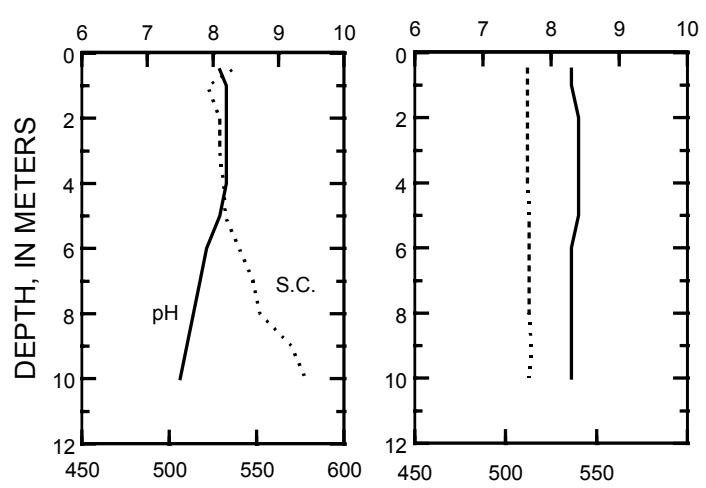

$\mathrm{PH}$, IN STANDARD UNITS
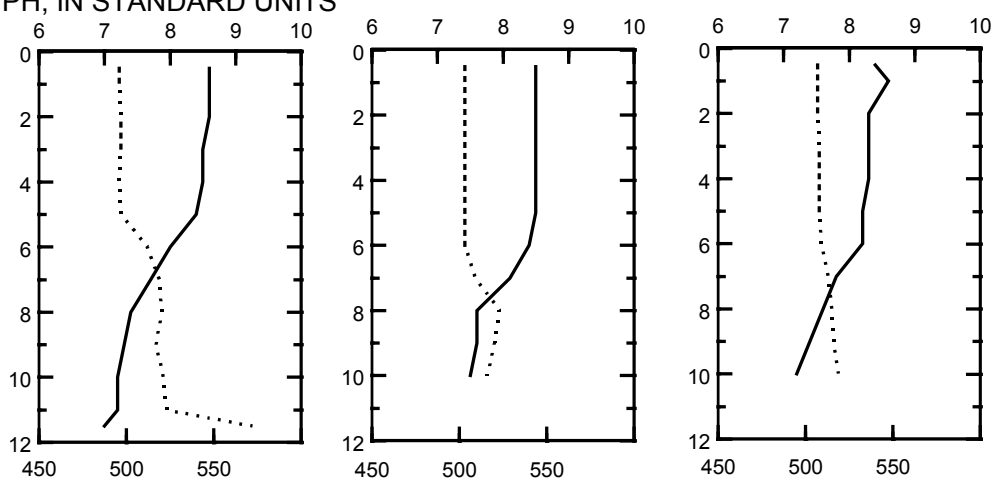

SPECIFIC CONDUCTANCE (S.C.), IN MICROSIEMENS PER CENTIMETER AT 25 DEGREES CELSIUS 

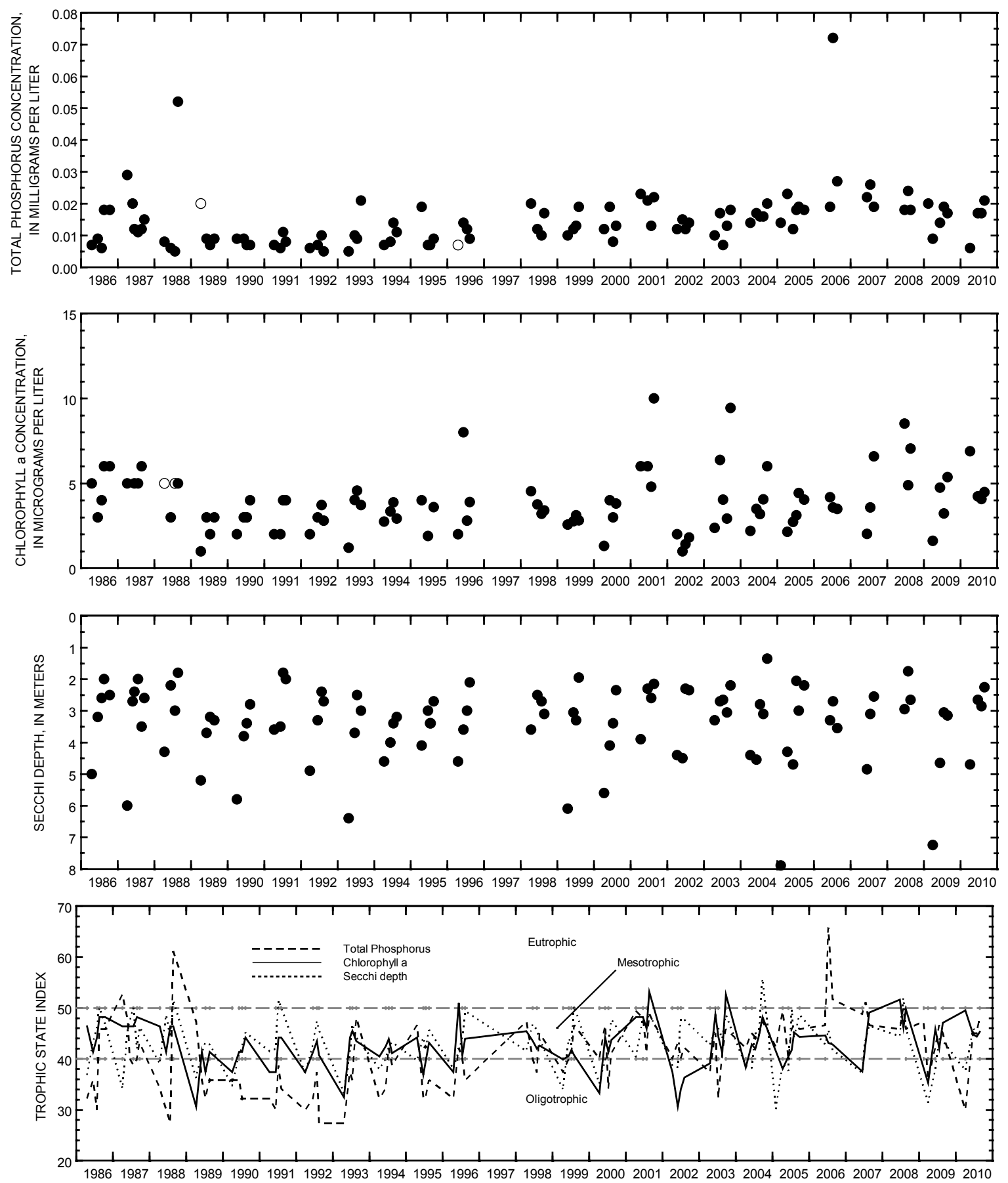

Surface total phosphorus, chlorophyll a concentrations, Secchi depths, and TSI data for Powers Lake, at Powers Lake, Wisconsin.

(Open circles on the first two plots indicate laboratory detection limit for selected analyses. Actual concentrations for these particular analyses are less than the plotted circles.) 


\section{TURTLE-FLAMBEAU FLOWAGE, DEEP HOLE, NEAR MERCER, WI}

LOCATION.--Lat 46²04'58", long 90¹0'27", in SW 1/4 SE 1/4 SE 1/4 Sec.25, T.42 W., R.2 E., Vilas County, Hydrologic Unit 07050002. PERIOD OF RECORD.-April 2009 to March 2010 (discontinued).

REMARKS.--Lake sampled at the deep hole. Water-quality analyses done by Wisconsin State Laboratory of Hygiene.

WATER-QUALITY DATA, APRIL 29, 2009 TO MARCH 15, 2010 (Milligrams per liter unless otherwise indicated)

\begin{tabular}{|c|c|c|c|c|c|c|}
\hline Parameter Code & Parameter Name & Apr. 29 & \multicolumn{2}{|c|}{ June 25} & \multicolumn{2}{|c|}{ Aug. 4} \\
\hline 00078 & Secchi-depth (m) & 1.8 & \multicolumn{2}{|c|}{2.1} & \multicolumn{2}{|c|}{1.5} \\
\hline 00098 & Sampling depth (m) & 0.5 & 0.5 & 13 & 0.5 & 13 \\
\hline 00010 & Water Temperature $\left({ }^{\circ} \mathrm{C}\right)$ & 7.3 & 25.7 & 9.7 & 20.1 & 10.1 \\
\hline 00400 & $\mathrm{pH}$ (standard units) & 7.6 & 8.1 & 6.9 & 7.2 & 6.8 \\
\hline 00095 & Specific conductance $(\mu \mathrm{S} / \mathrm{cm})$ & 89 & 90 & 116 & 94 & 134 \\
\hline 00300 & Dissolved oxygen & 10.8 & 10.4 & 0 & 9.6 & 0.3 \\
\hline 32210 & Chlorophyll a $(\mu \mathrm{g} / \mathrm{L})$ & 3.79 & 3.05 & -- & 3.19 & -- \\
\hline 00665 & Phosphorus, total (as P) & 0.025 & 0.045 & 0.056 & 0.034 & 0.079 \\
\hline 00671 & Orthophosphate, dissolved (as P) & 0.004 & -- & -- & -- & -- \\
\hline 00631 & Nitrate plus nitrite, dissolved (as $\mathrm{N}$ ) & $<.019$ & -- & -- & -- & -- \\
\hline 00608 & Ammonia, dissolved (as $\mathrm{N}$ ) & 0.034 & -- & -- & -- & -- \\
\hline 00625 & Ammonia plus organic nitrogen, total (as $\mathrm{N}$ ) & 0.48 & -- & -- & -- & -- \\
\hline 00600 & Total nitrogen & -- & -- & -- & -- & -- \\
\hline 63675 & Turbidity, (NTU) & $<1.0$ & -- & -- & -- & -- \\
\hline 00081 & Apparent color, (PTU) & 50 & -- & -- & -- & -- \\
\hline 00900 & Hardness (as CaCO3) & 42 & -- & -- & -- & -- \\
\hline 00915 & Calcium, dissolved $(\mathrm{Ca})$ & 11.8 & -- & -- & -- & -- \\
\hline 00925 & Magnesium, dissolved (Mg) & 3.1 & -- & -- & -- & -- \\
\hline 00930 & Sodium, dissolved $(\mathrm{Na})$ & 2.2 & -- & -- & -- & -- \\
\hline 00935 & Potassium, dissolved (K) & 0.7 & -- & -- & -- & -- \\
\hline 00417 & $\mathrm{ANC}$ (as $\mathrm{CaCO}$ ) & 38 & -- & -- & -- & -- \\
\hline 00940 & Chloride, dissolved $(\mathrm{Cl})$ & 3.1 & -- & -- & -- & -- \\
\hline 00945 & Sulfate, dissolved (SO4) & $<4.5$ & -- & -- & -- & -- \\
\hline 00955 & Silica, dissolved (SiO2) & 8.13 & -- & -- & -- & -- \\
\hline 01046 & Iron $(\mu \mathrm{g} / \mathrm{L})$ & 600 & -- & -- & -- & -- \\
\hline 01056 & Manganese $(\mu \mathrm{g} / \mathrm{L})$ & 80 & -- & -- & -- & -- \\
\hline 70300 & Solids, dissolved (at $180^{\circ} \mathrm{C}$ ) & 64 & -- & -- & -- & -- \\
\hline
\end{tabular}

\begin{tabular}{|c|c|c|c|}
\hline \multicolumn{2}{|c|}{ Sept. 3} & \multicolumn{2}{|c|}{ March 15} \\
\hline \multicolumn{2}{|c|}{1.7} & \multicolumn{2}{|c|}{-- } \\
\hline 0.5 & 13 & 1.0 & 12.0 \\
\hline 18.9 & 10.1 & 2.6 & 3.6 \\
\hline 8.1 & 7.3 & 7.5 & 6.9 \\
\hline 95 & 154 & 114 & 144 \\
\hline 9.2 & 0.6 & 7.6 & 0.5 \\
\hline 3.34 & -- & -- & -- \\
\hline 0.017 & 0.065 & 0.018 & 0.028 \\
\hline -- & -- & -- & -- \\
\hline -- & -- & 0.123 & -- \\
\hline -- & -- & -- & -- \\
\hline -- & -- & 0.33 & -- \\
\hline -- & -- & 0.453 & -- \\
\hline -- & -- & -- & -- \\
\hline -- & -- & -- & -- \\
\hline-- & -- & -- & -- \\
\hline-- & -- & -- & -- \\
\hline-- & -- & -- & -- \\
\hline-- & -- & -- & -- \\
\hline-- & -- & -- & -- \\
\hline-- & -- & -- & -- \\
\hline -- & -- & -- & -- \\
\hline -- & -- & -- & -- \\
\hline-- & -- & -- & -- \\
\hline-- & -- & -- & -- \\
\hline-- & -- & -- & -- \\
\hline-- & -- & -- & -- \\
\hline
\end{tabular}




\section{TURTLE-FLAMBEAU FLOWAGE, DEEP HOLE, NEAR MERCER, WI}

LAKE-DEPTH PROFILES, APRIL 29, 2009 TO MARCH 15, 2010

04-29-09
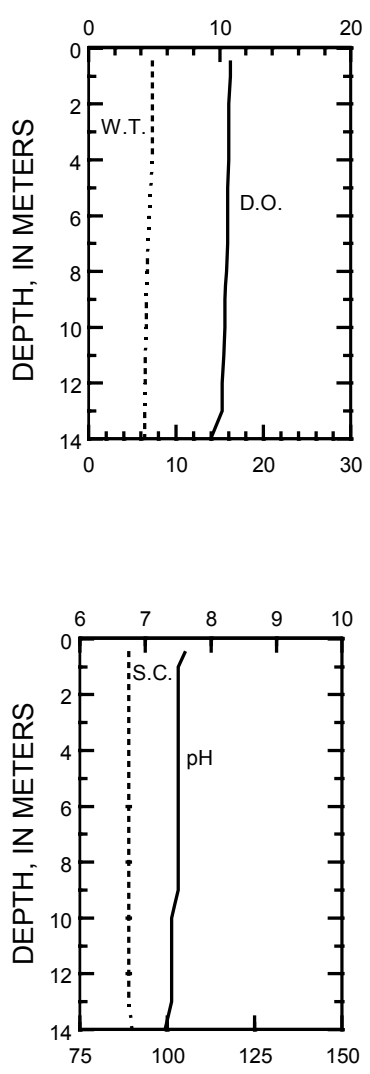

06-25-09

DISSOLVED OXYGEN (D.O.), IN MILLIGRAMS PER LITER
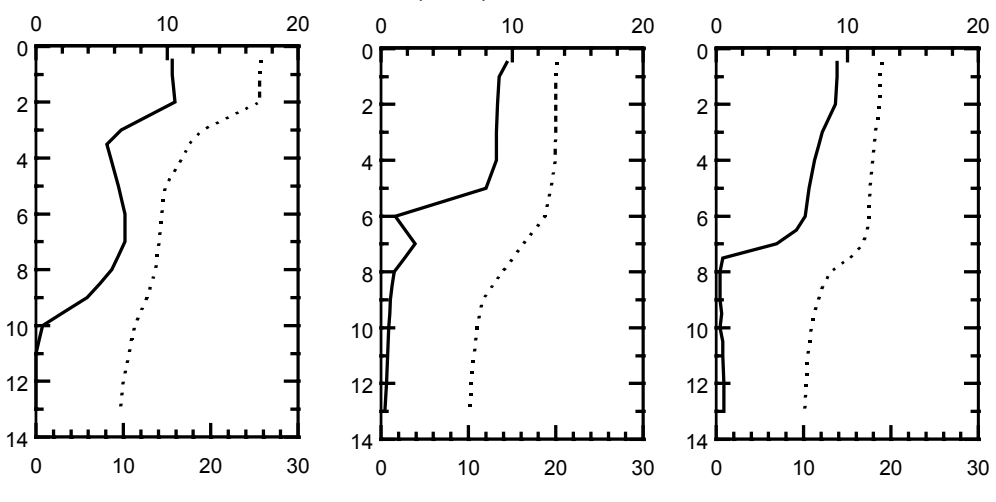

WATER TEMPERATURE (W.T.), IN DEGREES CELSIUS
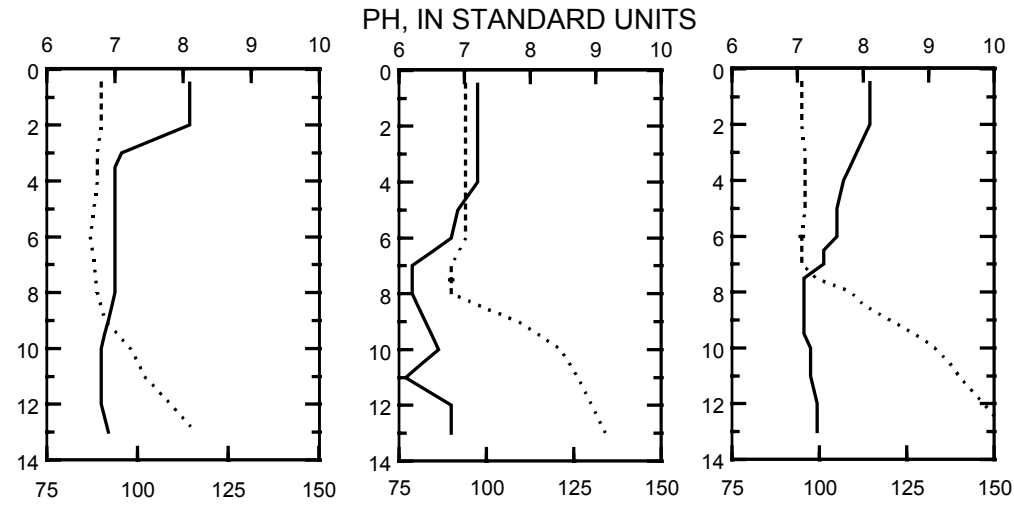

03-15-10
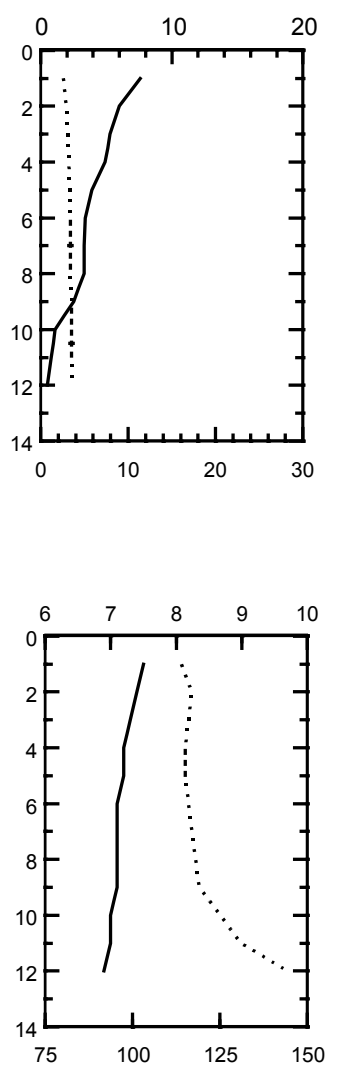

SPECIFIC CONDUCTANCE (S.C.), IN MICROSIEMENS PER CENTIMETER AT 25 DEGREES CELSIUS 


\section{TURTLE-FLAMBEAU FLOWAGE, SOUTHWEST BASIN, NEAR MERCER, WI}

LOCATION.--Lat 4603'44", long 90¹2'48", in NE 1/4 SW 1/4 NW 1/4 sec.2, T.41 N., R.2 E., Vilas County, Hydrologic Unit 07050002. PERIOD OF RECORD._-April 2009 to March 2010 (discontinued).

REMARKS.--Lake sampled in the deepest part of the southwest basin of the flowage. Water-quality analyses done by Wisconsin State Laboratory of Hygiene.

WATER-QUALITY DATA, APRIL 29 TO MARCH 15, 2010

(Milligrams per liter unless otherwise indicated)

\begin{tabular}{|c|c|}
\hline$\underline{\text { Parameter Code }}$ & $\underline{\text { Parameter Name }}$ \\
\hline 00078 & Secchi-depth $(m)$ \\
\hline 00098 & Sampling depth (m) \\
\hline 00010 & Water Temperature $\left({ }^{\circ} \mathrm{C}\right)$ \\
\hline 00400 & $\mathrm{pH}$ (standard units) \\
\hline 00095 & Specific conductance $(\mu \mathrm{S} / \mathrm{cm})$ \\
\hline 00300 & Dissolved oxygen \\
\hline 32210 & Chlorophyll a $(\mu \mathrm{g} / \mathrm{L})$ \\
\hline 00665 & Phosphorus, total (as P) \\
\hline 00631 & Nitrate plus nitrite, dissolved (as $\mathrm{N}$ ) \\
\hline 00625 & Ammonia plus organic nitrogen, total (as $\mathrm{N}$ ) \\
\hline 00600 & Total nitrogen \\
\hline
\end{tabular}

\begin{tabular}{ccccc} 
Apr. 29 & \multicolumn{2}{c}{ June 25 } & \multicolumn{2}{c}{ Aug. 4 } \\
\cline { 1 - 3 } 2.1 & \multicolumn{2}{c}{1.9} & & \multicolumn{2}{c}{2.4} \\
0.5 & 0.5 & 5.5 & 0.5 & 6.0 \\
8.7 & 25.1 & 16.4 & 19.8 & 19.0 \\
7.7 & 8.0 & 6.8 & 7.1 & 6.8 \\
95 & 90 & 95 & 90 & 90 \\
11.4 & 12.3 & 1.2 & 8.7 & 7.7 \\
1.57 & 3.63 & -- & 3.79 & -- \\
0.027 & 0.044 & 0.036 & 0.036 & 0.029 \\
-- & -- & -- & -- & -- \\
-- & -- & -- & -- & -- \\
-- & -- & -- & -- & --
\end{tabular}

\begin{tabular}{cccc}
\multicolumn{2}{c}{ Sept. 3 } & \multicolumn{2}{c}{ March 15 } \\
0.5 & 1.6 & \multicolumn{2}{c}{-} \\
18.6 & 16.9 & 1.0 & 4.0 \\
7.9 & 7.5 & 2.9 & 4.7 \\
91 & 93 & 7.7 & 7.2 \\
8.7 & 5.4 & 117 & 144 \\
5.95 & -- & 10.1 & 1.1 \\
0.020 & 0.026 & -- & -- \\
-- & -- & 0.013 & 0.118 \\
-- & -- & 0.39 & -- \\
-- & -- & 0.477 & --
\end{tabular}




\section{TURTLE-FLAMBEAU FLOWAGE, SOUTHWEST BASIN, NEAR MERCER, WI}

LAKE-DEPTH PROFILES, APRIL 29, 2009 TO MARCH 15, 2010
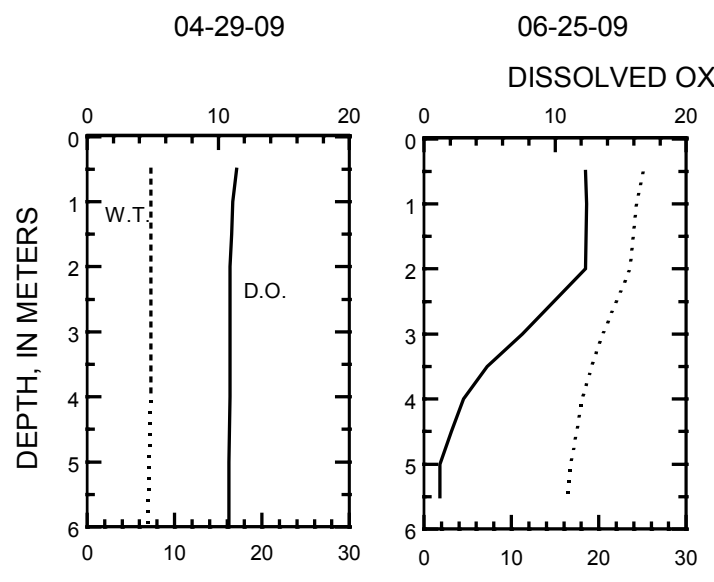

08-04-09

09-03-09

03-15-10
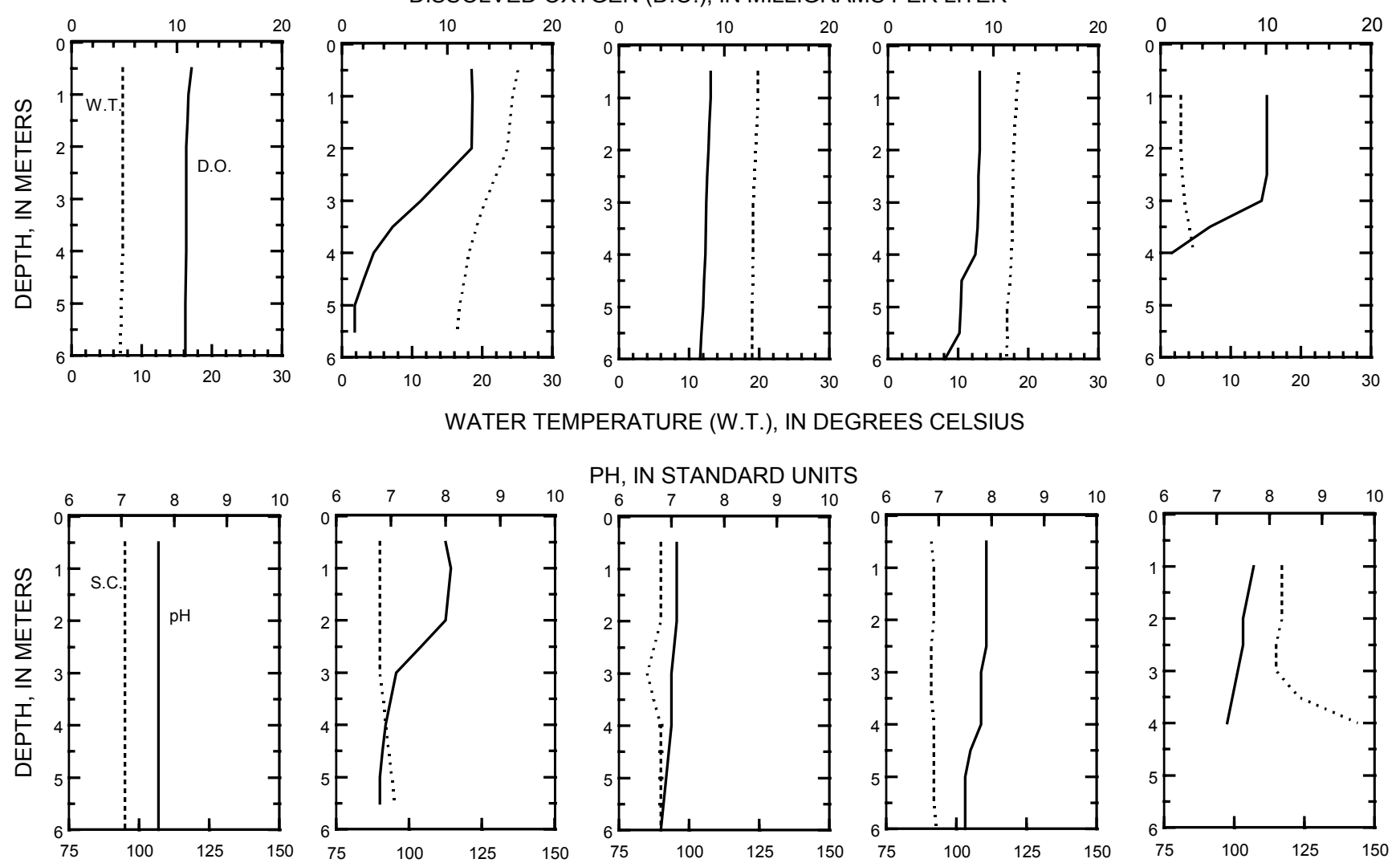

SPECIFIC CONDUCTANCE (S.C.), IN MICROSIEMENS PER CENTIMETER AT 25 DEGREES CELSIUS 


\section{LAKE BASTINE, DEEP HOLE, NEAR MERCER, WI}

LOCATION.--Lat 4605'11", long 90¹5'38", in NE 1/4 SE 1/4 SE 1/4 sec.29, T.41 N., R.2 E., Vilas County, Hydrologic Unit 07050002. PERIOD OF RECORD._April 2009 to March 2010 (discontinued).

REMARKS.--Lake sampled at the deep hole. Water-quality analyses done by Wisconsin State Laboratory of Hygiene.

WATER-QUALITY DATA, APRIL 29, 2009 TO MARCH 15, 2010

(Milligrams per liter unless otherwise indicated)

\begin{tabular}{cll}
\cline { 1 - 2 } Parameter Code & & Parameter Name \\
00078 & & Secchi-depth $(\mathrm{m})$ \\
00098 & & Sampling depth $(\mathrm{m})$ \\
00010 & & Water Temperature $\left({ }^{\circ} \mathrm{C}\right)$ \\
00400 & & $\mathrm{pH}$ (standard units) \\
00095 & Specific conductance $(\mu \mathrm{S} / \mathrm{cm})$ \\
00300 & Dissolved oxygen \\
32210 & Chlorophyll a $(\mu \mathrm{g} / \mathrm{L})$ \\
00665 & Phosphorus, total $($ as $\mathrm{P})$ \\
00671 & Orthophosphate, dissolved (as P) \\
00631 & Nitrate plus nitrite, dissolved (as N) \\
00625 & Ammonia plus organic nitrogen, total (as N) \\
00600 & Total nitrogen
\end{tabular}

\begin{tabular}{cccccc} 
Apr. 29 & \multicolumn{2}{c}{ June 25 } & \multicolumn{2}{c}{ Aug. 4 } \\
\hline 1.4 & \multicolumn{2}{c}{2.1} & \multicolumn{2}{c}{1.7} \\
0.5 & 0.5 & 11.0 & 0.5 & 12.0 \\
7.9 & 24.7 & 7.9 & 19.9 & 8.8 \\
6.9 & 7.9 & 6.8 & 7.0 & 6.9 \\
105 & 90 & 127 & 93 & 145 \\
10.5 & 11.2 & 0.0 & 8.6 & 0.4 \\
3.25 & 2.38 & -- & 2.86 & -- \\
0.021 & 0.042 & 0.067 & 0.026 & 0.064 \\
-- & -- & -- & -- & -- \\
-- & -- & -- & -- & -- \\
-- & -- & -- & -- & -- \\
-- & -- & -- & -- & --
\end{tabular}

\begin{tabular}{cccc}
\multicolumn{2}{c}{ Sept. 3 } & \multicolumn{2}{c}{ March 15 } \\
0.5 & 1.6 & 1.0 & 9.0 \\
18.2 & 9.0 & 3.0 & 4.1 \\
7.9 & 7.3 & 7.4 & 7.0 \\
94 & 164 & 112 & 130 \\
8.7 & 0.3 & 11.8 & 0.5 \\
8.36 & -- & -- & -- \\
0.021 & 0.075 & 0.012 & 0.212 \\
-- & -- & 0.001 & -- \\
-- & -- & 0.071 & -- \\
-- & -- & 0.45 & -- \\
-- & -- & 0.521 & --
\end{tabular}




\section{LAKE BASTINE, DEEP HOLE, NEAR MERCER, WI}

LAKE-DEPTH PROFILES, APRIL 29, 2009 TO MARCH 15, 2010

04-29-09
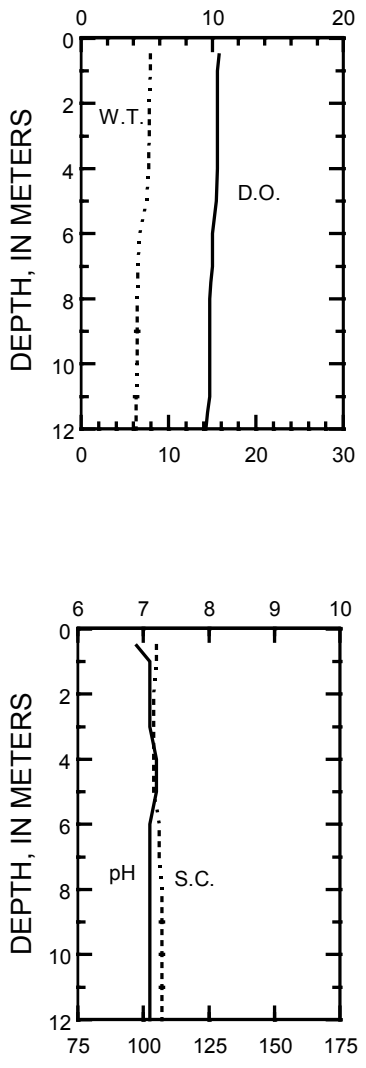

06-25-09

08-04-09

09-03-09

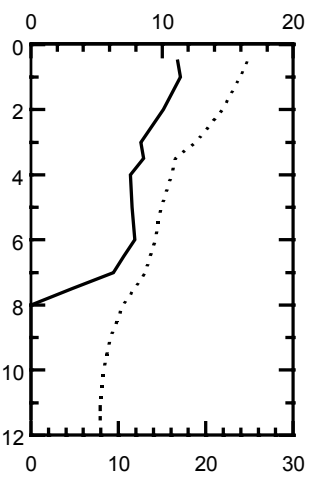

WATER TEIPP
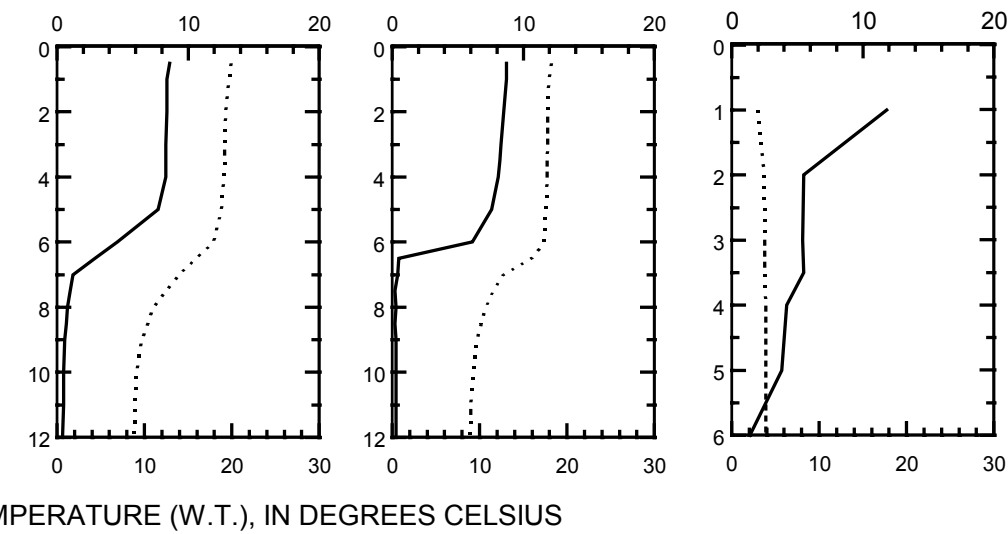

$\mathrm{PH}$, IN STANDARD UNITS
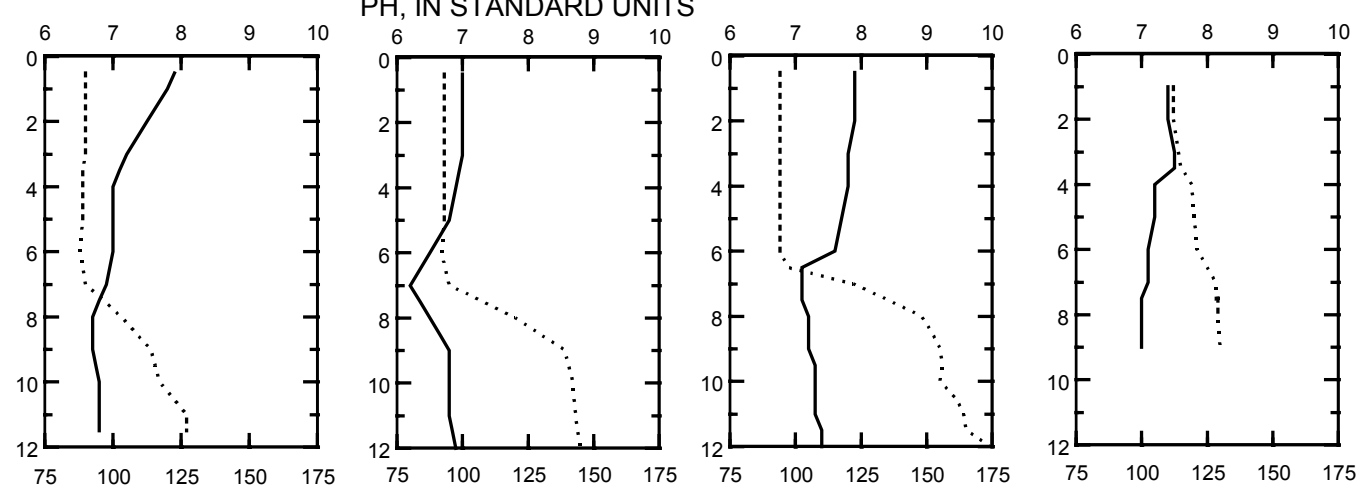

SPECIFIC CONDUCTANCE (S.C.), IN MICROSIEMENS PER CENTIMETER AT 25 DEGREES CELSIUS 


\section{TOWNLINE LAKE NEAR MERCER, WI}

LOCATION.--Lat 4604'09", long 9008'41", in NW 1/4 NW 1/4 NE 1/4 sec.5, T.41 N., R.3 E., Vilas County, Hydrologic Unit 07050002. PERIOD OF RECORD._April 2009 to March 2010 (discontinued).

REMARKS.--Lake sampled at the deep hole. Water-quality analyses done by Wisconsin State Laboratory of Hygiene.

WATER-QUALITY DATA, APRIL 29 TO MARCH 15, 2010

(Milligrams per liter unless otherwise indicated)

\begin{tabular}{|c|c|c|c|c|c|c|}
\hline Parameter Code & Parameter Name & Apr. 29 & \multicolumn{2}{|c|}{$\underline{\text { June } 25}$} & \multicolumn{2}{|c|}{ Aug. 4} \\
\hline 00078 & Secchi-depth (m) & 1.2 & \multicolumn{2}{|c|}{1.8} & \multicolumn{2}{|c|}{1.2} \\
\hline 00098 & Sampling depth (m) & 0.5 & 0.5 & 5.0 & 0.5 & 5.0 \\
\hline 00010 & Water Temperature $\left({ }^{\circ} \mathrm{C}\right)$ & 9.4 & 25.4 & 14.0 & 19.9 & 19.6 \\
\hline 00400 & $\mathrm{pH}$ (standard units) & 7.7 & 8.0 & 6.8 & 7.1 & 7.0 \\
\hline 00095 & Specific conductance $(\mu \mathrm{S} / \mathrm{cm})$ & 76 & 81 & 90 & 83 & 83 \\
\hline 00300 & Dissolved oxygen & 10.7 & 10.8 & 0.0 & 9.7 & 8.4 \\
\hline 32210 & Chlorophyll a $(\mu \mathrm{g} / \mathrm{L})$ & 5.9 & 3.83 & -- & 6.0 & -- \\
\hline 00665 & Phosphorus, total (as P) & 0.030 & 0.025 & 0.040 & 0.041 & 0.034 \\
\hline 00671 & Orthophosphate, dissolved (as P) & -- & -- & -- & -- & -- \\
\hline 00631 & Nitrate plus nitrite, dissolved (as N) & -- & -- & -- & -- & -- \\
\hline 00625 & Ammonia plus organic nitrogen, total (as $\mathrm{N}$ ) & -- & -- & -- & -- & -- \\
\hline 00600 & Total nitrogen & -- & -- & -- & -- & -- \\
\hline
\end{tabular}

\begin{tabular}{cccc}
\multicolumn{2}{c}{ Sept. 3 } & \multicolumn{2}{c}{ March 15 } \\
0.5 & 1.6 & & \multicolumn{2}{c}{-} \\
18.4 & 16.5 & 4.0 & 4.0 \\
8.0 & 7.4 & 7.7 & 4.0 \\
84 & 84 & 93 & 108 \\
9.1 & 5.3 & 8.7 & 2.3 \\
6.02 & -- & -- & -- \\
0.033 & 0.033 & 0.013 & 0.036 \\
-- & -- & 0.006 & -- \\
-- & -- & 0.127 & -- \\
-- & -- & 0.37 & -- \\
-- & -- & 0.497 & --
\end{tabular}




\section{TOWNLINE LAKE NEAR MERCER, WI}

LAKE-DEPTH PROFILES, APRIL 29, 2009 TO MARCH 15, 2010

04-29-09
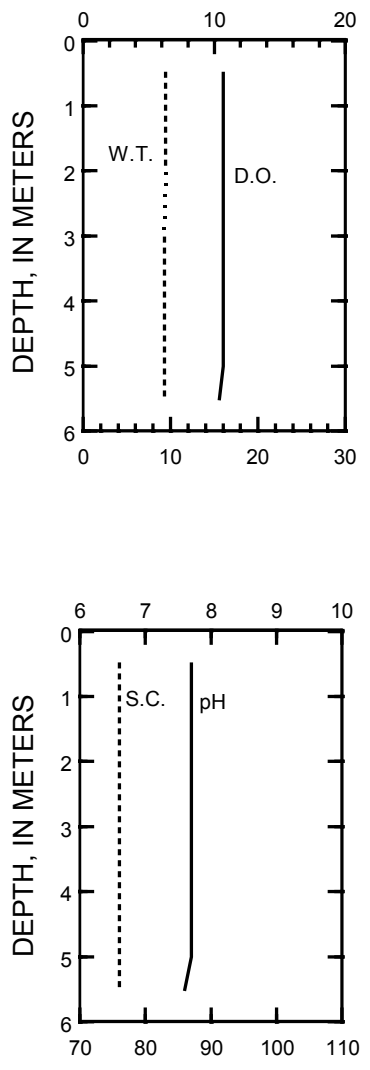

06-25-09

08-04-09

09-03-09

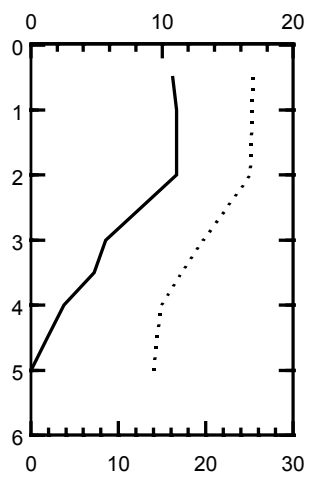

WATER TEMPE
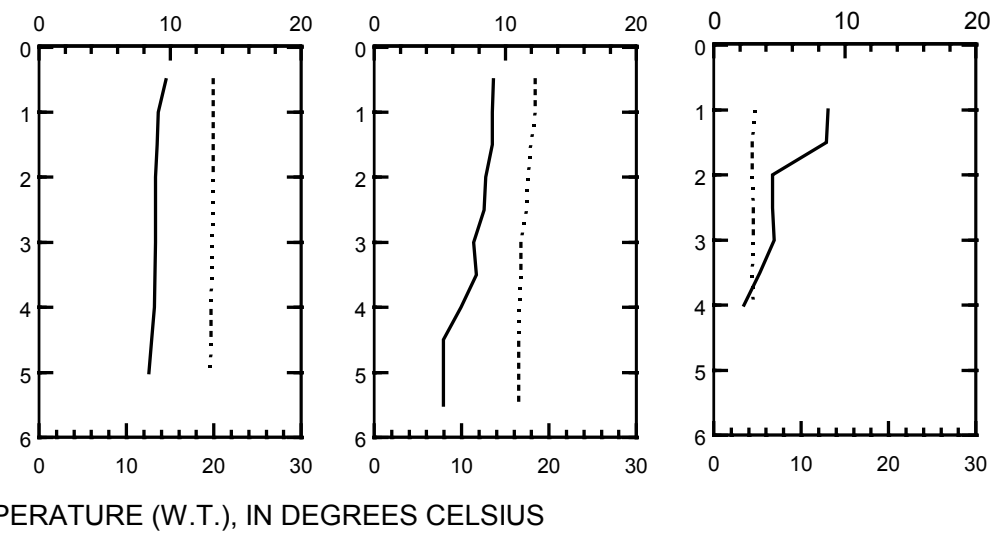

$\mathrm{PH}$, IN STANDARD UNITS
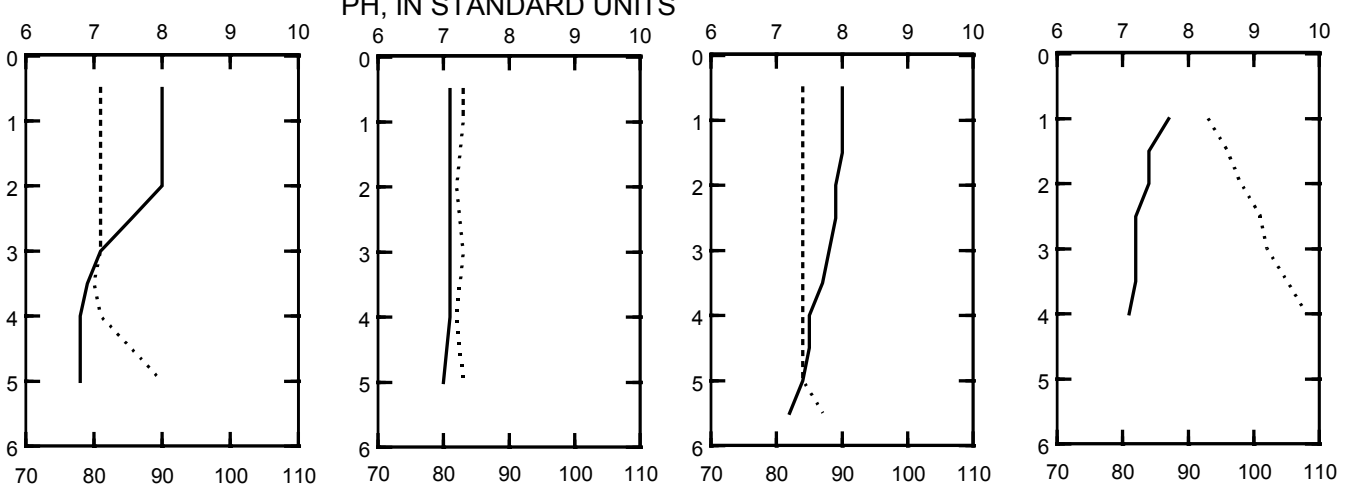

SPECIFIC CONDUCTANCE (S.C.), IN MICROSIEMENS PER CENTIMETER AT 25 DEGREES CELSIUS 


\section{TRUDE LAKE, DEEP HOLE, NEAR MERCER, WI}

LOCATION.--Lat 4606'46", long 9009'19", in SW 1/4 SW 1/4 SW 1/4 sec.17, T.42 N., R.3 E., Vilas County, Hydrologic Unit 07050002. PERIOD OF RECORD._April 2009 to March 2010 (discontinued).

REMARKS.--Lake sampled at the deep hole. Water-quality analyses done by Wisconsin State Laboratory of Hygiene.

\begin{tabular}{|c|c|c|c|c|c|c|}
\hline \multirow[b]{2}{*}{$\underline{\text { Parameter Code }}$} & \multirow[b]{2}{*}{$\underline{\text { Parameter Name }}$} & \multicolumn{5}{|c|}{ (Milligrams per liter unless otherwise indicated) } \\
\hline & & Apr. 28 & \multicolumn{2}{|c|}{$\underline{\text { June } 25}$} & \multicolumn{2}{|c|}{ Aug. 4} \\
\hline 00078 & Secchi-depth (m) & 2.8 & \multicolumn{2}{|c|}{3.2} & \multicolumn{2}{|c|}{2.3} \\
\hline 00098 & Sampling depth (m) & 0.5 & 0.5 & 13.0 & 0.5 & 13.0 \\
\hline 00010 & Water Temperature $\left({ }^{\circ} \mathrm{C}\right)$ & 7.4 & 25.0 & 12.1 & 19.4 & 12.0 \\
\hline 00400 & $\mathrm{pH}$ (standard units) & 7.5 & 8.0 & 6.7 & 7.0 & 6.6 \\
\hline 00095 & Specific conductance $(\mu \mathrm{S} / \mathrm{cm})$ & 78 & 81 & 90 & 81 & 115 \\
\hline 00300 & Dissolved oxygen & 10.8 & 8.6 & 0.0 & 8.6 & 0.4 \\
\hline 32210 & Chlorophyll a ( $\mu \mathrm{g} / \mathrm{L})$ & 1.47 & 0.88 & -- & 3.08 & -- \\
\hline 00665 & Phosphorus, total (as P) & 0.018 & 0.039 & 0.082 & 0.026 & 0.032 \\
\hline 00671 & Orthophosphate, dissolved (as P) & 0.003 & -- & -- & -- & -- \\
\hline 00631 & Nitrate plus nitrite, dissolved (as $\mathrm{N}$ ) & 0.058 & -- & -- & -- & -- \\
\hline 00608 & Ammonia, dissolved (as $\mathrm{N}$ ) & 0.029 & -- & -- & -- & -- \\
\hline 00625 & Ammonia plus organic nitrogen, total (as N) & 0.57 & -- & -- & -- & -- \\
\hline 00600 & Total nitrogen & 0.63 & -- & -- & -- & -- \\
\hline 63675 & Turbidity, (NTU) & $<1.0$ & -- & -- & -- & -- \\
\hline 00081 & Apparent color, (PTU) & 40 & -- & -- & -- & -- \\
\hline 00900 & Hardness (as CaCO3) & 37 & -- & -- & -- & -- \\
\hline 00915 & Calcium, dissolved (Ca) & 9.8 & -- & -- & -- & -- \\
\hline 00925 & Magnesium, dissolved (Mg) & 3 & -- & -- & -- & -- \\
\hline 00930 & Sodium, dissolved $(\mathrm{Na})$ & 1.6 & -- & -- & -- & -- \\
\hline 00935 & Potassium, dissolved (K) & 0.7 & -- & -- & -- & -- \\
\hline 00417 & ANC (as $\mathrm{CaCO} 3$ ) & 34 & -- & -- & -- & -- \\
\hline 00940 & Chloride, dissolved $(\mathrm{Cl})$ & 2.2 & -- & -- & -- & -- \\
\hline 00945 & Sulfate, dissolved (SO4) & $<4.5$ & -- & -- & -- & -- \\
\hline 00955 & Silica, dissolved (SiO2) & 8.24 & -- & -- & -- & -- \\
\hline 01046 & Iron $(\mu \mathrm{g} / \mathrm{L})$ & 100 & -- & -- & -- & -- \\
\hline 01056 & Manganese $(\mu \mathrm{g} / \mathrm{L})$ & 90 & -- & -- & -- & -- \\
\hline 70300 & Solids, dissolved (at $180^{\circ} \mathrm{C}$ ) & 58 & -- & -- & -- & -- \\
\hline
\end{tabular}

\begin{tabular}{cccc}
\multicolumn{2}{c}{ Sept. 3 } & \multicolumn{2}{c}{ March 15 } \\
0.5 & 12.0 & 1.0 & 10.0 \\
20.0 & 11.9 & 2.9 & 3.6 \\
8.1 & 7.2 & 7.5 & 7.1 \\
82 & 136 & 87 & 96 \\
7.9 & 0.1 & 11.0 & 4.7 \\
4.52 & -- & -- & - \\
0.010 & 0.058 & 0.016 & 0.018 \\
-- & -- & 0.012 & -- \\
-- & -- & 0.066 & -- \\
-- & -- & -- & -- \\
-- & -- & 0.39 & -- \\
-- & -- & 0.456 & -- \\
-- & -- & -- & -- \\
-- & -- & -- & -- \\
-- & -- & -- & -- \\
-- & -- & -- & -- \\
-- & -- & -- & -- \\
-- & -- & -- & -- \\
-- & -- & -- & -- \\
-- & -- & -- & -- \\
-- & -- & -- & -- \\
-- & -- & -- & -- \\
-- & -- & -- & -- \\
-- & -- & -- & -- \\
-- & -- & -- & -- \\
-- & -- & -- & --
\end{tabular}




\section{TRUDE LAKE, DEEP HOLE, NEAR MERCER, WI}

LAKE-DEPTH PROFILES, APRIL 29, 2009 TO MARCH 15, 2010

04-28-09
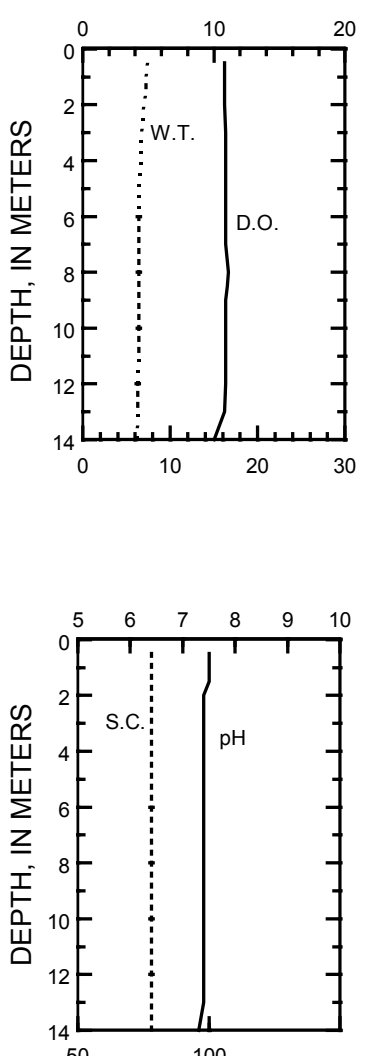

100
06-25-09

08-04-09

09-03-09

DISSOLVED OXYGEN (D.O.), IN MILLIGRAMS PER LITER
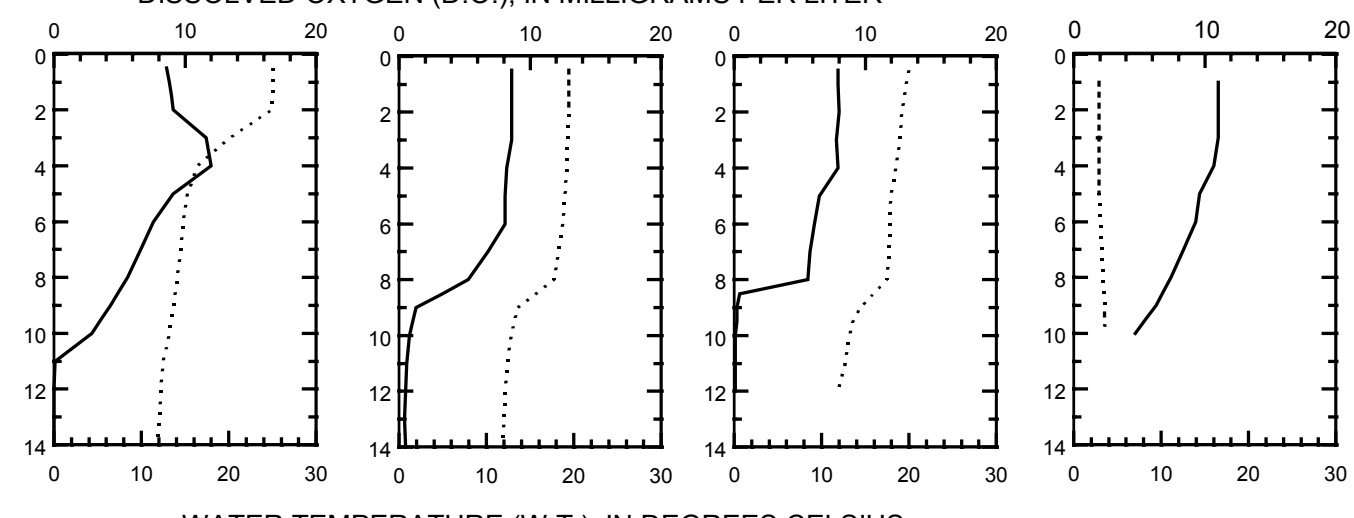

WATER TEMPERATURE (W.T.), IN DEGREES CELSIUS
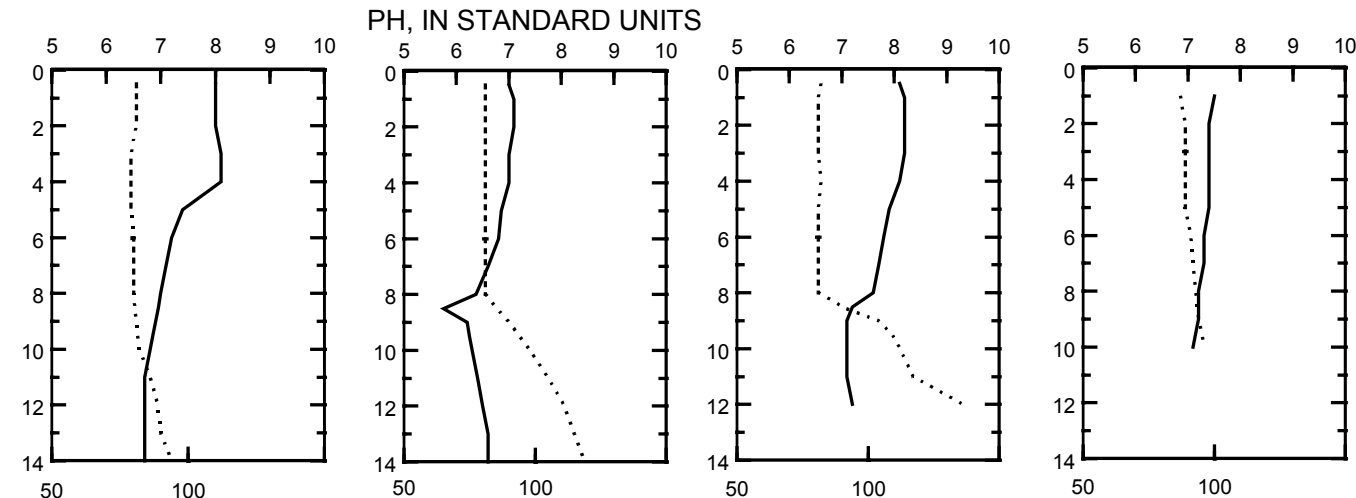

SPECIFIC CONDUCTANCE (S.C.), IN MICROSIEMENS PER CENTIMETER AT 25 DEGREES CELSIUS 


\section{LAKE WAUBESA AT MCFARLAND, WI}

LOCATION.--Lat 4300'32", long 89¹8'19" referenced to North American Datum of 1927, in SW 1/4 SW 1/4 sec.3, T.6 N., R.10 E., Dane County, WI, Hydrologic Unit 07090001, on left bank just upstream from bridge on U.S. Highway 51 , downstream of dam at outlet of Lake Waubesa and 1.0 mi southwest of McFarland.

SURFACE AREA.--3.25 $\mathrm{mi}^{2}$.

DRAINAGE AREA.--327 $\mathrm{mi}^{2}$ of which $36.6 \mathrm{mi}^{2}$ probably is noncontributing.

PERIOD OF RECORD.--October 2003 to current year.

REVISED RECORDS.--WSP 805, WDR WI-73-1: Drainage area.

GAGE.--Water-stage recorder. Datum of gage is $840.00 \mathrm{ft}$ above NGVD of 1929 (levels by Wisconsin Department of Natural Resources).

REMARKS.--Lake level regulated by dams at outlets of Lake Mendota and Lake Waubesa. Gage-height telemeter at station.

EXTREMES FOR PERIOD OF RECORD.--Maximum gage height observed, 7.22 ft, June 15-17, 2008; minimum observed, $3.50 \mathrm{ft}$, Feb.14, 2006, current datum.

EXTREMES FOR CURRENT YEAR.--Maximum recorded gage height, $6.63 \mathrm{ft}$, Aug. 15; minimum recorded, $3.99 \mathrm{ft}$, Mar. 9. 


\begin{tabular}{|c|c|c|c|c|c|c|c|c|c|c|c|c|}
\hline \multicolumn{13}{|c|}{$\begin{array}{c}\text { GAGE HEIGHT, FEET } \\
\text { WATER YEAR OCTOBER } 2009 \text { TO SEPTEMBER } 2010 \\
\text { DAILY MEAN VALUES }\end{array}$} \\
\hline Day & Oct & Nov & Dec & Jan & Feb & Mar & Apr & May & Jun & Jul & Aug & Sep \\
\hline 1 & 5.32 & 5.00 & 5.03 & 4.94 & 4.30 & 4.09 & 4.14 & 5.03 & \begin{tabular}{|l|}
5.28 \\
\end{tabular} & 5.89 & 6.37 & 6.10 \\
\hline 2 & 5.34 & 4.97 & 5.01 & 4.91 & 4.30 & 4.09 & 4.13 & 5.04 & \begin{tabular}{|l}
5.32 \\
\end{tabular} & 5.83 & 6.34 & 6.13 \\
\hline 3 & 5.34 & 4.94 & 5.00 & \begin{tabular}{|l}
4.89 \\
\end{tabular} & 4.28 & 4.08 & 4.13 & 5.04 & \begin{tabular}{|l|}
5.37 \\
\end{tabular} & 5.78 & 6.32 & \begin{tabular}{|l|}
6.24 \\
\end{tabular} \\
\hline 4 & 5.34 & 4.89 & 4.98 & 4.87 & 4.26 & 4.06 & 4.13 & 5.01 & \begin{tabular}{|l}
5.42 \\
\end{tabular} & 5.74 & 6.30 & 6.24 \\
\hline 5 & 5.31 & 4.86 & 4.94 & 4.85 & 4.25 & 4.04 & 4.14 & 5.00 & \begin{tabular}{|l|}
5.49 \\
\end{tabular} & 5.72 & 6.29 & \begin{tabular}{|l|}
6.21 \\
\end{tabular} \\
\hline 6 & 5.29 & 4.82 & 4.91 & 4.83 & 4.24 & 4.02 & 4.21 & 4.95 & 5.67 & 5.71 & 6.26 & 6.20 \\
\hline 7 & 5.30 & 4.80 & 4.90 & 4.83 & 4.22 & 4.00 & 4.48 & 4.92 & \begin{tabular}{|l|}
5.69 \\
\end{tabular} & 5.71 & 6.23 & \begin{tabular}{|l|}
6.17 \\
\end{tabular} \\
\hline 8 & 5.28 & $\begin{array}{l}4.79 \\
\end{array}$ & 4.89 & 4.82 & 4.21 & 4.00 & $\begin{array}{l}4.69 \\
\end{array}$ & 4.95 & \begin{tabular}{|l|}
5.74 \\
\end{tabular} & 5.74 & 6.27 & \begin{tabular}{|l|}
6.12 \\
\end{tabular} \\
\hline 9 & 5.24 & $\begin{array}{l}4.78 \\
\end{array}$ & 4.98 & 4.80 & 4.21 & 4.00 & 4.70 & 4.90 & \begin{tabular}{|l|}
5.77 \\
\end{tabular} & 5.73 & 6.38 & 6.08 \\
\hline 10 & 5.20 & 4.79 & 4.97 & \begin{tabular}{|l|l|}
4.78 \\
\end{tabular} & 4.22 & 4.06 & 4.69 & 4.82 & \begin{tabular}{|l|}
5.75 \\
\end{tabular} & 5.72 & 6.40 & 6.03 \\
\hline 11 & 5.15 & 4.80 & 4.96 & 4.76 & 4.21 & 4.15 & 4.68 & 4.83 & 5.78 & 5.70 & 6.39 & 6.00 \\
\hline 12 & 5.11 & 4.82 & 4.95 & 4.74 & 4.20 & 4.23 & 4.66 & 4.85 & \begin{tabular}{|l|}
5.77 \\
\end{tabular} & 5.70 & 6.38 & \begin{tabular}{|l|}
5.97 \\
\end{tabular} \\
\hline 13 & 5.08 & 4.83 & 4.94 & 4.71 & 4.18 & 4.28 & 4.64 & 4.96 & \begin{tabular}{|l}
5.76 \\
\end{tabular} & 5.69 & 6.41 & \begin{tabular}{|l|}
5.94 \\
\end{tabular} \\
\hline 14 & 5.04 & 4.86 & 4.93 & 4.67 & 4.18 & 4.30 & 4.63 & 5.01 & \begin{tabular}{|l}
5.75 \\
\end{tabular} & 5.67 & 6.59 & 5.90 \\
\hline 15 & 5.02 & $\begin{array}{l}4.89 \\
\end{array}$ & 4.92 & 4.62 & 4.17 & 4.29 & 4.63 & 4.99 & \begin{tabular}{|l}
5.75 \\
\end{tabular} & 5.71 & 6.62 & 5.86 \\
\hline 16 & 5.01 & 4.89 & 4.89 & 4.58 & 4.16 & 4.28 & 4.66 & 4.96 & \begin{tabular}{|l|}
5.76 \\
\end{tabular} & 5.74 & 6.60 & 5.83 \\
\hline 17 & 4.97 & 4.91 & 4.86 & 4.54 & 4.16 & 4.27 & 4.69 & 4.94 & \begin{tabular}{|l}
5.74 \\
\end{tabular} & 5.74 & 6.57 & $\begin{array}{l}5.79 \\
\end{array}$ \\
\hline 18 & 4.93 & 4.92 & 4.84 & 4.50 & 4.14 & 4.26 & 4.71 & 4.93 & \begin{tabular}{|l|}
5.73 \\
\end{tabular} & 5.76 & 6.52 & 5.82 \\
\hline 19 & 4.89 & 4.94 & 4.82 & 4.47 & 4.13 & 4.24 & 4.72 & 4.93 & \begin{tabular}{|l}
5.72 \\
\end{tabular} & 5.76 & 6.47 & 5.82 \\
\hline 20 & 4.88 & 4.96 & 4.81 & 4.43 & 4.13 & 4.26 & 4.76 & 4.93 & \begin{tabular}{|l|}
5.68 \\
\end{tabular} & 5.77 & 6.42 & \begin{tabular}{|l|}
5.81 \\
\end{tabular} \\
\hline 21 & 4.86 & 4.96 & 4.80 & \begin{tabular}{|l|}
4.40 \\
\end{tabular} & 4.12 & 4.25 & 4.76 & 4.97 & \begin{tabular}{|l|}
5.70 \\
\end{tabular} & 5.77 & 6.40 & \begin{tabular}{|l|}
5.78 \\
\end{tabular} \\
\hline 22 & 4.86 & 4.96 & 4.80 & 4.38 & 4.13 & 4.23 & 4.73 & 5.00 & \begin{tabular}{|l|}
5.88 \\
\end{tabular} & 5.87 & 6.37 & \begin{tabular}{|l|}
5.76 \\
\end{tabular} \\
\hline 23 & 5.01 & 4.96 & 4.79 & 4.36 & 4.13 & 4.22 & 4.74 & 5.01 & \begin{tabular}{|l|}
5.97 \\
\end{tabular} & 6.17 & 6.33 & 5.72 \\
\hline 24 & 5.05 & 4.97 & 4.80 & 4.39 & 4.12 & 4.21 & 4.73 & 5.04 & \begin{tabular}{|l|}
6.01 \\
\end{tabular} & 6.34 & 6.28 & $\begin{array}{l}5.74 \\
\end{array}$ \\
\hline 25 & 5.02 & 5.05 & 4.94 & 4.43 & 4.12 & 4.20 & $\begin{array}{l}4.81 \\
\end{array}$ & 5.07 & \begin{tabular}{|l|}
5.99 \\
\end{tabular} & 6.41 & $\begin{array}{l}6.24 \\
\end{array}$ & 5.70 \\
\hline 26 & 5.01 & 5.13 & 5.00 & 4.44 & 4.12 & 4.19 & 4.93 & 5.08 & 6.02 & 6.42 & 6.18 & 5.67 \\
\hline 27 & 4.99 & 5.13 & 5.02 & 4.42 & 4.11 & 4.18 & 4.98 & 5.14 & \begin{tabular}{|l|}
6.05 \\
\end{tabular} & 6.44 & 6.12 & 5.65 \\
\hline 28 & 4.96 & 5.10 & 5.02 & \begin{tabular}{|l|l|}
4.39 \\
\end{tabular} & 4.10 & 4.18 & 4.99 & 5.15 & \begin{tabular}{|l}
6.05 \\
\end{tabular} & 6.43 & 6.08 & \begin{tabular}{|l|}
5.64 \\
\end{tabular} \\
\hline 29 & 4.93 & 5.09 & 5.00 & 4.37 & ב-- & 4.18 & 4.96 & 5.21 & \begin{tabular}{|l|}
6.00 \\
\end{tabular} & 6.40 & 6.04 & 5.63 \\
\hline 30 & 5.02 & 5.07 & 4.98 & 4.34 & --- & 4.15 & 4.97 & 5.22 & \begin{tabular}{|l}
5.95 \\
\end{tabular} & 6.37 & 6.01 & 5.62 \\
\hline 31 & 5.04 & --- & 4.96 & 4.32 & --- & 4.13 & --- & 5.25 & --- & 6.39 & 5.99 & - \\
\hline Mean & 5.09 & 4.93 & 4.92 & 4.61 & 4.18 & 4.17 & 4.63 & 5.00 & \begin{tabular}{|l|}
5.75 \\
\end{tabular} & 5.93 & 6.33 & 5.91 \\
\hline Max & 5.34 & 5.13 & 5.03 & 4.94 & 4.30 & 4.30 & 4.99 & 5.25 & \begin{tabular}{|l|}
6.05 \\
\end{tabular} & 6.44 & 6.62 & 6.24 \\
\hline Min & 4.86 & 4.78 & 4.79 & 4.32 & 4.10 & 4.00 & 4.13 & 4.82 & \begin{tabular}{|l|}
5.28 \\
\end{tabular} & 5.67 & 5.99 & 5.62 \\
\hline
\end{tabular}




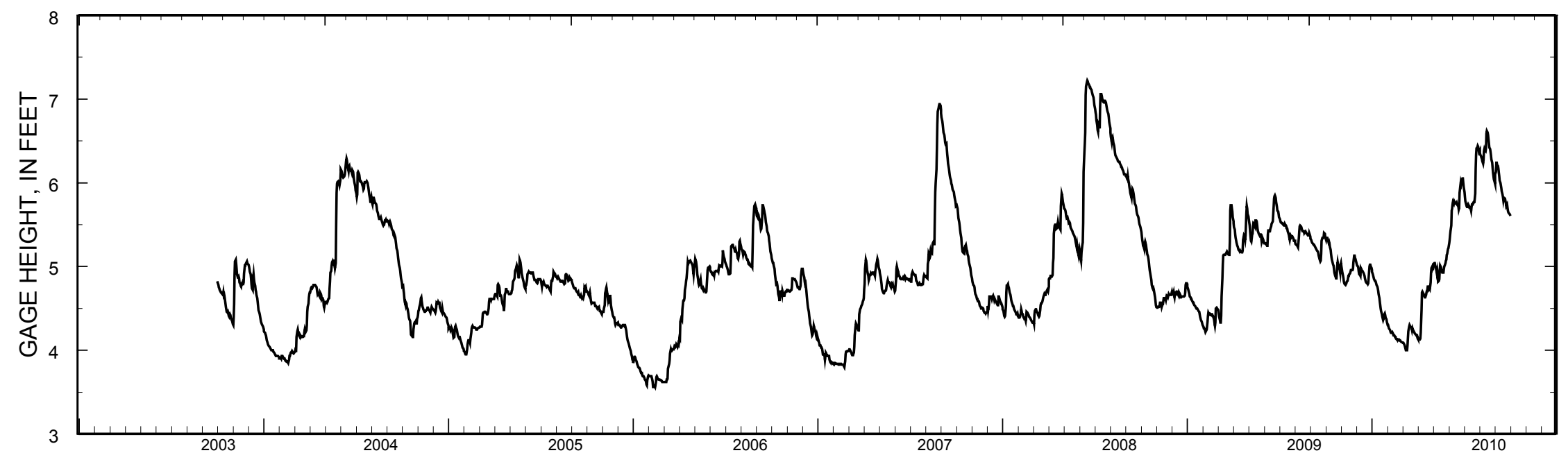

Stage hydrograph for Lake Waubesa, 2003-2010 


\section{WIND LAKE, HEADWATER, AT OUTLET AT WIND LAKE, WI}

LOCATION.--Lat 4248'48", long 8808'31" referenced to North American Datum of 1927, in NE 1/4 NW 1/4 sec.16, T.4 N., R.20 E.,

Racine County, WI, Hydrologic Unit 07120006, at Wind Lake.

SURFACE AREA.--1.46 $\mathrm{mi}^{2}$.

DRAINAGE AREA.--39.6 $\mathrm{mi}^{2}$.

PERIOD OF RECORD.--March 1985 to current year. Prior to October 2000, published as "Wind Lake Outlet".

REVISED RECORDS.--WDR WI-91-1: 1988(m).

REMARKS.--Lake level regulated by dam with two 10-foot gates at outlet. Lake ice-covered Dec. 3 to Mar. 14. Prior to October 1987, published as Wind Lake at Wind Lake, Wis. Gage-height telemeter at station.

EXTREMES FOR PERIOD OF RECORD.--Maximum gage height, 9.88 ft, June 14, 15, 2008; minimum recorded, $5.95 \mathrm{ft}$, Jan. 2 , 1996.

EXTREMES FOR CURRENT YEAR.--Maximum recorded gage height, $8.56 \mathrm{ft}$, July 15; minimum recorded, $8.08 \mathrm{ft}$, Jan. 11.

\begin{tabular}{|c|c|c|c|c|c|c|c|c|c|c|c|c|}
\hline \multicolumn{13}{|c|}{$\begin{array}{c}\text { GAGE HEIGHT, FEET (HEADWATER) } \\
\text { WATER YEAR OCTOBER } 2009 \text { TO SEPTEMBER } 2010 \\
\text { DAILY MEAN VALUES }\end{array}$} \\
\hline Day & Oct & Nov & Dec & Jan & Feb & Mar & Apr & May & Jun & Jul & Aug & Sep \\
\hline 1 & 8.18 & 8.30 & 8.35 & 8.27 & 8.38 & 8.27 & 8.36 & 8.25 & 8.29 & 8.32 & 8.34 & 8.31 \\
\hline 2 & 8.28 & 8.34 & 8.40 & 8.24 & 8.31 & 8.26 & 8.36 & 8.26 & 8.30 & 8.26 & 8.33 & 8.32 \\
\hline 3 & 8.28 & 8.39 & 8.44 & 8.21 & 8.24 & 8.26 & 8.35 & 8.30 & 8.33 & 8.36 & 8.35 & 8.33 \\
\hline 4 & 8.27 & 8.43 & 8.48 & 8.24 & 8.24 & 8.26 & 8.26 & 8.31 & 8.32 & 8.39 & 8.34 & 8.31 \\
\hline 5 & 8.26 & 8.46 & 8.50 & 8.33 & 8.32 & 8.27 & 8.22 & 8.33 & 8.36 & 8.33 & 8.35 & 8.29 \\
\hline 6 & 8.26 & 8.44 & 8.53 & 8.40 & 8.36 & 8.28 & 8.32 & 8.32 & 8.39 & 8.30 & 8.33 & 8.28 \\
\hline 7 & 8.26 & 8.38 & 8.50 & 8.43 & 8.34 & 8.29 & 8.25 & 8.30 & 8.26 & 8.42 & 8.34 & 8.27 \\
\hline 8 & 8.25 & 8.34 & 8.37 & 8.36 & 8.31 & 8.30 & 8.34 & 8.22 & 8.31 & 8.28 & 8.36 & 8.26 \\
\hline 9 & 8.26 & 8.33 & 8.36 & 8.26 & 8.29 & 8.29 & 8.31 & 8.19 & 8.38 & 8.24 & 8.40 & 8.25 \\
\hline 10 & 8.26 & 8.36 & 8.29 & 8.16 & 8.29 & 8.27 & 8.34 & 8.22 & 8.40 & 8.33 & 8.37 & 8.24 \\
\hline 11 & 8.24 & 8.37 & 8.33 & 8.11 & 8.26 & 8.30 & 8.41 & 8.30 & 8.35 & 8.45 & 8.31 & 8.29 \\
\hline 12 & 8.24 & 8.37 & 8.38 & 8.17 & 8.32 & 8.32 & 8.41 & 8.30 & 8.27 & 8.38 & 8.33 & 8.30 \\
\hline 13 & 8.23 & 8.37 & 8.43 & 8.24 & 8.37 & 8.32 & 8.37 & 8.36 & 8.24 & 8.26 & 8.35 & 8.30 \\
\hline 14 & 8.22 & 8.38 & 8.42 & 8.31 & 8.35 & 8.30 & 8.29 & 8.30 & 8.27 & 8.34 & 8.37 & 8.29 \\
\hline 15 & 8.23 & 8.38 & 8.27 & 8.35 & 8.30 & 8.27 & 8.29 & 8.28 & 8.32 & 8.43 & 8.35 & 8.29 \\
\hline 16 & 8.25 & 8.38 & 8.24 & 8.31 & 8.26 & 8.28 & 8.35 & 8.37 & 8.36 & 8.30 & 8.31 & 8.29 \\
\hline 17 & 8.24 & 8.38 & 8.28 & 8.28 & 8.23 & 8.29 & 8.37 & 8.42 & 8.32 & 8.40 & 8.26 & 8.27 \\
\hline 18 & 8.23 & 8.39 & 8.32 & 8.24 & 8.25 & 8.32 & 8.38 & 8.40 & 8.35 & 8.43 & 8.26 & 8.29 \\
\hline 19 & 8.22 & 8.39 & 8.36 & 8.24 & 8.28 & 8.26 & 8.36 & 8.35 & 8.37 & 8.34 & 8.26 & 8.30 \\
\hline 20 & 8.22 & 8.37 & 8.39 & 8.26 & 8.27 & 8.27 & 8.33 & 8.31 & 8.38 & 8.28 & 8.27 & 8.31 \\
\hline 21 & 8.22 & 8.35 & 8.41 & 8.31 & 8.25 & 8.30 & 8.30 & 8.32 & 8.38 & 8.33 & 8.37 & 8.32 \\
\hline 22 & 8.26 & 8.33 & 8.37 & 8.35 & 8.28 & 8.32 & 8.27 & 8.33 & 8.36 & 8.37 & 8.37 & 8.37 \\
\hline 23 & 8.37 & 8.32 & 8.30 & 8.31 & 8.29 & 8.25 & 8.27 & 8.36 & 8.29 & 8.35 & 8.37 & 8.36 \\
\hline 24 & 8.35 & 8.33 & 8.27 & 8.25 & 8.30 & 8.30 & 8.29 & 8.35 & 8.35 & 8.41 & 8.37 & 8.35 \\
\hline 25 & 8.34 & 8.39 & 8.29 & 8.27 & 8.31 & 8.39 & 8.35 & 8.28 & 8.34 & 8.42 & 8.36 & 8.35 \\
\hline 26 & 8.38 & 8.43 & 8.27 & 8.32 & 8.31 & 8.38 & 8.31 & 8.28 & 8.33 & 8.38 & 8.34 & 8.34 \\
\hline 27 & 8.36 & 8.37 & 8.31 & 8.38 & 8.31 & 8.32 & 8.25 & 8.28 & 8.31 & 8.32 & 8.32 & 8.33 \\
\hline 28 & 8.33 & 8.33 & 8.35 & 8.32 & 8.28 & 8.25 & 8.27 & 8.28 & 8.27 & 8.28 & 8.30 & 8.33 \\
\hline 29 & 8.32 & 8.34 & 8.36 & 8.24 & --- & 8.23 & 8.32 & 8.27 & 8.31 & 8.29 & 8.29 & 8.32 \\
\hline 30 & 8.36 & 8.33 & 8.35 & 8.23 & --- & 8.33 & 8.31 & 8.26 & 8.38 & 8.34 & 8.28 & 8.32 \\
\hline 31 & 8.32 & --- & 8.32 & 8.33 & --- & 8.36 & --- & 8.27 & --- & 8.39 & 8.28 & --- \\
\hline Mean & 8.27 & 8.37 & 8.36 & 8.28 & 8.30 & 8.29 & 8.32 & 8.30 & 8.33 & 8.35 & 8.33 & 8.31 \\
\hline Max & 8.38 & 8.46 & 8.53 & 8.43 & 8.38 & 8.39 & 8.41 & 8.42 & 8.40 & 8.45 & 8.40 & 8.37 \\
\hline Min & 8.18 & 8.30 & 8.24 & 8.11 & 8.23 & 8.23 & 8.22 & 8.19 & 8.24 & 8.24 & 8.26 & 8.24 \\
\hline
\end{tabular}




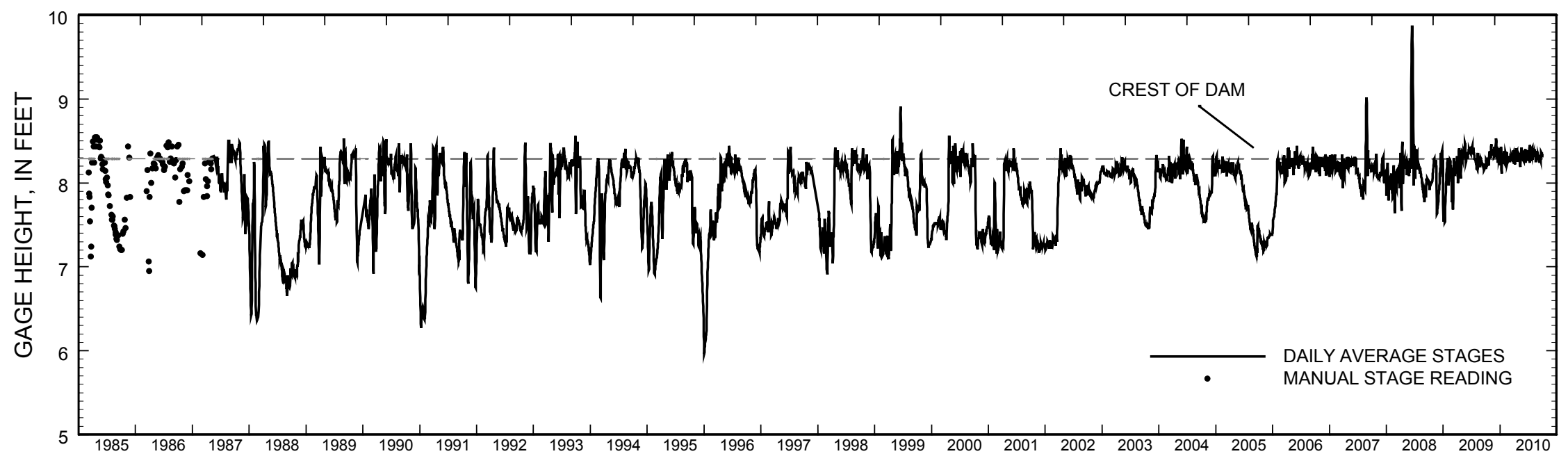

Stage hydrograph for Wind Lake, 1985-2010. 


\section{WIND LAKE AT WIND LAKE, WI}

LOCATION.--Lat 42 49'15", long $88^{\circ} 08^{\prime} 39 "$, in NW 1/4 SW 1/4 sec.9, T.4 N., R.20 E., Racine County, Hydrologic Unit 07120006 , at Wind Lake.

SURFACE AREA.--1.46 $\mathrm{mi}^{2}$.

PERIOD OF RECORD.--February 1985 to current year.

REMARKS.--Lake sampled near center at the deep hole. Lake ice-covered during February sampling. Water-quality analyses done by Wisconsin State Laboratory of Hygiene.

WATER-QUALITY DATA, FEBRUARY 17 TO AUGUST 30, 2010

(Milligrams per liter unless otherwise indicated)

\begin{tabular}{|c|c|}
\hline Parameter Code & Parameter Name \\
\hline 32210 & Chlorophyll a $(\mu \mathrm{g} / \mathrm{L})$ \\
\hline 00078 & Secchi-depth (m) \\
\hline 00098 & Sampling depth (m) \\
\hline 00010 & Water Temperature $\left({ }^{\circ} \mathrm{C}\right)$ \\
\hline 00400 & $\mathrm{pH}$ (standard units) \\
\hline 00095 & Specific conductance $(\mu \mathrm{S} / \mathrm{cm})$ \\
\hline 00300 & Dissolved oxygen \\
\hline 00665 & Phosphorus, total (as P) \\
\hline 00671 & Orthophosphate, dissolved (as P) \\
\hline 00631 & Nitrate plus nitrite, dissolved (as $\mathrm{N}$ ) \\
\hline 00608 & Ammonia, dissolved (as $\mathrm{N}$ ) \\
\hline 00623 & Ammonia plus organic nitrogen, dissolved (as $\mathrm{N}$ ) \\
\hline 00625 & Ammonia plus organic nitrogen, total (as $\mathrm{N}$ ) \\
\hline 00600 & Total nitrogen \\
\hline 63675 & Turbidity, (NTU) \\
\hline 00081 & Apparent color, (PTU) \\
\hline 00900 & Hardness (as $\mathrm{CaCO} 3$ ) \\
\hline 00915 & Calcium, dissolved $(\mathrm{Ca})$ \\
\hline 00925 & Magnesium, dissolved (Mg) \\
\hline 00930 & Sodium, dissolved $(\mathrm{Na})$ \\
\hline 00935 & Potassium, dissolved $(\mathrm{K})$ \\
\hline 00417 & $\mathrm{ANC}($ as $\mathrm{CaCO} 3)$ \\
\hline 00940 & Chloride, dissolved $(\mathrm{Cl})$ \\
\hline 00945 & Sulfate, dissolved (SO4) \\
\hline 00955 & Silica, dissolved (SiO2) \\
\hline 01046 & Iron $(\mu \mathrm{g} / \mathrm{L})$ \\
\hline 01056 & Manganese $(\mu \mathrm{g} / \mathrm{L})$ \\
\hline 70300 & Solids, dissolved (at $180^{\circ} \mathrm{C}$ ) \\
\hline
\end{tabular}

\begin{tabular}{|c|c|c|c|c|c|c|c|c|c|}
\hline \multicolumn{2}{|c|}{ February 17} & \multicolumn{2}{|c|}{ April 7} & \multicolumn{2}{|c|}{ June 25} & \multicolumn{2}{|c|}{ July 29} & \multicolumn{2}{|c|}{ August 30} \\
\hline \multicolumn{2}{|c|}{--} & \multicolumn{2}{|c|}{8.5} & \multicolumn{2}{|c|}{9.88} & \multicolumn{2}{|c|}{17.9} & \multicolumn{2}{|c|}{12} \\
\hline \multicolumn{2}{|c|}{--} & \multicolumn{2}{|c|}{2.65} & \multicolumn{2}{|c|}{2.4} & \multicolumn{2}{|c|}{1.25} & \multicolumn{2}{|c|}{1.35} \\
\hline 0.5 & 14 & 0.5 & 15 & 0.5 & 16 & 0.5 & 14 & 0.5 & 15 \\
\hline 1.2 & 3 & 11 & 9.3 & 25.1 & 12.8 & 26.9 & 13.2 & 25 & 13.1 \\
\hline 8.7 & 7 & 8.2 & 7.9 & 8.4 & 7.2 & 8.2 & 7.4 & 8.2 & 7 \\
\hline 697 & 923 & 709 & 729 & 616 & 689 & 519 & 695 & 491 & 710 \\
\hline 11 & 3.7 & 10.6 & 10.2 & 7.8 & 0.3 & 7.5 & 0.2 & 8.5 & 0.2 \\
\hline 0.048 & 0.131 & 0.021 & -- & 0.031 & 0.199 & 0.070 & 0.331 & 0.033 & -- \\
\hline -- & -- & $<.002$ & -- & -- & -- & 0.021 & -- & -- & -- \\
\hline-- & -- & 0.037 & -- & -- & -- & 0.033 & -- & -- & -- \\
\hline-- & -- & 0.029 & -- & -- & -- & 0.021 & -- & -- & -- \\
\hline -- & -- & -- & -- & -- & -- & 0.85 & -- & -- & -- \\
\hline-- & -- & 0.83 & -- & -- & -- & -- & -- & -- & -- \\
\hline-- & -- & 0.87 & -- & -- & -- & -- & -- & -- & -- \\
\hline -- & -- & $<1.0$ & -- & -- & -- & -- & -- & -- & -- \\
\hline-- & -- & 30 & -- & -- & -- & -- & -- & -- & -- \\
\hline -- & -- & 221 & -- & -- & -- & -- & -- & -- & -- \\
\hline -- & -- & 46.4 & -- & -- & -- & -- & -- & -- & -- \\
\hline-- & -- & 25.6 & -- & -- & -- & -- & -- & -- & -- \\
\hline -- & -- & 55.2 & -- & -- & -- & -- & -- & -- & -- \\
\hline -- & -- & 2.5 & -- & -- & -- & -- & -- & -- & -- \\
\hline-- & -- & 167 & -- & -- & -- & -- & -- & -- & -- \\
\hline -- & -- & 107 & -- & -- & -- & -- & -- & -- & -- \\
\hline -- & -- & 32.3 & -- & -- & -- & -- & -- & -- & -- \\
\hline-- & -- & 0.335 & -- & -- & -- & -- & -- & -- & -- \\
\hline -- & -- & $<100$ & -- & -- & -- & -- & -- & -- & -- \\
\hline -- & -- & 3.1 & -- & -- & -- & -- & -- & -- & -- \\
\hline -- & -- & 406 & -- & -- & -- & -- & -- & -- & -- \\
\hline
\end{tabular}


424915088083900 WIND LAKE AT WIND LAKE, WI

WATER-QUALITY DATA, SEPTEMBER 2, 2010

(Milligrams per liter unless otherwise indicated)

\begin{tabular}{|c|c|}
\hline Parameter Code & Parameter Name \\
\hline 32210 & Chlorophyll a ( $\mu \mathrm{g} / \mathrm{L})$ \\
\hline 00078 & Secchi-depth (m) \\
\hline 00098 & Sampling depth $(\mathrm{m})$ \\
\hline 00010 & Water Temperature $\left({ }^{\circ} \mathrm{C}\right)$ \\
\hline 00400 & $\mathrm{pH}$ (standard units) \\
\hline 00095 & Specific conductance $(\mu \mathrm{S} / \mathrm{cm})$ \\
\hline 00300 & Dissolved oxygen \\
\hline 00665 & Phosphorus, total (as P) \\
\hline
\end{tabular}

\begin{tabular}{ccccc}
\multicolumn{5}{c}{ September 2} \\
\hline 0.5 & \multicolumn{5}{c}{16.9} & \\
25.2 & 7 & 1.6 & 13.5 & 15 \\
8.2 & 23.1 & 12 & 13.3 & 13.1 \\
497 & 7.5 & 7.6 & 7.1 & 7 \\
7.6 & 530 & 702 & 705 & 710 \\
0.035 & 0.6 & 0.2 & 0.2 & 0.2 \\
& 0.093 & 0.439 & 0.426 & 0.445
\end{tabular}


424915088083900 WIND LAKE AT WIND LAKE, WI

LAKE-DEPTH PROFILES, FEBRUARY 17 TO JUNE 25, 2010
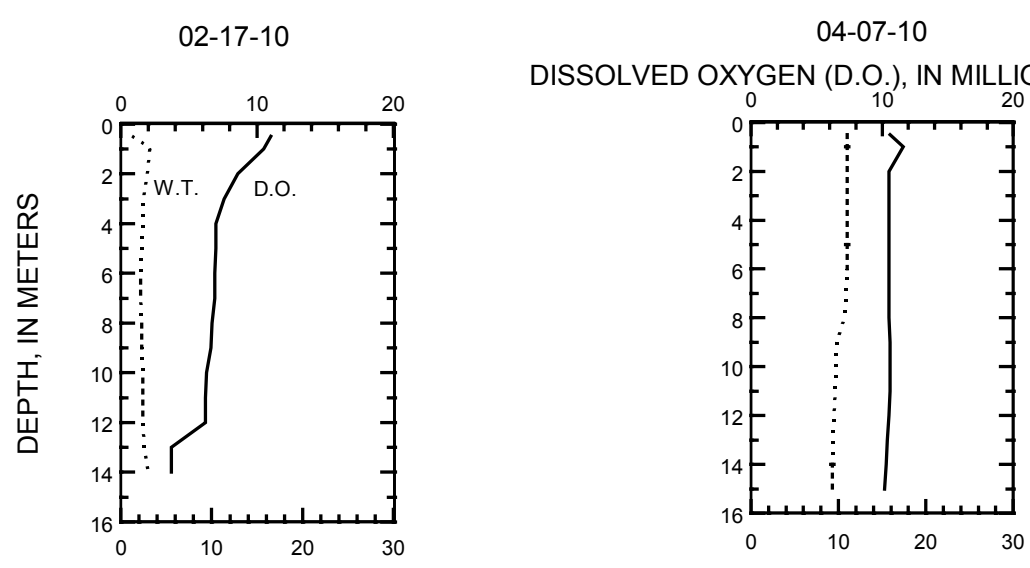

06-25-10

WATER TEMPERATURE (W.T.), IN DEGREES CELSIUS
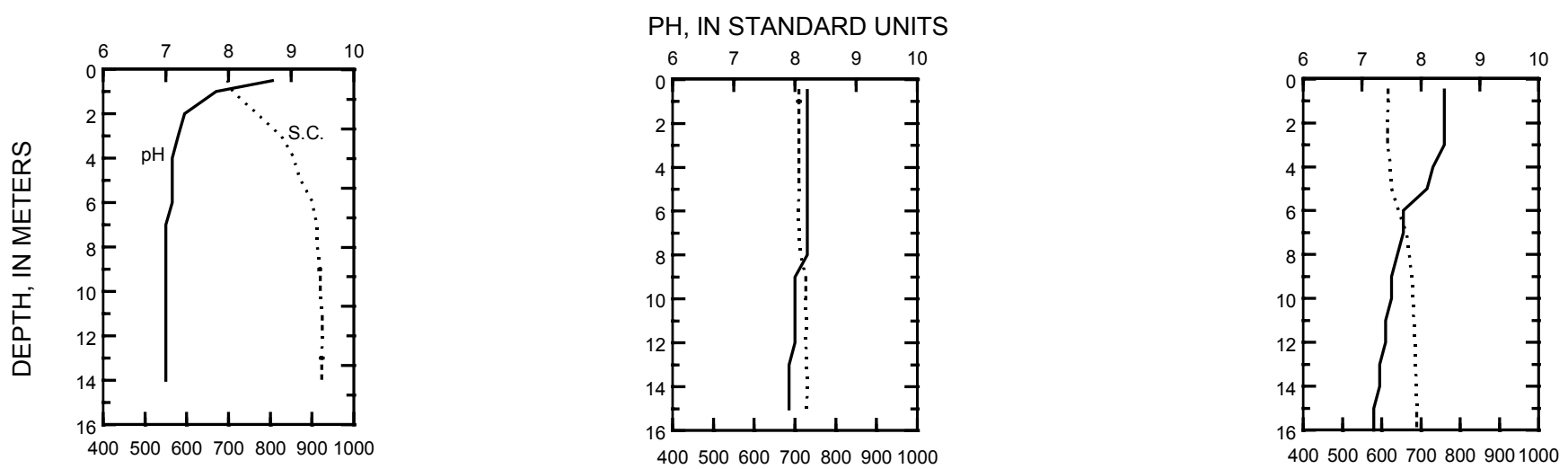

SPECIFIC CONDUCTANCE (S.C.), IN MICROSIEMENS PER CENTIMETER AT 25 DEGREES CELSIUS 
424915088083900 WIND LAKE AT WIND LAKE, WI

LAKE-DEPTH PROFILES, JULY 29 TO SEPTEMBER 2, 2009

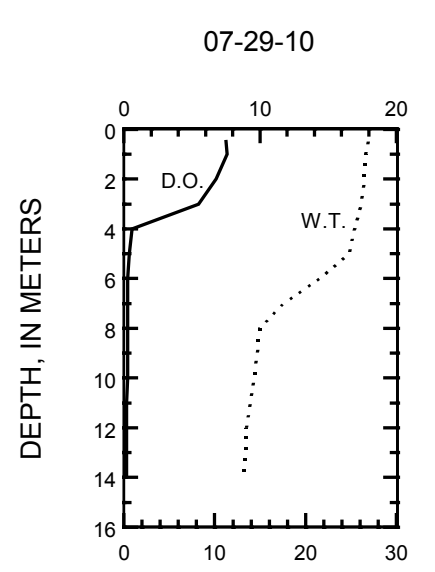

08-30-10

09-02-10 DISSOLVED OXYGEN (D.O.), IN MILLIGRAMS PER LITER
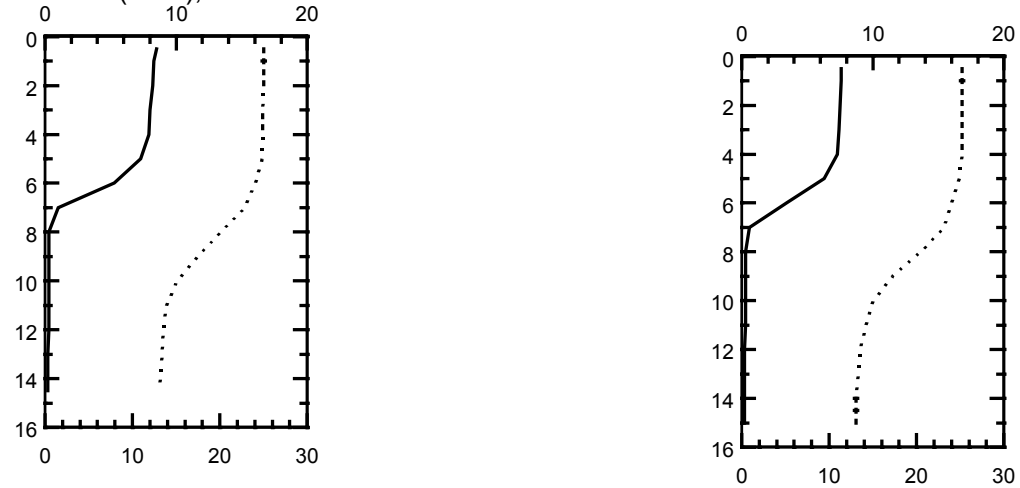

WATER TEMPERATURE (W.T.), IN DEGREES CELSIUS

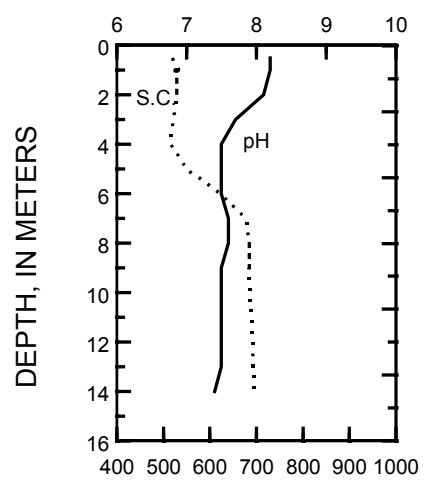

$\mathrm{PH}$, IN STANDARD UNITS
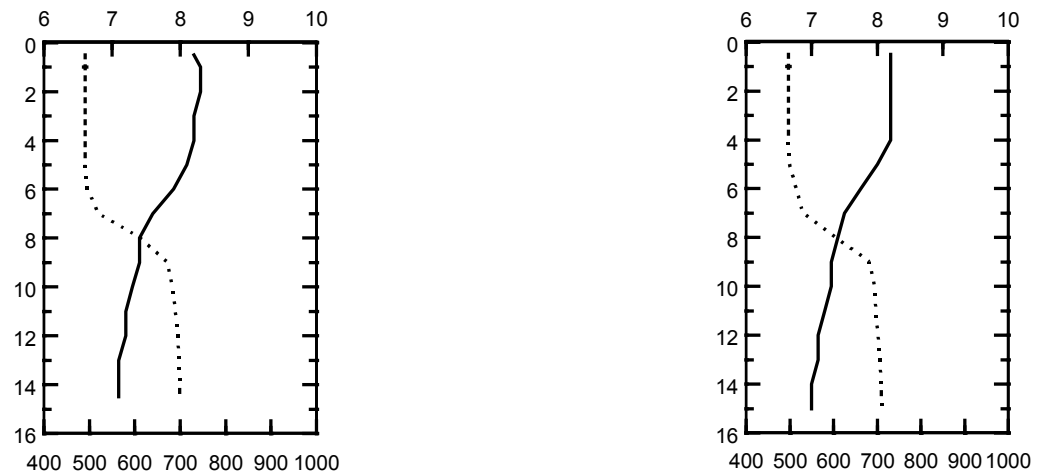

SPECIFIC CONDUCTANCE (S.C.), IN MICROSIEMENS PER CENTIMETER AT 25 DEGREES CELSIUS 

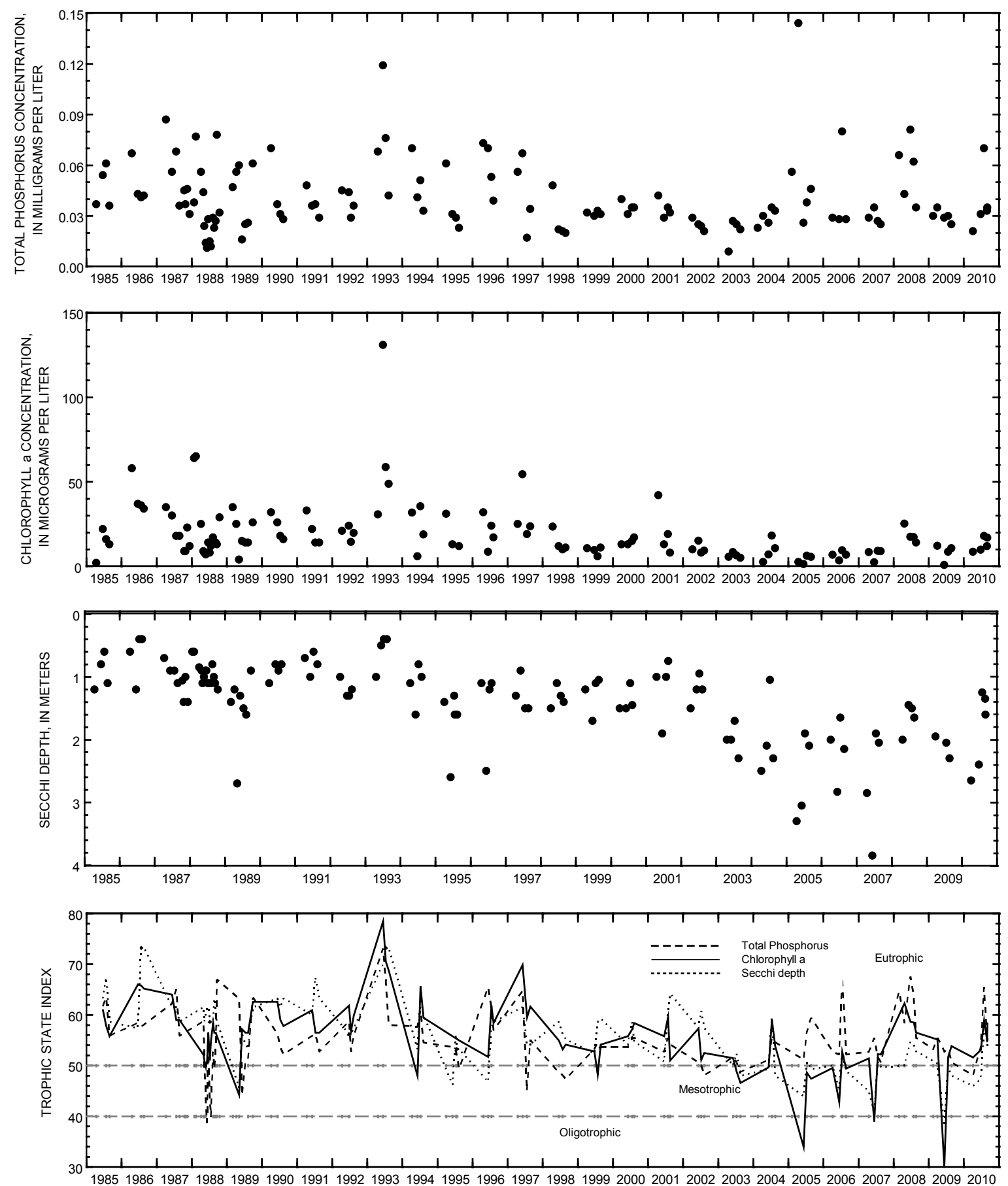

Surface total phosphorus, chlorophyll a concentrations, Secchi depths, and TSI data for Wind Lake, Deep Hole, at Wind Lake, Wisconsin. 


\section{LAKE WINNEBAGO AT OSHKOSH, WI}

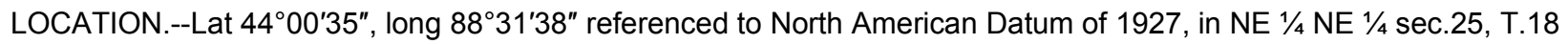
N., R.16 E., Winnebago County, WI, Hydrologic Unit 04030203, $800 \mathrm{ft}$ east of mouth of the upper Fox River.

SURFACE AREA.--215 $\mathrm{mi}^{2}$.

DRAINAGE AREA.--5,880 $\mathrm{mi}^{2}$.

PERIOD OF RECORD.--October 1938 to current year in reports of Geological Survey. Records from July 1882 to September 1938 in files of Geological Survey and U.S. Army Corps of Engineers. A report on Fox River by U.S. Army Corps of Engineers, published as House Document No. 146, 67th Congress, 2nd session, contains semimonthly records of inflow of Lake Winnebago for the period 1896-1917.

REVISED RECORDS.--WDR WI-83-1: Drainage area.

GAGE.--Water-stage recorder. Nonrecording gage read once daily October 1938 to October 1978. Datum of gage is $745.05 \mathrm{ft}$ above mean tide at New York City (levels by U.S. Army Corps of Engineers).

REMARKS.--Lake elevations controlled by dams at Menasha and Neenah, which are operated in the interest of navigation. Crests of both dams are at elevation $746.73 \mathrm{ft}$. Present limits of regulation are from $21 \frac{1 / 4}{4}$. above the crest of Menasha to crest during navigation season, plus additional 18 in. below crest during winter. Data-collection platform and gage-height telemeter at station.

EXTREMES FOR PERIOD OF RECORD.--Maximum gage height observed, 4.32 ft, Mar. 9, 1982; Minimum observed, $0.33 \mathrm{ft}$, May 17, 1960.

EXTREMES FOR CURRENT YEAR.--Maximum daily mean gage height, $3.58 \mathrm{ft}$, July 25; Minimum recorded, $1.68 \mathrm{ft}$, Mar. 5-9. 


\begin{tabular}{|c|c|c|c|c|c|c|c|c|c|c|c|c|}
\hline \multicolumn{13}{|c|}{$\begin{array}{c}\text { GAGE HEIGHT, FEET } \\
\text { WATER YEAR OCTOBER } 2009 \text { TO SEPTEMBER } 2010 \\
\text { DAILY MEAN VALUES }\end{array}$} \\
\hline Day & Oct & Nov & Dec & Jan & Feb & Mar & Apr & May & Jun & Jul & Aug & Sep \\
\hline 1 & 2.66 & \begin{tabular}{|l|}
2.57 \\
\end{tabular} & 2.26 & \begin{tabular}{|l|}
2.23 \\
\end{tabular} & 1.88 & 1.71 & 2.23 & 2.82 & 3.11 & 3.14 & 3.35 & 3.18 \\
\hline 2 & 2.60 & \begin{tabular}{|l|}
2.51 \\
\end{tabular} & 2.24 & \begin{tabular}{|l}
2.22 \\
\end{tabular} & $\begin{array}{l}1.88 \\
\end{array}$ & \begin{tabular}{|l}
1.70 \\
\end{tabular} & 2.26 & 2.87 & 3.13 & 3.12 & 3.28 & 3.17 \\
\hline 3 & 2.59 & \begin{tabular}{|l}
2.52 \\
\end{tabular} & 2.24 & \begin{tabular}{|l}
2.20 \\
\end{tabular} & $\begin{array}{l}1.88 \\
\end{array}$ & \begin{tabular}{|l|}
1.70 \\
\end{tabular} & 2.27 & 2.87 & 3.12 & 3.13 & 3.27 & 3.08 \\
\hline 4 & 2.59 & \begin{tabular}{|l|}
2.49 \\
\end{tabular} & 2.20 & \begin{tabular}{|l}
2.18 \\
\end{tabular} & $\begin{array}{l}1.87 \\
\end{array}$ & \begin{tabular}{|l}
1.69 \\
\end{tabular} & 2.33 & 2.89 & 3.12 & 3.12 & 3.26 & 3.09 \\
\hline 5 & 2.60 & \begin{tabular}{|l}
2.47 \\
\end{tabular} & 2.20 & \begin{tabular}{|l|}
2.16 \\
\end{tabular} & 1.86 & 1.69 & 2.36 & 2.78 & 3.15 & 3.16 & 3.21 & 3.06 \\
\hline 6 & 2.56 & 2.45 & 2.20 & 2.14 & 1.85 & 1.68 & 2.45 & 2.88 & 3.18 & 3.20 & 3.23 & 3.01 \\
\hline 7 & 2.60 & \begin{tabular}{|l|}
2.40 \\
\end{tabular} & 2.19 & \begin{tabular}{|l}
2.12 \\
\end{tabular} & 1.84 & \begin{tabular}{|l|}
1.68 \\
\end{tabular} & 2.60 & 2.86 & 3.18 & 3.21 & 3.26 & 2.86 \\
\hline 8 & 2.61 & \begin{tabular}{|l|}
2.41 \\
\end{tabular} & 2.23 & \begin{tabular}{|l}
2.12 \\
\end{tabular} & $\begin{array}{l}1.83 \\
\end{array}$ & \begin{tabular}{|l|}
1.68 \\
\end{tabular} & 2.58 & 2.79 & 3.18 & 3.20 & 3.31 & 2.98 \\
\hline 9 & 2.61 & \begin{tabular}{|l}
2.38 \\
\end{tabular} & 2.22 & \begin{tabular}{|l|}
2.09 \\
\end{tabular} & 1.83 & \begin{tabular}{|l|}
1.68 \\
\end{tabular} & 2.63 & 2.82 & 3.08 & 3.18 & 3.36 & 2.98 \\
\hline 10 & 2.56 & \begin{tabular}{|l|}
2.38 \\
\end{tabular} & 2.15 & \begin{tabular}{|l|}
2.07 \\
\end{tabular} & 1.83 & \begin{tabular}{|l|l|}
1.70 \\
\end{tabular} & 2.62 & 2.79 & 3.16 & 3.15 & 3.35 & $\begin{array}{l}2.98 \\
\end{array}$ \\
\hline 11 & 2.57 & \begin{tabular}{|l|}
2.37 \\
\end{tabular} & 2.21 & \begin{tabular}{|l|}
2.04 \\
\end{tabular} & 1.82 & 1.74 & 2.65 & 2.81 & 3.15 & 3.12 & 3.33 & 2.96 \\
\hline 12 & 2.56 & \begin{tabular}{|l|}
2.36 \\
\end{tabular} & 2.21 & \begin{tabular}{|l|}
2.03 \\
\end{tabular} & 1.81 & \begin{tabular}{|l|}
1.82 \\
\end{tabular} & 2.65 & 2.72 & 3.14 & 3.13 & 3.31 & 2.99 \\
\hline 13 & 2.55 & \begin{tabular}{|l|}
2.33 \\
\end{tabular} & 2.21 & \begin{tabular}{|l|}
2.02 \\
\end{tabular} & 1.80 & \begin{tabular}{|l}
1.85 \\
\end{tabular} & 2.65 & 2.74 & 3.13 & 3.10 & 3.23 & 3.01 \\
\hline 14 & 2.57 & \begin{tabular}{|l|}
2.31 \\
\end{tabular} & 2.21 & \begin{tabular}{|l|}
2.01 \\
\end{tabular} & 1.78 & \begin{tabular}{|l}
1.88 \\
\end{tabular} & 2.61 & 2.73 & 3.11 & 3.11 & 3.18 & 3.03 \\
\hline 15 & 2.56 & \begin{tabular}{|l|}
2.32 \\
\end{tabular} & 2.23 & \begin{tabular}{|l}
2.00 \\
\end{tabular} & 1.76 & \begin{tabular}{|l|}
1.92 \\
\end{tabular} & 2.62 & 2.83 & 3.12 & 3.31 & 3.09 & 3.03 \\
\hline 16 & 2.54 & \begin{tabular}{|l|}
2.33 \\
\end{tabular} & 2.24 & \begin{tabular}{|l|}
1.99 \\
\end{tabular} & 1.75 & \begin{tabular}{|l|}
1.94 \\
\end{tabular} & \begin{tabular}{|l|}
2.65 \\
\end{tabular} & 2.84 & 3.17 & 3.37 & 3.03 & 2.99 \\
\hline 17 & 2.53 & \begin{tabular}{|l|}
2.34 \\
\end{tabular} & 2.24 & \begin{tabular}{|l}
1.97 \\
\end{tabular} & 1.74 & $\begin{array}{l}1.97 \\
\end{array}$ & \begin{tabular}{|l|}
2.71 \\
\end{tabular} & 2.85 & 3.17 & 3.39 & 3.01 & 2.98 \\
\hline 18 & 2.52 & \begin{tabular}{|l|}
2.30 \\
\end{tabular} & 2.24 & \begin{tabular}{|l|}
1.96 \\
\end{tabular} & 1.74 & \begin{tabular}{|l|}
2.00 \\
\end{tabular} & \begin{tabular}{|l|l|}
2.70 \\
\end{tabular} & 2.86 & 3.10 & 3.41 & 3.00 & 2.96 \\
\hline 19 & 2.50 & \begin{tabular}{|l|}
2.29 \\
\end{tabular} & 2.24 & \begin{tabular}{|l|}
1.95 \\
\end{tabular} & 1.73 & \begin{tabular}{|l|}
2.02 \\
\end{tabular} & \begin{tabular}{|l|}
2.69 \\
\end{tabular} & 2.88 & 3.05 & 3.42 & 3.03 & 2.96 \\
\hline 20 & 2.52 & \begin{tabular}{|l|}
2.31 \\
\end{tabular} & 2.25 & \begin{tabular}{|c|}
1.94 \\
\end{tabular} & 1.73 & \begin{tabular}{|l|}
2.05 \\
\end{tabular} & \begin{tabular}{|l|}
2.69 \\
\end{tabular} & 2.90 & 3.05 & 3.42 & 3.04 & 2.95 \\
\hline 21 & 2.53 & \begin{tabular}{|l|}
2.32 \\
\end{tabular} & 2.25 & \begin{tabular}{|l|}
1.92 \\
\end{tabular} & $\begin{array}{l}1.72 \\
\end{array}$ & \begin{tabular}{|l|}
2.06 \\
\end{tabular} & \begin{tabular}{|l|l}
2.72 \\
\end{tabular} & 2.93 & 2.99 & 3.37 & 3.11 & 2.90 \\
\hline 22 & \begin{tabular}{|l|}
2.58 \\
\end{tabular} & \begin{tabular}{|l|}
2.31 \\
\end{tabular} & 2.25 & \begin{tabular}{|l|}
1.90 \\
\end{tabular} & 1.72 & 2.07 & \begin{tabular}{|l|}
2.69 \\
\end{tabular} & 2.95 & 2.97 & 3.42 & 3.14 & 2.95 \\
\hline 23 & \begin{tabular}{|l|}
2.57 \\
\end{tabular} & \begin{tabular}{|l}
2.31 \\
\end{tabular} & 2.24 & \begin{tabular}{|c|}
1.89 \\
\end{tabular} & 1.72 & \begin{tabular}{|l|}
2.09 \\
\end{tabular} & \begin{tabular}{|l|}
2.69 \\
\end{tabular} & 2.97 & 3.01 & 3.45 & 3.16 & 2.94 \\
\hline 24 & 2.52 & \begin{tabular}{|l|}
2.30 \\
\end{tabular} & 2.24 & \begin{tabular}{|c|}
1.91 \\
\end{tabular} & 1.72 & \begin{tabular}{|l|}
2.10 \\
\end{tabular} & \begin{tabular}{|l|}
2.72 \\
\end{tabular} & 3.00 & 3.04 & 3.55 & 3.15 & 2.83 \\
\hline 25 & 2.55 & \begin{tabular}{|l|}
2.31 \\
\end{tabular} & 2.28 & \begin{tabular}{|l|}
1.92 \\
\end{tabular} & 1.72 & \begin{tabular}{|l|}
2.11 \\
\end{tabular} & \begin{tabular}{|l|}
2.92 \\
\end{tabular} & 3.01 & 3.03 & 3.58 & 3.16 & 2.95 \\
\hline 26 & 2.54 & 2.31 & 2.30 & \begin{tabular}{|l|}
1.92 \\
\end{tabular} & 1.72 & 2.11 & 2.86 & 3.04 & 3.06 & 3.55 & 3.18 & 2.90 \\
\hline 27 & 2.55 & 2.34 & 2.30 & \begin{tabular}{|l|}
1.92 \\
\end{tabular} & 1.72 & \begin{tabular}{|l|}
2.12 \\
\end{tabular} & \begin{tabular}{|l|}
2.89 \\
\end{tabular} & 3.09 & 3.13 & 3.51 & 3.16 & 2.85 \\
\hline 28 & 2.54 & \begin{tabular}{|l}
2.30 \\
\end{tabular} & 2.30 & \begin{tabular}{|l|}
1.91 \\
\end{tabular} & 1.71 & \begin{tabular}{|l|}
2.14 \\
\end{tabular} & \begin{tabular}{|l|}
2.85 \\
\end{tabular} & 3.10 & 3.18 & 3.48 & 3.16 & 2.83 \\
\hline 29 & 2.54 & \begin{tabular}{|l}
2.28 \\
\end{tabular} & 2.28 & \begin{tabular}{|l|}
1.91 \\
\end{tabular} & --- & \begin{tabular}{|l|}
2.16 \\
\end{tabular} & \begin{tabular}{|l|}
2.82 \\
\end{tabular} & 3.10 & 3.17 & 3.48 & 3.16 & 2.80 \\
\hline 30 & 2.52 & \begin{tabular}{|l}
2.25 \\
\end{tabular} & 2.26 & \begin{tabular}{|l}
1.90 \\
\end{tabular} & --- & \begin{tabular}{|l}
2.18 \\
\end{tabular} & \begin{tabular}{|l|}
2.77 \\
\end{tabular} & 3.10 & 3.17 & 3.44 & 3.16 & 2.79 \\
\hline 31 & 2.49 & \begin{tabular}{|l|}
--- \\
\end{tabular} & 2.25 & \begin{tabular}{|l|}
1.89 \\
\end{tabular} & --- & \begin{tabular}{|l|}
2.18 \\
\end{tabular} & \begin{tabular}{|l|}
--- \\
\end{tabular} & 3.12 & --- & 3.39 & 3.16 & --- \\
\hline Mean & 2.56 & \begin{tabular}{|l|}
2.36 \\
\end{tabular} & 2.24 & 2.01 & 1.78 & 1.92 & \begin{tabular}{|l|}
2.63 \\
\end{tabular} & 2.90 & 3.11 & 3.31 & 3.19 & 2.97 \\
\hline Max & 2.66 & 2.57 & 2.30 & \begin{tabular}{|l|}
2.23 \\
\end{tabular} & 1.88 & \begin{tabular}{|l|}
2.18 \\
\end{tabular} & \begin{tabular}{|l|}
2.92 \\
\end{tabular} & 3.12 & 3.18 & 3.58 & 3.36 & 3.18 \\
\hline Min & 2.49 & \begin{tabular}{|l|}
2.25 \\
\end{tabular} & 2.15 & \begin{tabular}{|l|}
1.89 \\
\end{tabular} & 1.71 & 1.68 & 2.23 & 2.72 & 2.97 & 3.10 & 3.00 & 2.79 \\
\hline
\end{tabular}




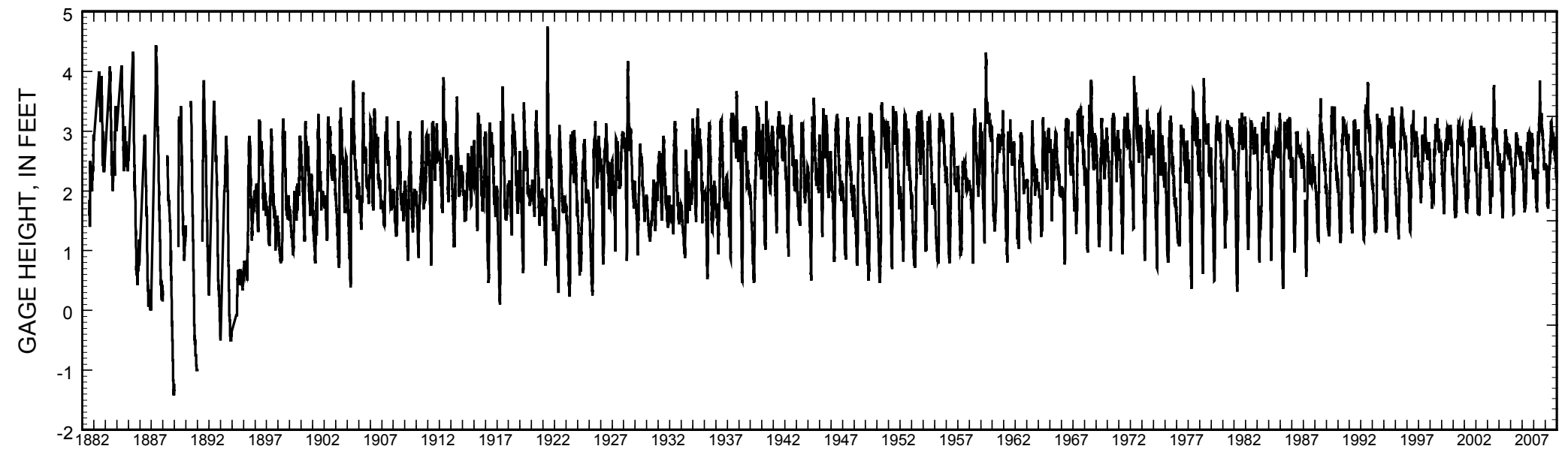

Stage hydrograph for Lake Winnebago at Oshkosh, WI, 1882-2010. 


\section{LAKE WINNEBAGO NEAR STOCKBRIDGE, WI}

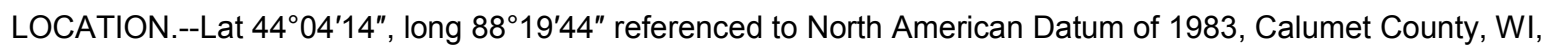
Hydrologic Unit 04030203, Stockbridge Indian Reservation, on east shore of Lake Winnebago, $300 \mathrm{ft}$ south of County Highway E and 1.6 mi west of Stockbridge.

SURFACE AREA.--215 $\mathrm{mi}^{2}$.

DRAINAGE AREA.--5,880 $\mathrm{mi}^{2}$.

PERIOD OF RECORD.--November 1982 to current year.

GAGE.--Water-stage recorder. Datum of gage is $745.05 \mathrm{ft}$ above mean tide of New York City (levels by U. S. Army Corps of Engineers).

REMARKS.--Lake elevations controlled by dams at Menasha and Neenah, which are operated in the interest of navigation. Crests of both dams are at elevation $746.73 \mathrm{ft}$. Present limits of regulation are from $211 / 4 \mathrm{in}$. above the crest of Menasha dam to crest during navigation season, plus additional 18 in. below crest during winter. Datacollection platform and gage-height telemeter at station.

EXTREMES FOR PERIOD OF RECORD.--Maximum daily mean gage height, 3.85 ft, July 9, 11, 1993, June 14, 2008; minimum observed, $0.30 \mathrm{ft}$, Mar. 1, 1986.

EXTREMES FOR CURRENT YEAR.--Maximum daily mean gage height, $3.48 \mathrm{ft}$, July 24, 25, 26; minimum recorded, $1.53 \mathrm{ft}$, Mar. 6, 7, 8, 9. 


\begin{tabular}{|c|c|c|c|c|c|c|c|c|c|c|c|c|}
\hline \multicolumn{13}{|c|}{$\begin{array}{c}\text { GAGE HEIGHT, FEET } \\
\text { WATER YEAR OCTOBER } 2009 \text { TO SEPTEMBER } 2010 \\
\text { DAILY MEAN VALUES }\end{array}$} \\
\hline Day & Oct & Nov & Dec & Jan & Feb & Mar & Apr & May & Jun & Jul & Aug & Sep \\
\hline 1 & 2.45 & 2.45 & 2.14 & 2.12 & 1.76 & 1.58 & 2.11 & 2.77 & \begin{tabular}{|l|}
3.03 \\
\end{tabular} & 3.05 & 3.24 & 3.11 \\
\hline 2 & 2.43 & 2.44 & 2.10 & 2.11 & $\begin{array}{l}1.76 \\
\end{array}$ & 1.58 & \begin{tabular}{|l|}
2.16 \\
\end{tabular} & 2.77 & \begin{tabular}{|l}
2.97 \\
\end{tabular} & 3.07 & 3.23 & $\begin{array}{l}3.09 \\
\end{array}$ \\
\hline 3 & 2.51 & 2.44 & 2.12 & 2.08 & 1.76 & 1.57 & 2.22 & 2.82 & \begin{tabular}{|l|}
3.00 \\
\end{tabular} & 3.07 & 3.18 & \begin{tabular}{|l|}
3.18 \\
\end{tabular} \\
\hline 4 & 2.56 & 2.38 & 2.21 & 2.06 & 1.74 & 1.57 & \begin{tabular}{|l}
2.25 \\
\end{tabular} & 2.77 & \begin{tabular}{|l|}
3.02 \\
\end{tabular} & 3.10 & 3.17 & $\begin{array}{l}3.09 \\
\end{array}$ \\
\hline 5 & 2.50 & 2.39 & 2.14 & 2.05 & 1.74 & $\begin{array}{l}1.56 \\
\end{array}$ & 2.26 & 2.88 & \begin{tabular}{|l|}
3.05 \\
\end{tabular} & 3.10 & 3.18 & 2.96 \\
\hline 6 & 2.52 & 2.31 & 2.06 & 2.02 & 1.73 & 1.55 & \begin{tabular}{|l|}
2.25 \\
\end{tabular} & 2.76 & 3.10 & 3.14 & 3.17 & 2.90 \\
\hline 7 & 2.59 & 2.30 & 2.04 & 2.01 & 1.71 & 1.55 & \begin{tabular}{|l|}
2.33 \\
\end{tabular} & 2.62 & \begin{tabular}{|l|}
3.05 \\
\end{tabular} & 3.12 & 3.20 & \begin{tabular}{|l|}
3.03 \\
\end{tabular} \\
\hline 8 & 2.52 & 2.28 & 2.01 & 2.00 & 1.70 & 1.55 & 2.45 & 2.72 & \begin{tabular}{|l|}
3.02 \\
\end{tabular} & 3.13 & 3.27 & 2.90 \\
\hline 9 & 2.48 & 2.26 & 2.05 & \begin{tabular}{|l|}
1.98 \\
\end{tabular} & 1.71 & 1.55 & \begin{tabular}{|l|}
2.54 \\
\end{tabular} & 2.71 & \begin{tabular}{|l|}
3.09 \\
\end{tabular} & 3.10 & 3.27 & \begin{tabular}{|l|}
2.84 \\
\end{tabular} \\
\hline 10 & 2.55 & 2.25 & 2.19 & 1.94 & $\begin{array}{l}1.72 \\
\end{array}$ & $\begin{array}{l}1.58 \\
\end{array}$ & \begin{tabular}{|l|}
2.54 \\
\end{tabular} & 2.62 & \begin{tabular}{|l|}
3.04 \\
\end{tabular} & 3.06 & 3.23 & 2.80 \\
\hline 11 & 2.49 & 2.24 & 2.10 & 1.93 & 1.70 & 1.63 & \begin{tabular}{|l|}
2.53 \\
\end{tabular} & 2.44 & 3.00 & 3.07 & 3.21 & 2.86 \\
\hline 12 & 2.43 & 2.23 & 2.08 & 1.91 & 1.68 & 1.69 & \begin{tabular}{|l|l|}
2.51 \\
\end{tabular} & 2.52 & \begin{tabular}{|l|}
3.00 \\
\end{tabular} & 3.01 & 3.20 & 2.92 \\
\hline 13 & 2.43 & 2.20 & 2.09 & 1.90 & 1.67 & 1.74 & \begin{tabular}{|l|}
2.45 \\
\end{tabular} & 2.60 & \begin{tabular}{|l|}
2.99 \\
\end{tabular} & 2.94 & 3.14 & 2.93 \\
\hline 14 & 2.38 & 2.20 & 2.11 & \begin{tabular}{|l|}
1.89 \\
\end{tabular} & 1.66 & 1.78 & \begin{tabular}{|l|}
2.48 \\
\end{tabular} & 2.73 & \begin{tabular}{|l}
2.95 \\
\end{tabular} & 2.95 & 3.08 & 2.90 \\
\hline 15 & 2.36 & 2.22 & 2.13 & 1.88 & 1.65 & 1.81 & \begin{tabular}{|l|}
2.56 \\
\end{tabular} & 2.70 & \begin{tabular}{|l}
2.97 \\
\end{tabular} & 3.28 & \begin{tabular}{|l}
3.09 \\
\end{tabular} & 2.86 \\
\hline 16 & 2.39 & 2.17 & 2.12 & 1.86 & 1.65 & 1.83 & 2.59 & 2.70 & \begin{tabular}{|l|}
3.09 \\
\end{tabular} & 3.38 & 3.03 & 2.83 \\
\hline 17 & 2.41 & 2.11 & 2.12 & $\begin{array}{l}1.85 \\
\end{array}$ & $\begin{array}{l}1.63 \\
\end{array}$ & $\begin{array}{l}1.86 \\
\end{array}$ & \begin{tabular}{|l|}
2.59 \\
\end{tabular} & 2.69 & \begin{tabular}{|l}
3.05 \\
\end{tabular} & 3.33 & 2.93 & 2.89 \\
\hline 18 & 2.42 & 2.13 & 2.13 & 1.84 & 1.62 & 1.89 & 2.56 & 2.72 & \begin{tabular}{|l|}
3.02 \\
\end{tabular} & 3.32 & 2.92 & 2.86 \\
\hline 19 & 2.41 & 2.20 & 2.13 & 1.82 & 1.61 & 1.91 & \begin{tabular}{|l}
2.55 \\
\end{tabular} & 2.77 & \begin{tabular}{|l}
3.01 \\
\end{tabular} & 3.32 & 2.91 & 2.84 \\
\hline 20 & 2.36 & 2.21 & 2.13 & 1.81 & 1.60 & 1.94 & \begin{tabular}{|l|}
2.57 \\
\end{tabular} & 2.79 & \begin{tabular}{|l|}
2.92 \\
\end{tabular} & 3.30 & 2.93 & 2.80 \\
\hline 21 & 2.37 & 2.19 & 2.13 & \begin{tabular}{|l|}
1.80 \\
\end{tabular} & 1.60 & 1.95 & \begin{tabular}{|l|}
2.53 \\
\end{tabular} & 2.79 & \begin{tabular}{|l|}
2.85 \\
\end{tabular} & 3.29 & 3.01 & \begin{tabular}{|l|}
2.83 \\
\end{tabular} \\
\hline 22 & 2.33 & 2.17 & 2.13 & \begin{tabular}{|l|l}
1.78 \\
\end{tabular} & 1.60 & 1.97 & 2.53 & 2.84 & \begin{tabular}{|l|}
2.87 \\
\end{tabular} & 3.27 & 3.03 & 2.80 \\
\hline 23 & 2.33 & 2.16 & 2.12 & 1.76 & 1.60 & 1.98 & \begin{tabular}{|l|}
2.54 \\
\end{tabular} & 2.86 & \begin{tabular}{|l|}
2.93 \\
\end{tabular} & 3.40 & 3.05 & 2.84 \\
\hline 24 & 2.49 & 2.16 & 2.13 & \begin{tabular}{|c|}
1.78 \\
\end{tabular} & 1.61 & 1.99 & 2.53 & 2.88 & \begin{tabular}{|l|}
2.97 \\
\end{tabular} & 3.48 & 3.08 & 3.04 \\
\hline 25 & 2.42 & 2.19 & 2.17 & $\begin{array}{l}1.79 \\
\end{array}$ & 1.60 & 1.99 & \begin{tabular}{|l|}
2.50 \\
\end{tabular} & 2.89 & \begin{tabular}{|l|}
2.95 \\
\end{tabular} & 3.48 & 3.09 & 2.85 \\
\hline 26 & 2.42 & 2.25 & 2.18 & 1.81 & 1.60 & 1.99 & \begin{tabular}{|l|}
2.67 \\
\end{tabular} & 2.92 & 2.94 & 3.48 & 3.08 & 2.75 \\
\hline 27 & 2.43 & 2.23 & 2.18 & 1.80 & $\begin{array}{l}1.59 \\
\end{array}$ & 2.00 & 2.67 & 2.96 & \begin{tabular}{|l|}
3.05 \\
\end{tabular} & 3.45 & 3.10 & 2.73 \\
\hline 28 & 2.40 & 2.18 & 2.19 & \begin{tabular}{c|}
1.80 \\
\end{tabular} & 1.58 & 2.01 & \begin{tabular}{|l|}
2.69 \\
\end{tabular} & 2.96 & \begin{tabular}{|l|}
3.11 \\
\end{tabular} & 3.43 & 3.09 & 2.70 \\
\hline 29 & 2.39 & 2.16 & 2.16 & $\begin{array}{ll}1.79 \\
\end{array}$ & ב-- & 2.03 & 2.64 & 2.97 & \begin{tabular}{|l|}
3.06 \\
\end{tabular} & 3.39 & 3.07 & 2.70 \\
\hline 30 & 2.51 & 2.23 & 2.14 & \begin{tabular}{|c|}
1.78 \\
\end{tabular} & --- & 2.05 & \begin{tabular}{|l|}
2.66 \\
\end{tabular} & 2.99 & \begin{tabular}{|l|}
3.04 \\
\end{tabular} & 3.35 & 3.08 & \begin{tabular}{|l|}
2.69 \\
\end{tabular} \\
\hline 31 & 2.60 & --- & 2.14 & $\begin{array}{ll}1.78 \\
\end{array}$ & --- & 2.07 & \begin{tabular}{|l|}
-- \\
\end{tabular} & 3.01 & --- & 3.27 & \begin{tabular}{|l|}
3.09 \\
\end{tabular} & - \\
\hline Mean & 2.45 & 2.24 & 2.12 & 1.89 & 1.66 & 1.80 & \begin{tabular}{|l|}
2.48 \\
\end{tabular} & 2.78 & 3.00 & 3.23 & 3.11 & 2.88 \\
\hline Max & 2.60 & 2.45 & 2.21 & 2.12 & 1.76 & 2.07 & 2.69 & 3.01 & \begin{tabular}{|l|}
3.11 \\
\end{tabular} & 3.48 & 3.27 & 3.18 \\
\hline Min & 2.33 & 2.11 & 2.01 & 1.76 & 1.58 & 1.55 & 2.11 & 2.44 & \begin{tabular}{|l|}
2.85 \\
\end{tabular} & 2.94 & 2.91 & 2.69 \\
\hline
\end{tabular}




\section{WISCONSIN DISTRICT PUBLICATIONS PERTAINING TO LAKES}

The r eports publ ished in a U .S. G eological S urvey s eries ar e f or $\mathrm{s}$ ale by the U.S. Geological S urvey, B ox 25425, Feder al C enter, D enver, C O 80225. Prepayment is required. $R$ emittance s hould be $s$ ent by $c$ heck or m oney or der pay able to the $U$.S. Geological Survey. Prices can be obtained by writing to the above address or by calling (303) 236-7476. R eprints of journal articles may be obt ained by writing directly to the author at U.S. Geological Survey, 8505 Research Way, Middleton, WI 53562.

2011

Feinstein, D.T., Dunning, C.P., Juckem, P.F., and Hunt, R.J., 2010, Application of the Local Grid Refinement package to an inset model simulating the interactions of lakes, wells, and shallow groundwater, northwestern Waukesha County, Wisconsin: U.S. Geological Survey Scientific Investigations Report 2010-5214, 30 p.

Robertson, D.M. and Rose, W.J., 2011, Response in the trophic state of stratified lakes to changes in hydrology and water level: potential effects of climate change: Journal of Water and Climate Change, vol. 2. No. 1, p. 1-18.

2010

Garn, H.S., Robertson, D.M., Rose, W.J., and Saad, D.A., 2010, Hydrology, water quality, and response to simulated changes in phosphorus loading of Minocqua and Kawaguesaga Lakes, Oneida County, Wisconsin, with special emphasis on effects of urbanization: U.S. Geol. Survey Scientific Invest. Report 2010-5196.

2009

Robertson, D.M., Rose, W.J., and Fitzpatrick, F.A., 2009, Water quality and hydrology of Silver Lake, Barron County, Wisconsin, with special emphasis on the responses of a terminal lake to changes in phosphorus loading and water level: U.S. Geol. Survey Scientific Invest. Report 2009-5077, 38 p.

Robertson, D.M., Rose, W.J., and Juckem, P.F., 2009, Water quality and hydrology of Whitefish Lake, Douglas County, Wisconsin, with special emphasis on the responses of an oligotrophic seepage lake to changes in phosphorus loading and water level: U.S. Geol. Survey Scientific Invest. Report 2009-5089, 41 p.

2008

Chung, E., Schladow, S.G., Perez-Losada, J., and Robertson, D.M., 2008, A linked hydrodynamic and water quality model for the Salton Sea: Hydrobiologia, v. 604, p. 57-75.

Robertson, D.M., and Rose, W.J., 2008, Water quality, hydrology, and simulated response to changes in phosphorus loading of Butternut Lake, Price and Ashland Counties, Wisconsin, with special emphasis on the effects of internal phosphorus loading in a polymictic lake: U.S. Geol. Survey Scientific Invest. Report 2008-5053, $46 \mathrm{p}$. 
Robertson, D.M., and Schladow, S.G., 2008, Response in the water quality in the Salton Sea to changes in phosphorus loading: An empirical modeling approach: Hydrobiologia, v. 604, p. 5-19.

Robertson, D.M., Schladow, S.G., and Holdren, G.C., 2008, Long-term changes in the phosphorus loading to and trophic state of the Salton Sea: Hydrobiologia, v. 604, p. 21-36.

2007

Robertson, D.M., Garn, H.S., and Rose, W.J., 2007, Response of calcareous Nagawicka Lake, Wisconsin, to changes in phosphorus loading. Lake and Reservoir Management, Vol. 23, p. 298-312.

Walker, J.F., Saad, D.A., and Hunt, R.J., 2007, Dynamics of CFCs in northern temperate lakes and adjacent groundwater. Water Resources. Research 43(4) W04423, http://www.agu.org/pubs/crossref/2007/2005WR004647.shtml

\section{6}

Garn, H.S., Robertson, D.M., Rose, W.J., Goddard, G.L., and Horwatich, J.A., 2006, Water quality, hydrology, and response to changes in phosphorus loading of Nagawicka Lake, a calcareous lake in Waukesha County, Wisconsin: U.S. Geological Survey Scientific Investigations Report: 2006-5273.

Hunt, R.J., Greb, S.R,, Graczyk, D.J., 2006, Evaluating the effects of nearshore development on Wisconsin lakes. USGS Fact Sheet FS-2006-3033, 4 p.

Magnuson, J.J., Benson, B.J., Lenters, J.D, and Robertson, D.M., 2006, Climate driven variability and change, Chapter 7, In Magnuson, J.J., Kratz, T.K, and Benson, B.J eds. Long-term dynamics of lakes in the landscape, Oxford University Press, p 123150.

Saad, D.A., 2005, Pesticides in surface water, bed sediment, and ground water adjacent to commercial cranberry bogs, Lac du Flambeau Reservation, Vilas County, Wisconsin: U.S. Geological Survey Scientific Investigations Report 2005-5262, 29 p.

2005

Hunt, R.J., Feinstein, D.T., Pint, C.D., and Anderson, M.P., 2005, The importance of diverse data types to calibrate a watershed model of the Trout Lake Basin, northern Wisconsin: Journal of Hydrology doi:10.1016/j.jhydrol.2005.08.005.

Marzolf, G.R., and Robertson, D.M., 2005, Reservoir, In Encyclopedia of Hydrological Sciences: Anderson, M.G., and McDonnell, J.J., eds., v. 4, part 9, John Wiley \& Sons, p. 1675-1680.

Robertson, D.M., Rose, W.J., and Saad, D.A., 2005, Water quality, hydrology, and phosphorus loading to Little St. Germain Lake, Wisconsin, with special emphasis on the effects of winter aeration and ground-water inputs: U.S. Geological Survey Scientific Investigations Report 2005-5071, 36 p.

2004

Dupre, D.H., and Robertson, D.M., 2004, Water quality of Nippersink Creek and Wonder Lake, M cHenry C ounty, I Ilinois, 1994 -2001: U .S. G eological S urvey S cientific Investigations Report 2004-5085. 
Rose, W.J., Robertson, D.M., and M ergener, E.A., 2004, Water quality, hydrology, and the e ffects of changes in phos phorus I oading to P ike La ke, Washington C ounty, Wisconsin, with s pecial em phasis on i nlet-to-outlet s hort-circuiting: U.S. Geological Survey Scientific Investigations Report 2004-5141, 32 p.

2003

Dunning, C.P., Thomas, J.C., and Lin, Y.F., 2003, Simulation of the shallow aquifer in the vicinity of Silver Lake, Washington County, Wisconsin, using analytic elements: U.S. Geological Survey Water-Resources Investigations Report 02-4204, 29 p.

Fitzpatrick, F.A., Garrison, P.J., Fitzgerald, S.A., and Elder, J.F., 2003, Nutrient, traceelement, and ec ological hi story of Musky Bay, Lac Courte O reilles, Wisconsin, as inferred from sediment c ores: $U$.S. Geological S urvey Water-Resources Investigations Report 02-4225, $141 \mathrm{p}$.

Fitzpatrick, F .A., and P eppler, M .C., 2003 , S edimentation and s ediment c hemistry, Neopit Mill Pond, Menominee Indian Reservation, Wisconsin, 2001: U.S. Geological Survey Open-File Report 03-23, 58 p.

Garn, H.S., Elder, J.F., and Robertson, D.M., 2003, Why study lakes? An overview of U.S. Geological Survey lake studies in Wisconsin: U.S. Geological Survey Fact Sheet FS-063-03, 8 p.

Graczyk, D .G., H unt, R .J., G reb, S .R., B uchwald, C .A., a nd K rohelski, J .T., 2 003, Hydrology, water quality, and y ields, from near-shore flows to four lakes in northern Wisconsin, 1999-2001: U.S. Geological Survey W ater-Resources Investigations Report 03-4144. 64 p.

Hunt, R.J., 2003, Ground water-lake interaction modeling us ing the LAK3 Package for MODFLOW2000: Ground Water, vol. 41, no. 2, p. 114-118.

Hunt, R.J., Haitjema, H.M., Krohelski, J.T., and Feinstein, D.T., 2003, Simulating ground water-lake interactions: approaches and insights: Ground Water, vol. 41, no. 22, p. 227-237.

Hunt, R.J., Pint, C.D., and Anderson, M.P., 2003, Using diverse data types to calibrate a watershed model of the Trout Lake Basin, northern Wisconsin, In MODFLOW and More 2003-Understanding through modeling: Proceedings of the 5th International Conference of $\mathrm{t}$ he I nternational $\mathrm{G}$ round Water $\mathrm{M}$ odeling $\mathrm{C}$ enter. Go Iden, CO: Colorado School of Mines, p. 600-604.

Hunt, R.J., Saad, D.A., and Chapel, D.M., 2003, Numerical simulation of ground water flow in La Crosse County, Wisconsin and into nearby pools of the Mississippi River: U.S. Geological Survey Water-Resources Investigations Report 03-4154. 36 p.

John, R., P int, C .D., A nderson, M .P., a nd H unt, R.J., 2003, The e ffects of $p$ otential climate change on I ake I evels and I ake c apture $z$ ones, In MODFLOW and M ore 2003-Understanding $\mathrm{t}$ hrough $\mathrm{m}$ odeling: Proceedings o $\mathrm{ft}$ he $5 \mathrm{t} \mathrm{h}$ International Conference of $\mathrm{t}$ he I nternational $\mathrm{G}$ round Water $\mathrm{M}$ odeling $\mathrm{C}$ enter. Go Iden, CO: Colorado School of Mines, p. 212-216. 
Magnuson, J.J., Krohelski, J.T., Kunkel, K.E., and Robertson, D.M., 2003, Wisconsin's waters and climate-historical changes and pos sible futures, In Wisconsin's waters: a confluence of perspectives: Transactions of the Wisconsin Academy, p. 23-36.

Pint, C.D., H unt, R.J., and Anderson, M .P., 2003, Fl ow pat $h$ del ineation and $g$ round water age, Allequash Basin, Wisconsin: Ground Water, vol. 41, no. 7, p. 895-902.

Robertson, D .M., Rose, W.J., and Garn, H.S., 2003, Water quality and the effects of changes in phosphorus loading, Red Cedar Lakes, Barron and Washburn Counties, Wisconsin: U.S. Geological Survey Water-Resources Investigations Report 034238, $42 \mathrm{p}$.

Robertson, D.M., R ose, W.J., and S aad, D .A., 2003, Water quality and the effects of changes in phosphorus loading to Muskellunge Lake, Vilas County, Wisconsin: U.S. Geological Survey Water-Resources Investigations Report 03-4011, 18 p.

2002

Anderson, M.P., Hunt, R.J., Krohelski, J.T., and Chung, K., 2002, Using high hydraulic conductivity nodes to simulate seepage lakes: Ground Water 40(2), p. 119-124.

Garn, H . S ., 2002, E ffects of I awn f ertilizer on nut rient c oncentration i $\mathrm{n} r$ unoff from lakeshore I awns, Lauder dale Lak es, Wisconsin: U SGS Water-Resources Investigations Report 02-4130, 6 p.

Kelson, V.A., Hunt, R.J., and H aitjema, H.M., 2002, Improving a regional m odel using reduced complexity and parameter estimation: Ground Water, vol. 40, no. 2, p. 138149.

Krohelski, J.T., Lin, Y., Rose, W.J., and Hunt, R.J., 2002, Simulation of Fish, Mud and Crystal Lak es and the s hallow g round-water s ystem, Dane County, $W$ isconsin: USGS Water-Resources Investigations Report 02-20.

Krohelski, J .T., R ose, W.J., and H unt, R .J., 2 002, H ydrologic i nvestigation of P owell Marsh and its relationship to Dead Pike Lake Vilas County, Wisconsin: USGS WaterResources Investigations Report 02-4034.

Madenjian, C .P., Fahen stiel, G.L., Johengen, T.H., N alepa, T.F., V enderploeg, H .A., Fleischer, G.W., Schneeberger, P.J., Benjamin, D.M., Smith, E.B., Bence, J.R., Rutherford, E.S., Lavis, D.S., Robertson, D.M., Jude, D.J., and E bener, M.P., 2002, Dynamics of the Lake Michigan food web, 1970-2000: Canadian Journal of Fisheries and Aquatic Sciences, Vol. 59, p. 736-753.

Robertson, D.M., Goddard, G.L, Mergerer, E.A., Rose, W.J., and Garrison, P.J., 2002, Hydrology and water qual ity of G eneva Lake, Walworth C ounty, Wisconsin: U .S. Geological Survey Water Resources Investigations Report 02-4039, 73 p.

Robertson, D.M., and Lenz, B.N., 2002, Response of the St. Croix River Pools, Wisconsin and Minnesota, to various phosphorus-loading scenarios: U.S. Geological Survey Water-Resources Investigations Report 02-4181, 36 p. 
Hunt, R.J., Bradbury, K.R., and Krohelski, J.T., 2001, The effects of large-scale pumping and diversion on the water resources in Dane County, Wisconsin: USGS Fact Sheet FS-127-01, $4 \mathrm{p}$.

Hunt, R .J., H aitjema, H.M., K rohelski, J .T., and Fei nstein, D .T., 2 001, S imulating groundwater-lake interactions with models: MODFLOW and analytic element approaches, In MODFLOW 2001 and Other Modeling Odysseys: Proceedings of the 4th I nternational $\mathrm{C}$ onference of the I nternational $\mathrm{G}$ round Water M odeling $\mathrm{C}$ enter. Golden, CO: Colorado School of Mines, p. 328-334.

Lin, Y., Krohelski, J.T., and Hunt, R.J., 2001, Simulation of lake stage in two seepage lakes i $\mathrm{n}$ s outhcentral $\mathrm{W}$ isconsin us ing $\mathrm{t}$ he $\mathrm{L} A K 3$ pac kage for M ODFLOW, In MODFLOW 2001 and $O$ ther $M$ odeling $O$ dysseys: Proceedings o $\mathrm{ft}$ he $4 \mathrm{t} \mathrm{h}$ International $C$ onference of the International $G$ round Water $M$ odeling $C$ enter. Golden, CO: Colorado School of Mines, p. 411-417.

Elder, J.F., Robertson, D.M., and Garrison, P.J., 2000, Chemical composition of surficial deposits in Geneva Lake, Wisconsin: U.S. Geological Survey Fact Sheet FS-12100.

Elder J.F., Rybicki, N.B., Carter, V.P., and Weintraub, V., 2000, Sources and yields of dissolved carbon in northern Wisconsin stream catchments with differing amounts of peatland: Wetlands, vol. 20, no. 1, p.113-125.

Hunt, R.J., Graczyk, D.J., and Rose, W.J., 2000, Water flows in the Necedah National Wildlife Refuge: U.S. Geological Survey Fact Sheet FS-068-00, 4 p.

Hunt, R.J., Lin, J., Krohelski, J.T., and J uckem, P.F., 2000, Simulation of the s hallow hydrologic system in the vicinity of Middle Genesee Lake, Wisconsin, using analytic elements and pa rameter estimation: U.S. G eological Survey Water R esources Investigations Report 00-4136, 16 p.

Lathrop, R.C., Carpenter, S.R., and Robertson, D.M., 2000, Interacting factors causing exceptional water c larity in La kes M endota and Monona, Wisconsin: P roc. of the International Limnological Society, SIL, Dublin, Ireland, August, 1998.

Magnuson, J.J., Robertson, D.M. Wynne, R.H., Benson, B.J., Livigstone, D.M., Arai, T., Assel, R.A., Barry, R.G., Card, V., Kuusisto, E., Granin, N.G., Prowse, T.D., Stewart, K.M., and V uglinski, V.S., 2000, Historical trends in lake and $r$ iver ice cover in the northern hemisphere: Science, Vol. 289, No. 5485, p. 1743-1746.

Magnuson, J.J., Wynne, R.H., Benson, B.J., and Robertson, D.M., 2000, Lake and river ice as a po werful indicator of past and pr esent climates: P roc. of the I nternational Limnological Society, SIL, Dublin, Ireland, August, 1998.

Robertson, D .M., 2000, O ne-dimensional s imulation of $s$ tratification a nd di ssolved oxygen i n McCook R eservoir, Illinois: U .S. G eological S urvey Water Resources Investigations Report 00-4258, 17 p. 
Robertson, D .M., Goddard, G.L., H elsel, D .R., and M acKinnon, K .L., 2000 , Rehabilitation of D elavan Lake, Wisconsin: La ke and R eservoir Management, $v$ ol. 20 , vo. 3, p. 155-176.

Robertson, D .M., and Rose, W.J., 2000 , H ydrology, w ater quality, a nd phos phorus loading of Little St. Germain Lake, Vilas County, Wisconsin: U.S. Geological Survey Water Resources Investigations Report 00-4209, 8 p.

Robertson, D.M., Wynne, R.H., and Chang, W.Y.B., 2000, Variability in ice cover across the nor thern he misphere dur ing the 190 0's associated w ith $E$ I N ino ev ents: Proceedings of the International Limnological Society, SIL, D ublin, Ireland, August, 1998.

Saad, D.A., and Robertson, D.M., 2000, Water-resources-related information for the St. Croix Reservation and vicinity, Wisconsin: U.S. Geological Survey Water Resources Investigations Report 00-4133, 65 p.

Johnson, G.P., Hornewer, N.J., Robertson, D.M., and Olson, D.T., 2000, Methodology, data collection, and data analysis for determination of water-mixing patterns induced by aer ators and mixers: U .S. Geological S urvey Water R esources I nvestigations Report 00-4101, 72 p.

Grannemann, N.G., Hunt, R.J., Nicholas, J.R. Reilly, T.E., and Winter, T.C., 2000, The importance of ground water to the Great Lakes Region: U.S. Geological Survey Water Resources Investigations Report 00-4008, 12 p.

Lathrop, R .C., C arpenter, S .R., and R obertson, D .M., 1999, S ummer w ater c larity responses to phos phorus, $\mathrm{D}$ aphnia grazing, and internal $\mathrm{m}$ ixing in La ke Mendota: Limnology and Oceanography, vol. 44, no. 1, p. 137-146.

Krohelski, J.T., Feinstein, D.T., and Lenz, B.N., 1999, Simulation of stage and hydrologic budget for Shell Lake, Washburn County, Wisconsin: U.S. Geological Survey WaterResources Investigations Report 99-4209, 23 p.

Panuska, J .C., and R obertson, D .M., 1999, E stimating phos phorus c oncentrations following al um t reatment us ing appar ent s ettling v elocities: Lak es and R eservoir Management, vol. 15, no. 1, p. 28-38.

1998

Hunt, R .J, A nderson, M.P., and K elson, V .A., 1998 , I mproving a complex f initedifference ground water flow model through the use of an analytic element screening model: Ground Water, vol. 36, no. 6, p. 1011-1017.

Hunt, R.J, Anderson, M.P., and Kelson, V.A., 1998, Linking an analytic el ement flow code to MODFLOW - Implementation and bene fits, In MODFLOW'98: Proceedings of the 3rd International Conference of the International Ground Water Center. Golden, CO: Colorado School of Mines, p 477-504. 
Krabbenhoft, D.P., Gilmour, C.C., Benoit, J.M., Babiarz, C.L., Andren, A.W., and Hurley, J.P., 1998, M ethyl $m$ ercury dy namics i $n$ I ittoral s ediments o f a $t$ emperate I ake: Canadian Journal of Fisheries and Aquatic Sciences, vol. 55, p. 835-844.

Robertson, D.M., Elder, J.F., Goddard, G.L., and James, W.F., 1998, Dynamics in phosphorus retention in wetlands upstream of Delavan Lake, Wisconsin: Lakes and Reservoir Management, vol. 14, no. 4, p. 466-477.

Rose, W.J., and R obertson, D .M., 1998, H ydrology, w ater quality, an d phos phorus loading of Kirby Lake, Barron County, Wisconsin: U.S. Geological Survey Fact Sheet FS-066-98, 4 p.

Walker, J.F. and Krabbenhoft, D.P., 1998, Groundwater and surface-water interactions in riparian and I ake-dominated s ystems, In Kendall, C . and M cDonnell, J .J. ed s., Isotope tracers in catchment hydrology, Elsevier Publishing, New York, 839 p.

1997

Elder, J.F., Manion, B.J., and Goddard, G.L., 1997, Mesocosm experiments to as sess factors af fecting phos phorus $r$ etention and $r$ elease $i n$ an e xtended $W$ isconsin wetland: U.S. G eological S urvey Water-Resources I nvestigations R eport 97-4272, $14 \mathrm{p}$.

Goddard, G.L., and Elder, J.F., 1997, Retention of sediments and nutrients in Jackson Creek Wetland near D elavan Lak e, Wisconsin, 1993-95: U .S. G eological S urvey Water-Resources Investigations Report 97-4014, 22 p.

Hornewer, N .J., J ohnson, G .P., R obertson, D .M. and H ondzo, M., 1997, Fi eld-scale tests $f$ or determining $\mathrm{m}$ ixing pat terns as sociated with $\mathrm{c}$ oarse-bubble ai $r$ di ffuser configurations, Egan Quarry, Illinois, In Environmental and Coastal Hydraulics: Protecting the Aquatic Habitat, Proceedings of the International Association of Hydraulic Research, San Francisco, CA, USA, p. 57-63.

Robertson, D .M., 1997, R egionalized I oads of s ediment and phos phorus t o La kes Michigan and S uperior-High flow and I ong-term average: J ournal of Great Lakes Research, vol. 23, p. 416-439.

1996

Anderson, W.L., Robertson, D.M., and Magnuson, J.J., 1996, Evidence of recent warming and EI Nino-related variation in ice breakup of Wisconsin lakes: Limnology and Oceanography, vol. 41, p. 815-821.

Elder, J .F. and G oddard, G.L., 1996, S ediment and nut rient t rapping efficiency of a constructed w etland near D elavan Lak e, Wisconsin, 1993-1995: U .S. G eological Survey Fact Sheet FS-232-96.

Garn, H.S., Olson, D.L., Seidel, T.L., and Rose, W.J., 1996, Hydrology and water quality of Lau derdale Lak es, Walworth C ounty, Wisconsin, 1993 -94: U .S. G eological Survey Water-Resources Investigations Report 96-4235, 29 p. 
Hunt, R.J. and Krohelski, J.T., 1996, The application of an analytical element model to investigate gr oundwater-lake i nteractions at $P$ retty Lak $e$, Wisconsin: Lak e and Reservoir Management, vol. 12, p. 487-495.

Imberger, J ., R obertson, D .M., and B oland, K ., 1996, Lak e N umber-A q uantitative indicator of mixing to be used in water quality management: Scientific Impeller, Solna, Sweden, no. 4, p. 9-15.

Kammerer, P .A., J r., 19 96, H ydrology and w ater quality of $P$ ark La ke, S outh-central Wisconsin: U.S. Geological Survey Fact Sheet FS-197-96.

Robertson, D .M., Fi eld, S .J, E Ider, J .F., Goddard, G.L., and J ames, W.F., 199 6, Phosphorus dy namics of $D$ elavan Lak e I nlet i n s outheastern Wisconsin: $U$.S. Geological Survey Water-Resources Investigations Report 96-4160, 18 p.

1995

Assel, R.A. and R obertson, D.M. 1995, Changes in winter air temperatures near Lake Michigan dur ing 1851 -1993, as det ermined from $r$ egional I ake-ice $r$ ecords: Limnology and Oceanography, v. 40, p 165-176.

Assel, R .A., R obertson, D .M., H off, M .H., a nd S elgeby, J .H., 1995, Climatic-change implications f rom long-term (1823-1994) i ce $r$ ecords nea $r t$ he Lau rentian $G$ reat Lakes: Annals of Glaciology, vol. 21, p. 383-386.

Krabbenhoft, D.P., and Webster, K.E., 1995, Transient hydrogeological controls on the chemistry of a s eepage lake: Water Resources Research, vol. 31, no. 9, p. 22952305.

Krohelski, J.T. and Batten, W.G., 1995, Simulation of stage and the hydrologic budget of Devils Lake, Sauk County, Wisconsin: U.S. Geological Survey Open-File Report 94348, $22 \mathrm{p}$.

Wentz, D.A., Rose, W.J., and Webster, K.E., 1995, Long-term hy drologic and biogeochemical responses of a s oft water seepage lake in north central Wisconsin: Water Resources Research, vol. 31, no. 1, p. 199-212.

1994

Elder, J.F., 1994, Distribution and grain-size partitioning of metals in bottom sediments of an experimentally acidified lake: Water Resources Bulletin, vol. 30, no. 2, p. 251259.

Goddard, G.L., and Fi eld, S .J., 1994, H ydrology and w ater quality of Whitewater and Rice Lak es in s outheastern Wisconsin, $1990-91$ : U .S. Geological S urvey WaterResources Investigations Report 94-4101, 36 p.

Greb, S.R., and Wentz, D.A., 1994, Chemical budgets, In Klepinger, K.E., ed., RILWAS 1983-86: Wisconsin R egional I ntegrated La ke Watershed A cidification S tudy, Volume 1: Madison, Wisconsin Department of Natural Resources, PUBL-RS-90994, Chapter 7, 20 p. 
Hurley, J .P., K rabbenhoft, D .P., B abiarz, C .L., and A ndren, A .W., 1994, C ycling processes of mercury across sediment/water interfaces in seepage lakes, In Baker, L.A. ed., Environmental Chemistry of Lakes and Reservoirs: Advances in Chemistry Series, American Chemical Society, Washington, D.C., p. 426-449.

Krabbenhoft, D.P., Bowser, C.J., Kendall, C., and Gat, J.R., 1994, Use of oxygen-19 and deuterium to assess the hydrology of ground-water/lake systems, In Baker, L.A. ed., Environmental Chemistry of Lakes and R eservoirs: Advances in Chemistry Series, American Chemical Society, Washington, D.C., p. 67-90.

Robertson, D .M., A nderson, W., and M agnuson, J .J., 1994, R elations bet ween E I Nino/Southern Oscillation ev ents and the $c$ limate and $i$ ce $c$ over o $f I$ akes $i \mathrm{n}$ Wisconsin, In Greenland, D . ed. , E I N ino and Long -Term E cological R esearch (LTER) Sites: Publication No. 18. LTER Network Office: University of W ashington, Seattle, WA, USA., p. 48-57.

Robertson, D.M. and Imberger, J. 1994, Lake Number, a quantitative indicator of mixing used to estimate changes in dissolved oxygen, Internationale Revue der gesamten Hydrobiologie, v. 79, p. 159-176.

Watras, C.J., Bloom, N.S., Hurley, J.P., Fitzgerald, W.F., Andren, A.W., Krabbenhoft, D.P., and Porcella, D.B., 1994, Sources and fates of mercury and methylmercury in Wisconsin I akes, In Watras a nd H uckabee ed s., Mercury as a Global P ollutant: Intergration and Synthesis, Lewis Pub., Chelsea, MI., p 153-177.

Wentz, D.A., 1994, Chemistry of s nowpack and ground water, In Klepinger, K.E., ed., RILWAS 1983-86: Wisconsin regional integrated lake watershed acidification study, volume 1: Madison, Wisconsin Department of Natural R esources, PUBL-RS-90994, chapter 6, $45 \mathrm{p}$.

Wentz, D.A., Krohelski, J.T., and Rose, W.J., 1994, Hydrology, In Klepinger, K.E., ed., RILWAS 1983-86: Wisconsin regional integrated lake watershed acidification study, volume 1: Madison, Wisconsin Department of Natural R esources, PUBL-RS-90994, chapter 7, $74 \mathrm{p}$.

1993

Field, S.J., 1993, Hydrology and water quality of Powers Lake, southeastern Wisconsin: U.S. Geological Survey Water-Resources Investigations Report 90-4126, 36 p.

Field, S.J., 1993, Hydrology and water quality of Wind Lake in southeastern Wisconsin: U.S. Geological Survey Water-Resources Investigations Report 91-4107, 61 p.

House, L.B., 1993, Simulation of the effects of hypothetical residential development on water levels in Graber Pond, Middleton, Wisconsin: U.S. Geological Survey WaterResources Investigations Report 92-4029, 10 p.

House, L.B., Waschbusch, R.J., and Hughes, P.E., 1993, Water quality of an urban wet detention pond in Madison, Wisconsin, 1987-88: U.S. Geological Survey Open-File Report 93-172, $57 \mathrm{p}$. 
Hughes, P.E., 1993, Hydrology, water quality, trophic status, and aquatic plants of Fowler Lak e, Wisconsin: U .S. Geological S urvey Water-Resources I nvestigations Report 91-4076, $44 \mathrm{p}$.

Rose, W.J., 1993, H ydrology o f Li ttle R ock La ke i n V ilas C ounty, nor th-central Wisconsin: U.S. Geological Survey Water-Resources Investigations Report 93-4139, $22 \mathrm{p}$.

Rose, W.J., 1993, Water and phos phorus bud gets and trophic state, Balsam La ke, northwestern W isconsin, 1987-1989: U .S. Geological S urvey Water-Resources Investigations Report 91-4125, 28 p.

1992

Elder, J.F., Krabbenhoft, D.P, and Walker, J .F., 1992, Water, energy, and biogeochemical budgets (WEBB) program: Data availability and research at the northern temperate lakes site, Wisconsin: U.S. Geological Survey Open-File Report 92-48, $15 \mathrm{p}$.

Krabbenhoft, D.P., and B abiarz, C.L., 1992, R ole of groundwater transport in aq uatic mercury cycling: Water Resources Research, vol. 28, no. 12, p. 3119-3128.

Krabbenhoft, D.P., and Krohelski, J.T., 1992, Data on water quality, lake sediment, and lake-level fluctuation, St. Croix Indian Reservation, Wisconsin, 1981-87: U.S. Geological Survey Open-File Report 92-26, 53 p.

Robertson, D.M., Ragotzkie, R.A., and Magnuson, J.J. 1992, Lake ice records used to detect historical and future climatic changes: Climatic Change, v. 21, p. 407-427.

1991

Wentz, D.A., and Rose, W.J., 1991, Hydrology of Lakes Clara and Vandercook in northcentral Wisconsin: U.S. Geological Survey Water-Resources Investigations Report 89-4204, 24 p.

Watras, C .J., A ndre, A .W., B loom, N .S., Fi tzgerald, W.F., H urley, J .P., K rabbenhoft, D.P., Rada, R.G., Wiener, J.G., 1991, Mercury in temperate lakes: a mechanistic field study: Verhandlungen Internat. Verein. Limnologie, 24, p. 2199-2202.

\section{Pre-1990}

Walker, J.F., Pickard, S.A., and Sonzogni, W.C., 1989 Spreadsheet watershed modeling for non point-source pollution m anagement in a Wisconsin bas in: Water Resources Bulletin, vol. 25, no. 1, p. 139-147.

Wentz, D .A., G arrison, P.J., and B ockheim, J .G., 1989 , S ection 7 -Chemical i nputoutput bud gets, In Knauer, D., and B rouwer, S .A., eds., The Wisconsin r egional integrated I ake w atershed acidification s tudy ( RILWAS)-1981-1983: P alo Alto, California, Electric Power Research Institute Report EA-6214, p. 7-1 to 7-30. 
Wentz, D .A., and R ose, W.J., 1989 , Interrelationships am ong hy drologic-budget components o fa no rthern Wisconsin seepage I ake a nd i mplications for ac iddeposition modeling: Archives of Environmental Contamination and Toxicology, vol. 18 , p. 147-155.

Wentz, D.A., Rose, W.J., and K rohelski, J.T., 1989, Section 5-Hydrologic component, in Knauer, D., and Brouwer, S.A., eds., The Wisconsin regional integrated lake watershed acidification study (RILWAS) -1981-1983: Palo Alto, California, Electric Power Research Institute Report EA-6214, p. 5-1 to 5-77.

Field, S .J., and D uerk, M.D., 1988, H ydrology and $w$ ater q uality of D elavan Lak e in southeastern W isconsin: U.S. Geological Survey W ater-Resources Investigations Report 87-4168, $61 \mathrm{p}$.

Krug, W.R., Ostenso, N.A., and Krohelski, J.T., 1988, Prediction of the effects of mine dewatering on four lakes near Crandon, Wisconsin, by use of a water-budget model: U.S. Geological Survey Open-File Report 87-471, 63 p.

Wentz, D.A., Krohelski, J.T., Rose, W.J., Bockheim, J.G., Garrison, P.J., Knauer, D.R., and Goldstein, R.A., 1987, Hydrologic and chemical budgets of Wisconsin lakes, In Perry, R., Harrison, R.M., Bel, J.N.B., and Lester, J.N., eds., Acid Rain: Scientific and Technical Advances, Selper Ltd., London, p. 309-316.

House, L. B., 1986, Stage fluctuations of Wisconsin Lakes: Wisconsin Geological and Natural History Survey Information Circular No. 49, 84 p.

House, L.B., 1984, Effects of urbanization on three ponds in Middleton, Wisconsin: U.S. Geological Survey Water-Resources Investigations Report 84-4051, 17 p.

Krug, W.R., and H ouse, L. B., 1984 , E valuation of al ternative r eservoir-management practices i $n$ t he $R$ ock River bas in, Wisconsin: U .S. G eological S urvey WaterResources Investigations Report 83-4186, 21 p.

House, L.B., 1981, An assessment of streamflow, water quality, and the effects of construction on $\mathrm{i}$ mpoundment on $\mathrm{B}$ ridge $\mathrm{C}$ reek at $\mathrm{A}$ ugusta, Wisconsin: $U$.S. Geological Survey Water-Resources Investigations Open-File Report 81-1192, 25 p.

Krug, W.R., 1981, Hydrologic effects of proposed changes in management practices, Winnebago P ool, Wisconsin: U .S. Geological S urvey Water-Resources Investigations 80-107, $19 \mathrm{p}$.

Batten, W.G., and Hindall, S.M., 1980, Sediment deposition in the White River Reservoir, nor thwestern Wisconsin: U.S. Geological Survey Water-Supply P aper 2069, 30 p.

Novitzki, R.P., and Holmstrom, B.K., 1979, Monthly and annual water budgets of Lake Wingra, Madison, Wisconsin, 1971-77: U .S. Geological S urvey Water-Resources Investigations 79-100, $31 \mathrm{p}$.

Rose, W.J., 1977, Hydrologic considerations as sociated with dredging spring ponds in Wisconsin: U.S. Geological Survey Water-Resources Investigations 77-18, 35 p.

Oakes, E.L., Hendrickson, G.E., and Zuehls, E.E., 1975, Hydrology of the Lake Wingra basin, Dane County, Wisconsin: U.S. Geological Survey Water-Resources Investigations 17-75, $31 \mathrm{p}$. 
Novitzki, R .P., 1971, H ydrologic i nvestigations of H eart La ke, Green Lak e C ounty, Wisconsin: U.S. Geological Survey Administrative Report, 9 p. 


\section{APPENDIX}

\section{Wisconsin Lakes Team Quality-Assurance Plan}

Most lake studies and monitoring programs that are conducted by the USGS Wisconsin Water Science Center entail water sampling and analysis to determine water quality and biological productivity. Because all sampling and analysis is subject to error and random variablility, a certain proportion of the sampling effort should include quality-assurance samples. Sampling by the USGS was done by the Lake Studies Team of the USGS Wisconsin Water Science Center. This team implements a quality-assurance plan each year that involves collecting three types of samples from a subset of the lakes studied each year, which include blanks, replicates, and spikes (U.S. Geological Survey, Wisconsin Water Science Center Lake Studies Team). These samples are collected and/or prepared solely for the purpose of assessing the magnitude of error and random variability so that the accuracy and precision of all data can be evaluated. The plan for this quality-assurance sampling is described below.

Three types of QA/QC samples are collected:

\section{blanks}

Provide information about accuracy and errors due to treatment or reagents replicates provide information about precision (variability) standard additions (spikes)

provide information about accuracy and matrix interferences

\section{Blank Sampling}

B1. A preservation blank consists of deionized water or inorganic blank water, to which is added any reagents or preservatives that are normally added to natural water samples. The blank is not taken to the field, but is shipped to the laboratory for analysis along with the natural water samples.

This blank sample is analyzed for the Nutrient Group ${ }^{1}$ and chlorophyll-a.

B2. A field blank consists of deionized water or inorganic blank water treated exactly the same as regular samples. During winter, the field blank is analyzed for total phosphorus (TP) only; during summer, it is analyzed for TP and chlorophyll-a, and in the spring it is analyzed for the Nutrient Group and chlorophyll-a.

\footnotetext{
${ }^{1}$ Nutrient Group = all phosphorus and nitrogen species that are commonly determined in lakes (total phosphorus, nitrate + nitrite, ammonia, total Kjeldahl nitrogen, total nitrogen)
} 


\section{Replicate Sampling}

Triplicate samples are taken near water surface in summer for analysis of total phosphorus and chlorophyll-a. For a portion of the sites where surface triplicates are collected, a set of triplicate samples is also taken from near-bottom water, for analysis of total phosphorus.

Triplicate samples collected in the spring are taken near the water surface for analysis of the Nutrient Group.

\section{Standard Addition Testing}

Replicate samples are collected for a standard addition (spike) test, which consists of an addition of a prepared phosphorus solution (standard) of known volume and concentration, such that the expected result of analysis is the natural water TP concentration plus the known addition. One sample from each set will receive no spike (the mean of these gives the natural water TP concentration).

Data and results of replicate sampling and field blank testing in water year 2008 are shown in Table A1. 


\begin{tabular}{|c|c|c|c|c|c|c|c|c|c|}
\hline \multirow{2}{*}{\multicolumn{10}{|c|}{ data in milligrams per liter; chlorophyll data in micrograms per liter. Symbol "<" indicates less than given detection limit (DL); mean and }} \\
\hline & & & & & & & & & \\
\hline \multicolumn{10}{|c|}{ standard deviation not calculated for datasets containing values less than DL. } \\
\hline Parameter & Lake & Date & \multicolumn{4}{|c|}{ Replicate Data } & Mean & $\begin{array}{l}\text { Standard } \\
\text { Deviation } \\
\end{array}$ & $\begin{array}{r}\text { Percent } \\
\text { Standard } \\
\text { Deviation } \\
\end{array}$ \\
\hline \multirow{14}{*}{ Total Phosphorus } & Big Cedar & $8 / 30 / 06$ & 0.035 & 0.034 & 0.032 & & 0.034 & 0.002 & 4.5 \\
\hline & Delavan & 6/13/06 & 0.062 & 0.045 & & & 0.054 & 0.012 & 22.5 \\
\hline & Delavan & $8 / 15 / 06$ & 0.030 & 0.028 & 0.029 & 0.026 & 0.028 & 0.002 & 6.0 \\
\hline & Beulah & $8 / 30 / 07$ & 0.017 & 0.015 & & & 0.016 & 0.001 & 8.8 \\
\hline & Delavan & $4 / 16 / 07$ & 0.040 & 0.038 & & & 0.039 & 0.001 & 3.6 \\
\hline & Spring & $9 / 6 / 07$ & 0.008 & 0.007 & & & 0.008 & 0.001 & 9.4 \\
\hline & Beulah & $3 / 4 / 08$ & 0.010 & 0.011 & & & 0.011 & 0.001 & 6.7 \\
\hline & Beulah & $8 / 26 / 08$ & 0.011 & 0.012 & & & 0.012 & 0.001 & 6.1 \\
\hline & Beulah & $2 / 23 / 09$ & 0.013 & 0.013 & & & 0.013 & 0.000 & 0.0 \\
\hline & Beulah & $8 / 24 / 09$ & 0.017 & 0.017 & & & 0.017 & 0.000 & 0.0 \\
\hline & Delavan & $9 / 15 / 09$ & 0.035 & 0.031 & 0.031 & & 0.032 & 0.002 & 7.1 \\
\hline & Beulah & $8 / 19 / 10$ & 0.015 & 0.016 & & & 0.016 & 0.001 & 4.6 \\
\hline & Big Cedar, South & $8 / 24 / 10$ & 0.015 & 0.014 & & & 0.015 & 0.001 & 4.9 \\
\hline & Powers & $8 / 30 / 10$ & 0.021 & 0.022 & & & 0.022 & 0.001 & 3.3 \\
\hline \multirow{3}{*}{$\begin{array}{c}\text { Total Phosphorus, near } \\
\text { bottom }\end{array}$} & Wind & $7 / 10 / 06$ & 0.380 & 0.378 & 0.394 & & 0.384 & 0.009 & 2.3 \\
\hline & Big Cedar, South & $8 / 24 / 10$ & 0.081 & 0.067 & & & 0.074 & 0.010 & 13.4 \\
\hline & Powers & $8 / 30 / 10$ & 0.036 & 0.038 & & & 0.037 & 0.001 & 3.8 \\
\hline \multirow{6}{*}{ Dissolved Phosphorus } & Beulah & $8 / 30 / 07$ & $<0.002$ & $<0.002$ & & & & & \\
\hline & Beulah & $3 / 4 / 08$ & 0.001 & 0.003 & & & 0.002 & 0.001 & 70.7 \\
\hline & Beulah & $8 / 26 / 08$ & $<0.002$ & $<0.002$ & & & & & \\
\hline & Beulah & $2 / 23 / 09$ & $<0.002$ & $<0.002$ & & & & & \\
\hline & Beulah & $8 / 24 / 09$ & $<0.002$ & $<0.002$ & & & & & \\
\hline & Beulah & $8 / 19 / 10$ & $<0.002$ & $<0.002$ & & & & & \\
\hline \multirow{6}{*}{ Dissolved Ammonia } & Beulah & $8 / 30 / 07$ & 0.170 & 0.190 & & & 0.180 & 0.014 & 7.9 \\
\hline & Beulah & $3 / 4 / 08$ & 0.083 & 0.046 & & & 0.065 & 0.026 & 40.6 \\
\hline & Beulah & $8 / 26 / 08$ & $<0.015$ & $<0.015$ & & & & & \\
\hline & Beulah & $2 / 23 / 09$ & 0.211 & 0.204 & & & 0.208 & 0.005 & 2.4 \\
\hline & Beulah & $8 / 24 / 09$ & 0.032 & 0.035 & & & 0.034 & 0.002 & 6.3 \\
\hline & Beulah & $8 / 19 / 10$ & $<0.015$ & 0.030 & & & & & \\
\hline \multirow{6}{*}{ Total Kjeldahl Nitrogen } & Beulah & $8 / 30 / 07$ & 0.510 & 0.420 & & & 0.465 & 0.064 & 13.7 \\
\hline & Beulah & $3 / 4 / 08$ & 0.570 & 0.450 & & & 0.510 & 0.085 & 16.6 \\
\hline & Beulah & $8 / 26 / 08$ & 0.530 & 0.580 & & & 0.555 & 0.035 & 6.4 \\
\hline & Beulah & $2 / 23 / 09$ & 0.660 & 0.690 & & & 0.675 & 0.021 & 3.1 \\
\hline & Beulah & $8 / 24 / 09$ & 0.160 & 0.530 & & & 0.345 & 0.262 & 75.8 \\
\hline & Beulah & $8 / 19 / 10$ & 0.580 & 0.680 & & & 0.63 & 0.071 & 11.2 \\
\hline \multirow{6}{*}{$\begin{array}{c}\text { Dissolved Nitrate plus } \\
\text { Nitrite }\end{array}$} & Beulah & $8 / 30 / 07$ & $<0.019$ & $<0.019$ & & & & & \\
\hline & Beulah & $3 / 4 / 08$ & 0.675 & 0.670 & & & 0.673 & 0.004 & 0.5 \\
\hline & Beulah & $8 / 26 / 08$ & $<0.019$ & $<0.019$ & & & & & \\
\hline & Beulah & $2 / 23 / 09$ & 0.673 & 0.721 & & & 0.697 & 0.034 & 4.9 \\
\hline & Beulah & $8 / 24 / 09$ & 0.074 & 0.073 & & & 0.074 & 0.001 & 1.0 \\
\hline & Beulah & $8 / 19 / 10$ & 0.022 & 0.022 & & & 0.022 & 0.000 & 0.0 \\
\hline \multirow{9}{*}{$\begin{array}{c}\text { Chlorophyll-a } \\
\text { (micrograms per liter) }\end{array}$} & Big Cedar, South & 8/29/06 & 8.02 & 7.56 & 8.20 & & 7.93 & 0.33 & 4.16 \\
\hline & Beulah & $8 / 30 / 07$ & 4.05 & 3.78 & & & 3.92 & 0.19 & 4.88 \\
\hline & Spring & $9 / 6 / 07$ & 2.47 & 2.79 & & & 2.63 & 0.23 & 8.60 \\
\hline & Beulah & $8 / 26 / 08$ & 6.97 & 7.45 & & & 7.21 & 0.34 & 4.71 \\
\hline & Beulah & $2 / 23 / 09$ & 0.55 & 0.55 & & & 0.55 & 0.00 & 0.0 \\
\hline & Beulah & $8 / 24 / 09$ & 2.66 & 2.90 & & & 2.78 & 0.17 & 6.1 \\
\hline & Delavan & $9 / 15 / 09$ & 10.80 & 10.10 & 9.8 & & 10.23 & 0.51 & 5.0 \\
\hline & Beulah & $8 / 19 / 10$ & 5.35 & 5.56 & & & 5.46 & 0.15 & 2.72 \\
\hline & Big Cedar, South & $8 / 24 / 10$ & 3.93 & 3.9 & & & 3.92 & 0.02 & 0.54 \\
\hline
\end{tabular}




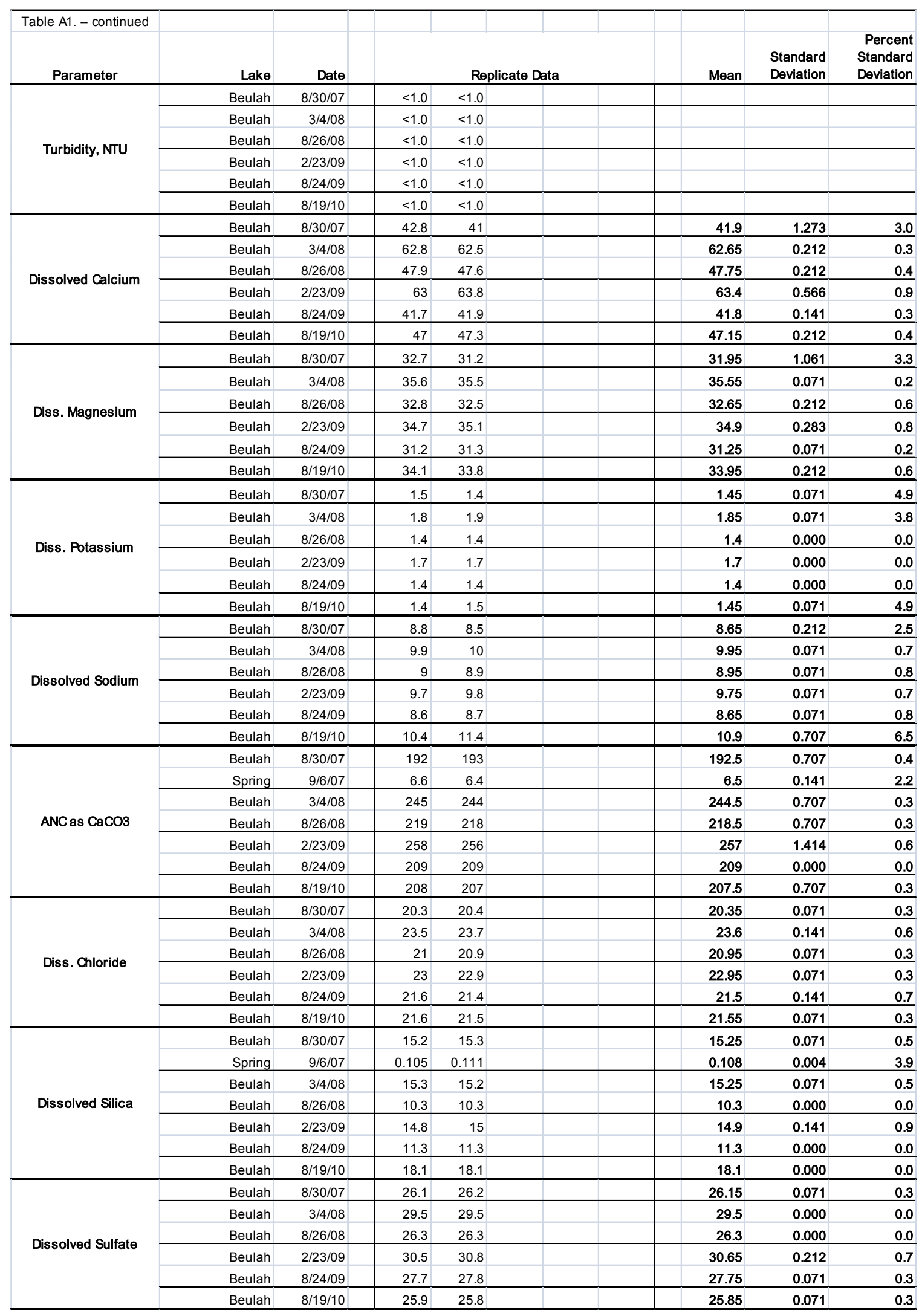




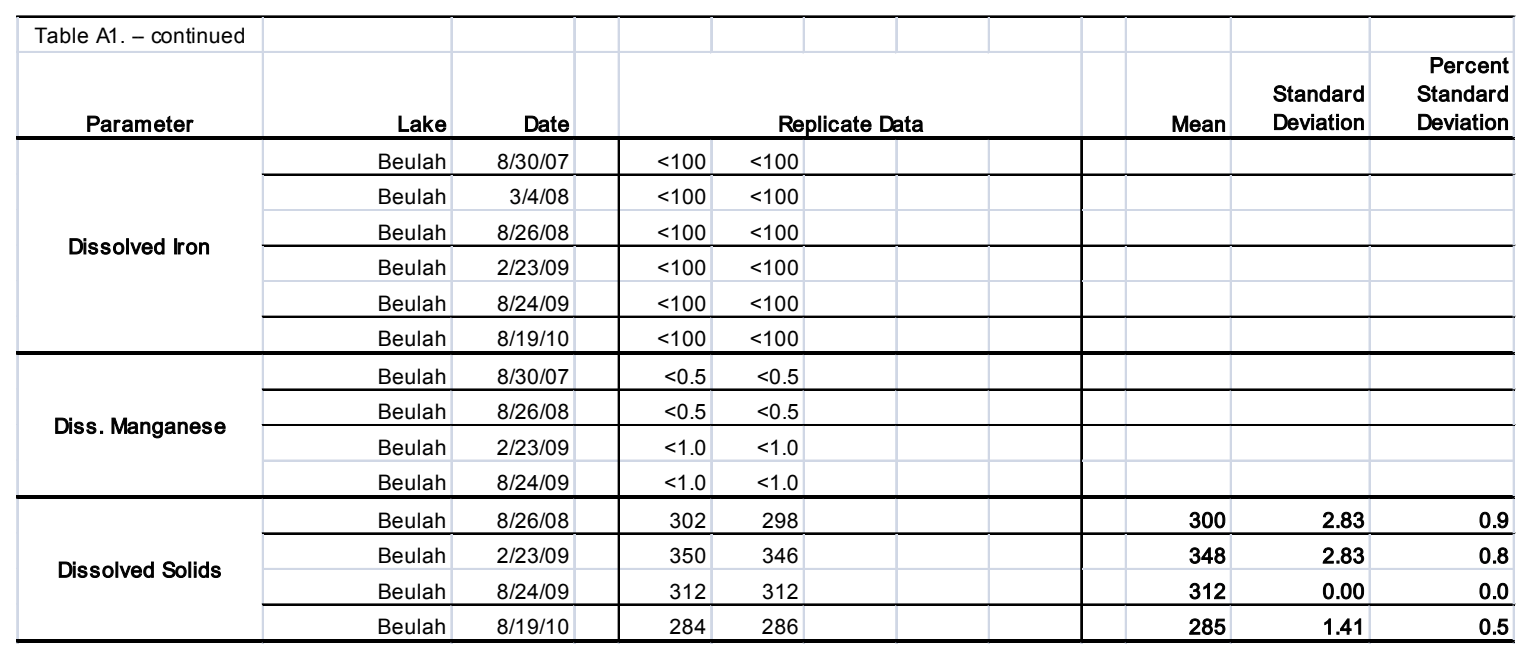


Table A2. Data from tests of blanks, 2006-2010. All data in milligrams per liter, unless otherwise indicated. $<=$ less than given detection limit; $\mathrm{E}=$ estimated value.

Delavan Lake. Analyses at USGS National Water Quality Laboratory, Lakewood, CO.

\begin{tabular}{lccccc} 
Parameter & $4 / 7 / 06$ & $6 / 13 / 06$ & $8 / 14 / 06$ & $4 / 16 / 07$ & $9 / 14 / 09$ \\
\hline Total P & $<0.004$ & $\mathrm{E} 0.002$ & $<0.004$ & $<0.004$ & $<0.008$ \\
Dissolved orthophosphate & $<0.006$ & $<0.006$ & $\mathrm{E} 0.003$ & $<0.006$ & $<0.008$ \\
Chlorophyll a & $<0.0260$ & & $<0.0260$ & $<0.260$ & \\
Chlorophyll b & & & & & \\
Total Kjeldahl Nitrogen (as N) & & & & & \\
Ammonia (as N) & & & & & \\
Nitrate + Nitrite (as N) & & & & & \\
\hline
\end{tabular}

Lake Beulah at Deep Hole near East Troy, WI. Analysis at Wisconsin State Laboratory of Hygiene, Madison, WI

Parameter $\begin{array}{llllll}8 / 29 / 07 & 2 / 27 / 08 & 8 / 26 / 08 & 2 / 22 / 09 & 8 / 20 / 09 & 8 / 19 / 10\end{array}$

Total P

$\begin{array}{llllll}<0.005 & <0.005 & <0.005 & <0.005 & <0.005 & <0.005\end{array}$

Dissolved orthophosphate

$0.005<0.002<0.002<0.002<0.002<0.002$

Total Kjeldahl

Dissolved Ammonia

Dissolved Nitrate plus Nitrite

$<0.14<0.14<0.14$

$<0.14<0.14<0.14$

$\begin{array}{llllll}<0.15 & <0.015 & <0.015 & <0.015 & <0.015 & 0.015\end{array}$

Chlorophyll a (ug/L)

Dissolved Calcium

Dissolved Magnesium

Dissolved Potassium

$<0.019<0.019<0.019$

$<0.260$

$<0.10<0.10$

$<0.260$

$<0.019<0.019<0.019$

Dissolved Sodium

$<0.10$

$<0.10$

$<0.10$

$<0.260$

$<0.10$

$<0.10$

$<0.10$

$<0.10$

$<0.260$

$0.200<0.10$

ANC as $\mathrm{CaCO} 3$

Dissolved Chloride

$<2$

$<1.0$

3

$<0.10$

$<0.10$

$<0.10$

$<0.260$

Dissolved Silica

Dissolved Sulfate

$<0.22$

$<0.10$

$<0.10$

$<0.10$

$<0.10$

$\begin{array}{lll}<0.10 & <0.10 & <0.10 \\ <0.10 & <0.10 & <0.10\end{array}$

Dissolved Iron

Dissolved Manganese

Dissolved Solids

$<4.5$

$<0.022$

$<1.0$

$<2$

$<0.10$

$<0.022$

$<1.0$

$<2$

$<0.10$

$<0.022$

$<1.0$

$<2$

$<4.5<4.5$

$<4.5$

$<0.022$

$<1.0$

$<4.5$

$<0.022$

$<100<100<100$

Turbidity, NTU

$--\quad-\quad<50$

$<50$

$<50$

$<50$

$-\quad<1.0 \quad<1.0 \quad<1.0<1.0$

Mercer Lake at Main Deep Hole at Mercer, WI, WI. Analysis at Wisconsin State Laboratory of Hygiene, Madison, WI Parameter $8 / 27 / 10$

Total P $\quad<0.005$

Rolling Stone Lake near Pickerel, WI. Analysis at Wisconsin State Laboratory of Hygiene, Madison, WI

\begin{tabular}{ll} 
Parameter & $8 / 29 / 07$ \\
\hline
\end{tabular}

Total P $<0.005$

Chlorophyll a (ug/L) $\quad<0.260$

ANC as $\mathrm{CaCO} 3$

Dissolved Silica $\quad<0.022$

Wind Lake at Wind Lake, WI. Analyses at Wisconsin State Laboratory of Hygiene, Madison, WI

\begin{tabular}{|lll}
\hline Parameter & $6 / 13 / 06$ & $8 / 30 / 10$ \\
\hline Total P & $<0.005$ & $<0.005$ \\
\hline
\end{tabular}

Chlorophyll a (ug/L) $\quad<0.260$

Silver Lake near West Bend, WI. Analyses at Wisconsin State Laboratory of Hygiene, Madison, WI

\begin{tabular}{|ll} 
Parameter & $8 / 31 / 09$ \\
\hline Total P & $<0.005$ \\
Chlorophyll a (ug/L) & $<0.260$ \\
\hline
\end{tabular}




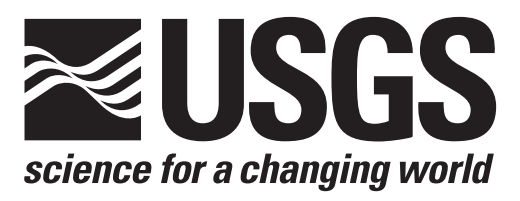

\section{Water-Quality and Lake-Stage Data for Wisconsin Lakes, Water Year 2011}





\section{CONTENTS}

Introduction

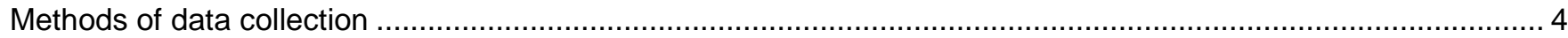

Explanation of physical and chemical characteristics of lakes ……............................................................. 13

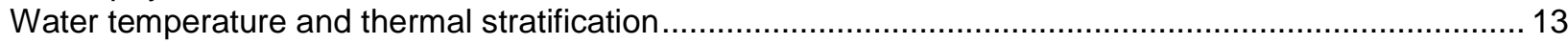

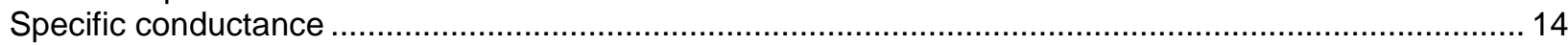

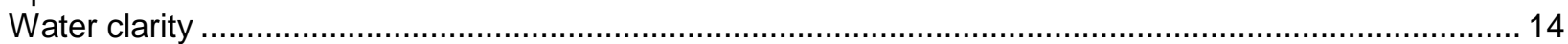

$\mathrm{pH}$

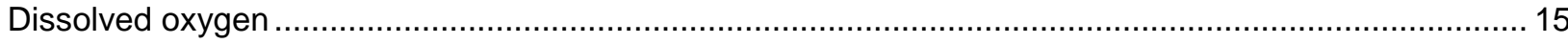

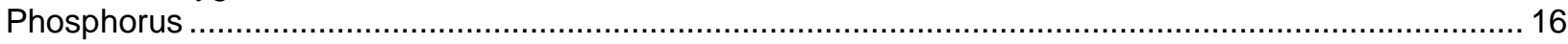

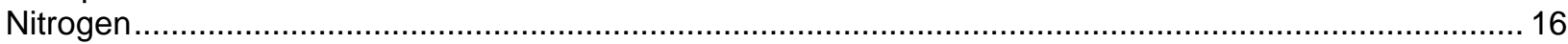

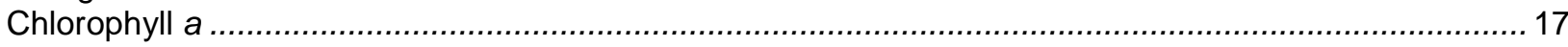

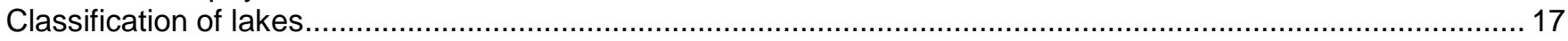

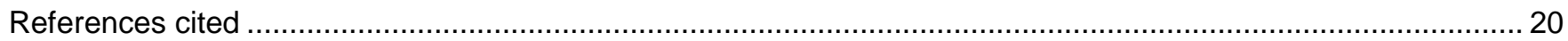

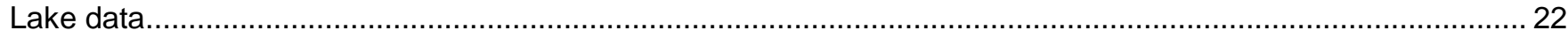

Beulah

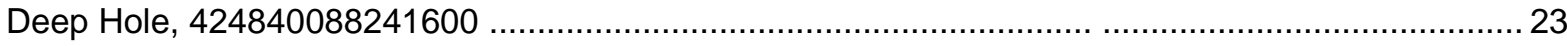

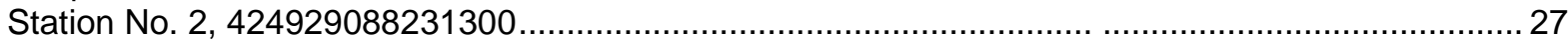

Big Cedar

North Site, near West Bend, 432409088151600......................................................................... 31

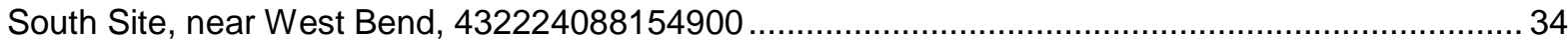

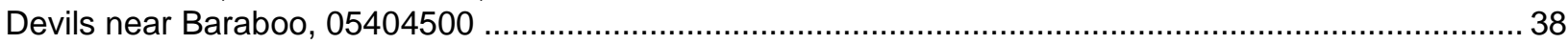

Geneva

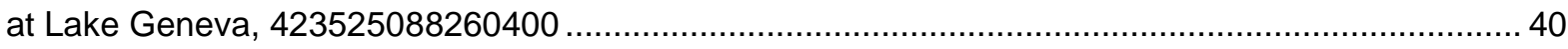

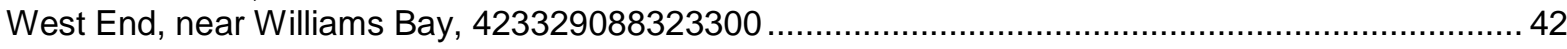

Green

at County Trunk Highway A near Green Lake (East End), 434928088553601 ................................. 46

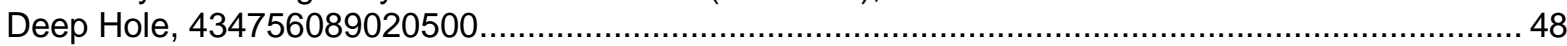

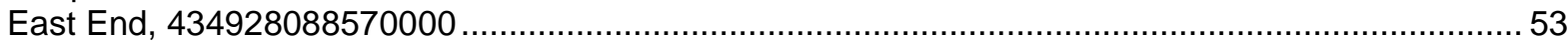

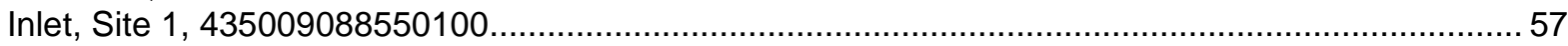

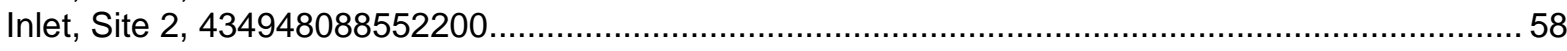

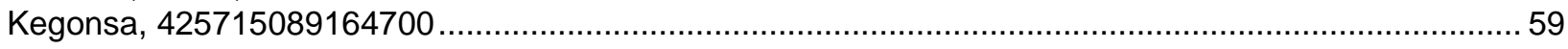

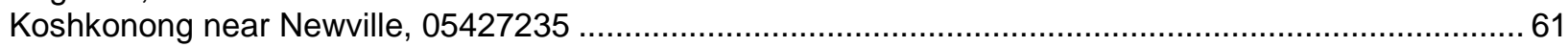

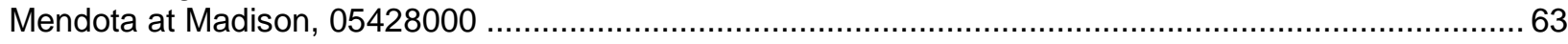

Middle Genesee at Genesee Lake Road, near Oconomowoc, 430251088284700 ..................................6 65

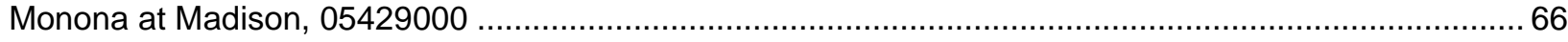

Oconomowoc

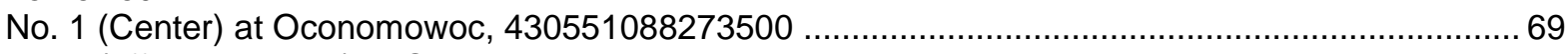

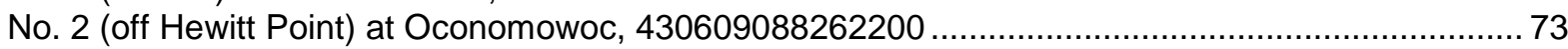

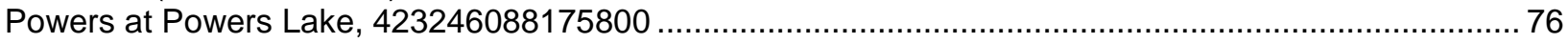

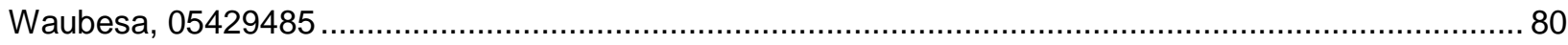

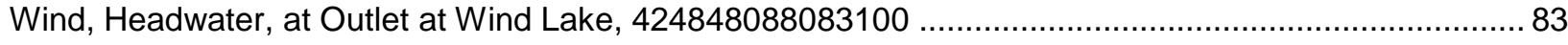

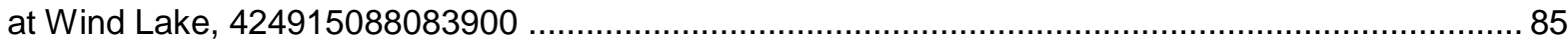

Winnebago

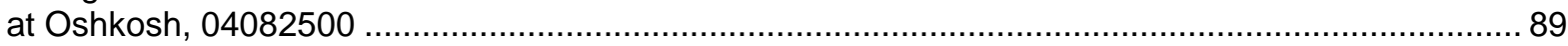

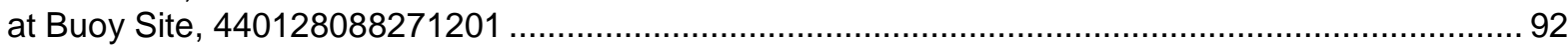

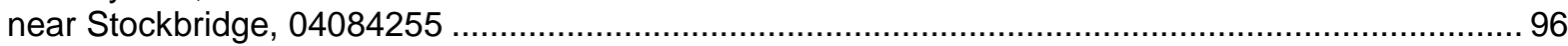

Wisconsin Water Science Center publications pertaining to lakes ...................................................................... 98

Appendix - Quality-Assurance/Quality-Control Plan ............................................................................ 110 


\section{FIGURE}

Figure 1. Map showing location of USGS lake water-quality and lake-stage stations in Wisconsin

\section{TABLES}

Table 1. Discontinued lake stations

2. Parameter identification numbers and laboratory reporting levels (LRL) for chemical parameters commonly measured in lakes, and analyzed at the National Water-Quality Laboratory (NWQL) or the Wisconsin State Laboratory of Hygiene (WSLH). 
CONVERSION FACTORS, VERTICAL DATUM, AND ABBREVIATED WATER-QUALITY UNITS

\begin{tabular}{rrl}
\hline Multiply & By & To Obtain \\
mile (mi) & 1.609 & kilometer \\
pound (lb) & 453.6 & gram \\
acre & 0.4048 & hectare \\
foot (ft) & 0.3048 & meter \\
meter (m) & 3.281 & foot \\
gallon $(\mathrm{gal})$ & 3.785 & liter \\
square mile $\left(\mathrm{mi}^{2}\right)$ & 2.590 & square kilometer \\
& & \\
Temperature, in degrees Celsius $\left({ }^{\circ} \mathrm{C}\right)$ can be converted to degrees Fahrenheit $\left({ }^{\circ} \mathrm{F}\right)$ by use of the following \\
& equation & \\
& ${ }^{\circ} \mathrm{F}=1.8\left({ }^{\circ} \mathrm{C}\right)+32$ & \\
\hline
\end{tabular}

Sea level: In this report "sea level" refers to either the National Geodetic Vertical Datum of 1929 (NGVD of 1929)-a geodetic datum derived from a general adjustment of the first-order level nets of both the United States and Canada, formerly called Sea Level Datum of 1929- or the North American Vertical Datum of 1988 (NAVD 88).

Abbreviated water-quality units: Chemical concentrations and water temperature are given in metric units. Chemical concentration is given in milligrams per liter $(\mathrm{mg} / \mathrm{L})$ or micrograms per liter $(\mu \mathrm{g} / \mathrm{L})$. Milligrams per liter is a unit expressing the concentration of chemical constituents in solution as weight (milligrams) of solute per unit volume (liter) of water. One thousand micrograms per liter is equivalent to one milligram per liter. For water with dissolved-solids concentrations less than 7,000 $\mathrm{mg} / \mathrm{L}$, the numerical values for concentrations expressed as $\mathrm{mg} / \mathrm{L}$ and $\mu \mathrm{g} / \mathrm{L}$ are the same as for concentrations in parts per million and parts per billion, respectively.

Specific conductance of water is expressed in microsiemens per centimeter at 25 degrees Celsius $(\mu \mathrm{S} / \mathrm{cm})$. This unit is equivalent to micromhos per centimeter $(\mathrm{mmho} / \mathrm{cm})$ at 25 degrees Celsius, formerly used by the U.S. Geological Survey. 


\section{WATER-QUALITY AND LAKE-STAGE DATA FOR WISCONSIN LAKES, WATER YEAR 2011 By Wisconsin Water Science Center Lake-Studies Team}

\section{INTRODUCTION}

The U.S. Geological Survey (USGS), in cooperation with local and other agencies, collects data at selected lakes throughout Wisconsin. These data, accumulated over many years, provide a data base for developing an improved understanding of the water quality of lakes. To make these data available to interested parties outside the USGS, the data are published annually in this report series. The locations of water-quality and lake-stage stations in Wisconsin for water year 2011 are shown in figure 1. A water year is the 12-month period from October 1 through September 30. It is designated by the calendar year in which it ends. Thus, the period October 1, 2010 through September 30, 2011 is called "water year 2011."

The purpose of this report is to provide information about the chemical and physical characteristics of Wisconsin lakes. Data that have been collected at specific lakes, and information to aid in the interpretation of those data, are included in this report. Data collected include measurements of in-lake water quality and lake stage. Time series of Secchi depths, surface total phosphorus and chlorophyll a concentrations collected during non-frozen periods are included for all lakes. Graphs of vertical profiles of temperature, dissolved oxygen, $\mathrm{pH}$, and specific conductance are included for sites where these parameters were measured. Descriptive information for each lake includes: location of the lake, area of the lake's watershed, period for which data are available, revisions to previously published records, and pertinent remarks. Additional data, such as streamflow and water quality in tributary and outlet streams of some of the lakes, are published in another volume: "Water Resources Data-Wisconsin, 2011."

Water-resources data, including stage and discharge data at most streamflow-gaging stations, are available through the World Wide Web on the Internet. The Wisconsin Water Science Center's home page is at http://wi.water.usgs.gov/. Information on the Wisconsin Water Science Center's Lakes Program is found at http://wi.water.usgs.gov/lakes/index.html and http://wi.water.usgs.gov/projects/index.html. 


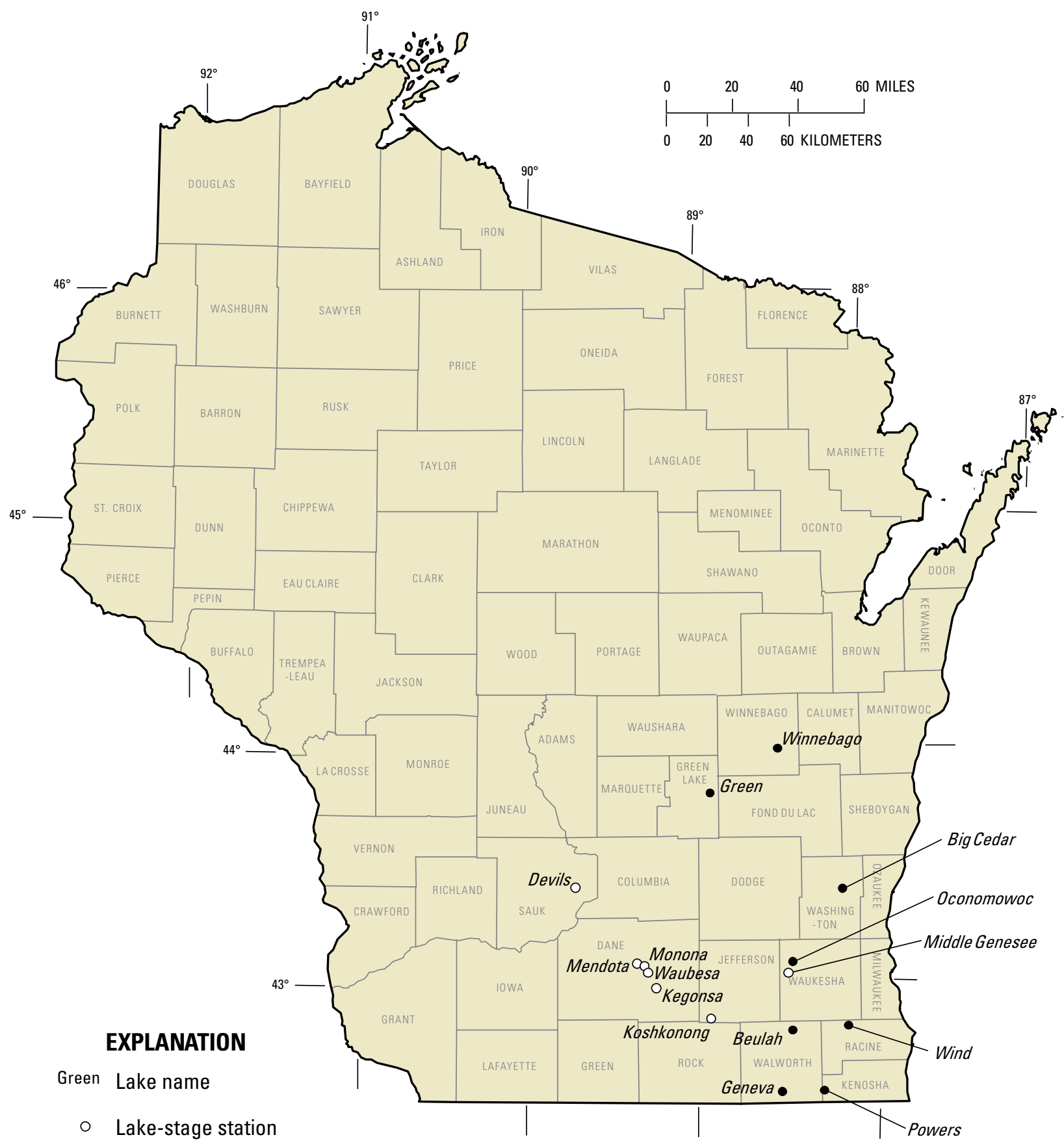

- Lake water-quality and stage station

Note: at some lakes more than one site may be monitored.

Figure 1. Location of USGS lake water-quality and lake-stage stations in Wisconsin. 
The USGS has done cooperative lake monitoring with local and other agencies since 1983. Cooperators in 2011 included:

Big Cedar Lake Protection and Rehabilitation District

Dane County

Geneva Lake Environmental Agency

Green Lake Sanitary District

Lake Beulah Management District

Middle Genesee Lake District

Powers Lake District

Rock County Public Works Department

U.S. Army Corps of Engineers

U.S. Environmental Protection Agency

Village of Oconomowoc Lake

Wind Lake Management District

Wisconsin Department of Natural Resources 
Lake data-collection sites are identified by a unique identification number. Lake waterquality sites are identified by a 15-digit number that is a concatenation of the site's latitude, longitude, and a two-digit sequence number. The sequence number is used to distinguish between sites located at the same latitude-longitude designation. The site identification number is permanently assigned to the site; actual latitude and longitude of the site are subject to update and are stored separately. For some lakes, which have historical records of lake stage, an eight-to-ten digit number is assigned according to downstream order. Gaps are left in the numerical series to allow for new stations; hence, the numbers are not consecutive. The first two digits of the complete eight-to-ten digit number, such as 04087000 or 054310157 , designate the major river basin. For example, "04" designates the St. Lawrence River Basin and "05" designates the Upper Mississippi River Basin.

The water-quality lake stations that were discontinued prior to water year 2011 are listed in table 1. Discontinued lake-stage stations are not included in this table.

This report is the culmination of a concerted effort by a number of people who collected, compiled, analyzed, verified, and organized the data, and who typed, edited, and assembled the report. The authors had primary responsibility for assuring that the information contained herein is accurate, complete, and adheres to USGS policy and established guidelines. Technicians in charge of the field offices are: B.W. Olson (Rhinelander), and S.A. March (Middleton). The data were collected and processed by D.E. Housner, S.B. Manteufel, D.L. Olson, P.C. Reneau, Z.T. Scott, B.J. Siebers and E.F. Younger. S.B. Manteufel assembled, edited, and formatted the report. Additional assistance in preparation of the report was provided by M.M. Greenwood, and D.L. Olson.

\section{METHODS OF DATA COLLECTION}

Depth profiles of water temperature, dissolved oxygen, $\mathrm{pH}$, and specific conductance were collected using multi-parameter meters. Prior to measurements, the meters were calibrated using standards for $\mathrm{pH}$ and conductance, and dissolved oxygen was calibrated using the air calibration method. Generally, field measurements in profiles were made at 0.5-m intervals if the maximum depth of the lake was $5 \mathrm{~m}$ or less and at 1.0-m intervals if the maximum depth was greater than $5 \mathrm{~m}$. 
Table 1. Discontinued lake stations

\begin{tabular}{|c|c|c|}
\hline Station name & Site identification number & Period of record \\
\hline Alma Lake near St. Germain & 455426089254700 & $\begin{array}{l}\text { Oct. 1984-Sept. } 1990 \\
\text { May } 1992-S e p t .1996\end{array}$ \\
\hline Balsam Lake, off Cedar Island, at Balsam Lake & 452755092264600 & Feb. 1991-Aug. 1994 \\
\hline off Little Narrows, near Balsam Lake & 452858092265300 & May 1991-Aug. 1994 \\
\hline off Rock Island, near Balsam Lake & 452754092234300 & May 1991-Aug. 1994 \\
\hline Balsam Lake near Birchwood & 453907091345800 & $\begin{array}{l}\text { Mar. 1993-Aug. 1994, } \\
\text { Mar. 1996-Aug. 1997, } \\
\text { Mar.-Sept. } 2001\end{array}$ \\
\hline Bass Lake near Shawano & 445215088300300 & Feb. 1990-Aug. 1992 \\
\hline Bear Lake at Deep Hole near Haugen & 453754091490900 & Mar. 1992-Aug. 1993 \\
\hline Beaver Dam Lake, South end, at Beaver Dam & 432814088515000 & June-Oct. 1991 \\
\hline North end, near Beaver Dam & 433122088545700 & June-Oct. 1991 \\
\hline Benedict Lake near Powers Lake & 423201088180800 & May 1998-Aug. 2000 \\
\hline Big Blacksmith Lake near Keshena & 445401088334500 & Feb. 1990-Aug. 1992 \\
\hline Big Hills (Hills) Lake near Wild Rose & 440912089092000 & $\begin{array}{l}\text { June 1983-Aug. 1984, } \\
\text { Feb.-Aug. 1987, } \\
\text { Feb.-Aug. 1990, } \\
\text { Feb.-Aug. 1993, } \\
\text { Feb.-Aug. 1996, } \\
\text { Feb.-Aug. } 1999\end{array}$ \\
\hline Big Muskego Lake, at North Site, near Muskego & 425301088061300 & Feb.-Aug. 1988 \\
\hline Research Base, near Muskego & 425235088075300 & May-June 1994 \\
\hline Big Round Lake near Milltown & 453142092180100 & Feb.-Sept. 2001 \\
\hline Big St. Germain Lake, near St. Germain & 455557089311000 & Feb. 1992-Aug. 1996 \\
\hline near Lake Tomahawk & 05390750 & 1991-2001 \\
\hline Big Sand Lake, Deep Hole, near Hertel & 454910092134000 & Feb.-Sept. 2001 \\
\hline East Site, near Hertel & 454921092124300 & Feb.-Sept. 2001 \\
\hline Big Sissabagama Lake, near Stone Lake & 454724091303600 & $\begin{array}{l}\text { Apr. 1986-Sept. 1996, } \\
\text { Oct. 1997-Sept. } 2002\end{array}$ \\
\hline North Site, near Stone Lake & 454800091312900 & Mar. 1998-Sept. 2001 \\
\hline Booth Lake near East Troy & 424800088254800 & $\begin{array}{l}\text { Feb. 1992-Aug. 1994, } \\
\text { Feb. 2001-Aug. } 2003\end{array}$ \\
\hline Buffalo Lake, Center Site, at Packwaukee & 434558089260600 & May 1998-Sept. 2001 \\
\hline East End, at Montello & 434720089201600 & May 1998-Sept. 2001 \\
\hline West End, near Endeavor & 434414089282400 & May 1998-Sept. 2001 \\
\hline
\end{tabular}


Table 1. Discontinued lake stations--continued

\begin{tabular}{|c|c|c|}
\hline Station name & Site identification number & Period of record \\
\hline Butternut Lake, near Park Falls & 455854090310300 & Oct. 2002-Oct. 2004 \\
\hline Deep Hole, near Park Falls & 455803090310800 & Mar. 2003-Sept. 2004 \\
\hline North Site, near Butternut & 455904090303400 & Mar. 2003-Sept. 2004 \\
\hline Far South Site, near Park Falls & 455651090312700 & Mar. 2003-Sept. 2004 \\
\hline Delavan Lake, Center, at Delavan & 423556088365001 & Oct. 1983-Oct. 2009 \\
\hline North end, near Lake Lawn & 423659088354401 & Oct. 1983-Oct. 2009 \\
\hline SW end, near Delavan & 423526088380101 & Oct. 1983-Oct. 2009 \\
\hline Denoon Lake at Wind Lake & 425044088100300 & Feb. 1991-Aug. 1996 \\
\hline Druid Lake near Hartford & 431643088243300 & Feb. 1991-Sept. 1996 \\
\hline Eagle Lake near Kansasville & 05544500 & $\begin{array}{l}\text { 1936-64, 1975-77, } \\
\text { 1979, } \\
\text { Feb. 1993-Sept. } 1996\end{array}$ \\
\hline Eagle Lake, at Deep Hole, near Kansasville & 424207088072400 & Feb. 1993-Aug. 1996 \\
\hline Eagle Spring Lake at Eagleville & 425103088261500 & Apr. 1991-Sept. 2001 \\
\hline Elizabeth Lake near Twin Lakes & 423051088155300 & Feb. 1995-Sept. 1997 \\
\hline Fish Lake near Sauk City & 05406050 & $\begin{array}{l}\text { Nov. 1966-Sept. 1981, } \\
\text { Apr. 1985-May 1987, } \\
\text { May 1988, Apr. 1989- } \\
\text { Oct. } 1990, \text { Oct. 1990- } \\
\text { Nov. } 1996 \text {, Nov. 1996- } \\
\text { Sept. } 2004\end{array}$ \\
\hline Fowler Lake, Center, at Oconomowoc & 430653088294601 & $\begin{array}{l}\text { Jan.-Dec. 1984, } \\
\text { Oct. 1986-Sept. } 1996\end{array}$ \\
\hline Fox Lake Deep Hole at Fox Lake & 433458088560600 & June 1991-Mar. 1993 \\
\hline Geneva Lake, Geneva Bay, at Lake Geneva & 423455088263800 & Apr. 1997-Feb. 1999 \\
\hline Williams Bay, at Williams Bay & 423420088320500 & Apr. 1997-Feb. 1999 \\
\hline Center, near Lake Geneva & 423402088301400 & Apr. 1997-Mar. 1999 \\
\hline East End, near Lake Geneva & 423421088272300 & Apr. 1997-May 2000 \\
\hline Hemlock Lake near Mikana & 453421091333700 & $\begin{array}{l}\text { Mar. 1993-Aug. 1994, } \\
\text { Mar. 1996-Aug. 1997, } \\
\text { Mar.-Sept. } 2001\end{array}$ \\
\hline Hooker Lake at Salem & 423335088060300 & Feb. 1992-Aug. 1993 \\
\hline Kawaguesaga, Deep Hole, near Minocqua & 455208089435800 & May-Sept. 2003 \\
\hline South Site, near Minocqua & 455145089442600 & May-Sept. 2003 \\
\hline Kirby Lake near Cumberland & 453554092042101 & Nov. 1995-Oct. 1996 \\
\hline (Site 1) near Cumberland & 453608092035801 & Nov. 1995-Nov. 1996 \\
\hline (Site 2) near Cumberland & 453601092035301 & Nov. 1995-Nov. 1996 \\
\hline
\end{tabular}


Table 1. Discontinued lake stations--continued

\begin{tabular}{|c|c|c|}
\hline Station name & Site identification number & Period of record \\
\hline (Site 3) near Cumberland & 453612092034901 & Nov. 1995-Nov. 1996 \\
\hline (Site 4) near Cumberland & 453603092035701 & Nov. 1995-Nov. 1996 \\
\hline (Site 5) near Cumberland & 453608092041201 & Nov. 1995-Nov. 1996 \\
\hline (Site 6) near Cumberland & 453555092040901 & Nov. 1995-Nov. 1996 \\
\hline Lac La Belle at Oconomowoc & 430733088305900 & $\begin{array}{l}\text { Feb. 1984-Aug. 1985, } \\
\text { Apr. -Aug. 1991, } \\
\text { Feb. 2001-Aug. } 2003\end{array}$ \\
\hline NW, at Oconomowoc & 430809088313900 & Feb. 1984-Aug. 1985 \\
\hline SE, at Oconomowoc & 430707088301400 & Feb. 1984-Aug. 1985 \\
\hline Lake Bastine, Deep Hole, near Mercer & 460511090153800 & Apr. 2009-Mar. 2010 \\
\hline Lake Blass at Lake Delton & 433545089482400 & Mar. 1989-Aug. 1990 \\
\hline Lake Desair near Rice Lake & 453446091465100 & Aug. 2004 \\
\hline $\begin{array}{l}\text { Lake Keesus, } \\
\text { East Bay, near Merton } \\
\text { North Bay, near Merton }\end{array}$ & $\begin{array}{l}430957088183400 \\
431006088191000\end{array}$ & $\begin{array}{l}\text { Apr. 1991-Aug. } 1995 \\
\text { Apr. 1991-Aug. } 1995\end{array}$ \\
\hline Lake Morris at Mount Morris & 440654089120500 & Jun. 1983-Sept. 1989 \\
\hline $\begin{array}{l}\text { Lake Nebagamon, Northeast Bay, at Lake } \\
\text { Nebagamon }\end{array}$ & 463050091412300 & May 1992-Aug. 1995 \\
\hline Southeast Bay, at Lake Nebagamon & 462928091413500 & Mar. 1992-Sept. 1995 \\
\hline West Bay, at Lake Nebagamon & 463034091425300 & May 1992-Aug. 1995 \\
\hline Lake Noquebay near Crivitz & 451511087550900 & $\begin{array}{l}\text { Feb. 1987-Aug. } 1988, \\
\text { Apr. 1991-Aug. } 1994\end{array}$ \\
\hline East End, near Crivitz & 451540087525700 & Apr. 1991-Aug. 1994 \\
\hline Lamotte Lake near Shawano & 445305088361200 & Feb. 1990-Aug. 1992 \\
\hline $\begin{array}{l}\text { Lauderdale Lakes at Lauderdale } \\
\text { Mill, at Lauderdale }\end{array}$ & $\begin{array}{l}424554088332700 \\
424555088335700\end{array}$ & $\begin{array}{l}\text { Oct. 1993-Oct. } 1994 \\
\text { Nov. 1993-Nov. } 1994 \text {, } \\
\text { Aug. } 2002\end{array}$ \\
\hline Green, Auxiliary, Number 1, near Lauderdale & 424640088341900 & June 1999-Sept. 2000 \\
\hline Green, near Lauderdale & 424652088341500 & $\begin{array}{l}\text { Nov. } 1993-N o v .1994, \\
\text { Aug. } 2002\end{array}$ \\
\hline Legend Lake (site 1) near Shawano & 445342088312700 & Feb. 1990-Feb. 1992 \\
\hline Little Arbor Vitae near Woodruff & 455446089370300 & Feb. 1991-Sept. 2002 \\
\hline Little Green Lake, at Center, near Markesan & 434412088590700 & Feb. 1991-Aug. 2003 \\
\hline Little Muskego Lake at Muskego & 425425088083500 & Oct. 1986-Aug. 2002 \\
\hline Little Rock Lake near Woodruff & 455946089415702 & Oct. 1983-Sept. 1996 \\
\hline Little St. Germain Lake, near Eagle River & 05390700 & (a) \\
\hline Upper East Bay, at St. Germain & 455532089253900 & $\begin{array}{l}\text { Dec. 1996-Mar. 97, } \\
\text { Mar. 1999, } \\
\text { Mar. 2000-Aug. } 2003\end{array}$ \\
\hline
\end{tabular}


Table 1. Discontinued lake stations--continued

\begin{tabular}{|c|c|c|}
\hline Station name & Site identification number & Period of record \\
\hline Northeast Bay, near St. Germain & 455545089262500 & $\begin{array}{l}\text { Apr. 1991-Aug. 1994, } \\
\text { Aug. 1996-Aug. 1997, } \\
\text { Mar. 1999-Aug. } 2003\end{array}$ \\
\hline South Bay, near St. Germain & 455437089270800 & $\begin{array}{l}\text { Apr. 1991-Aug. 1994, } \\
\text { Aug. 1996-Aug. 1997, } \\
\text { Mar. 1999-Aug. } 2003\end{array}$ \\
\hline West Bay, at St. Germain & 455428089282400 & $\begin{array}{l}\text { Apr. 1991-Aug. 1994, } \\
\text { Aug. 1996-Aug. 1997, } \\
\text { Mar. 1999-Aug. } 2003\end{array}$ \\
\hline Little Sand Lake - Site No. 2 - near Mole Lake & 452826088544101 & May1996-Sept. 2003 \\
\hline Long (Kee Nong Go-Mong) Lake at Wind Lake & 424937088103400 & $\begin{array}{l}\text { Feb. 1988-Aug. } 1989 \\
\text { Feb. 1991-Aug. } 1996\end{array}$ \\
\hline Loon Lake near Shawano & 445009088303700 & Feb. 1991-Aug. 1993 \\
\hline Lost Lake near Beaver Dam & 432640088580500 & June-Oct. 1991 \\
\hline \multicolumn{3}{|l|}{ McKenzie Lakes } \\
\hline \multicolumn{3}{|l|}{ McKenzie (Big McKenzie) } \\
\hline Deep Hole, near Spooner & 455507092013500 & Feb. 1987-Aug. 1998 \\
\hline Northern Site, near Spooner & 455540092022000 & June 1997-Aug. 1998 \\
\hline South Site, near Spooner & 455437092022300 & June 1997-Aug. 1998 \\
\hline Lower McKenzie, near Webb Lake & 455902092011900 & June 1997-Aug. 1998 \\
\hline Middle McKenzie, near Spooner & 455635092021800 & June 1997-Aug. 1998 \\
\hline Mary (Marie) Lake at Twin Lakes & 423128088151200 & Feb. 1995-Aug. 1997 \\
\hline Max Lake near Woodruff & 460128089423501 & Mar. 1988-Dec. 1996 \\
\hline Mead Lake, East Bay near Willard & 444720090445000 & Apr. 1991-Aug. 1995 \\
\hline West Bay near Willard & 444733090460100 & Feb. 1991-Sept. 1995 \\
\hline Mercer Lake, Deep Hole, at Mercer & 460937090033100 & Mar. 2008-Sept. 2009 \\
\hline West basin, at Mercer & 460945090040600 & Mar. 2008-Sept. 2009 \\
\hline \multicolumn{3}{|l|}{ Minocqua Lake } \\
\hline Deep Hole, at Minocqua & 455214089412800 & May-Sept. 2003 \\
\hline North Bay, at Minocqua & 455232089424100 & May-Sept. 2003 \\
\hline South Bay, at Minocqua & 455206089425200 & May-Sept. 2003 \\
\hline Montello Lake at Montello & 434748089195800 & Feb. 1995-Aug. 1998 \\
\hline Moon Lake near St. Germain & 455504089260500 & Feb. 1992-Aug. 1996 \\
\hline Morgan Lake near Fence & 454622088324801 & Oct. 1987-Sept. 1998. \\
\hline Moshawquit Lake near Shawano & 445352088295800 & Feb. 1990-Aug. 1992 \\
\hline \multicolumn{3}{|l|}{ Muskego (Big Muskego) } \\
\hline Auxiliary Number 1, near Muskego & 425329088054000 & June 1996-Aug. 2000 \\
\hline Bass Bay, near Muskego & 425344008807010 & Feb. 1988-Aug. 2002 \\
\hline
\end{tabular}


Table 1. Discontinued lake stations--continued

\begin{tabular}{|c|c|c|}
\hline Station name & Site identification number & Period of record \\
\hline near Wind Lake & 425109088075000 & $\begin{array}{l}\text { Oct. 1987-Sept. 1989, } \\
\text { Jan. 1991-Sept. } 2002\end{array}$ \\
\hline South Site, near Muskego & 425212088072800 & Feb. 1988-Aug. 2002 \\
\hline Muskellunge Lake near Eagle River & 455700089224900 & June 2000-Aug. 2001 \\
\hline $\begin{array}{l}\text { Muskellunge Lake, near Lake Outlet near Eagle } \\
\text { River }\end{array}$ & 455706089232400 & Nov. 2000-Oct. 2001 \\
\hline Nagawicka Lake, at Deep Hole, at Delafield & 430417088230300 & Feb. 2003-Sept. 2004 \\
\hline \multicolumn{3}{|l|}{ Namekagon Lakes } \\
\hline Garden, near Cable & 461224091033200 & Mar. 1998-Aug. 1999 \\
\hline Jackson, near Cable & 461457091065900 & Mar. 1998-Aug. 1999 \\
\hline \multicolumn{3}{|l|}{ Namekagon } \\
\hline Deep Hole, near Cable & 461308091065100 & Mar. 1998-Aug. 1999 \\
\hline East Basin, near Cable & 461228091044300 & Mar. 1998-Aug. 1999 \\
\hline Northeast Basin, near Cable & 461410091050700 & Mar. 1998-Aug. 1999 \\
\hline Park Lake (site 1) at Pardeeville & 433239089175800 & $\begin{array}{l}\text { Feb. 1986-Aug. 1987, } \\
\text { May-Nov. } 1993\end{array}$ \\
\hline (site 2) at Pardeeville & 433226089175500 & May-Nov. 1993 \\
\hline (site 3) at Pardeeville & 433245089173000 & May-Nov. 1993 \\
\hline (site 4) at Pardeeville & 433257089165100 & May-Nov. 1993 \\
\hline Pike Lake near Hartford & 431916088200501 & Dec. 1998-Dec. 2000 \\
\hline Pike Lake-QW Site-near Hartford & 431835088200600 & Feb.-Aug. 2000 \\
\hline Potter Lake near Mukwonago & 423246088175800 & Feb. 1993-Sept. 2007 \\
\hline Pretty Lake, at Deep Hole, near Dousman & 425722088295000 & Feb. 1993-Aug. 1997 \\
\hline Puckaway Lake, West Basin, near Marquette & 434515089124000 & Apr. 2005-Sept. 2007 \\
\hline East Basin, near Marquette & 43454208907300 & Apr. 2005-Sept. 2007 \\
\hline River site, near Marquette & 434824089083200 & Apr. 2005-Sept. 2007 \\
\hline Red Cedar Lake, at Mikana & 453522091360600 & $\begin{array}{l}\text { Mar. 1993-Aug. 1994, } \\
\text { Mar. 1996-Aug. 1997, } \\
\text { Oct. 2000-Sept. } 2001\end{array}$ \\
\hline Deep Hole, near Mikana & 453725091345100 & $\begin{array}{l}\text { Mar. 1993-Aug. 1994, } \\
\text { Mar. 1996-Aug. 1997, } \\
\text { Mar. -Sept. } 2001\end{array}$ \\
\hline South End, at Mikana & 453519091352500 & $\begin{array}{l}\text { Mar. 1993-Aug. 1994, } \\
\text { Mar. 1996-Aug. 1997, } \\
\text { Mar. -Sept. } 2001\end{array}$ \\
\hline Rice Lake at Deep Hole near Whitewater & 424629088415700 & Apr.-Nov. 1991 \\
\hline Round Lake near Shawano & 445328088335000 & Feb. 1990-Aug. 1992 \\
\hline Sand Lake (Deep Hole) near Keshena & 445321088323101 & June-Aug. 1992 \\
\hline
\end{tabular}


Table 1. Discontinued lake stations--continued

\begin{tabular}{|c|c|c|}
\hline Station name & Site identification number & Period of record \\
\hline Shell Lake at Shell Lake & 05334000 & Aug. 1936-Sept. 1999 \\
\hline Silver Lake near Oconomowoc & 430436088293300 & Apr. 1992-Aug. 1996 \\
\hline Silver Lake near West Bend & 432322088125000 & $\begin{array}{l}\text { Feb. 1996-Aug. } 1997 \\
\text { Feb. 2009-Aug. } 2009\end{array}$ \\
\hline Sinissippi Lake, off Anthony Is., at Hustisford & 432113088361100 & Feb. 1991-Aug. 1993 \\
\hline off Butternut Is., near Hustisford & 432240088363900 & Apr. 1991-Aug. 1993 \\
\hline off Sam Point, near Hustisford & 432300088374200 & Apr. 1991-Aug. 1993 \\
\hline Spirit Lake near Keshena & 445400088320100 & Apr.-Aug. 1992 \\
\hline Spooner Lake, Deep Hole, near Spooner & 455034091493300 & June 2002-Aug. 2004 \\
\hline Southeast Site, near Spooner & 454945091483900 & June 2002-Aug. 2004 \\
\hline Stewart Lake at Mt. Horeb & 430117089442701 & May 1992-Sept. 1993 \\
\hline Tichigan Lake near Waterford & 424854088123300 & $\begin{array}{l}\text { Mar. 1994-Aug. 1996, } \\
\text { Apr. 2003-Aug. 2004 }\end{array}$ \\
\hline Tombeau Lake near Powers Lake & 423153088184800 & May 1998-Aug. 2000 \\
\hline Townline Lake near Mercer & 460409090084100 & Apr. 2009-Mar. 2010 \\
\hline Trude Lake, Deep Hole, near Mercer & 460646090091900 & Apr. 2009-Mar. 2010 \\
\hline $\begin{array}{l}\text { Turtle-Flambeau Flowage, Deep Hole, near } \\
\text { Mercer }\end{array}$ & 460458090102700 & Apr. 2009-Mar. 2010 \\
\hline SW Basin, near Mercer & 460344090124800 & Apr. 2009-Mar. 2010 \\
\hline Lake Bastine, Deep Hole, near Mercer & 460511090153800 & Apr. 2009-Mar. 2010 \\
\hline Townline Lake, near Mercer & 460409090084100 & Apr. 2009-Mar. 2010 \\
\hline Trude Lake, Deep Hole, near Mercer & 460646090091900 & Apr. 2009-Mar. 2010 \\
\hline Twin Lake, East Twin, near Westfield & 435430089350700 & June 2002-Aug. 2004 \\
\hline West Twin, near Westfield & 435438089352300 & June 2002-Aug. 2004 \\
\hline
\end{tabular}

In most lakes, water samples were collected at two depths - near the surface and near the bottom. Chemical analyses of water samples were performed using standard analytical methods by either the USGS National Water Quality Laboratory (Wershaw and others, 1987; Fishman and Friedman, 1989; Fishman, 1993) or the Wisconsin State Laboratory of Hygiene (Wisconsin State Laboratory of Hygiene, 1993). Analyses for dissolved constituents were performed on samples that were filtered in the field through a $0.45-\mu \mathrm{m}$ (micrometer) pore-size filter. Total or total recoverable constituents were determined by analyzing unfiltered water samples. Preservation and shipment of samples followed standard protocols established by the 
laboratories. Water-quality data were archived in the Water Quality Data Base (QWDATA) of the National Water Information System (NWIS). Additional descriptive information about waterquality data is available in the data report: "Water Resources Data - Wisconsin, 2011". NWIS parameter codes and minimum laboratory reporting levels for chemical constituents are given in table 2. The parameter code for turbidity has changed from 00076 to 63675 or 63676 because the method of testing has changed.

Records of lake stage are considered complete when one or more manual or automatic measurements were obtained per day. Partial records of lake stage result when measurements were less frequent than daily. A complete description of manual or automatic measurements of lake stage is described by Rantz and others (1982). 
Table 2. Parameter identification numbers and laboratory reporting levels (LRL) for chemical parameters commonly measured in lakes, and analyzed at the National Water Quality Laboratory (NWQL) or the Wisconsin State Laboratory of Hygiene (WSLH).

\begin{tabular}{|c|c|c|c|c|c|c|c|c|c|}
\hline \multirow[b]{4}{*}{ Parameter Name } & \multirow[b]{4}{*}{ Units } & \multirow[b]{4}{*}{$\begin{array}{c}\text { CAS } \\
\text { Number }^{1}\end{array}$} & \multirow[b]{4}{*}{$\begin{array}{l}\text { Parameter } \\
\text { Code }^{2}\end{array}$} & \multicolumn{4}{|c|}{ (NWQL) } & \multicolumn{2}{|c|}{ (WSLH) } \\
\hline & & & & \multirow{2}{*}{\multicolumn{2}{|c|}{$\begin{array}{l}\text { Standard } \\
\text { Analysis }\end{array}$}} & \multirow{2}{*}{\multicolumn{2}{|c|}{$\begin{array}{l}\text { Low-Level } \\
\text { Analysis }\end{array}$}} & \multirow[b]{3}{*}{ LRL } & \multirow[b]{3}{*}{$\begin{array}{l}\text { Test } \\
\text { Code }\end{array}$} \\
\hline & & & & & & & & & \\
\hline & & & & LRL & $\begin{array}{l}\text { Lab } \\
\text { Code }\end{array}$ & LRL & $\begin{array}{l}\text { Lab } \\
\text { Code }\end{array}$ & & \\
\hline Calcium, diss. (Ca) & $\mathrm{mg} / \mathrm{L}$ & $7440-70-2$ & 00915 & 0.020 & 659 & 0.002 & 1895 & 0.02 & I230IUD \\
\hline Magnesium, diss. (Mg) & $\mathrm{mg} / \mathrm{L}$ & $7439-95-4$ & 00925 & 0.004 & 663 & 0.001 & 1897 & 0.02 & I390IUD \\
\hline Sodium, diss. (Na) & $\mathrm{mg} / \mathrm{L}$ & $7440-23-5$ & 00930 & 0.09 & 675 & 0.025 & 1898 & 0.09 & I80IUD \\
\hline Potassium, diss. (K) & $\mathrm{mg} / \mathrm{L}$ & $7440-09-7$ & 00935 & 0.24 & 54 & 0.01 & 833 & 0.3 & I540IUD \\
\hline Sulfate, diss. (SO4) & $\mathrm{mg} / \mathrm{L}$ & $14808-79-8$ & 00945 & 0.31 & 1572 & 0.01 & 1263 & 1.0 & I600DLD \\
\hline Chloride, diss. (Cl) & $\mathrm{mg} / \mathrm{L}$ & $16887-00-6$ & 00940 & 0.29 & 1571 & 0.01 & 1259 & 0.1 & I240ELD \\
\hline Fluoride, diss. (F) & $\mathrm{mg} / \mathrm{L}$ & $16984-48-8$ & 00950 & 0.100 & 31 & 0.01 & 1260 & 0.03 & I330FLD \\
\hline Iron, diss. (Fe) & $(\mu \mathrm{g} / \mathrm{L})$ & $7439-89-6$ & 01046 & 10 & 645 & 3 & 1896 & 10 & I370IUD \\
\hline Manganese, diss. (Mn) & $(\mu \mathrm{g} / \mathrm{L})$ & $7439-96-5$ & 01056 & 2.2 & 648 & 1 & 1793 & 0.4 & I400IUD \\
\hline Silica, diss. (SiO2) & $\mathrm{mg} / \mathrm{L}$ & $7631-86-9$ & 00955 & 0.1 & 56 & 0.02 & 1899 & 0.008 & I560LLD \\
\hline $\begin{array}{l}\text { Nitrogen, } \mathrm{NO} 2+\mathrm{NO} 3 \text {, } \\
\text { diss. }\end{array}$ & $\mathrm{mg} / \mathrm{L}$ & -- & 00631 & 0.05 & 1975 & 0.005 & 1979 & 0.01 & I460MLD \\
\hline $\begin{array}{l}\text { Nitrogen, ammonia, } \\
\text { diss. }\end{array}$ & $\mathrm{mg} / \mathrm{L}$ & 7664-41-7 & 00608 & 0.02 & 1976 & 0.002 & 1980 & 0.013 & I440NLD \\
\hline $\begin{array}{l}\text { Nitrogen, amm.+org., } \\
\text { total }^{4}\end{array}$ & $\mathrm{mg} / \mathrm{L}$ & $17778-88-0$ & 00625 & 0.100 & 1985 & -- & -- & 0.2 & I470BLT \\
\hline $\begin{array}{l}\text { Nitrogen, } \\
\text { amm.+org.,diss. }\end{array}$ & $\mathrm{mg} / \mathrm{L}$ & -- & 00623 & -- & -- & -- & -- & -- & I470DLD \\
\hline Nitrogen, total $^{5}$ & $\mathrm{mg} / \mathrm{L}$ & -- & 00600 & -- & -- & -- & -- & -- & -- \\
\hline Nitrogen, dissolved & $\mathrm{mg} / \mathrm{L}$ & -- & 00602 & -- & -- & -- & -- & -- & -- \\
\hline Phosphorus, total & $\mathrm{mg} / \mathrm{L}$ & 7723-14-0 & 00665 & 0.05 & 1984 & 0.004 & 2333 & 0.005 & I520PLT \\
\hline Phosphorus, ortho, diss. & $\mathrm{mg} / \mathrm{L}$ & $14265-44-2$ & 00671 & 0.01 & 1262 & 0.002 & 1978 & 0.002 & I530CLD \\
\hline $\begin{array}{l}\text { Chlorophyll a, } \\
\text { phytoplankton }\end{array}$ & $(\mu \mathrm{g} / \mathrm{L})$ & $479-61-8$ & 70953 & 0.1 & 586 & -- & -- & -- & -- \\
\hline $\begin{array}{l}\text { Chlorophyll a, } \\
\text { phytoplankton }\end{array}$ & $(\mu \mathrm{g} / \mathrm{L})$ & $479-61-8$ & 32210 & -- & -- & -- & -- & 0.26 & I250UNF \\
\hline
\end{tabular}

1: CAS (Chemical Abstracting Services) number = unique identification for each constituent

2: Parameter Code - unique number for storage of data in database

3: Calculated as difference between total ammonia + organic nitrogen and ammonia nitrogen

4: Also known as Total Kjeldahl Nitrogen (TKN)

5: Calculated as sum of TKN + Nitrogen as $(\mathrm{NO} 2+\mathrm{NO} 3)$ 


\section{EXPLANATION OF PHYSICAL AND CHEMICAL CHARACTERISTICS OF LAKES}

Following are brief, generalized explanations of some of the common measurements of water quality and some of the physical processes occurring in lakes that influence these measures of water quality. More detailed explanations of water-quality data and lake processes are given by Wetzel (1983), Hem (1985), and Shaw and others (1993).

\section{Water Temperature and Thermal Stratification}

Water temperature in lakes is important because of its role in stratification and because of the temperature dependence of many chemical reactions and life processes of aquatic organisms. The extent of thermal stratification in lakes depends on the interaction between the lake's shape, water clarity, solar heating, and wind-driven mixing. Complete mixing of the lake is usually inhibited by thermal stratification in summer and by ice cover in winter. Thermal stratification affects water quality and the distribution of organisms in the lake. Summer thermal stratification can occur in any lake, but in Wisconsin it commonly occurs in lakes deeper than about $6 \mathrm{~m}$ (Shaw and others, 1993).

The density of water increases with decreasing temperature down to a temperature of $4^{\circ} \mathrm{C}$, then decreases with decreasing temperature between $4^{\circ} \mathrm{C}$ and the freezing point of water $\left(0^{\circ} \mathrm{C}\right)$. For a brief period in the spring after the ice is out, water temperature is usually uniform through the entire water column and wind action causes the lake to mix completely. This process is known as "spring turnover." As the lake absorbs the sun's energy, the surface water becomes warmer and its density decreases, making it more resistant to complete mixing. The difference in density caused by different water temperatures can prevent warm and cold water from mixing. In most lakes, therefore, a density "barrier" forms between the warmer surface

water (epilimnion) and the underlying colder water (hypolimnion). This barrier is often marked by a sharp temperature gradient known as the "thermocline (metalimnion)." During the stratified summer period, these three distinct layers of lake water are often present. As the temperature difference between surface and deep water increases, this "stratified" condition stabilizes and can persist until surface temperatures decrease in the fall, which decreases the stability of the stratification. The mixing of the lake water in the fall is known as "fall turnover." 
Thermal stratification may also occur under ice cover in the winter. In the winter, the coldest water (near $0^{\circ} \mathrm{C}$ ) under the ice at the surface of the lake is less dense than water deeper in the lake with warmer temperatures.

\section{Specific Conductance}

Specific conductance is a measure of the ability of water to conduct an electrical current and is an indicator of the concentration of dissolved solids in the water. Because conductance is temperature related, reported values are normalized at $25^{\circ} \mathrm{C}$ and are termed specific conductance. As the concentration of dissolved minerals increases, specific conductance increases. During winter and summer thermal stratification, concentrations of dissolved constituents near the lake bottom increase due to the decomposition of materials settling from the epilimnion, or release of dissolved materials (such as iron, manganese, and phosphorus) from the bottom sediments during anoxic periods. Therefore, differences in specific conductance with depth indicate differences in concentrations of dissolved solids.

\section{$\underline{\text { Water Clarity }}$}

Water clarity, or transparency, is commonly measured using a Secchi disc. The range of depths within which photosynthetic activity occurs depends largely on depth of light penetration, which is influenced by water clarity. A Secchi disc, most commonly a 20-cm.-diameter disc with alternating black-and-white quadrants, is lowered to a depth at which it is no longer visible. This depth is referred to as the Secchi depth. Clarity can be reduced by algae, zooplankton, water color, and suspended sediment. Algae are often the most dominant influence on clarity in lakes and, therefore, Secchi depth is usually correlated with the algal abundance. Secchi depths are generally the least during summer when algal populations are largest.

\section{pH}

The $\mathrm{pH}$ is a measure of the acidity of the water. It is defined as the negative logarithm of hydrogen-ion concentration and varies over a 14-unit log scale, with a pH of 7 being neutral. Values less than 7 indicate acidic conditions; the lower the value, the stronger the acidity. Values greater than 7 indicate alkaline conditions. The $\mathrm{pH}$ of water is influenced in part by photosynthesis and respiration of planktonic algae and aquatic plants. It is important because it affects the solubility of many chemical constituents, and because aquatic organisms have 
limited $\mathrm{pH}$ tolerances. Planktonic algae and aquatic plants produce oxygen and consume carbon dioxide as they photosynthesize during daytime; they consume oxygen and produce carbon dioxide when they respire at night. Carbon dioxide combines with the water molecule to form carbonic acid; therefore respiration causes a decrease in $\mathrm{pH}$ at night and photosynthesis during the day causes an increase in $\mathrm{pH}$. The result is a daily cycle in $\mathrm{pH}$. Because phytoplankton are usually concentrated in the near-surface water, changes in $\mathrm{pH}$ in the epilimnion are more extreme than in the hypolimnion, where less photosynthesis usually occurs.

Lakes having good fish populations and productivity generally have a $\mathrm{pH}$ between 6.7 and 8.2. Values of $\mathrm{pH}$ greater than 8.5 have been shown to cause the release of phosphorus from lake sediments (James and Barko, 1991).

\section{Dissolved Oxygen}

Dissolved oxygen is one of the most critical factors affecting a lake ecosystem because it is essential to most aquatic organisms, and it is involved in many chemical reactions. Very low dissolved oxygen concentrations can control some types of chemical reactions. The solubility of oxygen in water is inversely related to temperature-that is, oxygen solubility decreases as water temperature increases. This relation is important because at warmer temperatures the metabolic rate of organisms increases but less oxygen is available for respiration. The primary sources of dissolved oxygen are from the air and from photosynthesis. The minimum dissolved oxygen concentration specified in national water-quality criteria for early life stages of warmwater aquatic life is 5.0 mg/L (U.S. Environmental Protection Agency, 1986).

In early summer, if thermal stratification develops, the metalimnion restricts the surface supply of dissolved oxygen to the hypolimnion. The hypolimnion can become isolated from the atmosphere. Thus, as summer progresses, the dissolved oxygen concentration can decrease in response to decomposition of dead algae that settle from the epilimnion and in response to the biological and chemical oxygen demand of the sediments. The oxygen demand from these processes may completely deplete the oxygen (anoxia) in the water near the lake bottom. The oxygen depletion then progresses upward but usually is confined to the hypolimnion.

Anoxia in the hypolimnion is common in stratified eutrophic (nutrient-rich) lakes in Wisconsin. Complete anoxia, however, is often not detected because of meter constraints. During anoxic conditions, many aquatic organisms cannot survive, but many other species 
(primarily bacteria) actually function only in such conditions. Therefore, a shift from oxic to anoxic conditions produces a rapid and dramatic change in the biological community and chemical environment. Anoxia also can cause release of phosphorus from the bottom sediments. This phosphorus then mixes throughout the water column during spring and fall turnover.

\section{Phosphorus}

Phosphorus is one of the essential nutrients for plant growth. High phosphorus concentrations can cause dense algal populations (blooms) and can therefore be a major cause of eutrophication in lakes. When phosphorus concentrations exceed $0.025 \mathrm{mg} / \mathrm{L}$ at the time of spring overturn in lakes and reservoirs, these water bodies may occasionally experience excess or nuisance growth of algae or other aquatic plants (U.S. Environmental Protection Agency, 1986). In many regions of the country, including the upper Midwest, other nutrients, particularly nitrogen, tend to be in abundant supply. Phosphorus is often the nutrient in shortest supply, therefore limiting or controlling plant growth. About 90 percent of the lakes in Wisconsin are limited by phosphorus (Shaw and others, 1993). In water, dissolved orthophosphate is that part of total phosphorus that is most readily available for use by algae.

Internal phosphorus recycling occurs in many lakes. Phosphorus used by algae, aquatic plants, fish, and zooplankton is stored within these organisms. As these organisms die and decompose, this phosphorus is returned to the lake water and sediments. Anoxia in the hypolimnion makes phosphorus more soluble, adding further to the release of phosphorus from the falling particles and the lake sediments. During spring and fall turnover the phosphorus, which was released from the bottom sediments into the hypolimnion during anoxia, is mixed throughout the lake. The phosphorus is then available for algal growth. These phenomena are part of the internal-recycling processes of lakes.

\section{Nitrogen}

Nitrogen, like phosphorus, is an essential nutrient for plant and algal growth. Usually in Wisconsin lakes, nitrogen is in abundant supply from the atmosphere and other sources. If phosphorus is abundant relative to algal needs, nitrogen can become the limiting nutrient. In that case, algal blooms are more likely to be triggered by increases in nitrogen than by increases in phosphorus. Some bluegreen algal species can fix nitrogen from the atmosphere 
(Wetzel, 1983). Therefore, in situations where other types of algae are excluded because of a shortage of nitrogen, the nitrogen-fixing bluegreen algae have a competitive advantage and may be present in abundance.

Lakes with a nitrogen to phosphorus ratio larger than 15 to 1 near the surface may generally be considered phosphorus limited; a ratio from 10 to 1 to 15 to 1 indicates a transition situation; and a ratio smaller than 10 to 1 generally indicates nitrogen limitation. Total nitrogen is the sum of ammonia, organic nitrogen, and nitrate-plus-nitrite nitrogen. The near-surface concentration is commonly used to compute the total nitrogen to phosphorus ratio because most algal species grow near the lake surface.

\section{Chlorophyll a}

Chlorophyll $a$ is a photosynthetic pigment found in algae (Wetzel, 1983) and other green plants. Its concentration, therefore, is commonly used as a measure of the density of the algal population in a lake. Chlorophyll a concentrations are generally highest during summer when algal populations are highest. Moderate populations of desirable algae are important in the food chain; however, excessive populations or algal blooms are undesirable. Algal blooms can cause taste and odor problems, and limit light penetration needed to support growth of submerged aquatic plants. Certain species of bluegreen algae can produce toxins (Rapavich and others, 1987).

\section{CLASSIFICATION OF LAKES}

Two methods are commonly used to classify and evaluate Wisconsin lakes according to their water quality or trophic state: Lillie and Mason's (1983) water-quality index and Carlson's (1977) trophic state index (TSI). In previous USGS data reports, a modification of Carlson's trophic state index for Wisconsin lakes by Lillie and others (1993) had been used; however, this approach did not properly classify oligotrophic and highly euthrophic lakes and, therefore, was discontinued. 
Lillie and Mason's (1983) water quality indices for Wisconsin lakes were developed based on summer measurements of total phosphorus and chlorophyll a concentrations, and Secchi depth from a random set of lakes in Wisconsin. These data were used to classify the lakes's water quality as shown below:

\begin{tabular}{lccc}
\hline Water-quality index & $\begin{array}{c}\text { Total phosphorus } \\
\text { range }(\mathrm{mg} / \mathrm{L})\end{array}$ & $\begin{array}{c}\text { Chlorophyll a range } \\
(\mu \mathrm{g} / \mathrm{L})\end{array}$ & $\begin{array}{c}\text { Water clarity range } \\
(\text { Secchi depth, in } \\
\text { meters })\end{array}$ \\
\hline "Excellent" & $<0.001$ & $<1.0$ & $>6.0$ \\
"Very good" & $.001-.009$ & $1.0-4.9$ & $3.0-6.0$ \\
"Good" & $.010-.029$ & $5.0-9.9$ & $2.0-2.9$ \\
"Fair" & $.030-.049$ & $10.0-14.9$ & $1.5-1.9$ \\
"Poor" & $.050-.149$ & $15.0-30.0$ & $1.0-1.4$ \\
"Very poor" & $>.150$ & $>30.0$ & $<1.0$ \\
\hline
\end{tabular}

Carlson's (1977) TSI approach to lake classification assigns numerical ranges to the three trophic conditions generally used to describe the wide range of lake water-quality conditions. Oligotrophic lakes are typically clear, algal populations and phosphorus concentrations are low, and the deepest water is likely to contain oxygen throughout the year. Mesotrophic lakes typically have a moderate supply of nutrients, experience moderate algal blooms, and have occasional oxygen depletions at depth. Eutrophic lakes are nutrient rich with relatively severe water-quality problems, such as frequent seasonal algal blooms, oxygen depletion in lower parts of the lakes, and poor clarity. When eutrophic conditions are very severe, the lake is considered hypereutrophic.

Carlson's (1977) TSI values are also based on near-surface total phosphorus and chlorophyll a concentrations, and Secchi depths. The indices were developed to place these three characteristics on similar scales to allow comparison of different lakes. TSI values based on phosphorus concentrations $\left(\mathrm{TSI}_{\mathrm{P}}\right)$, Secchi depths $\left(\mathrm{TSI}_{\mathrm{SD}}\right)$, and chlorophyll a concentrations $\left(\mathrm{TSI}_{\mathrm{C}}\right)$ typically are computed only for measurements collected during the open-water period.

TSI values for a lake can be calculated using the following equations (Carlson, 1977): 
$\mathrm{TSI}_{\mathrm{P}}=4.15+14.42 \times($ In [total phosphorus concentration $\left.\times 1,000]\right)$

$\mathrm{TSI}_{\mathrm{SD}}=60.0-14.41 \times($ In Secchi depth)

$\mathrm{TSI}_{\mathrm{C}}=30.6+9.81 \times$ (In chlorophyll a concentration)

where: total phosphorus is in milligrams per liter,

Secchi depth is in meters, and

chlorophyll $a$ is in micrograms per liter.

The three main trophic conditions are defined with the following boundaries for total phosphorus, Secchi disc, and chlorophyll a:

\begin{tabular}{|c|c|c|c|c|}
\hline Trophic level & $\begin{array}{c}\text { Trophic State } \\
\text { Index }\end{array}$ & $\begin{array}{c}\text { Total phosphorus } \\
\text { (mg/L) }\end{array}$ & Secchi depth (m) & $\begin{array}{c}\text { Chlorophyll a } \\
(\mu \mathrm{g} / \mathrm{L})\end{array}$ \\
\hline
\end{tabular}

Eutrophic

Mesotrophic

$-50$

0.024-------

$-2.0---------$

$-7.2---------$

$-40----------$

$-0.012$

$-4.0$

$-2.6--------$

Oligotrophic 


\section{REFERENCES CITED}

Carlson, R.E., 1977, A trophic state index for lakes: Limnology and Oceanography, March, v. 22, no. 2, p. 361-369.

Fishman, M.J., ed., 1993, Methods of analysis by the U.S. Geological Survey National Water Quality Laboratory-Determination of inorganic and organic constituents in water and fluvial sediments: U.S. Geological Survey Open-File Report 93-125, 217 p.

Fishman, M.J., and Friedman, L.C., eds., 1989, Methods for determination of inorganic substances in water and fluvial sediments ( $3^{\text {rd }}$ ed.): U.S. Geological Survey Techniques of Water-Resources Investigations, book 5, chap. A1, 545 p.

Hem, J.D., 1985, Study and interpretation of the chemical characteristics of natural water ( $3^{\text {rd }}$ ed.): U.S. Geological Survey Water-Supply Paper 2254, 263 p.

James, W.F., and Barko, J.W., 1991, Littoral-pelagic phosphorus dynamics during nighttime convective circulation: Limnology and Oceanography, v. 36, no. 5, p. 946-960.

Lillie, R.A., Graham, S., and Rasmussen, P., 1993, Trophic-State Index equations and regional predictive equations for Wisconsin lakes: Wisconsin Department of Natural Resources Research Management Findings No. 35, 4 p.

Lillie, R.A., and Mason, J.W., 1983, Limnological characteristics of Wisconsin lakes: Wisconsin Department of Natural Resources Technical Bulletin No. 138, 116 p.

Rantz, S.E., and others, 1982, Measurement and computation of streamflow: U.S. Geological Survey Water-Supply Paper 2175, $631 \mathrm{p}$.

Rapavich, W.M., Sonzogni, W.C., Standridge, J.H., Vennie J.G., and Wedepohl, R.E., 1987, Incidence of algal toxins in Wisconsin water experiencing blue-green algae blooms: Wisconsin State Laboratory of Hygiene and Wisconsin Department of Natural Resources, Informational Paper, 8 p. 
Shaw, B., Mechenich, C., and Klessig, L., 1993, Understanding Lake Data: University of Wisconsin Extension, G3582: Madison, Wis., 19 p.

U.S. Environmental Protection Agency, 1986, Quality Criteria for Water 1986: U.S. Environmental Protection Agency publication, EPA 440/5-86-001 [variously paged].

Wershaw, R.L., Fishman, M.J., Grabbe, R.R., and Lowe, L.E., eds., 1987, Methods for the determination of organic substances in water and fluvial sediments: U.S. Geological Survey Techniques of Water-Resources Investigations, book 5, chap. A3, 80 p.

Wetzel, R.G., 1983, Limnology ( $2^{\text {nd }}$ ed.): New York, W.B. Saunders, 767 p.

Wisconsin Department of Natural Resources, 1992, Wisconsin water quality assessmentReport to Congress, 1992: Wisconsin Department of Natural Resources Publ-WR25492-REV, 220 p.

Wisconsin State Laboratory of Hygiene, Environmental Sciences Section, 1993, Manual of analytical methods, inorganic chemistry unit: Wisconsin State Laboratory of Hygiene, revised November 1993 [variously paged]. 


\section{LAKE DATA}

Remarks codes and symbols used in the following tables:

[<, less than; >, greater than; --, not available; E, estimated] 


\section{LAKE BEULAH AT DEEP HOLE NEAR EAST TROY, WI}

LOCATION.--Lat 42 $48^{\prime} 40^{\prime \prime}$, long $88^{\circ} 24^{\prime} 16^{\prime \prime}$, in SW 1/4 NW 1/4 NW 1/4 sec.17, T.4 N., R.18 E., Walworth County, Hydrologic Unit 07120006, near East Troy. SURFACE AREA.--1.30 $\mathrm{mi}^{2}$.

PERIOD OF RECORD.--August 2007 to August 2011.

REMARKS.--Lake sampled at the deep hole at a depth of $19 \mathrm{~m}$. Water-quality analyses by Wisconsin State Laboratory of Hygiene.

WATER-QUALITY DATA, JUNE 11 TO AUGUST 10, 2011

(Milligrams per liter unless otherwise indicated)

\begin{tabular}{|c|c|c|c|c|c|c|c|c|c|c|c|c|c|}
\hline Date & $\begin{array}{c}\text { Trans- } \\
\text { parency } \\
\text { Secchi } \\
\text { disc, } \\
\text { meters } \\
(\odot \odot \odot 78)\end{array}$ & $\begin{array}{c}\text { Sam- } \\
\text { pling } \\
\text { depth, } \\
\text { meters } \\
(00098)\end{array}$ & $\begin{array}{c}\text { Temper- } \\
\text { ature, } \\
\text { water, } \\
\text { deg C } \\
(00010)\end{array}$ & $\begin{array}{c}\text { Specif- } \\
\text { ic } \\
\text { conduc- } \\
\text { tance, } \\
\text { wat unf } \\
\text { us/cm @ } \\
25 \text { degc } \\
(0 \odot \odot 95)\end{array}$ & $\begin{array}{c}\text { pH, } \\
\text { water, } \\
\text { unfltrd } \\
\text { field, } \\
\text { std } \\
\text { units } \\
(00400)\end{array}$ & $\begin{array}{c}\text { Dis- } \\
\text { solved } \\
\text { oxygen, } \\
\text { mg/L } \\
(00300)\end{array}$ & $\begin{array}{c}\text { Chloro- } \\
\text { phyll a } \\
\text { trichro } \\
\text {-matic } \\
\text { method, } \\
\text { uncorr, } \\
\text { ug/L } \\
(32210)\end{array}$ & $\begin{array}{c}\text { Phos- } \\
\text { phorus, } \\
\text { water, } \\
\text { unfltrd } \\
\mathrm{mg} / \mathrm{L} \\
\text { as } \mathrm{P} \\
(00665)\end{array}$ & $\begin{array}{l}\text { Ortho- } \\
\text { phos- } \\
\text { phate, } \\
\text { water, } \\
\text { fltrd, } \\
\text { mg/L } \\
\text { as P } \\
(00671)\end{array}$ & $\begin{array}{c}\text { Total } \\
\text { nitro- } \\
\text { gen, } \\
\text { water, } \\
\text { unfltrd } \\
\text { mg/L } \\
(00600)\end{array}$ & $\begin{array}{c}\text { Ammonia } \\
\text { water, } \\
\text { fltrd, } \\
\mathrm{mg} / \mathrm{L} \\
\text { as N } \\
(0 \circ 608)\end{array}$ & $\begin{array}{c}\text { Ammonia } \\
+ \\
\text { org-N, } \\
\text { water, } \\
\text { unfltrd } \\
\text { mg/L } \\
\text { as N } \\
(00625)\end{array}$ & $\begin{array}{c}\text { Nitrate } \\
+ \\
\text { nitrite } \\
\text { water, } \\
\text { fltrd, } \\
\text { mg/L } \\
\text { as N } \\
(00631)\end{array}$ \\
\hline \multicolumn{14}{|l|}{ JUN 2011} \\
\hline $21 \ldots$ & - - & .50 & 23.7 & 507 & 8.4 & 9.8 & 3.50 & $<.005$ & $<.0 \odot 2$ & 1.1 & .022 & .52 & .541 \\
\hline \multicolumn{11}{|l|}{ AUG } & & & \\
\hline $10 \ldots$ & - & 2.0 & 26.7 & 497 & 8.4 & 8.0 & 4.45 & .014 & $<.002$ & .63 & .032 & .56 & .067 \\
\hline $10 \ldots$ & - - & 8.0 & 15.3 & 574 & 7.8 & 1.4 & - - & .022 & $<.0 \odot 2$ & 1.3 & .180 & .58 & .686 \\
\hline $10 \ldots$ & -- & 14.0 & 8.9 & 589 & 7.6 & .1 & - - & .018 & $<.002$ & 1.4 & .046 & .33 & 1.08 \\
\hline $10 \ldots$ & -- & 17.0 & 8.0 & 599 & 7.6 & .0 & -- & .023 & $<.002$ & .98 & .551 & .91 & .069 \\
\hline $10 \ldots$ & - - & 18.0 & 7.8 & 600 & 7.5 & .0 & - - & .034 & .004 & 1.8 & 1.17 & 1.7 & .023 \\
\hline
\end{tabular}


424840088241600 LAKE BEULAH AT DEEP HOLE NEAR EAST TROY, WI

WATER-QUALITY DATA, JUNE 11 TO AUGUST 10, 2011

(Milligrams per liter unless otherwise indicated)

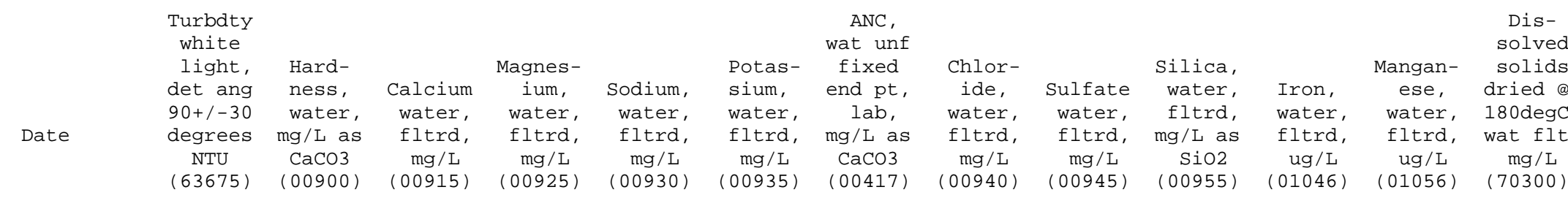

JUN 2011

$21 \ldots$
$21 \ldots$
AUG
$10 \ldots$
$10 \ldots$
$10 \ldots$
$10 \ldots$
$10 \ldots$
$10 \ldots$

$\begin{array}{rr}<1.0 & 258 \\ -- & -- \\ -- & -- \\ <1.0 & 245 \\ <1.0 & 303 \\ <1.0 & 311 \\ <1.0 & 310 \\ <1 . \odot & 308\end{array}$

45.6
--
--
37.4
59.9
64.3
64.0
64.4

34.9
--
.-
36.7
37.2
36.5
36.5
35.8
10.1
10.4

24.

31.0

6.89

$<100$

$<1$.

298

10.4

$1 .-$

1.50

- -

10.5

1.80
1.80

1.80
1.70

235

10.2

1.70
1.80

248
255

262

--
24.7
23.6
23.8
23.7
24.5

29.3

29.3

30.0

30.0
29.8

29.8
23.2

12.7

12.7

11.8
16.8
19.8

23.3

$<100$

$<100$

$<100$

$<100$
$<100$

-
3
3
50
330
680

--
270

320

344

342 
424840088241600 LAKE BEULAH AT DEEP HOLE NEAR EAST TROY, WI

LAKE-DEPTH PROFILES, JUNE 11 TO AUGUST 10, 2011

06-21-11

08-10-11

DISSOLVED OXYGEN (D.O.), IN MILLIGRAMS PER LITER

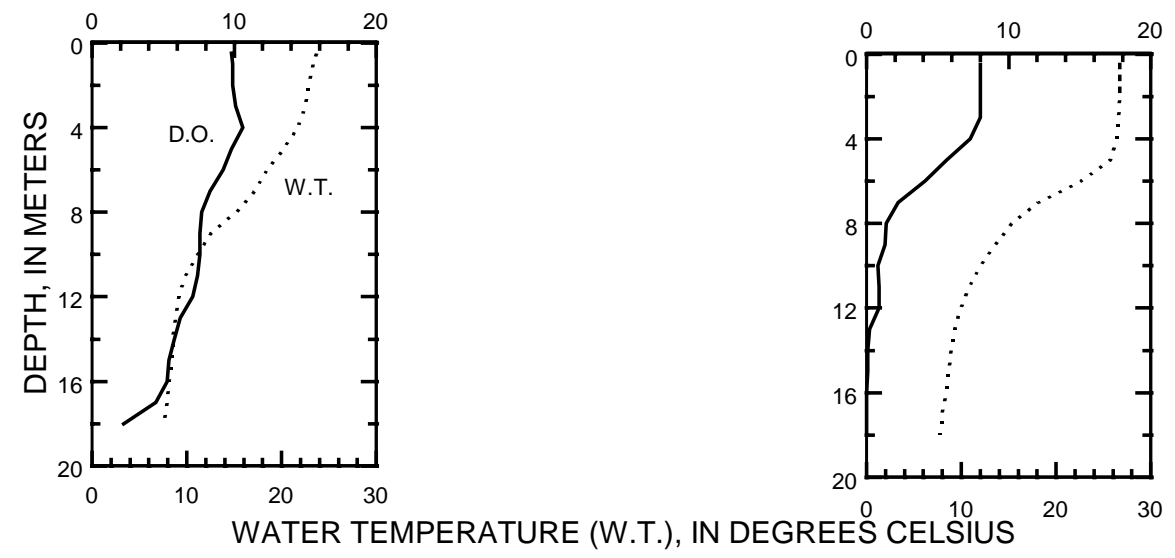

PH, IN STANDARD UNITS
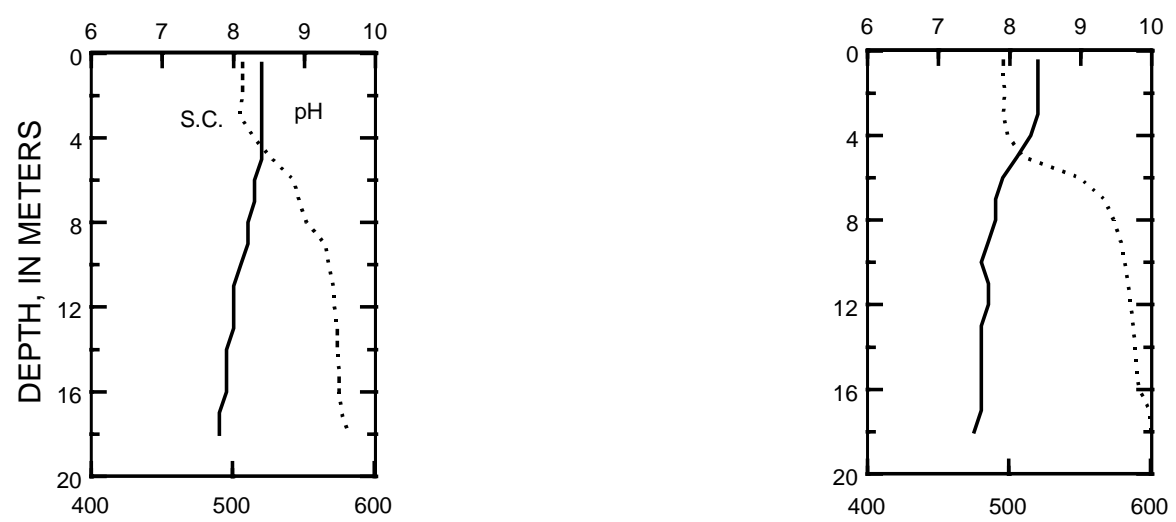

SPECIFIC CONDUCTANCE (S.C.), IN MICROSIEMENS PER CENTIMETER AT 25 DEGREES CELSIUS 

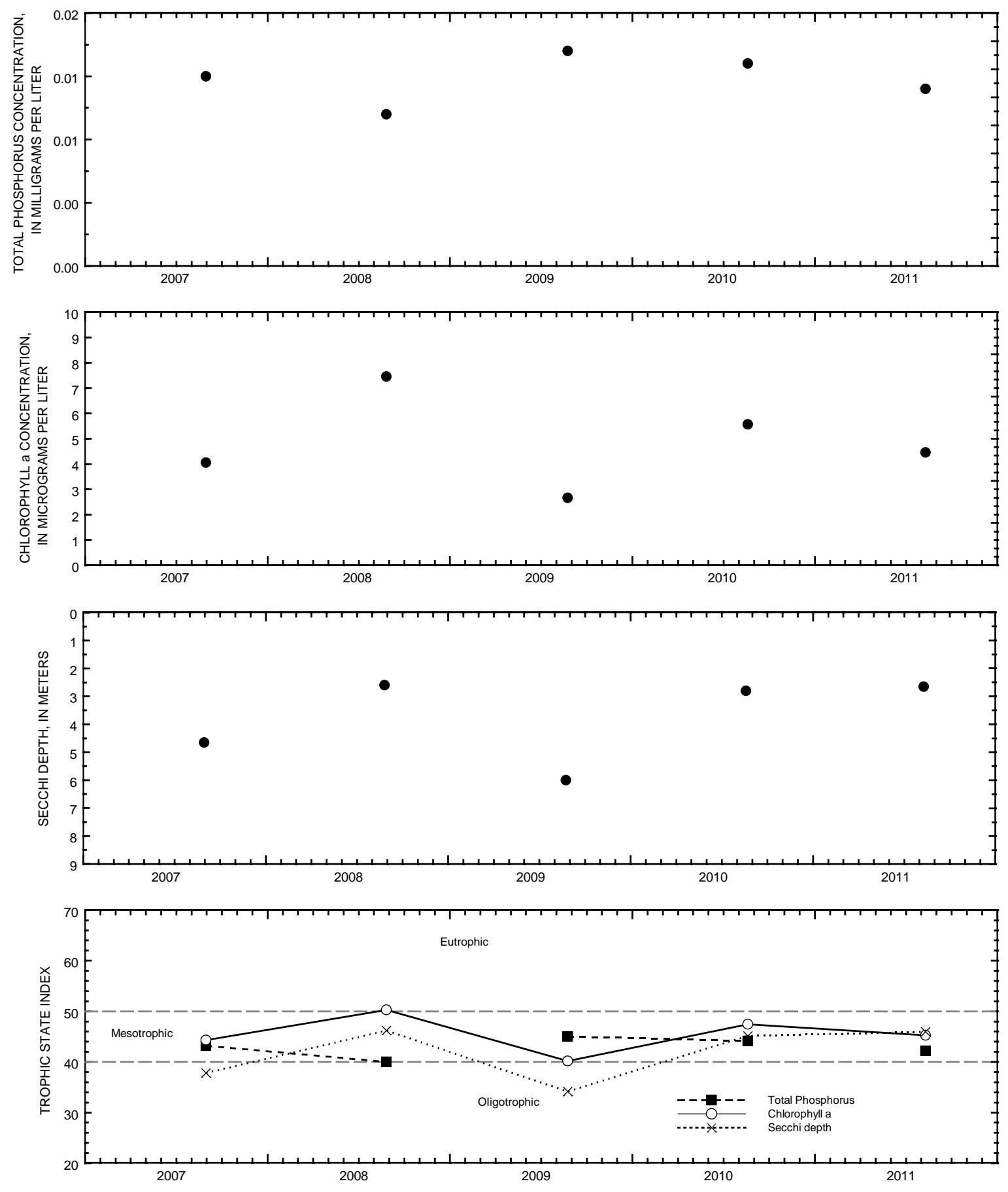

August surface total phosphorus, chlorophyll a concentrations, Secchi depths, and TSI data for Lake Beulah, Deep Hole, near East Troy, Wisconsin. 


\section{LAKE BEULAH STATION 2 NEAR EAST TROY, W}

LOCATION.--Lat 4249'29", long 88²3'13", in SE 1/4 NE 1/4 NE 1/4 sec.8, T.4 N., R.18 E., Walworth County, Hydrologic Unit 07120006, near East Troy. SURFACE AREA.--1.30 $\mathrm{mi}^{2}$.

PERIOD OF RECORD.--August 2007 to August 2011.

REMARKS.--Lake sampled at a depth of $15 \mathrm{~m}$. Water-quality analyses by Wisconsin State Laboratory of Hygiene.

WATER-QUALITY DATA, JUNE 11 TO AUGUST 10, 2011

(Milligrams per liter unless otherwise indicated)

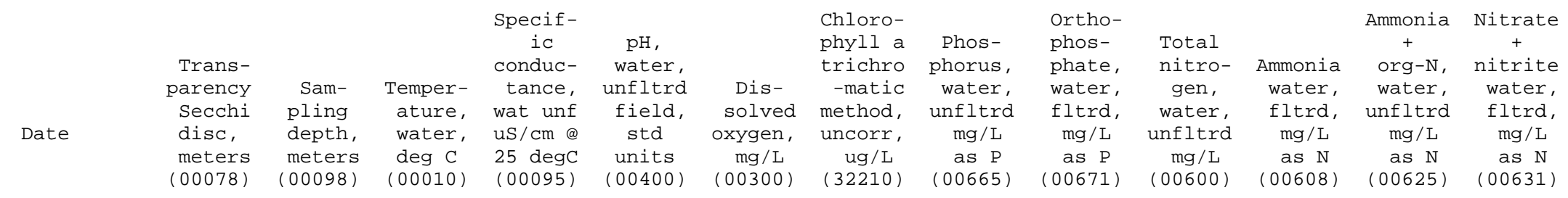

\begin{tabular}{|c|c|c|c|c|c|c|c|c|c|c|c|c|c|}
\hline \multicolumn{14}{|l|}{ JUN 2011} \\
\hline $21 \ldots$ & 3.40 & - - & - - & - - & - - & - - & - - & - - & - - & - - & -- & - - & - - \\
\hline $21 \ldots$ & - - & .50 & 24.1 & 454 & 8.7 & 10.1 & 5.81 & .017 & $<.0 \odot 2$ & .65 & .020 & .61 & .035 \\
\hline \multicolumn{14}{|l|}{ AUG } \\
\hline $10 \ldots$ & 2.55 & - - & - - & - - & - - & - - & - - & - - & -- & - - & - - & - - & - - \\
\hline $10 \ldots$ & - - & 2.0 & 27.1 & 442 & 8.7 & 8.4 & 5.13 & .016 & $<.002$ & $<.69$ & $<.015$ & .67 & $<.019$ \\
\hline $10 \ldots$ & - - & 8.0 & 14.2 & 515 & 7.8 & 1.5 & - & .015 & - & - - & - - & - & - \\
\hline $10 \ldots$ & - - & 12.0 & 8.3 & 536 & 7.7 & .1 & - - & .024 & - - & - - & - - & - - & - - \\
\hline $10 \ldots$ & - - & 14.0 & 7.6 & 546 & 7.6 & .0 & - - & .038 & - - & -- & - - & -- & - - \\
\hline $10 \ldots$ & - - & 15.0 & 7.0 & 557 & 7.5 & .0 & - - & - - & $<.002$ & $<2.4$ & 1.14 & 2.4 & $<.019$ \\
\hline
\end{tabular}


424929088231300 LAKE BEULAH STATION 2 NEAR EAST TROY, WI

WATER-QUALITY DATA, JUNE 11 TO AUGUST 10, 2011

(Milligrams per liter unless otherwise indicated)

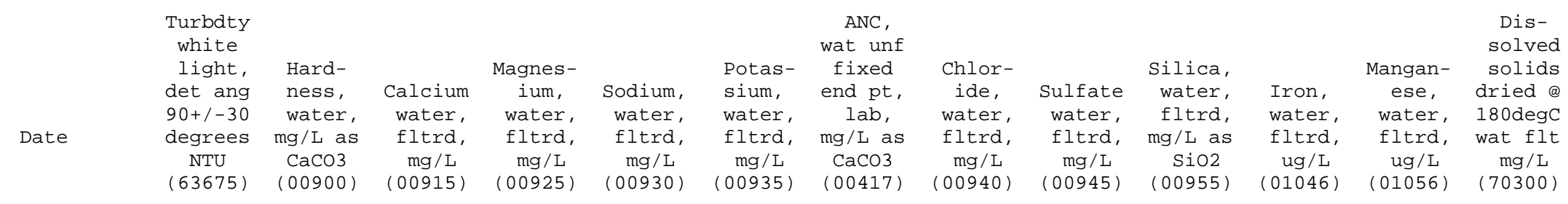

JUN 2011

$21 \ldots$
$21 \ldots$
AUG
$10 \ldots$
$10 \ldots$
$10 \ldots$
$10 \ldots$
$10 \ldots$
$10 \ldots$

$\begin{array}{rrrr}-- & -- & -- & -- \\ <1.0 & 214 & 33.1 & 32.0 \\ -- & -- & -- & -- \\ <1.0 & 217 & 27.7 & 36.0 \\ -- & -- & -- & -- \\ -- & -- & -- & -- \\ -- & -- & -- & -- \\ <1.0 & 261 & 49.4 & 33.5\end{array}$

--
10.9
--
11.7
--
--
--
11.1

--
181
--
164
--
--
--
233

$26 . \overline{2}$

28.1

$8 . \overline{5}$

$<100$

$<1.0$

260

$0 .$.

$0 .$.

$10 .$.

33.5

$-$

26

- -

$<100$

- -

$-$

- -

14. 1

- -

$1.70 \quad 233$

28.9

21.1

19.1

$<100$

290

318 
424929088231300 LAKE BEULAH STATION 2 NEAR EAST TROY, WI

LAKE-DEPTH PROFILES, JUNE 11 TO AUGUST 10, 2011

06-11-11

08-10-11

DISSOLVED OXYGEN (D.O.), IN MILLIGRAMS PER LITER

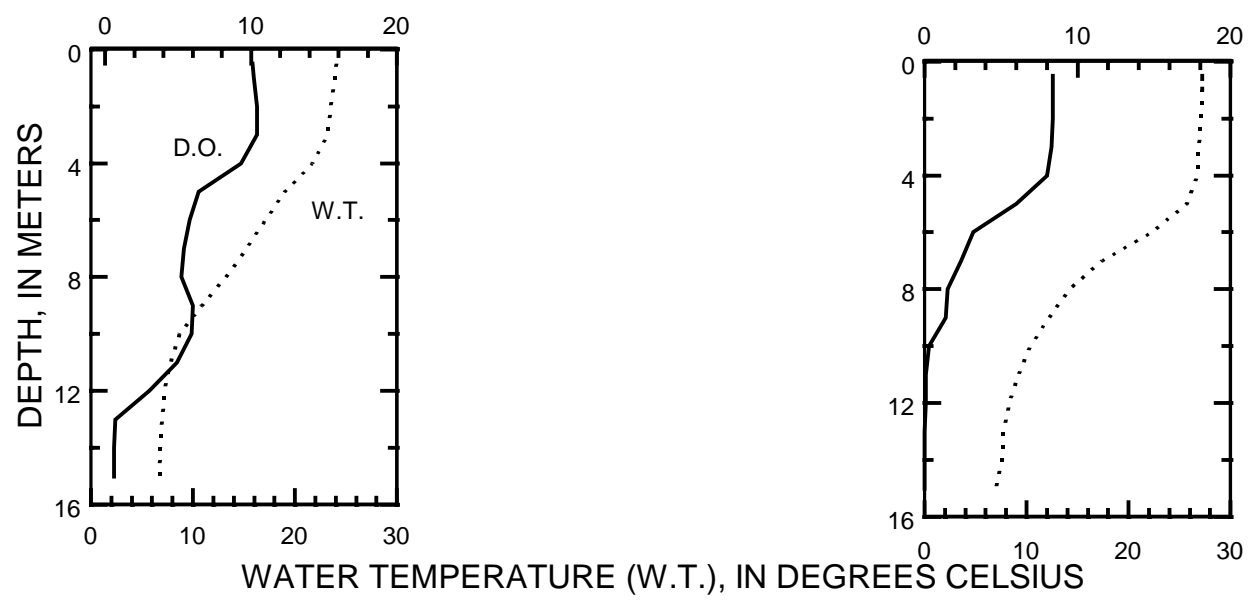

$\mathrm{PH}$, IN STANDARD UNITS
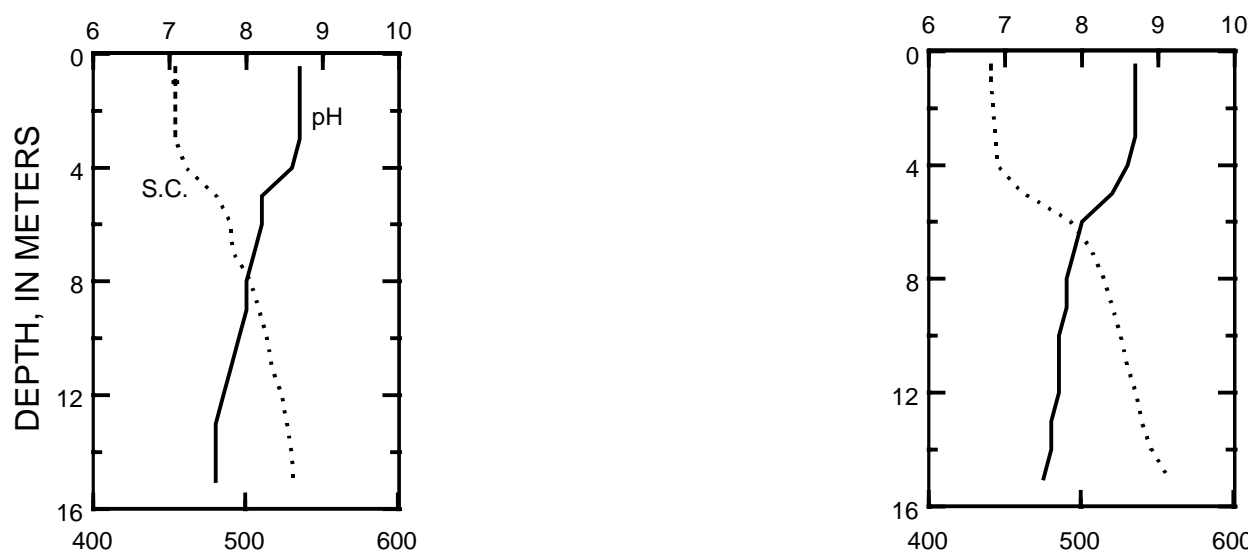

SPECIFIC CONDUCTANCE (S.C.), IN MICROSIEMENS PER CENTIMETER AT 25 DEGREES CELSIUS 

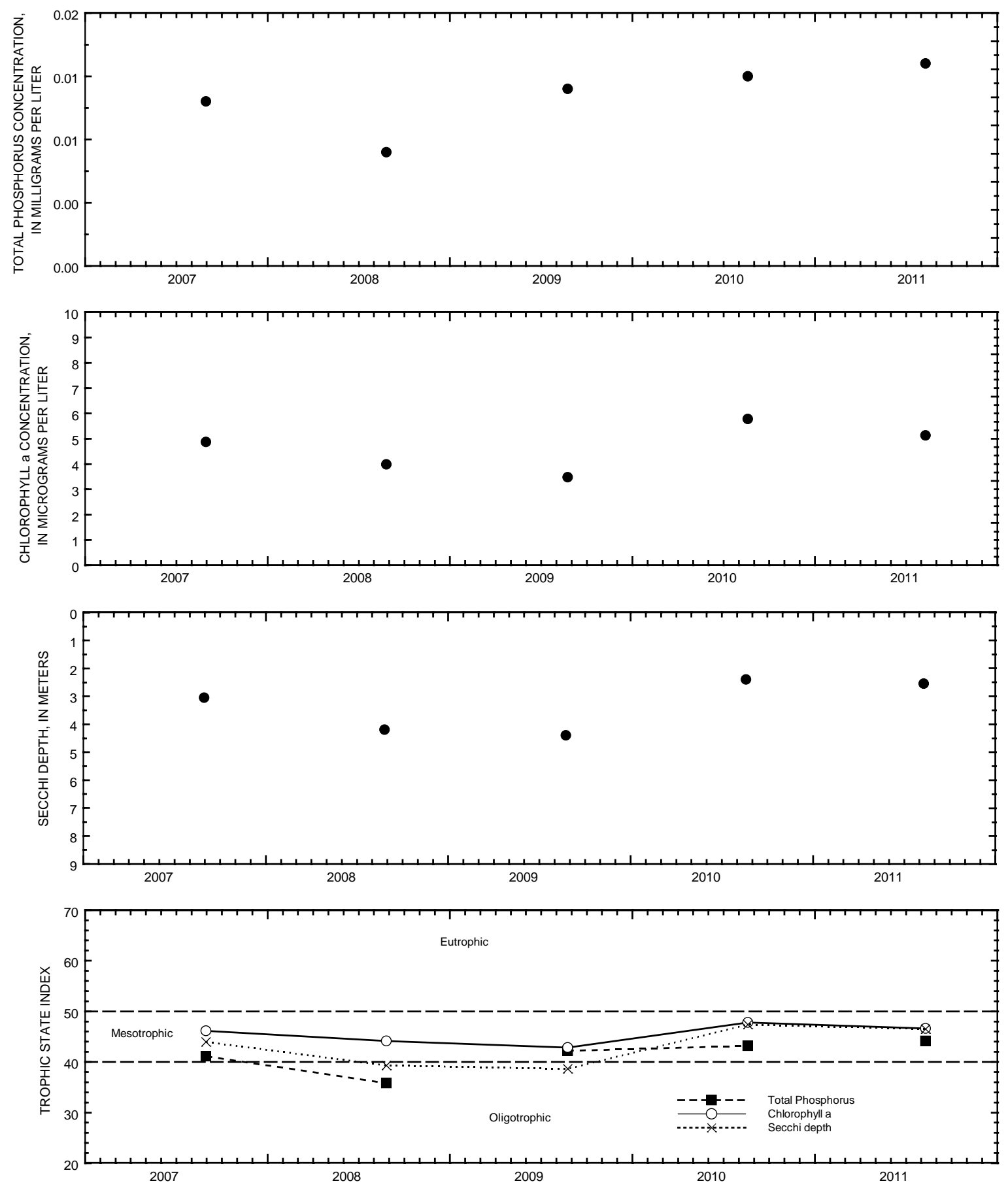

August surface total phosphorus, chlorophyll a concentrations, Secchi depths, and TSI data for Lake Beulah, Station 2, near East Troy, Wisconsin. 


\section{BIG CEDAR LAKE, NORTH SITE, NEAR WEST BEND, WI}

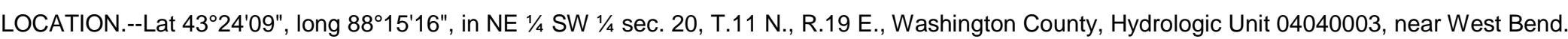
SURFACE AREA.--1.46 $\mathrm{mi}^{2}$.

PERIOD OF RECORD.--February 2000 to current year.

REMARKS.--Lake sampled on north side at a depth of $12 \mathrm{~m}$. Lake ice-covered during February sampling. Water-quality analyses by Wisconsin State Laboratory of Hygiene.

\section{WATER-QUALITY DATA, MARCH 9 TO AUGUST 26, 2011}

(Milligrams per liter unless otherwise indicated)

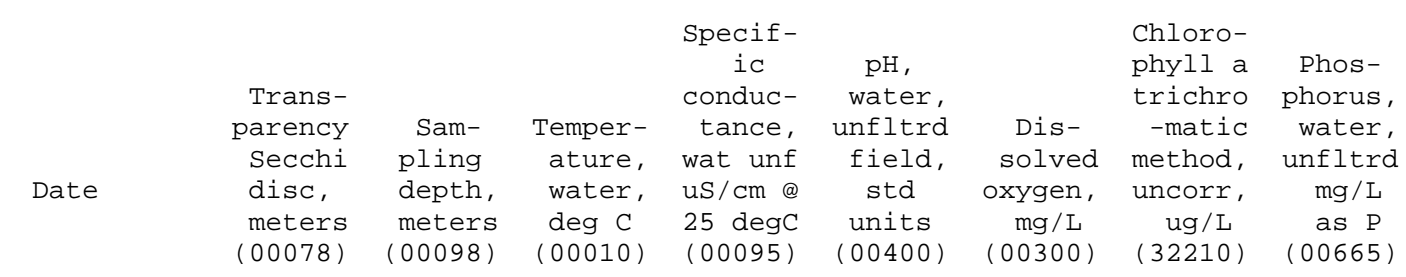

MAR 2011

\begin{tabular}{|c|c|c|c|c|c|c|c|c|}
\hline $09 \ldots$ & - - & .50 & 1.9 & 561 & 6.7 & 10.5 & - - & .014 \\
\hline $09 \ldots$ & - - & 10.5 & 3.7 & 779 & 6.5 & .8 & - - & .031 \\
\hline \multicolumn{9}{|l|}{ APR } \\
\hline $29 \ldots$ & 4.75 & - - & - - & - - & - - & - - & - - & - - \\
\hline $29 \ldots$ & - - & .50 & 8.5 & 539 & 7.6 & 10.8 & 1.47 & .010 \\
\hline \multicolumn{9}{|l|}{ JUN } \\
\hline $30 \ldots$ & 2.15 & - - & - - & - - & - - & - - & - - & - - \\
\hline $30 \ldots$ & - - & .50 & 23.3 & 545 & 8.8 & 10.4 & 5.44 & .015 \\
\hline $30 \ldots$ & - - & 11.0 & 13.6 & 568 & 7.7 & .2 & - - & .031 \\
\hline \multicolumn{9}{|l|}{ JUL } \\
\hline $29 \ldots$ & - - & .50 & 27.3 & 507 & 8.6 & 8.4 & 8.31 & .019 \\
\hline $29 \ldots$ & - - & 11.0 & 15.0 & 561 & 7.6 & .1 & - - & .034 \\
\hline $29 \ldots$ & 2.00 & - - & - - & - - & - - & - - & - - & -- \\
\hline \multicolumn{9}{|l|}{ AUG } \\
\hline $26 \ldots$ & - - & .50 & 24.3 & 519 & 8.6 & 9.0 & 6.12 & .020 \\
\hline $26 \ldots$ & - - & 11.0 & 14.7 & 603 & 7.4 & .1 & - - & .047 \\
\hline $26 \ldots$ & 1.95 & - - & - - & - - & - - & -- & - - & - \\
\hline
\end{tabular}


432409088151600 BIG CEDAR LAKE, NORTH SITE, NEAR WEST BEND, WI

LAKE-DEPTH PROFILES, MARCH 9 TO AUGUST 26, 2011

03-09-11

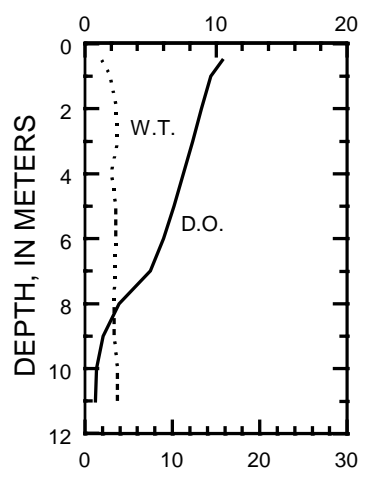

04-29-11

DISSOLVED OXYGEN (D.O.), IN MILLIGRAMS PER LITER

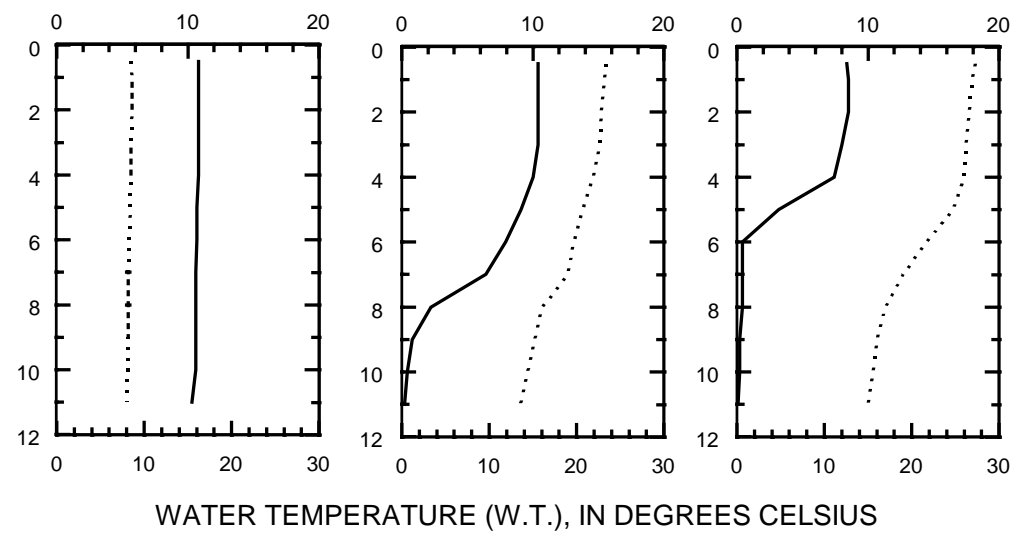

WATER TEMPERATURE (W.T.), IN DEGREES CELSIUS

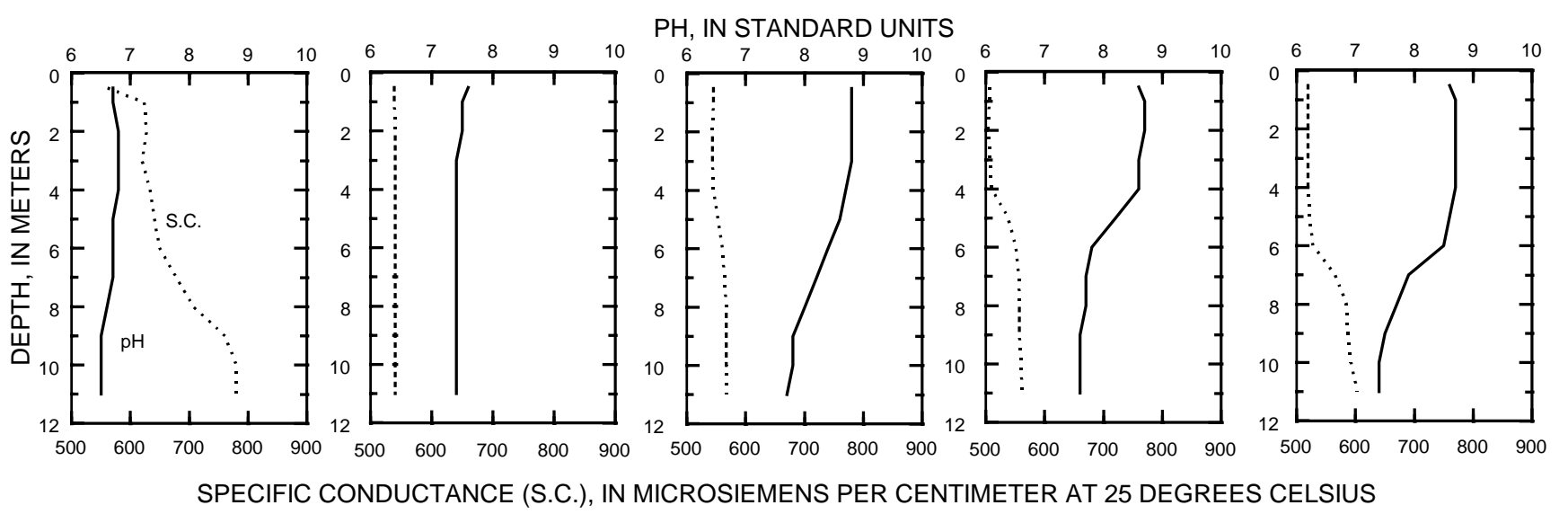

08-26-11

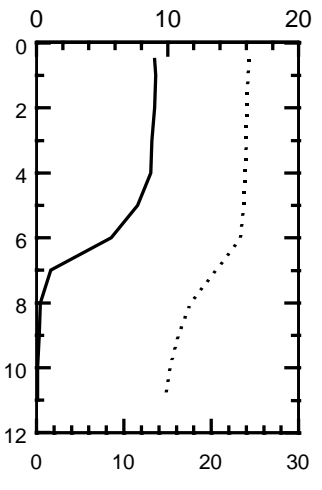



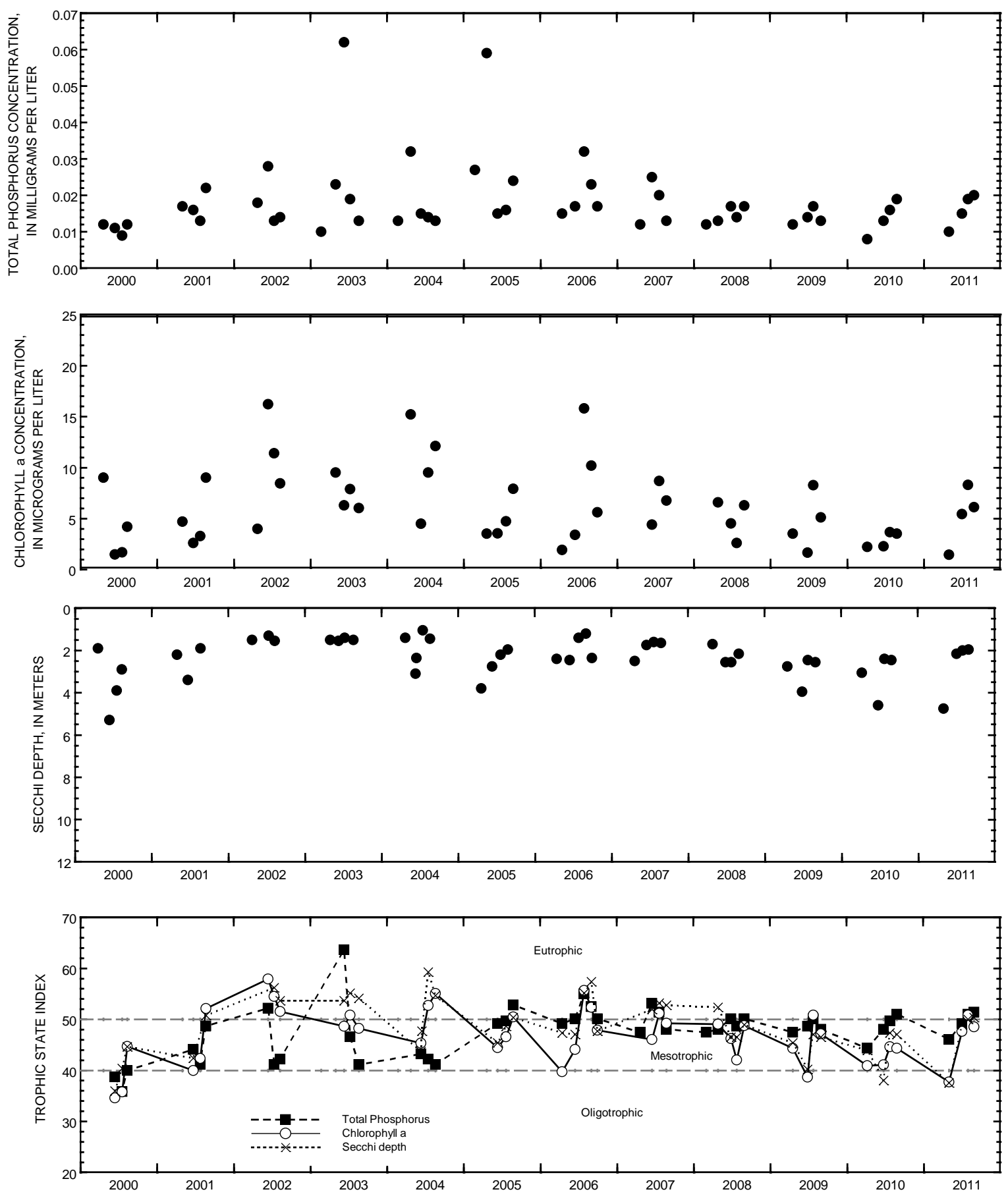

Surface total phosphorus, chlorophyll a concentrations, Secchi depths, and TSI data for Big Cedar Lake, North Site, near West Bend, Wisconsin. 
432224088154900 BIG CEDAR LAKE, SOUTH SITE, NEAR WEST BEND, WI

LOCATION.--Lat 43²2'24", long 88¹5'49", in NE 1/4 SE 1/4 sec.31, T.11 N., R.19 E., Washington County, Hydrologic Unit 04040003, near West Bend.

SURFACE AREA.--1.46 $\mathrm{mi}^{2}$.

PERIOD OF RECORD.--February 2000 to current year.

REMARKS.--Lake sampled on south side at deep hole. Lake ice-covered during February sampling. Water-quality analyses by Wisconsin State Laboratory of Hygiene.

WATER-QUALITY DATA, MARCH 9 TO AUGUST 26, 2011

(Milligrams per liter unless otherwise indicated)

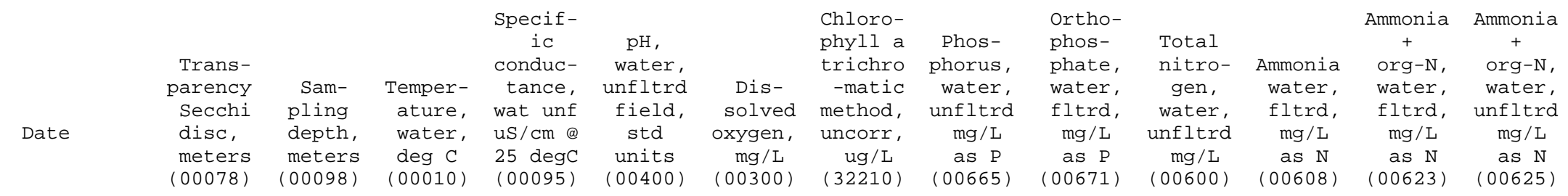

MAR 2011

\begin{tabular}{|c|c|c|c|c|c|c|c|c|c|c|c|c|c|}
\hline R 2011 & & & & & & & & & & & & & \\
\hline $09 \ldots$ & -- & .50 & .9 & 544 & 6.8 & 11.2 & - - & .011 & - - & - - & - - & - - & - - \\
\hline $09 \ldots$ & - - & 30.0 & 3.8 & 644 & 6.5 & .7 & - - & .127 & - - & - - & - - & -- & - - \\
\hline APR & & & & & & & & & & & & & \\
\hline $29 \ldots$ & 9.85 & - - & - - & - - & - - & - - & - - & - - & - - & - - & - - & - - & - - \\
\hline $29 \ldots$ & - - & .50 & 6.5 & 546 & 6.9 & 11.4 & .680 & .011 & .002 & .70 & .024 & - - & .29 \\
\hline JUN & & & & & & & & & & & & & \\
\hline $30 \ldots$ & 4.05 & - - & - - & - - & - - & - - & - - & - - & - - & - - & - - & - - & - - \\
\hline $30 \ldots$ & - - & .50 & 22.5 & 542 & 8.8 & 10.1 & 2.72 & .013 & - - & - - & - - & - - & - - \\
\hline $30 \ldots$ & - - & 30.0 & 6.0 & 566 & 7.8 & 2.1 & - - & .042 & - - & - - & - - & - - & - - \\
\hline JUL & & & & & & & & & & & & & \\
\hline $29 \ldots$ & - - & .50 & 27.1 & 498 & 8.7 & 9.6 & 5.11 & .011 & $<.0 \odot 2$ & .59 & - - & .54 & .56 \\
\hline $29 \ldots$ & - - & 30.0 & 6.1 & 565 & 7.5 & .1 & - - & .018 & - - & - - & - - & - - & - - \\
\hline $29 \ldots$ & 2.50 & - - & - - & - - & - - & - - & - - & - - & - - & - - & - - & - - & - - \\
\hline AUG & & & & & & & & & & & & & \\
\hline $26 \ldots$ & - - & .50 & 24.2 & 512 & 8.5 & 9.3 & 4.85 & .013 & - - & - - & - - & - - & - - \\
\hline $26 \ldots$ & - - & 30.0 & 6.1 & 593 & 7.3 & .2 & - - & .021 & - - & -- & - - & - - & - - \\
\hline $26 \ldots$ & 2.95 & - - & - - & - - & - - & - - & - - & - - & - - & - - & - - & - - & - - \\
\hline
\end{tabular}


432224088154900 BIG CEDAR LAKE, SOUTH SITE, NEAR WEST BEND, WI

WATER-QUALITY DATA, MARCH 9 TO AUGUST 26, 2011

(Milligrams per liter unless otherwise indicated)

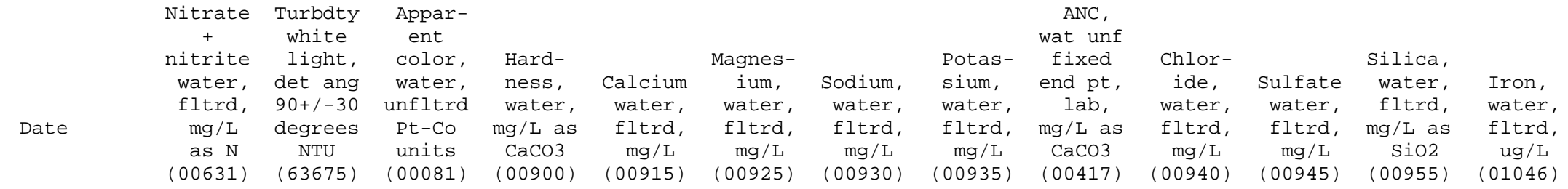

\begin{tabular}{|c|c|c|}
\hline MAR 2011 & & \\
\hline $09 \ldots$ & - - & - - \\
\hline $09 \ldots$ & - - & - - \\
\hline APR & & \\
\hline $29 \ldots$ & - - & -- \\
\hline $29 \ldots$ & .414 & $<1.0$ \\
\hline JUN & & \\
\hline $30 \ldots$ & - - & - - \\
\hline $30 \ldots$ & - - & - \\
\hline $30 \ldots$ & - - & -- \\
\hline JUL & & \\
\hline 29. & .025 & - \\
\hline $29 \ldots$ & - - & - \\
\hline $29 \ldots$ & -- & -- \\
\hline AUG & & \\
\hline $26 \ldots$ & - - & - - \\
\hline $26 \ldots$ & - - & -- \\
\hline $26 \ldots$ & -- & -- \\
\hline & & $\begin{array}{l}\text { Dis- } \\
\text { solved }\end{array}$ \\
\hline & $\begin{array}{c}\text { Mangan- } \\
\text { ese, }\end{array}$ & $\begin{array}{l}\text { solids } \\
\text { dried @ }\end{array}$ \\
\hline Date & $\begin{array}{l}\text { water, } \\
\text { fltrd, }\end{array}$ & $\begin{array}{l}\text { 180degc } \\
\text { wat flt }\end{array}$ \\
\hline & $\begin{array}{c}u g / L \\
(01056)\end{array}$ & $\begin{array}{c}\mathrm{mg} / \mathrm{L} \\
(7030 \odot)\end{array}$ \\
\hline
\end{tabular}

\begin{tabular}{|c|c|c|}
\hline MAR 2011 & & \\
\hline$\odot 9 \ldots$ & - - & - - \\
\hline$\odot 9 \ldots$ & - - & - - \\
\hline APR & & \\
\hline $29 \ldots$ & - - & - - \\
\hline $29 \ldots$ & $<1.0$ & 304 \\
\hline JUN & & \\
\hline $30 \ldots$ & - - & - - \\
\hline JUL & & \\
\hline 29. & -- & -- \\
\hline AUG & & \\
\hline $26 \ldots$ & - - & - \\
\hline
\end{tabular}




\section{BIG CEDAR LAKE, SOUTH SITE, NEAR WEST BEND, W}

LAKE-DEPTH PROFILES, MARCH 9 TO AUGUST 26, 2011

03-09-11
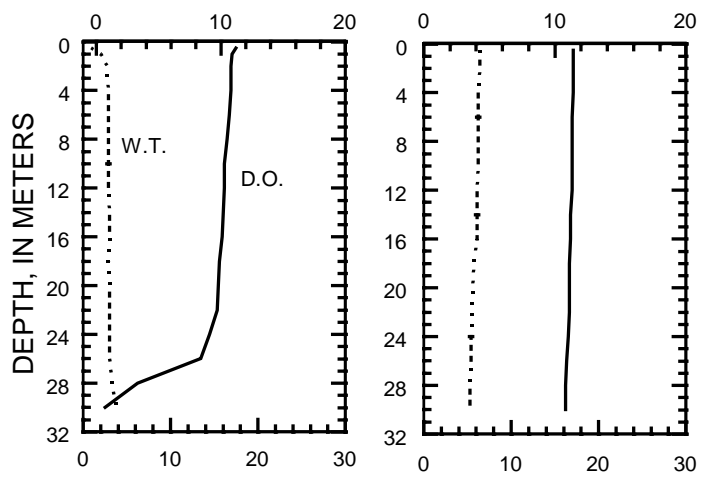

06-30-11

07-29-11

08-26-11

WATER TEMPERATURE (W.T.), IN DEGREES CELSIUS

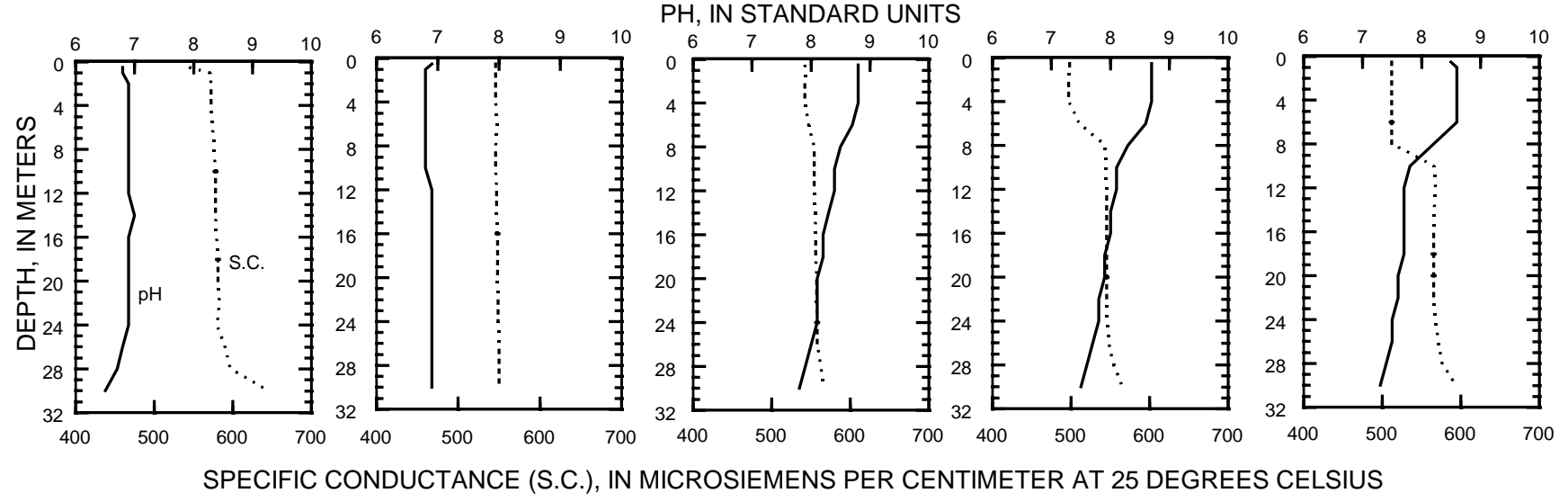



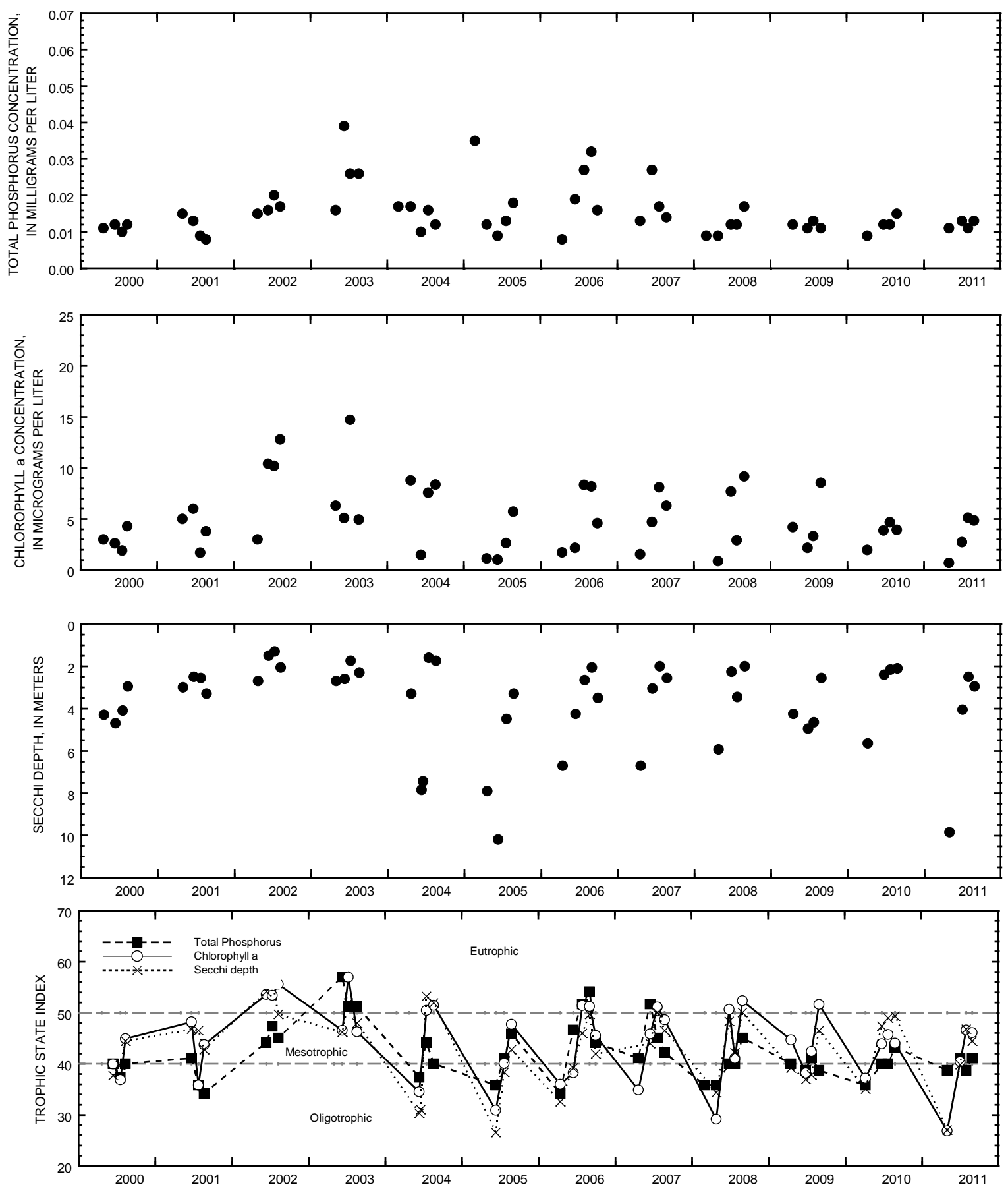

Surface total phosphorus, chlorophyll a concentrations, Secchi depths, and TSI data for Big Cedar Lake, South Site, near West Bend, Wisconsin. 
LOCATION.--Lat 43²5'35", long 8943'40" referenced to North American Datum of 1927, in SW 1/4 SE 1/4 sec.13, T.11 N., R.6 E., Sauk County, WI, Hydrologic Unit 07070004, in Devils Lake State Park, 3.5 mi south of Baraboo.

SURFACE AREA.--0.56 $\mathrm{mi}^{2}$.

DRAINAGE AREA.--4.79 $\mathrm{mi}^{2}$.

PERIOD OF RECORD.--June 1922 to August 1930, June to August 1932, June 1934 to September 1981 (fragmentary). October 1981 to September 1984, data unpublished in district files. October 1984 to current year.

REVISED RECORDS.--WDR WI-78-1: Drainage area.

GAGE.--Water-stage recorder installed July 17, 1991. Datum of gage is $954.88 \mathrm{ft}$, above NAVD of 1988.

REMARKS.--Lake has no surface outlet. Water removed from lake by bottom withdrawal pipe, October 1 to November 15, April 4 to June 28 and September 6-30.

EXTREMES FOR PERIOD OF RECORD.--Maximum observed, 14.83 ft, June 12, 2008; minimum observed, 1.49 ft, Feb. 8, 1965.

EXTREMES FOR CURRENT YEAR.--Maximum observed, 10.02 ft, May 1; minimum observed, 7.17 ft, Dec. 7-11.

\section{WATER YEAR OCTOBER 2010 TO SEPTEMBER 2011 \\ DAILY MEAN VALUES}

\begin{tabular}{|c|c|c|c|c|c|c|c|c|c|c|c|c|}
\hline Day & Oct & Nov & Dec & Jan & Feb & Mar & Apr & May & Jun & Jul & Aug & Sep \\
\hline 1 & 8.57 & 7.60 & 7.21 & 7.30 & 7.46 & 7.75 & 9.15 & 9.90 & 9.68 & 8.87 & 8.43 & 7.95 \\
\hline 2 & 8.52 & 7.57 & 7.20 & 7.31 & 7.50 & 7.76 & 9.16 & 9.88 & 9.64 & 8.85 & 8.42 & 7.94 \\
\hline 3 & 8.47 & 7.54 & 7.19 & 7.31 & 7.51 & 7.76 & 9.19 & 9.87 & 9.60 & 8.82 & 8.39 & 8.01 \\
\hline 4 & 8.43 & 7.51 & 7.21 & 7.31 & 7.50 & 7.78 & 9.33 & 9.85 & 9.56 & 8.80 & 8.37 & 8.01 \\
\hline 5 & 8.39 & 7.47 & 7.21 & 7.32 & 7.50 & 7.80 & 9.36 & 9.84 & 9.52 & 8.79 & 8.35 & 7.98 \\
\hline 6 & 8.35 & 7.45 & 7.20 & 7.32 & 7.50 & 7.80 & 9.38 & 9.81 & 9.52 & 8.82 & 8.33 & 7.95 \\
\hline 7 & 8.31 & 7.42 & 7.19 & 7.32 & 7.51 & 7.81 & 9.40 & 9.79 & 9.51 & 8.79 & 8.30 & 7.90 \\
\hline 8 & 8.27 & 7.39 & 7.18 & 7.33 & 7.51 & 7.81 & 9.40 & 9.77 & 9.46 & 8.76 & 8.28 & 7.87 \\
\hline 9 & 8.23 & 7.37 & 7.18 & 7.33 & 7.51 & 7.85 & 9.41 & 9.79 & 9.42 & 8.74 & 8.25 & 7.84 \\
\hline 10 & 8.20 & 7.35 & 7.18 & 7.33 & 7.51 & 7.86 & 9.42 & 9.82 & 9.38 & 8.71 & 8.21 & 7.81 \\
\hline 11 & 8.17 & 7.33 & 7.21 & 7.34 & 7.50 & 7.87 & 9.43 & 9.81 & 9.40 & 8.77 & 8.18 & 7.79 \\
\hline 12 & 8.13 & 7.31 & 7.30 & 7.35 & 7.50 & 7.87 & 9.43 & 9.81 & 9.36 & 8.76 & 8.17 & 7.77 \\
\hline 13 & 8.09 & 7.33 & 7.30 & 7.35 & 7.50 & 7.87 & 9.42 & 9.80 & 9.32 & 8.72 & 8.23 & 7.73 \\
\hline 14 & 8.05 & 7.32 & 7.29 & 7.35 & 7.50 & 7.88 & 9.41 & 9.79 & 9.28 & 8.70 & 8.25 & 7.69 \\
\hline 15 & 8.00 & 7.30 & 7.28 & 7.37 & 7.51 & 7.88 & 9.41 & 9.76 & 9.28 & 8.67 & 8.23 & 7.64 \\
\hline 16 & 7.96 & 7.29 & 7.28 & 7.37 & 7.50 & 7.89 & 9.43 & 9.72 & 9.28 & 8.67 & 8.21 & 7.60 \\
\hline 17 & 7.92 & 7.28 & 7.27 & 7.39 & 7.52 & 7.94 & 9.43 & 9.69 & 9.25 & 8.66 & 8.19 & 7.57 \\
\hline 18 & 7.88 & 7.27 & 7.27 & 7.41 & 7.55 & 8.03 & 9.42 & 9.66 & 9.21 & 8.66 & 8.18 & 7.55 \\
\hline 19 & 7.84 & 7.27 & 7.26 & 7.41 & 7.57 & 8.10 & 9.45 & 9.64 & 9.22 & 8.65 & 8.16 & 7.57 \\
\hline 20 & 7.80 & 7.25 & 7.26 & 7.41 & 7.62 & 8.31 & 9.51 & 9.62 & 9.20 & 8.63 & 8.14 & 7.55 \\
\hline 21 & 7.75 & 7.24 & 7.28 & 7.41 & 7.68 & 8.56 & 9.52 & 9.60 & 9.17 & 8.60 & 8.12 & 7.52 \\
\hline 22 & 7.71 & 7.24 & 7.28 & 7.41 & 7.70 & 8.73 & 9.56 & 9.59 & 9.15 & 8.58 & 8.10 & 7.49 \\
\hline 23 & 7.68 & 7.23 & 7.28 & 7.41 & 7.71 & 8.98 & 9.61 & 9.60 & 9.13 & 8.56 & 8.10 & 7.46 \\
\hline 24 & 7.75 & 7.23 & 7.28 & 7.41 & 7.72 & 9.06 & 9.63 & 9.57 & 9.09 & 8.54 & 8.08 & 7.45 \\
\hline 25 & 7.73 & 7.25 & 7.28 & 7.41 & 7.73 & 9.10 & 9.64 & 9.65 & 9.05 & 8.52 & 8.06 & 7.46 \\
\hline 26 & 7.79 & 7.23 & 7.28 & 7.41 & 7.74 & 9.12 & 9.76 & 9.79 & 9.01 & 8.49 & 8.04 & 7.55 \\
\hline 27 & 7.77 & 7.22 & 7.28 & 7.42 & 7.75 & 9.13 & 9.86 & 9.79 & 8.97 & 8.51 & 8.01 & 7.57 \\
\hline 28 & 7.72 & 7.22 & 7.28 & 7.42 & 7.75 & 9.13 & 9.88 & 9.77 & 8.92 & 8.51 & 7.99 & 7.56 \\
\hline 29 & 7.69 & 7.21 & 7.27 & 7.42 & --- & 9.14 & 9.90 & 9.76 & 8.90 & 8.49 & 7.97 & 7.55 \\
\hline 30 & 7.66 & 7.22 & 7.28 & 7.42 & --- & 9.14 & 9.90 & 9.75 & 8.88 & 8.47 & 7.95 & 7.53 \\
\hline 31 & 7.62 & --- & 7.29 & 7.43 & --- & 9.14 & --- & 9.73 & --- & 8.45 & 7.96 & --- \\
\hline Mean & 8.01 & 7.33 & 7.25 & 7.37 & 7.57 & 8.29 & 9.49 & 9.75 & 9.28 & 8.66 & 8.18 & 7.70 \\
\hline Max & 8.57 & 7.60 & 7.30 & 7.43 & 7.75 & 9.14 & 9.90 & 9.90 & 9.68 & 8.87 & 8.43 & 8.01 \\
\hline Min & 7.62 & 7.21 & 7.18 & 7.30 & 7.46 & 7.75 & 9.15 & 9.57 & 8.88 & 8.45 & 7.95 & 7.45 \\
\hline
\end{tabular}




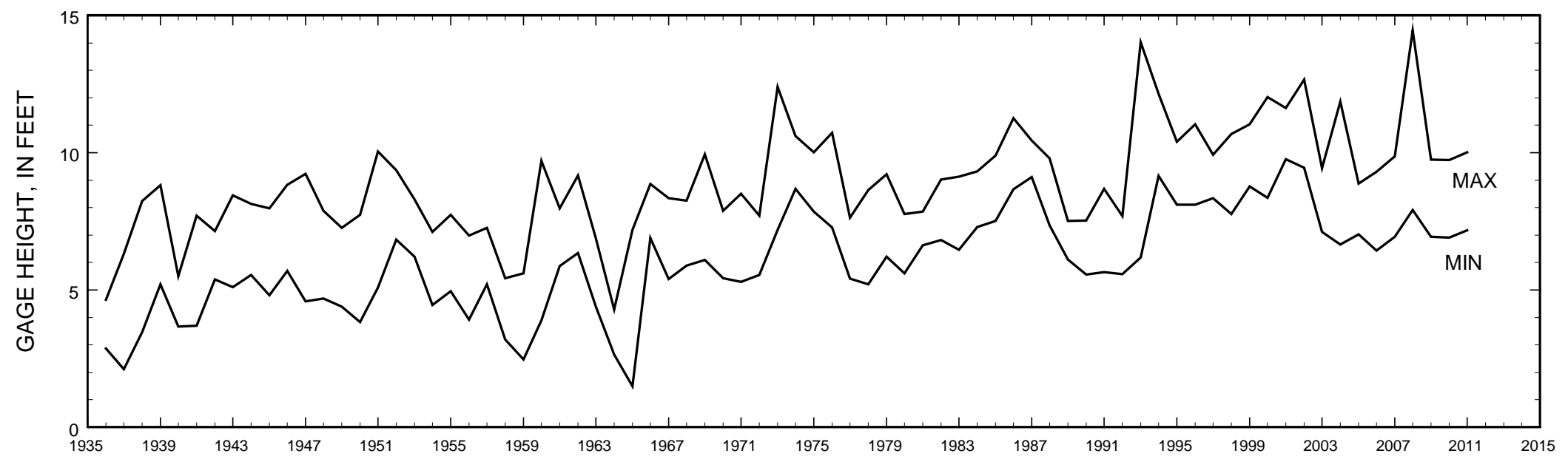

Annual minimum and maximum water levels for Devils Lake, 1936-2011. 
LOCATION.--Lat 42³5'25", long 88²6'04" referenced to North American Datum of 1927, in SE 1/4 NW 1/4 sec.36, T.2 N., R.17 E., Walworth County, WI, Hydrologic Unit 07120006, at Geneva Lake dam at Center Street at Lake Geneva.

SURFACE AREA.--8.22 $\mathrm{mi}^{2}$.

DRAINAGE AREA.--28.7 $\mathrm{mi}^{2}$.

PERIOD OF RECORD.--October 1997 to August 2002, December 2002 to current year.

GAGE.--Water-stage recorder. Datum of gage is $861.86 \mathrm{ft}$ above NAVD of 1988 or $862.08 \mathrm{ft}$ above NGVD of 1929. Intermittent staffgage readings during winter months.

REMARKS.--Records good except for estimated days, which are poor. Gage-height telemeter at station.

EXTREMES FOR PERIOD OF RECORD.--Maximum gage height, 3.35 ft, Aug. 20, 2007; minimum gage height, 1.44 ft, Nov. 5 , 2005 (affected by wind).

EXTREMES FOR CURRENT YEAR.--Maximum gage height observed, $2.94 \mathrm{ft}$ (affected by wind), Mar. 23; minimum gage height, 2.07 $\mathrm{ft}$ (affected by wind), Oct. 24.

GAGE HEIGHT, FEET

WATER YEAR OCTOBER 2010 TO SEPTEMBER 2011

DAILY MEAN VALUES

[e, estimated]

\begin{tabular}{|c|c|c|c|c|c|c|c|c|c|c|c|c|}
\hline Day & Oct & Nov & Dec & Jan & Feb & Mar & Apr & May & Jun & Jul & Aug & Sep \\
\hline 1 & 2.35 & 2.23 & 2.32 & 2.46 & 2.44 & 2.62 & 2.65 & 2.74 & 2.65 & 2.52 & 2.74 & 2.42 \\
\hline 2 & 2.32 & 2.23 & 2.29 & 2.42 & 2.45 & 2.62 & 2.65 & 2.72 & 2.61 & 2.51 & 2.74 & 2.43 \\
\hline 3 & 2.30 & 2.23 & 2.26 & 2.42 & 2.45 & 2.60 & 2.63 & 2.70 & 2.60 & 2.49 & 2.76 & 2.44 \\
\hline 4 & 2.29 & 2.22 & 2.26 & 2.42 & 2.45 & 2.63 & 2.64 & 2.69 & 2.61 & 2.48 & 2.73 & 2.47 \\
\hline 5 & 2.29 & 2.22 & 2.26 & $\mathrm{e} 2.42$ & 2.45 & 2.69 & 2.63 & 2.68 & 2.59 & 2.48 & 2.70 & 2.42 \\
\hline 6 & 2.29 & 2.21 & 2.26 & $\mathrm{e} 2.42$ & 2.46 & 2.68 & 2.61 & 2.67 & 2.59 & 2.46 & 2.68 & 2.39 \\
\hline 7 & 2.28 & 2.21 & 2.26 & 2.42 & 2.46 & 2.67 & 2.60 & 2.65 & 2.60 & 2.44 & 2.72 & 2.37 \\
\hline 8 & 2.29 & 2.20 & 2.26 & 2.42 & 2.46 & 2.66 & 2.63 & 2.64 & 2.61 & 2.43 & 2.71 & 2.34 \\
\hline 9 & 2.27 & 2.20 & 2.26 & 2.42 & 2.46 & 2.69 & 2.63 & 2.61 & 2.65 & 2.43 & 2.72 & 2.33 \\
\hline 10 & 2.28 & 2.21 & 2.26 & 2.42 & 2.46 & 2.69 & 2.64 & 2.62 & 2.63 & 2.42 & 2.67 & 2.33 \\
\hline 11 & 2.28 & 2.22 & 2.26 & 2.42 & 2.46 & 2.68 & 2.65 & 2.62 & 2.64 & 2.44 & 2.64 & 2.33 \\
\hline 12 & 2.28 & 2.21 & 2.26 & 2.42 & 2.45 & 2.68 & 2.63 & 2.63 & 2.62 & 2.43 & 2.61 & 2.34 \\
\hline 13 & 2.28 & 2.24 & 2.26 & 2.42 & 2.42 & 2.67 & 2.63 & 2.62 & 2.60 & 2.40 & 2.58 & 2.31 \\
\hline 14 & 2.27 & 2.26 & 2.26 & 2.42 & 2.42 & 2.65 & 2.60 & 2.62 & 2.58 & 2.38 & 2.56 & 2.29 \\
\hline 15 & 2.25 & 2.22 & 2.26 & 2.42 & 2.42 & 2.64 & 2.58 & 2.61 & 2.59 & 2.37 & 2.54 & 2.26 \\
\hline 16 & 2.25 & 2.22 & 2.26 & 2.42 & 2.44 & 2.64 & 2.67 & 2.60 & 2.61 & 2.37 & 2.53 & 2.24 \\
\hline 17 & 2.23 & 2.23 & 2.26 & 2.42 & 2.51 & 2.63 & 2.67 & 2.58 & 2.59 & 2.37 & 2.52 & 2.23 \\
\hline 18 & 2.22 & 2.22 & 2.26 & 2.44 & 2.55 & 2.63 & 2.66 & 2.58 & 2.58 & 2.39 & 2.50 & 2.23 \\
\hline 19 & 2.22 & 2.23 & 2.26 & 2.44 & 2.55 & 2.63 & 2.66 & 2.58 & 2.58 & 2.37 & 2.49 & 2.28 \\
\hline 20 & 2.22 & 2.20 & 2.26 & 2.44 & 2.58 & 2.66 & 2.71 & 2.57 & 2.58 & 2.38 & 2.52 & 2.27 \\
\hline 21 & 2.19 & 2.21 & 2.26 & 2.44 & 2.65 & 2.73 & 2.70 & 2.57 & 2.59 & 2.37 & 2.53 & 2.28 \\
\hline 22 & 2.18 & 2.28 & 2.26 & 2.44 & 2.66 & 2.72 & 2.69 & 2.59 & 2.63 & 2.49 & 2.51 & 2.24 \\
\hline 23 & 2.19 & 2.32 & 2.26 & 2.44 & 2.66 & 2.76 & 2.74 & 2.64 & 2.62 & 2.68 & 2.52 & 2.23 \\
\hline 24 & 2.25 & 2.28 & 2.26 & 2.44 & 2.65 & 2.76 & 2.72 & 2.61 & 2.60 & 2.67 & 2.53 & 2.22 \\
\hline 25 & 2.27 & 2.32 & 2.26 & 2.44 & 2.64 & 2.74 & 2.70 & 2.62 & 2.58 & 2.65 & 2.49 & 2.23 \\
\hline 26 & 2.38 & 2.32 & 2.26 & 2.44 & 2.63 & 2.72 & 2.76 & 2.62 & 2.56 & 2.62 & 2.48 & 2.33 \\
\hline 27 & 2.37 & 2.28 & 2.26 & 2.44 & 2.63 & 2.71 & 2.78 & 2.61 & 2.56 & 2.73 & 2.46 & 2.40 \\
\hline 28 & 2.29 & 2.27 & 2.26 & 2.44 & 2.64 & 2.69 & 2.78 & 2.62 & 2.55 & 2.83 & 2.45 & 2.43 \\
\hline 29 & 2.26 & 2.27 & 2.26 & 2.44 & --- & 2.68 & 2.76 & 2.62 & 2.52 & 2.82 & 2.44 & 2.44 \\
\hline 30 & 2.25 & 2.34 & 2.26 & 2.44 & --- & 2.66 & 2.74 & 2.65 & 2.52 & 2.79 & 2.42 & 2.42 \\
\hline 31 & 2.23 & --- & 2.29 & 2.44 & --- & 2.65 & --- & 2.66 & --- & 2.77 & 2.42 & --- \\
\hline Mean & 2.27 & 2.24 & 2.26 & 2.43 & 2.52 & 2.67 & 2.67 & 2.63 & 2.59 & 2.52 & 2.58 & 2.33 \\
\hline Max & 2.38 & 2.34 & 2.32 & 2.46 & 2.66 & 2.76 & 2.78 & 2.74 & 2.65 & 2.83 & 2.76 & 2.47 \\
\hline Min & 2.18 & 2.20 & 2.26 & 2.42 & 2.42 & 2.60 & 2.58 & 2.57 & 2.52 & 2.37 & 2.42 & 2.22 \\
\hline
\end{tabular}




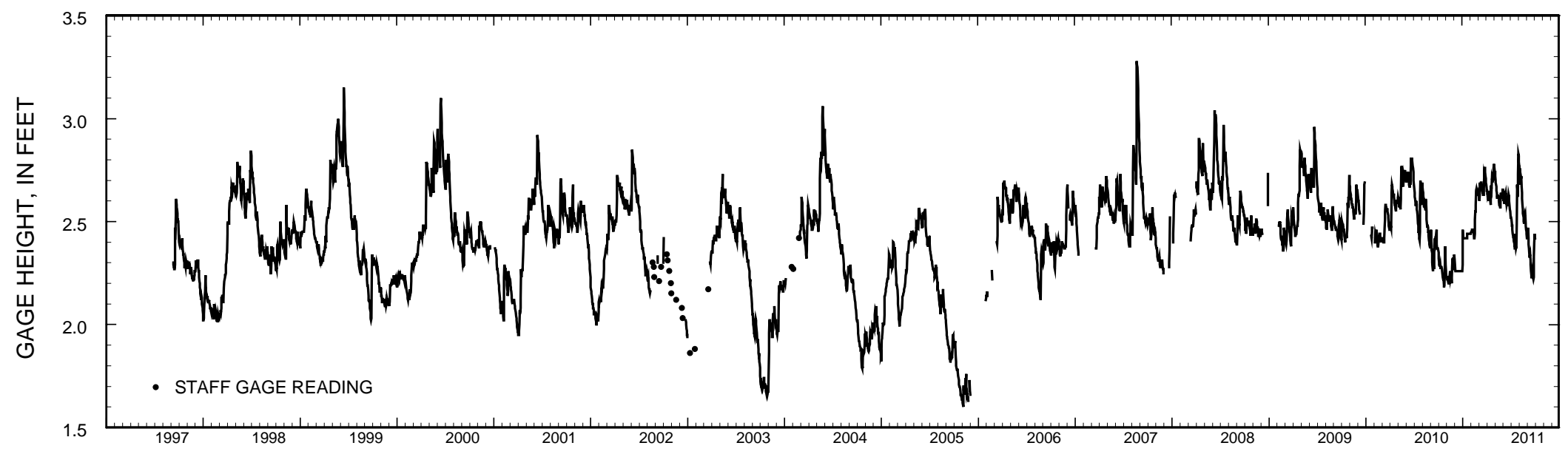

Stage hydrograph for Geneva Lake, 1997-2011. 


\section{GENEVA LAKE AT WEST END NEAR WILLIAMS BAY, WI}

LOCATION.--Lat 42³3'29", long 88³2'33", in NE 1/4 SE 1/4 sec.12, T.1 N., R.16 E., Walworth County, Hydrologic Unit 07120006, 1.3 mi south of Williams Bay.

SURFACE AREA.--8.22 $\mathrm{mi}^{2}$.

DRAINAGE AREA.--28.7 $\mathrm{mi}^{2}$.

PERIOD OF RECORD.--April 1997 to current year.

REMARKS.--Lake sampled at deep hole at a depth of about $43 \mathrm{~m}$. Lake ice-covered during February sampling. Water-quality analyses done by Wisconsin State Laboratory of Hygiene. Samples for determination of chlorophyll a concentration are collected from the top $0.5 \mathrm{~m}$ of the lake.

WATER-QUALITY DATA, APRIL 13 TO SEPTEMBER 7, 2011

(Milligrams per liter unless otherwise indicated)

\begin{tabular}{|c|c|c|c|c|c|c|c|c|c|c|c|c|c|}
\hline Date & $\begin{array}{c}\text { Trans- } \\
\text { parency } \\
\text { Secchi } \\
\text { disc, } \\
\text { meters } \\
(0 \odot \odot 78)\end{array}$ & $\begin{array}{c}\text { Sam- } \\
\text { pling } \\
\text { depth, } \\
\text { meters } \\
(\odot \odot \odot 98)\end{array}$ & $\begin{array}{c}\text { Temper - } \\
\text { ature, } \\
\text { water, } \\
\text { deg C } \\
(\odot \odot 010)\end{array}$ & 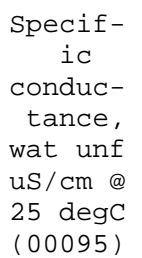 & $\begin{array}{c}\text { pH, } \\
\text { water, } \\
\text { unfltrd } \\
\text { field, } \\
\text { std } \\
\text { units } \\
(\odot \odot 4 \odot \odot)\end{array}$ & $\begin{array}{c}\text { Dis- } \\
\text { solved } \\
\text { oxygen, } \\
\text { mg/L } \\
(\odot \odot 3 \odot \odot)\end{array}$ & $\begin{array}{c}\text { Chloro- } \\
\text { phyll a } \\
\text { trichro } \\
\text {-matic } \\
\text { method, } \\
\text { uncorr, } \\
\text { ug/L } \\
(32210)\end{array}$ & $\begin{array}{c}\text { Phos- } \\
\text { phorus, } \\
\text { water, } \\
\text { unfltrd } \\
\text { mg/L } \\
\text { as } \mathrm{P} \\
(00665)\end{array}$ & $\begin{array}{l}\text { Ortho- } \\
\text { phos- } \\
\text { phate, } \\
\text { water, } \\
\text { fltrd, } \\
\text { mg/L } \\
\text { as P } \\
(0 \odot 671)\end{array}$ & $\begin{array}{c}\text { Total } \\
\text { nitro- } \\
\text { gen, } \\
\text { water, } \\
\text { unfltrd } \\
\text { mg/L } \\
(\odot \odot 6 \odot \odot)\end{array}$ & $\begin{array}{c}\text { Ammonia } \\
\text { water, } \\
\text { fltrd, } \\
\text { mg/L } \\
\text { as N } \\
(0 \odot 608)\end{array}$ & $\begin{array}{c}\text { Ammonia } \\
+ \\
\text { org-N, } \\
\text { water, } \\
\text { fltrd, } \\
\text { mg/L } \\
\text { as N } \\
(0 \odot 623)\end{array}$ & $\begin{array}{c}\text { Ammonia } \\
+ \\
\text { org-N, } \\
\text { water, } \\
\text { unfltrd } \\
\text { mg/L } \\
\text { as N } \\
(0 \odot 625)\end{array}$ \\
\hline
\end{tabular}

APR 2011

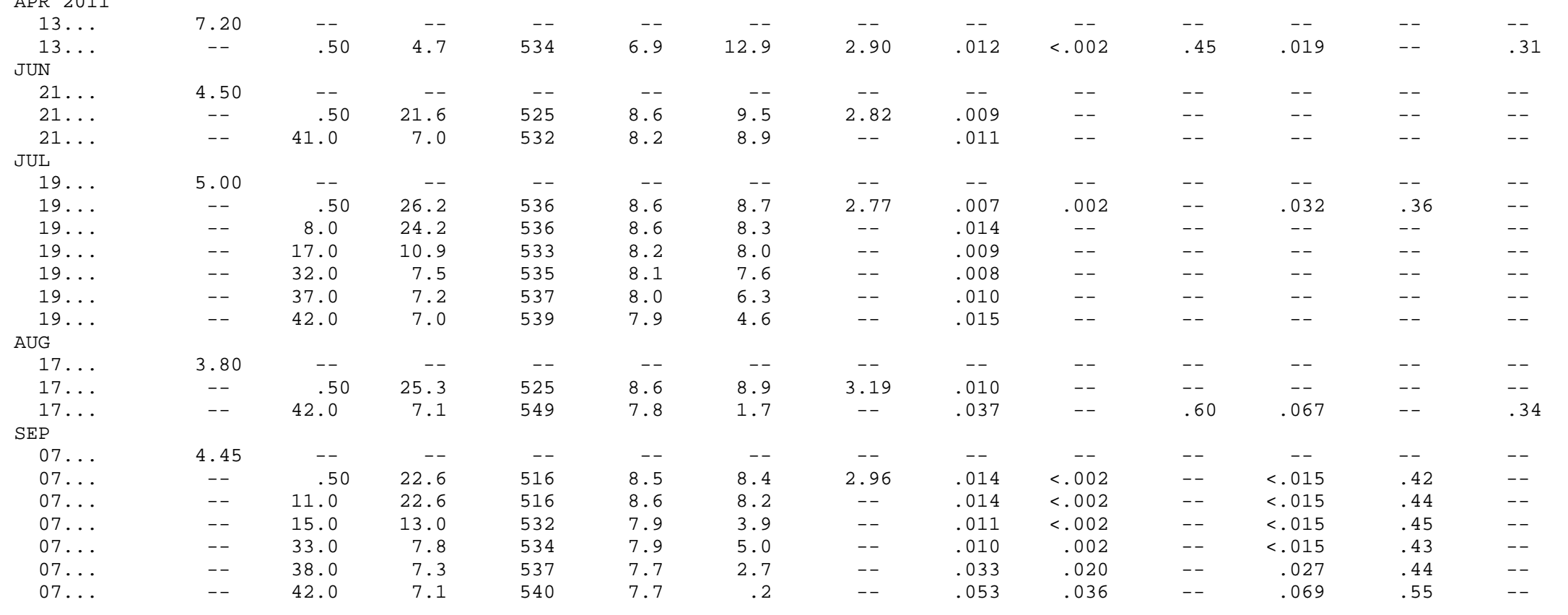




\section{GENEVA LAKE AT WEST END NEAR WILLIAMS BAY, W}

WATER-QUALITY DATA, APRIL 13 TO SEPTEMBER 7, 2011

(Milligrams per liter unless otherwise indicated)

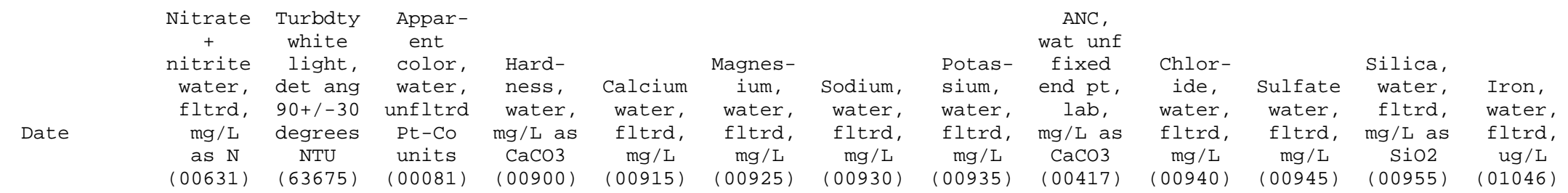

APR 2011

\begin{tabular}{|c|c|c|c|c|c|c|c|c|c|c|c|c|c|}
\hline $13 \ldots$ & - - & - - & - - & - - & - - & - & - - & - - & - - & - - & - - & - - & - - \\
\hline $13 \ldots$ & .137 & $<1.0$ & 10 & 222 & 34.3 & 33.1 & 20.5 & 1.50 & 189 & 43.9 & 29.2 & 3.02 & $<100$ \\
\hline \multicolumn{14}{|l|}{ JUN } \\
\hline $21 \ldots$ & -- & - - & - - & -- & - - & -- & -- & -- & - - & -- & -- & - - & -- \\
\hline $21 \ldots$ & -- & -- & - - & - - & - - & - - & - - & -- & - - & - - & - - & -- & -- \\
\hline $21 \ldots$ & - - & -- & - - & -- & - - & -- & -- & - - & - - & -- & - - & -- & -- \\
\hline \multicolumn{14}{|l|}{ JUL } \\
\hline $19 \ldots$ & - - & -- & - - & -- & -- & -- & -- & -- & - - & -- & - - & -- & -- \\
\hline $19 \ldots$ & $<.019$ & -- & - - & - - & - - & - - & - - & -- & -- & - - & -- & - - & -- \\
\hline $19 \ldots$ & -- & -- & - - & -- & - - & - - & - - & -- & -- & - - & -- & - - & -- \\
\hline $19 \ldots$ & - - & -- & - - & -- & -- & -- & -- & -- & - - & -- & - - & -- & -- \\
\hline $19 \ldots$ & -- & -- & - - & -- & -- & -- & -- & -- & - - & -- & -- & -- & -- \\
\hline $19 \ldots$ & -- & -- & - - & -- & -- & -- & -- & -- & - - & -- & - - & -- & -- \\
\hline $19 \ldots$ & -- & -- & - - & -- & -- & -- & -- & -- & - - & -- & - - & -- & -- \\
\hline \multicolumn{14}{|l|}{ AUG } \\
\hline $17 \ldots$ & - - & -- & - - & -- & -- & -- & -- & -- & -- & -- & -- & -- & -- \\
\hline $17 \ldots$ & - - & - - & - - & - - & - - & -- & - - & - - & - - & - - & - - & -- & -- \\
\hline $17 \ldots$ & .262 & -- & - - & -- & - - & -- & - - & - - & - - & -- & - - & -- & -- \\
\hline \multicolumn{14}{|l|}{ SEP } \\
\hline $07 \ldots$ & - & - - & - - & - & - & -- & - & -- & - - & - & - & -- & - - \\
\hline $07 \ldots$ & $<.019$ & -- & -- & -- & -- & -- & -- & -- & - - & -- & -- & -- & -- \\
\hline $07 \ldots$ & $<.019$ & -- & - - & - - & - - & -- & - & -- & - - & - - & - - & -- & -- \\
\hline $07 \ldots$ & .102 & - - & - - & -- & - - & -- & -- & - - & - - & -- & - - & -- & -- \\
\hline $07 \ldots$ & .242 & -- & -- & -- & -- & -- & -- & -- & - - & -- & - - & -- & -- \\
\hline $07 \ldots$ & .270 & -- & -- & -- & -- & -- & -- & -- & - - & -- & -- & -- & -- \\
\hline \multirow[t]{4}{*}{$07 \ldots$} & .258 & - - & - - & -- & - - & -- & -- & - - & -- & -- & -- & -- & -- \\
\hline & & $\begin{array}{l}\text { Dis- } \\
\text { solved }\end{array}$ & & & & & & & & & & & \\
\hline & $\begin{array}{c}\text { Mangan- } \\
\text { ese, }\end{array}$ & $\begin{array}{r}\text { solids } \\
\text { dried @ }\end{array}$ & & & & & & & & & & & \\
\hline & water, & 180degC & & & & & & & & & & & \\
\hline Date & $\begin{array}{c}\text { fltrd, } \\
\text { ug/L } \\
(01056)\end{array}$ & $\begin{array}{c}\text { wat flt } \\
\mathrm{mg} / \mathrm{L} \\
(70300)\end{array}$ & & & & & & & & & & & \\
\hline
\end{tabular}

APR 2011

$\begin{array}{lrr}13 \ldots & -- & - \\ 13 \ldots & <1.0 & 284\end{array}$


423329088323300 GENEVA LAKE AT WEST END NEAR WILLIAMS BAY, WI

LAKE-DEPTH PROFILES, APRIL 13 TO SEPTEMBER 7, 2011

04-13-11
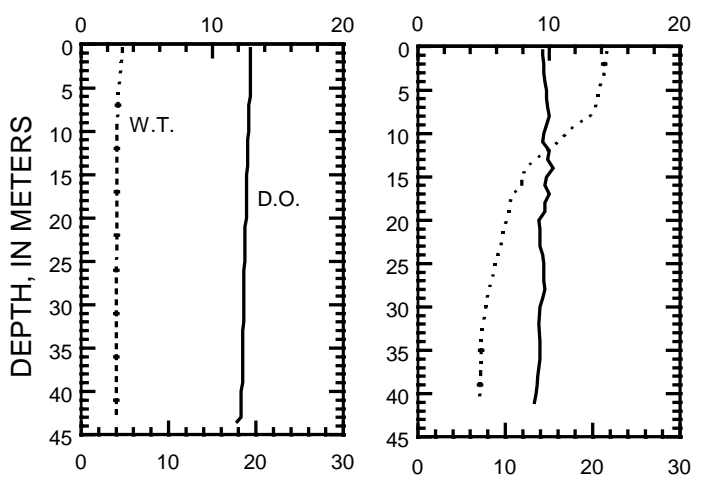

WATER TEMPE
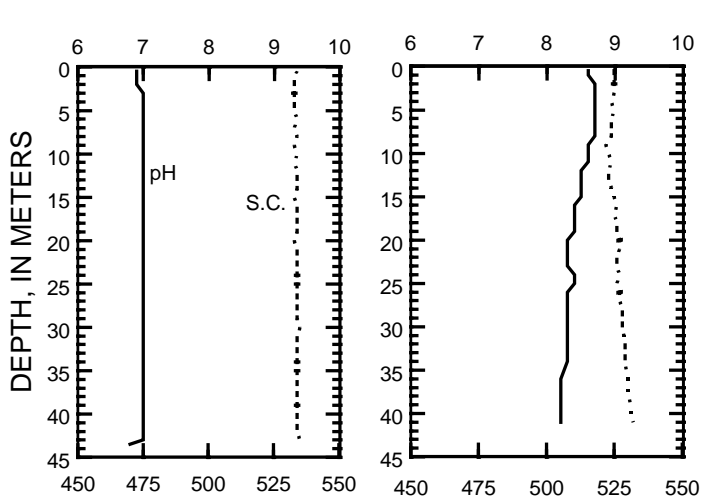

07-19-11

08-17-11

09-07-11
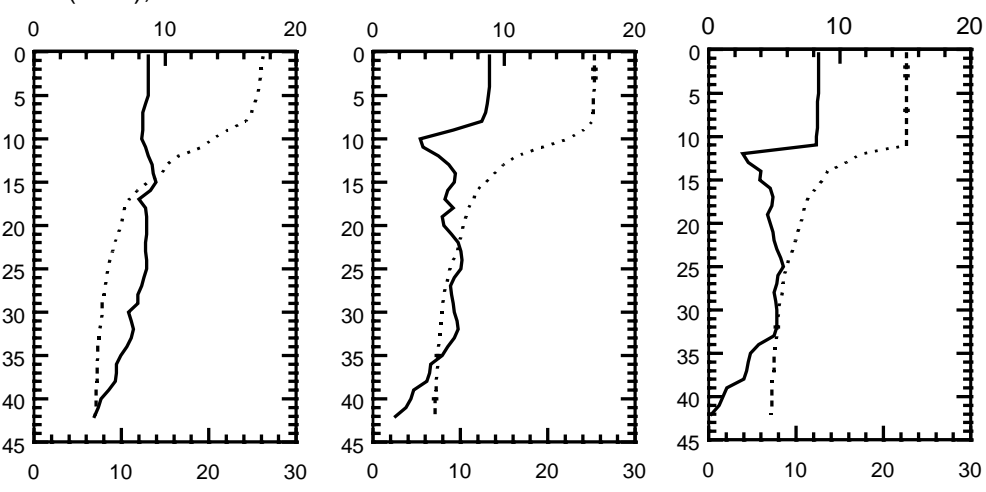

PH, IN STANDARD UNITS
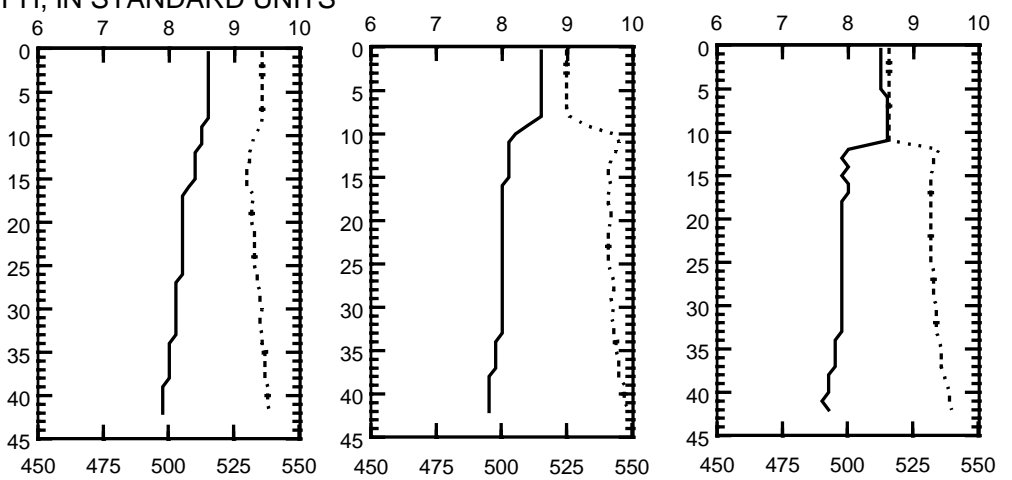

SPECIFIC CONDUCTANCE (S.C.), IN MICROSIEMENS PER CENTIMETER AT 25 DEGREES CELSIUS 

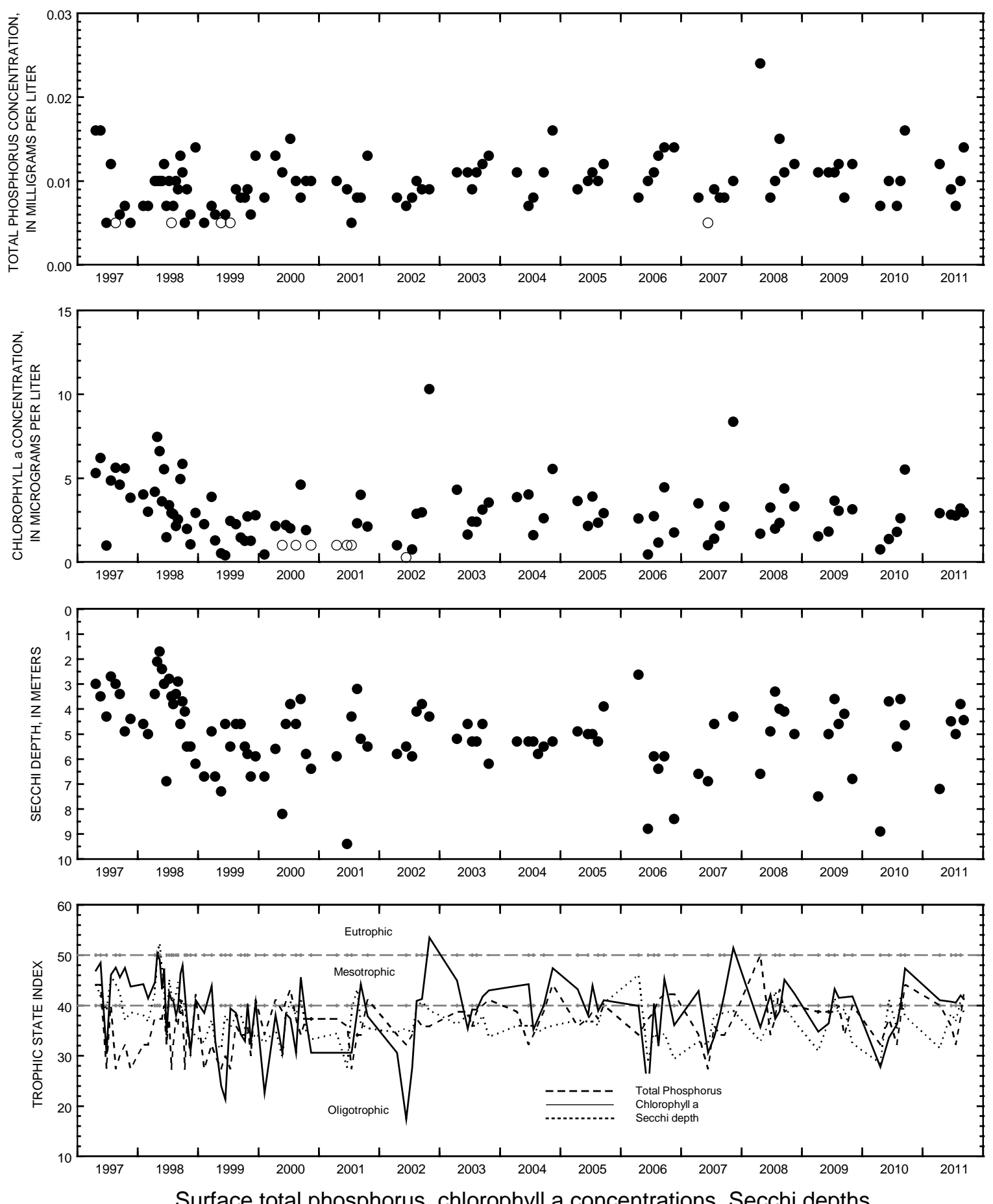

Surface total phosphorus, chlorophyll a concentrations, Secchi depths, and TSI data for Geneva Lake, West End, near Williams Bay, Wisconsin.

(Open circles on the first two plots indicate laboratory detection limit for selected analyses. 


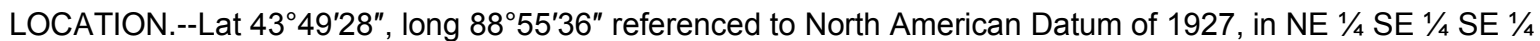
sec.27, T.16 N., R.13 E., Green Lake County, WI, Hydrologic Unit 04030201, on left bank at downstream side of County Trunk Highway A, 2.3 mi southeast of Green Lake.

SURFACE AREA.--11.48 $\mathrm{mi}^{2}$.

DRAINAGE AREA.--103 mi2; Area of Green Lake, 7,346 acres.

PERIOD OF RECORD.--October 1993 to current year.

GAGE.--Water-stage recorder. Datum of gage is $789.91 \mathrm{ft}$ above NAVD of 1988.

REMARKS.--Lake level regulated by dam at outlet at Green Lake. Gage-height telemeter at station.

EXTREMES FOR PERIOD OF RECORD.--Maximum recorded gage height, $8.67 \mathrm{ft}$, June 15, 2008; minimum recorded, $5.27 \mathrm{ft}$, Nov. 5, 2005.

EXTREMES FOR CURRENT YEAR.--Maximum recorded gage height, $6.76 \mathrm{ft}$, June 23; minimum recorded gage height, $5.90 \mathrm{ft}$, occurred many days.

GAGE HEIGHT, FEET

WATER YEAR OCTOBER 2010 TO SEPTEMBER 2011 DAILY MEAN VALUES

\begin{tabular}{|c|c|c|c|c|c|c|c|c|c|c|c|c|}
\hline Day & Oct & Nov & Dec & Jan & Feb & Mar & Apr & May & Jun & Jul & Aug & Sep \\
\hline 1 & 6.46 & 6.27 & 6.05 & 6.03 & 6.05 & 6.20 & 6.60 & 6.61 & 6.57 & 5.02 & 6.55 & 6.61 \\
\hline 2 & 6.44 & 6.26 & 6.05 & 5.99 & 6.08 & 6.19 & 6.59 & 6.62 & 6.59 & 4.86 & --- & 6.62 \\
\hline 3 & 6.44 & 6.24 & 6.06 & 5.98 & 6.07 & 6.19 & 6.60 & 6.61 & 6.58 & 4.84 & 6.49 & 6.67 \\
\hline 4 & 6.42 & 6.22 & 6.06 & 5.99 & 6.07 & 6.21 & 6.60 & 6.58 & 6.59 & 4.83 & 6.46 & --- \\
\hline 5 & 6.42 & 6.20 & 6.04 & 5.98 & 6.07 & 6.21 & 6.60 & 6.56 & 6.58 & 4.80 & 6.56 & --- \\
\hline 6 & 6.40 & 6.18 & 6.03 & 5.98 & 6.08 & 6.20 & 6.59 & 6.53 & 6.60 & 4.78 & 6.94 & --- \\
\hline 7 & 6.39 & 6.17 & 6.02 & 5.98 & 6.08 & 6.19 & 6.59 & 6.53 & 6.62 & 5.55 & 6.74 & --- \\
\hline 8 & 6.39 & 6.16 & 6.02 & 5.97 & 6.07 & 6.19 & 6.59 & 6.53 & 6.64 & 6.44 & 6.72 & --- \\
\hline 9 & 6.37 & 6.15 & 6.02 & 5.96 & 6.07 & 6.23 & 6.58 & 6.53 & 6.64 & 6.45 & 6.77 & 6.29 \\
\hline 10 & 6.37 & 6.15 & 6.01 & 5.96 & 6.07 & 6.24 & 6.54 & 6.52 & 6.65 & 6.46 & 6.76 & 6.33 \\
\hline 11 & 6.37 & 6.15 & 6.01 & 5.98 & 6.07 & 6.23 & 6.54 & 6.50 & --- & --- & 6.76 & 6.34 \\
\hline 12 & 6.36 & 6.14 & 6.08 & 5.99 & 6.07 & 6.22 & 6.57 & 6.50 & --- & --- & --- & 6.35 \\
\hline 13 & 6.35 & 6.14 & 6.09 & 5.99 & 6.07 & 6.21 & 6.55 & 6.52 & --- & --- & --- & 6.33 \\
\hline 14 & 6.34 & 6.14 & 6.08 & 5.99 & 6.06 & 6.21 & 6.53 & 6.51 & 6.41 & --- & --- & 6.33 \\
\hline 15 & 6.33 & 6.16 & 6.06 & 6.02 & 6.05 & 6.20 & 6.50 & 6.51 & 6.40 & --- & --- & 6.23 \\
\hline 16 & 6.32 & 6.16 & 6.06 & 6.01 & 6.05 & 6.21 & 6.54 & 6.50 & --- & --- & --- & 6.19 \\
\hline 17 & 6.30 & 6.15 & 6.06 & 6.03 & 6.05 & 6.23 & 6.51 & 6.50 & --- & --- & --- & 6.21 \\
\hline 18 & 6.29 & 6.14 & 6.04 & 6.03 & 6.07 & 6.27 & 6.53 & 6.49 & 5.11 & --- & --- & --- \\
\hline 19 & 6.28 & 6.12 & 6.03 & 6.04 & 6.08 & 6.31 & 6.53 & 6.49 & 5.13 & --- & 6.75 & --- \\
\hline 20 & 6.25 & 6.12 & 6.02 & 6.03 & 6.11 & 6.39 & --- & 6.49 & 5.14 & --- & 6.75 & --- \\
\hline 21 & 6.24 & 6.12 & 6.03 & 6.03 & 6.17 & 6.47 & --- & 6.49 & 5.12 & 6.50 & 6.74 & --- \\
\hline 22 & 6.24 & 6.11 & 6.03 & 6.03 & 6.19 & 6.52 & 6.59 & 6.50 & 5.33 & 6.47 & 6.73 & 4.91 \\
\hline 23 & 6.25 & 6.09 & 6.03 & 6.03 & 6.19 & 6.65 & 6.59 & 6.52 & --- & 6.50 & 6.74 & 4.88 \\
\hline 24 & 6.32 & 6.10 & 6.03 & 6.03 & 6.20 & 6.67 & 6.59 & 6.52 & --- & 6.54 & 6.75 & 4.86 \\
\hline 25 & 6.33 & 6.10 & 6.03 & 6.03 & 6.20 & 6.67 & 6.58 & 6.53 & 5.45 & 6.50 & 6.71 & 4.86 \\
\hline 26 & 6.36 & 6.07 & 6.03 & 6.02 & 6.20 & 6.67 & --- & 6.60 & 5.44 & 6.45 & 6.64 & --- \\
\hline 27 & 6.32 & 6.08 & 6.02 & 6.03 & 6.20 & 6.66 & 6.69 & 6.59 & 5.42 & 6.54 & 6.63 & --- \\
\hline 28 & 6.31 & 6.09 & 6.02 & 6.03 & 6.20 & 6.65 & 6.67 & 6.58 & 5.35 & 6.64 & 6.62 & --- \\
\hline 29 & 6.32 & 6.09 & 5.99 & 6.03 & --- & 6.64 & 6.69 & 6.57 & 5.34 & --- & 6.61 & 6.33 \\
\hline 30 & 6.31 & 6.07 & 5.98 & 6.03 & --- & 6.62 & 6.68 & 6.58 & 5.27 & --- & 6.60 & 6.33 \\
\hline 31 & 6.29 & --- & 5.99 & 6.03 & --- & 6.61 & --- & 6.60 & --- & 6.75 & 6.61 & --- \\
\hline Mean & 6.34 & 6.14 & 6.03 & 6.01 & 6.11 & 6.37 & --- & 6.54 & --- & --- & --- & --- \\
\hline Max & 6.46 & 6.27 & 6.09 & 6.04 & 6.20 & 6.67 & --- & 6.62 & --- & --- & --- & --- \\
\hline Min & 6.24 & 6.07 & 5.98 & 5.96 & 6.05 & 6.19 & --- & 6.49 & --- & --- & --- & --- \\
\hline
\end{tabular}




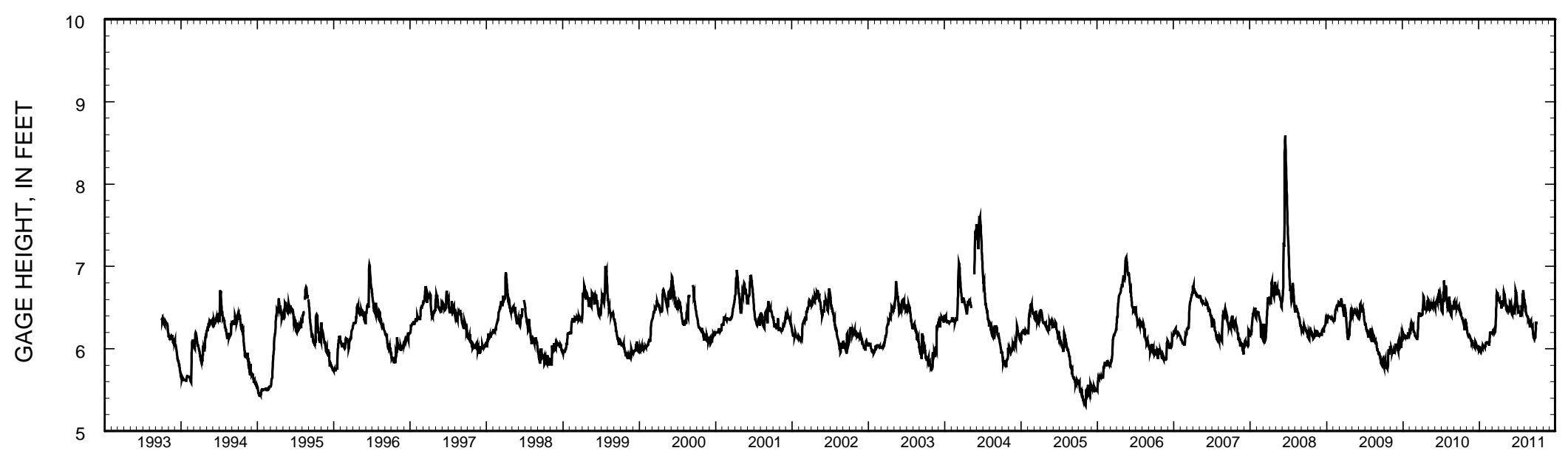

Stage hydrograph for Green Lake, 1993-2011. 
LOCATION.--Lat 4347'56", long 8902'05", in NW 1/4 SE 1/4 sec.2, T.15 N., R.12 E., Green Lake County, Hydrologic Unit 04030201 , about 5 miles southwest of the City of Green Lake.

SURFACE AREA.--11.48 $\mathrm{mi}^{2}$.

PERIOD OF RECORD.--May 2004 to current year. Lake sampled by Wisconsin Department of Natural Resources prior to 2004.

REMARKS.--Water-quality analyses done by Wisconsin State Laboratory of Hygiene. A “*” indicates data that were collected by Mary Jane Bumby, Citizen Lake Monitoring Volunteer.

WATER-QUALITY DATA, APRIL 12 TO SEPTEMBER 28, 2011

(Milligrams per liter unless otherwise indicated)

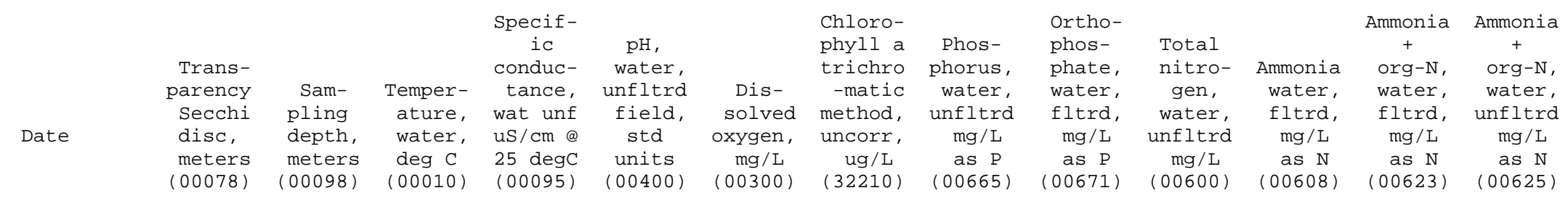

APR 2011

\begin{tabular}{|c|c|c|c|c|c|c|c|c|c|}
\hline $12 \ldots$ & 6.30 & - & -- & -- & -- & - - & -- & -- & -- \\
\hline $12 \ldots$ & -- & .50 & 2.8 & 516 & 6.8 & 11.7 & 4.19 & .043 & .032 \\
\hline $12 \ldots$ & - & 30.0 & 2.7 & 517 & 6.7 & 11.4 & - & .047 & -- \\
\hline \multicolumn{10}{|l|}{ JUN } \\
\hline${ }^{*} 03 \ldots$ & 1.20 & .10 & 14.4 & - - & - - & -- & - & -- & -- \\
\hline *17 ... & 1.40 & .10 & 18.9 & -- & - - & -- & -- & -- & - - \\
\hline$* 25 \ldots$ & 3.80 & .10 & 20.0 & -- & - - & -- & -- & -- & -- \\
\hline $29 \ldots$ & 6.15 & -- & -- & -- & -- & -- & -- & -- & -- \\
\hline $29 \ldots$ & -- & .50 & 19.9 & 483 & 8.9 & 9.1 & 4.98 & .030 & -- \\
\hline $29 \ldots$ & - - & 67.0 & 5.0 & 519 & 8.0 & .8 & -- & .067 & -- \\
\hline \multicolumn{10}{|l|}{ JUL } \\
\hline${ }^{*} 03 \ldots$ & 7.60 & .10 & 23.3 & -- & -- & -- & -- & -- & -- \\
\hline *14. . & 5.50 & .10 & 25.0 & -- & -- & -- & -- & -- & -- \\
\hline${ }^{*} 24 \ldots$ & 5.00 & .10 & 26.7 & - - & - - & -- & -- & -- & -- \\
\hline $25 \ldots$ & 5.70 & - - & -- & - - & - - & -- & -- & -- & -- \\
\hline $25 \ldots$ & -- & .50 & 27.1 & 493 & 8.9 & 8.9 & 2.28 & .015 & -- \\
\hline $25 \ldots$ & -- & 67.5 & 4.5 & 557 & 7.5 & .4 & -- & .175 & -- \\
\hline \multicolumn{10}{|l|}{ AUG } \\
\hline${ }^{*} 01 \ldots$ & 4.60 & .10 & 27.2 & - - & -- & -- & -- & -- & - - \\
\hline *15... & 4.90 & .10 & 25.0 & - - & - - & - - & -- & -- & -- \\
\hline $18 \ldots$ & 4.85 & - - & -- & -- & - - & - - & - - & - - & -- \\
\hline $18 \ldots$ & -- & .50 & 24.4 & 487 & 8.8 & 8.7 & 2.30 & .012 & $<.002$ \\
\hline $18 \ldots$ & -- & 13.0 & 10.2 & 519 & 8.0 & 4.5 & -- & .011 & - \\
\hline $18 \ldots$ & -- & 67.0 & 4.9 & 540 & 7.5 & .1 & -- & .263 & - - \\
\hline & 5.50 & & 6 & & & - - & - & & \\
\hline
\end{tabular}

\begin{tabular}{|c|c|c|c|}
\hline - - & - - & - - & -- \\
\hline .74 & $<.015$ & - - & .43 \\
\hline-- & -- & -- & -- \\
\hline - - & - - & - - & - - \\
\hline-- & -- & - - & -- \\
\hline - - & - - & - - & -- \\
\hline- & -- & -- & -- \\
\hline - - & - - & -- & -- \\
\hline-- & -- & -- & -- \\
\hline - - & - - & - - & -- \\
\hline - - & -- & -- & -- \\
\hline-- & -- & -- & -- \\
\hline-- & -- & -- & -- \\
\hline-- & -- & -- & -- \\
\hline-- & -- & -- & -- \\
\hline-- & -- & -- & -- \\
\hline- & - - & - - & - - \\
\hline-- & -- & -- & -- \\
\hline - - & $<.015$ & .54 & -- \\
\hline-- & -- & -- & -- \\
\hline-- & -- & -- & -- \\
\hline-1 & -- & -- & \\
\hline
\end{tabular}


434756089020500 GREEN LAKE AT DEEP HOLE NEAR GREEN LAKE, WI

WATER-QUALITY DATA, APRIL 12 TO SEPTEMBER 28, 2011

(Milligrams per liter unless otherwise indicated)

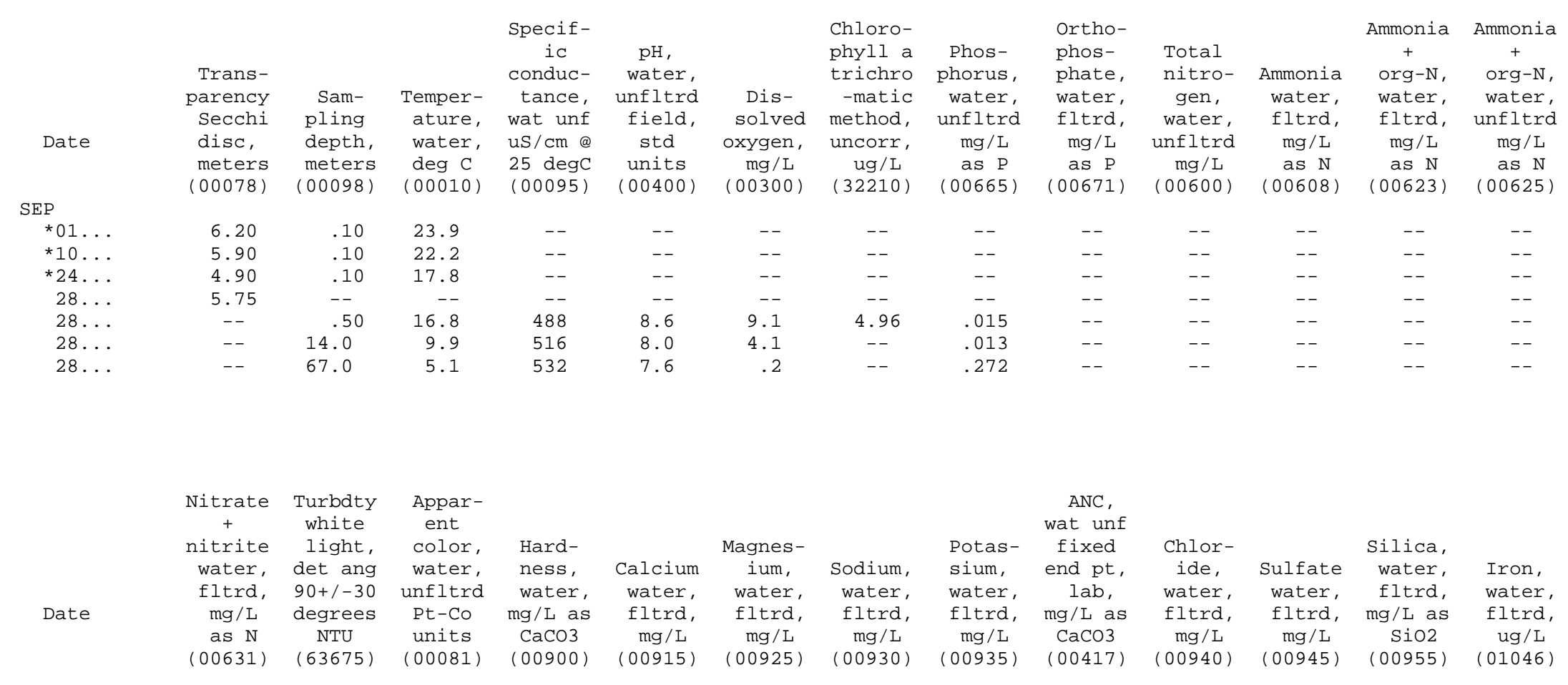

APR 2011

\begin{tabular}{|c|c|c|c|c|c|c|c|c|c|c|c|c|c|}
\hline $12 \ldots$ & - - & - - & - - & - - & - - & - - & - - & - - & - - & - - & - - & - - & - - \\
\hline $12 \ldots$ & .307 & $<1.0$ & 10 & 220 & 32.3 & 33.8 & 18.5 & 2.70 & 182 & 38.8 & 29.7 & .968 & $<100$ \\
\hline $12 \ldots$ & - - & -- & -- & - - & -- & - - & -- & -- & - - & - - & -- & -- & - - \\
\hline UG & & & & & & & & & & & & & \\
\hline${ }^{*} 01 \ldots$ & -- & - - & - - & -- & - - & -- & - - & -- & -- & - - & - - & - - & -- \\
\hline *15... & - - & -- & -- & -- & -- & - - & - - & - - & - - & - - & -- & -- & - - \\
\hline $18 \ldots$ & -- & -- & -- & -- & -- & - - & -- & -- & -- & -- & -- & -- & - - \\
\hline $18 \ldots$ & $<.019$ & -- & - - & -- & - - & - - & -- & - - & -- & - - & - - & -- & -- \\
\hline $18 \ldots$ & -- & -- & -- & -- & -- & - - & -- & - - & - - & -- & - - & -- & - - \\
\hline $18 \ldots$ & - - & - - & -- & -- & - - & - - & - - & - - & - - & -- & - - & -- & - - \\
\hline${ }^{*} 20 \ldots$ & -- & -- & -- & -- & -- & -- & -- & -- & -- & - - & -- & -- & - \\
\hline
\end{tabular}


434756089020500 GREEN LAKE AT DEEP HOLE NEAR GREEN LAKE, WI

WATER-QUALITY DATA, APRIL 12 TO SEPTEMBER 28, 2011

(Milligrams per liter unless otherwise indicated)

\begin{tabular}{|c|c|c|}
\hline & & $\begin{array}{l}\text { Dis- } \\
\text { solved }\end{array}$ \\
\hline & $\begin{array}{c}\text { Mangan- } \\
\text { ese, } \\
\text { water, }\end{array}$ & $\begin{array}{l}\text { solids } \\
\text { dried @ } \\
\text { 180degC }\end{array}$ \\
\hline Date & $\begin{array}{c}\text { fltrd, } \\
\text { ug/L } \\
(01056)\end{array}$ & $\begin{array}{c}\text { wat flt } \\
\mathrm{mg} / \mathrm{L} \\
(7030 \odot)\end{array}$ \\
\hline
\end{tabular}

APR 2011

$12 \ldots$

12.

$<1.0 \quad 276$ 
434756089020500 GREEN LAKE AT DEEP HOLE NEAR GREEN LAKE, WI

LAKE-DEPTH PROFILES, APRIL 12 TO SEPTEMBER 28, 2011

04-12-11
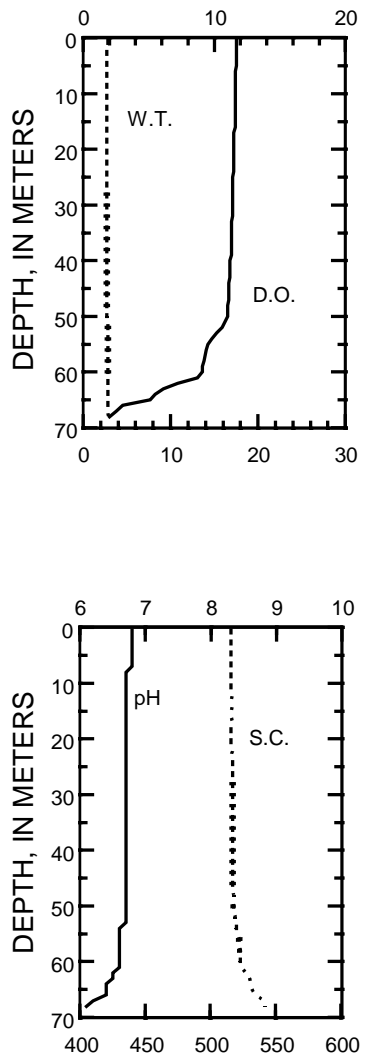

06-29-11

07-25-11

08-18-11

09-28-11

DISSOLVED OXYGEN (D.O.), IN MILLIGRAMS PER LITER
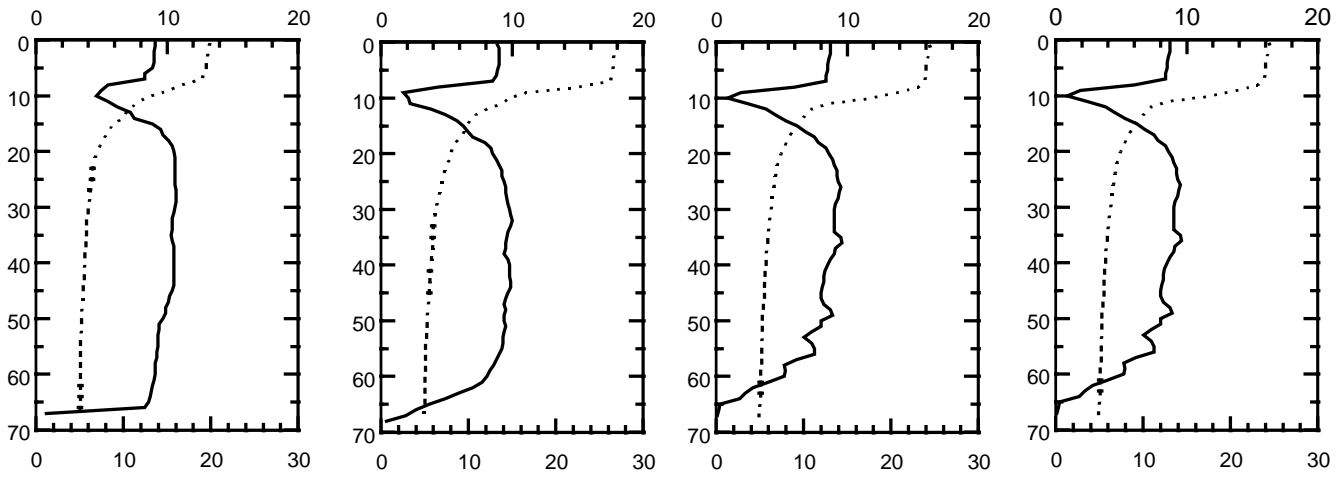

WATER TEMPERATURE (W.T.), IN DEGREES CELSIUS

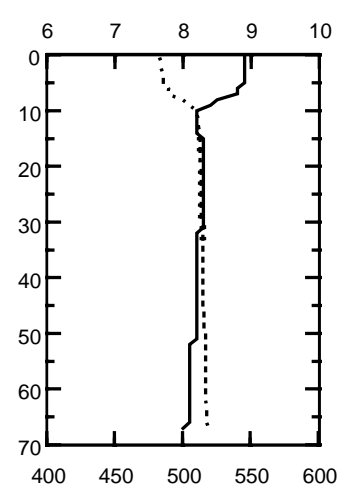

PH, IN STANDARD UNITS
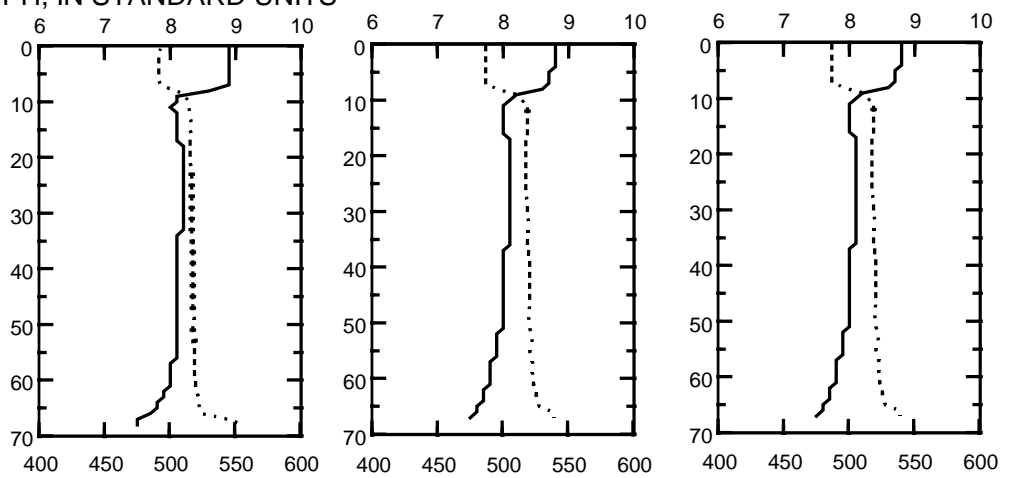

SPECIFIC CONDUCTANCE (S.C.), IN MICROSIEMENS PER CENTIMETER AT 25 DEGREES CELSIUS 

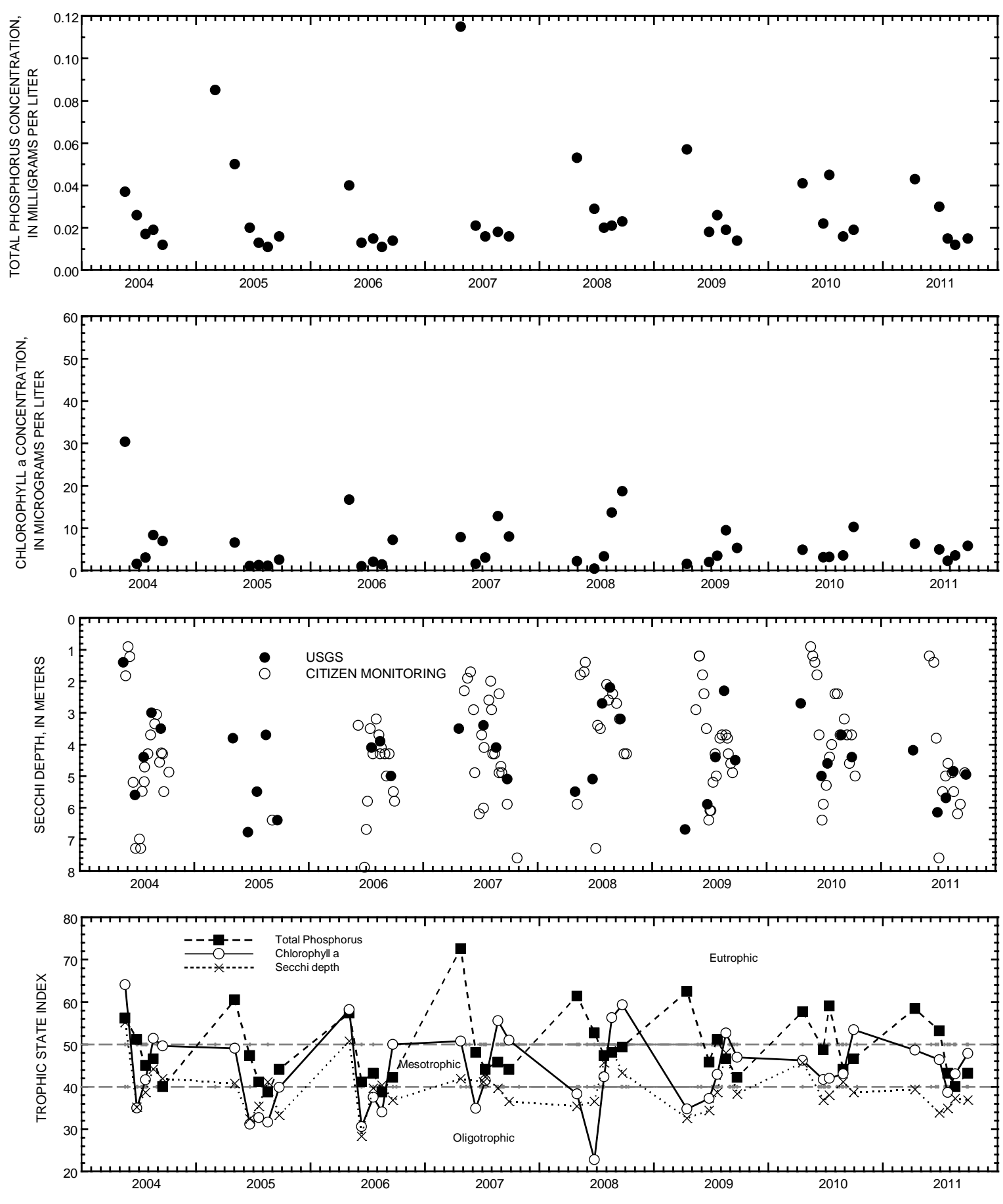

Surface total phosphorus, chlorophyll a concentrations, Secchi depths, and TSI data for Green Lake, Deep Hole, near Green Lake, Wisconsin. 


\section{GREEN LAKE AT EAST END NEAR GREEN LAKE, W}

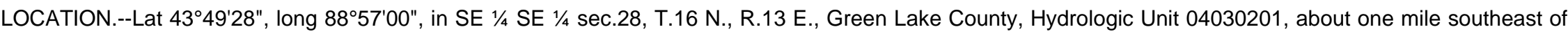
the City of Green Lake.

SURFACE AREA.--11.48 $\mathrm{mi}^{2}$.

PERIOD OF RECORD.--May 2004 current year. Lake sampled by Wisconsin Department of Natural Resources prior to 2004.

REMARKS.--Water-quality analyses done by Wisconsin State Laboratory of Hygiene. A "*” indicates data that were collected by Mary Jane Bumby, Citizen Lake Monitoring Volunteer.

WATER-QUALITY DATA, APRIL 12 TO SEPTEMBER 28, 2011

(Milligrams per liter unless otherwise indicated)

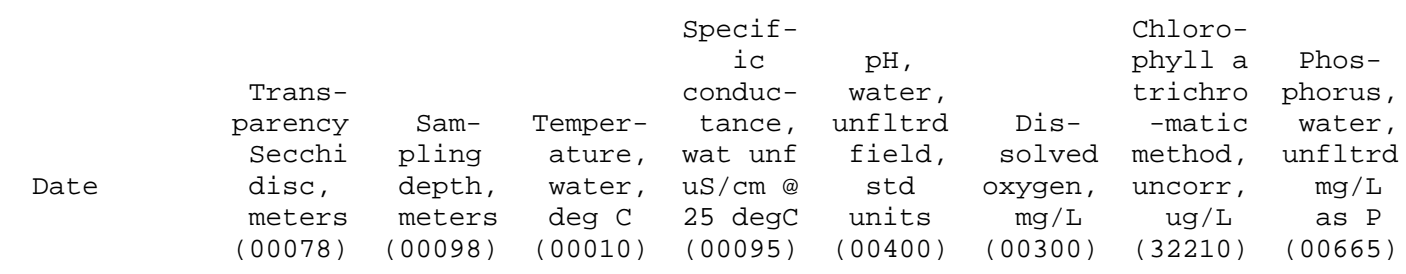

APR 2011

\begin{tabular}{|c|c|c|c|c|c|c|c|c|}
\hline $12 \ldots$ & 3.00 & - - & - - & - - & - - & - - & - & - - \\
\hline $12 \ldots$ & -- & .50 & 3.6 & 509 & 7.2 & 13.1 & 11.8 & .044 \\
\hline $12 \ldots$ & -- & 30.0 & 3.4 & 511 & 6.9 & 12.8 & -- & .045 \\
\hline \multicolumn{9}{|l|}{ UN } \\
\hline *03... & 1.20 & .10 & 13.3 & - - & - - & - - & - - & - - \\
\hline * $17 \ldots$ & 1.20 & .10 & 18.9 & - - & - - & - - & - - & - - \\
\hline * $25 \ldots$ & 2.40 & .10 & 20.0 & - - & -- & - - & - - & - \\
\hline $29 \ldots$ & 5.90 & - - & - - & - - & - - & - - & - - & - - \\
\hline $29 \ldots$ & - & .50 & 21.5 & 489 & 9.0 & 9.4 & 2.54 & .024 \\
\hline $29 \ldots$ & -- & 34.0 & 7.0 & 512 & 7.9 & .3 & - - & .060 \\
\hline \multicolumn{9}{|l|}{ JUL } \\
\hline *03... & 6.10 & .10 & 24.4 & - - & - - & - - & - - & - - \\
\hline$* 14 \ldots$ & 3.70 & .10 & 24.4 & -- & - - & - - & - - & -- \\
\hline * $24 \ldots$ & 5.80 & .10 & 27.8 & - - & - - & - - & - - & - - \\
\hline $25 \ldots$ & 5.40 & - - & -- & - - & -- & - & - - & - \\
\hline $25 \ldots$ & -- & .50 & 27.6 & 493 & 8.9 & 8.6 & 3.52 & .015 \\
\hline $25 \ldots$ & - - & 31.5 & 6.2 & 520 & 8.0 & 8.0 & - & .058 \\
\hline \multicolumn{9}{|c|}{ AUG } \\
\hline${ }^{*} 01 \ldots$ & 4.60 & .10 & 28.9 & - - & - - & - - & - - & - - \\
\hline *15... & 4.90 & .10 & 25.0 & - - & - - & - & - - & - \\
\hline $18 \ldots$ & 4.85 & - - & - - & - - & -- & - - & -- & - - \\
\hline $18 \ldots$ & -- & .50 & 25.2 & 488 & 8.8 & 9.0 & 3.14 & .012 \\
\hline $18 \ldots$ & -- & 15.0 & 12.0 & 518 & 7.9 & 2.3 & - & .013 \\
\hline $18 \ldots$ & - - & 31.0 & 6.1 & 523 & 7.9 & 7.0 & - - & .082 \\
\hline *20.. . & 4.30 & .10 & 26.7 & - - & - - & - - & - - & - - \\
\hline
\end{tabular}


434928088570000 GREEN LAKE AT EAST END NEAR GREEN LAKE, WI

WATER-QUALITY DATA, APRIL 12 TO SEPTEMBER 28, 2011

(Milligrams per liter unless otherwise indicated)

\begin{tabular}{|c|c|c|c|c|c|c|c|c|}
\hline${ }^{\star} 01 \ldots$ & 5.00 & 10 & 24.4 & - - & - - & - - & - - & - - \\
\hline$* 10 \ldots$ & 4.10 & .10 & 22.8 & - - & - - & - - & - - & - - \\
\hline * $24 \ldots$ & 4.30 & .10 & 17.8 & - - & - - & - - & - - & - - \\
\hline $28 \ldots$ & 4.95 & - - & - - & - - & - - & - - & - - & - - \\
\hline $28 \ldots$ & - - & .50 & 16.6 & 492 & 8.6 & 9.0 & 7.14 & .015 \\
\hline $28 \ldots$ & - - & 23.0 & 8.5 & 516 & 7.9 & 4.5 & - - & .022 \\
\hline $28 \ldots$ & - - & 31.5 & 6.1 & 518 & 7.9 & 3.4 & - - & .073 \\
\hline
\end{tabular}


434928088570000 GREEN LAKE AT EAST END NEAR GREEN LAKE, WI

LAKE-DEPTH PROFILES, APRIL 12 TO SEPTEMBER 28, 2011

$04-12-11$

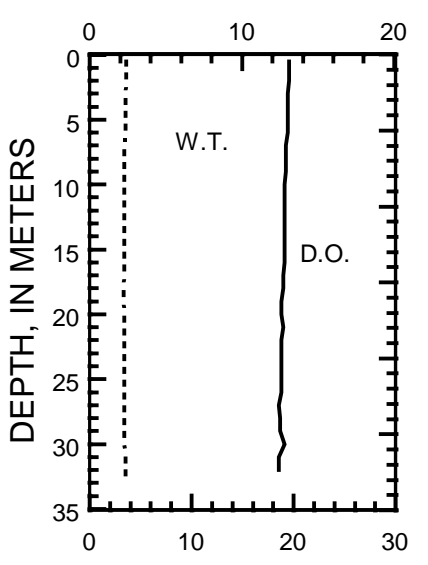

06-29-11

DSOLVED OXYGEN (D.O.), IN MILLIGRAMS PER LITER
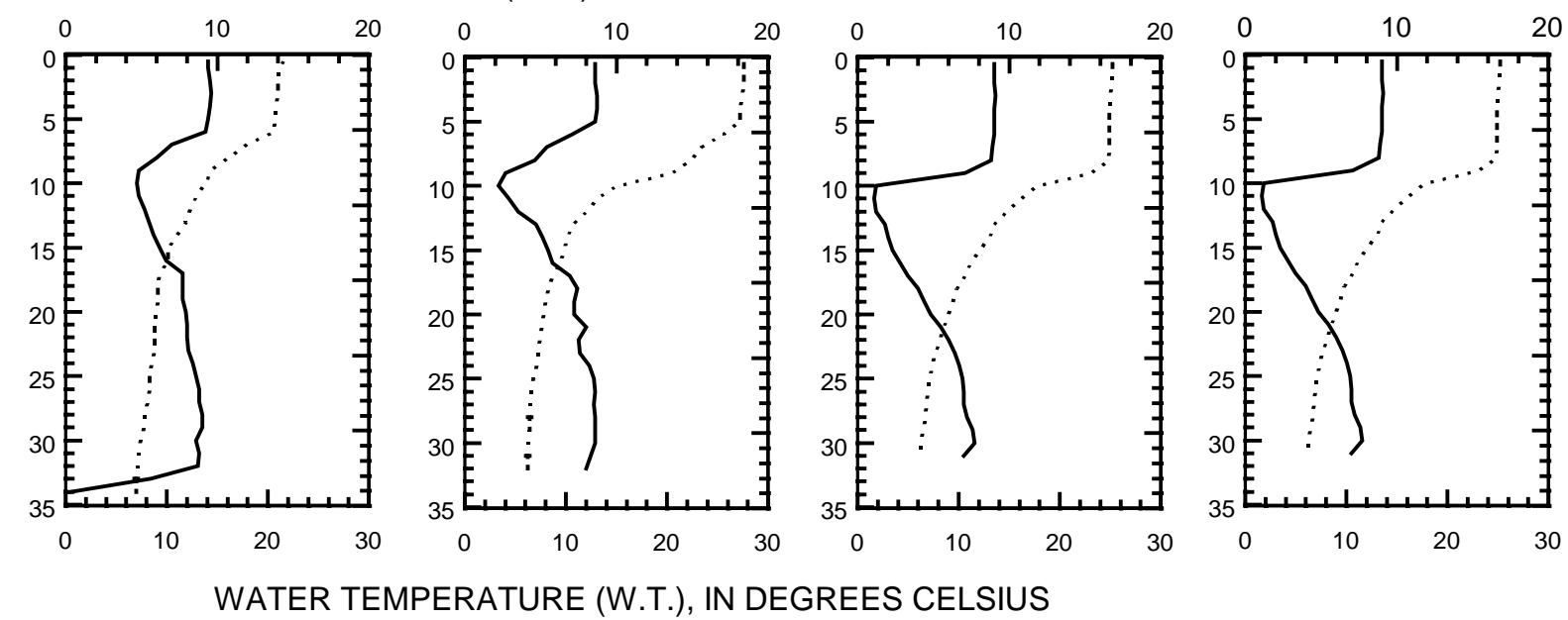

PH, IN STANDARD UNITS
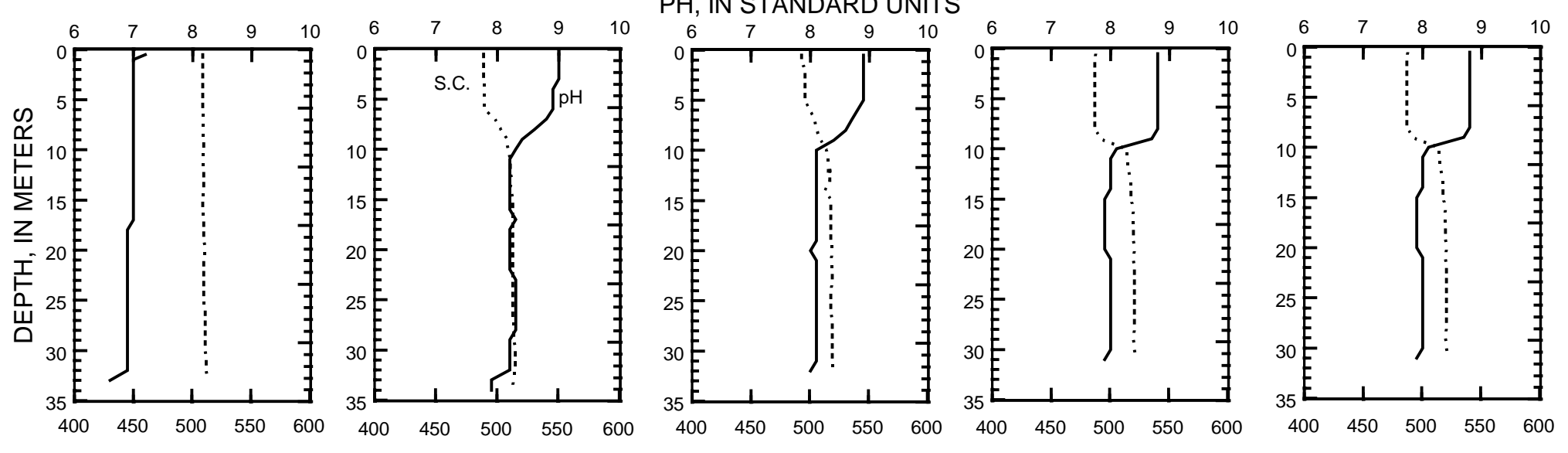

SPECIFIC CONDUCTANCE (S.C.), IN MICROSIEMENS PER CENTIMETER AT 25 DEGREES CELSIUS 

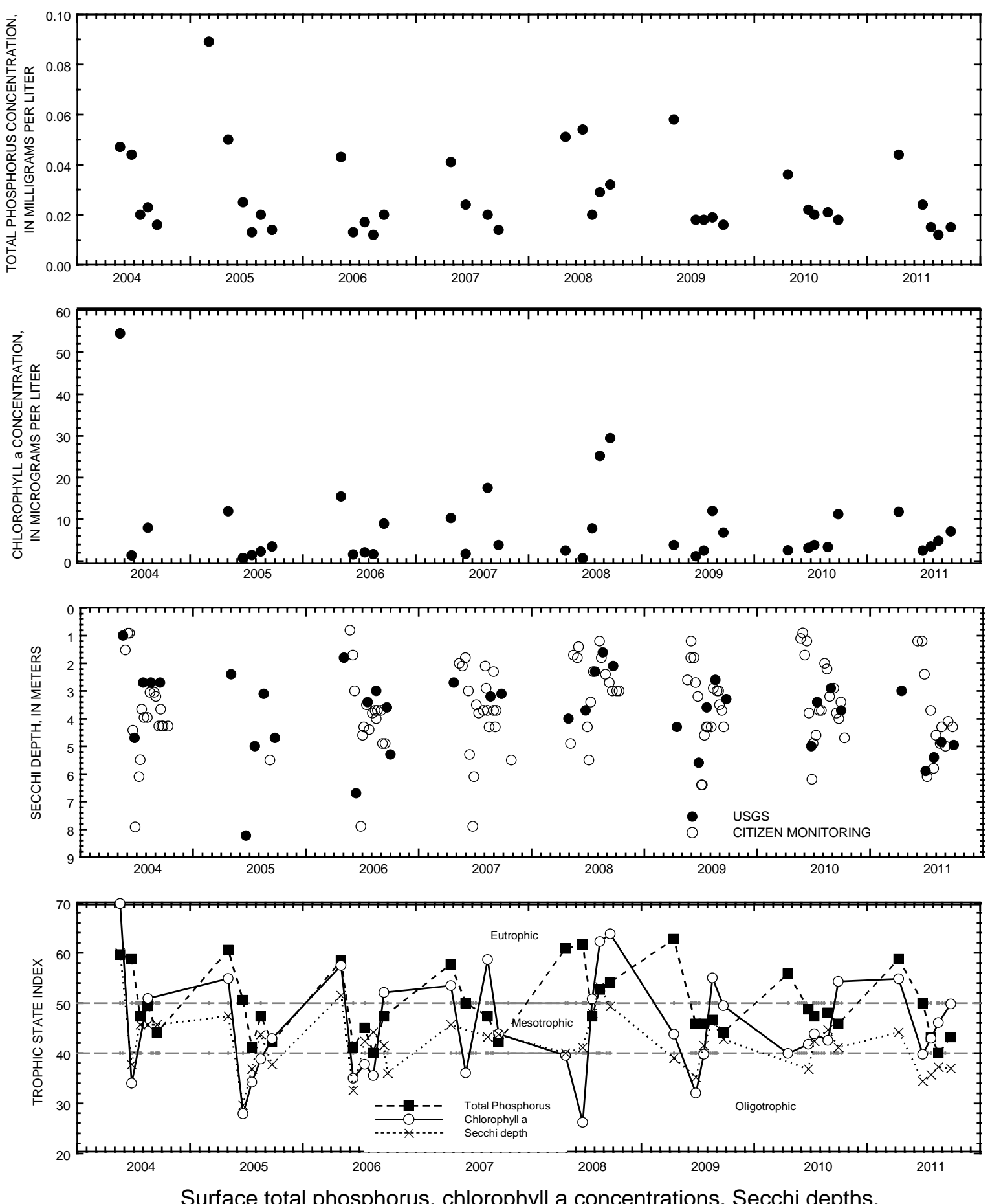

Surface total phosphorus, chlorophyll a concentrations, Secchi depths, and TSI data for Green Lake, East End, near Green Lake, Wisconsin. 


\section{GREEN LAKE INLET, SITE 1, NEAR GREEN LAKE, W}

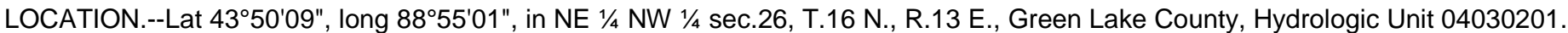

PERIOD OF RECORD.--May 2006 to current year.

REMARKS.--Water-quality analyses done by Wisconsin State Laboratory of Hygiene.

WATER-QUALITY DATA, APRIL 12 TO SEPTEMBER 28, 2011

(Milligrams per liter unless otherwise indicated)

\begin{tabular}{|c|c|c|c|c|c|c|c|}
\hline Date & $\begin{array}{c}\text { Trans- } \\
\text { parency } \\
\text { Secchi } \\
\text { disc, } \\
\text { meters } \\
(0 \odot \odot 78)\end{array}$ & $\begin{array}{c}\text { Sam- } \\
\text { pling } \\
\text { depth, } \\
\text { meters } \\
(00098)\end{array}$ & $\begin{array}{c}\text { Temper - } \\
\text { ature, } \\
\text { water, } \\
\text { deg C } \\
(00010)\end{array}$ & $\begin{array}{c}\text { Specif- } \\
\text { ic } \\
\text { conduc- } \\
\text { tance, } \\
\text { wat unf } \\
\text { us/cm @ } \\
25 \text { degC } \\
(00095)\end{array}$ & $\begin{array}{c}\text { pH, } \\
\text { water, } \\
\text { unfltrd } \\
\text { field, } \\
\text { std } \\
\text { units } \\
(0 \odot 40 \odot)\end{array}$ & $\begin{array}{c}\text { Dis- } \\
\text { solved } \\
\text { oxygen, } \\
\text { mg/L } \\
(00300)\end{array}$ & $\begin{array}{c}\text { Phos- } \\
\text { phorus, } \\
\text { water, } \\
\text { unfltrd } \\
\text { mg/L } \\
\text { as P } \\
(00665)\end{array}$ \\
\hline
\end{tabular}

APR 2011

$12 \ldots$

$>1.00$

JUN

29...

29...

JUL

$25 \ldots$

AUG

$18 \ldots$

18 .

28.

$28 \ldots$

$$
1.00
$$

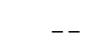

$$
10
$$

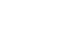

.50

--

.80

$>.80$

$\begin{array}{lrr}-- & -- & -- \\ .50 & 12.1 & 656 \\ -- & -- & -- \\ .10 & 25.5 & 698 \\ -- & -- & -- \\ .10 & 29.1 & 702 \\ -- & -- & -- \\ .10 & 24.4 & 813 \\ -- & -- & -- \\ .10 & 15.6 & 646\end{array}$

$\begin{array}{rrc}-- & -- & -- \\ 8.0 & 12.1 & .082 \\ -- & -- & -- \\ 8.4 & 10.6 & .113 \\ -- & -- & -- \\ 8.5 & 12.8 & .196 \\ -- & -- & -- \\ 7.9 & 4.3 & .112 \\ -- & -- & -- \\ 8.1 & 10.9 & .093\end{array}$




\section{GREEN LAKE INLET, SITE 2, NEAR GREEN LAKE, WI}

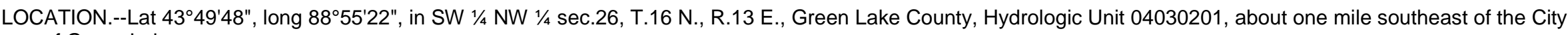
of Green Lake.

PERIOD OF RECORD.--May 2006 to current year.

REMARKS.--Water-quality analyses done by Wisconsin State Laboratory of Hygiene.

\section{WATER-QUALITY DATA APRIL 12 TO SEPTEMBER 28, 2011}

(Milligrams per liter unless otherwise indicated)

\begin{tabular}{|c|c|c|c|c|c|c|c|}
\hline Date & $\begin{array}{c}\text { Trans- } \\
\text { parency } \\
\text { Secchi } \\
\text { disc, } \\
\text { meters } \\
(\odot \odot \odot 78)\end{array}$ & $\begin{array}{c}\text { Sam- } \\
\text { pling } \\
\text { depth, } \\
\text { meters } \\
(0 \odot 098)\end{array}$ & $\begin{array}{c}\text { Temper - } \\
\text { ature, } \\
\text { water, } \\
\text { deg C } \\
(00010)\end{array}$ & $\begin{array}{c}\text { Specif- } \\
\text { ic } \\
\text { conduc- } \\
\text { tance, } \\
\text { wat unf } \\
\text { us/cm @ } \\
25 \text { degc } \\
(\odot \odot \odot 95)\end{array}$ & $\begin{array}{c}\text { pH, } \\
\text { water, } \\
\text { unfltrd } \\
\text { field, } \\
\text { std } \\
\text { units } \\
(\odot \odot 4 \odot \odot)\end{array}$ & $\begin{array}{c}\text { Dis- } \\
\text { solved } \\
\text { oxygen, } \\
\text { mg/L } \\
(\odot \odot 3 \odot \odot)\end{array}$ & $\begin{array}{c}\text { Phos- } \\
\text { phorus, } \\
\text { water, } \\
\text { unfltrd } \\
\text { mg/L } \\
\text { as } P \\
(00665)\end{array}$ \\
\hline
\end{tabular}

APR 2011

\begin{tabular}{|c|c|c|c|c|c|c|c|}
\hline $12 \ldots$ & .80 & -- & - - & -- & -- & -- & -- \\
\hline $12 \ldots$ & -- & .50 & 14.1 & 629 & 7.6 & 10.1 & .077 \\
\hline \multicolumn{8}{|l|}{ JUN } \\
\hline $29 \ldots$ & .50 & -- & - - & - - & - - & - - & - - \\
\hline $29 \ldots$ & -- & .10 & 25.8 & 698 & 8.4 & 9.6 & .121 \\
\hline \multicolumn{8}{|l|}{ JUL } \\
\hline $25 \ldots$ & 1.10 & -- & - - & - - & -- & - - & -- \\
\hline $25 \ldots$ & -- & .10 & 28.6 & 636 & 8.5 & 11.9 & .225 \\
\hline \multicolumn{8}{|l|}{ AUG } \\
\hline $18 \ldots$ & $>.90$ & -- & -- & -- & -- & -- & -- \\
\hline $18 \ldots$ & -- & .10 & 24.1 & 805 & 7.9 & 4.2 & .115 \\
\hline \multicolumn{8}{|l|}{ SEP } \\
\hline $28 \ldots$ & $>.80$ & -- & -- & - - & -- & - - & -- \\
\hline $28 \ldots$ & - - & .10 & 15.6 & 652 & 8.1 & 10.5 & .088 \\
\hline
\end{tabular}




\section{LAKE KEGONSA AT BARBER DRIVE NEAR STOUGHTON, WI}

LOCATION.--Lat 4257'15", long 89¹6'47" referenced to North American Datum of 1927, in SW 1/4 NE 1/4 NE 1/4 Sec.26, T.6 N., R.10 E.,

Dane County, WI, Hydrologic Unit 07090001, on downstream side of bridge on Barber Drive, 3.5 mi northwest of Stoughton.

SURFACE AREA.--1.05 $\mathrm{mi}^{2}$.

DRAINAGE AREA.--386 $\mathrm{mi}^{2}$.

PERIOD OF RECORD.--October 2003 to current year.

GAGE.--Water-stage recorder. Datum of gage is $840.00 \mathrm{ft}$ above sea level (levels from Wisconsin Department of Transportation benchmark).

EXTREMES FOR PERIOD OF RECORD.--Maximum gage height observed, $5.73 \mathrm{ft}$, June 16, 2008; minimum observed, $2.07 \mathrm{ft}$, Jan.27, 2006.

EXTREMES FOR CURRENT YEAR.--Maximum gage height observed, 3.63 ft, Sept. 30; minimum observed, $2.30 \mathrm{ft}$, Feb. 13.

GAGE HEIGHT, FEET

WATER YEAR OCTOBER 2010 TO SEPTEMBER 2011

DAILY MEAN VALUES

[e, estimated]

\begin{tabular}{|c|c|c|c|c|c|c|c|c|c|c|c|c|}
\hline Day & Oct & Nov & Dec & Jan & Feb & Mar & Apr & May & Jun & Jul & Aug & Sep \\
\hline 1 & 2.91 & 3.39 & 2.84 & 2.92 & 2.36 & 2.72 & 3.21 & 3.33 & 3.30 & 3.22 & 3.15 & 3.21 \\
\hline 2 & 2.91 & 3.35 & 2.89 & 2.89 & 2.49 & 2.71 & 3.19 & 3.30 & 3.30 & 3.24 & 3.15 & 3.22 \\
\hline 3 & 2.89 & 3.30 & 2.92 & 2.91 & 2.42 & 2.70 & 3.17 & 3.29 & 3.27 & 3.25 & 3.15 & 3.31 \\
\hline 4 & 2.88 & 3.27 & 2.92 & 2.90 & 2.41 & 2.70 & 3.16 & 3.26 & 3.28 & 3.25 & 3.13 & 3.36 \\
\hline 5 & 2.89 & 3.22 & 2.91 & 2.89 & 2.40 & 2.72 & 3.14 & 3.22 & 3.27 & 3.26 & 3.12 & 3.37 \\
\hline 6 & 2.89 & 3.18 & 2.88 & 2.86 & 2.40 & 2.72 & 3.13 & 3.21 & 3.26 & 3.27 & 3.11 & 3.36 \\
\hline 7 & 2.90 & 3.13 & 2.85 & 2.84 & 2.39 & 2.72 & 3.10 & 3.20 & 3.26 & 3.26 & 3.11 & 3.36 \\
\hline 8 & 2.90 & 3.10 & 2.84 & 2.78 & 2.39 & 2.71 & 3.09 & 3.18 & 3.25 & 3.25 & 3.11 & e3.38 \\
\hline 9 & 2.92 & 3.07 & 2.85 & 2.76 & 2.38 & 2.74 & 3.06 & 3.17 & 3.29 & 3.24 & 3.09 & 3.39 \\
\hline 10 & 2.94 & 3.04 & 2.86 & 2.74 & 2.39 & 2.75 & 3.04 & 3.14 & 3.31 & 3.22 & 3.07 & 3.39 \\
\hline 11 & 2.97 & 3.02 & 2.88 & 2.73 & 2.37 & 2.75 & 3.03 & 3.14 & 3.32 & 3.28 & 3.05 & 3.41 \\
\hline 12 & 2.99 & 3.02 & 2.94 & 2.71 & 2.36 & 2.76 & 3.03 & 3.17 & 3.32 & 3.30 & 3.03 & 3.41 \\
\hline 13 & 3.01 & 3.01 & 2.94 & 2.69 & 2.35 & 2.77 & 3.02 & 3.19 & 3.30 & 3.27 & 3.03 & 3.40 \\
\hline 14 & 3.02 & 2.98 & 2.96 & 2.66 & 2.35 & 2.78 & 3.04 & 3.24 & 3.29 & 3.24 & 3.03 & 3.38 \\
\hline 15 & 3.04 & 2.97 & 2.97 & 2.65 & 2.35 & 2.78 & 3.07 & 3.26 & 3.28 & 3.21 & 3.01 & 3.36 \\
\hline 16 & 3.06 & 2.96 & 2.98 & 2.62 & 2.35 & 2.79 & 3.00 & 3.22 & 3.28 & 3.19 & 3.01 & 3.35 \\
\hline 17 & 3.08 & 2.97 & 2.99 & 2.61 & 2.40 & 2.80 & 2.99 & 3.21 & 3.28 & 3.17 & 3.01 & 3.35 \\
\hline 18 & 3.10 & 2.96 & 2.99 & 2.61 & 2.45 & 2.84 & 3.01 & 3.20 & 3.27 & 3.15 & 3.01 & 3.34 \\
\hline 19 & 3.11 & 2.94 & 2.98 & 2.58 & 2.52 & 2.84 & 3.04 & 3.22 & 3.26 & 3.15 & 3.02 & 3.38 \\
\hline 20 & 3.11 & 2.94 & 2.97 & 2.56 & 2.62 & 2.92 & 3.07 & 3.24 & 3.26 & 3.12 & 3.05 & 3.38 \\
\hline 21 & 3.12 & 2.91 & 2.98 & 2.52 & 2.73 & 3.04 & 3.10 & 3.26 & 3.24 & 3.08 & 3.06 & 3.37 \\
\hline 22 & 3.12 & 2.91 & 2.97 & 2.51 & 2.75 & 3.13 & 3.14 & 3.26 & 3.22 & 3.06 & 3.06 & 3.37 \\
\hline 23 & 3.14 & 2.89 & 2.96 & 2.50 & 2.76 & 3.27 & 3.18 & 3.27 & 3.22 & 3.05 & 3.12 & 3.37 \\
\hline 24 & 3.27 & 2.90 & 2.95 & 2.47 & 2.76 & 3.34 & 3.22 & 3.28 & 3.22 & 3.03 & 3.15 & 3.37 \\
\hline 25 & 3.31 & 2.89 & 2.95 & 2.44 & 2.75 & 3.38 & 3.24 & 3.32 & 3.23 & 3.01 & 3.16 & 3.38 \\
\hline 26 & 3.40 & 2.88 & 2.93 & 2.42 & 2.75 & 3.39 & 3.28 & 3.33 & 3.23 & 2.99 & 3.17 & 3.48 \\
\hline 27 & 3.42 & 2.87 & 2.92 & 2.41 & 2.74 & 3.38 & 3.33 & 3.31 & 3.22 & 3.02 & 3.18 & 3.53 \\
\hline 28 & 3.44 & 2.87 & 2.90 & 2.40 & 2.73 & 3.35 & 3.35 & 3.30 & 3.21 & 3.14 & 3.19 & 3.55 \\
\hline 29 & 3.45 & 2.86 & 2.89 & 2.39 & --- & 3.31 & 3.37 & 3.31 & 3.22 & 3.16 & 3.18 & 3.55 \\
\hline 30 & 3.44 & 2.85 & 2.88 & 2.38 & --- & 3.28 & 3.36 & 3.32 & 3.23 & 3.16 & 3.18 & 3.58 \\
\hline 31 & 3.43 & --- & 2.89 & 2.37 & --- & 3.24 & --- & 3.31 & --- & 3.16 & 3.20 & --- \\
\hline Mean & 3.10 & 3.02 & 2.92 & 2.64 & 2.50 & 2.95 & 3.14 & 3.25 & 3.26 & 3.17 & 3.10 & 3.39 \\
\hline Max & 3.45 & 3.39 & 2.99 & 2.92 & 2.76 & 3.39 & 3.37 & 3.33 & 3.32 & 3.30 & 3.20 & 3.58 \\
\hline Min & 2.88 & 2.85 & 2.84 & 2.37 & 2.35 & 2.70 & 2.99 & 3.14 & 3.21 & 2.99 & 3.01 & 3.21 \\
\hline
\end{tabular}




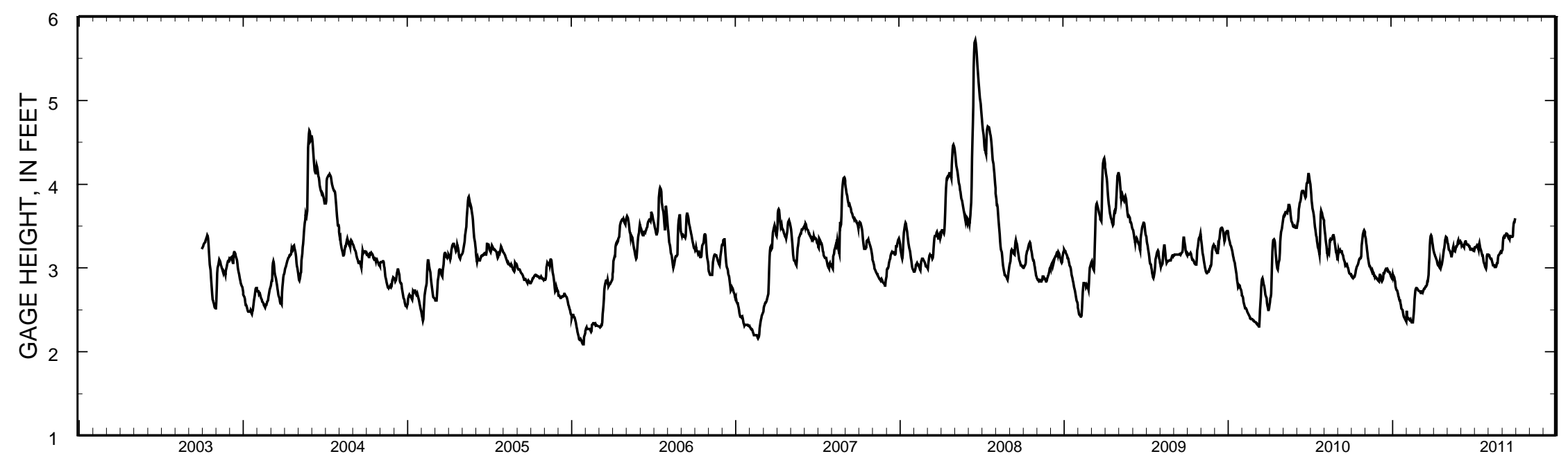

Stage hydrograph for Lake Kegonsa, 1993-2011. 


\section{LAKE KOSHKONONG NEAR NEWVILLE, WI}

LOCATION.--Lat 42 51 '27", long 8856'27" referenced to North American Datum of 1927, in NW $1 / 4$ NE $1 / 4$ sec.34, T.5 N., R.13 E., Jefferson County, WI, Hydrologic Unit 07090001, $80 \mathrm{ft}$ east of Pottawatomi Trail Bridge at Bingham Point Estates, and $4.5 \mathrm{mi}$ northeast of Newville.

SURFACE AREA.-16.34 $\mathrm{mi}^{2}$.

DRAINAGE AREA.--2,560 $\mathrm{mi}^{2}$.

PERIOD OF RECORD.--July 1987 to current year.

GAGE.--Water-stage recorder. Datum of gage is $769.77 \mathrm{ft}$ above NAVD of 1988 (Wisconsin Department of Transportation bench mark).

REMARKS.--Lake level regulated by dam at Indianford. Gage-height telemeter at station.

EXTREMES FOR PERIOD OF RECORD.--Maximum recorded gage height, $15.13 \mathrm{ft}$, June 21, 22, 2008; minimum recorded, $5.06 \mathrm{ft}$, Feb. 22, 2007

EXTREMES FOR CURRENT YEAR.--Maximum recorded gage height, 10.09 ft, Mar. 30; minimum recorded gage height, $5.93 \mathrm{ft}$, Sept. 18.

GAGE HEIGHT, FEET

WATER YEAR OCTOBER 2010 TO SEPTEMBER 2011

DAILY MEAN VALUES

[e, estimated]

\begin{tabular}{|c|c|c|c|c|c|c|c|c|c|c|c|c|}
\hline Day & Oct & Nov & Dec & Jan & Feb & Mar & Apr & May & Jun & Jul & Aug & Sep \\
\hline 1 & 6.43 & 7.04 & 6.69 & 6.39 & 6.30 & 7.77 & 10.04 & 9.49 & 7.62 & 6.70 & 6.26 & 6.13 \\
\hline 2 & 6.40 & 7.08 & 6.69 & 6.53 & 6.34 & 7.75 & 10.01 & 9.48 & 7.49 & 6.70 & 6.23 & 6.12 \\
\hline 3 & 6.32 & 7.11 & 6.68 & 6.63 & 6.35 & 7.73 & 9.95 & 9.45 & 7.38 & 6.65 & 6.21 & 6.14 \\
\hline 4 & 6.28 & 7.14 & 6.68 & 6.71 & 6.32 & 7.70 & 9.94 & 9.41 & 7.27 & 6.58 & 6.16 & 6.17 \\
\hline 5 & 6.25 & 7.12 & 6.67 & 6.77 & 6.30 & 7.71 & 9.88 & 9.34 & 7.16 & 6.53 & 6.17 & 6.13 \\
\hline 6 & 6.23 & 7.09 & 6.65 & 6.81 & 6.28 & 7.71 & 9.84 & 9.32 & 7.03 & 6.46 & 6.19 & 6.10 \\
\hline 7 & 6.21 & 7.06 & 6.62 & 6.83 & 6.27 & 7.72 & 9.81 & 9.25 & 6.89 & 6.39 & 6.20 & 6.10 \\
\hline 8 & 6.19 & 7.04 & 6.60 & 6.82 & 6.27 & 7.72 & 9.79 & 9.18 & e6.80 & 6.33 & 6.21 & 6.08 \\
\hline 9 & 6.16 & 7.01 & 6.58 & 6.80 & 6.27 & 7.76 & 9.76 & 9.08 & e6.85 & 6.27 & 6.28 & 6.06 \\
\hline 10 & 6.15 & 6.97 & 6.57 & 6.77 & 6.27 & 7.79 & 9.74 & 9.01 & e6.82 & 6.22 & 6.27 & 6.06 \\
\hline 11 & 6.12 & 6.94 & 6.57 & 6.73 & 6.27 & 7.84 & 9.75 & 8.93 & e6.78 & 6.26 & 6.25 & 6.07 \\
\hline 12 & 6.10 & 6.89 & 6.61 & 6.70 & 6.28 & 7.91 & 9.71 & 8.89 & e6.73 & 6.25 & 6.24 & 6.06 \\
\hline 13 & 6.10 & 6.81 & 6.58 & 6.66 & 6.29 & 7.98 & 9.67 & 8.85 & e6.68 & 6.19 & 6.28 & 6.07 \\
\hline 14 & 6.06 & 6.79 & 6.54 & 6.62 & 6.31 & 8.04 & 9.61 & 8.82 & e6.64 & 6.13 & 6.30 & 6.05 \\
\hline 15 & 6.13 & 6.75 & 6.51 & 6.59 & 6.32 & 8.11 & 9.51 & 8.74 & e6.59 & 6.12 & 6.29 & 6.01 \\
\hline 16 & 6.20 & 6.73 & 6.49 & 6.54 & 6.34 & 8.19 & 9.47 & 8.63 & e6.55 & 6.16 & 6.29 & 5.98 \\
\hline 17 & 6.28 & 6.71 & 6.47 & 6.52 & 6.39 & 8.25 & 9.43 & 8.54 & 6.52 & 6.18 & 6.29 & 5.96 \\
\hline 18 & 6.33 & 6.68 & 6.45 & 6.49 & 6.53 & 8.32 & 9.37 & 8.45 & 6.48 & 6.21 & 6.30 & 5.96 \\
\hline 19 & 6.36 & 6.64 & 6.43 & 6.45 & 6.72 & 8.41 & 9.33 & 8.38 & 6.44 & 6.21 & 6.29 & 6.00 \\
\hline 20 & 6.37 & 6.62 & 6.41 & 6.42 & 6.95 & 8.55 & 9.32 & 8.30 & 6.42 & 6.21 & 6.30 & 5.99 \\
\hline 21 & 6.36 & 6.59 & 6.40 & 6.40 & 7.22 & 8.75 & 9.29 & 8.22 & 6.41 & 6.20 & 6.29 & 6.04 \\
\hline 22 & 6.33 & 6.62 & 6.37 & 6.38 & 7.41 & 8.96 & 9.28 & 8.13 & 6.43 & 6.21 & 6.26 & 6.07 \\
\hline 23 & 6.33 & 6.64 & 6.35 & 6.36 & 7.55 & 9.24 & 9.32 & 8.12 & 6.50 & 6.21 & 6.27 & 6.09 \\
\hline 24 & 6.42 & 6.58 & 6.34 & 6.34 & 7.65 & 9.49 & 9.33 & 8.03 & 6.53 & 6.21 & 6.32 & 6.11 \\
\hline 25 & 6.43 & 6.65 & 6.33 & 6.32 & 7.71 & 9.70 & 9.34 & 7.97 & 6.57 & 6.20 & 6.29 & 6.14 \\
\hline 26 & 6.49 & 6.63 & 6.31 & 6.31 & 7.75 & 9.88 & 9.36 & 7.92 & 6.62 & 6.18 & 6.26 & 6.23 \\
\hline 27 & 6.61 & 6.62 & 6.29 & 6.30 & 7.77 & 9.98 & 9.41 & 7.83 & 6.67 & 6.24 & 6.24 & 6.29 \\
\hline 28 & 6.70 & 6.60 & 6.27 & 6.30 & 7.77 & 10.04 & 9.44 & 7.78 & 6.72 & 6.37 & 6.21 & 6.31 \\
\hline 29 & 6.77 & 6.59 & 6.24 & 6.29 & --- & 10.07 & 9.46 & 7.75 & 6.72 & 6.36 & 6.18 & 6.40 \\
\hline 30 & 6.90 & 6.64 & 6.23 & 6.29 & --- & 10.07 & 9.45 & 7.70 & 6.71 & 6.31 & 6.15 & 6.43 \\
\hline 31 & 6.99 & --- & 6.27 & 6.29 & --- & 10.06 & --- & 7.65 & --- & 6.28 & 6.15 & --- \\
\hline Mean & 6.35 & 6.81 & 6.48 & 6.53 & 6.72 & 8.55 & 9.59 & 8.60 & 6.77 & 6.31 & 6.25 & 6.11 \\
\hline Max & 6.99 & 7.14 & 6.69 & 6.83 & 7.77 & 10.07 & 10.04 & 9.49 & 7.62 & 6.70 & 6.32 & 6.43 \\
\hline Min & 6.06 & 6.58 & 6.23 & 6.29 & 6.27 & 7.70 & 9.28 & 7.65 & 6.41 & 6.12 & 6.15 & 5.96 \\
\hline
\end{tabular}




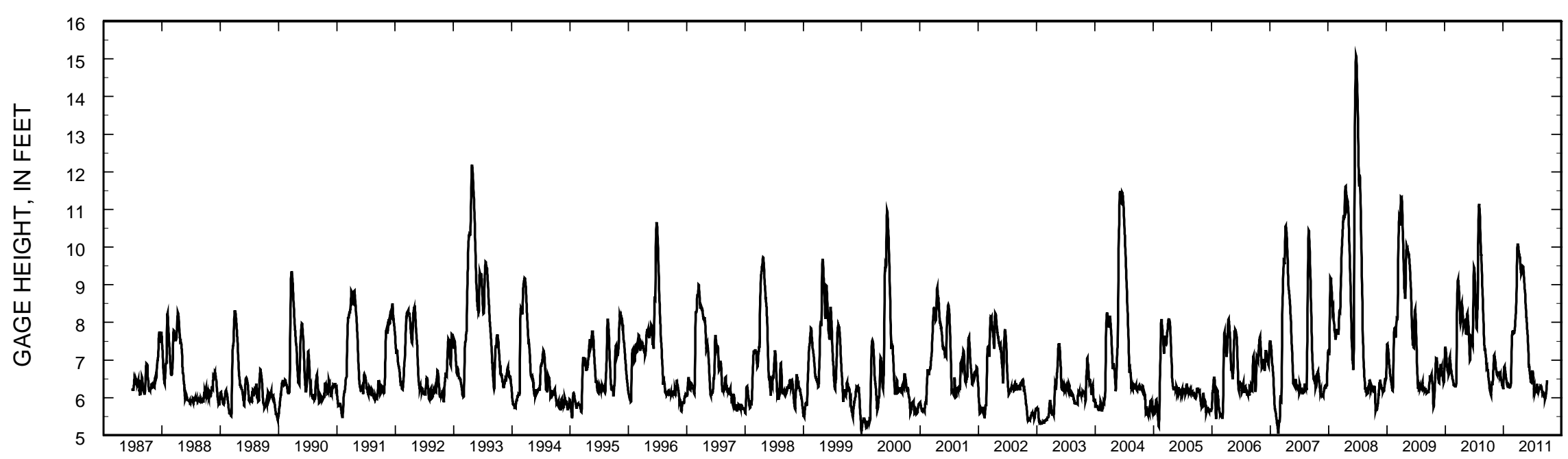

Stage hydrograph for Lake Koshkonong, 1987-2011. 


\section{LAKE MENDOTA AT MADISON, WI}

LOCATION.--Lat 4305'42", long 89²2'12" referenced to North American Datum of 1927, in NW 1/4 SE 1/4 sec.12, T.7 N., R.9 E., Dane County, WI, Hydrologic Unit 07090001, in county boat house at dam at outlet, in Madison.

SURFACE AREA.-15.2 $\mathrm{mi}^{2}$.

DRAINAGE AREA.--233 $\mathrm{mi}^{2}$ of which $36.6 \mathrm{mi}^{2}$ probably is noncontributing.

PERIOD OF RECORD.--January 1916 to January 1985 (incomplete), February 1985 to current year.

REVISED RECORDS.--WDR WI-73-1: Drainage area.

GAGE.--Water-stage recorder. Datum of gage is $840.00 \mathrm{ft}$ above NGVD of 1929, or $5.60 \mathrm{ft}$ below City of Madison datum. Prior to Oct. 1, 1979, gage datum was $847.82 \mathrm{ft}$; prior to Nov. 15, 1971, nonrecording gage at same site.

REMARKS.--Lake level regulated by concrete dam with two 12-foot gates and 20-foot lock at outlet. Gage-height telemeter at station.

EXTREMES FOR PERIOD OF RECORD.--Maximum gage height observed, $12.75 \mathrm{ft}$, June 5, 2000; minimum observed, $8.02 \mathrm{ft}$, Feb. 24 to Mar. 10, 1920, current datum.

EXTREMES FOR CURRENT YEAR.--Maximum recorded gage height, $10.71 \mathrm{ft}$, Oct. 1; minimum recorded, $8.39 \mathrm{ft}$, Dec. 30.

GAGE HEIGHT, FEET

WATER YEAR OCTOBER 2010 TO SEPTEMBER 2011

DAILY MEAN VALUES

[e, estimated]

\begin{tabular}{|c|c|c|c|c|c|c|c|c|c|c|c|c|}
\hline Day & Oct & Nov & Dec & Jan & Feb & Mar & Apr & May & Jun & Jul & Aug & Sep \\
\hline 1 & 10.68 & 9.72 & 8.94 & 8.49 & 8.57 & 8.90 & 9.77 & 10.13 & 9.79 & 9.91 & 9.88 & 9.85 \\
\hline 2 & 10.63 & 9.70 & 8.88 & 8.51 & 8.62 & 8.90 & 9.78 & e10.10 & 9.74 & 9.93 & 9.87 & 9.86 \\
\hline 3 & 10.56 & 9.68 & 8.83 & 8.52 & 8.60 & 8.89 & e9.79 & e10.07 & 9.72 & 9.92 & 9.87 & e9.92 \\
\hline 4 & 10.51 & 9.66 & 8.82 & 8.53 & 8.60 & 8.89 & e9.91 & e10.04 & 9.73 & 9.91 & 9.85 & e9.92 \\
\hline 5 & 10.46 & 9.62 & 8.80 & 8.53 & 8.60 & 8.92 & e9.94 & e10.00 & 9.72 & 9.90 & 9.84 & e9.88 \\
\hline 6 & 10.42 & 9.57 & 8.75 & 8.53 & 8.61 & 8.92 & e9.91 & 9.99 & 9.71 & 9.89 & 9.83 & e9.87 \\
\hline 7 & 10.38 & 9.53 & 8.69 & 8.53 & 8.61 & 8.92 & e9.93 & 9.96 & 9.72 & 9.87 & 9.87 & e9.86 \\
\hline 8 & 10.33 & 9.50 & 8.63 & 8.53 & 8.60 & 8.93 & e9.91 & 9.95 & 9.72 & 9.86 & 9.88 & e9.84 \\
\hline 9 & 10.29 & 9.48 & 8.61 & 8.52 & 8.60 & 8.96 & e9.91 & e9.92 & 9.78 & 9.84 & 9.88 & e9.84 \\
\hline 10 & 10.25 & 9.45 & 8.59 & 8.52 & 8.60 & 8.97 & e9.93 & e9.94 & 9.79 & 9.83 & 9.85 & e9.84 \\
\hline 11 & 10.20 & 9.43 & 8.58 & 8.53 & 8.59 & 8.97 & e9.94 & e9.94 & 9.79 & 9.83 & 9.83 & e9.85 \\
\hline 12 & 10.16 & 9.41 & e8.58 & 8.53 & 8.59 & 8.98 & e9.89 & e9.99 & 9.78 & 9.83 & 9.81 & e9.87 \\
\hline 13 & 10.12 & 9.39 & e8.59 & 8.52 & 8.59 & 8.99 & e9.88 & e9.97 & 9.76 & 9.80 & 9.86 & e9.80 \\
\hline 14 & 10.06 & 9.38 & e8.60 & 8.52 & 8.58 & 9.00 & e9.83 & e9.94 & 9.74 & 9.77 & 9.89 & e9.75 \\
\hline 15 & 10.0 & 9.35 & e8.60 & 8.53 & 8.58 & 9.00 & e9.85 & 9.91 & 9.74 & 9.76 & 9.89 & e9.72 \\
\hline 16 & 9.94 & 9.32 & 8.61 & 8.53 & 8.58 & 9.02 & 9.89 & 9.87 & 9.75 & 9.76 & 9.88 & e9.72 \\
\hline 17 & 9.90 & 9.31 & 8.59 & 8.54 & 8.59 & 9.04 & 9.87 & 9.84 & 9.75 & 9.77 & 9.88 & e9.71 \\
\hline 18 & 9.84 & 9.28 & 8.57 & 8.56 & 8.66 & 9.08 & 9.84 & 9.82 & 9.74 & 9.80 & 9.87 & e9.71 \\
\hline 19 & 9.79 & 9.23 & 8.55 & 8.56 & 8.75 & 9.11 & 9.87 & 9.81 & 9.80 & 9.80 & 9.86 & e9.73 \\
\hline 20 & 9.74 & 9.21 & 8.53 & 8.55 & 8.83 & 9.21 & 9.94 & 9.79 & 9.86 & 9.79 & 9.88 & e9.77 \\
\hline 21 & 9.69 & 9.17 & 8.53 & 8.55 & 8.92 & 9.38 & 9.94 & 9.77 & 9.88 & 9.79 & 9.88 & 9.77 \\
\hline 22 & 9.65 & 9.17 & 8.52 & 8.55 & 8.94 & 9.50 & 9.96 & 9.76 & 9.92 & 9.78 & 9.86 & 9.75 \\
\hline 23 & 9.64 & 9.15 & 8.50 & 8.54 & 8.94 & 9.66 & 10.01 & 9.76 & 9.96 & 9.79 & 9.88 & 9.74 \\
\hline 24 & 9.72 & 9.09 & 8.50 & 8.53 & 8.94 & 9.73 & 10.02 & 9.74 & 9.97 & 9.78 & 9.91 & 9.74 \\
\hline 25 & 9.74 & 9.13 & 8.49 & 8.53 & 8.93 & 9.76 & 10.01 & 9.80 & 9.96 & 9.77 & 9.89 & 9.74 \\
\hline 26 & 9.83 & 9.08 & 8.48 & 8.53 & 8.93 & 9.77 & 10.08 & 9.85 & 9.95 & 9.76 & 9.88 & 9.83 \\
\hline 27 & 9.87 & 9.04 & 8.46 & 8.53 & 8.93 & 9.77 & 10.15 & 9.84 & 9.95 & 9.81 & 9.88 & 9.90 \\
\hline 28 & 9.83 & 8.99 & 8.45 & 8.54 & 8.92 & 9.77 & 10.17 & 9.82 & 9.94 & 9.87 & 9.87 & 9.91 \\
\hline 29 & 9.78 & 8.97 & 8.43 & 8.53 & --- & 9.77 & 10.16 & 9.81 & 9.93 & 9.88 & 9.85 & 9.95 \\
\hline 30 & 9.76 & 8.97 & 8.43 & 8.54 & --- & 9.77 & 10.12 & 9.81 & 9.91 & 9.88 & 9.84 & 9.94 \\
\hline 31 & 9.74 & --- & 8.45 & 8.54 & --- & 9.77 & --- & 9.80 & --- & 9.88 & 9.85 & --- \\
\hline Mean & 10.05 & 9.33 & 8.60 & 8.53 & 8.71 & 9.23 & 9.94 & 9.89 & 9.82 & 9.83 & 9.87 & 9.82 \\
\hline Max & 10.68 & 9.72 & 8.94 & 8.56 & 8.94 & 9.77 & 10.17 & 10.13 & 9.97 & 9.93 & 9.91 & 9.95 \\
\hline Min & 9.64 & 8.97 & 8.43 & 8.49 & 8.57 & 8.89 & 9.77 & 9.74 & 9.71 & 9.76 & 9.81 & 9.71 \\
\hline
\end{tabular}




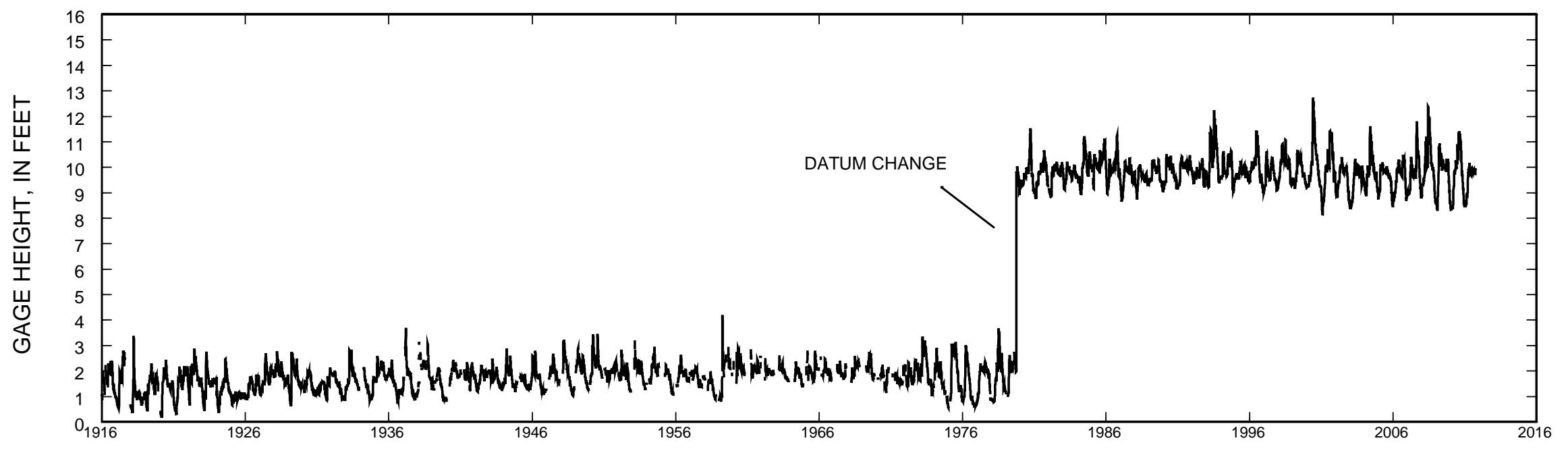

Stage hydrograph for Lake Mendota, 1916-2011.

64 


\section{MIDDLE GENESEE LAKE, AT GENESEE LAKE ROAD, NEAR OCONOMOWOC, WI}

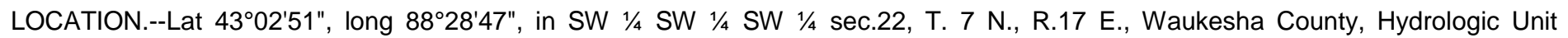
07090001 , at the southwest side of the lake about 2 miles south of Oconomowoc.

SURFACE AREA.--0.17 $\mathrm{mi}^{2}$.

DRAINAGE AREA.--Unknown.

PERIOD OF RECORD.--April 1996 to current year.

GAGE.--Staff gage. Local observer, Tom Schubring provided most readings of gage. Datum of gage is about $0.0 \mathrm{ft}$ above NGVD of 1929.

EXTREMES FOR THE PERIOD OF RECORD.--Maximum observed gage height, 869.65 ft, July 12, 2008; minimum observed, 863.88 ft, Oct. 31, 2005.

EXTREMES FOR CURRENT YEAR.--Maximum observed gage height, 867.48 ft, Oct. 3; minimum observed, 865.75 ft, Sept. 23.

GAGE HEIGHT, FT

WATER YEAR OCTOBER 2010 TO SEPTEMBER 2011

\begin{tabular}{|c|c|c|c|c|c|}
\hline Date & Gage Height, $\mathrm{ft}$ & Date & Gage Height, ft & Date & Gage Height, ft \\
\hline October 3 & 867.48 & May 18 & 867.07 & July 24 & 866.57 \\
\hline 10 & 867.40 & 23 & 867.11 & 31 & 866.59 \\
\hline 15 & 867.28 & 28 & 867.09 & August 1 & 866.59 \\
\hline 18 & 867.20 & 31 & 867.05 & 4 & 866.55 \\
\hline 21 & 867.14 & June 4 & 866.99 & 12 & 866.41 \\
\hline 24 & 867.22 & 7 & 866.97 & 18 & 866.35 \\
\hline 29 & 867.18 & 16 & 866.93 & 29 & 866.17 \\
\hline 31 & 867.12 & 19 & 866.89 & 31 & 866.15 \\
\hline November 2 & 867.10 & 21 & 866.87 & September 1 & 866.13 \\
\hline 7 & 867.02 & 25 & 866.93 & 10 & 865.97 \\
\hline 8 & 867.07 & 28 & 866.85 & 14 & 865.87 \\
\hline April 29 & 867.08 & July 5 & 866.75 & 21 & 865.79 \\
\hline 30 & 867.05 & 7 & 866.71 & 23 & 865.75 \\
\hline May 1 & 867.05 & 9 & 866.65 & 29 & 865.85 \\
\hline 5 & 867.03 & 11 & 866.71 & & \\
\hline 10 & 867.11 & 15 & 866.63 & & \\
\hline
\end{tabular}




\section{LAKE MONONA AT MADISON, WI}

LOCATION.--Lat 4303'48", long 89²3'49" referenced to North American Datum of 1927, in SE 1/4 SW 1/4 Sec.23, T.7 N., R.9 E., Dane County, WI, Hydrologic Unit 07090001, in Brittingham Park, in Madison.

SURFACE AREA.--5.3 $\mathrm{mi}^{2}$.

DRAINAGE AREA.--279 $\mathrm{mi}^{2}$ of which $36.6 \mathrm{mi}^{2}$ probably is noncontributing.

PERIOD OF RECORD.--September 1915 to current year (fragmentary) in reports of the Geological Survey. For 1856 to March 1917 in reports of Wisconsin Railroad Commission, volume 19.

REVISED RECORDS.--WSP 1338: Lake area. WDR WI-73-1: Drainage area.

GAGE.--Water-stage recorder. Datum of gage is $840.00 \mathrm{ft}$ above NGVD of 1929 , or $5.60 \mathrm{ft}$ below City of Madison datum. Prior to Oct. 1 , 1979, datum $843.61 \mathrm{ft}$; prior to Nov. 15, 1971, nonrecording gage at same site.

REMARKS.--Lake level regulated by concrete dam with four 12-foot stop-log sections and 12-foot lock at outlet of Lake Waubesa. Gage-height telemeter at station.

EXTREMES FOR PERIOD OF RECORD.--Maximum gage height observed, $7.92 \mathrm{ft}$, June 15, 2008; minimum observed, $3.22 \mathrm{ft}$, Jan. 20,1965 , current datum.

EXTREMES FOR CURRENT YEAR.--Maximum recorded gage height, 6.19 ft, Oct. 1, 2; minimum recorded, $4.31 \mathrm{ft}$, Feb. 1. 
GAGE HEIGHT, FEET

WATER YEAR OCTOBER 2010 TO SEPTEMBER 2011 DAILY MEAN VALUES

\begin{tabular}{|c|c|c|c|c|c|c|c|c|c|c|c|c|}
\hline \multicolumn{13}{|c|}{ [e, estimated] } \\
\hline Day & Oct & Nov & Dec & Jan & Feb & Mar & Apr & May & Jun & Jul & Aug & Sep \\
\hline 1 & 6.16 & 5.37 & 4.91 & 4.73 & e4.35 & 4.68 & 5.05 & 5.19 & 5.12 & 5.19 & 5.01 & 5.12 \\
\hline 2 & 6.15 & 5.32 & 4.92 & 4.72 & 4.39 & 4.66 & 5.03 & 5.16 & 5.14 & 5.17 & 5.01 & 5.12 \\
\hline 3 & 6.13 & 5.26 & 4.92 & 4.69 & 4.39 & 4.67 & 5.02 & 5.14 & 5.11 & 5.15 & 5.00 & 5.22 \\
\hline 4 & 6.12 & 5.20 & 4.94 & 4.66 & 4.38 & 4.67 & 5.01 & 5.12 & 5.08 & 5.14 & 5.00 & 5.25 \\
\hline 5 & 6.12 & 5.15 & 4.94 & 4.63 & 4.38 & 4.69 & 4.98 & 5.11 & 5.05 & 5.12 & 5.00 & 5.23 \\
\hline 6 & 6.11 & 5.12 & 4.96 & 4.60 & 4.38 & 4.68 & 4.98 & 5.12 & 5.03 & 5.13 & 5.00 & 5.21 \\
\hline 7 & 6.10 & 5.11 & 4.98 & 4.57 & 4.37 & 4.68 & 4.97 & 5.11 & 5.01 & 5.11 & 5.03 & 5.18 \\
\hline 8 & 6.09 & 5.10 & 4.99 & 4.54 & 4.36 & 4.68 & 4.97 & 5.10 & 5.00 & 5.08 & 5.06 & 5.16 \\
\hline 9 & 6.09 & 5.08 & 5.00 & 4.52 & 4.36 & 4.71 & 4.97 & 5.10 & 5.12 & 5.07 & 5.04 & 5.15 \\
\hline 10 & 6.08 & 5.07 & 5.00 & 4.50 & 4.36 & 4.71 & 4.96 & 5.09 & 5.12 & 5.06 & 5.02 & 5.13 \\
\hline 11 & 6.07 & 5.05 & 4.99 & 4.50 & 4.36 & 4.71 & 4.95 & 5.13 & 5.10 & 5.07 & 5.01 & 5.12 \\
\hline 12 & 6.05 & 5.05 & 5.03 & 4.48 & 4.35 & 4.72 & 4.94 & 5.24 & 5.08 & 5.06 & 5.01 & 5.10 \\
\hline 13 & 6.02 & 5.05 & 4.98 & 4.46 & 4.35 & 4.70 & 4.92 & 5.24 & 5.07 & 5.04 & 5.04 & 5.08 \\
\hline 14 & 5.98 & 5.03 & 4.96 & 4.45 & 4.34 & 4.71 & 4.92 & 5.23 & 5.06 & 5.02 & 5.06 & 5.04 \\
\hline 15 & 5.95 & 5.03 & 4.95 & 4.44 & 4.36 & 4.72 & 4.93 & 5.21 & 5.08 & 4.99 & 5.05 & 5.00 \\
\hline 16 & 5.92 & 5.01 & 4.94 & $\mathrm{e} 4.40$ & 4.38 & 4.72 & 4.91 & 5.16 & 5.07 & 4.98 & 5.04 & 4.98 \\
\hline 17 & 5.88 & 5.00 & 4.91 & e4.41 & 4.43 & 4.74 & 4.88 & 5.13 & 5.09 & 4.97 & 5.04 & 4.97 \\
\hline 18 & 5.85 & 4.98 & 4.89 & e4.40 & 4.51 & 4.76 & 4.89 & 5.11 & 5.09 & 4.96 & 5.04 & 4.97 \\
\hline 19 & 5.81 & 4.97 & 4.87 & e4.39 & 4.56 & 4.76 & 4.95 & 5.08 & 5.11 & 4.96 & 5.04 & 5.00 \\
\hline 20 & 5.77 & 4.96 & 4.85 & e4.38 & 4.63 & 4.89 & 5.01 & 5.06 & 5.12 & 4.94 & 5.07 & 4.98 \\
\hline 21 & 5.72 & 4.95 & 4.85 & e4.37 & 4.72 & 5.07 & 5.05 & 5.05 & 5.13 & 4.92 & 5.07 & 4.95 \\
\hline 22 & 5.63 & 4.95 & 4.82 & e4.36 & 4.74 & 5.17 & 5.08 & 5.03 & 5.21 & 4.92 & 5.07 & 4.93 \\
\hline 23 & 5.58 & 4.92 & 4.80 & e4.35 & 4.74 & 5.32 & 5.11 & 5.00 & 5.22 & 4.92 & 5.11 & 4.91 \\
\hline 24 & 5.67 & 4.94 & 4.79 & e4.35 & 4.73 & 5.32 & 5.11 & 4.99 & 5.20 & 4.91 & 5.14 & 4.90 \\
\hline 25 & 5.67 & 4.94 & 4.78 & e4.35 & 4.71 & 5.31 & 5.11 & 5.17 & 5.20 & 4.89 & 5.13 & 4.90 \\
\hline 26 & 5.73 & 4.91 & 4.76 & e4.35 & 4.70 & 5.28 & 5.18 & 5.20 & 5.21 & 4.89 & 5.13 & 5.03 \\
\hline 27 & 5.68 & 4.90 & 4.74 & e4.35 & 4.70 & 5.23 & 5.24 & 5.17 & 5.20 & 4.95 & 5.13 & 5.07 \\
\hline 28 & 5.63 & 4.90 & 4.73 & e4.35 & 4.68 & 5.18 & 5.23 & 5.17 & 5.16 & 5.00 & 5.12 & 5.05 \\
\hline 29 & 5.56 & 4.91 & 4.72 & e4.35 & --- & 5.14 & 5.22 & 5.17 & 5.16 & 5.01 & 5.11 & 5.02 \\
\hline 30 & 5.50 & 4.93 & 4.72 & e4.35 & --- & 5.11 & 5.23 & 5.16 & 5.17 & 5.01 & 5.11 & 4.98 \\
\hline 31 & 5.43 & --- & 4.72 & e4.35 & --- & 5.07 & --- & 5.16 & --- & 5.00 & 5.12 & --- \\
\hline Mean & 5.88 & 5.04 & 4.88 & 4.46 & 4.49 & 4.89 & 5.03 & 5.13 & 5.12 & 5.02 & 5.06 & 5.06 \\
\hline Max & 6.16 & 5.37 & 5.03 & 4.73 & 4.74 & 5.32 & 5.24 & 5.24 & 5.22 & 5.19 & 5.14 & 5.25 \\
\hline Min & 5.43 & 4.90 & 4.72 & 4.35 & 4.34 & 4.66 & 4.88 & 4.99 & 5.00 & 4.89 & 5.00 & 4.90 \\
\hline
\end{tabular}




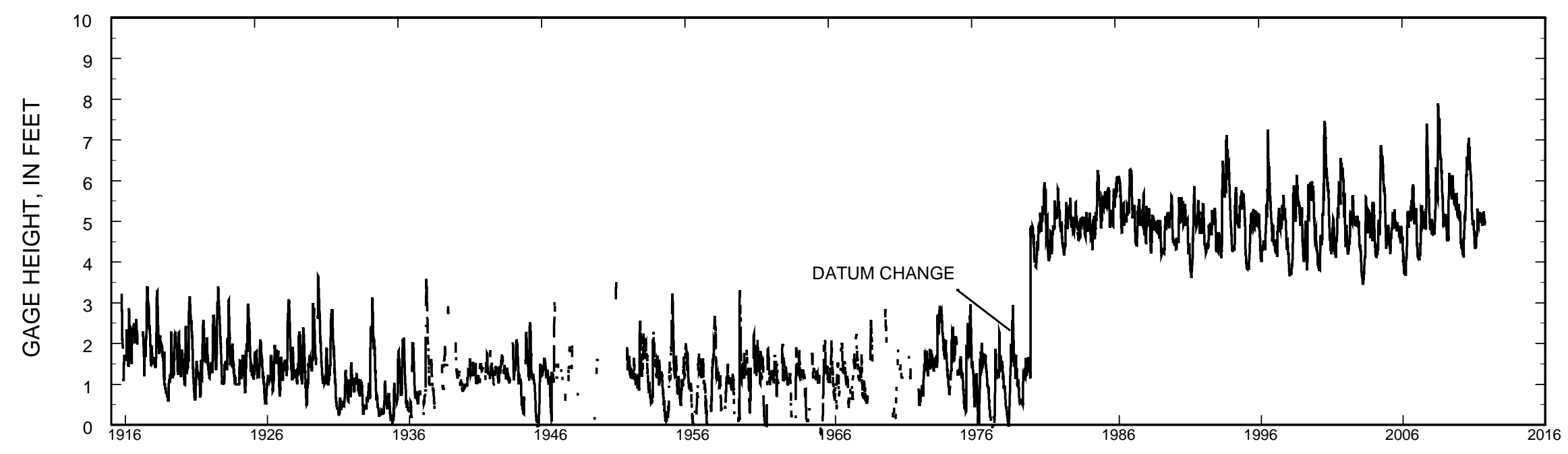

Stage hydrograph for Lake Monona, 1915-2011.

68 


\section{OCONOMOWOC LAKE NO. 1 (CENTER) AT OCONOMOWOC, WI}

LOCATION.--Lat 4305'51", long 88²7'35", in NW 1/4 SE 1/4 sec.2, T.7 N., R.17 E., Waukesha County, Hydrologic Unit 07090001, at Oconomowoc. SURFACE AREA.--1.20 $\mathrm{mi}^{2}$.

PERIOD OF RECORD.--March 1986 to current year.

REMARKS.--Lake sampled near center at the deep hole. Lake ice-covered during February sampling. Water-quality analyses done by Wisconsin State Laboratory of Hygiene.

WATER-QUALITY DATA, FEBRUARY 16 TO AUGUST 26, 2011

(Milligrams per liter unless otherwise indicated)

\begin{tabular}{|c|c|c|c|c|c|c|c|c|c|c|c|c|c|}
\hline Date & $\begin{array}{c}\text { Trans- } \\
\text { parency } \\
\text { Secchi } \\
\text { disc, } \\
\text { meters } \\
(\odot \odot \odot 78)\end{array}$ & $\begin{array}{c}\text { Sam- } \\
\text { pling } \\
\text { depth, } \\
\text { meters } \\
(\odot 0098)\end{array}$ & $\begin{array}{c}\text { Temper - } \\
\text { ature, } \\
\text { water, } \\
\text { deg C } \\
(00010)\end{array}$ & $\begin{array}{c}\text { Specif- } \\
\text { ic } \\
\text { conduc- } \\
\text { tance, } \\
\text { wat unf } \\
\text { us/cm @ } \\
25 \text { degc } \\
(00095)\end{array}$ & $\begin{array}{c}\text { pH, } \\
\text { water, } \\
\text { unfltrd } \\
\text { field, } \\
\text { std } \\
\text { units } \\
(00400)\end{array}$ & $\begin{array}{c}\text { Dis- } \\
\text { solved } \\
\text { oxygen, } \\
\text { mg/L } \\
(00300)\end{array}$ & $\begin{array}{c}\text { Chloro- } \\
\text { phyll a } \\
\text { trichro } \\
\text {-matic } \\
\text { method, } \\
\text { uncorr, } \\
\text { ug/L } \\
(32210)\end{array}$ & $\begin{array}{c}\text { Phos- } \\
\text { phorus, } \\
\text { water, } \\
\text { unfltrd } \\
\mathrm{mg} / \mathrm{L} \\
\text { as } \mathrm{P} \\
(00665)\end{array}$ & $\begin{array}{l}\text { Ortho- } \\
\text { phos- } \\
\text { phate, } \\
\text { water, } \\
\text { fltrd, } \\
\text { mg/L } \\
\text { as P } \\
(00671)\end{array}$ & $\begin{array}{c}\text { Total } \\
\text { nitro- } \\
\text { gen, } \\
\text { water, } \\
\text { unfltrd } \\
\text { mg/L } \\
(00600)\end{array}$ & $\begin{array}{c}\text { Ammonia } \\
\text { water, } \\
\text { fltrd, } \\
\text { mg/L } \\
\text { as N } \\
(00608)\end{array}$ & $\begin{array}{c}\text { Ammonia } \\
+ \\
\text { org-N, } \\
\text { water, } \\
\text { unfltrd } \\
\text { mg/L } \\
\text { as N } \\
(00625)\end{array}$ & $\begin{array}{c}\text { Nitrate } \\
+ \\
\text { nitrite } \\
\text { water, } \\
\text { fltrd, } \\
\mathrm{mg} / \mathrm{L} \\
\text { as N } \\
(00631)\end{array}$ \\
\hline \multicolumn{14}{|l|}{ FEB 2011} \\
\hline $16 \ldots$ & -- & .50 & 1.9 & 613 & 7.5 & 11.9 & - - & .012 & -- & -- & -- & -- & -- \\
\hline \multicolumn{14}{|l|}{ APR } \\
\hline $29 \ldots$ & -- & .50 & 8.6 & 577 & 7.5 & 11.4 & 1.56 & .012 & $<.002$ & .69 & .021 & .34 & .353 \\
\hline \multicolumn{14}{|l|}{ JUN } \\
\hline $28 \ldots$ & 4.30 & -- & -- & -- & -- & -- & -- & -- & - - & -- & -- & -- & -- \\
\hline $28 \ldots$ & -- & .50 & 21.9 & 564 & 8.4 & 11.1 & 2.03 & .013 & -- & -- & -- & -- & -- \\
\hline $28 \ldots$ & -- & 17.5 & 8.6 & 587 & 7.6 & 2.7 & -- & .030 & -- & -- & -- & -- & -- \\
\hline \multicolumn{14}{|l|}{ JUL } \\
\hline $26 \ldots$ & 3.35 & -- & -- & - - & -- & -- & -- & -- & -- & -- & -- & -- & -- \\
\hline $26 \ldots$ & -- & .50 & 28.7 & 531 & 8.6 & 9.2 & 2.42 & .012 & -- & - - & - - & -- & -- \\
\hline $26 \ldots$ & 2.85 & -- & -- & -- & -- & -- & -- & -- & -- & -- & -- & -- & -- \\
\hline $26 \ldots$ & -- & .50 & 25.1 & 530 & 8.5 & 9.3 & -- & .012 & -- & -- & -- & -- & -- \\
\hline $26 \ldots$ & -- & 18.0 & 8.6 & 620 & 7.4 & .1 & 2.24 & .025 & -- & -- & -- & -- & -- \\
\hline
\end{tabular}


430551088273500 OCONOMOWOC LAKE NO. 1 (CENTER) AT OCONOMOWOC, WI

WATER-QUALITY DATA, FEBRUARY 16 TO AUGUST 26, 2011

(Milligrams per liter unless otherwise indicated)

\begin{tabular}{|c|c|c|c|c|c|c|c|c|c|c|c|c|c|}
\hline & Turbdty & Appar - & & & & & & ANC, & & & & & \\
\hline ate & $\begin{array}{c}\text { light, } \\
\text { det ang } \\
90+/-30 \\
\text { degrees } \\
\text { NTU } \\
(63675)\end{array}$ & $\begin{array}{c}\text { color, } \\
\text { water, } \\
\text { unfltrd } \\
\text { Pt-Co } \\
\text { units } \\
(\odot \odot \odot 81)\end{array}$ & 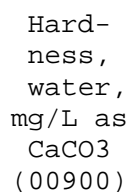 & $\begin{array}{c}\text { Calcium } \\
\text { water, } \\
\text { fltrd, } \\
\text { mg/L } \\
(00915)\end{array}$ & $\begin{array}{c}\text { Magnes - } \\
\text { ium, } \\
\text { water, } \\
\text { fltrd, } \\
\text { mg/L } \\
(\odot \odot 925)\end{array}$ & $\begin{array}{c}\text { Sodium, } \\
\text { water, } \\
\text { fltrd, } \\
\text { mg/L } \\
(\odot \odot 93 \odot)\end{array}$ & $\begin{array}{l}\text { Potas- } \\
\text { sium, } \\
\text { water, } \\
\text { fltrd, } \\
\text { mg/L } \\
(\odot \odot 935)\end{array}$ & $\begin{array}{c}\text { fixed } \\
\text { end pt, } \\
\text { lab, } \\
\mathrm{mg} / \mathrm{L} \text { as } \\
\mathrm{CaC0} 0 \\
(0 \odot 417)\end{array}$ & $\begin{array}{c}\text { Chlor - } \\
\text { ide, } \\
\text { water, } \\
\text { fltrd, } \\
\text { mg/L } \\
(\odot \odot 94 \odot)\end{array}$ & $\begin{array}{c}\text { Sulfate } \\
\text { water, } \\
\text { fltrd, } \\
\text { mg/L } \\
(00945)\end{array}$ & $\begin{array}{c}\text { Silica, } \\
\text { water, } \\
\text { fltrd, } \\
\text { mg/L as } \\
\text { Si02 } \\
(0 \odot 955)\end{array}$ & $\begin{array}{c}\text { Iron, } \\
\text { water, } \\
\text { fltrd, } \\
\text { ug/L } \\
(01046)\end{array}$ & $\begin{array}{c}\text { Mangan- } \\
\text { ese, } \\
\text { water, } \\
\text { fltrd, } \\
\text { ug/L } \\
(01056)\end{array}$ \\
\hline
\end{tabular}

$$
\begin{gathered}
\text { FEB } 2011 \\
16 \ldots \\
16 \ldots \\
\text { APR } \\
29 \ldots \\
29 \ldots \\
\text { JUN } \\
28 \ldots \\
28 \ldots \\
28 \ldots \\
\text { JUL } \\
26 \ldots \\
26 \ldots \\
26 \ldots \\
\text { AUG } \\
26 \ldots \\
26 \ldots \\
26 \ldots
\end{gathered}
$$

$$
\begin{array}{cr}
-- & - \\
- & - \\
\hline 1.0 & 15 \\
-- & - \\
-- & - \\
-- & - \\
-- & - \\
-- & - \\
-- & - \\
-- & - \\
-- & - \\
& \\
\text { Dis- } & \\
\text { solved } & \\
\text { solids } & \\
\text { dried @ } & \\
\text { 180degC } \\
\text { wat flt } \\
\text { mg/L } \\
\text { (70300) }
\end{array}
$$$$
<1.0 \quad 15
$$$$
--
$$

Date

FEB 2011

$$
\begin{gathered}
16 \ldots \\
16 \ldots \\
\text { APR }
\end{gathered}
$$$$
29 \ldots
$$ 
430551088273500 OCONOMOWOC LAKE NO. 1 (CENTER) AT OCONOMOWOC, WI

LAKE-DEPTH PROFILES, FEBRUARY 16 TO AUGUST 26, 2011

02-16-11

04-29-11

06-28-11

07-26-11

08-26-11

DISSOLVED OXYGEN (D.O.), IN MILLIGRAMS PER LITER
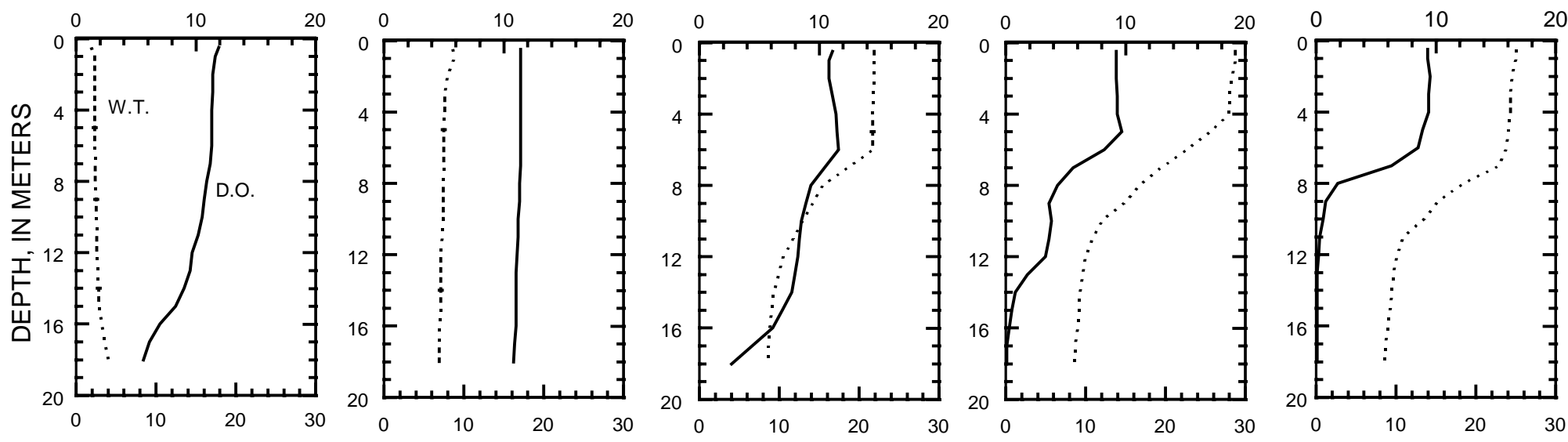

WATER TEMPERATURE (W.T.), IN DEGREES CELSIUS
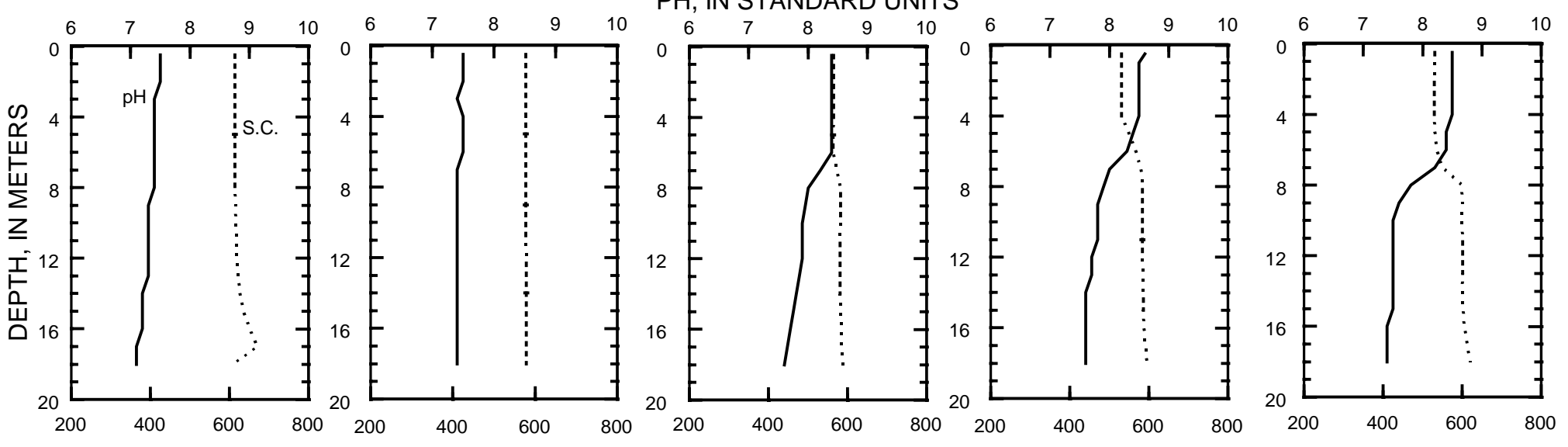

SPECIFIC CONDUCTANCE (S.C.), IN MICROSIEMENS PER CENTIMETER AT 25 DEGREES CELSIUS 

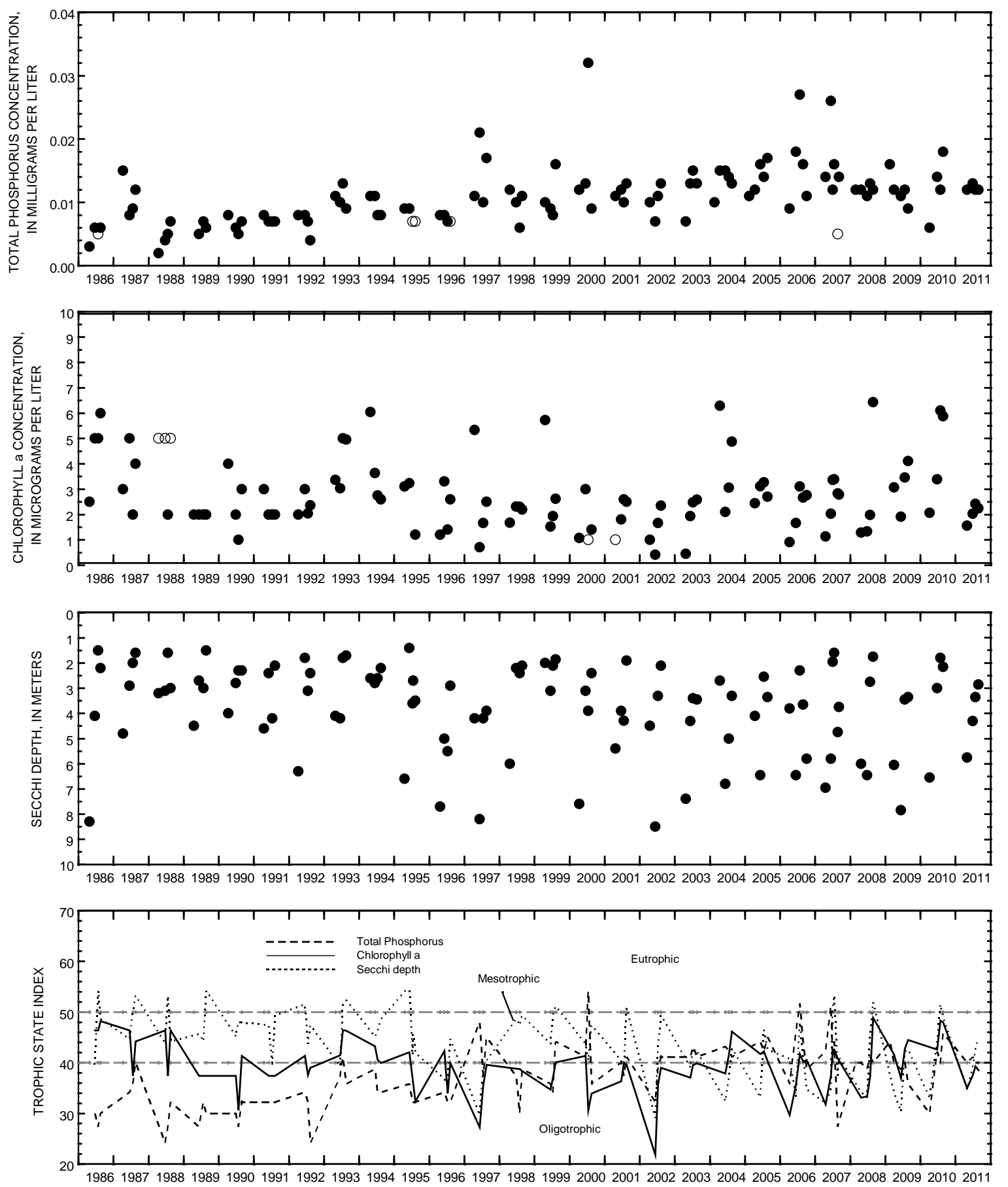

Surface total phosphorus, chlorophyll a concentrations, Secchi depths, and TSI data for Oconomowoc Lake, Center Site, at Oconomowoc, Wisconsin.

(Open circles on the first two plots indicate laboratory detection limit for selected analyses.

Actual concentrations for these particular analyses are less than the plotted circles.) 


\section{OCONOMOWOC LAKE NO. 2 (OFF HEWITT POINT) AT OCONOMOWOC, WI}

LOCATION.--Lat 4306'09", long 88²6'22", in NW 1/4 NW 1/4 sec.1, T.7 N., R.17 E., Waukesha County, Hydrologic Unit 07090001, at Oconomowoc.

SURFACE AREA.-1.20 $\mathrm{mi}^{2}$.

PERIOD OF RECORD.--March 1986 to current year.

REMARKS.--Lake sampled at the deepest point in northeast bay near Hewitt Point. Lake ice-covered during February sampling. Water-quality analyses done by Wisconsin State Laboratory of Hygiene.

WATER-QUALITY DATA, FEBRUARY 16 TO AUGUST 26, 2011

(Milligrams per liter unless otherwise indicated)

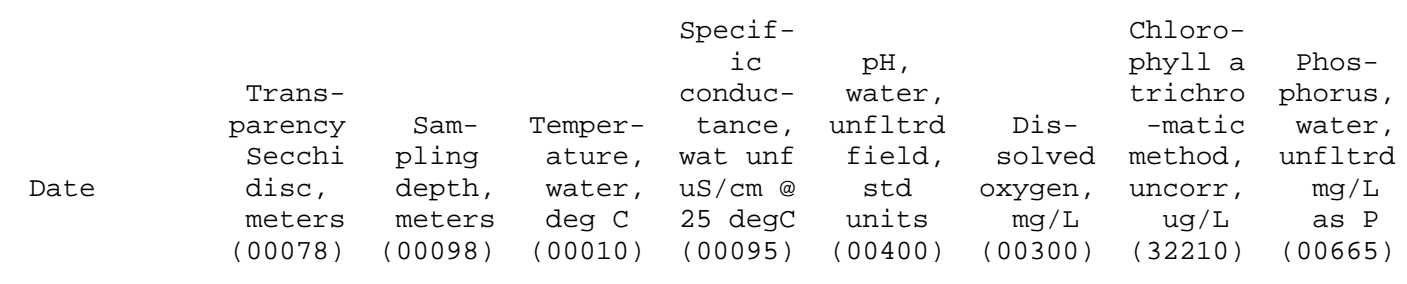

\begin{tabular}{|c|c|c|c|c|c|c|c|c|}
\hline \multicolumn{9}{|c|}{ FEB 2011} \\
\hline $16 \ldots$ & - - & .50 & 2.8 & 650 & 7.2 & 11.4 & - - & .011 \\
\hline $16 \ldots$ & - - & 14.0 & 4.4 & 737 & 7.1 & 4.0 & -- & .014 \\
\hline \multicolumn{9}{|l|}{ APR } \\
\hline $29 \ldots$ & - - & .50 & 9.7 & 629 & 7.8 & 11.1 & 2.17 & .010 \\
\hline $29 \ldots$ & 8.15 & - - & -- & - - & -- & -- & -- & - - \\
\hline \multicolumn{9}{|l|}{ JUN } \\
\hline $28 \ldots$ & 5.30 & - - & - - & - - & -- & - - & - - & - - \\
\hline $28 \ldots$ & -- & .50 & 22.1 & 601 & 8.4 & 11.3 & 1.49 & .009 \\
\hline $28 \ldots$ & - - & 15.5 & 8.6 & 641 & 7.5 & 2.4 & - - & .025 \\
\hline \multicolumn{9}{|l|}{ JUL } \\
\hline $26 \ldots$ & - - & .50 & 29.1 & 576 & 8.4 & 9.4 & 2.09 & .011 \\
\hline $26 \ldots$ & -- & 13.0 & 9.1 & 638 & 7.6 & .3 & - - & .019 \\
\hline $26 \ldots$ & 3.45 & - - & - - & - - & - - & - - & - - & -- \\
\hline \multicolumn{9}{|l|}{ AUG } \\
\hline $26 \ldots$ & - - & .50 & 25.0 & 578 & 8.4 & 9.9 & 2.08 & .010 \\
\hline $26 \ldots$ & - - & 13.0 & 9.1 & 670 & 7.4 & .1 & -- & .038 \\
\hline $26 \ldots$ & 3.40 & - - & - & - - & -- & - & - - & - - \\
\hline
\end{tabular}


430609088262200 OCONOMOWOC LAKE NO. 2 (OFF HEWITT POINT) AT OCONOMOWOC, WI

LAKE-DEPTH PROFILES, FEBRUARY 16 TO AUGUST 26, 2011

02-16-11

04-29-11

06-28-11

07-26-11

08-26-11

DISSOLVED OXYGEN (D.O.), IN MILLIGRAMS PER LITER
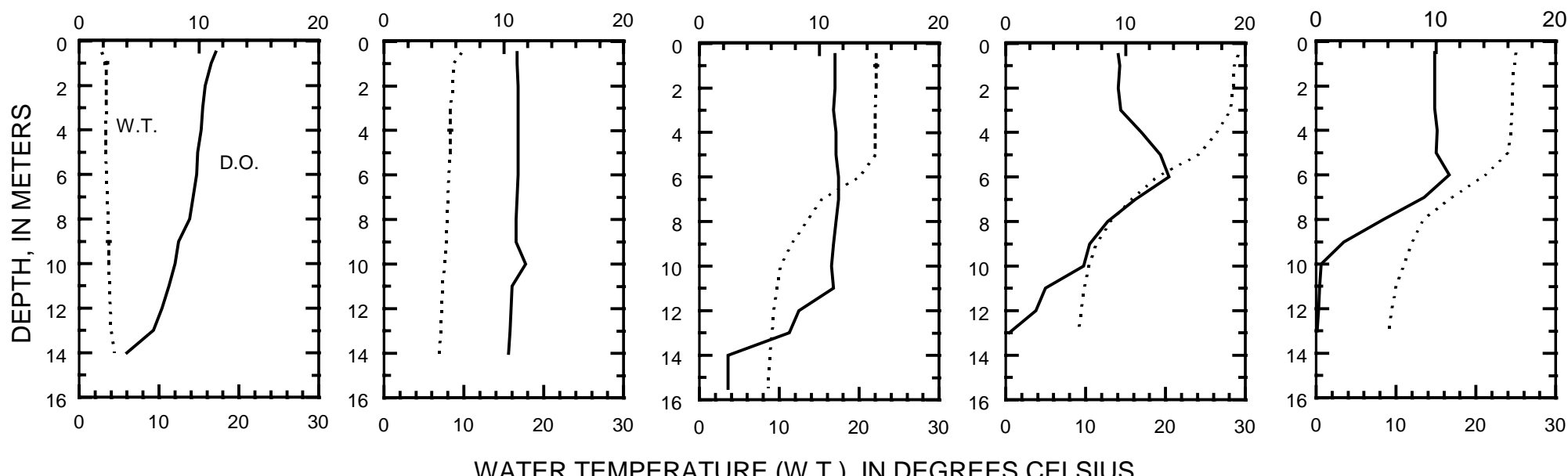

WATER TEMPERATURE (W.T.), IN DEGREES CELSIUS

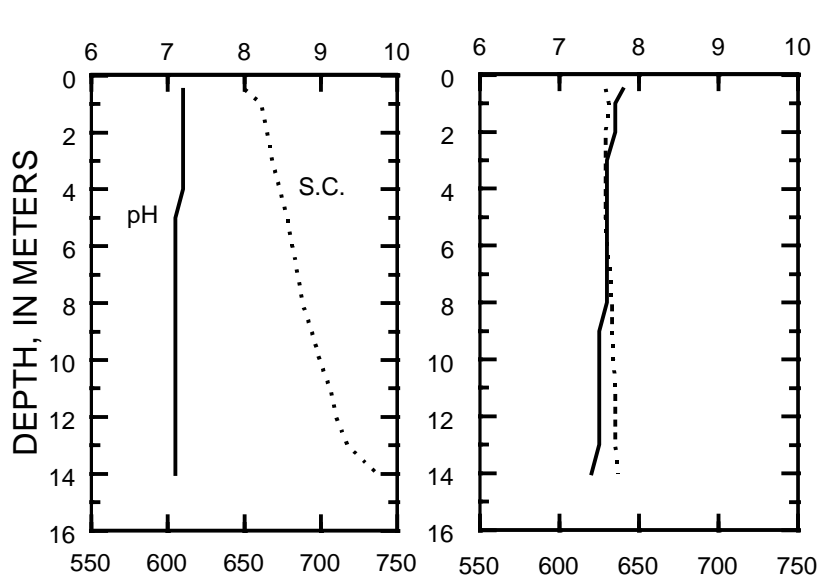

PH, IN STANDARD UNITS
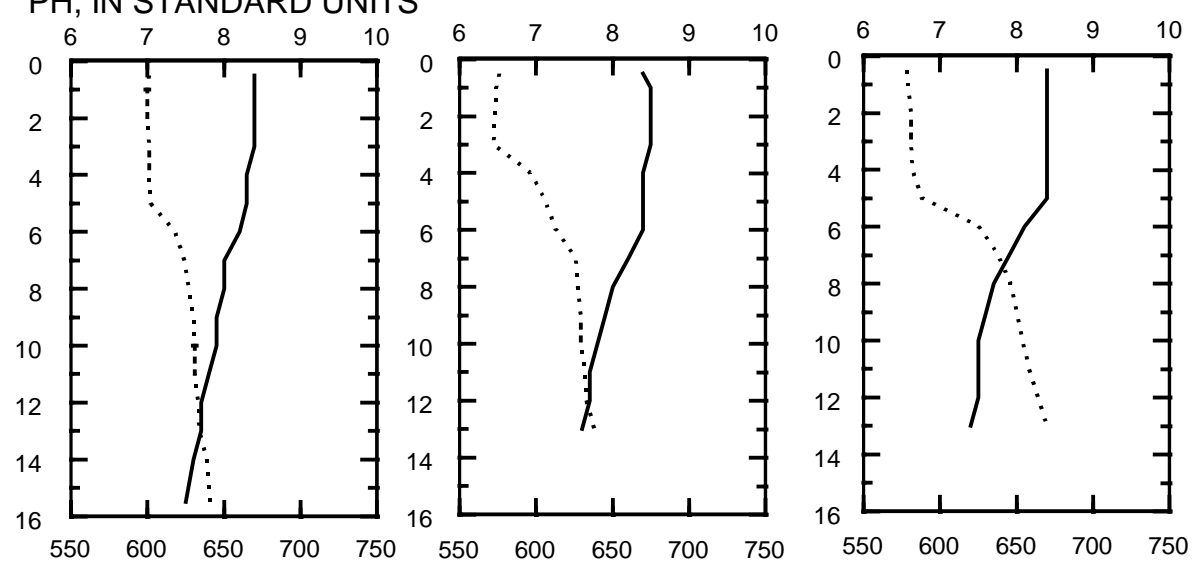

SPECIFIC CONDUCTANCE (S.C.), IN MICROSIEMENS PER CENTIMETER AT 25 DEGREES CELSIUS 

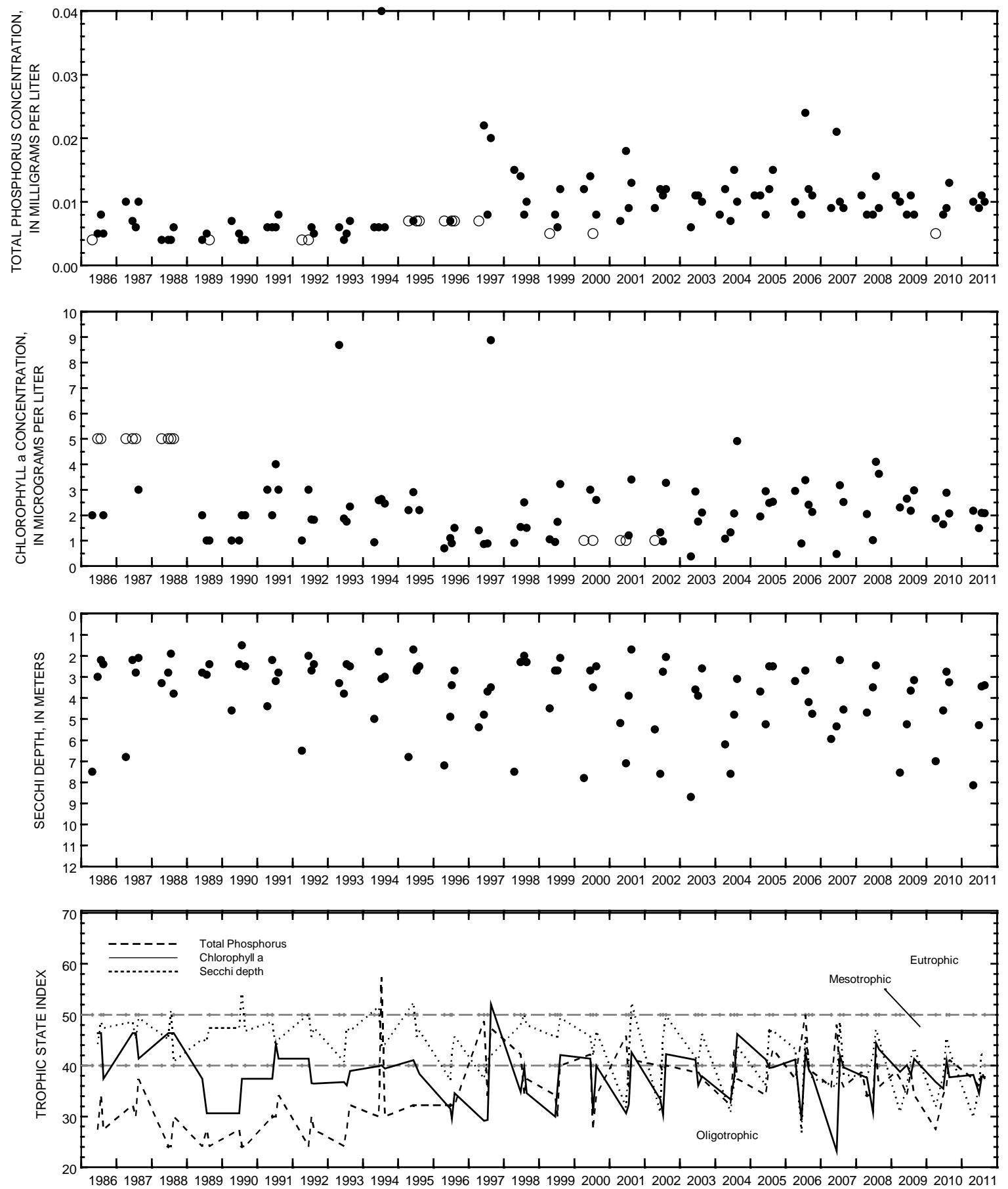

Surface total phosphorus, chlorophyll a concentrations, Secchi depths, and TSI data for Oconomowoc Lake, Hewitt Point, at Oconomowoc, Wisconsin.

(Open circles on the first two plots indicate laboratory detection limit for selected analyses. Actual concentrations for these particular analyses are less than the plotted circles.) 


\section{POWERS LAKE AT POWERS LAKE, WI}

LOCATION.--Lat 42³2'46", long 88¹7'58", in NW 1/4 SE 1/4 Sec.13, T.1 N., R.18 E., Walworth County, Hydrologic Unit 07120006, at Powers Lake.

SURFACE AREA.- $0.72 \mathrm{mi}^{2}$.

DRAINAGE AREA.--3.42 $\mathrm{mi}^{2}$.

PERIOD OF RECORD.--March 1986 to August 1996, and April 1998 to current year.

REMARKS.--Lake sampled near center at the deep hole. Lake ice-covered during February sampling. Water-quality analyses done by Wisconsin State Laboratory of Hygiene.

WATER-QUALITY DATA, FEBRUARY 16 TO AUGUST 17, 2011

(Milligrams per liter unless otherwise indicated)

\begin{tabular}{|c|c|c|c|c|c|c|c|c|c|c|c|c|c|}
\hline Date & $\begin{array}{c}\text { Trans- } \\
\text { parency } \\
\text { Secchi } \\
\text { disc, } \\
\text { meters } \\
(\odot \odot \odot 78)\end{array}$ & $\begin{array}{c}\text { Sam- } \\
\text { pling } \\
\text { depth, } \\
\text { meters } \\
(\odot 0098)\end{array}$ & $\begin{array}{c}\text { Temper - } \\
\text { ature, } \\
\text { water, } \\
\text { deg C } \\
(00010)\end{array}$ & $\begin{array}{c}\text { Specif- } \\
\text { ic } \\
\text { conduc- } \\
\text { tance, } \\
\text { wat unf } \\
\text { us/cm @ } \\
25 \text { degc } \\
(0 \odot \odot 95)\end{array}$ & $\begin{array}{c}\text { pH, } \\
\text { water, } \\
\text { unfltrd } \\
\text { field, } \\
\text { std } \\
\text { units } \\
(0040 \odot)\end{array}$ & $\begin{array}{c}\text { Dis- } \\
\text { solved } \\
\text { oxygen, } \\
\text { mg/L } \\
(0030 \odot)\end{array}$ & $\begin{array}{c}\text { Chloro- } \\
\text { phyll a } \\
\text { trichro } \\
\text {-matic } \\
\text { method, } \\
\text { uncorr, } \\
\text { ug/L } \\
(32210)\end{array}$ & $\begin{array}{c}\text { Phos- } \\
\text { phorus, } \\
\text { water, } \\
\text { unfltrd } \\
\text { mg/L } \\
\text { as P } \\
(00665)\end{array}$ & $\begin{array}{l}\text { Ortho- } \\
\text { phos- } \\
\text { phate, } \\
\text { water, } \\
\text { fltrd, } \\
\text { mg/L } \\
\text { as P } \\
(00671)\end{array}$ & $\begin{array}{c}\text { Total } \\
\text { nitro- } \\
\text { gen, } \\
\text { water, } \\
\text { unfltrd } \\
\mathrm{mg} / \mathrm{L} \\
(00600)\end{array}$ & $\begin{array}{c}\text { Ammonia } \\
\text { water, } \\
\text { fltrd, } \\
\text { mg/L } \\
\text { as N } \\
(00608)\end{array}$ & $\begin{array}{c}\text { Ammonia } \\
+ \\
\text { org-N, } \\
\text { water, } \\
\text { fltrd, } \\
\mathrm{mg} / \mathrm{L} \\
\text { as N } \\
(00623)\end{array}$ & $\begin{array}{c}\text { Ammonia } \\
+ \\
\text { org-N, } \\
\text { water, } \\
\text { unfltrd } \\
\text { mg/L } \\
\text { as N } \\
(00625)\end{array}$ \\
\hline
\end{tabular}

\begin{tabular}{|c|c|c|c|c|c|c|c|c|c|c|c|c|c|}
\hline \multicolumn{14}{|l|}{ FEB 2011} \\
\hline $16 \ldots$ & - - & .50 & 1.6 & 566 & 7.2 & 12.7 & - - & .018 & - - & - - & - - & - - & - - \\
\hline $16 \ldots$ & -- & 6.5 & 3.9 & 574 & 7.3 & 9.5 & -- & .014 & -- & -- & -- & -- & -- \\
\hline \multicolumn{14}{|l|}{ APR } \\
\hline $13 \ldots$ & 6.60 & - - & - - & - - & - & - - & - - & - & - - & - - & - - & - - & - - \\
\hline $13 \ldots$ & -- & $.5 \odot$ & 10.4 & 524 & 7.5 & 11.4 & 1.71 & .015 & $<.002$ & .57 & .045 & -- & .46 \\
\hline \multicolumn{14}{|l|}{ JUN } \\
\hline $28 \ldots$ & 3.25 & - - & - - & - - & - - & - - & - - & - - & - - & - - & - - & - - & - - \\
\hline $28 \ldots$ & -- & .50 & 22.4 & 504 & 8.4 & 10.6 & 3.73 & .021 & -- & - - & - - & -- & -- \\
\hline $28 \ldots$ & - - & 9.5 & 16.9 & 522 & 7.4 & .5 & - - & .025 & - - & - - & - - & - - & - - \\
\hline \multicolumn{14}{|l|}{ JUL } \\
\hline $26 \ldots$ & - - & .50 & 28.3 & 477 & 8.6 & 8.5 & 4.50 & .020 & $<.002$ & $<.59$ & - - & .66 & .57 \\
\hline $26 \ldots$ & -- & 10.0 & 16.6 & 529 & 7.6 & .1 & -- & .028 & -- & - - & -- & -- & -- \\
\hline \multicolumn{14}{|l|}{ AUG } \\
\hline $17 \ldots$ & 2.95 & - - & - - & -- & - - & - - & - - & -- & -- & -. & - - & - - & -. \\
\hline $17 \ldots$ & -- & .50 & 25.9 & 484 & 8.8 & 9.0 & 4.43 & .013 & -- & -- & -- & -- & -- \\
\hline $17 \ldots$ & - - & 10.0 & 16.6 & 569 & 7.5 & .2 & -- & .035 & - - & -- & - - & - - & -- \\
\hline
\end{tabular}


423246088175800 POWERS LAKE AT POWERS LAKE, WI

WATER-QUALITY DATA, FEBRUARY 16 TO AUGUST 17, 2011

(Milligrams per liter unless otherwise indicated)

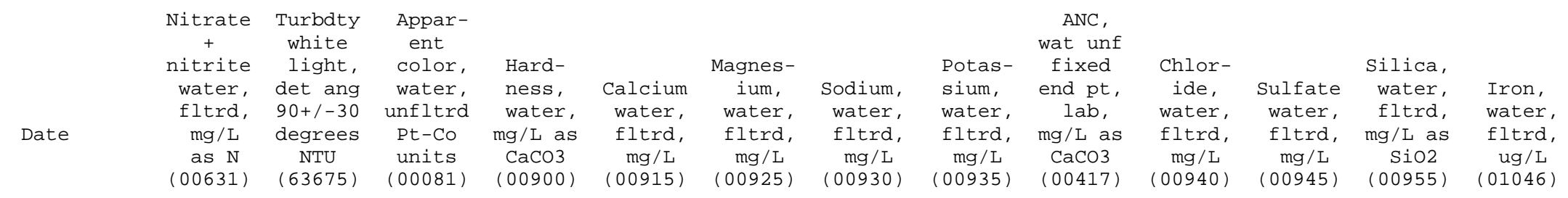

FEB 2011

\begin{tabular}{|c|c|c|}
\hline $16 \ldots$ & - - & - - \\
\hline $16 \ldots$ & - - & - - \\
\hline APR & & \\
\hline $13 \ldots$ & - - & - - \\
\hline $13 \ldots$ & .106 & $<1.0$ \\
\hline JUN & & \\
\hline $28 \ldots$ & - - & - \\
\hline $28 \ldots$ & - - & -- \\
\hline $28 \ldots$ & - - & -- \\
\hline JUL & & \\
\hline $26 \ldots$ & - - & -- \\
\hline $26 \ldots$ & $<.019$ & -- \\
\hline $26 \ldots$ & - - & - - \\
\hline AUG & & \\
\hline $17 \ldots$ & - - & -- \\
\hline $17 \ldots$ & - & - \\
\hline $17 \ldots$ & -- & -- \\
\hline & & $\begin{array}{l}\text { Dis- } \\
\text { solved }\end{array}$ \\
\hline & $\begin{array}{c}\text { Mangan- } \\
\text { ese, } \\
\text { water, }\end{array}$ & $\begin{array}{l}\text { solids } \\
\text { dried @ } \\
\text { 180degC }\end{array}$ \\
\hline Date & $\begin{array}{c}\text { fltrd, } \\
\text { ug/L } \\
(01056)\end{array}$ & $\begin{array}{c}\text { wat flt } \\
\mathrm{mg} / \mathrm{L} \\
(70300)\end{array}$ \\
\hline
\end{tabular}

FEB 2011

$\begin{array}{crr}16 \ldots & -- & -- \\ 16 \ldots & -- & -- \\ \text { APR } & & \\ 13 \ldots & -- & -- \\ 13 \ldots & <1.0 & 296\end{array}$


423246088175800 POWERS LAKE AT POWERS LAKE, WI

LAKE-DEPTH PROFILES, FEBRUARY 16 TO AUGUST 17, 2011

02-16-11

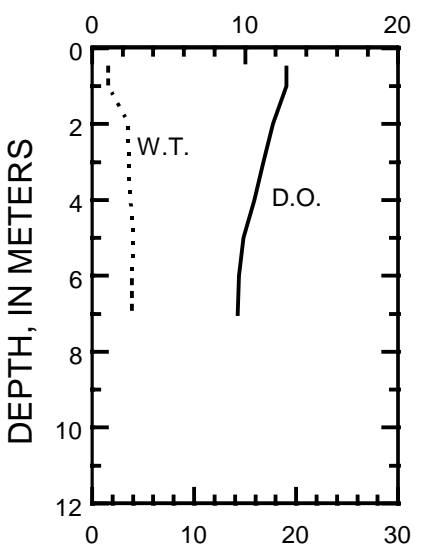

(1)

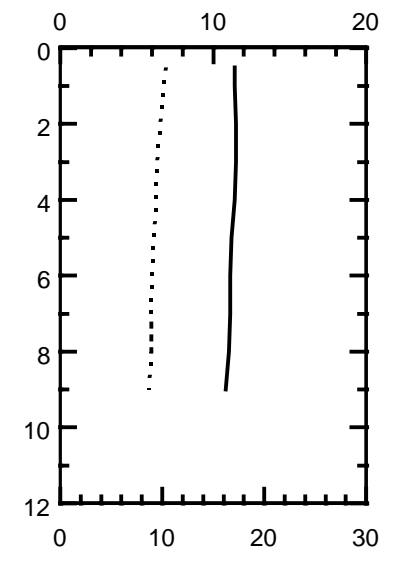

04-13-11
WATER TEMPERATURE (W.T.), IN DEGREES CELSIUS
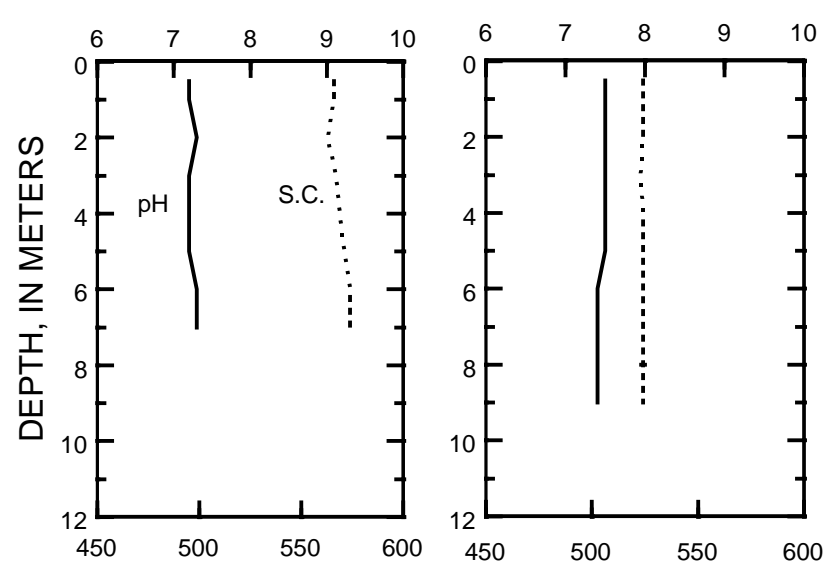

06-28-11

07-26-11

.), IN MILLIGRAMS PER LITER
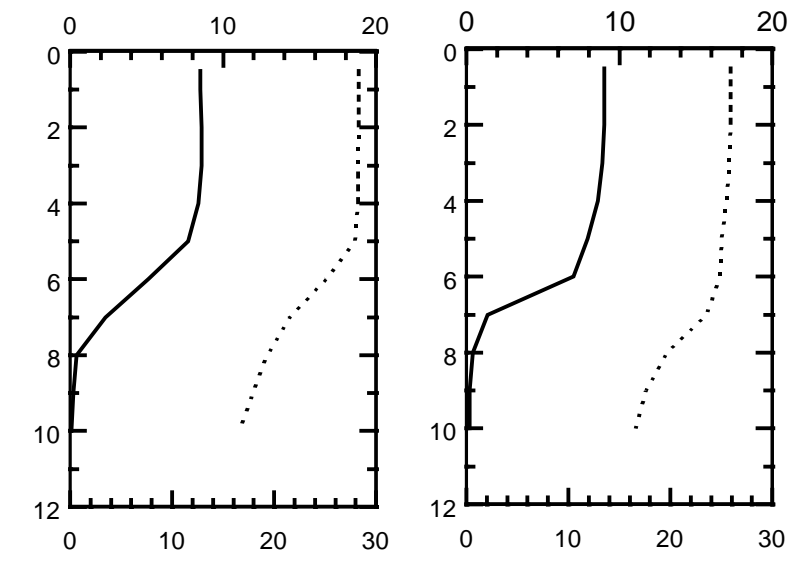

08-17-11

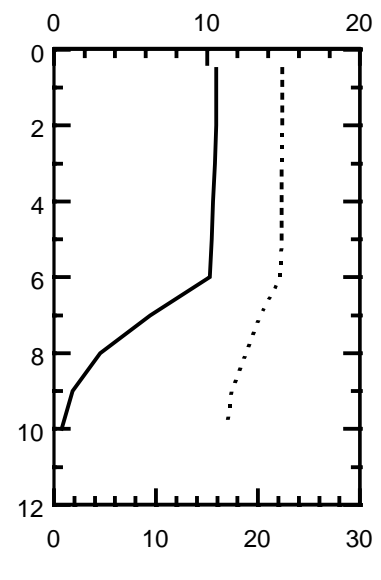

$\mathrm{PH}$, IN STANDARD UNITS
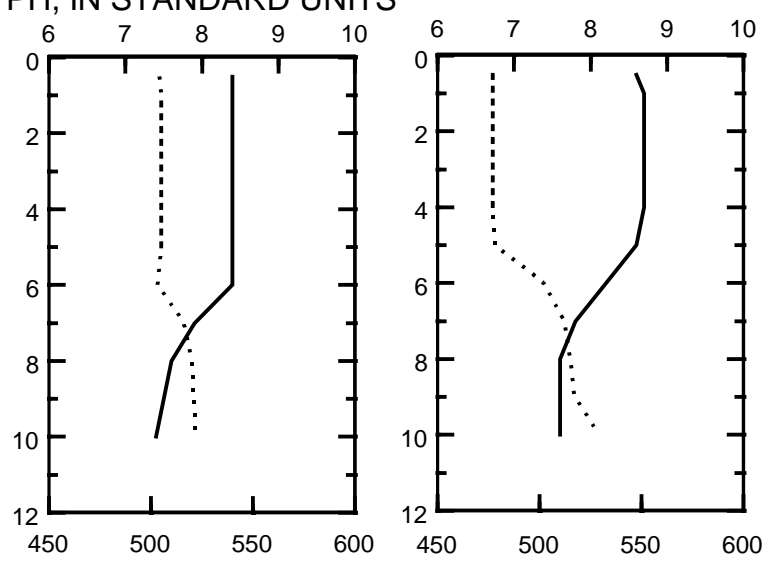

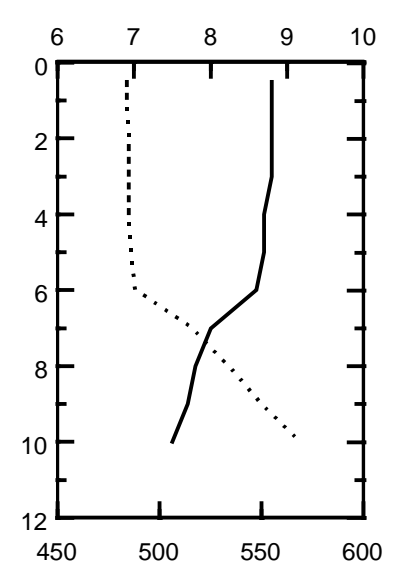

SPECIFIC CONDUCTANCE (S.C.), IN MICROSIEMENS PER CENTIMETER AT 25 DEGREES CELSIUS 

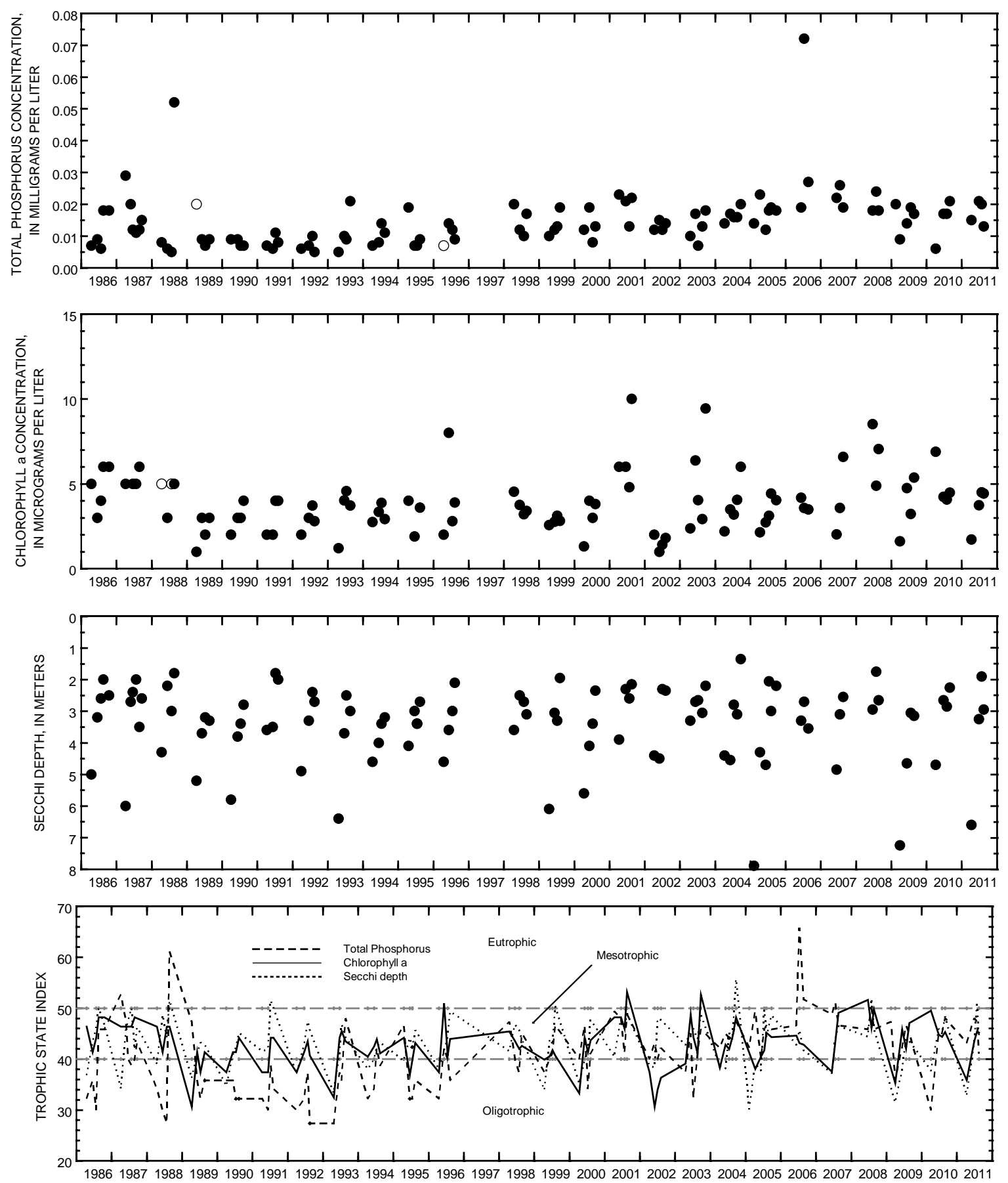

Surface total phosphorus, chlorophyll a concentrations, Secchi depths, and TSI data for Powers Lake, at Powers Lake, Wisconsin.

(Open circles on the first two plots indicate laboratory detection limit for selected analyses. Actual concentrations for these particular analyses are less than the plotted circles.) 


\section{LAKE WAUBESA AT MCFARLAND, WI}

LOCATION.--Lat 4300'32", long 89¹8'19" referenced to North American Datum of 1927, in SW $1 / 4$ SW $1 / 4$ Sec.3, T.6 N., R.10 E., Dane County, WI, Hydrologic Unit 07090001, on left bank just upstream from bridge on U.S. Highway 51 , downstream of dam at outlet of Lake Waubesa and 1.0 mi southwest of McFarland.

SURFACE AREA.--3.25 $\mathrm{mi}^{2}$.

DRAINAGE AREA.--327 $\mathrm{mi}^{2}$ of which $36.6 \mathrm{mi}^{2}$ probably is noncontributing.

PERIOD OF RECORD.--October 2003 to current year.

REVISED RECORDS.--WSP 805, WDR WI-73-1: Drainage area.

GAGE.--Water-stage recorder. Datum of gage is $840.00 \mathrm{ft}$ above NGVD of 1929 (levels by Wisconsin Department of Natural Resources).

REMARKS.--Lake level regulated by dams at outlets of Lake Mendota and Lake Waubesa. Gage-height telemeter at station.

EXTREMES FOR PERIOD OF RECORD.--Maximum gage height observed, $7.22 \mathrm{ft}$, June 15-17, 2008; minimum observed, $3.50 \mathrm{ft}$, Feb.14, 2006, current datum.

EXTREMES FOR CURRENT YEAR.--Maximum recorded gage height, $5.62 \mathrm{ft}$, Oct. 1-2; minimum recorded, $4.14 \mathrm{ft}$, Feb. 12-13. 
GAGE HEIGHT, FEET

WATER YEAR OCTOBER 2010 TO SEPTEMBER 2011

DAILY MEAN VALUES

\begin{tabular}{|c|c|c|c|c|c|c|c|c|c|c|c|c|}
\hline Day & Oct & Nov & Dec & Jan & Feb & Mar & Apr & May & Jun & Jul & Aug & Sep \\
\hline 1 & 5.62 & 5.01 & 4.62 & 4.50 & 4.17 & 4.44 & 4.74 & 4.89 & 4.82 & 4.92 & 4.88 & 4.94 \\
\hline 2 & 5.61 & 4.96 & 4.63 & 4.48 & 4.23 & 4.43 & 4.73 & 4.88 & 4.79 & 4.94 & 4.88 & 4.95 \\
\hline 3 & 5.59 & 4.92 & 4.61 & 4.46 & 4.22 & 4.42 & 4.71 & 4.87 & 4.74 & 4.95 & 4.89 & 5.05 \\
\hline 4 & 5.58 & 4.89 & 4.63 & 4.44 & 4.20 & 4.42 & 4.72 & 4.85 & 4.72 & 4.94 & 4.88 & 5.10 \\
\hline 5 & 5.58 & 4.84 & 4.58 & 4.41 & 4.20 & 4.44 & 4.72 & 4.82 & 4.71 & 4.95 & 4.88 & 5.08 \\
\hline 6 & 5.58 & 4.80 & 4.58 & 4.39 & 4.20 & 4.44 & 4.69 & 4.84 & 4.69 & 4.95 & 4.88 & 5.06 \\
\hline 7 & 5.57 & 4.76 & 4.64 & 4.37 & 4.19 & 4.43 & 4.67 & 4.83 & 4.66 & 4.91 & 4.91 & 5.03 \\
\hline 8 & 5.56 & 4.74 & 4.63 & 4.36 & 4.18 & 4.43 & 4.65 & 4.82 & 4.66 & 4.89 & 4.93 & 4.99 \\
\hline 9 & 5.54 & 4.73 & 4.63 & 4.33 & 4.18 & 4.46 & 4.64 & 4.80 & 4.74 & 4.87 & 4.95 & 4.97 \\
\hline 10 & 5.54 & 4.71 & 4.65 & 4.30 & 4.16 & 4.47 & 4.64 & 4.79 & 4.79 & 4.85 & 4.93 & 4.95 \\
\hline 11 & 5.52 & 4.70 & 4.67 & 4.29 & 4.16 & 4.47 & 4.65 & 4.82 & 4.80 & 4.89 & 4.91 & 4.94 \\
\hline 12 & 5.50 & 4.70 & 4.75 & 4.28 & 4.15 & 4.48 & 4.64 & 4.89 & 4.80 & 4.90 & 4.88 & 4.92 \\
\hline 13 & 5.48 & 4.71 & 4.84 & 4.26 & 4.15 & 4.47 & 4.63 & 4.93 & 4.79 & 4.87 & 4.89 & 4.90 \\
\hline 14 & 5.44 & 4.71 & 4.76 & 4.25 & 4.16 & 4.46 & 4.62 & 4.96 & 4.78 & 4.83 & 4.92 & 4.88 \\
\hline 15 & 5.39 & 4.69 & 4.70 & 4.24 & 4.16 & 4.46 & 4.59 & 4.94 & 4.78 & 4.81 & 4.92 & 4.84 \\
\hline 16 & 5.35 & 4.68 & 4.67 & 4.23 & 4.16 & 4.46 & 4.63 & 4.91 & 4.82 & 4.80 & 4.92 & 4.81 \\
\hline 17 & 5.32 & 4.68 & 4.64 & 4.23 & 4.21 & 4.47 & 4.64 & 4.88 & 4.82 & 4.79 & 4.91 & 4.79 \\
\hline 18 & 5.29 & 4.67 & 4.62 & 4.24 & 4.33 & 4.50 & 4.62 & 4.86 & 4.83 & 4.80 & 4.91 & 4.77 \\
\hline 19 & 5.26 & 4.64 & 4.60 & 4.23 & 4.36 & 4.50 & 4.64 & 4.85 & 4.85 & 4.80 & 4.90 & 4.80 \\
\hline 20 & 5.24 & 4.63 & 4.58 & 4.22 & 4.40 & 4.58 & 4.73 & 4.83 & 4.88 & 4.79 & 4.92 & 4.78 \\
\hline 21 & 5.21 & 4.62 & 4.58 & 4.22 & 4.47 & 4.74 & 4.75 & 4.80 & 4.88 & 4.78 & 4.93 & 4.76 \\
\hline 22 & 5.16 & 4.63 & 4.57 & 4.20 & 4.49 & 4.83 & 4.75 & 4.79 & 4.93 & 4.77 & 4.92 & 4.74 \\
\hline 23 & 5.12 & 4.63 & 4.55 & 4.19 & 4.49 & 4.97 & 4.82 & 4.79 & 4.99 & 4.76 & 4.96 & 4.73 \\
\hline 24 & 5.21 & 4.61 & 4.54 & 4.18 & 4.48 & 5.00 & 4.82 & 4.78 & 5.01 & 4.76 & 4.99 & 4.71 \\
\hline 25 & 5.22 & 4.64 & 4.52 & 4.17 & 4.48 & 4.99 & 4.82 & 4.82 & 5.00 & 4.76 & 4.99 & 4.70 \\
\hline 26 & 5.27 & 4.63 & 4.51 & 4.16 & 4.47 & 4.95 & 4.87 & 4.86 & 4.98 & 4.75 & 4.98 & 4.79 \\
\hline 27 & 5.29 & 4.62 & 4.50 & 4.16 & 4.46 & 4.91 & 4.94 & 4.84 & 4.96 & 4.77 & 4.97 & 4.83 \\
\hline 28 & 5.24 & 4.59 & 4.48 & 4.16 & 4.46 & 4.87 & 4.96 & 4.82 & 4.97 & 4.85 & 4.96 & 4.84 \\
\hline 29 & 5.17 & 4.57 & 4.47 & 4.16 & --- & 4.83 & 4.93 & 4.82 & 4.96 & 4.87 & 4.96 & 4.85 \\
\hline 30 & 5.11 & 4.60 & 4.46 & 4.15 & --- & 4.80 & 4.89 & 4.83 & 4.93 & 4.88 & 4.94 & 4.84 \\
\hline 31 & 5.06 & --- & 4.48 & 4.14 & --- & 4.76 & --- & 4.82 & --- & 4.88 & 4.94 & --- \\
\hline Mean & 5.37 & 4.71 & 4.60 & 4.27 & 4.28 & 4.61 & 4.73 & 4.85 & 4.84 & 4.85 & 4.92 & 4.88 \\
\hline Max & 5.62 & 5.01 & 4.84 & 4.50 & 4.49 & 5.00 & 4.96 & 4.96 & 5.01 & 4.95 & 4.99 & 5.10 \\
\hline Min & 5.06 & 4.57 & 4.46 & 4.14 & 4.15 & 4.42 & 4.59 & 4.78 & 4.66 & 4.75 & 4.88 & 4.70 \\
\hline
\end{tabular}




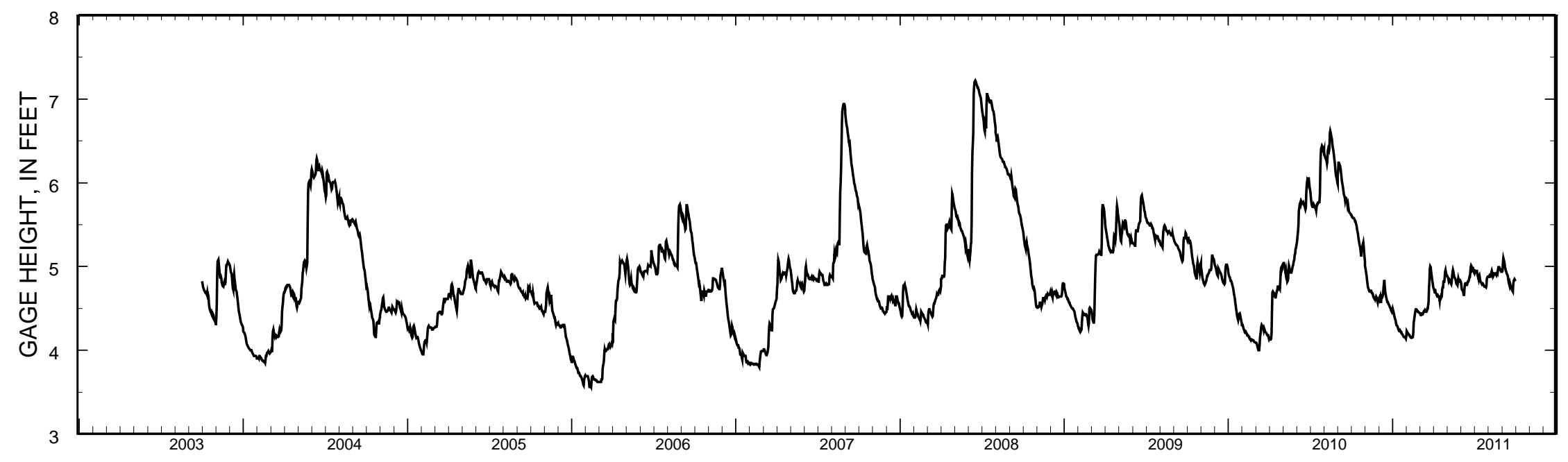

Stage hydrograph for Lake Waubesa, 2003-2011. 
LOCATION.--Lat 4248'48", long 8808'31" referenced to North American Datum of 1927, in NE 1/4 NW 1/4 Sec.16, T.4 N., R.20 E., Racine County, WI, Hydrologic Unit 07120006, at Wind Lake.

SURFACE AREA.--1.46 $\mathrm{mi}^{2}$.

DRAINAGE AREA.--39.6 $\mathrm{mi}^{2}$.

PERIOD OF RECORD.--March 1985 to current year. Prior to October 2000, published as "Wind Lake Outlet".

REVISED RECORDS.--WDR WI-91-1: 1988(m).

REMARKS.--Lake level regulated by dam with two 10-foot gates at outlet. Lake ice-covered Dec. 3 to Mar. 14. Prior to October 1987, published as Wind Lake at Wind Lake, Wis. Gage-height telemeter at station.

EXTREMES FOR PERIOD OF RECORD.--Maximum gage height, 9.88 ft, June 14, 15, 2008; minimum recorded, 5.95 ft, Jan. $2,1996$.

EXTREMES FOR CURRENT YEAR.-Headwater: Maximum recorded gage height, $8.50 \mathrm{ft}$, Oct. 25; minimum recorded, $7.37 \mathrm{ft}$, Sept. 18. Tailwater (Feb. 15, 2011 to Sept. 30, 2011): Maximum recorded gage height, $7.71 \mathrm{ft}$, Mar. 23; minimum recorded, $4.09 \mathrm{ft}$, May 10.

\section{GAGE HEIGHT, FEET \\ WATER YEAR OCTOBER 2010 TO SEPTEMBER 2011 DAILY MEAN VALUES}

\begin{tabular}{|c|c|c|c|c|c|c|c|c|c|c|c|c|}
\hline \multicolumn{13}{|c|}{ [e, estimated] } \\
\hline Day & Oct & Nov & Dec & Jan & Feb & Mar & Apr & May & Jun & Jul & Aug & Sep \\
\hline 1 & 8.31 & 8.44 & 8.28 & e8.27 & 8.36 & 8.18 & 8.30 & 8.22 & 8.19 & 8.19 & 7.99 & 7.61 \\
\hline 2 & 8.31 & 8.38 & 8.27 & e8.27 & 8.45 & 8.20 & 8.23 & 8.23 & 8.18 & 8.19 & 7.98 & 7.60 \\
\hline 3 & 8.29 & 8.27 & e8.26 & 8.28 & 8.43 & 8.22 & 8.19 & 8.25 & 8.16 & 8.18 & 7.97 & 7.61 \\
\hline 4 & 8.27 & 8.24 & e8.26 & 8.29 & 8.42 & 8.25 & 8.18 & 8.26 & 8.16 & 8.16 & 7.95 & 7.64 \\
\hline 5 & 8.26 & e8.24 & e8.26 & 8.32 & 8.42 & 8.34 & 8.12 & 8.24 & 8.15 & 8.15 & 7.93 & 7.61 \\
\hline 6 & 8.25 & e8.26 & e8.25 & 8.33 & 8.42 & 8.32 & 8.06 & 8.22 & 8.13 & 8.14 & 7.92 & 7.57 \\
\hline 7 & 8.24 & e8.28 & 8.24 & 8.34 & 8.39 & 8.25 & 8.02 & 8.14 & 8.13 & 8.11 & 7.96 & 7.55 \\
\hline 8 & 8.23 & e8.30 & 8.23 & 8.32 & 8.20 & 8.21 & 8.00 & 8.20 & 8.11 & 8.09 & 7.96 & 7.53 \\
\hline 9 & 8.23 & 8.29 & 8.23 & 8.30 & 8.20 & 8.26 & 7.98 & 8.27 & 8.15 & 8.07 & 7.95 & 7.50 \\
\hline 10 & 8.23 & 8.29 & 8.23 & 8.27 & 8.15 & 8.28 & 7.99 & 8.35 & 8.12 & 8.06 & 7.93 & 7.49 \\
\hline 11 & 8.22 & 8.28 & 8.25 & 8.26 & e8.19 & 8.23 & 8.08 & 8.32 & 8.12 & 8.07 & 7.90 & 7.48 \\
\hline 12 & 8.22 & 8.28 & 8.32 & 8.25 & e8.23 & 8.19 & 8.18 & 8.31 & 8.11 & 8.06 & 7.87 & 7.47 \\
\hline 13 & 8.22 & 8.27 & 8.31 & 8.23 & 8.24 & 8.18 & 8.24 & 8.38 & 8.09 & 8.04 & 7.87 & 7.46 \\
\hline 14 & 8.20 & 8.25 & 8.29 & 8.24 & e8.24 & 8.22 & 8.23 & 8.36 & 8.08 & 8.02 & 7.86 & 7.44 \\
\hline 15 & 8.19 & 8.24 & 8.28 & 8.27 & e8.24 & 8.36 & 8.21 & 8.30 & 8.08 & 8.00 & 7.84 & 7.42 \\
\hline 16 & 8.17 & 8.24 & 8.29 & 8.28 & 8.22 & 8.46 & 8.29 & 8.28 & 8.09 & 7.99 & 7.82 & 7.40 \\
\hline 17 & 8.17 & 8.25 & e8.30 & 8.30 & 8.21 & 8.43 & 8.27 & 8.30 & 8.08 & 7.98 & 7.81 & 7.39 \\
\hline 18 & 8.17 & 8.23 & e8.31 & 8.31 & 8.22 & 8.36 & 8.25 & 8.30 & 8.07 & 7.97 & 7.80 & 7.39 \\
\hline 19 & 8.22 & e8.22 & e8.31 & 8.29 & 8.20 & 8.26 & 8.28 & 8.29 & 8.07 & 7.96 & 7.78 & 7.44 \\
\hline 20 & 8.26 & e8.23 & e8.32 & 8.28 & 8.20 & 8.23 & 8.34 & 8.30 & 8.06 & 7.95 & 7.77 & 7.43 \\
\hline 21 & 8.31 & e8.24 & 8.34 & 8.27 & 8.29 & 8.38 & 8.27 & 8.31 & 8.07 & 7.94 & 7.76 & 7.41 \\
\hline 22 & 8.34 & e8.26 & 8.35 & 8.26 & 8.27 & 8.42 & 8.26 & 8.30 & 8.16 & 7.95 & 7.73 & 7.40 \\
\hline 23 & 8.37 & 8.29 & 8.35 & 8.24 & 8.24 & 8.42 & 8.32 & 8.32 & 8.19 & 8.01 & 7.72 & 7.40 \\
\hline 24 & 8.47 & 8.28 & 8.35 & 8.24 & 8.24 & 8.24 & 8.30 & 8.27 & 8.29 & 8.01 & 7.73 & 7.39 \\
\hline 25 & 8.42 & 8.29 & 8.36 & 8.25 & 8.22 & 8.13 & 8.25 & 8.28 & 8.31 & 7.99 & 7.71 & e7.45 \\
\hline 26 & 8.21 & 8.28 & 8.36 & 8.27 & 8.22 & 8.20 & 8.32 & 8.24 & 8.30 & 7.97 & 7.69 & 7.52 \\
\hline 27 & 8.21 & 8.27 & 8.33 & 8.30 & 8.21 & 8.33 & e8.41 & 8.20 & 8.28 & 8.00 & 7.68 & 7.57 \\
\hline 28 & 8.30 & 8.27 & 8.31 & 8.32 & 8.19 & 8.25 & 8.38 & 8.19 & 8.27 & 8.04 & 7.66 & 7.59 \\
\hline 29 & 8.37 & 8.27 & 8.27 & 8.34 & --- & 8.22 & 8.30 & 8.20 & 8.24 & 8.04 & 7.64 & 7.60 \\
\hline 30 & 8.41 & 8.28 & e8.26 & 8.34 & --- & 8.26 & 8.26 & 8.21 & 8.22 & 8.02 & 7.62 & 7.62 \\
\hline 31 & 8.44 & --- & e8.26 & 8.34 & --- & 8.36 & --- & 8.20 & --- & 8.01 & 7.62 & --- \\
\hline Mean & 8.27 & 8.27 & 8.29 & 8.29 & 8.27 & 8.28 & 8.22 & 8.27 & 8.16 & 8.04 & 7.82 & 7.50 \\
\hline Max & 8.47 & 8.44 & 8.36 & 8.34 & 8.45 & 8.46 & 8.41 & 8.38 & 8.31 & 8.19 & 7.99 & 7.64 \\
\hline Min & 8.17 & 8.22 & 8.23 & 8.23 & 8.15 & 8.13 & 7.98 & 8.14 & 8.06 & 7.94 & 7.62 & 7.39 \\
\hline
\end{tabular}




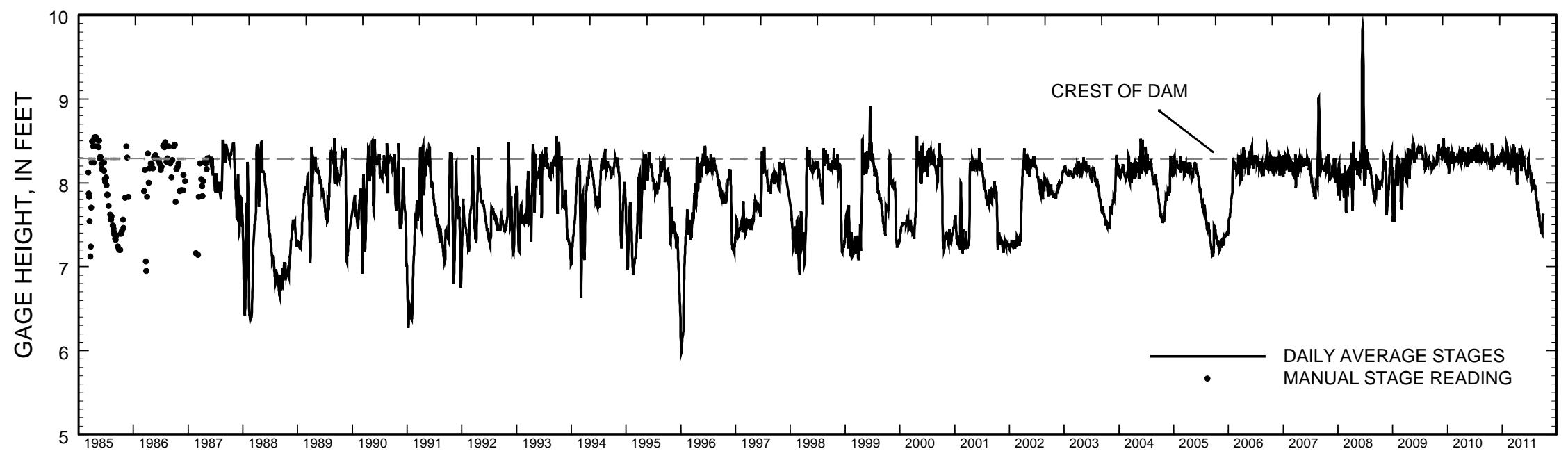

Stage hydrograph for Wind Lake, headwater, 1985-2011. 


\section{WIND LAKE AT WIND LAKE, WI}

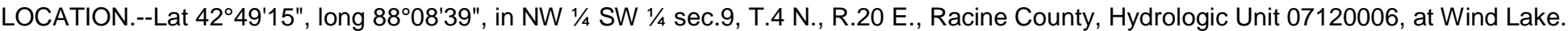

SURFACE AREA.--1.46 $\mathrm{mi}^{2}$.

PERIOD OF RECORD.--February 1985 to current year.

REMARKS.--Lake sampled near center at the deep hole. Lake ice-covered during February sampling. Water-quality analyses done by Wisconsin State Laboratory of Hygiene.

WATER-QUALITY DATA, FEBRUARY 16 TO AUGUST 17, 2011

(Milligrams per liter unless otherwise indicated)

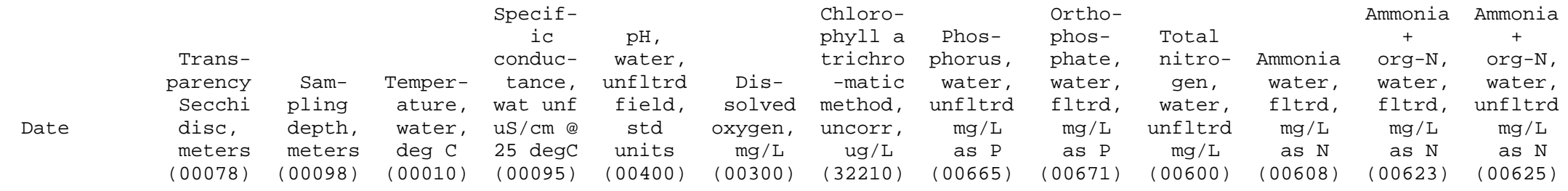

\begin{tabular}{|c|c|c|c|c|c|c|c|c|c|c|c|c|c|}
\hline \multicolumn{14}{|l|}{ FEB 2011} \\
\hline $16 \ldots$ & - - & .50 & 2.4 & 604 & 7.2 & 10.6 & - - & .056 & - - & - - & - - & - - & - - \\
\hline $16 \ldots$ & - - & 9.5 & 3.6 & 784 & 7.1 & 4.4 & - - & $.09 \odot$ & - - & - - & - - & - - & - - \\
\hline \multicolumn{14}{|l|}{ APR } \\
\hline $13 \ldots$ & 2.15 & - - & - - & - - & - - & - - & - - & - - & - - & - - & - - & - - & - - \\
\hline $13 \ldots$ & -- & .50 & 12.5 & 615 & 7.7 & 12.1 & 12.2 & .045 & $<.002$ & 1.2 & .023 & - - & 1.1 \\
\hline \multicolumn{14}{|l|}{ JUN } \\
\hline $28 \ldots$ & 3.10 & - - & - - & - - & - - & - - & - - & - - & - - & - - & - - & - - & - - \\
\hline $28 \ldots$ & -- & .50 & 22.1 & 615 & 8.4 & 9.9 & 2.32 & .018 & - - & - - & - - & - - & - - \\
\hline $28 \ldots$ & - - & 10.5 & 14.4 & 645 & 7.2 & .0 & - - & .022 & - - & - - & - - & - - & - - \\
\hline \multicolumn{14}{|l|}{ JUL } \\
\hline $26 \ldots$ & -- & 14.0 & 14.0 & 645 & 7.3 & .0 & -- & .037 & -- & -- & -- & -- & -- \\
\hline $26 \ldots$ & 1.90 & - - & - - & - - & - - & - - & - - & - - & - - & - - & - - & - - & - - \\
\hline \multicolumn{14}{|l|}{ AUG } \\
\hline $17 \ldots$ & 2.25 & -- & -- & -- & -- & -- & -- & -- & -- & -- & -- & -- & -- \\
\hline $17 \ldots$ & - - & .50 & 25.1 & 597 & 8.8 & 8.8 & 6.97 & .018 & - - & - - & - - & - - & - - \\
\hline $17 \ldots$ & - - & 5.0 & 24.3 & 594 & 8.9 & 8.1 & - - & .023 & - - & - - & - - & - - & - - \\
\hline $17 \ldots$ & - - & 10.0 & 14.7 & 663 & 7.5 & .1 & - - & .029 & - - & - - & - - & -- & - - \\
\hline $17 \ldots$ & - - & 11.5 & 14.4 & 666 & 7.5 & .1 & - - & .029 & - - & - - & - - & -- & - - \\
\hline $17 \ldots$ & - - & 13.0 & 14.1 & 668 & 7.4 & .0 & - - & .032 & - - & - - & - - & -- & - - \\
\hline
\end{tabular}


424915088083900 WIND LAKE AT WIND LAKE, WI

WATER-QUALITY DATA, FEBRUARY 16 TO AUGUST 17, 2011

(Milligrams per liter unless otherwise indicated)

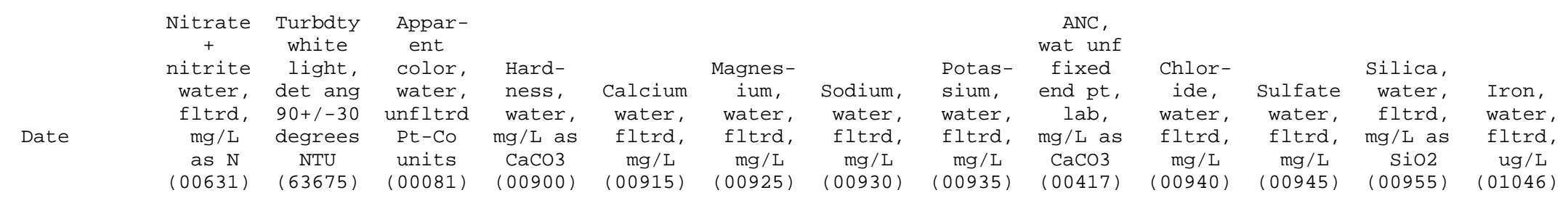

FEB 2011

$16 \ldots$
$16 \ldots$

APR

$13 \ldots$

JUN

$28 \ldots$

$28 \ldots$

JUL

$26 \ldots$

$26 \ldots$

26.

$\begin{array}{lll}-- & - & - \\ -- & -- & --\end{array}$

$.171<1.0 \quad 50$

- - $\quad-$

$-$

$<.019$

- -

--
--
--
203
--
--
--
--
--
--

$\begin{array}{cr}-- & -- \\ -- & -- \\ -- & -- \\ 42.9 & 23.2 \\ -- & -- \\ -- & -- \\ -- & -- \\ -- & -- \\ -- & -- \\ -- & --\end{array}$

--
--
--
45.3
--
--
--
--
--
--

--

$--$

\section{$--$}

- -

$2.70 \quad 157$

85.3

$\begin{array}{rrr}-- & -- & -- \\ 28.6 & .178 & <100\end{array}$

- -

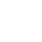

$\begin{array}{ll}-- & - \\ -- & - \\ -- & -\end{array}$

$\begin{array}{llll}-- & -- & - & - \\ -- & -- & - & -\end{array}$

$\begin{array}{ll}-- & - \\ -- & -\end{array}$

$--$

$-$

$\begin{array}{ccc} & & \text { Dis- } \\ \text { solved } \\ \text { solids } \\ \text { Mangan- } & \text { dried @ } \\ \text { ese, } & \text { water, } & 180 \mathrm{deg} \\ \mathrm{fltrd}, & \text { wat } \mathrm{flt} \\ \mathrm{ug} / \mathrm{L} & \mathrm{mg} / \mathrm{L} \\ & (01056) & (70300)\end{array}$

FEB 2011

$16 \ldots$
$16 \ldots$

APR

$13 \ldots$

$13 \ldots$

1

348 
424915088083900 WIND LAKE AT WIND LAKE, WI

LAKE-DEPTH PROFILES, FEBRUARY 16 TO AUGUST 17, 2011

02-16-11

04-13-11

06-28-11

07-26-11

08-17-11

DISSOLVED OXYGEN (D.O.), IN MILLIGRAMS PER LITER
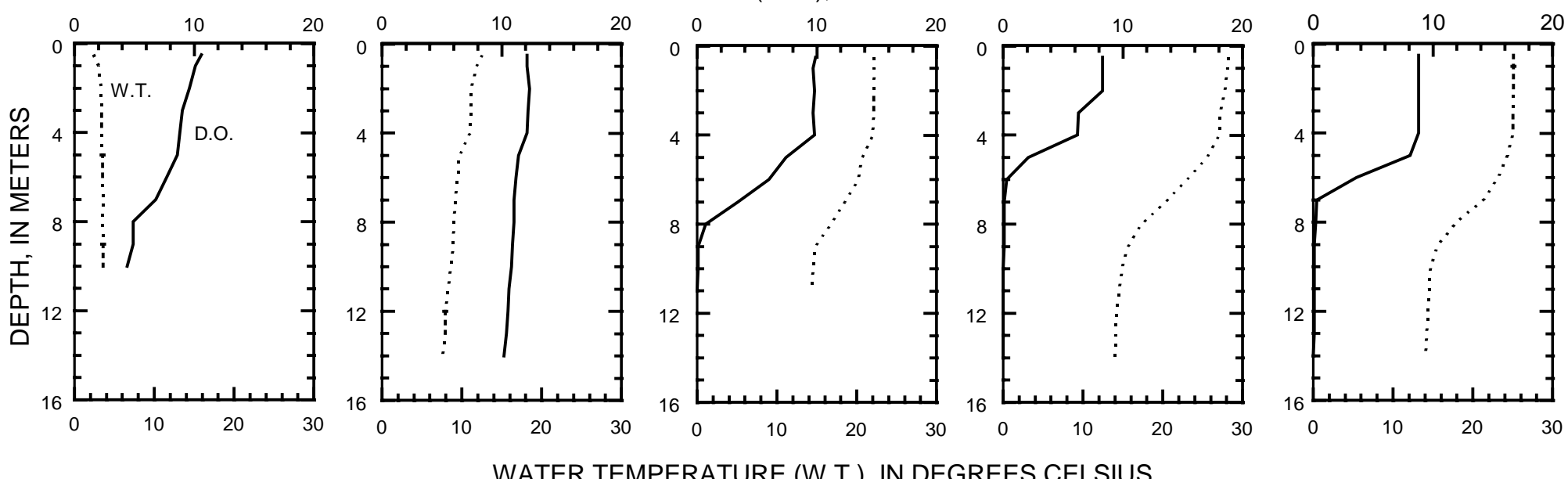

WATER TEMPERATURE (W.T.), IN DEGREES CELSIUS
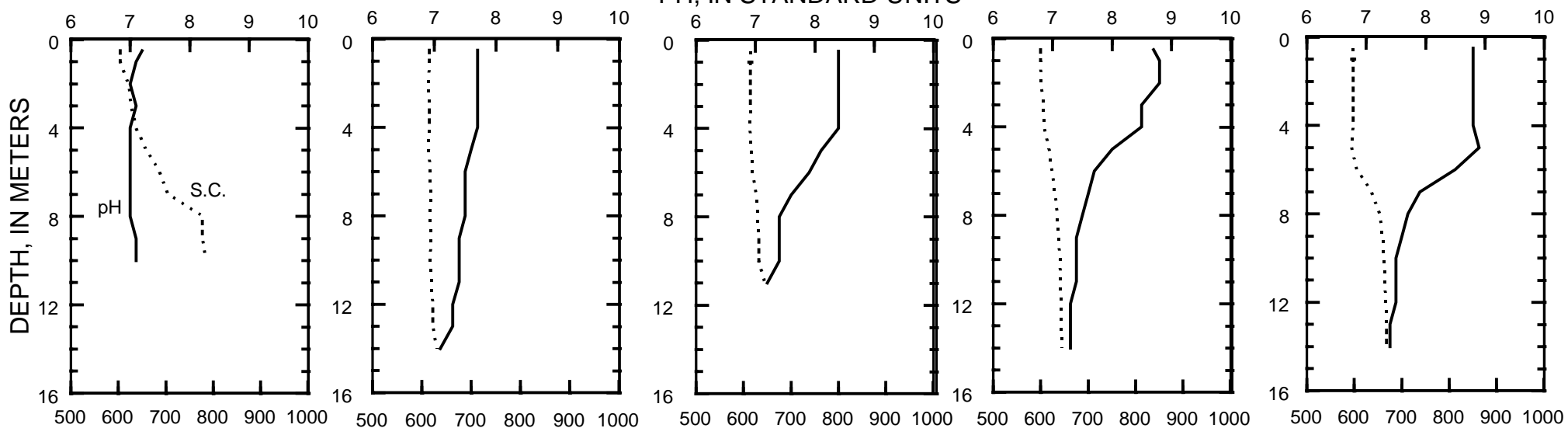

SPECIFIC CONDUCTANCE (S.C.), IN MICROSIEMENS PER CENTIMETER AT 25 DEGREES CELSIUS 

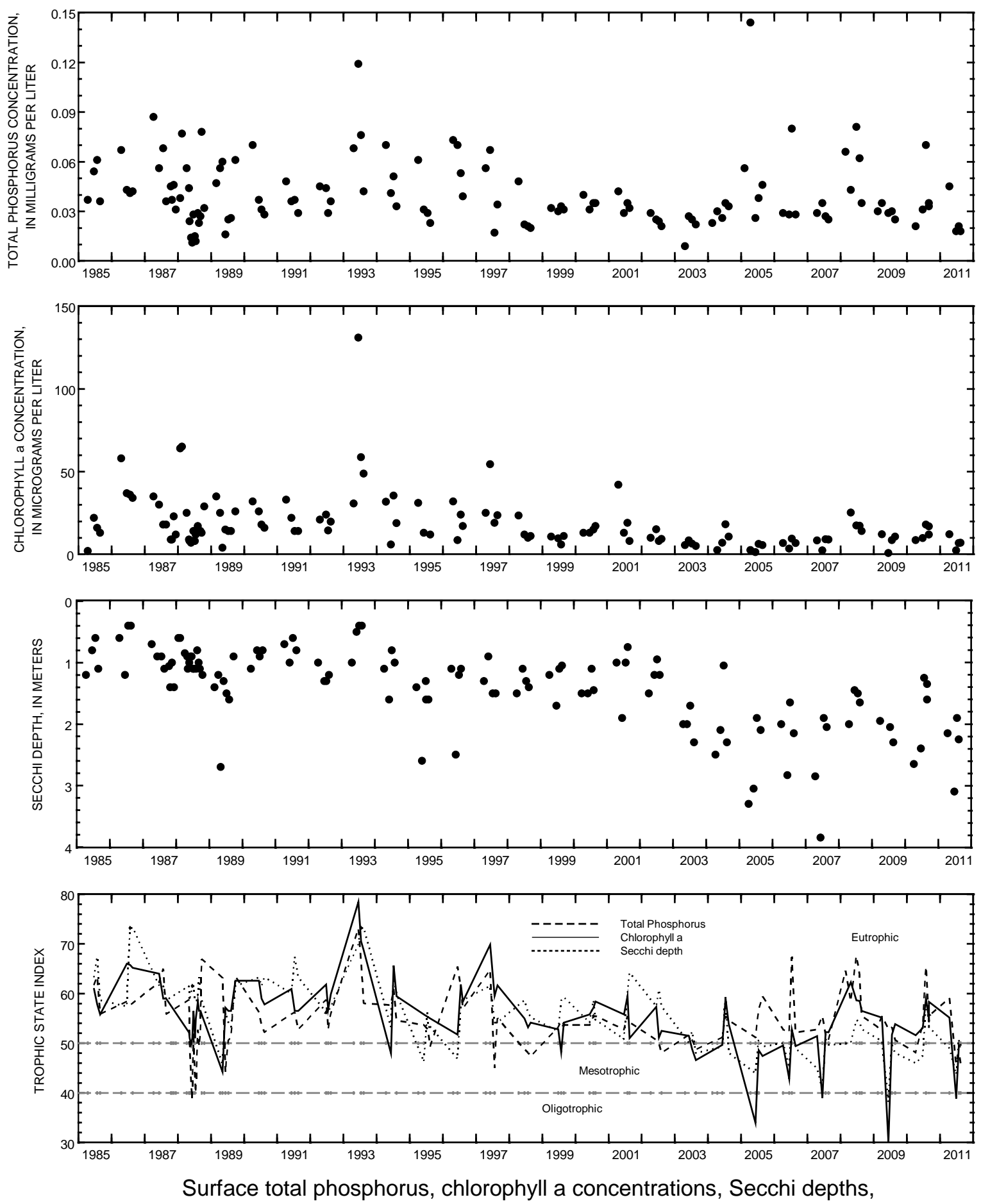

and TSI data for Wind Lake, Deep Hole, at Wind Lake, Wisconsin. 


\section{LAKE WINNEBAGO AT OSHKOSH, WI}

LOCATION.--Lat 4400'35", long 88³1'38" referenced to North American Datum of 1927, in NE 1/4 NE 1/4 Sec.25, T.18 N., R.16 E., Winnebago County, WI, Hydrologic Unit 04030203, $800 \mathrm{ft}$ east of mouth of the upper Fox River.

SURFACE AREA.--215 $\mathrm{mi}^{2}$.

DRAINAGE AREA.--5,880 $\mathrm{mi}^{2}$.

PERIOD OF RECORD.--October 1938 to current year in reports of Geological Survey. Records from July 1882 to September 1938 in files of Geological Survey and U.S. Army Corps of Engineers. A report on Fox River by U.S. Army Corps of Engineers, published as House Document No. 146, 67th Congress, 2nd session, contains semimonthly records of inflow of Lake Winnebago for the period 1896-1917.

REVISED RECORDS.--WDR WI-83-1: Drainage area.

GAGE.--Water-stage recorder. Nonrecording gage read once daily October 1938 to October 1978. Datum of gage is $745.05 \mathrm{ft}$ above mean tide at New York City (levels by U.S. Army Corps of Engineers).

REMARKS.--Lake elevations controlled by dams at Menasha and Neenah, which are operated in the interest of navigation. Crests of both dams are at elevation $746.73 \mathrm{ft}$. Present limits of regulation are from $21 \frac{1 / 4}{4}$. above the crest of Menasha to crest during navigation season, plus additional 18 in. below crest during winter. Data-collection platform and gage-height telemeter at station.

EXTREMES FOR PERIOD OF RECORD.--Maximum gage height observed, 4.32 ft, Mar. 9, 1982; Minimum observed, $0.33 \mathrm{ft}$, May 17, 1960.

EXTREMES FOR CURRENT YEAR.--Maximum daily mean gage height, $3.43 \mathrm{ft}$, Apr. 30; Minimum recorded, $1.70 \mathrm{ft}$, Feb. 15, 16, 17. 
GAGE HEIGHT, FEET

WATER YEAR OCTOBER 2010 TO SEPTEMBER 2011

DAILY MEAN VALUES

\begin{tabular}{|c|c|c|c|c|c|c|c|c|c|c|c|c|}
\hline Day & Oct & Nov & Dec & Jan & Feb & Mar & Apr & May & Jun & Jul & Aug & Sep \\
\hline 1 & 2.81 & 2.51 & 2.09 & 2.10 & 1.86 & 1.78 & 2.25 & 3.23 & 2.94 & 3.04 & 3.02 & 2.92 \\
\hline 2 & 2.83 & 2.50 & 2.14 & 2.09 & 1.86 & 1.78 & 2.25 & 3.31 & 3.04 & 3.05 & 3.04 & 2.92 \\
\hline 3 & 2.81 & 2.47 & 2.15 & 2.08 & 1.86 & 1.77 & 2.30 & 3.35 & 2.99 & 3.08 & 3.04 & 2.99 \\
\hline 4 & 2.80 & 2.49 & 2.14 & 2.08 & 1.84 & 1.78 & 2.30 & 3.33 & 2.99 & 3.08 & 3.07 & 3.03 \\
\hline 5 & 2.80 & 2.50 & 2.12 & 2.08 & 1.83 & 1.79 & 2.36 & 3.31 & 3.04 & 3.07 & 3.06 & 3.03 \\
\hline 6 & 2.80 & 2.46 & 2.10 & 2.08 & 1.81 & 1.79 & 2.38 & 3.25 & 3.04 & 3.11 & 3.06 & 3.03 \\
\hline 7 & 2.80 & 2.43 & 2.09 & 2.07 & 1.81 & 1.78 & 2.39 & 3.26 & 3.06 & 3.09 & 3.12 & 3.01 \\
\hline 8 & 2.80 & 2.43 & 2.09 & 2.06 & 1.80 & 1.78 & 2.40 & 3.21 & 3.06 & 3.08 & 3.14 & 3.00 \\
\hline 9 & 2.81 & 2.42 & 2.10 & 2.05 & 1.79 & 1.80 & 2.41 & 3.20 & 3.14 & 3.09 & 3.10 & 2.99 \\
\hline 10 & 2.79 & 2.41 & 2.11 & 2.03 & 1.77 & 1.82 & 2.44 & 3.14 & 3.12 & 3.08 & 3.10 & 2.98 \\
\hline 11 & 2.79 & 2.38 & 2.12 & 2.03 & 1.75 & 1.82 & 2.48 & 3.11 & 3.13 & 3.13 & 3.09 & 2.97 \\
\hline 12 & 2.76 & 2.41 & 2.21 & 2.03 & 1.73 & 1.83 & 2.56 & 3.06 & 3.14 & 3.14 & 3.09 & 2.94 \\
\hline 13 & 2.72 & 2.38 & 2.16 & 2.02 & 1.73 & 1.84 & 2.58 & 3.08 & 3.14 & 3.16 & 3.14 & 2.92 \\
\hline 14 & 2.70 & 2.26 & 2.14 & 2.01 & 1.72 & 1.83 & 2.67 & 3.11 & 3.14 & 3.14 & 3.13 & 2.89 \\
\hline 15 & 2.69 & 2.33 & 2.12 & 2.02 & 1.71 & 1.84 & 2.74 & 3.13 & 3.12 & 3.10 & 3.11 & 2.87 \\
\hline 16 & 2.63 & 2.32 & 2.10 & 2.01 & 1.70 & 1.85 & 2.67 & 3.03 & 3.09 & 3.12 & 3.11 & 2.84 \\
\hline 17 & 2.62 & 2.30 & 2.09 & 2.00 & 1.70 & 1.89 & 2.73 & 3.00 & 3.14 & 3.14 & 3.07 & 2.83 \\
\hline 18 & 2.59 & 2.29 & 2.09 & 2.00 & 1.71 & 1.94 & 2.93 & 2.98 & 3.15 & 3.16 & 3.07 & 2.80 \\
\hline 19 & 2.56 & 2.23 & 2.08 & 2.00 & 1.72 & 1.97 & 3.02 & 2.98 & 3.16 & 3.18 & 3.04 & 2.81 \\
\hline 20 & 2.54 & 2.28 & 2.08 & 1.98 & 1.73 & 2.00 & 3.02 & 2.98 & 3.18 & 3.19 & 3.03 & 2.83 \\
\hline 21 & 2.55 & 2.25 & 2.09 & 1.97 & 1.79 & 2.04 & 3.06 & 2.99 & 3.19 & 3.17 & 2.99 & 2.76 \\
\hline 22 & 2.55 & 2.21 & 2.09 & 1.95 & 1.81 & 2.11 & 3.14 & 3.00 & 3.19 & 3.16 & 2.97 & 2.81 \\
\hline 23 & 2.56 & 2.18 & 2.10 & 1.94 & 1.81 & 2.22 & 3.12 & 2.98 & 3.17 & 3.19 & 2.93 & 2.80 \\
\hline 24 & 2.62 & 2.30 & 2.09 & 1.92 & 1.80 & 2.24 & 3.17 & 3.04 & 3.18 & 3.20 & 2.91 & 2.80 \\
\hline 25 & 2.63 & 2.12 & 2.09 & 1.91 & 1.80 & 2.24 & 3.19 & 3.08 & 3.19 & 3.18 & 2.94 & 2.82 \\
\hline 26 & 2.50 & 2.12 & 2.10 & 1.89 & 1.80 & 2.24 & 3.30 & 3.09 & 3.18 & 3.16 & 2.91 & 2.91 \\
\hline 27 & 2.40 & 2.19 & 2.10 & 1.89 & 1.80 & 2.25 & 3.31 & 3.05 & 3.13 & 3.12 & 2.94 & 2.87 \\
\hline 28 & 2.57 & 2.19 & 2.10 & 1.88 & 1.79 & 2.25 & 3.34 & 3.01 & 3.07 & 3.10 & 2.93 & 2.86 \\
\hline 29 & 2.59 & 2.19 & 2.10 & 1.87 & --- & 2.25 & 3.38 & 3.02 & 3.14 & 3.09 & 2.91 & 2.79 \\
\hline 30 & 2.55 & 2.13 & 2.10 & 1.86 & --- & 2.25 & 3.43 & 3.02 & 3.10 & 3.07 & 2.91 & 2.87 \\
\hline 31 & 2.53 & --- & 2.10 & 1.86 & --- & 2.25 & --- & 2.96 & --- & 3.02 & 2.92 & --- \\
\hline Mean & 2.67 & 2.32 & 2.11 & 1.99 & 1.78 & 1.97 & 2.78 & 3.11 & 3.11 & 3.12 & 3.03 & 2.90 \\
\hline Max & 2.83 & 2.51 & 2.21 & 2.10 & 1.86 & 2.25 & 3.43 & 3.35 & 3.19 & 3.20 & 3.14 & 3.03 \\
\hline Min & 2.40 & 2.12 & 2.08 & 1.86 & 1.70 & 1.77 & 2.25 & 2.96 & 2.94 & 3.02 & 2.91 & 2.76 \\
\hline
\end{tabular}




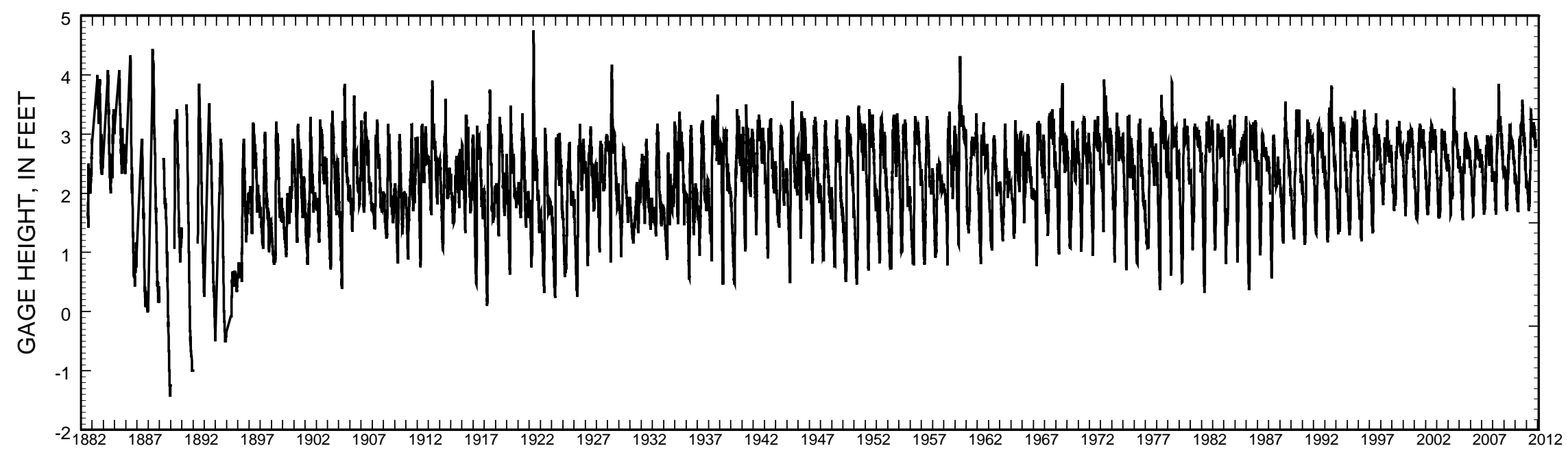

Stage hydrograph for Lake Winnebago at Oshkosh, WI, 1882-2011. 


\section{LAKE WINNEBAGO BUOY SITE NEAR OSHKOSH, WI}

LOCATION.--Lat 4401'28", long 88²7'12", in NE 1/4 NW 1/4, sec. 22, T 18 N., R 17 E., Winnebago County, WI, Hydrologic Unit 04030203. SURFACE AREA.--215 $\mathrm{mi}^{2}$.

DRAINAGE AREA.--5,880 $\mathrm{mi}^{2}$.

PERIOD OF RECORD.--May 2011 to September 2011.

REMARKS.--Lake sampled near buoy near the center of the lake.

\begin{tabular}{|c|c|c|c|c|c|c|c|c|}
\hline & & & & $\begin{array}{r}\text { WATER-QL } \\
\text { (Milligra }\end{array}$ & $\begin{array}{l}\text { LITY DA } \\
\text { per liter }\end{array}$ & $\begin{array}{l}\text {, MAY } 19 \\
\text { nless othe }\end{array}$ & $\begin{array}{l}\text { JULY 29, } \\
\text { ise indicate }\end{array}$ & 2011 \\
\hline Date & $\begin{array}{c}\text { Trans- } \\
\text { parency } \\
\text { Secchi } \\
\text { disc, } \\
\text { meters } \\
(\odot \odot \odot 78)\end{array}$ & $\begin{array}{c}\text { Sam- } \\
\text { pling } \\
\text { depth, } \\
\text { meters } \\
(\odot \odot \odot 98)\end{array}$ & $\begin{array}{l}\text { Temper - } \\
\text { ature, } \\
\text { water, } \\
\text { deg C } \\
(00010)\end{array}$ & $\begin{array}{c}\text { Specif- } \\
\text { ic } \\
\text { conduc- } \\
\text { tance, } \\
\text { wat unf } \\
\text { uS/cm @ } \\
25 \text { degC } \\
(\odot \odot \odot 95)\end{array}$ & $\begin{array}{c}\mathrm{pH}, \\
\text { water, } \\
\text { unfltrd } \\
\text { field, } \\
\text { std } \\
\text { units } \\
(\odot \odot 4 \odot \odot)\end{array}$ & $\begin{array}{c}\text { Dis- } \\
\text { solved } \\
\text { oxygen, } \\
\text { mg/L } \\
(00300)\end{array}$ & $\begin{array}{c}\text { Chloro- } \\
\text { phyll a } \\
\text { trichro } \\
\text {-matic } \\
\text { method, } \\
\text { uncorr, } \\
\text { ug/L } \\
(32210)\end{array}$ & $\begin{array}{c}\text { Phos- } \\
\text { phorus, } \\
\text { water, } \\
\text { unfltrd } \\
\text { mg/L } \\
\text { as P } \\
(00665)\end{array}$ \\
\hline MAY 201 & & & & & & & & \\
\hline $19 \ldots$ & 1.10 & - - & -- & -- & - - & -- & -- & - - \\
\hline $19 \ldots$ & -- & .50 & 12.5 & 353 & 8.0 & 11.2 & 36.1 & .052 \\
\hline $19 \ldots$ & - - & 5.5 & 12.1 & 352 & 7.6 & 10.6 & - - & .046 \\
\hline $27 \ldots$ & - - & .50 & 14.6 & 350 & 7.6 & 11.9 & 35.5 & .054 \\
\hline $27 \ldots$ & - - & 5.5 & 13.1 & 352 & 7.6 & 10.0 & -- & .050 \\
\hline JUN & & & & & & & & \\
\hline $17 \ldots$ & -- & .50 & - - & -- & -- & -- & -- & .051 \\
\hline $24 \ldots$ & -- & .50 & - - & -- & - - & - - & -- & .047 \\
\hline $29 \ldots$ & -- & .50 & - - & - - & - - & -- & -- & .056 \\
\hline JUL & & & & & & & & \\
\hline ๑8. . . & 1.50 & - - & - - & - - & - - & - - & - - & - - \\
\hline$\odot 8 \ldots$ & - - & .50 & 25.2 & 368 & 8.7 & 9.8 & 44.1 & .063 \\
\hline $08 \ldots$ & - - & 5.0 & 23.6 & 370 & 8.5 & 8.0 & -- & .038 \\
\hline$\odot 8 \ldots$ & - - & 5.8 & 22.6 & 383 & 7.8 & .8 & -- & .053 \\
\hline $15 \ldots$ & - - & .50 & -- & -- & - - & - - & -- & .069 \\
\hline $15 \ldots$ & .55 & -- & -- & -- & - - & -- & - - & -- \\
\hline $21 \ldots$ & -- & .50 & -- & -- & - - & - - & - - & .072 \\
\hline $29 \ldots$ & - - & .50 & - - & -- & -- & -- & -- & .072 \\
\hline
\end{tabular}




\section{LAKE WINNEBAGO BUOY SITE NEAR OSHKOSH, WI}

WATER-QUALITY DATA, AUGUST 4 TO SEPTEMBER 22, 2011 (Milligrams per liter unless otherwise indicated)

\begin{tabular}{|c|c|c|c|c|c|c|c|c|}
\hline Date & 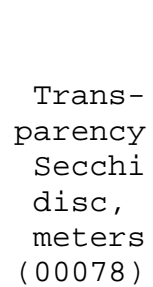 & $\begin{array}{c}\text { Sam- } \\
\text { pling } \\
\text { depth, } \\
\text { meters } \\
(\odot \odot \odot 98)\end{array}$ & $\begin{array}{l}\text { Temper - } \\
\text { ature, } \\
\text { water, } \\
\text { deg C } \\
(00010)\end{array}$ & $\begin{array}{c}\text { Specif- } \\
\text { ic } \\
\text { conduc- } \\
\text { tance, } \\
\text { wat unf } \\
\text { uS/cm @ } \\
25 \text { degC } \\
(\odot \odot \odot 95)\end{array}$ & $\begin{array}{c}\text { pH, } \\
\text { water, } \\
\text { unfltrd } \\
\text { field, } \\
\text { std } \\
\text { units } \\
(\odot \odot 4 \odot \odot)\end{array}$ & $\begin{array}{c}\text { Dis- } \\
\text { solved } \\
\text { oxygen, } \\
\text { mg/L } \\
(\odot \odot 3 \odot \odot)\end{array}$ & $\begin{array}{c}\text { Chloro- } \\
\text { phyll a } \\
\text { trichro } \\
\text {-matic } \\
\text { method, } \\
\text { uncorr, } \\
\text { ug/L } \\
(32210)\end{array}$ & $\begin{array}{c}\text { Phos- } \\
\text { phorus, } \\
\text { water, } \\
\text { unfltro } \\
\text { mg/L } \\
\text { as P } \\
(00665)\end{array}$ \\
\hline
\end{tabular}

AUG 2011

\begin{tabular}{|c|c|c|c|c|c|c|c|c|}
\hline $04 \ldots$ & - & .50 & - - & - & - & - & - & .094 \\
\hline $18 \ldots$ & - - & .50 & -- & - - & -- & -- & - - & .137 \\
\hline $26 \ldots$ & - - & .50 & -- & -- & - & -- & - - & .127 \\
\hline $30 \ldots$ & .85 & - & -- & -- & - & -- & - - & - \\
\hline $30 \ldots$ & -- & .50 & 22.8 & 359 & 8.9 & 9.6 & - & - \\
\hline $\begin{array}{l}30 \ldots \\
P\end{array}$ & -- & 5.5 & 22.7 & 360 & 8.9 & 8.7 & -- & -- \\
\hline$\odot 9$. & -- & .50 & - & - & - & - & - - & .150 \\
\hline $22 \ldots$ & .85 & - & - - & - & - & - - & - - & - \\
\hline $22 \ldots$ & -- & .50 & 16.6 & 360 & 8.8 & 9.2 & 74.0 & .151 \\
\hline $22 \ldots$ & -- & 5.0 & 16.6 & 360 & 8.8 & 9.1 & 74.2 & .155 \\
\hline
\end{tabular}


440128088271201 LAKE WINNEBAGO BUOY SITE NEAR OSHKOSH, WI

LAKE-DEPTH PROFILES, MAY 19 TO JULY 8, 2011

05-19-11
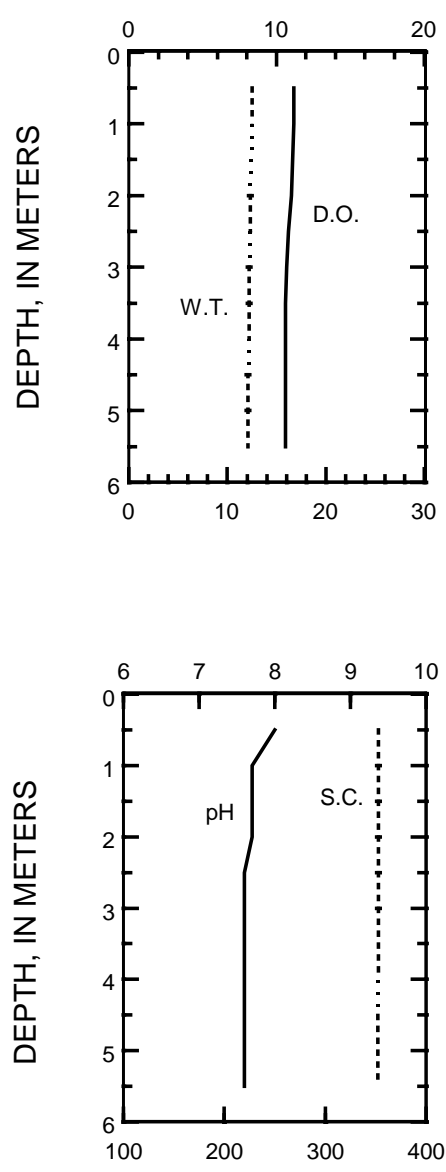

05-27-11

DISSOLVED OXYGEN (D.O.), IN MILLIGRAMS PER LITER

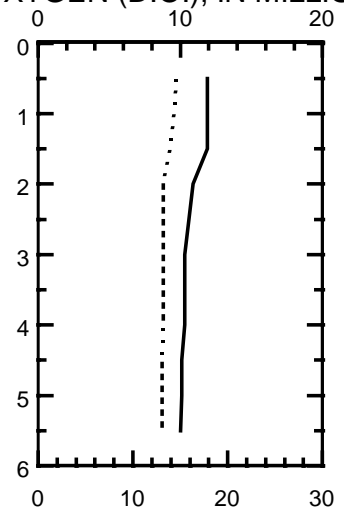

WATER TEMPERATURE (W.T.), IN DEGREES CELSIUS

$\mathrm{PH}$, IN STANDARD UNITS

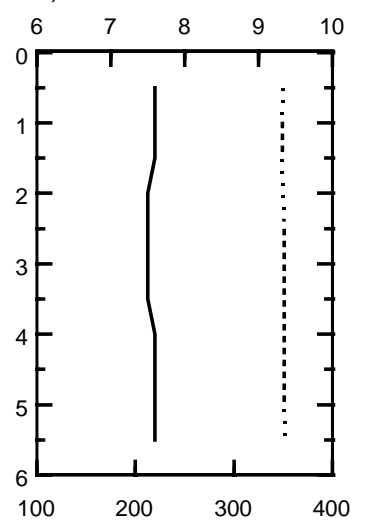

07-08-11
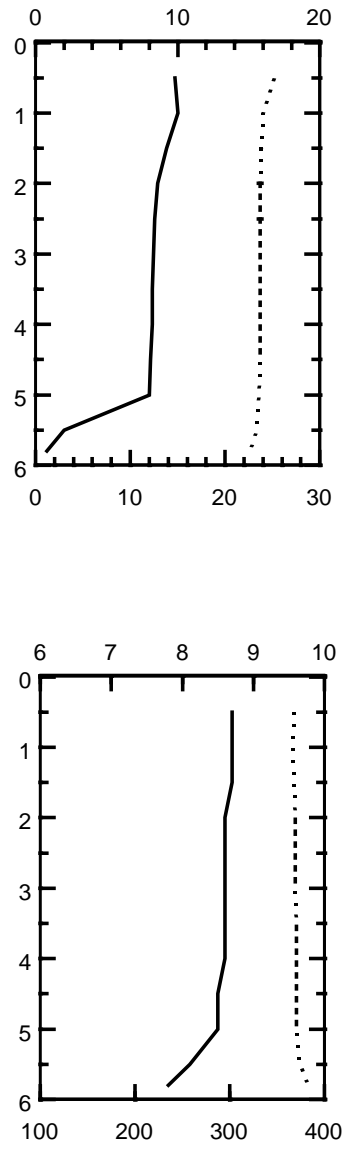

SPECIFIC CONDUCTANCE (S.C.), IN MICROSIEMENS PER CENTIMETER AT 25 DEGREES CELSIUS 


\section{LAKE WINNEBAGO BUOY SITE NEAR OSHKOSH, WI}

LAKE-DEPTH PROFILES, JULY 15 TO SEPTEMBER 22, 2011

07-15-11
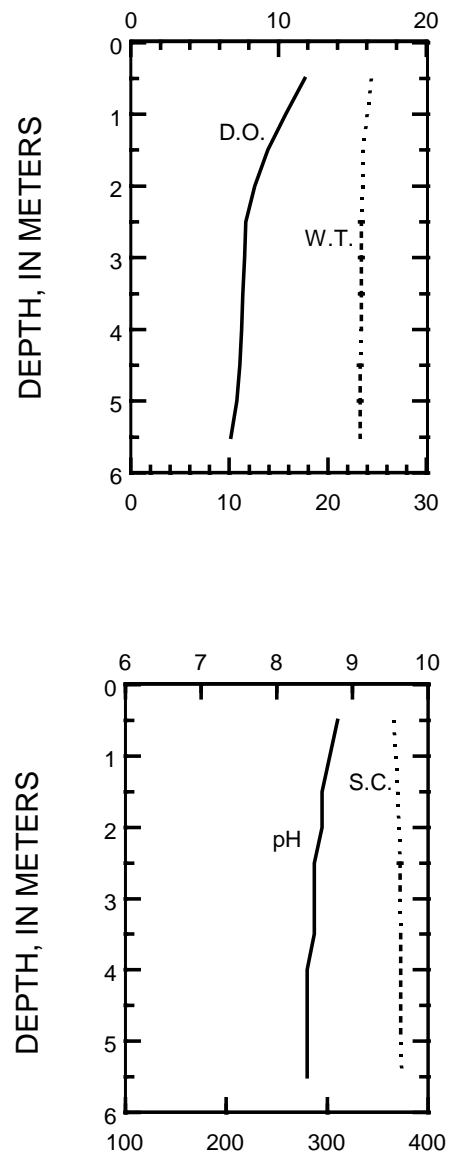

08-30-11

DISSOLVED OXYGEN (D.O.), IN MILLIGRAMS PER LITER

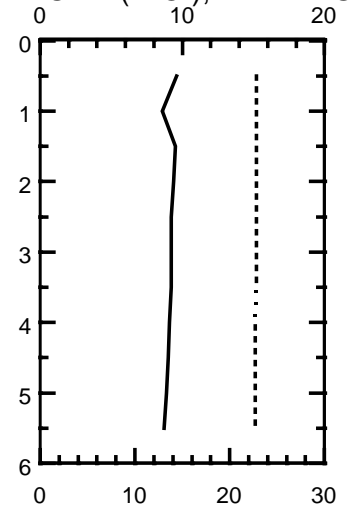

WATER TEMPERATURE (W.T.), IN DEGREES CELSIUS

$\mathrm{PH}$, IN STANDARD UNITS

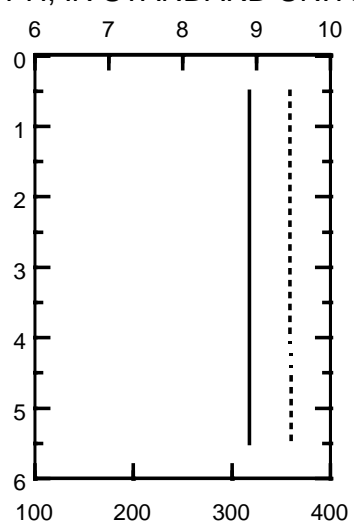

$09-22-11$
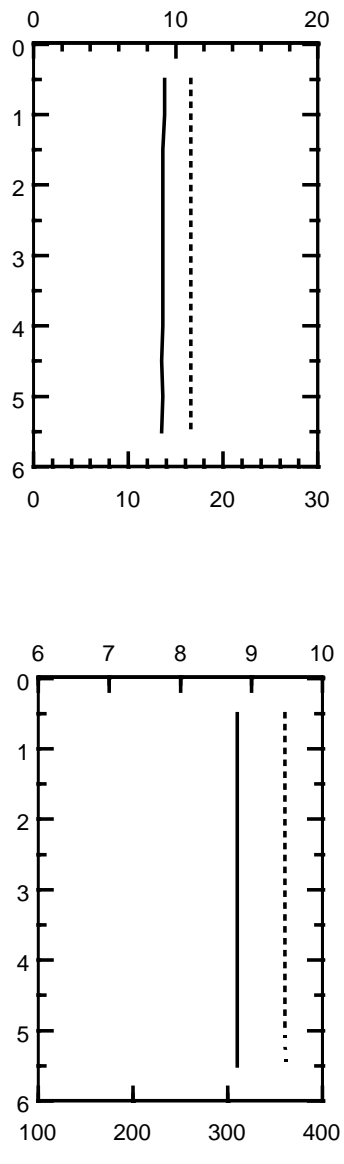


\section{LAKE WINNEBAGO NEAR STOCKBRIDGE, WI}

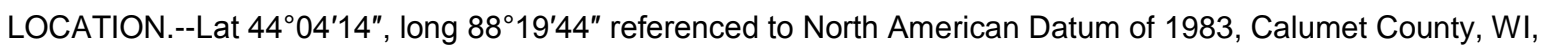
Hydrologic Unit 04030203, Stockbridge Indian Reservation, on east shore of Lake Winnebago, $300 \mathrm{ft}$ south of County Highway $\mathrm{E}$ and 1.6 mi west of Stockbridge.

SURFACE AREA.--215 $\mathrm{mi}^{2}$.

DRAINAGE AREA.--5,880 $\mathrm{mi}^{2}$.

PERIOD OF RECORD.--November 1982 to current year.

GAGE.--Water-stage recorder. Datum of gage is $745.05 \mathrm{ft}$ above mean tide of New York City (levels by U. S. Army Corps of Engineers).

REMARKS.--Lake elevations controlled by dams at Menasha and Neenah, which are operated in the interest of navigation. Crests of both dams are at elevation $746.73 \mathrm{ft}$. Present limits of regulation are from $21 \mathrm{1} / 4$ in. above the crest of Menasha dam to crest during navigation season, plus additional 18 in. below crest during winter. Datacollection platform and gage-height telemeter at station.

EXTREMES FOR PERIOD OF RECORD.--Maximum daily mean gage height, 3.85 ft, July 9, 11, 1993, June 14, 2008; minimum observed, $0.30 \mathrm{ft}$, Mar. 1, 1986.

EXTREMES FOR CURRENT YEAR.--Maximum daily mean gage height, $3.33 \mathrm{ft}$, Apr. 29; minimum recorded, $1.49 \mathrm{ft}$, Feb. 17. 
GAGE HEIGHT, FEET

WATER YEAR OCTOBER 2010 TO SEPTEMBER 2011

\begin{tabular}{|c|c|c|c|c|c|c|c|c|c|c|c|c|}
\hline Day & Oct & Nov & Dec & Jan & Feb & Mar & Apr & May & Jun & Jul & Aug & Sep \\
\hline 1 & 2.67 & 2.39 & 2.16 & 1.99 & 1.76 & 1.68 & 2.17 & 3.32 & 3.05 & 2.99 & 2.94 & 2.82 \\
\hline 2 & 2.60 & 2.39 & 2.09 & 1.99 & 1.77 & 1.68 & 2.18 & 3.30 & 2.88 & 3.00 & 2.94 & 2.87 \\
\hline 3 & 2.66 & 2.41 & 2.04 & 1.98 & 1.74 & 1.67 & 2.19 & 3.26 & 2.87 & 3.01 & 2.95 & 2.93 \\
\hline 4 & 2.69 & 2.35 & 2.03 & 1.99 & 1.72 & 1.69 & 2.25 & 3.25 & 2.92 & 3.01 & 2.97 & 2.96 \\
\hline 5 & 2.69 & 2.33 & 2.03 & 1.98 & 1.71 & 1.69 & 2.28 & 3.23 & 2.94 & 3.03 & 2.97 & 2.90 \\
\hline 6 & 2.70 & 2.38 & 2.02 & 1.98 & 1.70 & 1.69 & 2.30 & 3.20 & 2.95 & 3.02 & 2.99 & 2.90 \\
\hline 7 & 2.70 & 2.34 & 2.01 & 1.98 & 1.70 & 1.68 & 2.30 & 3.16 & 3.00 & 3.00 & 3.03 & 2.88 \\
\hline 8 & 2.70 & 2.31 & 2.00 & 1.96 & 1.69 & 1.68 & 2.31 & 3.12 & 3.05 & 2.99 & 3.04 & 2.87 \\
\hline 9 & 2.67 & 2.29 & 1.99 & 1.94 & 1.68 & 1.71 & 2.32 & 3.05 & 2.95 & 2.99 & 3.11 & 2.87 \\
\hline 10 & 2.67 & 2.28 & 2.01 & 1.93 & 1.66 & 1.72 & 2.35 & 3.02 & 2.94 & 3.02 & 3.06 & 2.88 \\
\hline 11 & 2.65 & 2.27 & 2.00 & 1.93 & 1.65 & 1.72 & 2.46 & 2.97 & 3.03 & 3.08 & 3.04 & 2.88 \\
\hline 12 & 2.64 & 2.24 & 2.13 & 1.93 & 1.63 & 1.73 & 2.48 & 2.97 & 3.04 & 3.08 & 3.01 & 2.90 \\
\hline 13 & 2.62 & 2.20 & 2.06 & 1.92 & 1.62 & 1.73 & 2.50 & 2.95 & 3.05 & 3.03 & 3.01 & 2.86 \\
\hline 14 & 2.61 & 2.32 & 2.03 & 1.90 & 1.62 & 1.73 & 2.46 & 2.87 & 3.00 & 3.00 & 3.00 & 2.83 \\
\hline 15 & 2.55 & 2.25 & 2.01 & 1.92 & 1.60 & 1.73 & 2.42 & 2.78 & 2.95 & 3.00 & 3.02 & 2.77 \\
\hline 16 & 2.57 & 2.20 & 2.00 & 1.90 & 1.59 & 1.75 & 2.65 & 2.83 & 3.02 & 3.04 & 3.02 & 2.74 \\
\hline 17 & 2.53 & 2.20 & 2.00 & 1.89 & 1.58 & 1.79 & 2.84 & 2.84 & 3.04 & 3.06 & 3.01 & 2.68 \\
\hline 18 & 2.50 & 2.21 & 1.99 & 1.90 & 1.62 & 1.86 & 2.81 & 2.84 & 3.04 & 3.11 & 2.98 & 2.65 \\
\hline 19 & 2.50 & 2.21 & 1.98 & 1.89 & 1.62 & 1.87 & 2.78 & 2.88 & 3.05 & 3.10 & 2.96 & 2.74 \\
\hline 20 & 2.49 & 2.13 & 1.98 & 1.87 & 1.64 & 1.90 & 2.94 & 2.89 & 3.06 & 3.16 & 2.93 & 2.73 \\
\hline 21 & 2.50 & 2.11 & 1.98 & 1.86 & 1.69 & 1.97 & 2.99 & 2.88 & 3.03 & 3.14 & 2.91 & 2.79 \\
\hline 22 & 2.44 & 2.16 & 2.00 & 1.85 & 1.70 & 2.02 & 3.00 & 2.90 & 3.11 & 3.09 & 2.87 & 2.74 \\
\hline 23 & 2.44 & 2.26 & 2.00 & 1.84 & 1.70 & 2.13 & 3.08 & 2.96 & 3.12 & 3.10 & 2.89 & 2.69 \\
\hline 24 & 2.50 & 2.08 & 2.00 & 1.82 & 1.70 & 2.15 & 3.12 & 2.90 & 3.14 & 3.11 & 2.89 & 2.66 \\
\hline 25 & 2.50 & 2.16 & 2.00 & 1.81 & 1.70 & 2.15 & 3.11 & 2.81 & 3.10 & 3.11 & 2.86 & 2.65 \\
\hline 26 & 2.70 & 2.25 & 2.00 & 1.80 & 1.70 & 2.16 & 3.11 & 2.84 & 3.08 & 3.06 & 2.84 & 2.67 \\
\hline 27 & 2.84 & 2.12 & 2.00 & 1.78 & 1.70 & 2.17 & 3.26 & 2.92 & 3.02 & 3.01 & 2.81 & 2.73 \\
\hline 28 & 2.63 & 2.08 & 2.00 & 1.78 & 1.69 & 2.17 & 3.31 & 2.95 & 3.08 & 3.00 & 2.80 & 2.74 \\
\hline 29 & 2.53 & 2.06 & 1.99 & 1.77 & --- & 2.17 & 3.33 & 2.93 & 3.03 & 3.00 & 2.84 & 2.78 \\
\hline 30 & 2.44 & 2.12 & 1.99 & 1.76 & --- & 2.17 & 3.28 & 2.92 & 2.99 & 2.98 & 2.83 & 2.70 \\
\hline 31 & 2.39 & --- & 1.99 & 1.75 & --- & 2.16 & --- & 2.98 & --- & 2.96 & 2.79 & --- \\
\hline Mean & 2.59 & 2.24 & 2.02 & 1.89 & 1.67 & 1.87 & 2.69 & 2.99 & 3.02 & 3.04 & 2.95 & 2.79 \\
\hline Max & 2.84 & 2.41 & 2.16 & 1.99 & 1.77 & 2.17 & 3.33 & 3.32 & 3.14 & 3.16 & 3.11 & 2.96 \\
\hline Min & 2.39 & 2.06 & 1.98 & 1.75 & 1.58 & 1.67 & 2.17 & 2.78 & 2.87 & 2.96 & 2.79 & 2.65 \\
\hline
\end{tabular}




\section{WISCONSIN DISTRICT PUBLICATIONS PERTAINING TO LAKES}

The reports published in a U.S. Geological Survey series are for sale by the U.S. Geological Survey, Box 25425, Federal Center, Denver, CO 80225. Prepayment is required. Remittance should be sent by check or money order payable to the U.S. Geological Survey. Prices can be obtained by writing to the above address or by calling (303) 236-7476. Reprints of journal articles may be obtained by writing directly to the author at U.S. Geological Survey, 8505 Research Way, Middleton, WI 53562.

2011

Feinstein, D.T., Dunning, C.P., Juckem, P.F., and Hunt, R.J., 2010, Application of the Local Grid Refinement package to an inset model simulating the interactions of lakes, wells, and shallow groundwater, northwestern Waukesha County, Wisconsin: U.S. Geological Survey Scientific Investigations Report 2010-5214, 30 p.

Robertson, D.M. and Rose, W.J., 2011, Response in the trophic state of stratified lakes to changes in hydrology and water level: potential effects of climate change: Journal of Water and Climate Change, vol. 2. No. 1, p. 1-18.

2010

Garn, H.S., Robertson, D.M., Rose, W.J., and Saad, D.A., 2010, Hydrology, water quality, and response to simulated changes in phosphorus loading of Minocqua and Kawaguesaga Lakes, Oneida County, Wisconsin, with special emphasis on effects of urbanization: U.S. Geol. Survey Scientific Invest. Report 2010-5196.

2009

Robertson, D.M., Rose, W.J., and Fitzpatrick, F.A., 2009, Water quality and hydrology of Silver Lake, Barron County, Wisconsin, with special emphasis on the responses of a terminal lake to changes in phosphorus loading and water level: U.S. Geol. Survey Scientific Invest. Report 2009-5077, 38 p.

Robertson, D.M., Rose, W.J., and Juckem, P.F., 2009, Water quality and hydrology of Whitefish Lake, Douglas County, Wisconsin, with special emphasis on the responses of an oligotrophic seepage lake to changes in phosphorus loading and water level: U.S. Geol. Survey Scientific Invest. Report 2009-5089, 41 p.

2008

Chung, E., Schladow, S.G., Perez-Losada, J., and Robertson, D.M., 2008, A linked hydrodynamic and water quality model for the Salton Sea: Hydrobiologia, v. 604, p. 57-75.

Robertson, D.M., and Rose, W.J., 2008, Water quality, hydrology, and simulated response to changes in phosphorus loading of Butternut Lake, Price and Ashland Counties, Wisconsin, with special emphasis on the effects of internal phosphorus loading in a polymictic lake: U.S. Geol. Survey Scientific Invest. Report 2008-5053, $46 \mathrm{p}$. 
Robertson, D.M., and Schladow, S.G., 2008, Response in the water quality in the Salton Sea to changes in phosphorus loading: An empirical modeling approach: Hydrobiologia, v. 604, p. 5-19.

Robertson, D.M., Schladow, S.G., and Holdren, G.C., 2008, Long-term changes in the phosphorus loading to and trophic state of the Salton Sea: Hydrobiologia, v. 604, p. 21-36.

2007

Robertson, D.M., Garn, H.S., and Rose, W.J., 2007, Response of calcareous Nagawicka Lake, Wisconsin, to changes in phosphorus loading. Lake and Reservoir Management, Vol. 23, p. 298-312.

Walker, J.F., Saad, D.A., and Hunt, R.J., 2007, Dynamics of CFCs in northern temperate lakes and adjacent groundwater. Water Resources. Research 43(4) W04423, http://www.agu.org/pubs/crossref/2007/2005WR004647.shtml

\section{6}

Garn, H.S., Robertson, D.M., Rose, W.J., Goddard, G.L., and Horwatich, J.A., 2006, Water quality, hydrology, and response to changes in phosphorus loading of Nagawicka Lake, a calcareous lake in Waukesha County, Wisconsin: U.S. Geological Survey Scientific Investigations Report: 2006-5273.

Hunt, R.J., Greb, S.R,, Graczyk, D.J., 2006, Evaluating the effects of nearshore development on Wisconsin lakes. USGS Fact Sheet FS-2006-3033, 4 p.

Magnuson, J.J., Benson, B.J., Lenters, J.D, and Robertson, D.M., 2006, Climate driven variability and change, Chapter 7, In Magnuson, J.J., Kratz, T.K, and Benson, B.J eds. Long-term dynamics of lakes in the landscape, Oxford University Press, p 123150.

Saad, D.A., 2005, Pesticides in surface water, bed sediment, and ground water adjacent to commercial cranberry bogs, Lac du Flambeau Reservation, Vilas County, Wisconsin: U.S. Geological Survey Scientific Investigations Report 2005-5262, 29 p.

2005

Hunt, R.J., Feinstein, D.T., Pint, C.D., and Anderson, M.P., 2005, The importance of diverse data types to calibrate a watershed model of the Trout Lake Basin, northern Wisconsin: Journal of Hydrology doi:10.1016/j.jhydrol.2005.08.005.

Marzolf, G.R., and Robertson, D.M., 2005, Reservoir, In Encyclopedia of Hydrological Sciences: Anderson, M.G., and McDonnell, J.J., eds., v. 4, part 9, John Wiley \& Sons, p. 1675-1680.

Robertson, D.M., Rose, W.J., and Saad, D.A., 2005, Water quality, hydrology, and phosphorus loading to Little St. Germain Lake, Wisconsin, with special emphasis on the effects of winter aeration and ground-water inputs: U.S. Geological Survey Scientific Investigations Report 2005-5071, 36 p.

2004

Dupre, D.H., and Robertson, D.M., 2004, Water quality of Nippersink Creek and Wonder Lake, McHenry County, Illinois, 1994-2001: U.S. Geological Survey Scientific Investigations Report 2004-5085. 
Rose, W.J., Robertson, D.M., and Mergener, E.A., 2004, Water quality, hydrology, and the effects of changes in phosphorus loading to Pike Lake, Washington County, Wisconsin, with special emphasis on inlet-to-outlet short-circuiting: U.S. Geological Survey Scientific Investigations Report 2004-5141, 32 p.

2003

Dunning, C.P., Thomas, J.C., and Lin, Y.F., 2003, Simulation of the shallow aquifer in the vicinity of Silver Lake, Washington County, Wisconsin, using analytic elements: U.S. Geological Survey Water-Resources Investigations Report 02-4204, 29 p.

Fitzpatrick, F.A., Garrison, P.J., Fitzgerald, S.A., and Elder, J.F., 2003, Nutrient, traceelement, and ecological history of Musky Bay, Lac Courte Oreilles, Wisconsin, as inferred from sediment cores: U.S. Geological Survey Water-Resources Investigations Report 02-4225, $141 \mathrm{p}$.

Fitzpatrick, F.A., and Peppler, M.C., 2003, Sedimentation and sediment chemistry, Neopit Mill Pond, Menominee Indian Reservation, Wisconsin, 2001: U.S. Geological Survey Open-File Report 03-23, 58 p.

Garn, H.S., Elder, J.F., and Robertson, D.M., 2003, Why study lakes? An overview of U.S. Geological Survey lake studies in Wisconsin: U.S. Geological Survey Fact Sheet FS-063-03, 8 p.

Graczyk, D.G., Hunt, R.J., Greb, S.R., Buchwald, C.A., and Krohelski, J.T., 2003, Hydrology, water quality, and yields, from near-shore flows to four lakes in northern Wisconsin, 1999-2001: U.S. Geological Survey Water-Resources Investigations Report 03-4144. 64 p.

Hunt, R.J., 2003, Ground water-lake interaction modeling using the LAK3 Package for MODFLOW2000: Ground Water, vol. 41, no. 2, p. 114-118.

Hunt, R.J., Haitjema, H.M., Krohelski, J.T., and Feinstein, D.T., 2003, Simulating ground water-lake interactions: approaches and insights: Ground Water, vol. 41, no. 22, p. 227-237.

Hunt, R.J., Pint, C.D., and Anderson, M.P., 2003, Using diverse data types to calibrate a watershed model of the Trout Lake Basin, northern Wisconsin, In MODFLOW and More 2003-Understanding through modeling: Proceedings of the 5th International Conference of the International Ground Water Modeling Center. Golden, CO: Colorado School of Mines, p. 600-604.

Hunt, R.J., Saad, D.A., and Chapel, D.M., 2003, Numerical simulation of ground water flow in La Crosse County, Wisconsin and into nearby pools of the Mississippi River: U.S. Geological Survey Water-Resources Investigations Report 03-4154. 36 p.

John, R., Pint, C.D., Anderson, M.P., and Hunt, R.J., 2003, The effects of potential climate change on lake levels and lake capture zones, In MODFLOW and More 2003-Understanding through modeling: Proceedings of the 5th International Conference of the International Ground Water Modeling Center. Golden, CO: Colorado School of Mines, p. 212-216. 
Magnuson, J.J., Krohelski, J.T., Kunkel, K.E., and Robertson, D.M., 2003, Wisconsin's waters and climate-historical changes and possible futures, In Wisconsin's waters: a confluence of perspectives: Transactions of the Wisconsin Academy, p. 23-36.

Pint, C.D., Hunt, R.J., and Anderson, M.P., 2003, Flow path delineation and ground water age, Allequash Basin, Wisconsin: Ground Water, vol. 41, no. 7, p. 895-902.

Robertson, D.M., Rose, W.J., and Garn, H.S., 2003, Water quality and the effects of changes in phosphorus loading, Red Cedar Lakes, Barron and Washburn Counties, Wisconsin: U.S. Geological Survey Water-Resources Investigations Report 034238, $42 \mathrm{p}$.

Robertson, D.M., Rose, W.J., and Saad, D.A., 2003, Water quality and the effects of changes in phosphorus loading to Muskellunge Lake, Vilas County, Wisconsin: U.S. Geological Survey Water-Resources Investigations Report 03-4011, 18 p.

2002

Anderson, M.P., Hunt, R.J., Krohelski, J.T., and Chung, K., 2002, Using high hydraulic conductivity nodes to simulate seepage lakes: Ground Water 40(2), p. 119-124.

Garn, H. S., 2002, Effects of lawn fertilizer on nutrient concentration in runoff from lakeshore lawns, Lauderdale Lakes, Wisconsin: USGS Water-Resources Investigations Report 02-4130, 6 p.

Kelson, V.A., Hunt, R.J., and Haitjema, H.M., 2002, Improving a regional model using reduced complexity and parameter estimation: Ground Water, vol. 40, no. 2, p. 138149.

Krohelski, J.T., Lin, Y., Rose, W.J., and Hunt, R.J., 2002, Simulation of Fish, Mud and Crystal Lakes and the shallow ground-water system, Dane County, Wisconsin: USGS Water-Resources Investigations Report 02-20.

Krohelski, J.T., Rose, W.J., and Hunt, R.J., 2002, Hydrologic investigation of Powell Marsh and its relationship to Dead Pike Lake Vilas County, Wisconsin: USGS WaterResources Investigations Report 02-4034.

Madenjian, C.P., Fahenstiel, G.L., Johengen, T.H., Nalepa, T.F., Venderploeg, H.A., Fleischer, G.W., Schneeberger, P.J., Benjamin, D.M., Smith, E.B., Bence, J.R., Rutherford, E.S., Lavis, D.S., Robertson, D.M., Jude, D.J., and Ebener, M.P., 2002, Dynamics of the Lake Michigan food web, 1970-2000: Canadian Journal of Fisheries and Aquatic Sciences, Vol. 59, p. 736-753.

Robertson, D.M., Goddard, G.L, Mergerer, E.A., Rose, W.J., and Garrison, P.J., 2002, Hydrology and water quality of Geneva Lake, Walworth County, Wisconsin: U.S. Geological Survey Water Resources Investigations Report 02-4039, 73 p.

Robertson, D.M., and Lenz, B.N., 2002, Response of the St. Croix River Pools, Wisconsin and Minnesota, to various phosphorus-loading scenarios: U.S. Geological Survey Water-Resources Investigations Report 02-4181, 36 p. 
Hunt, R.J., Bradbury, K.R., and Krohelski, J.T., 2001, The effects of large-scale pumping and diversion on the water resources in Dane County, Wisconsin: USGS Fact Sheet FS-127-01, 4 p.

Hunt, R.J., Haitjema, H.M., Krohelski, J.T., and Feinstein, D.T., 2001, Simulating groundwater-lake interactions with models: MODFLOW and analytic element approaches, In MODFLOW 2001 and Other Modeling Odysseys: Proceedings of the 4th International Conference of the International Ground Water Modeling Center. Golden, CO: Colorado School of Mines, p. 328-334.

Lin, Y., Krohelski, J.T., and Hunt, R.J., 2001, Simulation of lake stage in two seepage lakes in southcentral Wisconsin using the LAK3 package for MODFLOW, In MODFLOW 2001 and Other Modeling Odysseys: Proceedings of the 4th International Conference of the International Ground Water Modeling Center. Golden, CO: Colorado School of Mines, p. 411-417.

Elder, J.F., Robertson, D.M., and Garrison, P.J., 2000, Chemical composition of surficial deposits in Geneva Lake, Wisconsin: U.S. Geological Survey Fact Sheet FS-12100 .

Elder J.F., Rybicki, N.B., Carter, V.P., and Weintraub, V., 2000, Sources and yields of dissolved carbon in northern Wisconsin stream catchments with differing amounts of peatland: Wetlands, vol. 20, no. 1, p.113-125.

Hunt, R.J., Graczyk, D.J., and Rose, W.J., 2000, Water flows in the Necedah National Wildlife Refuge: U.S. Geological Survey Fact Sheet FS-068-00, 4 p.

Hunt, R.J., Lin, J., Krohelski, J.T., and Juckem, P.F., 2000, Simulation of the shallow hydrologic system in the vicinity of Middle Genesee Lake, Wisconsin, using analytic elements and parameter estimation: U.S. Geological Survey Water Resources Investigations Report 00-4136, 16 p.

Lathrop, R.C., Carpenter, S.R., and Robertson, D.M., 2000, Interacting factors causing exceptional water clarity in Lakes Mendota and Monona, Wisconsin: Proc. of the International Limnological Society, SIL, Dublin, Ireland, August, 1998.

Magnuson, J.J., Robertson, D.M. Wynne, R.H., Benson, B.J., Livigstone, D.M., Arai, T., Assel, R.A., Barry, R.G., Card, V., Kuusisto, E., Granin, N.G., Prowse, T.D., Stewart, K.M., and Vuglinski, V.S., 2000, Historical trends in lake and river ice cover in the northern hemisphere: Science, Vol. 289, No. 5485, p. 1743-1746.

Magnuson, J.J., Wynne, R.H., Benson, B.J., and Robertson, D.M., 2000, Lake and river ice as a powerful indicator of past and present climates: Proc. of the International Limnological Society, SIL, Dublin, Ireland, August, 1998.

Robertson, D.M., 2000, One-dimensional simulation of stratification and dissolved oxygen in McCook Reservoir, Illinois: U.S. Geological Survey Water Resources Investigations Report 00-4258, 17 p. 
Robertson, D.M., Goddard, G.L., Helsel, D.R., and MacKinnon, K.L., 2000, Rehabilitation of Delavan Lake, Wisconsin: Lake and Reservoir Management, vol. 20, vo. 3, p. 155-176.

Robertson, D.M., and Rose, W.J., 2000, Hydrology, water quality, and phosphorus loading of Little St. Germain Lake, Vilas County, Wisconsin: U.S. Geological Survey Water Resources Investigations Report 00-4209, 8 p.

Robertson, D.M., Wynne, R.H., and Chang, W.Y.B., 2000, Variability in ice cover across the northern hemisphere during the 1900's associated with El Nino events: Proceedings of the International Limnological Society, SIL, Dublin, Ireland, August, 1998.

Saad, D.A., and Robertson, D.M., 2000, Water-resources-related information for the St. Croix Reservation and vicinity, Wisconsin: U.S. Geological Survey Water Resources Investigations Report 00-4133, 65 p.

Johnson, G.P., Hornewer, N.J., Robertson, D.M., and Olson, D.T., 2000, Methodology, data collection, and data analysis for determination of water-mixing patterns induced by aerators and mixers: U.S. Geological Survey Water Resources Investigations Report 00-4101, 72 p.

Grannemann, N.G., Hunt, R.J., Nicholas, J.R. Reilly, T.E., and Winter, T.C., 2000, The importance of ground water to the Great Lakes Region: U.S. Geological Survey Water Resources Investigations Report 00-4008, 12 p.

Lathrop, R.C., Carpenter, S.R., and Robertson, D.M., 1999, Summer water clarity responses to phosphorus, Daphnia grazing, and internal mixing in Lake Mendota: Limnology and Oceanography, vol. 44, no. 1, p. 137-146.

Krohelski, J.T., Feinstein, D.T., and Lenz, B.N., 1999, Simulation of stage and hydrologic budget for Shell Lake, Washburn County, Wisconsin: U.S. Geological Survey WaterResources Investigations Report 99-4209, 23 p.

Panuska, J.C., and Robertson, D.M., 1999, Estimating phosphorus concentrations following alum treatment using apparent settling velocities: Lakes and Reservoir Management, vol. 15, no. 1, p. 28-38.

1998

Hunt, R.J, Anderson, M.P., and Kelson, V.A., 1998, Improving a complex finitedifference ground water flow model through the use of an analytic element screening model: Ground Water, vol. 36, no. 6, p. 1011-1017.

Hunt, R.J, Anderson, M.P., and Kelson, V.A., 1998, Linking an analytic element flow code to MODFLOW - Implementation and benefits, In MODFLOW'98: Proceedings of the 3rd International Conference of the International Ground Water Center. Golden, CO: Colorado School of Mines, p 477-504. 
Krabbenhoft, D.P., Gilmour, C.C., Benoit, J.M., Babiarz, C.L., Andren, A.W., and Hurley, J.P., 1998, Methyl mercury dynamics in littoral sediments of a temperate lake: Canadian Journal of Fisheries and Aquatic Sciences, vol. 55, p. 835-844.

Robertson, D.M., Elder, J.F., Goddard, G.L., and James, W.F., 1998, Dynamics in phosphorus retention in wetlands upstream of Delavan Lake, Wisconsin: Lakes and Reservoir Management, vol. 14, no. 4, p. 466-477.

Rose, W.J., and Robertson, D.M., 1998, Hydrology, water quality, and phosphorus loading of Kirby Lake, Barron County, Wisconsin: U.S. Geological Survey Fact Sheet FS-066-98, 4 p.

Walker, J.F. and Krabbenhoft, D.P., 1998, Groundwater and surface-water interactions in riparian and lake-dominated systems, In Kendall, C. and McDonnell, J.J. eds., Isotope tracers in catchment hydrology, Elsevier Publishing, New York, 839 p.

1997

Elder, J.F., Manion, B.J., and Goddard, G.L., 1997, Mesocosm experiments to assess factors affecting phosphorus retention and release in an extended Wisconsin wetland: U.S. Geological Survey Water-Resources Investigations Report 97-4272, $14 \mathrm{p}$.

Goddard, G.L., and Elder, J.F., 1997, Retention of sediments and nutrients in Jackson Creek Wetland near Delavan Lake, Wisconsin, 1993-95: U.S. Geological Survey Water-Resources Investigations Report 97-4014, 22 p.

Hornewer, N.J., Johnson, G.P., Robertson, D.M. and Hondzo, M., 1997, Field-scale tests for determining mixing patterns associated with coarse-bubble air diffuser configurations, Egan Quarry, Illinois, In Environmental and Coastal Hydraulics: Protecting the Aquatic Habitat, Proceedings of the International Association of Hydraulic Research, San Francisco, CA, USA, p. 57-63.

Robertson, D.M., 1997, Regionalized loads of sediment and phosphorus to Lakes Michigan and Superior-High flow and long-term average: Journal of Great Lakes Research, vol. 23, p. 416-439.

1996

Anderson, W.L., Robertson, D.M., and Magnuson, J.J., 1996, Evidence of recent warming and El Nino-related variation in ice breakup of Wisconsin lakes: Limnology and Oceanography, vol. 41, p. 815-821.

Elder, J.F. and Goddard, G.L., 1996, Sediment and nutrient trapping efficiency of a constructed wetland near Delavan Lake, Wisconsin, 1993-1995: U.S. Geological Survey Fact Sheet FS-232-96.

Garn, H.S., Olson, D.L., Seidel, T.L., and Rose, W.J., 1996, Hydrology and water quality of Lauderdale Lakes, Walworth County, Wisconsin, 1993-94: U.S. Geological Survey Water-Resources Investigations Report 96-4235, 29 p. 
Hunt, R.J. and Krohelski, J.T., 1996, The application of an analytical element model to investigate groundwater-lake interactions at Pretty Lake, Wisconsin: Lake and Reservoir Management, vol. 12, p. 487-495.

Imberger, J., Robertson, D.M., and Boland, K., 1996, Lake Number-A quantitative indicator of mixing to be used in water quality management: Scientific Impeller, Solna, Sweden, no. 4, p. 9-15.

Kammerer, P.A., Jr., 1996, Hydrology and water quality of Park Lake, South-central Wisconsin: U.S. Geological Survey Fact Sheet FS-197-96.

Robertson, D.M., Field, S.J, Elder, J.F., Goddard, G.L., and James, W.F., 1996, Phosphorus dynamics of Delavan Lake Inlet in southeastern Wisconsin: U.S. Geological Survey Water-Resources Investigations Report 96-4160, 18 p.

1995

Assel, R.A. and Robertson, D.M. 1995, Changes in winter air temperatures near Lake Michigan during 1851-1993, as determined from regional lake-ice records: Limnology and Oceanography, v. 40, p 165-176.

Assel, R.A., Robertson, D.M., Hoff, M.H., and Selgeby, J.H., 1995, Climatic-change implications from long-term (1823-1994) ice records near the Laurentian Great Lakes: Annals of Glaciology, vol. 21, p. 383-386.

Krabbenhoft, D.P., and Webster, K.E., 1995, Transient hydrogeological controls on the chemistry of a seepage lake: Water Resources Research, vol. 31, no. 9, p. 22952305.

Krohelski, J.T. and Batten, W.G., 1995, Simulation of stage and the hydrologic budget of Devils Lake, Sauk County, Wisconsin: U.S. Geological Survey Open-File Report 94348, $22 \mathrm{p}$.

Wentz, D.A., Rose, W.J., and Webster, K.E., 1995, Long-term hydrologic and biogeochemical responses of a soft water seepage lake in north central Wisconsin: Water Resources Research, vol. 31, no. 1, p. 199-212.

1994

Elder, J.F., 1994, Distribution and grain-size partitioning of metals in bottom sediments of an experimentally acidified lake: Water Resources Bulletin, vol. 30, no. 2, p. 251259.

Goddard, G.L., and Field, S.J., 1994, Hydrology and water quality of Whitewater and Rice Lakes in southeastern Wisconsin, 1990-91: U.S. Geological Survey WaterResources Investigations Report 94-4101, 36 p.

Greb, S.R., and Wentz, D.A., 1994, Chemical budgets, In Klepinger, K.E., ed., RILWAS 1983-86: Wisconsin Regional Integrated Lake Watershed Acidification Study, Volume 1: Madison, Wisconsin Department of Natural Resources, PUBL-RS-90994, Chapter 7, $20 \mathrm{p}$. 
Hurley, J.P., Krabbenhoft, D.P., Babiarz, C.L., and Andren, A.W., 1994, Cycling processes of mercury across sediment/water interfaces in seepage lakes, In Baker, L.A. ed., Environmental Chemistry of Lakes and Reservoirs: Advances in Chemistry Series, American Chemical Society, Washington, D.C., p. 426-449.

Krabbenhoft, D.P., Bowser, C.J., Kendall, C., and Gat, J.R., 1994, Use of oxygen-19 and deuterium to assess the hydrology of ground-water/lake systems, In Baker, L.A. ed., Environmental Chemistry of Lakes and Reservoirs: Advances in Chemistry Series, American Chemical Society, Washington, D.C., p. 67-90.

Robertson, D.M., Anderson, W., and Magnuson, J.J., 1994, Relations between El Nino/Southern Oscillation events and the climate and ice cover of lakes in Wisconsin, In Greenland, D. ed., El Nino and Long-Term Ecological Research (LTER) Sites: Publication No. 18. LTER Network Office: University of Washington, Seattle, WA, USA., p. 48-57.

Robertson, D.M. and Imberger, J. 1994, Lake Number, a quantitative indicator of mixing used to estimate changes in dissolved oxygen, Internationale Revue der gesamten Hydrobiologie, v. 79, p. 159-176.

Watras, C.J., Bloom, N.S., Hurley, J.P., Fitzgerald, W.F., Andren, A.W., Krabbenhoft, D.P., and Porcella, D.B., 1994, Sources and fates of mercury and methylmercury in Wisconsin lakes, In Watras and Huckabee eds., Mercury as a Global Pollutant: Intergration and Synthesis, Lewis Pub., Chelsea, MI., p 153-177.

Wentz, D.A., 1994, Chemistry of snowpack and ground water, In Klepinger, K.E., ed., RILWAS 1983-86: Wisconsin regional integrated lake watershed acidification study, volume 1: Madison, Wisconsin Department of Natural Resources, PUBL-RS-90994, chapter 6, $45 \mathrm{p}$.

Wentz, D.A., Krohelski, J.T., and Rose, W.J., 1994, Hydrology, In Klepinger, K.E., ed., RILWAS 1983-86: Wisconsin regional integrated lake watershed acidification study, volume 1: Madison, Wisconsin Department of Natural Resources, PUBL-RS-90994, chapter 7, 74 p.

1993

Field, S.J., 1993, Hydrology and water quality of Powers Lake, southeastern Wisconsin: U.S. Geological Survey Water-Resources Investigations Report 90-4126, 36 p.

Field, S.J., 1993, Hydrology and water quality of Wind Lake in southeastern Wisconsin: U.S. Geological Survey Water-Resources Investigations Report 91-4107, 61 p.

House, L.B., 1993, Simulation of the effects of hypothetical residential development on water levels in Graber Pond, Middleton, Wisconsin: U.S. Geological Survey WaterResources Investigations Report 92-4029, 10 p.

House, L.B., Waschbusch, R.J., and Hughes, P.E., 1993, Water quality of an urban wet detention pond in Madison, Wisconsin, 1987-88: U.S. Geological Survey Open-File Report 93-172, $57 \mathrm{p}$. 
Hughes, P.E., 1993, Hydrology, water quality, trophic status, and aquatic plants of Fowler Lake, Wisconsin: U.S. Geological Survey Water-Resources Investigations Report 91-4076, $44 \mathrm{p}$.

Rose, W.J., 1993, Hydrology of Little Rock Lake in Vilas County, north-central Wisconsin: U.S. Geological Survey Water-Resources Investigations Report 93-4139, $22 \mathrm{p}$.

Rose, W.J., 1993, Water and phosphorus budgets and trophic state, Balsam Lake, northwestern Wisconsin, 1987-1989: U.S. Geological Survey Water-Resources Investigations Report 91-4125, 28 p.

1992

Elder, J.F., Krabbenhoft, D.P, and Walker, J.F., 1992, Water, energy, and biogeochemical budgets (WEBB) program: Data availability and research at the northern temperate lakes site, Wisconsin: U.S. Geological Survey Open-File Report 92-48, 15 p.

Krabbenhoft, D.P., and Babiarz, C.L., 1992, Role of groundwater transport in aquatic mercury cycling: Water Resources Research, vol. 28, no. 12, p. 3119-3128.

Krabbenhoft, D.P., and Krohelski, J.T., 1992, Data on water quality, lake sediment, and lake-level fluctuation, St. Croix Indian Reservation, Wisconsin, 1981-87: U.S. Geological Survey Open-File Report 92-26, 53 p.

Robertson, D.M., Ragotzkie, R.A., and Magnuson, J.J. 1992, Lake ice records used to detect historical and future climatic changes: Climatic Change, v. 21, p. 407-427.

1991

Wentz, D.A., and Rose, W.J., 1991, Hydrology of Lakes Clara and Vandercook in northcentral Wisconsin: U.S. Geological Survey Water-Resources Investigations Report 89-4204, 24 p.

Watras, C.J., Andre, A.W., Bloom, N.S., Fitzgerald, W.F., Hurley, J.P., Krabbenhoft, D.P., Rada, R.G., Wiener, J.G., 1991, Mercury in temperate lakes: a mechanistic field study: Verhandlungen Internat. Verein. Limnologie, 24, p. 2199-2202.

Pre-1990

Walker, J.F., Pickard, S.A., and Sonzogni, W.C., 1989 Spreadsheet watershed modeling for nonpoint-source pollution management in a Wisconsin basin: Water Resources Bulletin, vol. 25, no. 1, p. 139-147.

Wentz, D.A., Garrison, P.J., and Bockheim, J.G., 1989, Section 7-Chemical inputoutput budgets, In Knauer, D., and Brouwer, S.A., eds., The Wisconsin regional integrated lake watershed acidification study (RILWAS)-1981-1983: Palo Alto, California, Electric Power Research Institute Report EA-6214, p. 7-1 to 7-30. 
Wentz, D.A., and Rose, W.J., 1989, Interrelationships among hydrologic-budget components of a northern Wisconsin seepage lake and implications for aciddeposition modeling: Archives of Environmental Contamination and Toxicology, vol. 18, p. 147-155.

Wentz, D.A., Rose, W.J., and Krohelski, J.T., 1989, Section 5-Hydrologic component, in Knauer, D., and Brouwer, S.A., eds., The Wisconsin regional integrated lake watershed acidification study (RILWAS)-1981-1983: Palo Alto, California, Electric Power Research Institute Report EA-6214, p. 5-1 to 5-77.

Field, S.J., and Duerk, M.D., 1988, Hydrology and water quality of Delavan Lake in southeastern Wisconsin: U.S. Geological Survey Water-Resources Investigations Report 87-4168, 61 p.

Krug, W.R., Ostenso, N.A., and Krohelski, J.T., 1988, Prediction of the effects of mine dewatering on four lakes near Crandon, Wisconsin, by use of a water-budget model: U.S. Geological Survey Open-File Report 87-471, 63 p.

Wentz, D.A., Krohelski, J.T., Rose, W.J., Bockheim, J.G., Garrison, P.J., Knauer, D.R., and Goldstein, R.A., 1987, Hydrologic and chemical budgets of Wisconsin lakes, In Perry, R., Harrison, R.M., Bel, J.N.B., and Lester, J.N., eds., Acid Rain: Scientific and Technical Advances, Selper Ltd., London, p. 309-316.

House, L.B., 1986, Stage fluctuations of Wisconsin Lakes: Wisconsin Geological and Natural History Survey Information Circular No. 49, 84 p.

House, L.B., 1984, Effects of urbanization on three ponds in Middleton, Wisconsin: U.S. Geological Survey Water-Resources Investigations Report 84-4051, 17 p.

Krug, W.R., and House, L.B., 1984, Evaluation of alternative reservoir-management practices in the Rock River basin, Wisconsin: U.S. Geological Survey WaterResources Investigations Report 83-4186, 21 p.

House, L.B., 1981, An assessment of streamflow, water quality, and the effects of construction on impoundment on Bridge Creek at Augusta, Wisconsin: U.S. Geological Survey Water-Resources Investigations Open-File Report 81-1192, 25 p.

Krug, W.R., 1981, Hydrologic effects of proposed changes in management practices, Winnebago Pool, Wisconsin: U.S. Geological Survey Water-Resources Investigations 80-107, 19 p.

Batten, W.G., and Hindall, S.M., 1980, Sediment deposition in the White River Reservoir, northwestern Wisconsin: U.S. Geological Survey Water-Supply Paper 2069, $30 \mathrm{p}$.

Novitzki, R.P., and Holmstrom, B.K., 1979, Monthly and annual water budgets of Lake Wingra, Madison, Wisconsin, 1971-77: U.S. Geological Survey Water-Resources Investigations 79-100, $31 \mathrm{p}$.

Rose, W.J., 1977, Hydrologic considerations associated with dredging spring ponds in Wisconsin: U.S. Geological Survey Water-Resources Investigations 77-18, 35 p.

Oakes, E.L., Hendrickson, G.E., and Zuehls, E.E., 1975, Hydrology of the Lake Wingra basin, Dane County, Wisconsin: U.S. Geological Survey Water-Resources Investigations 17-75, $31 \mathrm{p}$. 
Novitzki, R.P., 1971, Hydrologic investigations of Heart Lake, Green Lake County, Wisconsin: U.S. Geological Survey Administrative Report, 9 p. 


\section{APPENDIX \\ Wisconsin Lakes Team \\ Quality-Assurance Plan}

Most lake studies and monitoring programs that are conducted by the USGS Wisconsin Water Science Center entail water sampling and analysis to determine water quality and biological productivity. Because all sampling and analysis is subject to error and random variablility, a certain proportion of the sampling effort should include quality-assurance samples. Sampling by the USGS was done by the Lake Studies Team of the USGS Wisconsin Water Science Center. This team implements a quality-assurance plan each year that involves collecting three types of samples from a subset of the lakes studied each year, which include blanks, replicates, and spikes (U.S. Geological Survey, Wisconsin Water Science Center Lake Studies Team). These samples are collected and/or prepared solely for the purpose of assessing the magnitude of error and random variability so that the accuracy and precision of all data can be evaluated. The plan for this quality-assurance sampling is described below.

Three types of QA/QC samples are collected:

\section{blanks}

Provide information about accuracy and errors due to treatment or reagents replicates provide information about precision (variability) standard additions (spikes)

provide information about accuracy and matrix interferences

\section{Blank Sampling}

B1. A preservation blank consists of deionized water or inorganic blank water, to which is added any reagents or preservatives that are normally added to natural water samples. The blank is not taken to the field, but is shipped to the laboratory for analysis along with the natural water samples.

This blank sample is analyzed for the Nutrient Group ${ }^{1}$ and chlorophyll-a.

B2. A field blank consists of deionized water or inorganic blank water treated exactly the same as regular samples. During winter, the field blank is analyzed for total phosphorus (TP) only; during summer, it is analyzed for TP and chlorophyll-a, and in the spring it is analyzed for the Nutrient Group and chlorophyll-a.

\footnotetext{
${ }^{1}$ Nutrient Group = all phosphorus and nitrogen species that are commonly determined in lakes (total phosphorus, nitrate + nitrite, ammonia, total Kjeldahl nitrogen, total nitrogen)
} 


\section{Replicate Sampling}

Triplicate samples are taken near water surface in summer for analysis of total phosphorus and chlorophyll-a. For a portion of the sites where surface triplicates are collected, a set of triplicate samples is also taken from near-bottom water, for analysis of total phosphorus.

Triplicate samples collected in the spring are taken near the water surface for analysis of the Nutrient Group.

\section{Standard Addition Testing}

Replicate samples are collected for a standard addition (spike) test, which consists of an addition of a prepared phosphorus solution (standard) of known volume and concentration, such that the expected result of analysis is the natural water TP concentration plus the known addition. One sample from each set will receive no spike (the mean of these gives the natural water TP concentration).

Data and results of replicate sampling and field blank testing for the past five years are shown in Table A1. 
Table A1. Analyses of replicate samples from Wisconsin lakes in water years 2007-2011. See text for procedures used. Phosphorus data in milligrams per liter; chlorophyll data in micrograms per liter. Symbol "<" indicates less than given detection limit (DL); mean and standard deviation not calculated for datasets containing values less than DL.

\begin{tabular}{|c|c|c|c|c|c|c|c|c|}
\hline Parameter & \multirow{2}{*}{$\frac{\text { Lake }}{\text { Beulah }}$} & Date & \multicolumn{3}{|c|}{ Replicate Data } & Mean & \multirow{2}{*}{$\begin{array}{r}\begin{array}{r}\text { Standard } \\
\text { Deviation }\end{array} \\
0.001\end{array}$} & \multirow{2}{*}{$\begin{array}{r}\begin{array}{r}\text { Percent } \\
\text { Standard } \\
\text { Deviation }\end{array} \\
8.8\end{array}$} \\
\hline \multirow{15}{*}{ Total Phosphorus } & & $8 / 30 / 07$ & 0.017 & 0.015 & & 0.016 & & \\
\hline & Delavan & $4 / 16 / 07$ & 0.040 & 0.038 & & 0.039 & 0.001 & 3.6 \\
\hline & Spring & $9 / 6 / 07$ & 0.008 & 0.007 & & 0.008 & 0.001 & 9.4 \\
\hline & Beulah & $3 / 4 / 08$ & 0.010 & 0.011 & & 0.011 & 0.001 & 6.7 \\
\hline & Beulah & $8 / 26 / 08$ & 0.011 & 0.012 & & 0.012 & 0.001 & 6.1 \\
\hline & Beulah & $2 / 23 / 09$ & 0.013 & 0.013 & & 0.013 & 0.000 & 0.0 \\
\hline & Beulah & $8 / 24 / 09$ & 0.017 & 0.017 & & 0.017 & 0.000 & 0.0 \\
\hline & Delavan & $9 / 15 / 09$ & 0.035 & 0.031 & 0.031 & 0.032 & 0.002 & 7.1 \\
\hline & Beulah & $8 / 19 / 10$ & 0.015 & 0.016 & & 0.016 & 0.001 & 4.6 \\
\hline & Big Cedar, South & $8 / 24 / 10$ & 0.015 & 0.014 & & 0.015 & 0.001 & 4.9 \\
\hline & Powers & $8 / 30 / 10$ & 0.021 & 0.022 & & 0.022 & 0.001 & 3.3 \\
\hline & Beulah & $8 / 10 / 11$ & 0.140 & 0.170 & & 0.155 & 0.021 & 13.7 \\
\hline & Oconomowoc & $7 / 25 / 11$ & 0.013 & 0.010 & 0.012 & 0.012 & 0.002 & 13.1 \\
\hline & Powers & $7 / 25 / 11$ & 0.017 & 0.018 & 0.020 & 0.018 & 0.002 & 8.3 \\
\hline & Wind & $7 / 25 / 11$ & 0.018 & 0.019 & 0.021 & 0.019 & 0.002 & 7.9 \\
\hline \multirow{3}{*}{$\begin{array}{l}\text { Total Phosphorus, } \\
\text { near bottom }\end{array}$} & Wind & $7 / 10 / 06$ & 0.380 & 0.378 & 0.394 & 0.384 & 0.009 & 2.3 \\
\hline & Big Cedar, South & $8 / 24 / 10$ & 0.081 & 0.067 & & 0.074 & 0.010 & 13.4 \\
\hline & Powers & $8 / 30 / 10$ & 0.036 & 0.038 & & 0.037 & 0.001 & 3.8 \\
\hline \multirow{7}{*}{$\begin{array}{c}\text { Dissolved } \\
\text { Phosphorus }\end{array}$} & Beulah & $8 / 30 / 07$ & $<0.002$ & $<0.002$ & & & & \\
\hline & Beulah & $3 / 4 / 08$ & 0.001 & 0.003 & & 0.002 & 0.001 & 70.7 \\
\hline & Beulah & $8 / 26 / 08$ & $<0.002$ & $<0.002$ & & & & \\
\hline & Beulah & $2 / 23 / 09$ & $<0.002$ & $<0.002$ & & & & \\
\hline & Beulah & $8 / 24 / 09$ & $<0.002$ & $<0.002$ & & & & \\
\hline & Beulah & $8 / 19 / 10$ & $<0.002$ & $<0.002$ & & & & \\
\hline & Beulah & $8 / 10 / 11$ & $<0.002$ & $<0.002$ & & & & \\
\hline \multirow{7}{*}{ Dissolved Ammonia } & Beulah & $8 / 30 / 07$ & 0.170 & 0.190 & & 0.180 & 0.014 & 7.9 \\
\hline & Beulah & $3 / 4 / 08$ & 0.083 & 0.046 & & 0.065 & 0.026 & 40.6 \\
\hline & Beulah & $8 / 26 / 08$ & $<0.015$ & $<0.015$ & & & & \\
\hline & Beulah & 2/23/09 & 0.211 & 0.204 & & 0.208 & 0.005 & 2.4 \\
\hline & Beulah & $8 / 24 / 09$ & 0.032 & 0.035 & & 0.034 & 0.002 & 6.3 \\
\hline & Beulah & $8 / 19 / 10$ & $<0.015$ & 0.030 & & & & \\
\hline & Beulah & $8 / 10 / 11$ & 0.032 & 0.029 & & 0.031 & 0.002 & 7.0 \\
\hline \multirow{7}{*}{ Total Kjeldahl Nitrogen } & Beulah & $8 / 30 / 07$ & 0.510 & 0.420 & & 0.465 & 0.064 & 13.7 \\
\hline & Beulah & $3 / 4 / 08$ & 0.570 & 0.450 & & 0.510 & 0.085 & 16.6 \\
\hline & Beulah & $8 / 26 / 08$ & 0.530 & 0.580 & & 0.555 & 0.035 & 6.4 \\
\hline & Beulah & $2 / 23 / 09$ & 0.660 & 0.690 & & 0.675 & 0.021 & 3.1 \\
\hline & Beulah & $8 / 24 / 09$ & 0.160 & 0.530 & & 0.345 & 0.262 & 75.8 \\
\hline & Beulah & $8 / 19 / 10$ & 0.580 & 0.680 & & 0.63 & 0.071 & 11.2 \\
\hline & Beulah & $8 / 10 / 11$ & 0.560 & 0.460 & & 0.510 & 0.071 & 13.9 \\
\hline \multirow{7}{*}{$\begin{array}{l}\text { Dissolved Nitrate plus } \\
\text { Nitrite }\end{array}$} & Beulah & $8 / 30 / 07$ & $<0.019$ & $<0.019$ & & & & \\
\hline & Beulah & $3 / 4 / 08$ & 0.675 & 0.670 & & 0.673 & 0.004 & 0.5 \\
\hline & Beulah & $8 / 26 / 08$ & $<0.019$ & $<0.019$ & & & & \\
\hline & Beulah & $2 / 23 / 09$ & 0.673 & 0.721 & & 0.697 & 0.034 & 4.9 \\
\hline & Beulah & $8 / 24 / 09$ & 0.074 & 0.073 & & 0.074 & 0.001 & 1.0 \\
\hline & Beulah & $8 / 19 / 10$ & 0.022 & 0.022 & & 0.022 & 0.000 & 0.0 \\
\hline & Beulah & $8 / 10 / 11$ & 0.067 & 0.066 & & 0.067 & 0.001 & 1.1 \\
\hline
\end{tabular}




\begin{tabular}{|c|c|c|c|c|c|c|c|}
\hline Table A1. -- continued & Lake & Date & \multicolumn{2}{|r|}{ Replicate Data } & \multirow{3}{*}{$\begin{array}{r}\text { Mean } \\
3.92 \\
2.63 \\
\end{array}$} & \multirow{3}{*}{$\begin{array}{r}\begin{array}{r}\text { Standard } \\
\text { Deviation }\end{array} \\
0.19 \\
0.23 \\
\end{array}$} & \multirow{3}{*}{ 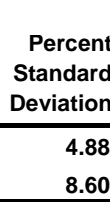 } \\
\hline \multirow{9}{*}{$\begin{array}{c}\text { Chlorophyll-a } \\
\text { (micrograms per liter) }\end{array}$} & Beulah & $8 / 30 / 07$ & 4.05 & 3.78 & & & \\
\hline & Spring & 9/6/07 & 2.47 & 2.79 & & & \\
\hline & Beulah & $8 / 26 / 08$ & 6.97 & 7.45 & 7.21 & 0.34 & 4.71 \\
\hline & Beulah & $2 / 23 / 09$ & 0.55 & 0.55 & 0.55 & 0.00 & 0.0 \\
\hline & Beulah & $8 / 24 / 09$ & 2.66 & 2.90 & 2.78 & 0.17 & 6.1 \\
\hline & Delavan & 9/15/09 & 10.80 & 10.10 & 10.23 & 0.51 & 5.0 \\
\hline & Beulah & $8 / 19 / 10$ & 5.35 & 5.56 & 5.46 & 0.15 & 2.72 \\
\hline & Big Cedar, South & $8 / 24 / 10$ & 3.93 & 3.9 & 3.92 & 0.02 & 0.54 \\
\hline & Beulah & $8 / 10 / 11$ & 4.45 & 5.24 & 4.85 & 0.56 & 11.53 \\
\hline \multirow{7}{*}{ Turbidity, NTU } & Beulah & $8 / 30 / 07$ & $<1.0$ & $<1.0$ & & & \\
\hline & Beulah & $3 / 4 / 08$ & $<1.0$ & $<1.0$ & & & \\
\hline & Beulah & $8 / 26 / 08$ & $<1.0$ & $<1.0$ & & & \\
\hline & Beulah & $2 / 23 / 09$ & $<1.0$ & $<1.0$ & & & \\
\hline & Beulah & $8 / 24 / 09$ & $<1.0$ & $<1.0$ & & & \\
\hline & Beulah & $8 / 19 / 10$ & $<1.0$ & $<1.0$ & & & \\
\hline & Beulah & $8 / 10 / 11$ & $<1.0$ & $<1.0$ & & & \\
\hline \multirow{7}{*}{ Dissolved Calcium } & Beulah & $8 / 30 / 07$ & 42.8 & 41 & 41.9 & 1.273 & 3.0 \\
\hline & Beulah & $3 / 4 / 08$ & 62.8 & 62.5 & 62.65 & 0.212 & 0.3 \\
\hline & Beulah & $8 / 26 / 08$ & 47.9 & 47.6 & 47.75 & 0.212 & 0.4 \\
\hline & Beulah & $2 / 23 / 09$ & 63 & 63.8 & 63.4 & 0.566 & 0.9 \\
\hline & Beulah & $8 / 24 / 09$ & 41.7 & 41.9 & 41.8 & 0.141 & 0.3 \\
\hline & Beulah & $8 / 19 / 10$ & 47 & 47.3 & 47.15 & 0.212 & 0.4 \\
\hline & Beulah & $8 / 10 / 11$ & 37.4 & 38 & 37.7 & 0.424 & 1.1 \\
\hline \multirow{7}{*}{ Diss. Magnesium } & Beulah & $8 / 30 / 07$ & 32.7 & 31.2 & 31.95 & 1.061 & 3.3 \\
\hline & Beulah & $3 / 4 / 08$ & 35.6 & 35.5 & 35.55 & 0.071 & 0.2 \\
\hline & Beulah & $8 / 26 / 08$ & 32.8 & 32.5 & 32.65 & 0.212 & 0.6 \\
\hline & Beulah & $2 / 23 / 09$ & 34.7 & 35.1 & 34.9 & 0.283 & 0.8 \\
\hline & Beulah & $8 / 24 / 09$ & 31.2 & 31.3 & 31.25 & 0.071 & 0.2 \\
\hline & Beulah & $8 / 19 / 10$ & 34.1 & 33.8 & 33.95 & 0.212 & 0.6 \\
\hline & Beulah & $8 / 10 / 11$ & 36.7 & 37.1 & 36.90 & 0.283 & 0.8 \\
\hline \multirow{7}{*}{ Diss. Potassium } & Beulah & $8 / 30 / 07$ & 1.5 & 1.4 & 1.45 & 0.071 & 4.9 \\
\hline & Beulah & $3 / 4 / 08$ & 1.8 & 1.9 & 1.85 & 0.071 & 3.8 \\
\hline & Beulah & $8 / 26 / 08$ & 1.4 & 1.4 & 1.4 & 0.000 & 0.0 \\
\hline & Beulah & 2/23/09 & 1.7 & 1.7 & 1.7 & 0.000 & 0.0 \\
\hline & Beulah & $8 / 24 / 09$ & 1.4 & 1.4 & 1.4 & 0.000 & 0.0 \\
\hline & Beulah & $8 / 19 / 10$ & 1.4 & 1.5 & 1.45 & 0.071 & 4.9 \\
\hline & Beulah & $8 / 10 / 11$ & 1.5 & 1.6 & 1.55 & 0.071 & 4.6 \\
\hline \multirow{7}{*}{ Dissolved Sodium } & Beulah & $8 / 30 / 07$ & 8.8 & 8.5 & 8.65 & 0.212 & 2.5 \\
\hline & Beulah & $3 / 4 / 08$ & 9.9 & 10 & 9.95 & 0.071 & 0.7 \\
\hline & Beulah & $8 / 26 / 08$ & 9 & 8.9 & 8.95 & 0.071 & 0.8 \\
\hline & Beulah & $2 / 23 / 09$ & 9.7 & 9.8 & 9.75 & 0.071 & 0.7 \\
\hline & Beulah & $8 / 24 / 09$ & 8.6 & 8.7 & 8.65 & 0.071 & 0.8 \\
\hline & Beulah & $8 / 19 / 10$ & 10.4 & 11.4 & 10.9 & 0.707 & 6.5 \\
\hline & Beulah & $8 / 10 / 11$ & 10.4 & 10.7 & 10.55 & 0.212 & 2.0 \\
\hline \multirow{8}{*}{ ANC as $\mathrm{CaCO} 3$} & Beulah & $8 / 30 / 07$ & 192 & 193 & 192.5 & 0.707 & 0.4 \\
\hline & Spring & $9 / 6 / 07$ & 6.6 & 6.4 & 6.5 & 0.141 & 2.2 \\
\hline & Beulah & $3 / 4 / 08$ & 245 & 244 & 244.5 & 0.707 & 0.3 \\
\hline & Beulah & $8 / 26 / 08$ & 219 & 218 & 218.5 & 0.707 & 0.3 \\
\hline & Beulah & $2 / 23 / 09$ & 258 & 256 & 257 & 1.414 & 0.6 \\
\hline & Beulah & $8 / 24 / 09$ & 209 & 209 & 209 & 0.000 & 0.0 \\
\hline & Beulah & $8 / 19 / 10$ & 208 & 207 & 207.5 & 0.707 & 0.3 \\
\hline & Beulah & $8 / 10 / 11$ & 194 & 194 & 194 & 0.000 & 0.0 \\
\hline
\end{tabular}




\begin{tabular}{|c|c|c|c|c|c|c|c|}
\hline Table A1. -- continued & Lake & Date & & Replicate Data & Mean & $\begin{array}{l}\text { Standard } \\
\text { Deviation }\end{array}$ & $\begin{array}{l}\text { Percent } \\
\text { Standard } \\
\text { Deviation }\end{array}$ \\
\hline \multirow{7}{*}{ Diss. Chloride } & Beulah & $8 / 30 / 07$ & 20.3 & 20.4 & 20.35 & 0.071 & 0.3 \\
\hline & Beulah & $3 / 4 / 08$ & 23.5 & 23.7 & 23.6 & 0.141 & 0.6 \\
\hline & Beulah & $8 / 26 / 08$ & 21 & 20.9 & 20.95 & 0.071 & 0.3 \\
\hline & Beulah & $2 / 23 / 09$ & 23 & 22.9 & 22.95 & 0.071 & 0.3 \\
\hline & Beulah & $8 / 24 / 09$ & 21.6 & 21.4 & 21.5 & 0.141 & 0.7 \\
\hline & Beulah & $8 / 19 / 10$ & 21.6 & 21.5 & 21.55 & 0.071 & 0.3 \\
\hline & Beulah & $8 / 10 / 11$ & 24.7 & 24.5 & 24.6 & 0.141 & 0.6 \\
\hline \multirow{8}{*}{ Dissolved Silica } & Beulah & $8 / 30 / 07$ & 15.2 & 15.3 & 15.25 & 0.071 & 0.5 \\
\hline & Spring & $9 / 6 / 07$ & 0.105 & 0.111 & 0.108 & 0.004 & 3.9 \\
\hline & Beulah & $3 / 4 / 08$ & 15.3 & 15.2 & 15.25 & 0.071 & 0.5 \\
\hline & Beulah & $8 / 26 / 08$ & 10.3 & 10.3 & 10.3 & 0.000 & 0.0 \\
\hline & Beulah & $2 / 23 / 09$ & 14.8 & 15 & 14.9 & 0.141 & 0.9 \\
\hline & Beulah & $8 / 24 / 09$ & 11.3 & 11.3 & 11.3 & 0.000 & 0.0 \\
\hline & Beulah & $8 / 19 / 10$ & 18.1 & 18.1 & 18.1 & 0.000 & 0.0 \\
\hline & Beulah & $8 / 10 / 11$ & 12.7 & 12.7 & 12.7 & 0.00 & 0.0 \\
\hline \multirow{7}{*}{ Dissolved Sulfate } & Beulah & $8 / 30 / 07$ & 26.1 & 26.2 & 26.15 & 0.071 & 0.3 \\
\hline & Beulah & $3 / 4 / 08$ & 29.5 & 29.5 & 29.5 & 0.000 & 0.0 \\
\hline & Beulah & $8 / 26 / 08$ & 26.3 & 26.3 & 26.3 & 0.000 & 0.0 \\
\hline & Beulah & $2 / 23 / 09$ & 30.5 & 30.8 & 30.65 & 0.212 & 0.7 \\
\hline & Beulah & $8 / 24 / 09$ & 27.7 & 27.8 & 27.75 & 0.071 & 0.3 \\
\hline & Beulah & $8 / 19 / 10$ & 25.9 & 25.8 & 25.85 & 0.071 & 0.3 \\
\hline & Beulah & $8 / 10 / 11$ & 29.3 & 29.2 & 29.25 & 0.071 & 0.2 \\
\hline \multirow{7}{*}{ Dissolved Iron } & Beulah & $8 / 30 / 07$ & $<100$ & $<100$ & & & \\
\hline & Beulah & $3 / 4 / 08$ & $<100$ & $<100$ & & & \\
\hline & Beulah & $8 / 26 / 08$ & $<100$ & $<100$ & & & \\
\hline & Beulah & $2 / 23 / 09$ & $<100$ & $<100$ & & & \\
\hline & Beulah & $8 / 24 / 09$ & $<100$ & $<100$ & & & \\
\hline & Beulah & 8/19/10 & $<100$ & $<100$ & & & \\
\hline & Beulah & 8/10/11 & $<100$ & $<100$ & & & \\
\hline \multirow{5}{*}{ Diss. Manganese } & Beulah & $8 / 30 / 07$ & $<0.5$ & $<0.5$ & & & \\
\hline & Beulah & $8 / 26 / 08$ & $<0.5$ & $<0.5$ & & & \\
\hline & Beulah & $2 / 23 / 09$ & $<1.0$ & $<1.0$ & & & \\
\hline & Beulah & $8 / 24 / 09$ & $<1.0$ & $<1.0$ & & & \\
\hline & Beulah & 8/10/11 & $<1.0$ & $<1.0$ & & & \\
\hline \multirow{5}{*}{ Dissolved Solids } & Beulah & $8 / 26 / 08$ & 302 & 298 & 300 & 2.83 & 0.9 \\
\hline & Beulah & 2/23/09 & 350 & 346 & 348 & 2.83 & 0.8 \\
\hline & Beulah & $8 / 24 / 09$ & 312 & 312 & 312 & 0.00 & 0.0 \\
\hline & Beulah & $8 / 19 / 10$ & 284 & 286 & 285 & 1.41 & 0.5 \\
\hline & Beulah & $8 / 10 / 11$ & 270 & 272 & 271 & 1.41 & 0.5 \\
\hline
\end{tabular}


Table A2. Data from tests of blanks, 2007-2011. All data in milligrams per liter, unless otherwise indicated. $<=$ less than given detection limit; $\mathrm{E}=$ estimated value.

Delavan Lake. Analyses at USGS National Water Quality Laboratory, Lakewood, CO.

\begin{tabular}{lccccc} 
Parameter & $4 / 7 / 06$ & $6 / 13 / 06$ & $8 / 14 / 06$ & $4 / 16 / 07$ & $9 / 14 / 09$ \\
\hline Total P & $<0.004$ & $\mathrm{E} \mathrm{0.002}$ & $<0.004$ & $<0.004$ & $<0.008$ \\
Dissolved orthophosphate & $<0.006$ & $<0.006$ & $\mathrm{E} 0.003$ & $<0.006$ & $<0.008$ \\
Chlorophyll a & $<0.0260$ & & $<0.0260$ & $<0.260$ & \\
\hline
\end{tabular}

\begin{tabular}{lccccccc}
\hline Lake Beulah at Deep Hole near East Troy, WI. Analysis at Wisconsin State Laboratory of Hygiene, Madison, WI \\
Parameter & $8 / 29 / 07$ & $2 / 27 / 08$ & $8 / 26 / 08$ & $2 / 22 / 09$ & $8 / 20 / 09$ & $8 / 19 / 10$ & $8 / 10 / 11$ \\
\hline Total P & $<0.005$ & $<0.005$ & $<0.005$ & $<0.005$ & $<0.005$ & $<0.005$ & $<0.005$ \\
Dissolved orthophosphate & 0.005 & $<0.002$ & $<0.002$ & $<0.002$ & $<0.002$ & $<0.002$ & $<0.002$ \\
Total Kjeldahl & $<0.14$ & $<0.14$ & $<0.14$ & $<0.14$ & $<0.14$ & $<0.14$ & $<0.14$ \\
Dissolved Ammonia & $<0.15$ & $<0.015$ & $<0.015$ & $<0.015$ & $<0.015$ & 0.015 & $<0.015$ \\
Dissolved Nitrate plus Nitrite & $<0.019$ & $<0.019$ & $<0.019$ & $<0.019$ & $<0.019$ & $<0.019$ & $<0.019$ \\
Chlorophyll a (ug/L) & $<0.260$ & --- & $<0.260$ & $<0.260$ & $<0.260$ & $<0.260$ & $<0.260$ \\
Dissolved Calcium & $<0.10$ & $<0.10$ & $<0.10$ & $<0.10$ & $<0.10$ & $<0.10$ & $<0.10$ \\
Dissolved Magnesium & $<0.10$ & $<0.10$ & $<0.10$ & $<0.10$ & $<0.10$ & $<0.10$ & $<0.10$ \\
Dissolved Potassium & $<0.10$ & $<0.10$ & $<0.10$ & $<0.10$ & $<0.10$ & $<0.10$ & $<0.10$ \\
Dissolved Sodium & 0.200 & $<0.10$ & $<0.10$ & $<0.10$ & $<0.10$ & $<0.10$ & $<0.10$ \\
ANC as CaCO3 & $<2$ & 3 & $<2$ & $<2$ & $<2$ & $<2$ & 3 \\
Dissolved Chloride & $<1.0$ & 1.2 & $<1.0$ & $<1.0$ & $<1.0$ & $<1.0$ & $<1.0$ \\
Dissolved Silica & $<0.22$ & $<0.022$ & $<0.022$ & $<0.022$ & $<0.022$ & $<0.022$ & $<0.022$ \\
Dissolved Sulfate & $<4.5$ & $<4.5$ & $<4.5$ & $<4.5$ & $<4.5$ & $<4.5$ & $<4.5$ \\
Dissolved Iron & $<100$ & $<100$ & $<100$ & $<100$ & $<100$ & $<100$ & $<100$ \\
Dissolved Manganese & $<0.5$ & $<0.5$ & $<100$ & $<1.0$ & $<1.0$ & $<1.0$ & $<1.0$ \\
Dissolved Solids & -- & -- & $<50$ & $<50$ & $<50$ & $<50$ & $<50$ \\
Turbidity, NTU & --- & $<1.0$ & $<1.0$ & & $<1.0$ & $<1.0$ & $<1.0$
\end{tabular}

Mercer Lake at Main Deep Hole at Mercer, WI, WI. Analysis at Wisconsin State Laboratory of Hygiene, Madison, WI

\begin{tabular}{ll} 
Parameter & $8 / 27 / 10$ \\
\hline Total P & $<0.005$
\end{tabular}

\begin{tabular}{lc}
\hline Rolling Stone Lake near Pickerel, WI. Analysis at Wisconsin State Laboratory of Hygiene, Madison, WI \\
Parameter & $8 / 29 / 07$ \\
\hline Total P & $<0.005$ \\
Chlorophyll a (ug/L) & $<0.260$ \\
ANC as CaCO3 & 2 \\
Dissolved Silica & $<0.022$ \\
\hline
\end{tabular}

Wind Lake at Wind Lake, WI. Analyses at Wisconsin State Laboratory of Hygiene, Madison, WI
\begin{tabular}{lll} 
Parameter & $6 / 13 / 06$ & $8 / 30 / 10$ \\
\hline Total P & $<0.005$ & $<0.005$ \\
Chlorophyll a (ug/L) & $<0.260$ & \\
\hline
\end{tabular}

\begin{tabular}{lr}
\hline Silver Lake near West Bend, WI. & Analyses at Wisconsin State Laboratory of Hygiene, Madison, WI \\
Parameter & $8 / 31 / 09$ \\
\hline Total P & $<0.005$ \\
Chlorophyll a (ug/L) & $<0.260$ \\
\hline
\end{tabular}


For more information concerning this report, contact: Director, Wisconsin Water Science Center

U.S. Geological Survey

8505 Research Way

Middleton, Wisconsin 53562

(608) 828-9901

Or visit the Wisconsin Water Science Center Web site at: https://www.usgs.gov/centers/wisconsin-water-science-center 

$\sum_{3}$

粟 